Facultad de Filología

DePARTAMENTO DE LENGUA EsPaÑola

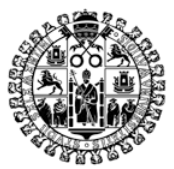

VNIVERSIDAD

DSALAMANCA

\title{
La fortificación y el arte militar en los tratados renacentistas: estudio lexicográfico
}

\section{TESIS DOCTORAL}

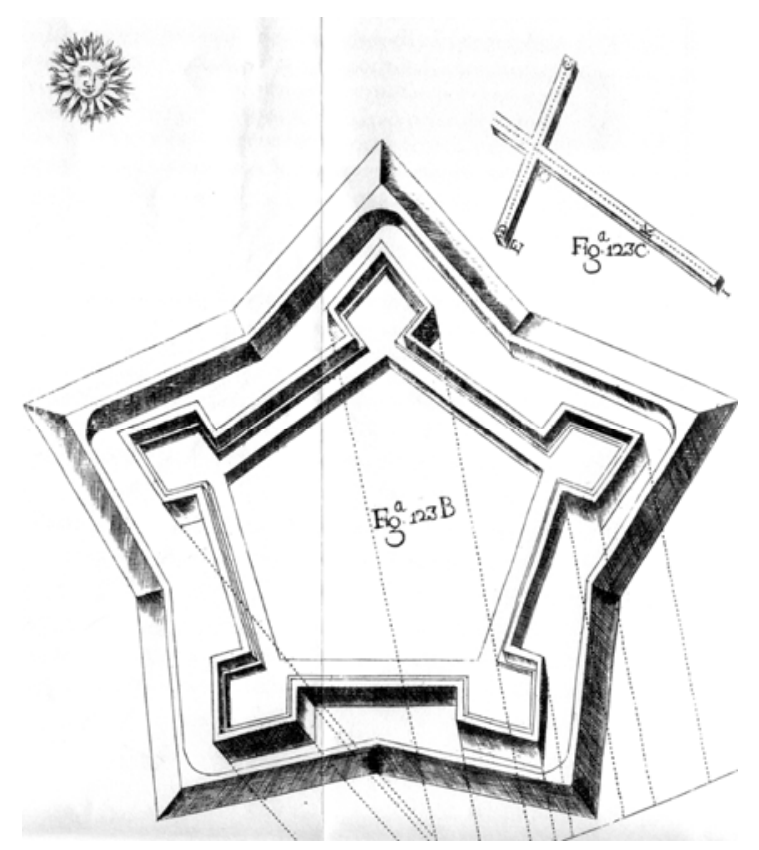

Marta Sánchez Orense

Directora: Dra. Ma Jesús Mancho Duque 





\section{ÍNDICE}

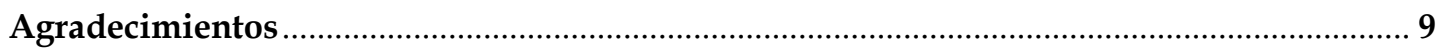

\section{Introducción}

1. Presentación y justificación del trabajo.................................................................................... 11

2. Objetivos del trabajo............................................................................................................. 13

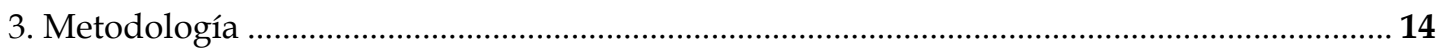

3.1. Consideraciones sobre la selección de la terminología militar objeto de estudio ....... 18

\section{Introducción histórica}

1. Aproximación al arte de hacer la guerra en la época moderna.................................................27

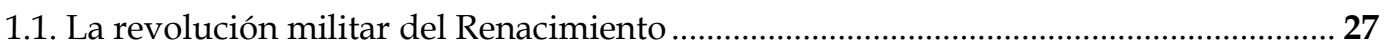

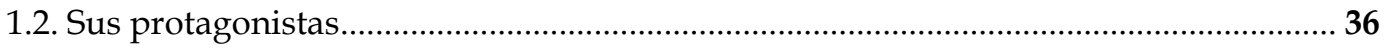

1.3. Consolidación y repercusiones de la revolución militar.................................................... 42

\section{Análisis lexicológico}

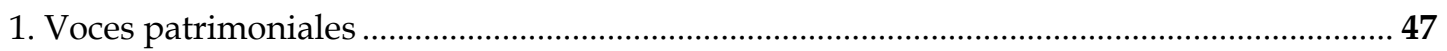

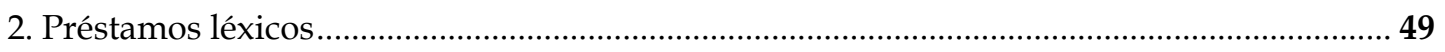

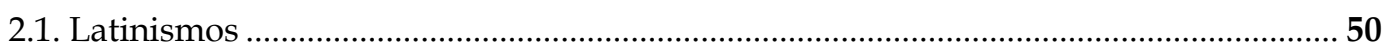

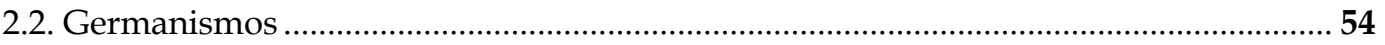

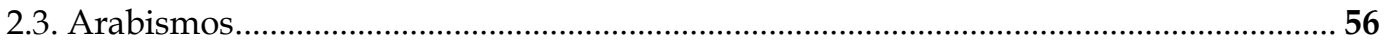

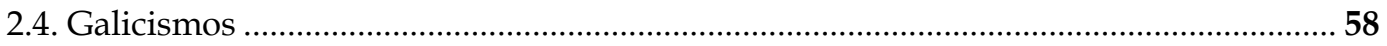

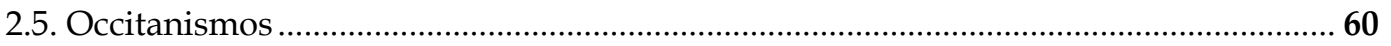

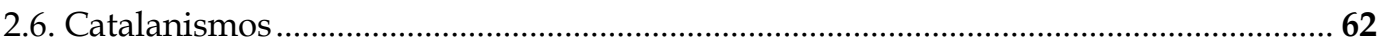

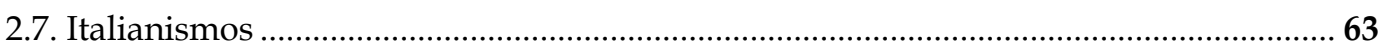

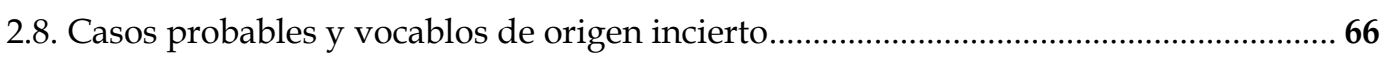

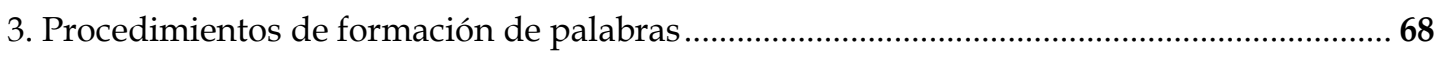

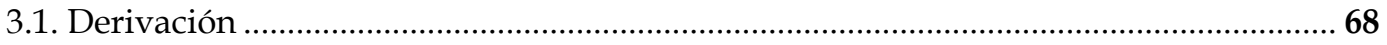




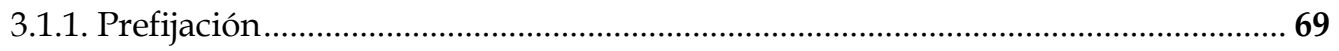

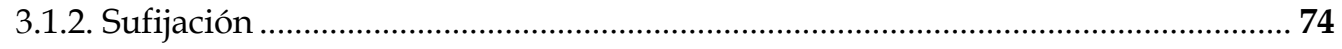

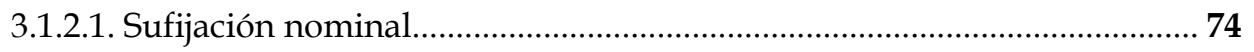

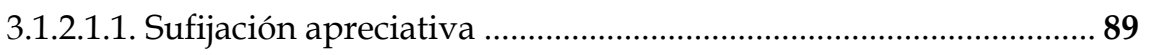

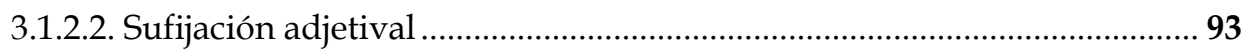

3.1.2.3. Sufijación adverbial ................................................................................ 99

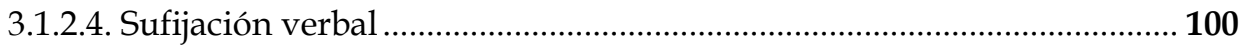

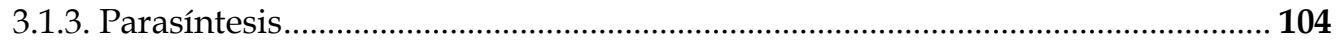

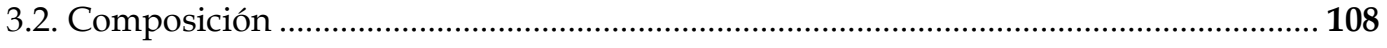

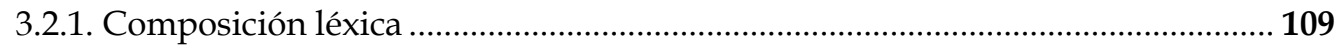

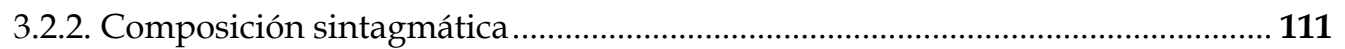

3.3. Unidades fraseológicas: locuciones adjetivales, adverbiales y verbales ...................... 115

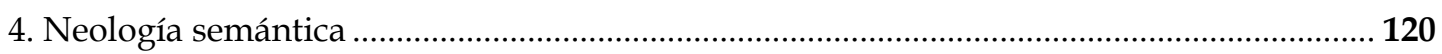

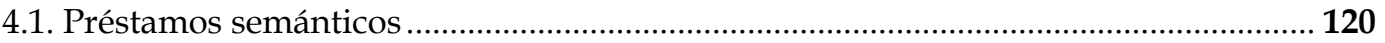

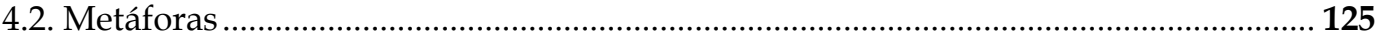

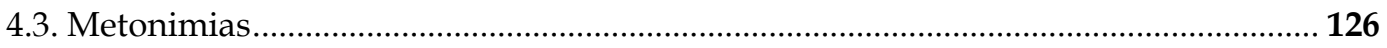

5. Otro mecanismo neológico: el calco ..................................................................................... 127

6. Recursos lingüísticos para la divulgación de los neologismos............................................... 128

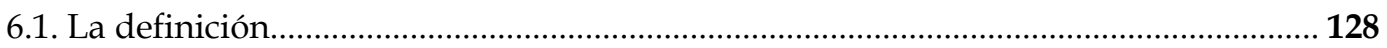

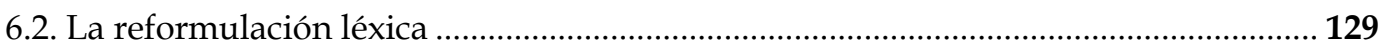

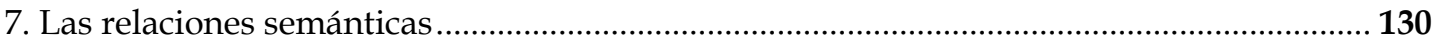

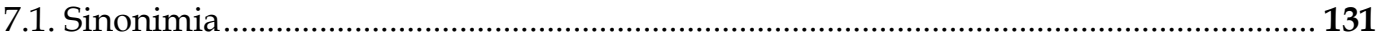

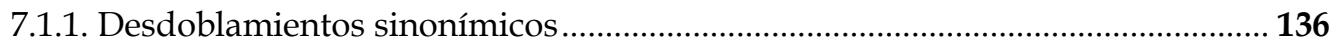

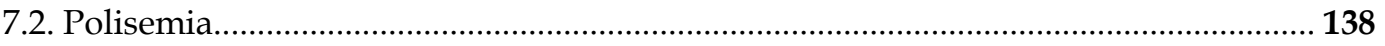

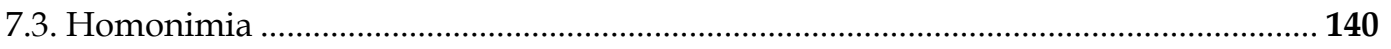

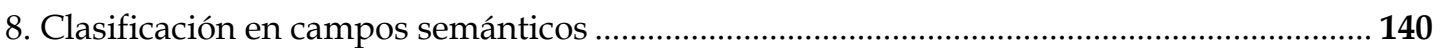

\section{Estudio lexicográfico}

1. Panorama de la lexicografía especializada relativa a la milicia ............................................. 153

1.1. El Diccionario militar (1749) de Raimundo Sanz............................................................... 154

1.2. Los Principios de fortificación (1772) de Pedro de Lucuze................................................... 156

1.3. La Encyclopedia metódica (1791-1792) de Luis Castañón................................................. 157

1.4. El repertorio de James Willson (1794) y demás diccionarios bilingües ....................... 158

1.5. El Diccionario militar portátil (1822) de Fernández Mancheño........................................ 159 
1.6. El Ensayo de un diccionario razonado sobre la ciencia de la guerra (1826) de Sánchez Cisneros

1.7. El Diccionario militar español-francés (1828) de Federico Moretti................................... 163

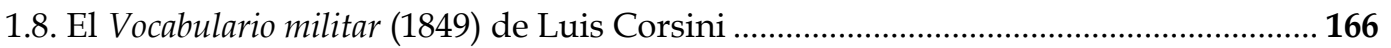

1.9. Los glosarios de los Catálogos de la Real Armería de 1849 y 1898 ................................ 169

1.10. El Vocabulario técnico del material de artillería e ingenieros (1853) de Emilio

de Tamarit

1.11. El Diccionario ilustrado de los pertrechos de guerra (1853-1866) de Luis

de Agar y el Diccionario militar (1856) de J. M. A ................................................................. 173

1.12. El Diccionario general militar (1857) de Deogracias Hevia.............................................. 173

1.13. El Diccionario militar (1863) de Jorge D'Wartelet ........................................................... 177

1.14. El Diccionario militar (1869) de José Almirante.............................................................. 179

1.15. El Diccionario de ciencias militares (1895-1901) de Rubió y Bellvé.................................. 183

1.16. El Diccionario militar (1897) de Nicolás Estévanez........................................................ 185

1.17. El Glosario de voces de armería (1912) de Leguina......................................................... 187

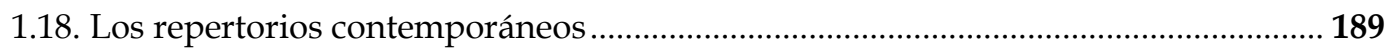

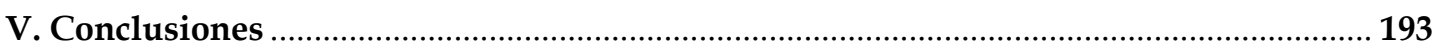

\section{Glosario}

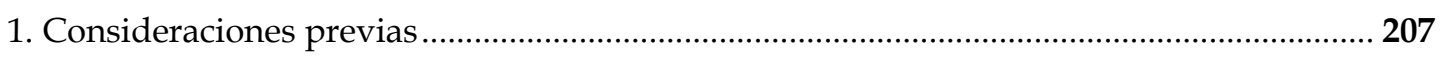

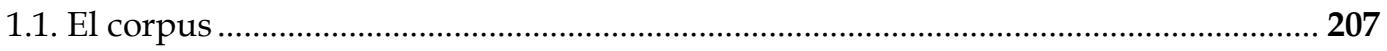

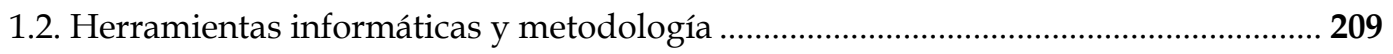

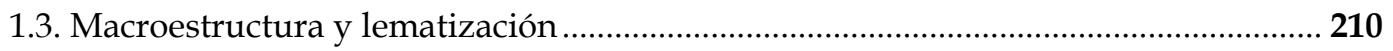

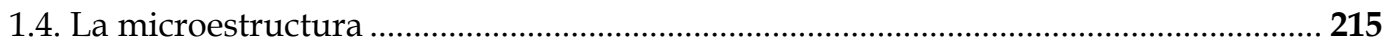

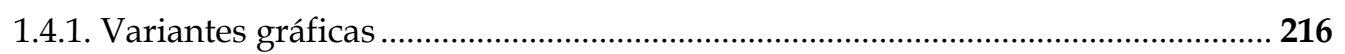

1.4.2. Información histórica, etimológica y morfológica .................................................. 219

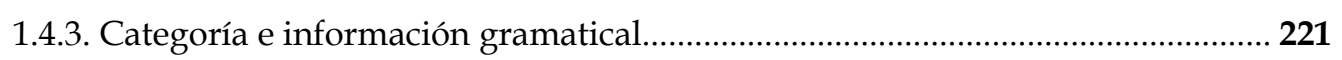

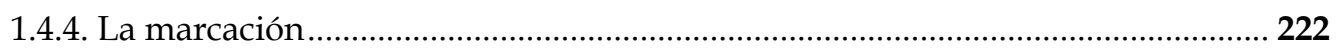

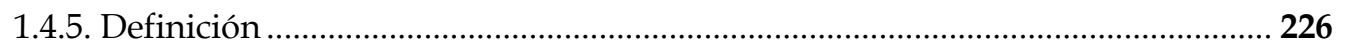

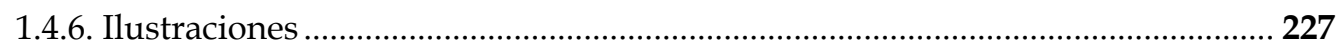

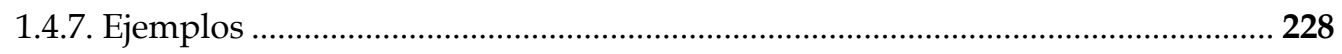

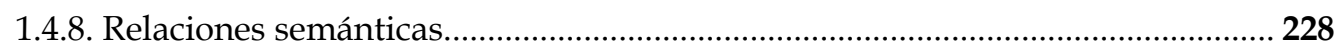

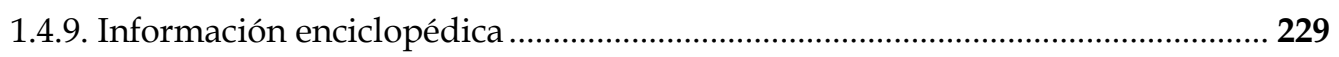


1.4.10. Acepciones y unidades pluriverbales

2. Glosario de fortificación y arte militar renacentistas...

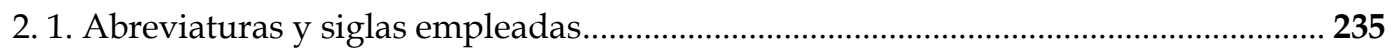

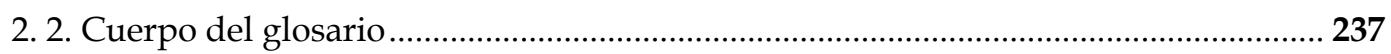

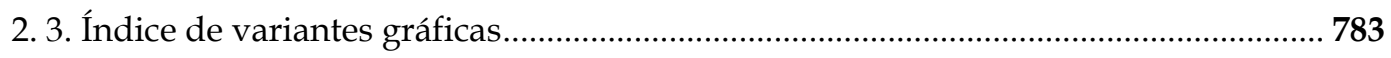

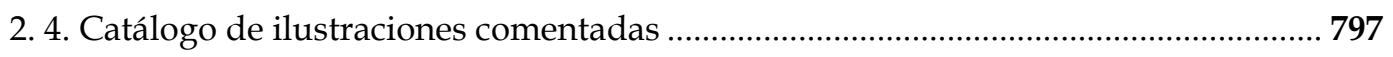

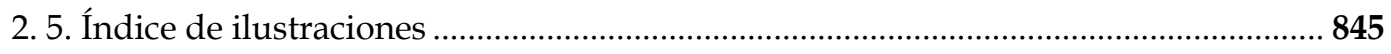

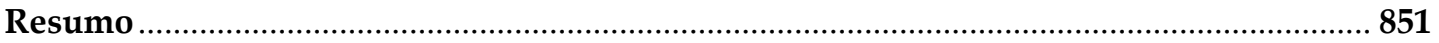

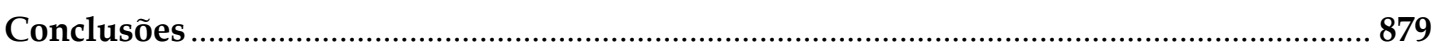

\section{Referencias bibliográficas consultadas}

1. Corpus del Diccionario de la ciencia y de la técnica del Renacimiento español (DICTER) .........889

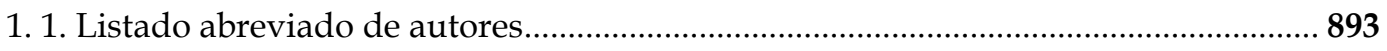

2. Repertorios lexicográficos generales y especializados ................................................. 897

3. Estudios lingüísticos e históricos...................................................................................... 901 


\section{AgradeCimientos}

Quero dedicar este trabajo a todas las personas que en algún momento de esta dura etapa de mi vida me han prestado su ayuda.

En primer lugar, a mi directora de Tesis, la doctora María Jesús Mancho Duque. Gracias por haberme propuesto este interesante tema de investigación, por sus constantes correcciones, por su disponibilidad, aun en la distancia, y por su paciencia.

Desde luego, sin el apoyo material del CILUS esta Tesis hubiera sido inviable. De todas formas, me quedo con los grandes amigos que he logrado hacer allí. Aún recuerdo mis primeros años con Javi, Cris, Guille y Antonio. ¡Qué buenos momentos! Muchas gracias, chicos. Sori, aunque llegaras más tarde, también has sido fundamental en mi etapa cilusiana. Gracias por nuestras largas conversaciones, por tu constante atención, por tu hospitalidad, por estar siempre dispuesta a hacerme algún favor, etc., etc. Ana, a ti, agradecerte tu amistad y apoyo constantes. Por último, a Atilano su amabilidad, paciencia $y$, desde luego, sus conocimientos informáticos.

No me olvido de los profesores Francisco Gago-Jover, Fernando Serrano Larráyoz y Germán Colón Doménech, que, a pesar de no conocerme, tuvieron la amabilidad de facilitarme algunos de sus trabajos, así como distintas referencias bibliográficas fundamentales para la gestación de esta Tesis. También, a la profesora Margarita Correia por su fantástica acogida en Lisboa: Muitíssimo obrigada por ter-me acolhido em Lisboa e mais tendo em conta as suas circunstâncias. Sempre estará no meu coração.

A mis padres. ¿Qué decirles? Me habéis ayudado tanto, que no tengo palabras. Siempre habéis estado ahí y eso que yo muchas veces no os lo he puesto nada fácil. Aunque no seamos mucho de decírnoslo, os quiero muchísimo. Esta Tesis es más un logro vuestro que mío.

Hermano, aunque no nos veamos mucho, siempre te tengo presente. Nunca olvidaré la visita que me hiciste en Lisboa. ¡Me encantó! A ver si vuelves ya a España, que no sólo papá y mamá te echan de menos... 
Javi, indudablemente has sido la persona que más ha luchado para que este trabajo viera por fin la luz, incluso más que yo misma, y sé que lo sabes. Nunca podré agradecértelo lo suficiente. Sobre todo, tu mayor mérito ha sido el haber conseguido convencerme de que yo era capaz de hacer una tesis. Gracias, gracias y mil gracias. Te quiero y deseo que sigamos juntos toda la vida.

Tampoco olvido a mi otra familia: a Amado, Abundia, Ana y Carlos. Desde el primer día me habéis tratado como a una reina. No tengo palabras...

A mis amigas de toda la vida, María V., Paloma, Sara, María C. y Cristina, deciros que sé que siempre habéis confiado en mí, mucho más que yo misma. ¡Muchas gracias! Siento no haber podido ir por Burgos ni veros demasiado a menudo, pero sabed que para vosotras siempre estaré ahí.

Indudablemente, son muchas más las personas que a lo largo de estos duros años de trabajo han estado siempre a mi lado y han soportado mis agobios. Es imposible que pueda nombraros a todos, pero confío en que alguna vez os haya expresado mi agradecimiento y que todos y cada uno de vosotros sepáis cuánto os aprecio.

Esta Tesis no hubiera sido posible sin la concesión de una beca de Posgrado para la Formación de Personal Investigador de la Junta de Castilla y León, así como de una beca de Posgrado para la Formación de Profesorado Universitario (FPU) del Ministerio de Educación, respectivamente. 


\section{INTRODUCCIÓN}

\section{Presentación y justificación del trabajo}

Gracias a la generalización del uso y la fabricación de la pólvora durante el siglo $\mathrm{XV}$, comienzan a surgir y a difundirse nuevas formas bélicas, especialmente patentes en los albores de la Edad Moderna. Es posible hablar de una verdadera revolución militar, ya que la aplicación de la pólvora a la artillería provocó importantes procesos de modernización en las armas, las construcciones militares, las técnicas, las tácticas y los métodos de hacer guerra que habían imperado hasta el momento.

Ahora bien, es especialmente significativo el caso de la arquitectura militar, puesto que el empleo de la pólvora en los conflictos bélicos contribuyó de manera decisiva al nacimiento de uno de los tipos de fortificación más relevante en la historia de Europa: la fortificación abaluartada.

Ya a principios del siglo XVI resulta patente el desequilibrio surgido entre los medios de ataque y los de defensa, inexistente antes. Las obsoletas fortificaciones medievales no podían hacer frente al enorme avance acaecido en el terreno artillero. En consecuencia, se inició un período de transición en el que los ingenieros ensayaron nuevas fórmulas capaces de resistir los estragos de las armas de fuego. El elemento fundamental en el nuevo sistema defensivo implantado desde este momento fue el baluarte, a cuyo alrededor fueron surgiendo el resto de miembros o elementos de las nuevas fortalezas.

Por otro lado, el impacto del humanismo renacentista en la milicia fue muy notable, propiciado por la industria de la imprenta, lo que contribuyó además a su legitimación social. Así, el ejercicio de la guerra se benefició inmensamente de la preocupación de los humanistas por el redescubrimiento, traducción y difusión de los textos antiguos. Las obras de los historiadores, matemáticos, militares y arquitectos griegos y romanos más destacados -de Procopio, Euclides, Vegecio y Vitruvio, entre otros-, editados por primera vez en lengua vernácula, proporcionaron a los soldados e ingenieros del 
Renacimiento los conocimientos técnicos a partir de los cuales desarrollaron su labor profesional.

En este sentido, uno de los objetivos de la creación de la Academia Real Matemática por Felipe II consistió en fomentar, además de la enseñanza de la geometría y la aritmética, el empleo de la lengua española en los textos científicos. Asimismo, como consecuencia del marcado carácter práctico alcanzado por la geometría en este momento, otra de las razones fundamentales que llevaron al rey a establecer este importante centro de enseñanza fue la formación matemática de ingenieros y arquitectos militares, ya que, entre otras cosas, de la posesión de una sólida instrucción militar por parte de los encargados de la defensa del territorio español dependían los límites del Imperio. De hecho, el más importante ingeniero militar del siglo XVI español, Cristóbal de Rojas, se encargó de enseñar en esta institución “fortificación” y “teórica y práctica de los escuadrones".

En definitiva, la elección de este período y temática responde a la constatación de su relevancia tanto por lo que respecta a la historia de la lengua como a la historia de la ciencia. En primer lugar, durante la época moderna la lengua española logra convertirse en uno de los principales vehículos para la transmisión de los saberes científico-técnicos; y, en segundo lugar, gracias al enorme progreso experimentado por la milicia moderna, así como a la gran repercusión que en la sociedad de aquel entonces tenían los asuntos bélicos, el lenguaje militar va a cobrar un gran impulso, sobre todo en los primeros momentos de esta nueva etapa histórica.

Se trata de un vasto campo de investigación con el que pretendemos lograr un mayor conocimiento del léxico de la fortificación y el arte militar del Quinientos, y contribuir, en la medida de nuestras limitadas posibilidades, a completar una de las múltiples carencias en la lexicografía histórica.

Este proyecto de tesis se relaciona, además, con otros trabajos que se han venido desarrollando a lo largo de estos últimos años en el Departamento de Lengua Española y, concretamente, en el Centro de Investigaciones Lingüísticas de la Universidad de Salamanca (CILUS), enfocados a la lengua de la ciencia y la 
técnica del Renacimiento. Es, por tanto, dentro de esta línea de investigación en donde insertamos la consecución de nuestra Tesis Doctoral, cuya realización servirá como material importante para la elaboración del Diccionario de la ciencia y de la técnica del Renacimiento español (DICTER), dirigido por la Dra. María Jesús Mancho Duque.

\section{Objetivos del trabajo}

Al situarse en los inicios del Renacimiento el origen de la milicia moderna, sistema que permanece en lo esencial sin cambios hasta el siglo XIX, consideramos que el siglo XVI es el más significativo a la hora de emprender un estudio lexicológico y lexicográfico sobre estos aspectos, en gran medida porque se asiste a la búsqueda, desarrollo y posterior establecimiento de la terminología precisa para esta nueva disciplina.

Por tanto, el objetivo de esta Tesis Doctoral es el análisis y estudio del léxico de la milicia, con especial atención a las disciplinas militares de la fortificación, la poliorcética, la táctica, la castrametación, la logística y la estrategia, en una etapa de gran desarrollo, tanto desde el punto de vista lingüístico, como científico: el Renacimiento. Para ello, nuestra investigación va acompañada de una consulta de obras especializadas en el ámbito filológico. Hemos manejado, asimismo, los principales textos de referencia sobre la ciencia y la técnica en el Renacimiento, puesto que también pretendemos ofrecer un panorama, desde distintos ámbitos, de la llamada revolución militar del Renacimiento y contribuir, de esta forma, a la difusión del conocimiento de sus principales características.

Ahora bien, nuestro principal objetivo, que aspiramos pueda constituir una contribución primordial al panorama científico de la milicia renacentista, es la elaboración de un Glosario de especialidad asentado sobre sólidos criterios filológicos. Pretendemos que nuestro glosario sirva para facilitar la interpretación de los cuantiosos tratados militares surgidos a lo largo del siglo XVI y primer cuarto del XVII, época en la que se asiste al apogeo en la 
producción de este tipo de textos. Completamos nuestra aportación lexicográfica con una serie de apéndices sobre variantes ortográficas, abreviaturas, siglas y marcas, además de ofrecer un catálogo de ilustraciones comentadas.

Por otro lado, a pesar de que la historia de la lexicografía hispánica militar es muy profusa, apenas ha sido estudiada y reivindicada por los especialistas, lo que ha determinado el casi total desconocimiento de este interesante y esencial capítulo de nuestra cultura. Por ello, consideramos relevante el apartado "Panorama de la lexicografía especializada relativa a la milicia" de la presente Tesis.

Aunque en los últimos años ha ido creciendo, paulatinamente, el interés de los historiadores, de los arquitectos y de otros estudiosos españoles por la fortificación y el arte militar modernos, afirmación que queda demostrada con los numerosos diccionarios, glosarios o vocabularios existentes sobre arquitectura defensiva y aspectos afines, creemos que nuestra lengua requiere también de trabajos sobre milicia elaborados desde un punto de vista filológico y lingüístico, en los que se recopilen y elaboren definiciones estrictamente lexicográficas. Faltan, igualmente, estudios léxicos sobre la terminología militar. Éstas van a ser, en definitiva, nuestras principales aportaciones al ámbito de la guerra renacentista.

\section{Metodología}

El punto de partida de nuestro estudio es el corpus del Diccionario de la ciencia y de la técnica del Renacimiento español (DICTER), que está formado por 74 obras científico-técnicas altamente especializadas ${ }^{1}$.

\footnotetext{
${ }^{1}$ Este corpus documental de 74 textos de la ciencia y de la técnica del período moderno se encuentra estructurado en 12 áreas temáticas: arte militar, astronomía, construcción, cosmografía y geografía, destilación, fortificación, legislación y comercio, maquinaria, matemáticas, metalurgia y minería, náutica y arquitectura naval y, por último, óptica. Con el fin de evitar una parcelación científica más acorde con los parámetros del siglo XXI que con los establecidos en el XVI, esta base textual fue diseñada en su momento por especialistas en la historia de las diferentes disciplinas ( $c f$. http://dicter.eusal.es). Además de en esta página web,
} 
Ahora bien, para la elaboración del glosario sobre la terminología de la fortificación y del arte militar del Renacimiento, en un primer momento, realizamos la delimitación de las obras centrales, las que sobresalen por albergar mayor contenido sobre este ámbito: entre otras, Examen de fortificación de Diego González de Medina Barba; Teórica y práctica de fortificación, Sumario de la milicia antigua y moderna y Compendio y breve resolución de fortificación, las tres de Cristóbal de Rojas; Discurso en que trata de la artillería y de todo lo necesario a ella, con un tratado de fortificación y otros advertimientos del capitán Cristóbal Lechuga; los Diálogos militares de Diego García de Palacio; El perfecto capitán instruido en la disciplina militar y nueva ciencia de la artillería de Diego de Álaba y Viamont; la Theórica y práctica de guerra de Bernardino de Mendoça o el Comentario en breve compendio de disciplina militar de Mosquera de Figueroa. Debe destacarse, asimismo, la traducción de Miguel de Urrea del tratado De Architectura de Marco Vitruvio Pollión, al dar cuenta de los conocimientos clásicos en torno a la fortificación, un arte que viene ya, por tanto, desde la Antigüedad clásica, si bien no puede hablarse de fortificación abaluartada hasta finales del siglo XV y comienzos del XVI.

De todas maneras, gracias a un programa de búsquedas complejas (UltraEdit) hemos podido rastrear el resto de los textos que integran el corpus del proyecto, tarea imprescindible si tenemos en cuenta que la relevancia alcanzada por la fortificación, entre otras disciplinas, durante el Renacimiento hace posible su presencia en obras sobre los más variados temas.

Por tanto, las directrices de esta tesis requieren de recursos informáticos que permitan trabajar de una manera más rápida y fiable con los textos. En consecuencia, nos hemos valido de los medios materiales imprescindibles que nos ofrecía el Centro de Investigaciones Lingüísticas de la Universidad de Salamanca (CILUS), como la base de datos Fichero de Vaciado, que nos ha permitido la 
constitución de la macroestructura y microestructura ${ }^{2}$ de nuestro glosario léxico especializado.

Después de la selección del conjunto de tratados y obras renacentistas que constituyen la base de nuestra Tesis, emprendimos su lectura meditada para poder, después, proceder a la selección y lematización del vocabulario científico y especializado relativo a la fortificación y el arte militar.

La ficha lexicográfica utilizada se compone de distintos campos que se agrupan en una serie de bloques temáticos, cada uno de los cuales se subdivide en otros campos donde recogemos la información lexicográfica pertinente. Estos bloques aglutinan la información relativa a la lematización, los datos históricos y etimológicos, la clasificación semántica, la definición e información lexicográfica, los ejemplos, la información enciclopédica, las observaciones semánticas, así como otras observaciones y, por último, las ilustraciones y sus referencias. Remitimos al lector al apartado VI, punto 1 "Consideraciones previas" para completar la información sobre cada uno de los campos y el proceso detallado de rellenado de la ficha lexicográfica en distintas etapas del trabajo.

En definitiva, la incorporación de los tecnicismos militares en esta base de datos informática y su posterior exportación a formato Word -mediante los precisos cambios- permitió la elaboración de nuestro glosario.

Posteriormente, tras todo el proceso anteriormente descrito, se procedió a la siguiente fase, concerniente a la explotación de los datos que conforman nuestro Fichero de Vaciado.

Los resultados de esta nueva etapa se concretan en el breve estudio que ofrecemos sobre la terminología bélica renacentista, centrado en los siguientes aspectos: lingüísticos, etimológicos, gramaticales y semánticos. Así pues, hemos estudiado el conjunto de los procedimientos exógenos y endógenos que

\footnotetext{
2 "Todo diccionario se halla construido y organizado en torno a dos ejes fundamentales: una macroestructura, constituida por todas sus entradas dispuestas de acuerdo con un determinado criterio ordenador, junto a una microestructura o conjunto de informaciones -también dispuestas de acuerdo con un determinado patrón o patrones- que se ofrecen dentro del artículo lexicográfico" (Porto Dapena 2002: 135).
} 
participan en la creación del vocabulario militar del siglo XVI y de las dos primeras décadas del siglo XVII. Se ha procedido, por tanto, al estudio del conjunto de los préstamos, de las lenguas cultas o no, a los que el castellano del Siglo de Oro acudió para expresar los conceptos de la fortificación, así como de la poliorcética, táctica, estrategia, logística y castrametación. Para el estudio etimológico nos hemos servido preferentemente del Diccionario crítico etimológico castellano e hispánico de Joan Corominas y José Antonio Pascual. También se ha recurrido a la consulta, cuando ésta ha sido necesaria, de otros diccionarios etimológicos como el Nuevo diccionario etimológico latín-español y de las voces derivadas de Santiago Segura Munguía y su más reciente Diccionario por raíces del latín y de las voces derivadas; Le Grand Gaffiot: dictionnaire latin-français, así como el Trésor de la langue française, el Tesoro della lingua italiana delle origini (TLIO), el Grande dizionario della lingua italiana de Salvatore Battaglia y el Dizionario etimologico italiano de Battisti y Alessio.

Dentro de los procedimientos endógenos, hemos analizado los distintos mecanismos (derivación, parasíntesis, composición y otras estructuras complejas) que intervienen en las unidades léxicas de nuestro vocabulario. Para el estudio de la morfología léxica y los aspectos referidos al análisis lingüístico de nuestro discurso especializado, las relaciones entre el léxico de especialidad y el vocabulario general, así como a las particularidades neológicas, semánticas y conceptuales del registro bélico ha resultado imprescindible la lectura de los estudios morfológicos y gramaticales, de carácter sincrónico muchos de ellos, pero que nos han permitido comparar los valores y frecuencias de determinadas formaciones; los estudios sobre aspectos morfológicos centrados en una determinada época histórica, así como el recurso a la bibliografía especializada de que se dispone.

Finalmente, nuestra investigación sería imposible si no estuviera acompañada de la consulta de obras de referencia en el ámbito de la Ciencia y la Técnica en el Siglo de Oro, especialmente las dedicadas a los saberes militares. Para esta tarea hemos utilizado, igualmente, el material extraído de los múltiples repertorios lexicográficos sobre milicia, por ejemplo, el Diccionario 
militar (1749) de Sanz, el primero dedicado íntegramente a la milicia en lengua castellana; el Diccionario militar portátil (1822) de Fernández Mancheño; el Diccionario militar español-francés (1828) de Federico Moretti; el Vocabulario militar (1849) de Luis Corsini; el Diccionario militar (1869) de José Almirante y el Diccionario de ciencias militares (1895-1901) de Rubió y Bellvé, por citar sólo algunos.

La información pertinente extraída de esta bibliografía especializada nos ha permitido, por consiguiente, salvar las lagunas científicas, conceptuales y terminológicas con las que contábamos al inicio de nuestra investigación doctoral.

Con esta tesis se cubre una parcela del conocimiento muy importante que afecta a varios campos de aplicación interdisciplinar: la historia del léxico español, la historia del léxico científico, particularmente del registro bélico, y la lexicografía y lexicología históricas de nuestra lengua; así como la historia de la ciencia y la técnica del Renacimiento.

\subsection{Consideraciones sobre la selección de la terminología militar} objeto de estudio

\footnotetext{
“Um dicionário temático pode tornar-se uma obra infinda se não tiver fixado um objectivo que o limite" (Lopes Pires Nunes 2005: 21).
}

Tras la lectura detallada de los textos que en el corpus del Diccionario de la ciencia y de la técnica del Renacimiento español (DICTER) versan sobre la milicia, la impresión o sensación que por encima de todas las demás predomina es la de que el objetivo de confeccionar un glosario sobre el léxico militar renacentista en términos generales resulta demasiado presuntuoso.

En esta época en la que los estados modernos comienzan a constituirse y a definir sus fronteras, la guerra se convierte en un asunto prioritario entre los dirigentes de las diversas potencias. Y si tenemos en cuenta que no solían ser éstos, como tampoco lo son ahora, los que saltaban a las primeras líneas de los 
campos de batalla, sino que los que se jugaban la vida eran los habitantes de los distintos territorios, resulta verosímil que los gobernantes de aquella época concedieran una importancia capital a la instrucción de sus ciudadanos en todos los aspectos que pudieran determinar o condicionar el resultado de una guerra. Es este contexto el que explica el elevado número de tratados militares surgidos durante el Renacimiento, cuya temática es fiel reflejo de las múltiples facetas implicadas en cualquier conflicto bélico ${ }^{3}$.

Así, para intervenir sin consecuencias demasiado catastróficas en una guerra era necesario, primero, dinero, con el que poder adquirir un rico y variado armamento, construir castillos o cualquier otro tipo de obras defensivas y pagar a los guerreros que arriesgaban sus vidas, a los albañiles, ingenieros, gastadores o municioneros, personal relacionado directa o indirectamente con el ejército ${ }^{4}$. En este sentido, tanto la economía como la arquitectura y la construcción fueron disciplinas o ramas científicas muy presentes en la vida militar. Además, según puede constatarse en los textos cuya temática central es la fortificación, también las matemáticas, y especialmente la geometría, desempeñaron un papel fundamental en el desarrollo y mejora de las técnicas militares. Igualmente, el estudio de la geografía se hizo indispensable para los que querían convertirse en perfectos soldados, puesto que el lugar geográfico donde tenía lugar una determinada batalla podía resultar determinante en la victoria o en la derrota de alguna de las partes enfrentadas. Asimismo, la mala ubicación de una fortaleza podía provocar que su presidio o guarnición la perdiese ante un ataque enemigo. E incluso, si tenemos en cuenta que no todas las empresas o facciones de guerra de los Siglos de Oro fueron emprendidas en

\footnotetext{
3 “Un invento trascendental de la Edad Moderna, la imprenta, ayudó a difundir las aplicaciones del uso de la pólvora en la industria militar, y desde entonces, desde la publicación de los primeros tratados editados en el siglo XVI, se observa la inmediata mentalización por parte de todos de que el arte de la guerra ya era necesario aprenderlo en los libros y con mayor motivo las nuevas técnicas de fortificación y artilleras por su base científico-matemática cada vez más evidente y reconocida al tiempo" (Herrero Fernández-Quesada 1992: 35).

${ }^{4}$ De acuerdo con Maravall (1972: 519), "los dineros son el nervio de la guerra" fue uno de los lemas más repetidos durante la época moderna.
} 
tierra firme, sino que muchas tuvieron lugar en contextos marítimos, resulta obvia la íntima relación existente entre la náutica y la milicia 5 .

Ante tal cantidad de temas susceptibles de ser incluidos en un trabajo que aborde la vida militar moderna desde cualquier tipo de enfoque, una de las primeras tareas ineludibles es la delimitación exacta de nuestro objeto de estudio. A saber, al ser extremadamente numerosas las esferas relacionadas con la guerra, lo que redunda en una cifra sumamente alta de voces con posibilidad de ser incluidas en cualquier estudio del léxico militar, antes de iniciar el rellenado de las fichas lexicográficas, que conforman el artículo de cada uno de los términos de nuestro glosario, tuvimos que adoptar una serie de decisiones para evitar que nuestra investigación se convirtiera en algo inabarcable e inacabable.

De esta manera, llegamos a la conclusión de que lo más acertado era prescindir de los vocablos que, si bien aparecen con asiduidad en tratados militares, su mayor frecuencia de uso tiene lugar en otro tipo de textos, lo que hace suponer que, en lugar de tecnicismos militares, son términos especializados de la economía, arquitectura, construcción, matemáticas, náutica, etc. Pero, además, debido a la amplitud semántica del concepto designado a través de las unidades léxicas arte militar y milicia, nos hemos visto obligados a relegar de nuestro trabajo palabras o unidades pluriverbales que, a diferencia del caso anterior, no tienen cabida fuera de un contexto bélico. Si tenemos en cuenta que el primer diccionario académico que recoge la unidad pluriverbal arte militar, el DRAE de 1817, la define como: “El arte de ofender y defenderse los ejércitos, atacar las plazas y defenderlas y de todo lo demás que corresponde a la guerra", es fácil suponer que cuando alguien emplea la etiqueta designativa arte de hacer la guerra, entre otras, se está refiriendo no a una única disciplina o rama científica, sino al conjunto formado por varias de ellas. De este modo, la

\footnotetext{
5 Sobre el elevado número de disciplinas que los militares necesitan dominar para el correcto desempeño de sus funciones es interesante el siguiente comentario que realiza Fernández Mancheño (1822) bajo el artículo milicia: "No hay ningún arte que tenga más complicaciones ni necesite de más estudio que éste; por lo que, para ser un militar consumado, es indispensable aplicarse a las ciencias infinitas que abraza desde los primeros años de la juventud hasta la ancianidad, y tal vez no conseguirá pasar de mediano como no tenga un talento superior".
} 
milicia, además de dar a conocer la historia militar de las potencias que han despuntado en el ejercicio de la guerra y analizar la organización interna, los cargos y grados militares existentes en el ejército, se encarga también del estudio de la fortificación, la poliorcética, la artillería, la táctica, la estrategia, la castrametación, la logística, etc. De todas estas cuestiones militares susceptibles de ser contempladas, la presente investigación se ha dedicado de manera prioritaria al análisis del léxico de la fortificación ${ }^{6}$ y de la poliorcética ${ }^{7}$, si bien los términos relativos a la táctica militar $^{8}$ han sido objeto asimismo de una atención preferente ${ }^{9}$. Ya en un segundo plano ha sido objeto de atención la gran cantidad de términos pertenecientes a otras ramas militares que designan conceptos relativos a la estrategia ${ }^{10}$, la logística ${ }^{11}$ y la castrametación ${ }^{12}$.

En cambio, hemos descartado hacernos eco del campo de la artillería ${ }^{13}$ fundamentalmente porque un estudio sobre el léxico artillero produciría un trabajo de la misma extensión o incluso mayor que el presente, lo que ha quedado demostrado tras el Estudio léxico de los tratados de artillería españoles del siglo XVI ${ }^{14}$ de Cristina Blas Nistal.

El presente glosario incorpora, sin embargo, algunos tecnicismos de la artillería, justificables por el hecho de que algunas de las voces lematizadas, además de poseer acepciones propias de la fortificación, designan algún concepto propio de la artillería. Estamos convencidos de que, al haber completado todas las significaciones militares relevantes de esos términos polisémicos, los usuarios de nuestro repertorio lexicográfico agradecerán tener

6 "Ciencia que enseña a disponer todas las fábricas y obras que son necesarias para conseguir el fin de la guerra" (Fernández Mancheño 1822).

7 "Arte de atacar y defender las plazas fuertes" (DRAE). Para más datos sobre esta voz, la cual, curiosamente, no cuenta con ocurrencias en los textos militares renacentistas, vid. Sánchez Orense (en prensa-b).

8 "Mil. Arte de disponer, mover y emplear la fuerza bélica para el combate" (DRAE).

9 "La fortificación y la táctica se enlazan sin confundirse; se engranan sin entorpecerse; se completan mutuamente; marchan, crecen, juegan con el mismo fin, en el mismo teatro, con reglas casi idénticas por lo análogas" (Almirante 1869: s.v. fortificación).

10 "Arte de dirigir las operaciones militares" (DRAE).

11 "Parte de la organización militar que atiende al movimiento y mantenimiento de las tropas en campaña" (DRAE).

12 "Arte de ordenar los campamentos militares" (DRAE).

13 "Arte de construir, conservar y usar todas las armas, máquinas y municiones de guerra" (DRAE).

${ }^{14}$ Tesis doctoral realizada en el marco del proyecto del DICTER. 
al alcance de su mano una información detallada sobre las voces en esta situación: batería, contrabatería, batir, explanada, hornillo y salchicha15.

Asimismo, hemos creído necesario dar cuenta de las acepciones artilleras que facilitan la comprensión de otros conceptos militares fundamentales, aunque sus respectivos términos sean monosémicos, como ocurre con flanquear o padrastro, voces que manifiestan una mayor frecuencia de uso en contextos centrados en la construcción de elementos u obras defensivas, más que en los relativos a la fabricación, empleo o conservación de las diversas armas de guerra. No obstante, sobre la íntima relación existente entre la fortificación y la artillería se ha afirmado que "la historia de ambas no sólo está profundamente relacionada, sino que durante siglos se entremezcla" (Herrero FernándezQuesada 2000: 171). En consecuencia, existen casos intermedios, que, en función del punto de vista adoptado, podrían ser adscritos a una u otra rama militar. Por ejemplo, flanquear, considerado en el Diccionario de uso del español (DUE) como término propio de la artillería con la correspondiente marca (Artill.), en un diccionario anterior aparece con la marca de Fort. (Rubió y Bellvé 1895-

\footnotetext{
15 Por la misma razón, hemos definido en nuestro glosario, además de las pertenecientes a la fortificación, las acepciones de banqueta, cortina y estacada más propias de la construcción civil que de alguna rama o disciplina militar. Y lo mismo puede decirse de la acepción geométrica que incorporamos de escala, así como de la que presa posee en el campo de la marina. Por su parte, la inclusión de albañil responde, en cambio, a otro tipo de necesidad: la de recoger, en la medida de lo posible, todos los sinónimos de las unidades léxicas analizadas. Resulta que, al completar la familia de muro, sumamente importante en cualquier estudio sobre el léxico de la fortificación, nos encontramos con que González de Medina Barba, autor de un importante tratado sobre arquitectura militar, emplea murador con el sentido de 'obrero que trabaja en hacer casas, paredes y otros elementos de construcción'. Es decir, este especialista utiliza murador como un sinónimo de albañil, lo que en su momento nos llevó a lematizar ambas voces, decisión que permitirá que los futuros usuarios de nuestro glosario conozcan y sean conscientes de esta sinonimia. Por último, es importante señalar que, a pesar de no constituir uno de nuestros objetivos, hemos dado también cabida a unas pocas voces que designan instrumentos o herramientas, las cuales, si bien aparecen en los tratados militares estudiados, no sólo tenían uso en la guerra. Es el caso de tenaza, tenazante y tenazón. Por lo que respecta a tenaza, al tiempo que cuenta con dos importantes acepciones en la fortificación, designa también un tipo especial de formación táctica, por lo que consideramos adecuado hacernos eco igualmente de su acepción de 'herramienta'. Mientras tanto, la lematización de tenazante y tenazón responde al deseo de dar a conocer estas dos curiosas unidades léxicas creadas por Ufano, el autor del tratado militar más tardío de todos los manejados, además de que, de esta forma, queda completa la familia léxica de tenaza. La presencia de zapa viene justificada, en cambio, por el hecho de tratarse de un instrumento con aplicaciones sólo en contextos bélicos, como es la creación de minas, trincheras y demás construcciones defensivas de campaña.
} 
1901) ${ }^{16}$. Por nuestra parte, decidimos marcar esta voz como propia de la artillería.

Tampoco hemos tenido en consideración las voces que designan armas propias de la Edad Media, e incluso de épocas más remotas, tales como la espada, lanza, azagaya, alabarda, flecha o saeta, cuya presencia suele ser habitual en los tratados de artillería del Renacimiento, como consecuencia de las reiteradas comparaciones establecidas por los tratadistas entre el viejo sistema y el que poco a poco va abriéndose paso. Esta decisión ha sido en parte motivada por nuestro pleno convencimiento de que reviste una mayor trascendencia el estudio de las transformaciones que la aplicación de la pólvora genera en otras ramas militares distintas de la artillería, así como las repercusiones que esta revolución militar trae consigo en el léxico castellano ${ }^{17}$. Resultan ser excepciones tanto falárica como ballesta. La presencia de la voz falárica en el siguiente fragmento del corpus explica su lematización en el glosario: “Las máquinas, pues, Real Magestad, con que los antiguos solían expugnar las fortalezas y batir las murallas eran éstas: las cathapultas, las balistras, las víneas, los arietes, las testúdines [...], el compago, el escorpión, las sambucas, las faláricas y otras muchas" (Collado 1592: 2v). A pesar de que falárica suele ser catalogada más como un $\operatorname{arma}^{18}$ que como una máquina militar ${ }^{19}$, su aparición junto a varias voces pertenecientes al campo léxico de las máquinas o ingenios de guerra, como son ariete, vínea y catapulta, de las que sí nos hemos ocupado, nos llevaron a dar cuenta de su verdadero sentido. Por su parte, la acepción de 'arma portátil para disparar flechas o saetas' de ballesta se

16 "Fort. Estar situada una obra de fortificación, alguna de sus partes, un punto importante del terreno, etc., de tal suerte, respecto de una línea defensiva, posición, etc. que pueda batir todo el frente de éstas con el fuego de la artillería o fusilería" (Rubió y Bellvé 1895-1901).

${ }_{17}$ De hecho, ni siquiera el estudio de Blas Nistal (2007), dedicado íntegramente a la artillería, da cuenta de este grupo léxico, probablemente como consecuencia del hecho constatable de que sólo con estudiar las voces relativas a la artillería renacentista se obtiene un trabajo sumamente amplio y completo.

18 "Objeto que sirve para atacar o defenderse" (DSAL: s.v. arma).

19 "Conjunto de piezas articuladas entre sí para hacer más fácil un trabajo o para transformar una forma de energía en otra" (DSAL: s.v. máquina). Falárica es para Mosquera de Figueroa (1596: 91v) claramente un arma: "Y halláronse algunas de aquellas armas arrojadizas que los antiguos llamavan phaláricas, que eran unas astas con hierros fuertes para herir y por de dentro estavan huecas y cargadas de resina, y cierto betum combustible, piedra sufre, y estopas y azeyte que abrasava con pegajosa y vehemente llama lo que tocava". 
ha registrado tras la anticuada ${ }^{20}$ de 'máquina para arrojar piedras de mucho peso', sinónima de balista, ballestón y ballestón de torno.

Si contemplamos la importancia que el Renacimiento otorga a la Antigüedad clásica, resulta lógico que los tratados militares examinados aludan tanto a la milicia griega como a la romana ${ }^{21}$. De ahí que sean habituales, por ejemplo, las enumeraciones de las distintas funciones o cargos militares existentes en la época romana. Dada la complejidad y amplitud del conjunto formado por las voces pertenecientes al arte militar grecorromano, hemos descartado su introducción, dado que su análisis requeriría un estudio particular. Ahora bien, en el caso de camisa22, luchar y triunfar ${ }^{23}$ sí hemos recogido las anticuadas por el deseo de completar todas sus significaciones militares. Por lo que respecta a luchar, además de la acepción más general de 'enfrentarse dos o más personas utilizando la fuerza o las armas para vencer al otro'24, empleada en la actualidad, indicamos el sentido específico de “contender o lidiar dos personas a brazo partido hasta que alguno caiga en tierra" (Aut.), que era más habitual en la Antigüedad clásica ${ }^{25}$.

Nos hemos hecho eco, asimismo, de las acepciones de metator y de tirón propias de la milicia romana. En este caso, su inclusión responde a una

\footnotetext{
20 "Naturalmente [ballesta] debió tener [sic] en la Edad Media el significado de máquina de proyección y de sitio, traduciendo la voz original greco-latina ballista" (Almirante 1869).

${ }^{21}$ En el estudio de la milicia antigua, fundamentalmente de la romana, destaca el manuscrito fechado en 1607 de Cristóbal de Rojas, titulado Sumario de la milicia antigua y moderna.

${ }^{22}$ Camisa designa en los textos manejados tanto la 'capa que se hace de diversos materiales para revestir y sostener el terraplén de cualquier obra de fortificación' como la 'prenda de vestir que emplean las tropas en un asalto para distinguirse del enemigo'. Se trata de un término polisémico, por lo que hemos creído oportuno dar cuenta también del empleo de camisa por parte de los griegos como la 'longitud del asta que usa cada soldado para combatir en una formación táctica'.

${ }^{23}$ El hecho de informar sobre la acepción de triunfar propia de épocas anteriores a la renacentista nos ha llevado a indicar también las de triunfo, triunfante, triunfador y ovación.

${ }^{24}$ El término consta de múltiples sinónimos: batirse, combatir, lidiar, pelear y revolverse.

${ }^{25}$ Por lo que respecta al sustantivo lucha, sólo aparece en el corpus con este sentido anticuado de ejercicio atlético o gimnástico: "Mandó el mesmo Licurgo que las vírgenes se exercitassen en luchas y otros exercicios honestos, porque los hijos heredassen esta fortaleza, que ellas avían granjeado del averse exercitado" (Álaba 1590: 39v). El lexicógrafo Moretti (1828) deja muy claro en qué consistían estas luchas: "[La lucha] era uno de los cinco juegos o ejercicios gimnásticos o del circo, que usaron los griegos y romanos, no sólo en público sino también en sus mismas casas. Consistía en una pelea entre dos, que abrazándose uno a otro, procuraba cada cual dar con su contrario en tierra. No debe confundirse con el pugilado; pues en la lucha no se daban golpes, y sólo se obtenía el premio derribando a su competidor".
} 
voluntad que podríamos denominar de diferenciación, surgida tras definir una ocupación militar, primero, y una posible cualidad de los soldados o ejércitos modernos, en segundo lugar. Es decir, aunque aposentador y bisoño designan el mismo concepto que metator y tirón, el hecho de que estas dos últimas voces sólo se empleen al hablar del arte militar romano ${ }^{26}$ ha impedido que podamos considerarlas sinónimas de aposentador y de bisoño, respectivamente. Conqueridor, en cambio, no tiene cabida en nuestro glosario por ser el equivalente antiguo de conquistador, como consideran la mayoría de los diccionarios consultados, sino por designar, como bien indica Álaba y Viamont, un oficio militar existente en época de los romanos: "Conqueridor era el que estava presente a las muestras y reseñas de los soldados" (Álaba 1590: 151r).

$\mathrm{Y}$, como consecuencia de su fuerte e importante presencia en el corpus manejado, debemos precisar que sí hemos atendido al campo de las máquinas de guerra, a pesar de estar compuesto casi exclusivamente por realidades que ya en el siglo XVI resultan obsoletas ${ }^{27}$.

No obstante, quedan excluidas de este estudio unidades terminológicas tales como capitán, furriel, maestre de campo, coronel, general, etc., a saber, las que designan cargos o grados militares existentes en el ejército moderno, las cuales conforman un conjunto léxico muy amplio. Éste es el principal motivo de haber prescindido de ellas, pero es que, además, dada su complejidad, pues se trata de voces cuyo significado varía mucho incluso en períodos de tiempo más bien cortos, así como de unos lugares a otros, creemos que un trabajo centrado sólo en este grupo léxico sería ya lo suficientemente rico e importante como para no tener que unirlo a otros.

Finalmente, hemos descartado la recopilación y definición del léxico relativo a la vestimenta de los guerreros $\mathrm{u}$ hombres que participaban en las guerras por considerar que desviaría los objetivos de nuestro glosario.

\footnotetext{
26 "Mil. Oficial de la milicia romana, encargado de determinar el terreno y colocación del campamento" (Alemany y Bolufer 1917: s.v. metator). "En la milicia romana el soldado o recluta bisoño" (Almirante 1869: s.v. tirón o tyrón).

${ }^{27}$ De las 35 voces que integran el campo de los ingenios militares, sólo 4 están exentas de llevar la marca diacrónica ant.
} 
Tras establecer como campos de selección léxica la fortificación, la poliorcética, la táctica, la estrategia, la logística y la castrametación, tuvimos que emprender la difícil tarea de catalogación de las unidades léxicas bien como voces generales o bien como especializadas. Mientras que las palabras cuyas ocurrencias se dan sólo en textos sobre milicia son, sin lugar a dudas, tecnicismos, las que, además de en contextos bélicos, aparecen en otras situaciones resultan problemáticas. Fue en este segundo tipo de casos en los que tuvimos presente el sentido amplio contemplado actualmente en terminología:

\footnotetext{
En lugar de sostener que existen en el componente léxico unidades especializadas y léxico general, las unidades léxicas son por principio polivalentes y, por lo tanto, además de su papel general, son potencialmente unidades de discurso especializado si se usan en un contexto determinado (Cabré y Gómez de Enterría 2006: 29).
}

Por tanto, aparte de los términos utilizados solamente por los autores de tratados militares, hemos lematizado aquellos otros que, si bien pertenecen al lenguaje general o incluso al especializado de algún otro ámbito técnico, su presencia en contextos bélicos es también relevante. 


\section{INTRODUCCIÓN HISTÓRICA}

\section{Aproximación al arte de hacer la guerra en la época moderna}

\subsection{La revolución militar del Renacimiento}

En las últimas centurias de la Edad Media se deja sentir un incipiente proceso de cambio que, acompañado de una sucesión de transformaciones en los órdenes social, cultural, económico y político, va a conducir a comienzos del siglo XVI al inicio de la ciencia moderna. De ahí el empleo de la denominación «revolución científica», que denota el carácter irreversible de estos cambios ${ }^{28}$. Decisivos resultarán aspectos tan destacados como la invención de la imprenta, los viajes y los descubrimientos geográficos, el afianzamiento del Estado moderno, etc.

Pues bien, el arte militar resultó ser una de las disciplinas donde más se dejó sentir la influencia de todas estas importantes innovaciones científicotécnicas. De hecho, fue de tal envergadura el impacto de la nueva mentalidad renacentista en la milicia que, a lo largo del período estudiado, se asiste a la configuración y posterior consolidación de una nueva manera de concebir y afrontar la guerra. Por consiguiente, una de las etapas más interesantes en el mundo bélico corresponde a los Siglos de Oro, de ahí nuestro convencimiento acerca de la trascendencia de la presente investigación.

En España, dadas las circunstancias de su conocida actividad militar en el siglo XVI, tal vez con más fuerza que en parte alguna, Estado y Ejército modernos evolucionan a la par" (Maravall 1972: 513).

\footnotetext{
${ }^{28}$ Ahora bien, no debe olvidarse que los progresos científicos y el desarrollo técnico de este tiempo son deudores de ricas herencias culturales. Así, buena parte de la actividad moderna cuenta con antecedentes medievales, de tal forma que los profundos cambios acaecidos en el Renacimiento responden en realidad a un inevitable proceso de prolongación y consolidación de avances iniciados previamente ( $c f$. Lindberg 2002). Por ejemplo, la revolución experimentada por la milicia sólo fue posible con la separación, iniciada en el siglo XV y mantenida en los siguientes, entre la vida civil y la militar (ápud Maravall 1972).
} 
Como tendremos ocasión de exponer más adelante, nuestro país ostenta el honor de alzarse como uno de los protagonistas clave de la revolución militar del Renacimiento ${ }^{29}$.

En primer lugar, ya en los inicios del Renacimiento se hace evidente el progresivo declinar de la caballería en provecho de la infantería ${ }^{30}$, frente a la preponderancia mantenida por la primera durante toda la Edad Media ${ }^{31}$. Esta inversión estuvo condicionada, entre otros motivos, por el creciente empleo de proyectiles en las numerosas batallas que se iban sucediendo (Parker 2002: 52) ${ }^{32}$. Ahora bien, mientras que esta decadencia de la caballería es visible en el tratado Arte della guerra (1521) de Maquiavelo, obra citada entre los primeros exponentes textuales del sistema bélico que implica el Renacimiento, en ella su autor resta importancia a los distintos avances acaecidos en el terreno artillero (Campillo 20082: 47). Es decir, en este importante tratado de la época moderna no se valora la trascendencia del empleo de las armas de fuego, lo que, a juicio de la mayoría de los autores, fue el principal factor desencadenante de la revolución militar. Por lo tanto, esta constatación apunta a que, en realidad, la transformación de la caballería debe ser explicada a partir del cambio de mentalidad propio de la época renacentista, en definitiva, por la inadecuación del sistema feudal caballeresco al nuevo orden.

Como coinciden en señalar los numerosos especialistas en arte militar, el primer síntoma del excelente momento por el que atravesaba la infantería provino de los cuadros tácticos compuestos de piqueros, obra de la milicia

\footnotetext{
29 "En el Renacimiento tiene lugar una auténtica "revolución militar", un cambio profundo en las armas, técnicas y tácticas, en los modos de reclutamiento, organización y financiación de los ejércitos, en las justificaciones y reglamentaciones jurídico-políticas de los conflictos bélicos, en sus implicaciones económicas, geopolíticas, sociales e intelectuales" (Campillo 20082: 26).

${ }^{30}$ Este traspaso de poderes posibilita la incorporación al ejército de personas ajenas a la nobleza, por ejemplo labradores, con las responsabilidades propias de cualquier soldado (Maravall 1972: 545).

${ }^{31}$ De todas formas, hay que tener en cuenta que la caballería nunca llegó a desaparecer, simplemente redujo su importancia, además de sus funciones, según evidencia el debate en torno a su consideración en algunos tratados renacentistas, como el de Álaba y Viamont: "Quál sea de más importancia en la guerra: la infantería o cavallería" (Álaba 1590: 67v).

${ }^{32}$ Como apunta Echarri Iribarren (2000: 36), "el efecto de las balas de hierro fue muy superior al que hasta ese momento habían producido las de piedra".
} 
suiza, al dar cuenta en múltiples ocasiones de su superioridad frente a la obsoleta caballería pesada propia de la época medieval:

En lugar de eludir el choque directo mediante una lluvia de flechas, los suizos lo afrontaban oponiendo al asalto de la caballería un abundante, firme y compacto bosque de picas (Campillo 20082: 53).

Poco a poco, gracias al despegue de la ciencia artillera, fue incrementándose el empleo de las armas de fuego de tipo portátil, principalmente arcabuces $\mathrm{y}$, en menor medida, mosquetes, por parte de las distintas agrupaciones bélicas de infantería, lo que condicionó que a partir de ese momento fuera una tarea recurrente la experimentación de nuevas disposiciones tácticas capaces de multiplicar las posibilidades de hacer fuego.

Por ejemplo, tanto en las escaramuzas como en las batallas de mayor trascendencia, se hizo habitual que los arcabuceros se organizasen en sendas formaciones volantes del escuadrón principal, una en el costado izquierdo y la otra en el derecho. En ellas, para paliar los inconvenientes con los que aún contaban las nuevas piezas de artillería 33 , los arcabuceros de la primera hilera, tras disparar su carga, se retiraban con destreza para que los de la segunda pudiesen a su vez descargar la suya; a continuación hacían acto de presencia los de la tercera, y así sucesivamente. En palabras de Rodríguez Hernández (2007: 42), "mediante este método se intentaba mantener un fuego constante por secciones contra los enemigos".

$\mathrm{Al}$ ámbito de la táctica moderna debemos adscribir, además, la constante preocupación, manifestada tanto en las obras militares como en los campos de batalla, acerca de la exacta composición y formación que, según las circunstancias, debía adoptar el escuadrón para ser efectivo. Para la definición de esta destacada unidad táctica, nos remitimos a la ofrecida por el tratadista Francisco Valdés:

Escuadrón es una congregación de soldados ordinariamente puesta, por lo cual se pretende dar a cada uno tal lugar que sin impedimento de otro puede pelear y unir la fuerza de todos juntos, de tal manera que se consiga el principal

\footnotetext{
33 "La cadencia de fuego de estas armas era reducida por el tiempo que se tardaba en cargar y por el recalentamiento que se producía en los cañones" (Rodríguez Hernández 2007: 42-43).
} 
intento y fin, que es hacernos invencibles (Francisco Valdés, Diálogo militar, 1586, ápud Merino Peral [2002: 46]).

Así pues, frente al valor y a la iniciativa individual propios de los caballeros en las batallas medievales, en los numerosos conflictos bélicos del Renacimiento sobresale como factor determinante el orden y la disciplina conjuntos (Maravall 1972: 529). Esto es, a partir del siglo XVI la organización de las tropas en escuadrones se convertirá en la única manera posible de hacer frente al enemigo, de ahí que en los tratados militares renacentistas el debate sobre su perfecta alineación sea un tema recurrente ( $c f$. Merino Peral 2002).

En cuanto a la artillería, como es bien sabido, la aplicación de la pólvora al lanzamiento de los proyectiles influyó de forma radical en la dirección y las condiciones de los subsiguientes conflictos armados, si bien la generalización de su uso no fue rápida. De hecho, a pesar de que en España los primeros testimonios de esta aplicación datan ya del siglo XIII ${ }^{34}$-lo que lo convierte en el primer país europeo en hacer un uso marcial de la pólvora ${ }^{35}$ - su desarrollo y extensión fue extremadamente lento, puesto que habrá que esperar hasta finales del siglo XV, con la Guerra de Granada, para encontrar un verdadero tren artillero en el ejército castellano de los Reyes Católicos. De todas formas, debe subrayarse que contaba aún con un sistema bastante precario: "Casi siempre sus sirvientes y sus arrastres fueron elementos y medios de circunstancia contratados para un período corto o un servicio determinado" (Becerra de Becerra 1997: 14).

A medida que la aplicación de la pólvora en los conflictos bélicos fue siendo cada vez mayor, el desequilibrio generado entre los medios de ataque y los de defensa - problema anteriormente inexistente- se hizo cada vez más evidente. Ahora bien, donde esta desigualdad se manifestó de manera más

\footnotetext{
34 "Se considera que los musulmanes andalusíes aprovecharon sus efectos ya en 1261 en el sitio de Niebla, asediada por Alfonso X de Castilla" (Becerra de Becerra 1997: 13).

35 No obstante, "se reconoce ahora, sin duda alguna, que todo el desarrollo de las armas de fuego tuvo su principio en China, desde el descubrimiento de la fórmula correcta de la pólvora (que actualmente se considera que tuvo lugar ya en el siglo IX) hasta el perfeccionamiento de los cañones de tubo metálico a mediados del siglo XIII. Cien años después, cuando en las fuentes árabes y europeas se hace la primera mención a la artillería de hierro, China poseía ya un refinado arsenal de artillería de hierro y bronce" (Parker 2002: 120-121).
} 
palpable fue en el ámbito de la construcción defensiva, ya que, a partir de ese momento, las fortalezas medievales comenzaron a dar muestras de su ineficacia ante las nuevas armas de fuego. Debe notarse que los avances en el terreno artillero condicionaron el nacimiento y posterior consagración de la llamada fortificación abaluartada ${ }^{36}$. Es la nueva mentalidad moderna, sin embargo, la que propicia aplicaciones más efectivas de la pólvora en los conflictos bélicos. En palabras de Merino Peral (2002: 27), "fueron necesarios los cambios amplios, generales, que acontecieron en la nueva situación histórica del Renacimiento, para poder extraer consecuencias de ese material y demás «ingenios»".

Las fortificaciones de la Edad Media se distinguieron por constar de muros extremadamente altos, además de que su ubicación solía establecerse en lugares de muy difícil acceso, por ejemplo, en la parte más abrupta de un terreno montañoso, lo que implicaba que su defensa en caso de asedio estuviera basada en un plano vertical. Por el contrario lo que caracteriza a la poliorcética moderna es la defensa asentada en el plano horizontal ${ }^{37}$ :

\begin{abstract}
Se redujeron las alturas para ofrecer el menor blanco posible y aumentose, en cambio, el diámetro o proporción horizontal para gozar de ventaja en la instalación de la artillería; son los sensibles cambios que se producen en la fortificación permanente antigua en su paso a la moderna o abaluartada (Zapatero 1963: 91).
\end{abstract}

Como se desprende de este pasaje, las primeras reformas en el ámbito de la arquitectura militar consistieron tanto en cubrir de tierra la parte interior de las murallas como en agrandar los reducidos espacios de las torres, típicamente medievales, con el fin de dar cabida a la nueva artillería.

\footnotetext{
36 "Fortificación es el conjunto de obras con que se hace fuerte un sitio. La fortificación abaluartada es una parte de la fortificación. Haciendo un símil con la Historia Natural, la fortificación abaluartada es una especie dentro del género de la fortificación, y como tal especie está compuesta por unidades que tienen caracteres comunes por los cuales se asemejan entre sí y se distinguen de las de otras especies. Esta especie está formada por el conjunto de obras defensivas levantadas, en el mundo occidental, desde el siglo XVI hasta principios del siglo XIX. Proyectada para hacer frente a los destructivos efectos de la artillería, esta fortificación fue necesaria y útil, desde el momento en que aquella adoptó los materiales de bronce, de ánima lisa, y los proyectiles esféricos metálicos, hasta que entraron en servicio los materiales de ánima rayada, con proyectiles cilíndricos de cabeza ojival" (Díaz Capmany 2004: 14).

37 "Poco a poco se fue abandonando el antiguo concepto de "poliorcética» medieval o «arte del ataque», por la forma moderna en la que «el mejor ataque es la mejor defensa»" (Merino Peral 2002: 74).
} 
Además, la preferencia por la ubicación de los distintos recintos fortificados en zonas orográficamente complejas, propia de la Edad Media, se sustituye por el pleno convencimiento de la superioridad estratégica de los lugares en llanura, "en los cuales la dificultad natural se sustituye por la artificial, «por Arte» humano" (Merino Peral 2002: 74). Por consiguiente, en las nuevas construcciones defensivas resulta esencial la ausencia de obstáculos, que, aparte de poder ser útiles a los atacantes a la hora de establecer el asedio, les impedían la correcta cobertura visual a los defensores.

Antes de que el baluarte, el principal miembro defensivo de la nueva fortificación, alcance su definitiva forma pentagonal, lo que se impone es una evolución a la que suele calificarse de gradual, a pesar de su temprano carácter irreversible:

Las innovaciones constructivas empezaron siendo puntuales, como la adopción del parapeto para desviar los tiros enemigos, hasta llegar a la modificación de la planta de los bastiones o torres angulares, en principio de planta triangular, carente de ángulos muertos o zonas sin cobertura visual por parte de los defensores, y posteriormente con la tradicional configuración pentagonal del baluarte moderno (Merino Peral 2002: 62-63).

La siguiente imagen extraída de la obra de Francesco di Giorgio Martini -uno de los primeros ingenieros modernos- sirve para ejemplificar este paso de las formas triangulares al baluarte pentagonal propiamente dicho, cuya última manifestación la constituye la ubicada en la esquina superior izquierda: 


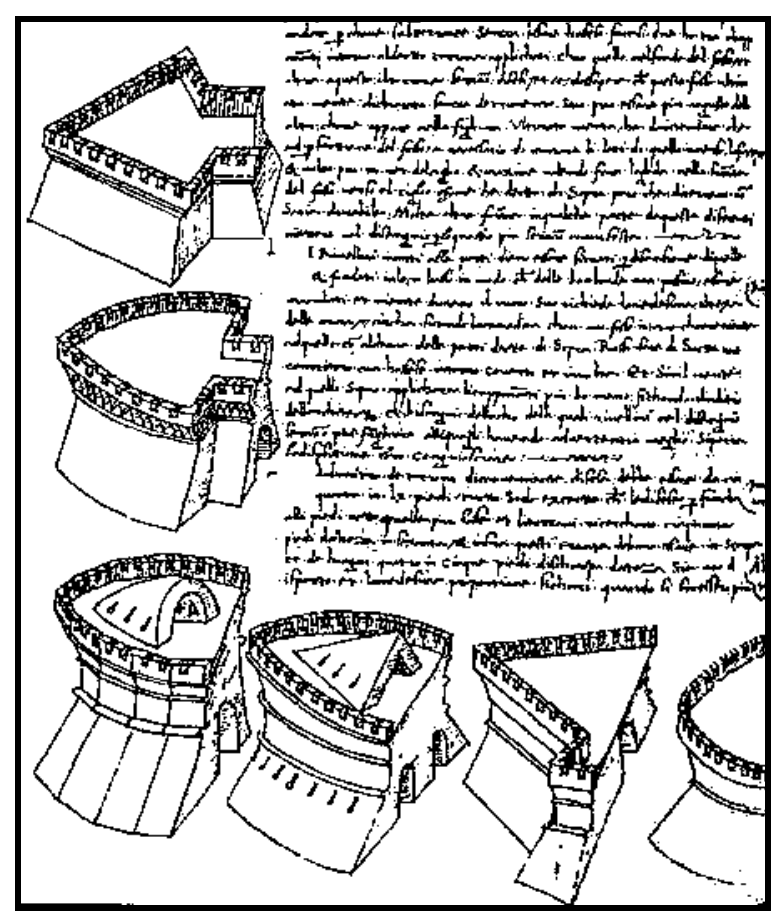

En Francesco di Giorgio Martini, Trattati di Architettura, Ingegneria e Arte Militare38, ápud Echarri Iribarren (2000: 53)

Si tenemos en cuenta que a partir de la época moderna se impuso como necesidad que las tradicionales torres medievales, circulares o cuadradas, fueran capaces de contrarrestar el impacto de las modernas armas de fuego, a la vez que se convirtió en un requisito esencial su capacidad para albergar esta misma artillería, no resulta extraño que poco a poco fueran adquiriendo una forma poligonal, además de una disposición escarpada.

Por otro lado, la etiqueta designativa fortificación abaluartada revela que el elemento más importante de la arquitectura militar moderna es indudablemente el baluarte, a cuyo alrededor surgieron los miembros restantes de las nuevas fortalezas, "los cuales no nacieron por generación espontánea, sino dentro de un complejo conglomerado de imbricaciones socio-políticas así como de una transformación de la esencia de la guerra" (Merino Peral 2002: 388-389).

En definitiva, los notables cambios en la mentalidad bélica acaecidos a comienzos de la época moderna fueron los que en última instancia posibilitaron

\footnotetext{
38 Aunque esta obra no llegó a publicarse hasta el siglo XIX, resulta evidente que fue conocida por sus coetáneos. Como advierte Echarri Iribarren (2000: 54), "la fecha en que di Giorgio escribió sus Trattati es incierta", si bien, de acuerdo con los investigadores, debió de producirse en algún momento del último cuarto del siglo XV.
} 
la aparición de unas soluciones arquitectónicas defensivas muy distintas a las de la etapa anterior:

\begin{abstract}
Si bien íntimamente relacionada con la Fortificación Moderna estuvo la aparición de las nuevas piezas de Artillería en Occidente, habría que desmitificar su alcance - en conexión con las corrientes historiográficas actualesincidiendo en la idea de su lenta evolución, que implicaría una disminución del determinismo en la concepción y creación de una Arquitectura Militar nueva, y en el que influyeron otros componentes como el cambio en la concepción de la guerra, la utilización diferente de la Infantería en los conflictos y las modificaciones en la forma de emprender los asedios contra los enclaves murados, la distinta utilización de los calibres, la diferente resistencia de los diversos espesores de muralla contra los ataques, etc. (Merino Peral 2002: 393).
\end{abstract}

Pero puede manifestarse además, de acuerdo con Maravall (1972), que en el origen de la revolución militar del Renacimiento yacen motivos puramente políticos ${ }^{39}$.

Un rasgo típico del período analizado es la aplicación a las distintas disciplinas científico-técnicas de las ciencias matemáticas, que "tuvieron como vertientes principales la aritmética práctica, o cálculo mercantil, y la geometría" (Sánchez Martín 2009: 48-49). Las distintas ramas militares también se beneficiaron de la excelencia concedida a la matemática durante la modernidad. Por lo que respecta a la fortificación, por ejemplo, la geometría junto a la perspectiva se convirtieron en los instrumentos apropiados para una correcta representación del plano, planta o perfil de una determinada construcción defensiva ${ }^{40}$. Y, a propósito de la artillería, todos los tratados centrados en este tema "ponen de manifiesto lo imprescindible del dominio matemático por parte de los artilleros para efectuar el cálculo de los alcances de los cañones y, en último término, para conseguir precisión en el tiro" (Echarri Iribarren 2000: 41).

\footnotetext{
39 "No son sólo [...] razones de técnica militar las que hacen cambiar las formas de la fortificación. No sólo aquello con que se ataca y aquello con que se resiste hacen transformar las fortificaciones militares. Hay que pensar también en quiénes son los que se defienden, por qué se defienden, por mandato de quién lo hacen, qué está detrás de ellos y qué esperanzas pueden poner en que otros los ayuden y en la intensidad de esta ayuda, incluso en las razones de la misma, etc. Pues bien, todos estos aspectos son de naturaleza netamente política" (Maravall 1572: 555).

${ }^{40}$ La naturaleza geométrica de la fortificación es especialmente patente en las acepciones de nuestro glosario representadas por las unidades léxicas cortina total, flanco $\mathrm{y}_{2}$ frente $_{3}$, por citar sólo algunas.
} 
Asimismo, los distintos ejércitos participantes en una guerra concedieron una posición privilegiada a las disciplinas matemáticas, entre otras muchas aplicaciones, por disminuir las probabilidades de error de una mina a la hora de alcanzar el objetivo deseado ${ }^{41}$.

Por último, el impacto del humanismo renacentista en la milicia fue muy notable, propiciado por la industria de la imprenta, lo que contribuyó además a su legitimación social. Así, el ejercicio de la guerra se benefició inmensamente de la preocupación de los humanistas por el redescubrimiento, traducción y difusión de los textos antiguos. Las obras de los historiadores, militares y arquitectos griegos y romanos más destacados -Vegecio, Vitruvio, Philon de Bizancio, Eliano el Táctico y Procopio, entre otros- proporcionaron a los soldados e ingenieros del Renacimiento los conocimientos técnicos a partir de los cuales desarrollaron su labor profesional. Fue tal la influencia del arte militar clásico en el moderno que, por ejemplo, en referencia a la construcción defensiva, algún investigador ha llegado a asegurar que "la ciencia de la fortificación no tuvo necesidad de inventar nada, bastó con acudir a los principios que habían sistematizado los tratadistas en esta materia en la Antigüedad clásica" (Becerra de Becerra 1997: 14). Dentro de esta tendencia se inscribe también el proceso de dignificación experimentado por el escuadrón, la unidad táctica por excelencia del Renacimiento, tras su igualación con la falange griega, así como con la legión romana:

Los antiguos que la milicia professaron ordenavan, señor, sus gentes, para entrar en batalla, por esquadrones o tropeles, los quales, aunque sean llamados de diversos nombres, casi siempre han correspondido a una qüenta e número, por manera que cada esquadrón o batallón de aquéllos antiguos se ordenava y hazía de siete u ocho mil hombres, a los quales los escriptores romanos llamaron legiones y los griegos falanjes (García de Palacio 1583: 145r).

En resumen, hemos pretendido dejar patente en este apartado que los cambios desde el siglo XV fueron sucediéndose de manera encadenada, hasta

\footnotetext{
${ }^{41}$ Acerca de la combinación entre ciencia, identificada con el conocimiento de las matemáticas, y experiencia que, a juicio de Cristóbal de Rojas, entre otros tratadistas, debía reunir un ingeniero militar para ser considerado un buen profesional, vid. Sánchez Martín y Sánchez Orense (2009).
} 
que posteriormente cristalizaron con la llamada revolución militar del Renacimiento.

\subsection{Sus protagonistas}

Todos los investigadores coinciden en señalar la campaña realizada en Italia en 1494 por las tropas francesas de Carlos VIII como el punto de inflexión que separa la guerra medieval de la moderna ${ }^{42}$. Como demuestra este episodio bélico, los numerosos estados italianos se convirtieron en "el primer escenario de contiendas internacionales durante la época moderna" (Merino Peral 2002: 78). Posteriormente, los campos de batalla más frecuentados pasaron a ser territorios de alguna de las 17 provincias vinculadas a la dinastía de los Habsburgo, con el estallido en 1567 de la llamada Rebelión de los Países Bajos.

Pues bien, en estos nuevos escenarios bélicos sobresale de manera extraordinaria el ejército español, probablemente debido a su marcado carácter guerrero propiciado por el estado permanente de guerras en el que nuestro país estuvo inmerso durante la Edad Media. Ahora bien, el principal responsable de esta hegemonía militar española lo constituye su acertado sistema de articulación de la infantería en tercios ${ }^{43}$. Estas unidades compuestas por un

42 "Carlos VIII llevó consigo a Italia un ejército de 18000 hombres y un tren de sitio con artillería hipomóvil de al menos 40 piezas" (Parker 2002: 35). Como advierte Echarri Iribarren (2000: 36), "aunque ha sido calificado como el primer ejército moderno, el éxito de la campaña se debió fundamentalmente al efecto de la artillería, por su evolución técnica, su organización como artillería móvil y el empleo de proyectiles de hierro por primera vez en la historia, que causaron un efecto mortal en las obsoletas fortificaciones del norte de Italia".

43 "La infantería estaba organizada desde 1534 en tercios, llamados así porque solían estar formados por un tercio de soldados armados de picas, otro tercio de arcabuces y otro de mosquetes. Al frente de cada tercio había un maestre de campo. Los tercios se dividían en doce a quince compañías, cada una con unos 250 hombres. Al mando de cada compañía estaba un capitán" (Navarro Loidi 2004: 41). En cambio, para Albi de la Cuesta (2005: 15), "1504 fue verdaderamente el año crucial, cuando los Reyes Católicos deciden formar en España la gente de ordenanza, es decir, la nueva infantería, articulada en compañías relativamente homogéneas y no ya en contingentes provinciales de muy diversa entidad", si bien admite que "el último paso documentado será la llamada Orden de Génova, de 1536, donde se acuña el término «tercio» para referirse a cada una de las tres agrupaciones de tropas entonces existentes, nombrándose expresamente a las de Nápoles y Sicilia; Lombardía y Málaga, y mencionando, sin más detalles, que cada una debe contar con compañías de 300 hombres" (Albi de la Cuesta 2005: 15). Por tanto, "da la impresión [...] que el concepto evolucionó con el tiempo pasando de describir, literalmente, a la tercera parte de una fuerza, a referirse a un tipo específico de unidad" (Albi de la Cuesta 2005: 15-16). En cuanto a su composición, admite que "aunque se 
número variable de soldados de a pie vivieron su etapa de máximo esplendor durante la vigencia del llamado Camino Español, esto es, desde el año 1567 hasta 165944. Este corredor militar, que cruzaba media Europa a lo largo de aproximadamente 1000 kilómetros, desde Génova hasta Namur, supuso una pieza clave del sistema español al permitir las comunicaciones y el envío de tropas por tierra desde Italia hasta los Países Bajos. Mediante esta ruta pudieron enviarse continuamente a las guerras de Flandes soldados españoles sumamante experimentados procedentes de los presidios italianos, lo que en buena medida propició la fama militar de España:

El envío periódico de estos soldados españoles veteranos y entrenados -que a su vez eran reemplazados por nuevos reclutas llegados desde España- permitió en cierta manera que la calidad de los hombres fuera muy alta, de ahí la tradicional buena fama y profesionalidad que mantuvieron los soldados españoles durante el Siglo de Oro, muchas veces considerados exageradamente invencibles (Rodríguez Hernández 2007: 26).

En resumen, al mismo tiempo que, como expondremos más adelante, los ingenieros italianos fueron los precursores de la teoría abaluartada, las tropas españolas fueron las más innovadoras en lo que a la forma de concebir los distintos aspectos de la guerra se refiere. Esto les permitió consagrarse como los dominadores del panorama efectivo de la guerra hasta 1630 aproximadamente (Merino Peral 2002: 390-391).

En palabras de Echarri Iribarren (2000: 72), "fue en las cortes de los distintos estados italianos donde en primer lugar los hombres de ciencia, favorecidos por los mecenas y las numerosas guerras que allí se desarrollaron, escribieron tratados de fortificación", de ahí que el sistema defensivo abaluartado haya sido también conocido con el nombre de la trace italienne (cf.

intentará atribuir una cierta cantidad de compañías o banderas a cada tercio, lo cierto es que nunca dejó de variar" (Albi de la Cuesta 2005: 25). En definitiva, la esencia del tercio reside en la subordinación de un número variable de compañías a un mando único. En palabras de Albi de la Cuesta (2005: 11), "se trataba de unidades de infantería, sólidas, duras, flexibles, maniobreras, que combinaban a la perfección los distintos tipos de armas disponibles y poseedoras de una casi religiosa fe en su propia valía".

${ }^{44}$ A este respecto, resulta fundamental la obra de Parker (1991): El ejército de Flandes y el Camino Español. 
Parker 2002 ${ }^{45}$. Ahora bien, el territorio italiano no sólo destaca por haber dado a luz los primeros textos centrados en esta importante rama militar, sino también por ser el lugar donde se levantaron las primeras obras defensivas que observaban principios militares modernos. Puede afirmarse, por lo tanto, que “fueron italianas en su mayoría las fórmulas nuevas" (Quatrefages 1983: 133).

En opinión de Merino Peral (2002: 78-79), “en la remodelación de Castelnuovo, Nápoles, [durante el reinado de Alfonso V de Aragón] se puede constatar uno de los más tempranos exponentes de dicho cambio constructivo". Aparte de este temprano ejemplo, podríamos enumerar otros muchos, ya que, sobre todo a partir de la segunda mitad del siglo $\mathrm{XV}$, se sucedieron las obras defensivas que trataban de aproximarse a planteamientos modernos, en detrimento de los medievales. Por ello, aún hoy se mantiene la especulación acerca de quién fue el pionero de la fortificación moderna. También se debate intensamente sobre qué ingeniero consiguió desarrollar y construir el primer frente abaluartado completo. Por nuestra parte, estamos de acuerdo con Echarri Iribarren (2000: 53) cuando asegura que "la invención del bastión, del sistema de fortificación bastionado que se impuso brillantemente durante el siglo XVI, no fue el resultado de la acción individual de un ingeniero, sino que fue el producto de una evolución gradual" 46 .

En todo caso, hay una serie de figuras, en su mayoría italianas, que, debido a sus relevantes aportaciones en los primeros compases del arte de la fortificación, destacan por encima de todas las demás: Leonardo, Miguel Ángel,

\footnotetext{
${ }^{45}$ No obstante, debe notarse que los primeros pasos hacia la modernización en materia de fortificación se dieron en el norte de Europa: "En Francia se produjo una transformación de las antiguas torres cuadrangulares y de los "donjons»" (Echarri Iribarren 2000: 51). Ahora bien, "fue Italia la nación que jugó el papel principal en la transformación durante las últimas décadas del XV, tomando como base el ejemplo francés" (Echarri Iribarren 2000: 51).

46 Echarri Iribarren (2000: 53-54) continúa así su argumentación: "Como recogen Moreno y Argüelles, la invención del bastión fue el resultado de la suma de los esfuerzos aislados que en toda Europa se hicieron para contrarrestar los avances del ataque, y aportan el dato -frente a la opinión que se tuvo por mucho tiempo de que el inventor del bastión fue Sanmicheli al construir las fortificaciones de Verona- de que la primera piedra del baluarte de la marina en Barcelona se puso en noviembre de 1526, un año antes de que se construyeran los de Verona". De este modo, si bien es cierto que en este ámbito hubo una clara preponderancia italiana, no lo es menos que también se dieron algunas aportaciones relevantes de parte de españoles, además de que se deben resaltar varias construcciones defensivas levantadas en territorio español por haber constituido hitos importantes de la fortificación abaluartada.
} 
Durero, Bramante, Antonio da Sangallo el Joven y los ya citados Sanmicheli y Francesco di Giorgio Martini, entre otros. Por lo que respecta a nuestro país, debe citarse como figura sobresaliente de esta primera etapa al ingeniero militar Ramiro López ${ }^{47}$, por haber diseñado en 1497 el castillo de Salses en el Rosellón, fortificación que supuso un enorme avance, aunque todavía posee múltiples reminiscencias medievales ${ }^{48}$.

Sin embargo, la fortificación española no se desarrolló durante el siglo XVI al ritmo de este primer impulso debido a los constantes conflictos e ingentes esfuerzos que hubo de mantener la corona en los diversos dominios europeos y americanos. La labor de fortificación más importante se llevó a cabo en Hispanoamérica ${ }^{49}$, norte de África ${ }^{50}$, Flandes, Nápoles y Milanesado, mientras que, de fronteras adentro, no pudo efectuarse una renovación de la fortificación acorde con las exigencias defensivas modernas (Echarri Iribarren 2000: 59).

Aun con todo, adquieren una gran trascendencia las construcciones defensivas de otro español, Pedro Luis Escrivá, durante la llamada etapa de transición, que alude a la primera mitad del siglo XVI, período en que se van encadenando las innovaciones que suponen el paso de la fortificación medieval a la abaluartada propiamente dicha. En esta ocasión la labor de este ingeniero se desarrolló fuera de nuestra península, en Nápoles concretamente. Fue tal el revuelo generado por sus fortalezas (San Telmo y L'Aquila), que Escrivá decidió redactar en 1538 la Apología en excusación y favor de las fábricas del reino de Nápoles, considerado el primer tratado en castellano de la fortificación moderna (cf. Cobos Guerra 2004)51.

\footnotetext{
47 Nótese que adoptamos, de acuerdo con Cobos Guerra y Castro Fernández (2000), este nombre, frente a quienes se refieren a este ilustre personaje a través del apellido Ramírez.

48 Para más detalles, vid. Echarri Iribarren (2000: 59), así como el trabajo de Cobos Guerra y Castro Fernández (2000) ya citado.

49 Sobre la fortificación en el continente americano, vid. Zapatero (1968) y Cámara Muñoz (1992).

${ }^{50}$ A este respecto, véase Cámara Muñoz (1991b).

51 Sobre este destacado ingeniero y tratadista vid., aparte de este trabajo, el de Cobos Guerra, Castro Fernández y Sánchez-Gijón (2000). Aunque esta Apología no llegó a publicarse en su tiempo, gracias a una versión manuscrita pudo conocerse su contenido. También el español Pedro Navarro, uno de los pioneros en el empleo de minas explosivas, logró despuntar en sus campañas fuera de la Península Ibérica (cf. Alonso Baquer 2000).
} 
Por consiguiente, el conjunto que conforman las fortalezas del interior de la Península Ibérica construidas o remodeladas ${ }^{52}$ de acuerdo a los nuevos parámetros no es demasiado profuso. En opinión de Merino Peral, ello se debe a que

tras la Guerra Civil con los Reyes Católicos y la Guerra de Granada, se fue imponiendo una paz interior, que fue dejando de lado las necesidades defensivas urgentes de la arquitectura, convirtiendo los castillos en castillospalacio más que en modernas fortificaciones, y en los que predominaron los rasgos civiles, e incluso decorativos en la construcción (Merino Peral 2002: 92).

Las únicas zonas sensibles de defensa de la Península Ibérica fueron los Pirineos y las costas, sobre todo las del Mediterráneo, debido a las hostilidades con Francia, así como al peligro turco ${ }^{53}$.

Debemos apuntar que los monarcas españoles contrataron a ingenieros italianos, entre los que destacan Gian Battista Antonelli, Tiburzio Spanocchi, Gian Battista Calvi, Fratín y Francesco Paciotto, por citar sólo algunos, tanto para la ejecución como para la dirección de la mayoría de las obras defensivas peninsulares. En opinión de Echarri Iribarren (2000: 61), si bien es cierto que las

\footnotetext{
52 El acercamiento a los nuevos modos de fortificar por parte del reino español se produjo en muchas ocasiones a través de la modernización de algunas fortalezas medievales, gracias a las licencias concedidas para ello tanto por Carlos V como por Felipe II. En palabras de Echarri Iribarren (2000: 59), "hasta bien entrado el siglo XVI convivieron fortalezas medievales, renacentistas y reformadas". Por lo que se refiere al contexto de remodelación, a él responden, primero, el apartado "De un discurso para fortificar una ciudad o castillo viejo, acomodando la fortificación antigua que tuviere hecha", que Rojas incluye en su Teórica y práctica de fortificación (1598: 77r-78r); y, segundo, esta pregunta que el príncipe dirige al maestro en el tratado dialogado Examen de fortificación de González de Medina (1599: 150): "Yo tengo una ciudad con muralla vieja y flaca, sin barbacana, a lo antiguo, con sus torreones redondos y muy juntos: ¿cómo lo remendaríades que quedasse en defensa?". En Merino Peral (2002: 94-95) se enumeran las principales reformas llevadas a cabo en construcciones defensivas de raigambre medieval ubicadas en suelo peninsular.

53 A este respecto resultan fundamentales los numerosos trabajos de Alicia Cámara Muñoz. Como resalta esta especialista, durante el reinado de Felipe II la labor de fortificación de la Península se intensifica, entre otros motivos por la necesidad de afianzar la frontera con Portugal, así como proteger las distintas zonas costeras tanto de ataques procedentes de turcos como de ingleses. "Una vez cruzada la barrera de la segunda mitad del siglo XVI existía ya lo que se ha denominado «corona de fortalezas» bordeando el perímetro peninsular. Al norte fortalezas como las de Fuenterrabía, San Sebastián, Pamplona, Perpignan y los llamados «castillos roqueros» en los Pirineos. En Galicia, las fortificaciones de La Coruña, Bayona y Vigo. La frontera portuguesa fue dotada de enclaves fortificados antes de 1580 [...], utilizados tras esa fecha por las tropas de Felipe II para la anexión de dicho reino. Interés especial por los constantes ataques de los ingleses recibó la zona de Cádiz, Sanlúcar, el Puerto de Santa María y Jerez de la Frontera a finales de Siglo"' (Merino Peral 2002: 96).
} 
trazas de todos estos ingenieros sirven para demostrar el poderío del imperio español en aquel entonces, "el éxito de ellas se debió en última instancia a la escuela italiana, donde se había forjado un nivel científico durante el siglo XVI superior al resto de los estados europeos".

Es a Felipe II a quien debemos el honorable esfuerzo realizado por intentar paliar la escasa formación técnica y científica de sus súbditos peninsulares, lo que se plasmó en una constante exaltación de la ciencia y la técnica modernas durante su reinado. Ahora bien, el momento de máximo esplendor de esta nueva corriente tuvo lugar en 1582 con la fundación en Madrid de la Academia Real Matemática por Felipe II. En palabras de Echarri Iribarren (2000: 61), "los múltiples intentos de Felipe II por elevar el nivel intelectual y científico de los ingenieros de origen español dio sus frutos en hombres como Rojas, González de Medina Barba y Lechuga". Especialmente significativo es el caso de Cristóbal de Rojas, puesto que impartió las clases de “fortificación" y "teórica y práctica de los escuadrones" en dicha Academia54. De todas formas, la decadencia española del siglo XVII impidió la proclamación de la trascendencia de estos primeros pasos $^{55}$.

Por último, ante la escasez de artilleros en nuestra península, también "los monarcas [...] hubieron de recurrir a importar artilleros extranjeros de los dominios europeos" (Echarri Iribarren 2000: 42), del mismo modo que ocurrió con los ingenieros, como ya hemos visto; y eso "pese a que España [...] por estar en el campo de batalla durante generaciones enteras tuvo solucionado el problema de la formación de oficiales en la experiencia, y ésta pasó a través de manuales militares a otras naciones" (Echarri Iribarren 2000: 42)56.

En conclusión, resulta innegable que en la época renacentista la milicia española recibió una enorme influencia tanto por parte de Italia como de

\footnotetext{
54 Vid. Sánchez Martín y Sánchez Orense (2009). Asimismo, Sánchez Martín (2009) analiza los estatutos y funciones de la Academia Real Matemática, además de las actividades desarrolladas en ella.

55 Para Merino Peral (2002: 394), la Academia de Madrid supone el antecedente más directo del Cuerpo de ingenieros militares de España, a pesar de que éste no logró constituirse hasta casi un siglo y medio después, en 1711.

56 En Merino Peral (2002: 392-393) pueden observarse algunas de las innovaciones hispanas en materia artillera.
} 
Francia, lo que en el ámbito lingüístico, como veremos, se traduce en el hecho de que dos de los grupos de préstamos más abundantes y relevantes en nuestra lengua sean los italianismos y galicismos concerniente a la vida militar.

\subsection{Consolidación y repercusiones de la revolución militar}

"Estos nuevos modos de hacer la guerra fueron acompañados, sobre todo, por un notable aumento en el tamaño de los ejércitos" (Parker 2002: 52), lo que pudo lograrse con relativa facilidad gracias a que por primera vez los poderes políticos de los distintos estados se convirtieron en los máximos responsables en la tarea de reclutar soldados. Lógicamente, mientras se mantuvo el feudalismo medieval, cuando los nobles eran los encargados de alistar hombres, no fue posible reunir un ejército numeroso, pues las posibilidades económicas de la nobleza no podían equipararse a las que después iban a poseer los monarcas de la era moderna. A este asunto alude Maravall (1972: 540) cuando apunta que "los ejércitos del Renacimiento tienen un carácter masivo, si no en relación a lo que se verá después, en la época postnapoleónica de las grandes concentraciones, sí en comparación a lo que se usaba en etapas preecedentes". Por su parte, para Merino Peral (2002: 39) el siglo XVI es el de la "creación de ejércitos nacionales fijos"57. Es decir, como rasgo característico de la guerra moderna debe citarse la existencia de un ejército permanente, frente a la Edad Media; etapa en la que sólo se reclutaban

\footnotetext{
${ }^{57}$ No obstante, advierte esta autora que "si bien las fuerzas que componían los ejércitos del siglo XVI estaban integradas [...] por unas fuerzas permanentes de carácter nacional, éstas no solían ser suficientes en unas guerras que se definían ya por el elevado número de contingentes que las protagonizaban" (Merino Peral 2002: 40). Por consiguiente, los ejércitos modernos no tuvieron más remedio que recurrir en numerosos conflictos bélicos a la incorporación de mercenarios. A este respecto véase Maravall (1972). De todas formas, según muestra este pasaje extraído del tratado de Álaba y Viamont (1590: 33r), como tónica general resalta la resistencia de los monarcas a emplear mercenarios en sus respectivos ejércitos: "Si en alguno de tres casos que a mi parecer piden el valerse un príncipe de gente estraña: o quando de hazerlo se disminuyen las fuerças del enemigo, o se contentan los aliados, o se granjea la voluntad de los que habitan la tierra donde se a de hazer la guerra, sucediere aver de admitir soldados mercenarios, sea mucho menor el número d'ellos que el de los naturales, porque, si se ofreciere alguna inobediencia de su parte, puedan ser forçados a obedecer y acudir a todo lo que estuviere de hazer a su cargo; y por otras razones semejantes a ésta que a qualquiera se le pueden, sin mucha consideración, ofrecer".
} 
soldados si era preciso, lo que normalmente redundó en la reunión de hombres con una deficiente instrucción militar.

Asimismo, durante el período analizado, gracias sobre todo a la excelencia alcanzada por la fortificación abaluartada, se vive una absoluta exaltación de los medios defensivos. Además, la cada vez mayor presencia de enclaves fortificados a lo largo de todo el Occidente europeo posibilitó también el desarrollo y perfeccionamiento del arte de la poliorcética. Del mismo modo, si tenemos en cuenta que "en el Estado absolutista, la búsqueda de expansión territorial y la consiguiente defensa de estas ganancias constituyó la mayor ambición política de las potencias, porque la riqueza principal en esta época todavía provenía de la tierra" (Rodríguez Hernández 2007: 57), tampoco resulta extraño que el "arte que enseña los ardides con que se debe ofender y defender cualquier plaza" (DRAE: s.v. polémica), esto es, la llamada polémica o poliorcética alcance entonces su momento de máximo esplendor. A este respecto Rodríguez Hernández añade, además, que

\begin{abstract}
la conquista de territorio y su defensa, la cual se lograba con la ocupación física del espacio, hará que la toma de las fortificaciones que aseguraban eficazmente dicha ocupación esté más próxima a la consecución de los objetivos marcados por los estados en las guerras que la destrucción de los ejércitos enemigos en una gran batalla campal y decisiva, que entrañaba grandes riesgos propios (Rodríguez Hernández 2007: 57).
\end{abstract}

En definitiva, la trascendencia otorgada por las distintas naciones a la expugnación del máximo número posible de fortalezas condiciona que tanto en el siglo XVI como en el XVII casi todas las operaciones militares emprendidas giren en torno al ataque y a la defensa de los distintos tipos de recintos fortificados. Los Siglos de Oro constituyen, en fin, la etapa de mayor florecimiento para la denominada guerra pasiva o de $\operatorname{sitio}^{58}$.

\footnotetext{
58 "Estas operaciones de sitio exigieron, por su duración, un esfuerzo sotenido y continuado de ambas partes, sitiador y sitiado, además de muchos conocimientos técnicos de arquitectura y balística, una organización administrativa y logística amplia, y la disposición de la infraestructura necesaria para todo ello. Por tal razón, los soldados y políticos de la época más versados en asuntos bélicos, consideraron los asedios como puntos de referencia básicos del arte militar y un signo de cultura" (Rodríguez Hernández 2007: 58).
} 
Los dos sistemas que habitualmente se utilizaban para realizar con éxito la toma de una fortaleza eran abrir brecha mediante el fuego intenso aplicado en los puntos débiles, o la voladura puntual del terraplén y la escarpa del recinto principalmente mediante una mina. Al hacer practicable la brecha en ambos casos se pasaba a realizar el asalto final (Echarri Iribarren 2000: 68).

Como a medida que transcurría el tiempo fueron construyéndose fortificaciones cada vez más perfectas, la extraordinaria complejidad de su conquista obligó a los ejércitos sitiadores a decantarse casi siempre por la modalidad bélica del bloqueo total. En ella, "los sitiadores debían realizar grandes obras de fortificación, que consistían en un doble recinto defensivo que abarcaba un perímetro muy extenso produciendo un aislamiento de los sitiados del mundo exterior y una protección del ejército sitiador frente a los posibles ejércitos de socorro" (Rodríguez Hernández 2007: 34). Este investigador añade, además, que la organización de un asedio de este tipo "era -salvo a excepción de la construcción de algún canal grande o de un gigantesco recinto fortificadola obra de ingeniería de más envergadura de cuantas se realizaban en esta época" (Rodríguez Hernández 2007: 34).

La supremacía de la que gozaron durante los siglos XVI y XVII las operaciones bélicas dirigidas contra lugares fortificados trajo también consigo cambios en las disciplinas militares más vinculadas a la poliorcética, a saber, la logística, la táctica, la estrategia y la castrametación. De acuerdo con Merino Peral (2002: 47), “la modificación en la guerra de sitio durante el Renacimiento fue acompañada por una transformación de la guerra en campaña, a medida que las tácticas que recurrían al empleo directo de la fuerza bruta (cargas frontales, lucha cuerpo a cuerpo) eran sustituidas por el empleo de la artillería".

Otra de las repercusiones en esta etapa de progresos militares se refiere a los constantes motines y levantamientos registrados en las filas de los distintos ejércitos, cuestión lógica si tenemos en cuenta que los soldados que los integraban, además de participar en largos asedios -muchas veces, además, sin recibir las pagas debidas por sus servicios-, permanecieron largas temporadas fuera de su lugar de origen, lejos incluso del territorio peninsular. En alguna 
ocasión los monarcas españoles, conscientes del sacrificio que iban a exigir a sus militares, desistieron de emprender un determinado cerco.

Finalmente, como ya hemos apuntado en alguna ocasión, desde finales del siglo XVI asistimos a un notable incremento en la publicación de tratados militares en lengua castellana ${ }^{59}$. Para Merino Peral, esta abundante tratadística responde en buena medida al deseo de nuestros militares de establecer una comunicación fluida con la Península Ibérica:

\begin{abstract}
Otra idea, no menos esencial y definitiva de los ejércitos hispanos, es la de que siempre peleaban fuera de España. Así sus residencias en el exterior de la Península Ibérica se muestran como verdaderas plazas de armas, tal era el caso de Flandes, el Milanesado y el reino de Nápoles. Esto conllevaba que los militares españoles viajasen mucho [...]. Con dichos desplazamientos había una doble corriente de comunicación, de manera que se adquirían conocimientos de los territorios donde se asentaban, o bien se transmitían las propias experiencias de los españoles. Y es en este caudal de comunicaciones, donde se introduce el elemento de la «Literatura Militar», destinada a la formación o a la crónica, pero con un carácter educacional, de autores que eran en muchos casos verdaderos veteranos de los mismos relatos que escribieron. Todos los tratados recordaban con mayor o menor número de detalles las acciones que pudieran servir de ilustración de conceptos teóricos expuestos en los textos.
\end{abstract}

Todos nuestros textos de fortificación fueron publicados en el último cuarto del siglo XVI y en los primeros años del XVII, por ello, la panorámica que esbozan se encuentra ya lejos del llamado período de transición. De

\footnotetext{
59 Como ha sido subrayado en multitud de ocasiones, en la época moderna se produce una defensa en el uso de la lengua castellana como vehículo de divulgación científica, frente a la lengua académica por antonomasia, es decir, la latina: “En los prólogos de sus obras, los autores ofrecen el testimonio vivo de sus inquietudes, bien acerca de disciplinas que estaban surgiendo pujantes y vigorosas por entonces, o bien de otras materias que ellos estaban contribuyendo a consolidar y a hacer progresar con su impagable esfuerzo. Pero, a la vez, los representantes de tal renovación científica ponen de manifiesto sus reflexiones sobre otra tarea, no menos ardua y original, como era la de plasmar esos nuevos contenidos y modelos de conocimiento en la lengua castellana o española, elevada de rango y ennoblecida gracias a su empeño" (Mancho Duque 2004b: 1242). Para estos aspectos puede consultarse también Mancho Duque (2001, 2005a). Por otro lado, acerca de los contenidos, así como de la estructura que presentan los textos militares más relevantes del período estudiado, vid. Mariátegui (1880), en concreto para las obras del ingeniero Cristóbal de Rojas; Blas Nistal (2007), en especial para los tratados más artilleros; Sánchez Martín (2009), para los autores militares más influidos por la geometría; Navarro Loidi (2004), para las manifestaciones textuales de Álaba, Collado, Lechuga, Ufano y Rojas; y, por último, el trabajo de Merino Peral (2002), el más completo de todos, puesto que analiza minuciosamente los tratados "de re militari" comprendidos entre los años 1536 y 1671.
} 
acuerdo con Echarri Iribarren (2000: 56), “es en la segunda mitad del siglo XVI cuando se producirán sistemas de fortificación eficaces frente a la artillería" 60 .

A continuación, procedemos a dar cuenta del estado de evolución en el que se encuentra la fortificación abaluartada permanente ${ }^{61}$ en la tratadística manejada, por lo que clasificamos las obras defensivas que registramos en nuestro glosario en esenciales, convenientes, accidentales y accesorias ${ }^{62}$. Eso sí, prescindimos de la catalogación del baluarte o bastión, por hallarse en el origen de este nuevo sistema de construcción defensiva militar.

\begin{tabular}{|c|c|}
\hline $\begin{array}{l}\text { Obras } \\
\text { esenciales }\end{array}$ & 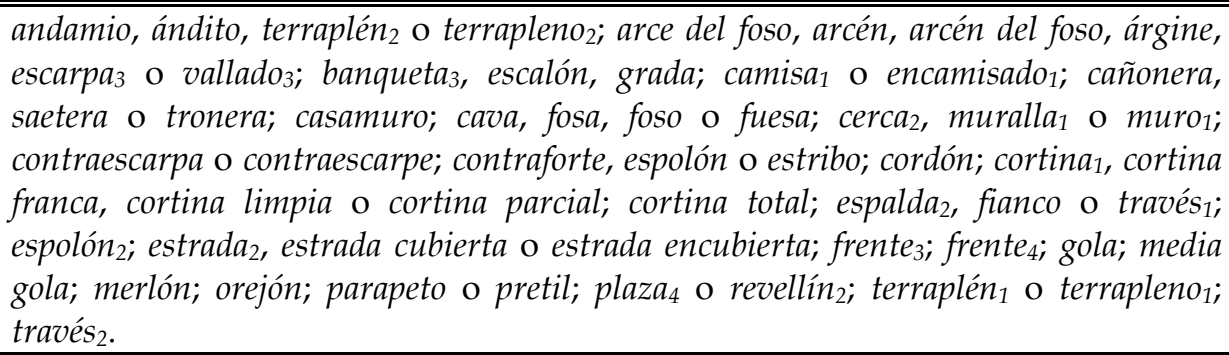 \\
\hline $\begin{array}{l}\text { Obras } \\
\text { convenientes }\end{array}$ & $\begin{array}{l}\text { banqueta }_{1}, \text { banqueta }_{2}, \text { boca, casamata, costado }{ }_{2} \text { o espalda } a_{3} \text {, espalda } a_{4} \text {, flanco del orejón, } \\
\text { media luna }{ }_{1} \text {, revellín } n_{1} \text {. }\end{array}$ \\
\hline $\begin{array}{l}\text { Obras } \\
\text { accidentales }\end{array}$ & $\begin{array}{l}\text { bastión }_{2} ; \text { caballero }_{2} \text { o plataforma } \\
\text { plataforma } a_{4} ; \text { plaza alta, plaza de arriba, plaza superior o través alto; plaza baja, plaza } \\
\text { de abajo o través bajo; refosete o refoso; tenaza } a_{2} ; \text { tenaza } a_{3} ; \text { tijera }_{1} ; \text { traviesa } a_{3} \text {. }\end{array}$ \\
\hline $\begin{array}{l}\text { Obras } \\
\text { accesorias }\end{array}$ & falda, garita, puerta del socorro, rastrillo, salida $a_{2}$ o surtida $a_{2}$, surtida $a_{3}$. \\
\hline
\end{tabular}

\footnotetext{
${ }^{60}$ A lo largo de los siglos XVII y XVIII, a medida que los diversos ingenieros militares consiguen depurar su método, esta trascendente modalidad de fortificación va perfeccionándose. Por ejemplo, para la mayoría de los investigadores la máxima figura del sistema abaluartado la constituye Sébastien Le Prestre, marqués de Vauban, cuyos trabajos en este ámbito no tuvieron lugar hasta la segunda mitad del siglo XVII.

61 "La que se construye con materiales duraderos, para que sirva de defensa por tiempo ilimitado" (DRAE: s.v. fortificación permanente). Lucuze (1772: 9) añade que este tipo de fortificación "está destinada a la conservación del estado".

62 "Las obras de una fortaleza se consideran de quatro géneros o clases, según su importancia, respecto que pueden ser esenciales, convenientes, accidentales y accesorias" (Lucuze 1772: 24).
} 


\section{ANÁLISIS LEXICOLÓGICO}

\section{Voces patrimoniales}

Las palabras patrimoniales o heredadas del latín constituyen el acervo léxico más numeroso e importante en cada una de las lenguas romances: Por lo que respecta al castellano,

lo primordial es el elemento latino, que constituye la base y cimiento del idioma; en realidad, la lengua española es la continuación del latín hablado en la Península; lo demás son algunos materiales advenedizos que la historia justifica o explica (Colón Doménech 2002a: 19).

En consecuencia, no resulta extraño que el conjunto formado por las voces patrimoniales sea el más nutrido de los establecidos dentro del vocabulario militar renacentista: abrojo 63 , ala, almena ${ }^{64}$, amigo, apellidar, apretar, arce, arcén, arte, asentar, ballesta, batir, boca, caballero, caballo, camisa65, campaña, campo, carnero, casa, castellano, castillo, cava, cavar, ceñir, cercar, cerco, césped, cesta, combatir, corneta66, correr, cortina, costado, cuadro, cuarto, cuento, cuerno, cuerpo, cuervo, cuño, despojar, diente, domar, domeñar67, ejército, enemigo, escala, espalda, estrada, estrella, explanada, explorador, fondo 68 , frente, fuerte, fuerza, fuesa, galería ${ }^{69}$,

63 “Contracción de la frase latina aperı̆ ócǔlos 'abre los ojos', originariamente advertencia al que segaba en un terreno cubierto de abrojos para que se guardara de los mismos, y luego nombre de la planta" (DECH).

64 «Del antiguo mena o amena y éste del lat. mina 'íd.'» (DECH).

65 "Del lat. tardío camisia, y a esta lengua parece haber llegado desde el céltico" (DECH).

66 "Probablemente sea el resultado de un cruce, producido en lenguas hispánicas, entre trompeta y el autóctono cuerna 'bocina de cuerno' y demás representantes iberorromances de cornu" (DECH: s.v. cuerno).

67 «Domeñar [domellar, 2 ejs. s. XIII, trads. de la Biblia; domeñar, 1529, Guevara, y frecuente desde entonces (...)], suele explicarse [...] por un verbo del lat. vg. domı̆nı̆are, derivado de domı̆nйum 'dominio' [...]; tal vez con razón, pero es algo dudoso en vista de la sucesión de las formas y lo tardío de domeñar, aunque domellar podría explicarse como disimilación de nasales; como el vocablo está muy aislado, así en España (falta en port. y cat.) como en los Alpes (falta en engadino), y como el primitivo dominium apenas ha dejado descendencia romance [...], deberá examinarse la posibilidad de un cruce entre domar y otra palabra, quizá mellar 'menoscabar'» (DECH: s.v. dueño).

68 "De perfondo, voz ant. y dial., que procede del lat. profŭndus 'íd.'. El prefijo per fue probte. interpretado como intensivo y se suprimió" (Segura Munguía 2007).

69 "Del b. lat. galilaea 'atrio o claustro de una iglesia', que a su vez procede del nombre de Galilea, región de Palestina [...]. Es probable [...] que el vocablo se empleara primero en el bajo latín monacal, y sólo después se secularizara en su aplicación, pasando al mismo tiempo a los 
gastar ${ }^{70}$, gente $^{71}$, gola, hecho, hila, hombre, horno, inexpuñable, infante, lengua, lid, lidiar, lienzo, ligarse, lobo, lucha, luchar, luna, manga, muro, nombre, orden, padrastro, paz, peón, pertrechos ${ }^{72}$, pie, plaza, portillo, postigo, pretil, prima, puente, puerta, rastrillo, rastro, real ${ }^{1}$, reconocer, rendir, revolver, riza ${ }^{73}$, romper, rota, roto, saco ${ }^{1}$, salto, sitiar $^{74}$, socorrer, sojuzgar, someter, suelo, tenaza ${ }^{75}$, terreno, tienda, tijera, torre, través, valla, vallado, vallar, velar, vencer, viga ${ }^{76}$ y vitualla.

De acuerdo con Lapesa (19819: 108), “tan antiguas como las voces populares, y pertenecientes como ellas a la lengua hablada, hay otras que no han tenido un proceso fonético desembarazado de reminiscencias cultas". Para aludir a este particular fenómeno la mayoría de los investigadores recurre a la denominación de semicultismo. En opinión de Corominas y Pascual, varios de los términos ya citados podrían considerarse representantes de esta modalidad lingüística:

Apellidar 'gritar', 'llamar (a alguien para algo)', 'nombrar, llamar' [h. 1295, 1. ${ }^{a}$ Crón. Gral. (...)], [...]; descendiente semiculto del lat. appellittare 'llamar repetidamente', frecuentativo de appellare (DECH: s.v. apelar).

Domar, del lat. dŏmare 'íd.' [...]. La ausencia total de formas diptongadas hace a este verbo sospechoso de semicultismo $(\mathrm{DECH})$.

Ligar, descendiente semiculto del lat. lı̆gare 'atar' (DECH).

Orden, descendiente semiculto del lat. ōrdo, -innis (DECH).

idiomas vulgares [...]. El cambio fonético de galilaea en galería es fácil también en un vocablo que oscilaba entre el uso culto de los conventos y el más vulgar de los palacios y castillos de señores feudales" (DECH).

70 «Del lat. vastare 'devastar, arruinar', pronunciado *wastare en la baja época por influjo del germ. occid. wôstan o wôstjan 'íd.'» (DECH).

71 "Latinización del antiguo yente, procedente del lat. gěns, gěntis 'raza', 'familia'; 'tribu', 'el pueblo de un país, comarca o ciudad'. Yente y gente en Cid" (DECH).

72 «Probablemente del lat. protactum, part. pas. de protahere 'hacer salir, revelar, producir'» (DECH: s.v. traer).

73 «Ateración de triza, en virtud de una etimología popular que lo relacionó secundariamente con el antiguo enrizar 'irritar o azuzar'» (DECH: s.v. enrizar).

74 "Adaptación occitana del b. lat. situare" (DECH: s.v. sitio).

75 “Tenazas, [...] alteración (a causa del género) de un más antiguo tenazes y éste del b. lat. hispánico tenāces 'íd.', abreviación de forcipes tenaces 'tenazas resistentes, pertinaces', expresión que con el carácter de epíteto emplea Virgilio" (DECH: s.v. tener).

76 «Probablemente del lat. bigga 'tronco de dos caballerías que tiran de un carro', 'carro tirado por ese tronco', suponiendo que tuviera más tarde el sentido 'timón de carreta'» (DECH). 
Plaza, del lat. vg. *plattĕa (lat. platěa) 'calle ancha', 'plaza' [...]. En cast. y port. (praça) el vocablo no presenta el tratamiento radicalmente popular del grupo $\mathrm{pl}$-, mas ello puede explicarse simplemente por la aparición preferente del vocablo en el uso oficial y administrativo, con el consiguiente predominio de la pronunciación de las clases elevadas en la fonética de plaza; también podría ser palabra propiamente semiculta, pues platea es voz frecuente en latín clásico y medieval (DECH).

Por otro lado, entre las voces patrimoniales enumeradas hallamos cuatro que también deben su existencia a la lengua griega: cuento, «del lat. cŏntus 'pértiga [...]', 'fuste de lanza, de pica, etc.', y éste del gr. xovtós 'íd.'» (DECH); espalda, «del lat. tardío spatǔla 'omóplato', antes 'espátula', 'pala de ciertos instrumentos', diminutivo de spatha que tenía esta última ac. y procedía del gr.

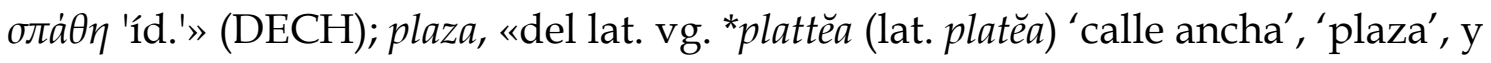

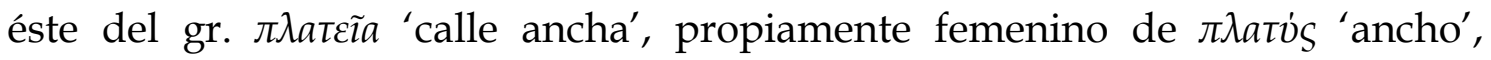
'plano'» (DECH); y saco, «del lat. saccus 'saco de trigo, de dinero, etc.', 'vestido grosero', y éste del fenicio por conducto del gr. oáxxos 'íd.' y 'arpillera'» (DECH).

\section{Préstamos léxicos}

Los hablantes de una lengua pueden elegir entre diversos procedimientos o recursos neológicos cuando hay una laguna léxica que cubrir, es decir, cuando se produce la necesidad de designar nuevos conceptos $u$ objetos. Pueden optar entre el préstamo, o neologismo «externo», y los neologismos o creaciones autóctonas -neologismo «interno»- cuando se hallan ante esa necesidad de verbalizar nuevos conceptos y de rellenar ese vacío léxico existente.

Por lo que se refiere al préstamo, el primero de esos dos mecanismos, esta incorporación y enriquecimiento léxico tiene que ver con razones de prestigio de las lenguas prestatarias. 


\subsection{Latinismos}

Tanto el latín como el griego son consideradas en el Occidente europeo las principales lenguas de cultura. Por consiguiente, dentro de los procedimientos de creación de la terminología militar renacentista debemos hablar, en primer lugar, de los préstamos cultos grecolatinos o cultismos:

El cultismo es un préstamo de una lengua culta, en nuestro caso el latín (clásico, tardío o eclesiástico) o el griego, a otra lengua; durante un período más o menos amplio, actúa como neologismo (Herrero Ingelmo 1994-1995: 21)77.

A diferencia de la situación mostrada en un trabajo anterior ${ }^{78}$, el vocabulario de la milicia manifiesta numerosos préstamos latinos, comúnmente denominados latinismos. No registramos, en cambio, ningún tecnicismo de origen helénico. Tan sólo podemos citar cinco préstamos del griego a través del latín:

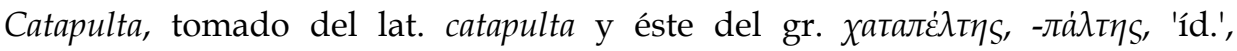
procedente de $\pi \dot{\lambda} \lambda \lambda_{\varepsilon} \imath v$ 'lanzar' (DECH).

Escorpión, tomado del lat. scorpio, -ōnis 'íd.' (a su vez derivado del gr. бхорлios) $(\mathrm{DECH})$.

Máquina, tomado del lat. machĭna 'íd.', 'andamio', 'artificio, maquinación',

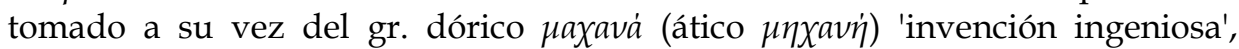
'máquina (de teatro, de guerra, etc.)', 'maquinación, astucia' (DECH).

Onagro, tomado del lat. ŏnăgĕr (-grus), -grī 'onagro, asno salvaje', 'máquina de guerra (que lanzaba piedras)', y éste del gr. óvarpos, compuesto de óvos 'asno' y àrplos 'silvestre' (Segura Munguía 2007).

Sambuca, tomado del lat. sambūca 'arpa', 'máquina de guerra en forma de puente

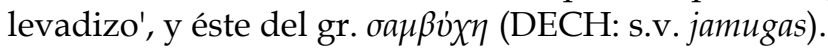

77 En la misma línea se expresa Azofra Sierra (2006: 234): “En nuestra opinión, el término cultismo englobaría a todas aquellas voces procedentes de una lengua de cultura, ya sea el latín, el griego o el hebreo, además de todas aquellas que, sin proceder directamente de estas lenguas, se han visto influidas por ellas. En el caso de los latinismos, que son con mucho los más numerosos, es necesario aclarar que el latín como lengua de cultura debe entenderse en su sentido más amplio: latín clásico o literario, pero también latín tardío, medieval o eclesiástico". ${ }^{78}$ Nos referimos a nuestro trabajo Estudio del léxico de la industria textil y de la sastrería en la época renacentista. Vid. Sánchez Orense (2007), en donde de las 130 voces de origen latino analizadas, sólo 4 son cultismos. 
La trascendencia que los hombres del Renacimiento otorgan a la Antigüedad clásica propicia abundantes referencias, en los textos manejados, a los mecanismos empleados por los griegos y romanos. Esta vuelta al pasado es especialmente recurrente cuando, al exponer los terribles efectos destructores de las nuevas armas de fuego, los tratadistas quieren demostrar que, a pesar de su excelencia, los ingenios bélicos grecorromanos son ineficaces para hacer frente a esa nueva artillería. Tanto los latinismos de origen griego catapulta, escorpión, onagro y sambuca, ya mencionados, como los cultismos arcubalista, ariete, balista, compago, falárica, lupo, músculo, plúteo, testúdine, testudo y vínea confirman que para referirse de manera eficaz a esas realidades ya anticuadas aquellos autores recurrieron a las mismas voces latinas ${ }^{79}$.

Debemos especificar que dos de esos latinismos disponen de su término patrimonial correspondiente, lo que origina dobletes léxicos: balista y ballesta, por un lado, y lobo y lupo, por otro. En el glosario, hemos lematizado estas cuatro formas por separado, debido a su diferente evolución, pero, al nombrar la misma realidad, hemos marcado la sinonimia existente, aunque somos conscientes de que, más que sinónimos, son estrictamente variantes o unidades etimológica y semánticamente emparentadas.

Por lo que respecta a la segunda pareja, la enorme difusión de la que gozó ya desde orígenes la palabra patrimonial lobo seguramente repercutió en su utilización, frente al latinismo lupo, cuando, como consecuencia de la revivificación de la Antigüedad grecolatina, los hombres renacentistas quisieron hacer referencia al otro significado que, aparte del de 'animal', poseía el latín lüpus, a saber, el de 'gancho, garfio' (cf. Segura Munguía 2007). En este caso, más que ante un préstamo léxico del latín, estaríamos ante uno semántico.

\footnotetext{
${ }^{79}$ Como puede comprobarse en Segura Munguía (2001, 2007), el étimo de cada uno de estos cultismos poseía ya en la lengua clásica el significado de 'máquina de guerra', por lo que en esta ocasión el castellano ha tomado en préstamo tanto el significante como el significado latino. A propósito de arcubalista, Segura Munguía (2007) admite que en latín existía el término arcŭballista, compuesto de arcus y ballista, y con el significado 'tipo de ballesta, arma'. Pese a ello, este cultismo tuvo una escasa popularidad en nuestra lengua, supuesto corroborado por las escasas ocurrencia en nuestro corpus, además del CORDE, donde contamos dos: la primera en el Tratado de Re Militari de Diego de Salazar (1536) y la segunda en el año 1596 en la obra Comentario en breve compendio de disciplina militar de Mosquera de Figueroa, precisamente nuestro ejemplo.
} 
Por el contrario, el uso de lupo con el significado de 'garfio fuerte de hierro que usan los sitiados desde lo alto de la muralla para defenderse de los sitiadores', cuya primera y única manifestación en nuestro corpus se produce, de nuevo, en la obra de 1596 de Mosquera de Figueroa, es un claro caso de préstamo léxico que el castellano moderno adquiere gracias a la lengua de cultura por antonomasia, es decir, al latín.

Por su parte, la pervivencia en la Edad Media de la máquina que los romanos denominaban ballǔsta explica la presencia en castellano de la voz popular ballesta desde mediados del siglo XIII80, en contraposición al cultismo balista, cuya primera documentación data de principios del siglo XVI ${ }^{81}$.

Damos cuenta, asimismo, de otros cinco latinismos pertenecientes al ámbito de los artilugios bélicos de épocas anteriores a la Edad Moderna:

\begin{abstract}
Arietario 'perteneciente al ariete', tomado del lat. ariětārŭus, a, um, de arǔes 'ariete' (Miguel 2003).

Arietino 'perteneciente al carnero', tomado del lat. ariětīnus, a, um, de ař̌es 'carnero' (Miguel 2003).

Ingenio ${ }^{82}$, tomado del lat. $\breve{n} g \breve{n}$ ium 'cualidades innatas de alguien' (DECH: s.v. genio).
\end{abstract}

Toro 83 , tomado del lat. tŏrus 'hinchazón en una planta', 'bulto o protuberancia en el terreno, en un madero, una cuerda, un músculo, etc.' (DECH: s.v. tuero).

Trabe ${ }^{84}$, tomado del lat. trabs, -is (DECH: s.v. trabar).

El resto de las voces con esta ascendencia pertenece a alguna de las siguientes esferas de la milicia:

\footnotetext{
80 “Med. s. XIII, Calila, Fn. Gonz., 1. ${ }^{a}$ Crón. Gral." (DECH: s.v. ballesta).

81 "1536, D. Salazar" (DECH: s.v. balista). Debemos advertir, por otro lado, que no sólo hemos detectado dobletes en el campo de las máquinas o ingenios bélicos, sino que otras muchas áreas nocionales de la milicia los acogen, por ejemplo la de los elementos de fortificación, a la que pertenecen la voz culta fosa y la popular fuesa, doblete al que se suma el italianismo foso, forma que finalmente triunfa sobre las otras, que acaban relegadas a apariciones muy esporádicas.

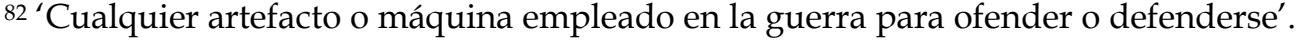

83 'Especie de madero o de barra de hierro cuya cabeza, dependiendo de la máquina mural de la que forma parte, adopta diferentes formas'.

84 Sinónimo de toro.
} 


\begin{tabular}{|c|c|}
\hline Acciones bélicas (verbos) & $\begin{array}{l}\text { defender, divertir, expugnar, militar }{ }^{1} \text {, ocupar, ofender, oprimir, } \\
\text { opugnar, pacificar, rebelar, resistir, sujetar y triunfar. }\end{array}$ \\
\hline $\begin{array}{l}\text { Acciones bélicas } \\
\text { (sustantivos) }\end{array}$ & $\begin{array}{l}\text { conquista, defensa, defensión, expugnación, facienda, incursión, } \\
\text { ofensa, pacificación, rebelión, resistencia, sedición, sujeción y victoria. }\end{array}$ \\
\hline Cualidades (adjetivos) & $\begin{array}{l}\text { bélico, belicoso, contrario, doméstico, expugnable, inexpugnable, } \\
\text { invicto, mercenario, militar }{ }^{2} \text {, pacífico, rebelde, sujeto y tirón. }\end{array}$ \\
\hline $\begin{array}{l}\text { Personas o unidades } \\
\text { militares (sustantivos) }\end{array}$ & adversario, defensor, facción, metator, mílite y presidio. \\
\hline Técnicas o artes (sustantivos) & arquitectura, fortificación y milicia. \\
\hline $\begin{array}{c}\text { Operaciones estratégicas } \\
\text { (verbos) }\end{array}$ & coligarse y confederarse. \\
\hline $\begin{array}{l}\text { Resultados estratégicos } \\
\text { (sustantivos) }\end{array}$ & confederación. \\
\hline $\begin{array}{c}\text { Acciones de fortificación } \\
\text { (verbos) }\end{array}$ & explanar, fortificar y reparar. \\
\hline $\begin{array}{c}\text { Construcciones defensivas } \\
\text { (sustantivos) }\end{array}$ & cunículo 85 y reparación ${ }^{86}$. \\
\hline $\begin{array}{c}\begin{array}{c}\text { Elementos de fortificación } \\
\text { (sustantivos) }\end{array} \\
\end{array}$ & fosa y pina ${ }^{87}$. \\
\hline $\begin{array}{c}\text { Magnitudes temporales } \\
\text { (sustantivos) }\end{array}$ & alba $^{88}$ y vigilia ${ }^{89}$. \\
\hline $\begin{array}{c}\text { Formaciones tácticas } \\
\text { (sustantivos) }\end{array}$ & cúneo y fórfice. \\
\hline $\begin{array}{l}\text { Acontecimientos bélicos } \\
\text { (sustantivos) }\end{array}$ & ovación ${ }^{90}$ y triunfo ${ }^{91}$. \\
\hline $\begin{array}{l}\text { Materiales de guerra } \\
\text { (sustantivos) }\end{array}$ & munición. \\
\hline
\end{tabular}

En síntesis, del estudio de los 209 términos de origen latino se concluye que, mientras que 123 son voces patrimoniales, 86 son cultismos latinos:

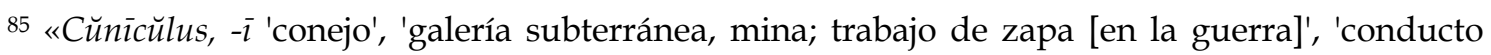
subterráneo'» (Segura Munguía 2001).

86 'Cualquier obra o trabajo provisional que se hace tras perder alguna defensa importante, para poder seguir resistiendo'.

87 "Del lat. pinna, pluma, almena” (DRAE).

88 'Última de las cuatro partes en que los centinelas dividen las noches'.

89 'Cada una de las cuatro partes en que los centinelas dividen las noches'.

90 "Uno de los triunfos menores que concedían los romanos por haber vencido a los enemigos sin derramar sangre, o por alguna victoria de no mucha consideración" (DRAE).

91 "En la antigua Roma, entrada solemne en la ciudad de un general vencedor con su ejército" (DRAE).
} 


\section{Voces de origen latino}

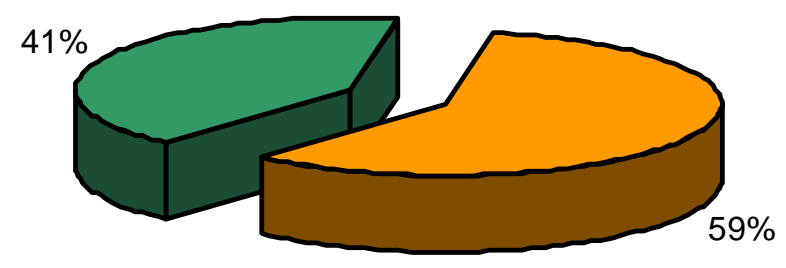

$\square$ Voces patrimoniales $\square$ Latinismos

\subsection{Germanismos}

De acuerdo con Kremer (2004: 134), el "germánico", que se trata de una denominación genérica, se divide en varias familias de lenguas bien diferenciadas entre sí: lengua vándala, gótico, fráncico, lengua sueva, lengua alana, etc.

A propósito de este tipo de préstamos, existe una opinión generalizada entre los investigadores sobre la limitada influencia de los elementos léxicos germanos en las lenguas iberorrománicas. Por lo que respecta al vocabulario militar renacentista, contabilizamos únicamente siete germanismos, cifra extremadamente baja en comparación con la ostentada por otro tipo de préstamos, por ejemplo los de origen galo o italiano.

Convendría, además, advertir que

los elementos germánicos que sobreviven en la lengua española están, en su menor parte, tomados directamente de un idioma germánico. En la mayoría de los casos estos elementos provienen o directamente del latín vulgar o de otra lengua románica, en primer lugar del francés (Gamillscheg 1967: 79).

De esta forma, Kremer establece una clasificación entre préstamos germánicos directos e indirectos: 
Préstamos directos son los lexemas de etimología germánica que sólo están documentados en la Península Ibérica ${ }^{92}$ [...]. Préstamos indirectos son los germanismos que se extendieron por medio del latín por todo (o gran parte) del Imperio [...] o que posteriormente entraron en las lenguas hispanorrománicas como préstamos románicos (Kremer 2004: 138-139).

Siguiendo este planteamiento, hemos detectado tres germanismos indirectos a través del latín en el vocabulario militar estudiado:

Guarda, del germ. warda 'acto de buscar con la vista', 'guardia, guarda', 'atalaya', 'garita' (que a su vez deriva de warôn 'atender, prestar atención') (DECH: s.v. guardar).

Guardar, del germ. wardôn, derivado de warda y éste de warôn 'atender, prestar atención' (DECH).

Guerra, del germ. occid. werra 'discordia', 'pelea' (DECH) $)^{93}$.

Estos tres préstamos indirectos pertenecen a la época de las invasiones, momento en el que muchas palabras germánicas, sobre todo las referentes a la vida militar, entraron en el latín vulgar:

Los germanos, enseñoreados del territorio romano, conservaban con plena vitalidad sus lenguas, y los latinos aprendían de ellos denominaciones de cosas y costumbres extrañas, familiarizándose con expresiones germánicas. El vocabulario militar adoptó muchas, primero a causa de la convivencia en las legiones; después porque la nobleza germánica, dedicada principalmente a las armas, impuso su propia terminología (Lapesa 19819: 112).

Por lo que se refiere a los germanismos directos, también son tres los recogidos: espía ${ }^{94}$ espiar ${ }^{95}$ y guardia ${ }^{96}$.

92 También Colón se refiere a los germanismos directos con este sentido: "No podemos considerar genuinos más que aquellos vocablos de etimología gótica clara, que no estén representados en las otras lenguas románicas extrapeninsulares, en particular que no estén en francés y en provenzal, puesto que el riesgo es grande de hallarnos ante préstamos posteriores" (Colón 2002a: 32).

93 "El latín bellum fue sustituido por werra (> it. guerra, fr. guerre, prov., cat., esp. y portugués guerra)" (Lapesa 19819: 112).

94 «Del gót. *spaíha 'íd.'» (DECH: espiar I).

95 «Del gót. *spaíhôn 'acechar, atisbar, espiar'» (DECH: espiar I).

96 "Del gót. wardja 'el que monta guardia', 'centinela, vigía', influido en su significado por el lat. custodia 'acción de guardar', 'retén de soldados'. h. 1570, dicc. de Cristóbal de las Casas; 1578, Ercilla; Quijote; Góngora; Oudin; Covarr., etc." (DECH: s.v. guardar). Dada la tardía incorporación de este vocablo en nuestro idioma, Corominas y Pascual no descartan la posibilidad de que haya llegado al castellano a través del italiano. No obstante, como sus primeras documentaciones datan realmente del siglo XIV (cf. López Vallejo 2008: s.v. guardia), finalmente hemos optado por incluirlo en el grupo de los germanismos directos. 
El pueblo godo estuvo asentado durante aproximadamente dos siglos (siglo V-VII) en el sur de Francia, con capital en Toulouse. Por su parte, los francos, mucho más numerosos, decidieron instalarse en el norte del país (Gamillscheg 1967: 81).

Pasados unos dos siglos y una vez vencidos por los francos, los godos trasladaron su centro, primero a Barcelona y después a Toledo (Gamillscheg 1967: 84-85). Es en esta etapa en la que se inscriben los únicos préstamos directos del gótico que posee el castellano. De acuerdo con Kremer (2004: 139), dentro de los germanismos directos sobresalen los vinculados al mundo bélico, de lo que dan buena cuenta espía, espiar y guardia.

En último lugar, los préstamos germánicos indirectos a través de alguna de las lenguas romances existentes son especialmente relevantes a partir de los siglos XII y XIII.

A esta modalidad pertenece fald $a^{97}$, puesto que, si bien su última filiación se halla en el fráncico *falda 'pliegue', al español ha llegado o bien por conducto del catalán o a través de la lengua de Oc. De todas formas, por lo que respecta al significado de falda registrado98, del que sólo hace uso González de Medina Barba en su Examen de fortificación ${ }^{99}$, resulta evidente su origen metafórico.

\subsection{Arabismos}

“La aportación arábiga a la lengua española es muy conspicua y posiblemente la más importante en número, si dejamos de lado el latín. Desde que en 711 los árabes ponen los pies en la Península Ibérica hasta su expulsión en 1492 el influjo semítico se dejó sentir considerablemente" (Colón 2002a: 33).

\footnotetext{
${ }^{97}$ Para Corominas y Pascual, su primera documentación se localiza en Berceo.

98 'Pasaje o subida, en forma escarpada, por la que los soldados acceden desde la plaza de armas hasta el andamio o parte superior de la fortaleza'.

99 "La falda ha de començar desde la perpendicular que haze el terrapleno a los cincuenta pies de ancho, y ha de yr tan escarpada del mismo terrapleno que tenga treynta pies de caýda para poder fácilmente subir el artillería y los soldados a la defensa, porque para esto no son buenas escaleras, por muchas y buenas que sean" (González de Medina 1599: 30).
} 
En definitiva, el elemento árabe es, después del latino, el más importante del vocabulario español, sobre todo hasta el siglo XVI.

Por su parte, Steiger (1967: 105) resalta que, si se analizan las bases lingüísticas del arabismo iberorrománico, se encontrará que éstas radican en el dialecto andalusí. En su opinión, la transmisión de vocablos de este dialecto árabe al romance peninsular tuvo lugar preferentemente por vía oral.

De esta forma, no debe sorprendernos que las huellas del árabe sean especialmente significativas en las parcelas léxicas que atañen a la vida cotidiana y social: guerra, agricultura, artesanía, nombres de árboles y frutas, el comercio, monedas, pesos y medidas. Por lo que respecta a nuestra terminología, a pesar de no registrar una cifra elevada de arabismos, son varios los campos semánticos de la milicia donde puede contabilizarse alguno.

Por ejemplo, documentamos cuatro términos de origen árabe que designan individuos relacionados con el mundo bélico:

Albañil, del ár. bannâ 'constructor', 'albañil', de la raíz bánā 'edificar' (DECH).

Atalaya, del ár. talâyic, plural de talîca 'centinela', 'avanzada de un ejército' (DECH).

Jinete, del ár. vg. zenêti (ár. zanātî) 'individuo de Zeneta', tribu bereber que acudió en defensa del reino de Granada en el s. XIII (DECH).

Ronda, del ár. rubt, pl. de râbita que también significa 'patrulla de jinetes guerreros' (DECH: s.v. rebato).

También hallamos influjo árabe en el ámbito de las construcciones defensivas. Así, el étimo de barbacana, voz que designa un elemento de fortificación típicamente medieval, se encuentra en el ár. vulgar b-al-baqára (clásico bâb al-báqara) 'puerta de las vacas' porque, en palabras de Corominas y Pascual, "la barbacana protegía un recinto intermedio entre esta fortificación y la muralla principal, en el cual los sitiados guardaban el ganado destinado a proveerlos de carne".

Por su parte, real, que se refiere al campamento militar, procede «del ár. rahl (vulgar rahál) que significa 'lugar donde se hace alto en un camino', 'campamento', 'majada, redil', 'rebaño'» (DECH: s.v. rehala). 
Posee igualmente esta filiación la unidad léxica alarde: «del ár. card, 'revista de tropas', perteneciente a la raíz cárad 'mostrar'» $(\mathrm{DECH})$. Como puede constatarse, en este caso estamos ante una acción estratégica.

Lógicamente, el vocablo que designa el griterío que dan los moros al atacar al enemigo, a saber, algazara, también se trata de un arabismo ${ }^{100}$.

Por último, rebato ${ }^{101}$ es asimismo un tecnicismo militar de ascendencia árabe: «del ár. ribât 'ataque contra los infieles', derivado de râbat 'dedicarse con celo a un asunto', 'amenazar las fronteras enemigas'» (DECH).

\subsection{Galicismos}

El elemento galo pone de manifiesto su importancia a lo largo de la Edad Media, especialmente durante los siglos XI al XIII, como consecuencia de la llegada de los cluniacenses y los cistercienses. Así pues, durante este período histórico se incorporan al castellano los siguientes galicismos:

Cordón [Cid], el valor diminutivo del sufijo -ón hace probable que, como otros tantos términos relativos al vestido, venga del francés antiguo, donde ya se halla también desde el s. XII'102 (DECH: s.v. cuerda).

Mina, probablemente tomado del fr. mine 'íd.' y éste procedente de un galo *mina, celta primitivo *mein-, conservado hasta hoy en los idiomas célticos insulares, con el significado de 'mineral' y en la forma *men- $(\mathrm{DECH})^{103}$.

Aliar, del fr. ant. aliier (fr. allier) 'juntar', 'aliar', y éste del lat. alligare 'atar a (algo)', derivado de ligare 'atar'. . $^{a}$ doc.: h. 1375, Crón. de Pedro el Cruel (DECH: s.v. aliar).

Pabellón, del fr. ant. paveillon 'tienda de campaña', que vino del lat. papilio, -ōnis 'mariposa' y más tarde 'tienda de campaña' (DECH) ${ }^{104}$.

100 «Del ár. vg. ġazâra 'locuacidad', 'murmullo, ruido', derivado del verbo ġázzar 'abundar', 'hablar mucho'» (DECH).

101 "Llamada precipitada hecha a la gente para que acudiese a la defensa, ante una súbita incursión enemiga, la cual se hacía tocando las campanas en cierta forma" (DUE).

102 Ahora bien, el significado especializado de cordón que nos atañe, a saber, el de "cinta o banda de piedras que se forma donde se concluye la muralla o empieza el parapeto, y circuye toda la plaza" (Sanz 1749), seguramente es fruto de una analogía entre este elemento de fortificación y el complemento vestimentario correspondiente, presente ya en el Cid.

103 Por lo que respecta a su primera documentación, si bien Corominas y Pascual la sitúan en la segunda mitad del siglo XIII, admiten que el empleo de esta voz es raro hasta finales del siglo XV.

104 "h. 1475, G. de Segovia; APal." (DECH). Por su parte, López Vallejo (2008: s.v. pabellón) adelanta en más de un siglo esta documentación: “Segundo tercio del s. XIII (1256-1263)". 
Rechazar [1430, Juan de Mena; Gómez Manrique (...); "rechaçar: repello", Nebr. (...)], tomado del fr. ant. y med. rechacier 'íd.' [...], derivado de chacier (hoy chasser 'expulsar, perseguir') (DECH: s.v. cazar).

Como ya ha sido puesto de manifiesto, son también típicos del período medieval los préstamos germanos indirectos ${ }^{105}$, sobre todo los introducidos a través del francés. Precisamente éste parece haber sido el camino seguido tanto por garita ${ }^{106}$ como por tropel ${ }^{107}$.

Con posterioridad a éstos se incorporan al castellano bordo, flanco, gasón, marchar y brecha, también galicismos germánicos:

Bordo, del fr. bord. y éste del fráncico bord 'íd.'. 1. ${ }^{a}$ doc.: Nebr ${ }^{108}$ (DECH: s.v. borde I).

Flanco, del fr. flanc 'costado, ijada' y éste del fráncico *hlanca (DECH).

Gasón, del fr. gazon 'césped', 'gleba de césped', y éste del fráncico *waso, -uns $(\mathrm{DECH})$.

Marchar, del fr. marcher, antiguamente 'pisar, pisotear', y éste del fráncico *markôn 'dejar una huella'. 1. ${ }^{a}$ doc.: h. 1550; 1568, Eugenio de Salazar (DECH).

Brecha, tomado del fr. brèche 'íd.' y 'mella', que viene del fráncico breka 'roto, hendidura' [...]. 1. ${ }^{a}$ doc.: $1643^{109}$ (DECH: s.v. brecha).

Según la opinión de Colón ${ }^{110}$, el influjo galo se redujo durante el Renacimiento, lo que no obsta, sin embargo, para que sigan penetrando voces,

\footnotetext{
${ }^{105}$ Nótese que también falda ha logrado engrosar el caudal léxico del castellano gracias a la mediación de alguno de los idiomas romances disponibles. No obstante, al no poder asegurar si el canal transmisor ha sido la lengua catalana o la de Oc, hemos decidido contabilizar este vocablo como un germanismo más, en lugar de como un préstamo del catalán o del occitano. Algo semejante ocurre con baluarte, lo que a su vez nos ha llevado a tratarlo como un galicismo: "Baluarte, del fr. ant. boloart, balouart 'íd.' (hoy boulevard), y éste del neerl. med. bolwerc, es decir, 'obra (werk) hecha con vigas gruesas $(b o l=$ alem. bohle)' [...]. Debió de llegar a través de la lengua de Oc. o del catalán (baluard), donde aparece también en el siglo XV (DECH).

106 "Del fr. ant. garite 'refugio', 'garita de centinela' (hoy guérite), quizá contracción de garite 'refúgiate', imper. sustantivado de se garir, o más probablemente de un participio sustantivado (irregular) de garir; del mismo origen germánico que nuestro guarecer" (DECH).

107 «Del fr. ant. tropel 'rebaño', diminutivo de trop, primitivamente 'rebaño' (luego empleado adverbialmente en el sentido de 'mucho' y 'demasiado'), a su vez de origen incierto, probablemente tomado de un fránc. *throp 'asamblea'» (DECH: s.v. tropa).

108 A este respecto, Corominas y Pascual aseveran que bordo "no se halla en la Edad Media".

109 En nuestro corpus, la primera documentación data de 1607: "Aviendo hecho el hornillo o mina al baluarte, se le dará fuego con la orden que allí digo en aquel libro, y como ya lo sabrá bien el tal yngeniero; y aviendo bolado el baluarte, se alojarán los soldados en la brexa que se hiçiere" (Roxas 1607: 104r).
} 
gracias sobre todo a los frecuentes contactos comerciales, políticos y militares establecidos entre España y Francia.

Así pues, "cabe mencionar una serie de voces militares que el español toma prestadas durante la primera mitad del siglo XVI" (Verdonk 2004: 901), como son trinchera, tropa y bagaje.

Ahora bien, la inmensa mayoría de voces técnicas de origen francés que documentamos en este estudio fueron introducidas en nuestro idioma mediada la centuria quinientista, dato que concuerda con la afirmación de Verdonk (2004: 899) de que “a partir de 1567, hay muchos términos militares que desde el francés de Flandes (y sus variedades regionales: el picardo y el valón) penetran en español"111. En el siguiente cuadro puede constatarse el reparto por campos semánticos de estos últimos préstamos:

\begin{tabular}{|c|c|}
\hline $\begin{array}{l}\text { Ámbito de los pertrechos y } \\
\text { municiones }\end{array}$ & $\begin{array}{l}\text { blinda, convoy, forraje, mantelete, munir } 112 \text {, pilote } \mathrm{y} \\
\text { vivandero }{ }^{113} \text {, víveres. }\end{array}$ \\
\hline Acciones bélicas & batería, contrabatería, interpresa, motín y surtida. \\
\hline Construcciones defensivas & aproche, plataforma y terraplén. \\
\hline Toques militares & botasilla114. \\
\hline Magnitudes espaciales & cuartel $^{115}$. \\
\hline Instrumentos de medición & pitipié. \\
\hline
\end{tabular}

\subsection{Occitanismos}

Normalmente se alude con este término a aquellos préstamos de carácter léxico procedentes de la lengua de Oc (lengua hablada en la Francia meridional), que con el paso del tiempo se han implantado en la lengua

\footnotetext{
110 “En los siglos XVI y XVII el influjo francés es más escaso que en la Edad Media o en la época moderna, aunque entonces no dejan de penetrar varias voces" (Colón 2002a: 36-37).

111 Para conocer las causas de la influencia del francés de los Estados de Flandes sobre la terminología militar española, vid. Verdonk (1980: 21-24).

112 'Proveer a un ejército o a una plaza de guerra de municiones o de cualquier cosa necesaria para su defensa y manutención'. Para Corominas y Pascual, "es grosero y superfluo galicismo". 113 "Persona que vende víveres a las tropas" (DUE).

114 "En los cuerpos de caballería, toque de clarín para ordenar a los soldados que ensillen los caballos" (DRAE).

115 "Cada una de las divisiones de un campamento" (Domínguez 1853).
} 
española. "Ello implica que consideremos hablas occitanas tanto al gascón y al bearnés, como al lenguadociano, lemosín, provenzal, etc." (Colón 1967a: 153).

Los occitanismos se adscriben a los campos semánticos de la vida religiosa, palaciega o cortesana y la comercial, y su introducción se limita a la Edad Media, época de mayor florecimiento de la literatura provenzal, ya que “los contactos de índole literaria, sociológica, religiosa y económica entre la Península Ibérica y las Galias del Norte y del Sur fueron entonces muy estrechos" (Colón 1967a: 157).

Con todo, dicha influencia es difícil de reconocer en ocasiones ya que "se dio conjuntamente con la del francés del Norte que, sin duda, fue mayor" (Colón 1967a: 192), lo que explicaría las dudas que para Corominas y Pascual suscita el establecimiento del origen de batalla: «del oc. ant. batalha o del bajo latín galicano battalia 'íd.', procedentes ambos del lat. tardío battualia 'esgrima', antiguo neutro plural de un adjetivo battualis derivado de battuere 'batir'» $(\mathrm{DECH})$.

Jornada y palizada son también probables occitanismos:

Jornada, tomada de otro romance, probablemente de la lengua de Oc, donde jornada es derivado de jorn 'día', procedente del lat. diŭrnus 'diurno, que ocurre durante el día', adjetivo que en el lat. tardío se sustantivó en el sentido de 'tiempo diurno', por oposición al nocturno $(\mathrm{DECH})$.

Palizada [paliçada, 1475, G. de Segovia (...); APal. (...), junto a -zada (...)], probablemente tomado del oc. ant. palissada 'íd.' (de donde asimismo el fr. palissade), en vista de las citadas formas en $c$, que no serían normales en castellano (DECH: s.v. palo).

En cambio, resulta incuestionable que el étimo del castellano fortaleza se halla en la lengua de Oc:

Fortaleza ['recinto fortificado', Berceo, Loores (...); Apol. (...); Conde Luc. (...); 'reciedumbre, fuerza', Berceo, S. Lor. (...)], tomado del oc. ant. fortalessa (o -aleza, menos común), ya con ambas acs., hermano del fr. forteresse, ambos derivados de fortis con el sufijo galo- e italorrománico -aricius, disimilado en este caso (DECH: s.v. fuerte). 


\subsection{Catalanismos}

Debe prestarse atención a los abundantes préstamos del catalán, ya que, como reconoce Colón Doménech (2002a: 38), el contacto geográfico, cultural y político de la lengua catalana con tierras castellanas permitió trasvases en ambas direcciones. Esta mutua influencia no queda relegada a la época medieval, ni temáticamente a ciertos campos, como en el caso de los occitanismos, sino que los contactos han sido más intensos y permanentes ${ }^{116}$.

Este influjo se manifiesta en la lengua española de manera más intensa en los siglos XIV y XV, y se mantiene con bastante fuerza en el siglo XVI. Se puede constatar la influencia catalana en todos los dominios léxicos, desde la alimentación, pasando por el comercio o la terminología marítima.

Es difícil decidir, en ocasiones, el origen catalán de un término ya que existen rasgos semejantes en la evolución fonética del occitano, del francés y del catalán (Colón 1967a). Esto ocurre en el caso de palenque117, que procede del cat. palenc 'empalizada, estacada donde se celebra una justa, etc.'; aunque el DECH (s.v. palo) también postula como probable un origen occitano (oc. palenc).

Idénticas dudas suscita la filiación etimológica de roca118:

Roca, voz tardía en cast. y port., sin duda tomada del cat. o el oc.; con viejo arraigo es común a estos dos romances y a los demás de Francia e Italia; de origen incierto, seguramente prerromano. $1 .^{a}$ doc.: Primer cuarto del s. XIV; APal (DECH: s.v. roca).

Por lo que respecta al vocablo trabuco, lo más seguro es que el castellano lo haya tomado en préstamo del catalán trabuc ( $c f$. DECH: s.v. trabucar). Para

\footnotetext{
116 vid. Colón (1967b: 194-199).

117 "Atrincheramiento que se construye de madera para defensa del enemigo" (López Vallejo 2008).

118 En el tratado Examen de fortificación de González de Medina funciona como sinónimo de la unidad pluriverbal torre del homenaje: "La dominante y más fuerte, en la que el castellano o gobernador hacía juramento de guardar fidelidad y de defender la fortaleza con valor" (DRAE).
} 
Colón (1967a: 189), por su parte, si bien en nuestra lengua sí sería éste el origen $^{119}$, en catalán debería estipularse, en cambio, un influjo occitano.

Más complejo parece ser el caso de revellín, a la vista del siguiente artículo extraído del DECH:

Revellín, término de fortificación, existente en fr. (ravelin), oc. (revelin) e it. (rivellino), de origen incierto, quizá derivado del lat. rebellis 'rebelde', de donde procede el oc. ant. revel 'resistencia'; el punto de partida del término de fortificación es dudoso, quizá la lengua de Oc; en cast. de todos modos se tomó de otro romance, probablemente el francés $(\mathrm{DECH})$.

Creemos que en uno de los últimos trabajos de Colón Doménech (2008: 120) se halla una solución plausible a este problema etimológico: “El castellà sembla, doncs, un catalanisme, i el català prengué el mot de l'italià".

Los demás catalanismos detectados los situamos en este cuadro:

\begin{tabular}{|c|c|}
\hline Elementos de formaciones tácticas & avanguarda $^{120}$, retaguarda ${ }^{121}$ y vanguarda ${ }^{122}$ \\
\hline Personas relacionadas con la guerra & alcaide $^{123}$. \\
\hline Acciones de castrametación & alojar $^{124}$. \\
\hline Construcciones defensivas & barraca. \\
\hline Municiones & presa $^{125}$. \\
\hline
\end{tabular}

\subsection{Italianismos}

Hasta el siglo XVII, la incorporación de términos italianos al castellano se llevó a cabo en dos épocas diferentes: una, la Edad Media, en la que los contactos

\footnotetext{
119 Ahora bien, para Colón (1967a: 189) el étimo exacto no sería trabuc, sino trebuc. De esta manera, en la fijación de la forma definitiva del castellano hubo de intervenir el verbo occitano trabucar.

${ }^{120}$ Del cat. avantguarda (formado con avant 'ante') (cf. DECH: s.v. guardar). En nuestro corpus también existen ocurrencias de la forma avanguardia, quizá influida por el it. vanguardia.

121 Del cat. reraguarda (formado con rera 'tras', del lat. retro) (cf. DECH: s.v. guardar). Documentamos, asimismo, retaguardia, que seguramente imita al italiano retroguardia.

122 Del cat. avantguarda (formado con avant 'ante'), modificado luego bajo el influjo del it. vanguardia (cf. DECH: s.v. guardar). Por su parte, el étimo de vanguardia seguramente sea el it. vanguardia.

${ }^{123}$ De acuerdo con el DECH (s.v. lacayo), el cat. alcaide, que habría pasado de alcait a *alcai y alacai, se transmitió al castellano y a los demás idiomas.

124 "Dar alojamiento a la tropa" (DRAE). «Alojar [2. ${ }^{\circ}$ cuarto del s. XV, Díaz de Gámez: Cuervo, Dicc. I (...); Torres Naharro (...); Cej. VII (...), también lojar una vez en el s. XV], tomado del cat. allotjar y éste del fr. loger, derivado de loge 'cámara, habitación'» (DECH: s.v. lonja II).

125 "En el sentido de 'cosa robada o saqueada' [...] se tomó del cat. presa, procedente del lat. praeda" (DECH: s.v. prender).
} 
ítalo-castellanos fueron esporádicos y se dieron fundamentalmente a través de las relaciones comerciales y marítimas (sirviendo muchas veces Cataluña y Aragón de intermediarios); otra época durante la dominación política española de la Península Italiana: es entonces cuando penetra la mayoría de los italianismos, ligados a las ideas, objetos, literatura, forma de vida, etc., que los españoles aprendieron en su «convivencia» con los italianos (Pascual 1974: 85).

Para la organización de los italianismos que entran en castellano a partir del siglo XV, Terlingen (1967: 267) establece ocho grupos temáticos distintos -la vida cultural, religiosa, política, militar, marítima, comercial e industrial, la vida social y la privada-, si bien el ámbito bélico es sin lugar a dudas el más profuso de todos ellos.

Dentro de esta parcela terminológica, el grupo más importante de italianismos lo constituye el relativo a la fortificación, lo que resulta lógico si tenemos en cuenta que los italianos, como ya hemos apuntado, fueron los maestros de esta particular técnica constructiva.

En primer lugar, destacamos los numerosos términos que designan elementos de fortificación: ándito ${ }^{126}$, árgine ${ }^{127}$, bastión , casamata ${ }^{128}$, contraescarpa ${ }^{129}$, contrafoso ${ }^{130}$, fianco, foso, merlón, muralla, parapeto y terrapleno.

Proceden igualmente del italiano muchos de los pertrechos que facilitan la construcción de obras defensivas: balón ${ }^{131}$, fajina, gavión ${ }^{132}$, salchicha133, salchichón ${ }^{134}$ y zapa ${ }^{135}$.

\footnotetext{
126 "Camino situado detrás del parapeto y en lo alto de una fortificación" (DUE: s.v. adarve).

127 Del it. àrgine 'terraplén', y éste del lat. agger (cf. DECH: s.v. arcen).

128 «Casamata 'bóveda muy resistente para instalar una o más piezas de artillería' [1536], del it. casamatta [1520], de donde procede también el fr. casemate [1539], parece tratarse de casa matta, propiamente 'loca', con el valor de 'falsa, impropia', probablemente en el sentido de 'algo que parece una casa'» (DECH: s.v. casa).

129 "Pared del foso, enfrente de la escarpa, también en pendiente" (DUE). «Contraescarpa [1572, F. de Herrera, en Terlingen; 1623, Minsheu], del it. contrascarpa 'íd.'» (DECH: s.v. escarpa). Proceden también del italiano las siguientes voces emparentadas con ésta: escarpa, escarpado y escarpar.

130 Vid. Terlingen (1967).

131 "Saco de lana que sirve en la guerra, comercio, etc." (Terr.). "Balón 'pelota grande' [3r. cuarto s. XVI, Cervantes de Salazar], tomado del it. pallone, aumentativo de palla" (DECH: s.v. bala II). 132 «Gavión 'cestón de mimbres lleno de tierra, que sirve para defender de los tiros enemigos' [s. XVI o XVII: Terlingen, 219], tomado del it. gabbione 'íd.'» (DECH: s.v. jaula).

133 "Fajina muy larga que se usa para abrazar y cruzar las demás" (DRAE).

${ }^{134}$ Del it. salsiccione (s. XIV) (cf. TLIO).

135 "Término militar tomado del it. zappa 'azada', derivado probablemente de zappo, que en los dialectos del Centro de Italia designa el chivo, por comparación de las dos puntas de las azadas antiguas con los dos cuernos de este animal; este nombre del chivo, muy extendido en los
} 
Asimismo, tanto ciudadela como reducto, voces que aluden a dos modalidades distintas de edificios militares, son italianismos. A propósito del segundo de ellos, Corominas y Pascual comentan que se trata de una “castellanización culta del it. ridotto 'íd.' [s. XIV], de donde procede también el fr. redoute [s. XVII]" (DECH: s.v. aducir).

Si tenemos en cuenta que el campo de las acciones bélicas es uno de los más nutridos de la presente investigación, no resulta extraño que éste sea también portador de múltiples italianismos: asalto, asedio136, atacar, desmantelar ${ }^{137}$, embestir, emboscada ${ }^{138}$, emboscar, empresa, escaramuza, escaramuzar ${ }^{139}$, saco ${ }^{2}$ 'acción de apoderarse violentamente de todo cuanto hay en territorio enemigo', sacomano, saquear ${ }^{140}$ y zapar ${ }^{141}$.

Por su parte, centinela ${ }^{142}$, escolta, estradiote ${ }^{143}$, infantería ${ }^{144}$ y soldado ${ }^{145}$ designan individuos o colectividades que intervienen en la guerra.

idiomas eslavos y balcánicos, es de origen incierto, pero es probable que proceda del grito ¡tsap! empleado en muchas partes para hacer acudir a este animal" (DECH: s.v. zapaI).

136 "El viejo verbo castellano era cercar [Cid], con el sustantivo correspondiente (cerca en el Cid, cerco después). En vista de ello puede sospecharse que el cast. asedio y el port. assédio [Freire, s. XVII: Moraes] sean italianismos ya antiguos, puesto que en italiano, donde no hay sinónimos concurrentes como nuestros cerco y sitio, es de uso más general y más antiguo: assediare h. 1300 en Dino Compagni, assedio principio del s. XIV en G. Villani, Petrarca, Boccaccio [...]" (DECH).

137 Del it. smantellare 'abbattere una construzione militar bombardandola o minandola, in modo de renderla inefficace per la defesa col privarla di guarnigione e di armamenti [...]' (cf. Battaglia 1961-2002).

138 Según Battaglia (1961-2002), el it. imboscata se documenta ya en la primera mitad del siglo XIV.

139 Al igual que el sustantivo correspondiente, para López Vallejo (2008: s.v. escaramuzar) este verbo se trata de un préstamo léxico de origen italiano: «Del it. scaramucciare, scaramuzzare 'sostener una escaramuza'».

140 "Saquear [1570, C. de las Casas], del it. saccheggiare [s. XVI, y probte. ya existente en 1376, a juzgar por un italianismo provenzal]" (DECH: s.v. saco).

${ }^{141}$ El termino italiano zappare se documenta ya en el siglo XIII con el significado de "lavorare con la zappa (un terreno da dissodare, un filare, un campo a coltura) smuovendo e rincalzando il terreno" (TLIO).

${ }^{142}$ También posee ascendencia italiana su posible sinónimo posta.

143 «Estradiote 'soldado mercenario de a caballo procedente del Epiro o Albania', del it. stradiotto,

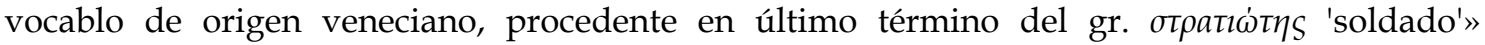
(DECH).

144 cf. TLIO, donde el it. fanterìa se documenta ya en la Cronaca Sen., fechada alrededor del año 1362.

145 “Del it. soldato [s. XIV], que pasó también al francés y demás lenguas europeas" (DECH: s.v. sueldo). 
En lugar de tratarse de aumentativos lexicalizados, tanto batallón como escuadrón, que se refieren al mismo tipo de organización táctica, derivan del italiano:

Batallón [1539], tomado del it. battaglione [Maquiavelo, muerto en 1527, de donde pasó al fr. bataillon desde 1543] (DECH: s.v. batalla).

Escuadrón, del it. squadrone [Maquiavelo (...)], de donde pasó también al fr. [escadron, fin. s. XV] (DECH: s.v. cuadro).

Para finalizar, proporcionamos otras dos unidades léxicas de ascendencia italiana: el adjetivo bisoño y el sustantivo diana146.

\subsection{Casos probables y vocablos de origen incierto:}

Contamos con una voz de difícil atribución, posiblemente se trate de un vasquismo: barrunte. Corominas y Pascual explican bajo el lema barruntar:

En la Edad Media junto al verbo existió el sustantivo femenino barrunte 'acción de espiar y noticia que trae el espía', 'espía, sujeto que trae noticias del enemigo', y ésta parece ser la idea fundamental del vocablo; puede tratarse de un vasco antiguo barrunti 'interioridad', hoy conservado en varias localidades del País Vasco oriental, en formas levemente alteradas (barronde, barrunda) y derivado de barru(n) 'dentro, interior' (DECH: s.v. barruntar).

Por su parte, el término galápago ${ }^{147}$ "probablemente [provenga] de un hispánico prerromano *calappăcu, quizá emparentado con *calapaccĕa 'calabaza' y con *carappaceu 'carapacho', 'caparazón'» (DECH).

Por otro lado, vaivén 148 , “quizá sea palabra de procedencia forastera; comp. fr. va-et-vient [...] y cat. vaivé 'íd.' (DECH: s.v. ir). Sobre este asunto también se pronuncia López Vallejo:

\footnotetext{
146 "Diana 'toque militar del alba' [Terr.], tomado del it. diana 'íd.' [Citolini, 1561; también en lombardo antiguo], del cual procede también el fr. diane [Rabelais, 1553]; se le dio este nombre por llamarse así en italiano la estrella matutina o planeta Venus [...], derivado del it. dì 'día' por ser la estrella del día" (DECH: s.v. día).

147 «Del mismo origen que el cat. calàpet o galàpet 'sapo' y que el port. cágado (ant. caágado), port. dial. cácavo, caganapo, 'galápago'» (DECH).

148 "No parece tratarse de los imperativos, sino de los indicativos de ir y venir, pero entonces no se comprende la forma del último" (DECH: s.v. ir).
} 
Descartamos la procedencia gala, puesto que en la lengua francesa esta fórmula no se registra hasta el s. XVIII, con significados distintos al que nos interesa ${ }^{149}$. En catalán existen, en cambio, ejemplos desde la época medieval, lo que podría apoyar que la voz se tomara de esta lengua. Proceda de donde proceda el significante, creemos que la acepción militar obedece a una asociación con el movimiento alternativo designado con igual nombre. Téngase en cuenta que el ingenio bélico cuando es manejado para atacar al enemigo describe reiteradamente la misma trayectoria en un sentido y otro, esto es, un vaivén (López Vallejo 2008: s.v. vaivén).

Por otro lado, a pesar de que todas ellas van acompañadas de una explicación plausible sobre su origen, tanto alambor, como chocar, estribo, sitio, tomar y zanja son aún para el DECH voces de origen desconocido o incierto.

A propósito por ejemplo de la etimología de chocar, Corominas y Pascual se pronuncian en los siguientes términos:

Chocar, voz común con el fr. choquer 'íd.', ingl. shock, neerl. y b. alem. schokken, 'sacudir violentamente', 'ofender', de origen incierto: suele admitirse que la voz francesa es de origen germánico, aunque no puede asegurarse que no se trate de una creación onomatopéyica común; en cuanto a la voz española parece haberse tomado del francés, pero una onomatopeya autóctona no es imposible ${ }^{150}$ (DECH: s.v. chocar).

Por lo que respecta a alambor, si bien su origen todavía es desconocido, lo más probable es que esté relacionado con algún dialecto arábigo. En cambio, estribo podría estar vinculado etimológicamente con una determinada variedad lingüística germánica:

Estribo, voz emparentada con el port. estribo, cat. estrep, oc. estreup, estriup, estrieu, fr. ant. estrieu, estrief (hoy étrier), de origen incierto, quizá germánico: las formas galorrománicas, al parecer, suponen un fráncico *streup, y la hispanoportuguesa podría venir de su correspondencia gótica *striup(s), pero formas equivalentes no se hallan documentadas directamente en los idiomas germánicos, y aun falta el simple estribo en el romance hispánico medieval, hallándose solamente los derivados estribera y estribote (DECH).

Por su parte, sitio quizá sea una alteración semiculta del lat. sĭtus, -ūs 'íd.', con influencia de asedio o del verbo sitiar para la terminación -io ( $c f$. DECH).

\footnotetext{
149 “Ariete, máquina militar” (López Vallejo 2008).

${ }^{150}$ También pueden ser creaciones de origen expresivo tepe y picar (cf. DECH: s.v. tupido y picar).
} 
En opinión de Corominas y Pascual, el vocablo castellano zanja151 ostenta el mismo origen incierto que el port. sanja.

Finalmente, en nuestro estudio recogemos tomar con la acepción especializada "ganar, mediante operación de guerra, un territorio, población, posición, etc." 152 (DRAE: s.v. conquistar), que es una voz de origen incierto y peculiar al castellano y el portugués, según el DECH153: “Y después de aquello passó Aníbal desde África y destruyó a Cigüença, e tomó mucha parte de España, e la dexó a sus hermanos y se bolvió" (Fernández de Enciso 1530: XXIVv).

\section{Procedimientos de formación de palabras}

El vocabulario español se ha ido enriqueciendo con un gran número de palabras formadas mediante procedimientos internos a la propia lengua, a través de diversos mecanismos morfológicos, lo que se conoce en el ámbito lingüístico como neología formal (cf. Gutiérrez Rodilla 1998) o morfología léxica ${ }^{154}$.

A ella pertenecen tanto los mecanismos derivativos como los compositivos, a los que, lógicamente, también recurre el registro militar para construir nuevos significantes especializados.

\subsection{Derivación}

A través de la derivación, el procedimiento de formación de palabras más productivo en español, se originan nuevos elementos léxicos al unir una

\footnotetext{
151 "Excavación larga y estrecha hecha en el suelo" (DSAL).

152 En la tratadística manejada también existen ocurrencias de la subacepción "ocupar un paso, entrada, salida, etc., para impedir que pase el enemigo" (DUE).

153 "Teniendo en cuenta que en la época arcaica es frecuente y aun predominante su empleo en textos legales, con el valor de 'apoderarse de algo', 'quitarlo', es verosímil que venga del lat. autŭmare 'afirmar' en el sentido de 'proclamar el derecho de uno a un objeto'; en lugar de autumare se diría *tumare en el latín hispánico, tal como ferre y fugere coexistían con auferre y aufugere. $1^{a}$ doc.: doc. de Castilla de 1074 (Oelschl.)" (DECH).

154 "La morfología léxica se ocupa de la formación de nuevas palabras y la morfología flexiva de las variaciones de una misma palabra" (Pena 1999: 4308).
} 
base con un prefijo (prefijación) ${ }^{155}$, una base con un sufijo (sufijación), o una base con un prefijo y un sufijo simultáneamente (parasíntesis).

El lenguaje especializado acude a los prefijos y sufijos de la lengua común para la obtención de derivados.

\subsubsection{Prefijación}

“El prefijo es un morfema que se adjunta al inicio de una palabra independiente (anti-natural, in-admisible) o de un tema o raíz ligada (antí-geno, in-erte)" (Varela y Martín García 1999: 4995). Ahora bien, en la terminología militar renacentista sólo existen representantes de la primera de estas dos modalidades.

Entre los rasgos caracterizadores de la prefijación se encuentran los siguientes: los prefijos no pertenecen a una categoría mayor, no cambian la categoría gramatical del tema al que se adjuntan, no suelen fundirse con la base léxica a la que se agregan y se limitan a indicar precisiones semánticas (cff. Varela Ortega 2005: 57-58). La autonomía de las formas prefijales no evita que, en algunos casos, se produzca su propia alteración; nótese, por ejemplo, la alomorfia del afijo derivativo en- que analizamos más adelante.

En el tecnolecto militar se han creado mediante este recurso morfológico tanto formas verbales como nominales, e incluso puede señalarse un prefijado adjetival. En cuanto a la selección categorial, debemos advertir que los prefijos no seleccionan bases de una categoría léxica exclusiva, aunque cabe apreciarse en nuestro vocabulario cierta preferencia de in- y des- a la adjunción de bases adjetivas y verbales respectivamente, mientras que otros eligen cualquiera independientemente de su categoría, por lo que resultan claramente multicategoriales.

\footnotetext{
155 De acuerdo con la postura más generalizada actualmente, consideramos que en caso de que intervenga un prefijo se obtiene como resultado un derivado y no un compuesto: "Era frecuente en la tradición asimilar la prefijación a la composición [...]. En la gramática contemporánea tiende a interpretarse la prefijación como una forma de derivación, no de composición" (Real Academia Española 2009: 663). No obstante, debe advertirse que determinadas características de la prefijación la singularizan de la sufijación, el mecanismo derivativo por antonomasia ( $c f$. Varela y Martín García 1999).
} 
A) El prefijo a- no forma palabras de manera productiva y general, sin embargo, es muy rentable en la formación de verbos parasintéticos (vid. más abajo el apartado 3.1.3).

En palabras de Pascual Rodríguez (1974: 128), “el castellano conoce y ha conocido la posibilidad de muchos dobletes entre formas que comienzan por $a$ / formas que comienzan por $\varnothing-$, como (a)caecer, (a)matar, (a)sentar, (a)(r)rascar, (a)baxar, (a)limpiar, (a)mostrar, etc.".

Ahora bien, lo normal es que a lo largo de la historia de la lengua el uso haya consagrado una de las dos formas disponibles. En este sentido, Garcia Medall (1994: 55) afirma que "la mayoría de las elecciones léxicas son prefijadas, lo cual supone un olvido sistemático de sus correlatos no prefijados".

Por lo que respecta a nuestro ámbito, encontramos tres verbos con este prefijo, acometer ${ }^{156}$, arremeter ${ }^{157}$ y asitiar. En el caso de los dos primeros ya la tratadística manejada manifiesta una clara preferencia por ellos, frente a sus correspondientes bases de derivación ${ }^{158}$.

De todas maneras, García Medall (1994: 52) también admite la posibilidad de que "el verbo no prefijado triunfe sobre el otro, el prefijado, hasta el punto de transformarlo en «arcaico», «desusado» o «antiguo»e «infrecuente»". Esto es lo que ocurre con la tercera de las formas verbales enumeradas, asitiar ${ }^{159}$, de la que sólo da cuenta el repertorio lexicográfico especializado de José Almirante ${ }^{160}$.

Pedro Sánchez-Prieto Borja sostiene que la alternancia entre lexemas con y sin prefijo es un rasgo característico de la lengua medieval, puesto que "la

\footnotetext{
156 "Cid, etc., pero menos frecuente que cometer [...] hasta el s. XIV" (DECH: s.v. meter).

157 "h. 1295, 1. ${ }^{a}$ Crón. Gral. [...]; J. Ruiz [...]; antes, desde el Cid, se dijo con este sentido remeter" (DECH: s.v. meter).

158 Mientras que no hay ocurrencias de cometer con el significado de 'atacar' en nuestro corpus, la unidad léxica remeter ostenta un carácter claramente residual, al contar sólo con esta manifestación: "Y si el enemigo huviesse hecho batería en la esquina del valuarte y mandasse remeter su gente a ella, digo que les hará mucho más daño la mosquetería y arcabuzería desde la defensa que no la pieça de artillería" (Rojas 1598: 32r).

159 Ésta es su única ocurrencia: "Quando los franceses ganaron a Apulla, el Gran Capitán se metió en Barleta con muy poca gente española que tenía y el visorrey de Francia, con poderoso exército, venía la vuelta d'él para le assitiar dentro, en Barleta" (Montes 1537: IXr).

160 Acerca de este diccionario, vid. bloque IV, apartado 1.14.
} 
historia de la prosa medieval es en buena parte la de la forja de los mecanismos de que se vale la lengua vernácula para verter nuevos conceptos expresados hasta entonces sólo en las grandes lenguas de cultura: árabe, hebreo y, sobre todo, latín" (Sánchez-Prieto Borja 1992: 1323). Coincide con Varela y Martín García (1999: 5017) al afirmar que, en muchas ocasiones, la presencia de un prefijo no conlleva una diferencia de significado léxico. Para Sánchez-Prieto Borja este fenómeno no sólo fue exclusivo del prefijo $a$-, sino que otros muchos prefijos experimentaron idéntico resultado ${ }^{161}$.

B) El afijo contra- "con el valor espacial de lo que está colocado «frente a», se prefija a nombres" (Varela y Martín García 1999: 5013): contraescarpe ${ }^{162}$, contrafosa ${ }^{163}$ y contramuro ${ }^{164}$. Otras veces indica "la réplica -para refuerzo y control- del elemento mencionado en la base" (Varela y Martín García 1999: 5013), como en contraforte ${ }^{165}$, contrarronda 166 , contraseña y contraseñno ${ }^{167}$.

En cambio, con el significado de oposición este prefijo puede adjuntarse, además de a sustantivos, a verbos, de lo que dan buena cuenta contramina ${ }^{168} \mathrm{y}$ contraminar169. Según Varela y Martín García (1999: 5020) actualmente “estas formaciones son muy frecuentes en el léxico militar (contraespionaje, contraguerrilla, contraofensiva)", lo que ya manifiesta -si bien tímidamente- el lenguaje renacentista de la milicia.

\footnotetext{
161 Como comprobamos en el sustantivo empalizada, de significado idéntico al de palizada, que ostenta una variante alomórfica del prefijo en-: "Si la empalizada se haze para vedar los socorros a los cercados y las vituallas traýdas de otra parte, cierto, de esta manera los conseguiréys a vuestra voluntad" (Alberto 1582: 140-141).

162 "Pared del foso, enfrente de la escarpa, también en pendiente" (DUE: s.v. contraescarpa). Recuérdese la vinculación etimológica de contraescarpa con el italiano.

$163 \mathrm{Su}$ variante masculina, contrafoso, también es un italianismo. Por tanto, resulta evidente que en la conformación de la terminología militar los ingenieros italianos optaron por el empleo de mecanismos morfológicos semejantes a los del castellano.

164 "Muro bajo que para mayor defensa se levanta delante del muro principal" (DRAE: s.v. falsabraga).

165 'Refuerzo que se coloca en el interior del terraplén para fortalecer la muralla'. Este derivado se ha creado a partir de la base latina fort $\breve{s},-e$ ( $c f$. DECH: s.v. fuerte).

166 "Segunda ronda que se hace para asegurarse más de la vigilancia de los puestos, en sentido inverso a la ordinaria" (López Vallejo 2008).

167 "Dándole el contraseño, si lo ay, el tal alcayde o castellano lo ha de dilatar hasta la última hora de las veyntiquatro del día que precissamente se le señaló" (Mendoça 1596: 138).

168 "Mina que se hace en oposición de otra, para que no haga efecto" (Aut.).

169 De acuerdo con el DRAE, se trata de un derivado formado por contra- y minar.
} 
c) En el caso del prefijo des- resulta fundamental el concepto de reversión, que hace referencia a la posibilidad de realizar una acción para volver a un estado previo:

La reversión está conectada semánticamente con una acción no-reversiva, de modo que las dos acciones (la reversiva y la no-reversiva) suponen el mismo proceso pero a la inversa [...]. Por ejemplo, en la acción reversiva expresada en deshacer ${ }^{170}$, se parte del estado final de la acción no-reversiva (algo hecho) para llegar al estado inicial de donde parte la acción de hacer (algo no hecho) (Varela y Martín García 1999: 5028).

Recogemos otros verbos complejos que entrañan la acción o el estado previo que denotan sus bases: desalojar, descercar, descoser171, descubrir, desguarnecer, desitiar172 y desocupar. Por lo que respecta a desbaratar en la acepción 'desconcertar, derrotar, descomponer', al no existir una vinculación semántica evidente con baratar, su base de derivación, el DECH (s.v. baratar) sugiere la posibilidad de que se trate de un verbo parasintético obtenido a partir de barata 'confusión'.

D) En palabras de Varela y Martín García (1999: 5012), el prefijo en"unido a verbos simples, no tiene actividad en el español actual si bien ha dejado algunas muestras en nuestro léxico [...], a menudo semánticamente opacas". Recogemos con este prefijo el verbo enfortalecer, que actúa en nuestro corpus como sinónimo de fortalecer 173 , lo que demuestra, al igual que el

\footnotetext{
170 Para este verbo registramos dos significados bélicos relevantes. Primero, el de "destruir completamente una cosa" (DUE) y, segundo, el que definimos como 'vencer completamente al enemigo, aniquilarlo, destrozarlo'.

171 Nótese que su acepción militar relevante es metafórica: 'Abrir una brecha o portillo en el muro de una fortaleza'.

172 Tanto este verbo como descercar resultan ser especiales, ya que constatamos, gracias al corpus manejado, que los agentes que realizan sus correspondientes acciones no-reversivas (sitiar y cercar) no son los mismos que los que emprenden éstas. Es decir, los que sitian y cercan son los atacantes, frente a los asediados, que tratan de obligar a sus enemigos a que desistan del cerco iniciado. Para más información al respecto, vid. Sánchez Orense (en prensa-b).

173 "Deven ser acorridos los castillos por los alcaydes enfortalesciéndoles, haziendo labrar a todos, sin escusar ninguno, en las lavores d'él, y socorriéndolos con gente si se hallare de fuera y con bastimentos, preferiendo siempre el socorro d'ellos a su proprio peligro y vida" (Celso 1553: LIXv).
} 
sustantivo empalizada, que en numerosas ocasiones este elemento afijal no aporta ningún valor semántico.

E) Por otro lado, el prefijo negativo in- es muy productivo unido a bases adjetivas, si bien con ciertas limitaciones. Por ejemplo, "in- no se prefija a adjetivos con un contrario léxico (guapo/feo > *inguapo/*infeo) y sólo se une a adjetivos calificativos, es decir, a adjetivos que denotan propiedades" (Varela y Martín García 1999: 5022). El único representante de esta modalidad derivativa en léxico militar analizado es invencible174: "De tal manera los exercitava en todas las obras que el que no veía manchado con sangre del enemigo quería que haziendo fosas y otros exercicios del campo anduviesse mojado con barro y, assí, los hizo casi del todo invencibles" (Álaba 1590: 20v).

F) Según Varela y Martín García (1999), el prefijo re- es susceptible de aportar alguno de estos tres valores semánticos: posicional ${ }^{175}$, intensivo, e iterativo. Por lo que respecta a los términos militares portadores de este afijo, resulta difícil establecer con exactitud a cuál de ellos se adscriben, sobre todo en el caso de los prefijados verbales: rebatir ${ }^{176}$, rebotar 177 , remeter y retirar ${ }^{178}$.

“Con los nombres no deverbales - proceso este muy poco productivo-, al valor de iteración del prefijo se suma el matiz significativo de lo que es posterior o está en segundo lugar" (Varela y Martín García 1999: 5031), lo que evidencia el término refoso ${ }^{179}$ : "Harase el foso bien profundo, con su fosillo, que se llama el refoso, con muchos poços por las cortinas porque no pasen las minas sin sentirlas" (Roxas 1607: 87v).

\footnotetext{
${ }^{174}$ De vencible y éste de vencer ( $c f$. DECH: s.v. vencer).

175 Aunque éste ya casi no es productivo en castellano (cf. Varela y Martín García 1999: 5013).

176 "Hacer retroceder al enemigo que ataca" (DUE: s.v. rechazar).

177 "Rebotados los enemigos dentro de la plaça, el maestre de campo general hará el alojamiento" (Mendoça 1596: 92). "Don Bernardino de Mendoza, en sus Comentarios, usa este verbo en sentido, desusado hoy, de repeler, rechazar" (Almirante 1869).

178 Aparte de poder ser sinónimo de rebatir y rebotar, en la tratadística manejada es muy frecuente su empleo pronominal con el sentido especializado de "abandonar un ejército o alguien que lucha el lugar de la lucha" (DUE).

179 "Segundo foso pequeño que se forma dentro del foso, en medio de su superficie ínfima" (Aut.: s.v. cuneta). Esta combinación de significados probablemente sea la existente en reseña "revista que se hace de la tropa".
} 
Por el contrario, en la creación de reencuentro ${ }^{180}$, así como en la de rezaga181 no parece haber operado ninguno de los valores morfológicos señalados para el prefijo re-.

G) Por último, el afijo sobre- posee el significado locativo 'encima'. "Esta posición superior puede ser real (lugar más alto) o figurada (lugar preeminente)" (Varela y Martín García 1999: 5013). A esta segunda posibilidad se adscriben los vocablos militares sobrerronda ${ }^{182}$ y sobrevela ${ }^{183}$.

\subsubsection{Sufijación}

De los procesos morfológicos de que dispone la lengua para crear nuevas unidades léxicas, la sufijación es el mecanismo neológico más productivo en español:

La derivación léxica mediante sufijación es el procedimiento de formación de palabras más productivo, general y variado de nuestra lengua. No sólo dispone el español de un número considerable de sufijos, con significados muy variados, y acepta que todas las clases de palabras principales (verbos, nombres y adjetivos) entren en este tipo de derivación, sino que, además, emplea la sufijación en todo tipo de lenguaje - técnico y científico, jurídico y administrativo, literario-, en todos los registros idiomáticos y tanto en la modalidad oral como en la escrita (Varela 2005: 41).

Realizamos la clasificación de la sufijación según la categoría sintáctica correspondiente del derivado.

\subsubsection{Sufijación nominal}

Nos ocupamos de la formación de sustantivos a partir de las tres categorías gramaticales posibles: verbos, adjetivos y otros nombres. De los tres

\footnotetext{
180 «Encuentro, combate, choque; todos los escritores del siglo XVI escriben rencuentro por "encuentro"» (Estévanez: 1897).

181 Para el DUE, por ejemplo, tanto esta unidad léxica como zaga, su base de derivación, designan la retaguardia de un ejército.

182 "Contrarronda: segunda ronda de vigilancia" (DUE). Como puede constatarse, en este caso las unidades morfológicas sobre- y contra- se hallan en competencia.

183 "Segunda vela que suele ponerse para más seguridad" (Gago-Jover: 2002).
} 
tipos, las formaciones más productivas en nuestro estudio son las que se forman a partir de verbos, seguidas por las denominales, lo que se corresponde con la opinión generalizada de que la formación de nombres a partir de verbos es la más frecuente en español ( $c f$. Lang 20023: 184). Por el contrario, no hemos hallado ni un solo ejemplo de derivación nominal deadjetival.

A) Las formaciones posverbales ${ }^{184}$ que registramos en nuestro corpus forman un amplio conjunto. Este procedimiento morfológico derivativo posee gran importancia en la historia del español. Se trata de formaciones afijales en las que una vocal átona $(a, e, o)$ se añade directamente a la raíz verbal, por lo que provoca un efecto de acortamiento fonológico de la base. Estos nombres reflejan su categoría gramatical y su género en la marca vocálica, es decir, en el sufijo posverbal.

La principal labor del sufijo - $a$ consiste en derivar nomina actionis a partir de verbos (Pharies 2002: s.v. $-a$ ), como ejemplifican leva185, muestra ${ }^{186}$, ronda y toma. De acuerdo con Santiago Lacuesta y Bustos Gisbert (1999: 4516), entre los nombres de acción generados a través de este afijo átono destacan los procedentes de verbos pugnandi, grupo del que contamos con tres exponentes: contienda, pelea y refriega ${ }^{187}$.

Por otro lado, "un gran número de los derivados en $-a$ [...] admiten también la interpretación de efecto" (Real Academia Española 2009: 376), como ocurre con liga188: “También podría Vuestra Alteza levantar gente en assistencia de algún príncipe con quien esté confederado en razón de las ligas que tiene con él , las quales se han de guardar con toda puntualidad" (Mendoça 1596: 30-31).

\footnotetext{
184 Acerca de esta denominación, vid. Varela Ortega (2005: 32).

185 "Acción de levar o reclutar" (DEA).

186 "En la milicia significa la reseña que se hace de la gente de guerra, para reconocer si está cabal o para otras cosas" (Aut.).

187 "Batalla de poca importancia o con pocas fuerzas" (DUE). Se trata de un derivado de refregar, verbo que para el DRAE designa, entre otras acepciones, "dar en cara a alguien con algo que le ofende, insistiendo en ello".

188 'Unión o pacto entre dos o más soberanos, territorios, etc., establecido con el fin de atacar a un enemigo común o para defenderse en alguna ofensiva'.
} 
Otro de los posibles valores semánticos que aporta - $a$ es el de ‘agente de la acción' (cf. Pharies 2002: s.v. -a), visible en escucha ${ }^{189}$ y en vela190.

Relacionados con - $a$ se encuentran los sufijos - - y - - , también posverbales, que pueden incluso coexistir a partir de la misma raíz verbal (cf. trata $\sim$ trato, alza $\sim$ alce, costa $\sim$ coste $\sim$ costo $).$

Por lo que respecta al sufijo $-e$, a pesar de que selecciona preferentemente bases verbales en -ar (cf. Santiago Lacuesta y Bustos Gisbert 1999: 4549-4550), en la terminología militar analizada los derivados de verbos de la tercera conjugación (combate < combatir y debate < debatir) igualan a los de la primera (desbarate < desbaratar y escarpe <escarpar).

Al igual que $-a$, el principal valor aportado por -e es el de acción o efecto. El primero de estos dos significados es palmario tanto en combate ${ }^{191}$ como en debate $^{192}$. Por su parte, el término desbarate ${ }^{193}$ presenta un matiz resultativo:

\begin{abstract}
Siendo, pues, regla cierta que todo infante toma la orden de su caminar del que marcha delante y los infantes que se hallaren en aquella mesma hilera deven, viendo al compañero que va delante caýdo, passar a su lugar, apresurado su movimiento, y el otro, al otro, de forma que la falta o vazío quede en la rectaguardia, como quedó referido en el citado lugar que hazían los griegos. Y, assí, podrán evitar los rompimientos y desbarates que se podrían seguir del dexallos en la frente (García de Palacio 1583: 181v-182r).
\end{abstract}

En palabras de Pharies (2002), “-e, al igual que $-o$ y $-a$, se extiende semánticamente a instrumentos [...], lugares [...] y agentes". Uno de estos valores, concretamente el locativo, es el que ostenta escarpe ${ }^{194}$.

Por otra parte, las bases a las que se une el sufijo -o para formar nombres de acción y efecto corresponden a verbos de las tres conjugaciones, de las que

\footnotetext{
189 "Es la centinela o atalaya de noche que procura oír lo que tratan los enemigos" (Cov.).

190 "Es la centinela que está despierta y velando las horas que le caben de la noche" (Cov.).

191 "Acción bélica o pelea en que intervienen fuerzas militares de alguna importancia" (DRAE).

192 Se trata de un sinónimo de combate, como puede constatarse en este pasaje: "Cesar dezía ser necessaria la buena ventura en todas las cosas y en ninguna más que en las ocasiones de rencuentros y debates de enemigos" (Álaba 1590: 23r).

193 'Confusión, desorden y desconcierto generado en la disposición de una tropa'.

194 'Plano inclinado que forma la muralla del cuerpo principal de una plaza, desde el cordón hasta el foso'.
} 
predomina la primera sobre las restantes: apellido ${ }^{195}$, despojo ${ }^{196}$, encuentro ${ }^{197}$, estrago 198 y reparo. Con este valor semántico también registramos socorro, derivado de socorrer.

Por su parte, el sustantivo puesto, que deriva de poner ${ }^{199}$, de nuevo un verbo de la segunda conjugación, ostenta un significado claramente locativo: “El lugar destinado para alguna tropa o soldado" (DRAE 1803).

Por último, -o muestra en zarzo $0^{200}$ una de sus posibles extensiones semánticas, a saber, la instrumental, al designar el 'tejido de cañas, juncos, mimbres o cosas semejantes, que forma una superficie plana, y que cuenta con diferentes usos en la guerra, especialmente en la construcción de defensas'.

в) En primer lugar, el sufijo -ada forma sustantivos derivados al ser añadido a una base nominal. En este caso, no puede hablarse de un significado homogéneo, sino, al menos, de cuatro interpretaciones semánticas diferentes: 'acción propia de', 'colectivos', 'acción' y 'contenido en $\mathrm{X}$ (base nominal)' (cf. Santiago Lacuesta y Bustos Gisbert 1999: 4519). Por lo que respecta al lenguaje militar, tres de sus tecnicismos con valor colectivo han sido originados mediante este sufijo: estacada ${ }^{201}$, fajinada ${ }^{202}$ y gavionada ${ }^{203}$. También hallamos tres vocablos portadores del último de los significados enumerados, a saber, el de 'contenido en $X^{\prime}$ :

195 “Convocación, llamamiento de guerra" (DRAE).

196 "La acción de despojar" (Aut.).

197 "Acción de guerra" (DUE).

198 "Daño hecho en guerra, como una matanza de gente, o la destrucción de la campaña, del país o del ejército" (DRAE). Se trata de un derivado de estragar, mientras que éste procede del lat. vg. *stragare 'asolar, devastar', derivado de strages 'ruinas', 'devastación', 'matanza' (cf. DECH: s.v. estragar).

199 Nótese que a partir del tema de participio latino se ha producido una irregularidad o alternancia y tanto vocálica como consonántica. Primero, en la diptongación y, en segundo lugar, en el cambio de /n/ a /s/. Puede observarse una transformación semejante, aunque en este caso de $/ \theta /$ a $/ \mathrm{tl} /$ en deshacer $>$ deshecho. Para más detalles a este respecto, vid. Pensado (1999).

200 Del ant. sarzo, con -z-sonora, y éste probablemente de sarzir, variante de zurcir existente en castellano antiguo y en catalán ( $c f$. DECH: s.v. zarza).

201 'Conjunto de estacas o de palos clavados en el suelo, y normalmente enlazados mediante travesaños de madera, que sirve para impedir el paso al enemigo'.

202 "Conjunto de fajinas" (DRAE).

203 “Conjunto de gaviones o estructura defensiva construida con éstos” (López Vallejo 2008). 
Alborada ${ }^{204}$. "Toque militar del amanecer" (DSAL).

Camarada ${ }^{205}$. "Compañero, asociado, amigo [...]. En la milicia usan mucho de la voz camaradas, aun los mismos oficiales respecto de los soldados. Camaradas, es menester asaltar esta muralla, etc." (Ter..).

Hilada ${ }^{206}$. "Serie de cosas colocadas una tras otra en línea recta" (DUE)207.

Además de derivar sustantivos a partir de nombres, este sufijo se adjunta a radicales verbales para la obtención de nomina actionis: ahumada ${ }^{208}$, cabalgada ${ }^{209}$, celada 210 , deshilada ${ }^{211}$, encamisada ${ }^{212}$, escalada, posada ${ }^{213}$ y retirada. Ahora bien, "como la mayoría de los derivados deverbativos designa el resultado de una acción (llamada, parada, matada), no sorprende que este significado sea frecuente entre los denominativos" (Pharies 2002: s.v. -ada), entre los que documentamos espolonada214: "Y, ansimesmo, ay otra especie de guerra que dizen spolonada, para tomar fuerça, o villa, o castillo" (Celso 1553: CLVIIIr).

En el caso de adjuntarse a bases verbales de la segunda y la tercera conjugación, este sufijo adopta la forma -ida215: acometida, arremetida, corrida $a^{216}$, remetida y salida.

\footnotetext{
204 De albor 'alba' y éste del lat. albor (cf. DECH: s.v. albo).

205 "Podemos interpretar que el término camarada se basa en la voz cámara con el sentido de 'aposento o estancia'. De éste derivaría apoyándose en una relación metonímica, puesto que recibe el nombre de camarada el soldado o conjunto de soldados que comparten la misma cámara o aposento" (López Vallejo 2008: s.v. camarada).

206 "De hilo" (DRAE).

207 Además, este diccionario señala que tanto fila como hilera son sinónimos de hilada.

208 "La señal que se hace regularmente en los lugares altos o atalayas quemando paja $u$ otra materia, para dar por este medio algún aviso, como de que hay embarcaciones de corsarios en la costa, o navíos que se encaminan a tomar puerto, o tropas $u$ otra cosa que se acerca al paraje que debe ser advertido de ello" (Aut.).

209 "La acción de correr a caballo la gente de guerra las tierras del enemigo y hacer daño en ellas; hoy se dice correría" (DRAE 1780).

210 "Adalid, es el que es escogido para descobrir el campo y exército y celadas de los enemigos" (Celso 1553: IXr). Según el DECH (s.v. celar II), se trata de un derivado de celar, mientras que éste procede del lat. celare 'encubrir, ocultar'.

211 Sustantivo que forma parte de la locución adverbial a la deshilada "dicho de marchar la tropa: Con los soldados uno tras otro" (DRAE).

212 "Sorpresa u operación nocturna, llamada así porque se acostumbraba ponerse las camisas, cuando las había, por encima de las armaduras para reconocerse; si no había camisas, recurríase a papeles u otra señal para evitar confusiones, tan fáciles en la noche cuando eran iguales las armaduras de amigos y enemigos" (Estévanez 1897).

${ }^{213}$ De acuerdo con el DECH (s.v. posar), deriva del verbo posar, del lat. pausāre 'cesar', 'pararse'.

214 “De espolón. f. Arremetida impetuosa de gente a caballo" (DRAE).

${ }^{215}$ La segmentación de este sufijo resulta problemática. Si bien la más aceptada es - $d a$, en detrimento de -ada e -ida, el principal obstáculo para su total generalización reside en que "entonces, no se explica por qué en los verbos de la segunda conjugación la vocal que aparece es una - $i$ - en lugar de una -e-“ (Santiago Lacuesta y Bustos Gisbert 1999: 4540).
} 
Por último, debemos señalar que para Santiago Lacuesta y Bustos Gisbert (1999: 4540), el afijo - $d a^{217}$ cuenta con un alomorfo masculino, presente en el lema de nuestro glosario encamisado, del que establecemos dos acepciones:

Encamisado. Capa que se hace de diversos materiales para revestir y sostener el terraplén de cualquier obra de fortificación.

2. Persona que asalta de noche a los enemigos, para cogerlos desprevenidos.

C) Por otro lado, la terminación -aje es visible en el vocablo especializado pilotaje: "Conjunto de pilotes hincados en tierra para consolidar los cimientos" (DRAE: s.v. pilotaje²).

El sufijo español -aje es un préstamo, cuya integración en la lengua se debe al gran número de palabras francesas (en -age), occitanas (en -atge) y catalanas (también en -atge) que desde la temprana Edad Media van acumulándose en español. Para el siglo XVII la desinencia se independiza de las raíces extranjeras con que hasta entonces ha aparecido exclusivamente y se hace productiva en español (Pharies 2002: s.v. -aje).

Debido a que las únicas ocurrencias de pilotaje se sitúan en el tratado de Diego Ufano de principios del siglo XVII 218 , hemos considerado la posibilidad de que se trate de un derivado interno del español, eso sí, con base sustantiva de origen francés ${ }^{219}$.

Son varios los significados que se pueden observar en los derivados en aje (cf. Santiago Lacuesta y Bustos Gisbert 1999: 4523). Ahora bien, el más importante cuantitativamente es sin lugar a dudas el colectivo, precisamente el que ostenta pilotaje.

\footnotetext{
216 'Acción de recorrer un territorio con el fin de arrasarlo y de saquearlo'.

217 Como puede constatarse, la segmentación preferida por parte de estos especialistas es $-d a$, si bien sólo en su función de derivar nomina actionis a partir de verbos, puesto que para los derivados denominales establecen - ada.

218 "Tócales yr a las villas y lugares con partidas de carros, a traer provisión de muniçiones de guerra y llevar recaudo y serviçio de todo menester a las baterías, así de muniçiones como de petrechos, pilotage, çestones y faxinas" (Ufano 1613: 138).

219 "Pilote, del fr. antic. pilot" (DECH: s.v. pila II).
} 
D) Por lo que respecta a la voz andamio ${ }^{220}$, parece tratarse de un derivado del verbo andar. Por ejemplo, es lo que determina el DRAE en su correspondiente paréntesis etimológico: "De andar ${ }^{1}$ y el suf. -amio". Ahora bien, en ninguno de los estudios morfológicos consultados hemos hallado información al respecto de este supuesto afijo.

Por lo que respecta al término en cuestión, sólo lo trata Fernández Ramírez, en el apartado de los adjetivos, y algunos sustantivos, con sufijo -io inacentuado. En él comenta que "son probablemente españolas, de origen incierto o proceden de una lengua que no es el latín: amplio (acaso del comparativo lat. amplĭus), m. andamio, m. barrio (de origen árabe) [...]".

E) De acuerdo con Santiago Lacuesta y Bustos Gisbert (1999: 4527), "consideramos a -al y a -ar como alomorfos de un mismo sufijo en la medida en que se combinan con idénticos tipos de bases y actualizan idénticos significados". En la terminología militar analizada sólo se halla la variante -ar, condicionada por la unidad léxica a la que se adjunta: vallado > valladar.

El significado básico aportado por este sufijo es el locativo, del que destacamos el de 'lugar en que abunda lo designado por la base', por ser el que posee valladar 221 .

F) El DRAE postula la existencia de un sufijo -araz, del que asegura que "forma adjetivos que significan cualidad intensa y tienen valor un tanto despectivo. Lenguaraz, montaraz". En el corpus manejado la segunda de esta dos palabras posee un sentido militar claro: "Montarazes, llaman a las velas e sobrevelas que tienen los alcaydes en los castillos" (Celso 1553: CCXXIIIv). Eso sí, como puede constatarse, se trata de un sustantivo, frente a la condición adjetival estipulada por el DRAE para este vocablo.

\footnotetext{
220 "Camino situado detrás del parapeto y en lo alto de una fortificación" (DUE: s.v. adarve). "Por lo alto tenga el muro sus defensas y andamios, con sus troneras, para que los arcabuzeros puedan tirar a los de fuera" (Montes 1537: XVIIr-XVIIv).

221 "El que cerca la calle para que no puedan libremente passar, pague XXX sueldos al Rey [...]. E qualquiera puede, sin pena alguna, deshazer la tal cerradura o valladar" (Celso 1553: LIv).
} 
Por su parte, Pharies (2002: s.v. -az), al enumerar las varias clases de palabras existentes en castellano cuya terminación -az no está emparentada etimológicamente con el sufijo latino $-a x-\bar{a} c i s$, comenta que «también es probable que tenga otro origen la terminación de montaraz 'guardabosque'», si bien no aclara cuál podría ser éste.

G) El sufijo nominalizador -ción presenta un elevado grado de alomorfia (Lang 20023: 187; Santiago Lacuesta y Bustos Gisbert 1999: 4530-4535). Así, constatamos la existencia en nuestro corpus del término diversión, formado a través de su alomorfo -sión. Como establece el DRAE ${ }^{222}$, en esta palabra el significado básico es el de acción, el más importante entre los derivados con este elemento morfológico.

Por su parte, guarnición revela una de las múltiples extensiones semánticas experimentadas por los nomina actionis, concretamente la agentiva: “Ganada esta plaça fuerte, se le rendirán todas las demás que estubieren alrededor, con que dará fin a la guerra de aquella provinçia que va a conquistar; luego se meterán guarniçión de soldados a esta plaça, con muchas muniçiones de pólvora, balas, armas ofensibas y defensibas" (Roxas 1607: fol. 104r-104v).

H) El sufijo -dor, además de nombres de agente, se utiliza para derivar nombres de instrumentos y de lugar, así como adjetivos de varios tipos, a partir de bases verbales.

No obstante, todas las formaciones de nuestro corpus han resultado ser nomina agentis. En primer lugar, distinguimos ocho nombres clasificadores, de acuerdo con el sistema establecido por Santiago Lacuesta y Bustos Gisbert (1999: 4543), que designan profesiones («alguien que profesionalmente hace $x »)$ : aposentador $^{223}$, conqueridor 224 , corredor 225 , descubridor 226 , fortificador, gastador 227 , minador y murador.

\footnotetext{
222 "Acción de distraer o desviar la atención y fuerzas del enemigo" (DRAE).

223 "Oficial encargado de aposentar las tropas en las marchas" (DRAE).

224 "Conqueridor era el que estava presente a las muestras y reseñas de los soldados" (Álaba 1590: $151 \mathrm{r})$.
} 
Como ya manifestamos en un trabajo anterior (Sánchez Orense 2007), durante la centuria renacentista, este sufijo es altamente productivo en la designación de nombres de profesión u oficio.

No obstante, en esta ocasión son más numerosos los derivados identificadores, que "designan personas que han llevado a cabo la acción referida por el verbo o que la realizan en el momento de la enunciación" (Santiago Lacuesta y Bustos Gisbert 1999: 4544): acometedor, asediador, cercador, combatidor 228 , conquistador, contendedor ${ }^{229}$, lidiador, sitiador, triunfador ${ }^{230}$ y vencedor.

I) Por su parte, el sufijo -dura se añade al lexema verbal incrementado con la vocal temática correspondiente a la conjugación verbal a la que se adscribe la base. Este sufijo se emplea para producir sustantivos de nomina actionis o con valor resultativo, y en muchos casos ambos simultáneamente.

Ahora bien, a partir de los significados abstractos de 'acción' o 'efecto', pueden señalarse ciertas ampliaciones semánticas -fenómeno habitual en los nomina actionis-, como los valores instrumentales, locativos, colectivos, etc. (Santiago Lacuesta y Bustos Gisbert 1999: 4548).

Así, para la Real Academia Española (2009: 370), “predomina el sentido de instrumento, utensilio, recurso o medio" entre otros, en cortadura, lo que podría explicar que en el ámbito de la fortificación abaluartada este término cuente con dos acepciones altamente especializadas:

\footnotetext{
225 'Soldado especializado en explorar o examinar el territorio para localizar al enemigo y analizar sus movimientos'.

226 "Corredor [...]; el que descubre o hace la descubierta" (Rubió y Bellvé 1895-1901).

227 "En el ejército se dicen gastadores la gente que trabaja con la pala y el azadón, y traen piedra y fajina y lo demás que es menester para hacer fosos, trincheras, revellines, caballeros, plataformas y todo lo demás" (Cov.).

228 "Como diximos de suso, versículo XXIII, los lidiadores no deven salir del campo sin licencia o mandado del Rey o de los fieles. Y qualquier que por su voluntad, o por premia, o fuerça del otro combatidor saliere del campo, es dado por vencido" (Celso 1553: CCXCIXr).

229 "Si no fuere acabada la lid el primero día, dévenlos sacar los fieles del campo, si lo quisieren y el Rey lo mandare, con toda la ygualdad, haziéndolos yguales en el aposento y comer; aunque, si alguno quisiere mas comer que su contendedor, dévenselo dar" (Celso 1553: CCXCIXr).

230 " $\mathrm{Y}$ en tanta estima era tenido el triunfo en Grecia que no querían que el triunfador entrasse por alguna de las puertas de la ciudad; y assí, para este propósito derribavan un pedaço de muro y no lo tornavan a rehazer, dando a entender que las ciudades que tales hombres criavan no avían menester muros" (Álaba 1590: 146v).
} 
1. $\rightarrow$ “La zanja o abertura que se hace en la tierra con su parapeto, así en campaña como en las plazas, para detener al enemigo" (Aut.).

2. $\rightarrow$ "Parapeto de tierra o ladrillo con cañoneras y merlones, y algunas veces con foso, que se hace en la brecha; en los baluartes grandes, desde uno de los ángulos de la espalda al otro; y en los pequeños, en las golas, a fin de impedir que el enemigo se aloje y fortifique en aquella" (Corsini 1849).

La presencia de este sufijo no es suficientemente elevada por lo que podemos sostener que éste acusa ya la pérdida de productividad descrita frente a los otros sufijos que expresan idéntico valor semántico.

J) El sufijo -ero, que se empleaba ya en latín para derivar adjetivos de pertenencia (ápud Pharies 2002), es muy productivo en castellano en la formación de adjetivos y sustantivos a partir de radicales nominales.

Los derivados internos españoles, además de ser muy numerosos, se documentan tempranamente, como guerrero, que, según el DECH (s.v. guerra), se halla ya en un texto del año 1076 (Oelschl.). Como muestran los siguientes pasajes, este término se trata o bien de un adjetivo o bien de un sustantivo:

De la otra parte del monte Cáucaso están los nómades, que son pastores, y más al Setentrión, las amazonas, que son gente guerrera (Fernández de Enciso 1530: XXXVIIIv).

Se infiere que el lugar con alguna disposición de ventaja suple el número de los soldados y lo demás se deve entender quando el campo es ygual y el número de los guerreros desygual (García de Palacio 1583: 70r).

Aunque en nuestro corpus forrajero sólo funciona como sustantivo 231 , de acuerdo con el DRAE, también este término dispone de la categoría gramatical adjetiva:

1. $\rightarrow$ adj. Dicho de una planta o de alguna de sus partes: Que sirve para forraje.

2. $\rightarrow \mathrm{m}$. ant. Soldado que iba a forrajear.

Según Pharies (2002), ya en latín era frecuente la sustantivación de las formaciones adjetivas creadas mediante -ero, utilizándose más tarde el sufijo

231 "Para assegurar los forrajeros, se ha de advertir, pudiéndolos el enemigo hazer daño, el embiar cavallos a descubrir y hazelles escolta, si lo pide la ocasión" (Mendoça 1596: 83-84). 
para la derivación de sustantivos sin intermediario adjetivo, posibilidad morfológica que hereda nuestra lengua, como demuestran ballestero, candelero, ingeniero, municionero, peonero 232 y viandero.

Semánticamente, "la mayoría de los derivados designa 'nombres de agente', especialmente profesiones" (Santiago Lacuesta y Bustos Gisbert 1999: 4557). Efectivamente, de los seis sustantivos que acabamos de enumerar, sólo uno, candelero, es ajeno a este valor.

Mediante este último término233 los ingenieros renacentistas aludían a uno de los pertrechos básicos en la fortificación de entonces, lo que coincide con el valor instrumental que otorga a este sufijo por ejemplo Fernández Ramírez (1986: 45).

Por otro lado, no parece existir acuerdo entre los diferentes estudiosos sobre el rango que debe concederse a -era: unos creen que es un alomorfo, mientras que otros optan por su caracterización independiente. Por nuestra parte, estamos de acuerdo con Santiago Lacuesta y Bustos Gisbert (1999: 4556) en que no parece aconsejable separar -ero de -era.

Son varios los tecnicismos militares portadores de esta variante alomórfica: barrera, cañonera, causera ${ }^{234}$, hilera ${ }^{235}$, lechera 236 , saetera y tronera. En todas estas voces el significado predominante es el instrumental, ya mencionado a propósito de candelero. Ahora bien, tanto en barrera, como en cañonera, saetera y tronera ${ }^{237}$ puede postularse la existencia también de la predicación "relación entre parte y todo", parafraseable como "X (derivado)

\footnotetext{
232 "Gastador o soldado encargado de preparar el camino para el paso del ejército, normalmente abriendo trincheras o realizando otro tipo de excavaciones" (López Vallejo 2008).

233 "Bastidor de madera, compuesto de una solera y dos montantes, entre los cuales se ponen fajinas o sacos terreros, y que se emplea como defensa contra el fuego enemigo" (DRAE: s.v. candelero).

${ }^{234}$ De la base latina causěa (-̌̆a), -ae 'sombrero', 'mantelete (máquina de guerra)' (cf. Segura Munguía 2001).

235 "El orden o formación en línea recta de un número de cosas o personas" (DRAE 1803).

236 "Tablado o armazón de madera sobre el cual se colocan las piezas en batería [...]. El término lechera era utilizado antiguamente con el significado de 'litera'. Metafóricamente el armazón sobre el que se apoyan o «descansan» las piezas de artillería puestas en batería ejerce la función de un lecho o litera y, además, existe parecido formal entre la realidad militar y las primitivas literas o lechos portátiles" (López Vallejo 2008: s.v. lechera).

${ }^{237}$ De trueno 'pieza de artillería' (cf. DRAE).
} 
está formado, construido, contiene, etc. Y (base de derivación)" (Santiago Lacuesta y Bustos Gisbert 1999: 4559).

K) El sufijo -ía es empleado para derivar sustantivos a partir de bases adjetivas y nominales, si bien "excepcionalmente se ha extendido gramaticalmente para aceptar bases verbales" (Pharies 2002: s.v. -ía), como puede observarse en correría 238 , que deriva de correr.

Acerca de este sufijo debe resaltarse su predilección por seleccionar bases léxicas terminadas en -ero, de lo que da buena cuenta uno de nuestros tecnicismos: caballería < caballero, que designa el "cuerpo de ejército formado por soldados montados a caballo" (DUE). Como comenta Pharies (2002: s.v. -ía), este elemento morfológico pronto se convierte en "un verdadero colectivo, refiriéndose a la totalidad de las personas que ejercen una profesión o participan de un mismo estado social".

Por otro lado, en el caso de combinarse con el sufijo -dor, se produce una alternancia alomórfica, a saber -duría (*-doría) (cf. Pharies 2002: s.v. -dor). Es lo que sucede en correduría, derivado de corredor. Para Fernández Ramírez (1986: 22), entre estas formaciones «es frecuente la significación de 'dicho o hecho particularmente descalificable y expresivo' o 'acto propio de'». A esta segunda modalidad correspondería correduría, al designar la 'acción bélica consistente en recorrer un determinado territorio con el fin de arrasarlo y saquearlo', típicamente ejecutada por los soldados denominados corredores ${ }^{239}$.

L) El sufijo -miento es uno de los más productivos del español en la derivación de sustantivos deverbativos que denotan la acción del verbo o su efecto: acometimiento, alojamiento, cavamiento ${ }^{240}$, combatimiento, defendimiento ${ }^{241}$, levantamiento, picamiento 242 , reconocimiento, rompimiento y vencimiento.

\footnotetext{
238 "En una guerra, acción de recorrer el territorio enemigo destrozando y saqueando" (DUE). 239 "Soldado de los que tomaban parte en una correría" (DUE: s.v. corredor).

240 "Tres cosas, comúnmente, se aplican a la expugnación de las fortalezas, que son: las artillerías, la pala y açadón, y el uso de las minas y hornillos, y otros cavamientos soterraños, los quales se acostumbran de hazer con la pólvora" (Collado 1592: 62r).
} 
Asimismo, constatamos la presencia de -mento, la variante culta del sufijo -miento 243 , en bastimento ${ }^{244}$. Además de su menor productividad, sobre todo en comparación con el alomorfo popular, la Real Academia Española (2009: 364) advierte de que las voces terminadas en -mento "raramente pueden asociarse con sus bases verbales mediante pautas sistemáticas". Así pues, los sustantivos derivados en -mento en los que puede relacionarse la base con el verbo originario conforman un reducido conjunto. Aun con todo, los académicos admiten que en unos pocos vocablos, entre ellos bastimento, es posible apreciarse un valor instrumental:

Destaca la interpretación de instrumento, medio o recurso en pegamento ('materia para pegar, lo que pega'), ornamento, ligamento, impedimento, divertimento, así como en bastimento (del antiguo bastir 'abastecer'), que se emplea en el área centroamericana para designar el alimento que sirve de guarnición o acompaña las comidas (Real Academia Española 2009: 365).

Por lo que respecta al ámbito militar, la voz bastimento alude a los víveres o vituallas del ejército: "Entre las cosas necessarias para la conservación y buen sucesso de un exército, que escribe Xenofón que son quatro: abundancia de bastimentos, salud en los soldados, sciencia del arte militar, obediencia y orden" (Mosquera 1596: 84v). También hallamos ocurrencias en los textos manejados de la forma diptongada bastimiento, y con este mismo significado245: "Si la provincia donde la guerra se hoviere de hazer es pobre, más guerra les haría la hambre que los enemigos, por la mucha falta de los bastimientos que no se

241 "Yantares deve aver el Rey quando por su persona llegare a qualquier ciudad o villa de sus reynos, o quando fuere en exército, o estuviere en cerco, o quando passare el puerto para yr a la frontera en servicio de Dios, y en defendimiento de la sancta fe y de la tierra" (Celso 1553: CCCXXXVIIV).

242 'Acción de golpear, mediante un pico u otra herramienta semejante, la muralla de una fortificación con la intención de abrir agujeros en ella'. "Qualquiera sería muy animoso y mostraría diligençia y brío al emprender qualquiera obrage, por diffíçil que fuesse, en los desembocaderos de los fossos y picamiento de la muralla" (Ufano 1613: 147).

243 "Parece ser opinión generalizada que -mento y -miento constituyen dos variantes alomórficas del mismo sufijo y no dos sufijos distintos" (Santiago Lacuesta y Bustos Gisbert 1999: 4574).

${ }^{244}$ Nótese que para Corominas y Pascual (s.v. basto I) hubo de producirse en este proceso derivativo una influencia catalana o galorrománica.

${ }^{245}$ No obstante, la forma culta seguramente gozó de una mayor vitalidad, puesto que hemos detectado 112 ocurrencias de bastimento, frente a sólo 16 de bastimiento. 
podrían haver, a cuya causa el exército les sería forçado de retirarse" (Montes 1537: IIIr).

M) Para Santiago Lacuesta y Bustos Gisbert (1999: 4583), el significado básico del sufijo -ncia, así como de su alomorfo -nza es el de 'acción' o 'resultado de esa acción'. Y, con respecto a las bases léxicas seleccionadas, confirman que éstas suelen ser verbales.

Por nuestra parte, registramos dos tecnicismos con este afijo: estancia y ordenanza. El primero de ellos manifiesta un significado altamente especializado, presente también en las voces cuartel y posada ${ }^{246}$ :

\begin{abstract}
Hase de mirar que media legua alrededor no aya cuesta, que son las que llaman padrastros, quando vienen a estar tan cerca que, puesta artillería en ellas, desaloxan a todos los que están en los reparos y en las estancias y plaça de armas, y que en ninguna parte están seguros (González de Medina 1599: 8).
\end{abstract}

Por otro lado, el término ordenanza designa 'cada una de las líneas o partes de que consta un orden de batalla, y conjunto de soldados que las integran'. Como demuestra este pasaje, además de disponer de otras muchas acepciones militares relevantes, también batalla alude a esta realidad:

Quando se vee y sabe que el enemigo trae su esquadrón más ancho o se quiere ensanchar más que el del enemigo, como vuestra merced dize, deve, quando viene una batalla o ordenança tras otra, la de la avanguardia hazer alto, arbolando las picas, para que la batalla o ordenança que viene en pos d'ella entre por ella con sus picas, entretexiéndose en la forma que se sigue, hasta poner los lados yguales (García de Palacio 1583: 161v).

N) "Se forman un gran número de sustantivos en -nte, de base verbal, que designan personas (cantante), instrumentos (tirante), lugares [...] y productos" (Real Academia Española 2009: 478).

Así, asaltante y combatiente ${ }^{247}$ pueden ser caracterizados mediante la paráfrasis 'persona que hace lo que denota el verbo'.

En cambio, el vocablo tenazante ejemplifica el valor instrumental:

\footnotetext{
246 'Cada una de las divisiones de un alojamiento, sea en campaña o dentro de una fortaleza'.

247 "La mayor parte de los verbos de la tercera conjugación eligen -iente" (Real Academia Española 2009: 560).
} 
El tenazante ${ }^{248}$ o rompedora tenaça se puede, çiertamente, creer que con su poca fuerça romperá fáçilmente las barras o rexas de hierro, aunque sean más gruesas que la muñeca del braço de un hombre, como las he visto romper en las ventanas de un castillo y barras tan fuertes como tengo dicho (Ufano 1613: 279).

N) Otro de los mecanismos de que dispone la lengua para construir el significante de nuevas palabras es el proceso morfológico de la derivación genérica.

“En español, la marca de género da lugar a resultados que invitan a pensar que se trata de una suerte de derivación". De este modo se expresaba Lang (20023: 245) para caracterizar las diferencias de significado existentes en las alternancias morfológicas de género, que se producen para marcar la diferencia de tamaño o matizar y diferenciar significados sobre la misma base.

Esta peculiaridad de la morfología española también es comentada por Théophile Ambadiang, a la que se refiere con el nombre de relación derivativa:

\footnotetext{
El requisito de la caracterización única obliga a interpretar dichos pares flexivos [cesto cesta, grada grado, manta manto, modorra modorro, ofensiva ofensivo, saca saco y traviesa travieso, en nuestro caso] en términos derivativos. Desde este punto de vista, los miembros de todos estos pares contraen una relación derivativa, y sus terminaciones son interpretadas exclusivamente como afijos derivativos que indicarían sexo, tamaño, árbol, etc. (Ambadiang 1999: 4880).
}

Así pues, contamos con siete casos interpretables en términos derivativos: cesto, grada, manta, modorra, ofensiva, saca y traviesa.

Estos sustantivos pueden ser adscritos a cuatro clases semánticas distintas: magnitud temporal de la milicia (modorra ${ }^{249}$ ), acción bélica (ofensiva), elementos de fortificación (grada 250 y traviesa ${ }^{251}$ ) y municiones (cesto, manta y saca).

Analizamos el caso particular del tecnicismo militar traviesa que presenta estas tres acepciones:

\footnotetext{
248 "La mayor parte de los nombres de instrumento en -nte son masculinos" (Real Academia Española 2009: 478).

249 "Segundo de los cuartos en que para los centinelas se dividía la noche, comprendido entre el cuarto de prima y el de la modorrilla" (DRAE).

250 'Peldaño construido en lo interior y al pie de un parapeto'.

251 “Travieso del lat. transvěrsus 'transversal'; traviesa 'travesía', h. 1600, Inca (Garcilaso)" (DECH: s.v. verter).
} 
1. $\rightarrow$ "La zanja o abertura que se hace en la tierra con su parapeto, así en campaña como en las plazas, para detener al enemigo" (Aut.): "Se ponen lienços a las bocas de las calles, para que los cercados no vean blanco a donde tirar en tanto que las fortifican con fossos y traviessas para impedir las salidas de las puertas sobre los quarteles" (Mendoça 1596: 90).

2. $\rightarrow$ 'Especie de corredor o pasadizo de madera que fabrican los sitiadores en el ataque a una plaza para, una vez cubierto de tierra, céspedes y otros materiales poco combustibles, poder pasar el foso a través de él': "Se estima por más fácil batería el quitar el un través y casamata que las dos, principalmente si ay en ellos plaça y cañonera para pieça de batir, contra quien resisten mal traviessas, aunque se camine por el fosso" (Mendoça 1596: 126).

3. $\rightarrow$ 'En una fortaleza susceptible de ser dominada por un padrastro es la masa de tierra que se levanta en la parte que puede ser vista por el enemigo, la cual sirve para ocultar determinados elementos defensivos': "Y si, por ventura, huviesse otro padrastro por las espaldas, se harán assimesmo otras traviessas y terraplenos que cubran aquella parte del segundo padrastro" (Rojas 1598: 71v).

\subsection{Sufijación apreciativa}

Dentro de la sufijación homogénea se encuentran los sufijos denominados apreciativos o potestativos que, desde el punto de vista morfológico, se caracterizan por no alterar la categoría gramatical de la base. Se distribuyen en diminutivos, aumentativos y peyorativos o despectivos, si bien "esta repartición es aproximativa, porque los límites de tales grupos son poco nítidos a veces" (Lázaro Mora 1999: 4648). En relación con este aspecto, resultan reveladoras las palabras de Varela (2005: 47):

Es costumbre hablar de diminutivos, aumentativos y despectivos, aunque estos significados no se pueden atribuir a un sufijo en concreto, pues la carga apreciativa o afectiva que puedan aportar está en función de la base léxica a la que se adjunten e, incluso, de la ocasión en que se producen y de la intención del hablante.

Los apreciativos, además de no alterar la categoría gramatical de la palabra base, se caracterizan también por preservar su contenido nocional básico.

Ahora bien, "adjuntados a ciertas bases nominales algunos de ellos llegan a perder su significado apreciativo, contribuyendo entonces, como cualquier otro sufijo derivativo, a formar palabras con un significado particular, no predecible" (Varela 2005: 48). Se produce entonces el fenómeno de la 
lexicalización que no resulta extraño al sistema lingüístico si tenemos en cuenta que los procesos de lexicalización de los morfemas evaluativos aparecen ya desde los orígenes de nuestra lengua ${ }^{252}$.

Todos los morfólogos coinciden en señalar como rasgo de lexicalización del afijo apreciativo la facultad del vocablo para recibir otros elementos morfológicos del mismo tipo. Contamos con varios términos portadores de sufijos apreciativos lexicalizados, entre otros, cestón, banqueta, hornillo y herreruelo, pues aceptan la adjunción de otros sufijos potestativos: ceston-c-illo, banquet-ita, hornill-ón y herreruel-ín. A la hora de aplicar esta prueba hay que tener presente que "los sufijos apreciativos se insertan tras todos los morfemas derivativos que pueda contener la palabra en cuestión, justo antes de los morfemas flexivos" (Varela 2005: 48).

A) Hallamos dos voces, banqueta y refosete, con el afijo -ete, -eta, de origen catalano-aragonés 253 . A este respecto, Pharies (2002) advierte que "aunque no hay duda de que -ete - eta se ha hecho productivo en castellano, no siempre resulta fácil identificar los derivados propios, pues muchos tienen equivalentes catalanes". Aunque el primero de nuestros términos dispone de su correspondiente homólogo en catalán, como, según el DCVB, su primera documentación es posterior a la estipulada por el DECH para el castellano ${ }^{254}$, concluimos que se trata de un derivado de banco, del mismo modo que establecen, entre otros, el DECH y el DRAE. Respecto a sus significados militares, son cuatro los establecidos:

1. $\rightarrow$ 'Muro de piedra que a veces se construye delante de los baluartes': "La banqueta ha de ser delante de la frente de los baluartes, del propio largo d'ellos, apartada diez pies de la muralla de su cimiento; ha de ser de piedra; de quatro pies de ancho es muy buena y de provecho, , para que lo que desmoronare de la

\footnotetext{
252 Vid. Clavería Nadal (2004: 488) quien ofrece ejemplos tempranos de lexicalización de términos en el castellano del siglo XIII.

253 "Sufijo de sustantivos y, raramente, adjetivos, que se remonta al sufijo catalano-aragonés -et eta, proveniente a su vez de -ittus, sufijo originariamente hipocorístico de origen no latino" (Pharies 2002: s.v. -ete, -eta).

254 “Doc. a. 1458 (arx. parr. de Sta. Col. de Q.)” (DCVB: s.v. banqueta). «'Asiento' (fin s. XIV, López de Ayala), 'andén a lo largo de varias construcciones' (1687)» (DECH: s.v. banco).
} 
batería que se hiziere cayga entre la banqueta y la muralla del baluarte y no ocupe el foso." (González de Medina 1599: 16).

2. $\rightarrow$ 'Espacio que en algunas fortalezas se deja entre el terraplén y el foso': "A las que an de ser de tierra es menester que, del principio de sus murallas hasta el del fosso, se les dexe tanta tierra como cinco pies en todo su circuito, que llaman banqueta, para que la fábrica quede segura y que baje al fosso a escarpa para mayor firmeza, mirando que desde la dicha banqueta se a de tomar la medida de la que an de tener los fossos" (Lechuga 1611: 249).

3. $\rightarrow$ 'Peldaño construido en lo interior y al pie de un parapeto': "El parapeto de la estrada cubierta a de ser alto, ocho pies, y a de tener su banqueta tan alta que los soldados puedan, puestos en ella, descubrir la campaña" (Lechuga 1611: 241).

4. $\rightarrow$ "En un cimiento, partes laterales de su grosor cuando éstas exceden la anchura del muro que se levanta sobre él" (Paniagua Soto 1998: s.v. zarpa): “Y si el fundamento se huviere de hazer sobre arena, y que la arena se halle a un estado o dos debaxo de la superficie de la tierra, en tal caso no ay que hazer otra cosa sino explanar bien la superficie del arena a la anchura que ha de tener la muralla, con más quatro o cinco pies de vanqueta" (Rojas 1598: 92v).

Por su parte, el término refosete, que deriva de refoso, es definido por Terreros (s.v. contra-foso, o refosete) de la siguiente forma: "Foso pequeño hecho a fin de ceñir y defender el foso principal, supliendo su poca profundidad".

B) Disponemos igualmente de otros dos términos en los que se ha producido una lexicalización del sufijo evaluativo, en este caso de -illo 255 : cabrilla y hornillo.

Fernández Ramírez (1986: 37) comenta que existen dos grupos de formaciones en -illo: las que designan algo que es una modalidad de lo representado por la base de derivación y las que se basan en una metáfora suscitada por el término del que se parte a la hora de crear la nueva voz. El primer grupo es el de los auténticos apreciativos, mientras que al segundo pertenecen todos los vocablos que han sufrido lexicalización. Por tanto, es a esta

\footnotetext{
255 En español, el sufijo diminutivo por excelencia hasta el siglo XV fue indudablemente -illo. Es a partir de entonces, con los primeros síntomas de la productividad del nuevo sufijo -ito, cuando -illo entra en un período de decadencia gradual, lo que impulsa una fuerte tendencia a su lexicalización (Pharies 2002: s.v. -illo). Esta observación explicaría por qué no hemos hallado ni un solo vocablo con el sufijo -ito, frente a los dos aportados con -illo.
} 
segunda modalidad a la que pertenecen nuestros términos militares cabrilla ${ }^{256}$ y hornillo257:

Aunque se truxesse la fagina de acarreto, de dos, o tres leguas del sitio, lo tendré por más acertado que no hazer los enrejados de madera ni andar con las cabrillas apuntalando los terraplenos (Rojas 1598: 51v-52r).

Haviendo, pues, llegado al punto G, el qual es el pie de la muralla, allí conviene de pararse con la mina y allí se ha de formar el hornillo para meter la pólvora (Collado 1592: 64v).

C) De los varios sufijos apreciativos existentes, el que origina un mayor número de tecnicismos militares es sin duda -ón: ballestón, cestón, escalón, espolón ${ }^{258}$, orejón, tenazón, torreón ${ }^{259}$ y trincherón.

Este sufijo, considerado aumentativo, peyorativo o expresivo, puede adoptar valores semánticos más complejos, como reflejan cestón y orejón por ejemplo:

Cestón. "Cilindro sin base o fondo, tejido con ramaje, de dimensiones varias, y que, relleno de tierra, sirve en fortificación y trabajos de sitio para cubrirse con rapidez, y también para revestimiento" (Almirante 1869). "En Berbería, donde ay tanta abundancia de arena, poca tierra y falta de árboles, se han armado algunas vezes los cestones, puestas las estacas para ellos, con sogas de esparto en lugar de los ramos, viniéndose a entretexer de suerte que se puedan llenar de arena" (Mendoça 1596: 96).

Orejón. "Parte saliente del flanco del baluarte, redonda o cuadrada" (Moretti 1828). "El orejón, aunque el de esquina viva tiene algo menos en qué batir que el redondo, pero, con todo esso, el redondo encubre más y es más dificultoso de derribar" (González de Medina 1599: 167).

D) El sufijo -uelo encierra un mayor matiz peyorativo dentro del sistema de los diminutivos. Este sufijo apreciativo "tiende a la lexicalización, que suele venir acompañada de importantes cambios de significado" (Lang 20023: 145).

256 'Armazón o soporte portátil formado por una solera, un pie derecho y dos riostras, que se emplea para sostener el terraplén que, por falta de fajina, debe construirse sin ella'.

257 "Concavidad que se hace en la mina, donde se mete la pólvora para producir una voladura" (DRAE).

258 "Del aum. de espuela" (DRAE). En la tratadística manejada, espolón designa o bien el 'refuerzo que se coloca en el interior del terraplén para fortalecer la muralla' o bien 'cualquier cara o lado de una fortaleza que conste de una cortina y de dos baluartes'.

${ }^{259}$ En este caso, Corominas y Pascual (s.v. torre) sugieren además la posibilidad de que se trate de una variante fonética leonesa de torrejón. 
Contamos con el derivado de herrero, el sustantivo herreruelo, lexicalizado con el significado de 'soldado alemán perteneciente a la caballería ligera':

Podría interpretarse que el nombre de herreruelo [...] viene motivado porque los soldados así llamados están provistos de armas ofensivas de hierro y armas defensivas de color oscuro como el color de aquel metal [...]. Sin embargo, hay quienes, al igual que Almirante, interpretan un cruce con la voz homónima herreruelo, que significa 'capa corta con cuello y sin capilla' (López Vallejo 2008: s.v. herreruelo).

\subsubsection{Sufijación adjetival}

La formación de adjetivos mediante sufijación constituye un ámbito menos productivo y más complejo que la nominalización deverbal dentro de la morfología derivativa. Están involucrados en este proceso derivativo estándar un número de sufijos en torno a la veintena (Lang 20023: 197).

En nuestro caso, contamos con ocho sufijos de este tipo, cuya función consiste en transformar nombres, verbos, adverbios, así como otros adjetivos en formaciones adjetivales. Ahora bien, al igual que sucede en la sufijación nominal, en esta modalidad morfológica la derivación deverbal es la más productiva.

A) En primer lugar, obtenemos tres casos de derivados con el sufijo -ble, procedente del sufijo latino -bilis: defendible 260 , defensible ${ }^{261}$ y minable ${ }^{262}$.

“Como en español, también en latín el uso más común es el de derivar adjetivos que expresan una posibilidad pasiva" (Pharies 2002: s.v. -ble), cf. expugnābŭlĭs 'qu'on peut prendre d'assaut, prenable' (Gaffiot 1934) y ı̌nexpugnābùlis 'impénétrable', 'qu'on ne peut arracher' (Gaffiot 1934).

260 "Los torreones redondos, algunos sacaría en ángulo y haría d'ellos baluartes con sus casas matas y orejones, los más perfectos que pudiesse, a buena y defendible distancia" (González de Medina 1599: 151).

${ }^{261}$ Del ant. defensar, con influencia de defender (DECH: s.v. defender). "Tengo, maestro, otra tierra con muy largas murallas y muy ruynes que toma mucho más sitio que la población es, porque se ha despoblado y caýdo las casas [...]. ¿Qué remedio se podría tener para fortificarla y assegurarla y poner en razón defensible?" (González de Medina 1599: 153).

262 "De la qualitad de los sitios de las minas y del modo como conoscerá el artífice si un sitio será minable" (Collado 1592: Vr). 
Así pues, este sufijo, que se une fundamentalmente a bases verbales, "tiene sentido pasivo y modal en su interpretación más productiva" (Real Academia Española 2009: 554), lo que ejemplifican claramente los tecnicismos militares aportados.

B) "Muchos participios se utilizan también en función adjetival263 y, como tales, parecen pertenecer al dominio de la formación de palabras" (Rainer 1999: 4608). En este sentido, confirmamos que todos los participios que incluimos en este estudio son empleados con función adjetival. El adjetivo muestra una propiedad, mientras que el participio verbal denota un estadio; en ocasiones el significado del adjetivo es el mismo que el del verbo que ejerce de base derivativa, aunque algunos de ellos se han lexicalizado e incluso perdido totalmente su original función participial ${ }^{264}$.

Pese a la opinión de Bosque (1999: 277), de que "la mayor parte de los participios regulares no están en el diccionario [...] porque su forma y su significado se obtienen de los principios básicos de la sintaxis", hemos decidido incluirlos en nuestro glosario de términos referentes a la milicia del dieciséis por estar en numerosas ocasiones empleados, efectivamente, como verdaderos adjetivos y en muchas ocasiones, además, "sin que intervenga para nada en nuestra interpretación su origen verbal" (Bosque 1999: 277)265.

El sufijo -do aparece en un número bastante considerable de tecnicismos militares: acampado, acometido, acosado, alamborado, aliado, alistado, alojado, apremiado, apretado, asediado, asentado, atrincherado, batido, ceñido, cercado, combatido, confederado, conquistado, contraminado, defendido, desbaratado, emboscado,

\footnotetext{
${ }^{263}$ Los morfólogos han fijado las condiciones y propiedades que posibilitan dicha función. Así, los verbos de los que pueden obtenerse participios adjetivos son los transitivos, pero también, según Pena (2005: 885), "los verbos intransitivos inacusativos de cambio de estado o lugar". No obstante, para Varela (2002: 174), las posibilidades se amplian no sólo a los intransitivosinacusativos, sino también a algunos verbos ergativos.

264 Para las vinculaciones y relaciones semánticas entre el adjetivo y el participio, vid. Bosque (1999) y Real Academia Española (2009: 2095-2104).

${ }^{265}$ A este respecto, resultan fundamentales los trabajos de Jiménez Ríos (1999) y Martín García (2008).
} 
fortalecido, fortificado, guardado, guarnecido, levantado, minado266, murado267, ocupado, ofendido, oprimido, rebelado, rebotado, reconocido, rendido, reparado, sitiado, sojuzgado, sujetado, terraplenado, torreado 268 , trabado y vencido.

Estos adjetivos participiales pueden nominalizarse con facilidad, de ahí que localicemos hasta once formaciones sustantivadas:

Pues en los casos de la guerra es notorio que el acometido, por la mayor parte, tiene notables ventajas, nescessaríssimamente el que acomete, para yr ordenado a hazer algún buen effecto, es menester recelarse y mirar muchas circunstancias, para no poner su salud y la de los suyos en riesgo (García de Palacio 1583: 69v-70r).

En alguno de tres casos que a mi parecer piden el valerse un príncipe de gente estraña: o quando de hazerlo se disminuyen las fuerças del enemigo, o se contentan los aliados, o se granjea la voluntad de los que habitan la tierra donde se a de hazer la guerra (Álaba 1590: 33r).

También son menester algunas culebrinas y algunas medias, las quales para quitar las defensas dichas son muy apropriadas; sacres, assimismo, y las demás pieças de campaña, para con ellas escombrar el campo y impedir los assaltos y escaramuças de los assediados (Collado 1592: 53v).

Si el tiempo offresciere alguna occasión para, con cautela y ventaja (sin arriesgar su ciudad), hazer alguna buena suerte en los enemigos, no se dexe ni pierda, que mucho enflaquecerá el brío del que tiene sitiada una ciudad ver que el cercado no solamente se defiende, mas que offende (García de Palacio 1583: 91r).

El hazer Vuestra Alteza armadas ha de ser atendiendo a medir el número de navíos, soldados y artillería, según la empresa que se ha de acometer y en qué razón, el poder del enemigo, confederados que puede tener y las demás consideraciones que apunté (Mendoça 1596: 157).

$\mathrm{Si}$, hallándose con gente y armas tales que entienda sobrepujar las fuerças del enemigo, paresce converná dar la batalla en tiempo que le quede día para proseguilla y seguir el alcance y rota, que, por falta de tiempo, con la obscuridad de la noche, muchas vezes los vencidos y desbaratados se han salvado, rehecho y tornado en sí y podido resisitir a los vencedores, que, si uviera día, no lo hizieran (García de Palacio 1583: 77v-78r).

\footnotetext{
266 "Del part. de minar" (DRAE). "Los de Apolonia, sabiendo que sus enemigos los tenían minados y el lugar por dónde, echaron por unos agujeros que passassen a la mina un cozimiento de agua hirviendo y pez encima, con que no sólo destruyeron la mina, mas dieron la muerte a los que en ella estavan" (Álaba 1590: 93v).

267 De murar. "Esto dará tiempo para poner en orden de buen hora el exército y bagaje al caminar, sin impedírselo el enemigo, estando a la vista en batalla, aviendo forçosamente, si no tiene villas muradas cerca, venir de lexos" (Mendoça 1596: 64).

268 "Del part. de torrear" (DRAE). "Les dio por instrución que, subidos en lo alto de los montes, a la parte del mediodía, viessen y considerassen qué tal era la provincia, y si el que la posseýa y governava era varón fuerte o flaco, y si los moradores d'ella eran pocos o muchos, y si las poblaciones o ciudades eran muradas, torreadas o fortalescidas" (García de Palacio 1583: 63v).
} 
Hecha por el capitán la señal con alguna pieça de artillería o de otra suerte, salgan los emboscados y, dando sobre ellos con buen orden, los desbaraten y hagan el daño que de ordinario reciben los que se hallan atajados y turbados de algún caso repentino que nunca imaginaron (Álaba 1590: 136r).

Mas, por ventura, convino assí que los dioses desbaratassen nuestro enemigo y su exército sin alguna humana ayuda, como quebrantador de los conciertos, y que nosotros, pues somos los ofendidos, ayamos de concluyr con lo que ellos començaron (Álaba 1590: 57r).

Era de su natural el Marqués afable y blando con los inferiores, y compassivo y agradable con los prisioneros y rendidos, y desseoso de reduzir a los que vía yr mal encaminados porque no creciessen sus culpas (Mosquera 1596: 80r-80v).

Las aguas manantiales, si las hay en los fossos, éstas son muy favorables a los sitiados, porque ni les pueden ser sangradas ni menos con la mina se puede passar por debaxo de ellas (Collado 1592: 63r).

Todas estas formaciones adjetivales derivan de la forma del participio verbal correspondiente, a excepción de alamborado, que parte del sustantivo alambor. De acuerdo con Rainer (1999: 4630), el elemento morfológico presente en este caso es -ado, de sentido posesivo, interpretación con la que concuerda la definición de la Real Academia Española: "Que tiene alambor" (DRAE: s.v. alamborado, da).

C) "Aunque muchos admiten en ocasiones usos nominales, son [...] adjetivos los derivados que se ajustan al esquema V-dor / -dora [...], cuya interpretación suele ser activa (aproximadamente, 'que V')" (Real Academia Española 2009: 550). Son dos los adjetivos de este tipo registrados: amotinador 269 y atalayador.

Amotinador. “adj. Que amotina u ocasiona motín. U. t. c. s.” (DRAE): “Mas si el soldado es amotinador o persona que tocasse en hazer concierto o alebosía con los enemigos, a estos tales no se les deve guardar ninguna preminencia, antes se deve hazer la justicia de presto" (Montes 1537: VIIIv).

Atalayador. 'Que domina o descubre gran extensión': “Assí que será la forma del lugar digna y de recreación, que no estuviere baja y como hundida, sino muy alta y muy atalayadora, y en donde se mueva el ayre alegre y con algún continuo espíritu" (Alberto 1582: 12).

269 “De amotinar. 1586, DHist.” (DECH: s.v. mover). 
D) A pesar de que "-esco/a juega un papel marginal en el campo de los adjetivos de relación normales" (Rainer 1999: 4620), damos cuenta de una formación de este tipo: soldadesco ${ }^{270}$.

Según Pharies (2002: s.v. -esco), este sufijo, que es reflejo del it. -esco, "por medio de numerosos préstamos italianos se arraiga en español, posibilitando la producción de derivados propios". Añade, además, que las primeras formaciones internas españolas datan del siglo $X^{271}$.

Por otro lado, disponemos de varios ejemplos de la forma soldadesca sustantivada: “Y en otro caso no hallo por qué devan ser escluydos los que professan otros oficios, pues puede aver en ellos hombres de importancia para professar la soldadesca" (Álaba 1590: 34v). En este caso, nos hallamos ante un sinónimo de milicia en el sentido de 'profesión que ejercen los militares o soldados'.

E) De acuerdo con Pharies (2002), -ivo es un sufijo culto en español, que, al igual que su reflejo latino, -ĩous, se usa para derivar adjetivos a partir de bases primordialmente participiales.

Pese a que para Pharies (2002: s.v. -ivo) los dos términos militares que presentamos con este sufijo, defensivo y ofensivo, son latinismos, al no haber encontrado en ninguno de los diccionarios latinos consultados sus supuestos étimos, a saber, dēfensīous y offensīous, concluimos que en realidad estas dos formaciones constituyen neolatinismos. Es decir, para su construcción la lengua española ha partido de sus correspondientes temas de perfecto latinos, como puede constatarse:

Defensivo, de defēnsum, participio latino de dēfendëre (cast. defender).

\footnotetext{
270 "Perteneciente o relativo a los soldados" (DRAE). "Passaron los atambores, y assimismo yvan entregando sus caxas ya sordas y destempladas, con los pífaros, con todos los demás instrumentos que dexavan en manos de los nuestros, y desarmándolos uno por uno de sus mosquetes, arcabuzes, picas y alabardas y de todas armas, se apartaron despojados de toda la gloria soldadesca y, casi desconocidos, por estar desautorizados y carecer del ornamento de sus personas, quedaron en una profunda tristeza" (Mosquera 1596: 96r).

${ }^{271}$ No obstante, para Pharies (2002) el término castellano soldadesco, al que documenta en 1517, se trataría en realidad de una adaptación del italiano soldatesco, existente ya en 1405. Al no haber podido confirmar esta solución, hemos preferido considerar soldadesco como un derivado interno del español, si bien es cierto que muestra una evidente influencia italiana.
} 
Ofensivo, de offensum, participio latino de offendere (cast. ofender).

Por lo que respecta al contenido semántico aportado por -ivo, frente a la situación latina, cuando el significado básico era el pasivo, en castellano sirve fundamentalmente para derivar adjetivos activos, lo que evidencian defensivo y ofensivo:

Defensivo. 'Que defiende o sirve para defender': “Dezidme, maestro, este fuerte en el agua, como avéys dicho, ¿de qué forma le haríades, y con qué miembros?, pues él, de suyo, es fuerte por naturaleza, el sitio, y no será de importancia hazerle de tantos miembros, ofensivos y defensivos" (González de Medina 1599: 144).

Ofensivo. "Que ataca o sirve para atacar" (DRAE): "De algunos años a esta parte más bellicosamente se a usado el alojar pieças de artillería en los puestos más offensivos la primera noche que se llega a sitiar tal plaça" (Ufano 1613: 121).

F) En un caso como levadizo272, la Real Academia Española (2009: 559) postula la existencia del sufijo -dizo / -diza273.

“Aunque de productividad mucho más reducida que las formas en -ble, los adjetivos derivados según la pauta V-dizo adquieren igualmente sentido pasivo" (Real Academia Española 2009: 559). Por eso, para Rainer (1999: 4610) los derivados arrojadizo, bebedizo, levadizo y serradizo, por ejemplo, se parafrasean simplemente por "que puede ser PP".

G) “Se forman en español un gran número de adjetivos derivados en -nte (con las formas -ante, -ente y -iente) [...]. Muchos de ellos admiten usos sustantivos" (Real Academia Española 2009: 560):

\footnotetext{
272 Del ant. levar 'levantar' y éste del lat. lěvare (DECH). "Ha de tener una parte de la puente levadiza y con un ponteçuelo, también levadizo, que salga por una puerta pequeña a dar en el puente, para si de noche huviere alguna necessidad de salir alguno o entrar dentro para cosa importante, que sea por el ponteçuelo" (González de Medina 1599: 253).

273 "Repárese en que en el análisis sincrónico no puede postularse -izo / -iza como sufijo adjunto a una raíz participial (resbalad-izo) porque este análisis predice las formas *movidizo, *traidizo, en lugar de las existentes movedizo, traedizo" (Real Academia Española 2009: 559). De la misma opinión parece mostrarse Rainer (1999) al fijar la forma -dizo como sufijo deverbal, frente a -izo, deadjetival y, más comúnmente, denominal. Por el contrario, para Pharies (2002: s.v. -izo) casos como olvidadizo, movedizo y levantadizo, entre otros, deben ser considerados derivados posparticipiales.
} 
Y también el arco, como la puente, tendrá tres sendas para andar: la de en medio servirá para los soldados, y las dos de los lados para las madres y para los que acompañaren al exército triumphante que buelve a su tierra para saludar a los dioses de su patria (Alberto 1582: 250).

Puesto todo el acompañamiento en este orden, yva el triunfante al Capitolio, al templo de Júpiter Capitolino, en el qual sacrificavan alguno de los capitanes presos y, acabado este sacrificio, baxavan al palacio, donde avía gran aparato de comidas, y allí comían todos públicamente, acompañando el comer con mucho regozijo y fiesta (Álaba 1590: 147r).

Respecto al adjetivo, al ser parafraseable con "que V"274, posee indudablemente un significado activo.

H) Uno de los sufijos más productivos para generar adjetivos que sugieren abundancia, propensión o semejanza es -oso, que se agrega principalmente a bases sustantivas, aunque a veces también a adjetivas y verbales, como señala Pharies (2002: s.v. -oso) ${ }^{275}$. Ahora bien, por lo que respecta al lenguaje militar, sólo hemos hallamos un adjetivo con este afijo: victorioso ${ }^{276}$, de victoria. Además, de acuerdo con Lang (20023: 203), consideramos que en este derivado el valor aportado por -oso es meramente atributivo, igual que el que transfieren otros sufijos adjetivos.

\subsubsection{Sufijación adverbial}

El sufijo -mente 277 “se emplea en español para derivar adverbios de modo a partir de la forma femenina de bases adjetivas" (Pharies 2002). Pese a tratarse

\footnotetext{
${ }^{274}$ cf. Rainer (1999: 4602).

275 También Mancho Duque (1987b: 37) muestra, pese a su escasa frecuencia, algunas formaciones deadjetivales y deverbales. Para más información sobre este sufijo, véase, asimismo, Mancho Duque (1989) y Martín García (2007).

276 "El que ha vencido y deshecho a sus enemigos" (Terr.). "De contrario parecer fue Licurgo, mandando en sus leyes que siempre que los griegos de alguna batalla saliessen vitoriosos y con buen sucesso siguiessen los enemigos hasta assegurar la vitoria" (Álaba 1590: 141r). Este adjetivo es susceptible de sustantivación, como muestra este pasaje: "También deve curar los heridos, y enterrar los muertos y agradescer con palabras y dones y mercedes a los victoriosos, repartiendo entre ellos los despojos del campo, para que, con el premio, en alguna manera queden pagados y, con las gracias, se animen a otros casos y victorias semejantes" (García de Palacio 1583: 81r).

277 "Oscila entre los morfólogos la caracterización formal del segmento -mente, ya que es sufijo para unos, pero elemento compositivo para otros" (Real Academia Española 2009: 571). Pese a
} 
de uno de los procesos morfológicos de adverbialización más rentables en español, sólo contamos con un representante, a saber, belicosamente:

\begin{abstract}
Solía ser en tiempos passados que, primero que se alojase la artillería sobre una plaça, llegava la ynfantería con las trincheras hasta querer desembocarlas al fosso; pero, de algunos años a esta parte más bellicosamente se a usado el alojar pieças de artillería en los puestos más offensivos la primera noche que se llega a sitiar tal plaça (Ufano 1613: 121).
\end{abstract}

\title{
3.1.2.4. Sufijación verbal
}

La verbalización es un proceso de formación de palabras que permite la creación de verbos a partir de bases pertenecientes a diversas categorías.

El español dispone de varios mecanismos morfológicos para la creación de verbos: además de la prefijación, analizada anteriormente, la sufijación verbal, de la que nos ocupamos a continuación, y la circunfijación o parasíntesis, que trataremos en el siguiente apartado.

En este apartado vamos a analizar los dos tipos de derivación verbal: homogénea y heterogénea278.

Por lo que se refiere al morfema derivativo verbalizador 279 , éste "puede unirse a la raíz léxica, sea directamente ('derivación inmediata'): ánimo > animar,

que aún mantiene varias de las propiedades que tuvo como unidad léxica independiente, para los académicos se impone su condición sufijal. De la misma opinión se mostraba Pharies unos años antes: "A causa de su origen perifrástico, el formante -mente manifiesta una serie de peculiaridades que lo distinguen de los demás sufijos derivativos [...]. Pero, por otra parte, [...] mente tiene características que permiten distinguirlo netamente de los compuestos. En concreto, el sentido de mente como palabra independiente es muy distinto, y el orden de palabras, con el adjetivo precediendo a -mente, contrasta con lo habitual en otros compuestos, cf. nochebuena, camposanto. En resumen, si bien la transformación de -mente en un sufijo derivativo todavía es incompleta, merece incluirse en un diccionario de sufijos" Pharies (2002: s.v. -mente).

278 "Como en cualquier otro tipo de derivación, en la morfología derivativa verbal cabe diferenciar dos tipos funcionales de derivación: la formación de verbos a partir de otras clases de palabras (derivación heterogénea) y la formación de verbos sobre verbos ya existentes (derivación homogénea)” (Pena 1993: 217).

279 "Aviertáse que en las terminaciones de infinitivo, la vocal temática es el morfema derivativo verbalizador, mientras que la $-r$ final es simplemente un morfema flexivo inherente a la forma de infinitivo" (Serrano-Dolader 1999: 4685). 
sea indirectamente ('derivación mediata'): dulce > dulcificar, memoria > memorizar, vara > varear, húmedo > humedecer" (Serrano-Dolader 1999: 4685) 280 .

A) Entre los verbos en -ar originados por derivación inmediata, disponemos de formaciones denominales, deadjetivales e incluso deverbales. Pertenecen al primer tipo asaltar, asediar281, conquistar282, empalizar283, escalar, minar, murar, talayar 284 , terraplenar 285 y trabar $^{286}$. Al segundo únicamente se adscribe domesticar 287 , mientras que levantar, al haber partido en su construcción de levante, el antiguo participio activo de levar (cf. DECH: s.v. leve), es un exponente del proceso morfológico de la derivación verbal homogénea.

En lo referente a los valores semánticos, como señala Pena (1993: 233), “la categoría de verbos en - $a$ - es semánticamente neutra, pues no dota al verbo derivado de una determinada nota de significación ni en cuanto al proceso en sí (aspectualidad) ni en cuanto al proceso en relación con sus actantes o argumentos (estructura argumental)". La verbalización en -ar no posee,

280 Esta clasificación es también recogida por Alvar Ezquerra (19952: 60-62), para quien la principal característica de la derivación mediata, en oposición a la inmediata, es su capacidad de añadir nuevos significados.

281 De asedio. 1569, Ercilla (DECH: s.v. asedio).

282 "De conquista deriva conquistar [h. 1334, Conde Luc.; frecuente desde el s. XV (...)] que reemplazó a conquerir, por una innovación común al cast. con el port., cat. [...], oc. e it." (DECH: s.v. querer).

283 "Palizada [...], probablemente tomado de oc. ant. palissada 'íd.' [...]; posteriormente empalizada [h. 1640, Ovalle, Aut.] y su derivado empalizar [Acad. s. XIX o XX] (DECH: s.v. palo). Sin embargo, la primera documentación de empalizar es bastante anterior, según nuestro corpus: " $Y$ conviene, cierto, guardar que no esté encima levantado algún monte apegado, el qual, occupado, moleste el enemigo, o que no se estienda al enemigo alguna segura llanura tan grande que en tal lugar pueda empalizar para sitiar o ordenar su esquadrón para dar assalto" (Alberto 1582: 102). Por otro lado, en el caso de que este verbo derive realmente del sustantivo empalizada, el resultado final es una formación regresiva. Como puede constatarse en empalizada > empalizar, la particularidad de esta modalidad morfológica reside en que la palabra derivada obtenida es más simple que la palabra base de la derivación (Sánchez Martín 2009: 194).

284 De atalaya, con posible influencia del cat. talaiar (cf. DECH: s.v. atalaya).

285 "De la forma terrapleno, pues la variante terraplén se documenta más tarde que este verbo" (López Vallejo 2008: s.v. terraplenar).

286 "En vista del port. trave es verosímil que su sinónimo el cast. traba venga directamente del femenino lat. trabs, y que de traba derive el verbo trabar. 1. ${ }^{a}$ doc.: travar, 1155, Fuero de Avilés" (DECH: s.v. trabar).

287 "Venían juntamente muchos de los naturales de las islas rendidos, de aquellos contra quien no se avía procedido, cosa que estoy por afirmar no acordarse las historias que se aya visto un exército junto, en proporción tan numeroso, y tan opuesto al nuestro y tan sobrado de armas y municiones, encastillado en tierra montuosa y fortificada que assí se aya domesticado, como el que de los nuestros oy se a visto" (Mosquera 1596: 97r). 
entonces, especificaciones semánticas que le sean propias y características. Por ello, Serrano-Dolader (1999: 4688) asegura que "el intento de ordenación de tales verbos no corresponde estrictamente a la morfología derivativa". En su mayoría, podemos adscribir las formaciones especializadas aquí analizadas al campo léxico de las acciones bélicas, uno de los más numerosos de este trabajo, como tendremos ocasión de comprobar.

B) El sufijo -ear, que pertenece a la derivación verbal mediata, es uno de los más productivos a la hora de originar verbos sobre bases adjetivales y, fundamentalmente, nominales. A excepción de señorear ${ }^{288}$, derivado deadjetival, todas las formaciones halladas con este afijo han resultado ser denominales: campear $^{289}$, carcavear 290 , flanquear, forrajear ${ }^{291}$, guerrear, pelear 292 , pilotear $^{293} \mathrm{y}$ saltear ${ }^{294}$.

De acuerdo con Serrano-Dolader (1999: 4690), los verbos deadjetivales en -ear pueden indicar una propiedad, estado o situación u ostentar un valor causativo. No obstante, "el grupo más significativo de verbos deadjetivales en ear es el constituido por verbos de significado frecuentativo, que expresan una modalidad aspectual de habitualidad" (Serrano-Dolader 1999: 4691). Por lo que respecta a señorear, el único verbo de este tipo registrado, definimos hasta cinco acepciones militares relevantes:

1. $\rightarrow$ 'Dicho de una cosa: dominar algo que está alrededor, por tener mayor altura o estar en una posición más elevada': "Y si se huviesse de hazer el tal castillo sobre alguna villa, se tendrá, assimesmo, cuidado de que esté a cavallero sobre la campaña y juntamente que señoree la villa" (Rojas 1598: 4r).

\footnotetext{
288 “De señor [h. 1275, 1. ${ }^{a}$ Crón. Gral. (...); Conde Luc. (...), APal. (...)]” (DECH: s.v. señor).

289 'Dicho de un ejército: salir al campo y desplazarse por él durante una operación militar'.

${ }^{290}$ De cárcava 'zanja o foso defensivo', 'hoya en general, y particularmente la destinada a enterrar muertos', que es alteración del antiguo cácavo, que viene de caccăbus 'olla', 'cazuela', procedente a su vez del gr. xáxxaßos 'íd.'. La forma carcavear ya está en Alex., Partidas, $1 .{ }^{a}$ Crón. Gral. y en A. de Cartagena, mientras que es posterior carcavar (fin s. XV: G. de Eugui) (DECH: s.v. cárcavo). "Fortificar un campo o ciudad haciéndole foso o cava alrededor" (Aut.). 291 "En particular en la guerra, ir a buscar forraje" (Terr.).

292 "Pelear, voz común al castellano con el portugués (pelejar) y la lengua de Oc (íd.), derivada de pelo: el sentido primero hubo de ser 'venir a las manos, reñir' y anteriormente 'agarrarse por el pelo'. 1. ${ }^{a}$ doc.: peliare, 1131, en el fuero latino de Calatayud; pelear, princ. s. XIV, Zifar, 18.15; J. Ruiz" (DECH).

293 'Clavar pilotes o piezas de madera semejantes'.

294 "Atacar a alguien por sorpresa" (DUE).
} 
2. $\rightarrow$ 'Divisar desde una altura determinadas cosas, como una extensión de terreno o las personas que se encuentran allí: "Un baluarte se lebanta de tierra y fajina enfrente de la muralla para señorear desde allí la plaça y tirar" (Roxas 1607: 46r).

3. $\rightarrow$ 'Poner una persona bajo su poder a individuos o territorios': "Estas gentes de los arrios e batrianos señorearon mucho tiempo a las Indias e a otras muchas provincias, en especial en el tiempo de Menánder, rey de los arrios e sodianos" (Fernández de Enciso 1530: XXXIXv).

4. $\rightarrow$ prnl. 'Apoderarse de algo': "Y, assí, trataron de fortalecer y adelantar tanto los ánimos de sus ciudadanos que con sola su determinación y brío resistieron el poder y contiendas de sus vezinos y de otros enemigos que no con menor ansia y cuydado trataron muchas vezes de señorearse d'ellos y de hazerse señores y dueños de toda su tierra" (Álaba 1590: 25v-26r).

5. $\rightarrow$ prnl. 'Someterse o ponerse bajo el poder de alguien': "Monsiur de Fox, aviéndose señoreado los venecianos de Bresa, de consentimiento de los moradores d'ella, y teniendo él por suyo el castillo, los saqueó y desbarató" (Álaba 1590: $85 \mathrm{v})$.

Por otro lado, "buena parte de los verbos denominales en -ear tienen valores muy próximos a los frecuentativos" (Serrano-Dolader 1999: 4691), como guerrear 295 "hacer la guerra" (DEA).

"Parece, sin embargo, que la verbalización a través de -ear de bases nominales da como resultado no tanto verbos frecuentativos cuanto verbos iterativos 296" (Serrano-Dolader 1999: 4692). Por lo tanto, lo más probable es que el resto de nuestros verbos en -ear se adscriba a este otro patrón.

c) Por último, el sufijo -ecer "se utiliza en español para derivar verbos factitivos e incoativos de la segunda conjugación a partir de bases verbales y nominales" (Pharies 2002: s.v. -ec(er)).

Según el DECH (s.v. fuerte), “de fortaleza [...] se derivó secundariamente el verbo fortalecer 297 , inicialmente en el lenguaje militar, después en el general; verbo ajeno al francés, occitano y catalán (sólo port. fortalecer, junto a fortalezar)".

\footnotetext{
295 "Naos y navíos. Ay diversas suertes y maneras de naos sobre la mar, de los quales unos son mejores que otros para guerrear" (Celso 1553: CCXXVIIv).

296 "Un proceso es iterativo cuando su realización supone la ejecución de una serie sucesiva de actos. Es un proceso de duración interna ilimitada, pero compuesto por procesos diminutos o mínimos que se manifiestan como actos acabados o perfectos de duración interna mínima (momentáneos o puntuales). Tal pluralidad, intermitencia o sucesión lineal de actos télicos momentáneos está integrada en un único y mismo proceso (o tiempo interno) de duración ilimitada" (Pena 1993: 235).

297 "Anteriormente se dijo afortalezar [...], donde se ve claramente como fue fortaleza el punto de partida" (DECH: s.v. fuerte).
} 
Como puede constatarse, en este derivado castellano se produce una cancelación de parte de la sustancia fónica de la base.

Por otro lado, "algunos verbos en -ecer sustituyeron a formaciones verbales existentes en castellano antiguo" (Serrano-Dolader 1999: 4700), como guarnecer 298 , de guarnir.

\subsubsection{Parasintesis}

El concepto de derivación admite varias interpretaciones, pero en la más amplia abarca también la parasíntesis. Este es el segundo de los procedimientos de formación de verbos derivados. Consiste en la adición de afijos discontinuos, en concreto un prefijo y un sufijo elegidos simultáneamente ${ }^{299}$ (Real Academia Española 2009: 577-578).

Para muchos especialistas existe un requisito imprescindible que deben cumplir los supuestos verbos originados mediante parasíntesis para poder ser considerados realmente como tales. Nos referimos al criterio formal de la no existencia o no sistematicidad de las etapas intermedias [base + sufijo] o [prefijo + base]. Serrano-Dolader (1999: 4701) añade, además, el principio semántico fundado en la posibilidad de que el significado del verbo resultante se conforme a partir del de la base y no a partir de una de las dos supuestas etapas intermedias. La combinación de ambos criterios es la que en definitiva nos ha determinado a analizar como parasintéticos los verbos acampar, acosar, acuartelar, alistar, allanar, amotinar, amunicionar, apremiar, apretilar, atrincherar, avituallar, descortinar, embarrar, encamisar, encastillar y enseñorear.

Como puede constatarse, los verbos parasintéticos con prefijo $a$ - o enconstituyen el grupo más abundante. En los esquemas formados por éstos "el significado de la formación parasintética integra combinadamente los de prefijo, base y sufijo, sin que parezca posible matizar separadamente el valor específico del prefijo en cada caso" (Serrano-Dolader 1999: 4703). Asimismo,

\footnotetext{
298 'Dotar o proveer un lugar de tropas que lo defiendan'.

299 Algunos autores hablan también de parasíntesis cuando hay síntesis de derivación y composición, como en ropavejero. Para estos casos, preferimos la clasificación de Soledad Varela, quien considera a estas formaciones compuestos con derivación externa (cf. Varela Ortega 2005: 34, nota3 y 73-84; Sánchez Orense 2007: 164-165).
} 
registramos una creación parasintética portadora del prefijo des-. Frente a los anteriores, en este tipo de derivados verbales es posible identificar el valor semántico que el prefijo aporta a la formación compleja.

Por otro lado, en esta modalidad derivativa el español selecciona como bases léxicas fundamentalmente sustantivos y adjetivos. A esta tendencia se adscribe el lenguaje militar renacentista, puesto que las dieciséis formaciones verbales parasintéticas detectadas son o bien denominales o bien deadjetivales.

Ahora bien, la casi totalidad de nuestros verbos parasintéticos se ha originado a partir de una base sustantiva, cuyo análisis, tal y como advierte Serrano-Dolader (1999: 4710), "es más complejo que el de la correspondiente serie de formaciones deadjetivales".

A) Esquema parasintético $a-+$ sustantivo + - ar

“El esquema [a--ar] es, junto a [en--ar], el más frecuente para la creación de verbos parasintéticos denominales" (Serrano-Dolader 1999: 4713).

A pesar de que la expresión del valor "introducir o meter en X" se produce mayoritariamente a través del esquema en- + sust. + -ar (SerranoDolader 1999: 4713), son varios los tecnicismos militares así parafraseables que ostentan en cambio la disposición $a_{-}+$sust. + -ar: acosar ${ }^{300}$, acuartelar, amotinar, apretilar $^{301} \mathrm{y}$ atrincherar.

Por otro lado, el valor instrumental ${ }^{302}$ es notorio en alistar 303 , amunicionar, apremiar $^{304}$ y avituallar. Y, "aunque menos frecuentes, existen algunos verbos habitualmente intransitivos" (Serrano-Dolader 1999: 4714). Es el caso de acampar.

\footnotetext{
300 "Acosar 'perseguir con empeño' [...], 'fatigar ocasionando molestias y trabajos', del cast. ant. cosso 'curso, carrera', procedente del lat. cǔrsus, - $\bar{u} s$, 'íd.' (de currere 'correr')" (DECH: s.v. correr). 301 'Colocar alguna cosa, especialmente una pieza de artillería, detrás de un parapeto o pretil con el fin de protegerla del fuego enemigo'.

302 "Ejecutar la acción con la ayuda o intervención del objeto designado por el sustantivo base" (Serrano-Dolader 1999: 4714).

303 "Sentar o escribir en lista algún hombre o muchos para servir al rey en la guerra; y porque las planas o libros donde escriben los nombres, patrias y señas del que entra a servir se llaman listas, se dijo de aquí alistar soldados, alistar gente" (Aut.).

304 "De premia. Oprimir, apretar" (DRAE: s.v. apremiar). "ant. Apremio, fuerza, coacción" (DRAE: s.v. premia).
} 
B) Esquema parasintético en- + sustantivo + -ar

De acuerdo con Serrano-Dolader (1999: 4712), la inmensa mayoría de derivados mediante este esquema designa valores locativos, como el direccional 'meter algo o a alguien en el objeto designado por el sustantivo base' o su inverso 'meter X en'. Así pues, creemos que tanto embarrar ${ }^{305}$ como encastillar 306 son representantes de la primera de estas dos modalidades, es decir, la de "meter en X".

"Algunos otros verbos denominales presentan valores locativos ligeramente diferentes [...]: «aproximar el objeto designado por el sustantivo base a un límite determinado, con o sin contacto»" (Serrano-Dolader 1999: 4713). Seguramente éste sea el valor semántico representado por encamisar 'cubrir o fortalecer con camisa el terraplén de una construcción'.

\section{c) Esquema parasintético des- + sustantivo + -ar}

"Las formaciones verbales que presentan el prefijo des- ofrecen en español una gran variedad de posibilidades significativas, tanto si se trata de verbos parasintéticos (descortezar, desnucarse,[...]), como de verbos prefijados sobre bases verbales preexistentes (desatar, desenganchar, $[\ldots]$ )" (Serrano-Dolader 1999: 4716). Ahora bien, los valores semánticos más importantes son el privativo y el reversativo. El primero es el más usual en los verbos originados mediante parasíntesis, mientras que el segundo es el normal en los verbos derivados con des-.

\footnotetext{
305 Embarrar 'introducir una barra', ant. 'encerrar' (h. 1275, $1 .^{a}$ Crón. Gral.), de barra, voz prerromana común a todas las lenguas romances menos el rumano (DECH: s.v. barra). "Embarrar se dize quando en guerra embarran a los contrarios, de manera que a ninguna parte osan salir, e que los han después entrar por fuerça" (Celso 1553: CLXr).

${ }^{306}$ No obstante, sólo documentamos esta voz en forma pronominal: "Se bolvían a los nuestros con ánimo y escaramuçavan hasta que se recogieron a dos montañuelas que están sobre la fortaleza principal, nombradas las montañas de la Señora, donde se encastillaron y entretuvieron la mayor parte del día" (Mosquera 1596: 109r). Según el DEA, en este caso significa "refugiarse en un castillo o en un paraje alto o de difícil acceso".
} 
El único de nuestros parasintéticos portador de esta estructura, descortinar307, señala efectivamente la idea de "privación, supresión o disminución":

A los de fuera mejor les está con el artillería, porque pretenden arruynar, descoser y descortinar las murallas, y no dexar en manera alguna asomar ni trabaxar a los sitiados para cubrirse (Ufano 1613: 172).

\section{D) Esquema parasintético $a-+$ adjetivo + -ar}

“El grupo de verbos parasintéticos deadjetivales en [a--ar] es, con diferencia, el más numeroso en nuestro idioma" (Serrano-Dolader 1999: 4707). A pesar de ello, sólo contamos con un ejemplo de esta modalidad derivativa, a saber, allanar 308 .

"Normalmente estos verbos tienen valor causativo y pueden pronominalizarse, tomando así valores incoativos" (Serrano-Dolader 1999: 4707). No obstante, ninguna de las tres acepciones de allanar detectadas en nuestro corpus se muestra en forma pronominal:

1. $\rightarrow$ "Dejar o poner expedito y transitable un camino u otro lugar de paso" (DRAE): "Y porque el gran peso d'estas pieças no da comodidad de poderse llevar sin carruage y para él no ay siempre caminos llanos, ay necessidad de gastadores para que allanen los passos ásperos" (Álaba 1590: 75r).

2. $\rightarrow$ "Poner a nivel del suelo, ya sea derribando o ya rellenando" (Zerolo 1895):

"Luego que está recogida la mayor parte del exército en la plaça de armas, el maestre de campo suele ordenar se allanen las trincheas y fortificación del alojamiento, para que pueda salir d'él la gente en esquadrón con mayor comodidad y presteza" (Mendoça 1596: 69).

3. $\rightarrow$ 'Poner una persona bajo su poder a individuos o territorios': “Mandó Su Magestad que se aprestasse otra Armada para el año siguiente y que a entrada de primavera el Marqués saliesse con ella a allanar la isla Tercera, con las demás circunvezinas que estavan alteradas, que eran: el Fayal, el Pico, la Graciosa, la isla de San Jorge, y de Flores y la del Cuervo" (Mosquera 1596: 12v).

E) Esquema parasintético en- + adjetivo + -ear

Según Serrano-Dolader (1999: 4708-4709), este tipo de combinación es muy extraña en español. De hecho, cita únicamente un ejemplo, enseñorear, precisamente el término que aportamos.

\footnotetext{
307 "Derribar una cortina o muralla de una fortificación, a cañonazos o de otro modo" (DUE). ${ }^{308}$ De llano y éste del lat. planus 'llano', 'plano'. 1240, F. Juzgo (DECH: s.v. llano).
} 


\subsection{Composición}

Otra gran parcela de la formación de palabras en español es la composición, procedimiento consistente en la unión de dos o más lexemas para formar una nueva palabra con un significado único y constante ${ }^{309}$.

La composición en español, a diferencia de otras lenguas, se caracteriza por ser uno de los procesos menos productivos con respecto a otros procedimientos de creación léxica como, por ejemplo, la derivación.

Por otro lado, el propio término de compuesto se aplica a estructuras que resultan de procesos de distinta clase. Así, se ha considerado que existen tres tipos compositivos fundamentales en español: composición léxica, composición culta y composición sintagmática. En la terminología militar, el mecanismo de la sintagmación es indudablemente el más explotado, puesto que un total de setenta y una formaciones así pueden ser catalogadas. Por lo que respecta a los compuestos léxicos, sólo dos integran nuestra macroestructura, mientras que no hemos localizado ninguna manifestación de la llamada composición culta, es decir, aquella en la que intervienen temas grecolatinos.

Los compuestos del español pueden pertenecer a las categorías nominal, verbal, adjetival y preposicional. En terminología, sólo aparecen compuestos de las tres primeras categorías $\mathrm{y}$, entre ellas, son especialmente importantes los compuestos nominales (Clavería y Torruella 1993: 323).

Efectivamente, todos los compuestos del ámbito de la milicia, y tantos los léxicos como los sintagmáticos, se adscriben a la categoría gramatical sustantiva.

\footnotetext{
309 "Se llama composición el proceso morfológico por el que dos o más palabras forman conjuntamente una tercera, llamada palabra compuesta o compuesto, como en lava + ropas > lavarropas o en verde + blanco > verdiblanco. Como el concepto de 'palabra' presenta numerosas dificultades, algunos autores prefieren definir el compuesto como 'aquella forma que contiene más de una raíz en su interior'. Son, pues, compuestos las voces altoaragonés, limpiacristales, sabelotodo y subibaja. También lo son hombre lobo y otros muchos que se forman sin integrar gráficamente sus componentes ni someterlos a otro proceso morfológico que la yuxtaposición" (Real Academia Española 2009: 735).
} 


\subsubsection{Composición léxica}

La concatenación de dos palabras en una nueva unidad léxica origina los llamados compuestos léxicos o propios ${ }^{310}$. De acuerdo con la Real Academia Española (2009: 736), las formaciones de este tipo pueden agruparse en varias clases atendiendo a tres criterios: primero, la categoría gramatical a la que corresponden sus segmentos constitutivos; en segundo lugar, la relación que se establece entre ellos; y, por último, su núcleo morfológico.

Según el primero de estos tres criterios, casamuro $^{311}$ y rodapié312, los dos compuestos propios de los que consta el vocabulario militar renacentista, pertenecen a dos grupos distintos, esto es, casamuro se adscribe al de nombre + nombre, mientras que rodapié está constituido por verbo + nombre.

En función del criterio 2, los compuestos se clasifican en coordinativos y subordinativos. Se suelen llamar compuestos coordinativos los que manifiestan una relación asimilable a la coordinación sintáctica entre sus componentes, aun cuando no haya razones para asociar la vocal $-i-$, en caso de que aparezca, con una conjunción copulativa [...]. Los compuestos subordinativos ponen de manifiesto la relación de subordinación entre un núcleo y algún complemento o modificador $^{313}$ (Real Academia Española 2009: 738).

310 Varela (2005: 74) los denomina también compuestos ortográficos, al considerar que se caracterizan por estar plenamente soldados $\mathrm{y}$, por tanto, con sus componentes unidos gráficamente. En cambio, para Val Álvaro (1999) la unión ortográfica no constituye una propiedad esencial en los compuestos léxicos, de ahí que, al explicar los compuestos creados mediante la unión de dos nombres sin vocal de enlace, establezca la siguiente distinción: "Hay compuestos (perfectos) cuyos constituyentes están sólidamente fusionados formando una sola palabra fonológica y hay compuestos (imperfectos) que presentan dos componentes que no han llegado a amalgamarse fonológicamente" (Val Álvaro 1999: 4778).

311 «Cpt. Casamuro 'pared maestra' arag. (1625), 'muralla ordinariamente sin terraplén' fortif. [1590: B. Mendoza], propiamente 'muro de casa'» (DECH: s.v. casa). "Al batir, quando las murallas son casamuro sin terrapleno, se han de plantar las pieças de manera que batan en la muralla al sesgo, porque entonces la quebrantan más con la resistencia que hallan" (Mendoça 1596: 100).

312 "En un cimiento, partes laterales de su grosor cuando éstas exceden la anchura del muro que se levanta sobre él" (Paniagua Soto 1998: s.v. zarpa). "Y si se ofreciere hazer la fábrica en alguna ladera o cuesta arriba, se procurará que las murallas de la parte de abaxo de la cuesta sean más gruessas que las de la parte de arriba, y que corra su nivel hazia la cuesta, dexando por la parte baxa gran banqueta o rodapié a la muralla, de suerte que no sea bastante todo el peso del edificio a cascar ni hender las murallas de la parte de abaxo" (Rojas 1598: 97r).

313 Esta misma distinción puede verse en Val Álvaro (1999: 4772): "La combinación de un elemento nuclear y otro no nuclear da lugar a una relación hipotáctica o subordinativa. La naturaleza del núcleo $(X)$ y la función que respecto del mismo desempeña el otro constituyente (X) determinan dos tipos básicos de relación, una de rección y otra de modificación (o de complemento no regido) [...]. La unión de dos elementos equipolentes puede interpretarse como una relación paratáctica o coordinativa". 
A este respecto, nuestros dos compuestos son subordinativos, si bien en el primero, en casamuro, se produce una relación de modificación, mientras que en rodapié ésta consiste más bien en una rección ${ }^{314}$.

Como todo compuesto tiene un núcleo, definido tradicionalmente como "el elemento léxico del que la voz compleja denota un subconjunto" (Val Álvaro 1999: 4766), se establece, por último, una división entre compuestos endocéntricos y compuestos exocéntricos. En los primeros el núcleo está dentro de la formación léxica, mientras que en los segundos se halla fuera ${ }^{315}$.

En consecuencia, casamuro se trata de un compuesto endocéntrico subordinativo con segundo nombre nuclear ${ }^{316}$. En él se caracteriza un tipo de muro, concretamente el que carece de terraplén, "acudiendo a propiedades percibidas en la entidad con que se compara, el primer constituyente" (Val Álvaro 1999: 4786).

Por otro lado, el esquema verbo + nombre, que ostenta rodapié, "es el más productivo de entre los que dan lugar a compuestos propios en todo el sistema morfológico del español" (Real Academia Española 2009: 770) ${ }^{317}$.

\footnotetext{
314 "La hipótesis más generalizada sobre el primer elemento de este tipo de compuestos [los de verbo + nombre] es que se trata de un elemento verbal. La estructura compositiva resultante responde, pues, a una relación de determinado-determinante o subordinado-subordinante con rección del verbo sobre el nombre. La estructura es de naturaleza exocéntrica" (Val Álvaro 1999: 4789).

315 "Atendiendo al criterio 3, los compuestos se clasifican en endocéntricos y exocéntricos. En los primeros puede identificarse un núcleo que caracteriza gramatical y semánticamente el conjunto [...]. Se suelen considerar exocéntricos aquellos compuestos cuyas propiedades gramaticales y semánticas no vienen impuestas por ninguno de sus constituyentes internos" (Real Academia Española 2009: 739).

316 "La formación de compuestos nominales con el segundo elemento nuclear ha sido un procedimiento históricamente menos vital que el anterior [el de primer nombre nuclear]" (Val Álvaro 1999: 4786).

317 "Es tradicional entre los morfólogos el debate en torno a la cuestión de si los compuestos verbonominales tienen o no núcleo. La controversia surge, en buena medida, porque los compuestos exocéntricos no suelen ser productivos. En cambio, los compuestos verbonominales están, como se ha explicado, entre los más numerosos del español, y poseen un significado transparente en un alto porcentaje. Se han propuesto varios análisis de estos compuestos como unidades endocéntricas, si bien ninguno de ellos es hoy aceptado de forma mayoritaria" (Real Academia Española 2009: 771). Por ello, consideramos que rodapié es un compuesto exocéntrico, opinión que, como ya hemos adelantado, coincide con la de Val Álvaro, para quien, además, los compuestos exocéntricos pueden distribuirse en dos clases: "aquellos en que la ausencia de núcleo se debe a su sentido figurado y aquellos en que hay una composicionalidad semántica parcial" (Val Álvaro 1999: 4766). Resulta evidente que rodapié pertenece al primer tipo, ya que
} 
El sustantivo que constituye el segundo elemento de este tipo de compuestos aparece normalmente en plural, aunque no son infrecuentes las voces en las que aparece en singular (Val Álvaro 1999: 4798), como se constata en rodapié. Según la Real Academia Española (2009: 774), para los nombres contables la pauta que predomina es la de su presentación en plural, de ahí que haya menos compuestos con pie en singular que en plural. Por ejemplo, entre los primeros los académicos sólo citan alzapié, hincapié y rodapié318, frente a los plurales buscapiés, calientapiés, guardapiés y reposapiés, por mencionar sólo algunos.

\title{
3.2.2. Composición sintagmática
}

Entendemos por compuestos sintagmáticos o impropios los que "resultan de la fijación de una estructura sintáctica en una forma determinada, lo que conlleva la pérdida de propiedades sintácticas y la hace hábil para expresar conceptos unitarios" (Val Álvaro 1999: 4760). Ahora bien, debemos advertir que en la actualidad coexisten varias líneas de investigación en torno a la sintagmación.

Por ejemplo, la identificación establecida por Varela Ortega (2005) entre los compuestos léxicos y los ortográficos condiciona su caracterización de la sintagmación, la cual necesariamente difiere de la de otros morfólogos:

\begin{abstract}
Hay determinadas agrupaciones de palabras que se comportan como los compuestos ortográficos en el sentido de que forman una unidad solidaria y tienen un significado único, a pesar de que sus componentes se realicen como palabras separadas. Son estos los 'compuestos sintagmáticos', entre los que se distinguen tres tipos de formaciones: 'compuestos preposicionales',
\end{abstract}

su significado no es predecible a partir de la suma del que poseen cada uno de sus componentes.

Por otro lado, este tipo de compuestos de verbo más nombre ha generado también controversia en torno a la consideración del primero de sus constituyentes. Como asegura la Real Academia Española (2009: 772), "el radical verbal de los compuestos verbonominales se ha analizado tradicionalmente de tres formas distintas: como un imperativo, como un presente de indicativo y como un tema verbal puro". Para más detalles, véase Val Álvaro (1999: 4789-4793).

318 No obstante, al principio debió de producirse una fluctuación entre esta forma y rodapiés, como evidencia el artículo lexicográfico: "Rodapies, un marchepied, un soubassement de lict" (Oudin 1607). 
'compuestos yuxtapuestos' (nominales y adjetivales) y 'compuestos de nombre y adjetivo' (Varela Ortega 2005: 80).

De acuerdo con esta investigadora, serían compuestos preposicionales los formados por "sustantivo + de + sustantivo" (por ejemplo, caballo de batalla); serían, en cambio, compuestos yuxtapuestos nominales los del tipo pantalón campana o falda-pantalón, mientras que político-económico pertenecería a los adjetivales. Finalmente, como representantes de los compuestos de "sustantivo + adjetivo" (o viceversa) cita alta mar.

Por otro lado, en la propuesta más actual de la Real Academia Española se restringe la consideración de compuestos sintagmáticos solamente a los yuxtapuestos, al considerar que las estructuras representadas por caballo de batalla y alta mar, por ejemplo, deben ser tratadas como locuciones nominales, ya que "presentan puntos de contacto con las locuciones adjetivales, verbales y preposicionales" (Real Academia Española 2009: 736), como es el hecho de constituir una sola pieza léxica. Ello es palpaple en poner sitio, que equivale a sitiar. También estrada cubierta puede equipararse a un sustantivo simple, lo que, según la clasificación académica, constituye un argumento fehaciente para denominarla locución nominal.

Sin embargo, dado que, de acuerdo con otros investigadores, las locuciones son las unidades fraseológicas con mayor grado de fijación e idiomaticidad ${ }^{319}$, consideramos, finalmente, que las combinaciones léxicas estrada cubierta, media luna y ballestón de torno, entre otras formaciones, son compuestos sintagmáticos, mientras que a caballero, de a pie y batir la estrada, por citar sólo algunas, son locuciones. Nuestra decisión radica en que la disposición de estas últimas no admite apenas variación y, además, generalmente la interpretación de su significado es una tarea mucho más compleja que en el caso de la sintagmación, como demuestran algunos investigadores ${ }^{320}$ :

\footnotetext{
319 "Los compuestos sintagmáticos estarían a caballo entre las colocaciones y las locuciones, pues presentan un mayor grado de fijación e idiomaticidad que las primeras pero menor que las segundas" (Ferrando Aramo 2002: 105).

320 Para más información, véase, entre otras, la propuesta doctoral de Buenafuentes de la Mata (2007).
} 
Cuanto mayor sea el grado de isomorfismo y de motivación, más compuesto será el sintagma. Cuanto menos isomórfico y menos motivado sea, más se acercará a las locuciones. De hecho, las locuciones prototípicas son las no isomórficas y no motivadas ${ }^{321}$ (Ruiz Gurillo 2002: 334).

Además, no debe olvidarse que la separación entre esta modalidad morfológica y la composición léxica resulta en muchas ocasiones difusa, en buena parte debido a procesos históricos: "Los compuestos sintagmáticos son susceptibles de sufrir un proceso histórico de asimilación a compuestos léxicos prototípicos" (Val Álvaro 1999: 4765).

En definitiva, creemos que en trabajos léxicos de vertiente diacrónica, como el presente, no es oportuna la inclusión de este grupo morfológico en el ámbito fraseológico (v. g. las locuciones), del que nos ocuparemos en el siguiente apartado.

Como ya hemos apuntado, las formaciones que incluimos en este apartado responden a pautas de combinación sintáctica, puesto que "se han originado a partir de una lexicalización de lo que inicialmente era una combinación ocasional de elementos léxicos" (Clavería y Torruella 1993: 327).

Así pues, los compuestos sintagmáticos están constituidos o por un sustantivo y uno o más adjetivos o por un sustantivo más un sintagma preposicional, generalmente encabezado por la preposición de, clasificación presente en Bustos Gisbert (1986: 69).

A) Sustantivo + adjetivo

Arquitectura militar, arte militar, batalla campal, caballería ligera, caballo ligero, casa fuerte, centinela perdida, cortina franca, cortina limpia, cortina parcial, cortina total, empresa militar, escuadrón falso, escuadrón volante, estrada cubierta, estrada encubierta, gente militar, guerra civil, guerra defensiva, guerra ofensiva, hombre militar, infante perdido, ingeniero

321 "El hecho de que una formación sea isomórfica implica que pueda ser analizada o descompuesta en sus componentes. Por otra parte, la motivación se relaciona con la transparencia semántica que presenta la unidad: si es posible interpretar su significado sólo a partir de la formación, ésta será motivada" (Buenafuentes de la Mata 2007: 106). 
militar, máquina mural, pie pequeño, plaza alta, plaza baja, plaza fuerte, plaza superior, puente levadizo, puerta principal, testudo arietaria, través alto y través bajo.

Aunque este esquema compositivo está presente en la mayoría de las esferas de que consta la milicia renacentista, su productividad es especialmente llamativa en la designación de los elementos que componen una determinada construcción defensiva, como constatan cortina franca, cortina limpia, cortina parcial, cortina total, estrada cubierta, estrada encubierta, plaza alta, plaza baja, plaza superior, puente levadizo, puerta principal, través alto y través bajo.

\title{
B) Adjetivo + sustantivo
}

\begin{abstract}
Los compuestos sintagmáticos del tipo $<\mathrm{A}+\mathrm{N}>$ tienen un campo más restringido que los equiparables con el orden de los constituyentes invertido $(<\mathrm{N}+\mathrm{A}>)[\ldots]$. Ello se debe a que la posición habitual del adjetivo en español es pospuesta al sustantivo (en estructura adnominal o predicativa) y al tipo de elementos que aparecen prenominalmente en esa estructura" (Val Álvaro 1999: 4828).
\end{abstract}

Ello explica por qué, frente a los treinta y cuatro compuestos sintagmáticos adscritos al anterior esquema, sólo hemos hallado tres ejemplos con éste: medio baluarte, media gola y media luna. Los tres designan elementos de fortificación y en su constitución ha intervenido exactamente el mismo adjetivo.

\section{C) Sustantivo $+d e+$ sustantivo}

Aproches de guerra, arce del foso, arcén del foso, ballestón de torno, campo de la batalla, cuerpo de (la) guarda, cuerpo de guardia, cuerpo de (la) batalla, empresa de (la) guerra, facción de guerra, flanco del orejón, gente de armas, gente de (la) batalla, gente de guerra, gente de pelea, gente de socorro, hecho de armas, hombre de armas, hombre de (la) guerra, hombre de pelea, hombre de socorro, hombre de soldadesca, levantamiento de guerra, munición de guerra, munición del sustento, munición del victo, orden de (la) batalla, 
pertrechos de guerra, plaza de abajo, plaza de armas, plaza de arriba, puerta del socorro, roca de homenaje y torre de (l) homenaje.

“El sintagma preposicional hace referencia generalmente al rango categorial del sustantivo núcleo del mismo, por ello tiene tendencia a presentarse desprovisto de artículo" (Clavería y Torruella 1993: 328). En varios de nuestros compuestos (por ejemplo en campo de la batalla ${ }^{322}$, documentado sólo con el artículo, y en orden de (la) batalla ${ }^{323}$, que presenta ocurrencias tanto con artículo como sin él) la presencia reiterada del artículo probablemente indique el carácter inconcluso del proceso de fijación que experimenta cualquier combinación léxica compositiva.

De nuevo sobresalen las unidades léxicas que designan miembros o partes de una fortaleza: arce del foso, arcén del foso, flanco del orejón, plaza de abajo, plaza de armas, plaza de arriba, puerta del socorro, roca de homenaje y torre de(l) homenaje. Ahora bien, gracias sobre todo a la productividad de que gozan tanto el término hombre como gente en el desempeño de la función nuclear en este tipo de compuestos, son también numerosos los referentes a individuos o grupos militares.

\subsection{Unidades fraseológicas: locuciones adjetivales, adverbiales y verbales}

Las locuciones forman parte de las unidades fraseológicas del sistema de la lengua y poseen rasgos distintivos, como son la fijación interna y la unidad de significado. No constituyen enunciados completos, puesto que necesitan combinarse con otros signos lingüísticos y funcionan como elementos oracionales (cf. Corpas Pastor 1996: 88).

Como ya hemos expresado, las locuciones son las unidades fraseológicas con mayor grado de fijación e idiomaticidad, frente a las colocaciones y a los

\footnotetext{
322 "Sitio donde combaten dos ejércitos" (DRAE: s.v. campo de batalla).

323 "Situación o formación de las tropas o de una escuadra del modo más favorable, para poder hacer fuego contra el enemigo o para otros fines" (DRAE: s.v. orden de batalla).
} 
compuestos sintagmáticos. Consideramos, por tanto, que las estructuras sintagmáticas constituyen un grupo autónomo, aunque emparentado con el de las locuciones ${ }^{324}$. En cambio, para Corpas, la sintagmación se incluye dentro del conjunto de las locuciones:

Ante la falta de criterios adecuados que permitan deslindar claramente los compuestos sintagmáticos (sin unión ortográfica) de las locuciones, hemos decidido considerar compuestos a todas aquellas unidades léxicas formadas por la unión gráfica (y acentual) de dos o más bases; y locuciones, a aquellas unidades que, presentando un grado semejante de cohesión interna, no muestran unión ortográfica (Corpas 1996: 93).

Frente a este criterio, dado el frecuente traslado de unidades compositivas desde el campo sintagmático al léxico, no consideramos conveniente separar estas dos clases de formaciones, según ya hemos comentado.

Las locuciones se clasifican tradicionalmente en adverbiales, verbales, nominales, adjetivales, prepositivas y conjuntivas, según la función oracional que desempeñan ${ }^{325}$. De ellas, la terminología militar analizada sólo cuenta con las adverbiales, las verbales y las adjetivales.

Por lo que respecta a las primeras, registramos un total de dieciséis: en ala, a la avanguardia, en avanguardia, a caballero, a caballo, en campaña, en campo, a la deshilada, a escala vista, a escarpa, a escarpe, en hilera, a pie, en retaguardia, en rezaga y en vanguardia.

Como puede constatarse, todas ellas se componen de una preposición seguida de un elemento nominal, modalidad a la que pertenece la mayoría de las locuciones adverbiales del español (Pavón 1999: 614).

Estas locuciones están encabezadas por distintas preposiciones: a (a la avanguardia, a caballero ${ }^{326}$ 'a mayor altura', a caballo, a la deshilada 327 'con los

\footnotetext{
324 De acuerdo con Buenafuentes de la Mata (2007: 107), la distinción entre locuciones y compuestos sintagmáticos es una cuestión de grados.

325 "Locución es una expresión constituida por varias palabras, con una forma fija, que se utiliza en el habla como pieza única y que presenta el comportamiento típico de una determinada categoría gramatical" (Pavón Lucero 1999: 568).

326 "Assí, este último requisito es materia de los soldados viejos, de los que han campeado en exércitos a la cara de los enemigos, escogiendo siempre buena plaça de armas, de forma que esté a cavallero sobre la campaña y cortadas las avenidas que huviere" (Rojas 1598: 1v).
} 
soldados uno detrás de otro', a escala vista, a escarpa 328 'de modo escarpado', a escarpe y a pie), de (de caballo 329 'a caballo') y, por último, en (en ala330 'en fila', en avanguardia, en campaña, en campo, en hilera331 'en línea recta', en retaguardia, en rezaga y en vanguardia).

Por lo que respecta al significado, son numerosas las que ostentan un valor modal: a caballo, de caballo, a escala vista, a escarpa, a escarpe y a pie. En varias de estas unidades puede apreciarse, además, un valor de localización en el espacio, como en a la avanguardia, en avanguardia, a caballero, en retaguardia, en rezaga y en vanguardia.

"Las locuciones adjetivas o adjetivales son grupos lexicalizados que se asimilan a los adjetivos en su funcionamiento sintáctico" (Real Academia Española 2009: 1017). Del análisis de la terminología militar renacentista se obtienen ocho locuciones de este tipo: de a caballo 332 , de caballo, de gente 333 , de infantes ${ }^{334}$, de a pie $e^{335}$, de pie, de suelo ${ }^{336}$ y de(l) terreno ${ }^{337}$. Como puede constatarse,

327 "Si yo estuviesse dentro en la defensa, con la mitad de la gente, guardaré mejor esta frente pequeña que la grande, y le obligaré al enemigo que venga por estrecho y a la deshilada, con su gente y trinchea, y assí con las salidas que yo hiziere le haré mucho daño, por hallarle en camino estrecho" (Rojas 1598: 32v-33r).

328 "A la llanura a de seguir la caída del terrapleno hasta el llano de la fuerza, que a de ser $a$ escarpa de dos pies, el uno para que los soldados puedan subir por todo él" (Lechuga 1611: 240).

329 "Y si fuere de luenga morada, hagan carcavear en derredor el exército, y de noche pónganse sus guardas, assí a pie como de cavallo" (Celso 1553: CXXXVIv).

330 "El Gran Capitán con presteza increýble, dexando sola una frente de cavallería a la orilla contraria del río, la qual estendida en ala representava un campo entero, hizo partir por un barranco abaxo todo su campo y guiarlo por la ribera del río adonde estava el vado, por el qual pasó todo su campo y passaron todos con el artillería" (Collado 1592: 90v-91r).

331 "Tienen generalmente en las puertas árboles plantados en hilera, que tienen verdura todo el año, para que les hagan sombra y hermoseen las calles" (Escalante 1577: 36v).

332 'Dicho de un soldado o de una tropa: que realiza sus funciones a caballo'. "Fue tan poderosa en tiempo de los machabeos que Antíoco la çercó con ciento y veinte mill hombres de pie y ocho mill de a cavallo" (Apiano 1575: 44r-44v).

333 'Dicho del orden de batalla cuadrado: que el número de soldados que posee de frente es exactamente igual al de los de fondo'. "Para hazer qualquiera esquadrón quadro de gente, se tendrá por regla general sacar la raíz quadrada de qualquier número de soldados que huviere, y aquéllas serán las hileras de frente y de fondo que tendrá dicho el esquadrón" (Rojas 1598: 102r).

334 Sinónimo de de gente. “¿En qué forma se puede ordenar una batalla quadrada de suelo y no de infantes?" (García de Palacio 1583: 160v).

335 "Dicho de un soldado, de un guarda, de un montero, etc.: Que no van a caballo para su cometido" (DRAE). "Muchos que resuelven la qüestión que he propuesto son de parecer que la gente de a pie es más útil que la de a cavallo y que en los casos en que sucediere pelear los unos con los otros, desbaratará la infantería a la cavallería" (Álaba 1590: 68r). 
en todas ellas aparece la preposición de, "la más frecuente entre las que forman locuciones adjetivas" (Real Academia Española 2009: 1018). Por otro lado, las seis designan propiedades de tipo clasificativo o relacional, una de las posibilidades semánticas más habituales entre las locuciones adjetivas con el esquema de + sustantivo, como manifiestan los académicos.

Como muestra Buenafuentes de la Mata (2007: 92-93), en general, no se emplea la composición sintagmática para crear voces con categoría verbal, razón por la cual hay que considerar estas formaciones, más bien, o locuciones o colocaciones $^{338}$.

Si bien somos conscientes de que la distinción entre colocaciones y locuciones verbales es extremadamente compleja ${ }^{339}$, consideramos que las siguientes unidades pluriverbales son exponentes de las segundas, entre otras cosas porque presentan el comportamiento de la categoría verbal, además de que la mayoría de ellas están lematizadas en los repertorios lexicográficos del español, lo que normalmente no sucede con las colocaciones.

Dar (el) asalto 340 , levantar el asedio, meter (el) asedio, poner asedio, representar (la) batalla 341 , dar (la) batería ${ }^{342}$, dar bordos, dar bordos y ramos,

\footnotetext{
336 'Dicho del orden de batalla cuadrado: que la extensión de terreno que ocupa cada una de sus dos alas es igual, o casi, a la ocupada por la vanguardia o retaguardia'. "Y ésta es aún muy más apta a llevar entre los cuernos el carruaje o artillería y a pelear aventajadamente con los cuernos, guarnesciéndolos de los soldados escogidos, fuertes, animosos, diestros y bien armados, poniendo los no tales ni tan buenos en el esquadrón quadrado de suelo, que está en medio" (García de Palacio 1583: 171v).

337 Sinónimo de de suelo. "Quando se quiere que el esquadrón esté reforçado por todas partes con igual proporción, se ha de formar quadro de gente; queriendo reforçar la frente o retaguardia, combatiendo más soldados, se compone quadro de terreno" (Mendoça 1596: 55). 338 Uno de los rasgos principales en las colocaciones es el de la selección léxica: "un lexema determina la presencia de otro" (Ferrando Aramo 2002: 101), es decir, un elemento muestra una clara preferencia por combinarse con un elemento, por seleccionarlo entre otros. Para Corpas (1996: 66), la colocación es la "propiedad de las lenguas por la que los hablantes tienden a producir ciertas combinaciones de palabras entre una gran cantidad de combinaciones teóricamente posibles".

339 "Deslindar las unidades fraseológicas pertenecientes a la clase de las colocaciones de los fraseologismos que son locuciones no es tarea fácil, y menos cuando hay que llevarla a cabo sobre una lengua, como la española, que todavía no tiene una tradición suficiente de estudios sobre colocaciones" (Penadés Martínez 2001: 74).

340 "fr. asaltar" (DRAE: s.v. dar asalto).
} 


\begin{abstract}
tocar a botasilla34, sonar a caballo, poner en celada, alzar el cerco ${ }^{344}$, levantar el cerco345, poner (el) cerco346, estar en defensa347, poner en defensa ${ }^{348}$, poner en emboscada, hacer escolta, batir la estrada ${ }^{349}$, hacer (la) gente $^{350}$, tomar lengua 351 , dar rebato, hacer retirar352, poner en rota, dar a saco $^{353}$, dar el salto, alzar el sitio, levantar el sitio 354 , poner (el) sitio 355 , abrir trinchera 356 , ir de vencida ${ }^{357}$, llevar de vencida ${ }^{358}$, continuar el vencimiento, ejecutar la victoria ${ }^{359}$, proseguir la victoria y seguir la victoria.
\end{abstract}

Como puede observarse, todas nuestras locuciones verbales, excepto hacer retirar, se componen de un verbo y un sustantivo.

\footnotetext{
341 "fr. Mil. Desplegar las tropas ante las del enemigo, provocándolo al combate" (DRAE: presentar la batalla). "En las justas empresas podría ser permitido a sacerdotes o religiosos animar a soldados para entrar y representar batalla, y atemorizar con armas y usar de toda industria, porque por ninguna vía muestren flaqueza, pero anse de guardar de cometer con su mano propria homicidios, o cortar miembro" (Mosquera 1596: 72v).

342 "fr. ant. Combatir una plaza o un muro" (DRAE: s.v. dar batería).

343 "Sonner le boute-selle" (Sobrino 1705: s.v. tocar a botasela). "Vuestra Alteza mandará tocar a botasela a hora que venga a recogerse la gente al alva y sonar entonces a cavallo, tiempo en que estará en la plaça de armas el maestre de campo general, quartelmaestre, capitanes de guías y oficiales de su séguito" (Mendoça 1596: 68).

344 "fr. Apartarse, desistir del sitio o asedio de una plaza" (DRAE).

345 "fr. alzar el cerco" (DRAE).

346 "fr. Sitiarla o ponerle sitio" (DRAE: s.v. poner cerco a una plaza). "Prevendrá también, antes del principio de la guerra, si estuviere en tierra de amigos, que los que habitaren en lugares poco fuertes los desamparen y se recojan con todos sus mantenimientos en las ciudades o al lugar donde espera que se pondrá el cerco" (Álaba 1590: 50v).

347 "Hallarse en estado de resistir, como las fortificaciones reparadas, etc." (Fernández Mancheño 1822).

348 "Frase que explica apercibirse de armas o de otros medios para resistir y propulsar la violencia o fuerza que se intenta ejecutar, o se ha ejecutado, en la mejor forma que se puede" (Aut.: s.v. ponerse en defensa). "Y assí, trataré aora de poner una plaça en toda defensa, considerando que siempre voy hablando de un castillo de 5 valuartes, que tenga dentro 1.000 soldados de guarnición ordinaria, y que, junto con esto, se ha de entender ser plaça capaz de otros 2.000 hombres de socorro a una grande necessidad" (Rojas 1598: 71r).

349 "fr. Mil. Reconocer, registrar la campaña" (DRAE).

350 "fr. reclutar" (DRAE: s.v. hacer alguien gente). "El Rey, nuestro Señor, haze gente para Alger, entre la qual ay españoles, alemanes e italianos" (Aurel 1552: 96v).

351 "frs. Informarse, tomar o adquirir noticias" (DRAE: s.v. tomar lengua, o lenguas).

352 "Rechazar" (Terr.).

353 "fr. Saquear" (Pagés 1902-1931).

354 "fr. Desistir del de una plaza o fortaleza sitiadas" (DRAE).

355 "fr. Sitiar, asediar" (DRAE: s.v. poner sitio).

356 "1. fr. Mil. Empezar a hacerla. 2. fr. Mil. Comenzar los ataques de una plaza" (DRAE).

357 "Llevar la peor parte" (Terr.).

358 "Lo mismo que alcanzar o conseguir la victoria, el triunfo, el vencimiento" (Terr.).

359 "fr. ant. Ir ganando la victoria" (Salvá 1846).
} 
"Son muchas las locuciones verbales que se forman con verbos transitivos" (Real Academia Española 2009: 2649), lo que se constata en la terminología militar renacentista. Ello explica por qué los grupos nominales que contienen nuestras locuciones generalmente desempeñan la función de complemento directo del verbo al que siguen.

\section{Neología semántica}

De acuerdo con Gutiérrez Rodilla (1998: 144), entendemos por neología de sentido o neología semántica el "procedimiento neológico que consiste en dotar de un nuevo significado a una palabra ya existente".

\subsection{Préstamos semánticos}

El español moderno no sólo se vio enriquecido por las numerosas unidades léxicas del ámbito de la milicia tomadas en préstamo del italiano o del francés, sino que la preponderancia de estas dos importantes potencias hizo también posible la transferencia de sentidos. En este sentido, debemos destacar los numerosos préstamos semánticos de origen italiano o francés que integran el vocabulario seleccionado.

Uno de los casos más significativos es infante, vocablo datado en el Cid, pero cuya acepción de "soldado que sirve a pie" (DRAE) no se registra hasta el siglo XVI ( $c f$. DECH). Para Corominas y Pascual resulta claro que se trata de una voz patrimonial que ha conseguido ampliar a lo largo de su historia sus posibilidades designativas:

Infante, del lat. infans, -tis, 'incapaz de hablar', 'niño de mantillas, niño pequeño', derivado de fari 'hablar' [...]. La ac. 'soldado de infantería' se tomó del it. fante, que además de 'muchacho, mozo' significaba 'servidor, criado' y de ahí pasó al significado militar $(\mathrm{DECH})$.

Pero hasta que ese intercambio no tuvo lugar -“h. 1550, D. Gracián” (DECH: s.v. infante)-, el castellano hubo de disponer de algún medio eficaz para poder hacer referencia a esa realidad militar, y éste fue el papel que durante 
mucho tiempo desempeñó peón ${ }^{360}$, voz popular que procede del latín vulgar pedo, -onis (DECH: s.v. pie). Si tenemos en cuenta que “durante la Edad Media, la caballería llegó a convertirse en la principal fuerza militar del Occidente cristiano" (Campillo 20082: 26) y que, aunque sí había tropas de a pie, éstas eran consideradas simplemente una fuerza auxiliar, no debe sorprendernos que, al producirse en el Renacimiento el reconocimiento de esta modalidad de soldados (ápud Maravall 1972), el castellano decidiera dotar a infante, término que ya formaba parte de su caudal léxico, del significado militar que ostentaba su equivalente en italiano. De este modo, nuestra lengua consiguió evitar las connotaciones negativas asociadas a peón fruto de la escasa participación de este tipo de guerreros en los conflictos bélicos medievales. Además lo hizo recurriendo de nuevo a la lengua de prestigio en materia militar, el italiano. En palabras de Malkiel (1951: 220),

el peón medieval español, humilde descendiente del soldado profesional romano, vivía de trabajos de ocasión, incluyendo la guerra (principalmente contra el moro), en que intervenía al margen de la fuerza regular de jinetes, como elemento adventicio.

Por tanto, en el momento de mayor prestigio de los soldados de a pie, se decidió que referirse a ellos mediante un término tan negativo como peón no era lo más adecuado.

En contraposición, al no existir ningún término que hiciera alusión al sentido colectivo, el castellano se vio obligado a tomar en préstamo el it. infanterìa (ahora fanterìa), incorporándose tanto el significante como el significado.

Por otro lado, según Corominas y Pascual (s.v. estrado), la voz patrimonial estrada, procedente del lat. strata o strata via 'camino empedrado', tuvo una "escasa frecuencia en la Edad Media (sólo en Alex. y en APal.) y, así, desde la segunda mitad del s. XVI (Fr. Luis de Granada), esta palabra muerta volvió a tomarse del it. strada, especialmente como vocablo militar y de

\footnotetext{
360 Sobre la historia lingüística de peón, vid. Malkiel (1951). Por lo que respecta a nuestro corpus, son varias las ocurrencias de peón, si bien resulta evidente la predilección de los tratadistas por la voz infante.
} 
fortificaciones". Estamos ante otro préstamo semántico y, de nuevo, debido al italiano. Quizá ésta sea la razón de que Terlingen señale estrada al hablar de los italianismos del español referentes a obras de fortificación (cf. 1967: 282).

En opinión de López Vallejo, la acepción de fajina de la que damos cuenta en nuestro glosario es también resultado de la apropiación, por parte de nuestra lengua, del sentido de fortificación con el que ya contaba el italiano fascina:

\begin{abstract}
Creemos que nos encontramos ante un italianismo semántico incorporado en el terreno militar a partir del s. XVI sobre un significante (fagina / faxina) que ya desde el s. XIV empleaba nuestra lengua con el sentido etimológico de 'haz, conjunto de ramas', aunque no fuese para un uso relacionado con la fortificación (López Vallejo 2008: s.v. fajina).
\end{abstract}

Esta investigadora apunta que ésta parece ser también la opinión de los académicos, puesto que el paréntesis etimológico del DRAE señala dicha influencia: "De un der. del lat. fascis, infl. por el it. fascina".

Ante la falta de una forma exacta del latín de la que derivaría fajina y la posible consideración de que ésta tan sólo sea una variante gráfica de hacina, hemos decidido finalmente tratar el vocablo castellano fajina como un italianismo léxico ${ }^{361}$, si bien somos conscientes de la disparidad de opiniones existentes.

En la nómina de palabras de origen italiano ofrecida por Terlingen (1967), constatamos cortina. Ésta cuenta con el sentido de 'paño con que se cubren puertas, ventanas, camas, etc.' en Berceo, sin embargo los primeros testimonios de 'porción de muralla comprendida entre dos baluartes' no aparecen hasta mediados del siglo XVI (cf. López Vallejo 2008: s.v. cortina), por lo que probablemente se trate de un préstamo semántico.

Otro de los italianismos enumerado por Terlingen (1967: 282) es explanada ${ }^{362}$. En este sentido, López Vallejo (2008: s.v. explanada) puntualiza que estamos ante un préstamo semántico, y, concretamente, en su acepción de fortificación, que define así: “Declive que va desde el parapeto del camino

${ }^{361}$ De este modo, hemos establecido en su correspondiente artículo lexicográfico que procede del it. fascina 'íd.', voz que, a su vez, deriva de fascio 'haz' (cf. DECH: s.v. haz I).

362 "Del lat. explanāta, allanada" (DRAE). 
cubierto de la fortaleza hacia el campo raso donde no hay construcción". Por lo que respecta a nuestra investigación, como estamos convencidos de que en el corpus manejado explanada no designa esa realidad ${ }^{363}$, sino otras bien distintas, que, además, tienen como principal característica la existencia de una superficie llana y lisa, concluimos que ninguna de las acepciones de explanada de las que nos hemos hecho eco en el glosario responde a una neología de sentido.

Por otro lado, en el Tesoro della lingua italiana delle origini (TLIO) puede comprobarse cómo ya en la primera mitad del siglo XIV el verbo italiano accampare contaba con el significado militar de "sistemarsi per una permanenza provvisoria in campo aperto, mettere l'accampamento", en cuya acepción funcionaba generalmente como pronominal ${ }^{364}$. 1548 sería, en cambio, la fecha exacta de la primera aparición de este sentido militar en nuestra lengua, según López Vallejo (2008: s.v. acampar). En palabras de esta investigadora, "si se tiene en cuenta que la voz acampar se empleaba en la época medieval con el sentido de 'enfrentarse en descampado o en mar abierto al enemigo', hemos de precisar que con el nuevo sentido de 'asentar el real' nos encontramos ante un italianismo semántico introducido en el s. XVI".

Otro ejemplo lo constituye puesto, sobre cuyo empleo sustantivo:

interesa saber que el fr. poste no aparece h. 1500, como decía Bloch en su 1. ${ }^{a}$ edic., sino solamente en el s. XVII, y en opinión de Wartburg, ZRPh. LXVI, 448, es préstamo del italiano (DECH: s.v. poner).

Nuevamente nos encontramos ante otro de los numerosos préstamos semánticos existentes en el vocabulario castellano de la milicia moderna. Completan esta lista, en opinión de López Vallejo (2008a), tanto el sentido de manga que ofrecemos en nuestro glosario ${ }^{365}$, como el de munición ${ }^{366}$, además de, por último, la primera de las dos acepciones de fortificación propuestas para

\footnotetext{
363 Para ello, los tratadistas disponían ya de varias etiquetas designativas: arce del foso, arcén, arcén del foso, árgine y vallado3.

364 En nuestro corpus los únicos ejemplos que hay de este verbo también muestran un uso pronominal.

365 'Cada una de las agrupaciones de infantería que, provistas de armas de fuego, normalmente arcabuces y mosquetes, se establecen fuera de un determinado orden de batalla para reforzarlo'. 366 "Pertrechos y bastimentos necesarios en un ejército o en una plaza de guerra" (DRAE).
} 
reparo $^{367}$. Ahora bien, esta autora tampoco descarta la posibilidad de que las acepciones tácticas de batalla las haya tomado en préstamo nuestra lengua del italiano ${ }^{368}$, lo que, a su parecer, también podría haber ocurrido con el sentido de 'parte de un baluarte' de frente, si bien admite que en este último caso la filiación podría ser en realidad francesa. Por su parte, el DECH afirma que con frente "como término de fortificación, por imitación del francés, se introdujo el género masculino en castellano, que luego se ha extendido a otros usos militares y más recientemente políticos", por lo que parece que Corominas y Pascual se decantan por esta segunda posibilidad. Debemos poner de manifiesto que no hemos hallado en nuestro corpus ni un solo ejemplo de frente con género masculino, y mucho menos en la acepción que nos ocupa.

“Como término de fortificación, el sustantivo fuerte (1595, Fuenmayor) pudo imitarse del fr. fort (1265)" (DECH), lo que confirmaría que en el origen de algunas neologías de sentido del vocabulario militar castellano podemos encontrar también al francés.

Por otro lado, al considerar que cuartel se trata de un catalanismo cuyas primeras manifestaciones no tienen nada que ver con la milicia, en el caso de la acepción de 'alojamiento de una tropa en campaña', Corominas y Pascual (s.v. cuarto) hablan de préstamo francés. Frente a esta solución, consideramos con Varela Merino (2009) que estamos en realidad ante un galicismo léxico o total y, además, en todos sus valores, no sólo en el militar.

Por último, podría también deberse a la lengua francesa, al menos, la segunda acepción de galería que ofrecemos (cf. López Vallejo 2008: s.v. galería).

En resumen, a la luz de los préstamos semánticos examinados, podemos concluir con lo esbozado por Gutiérrez Rodilla (1998: 146):

La mayoría de los tecnicismos creados en los primeros momentos de existencia de un área de conocimiento, suelen tener este origen [el de la neología de sentido] más que el de la neología de forma.

\footnotetext{
367 'Cualquier construcción que sirve para proteger un lugar o una posición de un ataque', concepto al que también pueden referirse otras muchas unidades léxicas, como defensa, defensión, fortificación y muralla.

${ }^{368} \mathrm{Al}$ registrarse esos significados en el italiano de la Edad Media (cf. López Vallejo 2008: s.v. batalla).
} 
Para esta investigadora, los términos que, procedentes del lenguaje común, pasan al especializado en virtud de distintos tipos de analogías constituyen también excelentes manifestaciones de la neología de sentido.

\subsection{Metáforas}

“La metáfora es el puente que permite el paso desde el vocabulario general al especializado y facilita la designación y el reconocimiento de realidades que, de otro modo, serían difíciles de nombrar y etiquetar" (Sánchez Martín 2009: 280).

En primer lugar, corroboramos cómo ya el latín recurrió al procedimiento de la metáfora en la ineludible tarea de dar nombre a cada uno de los ingenios bélicos que se iban inventando. Resulta evidente, por ejemplo, en scorpio $^{369}$ (cast. escorpión) y en lǔpus (cast. lobo y lupo), puesto que, aparte de hacer referencia a máquinas de guerra, también designaban dos animales de naturaleza sumamente violenta y agresiva, lo que explica que más tarde este matiz semántico lo adquirieran esos dos artilugios.

Ahora bien, esta transferencia semántica se constata en otros términos: ariete, onagro, testudo (o testúdine) y músculo 370.

Asimismo, la metáfora corporal actúa en el léxico militar en casos como boca, costado, diente y espalda. Y es que, en palabras de Mancho Duque (2005: 791), “entre las metáforas destacan, por su importancia en la formación de terminologías específicas de las ciencias y de las técnicas, las denominaciones de partes del cuerpo humano trasladadas a las de diversos objetos, en virtud de cierto parecido o similitud".

\footnotetext{
${ }^{369} \mathrm{El}$ término latino scorpio, -ōnis 'íd.' deriva a su vez del gr. бхорліоऽ, por lo que es posible que el significado metafórico de 'máquina de guerra' existiese ya en esta segunda lengua.

370 vid. Segura Munguía (2007: s.v. ărĭes, -ětis; mūscŭlus, -ī; ŏnăgěr [-grus], -grī y testūdō, -ĭnis), en donde se deja claro que cada una de estas voces latinas, que constituyen el étimo de las correspondientes castellanas, contaba ya con esa doble significación de 'animal' y 'máquina bélica cuya principal característica recuerda a la de ese animal'. Por otro lado, para conocer alguna otra metáfora animal del léxico de la milicia, vid. López Vallejo (2007).
} 
Si bien son menos habituales, debemos destacar los tecnicismos generados a partir del parecido o semejanza con algún objeto de la vida cotidiana: camisa, manta, rastrillo, tenaza, tijera, etc.

\subsection{Metonimias}

Igualmente, en la conformación del léxico militar son relevantes algunos esquemas metonímicos, como el consistente en denominar con el nombre del lugar donde se desempeña una determinada función o cometido a la persona encargada de realizarlo. Así, campo, además de designar el 'terreno que ocupa o por el que transita una tropa o una fuerza durante alguna empresa u operación de guerra', podía asimismo aplicarse a la 'tropa o ejército que se halla en operaciones de guerra'. Lo contrario ocurre en atalaya, ya que, mientras que del árabe, además del término, tomamos el sentido de 'centinela', es en castellano cuando por extensión metonímica pasa a poseer también el significado de "torre destinada a vigilar desde ella la lejanía" (DUE).

Otra solución metonímica opera cuando es necesario nombrar una acción bélica o una función esencial dentro de la milicia, a la vez que a las personas que la desempeñan. En este caso, celada designa tanto el 'ardid de guerra que consiste en ocultar gente en un lugar para una operación militar o para asaltar a alguien' como la "tropa apostada en lugar oculto para sorprender al enemigo" (Alemany y Bolufer 1917: s.v. emboscada). Asimismo, diana es el 'toque o música que se hace al comienzo de la jornada, para despertar a la tropa', pero también es el 'soldado encargado de hacer sonar la diana'. También constatamos la misma metonimia en ronda, al designar el 'recorrido de los distintos puestos de centinelas que hay en una plaza o campamento, para verificar que el trabajo de éstos se desempeña correctamente', así como el 'grupo de soldados encargado de rondar o recorrer los puestos de centinelas de una plaza o campamento'.

Finalmente, el uso de caballo con el sentido de 'caballero' responde al proceso metonímico basado en tomar el nombre del instrumento como designación del correspondiente agente. 


\title{
5. Otro mecanismo neológico: el calco
}

Para Gómez Capuz (1998: 61), “el calco consiste en reproducir en la lengua receptora, por síntesis y mediante unidades existentes en esta lengua, un elemento que tenga la misma articulación estructural y la misma motivación semántica del modelo extranjero". De acuerdo con este planteamiento, consideramos que, a diferencia del préstamo francés pitipié371, la unidad pluriverbal pie pequeño (o pequeño pie) responde más bien a un proceso de calco, situación lingüística de la que da buena cuenta Cristóbal de Rojas (1598: 35v): «El pitipié es nombre francés, que "peti” en francés quiere dezir 'pequeño' o 'chico', y assí es lo mesmo dezir en nuestra lengua castellana pequeño pie, como en francés "pitipié"»».

En la detección de otro posible calco, infante perdido, ha resultado fundamental la explicación de Albi de la Cuesta (2005: 115):

\begin{abstract}
Una última especialidad a la que hay que hacer referencia, aunque realmente se trataba de un Arma mixta, a medio camino entre la caballería y la infantería, era la formada por hombres que se desplazaban montados en el campo de batalla pero que combatían a pie. Los españoles destacan como una gran novedad a este tipo de soldados, que encontraron por primera vez en las campañas de Francia de fines del XVI, bajo el nombre de dragones, y a los que describieron como «mosqueteros en rocines». No obstante, se muestran poco impresionados, tan poco como los propios franceses que les llamaban "enfants perdus".
\end{abstract}

Creemos que es sumamente probable que la combinación léxica infante perdido esté emparentada con la francesa enfant perdu de la que habla este autor, pues, aparte de su evidente semejanza formal, parecen designar exactamente lo mismo.

${ }^{371}$ Del fr. petit pied, como consecuencia de la locución adverbial au petit pied 'en pequeño' (cf. DECH: s.v. pepitoria). 


\title{
6. Recursos lingüísticos para la divulgación de los neologismos
}

\subsection{La definición}

Debemos resaltar el hecho de que muchos tecnicismos aparecen acompañados de una definición, lo que delata su carácter neológico:

\begin{abstract}
El árgine, que es el terreno que tiene principio de la estrada encubierta y fin en la misma campaña a la parte de afuera, que va siempre a escarpa, tanto quanto fuere necessario para consumir la tierra que se saca del fosso después de dada la que a menester la fuerza, a de tener, por lo menos, veinte pies desde el parapeto de la estrada cubierta de la más llanura que se pudiere (Lechuga 1611: 241).
\end{abstract}

Se entiende por un césped lo mismo que un pedaço de tierra que no esté cultivado, y cada uno suele tener un pie en quadrado y medio de alto, y otros menos y más (Rojas 1598: 52r).

Plataforma, entre los ingenieros es [...] un edificio o máquina y género de defensa que se acostumbra de hazer de fábrica en el medio de la cortina de qualquier fortaleza y entre una casamata y la otra, las quales, por la mayor parte, se hazen y toman la figura de una planta exágona, que es aquélla que de 6 ángulos se forma (Collado 1592: 57v).

Solamente entiendo de aquellas plataformas sobre las quales, según diximos, juega el artillería, y se hazen de madera para que las ruedas de las pieças no se hundan y se atasquen en el suelo con el continuo tirar que en semejantes tiempos se ha usado (Collado 1592: 57v).

Ahora bien, dado que, según reflejamos en el glosario, plataforma cuenta con hasta cinco acepciones relevantes en la milicia, es posible que, más que por tratarse de un neologismo, Collado haya recurrido a las definiciones como un mecanismo eficaz de anunciar a sus lectores a cuál de todas esas realidades se refiere ${ }^{372}$.

\footnotetext{
${ }^{372}$ Las dos definiciones que ofrecemos en nuestro glosario como ejemplos de pina y toro pertenecen a un grupo bien distinto, pues están tomadas del vocabulario que compuso Urrea tras su traducción de la obra de Vitruvio De Architectura. Sobre éste y otros glosarios específicos, científicos y técnicos, que acompañaron a obras traducidas, vid. Carriazo Ruiz y Mancho Duque (2003).
} 


\title{
6.2. La reformulación léxica
}

Además de las definiciones, también son frecuentes en las obras estudiadas las reformulaciones léxicas, que normalmente se construyen con las distintas formas del verbo llamar, si bien es posible encontrar algún que otro ejemplo de paráfrasis explicativa creada a partir del verbo decir ${ }^{373}$.

No se le puede dar buen costado o espalda (como llaman los que tratan d'esta professión) al baluarte, de manera que las casas matas estén seguras (González de Medina 1599: 13-14).

Otro género ay de ofender, y batería, que se haçe por debaxo de tierra, qu'es la que llaman mina o cunículo, que quiere dezir conegera (Roxas 1607: 46r-46v).

A cuya causa, los que con más seguridad en saber esto procedían, embiavan esploradores, que son los que comúnmente llamamos espías, dando este oficio a los soldados de más esperiencia y entendimiento (Álaba 1590: 52r).

Campeando se embían de ordinario, y en particular quando se está algo lexos, gruessas tropas de cavallería para reconocer el un campo al otro encomendándolas a soldados de pecho y cuerdos, y con esto vienen a hazerse facciones, que se llaman rencuentros (Mendoça 1596: 110-111).

Estos sirven para asigurar el bastimento al real y que bayan los que llevan el bastimento, que en este tiempo se llaman bibanderos, porque llevan bíberes (Roxas 1607: 33r).

Si tenemos en cuenta que el origen de la Teórica y práctica de fortificación se encuentra en las lecciones que su autor, Cristóbal de Rojas, impartió en la Academia Real Matemática374, no resulta extraño que este tipo de aclaraciones aparezca en este tratado con cierta asiduidad ${ }^{375}$. Veamos algunas:

\begin{abstract}
$\mathrm{Si}$, por el contrario, no huviesse estos maderos en el sitio donde se haze la fábrica, y por escusar mucho gasto, se hará una docena de cavallos de madera, que quiere dezir cabrillas (Rojas 1598: 51r).
\end{abstract}

A este pitipié le llaman muchos escala, y los estrangeros ponen en sus traças por medida de petipié, canas, dándole diez palmos de valor a cada una (Rojas 1598: $36 r)$.

\footnotetext{
373 En relación con este asunto, pero centrado en el vocabulario geométrico renacentista, vid. Sánchez Martín (2009) y (2011).

374 A este respecto, vid. Sánchez Martín y Sánchez Orense (2009).

375 "El mecanismo de la reformulación es el procedimiento más productivo y característico del discurso científico y suele manifestarse unido al esfuerzo divulgador de ciertas disciplinas" (Sánchez Martín 2011: 137).
} 
Como manifiesta el siguiente pasaje, las reformulaciones se deben, en otras ocasiones, al deseo del tratadista de ofrecer, en aras de una mejor comprensión, el equivalente castellano de algún tecnicismo recientemente incorporado:

La escarpa, que es la que en España llamamos lambor, que han de tener estas fábricas de faxina y tierra, es ésta: que por cada seys pies, o palmos, o varas de alteza se le da una de scarpa (Collado 1592: 92r) ${ }^{376}$.

\section{Las relaciones semánticas}

Las relaciones semánticas, tanto sinonímicas como polisémicas, constituyen el rasgo más destacado del léxico militar recopilado, y eso a pesar de que, como suelen señalar los distintos estudios sobre los lenguajes de especialidad, la univocidad ${ }^{377}$ es una de las principales características de cualquier terminología:

En teoría, los términos, a diferencia de las palabras del léxico común, son unidades unívocas (la relación entre forma y concepto es única) y monorreferenciales (un término solo designa un objeto) (Cabré 1993: 213).

Ahora bien, como esta misma investigadora admite, "teoría y realidad [...] no siempre corren parejas, y la terminología no es una excepción a este principio" (Cabré 1993: 213).

Así, aun cuando la precisión, la neutralidad y la estabilidad son las propiedades más repetidas a la hora de hablar del léxico técnico, "los términos constituyentes de cada terminología se saltan con frecuencia alguno de estos rasgos, lo que origina no pocos problemas en el uso cotidiano" (Gutiérrez

\footnotetext{
376 Luis Collado de Lebrija trabajó como técnico de las tropas españolas en Italia y, antes del tratado del que extraemos esta cita, publicó en italiano una obra con el título Platica manuale di artigleria (cf. López Piñero et alii 1983: s.v. Collado de Lebrija, Luis). No resulta extraño que, en detrimento del arabismo alambor, emplee con más frecuencia el italianismo escarpa: "Escarpa, 'declive que forma la parte inferior de la muralla de una fortificación hasta el foso', del it. scarpa 'íd.', de origen incierto, quizá derivado de scarpa 'zapato' por comparación con el declive que forma el pie de una bota bajo su caña" (DECH).

377 "Relación unívoca entre concepto y denominación significa que a cada expresión le corresponde un solo contenido conceptual" (Arntz y Picht 1995: 145).
} 
Rodilla 1998: 94). Pues bien, de los varios fenómenos cuya simple presencia en el discurso especializado puede complicar su interpretación, subrayamos, en primer lugar, la sinonimia, seguida de la polisemia y la homonimia.

\subsection{Sinonimia}

Si tenemos en cuenta que en los períodos iniciales de cualquier disciplina científica o técnica es cuando la necesidad de hallar denominaciones precisas para los nuevos conceptos resulta más apremiante, no debe parecernos extraño que para la formación de los nuevos términos se acuda de manera simultánea a diversos mecanismos neológicos, lo que, inevitablemente, "lleva aneja la concurrencia sinonímica" (Gutiérrez Rodilla 1998: 95). En este sentido, Arntz y Picht (1995: 160) reconocen que "hay un gran número de sinónimos en los vocabularios de aquellas áreas de especialización en las que se producen importantes progresos", lo que, sin lugar a dudas, ocurre en los primeros momentos de la fortificación abaluartada, por mencionar sólo una de las disciplinas tomadas en consideración.

En el momento histórico que nos ocupa, los neologismos por préstamo fueron el recurso lingüístico más explotado ante la necesidad de denominar las nuevas realidades que iban apareciendo en el ámbito de la milicia. Y es lógico que tanto los italianismos como los galicismos sean los préstamos más representados en esta investigación, ya que Italia y Francia fueron las potencias cuya presencia resultó más habitual en los distintos escenarios bélicos del Renacimiento, además de que los principales avances en esta área del saber tuvieron su origen en estas naciones ${ }^{378}$. Asimismo, los continuos contactos de

\footnotetext{
378 En el vocabulario que conforma la macroestructura de nuestro glosario, sin contar otro tipo de influencias, como pueden ser las semánticas, por ejemplo, constatamos la existencia de 47 italianismos y de 35 galicismos, lo que supone que, tras los recibidos de la lengua madre, el italiano, primero, y el francés, después, sean las lenguas más importantes en la configuración del léxico militar castellano.
} 
algunos españoles con franceses e italianos posibilitaron muchos de estos trasvases léxicos 379 .

Constatamos que para referirse a la "fábrica de tierra apretada y oprimida con que se llena algún vacío o se levanta para defensa" (Aut.) los distintos autores vacilan entre la voz terrapleno, de origen italiano ${ }^{380}$, o terraplén, de ascendencia francesa ${ }^{381}$. Como señala Gutiérrez Rodilla (1998: 95), en situaciones como ésta "el paso del tiempo es el que favorece la estabilización de unos términos, mientras que otros se van esfumando". Curiosamente, la forma que goza de mayor vitalidad en los textos manejados no es la que finalmente acabó por imponerse. Así, terraplén cuenta sólo con tres ocurrencias, frente a las 208 de terrapleno ${ }^{382}$. En relación a la denominación de este nuevo elemento defensivo, por consiguiente, nuestro corpus refleja la preferencia por el empleo del italianismo en detrimento de la forma gala, situación contraria a la acontecida más adelante si tenemos en cuenta que fue el galicismo el que acabó triunfando al final. Ahora bien, hasta ese momento de la historia de la lengua española los vocablos terraplén y terrapleno funcionan como sinónimos, lo que manifiestan -si bien tímidamente- las obras estudiadas.

Otro miembro de las nuevas fortificaciones abaluartadas origina una nueva concurrencia sinonímica. En este caso, la necesidad de nombrar la parte del baluarte que une su frente con la cortina conduce a la coexistencia del

\footnotetext{
379 "En la segunda mitad del siglo XVI y durante el transcurso del siglo XVII la presencia constante de las tropas españolas en los Países Bajos va a permitir la incorporación de un amplio número de términos militares en el español, procedente del francés de Flandes y de sus variedades regionales: el picardo y el valón" (López Vallejo 2008a: 135). No obstante, las costumbres españolas dejaron profunda huella en la población flamenca, de ahí que, como señala Vidos (1972: 235), "el dominio cultural francés encontró en el castellano una viva competencia".

Sobre la influencia italiana, Terlingen (1967: 278) apunta que "el vocabulario militar, tomado en sentido lato, ha sido enriquecido mucho por las expediciones militares de los españoles en Italia, ya desde fines del siglo $\mathrm{XV}^{\prime \prime}$.

380 "Del it. terrapieno, como término de fortificación" (DECH: s.v. tierra).

381 “Del fr. terre-plein (1561), como término de fortificación" (DECH: s.v. tierra).

382 Además, esos tres ejemplos de terraplén proceden todos de la misma obra, concretamente del Tratado de artillería de Diego Ufano, ingeniero militar cuyo contacto con la lengua francesa fue constante, pues trabajó al servicio del ejército español en Flandes bajo las órdenes del general de artillería Luis Velasco (cf. López Piñero et alii 1983: s.v. Ufano, Diego).
} 
italianismo fianco ${ }^{383}$ con el galicismo flanco $^{384}$. De nuevo en esta ocasión fue la forma gala la que acabó por imponerse con el paso del tiempo ${ }^{385}$.

En cambio, en el caso de la pareja formada por asalto ${ }^{386}$ e interpresa ${ }^{387}$ finalmente triunfó el italianismo, en consonancia, además, con lo manifestado en la tratadística estudiada. Si bien es cierto que la acepción de 'ataque impetuoso y decisivo contra un lugar fortificado' no es la única que ostentan ni asalto ni interpresa ${ }^{388}$, creemos que el hecho de que la primera cuente con 194 ocurrencias frente a las 11 de interpresa, resultado de sumar las que poseen sus distintas variantes ${ }^{389}$, es ya una prueba irrefutable de la excelente vitalidad de la que gozaba asalto.

383 En el diccionario de Tommaseo y Bellini (1861-1879) fianco se define como el "lato que congiunge la faccia del bastione alla cortina", y se indica, además, que ya usaba este término Galileo.

384 "Flanco, del fr. flanc 'costado, ijada' y éste del fráncico *hlanca" (DECH). Según Varela Merino (2009), con el sentido de 'parte lateral del cuerpo' aparece ya en la Chanson de Roland, mientras que, por lo que respecta a los usos militares de flanc, los primeros ejemplos datan de mitad del siglo XVI. Para el DECH, por su parte, la primera documentación de este término en castellano se remonta a principios del siglo XVIII (h. 1700, Mateo Ibáñez). Sin embargo, nuestro corpus militar adelanta casi en un siglo esta fecha: año 1613, Tratado de la artillería de Ufano.

385 Ahora bien, conviene que advirtamos que en nuestro corpus fianco y flanco no son realmente sinónimos, pues, mientras que fianco se refiere a uno de los elementos más característicos de los baluartes, flanco alude a un trozo o segmento muy concreto de las murallas renacentistas: "Cuando la línea de defensa rasante ["linha constituída pela rasante à face do baluarte e seu prolongamento para o lado da cortina" (Lopes Pires Nunes 2005: s.v. linha de defesa rasante)] cortaba a la cortina en un punto distinto del encuentro del flanco, el espacio de cortina comprendido entre estos dos puntos recibía el nombre de flanco de la cortina o segundo flanco" (Díaz Capmany 2004: 33). Por tanto, fianco y flanco, los dos términos tomados en préstamo por el castellano del italiano y del francés, respectivamente, no son sinónimos al haberse repartido sus posibilidades designativas. $Y$, frente a fianco, flanco cuenta asimismo con aplicaciones en el ámbito de la táctica, de lo que es buena muestra la siguiente acepción que recogemos en nuestro glosario: 'Espacio o faja de terreno que, en cualquier orden de batalla, se extiende a partir del último hombre situado en el ala o costado de esa formación'.

386 «Del it. assalto, derivado de assalire 'asaltar', lat. assalire (clás. assilire) 'atacar', derivado del lat. salire 'saltar'» (DECH: s.v. saltar).

387 "Interpresa, término militar, del fr. entreprise" (DECH: s.v. prender).

388 Dentro del ámbito militar asalto designa también el 'ataque repentino y por sorpresa contra una persona o grupo'. Pero el caso más curioso es, sin duda, el de interpresa, puesto que, aparte de la acepción ya mencionada de 'ataque impetuoso y decisivo contra un lugar fortificado para entrar y apoderarse de él', puede aludir también a un combate o a cualquier otra operación militar llevada a cabo en una guerra, esto es, a una empresa, término que, de nuevo, procede del italiano.

${ }^{389}$ Consideramos, al igual que López Vallejo (2008: s.v. interpresa), que las formas documentadas en nuestro corpus antepresa, entrepresa e ynterpresa son simplemente variantes del lema interpresa: "La voz francesa entreprise se incorporó en nuestro idioma como tecnicismo militar que adoptó distintas manifestaciones formales, entre las que destacan interpresa, antepresa y entrepresa. Dichas variantes [...] no obedecen a ningún criterio semántico ni geográfico, sino al capricho del autor que las emplea y a la falta de fijación en nuestra lengua del extranjerismo en 
Otras dos voces sinonímicas son asediar y sitiar, que deben su presencia en la lengua militar española al italiano ${ }^{390}$ y al occitano ${ }^{391}$ respectivamente. Ahora bien, para referirse a la acción bélica consistente en rodear un lugar fortificado con el fin de forzar la rendición de quienes están en su interior, los autores de las obras estudiadas, aparte de asediar y sitiar, hacen uso de cercar, cuyo origen, en este caso, es popular ${ }^{392}$. Podemos afirmar, además, que las locuciones verbales formadas por un verbo soporte y el sustantivo de acción correspondiente son también habituales en este tipo de tratados: meter (el) asedio, poner (el) cerco y poner (el) sitio, por citar sólo algunas. En esta ocasión, por consiguiente, nos hallamos frente a una larga cadena de sinónimos.

La existencia en castellano de asediar y sitiar demuestra, por otro lado, que fue tal el prestigio alcanzado por Italia y Francia, que se tomaron en préstamo varios de sus términos, incluso en ocasiones en las que no era preciso.

Así, a pesar de la capacidad que ya poseía nuestra lengua para hacer alusión, mediante la voz salida, tanto a la 'operación de guerra llevada a cabo por un grupo de sitiados', como al 'lugar, generalmente oculto, por el que pasaban para realizar esta empresa', el galicismo surtida ${ }^{393}$ haya llegado a engrosar el vocabulario español de la milicia.

Por su parte, se tiene constancia de que desde el Cid, tanto cometer como su variante morfológica acometer eran las alternativas ofrecidas por el español para referirse a lo que en la actualidad designamos mediante el vocablo atacar

sus primeros años de vida. Entre la tres, la forma triunfante sería interpresa por la influencia del prefijo heredado del latín inter- y es la que registrarán las obras lexicográficas españolas".

390 Asediar se trata de un derivado de asedio, pero éste, pese a contar con un posible antecedente latino -la forma obsĭdium-, en palabras de Corominas y Pascual (s.v. asedio), "puede sospecharse que [...] sea italianismo ya antiguo, puesto que en italiano, donde no hay sinónimos concurrentes como nuestros cerco y sitio, es de uso más general y más antiguo". Según el DECH, la primera documentación de asediar es de 1569 (Ercilla), mientras que la de asedio está fechada hacia 1460 (poema de Diego de Burgos, secretario del Marqués de Santillana, llorando la muerte de éste, ocurrida en 1458).

391 Para el DECH (s.v. sitio) la explicación más lógica sobre el origen de sitiar es que se trata de una adaptación occitana del bajo latín situare. Por otro lado, por lo que respecta a la primera documentación, Corominas y Pascual sostienen que "sitiar 'sitiar' y 'situar' está en el aragonés Fdz. de Heredia, Grant Crónica; Cov.; Oudin; ejs. del s. XVII, en Aut.".

392 «Cercar (1099: Cuervo, Dicc. II), del lat. tardío črrcare 'dar una vuelta, recorrer'» (DECH: s.v. cerco).

393 "Del fr. sortie. Surtida 'salida de los sitiados', 'paso secreto para salir de una plaza'. Ya en autores del s. XVII (Aut.)" (DECH: s.v. surtir). 
(cf. DECH: s.v. meter). En las obras consultadas, mientras que la forma primitiva ya no tiene cabida, la prefijada acometer disfruta de una excelente vitalidad ${ }^{394}$. Y parece por el siguiente ejemplo que es en el siglo XVI cuando, con respecto a esta designación, las posibilidades léxicas de nuestra lengua se ven ampliadas:

Lo mismo se ha de procurar en el componer un exército en batalla; y si es para representación, darle la forma según el sitio, y a los esquadrones con que la hagan mayor; y si para tentar el enemigo, hazerlo con arcabuzería a cavallo, cavallería ligera, gente desembaraçada y alguna cavallería suelta, travando la escaramuça con tiento que quando se venga a atacar con mayor biveza, no sea apresurando las cargas, de suerte que se aya de venir al cerrar con los demás esquadrones (Mendoça 1596: 56).

Teniendo en cuenta que este fragmento supone la única ocurrencia del italianismo atacar en nuestro corpus ${ }^{395}$-frente a la predilección por el término acometer ${ }^{396}-$, lo más seguro es que su uso aún no se hubiera popularizado, tendencia que se invertirá a partir del siglo XVII.

Son muchísimos más los casos de términos italianos o franceses adoptados aun cuando para los conceptos a los que aludían nuestra lengua ya contaba con significantes apropiados. Para no resultar prolijos sólo enumeramos algunos de ellos:

- Desde su incorporación, la voz víveres, de origen galo ${ }^{397}$, se ve obligada a competir con las más castizas bastimento y vitualla.

- El galicismo tropa ${ }^{398}$, que aparece por primera vez en la primera mitad del siglo XVI399, acabará eliminando a las múltiples

\footnotetext{
394 "Bemos que aquel famoso Alexandro con un pequeño exérçito acometió las ynnumerables jentes de Darío y lo vençió" (Roxas 1607: 63r).

395 « Del it. attaccare 'pegar, clavar, unir', 'acometer'» (DECH).

396 Además, desde el siglo XV se encuentran ejemplos del latinismo ofender con el mismo significado que acometer y atacar ( $c f$. DECH: s.v. defender), conjunto sinonímico al que también pertenece embestir: "Embestir, probablemente del it. investire 'acometer, atacar con violencia', procedente del lat. investire 'revestir', 'rodear', derivado de vestire 'vestir'. 1554, 1561, Fr. L. de Granada" (DECH).

397 Corominas y Pascual contemplan la posibilidad de que se trate de un italianismo ( $c f$. DECH: s.v. vivo). La primera documentación en nuestro corpus es Sumario de la milicia antigua y moderna (1607) de Rojas.

398 “Del fr. troupe 'bandada de animales o de gente', 'tropa', que parece ser derivado regresivo de troupeau, fr. ant. tropel 'rebaño'. La o de tropa se debe al influjo del cast. tropel" (DECH).

399 "A la dicha çedula él no podría dexar de mandar tomar la dicha plata para su magestad y entregalla a su tropa por avyendo respeto a quel dicho capitán Martýn Estete es fallesçido y en su fallescimyento se an echo gastos e costas" (Anónimo, Orden por la que se autoriza a detraer a
} 
unidades pluriverbales, formadas a partir de gente, con las que el castellano contaba para referirse al "grupo regular y organizado de soldados" (DEA: s.v. tropa): gente de (la) batalla, gente de guerra, gente de pelea, gente militar, etc. Debemos mencionar, además, que, cuando se produjo esta sustitución, ya nuestra lengua había experimentado otra muy parecida, puesto que los variados compuestos sintagmáticos creados a partir de hombre (hombre de (la) guerra, hombre de pelea, hombre militar, etc.) se vieron postergados en el momento en el que comenzó a popularizarse el italianismo soldado ${ }^{400}$.

- Por lo que respecta al italianismo ciudadela, sus primeros ejemplos datan de principios del siglo XVI ${ }^{401}$. En esta adquisición, aparte de razones derivadas de la autoridad de los ingenieros italianos en materia de fortificación, debieron también de desempeñar un importante papel otras circunstancias, como puede ser el hecho de que castillo, la forma que el castellano poseía para designar el mismo concepto que cittadella en italiano, se utilizara ya desde la Edad Media en referencia a otro tipo de construcción defensiva, a la que también era posible nombrar mediante el vocablo fuerte.

\subsubsection{Desdoblamientos sinonímicos}

Sobre el último caso queremos mostrar el siguiente ejemplo, en el que, gracias al recurso de la duplicación léxica o desdoblamiento sinonímico, puede constatarse con total claridad la sinonimia existente entre ciudadela y castillo:

favor de María de Escobar..., 1536) [Consulta: 31 de enero de 2012]. Aunque el CORDE muestra testimonios anteriores a éste, siguiendo a Varela Merino (2009), son en realidad malas lecturas de la palabra ropa escrita con doble $r$.

400 “Del it. soldato (s. XIV), que pasó también al francés y demás lenguas europeas. 1463, Juan de Lucena con referencia a Sicilia; "soldado: mercenarius stipendiatus" Nebr.; todavía evita usarlo Boscán, h. 1530, en su versión de Castiglione" (DECH: s.v. sueldo).

401 "Del it. cittadella, diminutivo de città 'ciudad'. Andrés Bernáldez, fallecido en 1513" (DECH: s.v. ciudad). 
En caso que aya ciudadela o castillo en la tierra, se ha de acudir a la plaça d'él, impidiendo que no se retire dentro la gente; y quando no ay castillo, a la plaça o partes donde tienen señalado el juntarse en los cuerpos de guardia, señoreando enteramente la tierra, que se ha de dar a saco, y fortificarla, poniendo buena guarnición; y quando el castillo o ciudadela (aviéndola) no se aya rendido, previniendo no les entre socorro por las puertas que de ordinario tienen los castillos a la campaña para el efecto (Mendoça 1596: 155).

Suelen ser los lenguajes de especialidad los que recurren a este procedimiento, si bien, en palabras de Gutiérrez Cuadrado (1993: 333), su presencia no resulta extraña en otro tipo de registros: “Esta fórmula, si así merece llamarse, alcanza una difusión extraordinaria en muchos textos históricos, didácticos o narrativos del siglo $\mathrm{XV}$, de registro más o menos literario, y en otros que podemos clasificar genéricamente como la medicina, la filosofía y la teología escolástica y el ámbito de las leyes".

Por lo que respecta a nuestro ámbito, son habituales este tipo de dobletes:

Y el parapeto principal de encima de los baluartes ha de ser muy gruesso, o muy delgado; gruesso, para prueva del cañón; delgado, para sólo el mosquete. Para el cañón, tendrá 20 pies de gruesso, por lo menos, y de alto cinco pies, con su banqueta o grada para subir a ella el soldado que fuere pequeño de cuerpo (Rojas 1613: 36v).

Dándole el contraseño, si lo ay, el tal alcayde o castellano lo ha de dilatar hasta la última hora de las veyntiquatro del día que precissamente se le señaló, cumpliendo d'esta suerte con el obedecer a su príncipe y sin manchar la lealtad devida (Mendoça 1596: 138).

Es necessario que de la tierra por donde huviere de marchar tenga particular descripción y figurados en ella los montes, sierras, peñas, quiebras, pantanos, passos estrechos, selvas, bosques, valles, ríos, lagunas, arroyos, fuentes, ciudades, castillos, lugares y caserías que huviere, para que tenga presentes todos los puestos en que puede aver alguna emboscada o celada de enemigos que con ventaja le puedan ofender (Álaba 1590: 41v).

Si en la tal plaça ay sospecha o advertençia de pieças gruesas, mucho mejor es el alojamiento de espaldas que no de gabiones o sextones, lo uno por la seguridad y lo otro por ser tan poco durables los gabiones que los desentretege a todos el suflo y rebufo del resuello de la pieça (Ufano 1613: 127).

Que suelen hazerse los fundamentos solos, al principio de las fuerzas, de piedra o ladrillo, y lo demás de tierra, hasta que a hecho assiento; y que contrafortes o estrivos se an de hazer a un tiempo, travándolos con la muralla, y no de por sí, porque la fuerza sea unida (Lechuga 1611: 244). 
En todos estos casos, como puede comprobarse, los tratadistas han optado por reunir mediante la conjunción disyuntiva o los dos vocablos semánticamente equivalentes. No debe olvidarse, sin embargo, que también era posible el empleo de la conjunción copulativa y con esta misma función, como ya han puesto de manifiesto Díez de Revenga Torres y Puche Lorenzo (2007: 199-201). Por lo que respecta a nuestro ámbito, algunos de los ejemplos detectados son los siguientes:

El oficio de veedor general es atender a cómo se gasta la hazienda de Su Magestad y mandar hazer reseñas y alardes a la gente, y el despedir los soldados que no fueren suficientes para guerra (Álaba 1590: 151v).

Pues si esso es assí, ¿por qué se hazen las plataformas y caballeros y, al fin, se buscan los más altos puestos para con ventaja alojar pieças? (Ufano 1613: 157).

Y después se levantaron y revelaron los españoles contra Roma fasta que bolvió Cipión, el Africano, e la tornó a someter al Imperio Romano, e passó en África, y venció a Aníbal y destruyó a Cartago (Fernández de Enciso 1530: XXIVv).

El que está en lo alto señorea y sojuzga mejor al enemigo y, peleando con igualdad de armas, alcança más para poderle herir (Álaba 1590: 74r).

Qüestión sobre cómo se hará una batería con sacas y balones de lana hallándose con ellos y caresçiendo de otros qualesquier materiales (Ufano 1613: 189).

El último de estos fragmentos, el de saca y balón, es especialmente significativo, si tenemos en cuenta que más adelante en su exposición Ufano vuelve a agrupar esos términos, pero esta vez con $o$ :

Pues avemos ydo, Señor Capitán, hasta ahora discurriendo largamente de baterías, querría saber de cómo, no aviendo tierra ni faxina y hallándonos con sacas o balones de lana, se podrían seguramente alojar pieças a prueva (Ufano 1613: 189).

\subsection{Polisemia}

El fenómeno de la polisemia es constatable "en el lenguaje de la ciencia, incluso dentro de una misma zona de conocimiento, cuya presencia puede también dificultar la precisión" (Gutiérrez Rodilla 1998: 100). Quizá el caso más 
extremo en el léxico militar renacentista sea el del galicismo plataforma ${ }^{402}$. Para esta voz ofrecemos en nuestro glosario hasta cinco acepciones relevantes:

1. $\rightarrow$ Fort. Cualquier obra de fortificación construida para alojar cañones y otras piezas de artillería.

2. $\rightarrow$ Fort. Cualquier construcción elevada que permite al sitiador, con la artillería allí asentada, batir de forma dominante la fortaleza.

3. $\rightarrow$ Fort. En una fortaleza, defensa muy alta que se construye para descubrir las partes de la campaña por las que el enemigo puede acercarse sin ser visto, o para ofenderle desde allí aunque aún se encuentre lejos; y, en el caso de haber cerca cualquier monte o elevación, para igualar o superar su altura.

4. $\rightarrow$ Fort. Obra exterior que se construye delante de las cortinas demasiado largas o enfrente de un ángulo entrante, con la intención de mejorar las posibilidades de defensa de las fortalezas que cuentan con uno de estos dos inconvenientes.

5. $\rightarrow$ Art. Pavimento, generalmente de madera o de piedra, sobre el que se colocan las piezas de artillería, para que las ruedas de sus cureñas puedan deslizarse fácilmente.

A este respecto, resulta significativa la afirmación de Almirante (1869), para quien este tipo de casos, lejos de suponer una riqueza lingüística, no hace sino provocar ambigüedad e imprecisión dentro del discurso militar:

\begin{abstract}
Mayern, autor alemán de fortificación, dice que se dio el nombre italiano piattaforma a las primeras medias lunas. Otros llaman también así a los resaltos de la muralla, que no son baluartes, sino a manera de torres cuadradas irregulares. Plataforma llama el P. Casani (Fortif. pág. 112 y Comp. pág. 92) al caballero de trinchera. Plataforma se ha llamado también a la explanada de batería, que en
\end{abstract}

402 "Plataforma (1595), término de fortificación tomado del fr. plate-forme (s. XV)" (DECH: s.v. chato). Pese a esta afirmación, no existe unanimidad entre los distintos especialistas sobre el origen de este término. En este sentido, en este repertorio se cita a Terlingen, para quien no estaríamos ante un galicismo, sino ante un italianismo. Corominas y Pascual argumentan, sin embargo, que "no viene del it., donde aparece en la $2 .^{a}$ mitad del s. XVI, pues ya el orden de los componentes denuncia la procedencia francesa". Pese a este parecer, creemos con Varela Merino (2009) que el hecho de no documentarse ningún ejemplo de una variante próxima a piattaforma no juega a favor del origen italiano. Y, como en este caso, dada su gran proximidad cronológica, no podemos apoyarnos en las primeras documentaciones del español, francés e italiano (cf. López Vallejo 2008: s.v. plataforma), finalmente nos hemos decantado por la ascendencia gala, si bien esta categorización, como hemos puesto de manifiesto, no está exenta de problemas. De hecho, incluso en los textos se señala el origen italiano del mismo: "Adviértase que, haviendo de fortificar alguna tierra de cortinas largas, que se pueden en sus ángulos hazer los baluartes y entre dos baluartes, en forma de triángulo, otro asido con la muralla, para que d'él se puedan guardar las cortinas de los baluartes, y que ay en algunas, entre dos baluartes, un través hecho en forma de un paralelogramo con sus dos ángulos y la cortina de la frente derecha, que italianos llaman plataformas, y que no las tengo por tan fuertes como los triangulares, por no poderse guardar sus frentes de las cortinas de la ciudad, villa o lugar que las tiene" (Lechuga 1611: 253-254). 
francés es plate-forme. La parte superior de una torre es plataforma para Moretti.

Especie de caballero para Dicc. Acad. 5. Basta de plataforma.

\subsection{Homonimia}

En último lugar debemos mencionar el procedimiento de la homonimia. En la caracterización de ésta lo que se ha subrayado continuamente es el peso decisivo desempeñado por la etimología. Así, frente a la polisemia, se produce homonimia sólo cuando dos étimos distintos han llegado en su desarrollo a una confluencia en su forma fónica, lo que implica que haya una independencia semántica. En consonancia con este criterio, sólo hemos hallado tres casos de homónimos en el léxico militar renacentista:

Militar'1, «tomado del lat. mìlĭtare 'practicar el ejercicio de las armas'» $(\mathrm{DECH})$

Militar2, "millutaris 'perteneciente al soldado o a la guerra', derivado de miles, -itis" (DECH).

Real", "del lat. regalis" (DECH: s.v. rey).

Real2 $^{2}$ «del ár. rahl (vulgar rahál) que significa 'lugar donde se hace alto en un camino', 'campamento', 'majada, redil', 'rebaño'» (DECH: s.v. rehala).

$\mathrm{Saco}^{1}$, «del lat. saccus 'saco de trigo, de dinero, etc.'» (DECH: s.v. saco).

$\mathrm{Saco}^{2}$, «del it. sacco 'saqueo'» (DECH: s.v. saco).

\section{Clasificación en campos semánticos}

El vocabulario de una disciplina designa diferentes tipos de contenidos, lo que le otorga una de sus principales características, a saber, su carácter heterogéneo. $\mathrm{Y}$ es precisamente este importante rasgo, existente en cualquier lenguaje especializado, el que genera la necesidad de clasificar en distintos campos conceptuales o nocionales. Dicha organización taxonómica no está exenta, sin embargo, de ciertas dificultades, ya que no todo el léxico de una determinada especialidad puede ser delimitado con exactitud. La terminología militar no supone una excepción, por lo que no descartamos la presencia de inexactitudes o errores en la clasificación semántica que presentamos, si bien hemos intentado minimizarlos al máximo. Por otro lado, debemos advertir que 
el orden seguido en las enumeraciones de las unidades de cada campo es el alfabético. Ahora bien, como para confeccionar este apartado hemos tenido en cuenta tanto las relaciones semánticas de sinonimia como las de antonimia, éste se ha visto interrumpido frecuentemente.

En primer lugar, registramos dos términos referidos a técnicas o artes (arquitectura militar o fortificación 1 y arte militar o milicia 1 ), y otros dos para una profesión ( milicia $_{2}$ o soldadesca).

Damos cuenta, asimismo, de una serie de voces que designan acciones $u$ operaciones propias de la estrategia militar: alarde 1 , muestra o reseña; aliarse, coligarse, confederarse o ligarse; alistar o asentar2; apellidar; apellido1; asentar, hacer (la) gente o levantar1 y leva. Creemos que pueden adscribirse a este campo los siguientes términos, que designan, más que una acción, el efecto o resultado: confederación o liga ${ }^{403}$ y paz2 ${ }^{404}$.

Las siguientes son, en cambio, actividades de logística: amunicionar o munir, avituallar, campear 1 , contrarronda o sobrerronda $a_{1}$, ronda $a_{2}$ desalojar ${ }_{2}$, forraje, forrajear, jornada1, marchar y rondar.

Por su parte, acamparse, levantar 3 , acuartelar, acuartelar $_{2}$, alojamiento 1 , alojar1, alojar, desalojar, asentar 1 y levantar 2 pertenecen al ámbito de la castrametación.

Ahora bien, el ámbito militar más representado es, con gran diferencia, el de las acciones bélicas, puesto que a él pertenece toda esta terminología: acometer, atacar, combatir $r_{3}$ embestir 2 u ofender; defender 2 ; acometida, acometimiento, combate $_{2}$, combatimiento 2 , ofensa u ofensiva; defensa 2 ; acosar, apremiar o apretar1;

\footnotetext{
403 ‘Unión o pacto entre dos o más soberanos, territorios, etc., establecido con el fin de atacar a un enemigo común o para defenderse en alguna ofensiva'.

404 "Tratado o convenio por el que las partes enfrentadas ponen fin a una guerra" (DESAL).
} 
algazara405; allanar3, domar, domeñar, domesticar, señorear, sojuzgar, someter o sujetar $_{1}$; alojar,406; amotinar 1 o rebelar 1 ; amotinar 2 ; apretar 2 ; apretilar407; arremeter, embestir 1 o remeter; arremetida o remetida; asaltar1, dar (el) asalto1, dar el salto o saltear; asaltar 2 , dar (el) asalto 2 u opugnar; asalto 1 o salto; asalto 2 o interpresa $a_{2}$; asediar, asitiar, cercar, meter (el) asedio, poner asedio, poner (el) cerco, poner (el) sitio o sitiar; alzar el cerco, alzar el sitio, levantar el asedio, levantar el cerco o levantar el sitio;

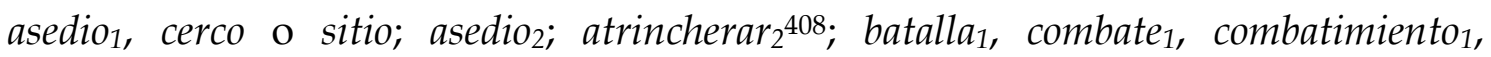
contienda $a_{2}$, debate, facienda, lid o pelea; batalla campal; representar (la) batalla; batería contrabatería $;$; batería $a_{2}$ brecha o portillo409; dar (la) batería o batir ${ }_{1}$; batir ${ }_{2}$; batir ${ }_{3}$, combatir, lidiar, luchar, pelear o revolver 2 ; dar bordos o dar bordos y ramos; cabalgada $;$ campear 2 ; celada $a_{1}$ o emboscada $a_{1}$; poner en celada, emboscar o poner en emboscada; centinela 2 o guardia 2410 ; ceñir 2 ; cercar 2 ; chocar; combatir 2 ; conquista, presa o toma; conquistar o tomar1; correduría, correría, corrida o incursión; correr 1 o descubrir 3 ; correr 2 ; defender 3 o guardar 3 ; defender 4 ; defender $;$;efensa $a_{3}$ o defensión di $_{2}$

405 "Conviene mirar bien y, sobre todo, acordarse que el turco bate con muy gruessa artillería, y el flamenco y el inglés se vale de la zapa, y el moro alarbe de ninguna cosa, si no es de algazara y dar vozes; pero bien es ponerse en defensa contra todos" (Rojas 1613: 26v-27r). Como puede observarse, algazara designa el método seguido por los moros a la hora de atacar, que consiste en gritar o dar voces para, así, confundir y aturdir al contrario. Por consiguiente, no es propiamente una acción bélica, pero, de todas formas, creemos que es éste el apartado en el que mejor encaja.

406 'Durante el intento de expugnación de una fortaleza: construir obras de fortificación pasajeras en los puntos estratégicos que se van ganando'. Pese a que esta acepción podría ser catalogada como propia de la arquitectura militar, dado que sólo tiene cabida cuando se pretende ganar una construcción defensiva, hemos creído más acertado clasificarla aquí. Un caso parecido es el de dar bordos o dar bordos y ramos, que hemos definido de la siguiente manera: 'Referido a las trincheras que se abren en el ataque a una plaza: formar una línea en zigzag para facilitar así, en el avance, la comunicación de unas a otras'.

407 'Colocar alguna cosa, especialmente una pieza de artillería, detrás de un parapeto o pretil con el fin de protegerla del fuego enemigo'.

408 "Ponerse una persona en una trinchera para defenderse" (DSAL). "Osaría dezir que ningún otro ynstrumento o máquina en el artillería es de más serviçio y utilidad que el del dicho carromato, además de que, a vezes, espeçialmente en campaña rasa, queriendo el enemigo acometer el campo por todas partes, al çircundarle se puede prestamente atrincherar con los carros matos y bloques que uviere la parte del exérçito que con ellos y otros carros bazíos se quisiere cubrir" (Ufano 1613: 91-92).

409 'Rotura o abertura en la muralla de una fortaleza producida por la artillería u otro ingenio militar'. Estamos, por tanto, ante el resultado de una acción bélica. Aparte de éstas, hay más voces en este campo que designan el efecto o la consecuencia de una determinada operación de guerra: nos referimos a desbarate, estrago, lengua, riza y rota.

410 'Servicio de vigilancia que prestan los soldados'. 
defensa 4 ; poner en defensa; desalojar1; desbaratar 1411 ; desbaratar 2 ; desbaratar 3 o poner en rota; desbarate; descercar o desitiar; descortinar; descoser; descubrir 2 , señorear 2 o sojuzgar, desguarnecer; guarnecer 1 ; deshacer 1 ; deshacer 2 ; a la deshilada ${ }_{2}^{412}$; desmantelar; desocupar; ocupar 2 o tomar2; despojar 1 ;espojar, dar a saco o saquear; despojo $_{1}$, presa $_{2}$, saco $^{2}$ o sacomano; diversión; divertir 2 ; embarrar; empresa, empresa de (la) guerra, empresa militar, encuentro 1 , facción 2 , facción de guerra, hecho de armas, interpresa $_{1}$ o reencuentro incamisada $_{1}$; encastillarse ${ }^{413}$; encuentro en reencuentro $_{2}$; enseñorearse o señorear 4 ; a escala vista; escalada; escalar; escaramuza 1 o refriega; escaramuza 2 ; escaramuzar 1 ; escaramuzar 2 ; escolta ${ }_{2}^{414}$; hacer escolta a alguien o algo;

${ }^{411}$ La clasificación en campos semánticos ha resultado sumamente compleja en el caso de las unidades léxicas que, además de estar presentes en tratados militares, poseen muchas ocurrencias en otro tipo de textos, como ocurre con desbaratar. Por lo que respecta a esta voz, pese a no contar únicamente con ejemplos en contextos bélicos ("suelen con la plata engendrarse unas substancias metállicas adustas y muy aquosas, assí como es el çufre y el mercurio o azogue no fixo, que llaman arsénico, y, deteniéndose al fundir la plata en el fuego, l'açufre lo quema y el arcénico lo desbarata y lleva en humo" [Pérez Vargas 1568: 33r]), la existencia de una gran cantidad de pasajes semejantes al siguiente hizo decantarnos por considerar el significado de 'destruir o arruinar algo' como característico del lenguaje militar: "Y aunque la traça de las minas en estos tiempos es la mesma que en los passados, los efetos son de mayor importancia, por la violencia notable con que los materiales que en ellas se ponen desbaratan y asuelan qualquier lienço de muro o fortaleza, por fuerte y inexpugnable que parezca" (Âlaba 1590: 256v).

No obstante, mediante la ausencia de marcas diatécnicas hemos querido dejar constancia de su empleo en ámbitos distintos al que nos ocupa, puesto que es precisamente este carácter, que podemos denominar "general", el que más ha dificultado la categorización de esta acepción. En casos como éste, la solución adoptada ha consistido en analizar cada una de sus ocurrencias para conocer, de esta forma, en qué tipo de contextos aparece con mayor frecuencia, lo que nos ha permitido decantarnos por una u otra adscripción. De este campo, se encuentran igualmente en esta situación: descubrir ${ }_{2}$, señorear ${ }_{2}$ o sojuzgar ${ }_{1}$; deshacer ${ }_{1}$; despojar ${ }_{1}$; enseñorearse o señorear ${ }_{4}$; espiar $_{1}$; fortalecer 1 o fortificar ${ }_{1}$; gastar; guarda $;$ guarda $a_{4}$; tomar lengua; reconocer; reconocimiento; rendir ${ }_{1}$; reparar 3 ; retirar 2 ; ronda $a_{1}$ y rondar $_{1}$. Ahora bien, dada la amplitud de estos conceptos, no descartamos que sean posibles otras interpretaciones.

$412 \mathrm{~A}$ falta de una mejor solución, incluimos en este campo esta locución adverbial, que aparece en el corpus en referencia al modo en el que se realiza una acción bélica: "Visto el estado de la batería y demostraciones que las centinelas descubren que hazen los de fuera para dar el assalto, recogiéndose más vanderas de las que suelen a las trincheas, sin ser hora de guardia, o $a$ la deshilada, como se suele hazer, queriendo reforçarlas, para gozar la ocasión de alguna mina o torreón que se aya de ocupar, puesto en el fosso, o otro alguno, la cabeça del sitio ha de advertir si el enemigo, por no poder llegar a la batería sin puente, la ha echado la noche antes o la ha de echar" (Mendoça 1596: 142). En el glosario, hemos acompañado este fragmento con la siguiente definición del DRAE: "Con disimulo". Otra locución adverbial recogida en este apartado es $a$ escala vista: "Haciendo la escalada de día y a vista de los enemigos" (DRAE).

413 "Refugiarse en un castillo o en un paraje alto o de difícil acceso" (DEA: s.v. encastillar). "Se bolvían a los nuestros con ánimo y escaramuçavan hasta que se recogieron a dos montañuelas que están sobre la fortaleza principal, nombradas las montañas de la Señora, donde se encastillaron y entretuvieron la mayor parte del día" (Mosquera 1596: 109r).

414 'Servicio de protección y seguridad prestado por un soldado o por una tropa, que consiste en acompañar en sus desplazamientos a una persona o alguna cosa'. 
espiar1; espiar 2 ; espolonada; batir la estrada; estrago; expugnación; expugnar; fortalecer 1 o fortificar $;$; gastar; guarda $;$ guarda $;$ guardar 2 ; guardia 1 jornada $;$ lengua; tomar lengua; levantamiento o rebelión; levantamiento de guerra o motín; levantar 4 o rebelar2; lucha; luchar ${ }_{1}^{415}$; minar $_{1}$; minar 3 ; ocupar 1 ; ocupar 3 ; oprimir o sojuzgar 3 ; pacificación; pacificar; picamiento; picar; rebatir, hacer retirar, rebotar, rechazar o retirar, reconocer; reconocimiento; rendir ${ }_{1} ;$ rendir $_{2} ;$ rendir $_{3} ;$ rendir $_{4} ;$ reparar $_{3} ;$ resistencia $_{1} ;$ resistir; retirada 1 retirar 2 ; retirar 3 ; revolver $r_{1}$ riza; romper; rompimiento; ronda r rondar $_{1}$; rota; salida $_{1}$ o surtida s $_{1}$ sedición; señorear o sujetar $_{2}$; socorrer $_{1}$; socorrer 2 ; socorro s $_{1}$ socorro 3 ; sujeción; talayar; trabar; abrir trinchera416; triunfar 1 ; velar; vencer; ir de vencida; llevar de vencida; vencimiento 1 o victoria; vencimiento ${ }_{2}$; continuar el vencimiento, ejecutar la victoria, proseguir la victoria o seguir la victoria y zapar417.

Muchos de los verbos insertos en este último grupo generan sustantivos que señalan los agentes o sujetos que participan en las distintas operaciones bélicas, los cuales pertenecen al siguiente conjunto. Aparte de éstos, integran también este apartado los múltiples términos que existen para designar a los miembros de las distintas unidades militares: acometedor, combatidor 2 o combatiente $_{2} ;$ acometido $_{2}$ u ofendido 2 ; adversario 1 , contendedor, contrario 2 o enemigo en amigos; alcaide o castellano; aliado 2 amigo 4 o confederado2; aposentador; asaltante; asediado $_{2}$, cercado $_{4}$ o sitiado $;$ asediador, cercador o sitiador; atalaya 2 ; ballestero ${ }^{418}$; barrunte; caballero 1 o caballo $;$ caballo ligero; camarada ${ }_{1}$; centinela ${ }_{1}$ o posta ; $_{1}$ centinela perdida; combatidor, combatiente 1 o lidiador; conqueridor; conquistador; corredor o

\footnotetext{
415 Tanto lucha como luchar, son conceptos en claro declive en la época renacentista. Se refieren, más que a una operación de guerra, a un ejercicio atlético o gimnástico: "Contender o lidiar dos personas a brazo partido hasta que alguno caiga en tierra" (Aut.: s.v. luchar).

416 "Empezarla para emprender el ataque o ataques de una plaza" (Corsini 1849).

${ }^{417}$ De esta larga lista, pertenecen a la poliorcética sólo las siguientes: alojar $_{3}$; apretar $_{2}$; asaltar ${ }_{2}$, dar (el) asalto $_{2}$ u opugnar; asalto $_{2}$ o interpresa $a_{2}$; asediar, asitiar, cercar 3 , meter (el) asedio, poner asedio, poner (el) cerco, poner (el) sitio o sitiar; alzar el cerco, alzar el sitio, levantar el asedio, levantar el cerco o levantar el sitio; asedio ${ }_{1}$, cerco o sitio; asedio ; batería 1 ; contrabatería 1 ; batería ${ }_{2}$, brecha o portillo; dar (la) batería o batir $r_{1}$ dar bordos o dar bordos y ramos; defender $r_{3}$ o guardar 3 ; defensa $a_{3}$ o defensión $n_{2}$; descercar o desitiar; descortinar; descoser; desmantelar; escalada; escalar; expugnación; expugnar; minar 1 ; minar 3 ; picamiento; picar; salida $a_{1}$ o surtida ${ }_{1}$; socorrer $_{2}$; socorro ${ }_{3}$; abrir trinchera y zapar.

418 Como ya hemos especificado, en este trabajo no hemos atendido el campo de las armas empleadas antes de la generalización del uso de la pólvora, lo que ha supuesto que hayamos descartado también las voces que se refieren a los guerreros caracterizados por luchar con una de ellas: flechero, piquero, lancero, alabardero, etc.
} 
descubridor; defensor, 2 defensor, guerrero 2 , hombre, hombre de (la) guerra, hombre de pelea, hombre de soldadesca, hombre militar, militar ${ }_{2}^{2}$, mílite $_{1}$ o soldado; desbaratado4; diana $_{2} ;$ emboscado2; encamisado $;$ escolta 1 escucha; espía o explorador; estradiote; forrajero; herreruelo; hombre de armas; hombre de socorro; infante o peón; infante perdido; jinete; mercenario ${ }_{2}$; metator; mílite 2 ; montaraz; rebelde 2 ; rendido 3 ; sobrevela; sujeto $_{2} ;$ vela $_{1} ;$ vencedor $_{2}$ o victorioso ${ }_{2}$ y vencido v. $_{\text {. }}$

Dada su alta representatividad, hemos decidido recopilar separadamente las unidades léxicas que se refieren a los conjuntos de personas que intervienen o se forman en una guerra: adversario , contrario $_{3}$ o enemigo ; batalla 6 o batallón 2 ; batallón $;$ cabalgada ; caballería; caballería ligera; campo; celada o emboscada2; corneta; cuerpo; cuerpo de (la) guarda, cuerpo de guardia 1 o guardia $a_{3}$ defensa ejército; encamisada2; facción1; fuerza $;$ gente, gente de (la) batalla, gente de guerra, gente de pelea, gente militar, milicia 3 o tropa; gente de armas; gente de socorro o socorro 2 ; guarnición; infantería; milicia 4 ; presidio $_{1} ;$ real $_{2}^{2}$; ronda $a_{3}$ y sobrerronda $a_{2}$.

Por su parte, albañil o murador; fortificador, ingeniero o ingeniero militar; gastador o peonero ${ }^{419}$; guarda ${ }_{1}^{420}$; guarda ${ }_{2}^{421}$; minador; municionero y viandero o vivandero deben ser clasificados en el campo de las personas que o bien desempeñan un oficio o una profesión, o bien cultivan una técnica.

Otro importante conjunto es el conformado por los adjetivos que indican cualidades propias de los soldados, de los ejércitos o de cualquier otra colectividad que esté involucrada en una contienda: acampado; acometido1, combatido u ofendido; ; acosado, apremiado o apretado ; $_{\text {aliado }}$, amigo o confederado ${ }_{1}$; alistado o asentado $;$ alojado $;$ alojado $;$ amigo ; contrario $_{1}$ o enemigo $;$ amotinador;

419 'Trabajador empleado en el ejército para realizar las distintas labores en las que lo esencial es mover la tierra, como allanar los caminos para facilitar el paso de la artillería, y abrir trincheras, minas y demás obras pasajeras'. "Y estando hecha esta prevención de materiales, se entregarán las herramientas de picos, palas y açadones a los gastadores, $y$, si no los huviere, se entregan a los ayudantes de sargentos mayores, para que los den a los soldados, que, donde yo me he hallado, por la mayor parte hemos hecho las trincheas con soldados" (Rojas 1598: 105v).

420 "El que tiene a su cuenta alguna cosa y está obligado a mirar por ella, como la guarda de las viñas, guarda del monte, la guarda del rey o del príncipe" (Cov.). Como consecuencia de su amplitud designativa, no hemos marcado guarda $_{1}$ diatécnicamente.

${ }^{421}$ Pese a designar 'grupo de personas encargadas de la vigilancia y conservación de una cosa' la hemos incluido en este apartado. Al igual que en guarda $a_{1}$, hemos desechado su marcación diatécnica. 
asediado, cercado 3 o sitiado ; atrincherado; belicoso $;$; bisoño; de a caballo o de caballo2; cercado 2 ; defensivo;_ofensivo; defensor ${ }_{1}$; desbaratado 2 ; desbaratado $;$;eshecho; doméstico, sojuzgado, sujetado o sujeto 1 ; emboscado1; fortificado 1 ; fortificado ${ }_{3} ;$ guerrero1; inexpugnable2; invencible; invicto; levantado, rebelado o rebelde1; mercenario1; oprimido; pacífico; de a pie o de pie; rebotado; rendido 1 ; reparado 3 ; roto; tirón; vencedor 1

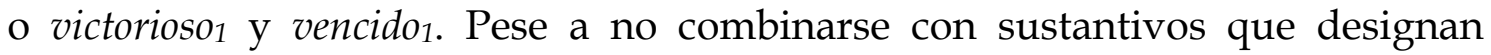
personas, también insertamos aquí a apretado 2 , asentado 1 , conquistado, defendido2, guardado 2 , guarnecido, ocupado ${ }_{1}$, ocupado ${ }_{2}$, reconocido y trabado, entre otras cosas porque se trata de propiedades que algunas operaciones de guerra pueden llegar a tener, las cuales son ejecutadas por soldados. Además, muchas de esas cualidades se aplican a los lugares o a las instalaciones susceptibles de ser ocupadas por una tropa. Por otro lado, al hacer referencia a una posible forma de actuar durante el desarrollo de cualquier empresa militar, incluimos en este grupo los adverbios belicosamente ${ }^{422}$, a caballo 1 o de caballo 1 y a pie. De la misma manera, contemplamos en esta parcela el sustantivo resistencia cuando designa la 'capacidad de alguien para oponerse o combatir con la persona o cosa que le ataca'. Y, por último, bélico o belicoso 2 , militar ${ }^{2} 1$ y soldadesco, conceptos en cierto modo hiperonímicos, se han adscrito igualmente a este amplio conjunto de cualidades militares.

Contamos, asimismo, con una serie de verbos y sustantivos que denotan actividades propias de la arquitectura militar: atrincherar ${ }_{1}^{423}$; carcavear; ceñir $1_{1} \mathrm{O}$ cercar $r_{1}$ contraminar; minar 2 ; estar en defensa ${ }^{424}$; empalizar; encamisar; enfortalecer,

\footnotetext{
422 ‘De manera agresiva o propia de la persona amiga o inclinada a la guerra'. "Solía ser en tiempos passados que, primero que se alojase la artillería sobre una plaça, llegava la ynfantería con las trincheras hasta querer desembocarlas al fosso; pero, de algunos años a esta parte más bellicosamente se a usado el alojar pieças de artillería en los puestos más offensivos la primera noche que se llega a sitiar tal plaça" (Ufano 1613: 121).

423 "Defender algo con trincheras o construir trincheras en un sitio" (DUE).

424 'Dicho de una fortificación: hallarse en estado de soportar cualquier acción ofensiva por parte del enemigo'. "Resuelto, pues, la forma y grandeza que ha de tener la tal fortificación, se començará por la parte más flaca a fabricar, procurando que primero que se derribe ninguna muralla vieja, esté ya en defensa lo que se fabricare de nuevo". Se trata de un estado, más que de una acción de fortificación. De todas formas, creemos que éste es el campo más adecuado para esta locución verbal. Algo semejante sucede con flanquear: 'Dicho de una fortificación: estar situada de tal manera que alcanza y domina a otras con su artillería'.
} 
fortalecer $_{2}$, fortificar 2 o reparar 2 ; escarpar; flanquear; fortificación $2 ;$ fortificar; guarnecer 2 ; murar; pilotear; reparar 4 terraplenar y vallar. Ahora bien, hemos lematizado también una serie de operaciones que, a pesar de no ser específicas de la construcción de fortalezas y demás obras defensivas, cuentan con una destacable presencia en tratados sobre fortificación: allanar 1 o explanar e $_{1}$ allanar 2 o explanar 2 ; cavar; defender 1 o guardar $r_{1}$ defendimiento, defensa $a_{1}$ o defensión i $_{1}$ descubrir 1 o señorear $;$; divertiri; reparar 1 y reparo1. Por último, dentro de este mismo campo, designan más bien efectos y resultados tanto cavamiento, como explanada, además de zanja.

Otra área léxica profusa es la compuesta por los elementos existentes en cualquier recinto fortificado, o que forman parte de construcciones defensivas de carácter más provisional: almena o pina; andamio, ándito, terraplén 2 o terrapleno $0_{2}$ arce del foso, arcén, arcén del foso, árgine, escarpa o vallado $a_{3}$; baluarte 1 o bastión $_{3}$; medio baluarte; banqueta ${ }_{1}$; banqueta $_{2}$; banqueta $_{3}$, escalón o grada; barbacana o

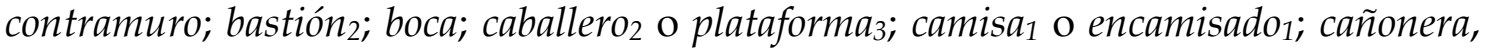
saetera o tronera; casamata; casamuro; cava, fosa, foso o fuesa; cerca, muralla 1 o muro1; contraescarpa o contraescarpe; contraforte, espolón o estribo; contrafosa o contrafoso; cordón; cortina, cortina franca, cortina limpia o cortina parcial; cortina total; costado o espalda $a_{3}$; espalda 1 ; espalda 2 , fianco o través 1 ; espalda 4 ; espolón 2 ; tenaza $a_{2}$, estrada $a_{2}$, estrada cubierta o estrada encubierta; falda; flanco ${ }_{2}$; flanco del orejón; frente 3 ; frente 4 ; galería 1 ; garita; gola; media gola; hornillo, horno o mina 2 ; media luna; merlón; orejón; parapeto o pretil; plataforma $;$; plaza $_{4}$ o revellín 2 ; plaza alta, plaza de arriba, plaza superior o través alto; plaza baja, plaza de abajo o través bajo; puerta del socorro; rastrillo; refosete o refoso; revellinin; roca, roca de homenaje o torre de(l) homenaje; ronda $a_{4}$ salida 2 o surtida 2 ; surtida 3 ; tenaza $a_{3}$; terraplén 1 o terrapleno; tijera $_{1}$; través $_{2} ;$ traviesa $_{3}$ y zapa 1 . Los siguientes términos, en cambio, aunque han sido detectados en contextos militares, no designan elementos exclusivos de una obra defensiva, sino que tienen cabida en cualquier tipo de edificaciones: 
banqueta $_{4}$ o rodapié $e^{425}$, cortina 2 o lienzo ${ }^{426}$, estacada 2 o palizada 2427 , postigo, puerta y puerta principal. Y, en tercer lugar, alambor ${ }_{1}$, escarpa 1 o escarpe ${ }_{1}^{428}$; alambor 2 , escarpa $_{2}$, escarpado 2 o escarpe ${ }_{2}^{429}$ y diente ${ }_{1}^{430}$ son unidades que designan las formas arquitectónicas o de construcción que en ocasiones adoptan algunas obras defensivas.

El siguiente campo semántico reúne todas las construcciones defensivas detectadas en el corpus. Queremos precisar que con esta denominación nos referimos a todas aquellas fábricas o edificios que, si bien pueden formar parte de un recinto mayor, lo normal es que sean ya por sí solas defensas lo suficientemente efectivas, a diferencia del grupo anterior, al que hemos llamado campo de los elementos o miembros de una fortaleza. Hecha esta aclaración, procedemos a enumerar la lista completa que integra esta área léxica: aproche1; atalaya $_{1}$; baluarte; baluarte $_{3}$, bastión ${ }_{1}$, caballero $_{3}$ o plataforma $;$; barraca o fajinada f $_{2}$ barrera; batería $_{4}$ o plataforma ; contrabatería $_{3} ;$ blinda $_{2}$; casa fuerte; castillo $_{1}$ o fuerte; castillo $_{2}$ o ciudadela; cerca; contramina; cunículo o mina 1 ; cortadura, través 3 o traviesa $_{1}$; cortadura $a_{2}$ o retirada $;$; empalizada, estacada 1 , palenque o palizada $a_{1}$ estrella; fortaleza, fuerza $a_{1}$ o plaza $;$ galería 2 o traviesa $a_{2}$ gavionada; hornillo 2 o mina 3 ; media luna $;$; laza $_{1}$ o plaza fuerte; presidio 2 ; reducto; reparación o reparo 3 ; torre 1 o torreón; trinchera; trincherón 1 ; trincherón 2 y valla, valladar o vallado2. Por lo que respecta a defensa, Domínguez (1853) ofrece esta significativa definición: “Fortificación y cualquiera de sus partes". Su referente puede ser, por consiguiente, tanto un amplio recinto fortificado como un simple miembro o parte de éste. A pesar de esta segunda posibilidad, adscribimos defensa $a_{5}$ a este ámbito de las construcciones defensivas, al igual que hacemos con sus sinónimos defensión, fortificación $_{3}$, muralla 2 o reparo. Idéntica actitud adoptamos con estrada, puente y

425 "En un cimiento, partes laterales de su grosor cuando éstas exceden la anchura del muro que se levanta sobre él" (Paniagua 19989: s.v. zarpa).

426 "Trozo continuo de pared o muralla" (DSAL: s.v. lienzo).

427 "Los maderos o estacas que se ponen por cimiento cuando no hay tierra firme para un edificio" (Terr.: s.v. palizada).

428 "Plano inclinado de los muros de las fortificaciones" (DSAL: s.v. escarpa).

429 'Plano inclinado que forma la muralla del cuerpo principal de una plaza, desde el cordón hasta el foso'.

430 'Cada uno de los ángulos salientes que, en ocasiones, se forman en una obra fortificada'. 
puente levadizo, pues si bien se refieren a construcciones no exclusivas de la arquitectura militar, pueden llegar a adquirir un fin militar.

Debemos mencionar, asimismo, una serie de cualidades susceptibles de aplicarse a las fábricas de fortificación, así como al lugar o al terreno que alberga una de esas construcciones: alamborado o escarpado ${ }_{1}$; batido; cercado ; $_{\text {; }}$ contraminado; minado; defensible; expugnable; inexpugnable 1 o inexpuñable; fortalecido, fortificado 2 , fuerte 1 o reparado 2 ; guardado 3 ; minable; murado; real ${ }^{1}$; terraplenado; torreado y vallado 1 . Junto a estos términos pueden mencionarse los adjetivos que, aunque pueden combinarse con otro tipo de unidades, cuentan con una gran frecuencia de uso junto a sustantivos que designan obras propias de la arquitectura militar: atalayador, defendible, defendido 1 o guardado, desbaratado, levadizo y reparado ${ }_{1}^{431}$. Pueden citarse en este punto, por último, los edificios que están a caballero o a caballo con respecto a otros, o los que se han dispuesto a escarpa o a escarpe.

En el ámbito militar son muy importantes las municiones, que son identificadas en el DRAE con los "pertrechos y bastimentos necesarios en un ejército o en una plaza de guerra". Por su parte, mientras que pertrechos designa 'toda clase de materiales e instrumentos, como pueden ser armas o máquinas, necesarios para cualquier empresa militar', bastimento se refiere al 'conjunto de comestibles destinados a la alimentación de un ejército'. Así pues, aparte de estos tres términos, así como sus posibles sinónimos ${ }^{432}$, pertenecen a este campo los siguientes: abrojo; bagaje o rastro; balón, saco ${ }^{1}$ o saca ${ }^{433}$; blinda 1 ; cabalgada 334 ;

${ }_{431}$ Como puede verse, la mayoría de los adjetivos lematizados indican cualidades resultativas. No faltan, sin embargo, otro tipo de adjetivos, como los relacionales, los de posibilidad o los que poseen un valor activo.

432 Aproche 2 , aproches de guerra, munición de guerra y pertrechos de guerra son sinónimos o variantes de pertrechos, mientras que bastimiento, munición del sustento, munición del victo, vitualla y víveres lo son de bastimento.

433 Tanto este objeto como las blindas, candeleros, tepes, cestos, cestones, fajinas, pilotes; salchichas, salchichones y zarzos son presentados por Lucuze (1772: 98-99) como los "pertrechos que facilitan la construcción de las obras de campaña y plaza".

${ }^{434}$ Aunque se trata del 'conjunto de cosas que los soldados de a caballo consiguen arrebatar al enemigo en una cabalgada', como muchas de ellas debían de ser pertrechos de guerra, recogemos esta acepción junto a las municiones propiamente dichas. En esta misma situación se 
caballo 2 o cabrilla; camisa 2 ; candelero; césped, gasón o tepe; cesta o cesto; cestón o gavión; convoy; cuento; despojo 2 o presa $a_{3}$ escala fajina $_{1}$; fajinada forraje $_{1}$; manta; pabellón; pilotaje; pilote; presa4; salchicha1; salchichón; socorro4; tienda y zarzo.

Un tipo especial de municiones lo constituyen las distintas máquinas de guerra que hemos recopilado: arcubalista; ariete, carnero o vaivén ${ }^{435}$; balista, ballesta ${ }_{1}$, ballestón o ballestón de torno; catapulta; causera; compago; cuervo; escorpión; galápago, testúdine o testudo; lobo o lupo; manta 2 o mantelete; máquina mural; músculo; onagro; plúteo; sambuca; testudo arietaria; torre 2 ; trabuco y vínea. Debemos mencionar, asimismo, el hiperónimo ingenio, que hace referencia a 'cualquier artefacto o máquina empleado en la guerra para ofender o defenderse'. Toro, trabe o viga designan, en cambio, uno de los elementos más destacados de las máquinas murales, las que sirven para romper muros o murallas, torres y demás elementos de una fortificación.

Por otro lado, menor número de voces son las que designan armas o explosivos empleados en la guerra: ballesta $a_{2}$; batería $a_{3}$ o camarada contrabatería $_{2}$; ceñido; ceñir 3 ; explanada, lechera o plataforma $;$; falárica; hornillo 3 y salchicha 2 . Son pocos los instrumentos o herramientas tenidos en consideración: tenaza $a_{1}$ tenazante, tenazón y zapa.

A diferencia de los últimos términos enumerados, conforman un grupo de entidad los relacionados con la táctica. Debemos mencionar, en primer lugar, batalla $_{3}$ así como su sinónimo orden de (la) batalla, ya que designan la 'disposición de las tropas que se juzga más adecuada para un combate, para atacar o para operaciones militares similares'. Denotan, en cambio, formaciones tácticas concretas los siguientes términos: batallón 1 , escuadrón o tropel ${ }^{436}$; cerca $_{3}$ o

encuentran también despojo ${ }_{2}$ o presa. $a_{3}$ Y lo mismo puede decirse de presa 4 : "La embarcación enemiga que se rinde o se toma por fuerza" (Salvá 1846).

435 Este artificio bélico adquiere una gran relevancia ya en la antigüedad clásica, lo que explica la existencia en nuestra lengua de los adjetivos arietario y arietino, que hemos tomado prestados del latín.

436 Ahora bien, "la voz escuadrón no expresaba el orden, el modo ni la figura de la formación, sino el hecho aislado de estar formado el ejército en un solo cuerpo como formación primitiva, o en varios combinados pero reunidos, como formación compuesta; pues cuando se quería distinguir una formación de otra se decía: escuadrón cuadrado de gente; escuadrón cuadrado de terreno; escuadrón de doble frente que fondo; triangulado [...]" (Almirante 1869: s.v. escuadrón). De este modo, 
muro 2 ; cuadro; cúneo, cuño o diente 2 ; escuadrón falso y fórfice, tenaza $a_{4}$ o tijera. Por su parte, ala, costado 1 o cuerno; avanguarda, avanguardia, vanguarda o vanguardia; retaguarda, retaguardia o rezaga; batalla $\mathrm{o}_{\mathrm{o}}$ cuerpo de (la) batalla; batalla $\mathrm{u}_{5}$ ordenanza; escuadrón volante; flanco ; frente2; hila, hilada, hilera u orden y manga aluden a partes o elementos constituyentes de las distintas agrupaciones creadas con el fin de luchar, marchar y realizar las empresas propias de los soldados. Completan esta serie las siguientes locuciones adverbiales: en ala; a la avanguardia, en avanguardia o en vanguardia; en retaguardia o en rezaga; a la deshilada y en hilera.

Damos cuenta, a continuación, de todos los vocablos relacionados con ceremonias o acontecimientos militares: alarde 2 ; ovación; rendido2; rendir 5 ; triunfador o triunfante2; triunfante1; triunfar 2 y triunfo. Por el contrario, batalla, contienda ${ }_{1}$ o guerra; paz 1 ; en campaña o en campo; guerra civil; guerra defensiva; guerra ofensiva; guerrear y militar ${ }^{1}$ sugieren estados o situaciones que se prolongan a lo largo del tiempo.

También ha tenido cabida en este trabajo la terminología concerniente a las señales, tanto verbales, como musicales e incluso visuales, de que se sirven los ejércitos con múltiples objetivos: ahumada, alborada, apellidon, tocar a botasilla, sonar a caballo, contraseña o contraseño, diana, nombre, rebato y dar rebato.

Por su parte, las siguientes indican localizaciones espaciales de relevancia en el ámbito de la milicia: alojamiento ${ }_{2}$, campaña o campo campo $_{2} \mathrm{o}$ real $^{2}{ }_{1}$, campo ${ }_{3}$ o campo de la batalla, cuerpo de (la) guarda ${ }_{2}$ o cuerpo de guardia explanada $a_{2}$, padrastro, plaza $a_{3}$ o plaza de armas, posta $a_{2}$ y posta $a_{3}$ o puesto.

Finalmente, hemos recogido escala, pie pequeño o pitipié, términos relativos al instrumento geométrico en el que están representadas una serie de

corresponde catalogar aquí las locuciones adjetivas de gente o de infantes, así como de suelo o de(l) terreno. 
medidas, cuyo uso era imprescindible en la elaboración del plano o perfil de una fortaleza. Debemos mencionar, por último, una serie de magnitudes temporales (alba, cuarto 437 , modorra y prima) y espaciales (camisa 3 , cuartel, estancia o posada, fondo y frente 1 ) propias del arte militar.

437 Tanto vela 2 como vigilia son sinónimos de cuarto. 


\section{ESTUDIO LEXICOGRÁFICO}

\section{Panorama de la lexicografía especializada relativa a la milicia}

Uno de los aspectos más decisivos en la confección de nuestro glosario militar ha sido el referente a la consulta de los diversos repertorios lexicográficos, tanto generales como especializados ${ }^{438}$.

A propósito de los diccionarios generales, debemos subrayar la deuda contraída con los más relevantes de nuestra historia lexicográfica: el Tesoro de la lengua castellana o española de Covarrubias, el Diccionario castellano con las voces de las ciencias y las artes de Terreros y, por último, el Diccionario de Autoridades de la Real Academia Española. Lógicamente, hemos tenido muy presentes las distintas ediciones del Diccionario de la lengua española, con especial atención a la última de ellas, la vigesima segunda 439 .

Aunque son repertorios contemporáneos y, por lo tanto, muy distantes de la época renacentista, hemos recurrido, asimismo, al Diccionario de uso del español de María Moliner, al Diccionario Salamanca de la lengua española coordinado por Gutiérrez Cuadrado, así como al Diccionario del español actual dirigido por Manuel Seco, los cuales han resultado fundamentales en la comprensión de aquellas voces de nuestro glosario que cuentan en la actualidad con una elevada frecuencia de uso, y no necesariamente en contextos

438 "La reconstrucción de la historia del lenguaje de la ciencia es algo insoslayable para poder conocer la historia de los conceptos que maneja la ciencia, la historia de su discurso, en definitiva, la historia de cada ciencia. Y esa labor se hace fundamentalmente a partir de los textos, estudiando las palabras en el interior de ellos, en sus contextos [...]. Los textos son, desde luego, las fuentes primarias, los documentos primarios para el estudio del léxico especializado y la reconstrucción de su historia. Pero, además de ellos, [...] existen unos instrumentos que, por más que en la terminología documental actual se califiquen como documentos terciarios, proporcionan una información de primer orden para llevar a cabo esta tarea de la que estamos hablando. Me refiero a los diccionarios, los glosarios, los vocabularios...; en definitiva, todos los repertorios lexicográficos que son de una ayuda inestimable para completar el estudio de las palabras en los textos" (Gutiérrez Rodilla 2003: 457).

439 No hemos olvidado tampoco la abundante lexicografía extraacadémica desarrollada principalmente a partir del siglo XIX: "Si hasta bien entrado el siglo XIX la Academia brillaba en solitario gracias a su continuada labor en este terreno, a partir de su segundo cuarto, la situación cambiará de manera radical con la irrupción de un extenso conjunto de diccionarios que, en principio, mostrarán como carta de presentación -y algunos, como única razón de serel hecho de superar el caudal léxico del Diccionario de la Academia" (Azorín Fernández 2004: 229). 
especializados, como acometer, batir, defender, guardar, barrera, guerra, resistencia, valla, etc. En este sentido, ha resultado también útil el Diccionario Estudio Salamanca.

Por lo que respecta a la lexicografía de especialidad, debemos señalar el notable número de diccionarios de temática militar publicados durante todo el siglo XIX. En este sentido, nos proponemos enumerar las principales características de los repertorios manejados con el fin de destacar sus aspectos más significativos, sobre todo de aquellos que han resultado de mayor utilidad en nuestra labor lexicográfica ${ }^{440}$. Con nuestra presentación, esperamos contribuir a una mejor difusión de estos repertorios, que no han gozado de gran repercusión por la propia especificidad del ámbito en el que se inscriben ${ }^{441}$.

\title{
1.1. El Diccionario militar (1749) de Raimundo Sanz
}

Este Diccionario militar tiene el mérito de ser el primer trabajo lexicográfico en lengua española sobre vocabulario militar ${ }^{442}$. Como ya se indica en la portada, se trata de una "traducción del idioma francés en el español". Y es en la cédula real donde encontramos más información al respecto:

\begin{abstract}
Por quanto por parte de vos Don Raymundo Sanz, Capitán de Minadores del primer Batallón de Artillería, se me ha representado teníais traducido del idioma francés al español un tomo en octava, con el título de Diccionario Militar, o Recopilación Alphabética de todos los términos propios al Arte de la Guerra, y el que el nombre del Autor era solamente el que se encontrava en la Dedicatoria que hacía al Príncipe de Turena, y se reconocía por A. D. L. C. que deseando dar esta obra a la luz pública, me suplicasteis fuesse servido concederos licencia y privilegio por diez años para su impressión.
\end{abstract}

Gago-Jover (2007: 61) nos informa de que la obra lexicográfica francesa que traduce Sanz es la de Aubert de la Chesnaye-Desbois titulada Dictionnaire

\footnotetext{
440 En consonancia con los campos léxicos contemplados, los repertorios a los que menor atención les dedicamos en este capítulo son los centrados mayoritariamente en la artillería y en el armamento.

441 Agradecemos a Gago-Jover el acceso a la versión electrónica de la mayoría de los diccionarios militares del español.

${ }^{442}$ A finales del siglo XVIII hay una nueva edición de este diccionario: Madrid, 1794, Oficina de D. Gerónimo Ortega y herederos de Ibarra. Por otro lado, la edición moderna del Diccionario militar de Sanz se la debemos a Gago-Jover y Tejedo-Herrero (2007).
} 
militaire, ou, Recueil alphabetique de tous les termes propres à l'art de la guerre publicada en París en 1742. Siguiendo a García Platero (2003: 266), “durante este siglo [el XVIII] se publican muchos diccionarios monolingües especializados, si bien la mayor parte de las veces podemos hablar únicamente de traducciones", lo que demuestra que el repertorio de Sanz no es un ejemplo aislado.

Ahora bien, "en contra de lo que inicialmente pudiéramos suponer, la labor de Raimundo Sanz no se limita a la traducción literal del original francés, sino más bien a la adaptación a la lengua y cultura militar españolas de una obra francesa" (Gago-Jover y Tejedo-Herrero 2007: X).

Además, como reconoce el propio Sanz en su prólogo:

\begin{abstract}
El curioso notará cotejando el original con la traducción que en partes he sido breve, en algunas dilatado y en otras no hago mención. En lo primero me ha parecido conveniente que una sucinta y clara explicación es bastante, sin tanta digressión. En lo segundo, como propio de mi facultad, he aplicado lo que corresponde a nuestro uso. $\mathrm{Y}$ en lo tercero he passado en silencio lo que he creído no ser essencial, a fin de no augmentar el volumen, pero todo sin salir del orden de traductor.
\end{abstract}

Es evidente que para Sanz la actividad traductora no sólo consiste en volcar una obra que está escrita en una determinada lengua a otra distinta, sino que para que el producto final sea legítimo es necesario que el traductor intervenga en ella de manera mucho más directa. De este modo, Sanz se ve obligado en su Diccionario militar a adoptar una serie de decisiones, que posibilitan el surgimiento de un repertorio lexicográfico en lengua castellana bastante alejado del francés que lo motiva. De acuerdo con Gago-Jover y Tejedo-Herrero (2007: XI-XIII), Sanz elimina de su obra, en primer lugar, la mayoría de las referencias a la historia o a las instituciones francesas presentes en la de Aubert de la Chesnaye-Desbois. En segundo lugar, cuando considera que es necesario concretar el uso o la función de una determinada realidad militar, amplía la definición del término en cuestión que la designa. Y, por último, prescinde de aquellas entradas que considera obsoletas, exclusivas de Francia o cuyas definiciones son muy parecidas a las que ya poseen otros lemas. 
Pero, "además de estos tres procedimientos básicos, Raimundo Sanz recurre también con frecuencia a otros dos, la combinación y la segregación de entradas" (Gago-Jover y Tejedo-Herrero 2007: XIV)443.

\subsection{Los Principios de fortificación (1772) de Pedro de Lucuze}

Hemos creído conveniente analizar los Principios de fortificación (1772) de Lucuze, puesto que, aunque no constituyen exactamente un diccionario, "contienen las definiciones de los términos principales de las obras de plaza y de campaña", como su mismo subtítulo anuncia ${ }^{444}$.

Su autor, Pedro de Lucuze, director de la Real Academia Militar de Matemáticas de Barcelona durante más de cuarenta años, fue quien redactó una de las tres aprobaciones de las que consta la primera edición, de 1749, del Diccionario militar de Sanz ${ }^{445}$.

Los Principios de fortificación, tras unas advertencias al lector, constan de un "cathálogo de algunos escritores militares españoles, en que se expresa el nombre, el empleo, el título de la obra, el lugar y año de su impresión, por el orden de su antigüedad" (Lucuze 1772: XII-XXII). En él, vemos citadas hasta seis de las trece obras de temática militar incluidas en el corpus del DICTER: $E l$ perfecto capitán de Diego de Álava y Viamont, la Práctica manual de Artillería de Luis Collado, el Comentario de disciplina militar de Christóbal Mosquera de

\footnotetext{
443 Para la clasificación tipológica de sus definiciones, pueden consultarse los estudios de Tejedo-Herrero y Gago-Jover (2006) y Gago-Jover (2007).

${ }^{444}$ Además, en el prólogo que titula "al lector", al explicar qué le motivó a redactar esta obra, es el propio Lucuze quien la denomina "diccionario": "El Capitán General Marqués de la Mina [...], habiendo trabajado la grande obra de sus Reflexiones, sacadas por las experiencias de la Guerra pasada en Italia, Cerdeña, Nápoles y Sicilia, me encargó escribiese un Diccionario de Fortificación, para incluirle con ella, y hacerse inteligible a la juventud militar, que carece ordinariamente de los principios mathemáticos, con la prevención de usar de vozes españolas, sin admitir las introducidas sin necesidad por los forasteros; y con arreglo a estas circunstancias le formé el año 1755. Pero habiendo fallecido este General, sin que se haya dado providencia para la impresión de su obra, me ha parecido sacar a la luz mi Diccionario, instado de los amigos que le han visto, y principalmente para que el público se utilice de mis tareas" (Lucuze 1772: II-III). Debe notarse que la paginación en números romanos no aparece en el original.

445 “Aprobación de don Pedro Locuze, Teniente Coronel de Infantería, Ingeniero en Gefe de los Exércitos, Fronteras y Plazas de su Magestad, y Director General de la Real Academia Militar de Mathemáticas, establecida en Barcelona". Las otras dos aprobaciones corresponden al padre Fray Francisco Galindo y a Bernardo de Berart.
} 
Figueroa, la Theórica y práctica de Fortificación de Christóbal de Roxas, el Discurso del capitán Christóbal Lechuga y, por último, el Tratado de la Artillería de Diego Ufano.

Por lo que respecta a su estructura, se compone, primero, de una introducción "por la explicación de algunos términos de la Geometría" y, a continuación, de tres secciones tituladas, respectivamente, "términos de la Fortificación Real”, "términos de la Fortificación de Campaña” y "aplicación de las obras de campaña al ataque y defensa de las plazas". Se incluyen, por último, diez láminas con dibujos que facilitan el entendimiento de algunas de las construcciones $\mathrm{u}$ objetos militares anteriormente explicados.

\subsection{La Encyclopedia metódica (1791-1792) de Luis Castañón}

En 1791 y 1792 la imprenta de Sancha (Madrid) publica dos tomos de la Encyclopedia metódica dedicados a la milicia. Se trata, de nuevo, de la traducción de una obra francesa, la Encyclopédie méthodique, vasta empresa lexicográfica que se dispuso por orden de materias. En el original francés, la parte de la milicia fue redactada por Louis-Félix Guinement de Kéralio, mientras que el encargado de traducirla a nuestra lengua fue Luis Castañón. Pero, al igual que Sanz, no se limitó a una mera traducción: como en la misma portada se adelanta, éste es un texto dedicado al arte militar y "traducido del francés al castellano con algunas adiciones por el teniente coronel de infantería don Luis Castañón".

En el "prólogo del traductor" se explican en qué consisten exactamente sus intervenciones: "Los artículos que principian con esta señal (N.) son nuevos; esto es, aumentados en la traducción; y lo contenido entre dos estrellitas o asteriscos, adicciones (sic) del Traductor" (Castañón 1791: III) ${ }^{446}$.

Le sigue el "discurso preliminar", que es ya obra del francés Kéralio. Y tras él se inserta el repertorio lexicográfico, que, como se advierte en el título, es más bien una enciclopedia, de ahí que los artículos sean, por lo general, extremadamente amplios y con abundantes referencias históricas. Una buena

${ }^{446}$ Debe notarse que la paginación en números romanos no aparece en el original. 
muestra la constituye el artículo lexicográfico batalla, que ocupa más de 100 páginas (de la página 183 a la 285), y donde resulta evidente que la incorporación de detalladas explicaciones de cada una de las batallas más importantes del último cuarto del siglo XVII y de los primeros años del XVIII, como la de Cassel, San Dinisio, Marsella, Cassano, etc., ha contribuido de manera decisiva a su desmesurada extensión.

De hecho, pese a la amplitud de cada uno de los dos tomos (poseen 563 y 632 páginas respectivamente), su macroestructura está incompleta al no incluir todas las letras del abecedario. El primer volumen abarca desde la letra $a$ hasta caz (su última palabra es, concretamente, cazadores), mientras que el segundo se extiende desde ce (ceguera) hasta gua (guarnición).

\subsection{El repertorio de James Willson (1794) y demás diccionarios bilingües}

En 1794 se publica el primero de una larga serie de diccionarios bilingües centrados en la milicia: A pocket vocabulary in six languages, viz. English, German, Dutch, French, Italian and Spanish; containing such words, terms and questions, as are most generally in use, particularly in military service del capitán James Willson. El propósito de esta obra, así como las continuadoras, es ofrecer el equivalente en uno o varios idiomas de distintos tecnicismos militares, por lo que su influencia en nuestro trabajo lexicográfico ha sido limitada. Éste es el motivo por el que simplemente enumeramos aquellas de las que tenemos constancia: el Vocabulario francés-español de términos de Artillería (1848) de Pedro de la Llave, el Vocabulario militar francés e inglés-español (1853) de Joaquín María Enrile, el Diccionario tecnológico inglés-español (1878) de Cañada y Gisbert, el Vocabulario militar (1883) de Gille447, el Vocabulario militar español-alemán (1885) de Garrido, el Vocabulaire militaire espagnol-français (1889) de Trépied, el Vocabulario militar

${ }^{447}$ De esta obra sólo hemos podido consultar su segunda edición, de 1885 (París, Librairie Abel Pilon). 
hispano-mogrebino (1907) de García Pérez y, finalmente, el Vocabulario hispanoárabe militar (1909) de Santa Olalla Millet.

\subsection{El Diccionario militar portátil (1822) de Fernández Mancheño}

El teniente coronel de infantería don José Fernández Mancheño publica en 1822 el Diccionario militar portátil o recopilación alfabética de todos los términos propios de las ciencias militares, explicación de los empleos de la milicia y sus obligaciones, y de las diferentes especies de tropas, clases distintas de armas antiguas y modernas, máquinas de guerra, etc., etc. Se trata del primer diccionario militar de nuestra lexicografía plenamente original.

Uno de sus aspectos más llamativos es el relativo a la inclusión de una "explicación de las abreviaturas usadas en esta obra", donde, junto a marcas como Fort. (Fortificación), Est. (Estrategia) y Táct. (Táctica), constatamos la presencia de otras en principio ajenas a la milicia: Alg. (Álgebra), Arit. (Aritmética), Ast. (Astronomía), Geom. (Geometría), Geog. (Geografía), Hid. (Hidráulica), Mat. (Matemática), Hidrom. (Hidrometría), etc. Fernández Mancheño justifica este modo de proceder en su "discurso preliminar":

Existe una porción de otras ciencias, cuya utilidad no podrá menos de conocer el observador curioso, y que aunque a primera vista no parezcan propias [de la profesión de las armas] son de suma importancia, especialmente en tiempo de guerra (Fernández Mancheño 1822: VI).

Al cotejar algunas definiciones del presente repertorio con las del Diccionario militar de Sanz, se hace patente que Fernández Mancheño tuvo muy en cuenta en su labor lexicográfica el primer vocabulario militar del español:

\section{Sanz (1749)}

Escalada. Es un ataque extraordinario contra las formas y precauciones regulares. Execútase empleando escalas para tomar por un insulto una muralla o rampar. Para librarse de una escalada, se hacen poner cavallos de frissa al rededor de todo el cuerpo de la plaza, pues en efecto son obstáculo contra ella.
Fernández Mancheño (1822)

Escalada. Es un ataque extraordinario contra las formas y precauciones regulares. Ejecútase empleando escalas para tomar por asalto una muralla o rampar. Para librarse de una escalada se hacen poner caballos de frisa al rededor de todo el cuerpo de la plaza; pues en efecto son un grande obstáculo para ella. 
Galería para passo de fosso. Es un pequeño passadizo hecho de carpintería que en piezas de madera se lleva al fondo del fosso, y le cubren de tablas cargadas de tierra para que pueda passar el minador y resista a los fuegos de artificio, y a las piedras que el enemigo echa sobre él.
Galería. fort. Para paso de foso. Es una especie de corredor en arco, que en piezas de madera se lleva al fondo del foso, y le cubren de tablas cargadas de tierra para que pueda pasar el minador y resista a los fuegos artificiales y a las piedras que el enemigo echa sobre él.

Muralla. Es una obra que circuye una plaza fortificada; a ésta se le dan diez y ocho pies de altura desde el plano del foso hasta el cordón, con un pie de declive por cada seis pies, y cuatro pies y medio desde el cordón a la altura del parapeto [....].

Terraplén. fort. Es la superficie orizontal de la muralla, esto es, la parte superior de ella, que poco más o menos es paralela al plano orizontal. El terraplén está determinado de la parte de la campaña por un parapeto, y de parte de la plaza por un talud interior.

Ronda. Es una patrulla que hace de noche un oficial al rededor del rampar o muralla de una plaza de guerra para observar si los centinelas hacen su deber con vigilancia y fidelidad.

El oficial que hace la ronda hace llevar una luz o cabo de mecha encendida.

Las rondas se conocen con los nombres de mayor $\mathrm{u}$ ordinaria. La mayor es la que hace el gobernador, teniente de rey o sargento mayor, y la ordinaria la arriba dicha. oficiales de guardia están obligados a poner los soldados en una fila, pero sin armas, y salirlo a recibir, adelantándose algunos passos para darle el santo. Las otras rondas deben dar el santo al sargento o cabo de esquadra, que los recibe con la espada desnuda y la punta acia el pecho del que lo da. Desde que el centinela aperciba la ronda, dice gritando: ¿Quién vive? Y tan alto, que el cuerpo de guardia lo pueda oír bien, y responden: Ronda de gobernador, ronda de mayor, etc. El centinela que está más vecino al cuerpo de guardia, después de haverle dicho: Deténgase allá, llama gritando: Cabo de esquadra de guardia, la ronda. El cabo de esquadra sale del cuerpo de guardia, pone la espada a la mano, y dice [...].

En el caso de ronda, la última de las entradas mostradas, puede observarse que Fernández Mancheño no se limita a reproducir literalmente la definición de Sanz, sino que elimina todo lo que considera superfluo. Es 
precisamente ésta una de sus principales características, según pone también de manifiesto el artículo de zapa, por citar sólo un ejemplo más.

Por otro lado, la influencia que el Diccionario de Autoridades ejerce sobre esta obra lexicográfica constituye otro de sus rasgos fundamentales. El artículo de zapa permite ejemplificar este aspecto, puesto que para la segunda acepción de esta palabra Fernández Mancheño se vale íntegramente de la definición que ofrece el primer diccionario académico:

\begin{abstract}
Instrumento de gastadores en la guerra para levantar tierra, y es una especie de pala herrada de la mitad abajo, con un corte acerado. El mango remata en una muesca hueca grande en la que se mete la mano para hacer fuerza (Aut.: s.v. zapa).

Instrumento de zapadores para la tierra, y es una especie de pala herrada de la mitad abajo con un corte acerado. El mango remata en una muesca grande hueca en que se mete la mano para hacer fuerza (Fernández Mancheño 1822: s.v. zapa).
\end{abstract}

En el artículo del lema contra fuertes o estribos puede apreciarse la enorme deuda contraída por Fernández Mancheño tanto con el Diccionario de Autoridades como con el Diccionario militar de Sanz:

\begin{tabular}{|c|c|c|}
\hline Aut. & Sanz (1749) & Fernández Mancheño (1822) \\
\hline $\begin{array}{l}\text { Contrafuerte. El fuerte que se } \\
\text { hace en oposición de otro. No } \\
\text { tiene uso. } \\
\text { Term. de los Guarnicioneros. } \\
\text { Correa de vaqueta de dos } \\
\text { dedos de ancho y más de } \\
\text { tercia de largo, la qual se clava } \\
\text { en el fuste delantero de la silla } \\
\text { y en el de respaldo, para } \\
\text { assegurar en ella las cinchas } \\
\text { con que se afianza la silla. }\end{array}$ & $\begin{array}{l}\text { Contra-fuertes o estribos. Son } \\
\text { ciertos pilares o prismas de } \\
\text { muralla distantes uno de otro, } \\
\text { de quince hasta a veinte pies, y } \\
\text { se construyen desde sus } \\
\text { cimientos con un gran talud } \\
\text { que va a fenecer su cola en el } \\
\text { cordón. Sirve para fortalecer la } \\
\text { muralla, sobstener el terraplén } \\
\text { y el camino de las rondas. }\end{array}$ & $\begin{array}{l}\text { Contra fuertes o estribos. } \\
\text { fort. Son ciertos pilares o } \\
\text { prismas de muralla, } \\
\text { distantes uno de otro de } 15 \text { a } \\
20 \text { pies, y se construyen } \\
\text { desde sus cimientos con un } \\
\text { gran talud; que va a fenecer } \\
\text { su cola en el cordón. Sirve } \\
\text { para fortalecer la muralla y } \\
\text { sostener el terraplén, etc. } \\
\text { Es también el fuerte que } \\
\text { hace oposición atro. } \\
\text { Es una correa de baqueta de } \\
\text { dos dedos de ancho, que se } \\
\text { clava en los fustes de la silla } \\
\text { para asegurar las cinchas } \\
\text { que la afianzan. }\end{array}$ \\
\hline
\end{tabular}


Aunque sólo mostramos unos pocos ejemplos, constatamos que el trasvase de definiciones entre estos tres repertorios fue constante ${ }^{448}$. Por último, cabe señalar que el Diccionario militar portátil termina con unas breves “adiciones", donde Fernández Mancheño añade algunos términos que faltaban en su repertorio.

1.6. El Ensayo de un diccionario razonado sobre la ciencia de la guerra (1826) de Sánchez Cisneros

En 1826 se publica el Ensayo de un diccionario razonado sobre la ciencia de la guerra del general Sánchez Cisneros, obra que, según reza la portada, era "importante para el uso de los generales, y útil y necesaria a los gefes y oficiales del ejército".

En las advertencias previas "al lector", Sánchez Cisneros (1826: IV) califica ésta de "ensayo ligero o pequeño Diccionario enciclopédico de la ciencia de mi Instituto". En correspondencia con sus propósitos, las entradas lexicográficas exhiben su carácter prolijo al lematizarse unidades pluriverbales tales como: abundancia de forrages y subsistencias, atributos esenciales de la estrategia, calidad de tropas para los ataques de mando, faltas estratégicas, motivos de la pérdida de las batallas, etc. La extensión de la microestructura ratifica el proceder enciclopédico de su autor.

Por otro lado, Sánchez Cisneros admite basarse en obras anteriores a la suya, si bien deja patente la aportación de nuevos datos. En este sentido precisa haberse dedicado a asuntos militares hasta ahora no tratados. Anhela, por consiguiente, que nadie pueda atreverse a tachar su obra de simple copia:

\footnotetext{
Me dirás quizás, Lector mío, que repito en mi obra lo que otros hombres eminentes han dicho, y yo te diré que es cierto en cuanto a la esencialidad de las doctrinas, mas no en el modo de exponerlas y esplanarlas; aquí hay caudal mío $\mathrm{y}$ ageno, $\mathrm{y}$ en muchas cosas parto de mi pobre cholla; esto puedo asegurarte para que no me trates de plagio, pues hay pocos sabios que se desdeñen de caminar por las sendas de sus maestros, aunque con alguna libertad de
}

\footnotetext{
448 Ya Seco (1987) señalaba que no sólo la Academia fue objeto de plagio, sino que también en la lexicografía extraacadémica se produjeron actos de rapiña. Para una muestra de este tipo de comportamientos en el ámbito de las matemáticas, vid. Sánchez Martín (2010b).
} 
separarse cuando lo crean conveniente, porque todos nos equivocamos (Sánchez Cisneros 1826: VIII-IX).

Al final de este repertorio se adjunta una "nota particular sobre el levantamiento de planos topográficos".

\subsection{El Diccionario militar español-francés (1828) de Federico Moretti}

Uno de los vocabularios especializados con mayor repercusión fue el Diccionario militar español-francés (1828) del napolitano Federico Moretti, quien llegó a España en 1794, donde permaneció hasta su muerte (Carpintero Fernández 2010) ${ }^{449}$.

Este diccionario comienza con la dedicatoria al rey Fernando VII ${ }^{450}$. A continuación inserta el "prólogo", en el que especifica las características más relevantes de su repertorio. Puede destacarse la siguiente declaración de intereses, de entre todas sus afirmaciones,:

Los más de los Diccionarios militares que he consultado incurren generalmente en el defecto de exceder los límites que no debe traspasar un lexicógrafo, y no contentos con dar el significado preciso de la voz y su definición, refieren su etimología, las trasformaciones que ha sufrido y la legitimidad de su uso, lo que hace penoso su manejo y resfría la curiosidad de muchos, que arredrados del tamaño y extensión no quieren tomarse el trabajo de consultarlos para salir de sus dudas. Por esto he procurado ceñirme, en el que presento, a la ley severa de la correspondencia y definición de las voces, omitiendo su parte histórica y todo lo que sirve más bien de erudición que de enseñanza útil, objeto esencial y verdadero de esta clase de obras (Moretti 1828: IX-X).

Así pues, en esta ocasión nos encontramos ante un verdadero diccionario de lengua, muy diferente, por tanto, de otros reseñados hasta el momento,

\footnotetext{
449 Además de militar, Federico Moretti fue un importante músico, como pone de manifiesto esta investigadora. Estamos, por consiguiente, ante un personaje ilustre del siglo XIX español. De hecho, su extraordinaria erudición resulta evidente al examinar la "noticia de las obras latinas, castellanas, italianas, francesas, inglesas y alemanas que se han consultado para la redacción de este Diccionario y su Apéndice", con la que Moretti acompaña su repertorio y donde cita cerca de trescientos trabajos.

450 “En 1817, solicita Real licencia para redactar el Diccionario Militar Español y Francés que comenzó a concebir en 1812, cuando se encontraba en Cádiz y que finalmente sería publicado en Madrid, en 1828, en la Imprenta Real y con la dedicatoria -al Rey Nuestro Señor que Dios Guarde-, para la que obtuvo permiso Real el 15 de mayo de 1818" (Carpintero Fernández 2010: 93).
} 
como la Encyclopedia metódica o el Ensayo de un diccionario razonado sobre la ciencia de la guerra. Para los distintos lemas, Moretti recurre a definiciones de tipo lingüístico, en consonancia con sus propósitos:

\begin{abstract}
Ala. s. f. Tact. Aile. La parte de tropa que cubre el centro del ejército por cualquiera de los costados.

Botín. s. m. Butin. Despojo que logran los soldados en el campo o país enemigo, en las entradas, combates y batallas.

Despojos. s. m. Dépouilles. Lo que se halla abandonado por la derrota de un ejército o toma por asalto de una ciudad, etc. (Véase botín).

Pertrechar. v. a. Munir. Reforzar o abastecer de municiones y defensas una plaza, fortaleza o sitio de campaña.
\end{abstract}

Admite, no obstante, que se ha apartado en varias ocasiones de este propósito:

Si alguna vez me he separado de este principio, adoptando algunas voces latinas, es porque de otro modo no me hubiera sido posible explicar la táctica, la castrametación, las armas y ordenanzas de los griegos, romanos, galos, cántabros, etc. (Moretti 1828: X).

En este sentido, las definiciones más extensas y enciclopédicas suelen hacer acto de presencia en los artículos lexicográficos referidos a realidades propias de épocas militares anteriores ${ }^{451}$, como en la caracterización de los distintos ingenios bélicos empleados por los romanos:

Ballesta. s. f. ant. Arbaléte. Máquina neurobalística que servía para arrojar piedras, saetas, etc. Esta arma se componía de un arco de madera, de cuerno o de acero, que atravesaba un fuste de madera de un pie y medio hasta tres de longitud, y algunas veces más. El fuste tenía en el medio una pequeña abertura o hendidura de dos dedos de largo y en ella una ruedecita de acero sólida y movible, por cuyo centro pasaba un tornillo que le servía de eje. La rueda salía en parte por encima del caballete y tenía una muesca para asegurar la cuerda de la ballesta cuando estaba tendida, y otra muesca mucho más chica en la parte opuesta de su circunferencia, por cuyo medio el resorte del fiador mantenía firme la rueda que se llamaba la nuez [...].

451 "[En este diccionario] se hallarán los términos técnicos antiguos del mismo modo que los modernos, fijando con precisión la diferencia que los tiempos o el uso han podido introducir" (Moretti 1828: XIV). Así, una de las abreviaturas más frecuentemente utilizada es "ant.", que significa, según indica en la "explicación de las abreviaturas que se ponen en este Diccionario, para denotar la calidad y censura de las voces", "palabra anticuada o perteneciente a la milicia antigua". No obstante, debe tenerse en cuenta que no hay una sistematización en el empleo de esta marca, puesto que Moretti suele alternarla con expresiones desarrolladas del tipo "que usaron los antiguos" o "usada por los antiguos" insertas dentro de la propia definición. Para más detalles, véase Sánchez Orense (en prensa-a). 
Músculo. n. p. ant. Máquina de guerra parecida a nuestro mantelete $(V$.) que usaron los romanos en el ataque de plazas. Consistía en un grueso barracón de madera cuadrado o cuadrilongo sin suelo, colocado sobre un telar formado con cuatro vigas, debajo del cual había varios cilindros o polines movibles, que con el auxilio de palancas le daban dirección en todos sentidos. El techo era triangular a manera de un tejado, y estaba cubierto de hojas de hierro y ladrillos [...].

Ovación. n. p. ant. Triunfo de segunda clase que concedía el senado romano, sin necesidad del consentimiento del pueblo, a los generales que habían obtenido ventajas sobre enemigos poco temibles, piratas, etc., y se verificaba con mucho menos aparato que el de primera clase ( $V$. triunfo.). El vencedor hacía su entrada a pie o a caballo, y nunca en carro triunfal, vestido con la túnica palmata $(V$.$) , y un ramo de olivo en la mano. Le precedían los primeros$ oficiales de su legión y algunos legionarios también con ramos de olivo [...].

\section{De todas formas, es posible hallar definiciones enciclopédicas en}

términos que designan realidades contemporáneas a Moretti, si bien es cierto que se trata de casos aislados:

Parapeto. s. m. Fort. Parapet. Parte superior de una muralla, formada de una masa de tierra a prueba de cañón, que se eleva por la parte anterior del terraplén y sirve para cubrir la tropa destinada a la defensa de aquella muralla. Su espesor debe ser de diez y ocho a veinte pies, y su altura de seis de parte de la plaza, y de cuatro a cinco de parte de la campaña. Esta diferencia de altura forma debajo del parapeto un declive o pendiente, que facilita a los soldados que guarnecen el parapeto el poder tirar de alto a bajo al foso [...].

Presa. s. f. Butin. El pillage, botín o robo que se hace y toma al enemigo en la guerra, así por tierra como por mar. Las leyes romanas no sólo no permitían al General tomar y repartir cosa alguna del botín o presa a los soldados, sino que los obligaba a presentarlo íntegro al tesoro público, para que el Cuestor, vendiendo todo lo que eran efectos y muebles, depositase en las arcas su producto; pero, a pesar de todo, los Generales hacían siempre algún reparto a la tropa tomándose para sí lo que les parecía [...].

Hay incluso artículos en los que Moretti aporta su opinión sobre el tema en cuestión, en lugar de limitarse a ofrecer una definición para los mismos.

Policía militar. s. f. Police militaire. La policía de los ejércitos se ha limitado a muy poca cosa hasta lo presente, o se la ha confundido con la disciplina; pero estas partes son infinitamente distintas, pues si sólo se considera un ejército como destinado a obrar contra los enemigos del estado, entonces es un cuerpo puramente militar, a quien es necesaria una disciplina; mas cuando se trata de los medios de procurar a los individuos que componen este ejército el alimento, el vestido y demás comodidades, como de libertarles de los males que intentan introducirse por todas partes [....].

Por último, como puede comprobarse en los artículos citados, normalmente el napolitano inserta entre las marcas y la definición su 
equivalente en francés. El último de los cuatro apéndices de los que dota a su diccionario 452 está formado por el "Vocabulaire français-espagnol, faisant suite au Dictionaire militaire espagnol-français":

Para que la obra fuese completa se hacía preciso poner la correspondencia de las voces francesas al castellano, con sus definiciones en francés, del mismo modo que están las españolas; mas con el fin de economizar su costo, y reducir el Diccionario a un solo volumen para su más fácil manejo, he limitado esta segunda parte a la simple correspondencia de las palabras del francés al español (Moretti 1828: XII).

\subsection{El Vocabulario militar (1849) de Luis Corsini}

En 1849 el brigadier Luis Corsini publica el Vocabulario militar, que, según señala su portada, "comprende las definiciones elementales del arte de la guerra, y la tecnología especial de las diversas armas que le constituyen, de la táctica peculiar a cada una, de la sublime, de la estrategia, de la logística, y de la fortificación, castrametación y equitación".

Este diccionario, dedicado al excelentísimo señor don Ramón María Narváez, consta de una serie de informaciones previas, incluidas bajo el título de "Advertencia", de las que queremos subrayar las relativas a la técnica lexicográfica adoptada, por ser la primera vez que este tipo de observaciones se incorporan en un diccionario militar. En primer lugar, Corsini especifica cuál ha sido su modo de proceder en la ordenación de las múltiples unidades pluriverbales de las que se hace eco, asunto en el que decide distanciarse del criterio académico:

${ }^{452}$ Las otras tres partes que conforman el diccionario de Moretti son: en primer lugar, un "suplemento de algunas voces omitidas en el Diccionario", a continuación, un "apéndice al Diccionario militar castellano y francés, que contiene el manual alfabético razonado de las monedas, pesos y medidas de todos los tiempos y países, con sus reducciones a las equivalencias españolas y francesas" y, por último, un "suplemento de algunas voces omitidas en el Apéndice". Sobre el apéndice relativo a monedas, pesos y medidas -el más extenso de los tres-, explica en el prólogo que en un principio no tenía intención de presentarlo por separado, pero que su censor, el señor don Martín Fernández de Navarrete, "bien conocido en la república de las letras", le persuadió de que esa era la mejor forma de presentarlo: "Siguiendo el plan de sujetarme a las reglas de un Diccionario había intercalado los nombres de los pesos, medidas y monedas antiguas y modernas, explicándolas en sus letras respectivas; pero habiéndome insinuado mi erudito censor que sería mejor formar un tratadito separado de la materia por vía de apéndice, lo he verificado así, bien convencido de la importancia de este asunto" (Moretti 1828: XI). 
El Vocabulario militar componiéndose más bien, en general, de denominaciones compuestas, que de voces sueltas y aisladas, hemos dudado un momento si en él seguiríamos el orden admitido comúnmente para los diccionarios, y que consiste en colocar la frase adverbial o denominadora en el lugar alfabético a que corresponde el primer substantivo que en ella se encuentre. Por fin nos hemos decidido a no admitir esta regla, persuadidos de que, bien que menos académica, y aunque se la tache de poco culta y de muy ramplona, es mucho más sencilla, pronta y cómoda la de buscar la denominación que se quiera encontrar, por la letra o letras iniciales con que de cualquier modo principie aquella (Corsini 1849: XIV).

Hacer frente. Phrase que significa resistir, rechazar y hacer oposición declarada a alguna cosa (Aut.: s.v. frente).

Hacer frente. Ponerse en disposición de oponerse al enemigo a viva fuerza, esperándolo para batirse con él (Corsini 1849: s.v. hacer).

En segundo lugar, informa a sus lectores acerca de la lematización y del tratamiento otorgado a los términos normalmente usados en número plural:

Advertiremos también que muchos substantivos o denominaciones compuestas se ponen en plural, ya porque su aplicación más general se hace de este modo, o ya porque el uso ha hecho que sean así más significativas, y mejor o más fácilmente comprendidas (Corsini 1849: XV).

Por otro lado, al comparar artículos lexicográficos como los siguientes, está claro que Corsini tuvo muy presente para la redacción de su obra el Diccionario militar español-francés de Moretti:

\begin{tabular}{|c|c|}
\hline Moretti (1828) & Corsini (1849) \\
\hline $\begin{array}{l}\text { Camisa. s. f. Fort. Chemise. El lado de la } \\
\text { muralla hacia la campaña, que suele hacerse } \\
\text { de piedra blanca o ladrillos blandos. Llámase } \\
\text { camisa por vestir la muralla por la parte de } \\
\text { afuera. }\end{array}$ & $\begin{array}{l}\text { Camisa. s. f. Fort. El lado de la muralla que cae } \\
\text { hacia la campaña, y que suele hacerse de } \\
\text { piedra o ladrillos blandos. Llámase camisa, en } \\
\text { atención a que reviste la muralla por la parte } \\
\text { de afuera. }\end{array}$ \\
\hline $\begin{array}{l}\text { Facción. s. f. Faction. Acto de servicio militar, } \\
\text { como guardia, centinela, patrulla, etc.; y así, } \\
\text { del militar que está ocupado en algunas de } \\
\text { estas fatigas se dice: está de facción; pero la } \\
\text { verdadera acepción de esta palabra es: estar de } \\
\text { centinela (Véase). }\end{array}$ & $\begin{array}{l}\text { Facción. s. f. Acto del servicio militar, como } \\
\text { guardia, centinela, patrulla, etc.; y así, del } \\
\text { individuo que está ocupado en cualquiera de } \\
\text { estas fatigas, se dice que está de facción. }\end{array}$ \\
\hline $\begin{array}{l}\text { Manga. s. f. Manche. Partida poco numerosa } \\
\text { de tropa escogida. En la milicia antigua } \\
\text { española era la tropa de arcabucería y } \\
\text { mosquetería con que se guarnecían las picas o } \\
\text { infantería. En el día sólo se usa esta voz } \\
\text { hablando de los granaderos, siempre que sea } \\
\text { una fracción de la compañía. }\end{array}$ & $\begin{array}{l}\text { Manga. s. f. Partida poco numerosa de tropa } \\
\text { escogida: se dice manga de granaderos, para } \\
\text { significar un cierto número, partida o } \\
\text { destacamento de ellos. Esta acepción va } \\
\text { caducando, y se halla ya apenas en uso. }\end{array}$ \\
\hline
\end{tabular}


Tenaza. s. f. Fort. Ouvrage à tenaille. Obra de campaña que se construye para fortificar la cabeza de un puente o sobre las líneas de defensa, parecida al hornabeque, y en el foso entre dos baluartes. La tenaza se distingue en simple y doble. Tenaza simple es una obra exterior, cuya cabeza se forma de dos frentes que hacen un ángulo entrante, y las alas o costados van seguidas desde la cabeza a la gola. Tenaza doble es una obra exterior, que su frente o cabeza está compuesta de cuatro caras que forman dos ángulos entrantes y salientes, y sus alas van seguidas desde la cabeza a la gola. Cuando las alas de esta obra son paralelas, no se conocen por otro nombre que el de tenaza simple o doble; pero cuando por el frente son más anchas que por la gola, se llaman cola de golondrina. Su terraplén está al nivel de la campaña, y diez o doce varas separado de los flancos de los baluartes colaterales. A la tenaza doble se le da el nombre de tenazón o tenallón. El mismo nombre se da a las grandes lunetas.
Tenaza. s. f. Fort. Obra de campaña que se construye con el objeto de fortificar la cabeza de un puente, o sobre las líneas de defensa, en el foso y entre los baluartes. La tenaza se distingue en simple y doble: la primera es una obra exterior cuya cabeza se forma de dos frentes que hacen un ángulo entrante, y cuyas alas o costados van seguidos desde la cabeza a la gola. Tenaza doble es una obra, también exterior, cuyo frente o cabeza se compone de cuatro caras, que forman dos ángulos entrantes y otros tantos salientes, yendo sus alas seguidas desde la cabeza a la gola. Cuando las alas de esta obra son paralelas, no se conocen por otro nombre que el de tenaza simple o doble; pero cuando son más anchas por el frente que por la gola, se llaman cola de golondrina. A la tenaza doble se le da también el nombre de tenazón o tenallón. El terraplén de toda tenaza está al nivel de la campaña, y diez o doce varas separado de los flancos de los baluartes colaterales.

No obstante, Corsini no comparte la opinión de Moretti en lo concerniente a la recepción de las voces pertenecientes a la milicia antigua: “Hemos dejado de comprender [...] cuanto tiene relación con las armas desusadas, con los ejércitos de la antigüedad, y con los sistemas y organizaciones caducas" (Corsini 1849: XI). Esto explica por qué Moretti sí se hace eco del significado táctico de tenaza, mientras que Corsini sólo ofrece la acepción ya anotada:

Formación de tenaza. ant. Formation à tenaille. Formación que usaron los antiguos para resistir al cúneo $(V$.$) , y consistía en pasar desde el orden de$ batalla al de tenaza, en la forma siguiente: el centro o la batalla formaba un semicírculo angosto por su garganta; y las alas, apoyando los extremos de aquélla, se abrían a manera de una cola de golondrina, por lo que el enemigo que había formado el cúneo, para romper la batalla del contrario, se veía obligado a entrar por las alas de aquél hasta llegar al frente que formaba el semicírculo, pasando precisamente por su garganta, y teniendo que sufrir las armas arrojadizas que por frente y flancos le batían. Ambas formaciones no están ya en uso (Moretti 1828).

Precisamente, al haber eliminado la referencia a la milicia antigua presente en la definición de Moretti, el artículo de manga constituye otro buen 
ejemplo del propósito expreso de Corsini de renunciar en su diccionario al estudio de la antigüedad.

Por otro lado, decide suprimir "las voces militares cuya definición ha llegado a ser ociosa, por demasiado vulgar y conocida" (Corsini 1849: XI), de nuevo en contraposición a su antecedente más directo. Según especifica más adelante, "sería [...] enteramente ocioso y hasta ridículo perder tiempo y papel en explicarles, con mucha seriedad, cual si fuesen unos doctrinos, los significados de una infinidad de voces comunes y olvidadas de puro sabidas, como son, por ejemplo, las de soldado, tiro, ataque central, ardid, etc.". Ahora bien, a pesar de esta afirmación, el término tiro se incorpora finalmente a la macroestructura de este diccionario ${ }^{453}$, seguramente debido a que éste designa “acepciones diferentes, que convenía deslindar a fin de evitar el que se confundiesen", tal como confiesa en su prólogo (Corsini 1849: XV).

\subsection{Los glosarios de los Catálogos de la Real Armería de 1849 y 1898}

En 1849 se publica en Madrid por Aguado, impresor de cámara de S. M. y de su Real Casa, el Catálogo de la Real Armería, "mandado formar por S. M. siendo director general de Reales Caballerizas, Armería y Yeguada el Excmo. Señor Don José María Marchesi"454, al que se le adjunta un "glosario compuesto de varias palabras cuya esplicación es necesaria para la intelijencia del catálogo que antecede", obra de Antonio Martínez del Romero, como el propio Marchesi señala en el prólogo del Catálogo:

Al Sr. Sensi se debe la colocación de los objetos, y al Sr. Martínez del Romero el Catálogo y Glosario que va a continuación; por mi parte no he tenido más mérito que haber pensado la reforma, y haberla continuado con sumo tesón al

\footnotetext{
453 "1.- La distancia a que alcanza una arma de fuego cualquiera. 2.- Art. Se llama así al total de caballos que tiran de cada carruage. 3.- Hábito que contraen algunos caballos, de apoyar los dientes en el pesebre, de morder el ronzal, etc., con contracción manifiesta de los músculos del cuello" (Corsini 1849: s.v. tiro).

454 En 1854 se reimprimió este Catálogo de la Real Armería, en este caso "siendo caballerizo, ballestero y montero mayor el Excmo. Señor D. Joaquín Fernández de Córdoba, marqués de Malpica, duque de Arion, y veedor de Reales Caballerizas el señor D. Gabriel Campuzano y Herrera".
} 
través de no pocos obstáculos, que siempre y en todas partes hallaron esta clase de empresas (Marchesi: XII).

En la página carente de título que antecede al glosario, Martínez del Romero advierte, "por si se echan de menos ciertos nombres", que faltan aquellos de los que sí se hace eco, y además de manera apropiada, la Real Academia Española en su diccionario455. Y añade: "El que desee saber su significación, que acuda al citado libro".

Otro glosario, cuya redacción también se debe a un inventario de las armas reales, ve la luz en 1898: el Catálogo histórico-descriptivo de la Real Armería de Madrid, redactado por el conde viudo de Valencia de Don Juan. Según el Catálogo Colectivo del Patrimonio Bibliográfico Español [http://www.mcu.es/bibliotecas/MC/CCPB/index.html], el nombre de este conde era Juan Crooke y Navarrot, quien alude en su prólogo a la obra de Martínez del Romero:

\begin{abstract}
Debiose a la reina D. ${ }^{a}$ Isabel II nueva y ordenada instalación, basada en el Catálogo que vio la luz por vez primera en 1849, obra meritoria de D. Antonio Martínez del Romero, la cual obtuvo el aplauso de los inteligentes por la reproducción de las marcas, por las notas históricas y por el glosario de voces técnicas con que lo ilustró (Crooke y Navarrot 1898: VII).
\end{abstract}

Debemos destacar que Martínez del Romero comenta su labor lexicográfica en la "Advertencia preliminar" que antecede a toda su obra. En cambio, Juan Crooke y Navarrot no realiza ninguna referencia a su glosario en el prólogo inicial de su obra de 1898. La única puntualización que efectúa al respecto se halla en la "Advertencia preliminar", que incorpora, junto con las abreviaturas empleadas, tras el catálogo y justo antes de su aportación lexicográfica:

455 En la "advertencia preliminar", comentaba, en cambio, que si bien "cierto es que el Diccionario del idioma español redactado por la Academia contiene [...] algunos nombres y definiciones correspondientes a las antiguas armas y armaduras [...], también lo es que no debimos adoptar como propias y verdaderas todas esas definiciones por lo que tienen muchas de inesactas" (Martínez del Romero 1849: XIII). Parece, por tanto, que este autor concibió su glosario como una fuente fiable de información, pero sólo para aquellos términos técnicos de la armería ausentes del Diccionario de la lengua española de la Real Academia o cuya definición, a su modo de ver, no era la más acertada. 
No pretendemos dar aquí un Glosario completo de las voces que comprende el tecnicismo de la panoplia española: sería trabajo superior a nuestros conocimientos, por la preparación que requiere y porque, de poderlo efectuar, traspasaría los límites del plan que nos hemos trazado.

Nos limitamos a que resulte de alguna utilidad el estudio que hemos hecho de numerosos Inventarios de armas y otros documentos que a ellas se refieren, para sacar del olvido muchas voces técnicas, cuya verdadera significación nos han facilitado textos de reconocida autoridad. De ellos también nos hemos valido para presentar, sometiéndolas a superiores juicios, ampliaciones o modificaciones al definir algunas palabras cuyo sentido difiere del de las contenidas en el Diccionario de la Lengua castellana de la Real Academia Española.

\section{A continuación, como muestra de sus similitudes y diferencias,} adjuntamos el artículo que ofrecen para almete estos dos glosario, por ser este lema el primero que, según el orden alfabético, forma parte de la macroestructura de ambos:

\begin{tabular}{|l|l|}
\hline \multicolumn{1}{|c|}{ Martínez del Romero (1849) } & \multicolumn{1}{|c|}{ Crooke y Navarrot (1898) } \\
\hline Almete. Voz francesa, corrompida de heaulme, & Almete o Helmete. (En fr. Armet.) "Pieza de la \\
yelmo pequeño. Hay quien afirme que de & armadura antigua, que cubría la cabeza." (Dicc. \\
yelmo, palabra goda, se dijo yelmete, y por & Acad.) (V.e p. I, n. 2.) Además transcribimos lo \\
corrupción almete. Esta voz se confunde muy & que dice Quijada de Reayo acerca de las \\
a menudo por los autores con yelmo y celada; & condiciones que debe tener el almete: “...ha de \\
y la vaga definición que de ella trae el & venir justo á la cabeça y quepa harta estofa con su \\
Diccionario de nuestro idioma es una prueba & barascudo detrás y armado puedas comer y beuer \\
patente de esta verdad. Cervantes en el cap. & con él y en las quixeras en ygual de las orejas cinco \\
19, part. I del Quijote, dice: aquel almete de & agujericos en cruz y la estofa por la parte de dentro \\
Malandrino; y en el cap. 21: yelmo de Mambrino. & en ygual de los cinco agujeros sacado un bocado tan \\
En el Paso Honroso de Suero de Quiñones se & redondo como la oreja y porque puedas bien \\
dice: “El primer paje llevaba los paramentos & entender lo que te dixeren y la vista sea ancha \\
del caballo de damasco colorado con & acabaxo que cubra bien las quixeras d'l almete y \\
cortapisas de martas cebellinas, e todos & medio barbote con su alpartaz de malla..." Esta \\
bordados de muy gruesos rollos de arjentería, & descripción conviene en todo con la forma del \\
e llevaban en la cabeza un almete, encima del & almete de la armadura atribuida a D. Fernando \\
cual iba figurado un árbol grande dorado con & el Católico, la cual está en el Museo de armas de \\
fojas verdes y manzanas doradas". Si almete, & Viena, y de ella hemos hecho mención en la p. \\
pues, es un yelmo pequeño, como quieren que & 58. \\
indique su terminación, en manera alguna era & \\
a propósito para colocar en él un árbol grande & \\
como los que se llevaban en los yelmos de los \\
torneos.
\end{tabular}




\subsection{El Vocabulario técnico del material de artillería e ingenieros (1853)}

\section{de Emilio de Tamarit}

Este repertorio, según leemos en su portada, "comprende la nomenclatura y definición de todas las máquinas y efectos del uso de ambos cuerpos; la de los instrumentos y herramientas de las artes y oficios que tienen relación con ella; verbos y voces genéricas correspondientes al armamento, pertrechos, construcciones y fortificación, con la clasificación del membrete a que corresponde cada uno de los nombres en los inventarios de efectos de la cuenta y razón especial de Artillería".

En primer lugar se sitúa la dedicatoria que Tamarit dirige al Excmo. Sr. D. Francisco de Mata y Alós, fragmento en el que, entre otras cosas, le recuerda que la presente obra es la primera que aparece en España consagrada a la clasificación de efectos del material de guerra, idea que repetida en el prólogo titulado "El autor".

En segundo lugar, al igual que en otros repertorios lexicográficos anteriores, es notoria la autoridad que Tamarit concede a la Real Academia Española, ya que en su prólogo se afana por dejar constancia de que se ha "ciudado mucho de nombrar los efectos con arreglo a la ortografía del Diccionario de la Lengua" (Tamarit 1853: VI).

Tras la parte propiamente lexicográfica, incluye una serie de "membretes que constituyen los inventarios de efectos del material de Artillería con arreglo a ordenanza". Gracias al siguiente fragmento del prólogo, podemos saber qué relación guardan estos listados con el vocabulario que les antecede:

Siendo la formación de inventarios uno de los ramos en que más escrupulosidad y conocimiento exige la cuenta y razón de Artillería, por la clasificación y aplicación a los diferentes membretes de que se componen aquellos, he creído oportuno marcar dicha colocación por medio de números, colocados al pie de cada voz, los cuales, correspondiendo a otros iguales que hay en la lista o membretario que se inserta al final del libro, determinan la verdadera clasificación de cada efecto, y obvian en estremo el trabajo en la formación de Inventarios al que no esté práctico en la materia (Tamarit 1853: VII). 
Finaliza este libro con la enumeración de las "obras consultadas para la redacción del Vocabulario técnico del material de artillería e ingenieros".

\subsection{El Diccionario ilustrado de los pertrechos de guerra (1853-1866) de} Luis de Agar y el Diccionario militar (1856) de J. M. A.

Durante los años 1853 y 1866 se publican las 38 entregas del Diccionario ilustrado de los pertrechos de guerra y demás efectos pertenecientes al material de artillería 456 . En él se incluyen "términos pertenecientes, directa o indirectamente, al material de artillería: piezas, afustes, explosivos, herramientas, medios de transporte, etc." (Gago-Jover 2008: 672).

Lo más destacable de este repertorio es que la mayoría de sus entradas va acompañada de ilustraciones, propiedad, como se indica en la portada, de Joaquín de Aramburu.

Por otro lado, de acuerdo con Gago-Jover (2008: 672), en la Revista Militar de octubre de 1856 se anuncia la inminente llegada del Diccionario militar, ayuda memoria del Oficial de Caballería en Campaña, cuyo autor responde a las iniciales J. M. A.; obra lexicográfica que al parecer finalmente nunca llegó a imprimirse.

\subsection{El Diccionario general militar (1857) de Deogracias Hevia}

Del Diccionario general militar de voces antiguas y modernas interesa resaltar que supone la primera vez que en el prólogo de un repertorio especializado de la milicia se incorpora "una ligera reseña comparativa de cuantos diccionarios y vocabularios militares, hasta hoy, en castellano vieron la luz pública" (Hevia 1857: V). Aunque ciertamente se trata de una historia de la lexicografía relativa a esta especialidad bastante completa, queremos apuntar la ausencia de unos cuantos diccionarios, además de la presencia de un par de afirmaciones incorrectas.

\footnotetext{
456 Se reeditó en edición facsimilar en 1975: Madrid: Asociación "El Cid", Museo del Ejército
} (ápud Gago-Jover 2008: 672). 
En primer lugar, Hevia (1857: V) explica que “en 1744 D. Raimundo Sanz tradujo del francés y publicó un Diccionario militar", cuando en realidad, como ya hemos precisado antes, la primera edición de esta obra apareció unos años después, en 1749. Por otro lado, aunque es verdad que cuando Hevia escribe su repertorio aún no se había publicado de manera íntegra el Diccionario ilustrado de los pertrechos de guerra de Luis de Agar, al proclamar categóricamente que "esta obra quedó incompleta" (Hevia 1857: VIII), sin tener en cuenta la posibilidad de aparición de futuras entregas, vuelve a incurrir en un error. En palabras de Gago-Jover (2008: 672), “la afirmación de Hevia [...] es incorrecta, ya que, tras el paréntesis de unos años, la obra [de Luis de Agar] continuó siendo publicada".

Respecto a los repertorios monolingües que faltan en su resumen de la lexicografía militar previa, Hevia olvida, en primer lugar, el Ensayo de un diccionario razonado sobre la ciencia de la guerra de Sánchez Cisneros; en segundo lugar, el Vocabulario técnico del material de artillería e ingenieros de Emilio de Tamarit; y, por último, los glosarios de los dos Catálogos de la Real Armería anteriormente descritos.

Por lo que respecta a los bilingües, Hevia sólo cita el Vocabulario francésespañol de términos de Artillería (1848) de Pedro de la Llave, del que dice que "por más que esta obrita es apreciable, tiene muy poca analogía con mi publicación" (Hevia 1857: VII). Quizá ésta sea la razón de que no mencione en su prólogo ningún otro diccionario bilingüe especializado en la milicia.

Antes de disponerse a explicar el sistema y medios empleados en la confección de su diccionario, Hevia introduce la siguiente reflexión, sumamente interesante:

\footnotetext{
Con el frecuente uso que largo tiempo hice, por necesidad y por gusto, de los Diccionarios, así militares como de la lengua, he podido advertir que, así como un periódico da una noticia, y luego la repite otro, y después todos la publican, sin citar la fuente de donde manó, asimismo los lexicógrafos se aprovechan sin el menor escrúpulo de las definiciones que hallan hechas y cumplen a su fin; siendo esta costumbre tan antigua y de tal modo autorizada, que hasta los académicos de la lengua plagiaron sin el menor escrúpulo a Covarrubias, desde la definición de la letra A, cuando publicaron su primer Diccionario, que se llamó de autoridades (Hevia 1857: IX).
} 
De esta forma, admite que "imitando tan eminentes ejemplos, [...] cuando de alguna voz técnica militar hallé hecha la explicación de una manera que me pareció clara, exacta y con las dimensiones adaptables a mi plan, la tomé literalmente" (Hevia 1857: IX). Y, probablemente para no incurrir en la falta que acababa de censurar, decide hacer públicas las obras de las que ha tomado más definiciones: "Y aun diré más, y es, que los Sres. Moretti y Corsini son los autores que más trabajo me ahorraron" (Hevia 1857: IX) ${ }^{457}$.

Ahora bien, al tener en cuenta en su repertorio, como precisa su título, no sólo los tecnicismos militares modernos, sino también los antiguos, es mucho más evidente la huella de Moretti en el Diccionario general militar de Hevia que la de Corsini:

\begin{tabular}{|c|c|}
\hline Moretti (1828) & Hevia (1857) \\
\hline $\begin{array}{l}\text { Cerca. s. f. ant. Cadre. Formación de infantería } \\
\text { en la que la tropa presentaba por todas partes } \\
\text { el frente al enemigo, teniendo los flancos } \\
\text { cubiertos unos con otros, y dejando el centro } \\
\text { vacío. Esta formación es muy semejante a las } \\
\text { que hoy se llaman cuadro y cuadrilongo. } \\
\text { (Véase cuadro y corral). }\end{array}$ & $\begin{array}{l}\text { Cerca. s. f. ant. Formación de infantería en la } \\
\text { que la tropa presentaba por todas partes el } \\
\text { frente al enemigo, teniendo los flancos } \\
\text { cubiertos unos con otros, y dejando el centro } \\
\text { vacío. Esta formación es muy semejante a las } \\
\text { que hoy se llaman cuadro y cuadrilongo. (V. } \\
\text { Cuadro y Corral). }\end{array}$ \\
\hline $\begin{array}{l}\text { Cuervo. s. m. Corbeau. Máquina ofensiva de } \\
\text { guerra de que se servían los antiguos para el } \\
\text { ataque y defensa de las plazas y en los } \\
\text { abordages de sus galeras, muy parecida a la } \\
\text { grulla, cigüeña, cabestrante, etc. Había } \\
\text { diferentes clases de cuervos que se distinguían } \\
\text { con los nombres siguientes: cuervo de asas, de } \\
\text { cajón, delfín, demoledor, doble, de garfios, de } \\
\text { hoz y de tenaza. (Véanse). }\end{array}$ & $\begin{array}{l}\text { Cuervo. s. m. Máquina ofensiva de guerra, de } \\
\text { que se servían los antiguos para el ataque y } \\
\text { defensa de las plazas y en los abordajes de sus } \\
\text { galeras, muy parecida a la grulla, cigüeña, } \\
\text { cabestrante, etc. Había diferentes clases de } \\
\text { cuervos, que se distinguían con los nombres de } \\
\text { Cuervo de asas, de cajón, delfin, demoledor, doble, } \\
\text { de garfios, de hoz y de tenaza (V.). }\end{array}$ \\
\hline $\begin{array}{l}\text { Cúneo. s. m. ant. Formation en coin, ou tête de } \\
\text { porc. Orden triangular de batalla en forma de } \\
\text { un cono truncado que termina en punta por el } \\
\text { frente y se ensancha hacia la base: le usaron } \\
\text { mucho los griegos y romanos para romper la } \\
\text { línea enemiga; y generalmente le formaban } \\
\text { con las tropas de reserva. Al cúneo se le oponía } \\
\text { el orden de tenaza. (Véase). }\end{array}$ & $\begin{array}{l}\text { Cúneo. s. m. ant. Formación de tropas de } \\
\text { infantería que han usado los griegos y } \\
\text { romanos, empleándola con frecuencia para } \\
\text { romper y desordenar la línea de batalla } \\
\text { enemiga; consistía el cúneo en un orden } \\
\text { triangular de batalla, en forma de un cono } \\
\text { truncado, que terminaba en punta por el } \\
\text { frente, y se ensanchaba hacia la base. A la } \\
\text { maniobra del cúneo se le oponía la Tenaza. }\end{array}$ \\
\hline
\end{tabular}

457 En su reseña sobre los diccionarios militares que le anteceden, observamos el siguiente comentario acerca del de Moretti: "Trae ya en la letra A el importante número de 770 voces, si bien es cierto que también abunda en ripio" (Hevia 1857: VI). Por lo que respecta al de Corsini, considera poca acertada su decisión de dejar al margen las voces antiguas, pues cree "que en un diccionario deben hallarse tanto los términos envejecidos como los usuales; los unos para poder entender los antiguos escritos, y los otros para poderlos aplicar con propiedad" (Hevia 1857: VIII-IX). Aun con todo, admite que estos dos diccionarios le han sido de enorme utilidad. 
Puede verse que Hevia copia de Moretti hasta el uso de una marca diacrónica, abreviada en la forma "ant.", e incluso sin intentar subsanar su falta de sistematización, según manifiesta el artículo de cuervo.

Es que es tal la influencia que la obra de Moretti ejerce sobre Hevia que hasta en términos más modernos se decanta por copiar sus definiciones, en detrimento de las de Corsini:

\begin{tabular}{|c|c|c|}
\hline Moretti (1828) & Corsini (1849) & Hevia (1857) \\
\hline $\begin{array}{l}\text { Batir. v. n. Battre. Arruinar, } \\
\text { asolar o echar por tierra alguna } \\
\text { pared, edificio, etc. Romper un } \\
\text { cuerpo de tropas, ponerlas en } \\
\text { fuga, etc.: atacar con artillería y } \\
\text { otras máquinas de guerra una } \\
\text { plaza fuerte. } \\
\text { Batir. Tact. Battre. Aplícase a los } \\
\text { toques del tambor; y así se dice: } \\
\text { batir la generala, la marcha, la } \\
\text { diana, la retreta, etc. (Véase } \\
\text { toques). }\end{array}$ & $\begin{array}{l}\begin{array}{l}\text { Batir. v. Fort. Destruir, } \\
\text { desmoronar, arruinar, }\end{array} \\
\text { echar por tierra un muro, } \\
\text { un recinto fortificado o un } \\
\text { edificio cualquiera, o } \\
\text { atacar con artillería una } \\
\text { plaza fuerte. } \\
\text { Batir. v. Vencer al } \\
\text { enemigo, derrotarlo, } \\
\text { romper y poner en fuga a } \\
\text { un cuerpo de tropas, } \\
\text { dispersarlo, etc. }\end{array}$ & $\begin{array}{l}\text { Batir. v. a. Arruinar, asolar o } \\
\text { echar por tierra alguna pared o } \\
\text { edificio. - Destruir un cuerpo } \\
\text { de tropas, poniéndolas en fuga. } \\
\text { - Atacar con artillería y otras } \\
\text { máquinas de guerra una plaza } \\
\text { fuerte. - También se usa de este } \\
\text { verbo aplicándole a los toques } \\
\text { de tambor, y suele decirse: batir } \\
\text { marcha, batir generala, batir diana, } \\
\text { etc. (V. Toques). }\end{array}$ \\
\hline $\begin{array}{l}\text { Combate. s. m. Combat. Pelea o } \\
\text { acción de guerra menos general } \\
\text { y decisiva que la batalla, ni tan } \\
\text { premeditada como aquella. El } \\
\text { combate puede ser general, } \\
\text { parcial y singular. Es general } \\
\text { cuando todo el ejército toma } \\
\text { parte en la pelea: es parcial } \\
\text { siempre que sólo una parte de } \\
\text { aquel entra en acción, y } \\
\text { singular cuando se verifica } \\
\text { entre dos personas, o entre un } \\
\text { número corto pero igual de } \\
\text { combatientes. Es preciso en este } \\
\text { caso no confundir el combate } \\
\text { singular con el duelo: el } \\
\text { primero solía decidir las } \\
\text { querellas de dos naciones o las } \\
\text { discordias de dos partidos: el } \\
\text { segundo sólo sirve para } \\
\text { castigar un insulto, las más } \\
\text { veces incierto, o satisfacer un } \\
\text { resentimiento personal, } \\
\text { generalmente infundado. (Véase } \\
\text { duelo). }\end{array}$ & $\begin{array}{l}\text { Combate. s. m. El acto de } \\
\text { batirse dos tropas o } \\
\text { individuos. } \\
\text { Combate. s. m. Pelea, } \\
\text { refriega de tropa en } \\
\text { número poco considerable, } \\
\text { y en que de consiguiente } \\
\text { no promedia una grande } \\
\text { combinación de } \\
\text { movimientos o maniobras. } \\
\text { Como contienda colectiva, } \\
\text { el combate se considera } \\
\text { como de entidad media } \\
\text { entre la escaramuza y la } \\
\text { acción. }\end{array}$ & $\begin{array}{l}\text { Combate. s. m. Pelea o acción } \\
\text { de guerra menos general y } \\
\text { decisiva que la batalla, ni tan } \\
\text { premeditada como aquella. El } \\
\text { combate puede ser general, } \\
\text { parcial y singular. Es general } \\
\text { cuando todo el ejército toma } \\
\text { parte en la pelea, es parcial } \\
\text { siempre que una parte de aquel } \\
\text { entra en acción, y singular } \\
\text { cuando se verifica entre dos } \\
\text { personas, o entre un número } \\
\text { corto, pero igual, de } \\
\text { combatientes. Es preciso en este } \\
\text { caso no confundir el combate } \\
\text { singular con el duelo: el } \\
\text { primero solía decidir las } \\
\text { querellas de dos naciones o las } \\
\text { discordias de dos partidos; el } \\
\text { segundo sólo sirve para castigar } \\
\text { un insulto, las más veces } \\
\text { incierto, o satisfacer un } \\
\text { resentimiento personal, } \\
\text { generalmente infundado. (V. } \\
\text { Duelo). }\end{array}$ \\
\hline
\end{tabular}


Artículos como el siguiente muestran, por último, la apropiación por parte de Hevia tanto de un pasaje de Moretti como de uno de Corsini, gracias a los que consigue construir una nueva definición:

\begin{tabular}{|l|l|l|}
\hline \multicolumn{1}{|c|}{ Moretti (1828) } & \multicolumn{1}{|c|}{ Corsini (1849) } & \multicolumn{1}{|c|}{ Hevia (1857) } \\
\hline $\begin{array}{l}\text { Asaltar. v. a. Assaillir. Dar el } \\
\text { asalto, escalar alguna plaza o } \\
\text { fortaleza. (Véase asalto). }\end{array}$ & $\begin{array}{l}\text { Asaltar. v. El acto de escalar e } \\
\text { introducirse a viva fuerza en } \\
\text { una plaza o fortaleza. }\end{array}$ & $\begin{array}{l}\text { Asaltar. v. a. Dar el asalto; } \\
\text { escalar alguna plaza o o } \\
\text { fortaleza, entrando a viva } \\
\text { fuerza. }\end{array}$ \\
\hline
\end{tabular}

\subsection{El Diccionario militar (1863) de Jorge D'Wartelet}

En 1863 aparece el Diccionario militar publicado "por el capitán retirado J. D' W. M.", iniciales que, según la Biblioteca Nacional de España [http://www.bne.es/], corresponden a Jorge D’Wartelet.

Por lo que respecta al contenido de este repertorio, se afirma en la portada que "contiene las voces técnicas, términos, locuciones y modismos antiguos y modernos de los ejércitos de mar y tierra". Por lo demás, al tratarse de una obra lexicográfica carente de prólogo, no contiene más información proveniente del autor.

Tras la portada D’Wartelet incluye la "esplicación de las abreviaturas". Si se tiene en cuenta que posee una marca específica para las voces pertenecientes a la marina -a saber, mar.-, además del compromiso por recopilar los "términos [...] de los ejércitos de mar y tierra", parece evidente que en la conformación de su macroestructura, además de a la terminología militar terrestre, ha dado cabida a la naval. El único lexicógrafo de especialidad, de todos los que hemos mencionado, que también utiliza marca diatécnica de marina, e incluso representada por la misma abreviatura, es Deogracias Hevia.

Después del catálogo de abreviaturas se ubica el diccionario propiamente dicho, del que debe notarse su vasta extensión, al componerse de 746 páginas, que van desde la número 5 hasta la 751, mientras que por ejemplo el de Hevia, 
quien remarcaba la amplitud de su trabajo ${ }^{458}$, consta de 465 , que se extienden desde la página 17 hasta la 482.

La incorporación de una mayor cantidad de información en sus artículos puede ser uno de los motivos que expliquen por qué D’Wartelet casi consigue doblar el número de hojas de su antecedente más directo:

\begin{tabular}{|c|c|}
\hline Hevia (1857) & D'Wartelet (1863) \\
\hline $\begin{array}{l}\text { Fortificación. s. f. Es la ciencia que enseña a } \\
\text { disponer todas las fábricas y obras que son } \\
\text { necesarias para conseguir el fin en la guerra. } \\
\text { Se llama también arquitectura militar. Son } \\
\text { varias las fortificaciones: antiguas, modernas, } \\
\text { regulares e irregulares. Fortificación antigua } \\
\text { es la que está construida con foso y una simple } \\
\text { muralla, aunque después le añadieron } \\
\text { torreones redondos y cuadrados, orlados de } \\
\text { almenas; lo que ha subsistido hasta la } \\
\text { invención de la pólvora y el cañón. La } \\
\text { fortificación moderna consiste en un común } \\
\text { recinto, que es un rampar o terraplén } \\
\text { revestido de mazonería o de tepes; de un foso, } \\
\text { que forma una escarpa del lado de la plaza y } \\
\text { una contraescarpa de parte de la campaña; } \\
\text { baluartes y torres bastionadas, etc. La } \\
\text { fortificación regular es aquella cuyas partes } \\
\text { semejantes son iguales entre sí. La fortificación } \\
\text { irregular es aquella que tiene sus partes } \\
\text { semejantes desiguales. La fortificación regular } \\
\text { es preferible a la irregular cuando es posible, } \\
\text { pero es difícil hallar un terreno perfecto } \\
\text { cuando conviene construirla en parajes } \\
\text { determinados. }\end{array}$ & $\begin{array}{l}\text { Fortificación. s. f. El arte que enseña a cercar } \\
\text { una plaza o terreno de manera que sus } \\
\text { defensores puedan hacer frente a mayor } \\
\text { número de tropas y valerse de sus armas del } \\
\text { modo más ventajoso para obligarles a emplear } \\
\text { en el asedio un tiempo más considerable, } \\
\text { durante el cual otros accidentes imposibiliten } \\
\text { o hagan más difícil la rendición. La } \\
\text { fortificación se reduce a construir varias obras } \\
\text { de mampostería, ladrillo, piedra, tierra, fajinas, } \\
\text { etc., según las reglas establecidas, y se divide } \\
\text { en natural, artificial y mista: en permanente o } \\
\text { real, pasajera o de campaña. Puede ser defensiva } \\
\text { u ofensiva, regular o irregular. Las obras de } \\
\text { fortificación reciben varios nombres; los más } \\
\text { comunes son: baluarte o bastión, cortina, media } \\
\text { luna, tenaza, corona, bonete, contraguardia, luneta, } \\
\text { foso, camino cubierto, glacis o esplanada, caballero, } \\
\text { plaza de armas, cortadura y otros. } \\
\text { Si nos remontamos a buscar el origen de la } \\
\text { fortificación, le encontraremos en los primeros } \\
\text { tiempos de la sociedad. El choque poderoso y } \\
\text { terrible de una grande masa de enemigos } \\
\text { armados hizo rodear los pueblos con estacas, } \\
\text { paredes de tierra y fosos, que las necesidades } \\
\text { y el arte fue mejorando hasta convertirlos en } \\
\text { murallas sólidas, con sus cortinas, torres, etc. } \\
\text { Las mejores y más importantes plazas se } \\
\text { construían sobre eminencias o terrenos } \\
\text { elevados, en los que la naturaleza contribuía } \\
\text { con sus obstáculos. Las de las llanuras o tierras } \\
\text { bajas solían tener dos o tres fosos, e igual } \\
\text { número de líneas de defensa. Sus murallas se } \\
\text { elevaban a } 10,12 \text { y aun más varas de altura, } \\
\text { coronadas de matacanes y almenas. Polibio }\end{array}$ \\
\hline
\end{tabular}

458 "He procurado, por todos los medios que a mi alcance tuve, reunir la colección más rica que jamás en España se haya publicado, de voces técnicas militares, así antiguas como modernas, con tal que hayan tenido y tengan uso en el ejército español" (Hevia 1857: VIII). Y, además, una de las frases con las que termina su prólogo es la siguiente: "Aquí encontrará más de mil y quinientas palabras técnicas explicadas, que no figuran en ninguno de los diccionarios de la lengua española" (Hevia 1857: XIV).

${ }^{459}$ Este artículo se alarga durante dos páginas más. 
Ahora bien, si se tiene en cuenta que es bastante copioso el conjunto de unidades léxicas que gracias a D'Wartelet entran a formar parte por primera vez de un diccionario de temática militar (algunas de esas voces son dársena, gardingo, voivode, voltigeur, walí y wingher), no debería resultarnos tan extraño el considerable volumen de esta obra.

\title{
1.14. El Diccionario militar (1869) de José Almirante
}

Aunque este diccionario no ve la luz hasta 1869, según afirma en el prólogo su autor, José Almirante, ya en 1865 estaba listo para ser publicado. La responsabilidad de este retraso parece tenerla la Junta Consultiva de Guerra de aquel año que se negó a condecerle la protección requerida, según asegura Almirante ${ }^{460}$. De todas maneras, precisa al final de su prólogo que

\begin{abstract}
a pesar de haber durado largo tiempo, contra la voluntad de todos, la impresión de este libro, no ha parecido conveniente retocar ni modificar el texto en lo más mínimo; pues así, aunque pierda algún interés de actualidad, conserva el de presentar en conjunto con bastante exactitud el estado militar de España antes de la revolución de 1868 (Almirante 1869: XXVII ${ }^{461}$ )
\end{abstract}

En primer lugar, debemos subrayar la extraordinaria magnitud del Diccionario militar de Almirante, ya que sólo la parte lexicográfica monolingüe 462 consta, en la edición consultada, de 1070 páginas, es decir, bastantes más que las que conforman el repertorio de D'Wartelet. De todas maneras, a partir de los cómputos realizados por Gago-Jover (2008), esta mayor extensión no se traduce en una macroestructura más completa, puesto que, mientras que el Diccionario militar de D’Wartelet posee 7716 entradas, el de Almirante sólo cuenta con 5502.

\footnotetext{
460 Para hacer partícipes a sus lectores de la injusticia sufrida, Almirante inserta, tras el prólogo, la "copia del informe de la extinguida Junta Consultiva de Guerra".

461 Citamos esta obra por la reimpresión de 2002 llevada a cabo por el Ministerio de Defensa.

462 "Siendo las dos lenguas francesa y alemana las más útiles para el militar español, van al fin dos copiosos Vocabularios, con sus principales equivalentes, cuya definición y explicación se encuentran en el cuerpo del Diccionario" (Almirante 1869: XXVII).
} 
Por consiguiente, este aumento se debe a la mayor extensión concedida a los artículos por parte de Almirante. En este sentido, la etimología463, que por primera vez aparece en un diccionario militar, contribuye al aumento de aquellos artículos en los que se contempla:

Batalla. El origen de esta voz se fija ordinariamente en el bajo latín batualia, que significó lucha individual, pugilato, ejercicio gimnástico o atlético, del verbo batuor, battere, golpear, percutere; y así batuator designaba más bien GLADIADOR ${ }^{464}$ que SOLDADO. Los ROMANOS para significar BATALLA en nuestro sentido actual, usaban las palabras proelium, pugna [...]. Por lo tanto es moderna, relativamente, esa voz original batualia, de que los italianos han hecho su bataglia y los franceses su bataille. En las tres lenguas de origen latino, y singularmente en el romance castellano desde su formación, la palabra BATALLA ha venido expresando conjuntamente, hasta últimos del siglo XVII, dos ideas y dos hechos distintos [...].

Fagina. El francés fascine y el italiano fascina comprueban la etimología probable de fascis. Dicc. Acad. escribe fagina y no fajina, como suele verse en libros de texto incorrectos y diccionarios descuidados. Covarrubias encuentra la etimología de esta voz en las latinas fascis, haz de ramas, o fagus, fagí, haya; y de una u otra manera él la da por leña menuda para encender la gruesa, hojarasca para este objeto o para envasar [...].

Guarda. Evidentemente la raíz es gótica o teutónica ward, pronunciada guard, y que en el latín bárbaro se convirtió en wardea, wardia guardia; pero no todos los etimologistas están de acuerdo. Monlau, por ejemplo, citando a Rosal, opina por la raíz árabe huad, mano, de donde se hizo huarid, amparo, defensa; de aquí guarida y de éste, guardar, guarecer, guarnecer [...].

Como él mismo apunta, "la acumulación de citas y textos, la excesiva nimiedad en señalar la obra, la edición, el volumen, la página, bien se ve que no es alarde de erudición, ni jactancia literaria; sino, todo lo contrario, modesto empeño en el autor de robustecer con la de los maestros su escasa autoridad personal" (Almirante 1869: XXVI). Como consecuencia, la presentación de este tipo de datos también contribuye al aumento del número de páginas de su obra:

Batallón. Nombre genérico con que la TÁCTICA moderna de todas las naciones designa una TROPA, una agrupación ELEMENTAL de INFANTERÍA, cuyos miembros están contiguos en FORMACIÓN. El BATALLÓN en España no es sólo UNIDAD TÁCTICA, sino constitutiva, orgánica, administrativa [...]. Leemos en

\footnotetext{
463 "El tecnicismo militar dista bastante de estar hecho. La misma lengua general no permanece estacionaria; sigue las evoluciones del pueblo que la habla; es, pues, indispensable alguna atención a la etimología, no para entrar en honduras con San Isidoro o Covarrubias, cayendo en la vaguedad o en la manía de forzarlas, sino en cuanto pueda percibirse el origen inmediato de la voz en alguna de las lenguas madres del castellano" (Almirante 1869: XXVII).

464 "El tipo versal, con que van impresas las palabras importantes y técnicas, las señala bastante para buscarlas en su respectivo lugar alfabético, sin la molesta repetición de la abreviatura (V. e. v.) véase esta voz, véase este vocablo" (Almirante 1869: XXVII).
} 
Vargas Machuca (Milic. ind. folio 160 vto. 1595): "Que se han de hacer tres quadrillas de Campo; la una para vanguardia y la otra para batallón". Aquí la voz está en sentido de batalla (V. e. v.) como CENTRO o GRUESO de ejército. Âlava y Viamont (El perfec. cap. fol. 28-1590) explicando un plan o proyecto suyo de EJÉRCITO DE RESERVA llamaba BATALLÓN al "Cuerpo compuesto de 8000 soldados, repartidos en 32 compañías de a 250 hombres [...].

Facienda. Esta voz, que también se ha escrito fascienda, facenda, facendera, tuvo en la EDAD MEDIA el significado genérico de acción de guerra, empresa, HECHO DE ARMAS. Según Rodríguez (Mem. para la vida de S. Fern. pág. 326) era expedición militar y acción concejil. Clonard (Hist. org. T. I. pág. 151) pretende que era combate o acción, al que no asistían textas coronadas; pero bien explícito es el texto de la ley de Partida que dice: "Et fazienda llamaron do hay caballeros de armas las partes en que face cada uno su poder, teniendo su seña é parando mientes en cabdillar su compaña. E batalla pusieron nombre do hai Reyes de cada parte é tienden estandarte é señas, etc.". No es fácil discernir en este punto, ni aun en vista de antiguos documentos. La Historia rimada del conde Fernán González dice, por ejemplo, de Gonzalo Díez:

Era en los consejos muy bueno de toda paz.

Era para en faziendas crudo como agráz.

Quiquier que lo demandás fallarlo ye de faz...

Estydo la facienda en peso todo el día

Sobre ganar el campo era grande la porfía...

Estuvo byen medio día en pese la facienda [...].

\section{Otra práctica habitual en Almirante es el comentario de las definiciones}

que ofrecen algunos de los diccionarios militares precedentes, normalmente con

el objetivo de criticarlos, lo que conlleva necesariamente artículos lexicográficos

sumamente extensos:

Batalla. [...] Acudamos en última instancia a los tres Diccionarios militares españoles que inmediatamente nos preceden. Dice Moretti: "La lid, combate o pelea entre dos ejércitos, o la mayor parte de ellos, que se atacan, con el fin de derrotarse (repare el lector que aquí ya por lo pronto se da una distinción positiva: en la batalla los ejércitos se atacan con el fin de derrotarse: lo cual supone que no hay ese mismo fin en otras lides, combates o peleas). No debe confundirse una batalla con una acción: pues la batalla se verifica, como se ha dicho, entre dos ejércitos o la mayor parte de ellos; y la acción puede tener lugar entre dos cuerpos pequeños de tropas. La batalla obliga necesariamente a uno de los dos generales a cambiar las bases (sic) de operaciones, etc.; pero si las bases de operación de ambos ejércitos permanecen en el mismo estado de seguridad, o si solo la acción se verifica sin que concurra todo el ejército etc. entonces toma el nombre de acción, encuentro, etc. (Interrumpiremos de nuevo para advertir que las tres ect. son de Moretti, y que este autor escribía hacia 1828, en que ya la ESTRATEgia (V. e. v.) había hecho algunos prosélitos y algunos estragos en España). La batalla se da o se recibe [...]". Hevia, que en 1858 [sic.] ha tenido la humorada de reimprimir a Moretti, copia el artículo anterior sin mudar una tilde; sin omitir "que se atacan, con el fin de derrotarse", ni las “bases de operación”. J. D’W. M. (1863) define así la batalla [...].

Ninguno de los artículos citados parece pertenecer al grupo de los que Almirante (1869: XXVII) denomina de "importancia capital", del que cita tres 
ejemplos: guerra, táctica y artillería. Según él mismo confiesa, era inevitable que términos como éstos estuviesen en el origen de los artículos más largos de su obra lexicográfica. Así, no debería sorprendernos que, según nuestra edición, se compongan de 111, 36 y 24 páginas respectivamente.

Con respecto a la técnica lexicográfica empleada en sus definiciones ${ }^{465}$, asegura que ha puesto "singular empeño y diligencia en que la definición sea clara, exacta, precisa y breve en lo posible; mas, considerando también que el mejor modo de definir ciertas cosas es trazar su historia, no hemos retrocedido ante la extensión unas veces, ante la divagación otras, en forma de consideraciones técnicas, críticas o filosóficas" (Almirante 1869: XXVI).

Aun con todo, "para disminuir volumen $[. .$.$] , ha parecido conveniente$ apartarse un poco del camino trillado, haciendo [algunas] supresiones" (Almirante 1869: XXIII). De esta forma, tanto el léxico heráldico, como el relativo a la albeitería quedan al margen de este diccionario. Tampoco admite ni las órdenes militares ni las condecoraciones extranjeras, además de descartar también los términos correspondientes a ejércitos antiguos, como el egipcio, el chino o el tártaro. Sobre este último ámbito, considera que "basta con remontarse a las fuentes de Grecia y Roma"466 (Almirante 1869: XXIV).

Por último, es habitual que ofrezca su opinión sobre algunas cuestiones lingüísticas:

465 Es la primera vez que vemos en un diccionario de este tipo alguna consideración acerca del modo de proceder seguido en el establecimiento de uno de los elementos lexicográficos más importantes, a saber, la definición. De hecho, Almirante comienza a referir los tipos de definición existentes, convirtiéndose así en el primer autor de un repertorio especializado de la milicia que considera este tema: "Los lexicógrafos reconocen dos clases de definiciones, la explicativa y la sinonímica: esto es, la que admite descripción y la que se limita a dar equivalencias o sinónimos. Algunos sostienen que no puede haber dos palabras rigurosamente sinónimas; pero este segundo método es el más generalmente seguido, porque evita dificultades de redacción y da cierto aspecto de generalidad, que suele degenerar en confusión" (Almirante 1869: XXVI). Por su parte, aboga por el uso de una definición explicativa, frente a la sinonímica, aunque la mayor parte de las veces, al introducir en ella datos históricos e información enciclopédica, traspasa los límites de la definición estrictamente lingüística.

466 Así, en relación a esta concesión, revela más adelante lo siguiente: "Se da en este libro lugar muy principal a los vocablos anticuados; porque no todos son arcaísmos, como vulgarmente se cree, y porque, si se han de regenerar nuestro lenguaje y literatura militar, sólo puede ser inspirándose en los clásicos. $\mathrm{Y}$ ¡cuántas veces se hace oscura y penosa su lectura, por desconocer el sentido de alguna palabra desusada!" (Almirante 1869: XXVI). 
Embrasura. Los traductores del francés que no saben castellano encuentran embrasure y dicen muy frescos embrasura; otros lo copian, y al verlo impreso en "libros de texto" se ha llegado a creer, no sólo que esta voz es española, sino que da cierto relieve "técnico" al que la pronuncia, por ser algo extraña en efecto. Conste que los franceses son dueños de decir embrasure; pero los españoles tenemos suficiente con CAÑONERA y TRONERA, sin necesidad de embrasura.

Es por artículos como éste por los que en su prólogo Almirante (1869: XXVI) declara que "también se apuntan algunos galicismos usuales, pero innecesarios". Comenta, además, que le preocupa mucho "censurar la expresión impropia, el giro falso, la locución incorrecta; siguiendo en este punto el razonable precepto de rechazar lo que desnaturaliza el lenguaje, de admitir lo que real y forzosamente lo enriquece".

\subsection{El Diccionario de ciencias militares (1895-1901) de Rubió y Bellvé}

Entre los años 1895 y 1901 se publican los tres tomos del Diccionario de ciencias militares del capitán de ingenieros Mariano Rubió y Bellvé. Ya sólo por los tres volúmenes que conforman esta obra puede apreciarse la envergadura de la misma ${ }^{467}$.

Por lo que respecta al prólogo, queremos subrayar el empeño que en él pone su autor en explicar las causas que le han motivado a titular su repertorio de la forma en la que lo ha hecho:

La ciencia estudia, el arte ejecuta; la primera analiza, examina, compara, deduce; el segundo da preceptos más o menos terminantes y obra, por cuyo motivo, y prescindiendo de consideraciones de otra índole, no repugna a la lógica llamar ciencias militares al conjunto sistemático de verdades de un mismo orden, y que tienden reunidas a la perfección del arte militar (Rubió y Bellvé 1895: VI).

Según este criterio, el arte militar es un "compendio de todas las ciencias militares" (Rubió y Bellvé 1895: VII). Y, citando de nuevo sus propias palabras, “el arte militar, siguiendo un orden lógico, resulta subdividido en tres partes

${ }_{467}$ El primer tomo, que abarca desde la letra A hasta el dígrafo $\mathrm{CH}$, posee 986 páginas, el segundo, que contempla los términos comprendidos entre las letras D y H, cuenta con 1015, mientras que el último, en el que tienen cabida las voces cuya letra inicial es una de las restantes, tiene 963. Este diccionario se compone, por lo tanto, de un total de 2964 páginas. 
esenciales: los prolegómenos o primeros principios, los medios de guerra, o sea la descripción de la herramienta, y la ejecución de la guerra, o sea el empleo para los fines sociales" (Rubió y Bellvé 1895: VII). Tras estas reflexiones, decide insertar, sobre todo para facilitar el entendimiento de su anterior exposición, el siguiente cuadro, donde sintetiza de manera eficaz su concepción acerca del arte militar, así como su correspondiente clasificación epistemológica:

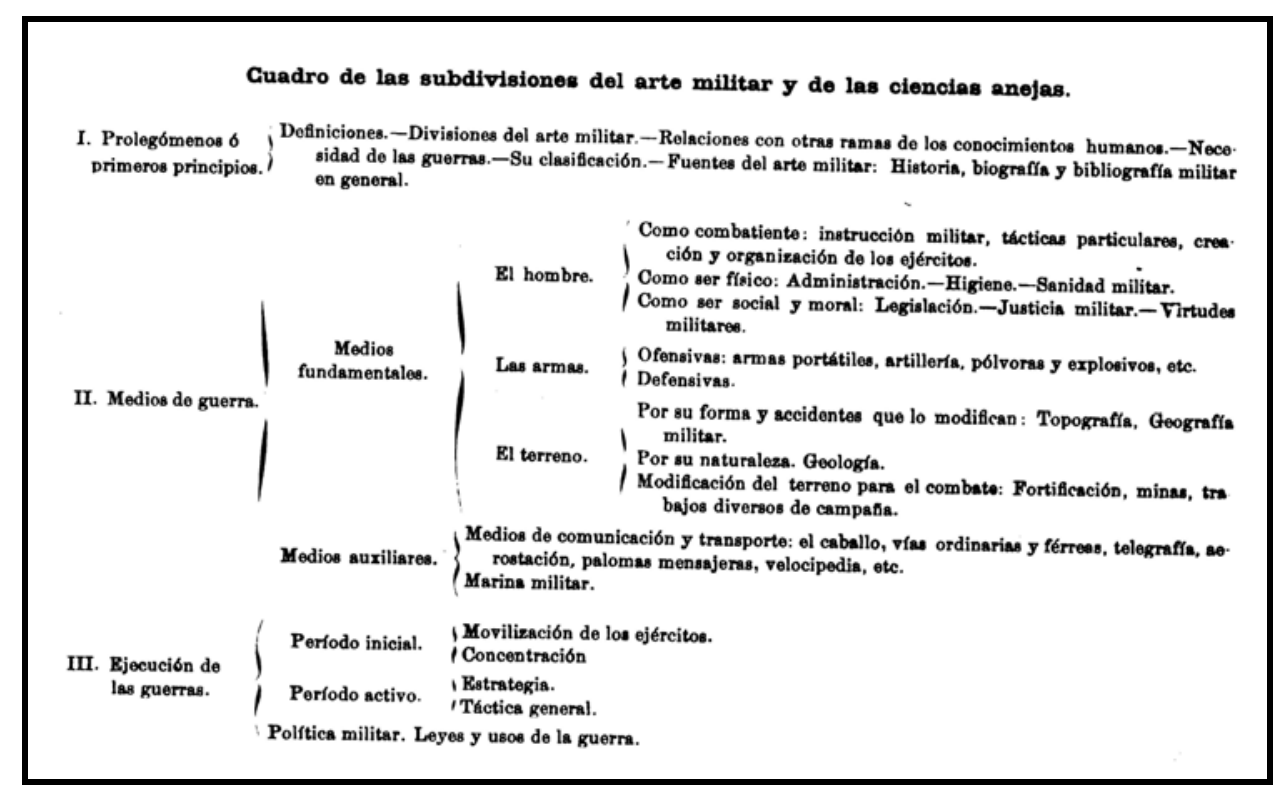

(Rubió y Bellvé 1895: VIII)468.

Dado que es la primera vez que en un repertorio centrado en la milicia se incorporan los términos técnicos de todas estas áreas temáticas, éste es el más completo, amplio y dilatado de todos los mencionados hasta ahora.

Como "en la historia de las ciencias militares brillan algunos individuos cuyos pensamientos y cuyas acciones son casi el arte de la guerra" (Rubió y Bellvé 1895: IX), considera conveniente incluir las biografías de esos personajes, así como las de algunos militares ilustres. Rubió y Bellvé se hace eco de unidades tradicionalmente consideradas exclusivas de las obras enciclopédicas, de las que algunos citamos algunos ejemplos: Alba (Duque de), Espínola

\footnotetext{
468 A la vista de este esquema, resulta indiscutible la influencia que llegó a ejercer sobre Rubió y Bellvé su antecedente más directo, puesto que el pasaje que citamos a continuación está extraído del prólogo con el que Almirante publica su Diccionario militar de 1869: "El Arte Militar de todos los tiempos y de todos los pueblos no ha tenido ni podido tener más elementos realmente constitutivos, esenciales, constantes que tres: los hombres, las armas, el terreno" (Almirante 1869: XXIV).
} 
(Ambrosio de), Fernández de Medrano o San Miguel (Evaristo). Ahora bien, no sólo hay antropónimos en este diccionario, sino que los topónimos son también habituales: España, Castilla, Fernando Póo y San Quintín, por nombrar sólo algunos.

“De muchas palabras se inserta la etimología, y la correspondencia en voces extranjeras" (Rubió y Bellvé 1895: IX), como muestra el siguiente artículo lexicográfico. Admite, no obstante, que no ha sido éste su modo de proceder en todos los casos, "por no ser siempre fácil, ni quizá de gran utilidad".

Bastida: Etim.: de bastir, disponer, edificar - Corresp.: Fr. bastide; bastillon; bastille \| It. bastita = Máquina militar que se empleaba antiguamente en la expugnación de las fortalezas, y que consistía en un castillo de madera movible, con el cual el atacante se aproximaba a las murallas, pudiendo batir desde él a los defensores que ocupaban el andamio o adarve.

«E entró por la comarca de entre Duero e Miño, é cercó la cibdad de Braga, é fízole bastidas e otros pertrechos, fasta que la tomó.» (Crónica de don Enrique II) ${ }^{469}$.

Finalmente, un elevado número de entradas va acompañado de ilustraciones, práctica que, exceptuando al Diccionario ilustrado de los pertrechos de guerra de Luis de Agar, apenas ha sido explotada por parte de los diccionarios especializados de la milicia, pese a su evidente utilidad.

\subsection{El Diccionario militar (1897) de Nicolás Estévanez}

De acuerdo con su contraportada, comprende, además de la parte monolingüe en nuestra lengua, "un vocabulario español-francés-alemán", por lo que ya sólo por esta decisión resulta patente que para Nicolás Estévanez la obra de Almirante se trataba de una eminente autoridad, lo que vemos corroborado en la siguiente consideración de su prólogo:

Uno de los mejores [diccionarios], por no decir el mejor de los que existen, el de Almirante, es un verdadero archivo, es un prodigio de erudición militar; pero, como escrito hace cuarenta años, faltan en él todos los términos técnicos y usuales que corresponden a lo mucho nuevo adoptado en el tiempo transcurrido desde que se escribió (Estévanez 1897: V).

${ }^{469}$ Nótese la huella de Almirante, y tanto en la inclusión de la etimología como en las citas y referencias a otros textos. 
Es éste uno de los motivos que le impulsan a sacar a la luz su trabajo lexicográfico. Ahora bien, parece ser, ya que lo reitera en su prólogo en varias ocasiones, que la razón principal radica en la constatación de la falta para el castellano de un diccionario militar manual, "que todos los subalternos puedan adquirir y llevar consigo a todas partes" (Estévanez 1897: VI) ${ }^{470}$.

Pues bien, la mayoría de las características que pueden aducirse sobre este diccionario de 1897, como son la ausencia de datos etimológicos ${ }^{471}$ o la utilización de definiciones brevísimas ${ }^{472}$, responden a este objetivo de lograr un texto conciso, pero a la vez práctico.

Con la intención de que se conozca un poco mejor este repertorio, reproducimos a continuación, tras escogerlos al azar, varios de sus artículos, en concreto los tres primeros que aparecen bajo la letra $\mathrm{H}$ :

Haber. El sueldo o paga personal de cada uno.

Habilitado. El oficial que se elige anualmente para recibir los fondos que corresponden al cuerpo.

Habilitar. Se dice de un camino, de un paso, de un vado, de un puente, que se arreglan para el paso de las tropas. - También a falta de cabo se habilita a un soldado para que haga sus veces.

Después de los respectivos vocabularios, tanto del monolingüe como del bilingüe, Estévanez (1897: 250-252) incluye un listado de los "autores, inventores y personajes citados en este libro".

470 Con respecto a esta cuestión, en las primeras líneas de su prólogo se expresaba en los siguientes términos: "Ofrecer al público un nuevo Diccionario militar, escrito en una lengua en la que existen varios y casi todos buenos, parecerá tal vez innecesario. Pero si se considera que todos los existentes son demasiado voluminosos y por consiguiente caros, habrá de reconocerse que un diccionario manual puede ser útil, especialmente para la gente moza. Es cierto que no faltan diccionarios militares para las bibliotecas, pero faltan sin duda los que con holgura quepan en el maletín de un oficial" (Estévanez 1897: V).

471 "Nuestro objeto no es dilucidar si una voz técnica procede del latín, del escandinavo o del caldeo, sino ofrecer un índice de expresiones militares, de términos empleados en la milicia española, de palabras hoy en desuso, que a veces llenan de dudas y confusiones al lector de libros militares" (Estévanez 1897: V).

472 "En general nos hemos limitado a la definición brevísima de cada voz, con el propósito de hacer un libro portátil y barato" (Estévanez 1897: VI). 
Antes de concluir queremos dejar constancia de la mención realizada por Gago-Jover (2008: 673) acerca de la existencia de un manuscrito del siglo XIX titulado Diccionario militar razonado, que, desgraciadamente, no hemos tenido ocasión de consultar. Según el Catálogo Colectivo del Patrimonio Bibliográfico Español, está escrito por el coronel de Infantería cuyas iniciales son D. M. A. En esta página electrónica podemos comprobar que el único ejemplar del que se tiene constancia es el que guarda la Real Academia de la Historia de Madrid.

\subsection{El Glosario de voces de armería (1912) de Leguina}

De todos los temas susceptibles de ser tratados en un diccionario militar, Leguina se restringe al léxico de la armería, ámbito del que ciertamente opina que es urgente su estudio ${ }^{473}$, por lo que en su “Advertencia" cita a Martínez del Romero, el primero de los lexicógrafos de especialidad que publica un vocabulario de este tipo:

A Martínez del Romero se debe el primer intento de aclarar la confusión existente, y si bien el Glosario que acompaña a su Catálogo de la Real Armería, es incompleto y adolece de errores, no se debe desconocer las dificultades que presentaba lo complejo de la materia, la falta de documentos y el atraso de la época en que se escribía, por lo cual merece elogios, que no sólo su trabajo hubo de ser útil, sino que además vino a despertar la afición a estos estudios de armería (Leguina 1912: 7).

Leguina redacta su Glosario con la vista puesta en el de Martínez de Romero, si bien no sólo se limita a esta fuente lexicográfica, tal y como acredita

\footnotetext{
473 Dos son a su juicio las causas de esta necesidad. En primer lugar, el desconocimiento absoluto que existe sobre el significado exacto de muchos de esos términos: "Advierte el estudioso, si repasa antiguos documentos o se complace en la lectura de clásicas obras, multitud de voces cuya aplicación desconoce por falta de textos que consultar y de vocabularios donde acudir, en demanda de explicaciones exactas" (Leguina 1912: 6). En segundo lugar, Leguina constata que demasiados errores e incorrecciones se han convertido en verdades inmutables, lo que debe ser enmendado: "Hasta distinguidos escritores, académicos ilustres y sabios arqueólogos han incurrido en graves errores, han sostenido verdaderos absurdos y han confundido épocas y estilos cada vez que han hablado de armas y armaduras antiguas" (Leguina 1912: 7).
} 
el listado de "inventarios, glosarios y diccionarios consultados" que Leguina inserta tras su "Advertencia" 474 .

Leguina es consciente de las carencias del español en este ámbito especializado. Por tanto, opina que su trabajo simplemente constituye el punto de partida de futuras investigaciones: "En algún caso en que no hemos conseguido averiguar lo que la palabra quiere expresar, consignarla simplemente, dejando a otros que, con mayor fortuna, logren el placer de traducirla a lenguaje vulgar" (Leguina 1912: 8).

Por lo que respecta a la macroestructura, además de las armas ofensivas y defensivas, tiene también en cuenta otros campos nocionales en estrecha relación con el léxico de la armería, objeto principal de este estudio. Así, podemos encontrar en este repertorio tanto voces que designan telas y trajes usados con las armaduras, como tipos de caballos, además de "algunos términos de esgrima usados cuando la destreza de las armas alcanzaba la categoría de verdadera Sciencia" (Leguina 1912: 8).

Mostramos los cinco primeros artículos de la letra $\mathrm{M}$ que ofrece este glosario:

\footnotetext{
Macana.-V. Espadas. Macana.

Macara.-Verea y Aguilar, en su Historia de Galicia, clasifica a las mámoas, sepulcros guardadores de las urnas cinerarias de los héroes celtas, coetáneas de los castros y anteriores al cristianismo, "por las cosas que se encuentran en ellas, como una especie de puñal llamado Macara".

V. Espadas. Maquera.

Macear.-Golpear con la maza.

Macero.-El que lleva maza.

Macuahuitl-_Arma de los antiguos mejicanos.

Solís en su Historia la llama espada, pero parece que era una maza de madera en forma de remo, con los bordes provistos de afilados pedazos de obsidiana.

Alrededor del Mundo, núm. 279, 1904.
}

\footnotetext{
474 Como era de esperar, para lograr su objetivo Leguina también consulta el glosario que acompaña al Catálogo de la Real Armería de 1898, redactado por el conde viudo de Valencia de Don Juan, que junto con el de Martínez del Romero conforman los dos únicos casos de esta modalidad lexicográfica de los que dispone nuestra lengua. Desgraciadamente, en más de un ocasión el recurso a las obras lexicográficas sólo le ha servido para confirmar la deficiencia de las definiciones disponibles. Ante esta constatación, Leguina se compromete a denunciar en su glosario cada uno de los casos en los que detecta una incoherencia entre lo establecido por los diccionarios para un determinado vocablo y su verdadero sentido: "En su lugar oportuno, hacemos notar algunas definiciones poco exactas aceptadas por el Diccionario de la Lengua y los Glosarios especiales que, como es moda, suelen acompañar a las reimpresiones de obras antiguas para facilitar al lector la inteligencia de palabras anticuadas" (Leguina 1912: 8).
} 


\subsection{Los repertorios contemporáneos}

Como era de esperar, dados los inevitables obstáculos que genera una distancia cultural y cronológica tan dilatada, los repertorios lexicográficos de finales del siglo XX y principios del XXI no han resultado ser de tanta utilidad en la confección de nuestro glosario como los hasta ahora reseñados. Aun con todo, puede hablarse de varios trabajos brillantes centrados en el léxico militar de tiempos pretéritos, de los que queremos resaltar los siguientes:

- El Glosario de arquitectura defensiva medieval de Luis de MoraFigueroa, cuya primera edición data de 1994. A pesar de que su macroestructura la forman casi doscientos términos vinculados al estudio de la fortificación medieval, en las numerosas ocasiones en las que los tratadistas modernos aluden al sistema defensivo que les precede, para un perfecto y total entendimiento, ha resultado decisiva la consulta de esta obra, de la que, por otro lado, sobresalen sus numerosas ilustraciones.

- También se centra preferentemente en la fortificación medieval Ángel Lorenzo Celorrio en su Compendio de vocablos referidos a los castillos, breve glosario publicado en 1996. Aparte de la consulta semasiológica, los varios montajes pictóricos de que consta esta obra, en los que el autor ha aglutinado el mayor número posible de elementos castellológicos, dan pie a una nueva forma de explotación al margen de la tradicional:

$\mathrm{Al}$ ver un elemento del castillo que no conocemos y del que, por supuesto, ignoramos el nombre, acudimos a los dibujos en los que lo buscamos. Una vez encontrado en la imagen, y puesto que figura con el nombre sobreimpresionado, lo buscamos en las definiciones (Lorenzo Celorrio 1996: 7).

- En el año 2000 se publica el Diccionario de historia militar de Cristina Borreguero Beltrán, que, como su propia portada indica, atiende el período comprendido "desde los reinos medievales hasta nuestros días". Se trata de un diccionario de lengua, ya que 
da cuenta de un amplio conjunto de tecnicismos militares, si bien, al no renunciar al establecimiento de artículos para los hechos y protagonistas más relevantes de la historia de la milicia, presenta también un carácter enciclopédico. En todo caso, en palabras de su autora, "este diccionario no tiene otro objetivo que servir de instrumento inicial, no sólo a los historiadores e investigadores, sino también a los militares, estudiosos, profesores e interesados en estos temas" (Borreguero Beltrán 2000: 8).

- Con su Vocabulario militar castellano, Francisco Gago-Jover, "quiere llenar el vacío existente en el campo del léxico militar medieval hispano, proporcionando al estudioso una nueva herramienta de trabajo que le facilite la comprensión de las fuentes literarias e históricas" (Gago-Jover 2002: 9). Por ello, recopila en él todos los sustantivos con significado militar presentes en un corpus representativo de textos producidos entre los siglos XIII y XV.

- Dirigen su atención hacia la milicia también varias tesis doctorales. Una de las más significativas, por su aportación lexicográfica, es la titulada Historia del léxico militar en el español áureo: La conquista de Granada, el conflicto hispano-italiano y las guerras de Flandes de María Ángeles López Vallejo. Del Glosario de términos militares incluido en este estudio doctoral debemos destacar la incorporación de detalladas explicaciones acerca del origen de cada una de las unidades léxicas que conforman la macroestructura, con especial atención a los diversos mecanismos disponibles en la formación de neologismos.

- Aunque se trata de una obra lexicográfica en portugués, dada la enorme deuda contraída con ella, hemos querido mencionar, por último, el Dicionário de arquitectura militar (2005) del especialista en milicia António Lopes Pires Nunes, quien presenta esta nueva obra coma una revisión, ampliación y corrección de su Dicionário temático de arquitectura militar e arte de fortificar, editado con 
anterioridad, concretamente en $1991^{475}$. De gran ayuda nos han resultado las numerosas ilustraciones que contiene, así como la determinación del período histórico concreto al que se adscribe cada uno de los tecnicismos recogidos. Resaltamos, finalmente, la lematización de varios nombres propios, como por ejemplo los de Manuel de Azevedo Fortes o Luís Serrão Pimentel, autores de los dos tratados de fortificación más importantes de Portugal.

475 Desgraciadamente, no hemos tenido acceso a este diccionario. 


\section{CONCLUSIONES}

El conjunto formado por los distintos tipos de repertorios, cuyo objeto de estudio lo constituye alguna de las múltiples ramas de la milicia, es muy profuso. No obstante, la mayoría son desconocidos para los especialistas en lexicografía hispánica, lo que ha impedido su divulgación y, consecuentemente, su aprovechamiento. Por esto, muchas obras históricas centradas en un determinado tema militar, sobre todo la fortificación, ofrecen pequeños glosarios -Calabro (1991), Echarri Iribarren (2000) y Navarro Loidi (2004), entre otras-. Con ellos, los autores pretenden hacer más asequibles los contenidos tratados, además de facilitar al lector la total comprensión de conceptos antiguos. No rechazamos la conveniencia de este tipo de vocabularios, simplemente queremos dejar constancia de que su elaboración responde a la falta de difusión del significado exacto de numerosos tecnicismos militares.

Por otro lado, consideramos que, aunque su contribución resulta fundamental, la finalidad con la que fueron concebidos estos lacónicos repertorios condiciona su insuficiencia para cubrir las numerosas carencias semánticas existentes en este ámbito léxico. Además, la mayor parte de estos glosarios no se asienta sobre sólidos principios lingüísticos, entre otras cosas porque generalmente son obra de historiadores o arquitectos, y no de filólogos. A nuestro modo de ver, era preciso sacar a la luz un diccionario de especialidad centrado en el arte militar, fortificación y temas afines, en el que, por ejemplo, no se dé cabida a los nombres propios y que, como resultado de la aplicación de una coherencia y un rigor filológicos, persiga ofrecer definiciones estrictamente lexicográficas.

Por todo ello, aspiramos a que nuestro glosario sirva para facilitar la interpretación de los cuantiosos tratados militares surgidos a lo largo del siglo XVI y primer cuarto del XVII, época en la que se asiste al apogeo en la producción de este tipo de textos.

Ahora bien, tras constatar la imposibilidad de abordar, por su extremada amplitud, la milicia moderna en términos generales, decidimos restringir su 
análisis al léxico de la fortificación y de la poliorcética, además de la táctica, la estrategia, la logística y la castrametación. Esta especificidad no obsta, sin embargo, para que los campos léxicos representados por los vocablos que conforman la macroestructura de nuestro glosario sean muy variados.

En primer lugar, el ámbito militar más fecundo corresponde, sin duda, a las acciones bélicas, al disponer de hasta 160 manifestaciones. En referencia a los campos léxicos o nocionales, advertimos que las cifras que ofrecemos representan conceptos y no unidades léxicas.

Consecuentemente, otra área semántica profusa es la constituida por los numerosos sujetos que intervienen en alguna operación de guerra. Dentro de este conjunto debemos incluir también los miembros de las distintas unidades o grupos militares, lo que genera un total de 50 conceptos, frente a los 26 que se refieren más bien a los grupos o conjuntos militares en sí.

El hecho de haber atendido a los personajes que actúan en una guerra, nos ha conducido a recopilar igualmente los adjetivos que indican cualidades propias de los soldados, de los ejércitos o de cualquier otra colectividad susceptible de participar en un conflicto armado, de los que hemos contabilizado un total de 59.

Los tratados manejados revelan distintos tipos de cualidades o atributos, como demuestra la detección de otras 24 propiedades aplicables no a individuos, sino a objetos de relevancia en la fortificación e incluso al lugar que alberga alguna construcción defensiva, por ejemplo.

Las voces técnicas que designan las partes que componen un recinto fortificado conforman otro campo semántico importante, al aglutinar 69 elementos susceptibles de hallarse en una fortaleza moderna y 3 más bien específicos de las medievales.

Por su parte, las 37 construcciones halladas que, frente a las del grupo anterior, pueden constituir por sí solas defensas lo suficientemente efectivas dan buena cuenta de la alta representatividad de que goza este ámbito en nuestra parcela terminológica. 
También hemos atendido una serie de verbos y sustantivos que denotan hasta 31 trabajos distintos típicamente desarrollados en la edificación de fortalezas.

Debemos destacar, asimismo, el campo de las municiones, esto es, el de los "pertrechos y bastimentos necesarios en un ejército o en una plaza de guerra" (DRAE: s.v. munición), encarnado por 31 modalidades diferentes. Somos conscientes de que las 24 máquinas de guerra de las que nos ocupamos deberían ser contabilizadas junto con el resto de los pertrechos militares, sin embargo, dada su trascendencia, hemos considerado más oportuno consignarlas aparte.

Los tecnicismos de la táctica resultan igualmente numerosos, mientras que otras áreas léxicas menos productivas son las de la logística, castrametación y estrategia, además de las conformadas por las unidades léxicas que designan distintos tipos de acontecimientos o ceremonias militares, por un lado, y las técnicas u oficios, así como las personas que las cultivan, por otro.

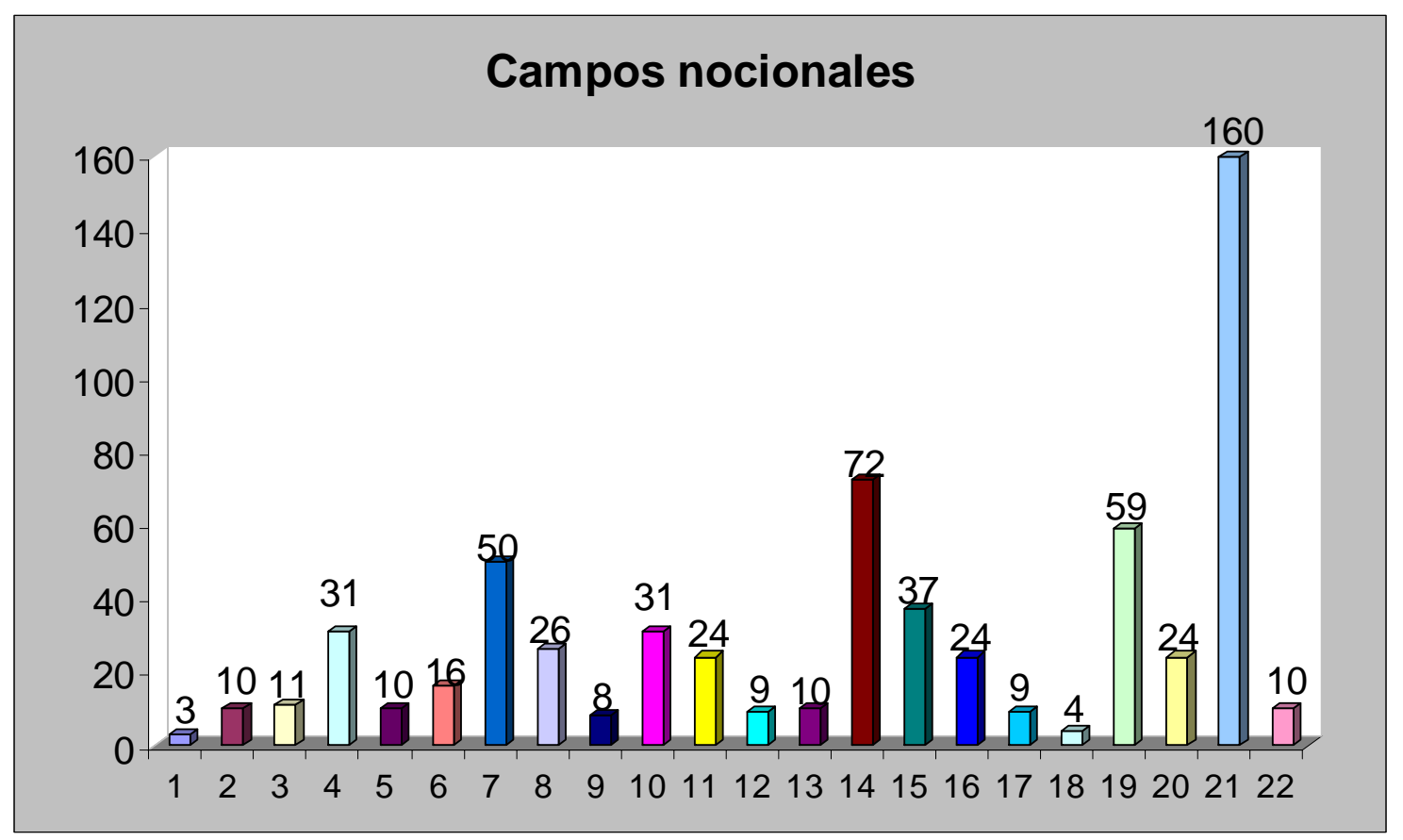




\begin{tabular}{|c|c|}
\hline \multicolumn{2}{|l|}{ LEYENDA } \\
\hline Campo nocional & $n^{o}$ \\
\hline Técnicas o artes y profesiones & 1 \\
\hline Acciones de castrametación & 2 \\
\hline Acciones de logística & 3 \\
\hline Acciones de fortificación y de construcción & 4 \\
\hline Acciones de estrategia & 5 \\
\hline Acontecimientos o ceremonias militares & 6 \\
\hline Miembro de unidades o grupos militares & 7 \\
\hline Unidades o grupos militares & 8 \\
\hline Persona que desempeña oficio/cultiva técnica & 9 \\
\hline Municiones & 10 \\
\hline Táctica & 11 \\
\hline Magnitudes temporales y espaciales & 12 \\
\hline Toques y señales militares & 13 \\
\hline Elementos de fortificación & 14 \\
\hline Construcciones defensivas & 15 \\
\hline Máquinas de guerra & 16 \\
\hline Armas o explosivos & 17 \\
\hline Instrumentos o herramientas & 18 \\
\hline Cualidades militares & 19 \\
\hline Cualidades de fortificación & 20 \\
\hline Acciones bélicas & 21 \\
\hline Lugares militares & 22 \\
\hline
\end{tabular}

Respecto a nuestro trabajo lexicográfico, precisamos que su macroestructura se halla constituida por 1149 entradas, que se reparten de la siguiente manera: 593 lemas encabezan el artículo lexicográfico, 133 son remisiones de unidades pluriverbales (estructuras sintagmáticas y locuciones) y 423 son remisiones de variantes ortográficas. A ellas deben sumarse otras 421 fichas lexicográficas que corresponden a subentradas tratadas en la microestructura, las cuales se reparten entre acepciones (290) y unidades sintagmáticas y locuciones (131 en total), respectivamente.

Con respecto a las entradas, éstas comprenden 387 sustantivos, 121 verbos, 84 adjetivos y un único adverbio, si bien esta última clase de palabras cuenta con una mayor representación gracias a las 16 locuciones adverbiales recogidas. Como también hemos tenido en consideración el resto de unidades pluriverbales, las distintas categorías gramaticales han visto acrecentado su dominio. De esta forma, al incorporar en nuestro glosario 8 locuciones adjetivas 
y 36 verbales, 92 han sido los adjetivos definidos en total, mientras que la cifra exacta de verbos es 157.

Por lo que respecta a los compuestos sintagmáticos, un total de 71 unidades pluriverbales de nuestro glosario pueden ser catalogadas como tales. Al generar "nuevas unidades terminológicas de significado transparente" (Ferrando Aramo 2002: 99), la sintagmación es uno de los recursos más empleados en los lenguajes especializados, lo que confirmamos en el presente estudio. Gracias a este peculiar mecanismo de formación de palabras, cuyo producto final equivale a un nombre, integran nuestro trabajo lexicográfico 458 formas nominales finalmente. En cualquier caso, a este cómputo deberían sumarse 25 sustantivos más, producto de un proceso de recategorización, llamado también neología sintáctica, "consistente en el cambio de categoría gramatical de un elemento o en su cambio de función" (Gutiérrez Rodilla 1998: 152).

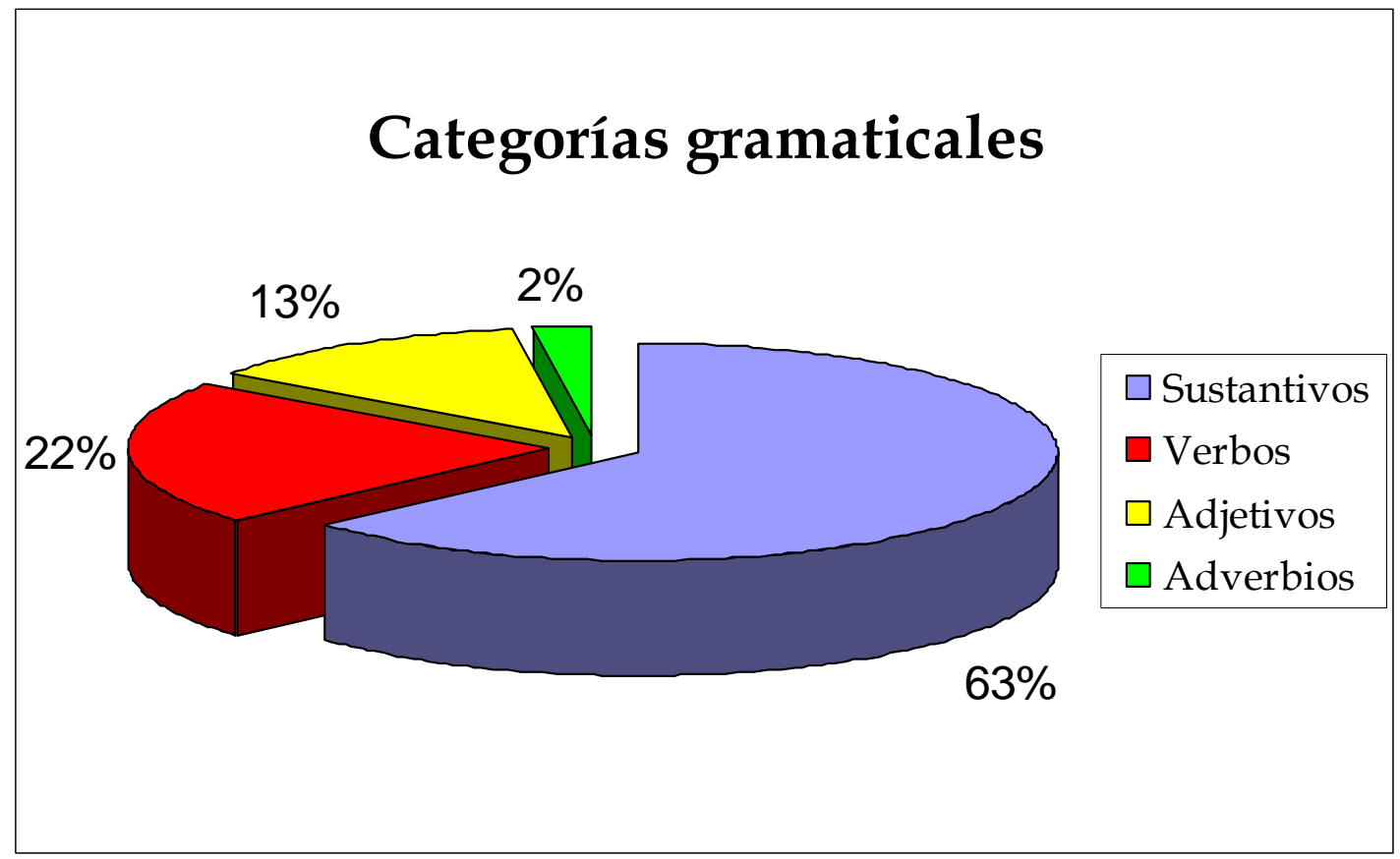




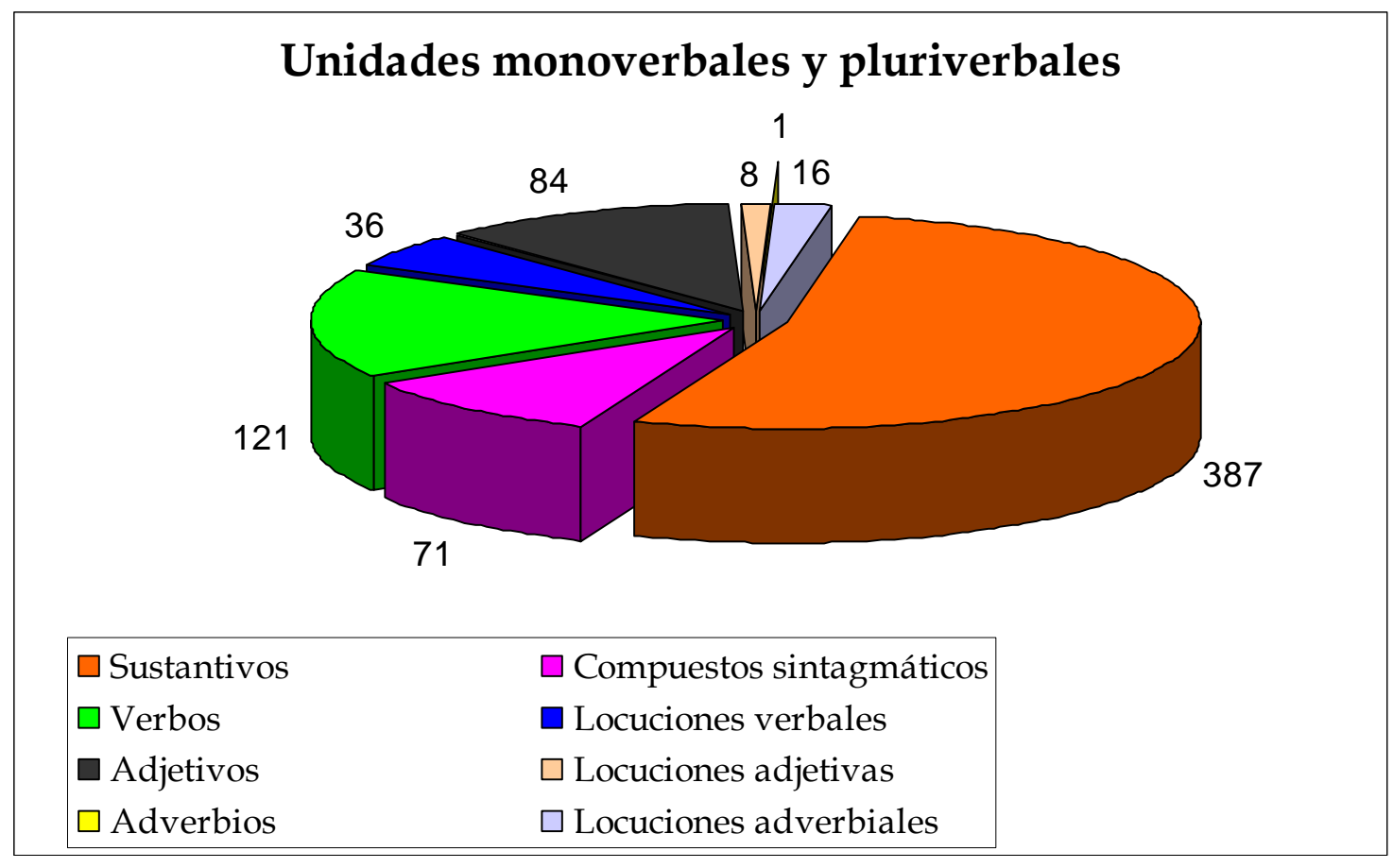

Por consiguiente, al igual que cualquier otro lenguaje de especialidad, el de la milicia se caracteriza por un empleo mayoritario de formas nominales, mientras que ocupan la segunda y tercera posición las formas verbales y las adjetivas, respectivamente. Con respecto a estas últimas clases de palabras, el hecho de que el número de verbos lematizados sea llamativamente superior al del total de adjetivos, nos impulsa a subrayar la relevancia que en el lenguaje de la milicia adquiere la clase gramatical verbo, frente a otros lenguajes especializados donde apenas existen tecnicismos verbales. En nuestro ámbito, los adverbios son los que presentan menor repercusión.

Destacamos la explotación de los distintos recursos disponibles para la formación de neologismos como la principal conclusión de la presente investigación sobre el léxico de la milicia moderna. Además, colegimos que este proceso fue motivado por la necesidad imperiosa de alcanzar una terminología eficaz con la que aludir a las nuevas realidades militares que implica el inicio de la modernidad. Es ésta una cuestión que apenas había sido resaltada, como consecuencia de la escasez de estudios centrados en el tema militar y a la vez elaborados desde un punto de vista lingüístico. 
Creemos que la exposición que sigue ejemplifica de manera muy clara esta conclusión. Como sabemos, con la instauración del sistema de fortificación abaluartado nuestra lengua se vio obligada a dar nombre a cada uno de los elementos que iban configurando esa nueva modalidad defensiva. Uno de los miembros más característicos de las fortalezas modernas es la superficie que desde el parapeto de la estrada cubierta va descendiendo hasta alcanzar el nivel de la campaña, que -dispuesta en forma inclinada- servía para impedir que el enemigo pudiese aproximarse a las murallas a cubierto. Pues bien, según los repertorios lexicográficos consultados y los tratados de fortificación posteriores a los de nuestro corpus (de los que es un buen representante el de Lucuze de 1772), explanada era el término que servía para designar ese concepto. Sin embargo, aunque recogemos este vocablo, ninguna de las tres acepciones corresponde al "declive que se continúa desde el camino cubierto hacia la campaña" (DRAE: s.v. explanada), como puede comprobarse:

1. $\rightarrow$ Espacio de terreno allanado, es decir, aquel del que se han eliminado, entre otras cosas, los árboles, matas, arbustos, altos y bajos.

2. $\rightarrow$ Fort. Terreno acondicionado para poder establecer en él una batería de cañones y demás piezas de artillería.

3. $\rightarrow$ Art. Pavimento, generalmente de madera o de piedra, sobre el que se colocan las piezas de artillería, para que las ruedas de sus cureñas puedan deslizarse fácilmente.

Tras un análisis detallado de los textos que conforman nuestro corpus, podemos certificar que los ingenieros y especialistas en fortificación de aquel entonces disponían de otras muchas unidades léxicas para hacer referencia a este concepto militar: arcén del foso o su elipsis arcén, los italianismos árgine y escarpa e, igualmente, la voz patrimonial vallado.

Este mismo caso confirma otras dos conclusiones obtenidas: las numerosas voces sinónimicas de que consta la terminología militar renacentista, por un lado, y la fuerte presencia de unidades léxicas polisémicas en ella, por otro. Consideramos que estos dos rasgos esenciales del lenguaje analizado se encuentran estrechamente ligados con el importante momento histórico que atraviesa la milicia española del dieciséis. 
A propósito de la procedencia de los términos lematizados, la lengua latina es sin lugar a dudas la más representada, puesto que, de las 336 voces castellanas debidas a influencias externas, la mayoría (209, un poco más del $62 \%)$, deriva única y exclusivamente de ella. Por otro lado, al contabilizar 123 voces patrimoniales y 86 latinismos, resulta evidente la supremacía del caudal hereditario o popular, si bien es cierto que también el culto cuenta con una fuerte presencia.

Los restantes términos, que conforman casi un 38\%, o son préstamos de otras lenguas o creaciones de origen expresivo, como tepe y picar. Aunque en el caso de chocar "una onomatopeya autóctona no es imposible" (DECH), como nuestra lengua también podría haber adoptado esta voz a partir de la francesa choquer, hemos considerado finalmente su origen incierto, en consonancia con Corominas y Pascual. Ahora bien, no es ésta la única etimología dudosa existente en el léxico militar moderno, según acreditan varios vocablos más, estribo y tomar por ejemplo, cuyo origen también es considerado problemático por el DECH.

Con respecto a las lenguas prestatarias, los tecnicismos militares detectados provienen, además del latín, del árabe, germánico, francés, occitano, catalán e italiano, si bien lo más seguro es que también podamos hablar, en el caso de la palabra barrunte, de un vasquismo.

Sin duda, los italianismos, primero, y los galicismos, después, con 47 y 35 casos cada uno, después de los de origen latino, son los tipos de préstamos más representados.

Son también numerosos los catalanismos, entre los que hallamos construcciones defensivas, como barraca, palenque y revellín, partes o elementos de que constan algunas formaciones tácticas, por ejemplo vanguardia y retaguardia, junto a otras realidades militares bien diferentes a éstas.

A pesar de la limitada influencia árabe a la que nuestro sistema militar se vio sometido durante el Renacimiento, hemos podido localizar 9 arabismos, si bien es cierto que muchos ya eran usuales en la Edad Media (alarde, atalaya, barbacana y real). 
Por último, mientras que 4 vocablos poseen un origen occitano, 7 deben su presencia en castellano a alguna modalidad lingüística germánica.

\section{Origen de los términos}

Préstamos

213. $63 \%$

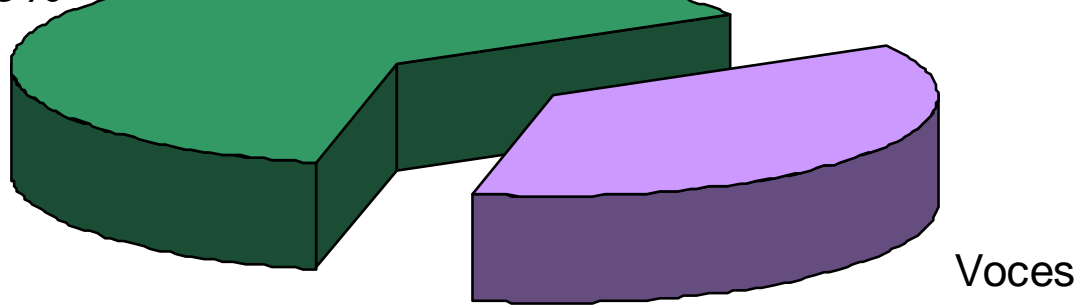

patrimoniales

123. $37 \%$

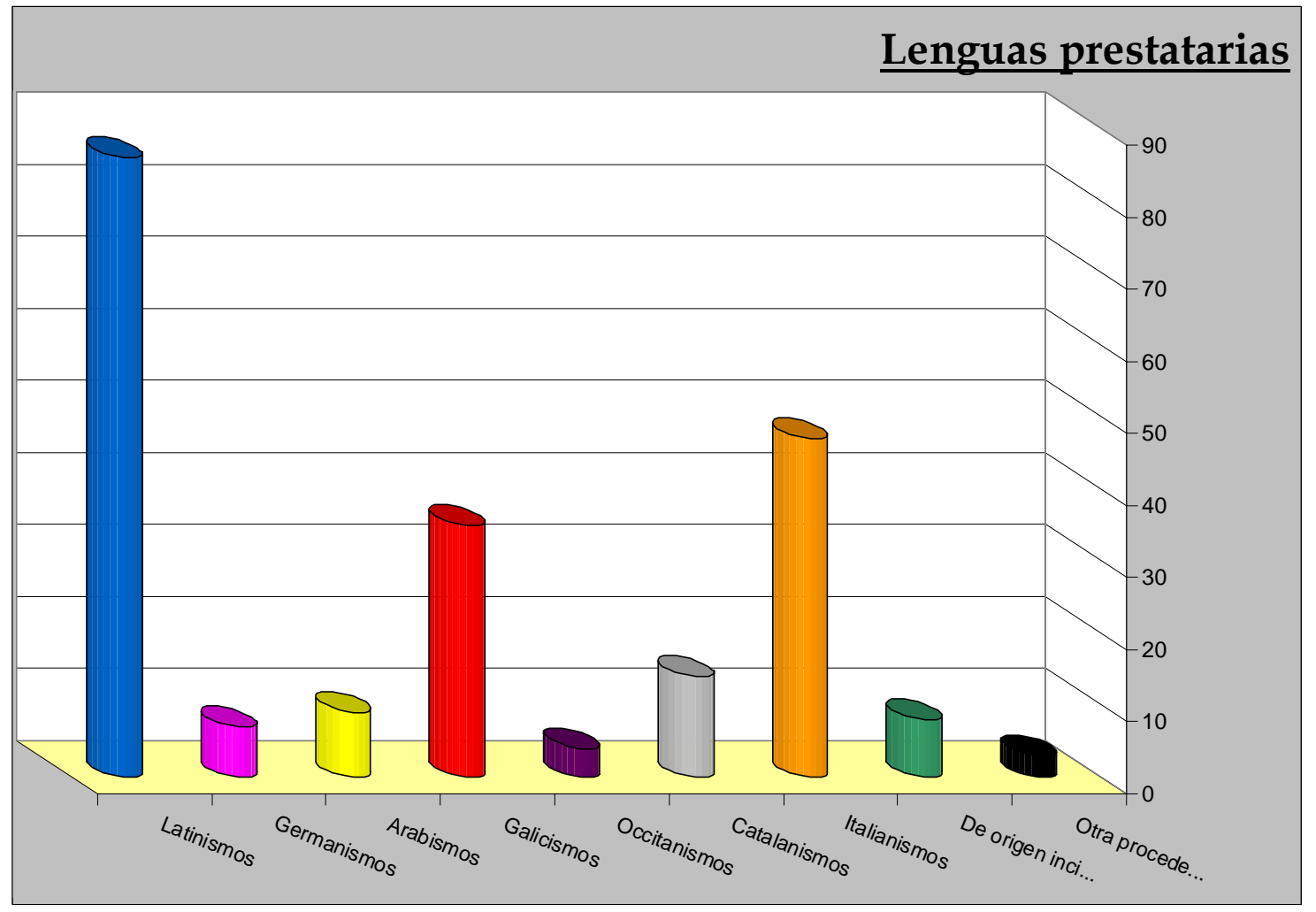


De acuerdo con lo anteriormente expuesto, de los 593 lemas de cabecera establecidos 123 han resultado ser voces patrimoniales y 213 préstamos de otras lenguas, por lo que, en definitiva, 257 términos de nuestro ámbito terminológico responden a alguno de los mecanismos internos de creación léxica disponibles en castellano, entre los que sobresalen la derivación y la composición.

Con respecto a estos mecanismos, las unidades creadas por medio de la sufijación nominal son las más numerosas (contabilizamos 126 voces), grupo del que despuntan en especial los nomina actionis, originados mediante una gran variedad de sufijos: los átonos posverbales $-a,-e$ y $-o$, además de -miento, -sión y los alomorfos -ada, en el caso de adjuntarse a verbos de la primera conjugación (escalada y retirada, entre otros ejemplos), e -ida, para los verbos de la segunda y tercera (como manifiestan acometida, arremetida, corrida y salida).

De todas formas, entre los sufijados nominales también hallamos otros significados, de los que subrayamos los siguientes:

- Colectividad o pluralidad con el afijo $-a d a$, y en esta ocasión a partir de bases nominales: estacada, fajinada, gavionada e hilada.

- Nomina agentis, entre los que debemos resaltar, dada su profusión, los originados mediante el sufijo deverbal -dor y el denominal ero: asediador, acometedor, conquistador, fortificador, murador, ballestero, forrajero y viandero, por citar sólo algunos. También ofrecemos un par de casos portadores de -nte: asaltante $\mathrm{y}$ combatiente.

- Por su parte, el alomorfo femenino de -ero desarrolla la capacidad de derivar sustantivos con valor instrumental: barrera, cañonera, saetera y tronera.

Asimismo, en la conformación del léxico militar desempeña una función esencial el fenómeno de la lexicalización de varios sufijos apreciativos, sobre todo -ón (ballestón, cestón, escalón y trincherón, entre otros), pero también -ete (refosete), o su alomorfo -eta (banqueta), así como -illo (hornillo) y -uelo (herreruelo). 
Por último, recogemos 7 sustantivos que responden al procedimiento morfológico de la derivación genérica o relación derivativa.

Por su parte, contabilizamos 56 adjetivos originados a través de varios sufijos, entre los que destacamos - do, dada su extraordinaria productividad.

Constituyen otra modalidad derivativa los 22 sufijados verbales. De éstos, son predominantes los portadores de los afijos -ar y -ear, mientras que son más escasos los derivados con-ecer.

A propósito de la categoría verbal, hallamos 18 verbos resultado de un procedimiento de derivación prefijal: acometer, arremeter, asitiar, contraminar, desalojar, desbaratar, descercar, descoser, descubrir, desguarnecer, deshacer, desitiar, desocupar, enfortalecer, rebatir, rebotar, remeter y retirar. Podemos confirmar la relevancia del prefijo des-, especialmente en su función de transferir a los verbos resultantes un significado reversivo.

En el origen de 16 tecnicismos verbales del arte militar, subyace el mecanismo morfológico de la parasíntesis. De los varios esquemas existentes, debemos subrayar la relevancia de $a-+$ sustantivo $+-a r$, al ajustarse a él 10 de nuestros parasintéticos.

Por otra parte, contamos con 15 sustantivos originados por alguno de estos prefijos: contra-, en-, re- y sobre-. Ahora bien, el más rentable de todos ellos es indudablemente contra-, ya con un significado posicional ya con el de oposición, al estar presente en 8 de esas 15 formas nominales.

Finalmente, los procedimientos derivativos menos rentables, con un representante cada uno, son la prefijación adjetival (invencible, de vencible) y la sufijación adverbial (belicosamente). 


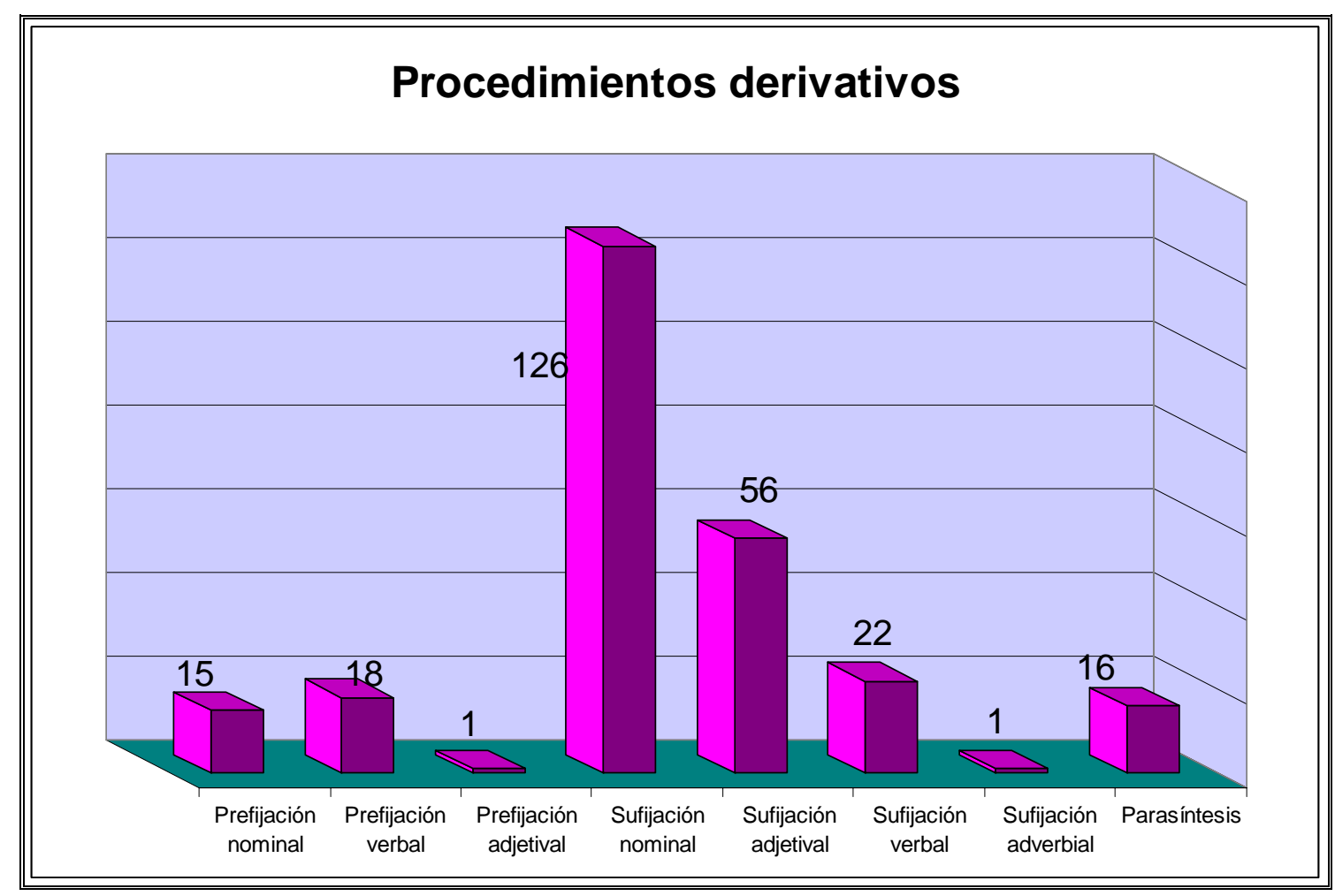

En consecuencia, mientras que 255 lemas han sido generados mediante alguno de los distintos mecanismos derivativos de que dispone nuestra lengua, sólo 2 entradas responden al procedimiento morfológico de la composición léxica: casamuro y rodapié. Como puede constatarse, el primero es resultado de la combinación de dos sustantivos y el segundo, en cambio, de la de un verbo y un nombre. Puede observarse la representatividad de los distintos procedimientos morfológicos en el siguiente gráfico, en el que se contemplan además las unidades pluriverbales. 


\section{$\underline{\text { Procedimientos morfológicos }}$}

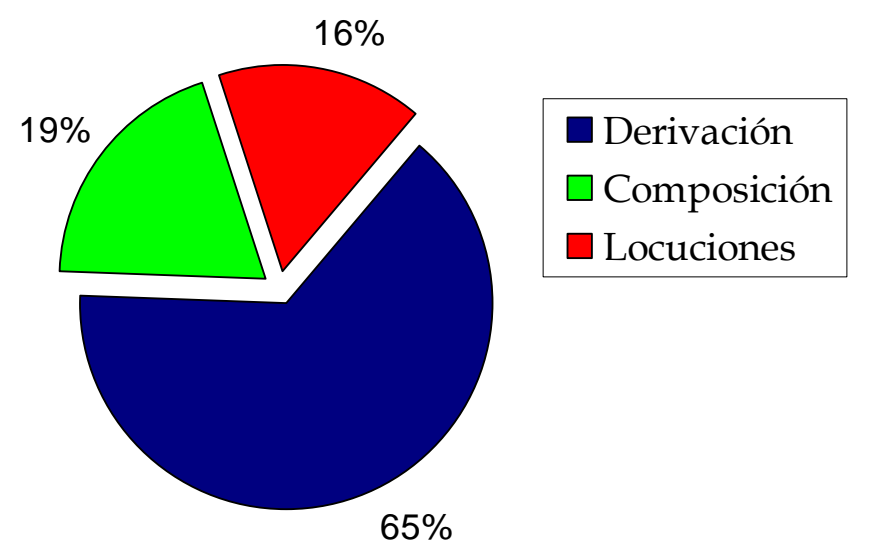

En definitiva, nuestro principal objetivo es contribuir a mejorar el conocimiento sobre la terminología relativa a los dominios de la fortificación y del arte militar en una época -el Renacimiento- clave para entender la evolución de la lengua y de la ciencia y la técnica españolas, aunque somos conscientes de que en esta investigación doctoral no han podido agotarse todas las posibilidades de estudio. 


\title{
VI. GLOSARIO
}

\begin{abstract}
"No ignoro que un lexicógrafo se tiene generalmente por un mero compilador más o menos exacto y claro y más o menos abundante o conciso; pero deseo, sí, que mis lectores se persuadan del penoso como ingrato y aun desagradable trabajo que ofrece la redacción de un Diccionario"
\end{abstract}

(Moretti 1828: XV).

\section{Consideraciones previas}

\subsection{El corpus}

El presente glosario constituye nuestra aportación al Diccionario de la ciencia y de la técnica del Renacimiento español (DICTER). Por consiguiente, la fuente documental manejada, necesaria en cualquier análisis léxico de este tipo, la conforma el corpus textual de dicho diccionario, constituido por un conjunto de 74 obras científico-técnicas repartidas en 12 áreas de especialidad, como ya hemos señalado, que comprenden el período cronológico que va desde comienzos del siglo XVI hasta el primer tercio del siglo XVII ${ }^{476}$.

El punto de partida es, efectivamente, este corpus, pero, como es lógico, las principales obras de las que hemos extraído los tecnicismos militares que conforman nuestra macroestructura son las siguientes, que constituyen las áreas del arte militar y de la fortificación:

- Arte militar

Montes, Diego (1537): Instrucción y regimiento de guerra. Zaragoza: George Coci.

García de Palacio, Diego (1583): Diálogos militares. México: Pedro Ocharte. Álaba y Viamont, Diego de (1590): El perfeto capitán instruido en la diciplina militar y nueva ciencia de la Artillería. Madrid: Pedro Madrigal.

\footnotetext{
476 El listado completo de los textos que conforman este corpus se halla en el apartado IV ("Referencias bibliográficas consultadas"). En "Corpus del Diccionario de la ciencia y de la técnica del Renacimiento español (DICTER)" aportamos todos los datos bibliográficos pertinentes, mientras que en "Listado abreviado de autores" anotamos la forma exacta en la que se citan las obras del corpus en el glosario.
} 
Collado de Lebrixa, Luys (1592): Plática manual de Artillería. Milán: Pablo Gotardo Poncio.

Mendoça, Bernardino de (1596): Theórica y práctica de guerra. Anveres: Imprenta Plantiniana (1. a ed., Madrid, Viuda de P. Madrigal, 1595).

Mosquera de Figueroa, Christóval (1596): Comentario en breve compendio de disciplina militar. Madrid: Luis Sánchez.

Ferrofino, Julián (mss. 1599): Descrizión y tratado muy breve y lo más probechoso de Artillería.

Lechuga, Cristóval (1611): Discurso del Capitán Cristóval Lechuga, en que trata de la Artillería y de todo lo necessario a ella. Milán: Marco Tulio Malatesta.

Ufano, Diego (1613): Tratado de la Artillería. Brusselas: Juan Momarte.

- Fortificación

Rojas, Christóval de (1598): Teórica y práctica de fortificación. Madrid: Luis Sánchez.

González de Medina, Diego (1599): Examen de fortificación. Madrid: Pedro Várez de Castro.

Roxas, Christóval de (mss. 1607): Sumario de la milicia antigua y moderna.

Rojas, Christóval de (1613): Compendio y breve resolución de fortificación. Madrid: Juan de Herrera.

Ahora bien, dada la estrecha relación que, como es lógico, existe entre la arquitectura civil y la militar, debemos resaltar la trascendencia de los textos pertenecientes al ámbito de la construcción, especialmente de la siguiente pareja:

Alberto, León Baptista (1582): Los diez libros de Architectura. Madrid: Alonso Gómez, trad. Francisco Loçano.

Vitruvio Pollión, Marco (1582): De Architectura. Alcalá de Henares: Juan Gracián, trad. Miguel de Urrea. 
Como puede constatarse, ambas son traducciones de dos obras anteriores: la primera, de la latina De re aedificatoria escrita en el siglo XV por el italiano Leon Battista Alberti; la segunda, del famoso texto de la Antigüedad clásica De Architectura de Marco Vitruvio Polión. Si tenemos en cuenta, sobre todo en el caso de la segunda, que en el momento en el que se redactan las obras originales aún no había una separación clara entre la construcción civil y la defensiva o militar, no debe resultar extraño que una gran cantidad de términos de la milicia haya sido documentado en alguna de ellas.

\subsection{Herramientas informáticas y metodología}

Para el establecimiento de las diversas unidades del vocabulario militar se procedió, en primer lugar, a la lectura meditada de los textos renacentistas ya enumerados. Ahora bien, nuestro pleno convencimiento acerca de que en la época moderna la milicia supuso un aspecto crucial, nos persuadió de que era posible la presencia de términos relativos a la fortificación, poliorcética, táctica y demás disciplinas afines en obras sobre los más variados temas. Para facilitar el rastreo del léxico que nos propusimos analizar nos valimos de un programa de búsquedas complejas, denominado UltraEdit, que posee la ventaja de localizar las voces en las concordancias del corpus. Como es sabido, el empleo de los

recursos informáticos en las investigaciones lexicográficas resulta imprescindible (cf. Arntz y Picht 1995: 219).

Posteriormente, procedimos a la lematización de este caudal léxico en una base de datos informatizada, el fichero de vaciado, que constituye la ficha lexicográfica propiamente dicha. Debemos especificar que desde el comienzo del proyecto del DICTER hasta el momento actual esta base de datos, diseñada con FileMaker, ha experimentado constantes mejoras. A día de hoy, comprende distintos campos que se agrupan bajo los nueve bloques temáticos siguientes:

1. Datos relativos a la lematización.

2. Información histórica, etimológica y morfológica.

3. Clasificación semántica. 
4. Definición e información lexicográfica.

5. Ejemplos.

6. Información enciclopédica.

7. Observaciones semánticas.

8. Otras observaciones.

9. Imagen e información sobre la misma.

Estos bloques temáticos enumerados se encuentran organizados en cuatro pestañas, lo que permite una mejor visualización de la información que se va incorporando: forma e historia, clasificación semántica, ejemplos e información y, por último, imagen, que en nuestro caso ha resultado ser de una gran utilidad dados los numeros tecnicismos recogidos a los que ha sido preciso adjuntarles una determinada ilustración para una mejor comprensión.

\subsection{Macroestructura y lematización}

Si por nomenclatura o macroestructura entendemos la suma de lemas o entradas que se registran en la obra lexicográfica, podemos comprobar que la de nuestro glosario está formada por un total de 1149 entradas, que se reparten de la siguiente manera: 593 lemas encabezan el artículo lexicográfico, 133 son remisiones de unidades pluriverbales (estructuras sintagmáticas y locuciones) y 423 son remisiones de variantes ortográficas, cifras que ya hemos tenido ocasión de proporcionar.

Como es habitual en la práctica lexicográfica, hemos dispuesto en orden alfabético las unidades léxicas simples que constituyen nuestras 1149 entradas.

En la lematización de las voces el criterio seguido ha sido la norma ortográfica del castellano actual, por lo que la consulta de las últimas obras lexicográficas y ortográficas de la Real Academia Española ha resultado fundamental. En este sentido, son entradas de nuestro glosario acosado, acuartelar, amunicionar, aproche, asaltante, asediado, asediar, asitiar, avanguarda, belicosamente, botasilla, brecha, cabalgada, contrafosa, convoy, cuartel, descercar, desitiar, enfortalecer, espolonada, facienda, fajinada, flanquear, forrajear, fuesa, gasón, 
gavionada, inexpuñable, interpresa, jinete, ofensiva, pilotaje, rebelado, rezaga, sobrerronda, tenazón, vaivén y zapar, a pesar de que ninguna de estas formas se documenta en el corpus analizado, sino sólo sus variantes acossado, aquartelar, amuniçionar, aproge, aproje, aproxe, assaltante, assediado, assediar, assitiar, abanguarda, bellicosamente, botasela, brexa, cavalgada, contrafossa, comboy, quartel, decercar, dessitiar, enfortalescer, spolonada, fazienda, hazienda, faxinada, franquear, forregear, fuessa, gazón, gabionada, ynspuñable, antepresa, entrepresa, ynterpresa, ginete, offensiva, pilotage, rebellado, revelado, reçaga, sobreronda, tenaçón, baibén, baybén, bayvén, vaybén y çapar.

A propósito de la lematización de las voces, en los casos de fianco y terrapleno se ha decidido presentarlos como lemas independientes de flanco y terraplén, de acuerdo a su diferente origen, aunque estas dos últimas formas sean las empleadas en la actualidad. Es decir, fianco y terrapleno son voces que proceden del italiano, frente a flanco y terraplén, que lo hacen de la lengua gala, lo que invalida la consideración como meras variantes de las unas con las $\operatorname{otras}^{477}$.

La diferente procedencia que, según creemos, poseen acometido ${ }^{478} \mathrm{y}$ acometida ${ }^{479}$ nos ha decantado, igualmente, por su lematización independiente, al igual que ocurre en ofensivo ${ }^{480}$ y ofensiva ${ }^{481}$.

Por otro lado, la tratadística militar renacentista da cuenta de una gran variedad de formas para referirse a la "parte de una fuerza armada que en una marcha, ataque, etc., va delante" (DUE: s.v. vanguardia): abanguarda, abanguardia, avanguardia, banguardia, vanguarda y vanguardia. A pesar de haber considerado en nuestro glosario que el término catalán avantguarda es el principal responsable de todos estos significantes, como en la existencia de muchos de

\footnotetext{
477 Por lo que respecta al DRAE, sólo se contempla esta doble lematización en el caso de terraplén-terrapleno, aunque, como sus correspondientes paréntesis etimológicos revelan, no porque los académicos consideren que terrapleno es un italianismo, frente al galicismo terraplén, sino por tratarse a su juicio de un derivado de terraplenar.

478 De acometer, con sufijo -do.

${ }^{479}$ De acometer, con sufijo -(i)da.

480 De offensum, participio latino de offendere (cast. ofender), con sufijo -ivo.

481 De ofensivo. "Es importante en la historia de -ivo el proceso de sustantivación, producto de la elipsis en frases nominales del antecedente sustantivo de un adjetivo en -ivo" (Pharies 2002: s.v. $-i v o)$.
} 
ellos ha podido influir de manera decisiva la voz italiana vanguardia, según admite el DECH (s.v. guardar), finalmente nos hemos decantado por establecer cuatro entradas distintas para este concepto: avanguarda, cuya variante es abanguarda; avanguardia, y abanguardia y avanguardia como sus variantes; vanguarda, que sólo se documenta en esta forma; y, por último, vanguardia, lema susceptible de aparecer en el corpus con variación ortográfica $(b$ o v).

El hecho de que los autores más imbuidos en la cultura y en la lengua de Italia, como es el caso de Luis Collado, hagan uso de vanguardia, en detrimento del resto de unidades léxicas, nos persuadió de que tomábamos la decisión correcta. Además, de acuerdo con los etimologistas, las voces simples guarda 482 y guardia ${ }^{483}$ derivan de distintos étimos, circunstancia que, en el caso de estar presente en la conciencia lingüística de los hablantes, puede condicionar su selección léxica, lo que creemos que corrobora nuestra determinación.

Por las mismas razones, tanto retaguarda como retaguardia adquieren en este glosario el rango de lemas de cabecera o entradas:

retaguarda, retaguarda [del cat. reraguarda (formado con rera 'tras', del lat. retro). Covarr.; Oudin y Aut. (DECH). García de Palacio, Diálogos militares, 1583]. sust. Mil. Parte de una fuerza armada que en una marcha, ataque, etc., va detrás.

García de Palacio, Diálogos militares, 1583, fol. 146r: En cayendo, pues, alguno de los de la primera hilera, entrava luego el que estava detrás d'él, en la segunda, y el de la tercera, en la segunda; el de la quarta, en la tercera. Y, assí, con mucha presteza se rehazían todas las órdenes, consumiéndose y cevando solamente de la retaguarda, que todas las otras siempre avían de estar enteras y pelear ordinaria y ordenadamente, de manera que antes eran consumidas, que rotas ni desbaratadas.

retaguardia, rectaguardia, retaguardia [del cat. reraguarda (formado con rera 'tras', del lat. retro), modificado luego bajo el influjo del it. retroguardia. 1590, Juan de Castellanos, Hist. N. Granada; Oudin y Aut. (DECH). Montes, Instrucción y regimiento,

\footnotetext{
482 "Del germ. warda" (DECH: s.v. guardar).

483 «Del gót. wardja 'el que monta guardia', 'centinela, vigía', influido en su significado por el lat. custodia 'acción de guardar', 'retén de soldados'» (DECH: s.v. guardar).
} 
1537]. sust. Mil. Parte de una fuerza armada que en una marcha, ataque, etc., va detrás.

Montes, Instrucción y regimiento, 1537, fol. Xr: Quando el exército començare a marchar la buelta adonde están los enemigos, han de echar de banguardia la gente más plática en la guerra y, tras aquélla, vaya el cuerpo de la batalla, y luego la artillería, y de retaguardia vaya la gente que no es tan plática [...]. Mas si conosciere que los enemigos estuvieren más pujantes que no ellos y se quisieren retirar, echen la gente más plática de retaguardia y la que no es tan plática vaya de banguardia con la artillería.

Asimismo, somos conscientes de que nuestro modo de proceder en la lematización de los verbos pronominales requiere también de explicaciones adicionales. Para este importante aspecto, partimos de la declaración de intereses de los autores del DRAE, especificada en las "Advertencias" a la vigésima segunda edición: “Los verbos aparecen en infinitivo. Si sólo tienen conjugación pronominal se representan de este modo". De esta forma, cuando uno de nuestros tecnicismos verbales ostenta varias acepciones, aunque alguna sea pronominal, si al menos uno de sus sentidos relevantes es ajeno a ese régimen verbal, de acuerdo con el DRAE, el lema del verbo en cuestión no termina en -se:

atrincherar, atrinchear, atrincherar [de trinchera (DECH). Rojas, Teórica fortificación, 1598]. v. tr. Fort. Defender algo con trincheras o construir trincheras en un sitio (DUE).

2 [Collado, Plática Artillería, 1592]. v. prnl. Fort. Ponerse una persona en una trinchera para defenderse (DSAL).

Ahora bien, al ser el DRAE un diccionario general, está claro que sus lemas en -se, como acaserarse, el que les sirve a los académicos para ejemplicar esta situación, o arrepentirse, entre otros, responden al hecho constatado de que en ellos la conjugación pronominal es la única posible. En cambio, nuestras entradas acamparse, aliarse, coligarse, confederarse, encastillarse, enseñorearse y ligarse, al formar parte de un repertorio de especialidad centrado en la época renacentista, no conllevan necesariamente que el pronominal sea el único régimen verbal posible. De hecho, excepto en el caso de coligarse, del que los 
académicos sólo admiten esta posibilidad, el resto de los verbos enumerados cuentan también con usos transitivos e intransitivos. Queremos advertir, en definitiva, que el modo en el que han sido lematizados estos términos simplemente certifica que sus significados atendidos sólo han sido detectados en construcciones pronominales, con independencia de que en otro tipo de acepciones su régimen verbal pueda o no ser éste.

Por último, con respecto a la presencia en la macroestructura de voces homonímicas, como comentamos al analizar la homonimia, el criterio etimológico y diacrónico es el que ha predominado en su tratamiento lexicográfico ${ }^{484}$. Según este criterio, se produce homonimia si dos étimos distintos han llegado en su desarrollo a una confluencia en su forma fónica. Por tanto, estas unidades poseen una representación autónoma en nuestro glosario, es decir, hemos procedido a asignar a cada unidad homónima su propia entrada:

militar $^{1}$, militar [tomado del lat. mìlitare 'practicar el ejercicio de las armas'. Alonso de Palencia; Quijote; Aut. (DECH). García de Palacio, Diálogos militares, 1583]. v. intr. Profesar la milicia o combatir en una guerra bajo el mando de un determinado ejército.

militar', militar [tomado del lat. millütaris 'perteneciente al soldado o a la guerra', derivado de miles, -itis. h. 1440, A. Torre (DECH). Montes, Instrucción y regimiento, 1537]. adj. De la milicia, del ejército o que tiene relación con ellos.

real1, real [del lat. regalis. Real 'perteneciente al rey'. Doc. de 1188; Berceo (DECH). Collado, Plática Artillería, 1592]. adj. Fort. Dicho de una construcción defensiva: permanente, sólida y mayor que otras de su misma clase.

real $^{2}$, real [del ár. rahl (vulgar rahál) que significa 'lugar donde se hace alto en un camino', 'campamento', 'majada, redil', 'rebaño'. Real 'predio rústico', 'campamento', 'cabaña'. Reyal, Cid; real, doc. murciano de 1275 (DECH). Fernández de Enciso, Suma de Geographía, 1530]. sust. u. t. en pl. con el mismo significado que en

${ }^{484}$ Cf. Castillo Carballo (2003: 99-100) respecto a la disposición de las entradas para los homónimos que se sigue en la práctica lexicográfica. 
sing. Mil. Campamento o conjunto de instalaciones donde se establece temporalmente un ejército en campaña.

saco $^{1}$, saco [del lat. saccus 'saco de trigo, de dinero, etc.', 'vestido grosero', gr. oáxXos 'íd.' y 'arpillera', voz de origen fenicio. Berceo (DECH). Loçano, Alberto, Architectura, 1582]. sust. Fort. Bolsa o recipiente de lienzo $\mathrm{u}$ otro material semejante que, relleno de tierra, arena o lana, se emplea para hacer defensas o reparos.

saco $^{2}$, saco [del it. sacco 'saqueo' (med. s. XIV). Saco de Roma en 1527; ej. de G. de Alfarache en Aut. (DECH). Celso, Reportorio universal leyes Castilla, 1553]. sust. Mil. Acción de apoderarse violentamente de todo cuanto hay en territorio enemigo.

\subsection{La microestructura}

La microestructura es la ordenación de los elementos que conforman el artículo lexicográfico y está formada por la entrada o lema y por las informaciones proporcionadas acerca de esa unidad léxica. En nuestro caso, son múltiples las informaciones que proporcionamos sobre cada uno de los lemas establecidos, las cuales derivan de los nueve bloques temáticos anteriormente enumerados a propósito de la descripción de la ficha lexicográfica empleada. Uno de los artículos lexicográficos de este glosario más completo es el de cortina 485 :

cortina, cortina [del lat. tardío cortina 'íd.', derivado del lat. vg. cors, -tis, lat. cohors 'recinto'. Cortina 'paño con que se cubren puertas, ventanas, camas, etc.'. Berceo, Mil. (DECH). Álaba, Perfeto capitán, 1590]. sust. Fort. La porción de muralla comprendida entre dos baluartes. 6 (fig. 48)

Álaba, Perfeto capitán, 1590, fol. 88v: Y desde que se començare a batir siempre se vaya continuando con gran priessa de día y de noche, cruzando la batería, dándola a los lados de los baluartes, por estorvar el daño que las pieças de las casamatas hazen, echándolas por tierra, con que quedará el lugar más acomodado de subir la fortaleza, batiendo también la cortina que está en medio de los dichos baluartes. // Rojas, Teórica fortificación, 1598, fol. 35v: Y, supuesto este fundamento, daré principio a mi opinión, guardando por regla general que la mayor

485 Por motivos de espacio, renunciamos a ofrecer este artículo lexicográfico de manera totalmente íntegra. 
cortina que daré en todas las plaças que pusiere será de 400 pies de largo, y la cortina menor será de 350 , porque en estas dos medidas se hallan buenos ángulos a los valuartes y buenas espaldas a las casas matas.

SIN.: cortina franca, cortina limpia, cortina parcial.

FAM.: descortinar.

ENCICL.: Díaz Capmany (2004: 30): "La cortina era el tramo de terraplén comprendido entre dos baluartes; por estar entre dos flancos era la parte más defendida. La longitud de las cortinas estuvo siempre íntimamente relacionada con el alcance de las armas empleadas en su defensa, es decir, las que tenían que flanquearlas".

2 [Roxas, Sumario milicia, 1607]. sust. Constr. Trozo continuo de pared o muralla (DSAL: s.v. lienzo).

Roxas, Sumario milicia, 1607, fol. 77r: Largo de la frente o cortina del baluarte, 250 pies. // Lechuga, Discurso de la Artillería, 1611, pág. 241: El fosso a de ser ancho, por la parte de las cortinas de los baluartes, quando menos, 120 pies, y por las otras partes, lo que precisamente pide, para que los baluartes puedan guardar el fosso.

SIN.: lienzo.

ENCICL.: Lorenzo Celorrio (1996): Lienzo. Porción de muralla comprendida entre dos elementos cualesquiera que rompan la uniformidad del muro tales como torres, cubos, esquinas o precipicios.

$\sim$ franca [Rojas, Teórica fortificación, 1598]. cmpt. sintag. Fort. La porción de muralla comprendida entre dos baluartes. Rojas, Teórica fortificación, 1598, fol. 41r: Para hazer el repartimento en esta plaça en triángulo, se dividirá, como dicho es, en cinco partes la frente del recinto, que en este caso es la $\mathrm{AB}$ y tiene de frente 600 pies, que, divididos en cinco partes, caben a cada una a 120. Y éstos se rebatirán de ambos estremos de la frente del recinto para sacar los traveses, como lo muestran $\mathrm{AC}$ y $\mathrm{CB}$ en la passada figura, dexando la cortina franca, del un través al otro, de 360.

SIN.: cortina, cortina limpia, cortina parcial.

\subsubsection{Variantes gráficas}

Al habernos centrado en un período histórico esencial en la evolución del español, debido a su gran riqueza gráfica, hemos creído fundamental recoger en 
la microestructura todas las posibles formas con las que aparecen los lemas en el corpus. Por consiguiente, después de la entrada hemos especificado sus variantes.

Asimismo, esta información aparece también en la macroestructura del glosario en forma de reenvíos o remisiones de las variantes gráficas a la forma canónica lematizada, además de contar con un índice final que recoge todas estas formas.

Con respecto a este destacado asunto, queremos realizar algunas precisiones. En primer lugar, consideramos que çitadela es una variante del lema ciudadela, significante que acaba imponiéndose como adaptación castellana del término italiano cittadella, porque, si bien es bastante probable que en esta fijación haya desempeñado un papel fundamental la voz patrimonial ciudad, no es menos cierto que tanto ciudadela como çitadela poseen el mismo origen, esto es, el italiano cittadella.

Tanto en éste como en el caso del galicismo botasilla486, presente en nuestro corpus sólo en la forma botasela, estaríamos en las primeras fases del proceso de integración formal que todo préstamo experimenta en la lengua receptora, de acuerdo con la clasificación de Otaola Olano (2004: 78-79), a saber, las de préstamo sin alteración o sólo adaptado bien fónica o bien morfológicamente, frente a la situación final de préstamo plenamente integrado. Exactamente lo mismo ocurre con el galicismo interpresa ${ }^{487}$, puesto que, como atestigua la confluencia en los textos manejados de las unidades léxicas antepresa, entrepresa e ynterpresa, aún no contaba en el siglo XVI con una forma fija en castellano

Por otro lado, en referencia al período cronológico estudiado, se ha señalado ya "una fluctuación de tendencias en la lexicalización de ciertos vocablos compuestos, como sucede con carromato / carros matos; aguardiente / agua ardiente, etc., lo que pone de manifiesto la falta de fijación terminológica en esta época" (Mancho Duque 2003: 34). Como demuestra la tratadística

486 “Del fr. boute-selle (s. XVI). La forma más antigua fue botasela (1595-1794), que más tarde fue castellanizada en botasilla (1705, Gili)" (DECH: s.v. botar).

487 "Del fr. entreprise" (DECH: s.v. prender). 
manejada, este fenómeno también puede producirse en términos que, si bien no son compuestos en última instancia, están relacionados grosso modo con este procedimiento morfológico: por ejemplo, casamata, término que en nuestra lengua es un italianismo, del it. casamatta, formado a su vez por la combinación de casa y matta ( $c f$. DECH: s.v. casa); y contrabatería, que pese a contar con una ascendencia gala, seguramente llegó a interpretarse como el resultado de la unión de contra más batería. En conclusión, la presencia en el corpus de ocurrencias como las siguientes, nos ha llevado a establecer las formas casa mata y contra batería como variantes de los lemas casamata y contrabatería:

\begin{abstract}
El muro ha de ser bien fraguado; ha de tener sus traveses que jueguen por lo baxo del fosso, con que haya de través a través ciento y cinqüenta passos o, a lo menos, casas matas, para que la artillería pueda jugar dentro d'ellas por lo alto y por lo baxo (Montes 1537: XVIIr).

No quiero aprovar por esso que, pieça contra pieça, no serán mejores los cañones que los medios, empero, por quanto el deffender una plaça y hazer la contra dicha batería a la de afuera, tomaría de mejor gana los medios cañones (Ufano 1613: 170).
\end{abstract}

Por último, con respecto a la entrada bastión ${ }^{488}$, además de la forma coincidente con ella, también establecemos como variante suya bestión, sobre todo porque así parecen juzgarla Corominas y Pascual: "La variante bestión, frecuente en el s. XVI, se debe a influencia de vestir" (DECH: s.v. bastión). De todas formas, debemos advertir que el DRAE, a diferencia de nuestro modo de proceder, sí reserva una entrada para bestión, donde remite a bastión. Probablemente esta lematización esté directamente relacionada con el hecho de recoger otro bestión, derivado de bestia, es decir, un término homónimo del bestión dependiente de bastión. En definitiva, al obrar de este modo, los académicos consiguen marcar distancia entre estas dos formas léxicas homónimas, lo que evidentemente no precisamos hacer nosotros ${ }^{489}$.

\footnotetext{
488 «Del it. bastione 'íd.', derivado de bastìa 'obra fortificada', forma de origen dialectal genovés, piamontés o lombardo, en lugar de bastita derivado de bastire 'construir'» (DECH).

${ }^{489}$ En cambio, en el caso de arce y arcén nos hemos decantado por la solución adoptada por el DRAE. Por consiguiente, para estas dos unidades léxicas nuestro glosario consta de dos lemas, arce y arcén, cada uno de los cuales posee distintas variantes: arce, arçe, arço y arze, por lo que respecta al primero; y arcén y arzén en el caso del segundo. La razón reside en que, a pesar de considerar como responsable directo de estas dos formas al latín arcaico y vulgar arger, argěris,
} 


\subsubsection{Información histórica, etimológica y morfológica}

En cualquier glosario de tipo histórico resulta imprescindible la información relativa a la etimología y a la datación de cada una de las voces, motivo por el que hemos tenido en cuenta estos aspectos. Así, nos servimos, preferentemente, del Diccionario crítico etimológico castellano e hispánico (DECH). Queremos resaltar la enorme deuda que nuestro glosario ha contraído con este repertorio histórico y etimológico. Sólo para aquellos términos no recogidos en este repertorio, o cuyo origen no estaba claro con los escasos datos ofrecidos, hemos recurrido a la consulta de, entre otros, Le Grand Gaffiot: dictionnaire latinfrançais, el Nuevo diccionario etimológico latín-español y de las voces derivadas de Santiago Segura Munguía y su más reciente Diccionario por raíces del latín y de las voces derivadas, el Nuevo diccionario latino-español etimológico de Raimundo de Miguel, así como el Trésor de la langue française, el Tesoro della lingua italiana delle origini (TLIO), el Grande dizionario della lingua italiana de Salvatore Battaglia y el Dizionario etimologico italiano de Battisti y Alessio. Nos hemos valido, asimismo, de los trabajos de destacados etimologistas, como es el caso de Colón Doménech (2008), cuyas investigaciones acerca del origen del término revellín, por ejemplo, han resultado ser fundamentales. Por último, en conqueridor, contraminar, contramuro, espolón, explanada y pina hemos considerado acertado anotar el origen postulado por el DRAE, debido a que, si bien no se trata de un diccionario etimológico, es el que de manera más clara, de todos los consultados, se pronuncia al respecto del origen de estas voces.

Debemos matizar que no sólo ofrecemos información sobre los vocablos cuya presencia en español se explica por los frecuentes préstamos de unas lenguas a otras, sino que, efectivamente, nos hemos preocupado también por indicar si se está ante un término derivado o ante uno compuesto, al igual que

de ahí que en nuestro glosario el étimo propuesto en ambas sea éste, como, según indica la mayoría de las obras lexicográficas consultadas, resulta que las primeras documentaciones de arce son anteriores a las de arcén, no podemos descartar que, en realidad, esta última derive de la primera. En resumen, en este caso hemos optado por la doble lematización por considerar que, dado su carácter tan especial, ésta era la decisión más acertada. 
especificamos la base de derivación y las unidades simples que integran el compuesto.

De hecho, si es posible, tras aportar todos los datos pertinentes relativos al lema de cabecera, con la excepción de la información enciclopédica, si la hay, señalamos la familia de palabras (FAM.), que da cuenta de la serie completa de voces emparentadas morfológicamente con la entrada:

acometer, acometer, hacometer [de cometer y éste del lat. committěre. Cid, etc., pero menos frecuente que cometer hasta el s. XIV (DECH). Fernández de Enciso, Suma de Geographía, 1530]. v. tr. u. t. c. intr. Mil. Lanzarse contra alguien para causarle daño o para vencerle.

Montes, Instrucción y regimiento, 1537, fol. Xv: Y por los lados, y en las postreras hileras del esquadrón, van también otras hileras de cosseletes; y la arcabuzería va delante, y en torno del esquadrón. Y esto se haze quando son los enemigos muchos, porque el esquadrón vaya más fortificado, y no puede ser roto por ninguna parte que le acometan.

SIN.: atacar, combatir 3 , embestir 2 , ofender.

ANT.: defender 2.

FAM.: acometedor, acometida, acometido, acometimiento.

ENCICL.: Terr.: En la Milicia, V. atacar. // DUE: Atacar físicamente a alguien, o atacar un sitio donde hay alguien: 'Acometieron nuestras posiciones de madrugada'.

En todo caso, debemos precisar que, pese a mantener al margen de este apartado los préstamos, en los casos en los que se documenta tanto el vocablo patrimonial como el cultismo correspondiente, atendiendo a su evidente vinculación, consignamos cada uno de ellos en la familia del otro:

fosa, fosa, fossa [tomado del lat. fŏssa 'excavación', 'fosa', 'tumba', 'canal', propiamente participio femenino de fŏdĕre 'cavar'. 1542 Diego Gracián (DECH). Montes, Instrucción y regimiento, 1537]. sust. Fort. Zanja profunda que circunda toda la plaza, fortaleza, etc. (Terr.: s.v. foso).

FAM.: contrafosa, fuesa. 
fuesa, fuessa [del lat. fŏssa 'excavación', 'fosa', 'tumba', 'canal', propiamente participio femenino de födĕre 'cavar'. Fuesa tiene, por lo común, la ac. de 'tumba. Doc. de 1200, Burgos; Berceo (DECH). Montes, Instrucción y regimiento, 1537]. sust. Fort. Zanja profunda que circunda toda la plaza, fortaleza, etc. (Terr.: s.v. foso).

FAM.: contrafosa, fosa.

Finalmente, cuando existe, añadimos la información histórica que propone el DECH. Junto a ésta, nuestra aportación consiste en facilitar la primera documentación del corpus textual manejado, y tanto del lema de cabecera como de cada acepción, además de las distintas unidades pluriverbales.

\subsubsection{Categoría e información gramatical}

Damos cuenta igualmente de la categoría gramatical, aspecto del que las únicas posibilidades, como ya hemos señalado, son sustantivo, adjetivo, verbo y adverbio. Además, por lo que respecta a las unidades pluriverbales, comunicamos mediante las siguientes abreviaturas el tipo de que se trata en cada caso: loc. adj. (locución adjetiva), loc. v. (locución verbal), loc. adv. (locución adverbial) y, por último, cmpt. sintag. (compuesto sintagmático).

Por otro lado, sólo consignamos el género gramatical cuando éste es relevante, como ocurre cuando, en lo que respecta a esta importante cuestión, el uso de un determinado término, de acuerdo con el corpus manejado, difiere del que posee en la actualidad. Así pues, la razón de que en nuestro glosario en el lema centinela, por citar sólo un ejemplo, se especifique que su género es el femenino se debe a la constatación de que en la tratadística renacentista los determinantes que acompañan a esta voz adoptan siempre la forma femenina, frente al género masculino que coinciden en señalarle todos los diccionarios contemporáneos.

Por consiguiente, no se encuentra entre nuestros objetivos la indicación del género gramatical de cada una de las unidades léxicas recogidas, sino que, 
en relación con este aspecto, consideramos que lo único útil e interesante es advertir de las anomalías detectadas, de lo que, efectivamente, nos ocupamos. Por ello, tras haber localizado varias ocurrencias que muestran un empleo masculino del sustantivo blinda, a pesar de que ciertamente, y en consonancia con el DRAE por ejemplo, lo más habitual es que su género sea femenino, hemos optado por adjuntarle a f. (femenino) u. t. c. m. (usado también como masculino). Disponemos, paralelamente, de la abreviatura u. t. c. f., presente en alarde, camarada y puente, entre otras voces.

En el caso del número nos hemos valido del acertado sistema establecido en el Diccionario de la lengua española: pl. plural (como en aproche, fuerza, pertrechos y víveres), u. m. en pl. con el mismo significado que en sing. usado más en plural con el mismo significado que en singular (por ejemplo, en bastimento, despojo2, munición y vitualla), u. t. en pl. con el mismo significado que en sing. usado también en plural con el mismo significado que en singular (en $\operatorname{pres}_{3}$ y en real ${ }_{1}$ ) y u. m. en pl. usado más en plural (abrojo, cuartel, diente 1 , través 2 , etc.).

En varias ocasiones ha sido preciso ofrecer otros tipos de información gramatical diferentes de los hasta ahora tratados. Por ejemplo, debido a la asiduidad con la que se sustantivan las locuciones adjetivas de (a) caballo y de (a) pie, ha resultado necesario el empleo en ellas de la abreviatura $u$. t. c. sust., que marca "usado también como sustantivo". Incluimos, del mismo modo, las abreviaturas del DRAE "prnl." y “u. t. c. prnl." sobre el uso pronominal de algunos verbos. Ahora bien, la información gramatical más relevante en relación a las numerosas formas verbales recogidas es la relativa a su régimen transitivo o intransitivo, aspecto del que dependen estas abreviaturas: tr. (transitivo), intr. (intransitivo) y u. t. c. intr. (usado también como intransitivo).

\subsubsection{La marcación}

En palabras de Fajardo Aguirre (1996-1997: 31), “la marcación es el recurso o procedimiento que se utiliza en el diccionario para señalar la 
particularidad de uso, de carácter no regular, que distingue a determinados elementos léxicos".

De acuerdo con la ordenación de Porto Dapena (2002), las marcas se clasifican en cuatro grupos: diacrónicas, diatópicas, diafásicas y, por último, las diastráticas, "entre las que por cierto podemos incluir las técnicas y de especialidad" (Porto Dapena 2002: 257-258). Para Garriga Escribano (2003), en cambio, estas últimas deben incluirse en un apartado específico, mientras que son las diafásicas y las diastráticas las que para él forman un grupo único.

En cualquier caso, resulta evidente que en un repertorio lexicográfico de especialidad, como el que presentamos, la distinción de la ciencia o de la técnica a la que pertenece cada una de sus palabras o acepciones se convierte en una tarea de vital importancia. En consonancia con la práctica lexicográfica actual, hemos hecho uso de un completo sistema de abreviaturas.

En primer lugar, hemos marcado con Mil. (milicia) todas aquellas realidades militares que o bien no pertenecen o no son exclusivas de la fortificación, de la poliorcética o de la artillería, puesto que, dada su gran trascendencia, estas tres ramas del arte militar cuentan con una marca propia: Fort. (fortificación), en el caso de las dos primeras, y Art. para la artillería.

A pesar de que en la confección de nuestro glosario también nos hemos valido de las correspondientes marcas de geometría y construcción, a saber Geom. y Constr., como evidencia el siguiente gráfico, son escasas las acepciones que disponen de una de ellas: 


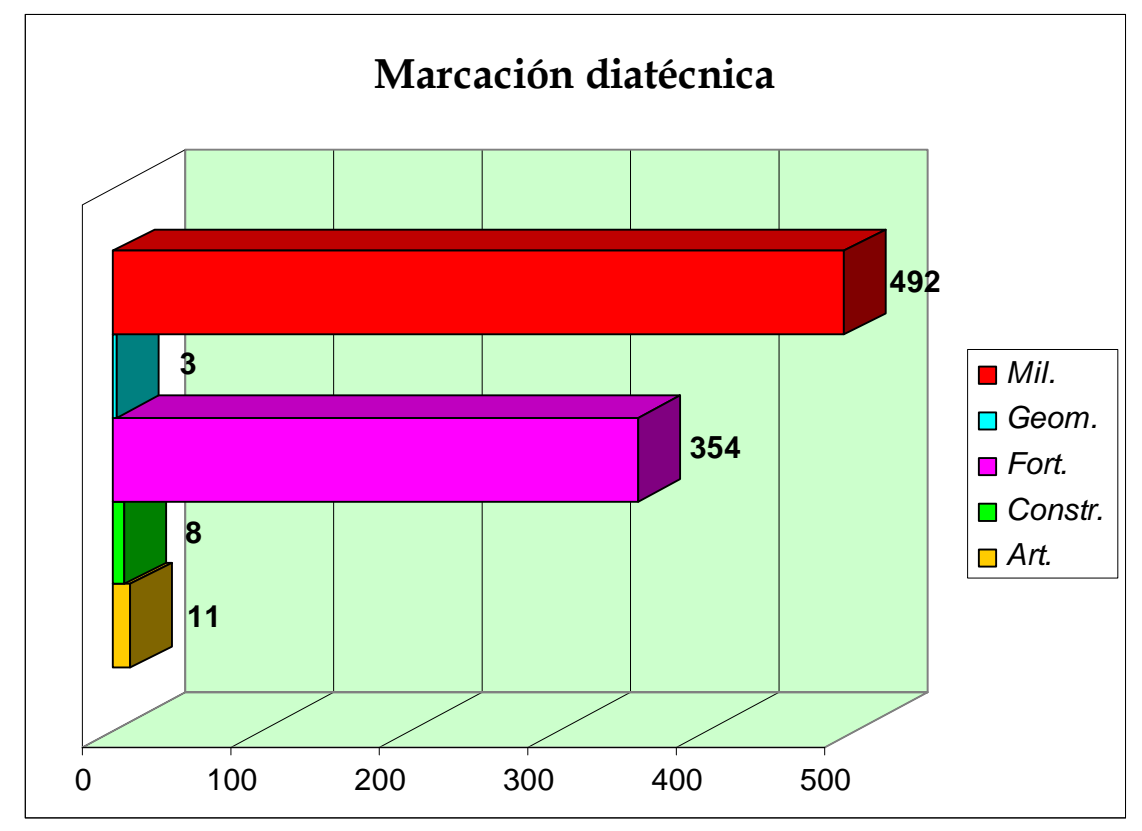

Debemos precisar, por otro lado, que "las marcas no son excluyentes, de tal manera que donde aparezca una no hay ninguna razón para que no aparezca otra" (Jiménez Ríos, 2001: 245). Por consiguiente, no debe resultar extraño que le hayamos adjuntado a la acepción de presa "embarcación enemiga que se rinde o se toma por fuerza" (Salvá 1846) tanto Mil. como Mar. (marina).

Además, exactamente en 56 ocasiones ha sido preciso recurrir al empleo de la marca diacrónica ${ }^{490}$ ant. ([acepción] antigua o anticuada), lo que de nuevo conlleva la simultaneidad de dos marcas, eso sí, en este caso entre la temporal ant y alguna de las marcas diatécnicas ya especificadas, a excepción de lucha y luchar1, acepciones que, aunque portan la marca diacrónica mencionada, carecen en cambio de la de especialidad.

490 "Entre [las marcas diasistemáticas] cabe citar las, a nuestro juicio, mal denominadas marcas diacrónicas, que sería preferible llamar simplemente temporales, puesto que su misión no es tanto asignar la palabra a una variedad diacrónica como indicar su grado de uso en el momento actual en relación o no con su antigüedad" (Porto Dapena 2002: 257). 


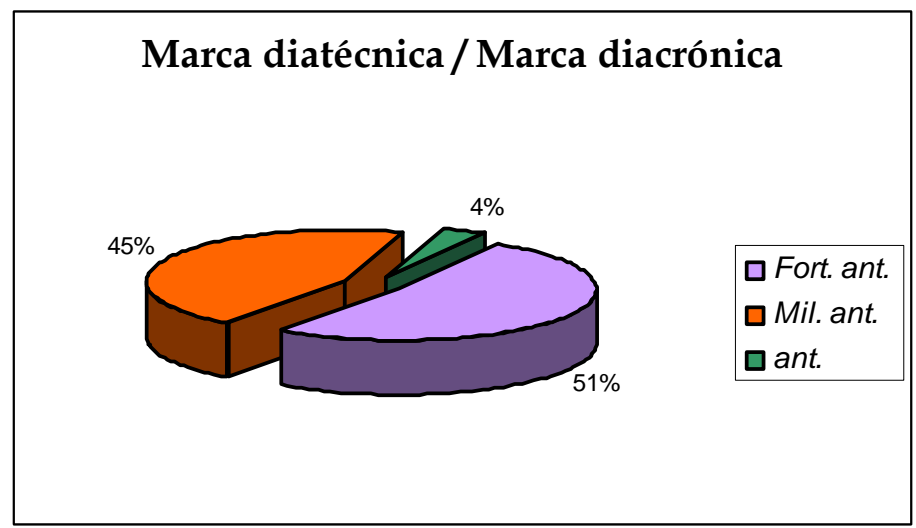

Tras la realización de la presente investigación nos atrevemos a afirmar que, gracias a su léxico, el mundo militar antiguo está muy presente en la tratadística militar renacentista. A este respecto, consideramos que la siguiente cita resulta sumamente clarificadora:

\begin{abstract}
Conviene recordar que, contra lo que comúnmente tiende a pensarse, la desaparición de un referente no tiene por qué acarrear la del signo que a él se refiere, pues la lengua sirve permanentemente, entre otras cosas, para evocar un pasado ya ido. Ni la palabra maravedí ni, menos aún, la palabra peseta son arcaísmos léxicos, por más que hayan desaparecido ambas monedas (Álvarez de Miranda 2008: 31).
\end{abstract}

Esto es, como demuestra el hecho de que las voces que sirven para designarlas son recurrentes en el corpus manejado, debe notarse que las acepciones que en nuestro glosario van acompañadas de la marca ant. no son arcaísmos lingüísticos, sino que simplemente dan cuenta de realidades militares ya superadas en el Renacimiento. Por ejemplo, resulta especialmente significativa la frecuencia con la que los tratadistas aluden a las máquinas militares de otras épocas, con la intención de que con la comparación queden recalcados los beneficios de las modernas armas de fuego. Ahora bien, en nuestro caso, para dejar constancia de que no son términos propios de la fortificación abaluartada, hemos considerado adecuado emplear para estos la marca diacrónica ant.

Por último, además de lucha y luchar, otras 144 acepciones carecen de marca diatécnica o temática. Si tenemos en cuenta que la lengua técnica implica lo marcado, resulta evidente que su ausencia tiene también su propio valor. Por 
lo que se refiere a nuestro glosario, si bien, como ocurre con el resto, esos 146 sentidos son propios de la milicia, su particularidad reside en que han salido del ámbito estrictamente especializado.

\subsubsection{Definición}

A pesar de que la definición es la cuestión lexicográfica que mayor interés ha despertado entre los estudiosos, aún hoy sigue siendo la principal dificultad dentro de la redacción lexicográfica (ápud Porto Dapena 2002: 266).

Por consiguiente, para la consecución de esta delicada y costosa labor del lexicógrafo, además de ser ésta una de las directrices del Diccionario de la ciencia y de la técnica del Renacimiento, hemos tratado de adaptar, cuando ha sido posible, las definiciones existentes en otros repertorios. De este modo, la mayor parte de las definiciones prestadas proceden del Diccionario de Autoridades, del Diccionario castellano con las voces de las ciencias y las artes de Terreros, del Diccionario de uso del español (DUE) de María Moliner, del Diccionario Salamanca de la lengua española (DSAL), del Diccionario del español actual (DEA), así como de la última edición del repertorio académico. Ahora bien, también hemos hallado definiciones útiles en varios de los numerosos diccionarios recopilados en el Nuevo tesoro lexicográfico de la lengua española: entre otros, el Nuevo diccionario de la lengua castellana de Vicente Salvá, el Diccionario de la lengua española de José Alemany y Bolufer y el Diccionario general y técnico hispano-americano de Manuel Rodríguez Navas.

Lógicamente, aparte de estos diccionarios generales, también han sido fundamentales los cuantiosos repertorios militares, ya descritos anteriormente, de los que dispone nuestra lexicografía.

Como se deduce de las múltiples definiciones carentes del paréntesis indicador de la fuente lexicográfica empleada, no han sido pocas las ocasiones en las que nos hemos visto obligados a emprender la difícil tarea de redactar nuestra propia definición lexicográfica, obstáculo generado por la ausencia del 
término en cuestión en los diccionarios manejados, o por no resultar conveniente la definición hallada para nuestro caso.

Somos conscientes de que la mayoría de nuestras definiciones sobrepasa los límites impuestos por las estrictamente lexicográficas. Sin duda, el ejemplo más extremo de esta tendencia la constituye la explicación aportada en caballero $_{2}$, al igual que en su sinónimo plataforma, pero se ha tratado de mantener el paralelismo en las definiciones (vid. expugnar y conquistar). No obstante, en aras de una mejor comprensión, hemos preferido anteponer la claridad a la concisión, pese a ser ésta una de las principales reglas que rige la elaboración de definiciones puramente lingüísticas.

Si se tiene en cuenta que uno de los objetivos del presente glosario es la de servir de ayuda al lector contemporáneo en la interpretación y completo entendimiento de la tratadística militar renacentista, se entenderá fácilmente el porqué de esta decisión.

\subsubsection{Ilustraciones}

Estamos plenamente de acuerdo con la opinión de Lerat (1997: 177) acerca de las ilustraciones: "Son de suma importancia cuando se trata de lenguas especializadas". Ahora bien, debemos advertir que de todas las ramas militares contempladas la que ha generado el mayor número ha sido, indudablemente, la fortificación, lo que no es extraño si tenemos en cuenta la complejidad de sus contenidos. De hecho, muchos de los dibujos contenidos en nuestro glosario han sido tomados de tratados centrados en esta materia, como los Principios de fortificación de Lucuze.

Por ello, tras la definición, en todas las acepciones en las que hemos localizado una valiosa imagen que, a nuestro juicio, facilita la comprensión del concepto en cuestión, insertamos la ilustración a la que remitimos. Para no sobrecargar en exceso los artículos lexicográficos, las 173 figuras de que consta nuestro glosario se encuentran 
agrupadas en el "Catálogo de ilustraciones comentadas", apéndice situado justo después del "Índice de variantes gráficas".

\subsubsection{Ejemplos}

Además, para cada acepción ofrecemos de uno a tres ejemplos ilustrativos, extraídos, lógicamente, del corpus del DICTER. Con respecto a su extensión, coincidimos con Pascual y García (2007: 206) en señalar que sean tan largos como "exija la correcta interpretación de la palabra".

Debemos precisar que, en la selección de estos pasajes, que sirven para avalar la definición, nos hemos basado en la claridad del contexto para la determinación del contenido semántico del vocablo en cuestión.

En principio partimos de la idea de aprovechar el ejemplo más antiguo de cada acepción detectada. Sin embargo, como también hemos atendido al principio de transparencia y sentido completo, en el caso de no cumplirlo hemos desechado esa temprana ocurrencia (cf. asedio, entre otros).

\subsubsection{Relaciones semánticas}

Después de los ejemplos, pese a ser conscientes de las dificultades que conlleva esta tarea, hemos colocado la información relativa a las relaciones semánticas que se establecen entre las unidades léxicas incorporadas en el glosario. Así pues, hemos indicado todos los casos de antonimia y sinonimia que hemos detectado, precedidos por ANT. y SIN. respectivamente.

Como hemos puesto de manifiesto en el punto 7.1. del tercer bloque de la presente investigación, el léxico militar del período estudiado se caracteriza por una fuerte presencia de voces sinónimas, lo que implica que la información acerca de este fenómeno semántico sea una de las principales características de este glosario.

Téngase en cuenta, además, que, de acuerdo con una de las reglas establecidas para el Diccionario de la ciencia y de la técnica del Renacimiento, los 
términos sinonímicos de nuestro glosario poseen exactamente la misma definición, eficaz sistema con el que conseguimos evitar los obvios inconvenientes que conlleva el uso desmedido de las remisiones o definiciones sinonímicas.

\subsubsection{Información enciclopédica}

En numerosas ocasiones proporcionamos información adicional con el fin, entre otros, de facilitar la total comprensión del significado exacto de los conceptos militares atendidos. Así pues, estas peculiares explicaciones, que van siempre precedidas de ENCICL., pueden referirse tanto al lema de cabecera, como a alguna de sus acepciones e incluso a las distintas unidades pluriverbales recogidas.

En definitiva, se trata de un apartado que permite ampliar aquellos casos en los que juzgamos que la combinación de la definición con los ejemplos no resulta suficientemente clarificadora, o para ofrecer una mayor precisión, sobre todo en los conceptos más problemáticos.

Bajo esta denominación se agrupan, por lo tanto, distintos tipos de información: otros ejemplos ilustrativos del corpus, aclaraciones y explicaciones extraídas de las más variadas obras, otras definiciones, etc.

Si se tiene en consideración que en la realización de este trabajo nos hemos propuesto ser totalmente exhaustivos a la hora de dar cuenta de los conceptos técnicos de la milicia renacentista, lo que, a nuestro juicio, contribuirá a salvar las múltiples lagunas terminológicas existentes, se comprenderá fácilmente la trascendencia que le hemos otorgado a este apartado. Lógicamente, a esta consideración responden los numerosos casos en los que la información enciclopédica aportada destaca por su llamativa extensión.

\subsubsection{Acepciones y unidades pluriverbales}

Como ya hemos adelantado, el Glosario de fortificación y arte militar renacentistas, aparte de las entradas, consta de otras acepciones, así como de 
unidades pluriverbales. En concreto, hasta 290 acepciones se encuentran en el interior de algún artículo lexicográfico, mientras que 131 es el total de unidades pluriverbales registradas.

Muchos artículos lexicográficos están compuestos por más de una acepción. Estas acepciones van enumeradas y funcionan autónomamente, de manera que, además de su definición, pueden estar categorizadas, tener sus propias marcas de uso, sus ejemplos, sus sinónimos y antónimos, etc. (Garriga 2003: 107).

Nótese que las acepciones se han dispuesto en párrafos distintos, separadas por dos saltos adicionales de línea, y aparecen numeradas correlativamente, con excepción de la primera.

Con respecto al orden de las acepciones, hemos acordado finalmente situar en primer lugar la acepción más general o difundida dentro del área de especialidad o, incluso, dentro de la lengua estándar, y seguir por las más particulares hasta llegar a las unidades pluriverbales ${ }^{491}$.

Advertimos para facilitar su localización que en la colocación de las formas complejas nos remitimos a lo estipulado por el DRAE, a saber, que se ha procedido a unicarlas bajo "el artículo correspondiente al elemento sustantivo", motivo por el que media luna, por ejemplo, no se define bajo media, o la forma canónica medio, sino bajo luna:

luna, luna [del lat. lūna 'íd.'. Orígenes del idioma (DECH)]. media [Mendoça, Theórica y práctica, 1596]. cmpt. sintag. Fort. Obra de fortificación que se construye delante de los baluartes, la cual consta de dos caras que forman un ángulo saliente y de una gola o parte trasera curvada hacia el interior. Mendoça, Theórica y práctica, 1596, pág. 142: Y a la fin se ha de [...] procurar mantener siempre la muralla (sin dar lugar al miedo, que es poderoso señor, siempre que se le abre la puerta) para formar detrás d'ella nuevos fossos, reparos o medias lunas, que raras vezes defendieron tierra, perdiéndose la muralla d'ella.

491 "Las acepciones tratan de distinguir diversos sentidos dentro del hilo conductor que constituye la rama semántica general. Sabemos que la separación entre ellas y su redacción es una tarea difícil sobre la que la lexicografía no ha establecido criterios únicos e indiscutibles" (Pascual y García Pérez 2007: 97). 
Ahora bien, como puede constatarse, en este caso sólo recogemos el sentido especializado designado por la forma compuesta, al no resultar pertinentes, desde el punto de vista terminológico, los sentidos de la voz que la encabeza. No obstante, hemos considerado necesario ofrecer la procedencia etimológica de la lexía simple de referencia. Esto sucede, aparte de con media luna, con los términos arquitectura militar, arte militar, a la deshilada, hecho de armas, de suelo y de(l) terreno, entre otros. 


\section{GLOSARIO DE FORTIFICACIÓN Y ARTE MILITAR RENACENTISTAS}

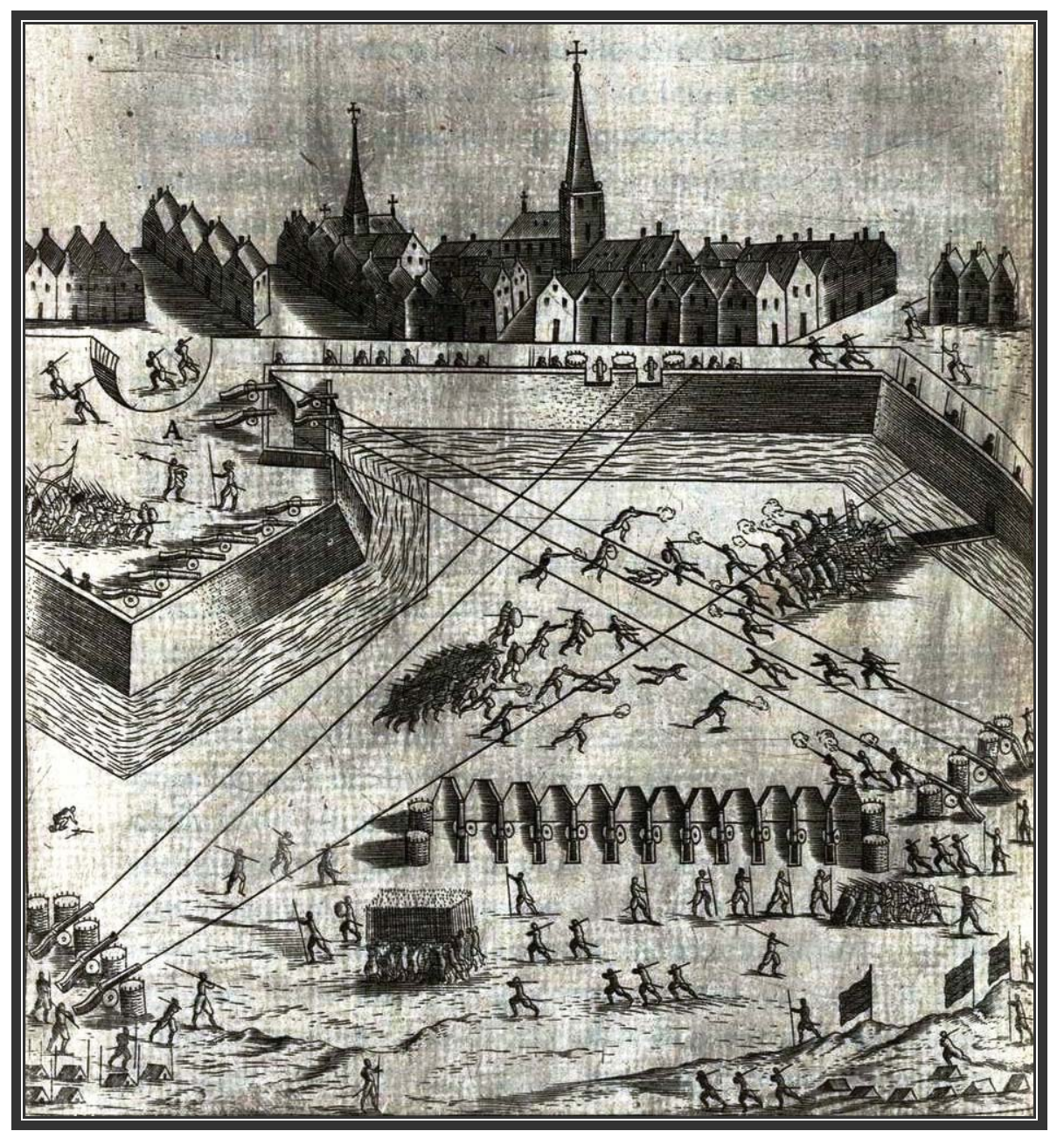

Ataque y defensa de una plaza abaluartada. En Ufano (1613: 175). 



\section{ABREVIATURAS Y SIGLAS}

\section{ABREVIATURAS}

(Las abreviaturas en cursiva corresponden a marcas diatécnicas y diacrónicas)

ac. acepción

acs. acepciones

adj. adjetivo

adv. adverbio

ant. antiguo

ant. (acepción) antigua o anticuada

ANT. antónimo

ár. árabe

Art. artillería

b. lat. bajo latín

cast. castellano

cat. catalán

cmpt. compuesto

cmpt. sintag. compuesto sintagmático

Constr. construcción

ENCICL. información enciclopédica

f. femenino

FAM. familia léxica

fr. francés

Fort. fortificación

Geom. geometría

germ. germánico

gót. gótico

gr. griego

h. hacia

it. italiano

intr. intransitivo

lat. latín

lat. cl. latín clásico

lat. vg. latín vulgar

loc. adj. locución adjetiva

loc. adv. locución adverbial

loc. v. locución verbal m. masculino

Mar. marina

Mil. milicia

mozár. mozárabe

oc. occitano

pl. plural

port. portugués

prnl. pronominal

SIN. sinónimo

sust. sustantivo

s.v. sub voce 'bajo la palabra'

tr. transitivo

u. m. en pl. Usado más en plural

u. m. en pl. con el mismo significado que en sing. Usado más en plural con el mismo significado que en singular

u. t. c. f. Usado también como femenino

u. t. c. m. Usado también como masculino

u. t. c. intr. usado también como intransitivo

u. t. c. prnl Usado también como pronominal

u. t. c. sust. Usado también como sustantivo

u. t. en pl. con el mismo significado que en sing. Usado también en plural con el mismo significado que en singular

v. verbo

$\mathrm{V}$. , vid. véase 


\section{SIGLAS Y ABREVIATURAS DE DICCIONARIOS}

(Para los diccionarios citados sin sigla ni abreviatura, véase, en la biliografía, el apartado "Repertorios lexicográficos generales y especializados”)

Aut. $=$ Real Academia Española: Diccionario de Autoridades

Cov. $=$ Sebastián de Covarrubias: Tesoro de la lengua castellana o española

DEA = Manuel Seco (dir.): Diccionario del español actual

$\mathrm{DECH}=\mathrm{J}$. Corominas y J. A. Pascual: Diccionario crítico etimológico castellano $e$ hispánico

DESAL = Diccionario estudio Salamanca

Dicc. Hist. = Real Academia Española: Diccionario histórico de la lengua española

DRAE = Real Academia Española: Diccionario de la lengua española

DSAL = Juan Gutiérrez Cuadrado (dir.): Diccionario Salamanca de la lengua española

DUE = María Moliner: Diccionario de uso del español

Nebr. = Nebrija: Vocabulario español-latino

Terr. = Esteban de Terreros y Pando: Diccionario castellano con las voces de las ciencias

$y$ las artes

$\mathrm{TLF}=$ Trésor de la langue française

TLIO = Tesoro della lingua italiana delle origini 
abajo, V. plaza de .

abanguarda, V. avanguarda.

abanguardia, V. avanguardia.

abrir, V. trinchera.

abrojo, abrojo [contracción de la frase latina aperĭ ǒcǔlos 'abre los ojos', originariamente advertencia al que segaba en un terreno cubierto de abrojos para que se guardara de los mismos, y luego nombre de la planta. Med. s. XIV Castigos de D. Sancho (DECH). Loçano, Alberto, Architectura, 1582]. sust. u. m. en pl. Mil. Pieza de hierro en forma de estrella con púas o cuchillas que se disemina por el terreno para dificultar el paso al enemigo. 3 (fig. 1)

Loçano, Alberto, Architectura, 1582, pág. 139: En lugares campestres y hondos, henchirse han las dichas cavas de agua del río o lago, guiada o traýda de la mar. Y si esto no fuere lícito, sembrarás el fondo de puntas de hierro o abrojos. // Álaba, Perfeto capitán, 1590, fol. 74r-74v: Tratavan de impedir sus efetos con abrojos, que son unos instrumentos de hierro de quatro puntas, dispuestos en forma piramidal, todos iguales, que, por tener esta forma, 
de qualquiera suerte que los arrojen dexan una punta arriba, de los quales se aprovechó Darío, como refiere Quinto Curcio, en lugar donde avía abundancia de yerva, que es necessaria porque estén ocultos. // Roxas, Sumario milicia, 1607, fol. 83r: Les faboreze en que el enemigo no tenga abrigo ni comodidad alguna, si no fuere el suelo limpio, y ése se les pueda sembrar en secreto de abrojos para clabar la caballería.

ENCICL.: Moretti (1828): Arma ofensiva de hierro compuesta de cuatro puntas de cuatro pulgadas de largo, de las cuales una queda siempre hacia arriba, y las otras se hincan en tierra. Se siembran los abrojos en las brechas y desfiladeros por donde han de pasar las tropas, especialmente la caballería, a quien este instrumento es más dañoso. También se usan de tres y de cinco puntas, dándoles tres pulgadas en el primer caso, y cinco en el segundo. Esta arma fue conocida por los antiguos, que la empleaban para los mismos usos. // Terr.: Se llama abrojo por la semejanza con el de tierra y agua.

acampado, acampado [de acampar. Mendoça, Theórica y práctica, 1596]. adj. Mil. Dicho de un ejército: instalado en el campo o en el lugar despoblado donde va a permanecer durante un tiempo.

Mendoça, Theórica y práctica, 1596, pág. 112-113: En el alojarse en esta vezindad, por lo que escrivo o otras algunas ocasiones, se ha de advertir que siempre que dos exércitos están muy cerca acampados, el que desaloja primero es con gran desaventaja, por la que da a su enemigo, moviéndose con todo el embaraço de su exército, y poder su contrario combatir con él sin ninguno.

FAM.: acamparse, campear, campo.

acamparse, acamparse [de campo. Berceo (DECH). Mosquera, Comentario disciplina militar, 1596]. v. prnl. Mil. Dicho especialmente de un grupo de soldados: instalarse temporalmente en el campo, por ejemplo con tiendas.

Mosquera, Comentario disciplina militar, 1596, fol. 8r: Quanto más que lo que es policía, primores y ardides de guerra que espantan a toda invención humana, en la Escritura Sagrada se hallarán; pues vemos que el primero que dividió el exército en avanguardia, batalla y retaguardia fue David, como parece por el Libro de los Reyes, y el enseñar a acamparse, reconocer las fuerças y tierra del enemigo, y la forma como han de estar y ser los exércitos. // Mosquera, Comentario disciplina militar, 1596, fol. 46r: Todo esto consiste en saber elegir lugar a propósito para acamparse, y hazer trincheas y plantar artillería, entendiendo bien la planta y disposición de la ciudad, y los lugares fortificados y flacos d'ella. // Mosquera, Comentario disciplina militar, 1596, fol. 81v: Estuvo aquella noche todo nuestro campo cerrado con trincheas, que eran las que avían ganado los nuestros en lo último de las escaramuças a los enemigos, con que nuestro esquadrón quedó más assegurado para la noche siguiente; y assí, el prevenido capitán nunca se ha de acampar en lugar abierto por el peligro que d'esto se puede seguir.

ANT.: levantar 3. 
FAM.: acampado, campear, campo.

ENCICL.: Domínguez (1853: s.v. acampar): v. n. Quedarse o instalarse un ejército o parte de él en el campo, ya sea con tiendas de campaña, ya sin ellas. / / Domínguez (1853): v. pron. V. acampar como v. n. // Corsini (1849: s.v. acampar): Cast. Establecerse un ejército o tropa en un paraje o sitio despoblado, disponiéndose ordenadamente para pasar más o menos tiempo en él, bien sea en tiendas de campaña o de cualquier otro modo.

acometedor, acometedor [de acometer (DECH). Loçano, Alberto, Architectura, 1582]. sust. Mil. Persona que acomete, combate u ofende.

Loçano, Alberto, Architectura, 1582, pág. 250: Porque, acrecentada la ciudad, les parecía que, por causa de utilidad, se avían de conservar las puertas antiguas, assí por otras cosas como también, por ventura, para que en los casos adversos estuviessen más seguros contra la fuerça de los acometedores.

SIN.: combatidor 2 , combatiente 2 .

ANT.: acometido $_{2}$, ofendido 2 .

FAM.: acometer, acometida, acometido, acometimiento.

acometer, acometer, hacometer [de cometer y éste del lat. commĭttěre. Cid, etc., pero hasta el s. XIV menos frecuente que cometer (DECH). Fernández de Enciso, Suma de Geographía, 1530]. v. tr. u. t. c. intr. Mil. Lanzarse contra alguien para causarle daño o para vencerle.

Montes, Instrucción y regimiento, 1537, fol. Xv: Y por los lados, y en las postreras hileras del esquadrón, van también otras hileras de cosseletes; y la arcabuzería va delante, y en torno del esquadrón. Y esto se haze quando son los enemigos muchos, porque el esquadrón vaya más fortificado, y no puede ser roto por ninguna parte que le acometan. // Álaba, Perfeto capitán, 1590, fol. 73r-73v: El último acto es acometer al enemigo, el qual es de mucho mayor peligro que el esperarle, pues el que acomete a de yr algo descompuesto y el que espera puede no descomponerse en nada, sino aguardar con su gente muy bien ordenada, en la forma que mayor fortaleza pueda tener para resistir. // Roxas, Sumario milicia, 1607, fol. 63r: Conforme al pareçer de grandes cappitanes no consisten las vitorias d'ellos y buenos suçesos de la guerra en el número de la jente, sino en el yngenio y valor del general, y en la obediençia y esfuerço de sus soldados; y así bemos que aquel famoso Alexandro con un pequeño exérçito acometió las ynnumerables jentes de Darío y lo vençió.

SIN.: atacar, combatir 3 , embestir 2 , ofender.

ANT.: defender 2 .

FAM.: acometedor, acometida, acometido, acometimiento. 
ENCICL.: Terr.: En la Milicia, V. atacar. // DUE: Atacar físicamente a alguien, o atacar un sitio donde hay alguien: 'Acometieron nuestras posiciones de madrugada'.

acometida, acometida [de acometer (DECH). Álaba, Perfeto capitán, 1590]. sust. Mil. Acción violenta contra alguien o contra un lugar donde hay personas.

Álaba, Perfeto capitán, 1590, fol. 61v: Y no será menos sano consejo hazer algunas acometidas para obligar a los enemigos que los sigan, teniendo dispuesto su campo de manera que, viniendo ellos descompuestos y encarnizados en su seguimiento, puedan ser muertos o heridos. // Álaba, Perfeto capitán, 1590, fol. 136r: Podrá mandar el capitán, siendo el lugar acomodado para emboscadas, que en el otro lado del esquadrón, por donde los enemigos no acostumbran acometer, se esconda buena parte de la gente más florida de su campo, y que por el lado donde se suele de ordinario escaramuçar se hagan acometidas a los contrarios.

SIN.: acometimiento, combate, combatimiento 2 , ofensa, ofensiva.

ANT.: defensa ${ }_{2}$.

FAM.: acometedor, acometer, acometido, acometimiento.

acometido, acometido [de acometer. García de Palacio, Diálogos militares, 1583]. adj. Mil. Dicho de una persona o de un lugar donde hay personas: atacado.

García de Palacio, Diálogos militares, 1583, fol. 12r: Vemos que ay dos maneras de guerras, unas en las quales el príncipe acometido no haze más que defenderse en la mejor forma que puede, otras en que acomete y offende, levantando sus gentes y entrando por las tierras de su contrario. // Lechuga, Discurso de la Artillería, 1611, pág. 262: Y assimismo, es necessario que el governador o castellano tenga alguna gente para acudir con ella a la parte que viere ser necessario o a la que supiere le an acometido su fuerza, para remediar el ímpetu, entre tanto que puede quitar soldados de las partes no acometidas, para ayudar a la que lo es.

SIN.: combatido, ofendido .

FAM.: acometedor, acometer, acometida, acometimiento.

2 [García de Palacio, Diálogos militares, 1583]. sust. Mil. Persona que recibe un ataque o una ofensa.

García de Palacio, Diálogos militares, 1583, fol. 69v-70r: Y, pues en los casos de la guerra es notorio que el acometido, por la mayor parte, tiene notables ventajas, nescessaríssimamente el que acomete, para yr ordenado a hazer algún buen effecto, es menester recelarse y mirar muchas circunstancias, para no poner su salud y la de los suyos en riesgo. // García de Palacio, Diálogos militares, 1583, fol. 90r-90v: Y, assí, quando se 
offresciere contra algún príncipe o provincia, república o ciudad, ora venga por los peccados de los acometidos, o por otra qualquier causa, es nescessario que el capitán y su gente occurran a mitigar y aplacar la yra y castigo de Dios con sacrificios y oraciones, suplicando a su Divina Magestad les perdone y libre de la afflición que esperan.

SIN.: ofendido 2 .

ANT.: acometedor, combatidor, combatiente 2 .

acometimiento, acometimiento [de acometer (DECH). Loçano, Alberto, Architectura, 1582]. sust. Mil. Acción violenta contra alguien o contra un lugar donde hay personas.

Loçano, Alberto, Architectura, 1582, pág. 141: A estas cosas se ha de añadir lo que aprovecha para el uso del defenderse y fortificarse, porque conviene aver fortalecido la cava, el vallado, la torre y las semejantes contra los del pueblo y contra las escaramuças de los de la provincia, y para que éstos, con su salida, concurso y acometimiento no dañen. // Álaba, Perfeto capitán, 1590, fol. 78r: Y porque es punto puesto muchas vezes en disputa entre los que apuran con particular cuydado las sutilezas del arte militar, si el acometimiento que haze un esquadrón a de ser caminando apriessa y con grita y bozería o despacio y con silencio, digo que las bozes son de efeto para encender y animar los coraçones de los que las dan y poner algún temor y miedo a los enemigos. // Roxas, Sumario milicia, 1607, fol. 38r-38v: Los acometimientos de repente sigún la ocasión, la qual el capitán del exérçito jamás ha de dejar pasar, y así se haçe otra guerra bien opurtuna, como es contra los que están fatigados del camino, y quando están dibididos al pasar de un río, y allí ocupados en pasar lagunas, o estando desparçidos por el campo, o durmiendo en su alojamiento, porque, estando en tales negoçios, es fuerça que en tales ocasiones se procure la muerte antes que se pueda aparejar.

SIN.: acometida, combate, combatimiento ${ }_{2}$, ofensa, ofensiva.

ANT.: defensa $a_{2}$.

FAM.: acometedor, acometer, acometida, acometido.

acosado, acossado [de acosar. Arphe, Varia Commensuración, 1585-87]. adj. Mil. Dicho de una persona: inquieta por pequeños ataques sufridos, o por la amenaza de posibles acciones en su contra.

Álaba, Perfeto capitán, 1590, fol. 94r: También será medio no de poca importancia para obligar a dexar el cerco hazer que los capitanes amigos o la persona de quien espera socorro acuda a cercar otro lugar de los enemigos, para que, viéndose acossados, los cercados pidan favor a los que a él le tenían cercado y, acudiendo a darle, lo dexen libre.

SIN.: apremiado, apretado 1. 
FAM.: acosar.

acosar, acosar, acossar [del cast. ant. cosso 'curso, carrera' y éste del lat. cǔrsus, ùs, 'íd.', de currere 'correr'. Acosar 'perseguir con empeño', 'fatigar ocasionando molestias y trabajos'. Princ. s. XV, Canc. de Baena (DECH). Loçano, Alberto, Architectura, 1582]. v. tr. Mil. Inquietar al enemigo con pequeños ataques, o tenerlo bajo la amenaza de acciones en su contra.

Loçano, Alberto, Architectura, 1582, pág. 140: Se ha de advertir y procurar que el fuerte sea poderoso, fuerte, firme y aparejado para se defender, y para enflaquecer al enemigo y rechazalle, y seguro y no dañado contra todos los ímpetus y porfía del ser cercado. Pero en los alojamientos en que apremiéys y acosséys al enemigo encerrado, en ninguna manera todas las cosas semejantes se han de guardar con menos diligencia. // Álaba, Perfeto capitán, 1590, fol. 70v-71r: Y a esta causa los capitanes, de cuya industria en las cosas de la guerra más cierta noticia se tiene, lo que con todas sus fuerças procuravan era acossar y descomponer sus enemigos con cautelas, assechanças y ardides, esperando el acometerlos en tiempo que su resistencia fuesse de muy poco efeto. // Álaba, Perfeto capitán, 1590, fol. 77r: Temístocles, después de aver vencido a Xerxes, prohibió a los griegos romper una puente por donde podía huyr, pareciéndole que convenía más echarle de Europa que acossarle de nuevo.

SIN.: apremiar, apretar 1 .

FAM.: acosado.

ENCICL.: Almirante (1869): Verbo venatorio, expresivo también en la guerra. Perseguir con empeño, estrechar, hostigar, apurar al enemigo en retirada. // Estévanez (1897): Equivale a hostigar al enemigo, a no darle punto de reposo, ya en sus posiciones, ya en su retirada. // Dicc. Hist. (1960-): En la guerra, atacar duramente, sin darle tregua ni reposo, al adversario; reducir su capacidad combativa por la superioridad de la fuerza o por cualquier otra ventaja; perseguirle estrechamente, ponerle en aprieto.

acossado, V. acosado.

acossar, V. acosar.

acuartelar, aquartelar [de cuartel (DECH). Ufano, Tratado de la Artillería, 1613]. v. tr. Mil. Distribuir e instalar en cuarteles a las tropas, así como al material de guerra.

Ufano, Tratado de la Artillería, 1613, pág. 103: Deve, asimismo, el general encomendar encaresçidamente a sus tinientes que, en los alojamientos, la gente del traén y maestrança, así artilleros como offiçiales, contenten con lo bueno y moderado que les fuere ordenado y no hagan desorden; castiguen y den gran pena a los que atrabesaren los jardines, labores y 
sembrados, y que quando el trahén se aquartele, si se puede, escusar el hazer la plaça de armas de las pieças y carros en tierras labradas, siendo possible el escusarlo, porque, teniendo esta consideraçión, estimarán en mucho al general y será amado de todos y tenido por muy christianíssimo servidor de su prínçipe y, al fin, quedará en gran reputaçión y graçia del pueblo.

FAM.: cuartel.

ENCICL.: Rubió y Bellvé (1895-1901): Poner la tropa en "cuarteles" [...]. Antiguamente tenía un sentido más general, aplicándose al alojamiento o instalación de la tropa aunque no fuese en los edificios especiales llamados cuarteles. De aquí que los soldados se acuartelaban en las operaciones de campaña.

2 [Ufano, Tratado de la Artillería, 1613]. v. prnl. Mil. Dicho de una tropa o del ejército: instalarse cada uno de sus componentes en los cuarteles de alojamiento que les corresponde.

Ufano, Tratado de la Artillería, 1613, pág. 73: Siempre que el exérçito sale en campaña, hora sea por occasión de alguna preçisa ynterpresa, o bien por bien aquartelarse, lleva a su cargo el general del artillería la una partida y, en ausençia del generalíssimo, lo he visto siempre governar el exérçito. // Ufano, Tratado de la Artillería, 1613, pág. 179-180: Antes que el exérçito contrario se le arrime, a de tener prudentemente reconosçido de dónde le puede venir más daño, para que no le desmonten sus pieças, mas conservarlas para la mayor occasión, previniéndose con tiempo d'espaldas fuertes sus cubrimientos y blindas, conforme el artillería que tuviere de provecho que cubrir, y no quitarla de las murallas hasta que los enemigos se ayan aquartelado y comiençen abrirle trincheas y hazerle baterías, sino en el ýnter, hazerles todo el daño con ellas que pudiere y le fuere possible. // Ufano, Tratado de la Artillería, 1613, pág. 239: Yo, según mi opinión, los medios cañones los emplearía al tiempo que los sitiadores se aquartelasen, para con ellos deshazerles sus tropas y para barrer toda la campaña y batirles sus gabionadas y reparos que truxesen.

adbersario, V. adversario.

adversario, adbersario, adversario [tomado del lat. adversārǐus, $-\bar{\imath}$ 'enemigo, rival', de adversus. 1240 (Segura Munguía 2007). García de Palacio, Diálogos militares, 1583]. sust. Mil. Con respecto a una persona, otra que lucha contra ella (DUE).

García de Palacio, Diálogos militares, 1583, fol. 68v: Y el Señor de las batallas mandó a los de su pueblo que, quando por tierras de amigos o enemigos pasassen con sus exércitos y gente de guerra, se velasen con mucho cuydado y diligencia, porque, como en la Divina Escriptura se dize, el capitán o exército que se vela o está apercibido en todo tiempo es temido de sus adversarios. // Collado, Plática Artillería, 1592, fol. 1v: Unos, de diversos simples componían inextinguibles fuegos con que poder reprimir el ímpetu de sus adversarios y hazer otros nocivos effectos. // Ufano, Tratado de la Artillería, 1613, pág. XV: 
Porque verdaderamente el que pelea y combate contra sus adversarios, mal puede escrivir lo verdadero y çierto, como aquél que con razón anda muy occupado y embeveçido en la deffensión de su persona y en el uso y exerçiçio de las armas.

SIN.: contendedor, contrario 2 , enemigo ${ }_{2}$.

ANT.: amigo $_{3}$.

ENCICL.: Aut.: El contrario o enemigo.

2 [García de Palacio, Diálogos militares, 1583]. sust. Mil. Respecto a un grupo de personas, otro que lucha contra él.

García de Palacio, Diálogos militares, 1583, fol. 166r: Suelen, pues, yr los tales sobresalientes repartidos en una, o dos o tres partes de la batalla. Si van en una, es en el cuerno yzquierdo de la batalla, para acometer al adversario por el derecho, o en la rectaguardia, para dar en la parte más descubierta o para socorrer a la parte más necessitada. // Ufano, Tratado de la Artillería, 1613, pág. 75: Señor mío, soy de paresçer en tal particular que las 30 pieças sean bastantes para salir a campaña contra otro qualquier exérçito por pujante que sea, o bien para ganar alguna villa y expugnable fortaleza, por bien fornida y guardada que sea del adversario. // Ufano, Tratado de la Artillería, 1613, pág. 363: Porque, ciertamente, no ay cosa de que más se tema la caballería que es de tronidos, humo y fuego; y así, creo sería fácil de romper por tal medio y ocasión, tanto por el estrépito de las bombas que de los mosqueteros y arcabuzeros supuestos al amparo de las cubiertas y enmantadas picas abrigadas de las tropas que fuesen prestas a la execución de tal combate, aunque en número fuese la mitad de gente de guerra menos que la del adversario.

SIN.: contrario $_{3}$, enemigo 3.

ENCICL.: DSAL: s. m. (no contable) Conjunto o grupo de personas contrarias o enemigas.

ahumada, ahumada [de ahumar y éste de humo, del lat. fümus (DECH). Mosquera, Comentario disciplina militar, 1596]. sust. Mil. Humareda que se hace en las atalayas o lugares altos como señal o aviso.

Mosquera, Comentario disciplina militar, 1596, fol. 62v-63r: Y, descubiertos los nuestros por los enemigos, luego hizieron diversas señales con ahumadas y llamaradas de pólvora, pidiendo socorro por aquella parte de un cerro, o montaña alta, donde tenían una campana que tañían a gran priessa, y a trechos avía otras que se correspondían para el mismo efeto.

ENCICL.: Aut.: La señal que se hace regularmente en los lugares altos o atalayas quemando paja u otra materia, para dar por este medio algún aviso, como de que hay embarcaciones de corsarios en la costa, o navíos que se encaminan a tomar puerto, o tropas $u$ otra cosa que se acerca al paraje que debe ser advertido de ello. // Terr.: La señal con que se da algún aviso que mande algo, en este o en el otro monte, paraje, etc. V. angaros. // Terr. 
(s.v. angaros): [...] En castellano lo toman algunos por el humo con que se avisa. // Almirante (1869): La ahumada fue el telégrafo militar primitivo, y muy usado en las continuas algaras de nuestra Reconquista.

ala, ala [del lat. ala. Berceo (DECH). Montes, Instrucción y regimiento, 1537]. sust. Mil. En cualquier orden de batalla, cada uno de sus dos lados o partes extremas. 주 (fig. 2)

Montes, Instrucción y regimiento, 1537, fol. XIVr: Y los arcabuzeros vayan adelante y en torno del escuadrón por las dos alas, y si los enemigos fueren muchos, pongan arcabuzería en la reçaga, porque el esquadrón vaya fortificado por todas partes. // Montes, Instrucción y regimiento, 1537, fol. XIVv: Mas en la Chirinola no se puso el Gran Capitán en el ala derecha de la batalla, quando rompió a los franceses, sino en medio de los suyos; mas hízolo aquello el Gran Capitán porque tenía poca gente y por dar ánimo a los suyos, y porque ellos le viessen mejor. // Mendoça, Theórica y práctica, 1596, pág. 171-172: Estando en medio la capitana, guarneciendo los cuernos, o alas que llaman, con algunas galeras de las más reforçadas, en esta disposición caminan aviendo ganado el viento con los remos en las manos, cerrados unos navíos con otros, quanto les permite el navegar, apresurando el hazello según el motivo que descubre el enemigo.

SIN.: costado 1 , cuerno.

ENCICL.: DEA: En un ejército o una escuadra: Extremo de los dos de una formación en orden de combate. Tb la fuerza que lo ocupa. / / Sanz (1749: s.v. alas): En término de guerra, son los dos extremos de un ejército puesto en batalla. Regularmente se suele poner la caballería en las alas, flancos o extremidades de líneas. Este término, ala, viene de los romanos, que llamaron así a las extremidades de su ejército. // Rubió y Bellvé (1895-1901): En táctica significa las partes extremas de una formación o agrupación de fuerzas preparadas para el combate. Efectivamente, en todo orden de combate las tropas extendidas pueden considerarse subdivididas en tres partes: una central o centro y dos laterales, que se denominan alas derecha e izquierda, mirando al enemigo. Debe distinguirse el ala del flanco, pues la primera es la extremidad de una línea, considerada en el sentido de su frente, mientras que el segundo es una faja de terreno, considerada en el sentido de la profundidad, o sea perpendicularmente a la dirección del ala que en él se apoya [...]. Modernamente, las alas del orden de batalla no han perdido su importancia; antes al contrario, desempeñan una función táctica interesantísima. En el ataque, el ala que rebasa la del adversario puede servir para envolverla, resultando así combinado un ataque de frente con uno de flanco.

en [Collado, Plática Artillería, 1592]. loc. adv. Dicho de una serie de personas: en fila o colocadas unas al lado de otras.

Collado, Plática Artillería, 1592, fol. 90v-91r: Mientras que el eloqüente embaxador con dulces palabras al massieur Dobeñi, que assí se llamava el general de Francia, entretenía, el Gran Capitán con presteza increýble, dexando sola una frente de cavallería a la orilla contraria del río, la qual estendida en ala representava un campo entero, hizo partir por 
un barranco abaxo todo su campo y guiarlo por la ribera del río adonde estava el vado, por el qual pasó todo su campo y passaron todos con el artillería.

ENCICL.: Aut. (1770): Mod. adv. Lo mismo que en fila. Dícese más frecuentemente de las personas que de las cosas. // Hevia (1857: s.v. formar en ala): Pasar una tropa a la formación de una sola fila, bien sea a pie firme o marchando.

ala, V. en $\sim$.

alambor, alambor, lambor [de origen desconocido, probablemente arábigo. 1583 (DECH). Collado, Plática Artillería, 1592]. sust. Fort. Plano inclinado de los muros de las fortificaciones (DSAL: s.v. escarpa).

Collado, Plática Artillería, 1592, fol. 92r: La escarpa, que es la que en España llamamos lambor, que han de tener estas fábricas de faxina y tierra, es ésta: que por cada seys pies, o palmos, o varas de alteza se le da una de scarpa; pero si al bestión dicho, con el tiempo, se le quisiesse hazer la camisa de muralla de ladrillo o de piedra, entonces se le dan de escarpa, de quatro, uno de caýda; y con esta regla siempre se ha hecho en todas las fábricas de fortificaciones donde yo me he hallado hasta agora.

SIN.: escarpa ${ }_{1}$, escarpe 1 .

FAM.: alamborado.

2 [Rojas, Teórica fortificación, 1598]. sust. Fort. Plano inclinado que forma la muralla del cuerpo principal de una plaza, desde el cordón hasta el foso.

Rojas, Teórica fortificación, 1598, fol. 93r: Y desde allí se levantarán las murallas, guardando la buena regla de fabricar, echando siempre la piedra más crecida en los cimientos y la más menuda de la mitad de la muralla arriba, y sobre todo la buena mezcla de cal y arena, de forma que quede todo muy conglutinado y sólido, guardando el alambor o escarpa de cinco pies uno, como dicho es. // Roxas, Sumario milicia, 1607, fol. 78r: La escarpa o alambor de la fábrica será de cinco uno, que es el perfecto medio de proporçión para contra el artillería; y para la firmeza de la fábrica lo demás es biolento, según la causa de lo que suçediere ser neçesario en el tal sitio; $1 / 5$, de cinco uno.

SIN.: escarpa ${ }_{2}$, escarpado 2 , escarpe 2 .

ENCICL.: Fernández Mancheño (1822): Fort. Lo mismo que escarpa.

alamborado, alamborado, lamborado [de alambor (DECH). Rojas, Teórica fortificación, 1598]. adj. Fort. Dicho de una construcción, especialmente de la defensiva: que forma un plano inclinado o tiene mucha pendiente. (fig. 3) 
Rojas, Teórica fortificación, 1598, fol. 69r: Y acabará la muralla en el cordón con 5 pies de gruesso, advirtiendo que por la parte de adentro ha de yr la muralla a plomo, y por defuera, a escarpa o lamborada. // Rojas, Teórica fortificación, 1598, fol. 73r: Y quando el enemigo batiesse los parapetos, se pondrán los soldados detrás de la espalda, la qual tendrá de alto poco más de 5 pies, porque, en aviendo derribado el enemigo el parapeto de piedra y peynado toda la delantera de la dicha espalda, quedará en forma lamborada, porque el enemigo lo avrá puesto assí con su batería. // Juanelo Turriano, Veinte y un libros, a. 1605, fol. 135: Y estas gradas an de yr alamboradas, a modo de barbacana, como se acostumbran a hazer en las murallas de los castillos.

SIN.: escarpado 1 .

FAM.: alambor.

alarde, alarde [del ár. card, 'revista de tropas', perteneciente a la raíz cárad. 'mostrar'. s. XIII (DECH). Celso, Reportorio universal leyes Castilla, 1553]. sust. m. u. t. c. f. Mil. Revista o inspección de una tropa o fuerza para comprobar su estado.

Celso, Reportorio universal leyes Castilla, 1553, fol. XIVv: Alarde deven hazer de la armada o compañía de gente de guerra, veyendo los que la hazen a los hombres de guerra e soldados por sus ojos, e contando y nombrándolos a cada uno por su nombre, passándolos todos por debaxo una lança que tengan dos hombres en sus manos atravessada, para que el Rey o sus capitanes sepan ciertamente quántos son los de su exército, e cómo van adereçados de armas e cavallos, y para que sepan los que aý no fueren o se fuessen del dicho exército, e para proveer en los lugares de los muertos o enfermos de otros. / / Álaba, Perfeto capitán, 1590, fol. 27v-28r: Y antes que un soldado se reciba, será bien que dé fianças y por su persona se obligue a que no hará ausencia del lugar que se le señalare para su ordinaria habitación y morada, ni tratará de alguna suerte de salir de su obligación sin consentimiento de las personas a quien se huviere de dar este cargo y espressa licencia de su superior [...], y que yrá a todos los alardes que se hizieren el día que para ellos fuere señalado. // Álaba, Perfeto capitán, 1590, fol. 151v: El oficio de veedor general es atender a cómo se gasta la hazienda de Su Magestad y mandar hazer reseñas y alardes a la gente, y el despedir los soldados que no fueren suficientes para guerra.

SIN.: muestra, reseña.

ENCICL.: Cov.: Vale la muestra o reseña que se hace de la gente de guerra, y el nombre es arábigo. // Aut.: La muestra o reseña que se hace de los soldados, la cual ejecuta el comisario destinado para este efecto a fin de reconocer si está completo el número que cada compañía debe tener, y si tienen las armas limpias y bien acondicionadas y todo lo demás de su uso en buena disposición.

2 [Martínez de Burgos, Reportorio premáticas y Cortes, 1551]. sust. m. u. t. c. f. Mil. Formación militar en que se hace exhibición de los soldados y de sus armas. 
Martínez de Burgos, Reportorio premáticas y Cortes, 1551, fol. XLVIr: Alarde que los cavalleros armados son obligados a hazer, que lo hagan conforme a las leyes del reyno, y los corregidores tengan d'ello especial cuydado. // Celso, Reportorio universal leyes Castilla, 1553, fol. LXIIr: Dízese el cavallero vivir por armas, aquél que continuamente tuviesse armas y cavallo y haze alarde con ello, y se sabe de cierto que lo mantiene en su casa, y es público y notorio que este tal no vive por officio de sastre, ni de pellegero, ni carpentero, ni de pedrero, ni terrero, ni tondidor, ni çapatero, ni barvero, ni especiero, ni regatón, ni de otros officios baxos y viles. // Álaba, Perfeto capitán, 1590, fol. 31v: En Francia se hazen los alardes del Ririeban para que en ellos se vean los adereços de guerra que para el tiempo del menester tiene la gente noble de todo el reyno, y siempre que de parte de su príncipe se les manda acuden a servir con sus personas o con otras que con mucha descomodidad para este tiempo buscan y grangean.

ENCICL.: Estévanez (1897): Voz de origen árabe que expresa formación aparatosa, ostentación de fuerzas.

alba, alba, alva [tomado del lat. alba, femenino de albus 'blanco'. Alba 'aurora', h. 1140 (Segura Munguía 2007). González de Medina, Examen fortificación, 1599]. sust. Mil. Última de las cuatro partes en que los centinelas dividen las noches.

González de Medina, Examen fortificación, 1599, pág. 182: Bolviendo a la que de ordinario ha menester para servirse, tendría por acertado que no se tuviesse con menos soldados que de quatrocientos y cincuenta a quinientos, por razón de que cada cortina requiere dos centinelas, que son diez; los baluartes, tres cada uno, que son quinze [...]; que, aviendo de remudarse los de prima a la modorra, y los de la modorra, los del alva, vienen a ser menester entrar cada noche de guardia para este servicio ciento y quarenta y siete soldados [...].

ENCICL.: Nebr. (1495: s.v. alva vela de la mañana): Vigilia quarta.

albañí, V. albañil.

albañil, albañí, albañil, albañir [del ár. bannâ 'constructor', 'albañil', de la raíz bánā 'edificar'. Albañí, 1268; albañil, h. 1400, Glos. de Toledo (DECH). Pérez Vargas, De re metallica, 1568]. sust. Constr. Obrero que trabaja en hacer paredes y otros elementos de construcción en que se unen piedras, ladrillos, etc. con un material aglomerante (DUE).

Collado, Plática Artillería, 1592, fol. 63v: Del modo de apuntalar el cielo y lados de la mina no ha para qué hazer particular plática, porque no hay albañir que no se entienda, mayormente que muchas vezes se hallan terreros de tierra y de greda tan maciça y dura y otras venas de piedra tan tierna y blanda qu' el maestro, sin tener necessidad de apuntalar, prosigue su hobra. // Rojas, Teórica fortificación, 1598, fol. 92r: Convendrá mucho que se remedie esto con diligencia, en que vaya todo por camino verdadero, poniendo los sobreestantes que fueren necessarios y no más, $\mathrm{y}$, si fuere possible, se escogerán los tales 
sobreestantes que sean oficiales canteros o albañires, porque no puedan ser engañados en la fábrica, y que sean hombres de conciencia y confiança. // Rojas, Compendio fortificación, 1613, fol. 38v-39r: Sólo digo que, para que el ingeniero no se engañe ni sea engañado, que conviene mucho la experiencia, por no estar sujeto al poco saber de los albañíes, que, en oliendo que el ingeniero no es prático, a bueltas de espaldas burlan y mofan d'él, y todo viene en daño de la fábrica y hazienda.

SIN.: murador.

ENCICL.: Terr.: Artífice que se ocupa y entiende en labrar casas o edificios [...]. Algunos dicen que el Albañil sólo trabaja con materiales menudos y que el Cantero lo ejecuta con piedra que labra y ajusta; pero comúnmente se entiende que el Cantero labra o corta la piedra y el Albañil la ajusta y aploma. El Albañil usa de nivel, regla, plomada, llana, paleta, pico, cartabón, cuchara, escuadra, aguja, palanca, guía de suelos, etc. Los materiales son arena, cal, ladrillo, piedra, ripio, casquijo, mortero; dice abrir zanjas, sacar cimientos, almohadillar, zanjar, cimentar, poner la primera piedra; rafe o rafa de ladrillo, lienzo de pared, pared maestra, tapia, danza de arcos, cindrias o cimbrias; vaciar una pared; estribos de los arcos, arbotantes, remates; asentar las piedras; hacer asiento la obra, fraguar, revocar, rehenchir, repelar, rebatir; labrar de mampostería, de sillería, de piedra, lodo; tapiar, tapiales; blanquear, enjalvegar, mezclar, apilar, cantear de falso; abrir ventanas. Hay Maestro, a quien llaman Maestro de Obras, y peones, ya a destajo y ya a jornal. Usan también traza, modelo, figura, andamio, andamiar, andamiado. Asimismo son precisas en esta arte las máquinas de cabrias, grúas, tímpanos y toda especie de ingenios, cuerdas, cables, guindaletas, cabrillas para cargar la piedra, etc. El paraje se llama sitio, planta, obra o labor. Antiguamente se decía Albañi, V. Oud. // Dicc. Hist. (1960-): El que tiene por oficio la albañilería. A veces se especifica el grado dentro del oficio: maestro, oficial, peón de albañil.

albañir, V. albañil.

alborada, alborada [de albor y éste del lat. albor. Berceo (DECH). Mendoça, Theórica y práctica, 1596]. sust. Mil. Toque o música que, en ocasiones, se ejecuta al amanecer para celebrar la llegada del nuevo día.

Mendoça, Theórica y práctica, 1596, pág. 164: A la mañana, al romper del día, los trompetas suenan al alborada y todos los navíos vienen sotaviento a saludar la capitana, con lo qual sabe si falta alguno de la armada. // Anónimo, Diálogo fábrica de navíos, ca. 1631, fol. 26r: Los atambores y pífanos ternán cuydado cada uno con su ystrumento, para que esté a punto quando sea necessario, y todas las mañanas se levantarán al romper del día a dar el alborada con ellas, estando en el puerto, porque en la mar no se usan.

ENCICL.: Aut.: La acción que se ejecuta al amanecer para dar a entender que viene el día, celebrando la primera luz; como tocar cajas o tambores $\mathrm{u}$ otros instrumentos de guerra $\mathrm{o}$ música. 
alcaide, alcaide, alcayde [del cat. alcaide, que en esta lengua habría pasado de alcait a *alcai y alacai, y de ahí se habría transmitido al castellano y a los demás idiomas. Alcaide 'jefe de la fortaleza' (DECH). Anónimo, Ordenanças paños, 1527]. sust. Fort. Persona responsable de la conservación y defensa de un castillo y también, por extensión, de otro tipo de fortalezas.

Montes, Instrucción y regimiento, 1537, fol. VIr: Es de culpar el alcayde que tiene bien proveýda su fortaleza y se puede defender de sus enemigos y se rende, y a este tal nunca le falta un color con que cierre las bocas a todos. / / Celso, Reportorio universal leyes Castilla, 1553, fol. LIXv: Si el castillo fuesse cercado de sus enemigos, deve el alcayde, con buen esfuerço, animar la gente del castillo, demostrándoles que, pues no deven dar el castillo a ninguno, salvo a su señor, que le deven defender $\mathrm{y}$, si fuere menester, morir con lealtad. // González de Medina, Examen fortificación, 1599, pág. 191: El alcayde que en esta fuerça se huviere de poner, conviene que sea muy considerado y eche de ver y piense en lo que toma a su cargo, que no va en ello menos que vidas de hombres y conservación de estados.

SIN.: castellano.

ENCICL.: Cov.: Es el castellano de un castillo o fuerza con gente de guarnición. // Hevia (1857): Gobernador de alguna fortaleza o plaza fuerte, que la guardaba bajo su responsabilidad.

\section{alcayde, V. alcaide.}

algazara, algazara [del ár. vg. ġazâra 'locuacidad', 'murmullo, ruido', derivado del verbo ǵázzar 'abundar', 'hablar mucho'. Princ. s. XV, Canc. de Baena (DECH). Rojas, Compendio fortificación, 1613]. sust. Mil. Gritería o voces que dan los moros al atacar al enemigo.

Rojas, Compendio fortificación, 1613, fol. 26v-27r: Conviene mirar bien y, sobre todo, acordarse que el turco bate con muy gruessa artillería, y el flamenco y el inglés se vale de la zapa, y el moro alarbe de ninguna cosa, si no es de algazara y dar vozes; pero bien es ponerse en defensa contra todos.

ENCICL.: Cov.: Es propiamente la vocería que dan los moros cuando salen de la emboscada y cogen de sobresalto a los cristianos, o a otros sus contrarios.

aliado, aliado [de aliar. Santillana (DECH). Álaba, Perfeto capitán, 1590]. adj. Mil. Dicho de un soberano, de un territorio, de un ejército o de un miembro de éste: unido a otro $u$ otros, en virtud de un tratado o convenio, para gozar de esta manera de una mayor fuerza a la hora de defenderse o de atacar.

Álaba, Perfeto capitán, 1590, fol. 81r: Y él mesmo, aviendo embiado a algunos de los soldados aliados y mercenarios a que resistiessen cierto daño que el enemigo pretendía hazer, como en la refriega muriessen todos excepto uno y d'esta nueva conociesse averse 
atemorizado todo su campo, para sossegar sus ánimos mandó pregonar por todo el real que aquellos soldados avían sido muertos por su consejo y traça, porque supo que ellos tenían determinado de seguir el partido de los enemigos; y assí atajó el peligro que podía aver de huyr su gente y con esta traça les restituyó su perdido brío y valor.

SIN.: amigo $_{2}$, confederado 1.

FAM.: aliarse.

ENCICL.: DRAE: adj. Dicho de un Estado, de un país, de un ejército, etc.: Que está ligado con otro para fines comunes. / / Hevia (1857): Se dice de los soberanos o pueblos que han celebrado tratados en virtud de los cuales se ofrecen ayuda mutua en casos de guerra con potencias no aliadas. Las alianzas son ofensivas o defensivas, según se estipulan.

2 [Álaba, Perfeto capitán, 1590]. sust. Mil. Cada miembro de un convenio o alianza militar respecto a los otros.

Álaba, Perfeto capitán, 1590, fol. 33r: En alguno de tres casos que a mi parecer piden el valerse un príncipe de gente estraña: o quando de hazerlo se disminuyen las fuerças del enemigo, o se contentan los aliados, o se granjea la voluntad de los que habitan la tierra donde se a de hazer la guerra. // Álaba, Perfeto capitán, 1590, fol. 80v-81r: Tulio Hostilio, conociendo que su gente estava acovardada y muy sujeta a huyr a causa de averse retirado sin pelear todos los aliados y advenedizos, previno a este miedo y covardía mandando publicar por todo su campo que la retirada de aquellos soldados se avía hecho por orden y espresso mandato suyo, con lo qual quietó y sossegó los ánimos encogidos de los suyos. // Álaba, Perfeto capitán, 1590, fol. 133r: Hizo poner delante de su esquadrón ochenta elefantes y en la vanguardia todos los aliados y advenedizos, y, después d'ellos, los cartagineses, que era de quien él tenía entera seguridad, para que, estando éstos a las espaldas de los aliados y los enemigos delante, les fuesse forçoso combatir y oponerse a la furia y golpes de sus enemigos.

SIN.: amigo $_{4}$, confederado 2 .

ENCICL.: Terr.: Se llama en la milicia el príncipe o cuerpo de ejército que defiende las partes de aquel de quien es aliado, v. g. del que hace la guerra. // Castro y Rossi (1852): s. m. y f. El soberano, el pueblo o la nación ligado con otro $u$ otra para la defensa $u$ ofensa de sus contrarios.

aliarse, aliarse [del fr. ant. aliier (fr. allier) 'juntar', 'aliar', y éste del lat. allĭgare 'atar a (algo)', derivado de ligare 'atar'. h. 1375, Crón. de Pedro el Cruel (DECH). Álaba, Perfeto capitán, 1590]. v. prnl. Mil. Dicho de dos o más soberanos, territorios, etc.: unirse o aunarse, en virtud de tratado, para tener más fuerza a la hora de defenderse o de atacar.

Álaba, Perfeto capitán, 1590, fol. 145v: Y queriendo assegurarse el capitán de la fidelidad de alguna provincia o ciudad y saber qué es lo que podrá fiar en ella, usará de alguna cautela, 
semejante a la de Mario, el qual, assistiendo a la guerra de los cimbros y desseando saber lo que podría fiar de la gente de Lombardía, por ser aliada esta provincia de los romanos, les embió unas cartas duplicadas, con orden que las unas abriessen luego y las otras no, hasta cierto día señalado; y como, llegado el plaço, acudiesse a saber si su instrución y mandato se avía cumplido y hallasse que luego que las recibieron leyeron ambas cartas, conoció que sus ánimos no estavan dispuestos a obedecerle y seguir su partido. / Álaba, Perfeto capitán, 1590, fol. 260v: Cautela de Mario para examinar los ánimos de los lombardos en la fidelidad, porque eran aliados con los romanos.

SIN.: coligarse, confederarse, ligarse.

FAM.: aliado.

ENCICL.: Castro y Rossi (1852): Unirse dos o más reyes o pueblos por medio de tratados para defensa u ofensa de sus enemigos. // Corsini (1849: s.v. alianza): Convenio o tratado ajustado entre dos o varias potencias, con el objeto de protegerse y auxiliarse recíprocamente contra la agresión de otra u otras contrarias. Se llama defensiva cuando se hace sólo para defender las fronteras respectivas; y ofensiva cuando es para atacar concertadamente al enemigo en su propio país.

alistado, alistado [de alistar (DECH). Cano, Arte para fabricar naos, 1611]. adj. Mil. Inscrito o incluido en el ejército.

Cano, Arte para fabricar naos, 1611, fol. 39r: Porque, aviéndolos querido contar, mando hazer un cerco en que cabían diez mill soldados y los del exército lo llenaron ciento y setenta vezes; que por ventura serían éstos con los marineros y más gente del mar; y los que Trogo dize solos los que yvan alistados y debaxo de vanderas assentados.

SIN.: asentado .

FAM.: alistar.

alistar, alistar [de lista. Alguna vez listar. h. 1660, Mariana (DECH). Roxas, Sumario milicia, 1607]. v. tr. Mil. Inscribir o incluir a alguien en el ejército.

Roxas, Sumario milicia, 1607, fol. 9r: Y la hedad que havían de tener para que los resçibiessen y alistasen hera quando comenzaban a barbar, porque quedan más impresas las cossas que se aprenden quando mozos, antes qu' el cuerpo empereze con la hedad. // Anónimo, Diálogo fábrica de navios, ca. 1631, fol. 20v: Es ansí que en la Armada tripulan los galeones como Vuestra Merced dize, pero es un yerro muy grande, y los navíos quedan faltos de marineros, mediante el no ser de servicio todos los que se alistan debajo d'este nombre.

SIN.: asentar 2 .

FAM.: alistado. 
ENCICL.: DUE: Inscribir soldados para el servicio militar. // Aut.: Sentar o escribir en lista algún hombre o muchos para servir al rey en la guerra; y porque las planas o libros donde escriben los nombres, patrias y señas del que entra a servir se llaman listas, se dijo de aquí alistar soldados, alistar gente. // D'Wartelet (1863): Sentar o escribir en una lista a los que han de servir al rey en clase de soldados, sea voluntariamente, por suerte o por condena.

allanar, allanar, allañar [de llano y éste del lat. planus 'llano', 'plano'. 1240, F. Juzgo (DECH). García de Palacio, Diálogos militares, 1583]. v. tr. Poner o hacer transitable un camino u otro lugar de paso.

García de Palacio, Diálogos militares, 1583, fol. 66v-67r: Movido, pues, el exército, y prevenida la orden del marchar, y corredores de a cavallo que descubran y allanen los caminos, con orden y silencio en los soldados, ha de advertir que, si se huviere de dar algún repente sobre qualquier enemigo, ningún soldado entienda dónde ni contra quién va, que, encubriendo el capitán sus disignios y haziendo esto assí, no podrá el enemigo ser avisado, a cuya causa el exército va y marcha más seguramente. // Álaba, Perfeto capitán, 1590, fol. 75r: Y porque el gran peso d'estas pieças no da comodidad de poderse llevar sin carruage y para él no ay siempre caminos llanos, ay necessidad de gastadores para que allanen los passos ásperos. // Lechuga, Discurso de la Artillería, 1611, pág. 203: Advierto que por la parte que a de marchar exército se embía delante d'él alguna gente de guerra y los gastadores que van abriendo y allanando el camino, de manera que la artillería pueda passar.

SIN.: explanar ${ }_{1}$

2 [Álaba, Perfeto capitán, 1590]. v. tr. Rellenar de tierra alguna cosa, por ejemplo una trinchera, o derribar algo, como una montaña o una construcción, para dejar el terreno a nivel del suelo.

Álaba, Perfeto capitán, 1590, fol. 92v: Y si alguna parte notable de la habitación del lugar está más alta, igual o más baxa que el muro por algún lado, echará por tierra los edificios y plaças que pudieren ser de algún daño, allanando y igualando en quanto fuere possible las partes altas, de donde puede la batería de los enemigos ofender la ciudad. / / Collado, Plática Artillería, 1592, fol. 67r: Quiriendo, pues, el artífice allanar algún padrastro de los dichos por evitar el mal y daño propuestos o por abrir nuevo passo a las aguas de algún río, de las quales se espera haver algún muy particular provecho, o por divertirlo y alexarlo de sí, siéndole offensivo y dañoso, en diversas maneras los hombres antiguos solían allanar los semejantes lugares eminentes y altos. // Mendoça, Theórica y práctica, 1596, pág. 69: Luego que está recogida la mayor parte del exército en la plaça de armas, el maestre de campo suele ordenar se allanen las trincheas y fortificación del alojamiento, para que pueda salir d'él la gente en esquadrón con mayor comodidad y presteza.

SIN.: explanar ${ }_{2}$.

ENCICL.: Zerolo (1895): Poner a nivel del suelo, ya sea derribando o ya rellenando. 
3 [Micón, Diario grande cometa, 1578]. v. tr. Mil. Poner una persona bajo su poder a individuos o territorios.

Micón, Diario grande cometa, 1578, pág. 107-108: Y Scicilia fue por los moros saqueada en tiempo de Georgio Trapezuntio, año de 1403, a quien luego siguió la horrenda venida de Levante a la Asia Menor de Thamyris, Grande Tamorlán allanando con un millón de soldados toda la Turquía o Natolia, hasta tomar a su Emperador Bayazeto y llevarle en una jaula por sus tierras. // Álaba, Perfeto capitán, 1590, fol. 145r: Y porque, después de aver allanado alguna ciudad o ciudades principales de un reyno, de ordinario quedan alguna provincia o villas d'él con el desseo de libertad que tienen siempre los que a fuerça de armas la rindieron a nuevo dueño y señor, es necessario que el caudillo en tal caso se aya prudentemente, previniendo el daño que de su rebelión y infidelidad espera, haziendo los empleos que he dicho de los hombres principales y señalados y usando de otros ardides. // Mosquera, Comentario disciplina militar, 1596, fol. 12v: Mandó Su Magestad que se aprestasse otra Armada para el año siguiente y que a entrada de primavera el Marqués saliesse con ella a allanar la isla Tercera, con las demás circunvezinas que estavan alteradas, que eran: el Fayal, el Pico, la Graciosa, la isla de San Jorge, y de Flores y la del Cuervo.

SIN.: domar, domeñar, domesticar, señorear, sojuzgar, someter, sujetar,

ENCICL.: DUE: (ant.) Pacificar, aquietar, sujetar.

\section{allañar, V. allanar.}

almena, almena [del antiguo mena o amena y éste del lat. mĭna 'íd.' (del mismo origen que eminère, imminère, prominère 'ser saliente'. Alex., amena; h. 1270 (Hist. Troyana), almena (DECH). Fernández de Enciso, Suma de Geographía, 1530]. sust. u. $\mathrm{m}$. en pl. Fort. ant. Cada uno de los bloques de piedra que hay en la parte superior del muro de una fortaleza, utilizados como escudo por los defensores (DSAL). 色 (fig. 4)

Fernández de Enciso, Suma de Geographía, 1530, fol. XXXIr: Quando Aníbal cercó a la ciudad de Calahorra, estuvo tanto tiempo sobre ella que los de la ciudad acabaron las provisiones e manteníanse de la carne de los hombres que matavan del real, e a los que a ellos matavan poníanlos en la cerca armados e arrimados a las almenas y, por el temor d'estos que veýan en la cerca, no osavan los del real allegarse a la ciudad. // Loçano, Alberto, Architectura, 1582, pág. 139: Encima se pondrán las almenas salidas. Finalmente, se applicará a la obra todo aquello con que pueda menos ser derribada, cortada y subida, y con que esté el soldado más cubierto en la defensa y seguro. // Roxas, Sumario milicia, 1607, fol. 44v-45r: Demás d'esto se acudirá con tiempo aquella multitud de flecheros no ocupe la muralla, abiendo huyentado de las torres los defensores de ellas arrimándoles las escalas, contra lo cual conviene aya en las ciudades una gran copia de coraças y escudos, y 
muchos cestos de mimbres llenos de piedras entre almena y almena, para quando suban por la escala dexarles caer ençima las piedras.

SIN.: pina.

ENCICL.: Lopes Pires Nunes (2005: s.v. ameia): Elementos maciços, de configuração variada, implantados sobre o parapeito, que coroam as torres e as muralhas da fortificação medieval e destinados a proteger os defensores colocados nos adarves. // Estévanez (1897): Se daba este nombre a cada uno de los prismas, equidistantes, que se elevaban sobre el adarve o en lo alto de las torres y torreones de los antiguos muros; servían las almenas para cubrir a los defensores, como los merlones cubren a los artilleros en la fortificación actual. // Vera Botí (2004): [...] En el Renacimiento pervivieron como signos del pasado en muchas construcciones suburbanas, aunque carentes de utilidad. El uso de la artillería las convirtió en peligrosas defensas ya que el impacto de las bolas las trituraba y convertía en metralla. Francesco di Giorgio en sus últimos escritos ya había puesto en duda su validez defensiva frente a las bocas artilleras. El año 1503 una comisión de ingenieros militares convocada en Roma por el papa Giulio II propuso la supresión de las almenas en las murallas, cuya ineficacia había quedado probada en la invasión del rey francés Charles VIII en 1494.

\section{alogamiento, V. alojamiento.}

alojado, alojado [de alojar. Roxas, Sumario milicia, 1607]. adj. Mil. Dicho de un grupo de soldados y de su material de guerra: organizados o repartidos por el lugar donde esa fuerza militar va a establecerse temporalmente.

Roxas, Sumario milicia, 1607, fol. 68r: Y no se alojará la cavallería ni se apeará ningún soldado hasta que todo el exérçito esté alojado, y después se les dará la parte más çercana del agua, de forma que los cubra la ynfantería. // Ufano, Tratado de la Artillería, 1613, pág. 120-121: Deve el tal general reconosçer el contorno de la campaña acompañado con uno de sus tinientes y el yngeniero, reconosçiendo por el presente adónde se podrán alojar más seguramente algunas pieças de artillería la noche venidera, para con ellas, el siguiente día, saludar al enemigo y darle los buenos días que, çierto, para los sitiados es grande affligimiento y fatiga ver que aún no está bien alojado el campo quando ya los comiençan a despertar a términos de cruda guerra.

FAM.: alojamiento, alojar, desalojar.

2 [Álaba, Perfeto capitán, 1590]. adj. Mil. Dicho de un ejército: instalado en el lugar donde va a permanecer durante un tiempo.

Álaba, Perfeto capitán, 1590, fol. 53r: O como echó de ver Asdrúbal, hermano de Aníbal, aver juntado exércitos contra él Livio y Nerón con sólo ver algunos soldados con rostros quemados y espeluzados los cabellos, coligiendo d'esto que aquéllos avían venido de nuevo y que avía crecido el número de la gente que antes estava alojada. // Rojas, Teórica 
fortificación, 1598, fol. 3v: Y también se tendrá cuidado de no erigir el castillo cerca de algún valle o cañada donde pueda estar alojado algún exército enemigo, y quando por algunos respetos fuesse fuerça hazerlo allí, se pondrá mucho cuidado en plantar la fortaleza a vista y de forma que descubra y varra todo el valle, de manera que el enemigo no se pueda allí alojar.

alojamiento, alogamiento, alojamiento, aloxamiento [de alojar (DECH). Álaba, Perfeto capitán, 1590]. sust. Mil. Acción de repartir e instalar en un lugar a las tropas y su material de guerra.

Álaba, Perfeto capitán, 1590, fol. 49v: Y porque lo que hasta aquí se a dicho es lo principal que se a de considerar en el alojamiento de campaña, quando se huviere de hazer en alguna fuerça, el sargento mayor reconozca la tierra, dentro y fuera, mirando los lugares más cómodos para los cuerpos de guardia y centinelas y las plaças de armas donde estarán mejor. // Rojas, Teórica fortificación, 1598, fol. 101r-101v: Y de aquí passo a tratar un poco de la materia de esquadrones y alojamiento d'ellos, y poner sitio a una plaça que esté muy prevenida de todos los aproges dichos en la fortificación, con que daré fin a este libro. // Ufano, Tratado de la Artillería, 1613, pág. 103: Deve, asimismo, el general encomendar encaresçidamente a sus tinientes que, en los alojamientos, la gente del traén y maestrança, así artilleros como offiçiales, contenten con lo bueno y moderado que les fuere ordenado y no hagan desorden.

FAM.: alojado, alojar, desalojar.

2 [Loçano, Alberto, Architectura, 1582]. sust. Mil. Lugar, sitio o punto donde se establecen de forma temporal fuerzas militares.

Loçano, Alberto, Architectura, 1582, pág. 137: Querría también que los alojamientos estuviessen levantados tanto, que viéssedes todo el campo en torno del enemigo, para que ninguna cosa procure o comience que luego no sea de ti vista y entendida. // Álaba, Perfeto capitán, 1590, fol. 44r: Conviene, también, tenga reconocido el alojamiento a donde va $y$, en llegando, forme su esquadrón en la plaça de armas, sin consentir que alguno se desmande hasta que se dé licencia a las vanderas, que será quando el alojamiento estuviere del todo fortificado, las quales se pongan enfrente de sus quarteles. // Mendoça, Theórica y práctica, 1596, pág. 109: En caso que el enemigo caminasse con exército poderoso para hazer levantar el sitio, en la manera que Vuestra Alteza se ha de governar [...] eligiendo [...] si será mejor esperarle en los quarteles o, dexándolos, y alojamiento, caminar a combatirle con todo el exército o alguna parte d'él, quedando la resta a la guardia de las trincheas, artillería y quarteles o resolver de levantar enteramente el cerco.

ENCICL.: Cov. (s.v. aloxamiento): La estancia que señalan a la gente de guerra [...]. Es término usado entre soldados.

alojar, alojar, aloxar [del cat. allotjar y éste del fr. loger, derivado de loge 'cámara, habitación'. 2. ${ }^{\circ}$ cuarto del s. XV, Díaz de Gámez; Torres Naharro; Cej. VII, también 
lojar una vez en el s. XV (DECH). Montes, Instrucción y regimiento, 1537]. v. tr. u. t. c. intr. Mil. Repartir o distribuir a las tropas y el material de guerra por el lugar donde esa fuerza militar va a establecerse temporalmente.

García de Palacio, Diálogos militares, 1583, fol. 190v: Conviene [...] embiar personas que sepan elegir convenientes puestos para alojar el exército y parésceme que será tal quando un sitio fuere alto y ayroso, sano y seco, que, como el suelo no sea húmedo, no paresce que podrá aver sereno ni humedad alguna que offenda a la salud de los soldados. / / Collado, Plática Artillería, 1592, fol. 97r: Como vuestra merced sabe, diversas vezes me he hallado a marchar con un exército, y conduzido a bueltas de los otros tercios y governado el mío, pero, en lo que toca a alojar el artillería, formar y guarnecer los quarteles d'ella y de las municiones y maestrança, en esto jamás me impidía, como cosa que no me tocava. // Mendoça, Theórica y práctica, 1596, pág. 83-84: Al alojar Vuestra Alteza convendrá llegue de buena hora, assí porque lo haga la gente con más comodidad, como porque aya tiempo para fortificarse, si es necessario, estando vezino el enemigo, cosas que se hazen mal de noche.

FAM.: alojado, alojamiento, desalojar.

ENCICL.: DRAE: tr. Dar alojamiento a la tropa.

2 [García de Palacio, Diálogos militares, 1583]. v. prnl. Mil. Dicho de un grupo de soldados: instalarse en el lugar donde va a permanecer durante un tiempo.

García de Palacio, Diálogos militares, 1583, fol. 190v: ¿Qué orden puede aver, que sea buena, para que un exército se aloje, y qué calidades ha de tener un lugar, do se pueda alojar un campo? // Mendoça, Theórica y práctica, 1596, pág. 80: Alojándose en ladera, se señala de ordinario la plaça de armas en lo alto d'ella, advirtiendo que no aya tanta distancia de los quarteles a ella que los soldados lleguen con el arma desalentados por la subida a combatir, que es un gran inconveniente. // Rojas, Teórica fortificación, 1598, fol. 3v: Y assí, se tendrá por regla general que donde se hiziere el castillo no tenga en mucha distancia parte donde el enemigo se pueda alojar, y siendo lance forçoso aver de hazer el castillo en aquella parte ya dicha, entonces bastarán los mil passos descubiertos y esplanados, como dicho es.

ANT.: desalojar 3.

3 [Rojas, Teórica fortificación, 1598]. v. prnl. Fort. Durante el intento de expugnación de una fortaleza: construir obras de fortificación pasajeras en los puntos estratégicos que se van ganando.

Rojas, Teórica fortificación, 1598, fol. 106r: Y allí encima se yrá haziendo un trincheón y se atravessará el fosso hasta topar con la esquina del valuarte, que ya estará batida y derribada por el suelo, y en la batería d'ella se alojarán los soldados, haziendo allí pie. // Rojas, Teórica fortificación, 1598, fol. 106r: Y de la mesma manera y a un tiempo se irán haziendo las demás trincheas con sus puentes de madera hasta desembocar el fosso y cegarlo de la mesma suerte que en lo primero, y passar los soldados y alojarse en la otra 
esquina del valuarte de a mano derecha. // Roxas, Sumario milicia, 1607, fol. 104r: Y, bolviendo a mi propósito, digo que, aviendo hecho el hornillo o mina al baluarte, se le dará fuego con la orden que allí digo en aquel libro, y como ya lo sabrá bien el tal yngeniero; y aviendo bolado el baluarte, se alojarán los soldados en la brexa que se hiçiere, y de allí yrán poco a poco ganando lo demás hasta darle fin por el camino que más conbenga

ENCICL.: Almirante (1869: s.v. alojar, alojarse): Fortificarse, atrincherarse en un punto con miras ofensivas o expugnadoras. // Sanz (1749: s.v. alojamiento de un ataque): Es un trabajo que se ejecuta en un puesto peligroso, mientras se adelantan los ataques de una plaza, como en un camino cubierto, sobre una brecha, en un foso y en cualquiera parte que conviene librarse del fuego del enemigo, sea con montones de tierra, sacos a tierra, traversas, cestones llenos, palizadas, sacos llenos de lana, fajinas, manteletes y generalmente con todo aquello que puede asegurar y cubrir al soldado en un terreno que se quiera conservar después de haberlo ganado. // Corsini (1849: s.v. alojarse sobre la brecha): Se llama así el acto de establecerse y guarecerse en ella, después de haberse hecho dueño de la misma, colocando allí algunas bocas de fuego para destruir las defensas y reparos que los sitiados hayan construido detrás de la brecha a fin de inutilizar en parte el asalto y de impedir a los sitiadores que pasen adelante.

aloxamiento, V. alojamiento.

aloxar, V. alojar.

alto, V. plaza .

alto, V. través $\sim$.

alva, V. alba.

alzar, V. $\sim$ el cerco.

alzar, V. el sitio.

amigo, amigo [del lat. amīcus 'íd.'. Cid (DECH). García de Palacio, Diálogos militares, 1583]. adj. Mil. Dicho de un individuo, de una colectividad o de un lugar donde hay personas: que es partidario o lucha junto a otro $u$ otros en un enfrentamiento bélico concreto. 
García de Palacio, Diálogos militares, 1583, fol. 177v: Yendo las batallas caminando, y los arcabuzeros de a cavallo por sí a las partes de más dispusición que les paresce, van prestos para poderlos mudar a la parte que conviene, que ordinariamente suele ser a estorvar el artillería del contrario, o a rescebir su batalla antes que llegue al esquadrón amigo, y, en juntándose, darles por el costado, desordenándolos y offendiéndolos con su ligereza y furia. // García de Palacio, Instrución náuthica, 1587, fol. 128r: El atambor, pífano y trompetas han de tocar siempre la batalla sin cessar y con la mayor arrogancia, braveza que pudieren, que allende que animan la gente amiga, suelen amedrentar los enemigos. // Ufano, Tratado de la Artillería, 1613, pág. 215: Y, asimismo, Señor, me he hallado ynfinitas vezes en la abra y canal de Nioporte acañoneando las barcas enemigas y baxeles de guerra para que diesen lugar a que pudiesen libremente entrar los baxeles y barcas amigas.

ANT.: contrario ${ }_{1}$, enemigo 1 .

ENCICL.: Rubió y Bellvé (1895-1901): Nombre con que uno distingue al ejército, bando o individuo que defiende la misma causa. Viene a ser sinónimo de aliado, e inverso de enemigo o adversario.

2 [Collado, Plática Artillería, 1592]. adj. Mil. Dicho de un soberano, de un territorio, de un ejército o de un miembro de éste: unido a otro u otros, en virtud de un tratado o convenio, para gozar de esta manera de una mayor fuerza a la hora de defenderse o de atacar.

Collado, Plática Artillería, 1592, fol. 1v: Domaron aquéllos por sola ambición tantos reynos y provincias, pero Vuestras Magestades, por castigar los herejes y rebeldes vassallos, tomaron siempre las armas; aquéllos, por usurpar agenos dominios, Vuestras Magestades, por conservar los suyos propios, favorescer los príncipes amigos y confederados, conquistar y restituyrles reynos y estados. // Mendoça, Theórica y práctica, 1596, pág. 6768: Previniendo con esto, si sucede desgracia, el estar apercebido para que la ocasión d'ella no la dé a otros príncipes al acometer los estados de Vuestra Alteza con el ver rotas sus fuerças y desarmado, quedando el enemigo gallardo y vitorioso, que haze perder la reputación y enflaquecer el brío y ánimo de los soldados, entibiándose la fe y afición de los pueblos amigos y confederados, con que se disminuyen las más vezes las rentas situadas para el gasto de la guerra.

SIN.: aliado 1 , confederado 1 .

3 [García de Palacio, Diálogos militares, 1583]. sust. Mil. Respecto a una persona, otra que lucha en su bando.

García de Palacio, Diálogos militares, 1583, fol. 63r: Para no caer inadvertidamente en las manos de los enemigos, y destruyrse, y acabar a sí y a sus amigos, nescessaríssimo es saber los caminos más cómmodos por do se deve marchar para reposar y reformarse de lo que fuere nescessario. // Rojas, Teórica fortificación, 1598, fol. 38r: Y siendo estrecha la estrada, la cubre mejor la gente de la muralla que no si estuviesse más afuera, porque, al tiempo que el enemigo llegasse con su trinchea al bordo de la estrada, los de la muralla no 
le podrían ofender, porque darían en las espaldas a los amigos, por estar muy afuera del fosso. / Lechuga, Discurso de la Artillería, 1611, pág. 216-217: Acostúmbrase, quando se da assalto, disparar algunas pieças de las de la batería a tiempos, según las necessidades, sin bala, para miedo de los enemigos, pero sin que con ella se haga daño a los amigos.

ANT.: adversario ${ }_{1}$, contendedor, contrario 2 , enemigo ${ }_{2}$.

4 [Medina, Arte de navegar, 1545]. sust. Mil. Cada miembro de un convenio o alianza militar respecto a los otros.

Medina, Arte de navegar, 1545, fol. 14v: También escrive Diodoro que Xerxes, rey de los persas, truxo en su hueste contra Grecia setecientos mil hombres suyos y trecientos mil de sus amigos. // Roxas, Sumario milicia, 1607, fol. 20r: La ynfantería se divide en gente de socorros y lejiones; los socorros benían de los amigos o de naçiones confederadas, mas la fuerça romana se fundava en las lejiones. // Roxas, Sumario milicia, 1607, fol. 20v: Y, bolbiendo al propósito, diçen los autores que un solo cónsul no llevava más de dos lejiones contra qualquier multitud de enemigos, demás de los socorros de amigos: tanto era el exérçito de las lejiones y la confiança que en ellos se tenía que para qualquier guerra pareçían que bastaban dos lejiones.

SIN.: aliado $_{2}$, confederado 2 .

ENCICL.: Zerolo (1895): Persona o región que favorece o no se opone a nuestros propósitos.

amotinador, amotinador [de amotinar. 1586, DHist. (DECH). Montes, Instrucción y regimiento, 1537]. adj. u. t. c. sust. Mil. Dicho de una persona: que promueve motines.

Montes, Instrucción y regimiento, 1537, fol. IVv: Si el delito no fuere muy grave, el capitán lo puede castigar, no en la persona, sino en despedirlo de su compañía; y esto por tres cosas: por ladrón, o rebolvedor, o ruffián, o por otra sinrazón que el capitán conosciere que meresce ser castigado. Mas si el delito es por amotinador, es más grave, y este tal delito halo de castigar el maestro del campo o el señor del exército. // Montes, Instrucción y regimiento, 1537, fol. VIIIv: Mas si el soldado es amotinador o persona que tocasse en hazer concierto o alebosía con los enemigos, a estos tales no se les deve guardar ninguna preminencia, antes se deve hazer la justicia de presto. // Mosquera, Comentario disciplina militar, 1596, fol. 117r-117v: Antonio Gómez, merino que fue de la aduana [...]; Thomé Gómez, que era su oficio proveer el campo de los enemigos de todo lo necessario [...]; y Manuel de Acosta, que servía a don Antonio, público amotinador; éstos tres fueron condenados en ciertas penas corporales y diez años de galeras a cada uno d'ellos.

FAM.: amotinar, motín.

ENCICL.: Aut.: El que subleva, levanta y altera los ánimos, ocasionando tumulto y motín. Es verbal del verbo amotinar. // Rubió y Bellvé (1895-1901: s.v. amotinar): Amotinador, el cabeza o promovedor del motín. 
amotinar, amotinar [de motín. h. 1600, Fr. J. de los Ángeles (DECH). García de Palacio, Diálogos militares, 1583]. v. tr. Mil. Poner a un grupo de personas, preferentemente soldados o a los habitantes de un territorio, en contra de sus superiores o del poder establecido.

García de Palacio, Diálogos militares, 1583, fol. 89r: Si, con la ambición referida, los que pretendieren el señorío de la tierra o el pueblo y algunos particulares amotinassen e hiziessen bullicio, ¿qué otras diligencias deve hazer el capitán vencedor para conservar su tierra seguramente?

SIN.: rebelar1.

FAM.: amotinador, motín.

ENCICL.: Aut.: Concitar, conmover, tumultuar el pueblo, reino o ejército contra su superior, turbando y alterando los ánimos y ocasionando inquietudes y escándalos.

2 [Micón, Diario grande cometa, 1578]. v. prnl. Mil. Dicho especialmente de un grupo de soldados: tomar una actitud de oposición hacia sus superiores, manifestada con protestas, acciones violentas o desobediencia.

Micón, Diario grande cometa, 1578, pág. 99: ¡Ay de los primeros que llevarán la pasta al horno!, que lo pagarán por las setenas, como lo sintieron aquellos atrevidos en el cometa passado en Flandes y Alemaña, que fueron sentenciados por sus desacatos; y de los soldados alemanes que se amotinaron contra su capitán y, con cordura, llevados a Anveres: lo pagaron bien. // Álaba, Perfeto capitán, 1590, fol. 62v-63r: Mandó a uno de sus soldados de quien más confiança tenía que se passasse al campo contrario, fingiendo usar d'esta infidelidad por los malos tratamientos que su capitán le hazía, y que persuadiesse al enemigo que todo el campo de Menón se avía amotinado. // Mendoça, Theórica y práctica, 1596, pág. 125: Juntamente se ha de advertir qué calidad de soldados ay en la plaça y de los que se ha de guarnecer, siendo necessario reforçarla, y que no sean bisoños y fáciles a amotinarse.

ENCICL.: Cov. (s.v. amotinarse): Alterarse y quitar la obediencia a su superior, moviendo juntamente a otros. Es término de la soldadesca. // Borreguero Beltrán (2000): Las tropas españolas se amotinaron con relativa frecuencia en Flandes durante los siglos XVI y XVII por el retraso de los haberes o pagas. // Roxas, Sumario milicia (1607: fol. 65v): "Y poco menos sucedió al Basta en Ungría por tener todo su exérçito de alemanes, que, aviendo ganado todo lo que avemos dicho en Ungría el dicho año de 1603, estando en la ciudad de Eperia y teniendo alojado su exérçito alrededor de ella, por sólo que se les devían seis pagas, se amotinaron todos, así la cavallería como la ynfantería y, dejando perdido todo lo ganado, y la onra y reputaçión de su señor, con ello se binieron ha Alemania, dejando hecho rey y señor de todo a un rebelde que se llamava el Baxicay, con el qual fue neçesario que el emperador hiçiese paces, no a gusto, por la falta de sus vasallos". 
amunicionar, amuniçionar [de munición (DECH). Roxas, Sumario milicia, 1607]. v. tr. Mil. Proveer a un ejército o a una plaza de guerra de municiones o de los efectos necesarios para su defensa y manutención.

Roxas, Sumario milicia, 1607, fol. 102r: Pasaré a tratar de sitiar una plaça muy fuerte, pues ya sabemos algo de la miliçia antigua y moderna, y de fortificaçión y artillería, y entender que una plaça fuerte a de estar muy amuniçionada de todo lo necesario, así de bastimentos, pertrechos, gente de guerra y las demás cosas necesarias. // Ufano, Tratado de la Artillería, 1613, pág. 164-165: Digo que, por lo menos, la tal tierra y fortaleza, para deffenderse y cumplidamente ser proveída por tiempo de seis meses, a lo más largo, que es lo que más cómodamente una tal plaça en su devido ser se podría sustener, no esperando, como tengo dicho, socorro ni refrigerio alguno, mediata y plenamente se podría bien proveer y amuniçionar de todo lo siguiente.

SIN.: munir.

FAM.: munición, municionero.

ENCICL.: DRAE: municionar. // DEA (s.v. municionar): Proveer de medios de subsistencia y de defensa, esp. de munición al ejército o a una plaza. // Terr. (s.v. municionar): 1Proveer de municiones de guerra algún ejército, ciudad, castillo, etc. 2- Proveer de bastimentos.

amuniçionar, V. amunicionar.

andamio, andamio [de andar. Andamio ant. 'camino detrás del parapeto en lo alto de una fortificación'. Glosas de Silos (2. ${ }^{a}$ mitad del s. X); doc. leonés de 997 (DECH). Montes, Instrucción y regimiento, 1537]. sust. Fort. Camino situado detrás del parapeto y en lo alto de una fortificación (DUE: s.v. adarve).

Montes, Instrucción y regimiento, 1537, fol. XVIIr-XVIIv: Y por lo alto tenga el muro sus defensas y andamios, con sus troneras, para que los arcabuzeros puedan tirar a los de fuera.

SIN.: ándito, terraplén2, terrapleno.

ENCICL.: DUE: (ant.) Adarve. // Rubió y Bellvé (1895-1901): Fort. En los antiguos castillos, el adarve o camino que existía en lo alto de la muralla, por donde se transitaba y desde el que se podía combatir al enemigo.

ándito, ándito [del it. àndito 'corredor de comunicación', procedente del lat. ambitus 'circuito, contorno', alterado por influjo del it. andare 'ir'. Ándito 'corredor que rodea exteriormente un edificio'. 1600, Sigüenza (DECH). Rojas, Teórica 
fortificación, 1598]. sust. Fort. Camino situado detrás del parapeto y en lo alto de una fortificación (DUE: s.v. adarve).

Rojas, Teórica fortificación, 1598, fol. 78r-78v: Y si los planos de los terraplenos o ánditos d'ellos pudiessen ser ofendidos, alçarse han tanto las murallas con unas traviessas que los cubra; y si esto no bastasse a cubrir los soldados, se levantarán los parapetos más altos que lo ordinario, poniendo detrás d'ellos espaldas de tierra y fagina.

SIN.: andamio, terraplén 2 , terrapleno.

ENCICL.: Rodríguez Navas (1918): Corredor que rodea una parte o la totalidad de un edificio. // DEA: (raro) Zona destinada a andar las personas.

antepresa, V. interpresa.

apellidar, apellidar [del lat. appellĭtare 'llamar repetidamente', frecuentativo de appellare. Apellidar 'gritar', 'llamar (a alguien para algo)', 'nombrar, llamar'. h. 1295, 1. ${ }^{a}$ Crón. Gral (DECH). Celso, Reportorio universal leyes Castilla, 1553]. v. tr. Mil. Convocar a un grupo de personas para que tome las armas contra un enemigo común.

Celso, Reportorio universal leyes Castilla, 1553, fol. CLXVIIv: Y cada y quando los unos llegaren en cabo de las $\mathrm{V}$ leguas, dexen el rastro a los otros, y todavía se multipliquen los quadrilleros y otras personas que fueren apellidando y repartiéndose por diversas partes, prosiguiéndolos de lugar en lugar hasta echarlos fuera del reyno, o prenderlos, o cercarlos.

FAM.: apellido.

ENCICL.: Zerolo (1895): Llamar a las armas, convocar en son de guerra.

apellido, apellido, appellido [de apellidar. 942 (DECH). Celso, Reportorio universal leyes Castilla, 1553]. sust. Mil. Llamamiento a tomar las armas contra alguien.

Celso, Reportorio universal leyes Castilla, 1553, fol. CLVIIIv: Ansimesmo, ay otra especie de guerra que dizen de appellido, que quiere tanto dezir como boz de llamamiento que hazen algunos para juntarse y defender lo suyo quando reciben fuerça o daño, o son para recebirlas, dando para esto clamores de los hombres, o de compañas, o de trompetas o añafiles, o en otra qualquier manera que sea, para allegar y ayuntar la gente. // Celso, Reportorio universal leyes Castilla, 1553, fol. CLVIIIv: Y se hazen estos appellidos en tiempo de paz y de guerra. $\mathrm{Y}$ en qualquier tiempo que se hizieren, todos deven salir al dicho appellido, ansí a pie como a cavallo. Empero, si fuere en tiempo de paz, después que hovieren cobrado lo suyo no deven seguir los que les hizieren aquel daño. // Celso, Reportorio universal leyes Castilla, 1553, fol. CLVIIIv: Si se hiziere el tal appellido en tiempo 
de guerra, ante de seguir los enemigos deven mirar y considerar con auctoridad si ellos son bastantes para cobrar lo suyo, y dexar los lugares de donde salen proveýdos.

FAM.: apellidar.

2 [Celso, Reportorio universal leyes Castilla, 1553]. sust. Mil. Señal, como puede ser un grito o el toque realizado con algún instrumento, que se hace para indicar a los soldados que se apresten a tomar las armas contra alguien.

Celso, Reportorio universal leyes Castilla, 1553, fol. CLXVIIv: Y siendo denunciados algunos de los casos susodichos, o luego que lo supiere en qualquier manera, los dichos quadrilleros son tenudos de seguir y mandar que sigan los malhechores hasta $\mathrm{V}$ leguas dende, haziendo todavía dar apellido y repicando las campanas en todo lugar donde ellos llegaren, porque, ansimesmo, salgan los de los tales lugares en persecución de los malhechores.

ENCICL.: Terr.: Antic. Señal para prevenir las armas. // Zerolo (1895): ant. Seña que se daba a los soldados para que se aprestasen a tomar las armas. Esta seña se daba ya por voces, toque de campanas, trompas, bocinas, tambores, etc., para juntarse y defenderse. // Almirante (1869): Y para aviso de los vecinos que se hallaban fuera de la villa solían poner hogueras en puntos altos.

aposentador, aposentador [de aposentar y éste de posar. Pos-, APal. (DECH). Mendoça, Theórica y práctica, 1596]. sust. Mil. Persona que reparte y distribuye a las tropas y su material de guerra por los distintos cuarteles o posadas de un alojamiento.

Mendoça, Theórica y práctica, 1596, pág. 82: Aviendo dividido el maestre de campo general los quarteles y plaça de armas en la manera que signifiqué a Vuestra Alteza en el primer alojamiento, el quartelmaestre lo repartirá en particular a los aposentadores o furrieles. // Roxas, Sumario milicia, 1607, fol. 62r: Los dos cavallos que sobran de treinta y dos, que son las tres esquadras, devían de ser oficiales, d'este número de 32 cavallos, como aora diríamos, contador y aposentador, que el uno tiene qüenta del feno que se da a los cavallos y el aposentador tiene cuidado de alojarlos. / / Lechuga, Discurso de la Artillería, 1611, pág. 234: Avrá tantos conductores a cavallo quantos fueren menester, según el trein fuere grande, los quales servirán de estar cerca de las pieças y municiones para hazerlas caminar antes que otros qualesquier carros; y el uno de los dichos conductores servirá de aposentador para alojar y tomar posadas para el general, tenientes, officiales, artillería y municiones, y todos los que sirven en ella.

FAM.: posada.

ENCICL.: Cov. (s.v. aposentar): Los que tienen oficio de aposentar llamamos aposentadores, y aposentador mayor al que es sobre todos. Hay aposentadores de Corte, y aposentadores de camino y aposentadores del ejército, que en el real reparten los sitios. 
appellido, V. apellido.

appremiar, V. apremiar.

apremiado, apremiado [de apremiar. Ufano, Tratado de la Artillería, 1613]. adj. Mil. Dicho de una persona: inquieta por pequeños ataques sufridos, o por la amenaza de posibles acciones en su contra.

Ufano, Tratado de la Artillería, 1613, pág. 262: Aunque la prática y operaçión de las minas antiguamente se a usado en las guerras de los persas, parthos y romanos con otras diversas máchinas y petrechos, ningún arte al uso de la guerra a sido más perfeto y conveniente para oprimir a los sitiados ni ay cosa de que más teman los sitiadores que es de las contraminas hechas en su daño por el enemigo viéndose tan çercado y apremiado.

SIN.: acosado, apretado1.

FAM.: apremiar.

apremiar, appremiar, apremiar [de premia y éste o del lat. *prĕmĭa o, más bien, del lat. praemia, plural de praemium. Berceo; "compello, ago", Nebr. (DECH). Loçano, Alberto, Architectura, 1582]. v. tr. Mil. Inquietar al enemigo con pequeños ataques, o tenerlo bajo la amenaza de acciones en su contra.

Loçano, Alberto, Architectura, 1582, pág. 137: Otro género de alojamientos será quieto, para donde te estés firme, para apremiar y occupar al enemigo que desconfía de sus huestes de gentes armadas, en tanto que estuviere en algún lugar fortalecido. // Loçano, Alberto, Architectura, 1582, pág. 140: Por tanto (como diximos), se ha de advertir y procurar que el fuerte sea poderoso, fuerte, firme y aparejado para se defender, y para enflaquecer al enemigo y rechazalle, y seguro y no dañado contra todos los ímpetus y porfía del ser cercado. Pero en los alojamientos en que apremiéys y acosséys al enemigo encerrado, en ninguna manera todas las cosas semejantes se han de guardar con menos diligencia. // Loçano, Alberto, Architectura, 1582, pág. 247: En una d'ellas escriven aver muerto Mario, apremiado con ser cercado dentro.

SIN.: acosar, apretar.

FAM.: apremiado.

ENCICL.: DRAE (1780): Estrechar, apretar. 
apretado, apretado [de apretar (DECH). Mosquera, Comentario disciplina militar, 1596]. adj. Mil. Dicho de una persona: inquieta por pequeños ataques sufridos, o por la amenaza de posibles acciones en su contra.

Mosquera, Comentario disciplina militar, 1596, fol. 31r: Declararon que la carabela en que venían es la que tiene Manuel de Silva prevenida y que nunca la a dexado salir del puerto, sino fue para que ellos viniessen, y sospéchase que la quiere para yrse quando se viere apretado.

SIN.: acosado, apremiado.

FAM.: apretar.

2 [Mendoça, Theórica y práctica, 1596]. adj. Fort. Dicho de un cerco, asedio o sitio: que se ha estrechado, que se ha hecho más severo o duro.

Mendoça, Theórica y práctica, 1596, pág. 124: Es muy provable el aver de defender los capitanes de Vuestra Alteza muchas tierras, y puesto en razón escrevir, entre las otras facciones de guerra, en la manera que se ha de defender una plaça, siendo esto lo que apura un soldado, y su piedra de toque, mostrando los quilates de valor y industria que tiene partes de prudencia y sufrimiento en los trabajos que se passan en sitio o assedio apretado, llevándolos con alegría y contento que anime a los soldados que tiene consigo a juzgar no ser grandes y haga a los pusilánimos tenellos por menores que el castigo de la muerte $[\ldots]$.

apretar, apretar [de *apetrar y éste del lat. tardío appěctǒrare 'estrechar contra el pecho', derivado de pĕctus, pěctǒris, 'pecho'. Apretar 'estrechar contra el pecho', 'comprimir'. 2. ${ }^{a}$ mitad del s. X, Glosas de Silos (DECH). Mendoça, Theórica y práctica, 1596]. v. tr. Mil. Inquietar al enemigo con pequeños ataques, o tenerlo bajo la amenaza de acciones en su contra.

Mendoça, Theórica y práctica, 1596, pág. 73: Y si los enemigos apretaren a los corredores con tanta gallardía y fuerças que los obliguen a retirarse hasta la retaguardia, los ha entonces de sustentar, bolviendo el rostro con el hazer alto, de que advertirá a Vuestra Alteza para que los refuerce o socorra, conforme fuere la necessidad. // Mosquera, Comentario disciplina militar, 1596, fol. 82v: Y encendidos en la gloria de vençer y alentados con el frescor de la mañana, que podía entonces templar la sed, apretaron de suerte a los franceses y portugueses que desampararon la fuente que con tanto cuydado guardavan y perdieron el artillería y la villa de San Sebastián. // Ufano, Tratado de la Artillería, 1613, pág. 258: Y viendo el Conde de Busquoy que con tan buen adereço se podía cómodamente hazer un fuerte, trabajando en fabricarle a las baxas mareas lo más çerca de la villa que possible fuesse para por tal medio apretar más a los enemigos y a la entrada de su canal romperle los bajeles que le fuessen entrando de socorro o saliendo [...], propuso a $\mathrm{Su}$ Alteza lo que ymportava.

SIN.: acosar, apremiar. 
FAM.: apretado.

ENCICL.: DRAE: Acosar, estrechar a alguien persiguiéndole o atacándole.

2 [Mendoça, Theórica y práctica, 1596]. v. tr. Fort. Aplicado al cerco, asedio o sitio de cualquier lugar fortificado, estrecharlo, hacerlo más severo o duro.

Mendoça, Theórica y práctica, 1596, pág. 139: Quando se aprietan los cercos acontece dar muestra de cobardes algunos de quien menos se pensava. / / Mendoça, Theórica y práctica, 1596, pág. 144: Quando los sitios se vienen a apretar mucho, es difícil cosa el dar aviso los de dentro de su estado y calidad de socorro que han menester.

ENCICL.: DUE: Refiriéndose al cerco de una plaza, estrechar.

apretilar, apretilar [de pretil. Ufano, Tratado de la Artillería, 1613]. v. tr. Fort. Colocar alguna cosa, especialmente una pieza de artillería, detrás de un parapeto o pretil con el fin de protegerla del fuego enemigo.

Ufano, Tratado de la Artillería, 1613, pág. 123: Antes será mejor un poco menos, porque no deve ser más de tanto quanto el afuste de la pieça se tenga sobre la explanada en disparando y que, amorosamente cargada, poca gente pueda apretilar y meter la pieça en batería. / / Ufano, Tratado de la Artillería, 1613, pág. 332: De forma que, apretilada y metida la pieça a batería sobre la barba de la desembocadura de su tronera, quiriendo tirar con caça, de la puntería natural a fuera.

FAM.: pretil.

aproche, aproge, aproje, aproxe [del fr. approches 'aproximación', derivado de approcher 'acercarse', y éste del lat. vg. appropiare, derivado de prope 'cerca'. Aproches, m. pl., 'trabajos que van haciendo los que atacan una plaza para acercarse a batirla'. Aproge ya en 1594, B. Mendoza. Aproches en 1648, Saavedra Fajardo $(\mathrm{DECH})$. Mendoça, Theórica y práctica, 1596]. sust. u. m. en pl. con el mismo significado que en sing. Fort. Conjunto de trabajos que realizan los que atacan una plaza para aproximar sus posiciones (DEA: s.v. aproches).

Mendoça, Theórica y práctica, 1596, pág. 100: Hecho el aproge, llegando las trincheas lo más cerca que puede de la tierra, se tiene plantada la batería a que se da principio con esta orden, que es tirar las pieças con que se bate determinadamente por camaradas una tras otra, siendo de más efecto que si se disparasse cada una de por sí. / / González de Medina, Examen fortificación, 1599, pág. 188: De las culebrinas, de diez y ocho hasta veynte y quatro libras de bala, pondría dos en cada baluarte, una al un lado y otra al otro, y en la cortina otra para tirar a los aloxamientos y quartel de la cavallería, y a los pavellones y tiendas, y para trabajarlos en las trincheas y en los aprojes que hizieren de lo más largo. // Ufano, Tratado de la Artillería, 1613, pág. 173: Los morteros son de mucho serviçio en una plaça, porque siempre juegan de alto abaxo donde ay más concurso de gente, en las trincheas y 
aproxes, y como de peso caen dentro las granadas, bombas y balas artiffiçiadas, ay otros fuegos ynistinguibles y lethales que se arroxan con ellos.

ENCICL.: Terr. (s.v. aproches): Término de fortificación de campaña. Son todos los trabajos que hacen los que sitian una plaza para acercarse a ella y entrarla [...]. Las trincheras se llaman líneas de aproche, y se hacen culebreando para que no las enfile el enemigo. // Moretti (1828: s.v. aproches): Nombre genérico y colectivo que comprende todos los trabajos que hacen las tropas que sitian una plaza para acercarse y hacerse dueños de ella, tales como trincheras, baterías, zapas, alojamientos sobre la explanada [o escarpa], galerías para el paso del foso, espaldones [o espaldas], minas, etc. // Mendoça, Theórica y práctica (1596: pág. 94-95): "En el hazer el aproge que llaman, que es allegarse a las murallas y fossos, estando la artillería y municiones prestas, se acostumbra, retirado el enemigo dentro de las murallas y reconocido por el general de la artillería y otros cabos del exército la parte por donde se ha de batir, caminar con las culebrinas gruessas y, apuntándolas de donde mejor se puede a los parapetos, plataformas y cavalleros, dar principio al quitar algunas defensas acercando (en tanto que juegan las culebrinas) los cañones lo que más se puede para quitar troneras y defensas que no descubren las culebrinas y se veen de más cerca, siendo partes de donde el enemigo puede hazer daño, siguiendo a los cañones, los medios y culebrinas y quartos de cañones, que se avezinan más y tiran donde las culebrinas y cañones han batido, derribando las defensas como mejor se puede; y esto con priessa y diligencia, atendiendo, en uno, dos días o más, al quitar al enemigo las cañoneras y travesses; lo qual hecho, o continuándose el procurarlo, se da principio, por no perder tiempo, al labrar más fácilmente de noche y con mayor seguridad las trincheas, no teniendo el enemigo parte segura donde disparar pieça para defenderlo, pudiéndose mejorar entonces los cañones gruessos al puesto donde se ha de afirmar la batería y dar principio, o continuar, las trincheas".

2 [Rojas, Teórica fortificación, 1598]. sust. pl. Mil. Toda clase de materiales e instrumentos, como pueden ser armas o máquinas, necesarios para cualquier empresa militar.

Rojas, Teórica fortificación, 1598, fol. 101r-101v: Y de aquí passo a tratar un poco de la materia de esquadrones y alojamiento d'ellos, y poner sitio a una plaça que esté muy prevenida de todos los aproges dichos en la fortificación, con que daré fin a este libro. // Roxas, Sumario milicia, 1607, fol. 102v: Aviendo ya el general hecho las diligençias que conbiene, y aperçevido su artillería y muniçiones, y los demás aprojes neçesarios, mandará un día antes aperçevir para marchar el campo otro día.

SIN.: aproches de guerra, munición de guerra, pertrechos, pertrechos de guerra.

>s de guerra [Rojas, Teórica fortificación, 1598]. cmpt. sintag. pl. Mil. Toda clase de materiales e instrumentos, como pueden ser armas o máquinas, necesarios para cualquier empresa militar.

Rojas, Teórica fortificación, 1598, fol. 71v-72r: Supuestos todos estos fundamentos, digo que, para defenderse esta plaça que aquí pongo, tendrá dentro todos los aproges de guerra necessarios: lo primero, dos pieças de artillería en cada casamata. // Rojas, Teórica 
fortificación, 1598, fol. 78v-79r: Y no teniendo agua de pie, se harán cisternas para la llovediza, y generalmente tendrá todos los aproges de guerra dichos, de los quales tendrá una lista por escrito el castellano, de forma que no le falte pieça de su arnés el día que cargare el enemigo, porque se remedia mal lo que faltasse el día que el enemigo huviesse sitiado la tal plaça. // Rojas, Teórica fortificación, 1598, fol. 102v: Será bien hazer un alojamiento, para que esté la gente junta y recogida en el ínterin, que se aprestaren las municiones y aproges de guerra que faltaren para la tal fación.

SIN.: aproche2, munición de guerra, pertrechos, pertrechos de guerra.

aproge, V. aproche.

aproje, V. aproche.

aproxe, $\mathrm{V}$. aproche.

aquartelar, V. acuartelar.

arce, arce, arçe, arço, arze [del lat. arcaico y vulgar arger, argĕris (lat. agger 'terraplén', derivado de aggerĕrere 'acumular'). Mariana, Coloma y Medrano (que Aut. confunde semánticamente con el latín arx 'ciudadela') (DECH)].

$\sim$ del foso [Lechuga, Discurso de la Artillería, 1611]. cmpt. sintag. Fort. Terreno o superficie que desde el parapeto de la estrada cubierta va descendiendo, con una pendiente o declive muy suave, hasta alcanzar el nivel de la campaña.

Lechuga, Discurso de la Artillería, 1611, pág. 212: Digo veinte porque, siendo la más que se puede batir con una batería la cortina de un baluarte y necessario el día de oy el ponerla en la contraescarpa o arze del fosso para poderla hazer, harto será que en el lugar que ay de donde se pueda batir, dando el que cada pieça a menester, puedan estar veinte. / / Ufano, Tratado de la Artillería, 1613, pág. 165: 10 quartos de cañón de a 10 libras de bala para continuamente con ellos tirar a las obras que el enemigo començare a levantar, y a las guardias que fueren entrando o saliendo de las trincheas y para, dende los traveses, con ellos asegurar el arçe y ampleza del fosso, con sus estradas cubiertas. // Ufano, Tratado de la Artillería, 1613, pág. 226: Hartos, y muchos y diversos remedios, Señor, se pueden hazer con costa y derramamiento de sangre; pero quando se viene a tal punto de hazer la batería ya se tiene ganado el arçe del fosso y echada para çegarle mucha tierra y faxina $y$, asimismo, lo que va cayendo de la ruyna de la batería viene a hazer escala a modo de escarpa, por donde se viene a façilitar el dar del asalto.

SIN.: arcén, arcén del foso, árgine, escarpa $a_{3}$ vallado3.

ENCICL.: DRAE (s.v. $\left.\operatorname{arce}^{2}\right)$ : desus. arcén. 
arçe, V. arce.

arcén, arcén, arzén [del lat. arcaico y vulgar arger, argěris (lat. agger 'terraplén', derivado de aggerĕrere 'acumular'). 1570, C. de las Casas; 1590, B. de Mendoza (DECH). Collado, Plática Artillería, 1592]. sust. Fort. Terreno o superficie que desde el parapeto de la estrada cubierta va descendiendo, con una pendiente o declive muy suave, hasta alcanzar el nivel de la campaña.

Collado, Plática Artillería, 1592, fol. 95r: ¿Quién le enseñó que las fortalezas, o son fuertes por la materia o son fuertes por la forma?: por la materia, quando son fabricadas de grosíssimas murallas, y por la forma, por tener baluartes anchos y plaças espaciosas, gruessos y maçiços orejones, anchos terraplenos, arzenes altos, gruessos parapetos y no pedregosos, [...]. // Rojas, Teórica fortificación, 1598, fol. 70v-71r: De la mitad arriba que está descubierto del arcén de la estrada cubierta, han de ser los sillares de pie y medio de largo, y un palmo de alto, y el mayor será dos pies de largo y un pie de alto. / González de Medina, Examen fortificación, 1599, pág. 42: También es buena para más fácilmente recebir socorro y defender el arzén o ballado, por si de al largo huviesse quitado el enemigo las defensas de la muralla.

SIN.: arce del foso, arcén del foso, árgine, escarpa $a_{3}$, vallado 3.

ENCICL.: Mariátegui (1876): La cresta del camino cubierto.

$\sim$ del foso [Mendoça, Theórica y práctica, 1596]. cmpt. sintag. Fort. Terreno o superficie que desde el parapeto de la estrada cubierta va descendiendo, con una pendiente o declive muy suave, hasta alcanzar el nivel de la campaña.

Mendoça, Theórica y práctica, 1596, pág. 96: Las trincheas no es possible dezir a Vuestra Alteza el puesto de donde se les da principio, ni si serán largas o cortas, ni si han de llegar a cubrir la artillería con que se bate hasta el arzén del fosso o venir a desembocar en él. // González de Medina, Examen fortificación, 1599, pág. 42-43: El arzén del foso o vallado, que se dize, ha de descender desde lo alto del parapeto de la estrada cubierta muy pendiente, que apenas se eche de ver que le ay. Hase de descubrir todo él de lo alto de la muralla para poderle defender. Házese para que encubra la muralla y que se vea poquíssimo que batir d'ella. // Roxas, Sumario milicia, 1607, fol. 81v-82r: Las puertas de la çiudad se han de hazer en las partes que estén más a propósito para entrar y salir la gente fuera y meter los carros y bastimentos acomodadamente, aunque aya guerra, pues se puede remediar con que el arzén del foso cubra la dicha puerta, de manera que de la campaña no la descubra el enemigo.

SIN.: arce del foso, arcén, árgine, escarpa $a_{3}$, vallado ${ }_{3}$.

ENCICL.: Terr.: En la milicia es el borde de él, y todo lo que es orilla y sobrepuja a la estrada encubierta. 
architectura, V. arquitectura.

architettura, V. arquitectura.

architetura, V. arquitectura.

architeturia, V. arquitectura.

arço, V. arce.

arcubalista, arcubalista [tomado del lat. arcuballista, compuesto de arcus 'arco' y ballista (DECH). Mosquera, Comentario disciplina militar, 1596]. sust. Mil. ant. Pequeña balista manejada por dos hombres.

Mosquera, Comentario disciplina militar, 1596, fol. 5v: Y en la mesma antigüedad (como dize Vitruvio) los primeros arietes que salieron a luz en el mundo fueron los que los cartagineses en España inventaron, con que allanaron los muros de la ciudad de Cádiz, y, después, subiendo en la mayor fineza que jamás estuvo, la artillería e ingenios de fuego y artificios modernos que sucedieron a las balistas, y a los escorpiones o arcubalistas, y a los trabucos tiradores de piedras.

aretino, V. arietino.

árgine, árgine [del it. àrgine 'terraplén', y éste del lat. agger (DECH). Lechuga, Discurso de la Artillería, 1611]. sust. Fort. Terreno o superficie que desde el parapeto de la estrada cubierta va descendiendo, con una pendiente o declive muy suave, hasta alcanzar el nivel de la campaña.

Lechuga, Discurso de la Artillería, 1611, pág. 241: El árgine, que es el terreno que tiene principio de la estrada encubierta y fin en la misma campaña a la parte de afuera, que va siempre a escarpa, tanto quanto fuere necessario para consumir la tierra que se saca del fosso después de dada la que a menester la fuerza, a de tener, por lo menos, veinte pies desde el parapeto de la estrada cubierta de la más llanura que se pudiere, para que la gente que estubiere dentro la estrada cubierta esté segura de las balas de cañón, que no lo estará si desde el principio va haziendo la declinación, porque quedará la estrada cubierta poco fuerte y flaca.

SIN.: arce del foso, arcén, arcén del foso, escarpa 3 , vallado ${ }_{3}$. 
ENCICL.: TLIO (s.v. àrgine): Terrapieno che delimita un fossato o un corso d'acqua.

arietario, arietario [tomado del lat. ariĕtārŭus, a, um, de ařes 'ariete'. Arietario 'perteneciente al ariete'. Ariětārĭus, Vitr. (Miguel 2003). Urrea, Vitruvio, Architectura, 1582]. adj. Fort. ant. Perteneciente o relativo al ariete (DRAE).

Urrea, Vitruvio, Architectura, 1582, fol. 135v: Poníase también en ella la máchina arietaria, que en griego se llama criedochi, que es viga arietaria, en la qual estava el toro, que es un gruesso leño y redondo, hecho a torno, adonde está puesto el ariete. Hazía grandes effectos arrojándolo y recogiéndolo con las maromas. / Urrea, Vitruvio, Architectura, 1582, fol. 143v: Toro: un leño gruesso torneado de la máchina arietaria, en el qual, puesto el ariete, arrojándolo y recogéndolo, haze grandes effectos.

\section{arietario, V. testudo $\sim$.}

ariete, ariete [tomado del lat. arǐes, ariětis 'morueco (carnero padre)', 'ariete'. Ariete 'viga de cabeza reforzada que se empleaba para batir murallas'. APal. (DECH). Loçano, Alberto, Architectura, 1582]. sust. Fort. ant. Máquina empleada para batir murallas, consistente, fundamentalmente, en una viga o trabe larga y pesada, uno de cuyos extremos está reforzado con una pieza de hierro o bronce, labrada, por lo común, en forma de cabeza de carnero.

Loçano, Alberto, Architectura, 1582, pág. 107: Finalmente, qualquiera designo que tú aprueves de redondez, Vegecio piensa averse tenido cuydado harto según la necessidad de la cosa: si tan anchos pusieres los muros, que no se impidan los defensores entre sí encontrándose el uno al otro; si los levantares tan altos, que no puedan ser subidos con escalas arrimadas; si de tal suerte los firmáremos con cal y con fábrica, que no cedan al ariete y a las máchinas. // Roxas, Sumario milicia, 1607, fol. 45v-46r: El ariete es un madero con una punta de hierro a hechura de cabeça de carnero; y la hoz es otro madero con la punta torcida para sacar las piedras de la muralla quando estén movidas del ariete. // Rojas, Compendio fortificación, 1613, fol. 5v: De aquí nace la estimación de los hombres experimentados en su larga edad, para lo qual sabemos que antiguamente no avía otras armas, sino ballestas de palo, y para romper las murallas, un madero aforrado de hierro que llamavan ariete; y luego se inventó la pólvora, y de allí la horrible artillería, que, si no se experimentara, no se supiera su eficacia.

SIN.: carnero, vaivén.

ENCICL.: Terr.: Antigua máquina de guerra con que, en lugar de artillería, batían las murallas y fortalezas. Esta máquina era una viga o madero grande, armado de hierro por la punta y algunas veces con hierros agudos que formaban cierta especie de cuernos como los del carnero; y ya se suspendía con maromas para dejarla caer, ya se conducía en ruedas y ya se sostenía por los mismos que la impelían en declive contra el muro. En orden a su invención, unos dicen que es de los Cartagineses, otros de los Griegos en el Cerco de Troya, etc. El nombre, según algunos, se le dio por batirse con ella, como se golpean 
mutuamente los carneros. Los Arietes eran tan formidables que los había de 120 codos de largo, y a proporción de anchos. La Máquina que oponían los sitiados se llamaba lobo. // Urrea, Vitruvio, Architectura (1582: fol. 135r): "Primeramente, el ariete, que es máchina para batir, dizen que se halló d'esta manera: los carthaginenses pusieron campo sobre Cáliz para tomarla. Y aviendo tomado primero el castillo, se esforçaron de arruynalle. Y no teniendo instrumento conveniente para ello, tomaron una viga, y sosteniéndola con las manos y la cabeça, hiriendo continuamente el alto muro, derribavan por orden las piedras. Y assí, de grado en grado, deshizieron toda la muralla". / / Collado, Plática Artillería (1592: fol. 4v): "La máquina llamada ariete, que quiere dezir 'carnero', se aplicava, assimismo, al combatir las fortalezas y derribar las murallas; llamáronla de este nombre y aun diéronle la figura y forma de aquel animal por el effecto que con ella se hazía y modo como se exercitava, porque, assí como el carnero con los duros cuernos conbate con otros animales $\mathrm{y}$, para de nuevo y con mayor ímpetu arremeter, torna atrás, assimismo se hazía con esta máquina y con la trabe aretina que dentro de síllevava; era esta trabe semejante a aquélla de la testudine, pero aquella cabeça de bronzo que atormentava las murallas era semejante a una gruessa cabeça de carnero [...]. Su cubierta era afforrada, como arriba diximos, por encima, de pieles de bueyes crudas y aun, según algunos, las cubrían de hazes de paja remojada en vinagre, la qual affirman que en manera alguna no puede enprender el fuego en ella".

arietino, aretino, arietino [tomado del lat. ariětīnus, a, um, de ařes 'carnero'. Arietino 'perteneciente al carnero'. Ariětīnus, Plin. (Miguel 2003). Collado, Plática Artillería, 1592]. adj. Semejante a la cabeza del carnero (DRAE).

Collado, Plática Artillería, 1592, fol. 4v: La máquina llamada ariete, que quiere dezir 'carnero', se aplicava, assimismo, al combatir las fortalezas y derribar las murallas; llamáronla de este nombre y aun diéronle la figura y forma de aquel animal por el effecto que con ella se hazía y modo como se exercitava, porque, assí como el carnero con los duros cuernos conbate con otros animales y, para de nuevo y con mayor ímpetu arremeter, torna atrás, assimismo se hazía con esta máquina y con la trabe aretina que dentro de sí llevava.

arma, V. gente de $\sim$ s.

arma, V. hecho de $\sim$ s.

arma, V. hombre de $\sim$ s.

arma, V. plaza de $\sim$ s.

arquictectura, V. arquitectura. 
arquitectura, architectura, architettura, architetura, architeturia, arquictectura, arquitectura, arquitetura [tomado del lat. architectūra (DECH)].

militar [Lechuga, Discurso de la Artillería, 1611]. cmpt. sintag. Ciencia que enseña a disponer todas las fábricas y obras que son necesarias para conseguir el fin de la guerra (Fernández Mancheño 1822: s.v. fortificación).

Lechuga, Discurso de la Artillería, 1611, pág. 243: Y esto por la mucha experiencia y por el uso, padre de la sabiduría como la memoria madre, tomando de ellos el pareçer, sin aguardar medidas ni proporciones, por ser cosa que no la entienden todos y propias de los ingenieros, profesores de la architectura militar. // Lechuga, Discurso de la Artillería, 1611, pág. 278: De lo dicho saquen los ingenieros que, si para serlo de medir terrenos, dividir erencias, hazer particiones, estimaciones de fábricas y de qualesquiera otras cosas de campaña, guiar aguas, y juzgar differencias de ellas, no les vale la ciencia sin experiencia, quánto más razón será que, en las obras de architectura militar, no se fíen de ellos hasta que la experiencia de ellas no los aya hecho maestros de quien sólo se pueden fiar.

SIN.: fortificación 1 .

\section{arquitetura, V. arquitectura.}

arremeter, arremeter [de remeter. h. 1295, 1. ${ }^{a}$ Crón. Gral.; J. Ruiz (DECH). Fernández de Enciso, Suma de Geographía, 1530]. v. intr. Mil. Ir con ímpetu y furia sobre alguien o sobre algo.

Micón, Diario grande cometa, 1578, pág. 53: Y, entendiendo que era negocio de Dios, arremetieron otra vez sobre los moros, que los quebraron bien la cabeça. // Mosquera, Comentario disciplina militar, 1596, fol. 67r-67v: Como hizo Marcelo que, después de aver adorado a Júpiter, arremetió contra el exército de Virdumaro y, teniéndole ya muerto, le desnudó las armas y ofreciolas al templo. // Roxas, Sumario milicia, 1607, fol. 68v: Y para haçerlo en un llano donde no aya ninguna comodidad de las dichas, se hará en quadro del terreno, porque allí son yguales las frentes, aunque el fondo o lado no tiene tantos soldados como la frente, porque en el lado ay de distancia de uno a otro siete pies, y de uno a otro, en la frente, tres, y si el enemigo arremetiese por el lado lo hallaría muy flaco por allí; y si le suçediese semejante caso, a de adbertir mandar bolver las pieças haçia aquel lado que el enemigo arremete, y mandar que se junten los soldados de tal manera que no se deshordene el dicho esquadrón.

SIN.: embestir 1 , remeter.

FAM.: arremetida, remeter, remetida.

ENCICL.: Cov.: Acometer corriendo a alguna cosa con ímpetu y furia, del latino immitto. Arremeter a los enemigos es entrarse en ellos. Arremetida, la tal entrada. // Almirante (1869): Acometer con ímpetu y furia. Embestir, arrojarse con presteza. "Creyendo que dijese 
Santiago, como es costumbre en España, para acometer los enemigos, arremetieron sin más orden" (Mendoza. G. de Gran. lib. 1, núm. 14). Aquí se ve clara la diferencia entre acometer y arremeter. // DUE: ("contra"; menos frec., "a, con, para") intr. Atacar o acometer con ímpetu.

arremetida, arremetida [de arremeter (DECH). García de Palacio, Diálogos militares, 1583]. sust. Mil. Acción de ir con ímpetu y furia sobre alguien o sobre algo.

García de Palacio, Diálogos militares, 1583, fol. 75v: Opuestos dos campos, ¿qué orden terná el uno para consumir y deshazer al otro?, y si es más cordura suffrir con ánimo y ossadía el ímpetu y arremetida de los enemigos o asaltallos y acometellos en sus principios, con toda su furia. // Mosquera, Comentario disciplina militar, 1596, fol. 70r: Y assí, con mucha destreza, los franceses davan cargas en los nuestros y las recebían, que en esto del escaramuçar tienen agilidad y presteza, y los primeros ímpetus y arremetidas son de mucha demostración. // Roxas, Sumario milicia, 1607, fol. 82r: El terrapleno es único remedio contra el artillería; se haze detrás de la muralla, así del baluarte como de la cortina, de cada cosa, y se ha de haçer de tal manera que después de caýda la muralla parezca un monte espantoso a los enemigos; ha de declinar hazia la ciudad y de tal manera que suban por él con mucha suavidad los soldados a qualquiera arremetida.

SIN.: remetida.

FAM.: arremeter, remeter, remetida.

ENCICL.: Aut:: Acometida o entrada hecha deprisa con ímpetu y furia. // DRAE: Acción de arremeter.

arriba, V. plaza de .

arte, arte, harte [del lat. ars, -tis. Art en el Cid; arte, 1144 (DECH)].

$\sim$ militar [Montes, Instrucción y regimiento, 1537]. cmpt. sintag. Arte o técnica que enseña los conocimientos y preceptos necesarios para hacer la guerra.

Montes, Instrucción y regimiento, 1537, fol. IIIr: Cosa muy necessaria es a los cavalleros y grandes señores leer las cosas de famosos hechos del arte militar que los príncipes y sus capitanes hazen en las guerras y batallas que emprenden. // Álaba, Perfeto capitán, 1590, fol. 3v: Es llano que sabrá más de la milicia el que sabe de los sucessos y guerras de más de quatro mil años atrás, que el que sólo la huviere exercitado por algún tiempo breve y que, como no se puede llamar buen arquitecto el que no sabe el arte de la Arquitectura, tampoco podrá merecer nombre de buen soldado el que no supiere lo que toca a la arte militar. // Rojas, Teórica fortificación, 1598, fol. 3r: Y para esto, es de advertir que todas las medidas y defensas de fortificación que están escritas de los ingenieros antiguos no nos sirven en este tiempo, conforme que el arte militar presente. 
SIN.: milicia $_{1}$.

ENCICL.: DRAE (1817): El arte de ofender y defenderse los ejércitos, atacar las plazas y defenderlas y de todo lo demás que corresponde a la guerra. / / García de Palacio, Diálogos militares (1583: fol. 38v-39r): "Que mal se pueden conquistar ni ganar reynos no descubiertos; mal se pueden saber sitiar las ciudades sabidas, vistas y andadas sin Mathemática; mal se puede saber ordenar un exército sin Aristhmética, $\mathrm{y}$, finalmente, mal se pudiera aver sacado la brújola, dimensión y orden del artillería sin ellas. Por manera, señor, que las sciencias dichas son muy principales miembros del arte militar, sin las quales no puede dexar de quedar muy imperfecta en algunas occasiones que en las guerras se offrescen".

arze, V. arce.

arzén, V. arcén.

asaltante, assaltante [de asaltar (DECH). Collado, Plática Artillería, 1592]. sust. Fort. Persona que asalta o acomete un lugar fortificado.

Collado, Plática Artillería, 1592, fol. 53v: Impídeseles, finalmente, con la presteza que no puedan retirar adentro la ruyna que la batería ha hecho caer en el fosso, porque a los assaltantes no les sirva de escala al hora del assalto.

FAM.: asaltar, asalto.

asaltar, asaltar, assaltar [de asalto. Quijote, I; Oudin. Falta todavía en C. de las Casas, Percivale y Cov. (DECH). García de Palacio, Diálogos militares, 1583]. v. tr. Mil. Acometer o atacar repentinamente y por sorpresa a una persona o a un grupo. García de Palacio, Diálogos militares, 1583, fol. 185v-186r: Pero, si acaso la gente estuviesse desordenada, a causa de aver sido desbaratados, o asaltados o por otra qualquier sobrevienta, ¿qué orden se podrá tener para recojerlos, y ordenarlos y bolver con mucha presteza a pelear? // Collado, Plática Artillería, 1592, fol. 97v: Al tiempo qu'el exército vadea algún río o passa sobre puentes el exército, o se aloja o se desaloja con priessa el campo, entonces al artillería se le offresce mayores inconvenientes y más peligro y d'ella se deve de tener mayor recelo, por quanto, en semejantes occasiones, cada uno procura de passar seguro el agua, o de alojarse primero y lo mejor que pueda, y entonces el cauto enemigo está prompto y vigilante para assaltarlo y impedirlo. // Roxas, Sumario milicia, 1607, fol. 31v: Asimesmo los que han aprendido el arte militar con mucho cuydado que otros afirman que más peligros suelen aconteçer quando el exérçito marcha que no en el mismo esquadrón quando está peleando, porque allí todos están armados y miran y ven a sus enemigos y bienen con ánimo para combatir; y el soldado quando camina va con más descuydo y, siendo asaltado, luego se turba; por tanto, el capitán deve tener cuydado de que vayan todos alerta. 
SIN.: dar (el) asalto 1 , dar el salto, saltear.

FAM.: asaltante, asalto.

ENCICL.: DRAE (1884): Acometer repentinamente y por sorpresa a las personas, como los ladrones a los pasajeros en los caminos. // Zerolo (1895): Sinon. Asaltar, acometer. Lanzarse sobre alguna persona para hacerle daño, es la idea que presenta la sinonimia de estas dos palabras. Asaltar significa arrojarse atropellada y repentinamente, y acometer hacerlo abiertamente y sin sorpresa alguna. Al que es acometido, parece que no debe cogerle de sorpresa, y de consiguiente que ha de estar preparado para la defensa. El que se ve asaltado se halla en cierto modo sorprendido ya sea por el instante del asalto, que él no había previsto, ya por la impetuosidad o por el número de los que le asaltan.

2 [García de Palacio, Diálogos militares, 1583]. v. tr. Fort. Acometer o atacar impetuosamente un lugar fortificado para entrar en él y tomarlo.

García de Palacio, Diálogos militares, 1583, fol. 87r-87v: ¿Qué se deve hazer antes de asaltar la ciudad cercada y qué advertencias se han de tener en el asaltalla y, después de entrada y rendida, qué se deve hazer con los amigos vencidos y de los despojos y robo? // Álaba, Perfeto capitán, 1590, fol. 89v-90r: Y lo mesmo hizo Alcibíades quando, de repente acometiendo una noche a Eutico, la tomó, poniendo en otra parte de la que pensava assaltar sus trompetas, para que, acudiendo los cercados hazia donde sonavan, entrasse por los lugares desamparados y, estando sin guarda la ciudad, la tomasse. / / González de Medina, Examen fortificación, 1599, pág. 186: Por donde tengo para mí que ha menester ygual defensa una fuerça pequeña que una mediana y también grande, quando la potencia del enemigo no sea tan desaforada que por todas partes bata, y por todas la assalte y escale a un tiempo, que esto, sino es el Turco, nadie tiene potencia para ello.

SIN.: dar (el) asalto 2 , opugnar.

ENCICL.: A partir de la generalización del uso de la pólvora en las operaciones militares, la forma más común de apoderarse de una fortaleza, de un fuerte, de un castillo o de cualquier otro recinto fortificado era entrar por la brecha abierta con la artillería en los muros de esas construcciones, de ahí la siguiente información que sobre las voces asaltar y asalto ofrece Almirante (1869: s.v. asaltar): "En el día, como voz técnica militar, es puramente polémica o poliorcética, y señala el último acto del ataque metódico, formal o regular de una fortaleza. Los trabajos de trinchera o de aproche tienen por objeto acercarse al cuerpo de plaza o recinto; y el coronamiento del camino cubierto, es decir, la posesión de las obras exteriores facilita ver y batir en brecha las escarpas. Arruinado y aportillado el muro, el sitiador asalta, esto es, monta la brecha, trepa y entra por ella para combatir cuerpo a cuerpo con el sitiado, y quedar dueño de la fortaleza. Si el sitiado no se rinde $\mathrm{y}$, aunque desalojado de la brecha, se atrinchera en el interior o en la gola de la obra asaltada, el sitiador corona la brecha, se aloja en ella y bate el nuevo reparo por los mismos medios que el muro anterior, para asaltarlo a su vez. Asalto envuelve técnicamente la idea de brecha o portillo abierto con artillería o mina, como resultado de ataque lento y metódico, como objeto final y decisivo de un sitio". 
asalto, asalto, assalto [del it. assalto, derivado de assalire 'asaltar', lat. assalire (clás. assilire) 'atacar', derivado del lat. salire 'saltar'. 1570, C. de las Casas; Quijote, I; Cov.; ejs. s. XVII, Aut. (DECH). Muñoz, Libro nuevo cometa, 1573]. sust. Mil. Ataque repentino y por sorpresa contra una persona o grupo.

García de Palacio, Diálogos militares, 1583, fol. 68r: Nescessario es, señor, que un campo formado, aviendo hecho alto o marchando en tierra de amigos o enemigos, se vele con gran cuydado y que los soldados de las velas sean tales y tantos que puedan resistir a qualquiera asalto de enemigos, en el entretanto que la demás parte del exército toma las armas y se ordena para pelear. // García de Palacio, Diálogos militares, 1583, fol. 68r-68v: En este particular era César vigilantíssimo y cuydadoso, de que sacó mucho fructo y escusó grandes daños a sí y a su gente, especial en lo que refiere de un asalto y repentino acometimiento que los burgueses hizieron, los quales, rebatidos por las buenas guardas y velas que tenía, desesperaron de poderse defender de un capitán tan cuydadoso y se le rindieron y subjetaron. // Álaba, Perfeto capitán, 1590, fol. 73v: Y para los assaltos, el tiempo más conveniente es aquél en que la gente atiende a las obras naturales del comer o dormir y, assí, será lo más conveniente darlos de medianoche abaxo o a mediodía, como aconseja Vegecio.

SIN.: salto.

FAM.: asaltante, asaltar.

ENCICL.: Domínguez (1853): Embestida hecha con sorpresa y con objeto de hacer daño, especialmente de robar.

2 [García de Palacio, Diálogos militares, 1583]. sust. Fort. Ataque impetuoso y decisivo contra un lugar fortificado para entrar y apoderarse de él.

García de Palacio, Diálogos militares, 1583, fol. 87v: Prevenciones y disposiciones se han referido arriba, que son nescessaríssimas para el combate y asalto de las ciudades y fortalezas sitiadas. Y para lo que vuestra merced pregunta, exemplos tenemos en la Divina Escriptura, que, por ser tan a propósito, es razón se imiten. // Collado, Plática Artillería, 1592, fol. 62r: Si aquel ingeniero piensa y se persuade que una grossísima muralla le ha de deffender de la potencia del artillería, verdaderamente se engaña, porque a la tal potencia no ay muralla que resista, antes la misma materia de una muy gruessa muralla, siendo batida del artillería, hinche el fosso y haze escala al enemigo, con que a los soldados se les facilita el passo a la hora de el assalto. // González de Medina, Examen fortificación, 1599, pág. 198-199: Son buenas tablas con clavos para echarlas en el suelo por donde huvieren de venir al assalto, los clavos hazia arriba, porque como vienen con furia y puestos los ojos en lo que van a hazer, o se mancan en ellas, o se han de ocupar algo en quitarlas para passar.

SIN.: interpresa $a_{2}$. 
ENCICL.: Cov.: Término militar, vale el impetuoso acometimiento que se hace a los muros de una ciudad para entrarla por fuerza de armas. // D'Wartelet (1863): Ataque a viva fuerza y a pecho descubierto contra una plaza de guerra o punto fortificado para tomarle. El asalto se da por medio de escaladas, entrando por la brecha o del mejor medio que permitan las circunstancias. Las columnas de asalto las forman soldados escogidos o voluntarios para este servicio.

dar $\sim$, o dar el $\sim$ [Mosquera, Comentario disciplina militar, 1596]. loc. v. Mil. Acometer o atacar repentinamente y por sorpresa a una persona o a un grupo.

Mosquera, Comentario disciplina militar, 1596, fol. 45v: Ya sabemos que es cosa cierta la mayor parte de la noticia estar en saber el capitán escoger los lugares para combatir y dar el assalto, como dize Plutarco de Timoleón que junto al río Crimessio, por esta ventaja, venció con cinco mil infantes y mil cavallos sesenta mil cartagineses. // Mosquera, Comentario disciplina militar, 1596, fol. 62v: Y aviendo apercebido a todos para la ocasión en que se avía de dar el assalto, se fue llegando la galera capitana con las demás [...], y la galera del capitán Munguía y la Vitoria [...] éstas andavan inquietando por otra parte a los enemigos, por la vanda de la playa [...]. Saltó la gente con ímpetu y de improviso, que assí se ha de hazer pudiendo, por coger desapercebido al enemigo en tanto que las fuerças están divisas y antes que vengan a unirse.

SIN.: asaltar ${ }_{1}$, dar el salto, saltear.

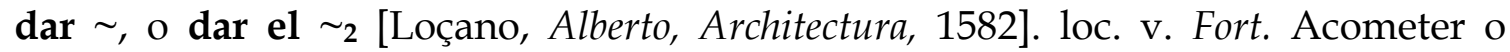
atacar impetuosamente un lugar fortificado para entrar en él y tomarlo.

Loçano, Alberto, Architectura, 1582, pág. 104: Los antiguos architectos reprovaron los ángulos de los muros en el cercar de los lugares, porque ayudan más a los enemigos en el dar el assalto, que no a los moradores en el deffenderse, y porque también en ninguna manera sean fuertes para suffrir las injurias de las máchinas. // Álaba, Perfeto capitán, 1590, fol. 88v: Y desde la trinchea más cercana al fosso donde se da la batería aya arcabuzeros que tiren pelotas de dos onças a los que vieren en las partes batidas hazer defensas, como son contrafossas, trincheas, reparos, cavalleros, estorvando el echar leña en las partes batidas, que muchas vezes se haze, para que los que dieren el assalto con fuegos que en ella echen sean estorvados. / González de Medina, Examen fortificación, 1599, pág. 167: El orejón, aunque el de esquina viva tiene algo menos en qué batir que el redondo, pero, con todo esso, el redondo encubre más y es más dificultoso de derribar. Y aunque tenga más que caer en el foso, no es en parte que el enemigo se determinará a dar por allí assalto, por estar el través tan cerca y no quitado.

SIN.: asaltar, opugnar.

ascolta, V. escolta. 
asediado, assediado [de asediar. Collado, Plática Artillería, 1592]. adj. Fort. Dicho de un lugar fortificado o de las personas que están dentro: que sufren un sitio, un asedio o un cerco.

Collado, Plática Artillería, 1592, fol. 67v: Antes de venir a la plática conviene notar lo que se sigue, conviene a saber, que o el artífice de la mina va minando al enemigo por debaxo de tierra y entonces pretende saber si aquél le contramina o, estando él en campaña o assediado en alguna fortaleza, dessea de saber si el enemigo le viene minando, y aun para saber si, teniendo al enemigo assediado y por faltarle vituallas o por temor alguno, él pretendiesse de escapársele saliendo de noche por debaxo de tierra y por la mina, lo que cada día se vee por experiencia.

SIN.: cercado $_{3}$, sitiado . $_{\text {. }}$

FAM.: asediador, asediar, asedio.

2 [Collado, Plática Artillería, 1592]. sust. Fort. Persona que se halla en una construcción defensiva sitiada, asediada o cercada.

Collado, Plática Artillería, 1592, fol. 53v: También son menester algunas culebrinas y algunas medias, las quales para quitar las defensas dichas son muy apropriadas; sacres, assimismo, y las demás pieças de campaña, para con ellas escombrar el campo y impedir los assaltos y escaramuças de los assediados que saliessen fuera a impedir la batería o si por las espaldas de el campo viniessen enemigos a offender el exército.

SIN.: cercado $_{4}$, sitiado $_{2}$.

ANT.: asediador, cercador, sitiador.

asediador, asediador [de asediar. Collado, Plática Artillería, 1592]. sust. Fort. Persona que sitia, asedia o cerca.

Collado, Plática Artillería, 1592, fol. 37r: Por ser los trabucos o morteros pieças, assimismo, de este tercero género, me ha parescido hazer de ellos particular capítulo en este tratado; los quales trabucos, sabiéndose el artillero bien servir de ellos, ponen con sus balas gran terror y espanto en los ánimos de los sitiados quando los asediadores se sirven de ellos.

SIN.: cercador, sitiador.

ANT.: asediado $_{2}$, cercado $_{4}$, sitiado $_{2}$.

FAM.: asediado, asediar, asedio. 
asediar, assediar [de asedio. 1569, Ercilla (DECH). Collado, Plática Artillería, 1592]. v. tr. Fort. Establecerse en torno a un lugar fortificado para impedir que los que están dentro puedan salir o recibir ayuda, con el fin de obligarlos a rendirse. Collado, Plática Artillería, 1592, fol. 53v: En el presente modo de tirar se trata en qué manera, veniendo a assediar una ciudad, fuerte o otra fortaleza, deva qualquiera governarse con su artillería, quitalle las deffensas y abrir y romperle las murallas, de modo que los soldados fácilmente puedan entrar por ellas. // Collado, Plática Artillería, 1592, fol. 95r: ¿Quién enseñó al ingeniero que nunca assedió tierra ni menos se halló sitiado, a saber hazer la devida electión de un fuerte sitio? // Mendoça, Theórica y práctica, 1596, pág. 80: Por estas causas son mejores los alojamientos en llano, no teniendo padrastro, principalmente si se pone las espaldas a algún bosque, o el costado, o ay lagunas, quebradas o ribera con que guardar los costados o espaldas, advirtiendo que no estén los quarteles de manera que, si la ribera creciesse, los pueda dañar con su avenida, ni el enemigo, sacando algún braço d'ella, anegarlos, ni assimismo assediar el alojamiento con ponerse a la frente de la entrada, no teniendo otra salida el que le ocupa.

SIN.: asitiar, cercar, meter (el) asedio, poner asedio, poner (el) cerco, poner (el) sitio, sitiar.

ANT.: alzar el cerco, alzar el sitio, levantar el asedio, levantar el cerco, levantar el sitio.

FAM.: asediado, asediador, asedio.

asedio, asedio, assedio [probablemente del it. assedio y éste del lat. obsĭdium 'íd.', derivado de obš̀dère 'instalarse enfrente', 'asediar', derivado de sědère 'estar sentado'. Asedio 'acción de cercar un punto fortificado'. h. 1460, poema de Diego de Burgos, secretario del Marqués de Santillana (Canc. de Castillo I), llorando la muerte de éste, ocurrida en 1458 (rima con remedio). En it., assedio desde principios del s. XIV en G. Villani, Petrarca, Boccaccio, etc. (DECH). Loçano, Alberto, Architectura, 1582]. sust. Fort. Operación que se lleva a cabo contra un lugar fortificado con el fin de rendir a los que están dentro.

Collado, Plática Artillería, 1592, fol. 53r: [...] como sería que en el real castillo de Milán tuviesse, a lo menos, dos dozenas de estos cañones, los quales serían bien bastantes para, en tiempo de un assedio, poder grandemente offender el enemigo y defenderle de qualquier assalto, por quanto, por la ligereza de estas pieças, fácilmente se mudan y se socorre de las unas casas matas a las otras. // Collado, Plática Artillería, 1592, fol. 67r: Antes que de la artillería se tuviesse alguna noticia en el mundo, muchas ciudades y fortalezas se hallan fundadas de aquel tiempo, las quales, acerca de sí tienen cerros y montañas que están superiores a ellas, que en estos tiempo en gran manera les son offensivas, por quanto, en tiempo de un assedio y plantándoles el artillería encima el enemigo, las baten y las sojuzgan de tal manera que los sitiados no pueden un punto estar a la defensa ni tenerse por seguros tan sola una hora, de donde viene el ser constreñidos a rendirse con increýble presteza y jamás pensada. // Mendoça, Theórica y práctica, 1596, pág. 124: [...] puesto en razón escrevir, entre las otras facciones de guerra, en la manera que se ha de defender una plaça, siendo esto lo que apura un soldado, y su piedra de toque, 
mostrando los quilates de valor y industria que tiene partes de prudencia y sufrimiento en los trabajos que se passan en sitio o assedio apretado, llevándolos con alegría y contento que anime a los soldados que tiene consigo.

SIN.: cerco, sitio.

FAM.: asediado, asediador, asediar.

ENCICL.: Aut. (s.v. assedio): El cerco o sitio que se pone a algún castillo, ciudad o plaza. // Terr.: En términos de guerra, el acampamento de un ejército o colocación de una armada alrededor de alguna plaza para rendirla.

2 [Mendoça, Theórica y práctica, 1596]. sust. Fort. Operación contra un lugar fortificado consistente en ocupar los sitios por donde suelen entran los víveres, con el fin de tomarlo por hambre.

Mendoça, Theórica y práctica, 1596, pág. 136-137: Este inconveniente se viene a remediar muchas vezes aguzando la propia necessidad los ingenios, valiéndose de cosas para algunos efectos, inventando otras que no eran antes imaginables, particular que confirma las invenciones de que se han valido en los sitios los hombres quando han sido apretados; y en uno de tres en que me he hallado, viniendo a la fin a ser assedio y passarse gran hambre, para dar aviso del estado d'él a los ministros del Rey Nuestro Señor, faltándonos todos los medios para embiar hombres, por aver tomado el enemigo los fossos y puertas de suerte que no podía salir ninguno sin dar en sus manos, nos valimos, atravessando una ribera por la tierra, de embiar hombres en barca y a nado [...].

ENCICL.: Estévanez (1897): Cordón puesto a una plaza para rendirla sin bombardearla ni asaltarla. Si se hicieren trabajos serán puramente defensivos, contra salidas eventuales de la plaza o contra fuerzas auxiliares que puedan venir del exterior, nunca los que se llaman "aproches". // Lucuze (1772: 105): "Se practica ordinariamente en pequeñas fortalezas, que por su ventajosa situación hacen impracticable el ataque, o cuando es numerosa la guarnición y población, sabiendo que carece de los víveres necesarios a la subsistencia".

levantar el [Collado, Plática Artillería, 1592]. loc. v. Fort. Apartarse, desistir del sitio, asedio o cerco de un lugar fortificado.

Collado, Plática Artillería, 1592, fol. 32r: Acontesciole assí al Mustafá, general de la Armada del Turco, en el año de 1565, quando quiso retirarse y levantar el assedio de Malta, donde, a pesar suyo, dexó dos basiliscos, de 200 libras el uno y el otro de 150. // Collado, Plática Artillería, 1592, fol. 103v: Tiros señalados se llaman, señor, aquéllos que, como muchas vezes se ha visto, dando en la tienda de un general de un exército, lo matan o espantan de tal manera que, levantando el assedio, dexa libre una fortaleza.

SIN.: alzar el cerco, alzar el sitio, levantar el cerco, levantar el sitio.

ANT.: asediar, asitiar, cercar, meter (el) asedio, poner asedio, poner (el) cerco, poner (el) sitio, sitiar. 
meter , o meter el [Collado, Plática Artillería, 1592]. loc. v. Fort. Establecerse en torno a un lugar fortificado para impedir que los que están dentro puedan salir o recibir ayuda, con el fin de obligarlos a rendirse.

Collado, Plática Artillería, 1592, fol. 56v: Quando se va meter assedio a qualquier ciudad o otra fortaleza sobre de la qual se haya de plantar el artillería, sobre todas las importantíssimas y más necessarias consideraciones que acerca de esto se han de haver es ésta de saber hazer electión de el sitio donde cómodamente se puede plantar el artillería y ocupar con ella aquellos lugares que más aptos son para offender al enemigo y cubrir y reparar aquéllos de trincheas, reparos y cestones que cubran su artillería y la gente que trabaja acerca de ella. // Collado, Plática Artillería, 1592, fol. 57r: Lo mismo se vio sobre Navarino quando el excellentíssimo señor don Johan de Austria le metió el assedio con la armada de la sancta Liga Christiana, donde, por no hallarse hechos los cestones, ni menos, en aquella playa arenosa, comodidad de poderlos hazer, sacaron los artilleros pipas de tener vino de las galeras y aquéllas plantaron [...]. / / Collado, Plática Artillería, 1592, fol. 96v-97r: Ya, señor, en las siestas passadas vuestra señoría havrá notado las muchas y muy importantes consideraciones y advertimientos que ha de tener un egregio general de artillería en conduzirla y plantarla, y meter assedio y batir una fortaleza.

SIN.: asediar, asitiar, cercar, poner asedio, poner (el) cerco, poner (el) sitio, sitiar.

ANT.: alzar el cerco, alzar el sitio, levantar el asedio, levantar el cerco, levantar el sitio.

poner [Collado, Plática Artillería, 1592]. loc. v. Fort. Establecerse en torno a un lugar fortificado para impedir que los que están dentro puedan salir o recibir ayuda, con el fin de obligarlos a rendirse.

Collado, Plática Artillería, 1592, fol. 95v: La primera, quando, con exército formado, le convendrá poner assedio sobre alguna ciudad o castillo; la segunda, hallándose sitiado dentro y puesto a la deffensa de qualquier presidio; la tercera, quando, en facción de tierra y con la artillería en campaña, será forçado de venir con el enemigo a la batalla; la quarta y última occasión será quando, con marítima armada, se hallará en naval empresa y vendrá a las manos con la armada enemiga. // Collado, Plática Artillería, 1592, fol. 112r: Y llegada que será la armada al lugar que se dessea, que es allá adonde se ha de hazer facción de artillería o poner assedio y expugnar alguna fortaleza, en tal caso, ¿cómo se ha de haver el artillero?

SIN.: asediar, asitiar, cercar, meter (el) asedio, poner (el) cerco, poner (el) sitio, sitiar.

ANT.: alzar el cerco, alzar el sitio, levantar el asedio, levantar el cerco, levantar el sitio.

asentado, asentado, assentado [de asentar (DECH). Montes, Instrucción y regimiento, 1537]. adj. Mil. Dicho de un real o de un campamento: montado o armado y con las tropas ya instaladas en él. 
Montes, Instrucción y regimiento, 1537, fol. IXr: Después de affirmado un exército en una parte, no deven tenello mucho tiempo affirmado, por tres razones que daré para ello: la primera, porque los que están en campaña duermen en el sereno, y al agua, y al sol, y estando d'esta manera vienen a enfermar; lo segundo, que de las tales enfermedades se suele inficionar un exército y venir peste en él, que es gran desasosiego para un exército; lo otro, que quando está mucho tiempo en un sitio, la gente del exército se le derrama, unos a correr, otros a buscar de comer y otros se van a sus tierras, de cansados de la luenga guerra o por no dormir en el sitio donde el campo está assentado por ser malsano. // Álaba, Perfeto capitán, 1590, fol. 84r: Y, llegado cerca del lugar que pretende cercar, dexando el bagaje en el alojamiento que atrás dexó hasta que esté assentado su real y hecho esquadrón de todos los suyos, pondralos en parte que la artillería de los enemigos no les pueda ofender.

FAM.: asentar.

2 [Martínez de Burgos, Reportorio premáticas y Cortes, 1551]. adj. Mil. Inscrito o incluido en el ejército.

Martínez de Burgos, Reportorio premáticas y Cortes, 1551, fol. XXVIIr: Hemos sido informados que los capitanes y soldados, quando se haze gente, comen a discreción en los pueblos y, so color de estar assentados, andan con ellos muchos vagabundos, y cohechan a los pueblos y huéspedes por mudarse de unos lugares a otros.

SIN.: alistado.

asentar, asentar, assentar, hasentar [del lat. vg. *adsĕdĕntare, derivado de sĕdēre 'estar sentado'. Assentar (Cid) (DECH). Montes, Instrucción y regimiento, 1537]. v. tr. Mil. Dicho especialmente de quien ostenta cargos de mando en la milicia: montar el campamento $\mathrm{u}$ ordenar a los soldados que procedan a instalarse en un determinado lugar en despoblado.

Montes, Instrucción y regimiento, 1537, fol. IXr: Por esto, deven de mirar que el exército, quando se hoviere de assentar, no se assiente entre lagunas y lugares empantanosos, porque son muy dañosos para la salud del exército. // Álaba, Perfeto capitán, 1590, fol. 46r: Y aviendo los cimbros seguido a Quinto Luctacio hasta la orilla de un río el qual a él le convenía passar, para divertirlos de su intento, bolvió a hazerles rostro y dio muestra de assentar allí su real, haziendo poner algunas tiendas y pavellones y dando otras señales de assistencia, con las quales assegurados los enemigos, començaron a esparcirse para buscar mantenimientos y las demás cosas necessarias para el exército. // Álaba, Perfeto capitán, 1590, fol. 91v: Fortificado el lugar donde a de assentar el campo para dar la batería, para mostrar que el cerco a de ser largo y que su intento es no desampararle hasta llevar al cabo lo començado, las trincheas y otros reparos que huviere hecho hará que se cubran de piedra por la parte que miran a la ciudad.

ANT.: levantar 2. 
FAM.: asentado.

ENCICL.: Aut. (s.v. assentar los reales o el campo): Es lo mismo que acampar el ejército y las tropas, señalando el lugar que han de ocupar. // Zerolo (1895): Hablando de campamentos, ranchos, aduares, etc., establecerlos temporalmente en algún sitio. // DUE: Instalar un campamento: 'Asentó sus reales en la orilla derecha del río'. // López Vallejo (2008): Colocar o situar [el ejército o campamento en un lugar].

2 [Montes, Instrucción y regimiento, 1537]. v. tr. Mil. Inscribir o incluir a alguien en el ejército.

Montes, Instrucción y regimiento, 1537, fol. IVr: De la tal bandera terná cargo su alférez, que el capitán, para hazer la gente, oviere criado, con el qual alférez o capitán, estará su canciller o fúrer, o un escrivano que assiente todos sus soldados que se vinieren a assentar para seguir la bandera del dicho capitán en servicio de su rey. // García de Palacio, Diálogos militares, 1583, fol. 50v-51r: Para poder escojer en un reyno soldados de quienes se pueda tener buena esperança, deven los capitanes tomar conviniente tiempo para poderlos hazer, porque, por la brevedad d'él, muchas vezes son forçados a assentar y rescebir buenos y malos. // Álaba, Perfeto capitán, 1590, fol. 34v: Y aunque parezca tener estas partes que he dicho, tengo por sano consejo no assentarlos en la lista luego como vienen a ser recebidos, hasta esperar tiempo en que se pueda conocer por alguna esperiencia si con promptitud y fuerça acudirán al uso y trato de la milicia, pues muchos que dan de sí buenas esperanças, provados en algunas ocasiones, descubren la poca suficiencia que tienen.

SIN.: alistar.

ENCICL.: Terr.: Asentar plaza de soldado.

3 [Montes, Instrucción y regimiento, 1537]. v. prnl. Mil. Dicho de una persona: inscribirse en el ejército o entrar voluntariamente a servir como soldado.

Montes, Instrucción y regimiento, 1537, fol. IVr: De la tal bandera terná cargo su alférez, que el capitán, para hazer la gente, oviere criado, con el qual alférez o capitán, estará su canciller o fúrer, o un escrivano que assiente todos sus soldados que se vinieren a assentar para seguir la bandera del dicho capitán en servicio de su rey. // García de Palacio, Diálogos militares, 1583, fol. 17r-17v: Pregunto si el soldado está obligado, antes que se asiente para yr a la guerra, a inquirir si la guerra que el príncipe haze sea justa y a inquirir y examinar si tiene las circunstancias requisitas que vuestra merced ha declarado.

ENCICL.: Cov. (s.v. assentar): Asentar a la guerra, ser soldado. // Zerolo (1895: s.v. asentarse): Inscribirse, alistarse como individuo de alguna congregación, sociedad o cuerpo.

asitiar, assitiar [de sitiar. Raro asitiar, h. 1300, Dicc. Hist.; traducción de las Ilustres Mujeres, Zaragoza 1494 (DECH). Montes, Instrucción y regimiento, 1537]. v. 
tr. Fort. Establecerse en torno a un lugar fortificado para impedir que los que están dentro puedan salir o recibir ayuda, con el fin de obligarlos a rendirse.

Montes, Instrucción y regimiento, 1537, fol. IXr: Quando los franceses ganaron a Apulla, el Gran Capitán se metió en Barleta con muy poca gente española que tenía y el visorrey de Francia, con poderoso exército, venía la vuelta d'él para le assitiar dentro, en Barleta.

SIN.: asediar, cercar, meter (el) asedio, poner asedio, poner (el) cerco, poner (el) sitio, sitiar.

ANT.: alzar el cerco, alzar el sitio, levantar el asedio, levantar el cerco, levantar el sitio.

FAM.: desitiar, sitiado, sitiador, sitiar.

assaltante, $V$. asaltante.

assaltar, V. asaltar.

assalto, V. asalto.

assediado, V. asediado.

assediar, V. asediar.

assedio, V. asedio.

assentado, V. asentado.

assentar, $V$. asentar.

assitiar, V. asitiar.

atacar, atacar [del it. attaccare 'pegar, clavar, unir', 'acometer'; éste probablemente se sacó de staccare, que hoy vale 'separar, despegar', pero primitivamente significaría 'atar'. Atacar 'acometer, combatir'. 1639, dicc. de Trogney (DECH). Mendoça, Theórica y práctica, 1596]. v. tr. u. t. c. intr. Mil. Lanzarse contra alguien para causarle daño o para vencerle. 
Mendoça, Theórica y práctica, 1596, pág. 56: Lo mismo se ha de procurar en el componer un exército en batalla; y si es para representación, darle la forma según el sitio, y a los esquadrones con que la hagan mayor; y si para tentar el enemigo, hazerlo con arcabuzería a cavallo, cavallería ligera, gente desembaraçada y alguna cavallería suelta, travando la escaramuça con tiento que quando se venga a atacar con mayor biveza, no sea apresurando las cargas, de suerte que se aya de venir al cerrar con los demás esquadrones.

SIN.: acometer, combatir 3 , embestir 2 , ofender.

ANT.: defender 2.

ENCICL.: DUE: Lanzarse contra alguien para causarle un daño como golpearle, herirle, matarle o robarle. En la guerra o en una lucha, tener la iniciativa en el empleo de las fuerzas o las armas contra el enemigo, para conseguir un objetivo: 'El enemigo ataca duramente'. El complemento directo puede ser también el sitio donde están las personas o animales atacados: 'Atacar una posición [o un castillo]'. // Almirante (1869): Este verbo, tan militar hoy, es moderno en la milicia. En el siglo XVII, su significado vulgar, que aún se conserva, era atar, ajustar, abrochar una pieza del vestido, como las calzas, el coleto o jubón: de aquí la voz "calzas atacadas". Covarrubias lo trae en este sentido (1612) (sic.). Luego empezó a significar meter y apretar el taco en las armas de fuego, y por extensión cerrar y atrancar la cámara de la mina donde se coloca el cajón de la pólvora. Hoy se sigue con estos significados y además acometer, arremeter, embestir, cargar, sitiar, batir, combatir, cercar, insultar.

atalaya, atalaya [del ár. talâyic, plural de țalîca 'centinela', 'avanzada de un ejército'. Atalaya, m., ant., 'centinela diurno', f. 'lugar donde estaba el atalaya: eminencia o torre desde donde se descubre al país'. 1017 (DECH). Loçano, Alberto, Architectura, 1582]. sust. f. Fort. Torre destinada a vigilar desde ella la lejanía (DUE). .

Loçano, Alberto, Architectura, 1582, pág. 81: Hasta el tiempo de Plinio se vieron torres y atalayas de tierra puestas en las cumbres de los montes, desde el de Anníbal. // Loçano, Alberto, Architectura, 1582, pág. 244: Principal ornamento traen las atalayas quando se hazen en lugares convenientes y con lineamentos cómmodos, y si no estuvieren muy ralas, dexarse han ver desde lexos, aun con dignidad. // Loçano, Alberto, Architectura, 1582, pág. 384: Torres o atalayas, cómo y dónde se han de hazer.

FAM.: atalayador, talayar.

ENCICL.: Cov.: Lugar alto desde el cual se descubre la campiña. Los que asisten en ellas también se llaman atalayas. Éstos dan aviso con ahumadas de día y fuegos de noche, si hay enemigos o si está seguro el campo [...]. Estas atalayas son unas torrecillas puestas en algunos lugares altos y dificultosos de subir a ellos. // Lorenzo Celorrio (1996): Torre situada en un lugar estratégico para controlar visualmente una zona y dar aviso en caso de emergencia mediante señales ópticas y/o acústicas al castillo o fortaleza de la que depende. Lo habitual es que alrededor de una fortaleza se establezca una compleja red de 
atalayas para un efectivo control militar de la zona. // Almirante (1869): Verdaderas torres telegráficas de la Edad Media, constituían redes formales y sistemáticas, y formaban el primer elemento defensivo.

2 [Celso, Reportorio universal leyes Castilla, 1553]. sust. m. u. t. c. f. Fort. Hombre destinado a registrar desde la atalaya y avisar de lo que descubre (DRAE).

Celso, Reportorio universal leyes Castilla, 1553, fol. CLXr: Y después deven ser pagados, primeramente y ante que los otros, las atalayas, y escuchas, y espías y guardas, porque es razón que los que se ponen en mayor peligro que los otros sean primeramente pagados. // Celso, Reportorio universal leyes Castilla, 1553, fol. CLXr: Si por caso no se avinieron en cierta cosa los dichos atalayas, y guardas, y escuchas y espías de la presa o saco, dévense escojer tres o cinco buenas personas que sepan qué es de los tales hechos, y tassen lo que deven aver, y lo que la mayor parte d'ellos tassare y hiziere deve ser cumplido como si todos lo hoviessen hecho. // Mendoça, Theórica y práctica, 1596, pág. 64: D'estos maderos se podía assimismo componer otro ingenio en altura de cinqüenta pies o más, por el qual subía un hombre y baxava con facilidad, descubriendo la campaña en quanto da lugar el altura, viniendo a servir como de atalaya y tocar alerta y arma en caso que viniesse gente, reconociéndolo de lexos.

ENCICL.: Gago-Jover (2002): También atalayero, el que servía en el ejército en puestos avanzados para observar y avisar los movimientos del enemigo.

atalayador, atalayador [de atalayar y éste de atalaya. Loçano, Alberto, Architectura, 1582]. adj. Dicho de una cosa: que domina o descubre gran extensión. Loçano, Alberto, Architectura, 1582, pág. 12: Assí que será la forma del lugar digna y de recreación, que no estuviere baja y como hundida, sino muy alta y muy atalayadora, y en donde se mueva el ayre alegre y con algún continuo espíritu.

FAM.: atalaya, talayar.

atrincheado, V. atrincherado.

atrincherado, atrincheado, atrincherado [de atrincherar. Rojas, Teórica fortificación, 1598]. adj. Fort. Dicho de una persona o de una cosa: protegida con trincheras.

Rojas, Teórica fortificación, 1598, fol. 106r: Y porque el enemigo podría tener hechas algunas retiradas y medias lunas, se advertirá de no entrar por mitad de la media luna, porque desde sus cuernos darán por las espaldas a los amigos, y assí se procurará yr arrimándose a los estremos y puntas de la media luna, procurando siempre de yr cubiertos y bien atrincheados. // Lechuga, Discurso de la Artillería, 1611, pág. 207: Todas las cosas dichas, se traen a la plaça de armas de la artillería donde las municiones estén atrincheradas, 
como digo en mi libro de maestre de campo general, para desde ella yr proveyendo a todas partes, conforme el menester.

FAM.: atrincherar, trinchera, trincherón.

ENCICL.: Almirante (1869): Ordinariamente se dice de un lugar, campo o posición que se fortifica pasajeramente y del ejército que lo ocupa.

atrincherar, atrinchear, atrincherar [de trinchera (DECH). Rojas, Teórica fortificación, 1598]. v. tr. Fort. Defender algo con trincheras o construir trincheras en un sitio (DUE).

Rojas, Teórica fortificación, 1598, fol. 105r: Y luego la cavallería la alojarán de tal manera que cubra a la infantería, y luego se atrinchearán muy bien los quarteles alrededor del castillo. // Roxas, Sumario milicia, 1607, fol. 17r: Y la forma del asiento de los reales se haçen algunas veçes quadrados y otras prolongados, sigún el sitio pidiere, el qual se a de atrincherar alrededor. // Lechuga, Discurso de la Artillería, 1611, pág. 266: De saquillos pequeños, muchos, o recaudo de tela y hilo bramante para hazerlos, por ser con los que se hazen troneras, llenos de tierra, y los que sirven de reparar de presto, por ser portábiles, a la parte que sea necessario henchirla, guardarla o atrincherarla.

FAM.: atrincherado, trinchera, trincherón.

2 [Collado, Plática Artillería, 1592]. v. prnl. Fort. Ponerse una persona en una trinchera para defenderse (DSAL).

Collado, Plática Artillería, 1592, fol. 95r: ¿De dónde se sacó el modo de atrincherarse y cubrirse la gente en un campo? Y, finalmente, ¿quién halló el uso de las minas de fuego, con otras innumerables cosas que dexan aquí de traerse por no ser éste su lugar competente? // Rojas, Teórica fortificación, 1598, fol. 38r: Y por esto, digo que me holgaría, quando yo metiesse trincheas a una plaça, hallarle la estrada muy afuera, y en metiéndole las trincheas hasta el bordo d'ella, por ser tan ancha, haré pie en ella como en campaña rasa y me iré atrincheando hasta el canto del fosso, lo qual no haré si la estrada fuesse estrecha. // Ufano, Tratado de la Artillería, 1613, pág. 91-92: Osaría dezir que ningún otro ynstrumento o máquina en el artillería es de más serviçio y utilidad que el del dicho carromato, además de que, a vezes, espeçialmente en campaña rasa, queriendo el enemigo acometer el campo por todas partes, al çircundarle se puede prestamente atrincherar con los carros matos y bloques que uviere la parte del exérçito que con ellos y otros carros bazíos se quisiere cubrir.

avanguarda, abanguarda [del cat. avantguarda (formado con avant 'ante'). Usual en los siglos XV y XVI (DECH). Ufano, Tratado de la Artillería, 1613]. sust. Mil. Parte de una fuerza armada que en una marcha, ataque, etc., va delante (DUE: s.v. vanguardia). 
Ufano, Tratado de la Artillería, 1613, pág. 145-146: También le obliga, quando parte el trahín, estar presente, porque no aya diferençias sobre el tomar la primiçia y abanguarda del camino, hallándose en presençia de su tiniente de general para lo que sobre tal jornada y su orden le mandare.

SIN.: avanguardia, vanguarda, vanguardia.

ANT.: retaguarda, retaguardia, rezaga.

FAM.: avanguardia, vanguarda, vanguardia.

avanguardia, abanguardia, avanguardia [del cat. avantguarda (formado con avant 'ante'), modificado luego bajo el influjo del it. vanguardia. h. 1375, forma usual hasta la primera mitad del s. XVII (DECH). García de Palacio, Diálogos militares, 1583]. sust. Mil. Parte de una fuerza armada que en una marcha, ataque, etc., va delante (DUE: s.v. vanguardia).

García de Palacio, Diálogos militares, 1583, fol. 159r-159v: Muchas vezes acontesce ser los esquadrones acometidos por la avanguardia y rectaguardia, y aver necessidad de pelear por ambas partes. // García de Palacio, Diálogos militares, 1583, fol. 184v: Deven, pues, también los capitanes traer los mejores soldados de sus compañías apartados de los otros, para hazer d'ellos la avanguardia, rectaguardia y costados. // Roxas, Sumario milicia, 1607, fol. 67r: El que llebare la abanguardia a de caminar con tanta orden que jamás pierda de bista la retaguardia y el bagaje, por si fuere necesario socorrerlo, y que se pueda haçer el socorro a tiempo que no sea perdido o desbaratado.

SIN.: avanguarda, vanguarda, vanguardia.

ANT.: retaguarda, retaguardia, rezaga.

FAM.: avanguarda, vanguarda, vanguardia.

ENCICL.: Cov.: Comúnmente dicha vanguardia. Es en el ejército la primera orden de los escuadrones. // D'Wartelet (1863): Lo mismo que vanguardia en otro tiempo. Ya en el reinado de don Juan II de Castilla se daba este nombre al cuerpo de tropas que precedía al ejército en las operaciones de guerra.

a la [García de Palacio, Diálogos militares, 1583]. loc. adv. En cualquier acción, en primera posición o delante de todos los demás.

García de Palacio, Diálogos militares, 1583, fol. 186v: Y el que, entre los alemanes, se pone en parte do cause desorden, que es a la avanguardia, después de estar puesta la primera orden de los que primero llegaron, es castigado con pena capital.

SIN.: en avanguardia, en vanguardia. 
ANT.: en retaguardia, en rezaga.

en $\sim$ [Ufano, Tratado de la Artillería, 1613]. loc. adv. En cualquier acción, en primera posición o delante de todos los demás.

Ufano, Tratado de la Artillería, 1613, pág. 107-108: Y si marchase el exérçito, asimismo, en solo un cuerpo, marcharía el artillería del modo preferido en abanguardia y retaguardia.

SIN.: a la avanguardia, en vanguardia.

ANT.: en retaguardia, en rezaga.

avanguardia, V. a la .

avanguardia, $\mathrm{V}$. en $\sim$.

avituallar, avituallar [de vitualla. princ. s. XVI, Dicc. Hist. (DECH). Collado, Plática Artillería, 1592]. v. tr. u. t. c. prnl. Mil. Proveer de vituallas (DRAE).

Collado, Plática Artillería, 1592, fol. 96r: Conviene, assimismo, informarse si los de dentro hazen buena guardia o son negligentes en hazerla; si se avitualla de presente aquella fuerça o si a largo tiempo que está bastecida; si le puede entrar, y por dónde, nuevo socorro sin que le pueda ser prohibido [...]. / / Mendoça, Theórica y práctica, 1596, pág. 147: Y quando los labradores y villanage del contorno no se puede despoblar por consideraciones que ay y avituallarse con sus labranças las tierras, se ha de atender tenelle contento y que los soldados no les hagan, saliendo de la plaça a correr, ningún mal tratamiento, porque con esto vienen a dar buenos avisos y espiar con mucho cuydado las acciones del enemigo, juzgando ser el dañarle su mismo provecho.

FAM.: vitualla.

ENCICL.: Aut.: Proveer y abastecer alguna ciudad, villa, plaza o ejército de los víveres o mantenimientos necesarios. Es formado del nombre vitualla y usado en términos militares. // Terr.: En la milicia es introducir víveres en alguna plaza sitiada o que se recela que la sitien. 


\section{bagage, V. bagaje.}

bagaje, bagage, bagaje, bagaxe, vagage, vagaje [del fr. bagage 'equipaje'. 1555, Laguna (DECH). Loçano, Alberto, Architectura, 1582]. sust. Mil. Conjunto de cosas que forman el equipaje de un ejército o de una tropa en marcha, así como las bestias de carga o carros imprescindibles para su traslado.

Loçano, Alberto, Architectura, 1582, pág. 109: Ay caminos reales por donde se camina en la provincia con el exército y vagajes, luego conviene que los reales sean mucho más espaciosos que no los que no lo son. / / Álaba, Perfeto capitán, 1590, fol. 43v: Si no ay temor de enemigos, el vagaje vaya en la vanguardia con una compañía de arcabuzeros, assí porque, si algo se les cayere, aya quien lo vea y avise, como porque, quando los soldados lleguen, hallen armadas las tiendas y aparejado todo lo necessario para su sustento y descanso. // Roxas, Sumario milicia, 1607, fol. 67r: El que llebare la abanguardia a de caminar con tanta orden que jamás pierda de bista la retaguardia y el bagaje, por si fuere necesario socorrerlo, y que se pueda haçer el socorro a tiempo que no sea perdido o desbaratado.

SIN.: rastro.

ENCICL.: Dicc. Hist. (1933-36): Impedimenta, que comprende las bestias y equipaje militar de un ejército o tropa cualquiera en marcha. // Almirante (1869): Bagaje, en general, es el equipaje, la impedimenta de un ejército: todo carruaje o animal que "no entra en combate o formación táctica"; todo lo que un ejército lleva consigo para manutención y comodidad [...]. El equipaje de un ejército moderno no lo forman sólo las maletas de los oficiales; es el conjunto 
de municiones y pertrechos indispensables a la artillería, ingenieros y administración, para batallas, sitios, atrincheramientos y puentes.

bagaxe, V. bagaje.

baibén, $V$. vaivén.

bajo, V. plaza .

bajo, V. través .

balista, balista, balistra [tomado del lat. ballı̌sta 'íd.'. Balista 'máquina de sitio usada en la Antigüedad'. 1536, D. Salazar (DECH). Collado, Plática Artillería, 1592]. sust. Mil. ant. Máquina para arrojar piedras de mucho peso. (fig. 8)

Collado, Plática Artillería, 1592, fol. 2v: Las máquinas, pues, Real Magestad, con que los antiguos solían expugnar las fortalezas y batir las murallas eran éstas: las cathapultas, las balistras, las víneas, los arietes, las testúdines [...], el compago, el escorpión, las sambucas, las faláricas y otras muchas. // Collado, Plática Artillería, 1592, fol. 3v: Nono Marcello dize que balistra propriamente es aquella máquina con la qual se tiravan piedras de grave peso y forma redonda. // Mosquera, Comentario disciplina militar, 1596, fol. 5v: Y en la mesma antigüedad (como dize Vitruvio) los primeros arietes que salieron a luz en el mundo fueron los que los cartagineses en España inventaron, con que allanaron los muros de la ciudad de Cádiz, y, después, subiendo en la mayor fineza que jamás estuvo, la artillería e ingenios de fuego y artificios modernos que sucedieron a las balistas, y a los escorpiones o arcubalistas, y a los trabucos tiradores de piedras.

SIN.: ballesta $a_{1}$, ballestón, ballestón de torno.

FAM.: ballesta, ballestero, ballestón.

ENCICL.: Collado, Plática Artillería (1592: fol. 3v): "Capítulo VII. Que trata de la máquina que los antiguos llamaron balistra y de su forma y effectos que hazía. Usavan, assimismo, Cathólica Magestad, los antiguos en la expugnación de las ciudades de otra máquina que para en aquel tiempo era de importancia grandíssima, por quanto no solamente con ella aquellas gentes, con el grave movimiento de el contrapeso B, tiravan balas de piedra, las quales, con el motu violento de la máquina, subían hazia el cielo y, de motu natural, offendían gravemente a do caýan, matavan las gentes, ahondavan los techos de las casas, assí como el día de oy se haze con los trabucos o morteros, pero aun con aquellas mismas, y de puntería, tiravan grosíssimas balas de piedra, como demuestra la letra A, la qual es la bala que se tira, y con ellas batían las torres y murallas". / / Varela Soares y Neves Adelino (1962-1963: s.v. balista): Engenho de arremeso que dispunha de dois braços no dispositivo 
de arremeso, podendo lançar pedras de $3 \mathrm{kgs}$. à distância de $400 \mathrm{~m}$. atingindo assim o centro das cidades antigas. // Lopes Pires Nunes (2005: s.v. assédio (Engenhos de)): Engenhos utilizados no ataque aos castelos. Estes engenhos agrupamse em três tipos: engenhos de escalamento (escada, escala e torre móvel ou bastida), engenhos de embate ou vaivém (aríete coberto ou descoberto) e, ainda, os engenhos de lançamento (de tiro tenso, como a balista e o escorpião e, de tiro curvo, como o trabuco, o trabuquete e a manganela).

balistra, $\mathrm{V}$. balista.

balla, V. valla.

ballado, V. vallado.

ballesta, ballesta, vallesta [del lat. ballǔsta 'balista'. Med. s. XIII, Calila, Fn. Gonz., 1. ${ }^{a}$ Crón. Gral. (DECH). Urrea, Vitruvio, Architectura, 1582]. sust. Mil. ant. Máquina para arrojar piedras de mucho peso.

Urrea, Vitruvio, Architectura, 1582, fol. 5r-5v: Assí que estuve presente con Marco Aurelio y Publio Minidio y Gneyo Cornelio al aparejar las vallestas y escorpiones y la artillería y todas las otras máchinas de guerra. / / Urrea, Vitruvio, Architectura, 1582, fol. 137r: Hízola con cilicios con que se cubren los tablados y con cueros crudos, de tal arte que pudiessen suffrir el golpe de las piedras que echava la ballesta, de peso trecientas y sessenta libras. // Álaba, Perfeto capitán, 1590, fol. 47v: Otros ponen por mejor la quadrada, la qual reparten d'esta manera: la parte de dentro ocupavan con tiendas y pavellones, lo de fuera yva ordenado en forma de muro, con sus torres en iguales espacios, y en los que avía de una a otra ponían ballestas y todos los géneros de máquinas para armas arrojadizas, y en los quatro lados del alojamiento hazían puertas.

SIN.: balista, ballestón, ballestón de torno.

FAM.: balista, ballestero, ballestón.

ENCICL.: Almirante (1869): [...] Naturalmente debió de tener en la Edad Media el significado de máquina de proyección y de sitio, traduciendo la voz original greco-latina ballista [...]. // Terr.: [...] Los antiguos tenían unas grandes máquinas de arrojar, y algunas se llamaron también ballestas. // Cov. (s.v. vallesta): Y también se llamaban vallestas unas ciertas máquinas con que arrojaban piedras gruesas.

2 [Celso, Reportorio universal leyes Castilla, 1553]. sust. Mil. Arma portátil para disparar flechas o saetas, que consiste, principalmente, en un palo, un arco flexible 
en el remate de éste, una cuerda atada a los extremos del arco y un disparador, hacia el que se lleva la cuerda violentamente para que salga el proyectil con fuerza. (f) (fig. 9)

Celso, Reportorio universal leyes Castilla, 1553, fol. XLIVr: El ballestero, si tirare de la ballesta donde acostumbra de atravessar y passar gente, si su ballesta desarmare o desparare contra su voluntad, y con el passador o saeta él hiriere o matare algún hombre por caso, tenido es el ballestero al daño, porque él no devía tirar ni jugar con la ballesta donde acostumbra de passar gente. // García de Palacio, Diálogos militares, 1583, fol. 55r: También traen montantes, lanças, dardos, arcos, ballestas, las quales ya no son muy usadas a causa de no poder traer consigo la munición nescessaria, y, sin dubda ninguna, que, en tiempo de pluvias y tierra húmeda, siendo buenas y bien adereçadas, assí por la facilidad y presteza con que se arman y desarman, como porque sus efectos son fortíssimos, no se devían deshusar ni tener en poco. // Álaba, Perfeto capitán, 1590, fol. 130r: Los arcos y ballestas, aunque no están muy puestas en uso, son armas de mucho efeto contra la gente que no está muy armada; y, tiradas de cerca, en alguna ocasión podrían ser de tanto daño como los arcabuzes y aun de mayor en tiempo de lluvias, por la humedad de la pólvora.

ENCICL.: Almirante (1869): Arma manual de tiro en la Edad Media, con propagación cierta en Europa después de las Cruzadas (donde se tomaría de la milicia bizantina) que vino a ser el arco primitivo perfeccionado, y cuya aparición o resurrección, precursora de la de las armas de fuego, revela de suyo perfección en las artes mecánicas, y anuncia modificaciones, en la fortificación, espaciando las torres; en la táctica, por la importancia que comienza a dar a la infantería, hasta entonces poco apreciada. // Estévanez (1897): La ballesta no fue desechada ni aún después de la invención de la pólvora y del arcabuz, pues alternó con éste en los campos de batalla más de la mitad del siglo XVI. / / Aut.: Arma de que se usaba antiguamente en la guerra para disparar flechas. Plinio, lib. 7. cap. 56, dice que fue invención de los Phenices. Hoy sólo tiene uso para la diversión de la caza, poniendo en ella una bolillas de barro, que se llaman bodoques, en lugar de las flechas. Es un palo de cuatro a cinco palmos de largo, de dos a tres dedos de grueso y en la parte ulterior tiene fijado un arco de acero flexible, en el cual atraviesa de una punta a otra una cuerda doblada y en medio tiene una caja hecha con dos palitos y cuerda de vigüela, donde se pone el bodoque, y trayendo la cuerda con violencia a un disparador que está en medio del palo, como está oprimida y violenta, arroja la flecha o el bodoque con gran fuerza. Encima del arco o media luna de acero tiene una puentecilla con una cuenta, y en medio del palo una mira como la de los arcabuces, que uno y otro sirve para hacer la puntería.

ballestero, ballestero, vallestero, vallestrero [de ballesta. s. XIII (DECH). Celso, Reportorio universal leyes Castilla, 1553]. sust. Mil. Soldado armado de ballesta.

Celso, Reportorio universal leyes Castilla, 1553, fol. XLIVr: Ballestero, son muy necessarios para la guarda y defensión de un castillo. / / García de Palacio, Diálogos militares, 1583, fol. 187v: Que siempre se haga y deshaga a la parte de fuera, para poder pelear libremente todos los de la batalla, assí piqueros y alavarderos, como escopeteros e ballesteros, los quales no podrían tirar ni pelear bien si lo dicho se hiziesse para dentro. // Álaba, Perfeto capitán, 1590, fol. 130r: Y no tendría por negocio de poco provecho el traer una rodela atrás 
para valerse d'ella en las ocasiones que la pica no pudiere aprovechar, como es quando se pelea con flecheros y ballesteros, y en otros semejantes casos.

FAM.: balista, ballesta, ballestón.

ENCICL.: Almirante (1869): Los extranjeros, unánimes, nos conceden a los españoles suma destreza en la ballesta [...].

ballestón, ballestón [de ballesta. Álaba, Perfeto capitán, 1590]. sust. Mil. ant. Máquina para arrojar piedras de mucho peso.

Álaba, Perfeto capitán, 1590, fol. 142r: Y Domicio Córbulo, teniendo cercados los armenios que, huyendo, se retiraron en Certa, cortando la cabeça a uno de los magesanos que tenían cautivos, con un ballestón la arrojó en los reales de sus enemigos, con cuya vista desmayando ellos, se vinieron a rendir y sujetar. // Roxas, Sumario milicia, 1607, fol. 45v: Y asimismo es necesario recojer gran copia de nierbos con mucha diligencia para los onagros o ballestones, los quales son buenos de las cerdas y clines de cavallos y bueyes y otros animales semejantes $\mathrm{y}$, aun a falta, los cavellos de las mugeres son buenos.

SIN.: balista, ballesta $a_{1}$, ballestón de torno.

FAM.: balista, ballesta, ballestero.

ENCICL.: Aut.: Máquina militar de que se servían antiguamente para arrojar piedras y ofender con ellas. // Almirante (1869: s.v. ballesta): [...] Fuera de esta significación vulgar y principal, como arma portátil y manual, naturalmente [ballesta] debió de tener en la Edad Media el significado de máquina de proyección y de sitio, traduciendo la voz original grecolatina ballista que como hemos dicho se confunde con catapulta. Pero al propagarse la ballesta de mano, ya se ve en las Crónicas distinguir la antigua máquina con el nombre aumentativo de ballestón o ballesta de torno.

$\sim$ de torno [Álaba, Perfeto capitán, 1590]. cmpt. sintag. Mil. ant. Máquina para arrojar piedras de mucho peso.

Álaba, Perfeto capitán, 1590, fol. 44v: Emilio Paulo, cónsul, llevando su armada contra los lucanos por un camino estrecho que estava junto a la orilla de la mar, que, impidiéndole el passo con gran resistencia de armas para reprimir su furia, puso delante todos los captivos de Lucania que traía y, por no ofenderlos, dexaron de tirar con unos ballestones de torno con que los ofendían gravemente, dándoles lugar a passar.

SIN.: balista, ballesta 1 , ballestón.

balón, balón [del it. pallone, aumentativo de palla. Balón 'pelota grande'. $3^{r}$. cuarto s. XVI, Cervantes de Salazar (DECH). Ufano, Tratado de la Artillería, 1613]. sust. 
Fort. Bolsa o recipiente de lienzo u otro material semejante que, relleno de tierra, arena o lana, se emplea para hacer defensas o reparos.

Ufano, Tratado de la Artillería, 1613, pág. 189: Qüestión sobre cómo se hará una batería con sacas y balones de lana hallándose con ellos y caresçiendo de otros qualesquier materiales. // Ufano, Tratado de la Artillería, 1613, pág. 189: Pues avemos ydo, Señor Capitán, hasta ahora discurriendo largamente de baterías, querría saber de cómo, no aviendo tierra ni faxina y hallándonos con sacas o balones de lana, se podrían seguramente alojar pieças a prueva.

SIN.: saca, saco ${ }^{1}$.

ENCICL.: Terr.: Saco de lana que sirve en la guerra, comercio, etc.

baluarte, baluarte, valuarte [del fr. ant. boloart, balouart 'íd.' (hoy boulevard), y éste del neerl. med. bolwerc, es decir, 'obra (werk) hecha con vigas gruesas (bol = alem. bohle)'. Al castellano debió de llegar a través de la lengua de Oc. o del catalán (baluard), donde aparece también en el siglo XV. h. 1460, Vida de D. Álvaro de Luna (DECH). Escalante, Discurso de la navegación, 1577]. sust. Fort. Elemento u obra de fortificación de forma pentagonal, que se destaca y sobresale en los ángulos o esquinas de una fortaleza. 5 (fig. 10)

Escalante, Discurso de la navegación, 1577, fol. 85v: En todos los baluartes en que ay sus garitas, assisten de noche centinelas que las remudan por sus quartos del cuerpo de guardia que es ordinario, andando siempre los oficiales como les toca, con el número de soldados que les parece en ronda y contraronda. // Rojas, Teórica fortificación, 1598, fol. $38 \mathrm{v}$ : Si me piden una plaça que la puedan cubrir y guardar 800 hombres, la haré de cinco valuartes, y si la quieren que no sea más de para trezientos o quatrocientos, la haré de quatro; mas si me pidiessen una plaça para solos 100 hombres, haré una torre sin valuartes, porque 100 hombres no pueden guardar ninguna plaça que tenga cortinas y valuartes. / González de Medina, Examen fortificación, 1599, pág. 24-25: Los baluartes han de tener de frente, cada lado, las dos tercias partes de la cortina o dozientos y cincuenta pies de largo, y de alto dos pies más que las cortinas, porque es bien que estén aquellos más eminentes y que descubran más que ellas.

SIN.: bastión 3.

ENCICL.: Aut.: Es un cuerpo pentágono que, puesto en los ángulos de la plaza, sale avanzado hacia la campaña para defender el muro. Son de diferentes modos y figuras. // Terr.: Término de fortificación, es una gran masa de tierra, algunas veces reforzada con ladrillo y otras con piedra, que sale fuera de la plaza para fortificarla a la moderna [...]. Hay baluartes vacíos y terraplenados, éstos son mucho mejores por la facilidad que hay de hacer cortaduras en ellos, si acaso el enemigo gana alguna parte del baluarte. // Lorenzo Celorrio (1996): Fortificación pentagonal que sobresale al exterior en el encuentro de dos lienzos de muralla. Es una "evolución" del cubo en las esquinas de las murallas para no presentar ángulos muertos de tiro en la defensa de una fortaleza. Se generaliza a partir del siglo XVI, siendo el origen de una serie de técnicas defensivas que permanecerán vigentes 
hasta el siglo XIX. // Lopes Pires Nunes (2005: s.v. baluarte): Na planta de um baluarte definem-se três partes -a gola, os flancos e as faces. O baluarte acabou por ser o elemento onde a artilharia se concentrava no flanco, protegida ou não por um orelhão e era pela sua face que os ataques inimigos se conduziam [...]. Duarte d'Armas e outros autores do início do séc. XVI, numa época em que a nova terminologia da fortificação abaluartada ainda não era muito clara, utilizam o termo baluarte para designar qualquer obra fortificada. / / Para saber cómo fueron evolucionando los baluartes desde finales de la Edad Media hasta su total desarrollo ya avanzada la época moderna, vid. Lopes Pires Nunes, s.v. transição (baluarte de), s.v. bastilha, s.v. cubelo, s.v. puntoni, s.v. rondelle y s.v. transição (fortificação de). Además, acompaña muchos de estos artículos lexicográficos con interesantes imágenes en las que pueden verse las diversas transformaciones que fue experimentando este importantísimo elemento de fortificación. // Rojas, Teórica fortificación (1598: fol. 39v): "El valuarte es aquél donde están las dos casas matas, y dízese valuarte de vallo, vallas, que quiere dezir 'fortificar', o belli arte, que quiere dezir, 'arte de guerra'; porque en el valuarte están las casas matas y traveses, y las espaldas y orejones, que, en efeto, está allí todo el arte de la fortificación y, por esto, se dize valuarte". // Roxas, Sumario milicia (1607: fol. 73r): "En la fortificaçión de una ciudad los baluartes son los más principales miembros que ay, los quales se han de poner en las partes que pueda más ofender al enemigo y defenderse a sí mismos y a la ciudad, y se ha de guardar devida distançia, de manera que el uno se guarde al otro con el artillería y arcabuzería, y, ansimismo, las cortinas de entre el uno y otro baluarte". // Roxas, Sumario milicia (1607: fol. 76r): "Los baluartes se hazen sobre los ángulos, de la forma que fuere la çiudad; haçerse an de la medida que se verá en su tabla, y deben de ser siempre que se pudiere obtusos, porque son más fuertes y más capazes, que se entiende que la punta sea obtusa y no aguda".

2 [Álaba, Perfeto capitán, 1590]. sust. Fort. Cualquier fortificación o defensa en forma de baluarte.

Álaba, Perfeto capitán, 1590, fol. 46r: Y si, para estorvar el passo del río, viniere detrás el enemigo, hará lo que hizo Sertorio que, teniendo en España a las espaldas el campo contrario, aviendo de passar un río, hizo un baluarte en la ribera, a manera de corva luna y, cargándole de madera seca, le puso fuego con que, desviando los enemigos, pudo passar su exército con libertad. // Rojas, Teórica fortificación, 1598, fol. 78r: Ay algunos assientos de ciudades que son ofendidas de algunas alturas o padrastros [...]. El mejor y más seguro remedio de todos es, si fuere possible, tomar las alturas y padrastros con las murallas de la ciudad. Mas quando por algunos respetos no se pudiesse comprehenderlo y ceñirlo todo, se deve retirar tanto adentro que la ofensa de aquel monte o padrastros, por quedar mucho afuera, no sean de ningún valor. $Y$ quando no se pudiesse hazer ninguna d'estas dos cosas, será necessario fortificarse el encuentro de los padrastros, de tal forma que se pueda resistir a todo el daño que d'ellos se pueda hazer, poniendo delante un valuarte por esquina, si el sitio lo sufriere. // Roxas, Sumario milicia, 1607, fol. 87r: Y si no se pudiere poner la punta del baluarte, se hará una tenaza que tenga su cortina con dos traveses fuertes y más altos, que cubran la gente con un cavallero en el lugar que más conbenga, que sea ygual al monte y algo más, porque se entiende que está muy çerca, y con tal parapeto o capaçidad qual combiene a tan grande ofensa. 
ENCICL.: DUE: Recinto fortificado u obra de fortificación. // Moretti (1828: s.v. baluarte destacado): Es un reducto en forma de baluarte.

3 [Collado, Plática Artillería, 1592]. sust. Fort. Cualquier construcción elevada que permite al sitiador, con la artillería allí asentada, batir de forma dominante la fortaleza.

Collado, Plática Artillería, 1592, fol. 91v: Algunas vezes se le offrescerá al artillero la necessidad de alçar el sitio o plaça donde se ha de plantar el artillería, allanarla y ensancharla, y otras, por no haver la comodidad de sitio donde plantarla, levantar bestiones de tierra para, dende allí, batir la fortaleza enemiga, y aun muchas vezes será forçado el ingeniero a querer levantar un baluarte o cavallero de faxina y tierra, para poder después guarnescerlo por defuera con su camisa de muralla. // Roxas, Sumario milicia, 1607, fol. 46r: Un baluarte se lebanta de tierra y fajina enfrente de la muralla para señorear desde allí la plaça y tirar. // Ufano, Tratado de la Artillería, 1613, pág. 194: Qüestión de cómo, dentro de un caballero o baluarte, se puede hazer una contrabatería y alojar en ella pieças secretamente cubiertas con espaldas, para con ellas, sin peligro alguno, desmontar la enemiga artillería.

SIN.: bastión 1 , caballero 3 , plataforma 2 .

medio [Rojas, Teórica fortificación, 1598]. cmpt. sintag. Fort. El que consta, por un lado, de flanco y frente y, por el otro, de una línea recta. 3 (fig. 11)

Rojas, Teórica fortificación, 1598, fol. 46r: Esta figura hecha de quatro medios valuartes es muy a propósito para un fuerte en campaña, echando el ojo a hazerles las troneras en cada ángulo, como lo muestran las OO. // González de Medina, Examen fortificación, 1599, pág. 105: Hazerse ha con unos medios baluartes, a manera de estrella, que, pues no puede ser batida de tierra, sino del agua, donde la artillería no tiene la fuerça que es menester para batir un baluarte de los perfectos, no ha menester más de medio ni más de una casamata. // González de Medina, Examen fortificación, 1599, pág. 108: El terrapleno de la cortina a la mar no tiene necessidad de ser tan ancho como los otros, por lo mal y incierto que se bate de la mar, a cuya causa y el no ser más de medios baluartes los dos que cierran con la cortina, se escusa muy gran gasto.

ENCICL.: Lopes Pires Nunes (2005: s.v. meio baluarte): Baluarte incompleto. O meio baluarte tem, de um lado, o flanco e a face normais e, no outro, é rectilíneo.

banguardia, V. vanguardia.

banqueta, banqueta, vanqueta [de banco. 'Asiento' (fin s. XIV, López de Ayala), 'andén a lo largo de varias construcciones' (1687) (DECH). González de Medina, Examen fortificación, 1599]. sust. Fort. Muro de piedra que a veces se construye delante de los baluartes. (fig. 12) 
González de Medina, Examen fortificación, 1599, pág. 16: Señor, ha de hazerse de muchos, los quales, pues assí lo mandáys, son: cortinas, baluartes, parapeto, casas matas, orejones, terraplenos, contrafortes, banqueta, foso, refosete, contraescarpe, estrada, cubierta, contraminas, vallado, puente, puerta principal, puerta del socorro, cuerpo de guardia, yglesia, casas, calles, magazenes para artillería y municiones y instrumentos de defensa. // González de Medina, Examen fortificación, 1599, pág. 37: La banqueta ha de ser delante de la frente de los baluartes, del propio largo d'ellos, apartada diez pies de la muralla de su cimiento; ha de ser de piedra; de quatro pies de ancho es muy buena y de provecho, , para que lo que desmoronare de la batería que se hiziere cayga entre la banqueta y la muralla del baluarte y no ocupe el foso. // González de Medina, Examen fortificación, 1599, pág. 217: La banqueta, CC, del largo de los baluartes, de duzientos y noventa pies, diez de alto, quatro de gruesso y diez del baluarte apartado.

ENCICL.: Paniagua Soto (1998): Muro de fortificación coronado por un andén y guarnecido con una pared y paramento.

2 [Lechuga, Discurso de la Artillería, 1611]. sust. Fort. Espacio que en algunas fortalezas se deja entre el terraplén y el foso.

Lechuga, Discurso de la Artillería, 1611, pág. 249: A las que an de ser de tierra es menester que, del principio de sus murallas hasta el del fosso, se les dexe tanta tierra como cinco pies en todo su circuito, que llaman banqueta, para que la fábrica quede segura y que baje al fosso a escarpa para mayor firmeza, mirando que desde la dicha banqueta se a de tomar la medida de la que an de tener los fossos. // Ufano, Tratado de la Artillería, 1613, pág. 180: $\mathrm{Si}$ en el arçe del fosso y banqueta del pie de la muralla uviere plaça cubierta de orejones, tenazas o bestiones para alojar pieças, algunas de menor calibre serán de grandíssimo effecto, porque de tales puestos resulta el mayor daño que los sitiadores reçiben.

ENCICL.: Clairac y Sáenz (1877-1891): La faja de terreno que se deja en los desmontes entre su arista superior y el pie de los caballeros, y en los terraplenes entre su pie y las zanjas de préstamos o los cierres. También se llama berma. // DRAE (s.v. berma): Mil. Espacio al pie de la muralla y declive exterior del terraplén, que servía para que la tierra y las piedras que se desprendían de ella al batirla el enemigo, se detuviesen y no cayeran dentro del foso. // Lucuze (1772: 26): "En Países que carecen de buena mampostería y abundan de praderías revisten con tepes o céspedes el terraplén, dejando entre éste y el foso un espacio de cinco o seis pies, llamado el bancón o berma, en que ponen estacada, para que las ruinas de la muralla no caigan en el foso".

3 [Lechuga, Discurso de la Artillería, 1611]. sust. Fort. Peldaño construido en lo interior y al pie de un parapeto. $\$$ (fig. 14)

Lechuga, Discurso de la Artillería, 1611, pág. 241: El parapeto de la estrada cubierta a de ser alto, ocho pies, y a de tener su banqueta tan alta que los soldados puedan, puestos en ella, descubrir la campaña. // Rojas, Compendio fortificación, 1613, fol. 36v: Y el parapeto principal de encima de los baluartes ha de ser muy gruesso, o muy delgado; gruesso, para prueva del cañón; delgado, para sólo el mosquete. Para el cañón, tendrá 20 pies de gruesso, por lo menos, y de alto cinco pies, con su banqueta o grada para subir a ella el 
soldado que fuere pequeño de cuerpo. // Rojas, Compendio fortificación, 1613, fol. 37v: Tendrá de hancho la gola 100 pies, tendrá el parapeto de encima de las murallas y baluartes a 20 pies de grueso, y de alto cinco pies con su vanqueta, y, para más perfección y fortaleza del baluarte, se hará una espalda en lugar del parapeto que tenga quarenta pies de grueso y cinco pies en alto.

SIN.: escalón, grada.

ENCICL.: Aut.: Uno como poyo que se levanta en la muralla, estrada encubierta u otra fortificación al pie del parapeto, para que el soldado subiendo en él pueda disparar descubriendo más la campaña y bajarse después para cargar el arma estando a cubierto. Es voz de la fortificación. / / Sanz (1749): Es una pequeña elevación de tierra o mampostería de ladrillo en forma de un escalón, que corre todo lo largo del parapeto y facilita la subida para poder tirar sobre él, hacer fuego al foso y al camino cubierto. La altura de una banqueta es de pie y medio y su ancho de tres pies.

4 [Rojas, Teórica fortificación, 1598]. sust. Constr. En un cimiento, partes laterales de su grosor cuando éstas exceden la anchura del muro que se levanta sobre él (Paniagua Soto 1998: s.v. zarpa). $\$$ (fig. 15)

Rojas, Teórica fortificación, 1598, fol. 92v: Y si el fundamento se huviere de hazer sobre arena, y que la arena se halle a un estado o dos debaxo de la superficie de la tierra, en tal caso no ay que hazer otra cosa sino explanar bien la superficie del arena a la anchura que ha de tener la muralla, con más quatro o cinco pies de vanqueta. // Rojas, Teórica fortificación, 1598, fol. 93v: Y por la parte que huviere de aver fosso se ahondarán los cimientos de tal forma que salgan desde el plan del fosso, después de ahondado, y dos pies más, y allí se bolverá a echar los maderamientos que he dicho, guardando siempre en estos fundamentos buena banqueta. // Rojas, Teórica fortificación, 1598, fol. 97r: Y si se ofreciere hazer la fábrica en alguna ladera o cuesta arriba, se procurará que las murallas de la parte de abaxo de la cuesta sean más gruessas que las de la parte de arriba, y que corra su nivel hazia la cuesta, dexando por la parte baxa gran banqueta o rodapié a la muralla, de suerte que no sea bastante todo el peso del edificio a cascar ni hender las murallas de la parte de abaxo.

SIN.: rodapié.

barbacana, barbacana, barvacana [del ár. vulgar b-al-baqára (clásico bâb albáqara) 'puerta de las vacas' porque la barbacana protegía un recinto intermedio entre esta fortificación y la muralla principal, en el cual los sitiados guardaban el ganado destinado a proveerlos de carne; balbacara se cambió en barbacana probablemente por influjo de albarrana 'torre rodeada por la barbacana'. Barbacana 'obra de fortificación avanzada, para defender puertas de plazas y cabezas de puente'. s. XIV, Juan Manuel; med. s. XIII en gallego ("nen torre nen barvacãa nen muro" Ctgs.) (DECH). Loçano, Alberto, Architectura, 1582]. sust. Fort. ant. Muro bajo 
que para mayor defensa se levanta delante del muro principal (DRAE: s.v. falsabraga). (fig. 16)

Loçano, Alberto, Architectura, 1582, pág. 20: También me agrada la razón de Vitruvio, la qual veo ser guardada a cada paso en Roma por los antiguos architectos, y principalmente en las murallas de Tarquino, que se le pongan en bajo barbacanas. // González de Medina, Examen fortificación, 1599, pág. 111: No se hará con foso, si no fuere quedando mucho terreno fuera de la muralla, por no enflaquezer el edificio, sino muchas contraminas, con muy hondos poços, para reservarse de las minas; y alrededor de la fuerça una estrada con un parapeto, levantado a modo de barbacana, para que sirva de surtida o salida, y que lo que se batiere de la muralla cayga entre ello y la muralla y dificulte la entrada. / / González de Medina, Examen fortificación, 1599, pág. 150: Por tanto, yo tengo una ciudad con muralla vieja y flaca, sin barbacana, a lo antiguo, con sus torreones redondos y muy juntos: ¿cómo lo remendaríades que quedasse en defensa?

SIN.: contramuro.

ENCICL.: Cov.: La muralla baja, cerca del foso, que está delante del muro. // Aut.: Fortificación que se coloca delante de las murallas, que es otra muralla más baja, y se usaba de ella antiguamente para defender el foso y modernamente ha tenido uso, aunque con el nombre de Falsabraga. Hoy está reformado enteramente este género de fortificación, por haberse reconocido que es más contrario que favorable. / Martinena Ruiz (1994: 213214): "En las partidas de las distintas obras que hemos tenido ocasión de manejar, suele diferenciarse con bastante claridad la barbacana, como defensa exterior, de lo que constituye propiamente el recinto principal del castillo. Este elemento defensivo podía rodear por completo el perímetro o proteger únicamente una zona de particular interés estratégico: la puerta, un flanco o uno cualquiera de los frentes".

barraca, barraca [del cat. barraca y éste de origen desconocido, quizá prerromano. 1569 (DECH). Ufano, Tratado de la Artillería, 1613]. sust. Fort. Defensa o fortificación hecha con fajinas.

Ufano, Tratado de la Artillería, 1613, pág. 381: Si se quisiere dar fuego a una barraca o faxinada, hazer un ballestón grande que su berga sea flexible y se dexe vencer en tiempo de su operación, de forma que dulce y fácilmente se arme con un ynstrumento o gaffón y pueda tirar una pequeña bomba encaxada en un flechón, de suerte y manera que en la presente figura se representa, con aquel harpón a la punta que es el que haze presa y se hinca en la faxina o techo de barraca, casa o baxel donde acierta a dar, según y para el effeto que se tira.

SIN.: fajinada $a_{2}$

ENCICL.: Aut.: La choza o habitación rústica cubierta de fajina que, para defenderse de las inclemencias del tiempo, disponen los que habitan en el campo o los soldados cuando están en campaña y no tienen tiendas. 
barrera, barrera [de barra, voz prerromana común a todas las lenguas romances menos el rumano. h. 1300 (DECH). Mendoça, Theórica y práctica, 1596]. sust. Fort. Cualquier obra o elemento con que se cierra el acceso a un lugar fortificado. Mendoça, Theórica y práctica, 1596, pág. 91: Assimismo ha acontecido mezclarse de manera con el enemigo que se ha ganado la plaça, entrando a buelta los unos con los otros en ella, a causa del averse desordenado al retirarse y no tener prevenida la guardia de las puertas con barreras y otras cosas que se acostumbran en las plaças donde se bive con recato y buena guardia. // Mendoça, Theórica y práctica, 1596, pág. 132: Y aviendo cavallería en ella de guarnición, se les ordena ronden a cavallo de noche, y entre las dos puertas o rastrillos están los cavallos de los soldados que se han de poner fuera de la tierra de centinela, si los caminos dan lugar para ello, teniendo hecho barreras, para que, en caso que sientan rumor, se puedan retirar con seguridad, dando aviso d'ello. // Ufano, Tratado de la Artillería, 1613, pág. 158: Y visto que por ninguna vía alcançava sino solamente a las barreras y paresçiéndole que la falta venía de tener su plataforma muy baxa, al momento la hizo alçar seis pies más alta y, plantando su artillería ençima, siempre que tirava de allý adelante, metía sus balas en la villa.

FAM.: embarrar.

ENCICL.: DUE (s.v. barrera ${ }^{1}$ ): Cualquier dispositivo con que se obstaculiza el paso por un sitio. // Rubió y Bellvé (1895-1901): Tienen variedad de formas y dimensiones, según el uso a que se destinan.

\section{barrunta, V. barrunte.}

barrunte, barrunta, barrunte [puede tratarse de un vasco antiguo barrunti 'interioridad', hoy conservado en varias localidades del País Vasco oriental, en formas levemente alteradas (barronde, barrunda) y derivado de barru(n) 'dentro, interior'. Barrunte 'acción de espiar y noticia que trae el espía', 'espía, sujeto que trae noticias del enemigo' (DECH). Celso, Reportorio universal leyes Castilla, 1553]. sust. m. u. t. c. f. Mil. ant. Persona que se envía a observar con cuidado y disimuladamente al enemigo para que, después, informe de sus movimientos.

Celso, Reportorio universal leyes Castilla, 1553, fol. XLIVv: Barruntes, llamavan los antiguos espías, de los quales y de su officio dezimos de yuso, en el capítulo espías. // Celso, Reportorio universal leyes Castilla, 1553, fol. CXXXIIIr: Espías, los antiguos las llamaron barruntas, y son aquéllos que andan con los enemigos para saber hechos, para que puedan apercebir y avisar aquéllos que los embían.

ENCICL.: DRAE: m. ant. espía ${ }^{1}$.

barvacana, V. barbacana. 
bastimento, bastimento [de bastir, con influencia catalana o galorrománica, y éste de basto. Bastimento 'provisión'. 1242 M. P., D. L. (DECH). Fernández de Enciso, Suma de Geographía, 1530]. sust. u. m. en pl. con el mismo significado que en sing. Mil. Conjunto de comestibles destinados a la alimentación de un ejército.

Martínez de Burgos, Reportorio premáticas y Cortes, 1551, fol. XXVIIv: Otrosí, es nuestra merced y voluntad de hazer visitar de dos en dos años las fortalezas fronteras d'estos reynos como conviene, y proveeremos que las dichas fortalezas tengan la munición y bastimentos que son menester. // Mosquera, Comentario disciplina militar, 1596, fol. 84v: Y entre las cosas necessarias para la conservación y buen sucesso de un exército, que escribe Xenofón que son quatro: abundancia de bastimentos, salud en los soldados, sciencia del arte militar, obediencia y orden. // Roxas, Sumario milicia, 1607, fol. 81v-82r: Las puertas de la çiudad se han de hazer en las partes que estén más a propósito para entrar y salir la gente fuera y meter los carros y bastimentos acomodadamente, aunque aya guerra, pues se puede remediar con que el arzén del foso cubra la dicha puerta, de manera que de la campaña no la descubra el enemigo.

SIN.: bastimiento, munición del sustento, munición del victo, vitualla, víveres.

FAM.: bastimiento.

ENCICL.: Almirante (1869): Víveres, vituallas.

bastimiento, bastimiento [de bastir y éste de basto. Bastimiento 'provisión'. Desde Alfonso X hasta fin s. XVI (DECH). Montes, Instrucción y regimiento, 1537]. sust. u. m. en pl. con el mismo significado que en sing. Mil. Conjunto de comestibles destinados a la alimentación de un ejército.

Montes, Instrucción y regimiento, 1537, fol. IIIr: Si la provincia donde la guerra se hoviere de hazer es pobre, más guerra les haría la hambre que los enemigos, por la mucha falta de los bastimientos que no se podrían haver, a cuya causa el exército les sería forçado de retirarse. // Montes, Instrucción y regimiento, 1537, fol. XIIv: El pequeño exército no da batalla al copioso exército si no es sobre seguro, viéndole necessitado de bastimientos o faltoso de dineros o faltoso de gente; y entonces, sobre cosa pensada, dan la batalla a los enemigos y, assí, alcançan la vitoria los pocos de los muchos. // Álaba, Perfeto capitán, 1590, fol. 52v-53r: Y no con menor diligencia se informavan de los bastimientos que tenían, para juzgar, según la cantidad d'ellos, si podían esperar a ser acometidos o les era forçoso acometerlos con brevedad porque, conforme a lo que en esto huviesse, tratassen de la prevención de todo lo necessario para la guerra.

SIN.: bastimento, munición del sustento, munición del victo, vitualla, víveres.

FAM.: bastimento. 
bastión, bastión, bestión [del it. bastione 'íd.', derivado de bastia 'obra fortificada', forma de origen dialectal genovés, piamontés o lombardo, en lugar de bastita derivado de bastire 'construir' (para el cual V. bastir). Ya en 1526, BHisp; 1569; bestión, 1536 (esta variante, frecuente en el s. XVI, se debe a influencia de vestir (DECH). Álaba, Perfeto capitán, 1590]. sust. Fort. Cualquier construcción elevada que permite al sitiador, con la artillería allí asentada, batir de forma dominante la fortaleza.

Álaba, Perfeto capitán, 1590, fol. 93r: Procure también assentar su artillería en lugar donde más pueda dañar a su enemigo, y sea de la gruessa, porque pueda con su fuerça y vigor aterrar los bestiones, escalas, reparos y ingenios que en su defensa hizieren los contrarios. // Collado, Plática Artillería, 1592, fol. 110r: THENIENTE. - Si estando en una batería os conviniesse alçar algún bestión o plataforma por beneficio de la empresa, ¿cómo haríades acerca del modo de alçarla? ARTILLERO. - Procuraría de alçarla con maderos, estacas, clavos, céspedes y faxina o hacezillos y tierra. // González de Medina, Examen fortificación, 1599, pág. 203-204: Si el enemigo se dispusiesse a hazer bestiones o plataformas, como las quisiéredes llamar, como los turcos hazen para igualar con las fortificaciones y quitar las defensas, y otras vezes para sobrepujar y señorearlas y descubrirlas, que nadie se pueda assomar a ningún servicio ni defensa, ¿qué es lo que haríades para contra ello?

SIN.: baluarte ${ }_{3}$, caballero $_{3}$, plataforma ${ }_{2}$.

ENCICL.: Terr.: Antiguamente se decía bestión. // Almirante (1869): Su sentido no era fijo [...]. [Hay casos] en que indica un trabajo de sitio [...]. Y, en efecto, bestión, que se lee en varios autores del siglo XVI, no parece indicar la forma, traza o planta de baluarte, sino la obra, como hoy diríamos, avanzada, aislada o destacada, quizá reducto.

2 [Montes, Instrucción y regimiento, 1537]. sust. Fort. Cualquier elemento defensivo, dependiente de una fortaleza, cuya principal característica es su gran altura.

\& (fig. 17)

Montes, Instrucción y regimiento, 1537, fol. XVIIv: Otras formas se podrían dar para la defensa de una ciudad, assí como bastiones y reparos que descubran la campaña, huviendo abundancia de artillería. // Mendoça, Theórica y práctica, 1596, pág. 125-126: Assimismo se ha de advertir si la plaça está fortificada, siendo frontera, o se ha de fortificar de nuevo y en qué manera ha de ser, governándose en esto, según el tiempo que diere el enemigo para ello, con ingenieros y personas que sepan qué es fortificación, por acontecer muchas vezes, queriendo fortificar alguna plaça, ayudándola con revelín, cavallero y bestión, tenaza o espolón, venirse a enflaquecer más por no estar bien entendidos. // González de Medina, Examen fortificación, 1599, pág. 170: No se ha tratado de hazer ningún bestión fuera de la muralla, por no hazer cosa que, sin poderlo remediar, se entre, perdiendo la primera reputación con perderle, y que le quede al enemigo por amparo y defensa.

3 [Álaba, Perfeto capitán, 1590]. sust. Fort. Elemento u obra de fortificación de forma pentagonal, que se destaca y sobresale en los ángulos o esquinas de una fortaleza. 
Álaba, Perfeto capitán, 1590, fol. 85v-86r: No conviene que sea menor la advertencia de un capitán en reconocer las dificultades que en ganar una ciudad o fuerça puede aver [...]; y assí, el tiempo que en semejantes conquistas se gastare se podrá llamar perdido [...], como sería quando se pusiesse cerco a una ciudad o villa bien reparada de muros y tan proveýda de gente y de todo lo demás como lo está quien le quiere poner sitio; o si fuesse algo flaca de muros y tan proveýda de gente que huviesse harta para bastecer y proveer las murallas y bestiones por todas las partes y la que bastasse para defender los portillos que se hiziessen de la parte de fuera. // Mosquera, Comentario disciplina militar, 1596, fol. $5 \mathrm{v}$ : Y subiolo en más alto grado que ningún español ni otra nación el conde Pedro Navarro, bravo artífice de máquinas y minas de fuego, que minando los bestiones de la isla de Megara, los arrancó bolando.

SIN.: baluarte .

ENCICL.: Frente a lo que normalmente se piensa, bastión no es en la época moderna un sinónimo claro y evidente de baluarte. Aunque sí puede adquirir esta significación, como puede comprobarse en los dos ejemplos seleccionados, no es, en absoluto, la más habitual. Cualquiera de las dos acepciones anteriores posee una frecuencia de uso muchísimo mayor que ésta.

batalla, batalla, vatalla [del oc. ant. batalha o del bajo latín galicano battalia 'íd.', procedentes ambos del lat. tardío battualia 'esgrima', antiguo neutro plural de un adjetivo battualis derivado de battuere 'batir'. 1131 y Cid (DECH). Sagredo, Medidas Romano, 1526]. sust. Mil. Acción bélica en la que se enfrentan soldados o formaciones militares enemigas.

Fernández de Enciso, Suma de Geographía, 1530, fol. XLIr: Este Éctor escriven que muchas vezes, quando salía a pelear, matava en una batalla mil hombres y más por su espada; e afirman las corónicas ser verdad. // Montes, Instrucción y regimiento, 1537, fol. Vv-VIr: E muchas tierras e castillos fuertes se han rendido por falta de vituallas más que por combate de los enemigos; y en esto han de mirar mucho los generales, que las fuerças que ganaren que las hagan proveer de vituallas, porque los enemigos no las tomen por hambre, porque mejor es, ya que sucede la fortuna, que una fuerça se pierda por batalla que no por hambre. // Álaba, Perfeto capitán, 1590, fol. 71r-71v: Y los egypcios, aviendo de combatir en unos campos de muchas lagunas y atolladeros, cubriéndolos de ovas, luego que se començó la batalla fingieron huyr, y huyendo, como gente que conocía la tierra, por partes seguras, metieron a los que en su seguimiento venían por aquellas lagunas y pantanos $\mathrm{y}$, rebolviendo sobre ellos, salieron vencedores.

SIN.: combate ${ }_{1}$, combatimiento ${ }_{1}$ contienda $a_{2}$, debate, facienda, lid, pelea.

ENCICL.: Sanz (1749): Es un combate o pelea de dos ejércitos enemigos. // DUE: Cada episodio de una guerra en que se encuentran y luchan los ejércitos enemigos. // DECH: La vieja palabra genuina era lid y también se dijo fazienda. Aunque en el Cid ya es usual en el sentido moderno, las Partidas todavía consideran batalla como neologismo, al contraponer lid, como decían "antiguamente los de España" con el combatir de las "tierras 
do se fabla el lenguage latino". Batalla se consolidó primero como nombre de los encuentros "do ha reyes de armas las partes, e tienen estandartes et señas, et para sus haces con delantera et con costaneras et con zapa", es decir, los ajustados al arte teórico de la guerra medieval, o bien para designar los combates entre dos individuos (ac. que todavía llega hasta princ. s. XVII, aunque va sustituyéndolo más y más singular batalla); partiendo de estas acs. típicas de la caballería o del guerrear internacionales, poco a poco fue desalojando a lid y a fazienda en todas las acs.

2 [Fernández de Enciso, Suma de Geographía, 1530]. sust. Conflicto o enfrentamiento armado entre dos o más naciones o entre bandos de una misma nación, que dura considerable tiempo, con diversas batallas y episodios.

Fernández de Enciso, Suma de Geographía, 1530, fol. XLIr: Este monte es muy alto y seco, y es remedio de los ladrones de aquella tierra, que se acogen a él, aunque Pompeo quando ganó aquella tierra los destruyó y echó muchos del monte e muchos d'ellos justició. A este monte se acogió Antonio, quando la batalla de Mitrídato. // Montes, Instrucción y regimiento, 1537, fol. XVIIIv: Y no se deve rendir por batalla ni por otro combate ninguno, porque el alcayde rendido no puede ser alcayde de otro castillo, pues se rendió, porque más sano le sería morir peleando con los enemigos que no vivir habiéndose rendido, porque regla es entre gente de guerra que un hombre rendido no puede combatir con otro sin licencia de aquél a quien le rendió. // Escalante, Discurso de la navegación, 1577, fol. 86v: Son los chinas muy mañosos y astutos en todas las facciones que se ofrecen de guerra $\mathrm{y}$, aunque tienen valor para esperar y acometer a los enemigos, usan siempre de ardides estraños en todas ellas, y de todo género de máquinas e instrumentos de fuego en las batallas de mar y tierra.

SIN.: contienda, guerra.

ANT.: $p a z_{1}$.

ENCICL.: DRAE: Serie de combates de un ejército con otro, o de una armada naval con otra. La batalla del Atlántico.

3 [García de Palacio, Diálogos militares, 1583]. sust. Mil. Disposición de las tropas que se juzga más adecuada para un combate, para atacar o para operaciones militares similares.

García de Palacio, Diálogos militares, 1583, fol. 149v: ¿De qué manera podría marchar un campo de infantería, para que, offresciéndose nescessidad, se pudiessen poner con presteza en batalla quadrada, de manera que la vandera venga a hallarse en medio de la ordenança? // García de Palacio, Diálogos militares, 1583, fol. 176v: Y en todas estas batallas y posturas, deven ir los arcabuzeros entre las órdenes de las picas, conforme a la dispusición de la tierra y a como la occasión lo pidiere. // Mendoça, Theórica y práctica, 1596, pág. 73: Y si los enemigos apretaren a los corredores con tanta gallardía y fuerças que los obliguen a retirarse hasta la retaguardia, los ha entonces de sustentar, bolviendo el rostro con el hazer alto, de que advertirá a Vuestra Alteza para que los refuerce o socorra, conforme fuere la necessidad, pues podría ser tanta que, poniéndose en batalla, viniessen 
a combatir, cosa que han de escusar, si no son forçados, atendiendo a seguir el campo, que ha de ser su fin.

SIN.: orden de (la) batalla.

ENCICL.: Almirante (1869): En el romance castellano desde su formación la palabra batalla ha venido expresando conjuntamente, hasta últimos del siglo XVII, dos ideas y dos hechos distintos. Uno, de agregación, constitución, composición, organización, formación, como núcleo, nervio, masa principal, como centro o grueso del ejército por oposición a tropas sueltas o ligeras o auxiliares; por distinción de alas o cuernos; por separación de vanguardia y retaguardia. Otro, que hoy le queda como técnico de combate, lucha o pelea material entre dos ejércitos.

4 [Álaba, Perfeto capitán, 1590]. sust. Mil. Aquella parte del ejército ordenado que está en medio de él, o entre la vanguardia y retaguardia (Terr.: s.v. cuerpo de batalla).

Álaba, Perfeto capitán, 1590, fol. 43r: Lo que en nuestros tiempos está recebido en el marchar es esto: el sargento mayor, a cuyo cargo, como e dicho, está el hazer caminar el campo en orden, después de aver sabido la noche antes del capitán general si a de acudir con su tercio a la vanguardia, batalla o retaguardia, mandará al atambor mayor que toque a recoger y hará cargar el vagaje al capitán de campaña. // Mendoça, Theórica y práctica, 1596, pág. 50: He apuntado a Vuestra Alteza esta disposición de quarteles, en caso que esté dividida la gente en vanguardia, batalla y retaguardia y con cabos señalados determinadamente para el efecto del caminar y combatir con ellas, porque en razón de guerra la gente de la vanguardia ha de ser la más diestra y exercitada y, por el consiguiente, forçoso darle el cuerno drecho en el aloxar y combatir. // Mendoça, Theórica y práctica, 1596, pág. 59-60: Quando ay poca gente se divide el exército en dos partes para caminar, que es vanguardia y retaguardia; y de ordinario, si ay número de esquadrones, en tres, haziendo batalla con parte que tenga igual proporción con la vanguardia y retaguardia, con lo qual viene a ser medio, sin participar de los dos extremos, y cuerpo proporcionado, por la igualdad que se da a cada una de por sí para el unirse juntas.

SIN.: cuerpo de (la) batalla.

ENCICL.: Borreguero Beltrán (2000): Hasta mediados del siglo XVII, la palabra batalla se empleaba indiferentemente para indicar la lucha material entre dos ejércitos y el centro o el grueso de estos mismos ejércitos en su formación de marcha o de combate. // Corsini (1849: s.v. cuerpo de batalla): Táct. El grueso de un ejército que marcha entre la vanguardia y retaguardia, y que en las formaciones en batalla es el centro de ellas.

5 [García de Palacio, Diálogos militares, 1583]. sust. Mil. Cada una de las líneas o partes de que consta un orden de batalla, y conjunto de soldados que las integran. García de Palacio, Diálogos militares, 1583, fol. 161v: Quando se vee y sabe que el enemigo trae su esquadrón más ancho o se quiere ensanchar más que el del enemigo, como vuestra merced dize, deve, quando viene una batalla o ordenança tras otra, la de la avanguardia 
hazer alto, arbolando las picas, para que la batalla o ordenança que viene en pos d'ella entre por ella con sus picas, entretexiéndose en la forma que se sigue, hasta poner los lados yguales. // García de Palacio, Diálogos militares, 1583, fol. 162v: Y, en llegando estas batallas a juntarse e ponerse avanguardia con avanguardia, deven arbolar las picas, quedando cada una de las órdenes, que van con la que le toca de las que le están arboladas, con mucha orden y concierto.

SIN.: ordenanza.

ENCICL.: Castro y Rossi (1852): (ant.) Cada una de las líneas o haces de un ejército; y así se decía primera batalla, segunda batalla, etc.

6 [Montes, Instrucción y regimiento, 1537]. sust. Mil. Grupo numeroso y ordenado de soldados, establecido preferentemente para un combate, y ocasionalmente para una marcha, una acampada o alguna otra operación militar semejante.

Montes, Instrucción y regimiento, 1537, fol. XIVv: Mas en la Chirinola no se puso el Gran Capitán en el ala derecha de la batalla, quando rompió a los franceses, sino en medio de los suyos; mas hízolo aquello el Gran Capitán porque tenía poca gente y por dar ánimo a los suyos, y porque ellos le viessen mejor. // Montes, Instrucción y regimiento, 1537, fol. XVIv: Algunos pensarán que sería mejor affrontar primero con la gente más plática en la guerra, mas engáñanse, porque, rompiendo lo más flaco de la batalla, después queda junto todo el cuerpo del exército para dar en los pláticos. Y d'esta manera no se puede perder la vitoria. // Collado, Plática Artillería, 1592, fol. 98v: GENERAL. - ¿Paréscele a vuestra merced, señor theniente, que haya alguna mejor manera para conduzir el artillería? THENIENTE. - Cierto, señor, mejor me parescería que a los lados de el esquadrón fuesse puesta. GENERAL. - ¿Por qué razón? THENIENTE. - La razón es que, llevándola a los lados, juega por frente y por través sin que nadie se lo impida y, cerrada la batalla, quédase atrás con su guardia.

SIN.: batallón . $^{2}$

ENCICL.: Aut.: Se ha usado en lo antiguo por cuerpo de tropas, o trozo de gente de guerra unido. // Moretti (1828): Tact. Un ejército o un cuerpo en el orden de batalla. // Almirante (1869: s.v. escuadrón): Batalla significaba no sólo choque o conflicto, sino también el cuerpo de tropas ordenado a punto de combatir [...]; Zurita que es notable por la propiedad y primor con que emplea las voces que usa, aplica la de batalla a cuerpos formados en disposición de combatir, con abstracción de si se verificaba o no el combate.

campal [Roxas, Sumario milicia, 1607]. cmpt. sintag. Mil. La dada entre dos ejércitos completos, especialmente si es en campo abierto y se considera decisiva (DUE).

Roxas, Sumario milicia, 1607, fol. 33r-33v: Por esto combiene que se consideren bien todas las cosas antes que se bengan al último rompimiento, porque los buenos capitanes, no con batalla campal, en que consiste en el peligro de ambas partes, antes de secreto an de procurar su provecho y daño del enemigo espantándole. // Roxas, Sumario milicia, 1607, 
fol. 37r: Açies o haz se llama un exérçito hordenado, que su frente, la que mirare al enemigo en vatalla campal, se hordenará saviamente porque ymporta mucho, y si es neçiamente, aunque aya guerreros muy escogidos, serán desbaratados por su mala horden. // Ufano, Tratado de la Artillería, 1613, pág. 117: ¿Sería bueno, Señor Capitán, en una batalla campal alojar todas las pieças a los dos costados y fondos del batallón, dexando la plaça de armas franca y libre?

ENCICL.: Domínguez (1853): La que se da entre dos ejércitos, regularmente como decisiva, de poder a poder.

representar $\sim$, o representar la $\sim$ [Mosquera, Comentario disciplina militar, 1596]. loc. v. Mil. Desplegar las tropas ante las del enemigo, provocándolo al combate (DRAE: S.v. presentar la batalla).

Mosquera, Comentario disciplina militar, 1596, fol. 11r: Viendo que cada día más [...] le yva faltando el poder para passar adelante en sus determinaciones, acordó de valerse de fuerças agenas invocando el auxilio de gente francesa, los más d'ellos piratas y públicos robadores, y diferentes en religión, [...] en que vino a traer de Francia en su favor a Filipe Stroci [...]; contra quien el Marqués de Santa Cruz, Capitán General, consiguió aquella tan señalada vitoria [...], que con veynte y cinco navíos con que se halló cerca de Punta Delgada le representó la batalla, donde fue el francés vencido y muerto, y toda la demás gente muerta, desbaratada, y rendida. // Mosquera, Comentario disciplina militar, 1596, fol. $72 \mathrm{v}$ : En las justas empresas podría ser permitido a sacerdotes o religiosos animar a soldados para entrar y representar batalla, y atemorizar con armas y usar de toda industria, porque por ninguna vía muestren flaqueza, pero anse de guardar de cometer con su mano propria homicidios, o cortar miembro.

ENCICL.: Domínguez (1853: s.v. presentar la batalla): Formar a vista del enemigo, ordenar y distribuir la gente como para pelear, retándolo y provocándolo para que acepte el combate, para que se comprometa o se reconozca inferior, casi moralmente derrotado, etc.; antiguamente se decía representar. // DEA (s.v. presentar batalla): Desplegar la tropas ante el enemigo, provocándolo al combate. Tb fig. A veces con ci: Los arévacos habían elegido jefe a un segedense, Caro ..., el cual estaba dispuesto a presentar, con 20000 infantes y 5000 jinetes, batalla a los romanos.

batalla, V. campo de la .

batalla, V. cuerpo de (la) .

batalla, $V$. gente de (la) .

batalla, V. orden de (la) . 
batallón, batallón [del it. battaglione. 1539 (DECH). García de Palacio, Diálogos militares, 1583]. sust. Mil. Cualquier tipo de unidad o agrupación táctica de soldados.

García de Palacio, Diálogos militares, 1583, fol. 145r: Los antiguos que la milicia professaron ordenavan, señor, sus gentes, para entrar en batalla, por esquadrones o tropeles, los quales, aunque sean llamados de diversos nombres, casi siempre han correspondido a una qüenta e número, por manera que cada esquadrón o batallón de aquéllos antiguos se ordenava y hazía de siete $\mathrm{u}$ ocho mil hombres, a los quales los escriptores romanos llamaron legiones y los griegos falanjes. // García de Palacio, Diálogos militares, 1583, fol. 147r: Varios modos tuvieron, señor, en el ordenar de sus esquadrones, porque formavan batallones quadrados, cruzados, cornudos, ochavados, lúneos o triangulares, fórfices, para opponer a la forma cúnea. // Álaba, Perfeto capitán, 1590, fol. 137v: Esto enseñó bien Cipión, el qual, como supiesse que Aníbal traía ochenta elefantes delante la frente de su esquadrón para romper la del batallón de los romanos y que la fuerça d'estos animales necessariamente avía de hazer este daño, hizo de la necessidad virtud y ordenó la frente de su exército muy llena de intervalos y vacíos, en los quales puso sus vélites por dissimular estos espacios, con orden que, quando los elefantes arremetiessen, les abriessen el passo y ellos se retirassen dentro de las legiones.

SIN.: escuadrón, tropel.

ENCICL.: Hasta el siglo XVIII, cuando tuvo lugar con la entrada de los Borbones una amplia remodelación militar, la palabra batallón no designa, además de una unidad táctica, una división constitutiva, orgánica y administrativa del ejército. Es decir, las definiciones de batallón del tipo "unidad militar compuesta de varias compañías, y mandada normalmente por un teniente coronel o un comandante" (DRAE), que de una manera más o menos exacta se encuentran en todos los diccionarios consultados, no son válidas para los siglos que nos ocupan. Como afirma Almirante (1869), "la voz batallón anduvo, por decirlo así, flotante, sin consolidación oficial o técnica durante largo tiempo"; y, en palabras de Borreguero Beltrán (2000), "hasta el siglo XVII [batallón] era simplemente una reunión temporal de un número variable de compañías que formaban un cuerpo de batalla". Es decir, pese a que desde el siglo XV escuadrón era la denominación más frecuente para referirse a una unidad táctica temporal, tanto de caballería como de infantería, o de ambas a la vez, ya desde esa centuria coexiste con batallón, voz que, eso sí, durante los siglos XVI y XII cuenta con una frecuencia de uso mucho más reducida que escuadrón. No obstante, con el advenimiento de los Borbones se generaliza la palabra batallón para designar una de las divisiones orgánicas y administrativas de la infantería, mientras que escuadrón se refiere también a una unidad constitutiva del ejército, pero sólo del cuerpo de caballería. Para más datos sobre la imprecisión semántica de batallón y su relación con escuadrón, vid. la múltiple información que aporta Almirante (1869) de estas dos voces, la cual resume de la siguiente manera al concluir el artículo de escuadrón: "Resultado final. Si se aprecia por épocas el valor significativo de las voces escuadrón y batallón, las encontraremos homónimas, y si esta apreciación se hace dentro de cada una de ellas, resultarán sinónimas en la primera y diferentes en la segunda y última, que es la actual. La homonimia consiste 
en que habiendo pertenecido ambas voces, primero a la táctica y a la organización después, significaron respectivamente formación para operar y organización para existir".

2 [García de Palacio, Diálogos militares, 1583]. sust. Mil. Grupo numeroso y ordenado de soldados, establecido preferentemente para un combate, y ocasionalmente para una marcha, una acampada o alguna otra operación militar semejante.

García de Palacio, Diálogos militares, 1583, fol. 155r-155v: Muy buena orden es, señor, la que vuestra merced ha dado para marchar la gente en ordenança, pero parésceme que, si no es de tres en tres, de cinco en cinco o de siete en siete, no es possible marchar bien, ni con orden y concierto, a causa de que continuadamente no podría hallarse conveniente camino, e, yendo de nueve en nueve, o donde en adelante más justamente se podría llamar batalla o batallón, e, yendo tantos juntos, yrían muy fatigados, assí en el estío, por la calor, como en el invierno, por el lodo, barrancas y malos caminos, de donde infiero que, por solas las tres divisiones, que vuestra merced dize, no podría marchar sino muy poca gente. // García de Palacio, Diálogos militares, 1583, fol. 166v: Las armas con que más pueden offender estos sobresalientes son arrojadizas, espadas y rodelas, porque, tiradas, quedan con sus espadas y rodelas, y con ellas pueden seguir la victoria, pues el batallón no la puede seguir sin mucho riesgo de desordenarse. // García de Palacio, Instrución náuthica, 1587, fol. 124v-125r: Y quando, barloando con la contraria, se le hechare gente, ha de ser una de las esquadras de las amuras de proa. $Y$, si hallaren tanta resistencia que tuviessen nescessidad de más socorro, podrá yr la otra esquadra, y si entrambas no pudiessen rendir al enemigo, el batallón se ha de estar quedo por no poner la nao que ha de aguardar en riesgo.

SIN.: batalla 6 .

ENCICL.: Terr.: Cuerpo de infantería, que se dice así por considerarle como colocado en orden de batalla, pronto siempre a combatir.

3 [Álaba, Perfeto capitán, 1590]. sust. Mil. Parte del ejército que se destina a un servicio menos activo o de reserva.

Álaba, Perfeto capitán, 1590, fol. 28r: A cuya imitación me pareció repartir los quarenta mil hombres que he propuesto en cinco partes, dando a un batallón, que assí soy de parecer que cada parte se llame, ocho mil soldados, poniéndole el nombre de alguna de las provincias del reyno donde assistieren, como sería, en España, de la provincia de Andaluzía, Castilla la Vieja, Galizia o Vizcaya, para que, estando entretenido en alguna d'ellas, se entienda quando se hablare d'estos batallones de quál d'ellos se trata. / / Álaba, Perfeto capitán, 1590, fol. 28r-28v: El govierno de cada uno d'estos batallones del número de los ocho mil soldados de que se compone, me a parecido dividir en treinta y dos partes, por ser esta división acomodada, pues a cada parte o compañía le caben dozientos y cincuenta hombres, los quales con facilidad se podrán governar.

ENCICL.: Almirante (1869): Álava y Viamont (El perfec. cap. fol. 28 -1590) explicando un plan o proyecto suyo de ejército de reserva llama batallón al "cuerpo compuesto de 8000 soldados, 
repartidos en 32 compañías de a 250 hombres, mandadas por capitán, alférez, un sargento, un furrier y diez conservadores de disciplina para tener a su cargo la de cada una de las diez escuadrillas de a 25 hombres". Este sentido de batallón como milicias o reserva, a distinción del escuadrón como unidad táctica de infantería activa, se encuentra por entonces en varios libros y documentos.

batería, batería, vatería [del fr. batterie 'íd.', derivado de battre 'batir'. 1547 (DECH). García de Palacio, Diálogos militares, 1583]. sust. Fort. Acción de golpear repetidamente, mediante la artillería u otras máquinas de guerra, una construcción defensiva con la finalidad de derribarla. (fig. 18)

García de Palacio, Diálogos militares, 1583, fol. 127r: Y, aunque en las baterías de ordinario se buscan padrastros que ygualen o sobrepujen la cosa que se quiere batir, no es porque contradiga a lo dicho, mas por ver y asestar mejor a la cosa ygual o más baxa, que se puede hazer a la alta. // Collado, Plática Artillería, 1592, fol. 55r: El artillero que dessea ser tenido por plático y hazer bien su officio, sabiendo que se ha de hallar en una batería o otra facción alguna donde será menester tirar muchos tiros con su pieça, él deve, primero, hazer una buena provisión de agua y que ésta sea la más fría que haver se pueda. // Ufano, Tratado de la Artillería, 1613, pág. 102: En las occasiones de batallas y baterías se muestre a sus súbdictos mansa y amorosamente, usando con ellos de magnanimidad y largueza quando açiertan a servir y agradar, máximamente con los artilleros, gentiles hombres y constables, en los tiros señalados que hizieren, para levantarles al ánimo a hazerlo siempre mejor.

ANT.: contrabatería 1 .

ENCICL.: DUE: Acción de batir una fortificación.

2 [Montes, Instrucción y regimiento, 1537]. sust. Fort. Rotura o abertura en la muralla de una fortaleza producida por la artillería u otro ingenio militar.

Montes, Instrucción y regimiento, 1537, fol. XVIIIv: Por quatro maneras de batalla se puede ganar un castillo: por batalla de manos, o por batería, o por mina, o por hambre. Si se gana por mina, puédese defender por contramina; si se gana por batería, puédese defender reparando el muro por la parte de dentro, haziendo un contramuro, echando entre muro y muro muchos barriles de pólvora, [...]. // Mendoça, Theórica y práctica, 1596, pág. 93-94: Advertir [...] si ay espacio en lo que se bate de un torreón a otro o baluarte para hazer batería por donde puedan entrar ocho o nueve soldados por hilera, la qual estiman por buena, si bien en los assaltos no se arremete en hilera, se tiene por gran batería la de semejante distancia. // Rojas, Teórica fortificación, 1598, fol. 51r: He visto batir un terrapleno con fagina dos días, y después de aver batido y peinado la frente del terrapleno, quedavan las faginas boladas por sus hileras, que parecía frente de esquadrón, caladas las picas. Y assí, nos fue forçoso meter la trinchea hasta la batería, y, llegados allí, cortamos las faginas poco a poco por sus hileras, con mucho trabajo y riesgo de algunos soldados [...]; y si fuera tierra limpia, se hiziera la batería en un día y se diera el assalto en menos tiempo y sin tanto peligro de soldados. 
SIN.: brecha, portillo.

ENCICL.: Cov. (s.v. batir): Batir los muros es dispararles la artillería; y batería el estrago que en ellos se hace con ella y con los asaltos.

3 [Álaba, Perfeto capitán, 1590]. sust. Art. Conjunto de piezas de artillería, instalado en una posición estratégica y dispuesto para disparar.

Álaba, Perfeto capitán, 1590, fol. 92v: Si alguna parte notable de la habitación del lugar está más alta, igual o más baxa que el muro por algún lado, echará por tierra los edificios y plaças que pudieren ser de algún daño, allanando y igualando en quanto fuere possible las partes altas, de donde puede la batería de los enemigos ofender la ciudad. / / Collado, Plática Artillería, 1592, fol. 53v: La diligencia y presteza del buen artillero ha de ser tanta que al romper del alva tenga ya plantada y puesta a punto su batería y comiençe a saludar con ella la fortaleza enemiga. / / González de Medina, Examen fortificación, 1599, pág. 164165: Y dexar hecha una muy fuerte trinchea contra la ciudad sobre el mesmo foso, adonde le podrá plantar la batería sin el trabajo y peligro que en las fuerças que quedan dichas se tiene.

SIN.: camarada 2 .

ANT.: contrabatería $a_{2}$.

ENCICL.: Aut.: Es el agregado de algunas piezas de artillería puestas en la forma conveniente para batir alguna parte de la fortificación de una plaza, o el de morteros para disparar bombas. / / Corsini (1849): Art. Nombre genérico y colectivo que se da a un cierto número de piezas de artillería, cualesquiera que sean sus calibres o especies, y reunidas en la forma conveniente con el objeto de hostilizar al enemigo en el campo, de atacarlo en las plazas batiendo y derruyendo sus obras de fortificación, o de defender éstas, etc.

4 [Álaba, Perfeto capitán, 1590]. sust. Fort. Cualquier obra de fortificación construida para alojar cañones y otras piezas de artillería. (fig. 19)

Álaba, Perfeto capitán, 1590, fol. 204r: Lo qual es de tanta importancia que, con sólo saber con curiosidad este modo de medir, se podrá conocer el circuyto de qualquiera fortaleza, por lexos que esté, que no será de poco momento para traçar la batería por la parte que menos resistencia tenga. // Roxas, Sumario milicia, 1607, fol. 78v: Para acabar la camisa de la muralla de 4 pies de grueso, haviendo de yr a plomo por la parte de dentro, se eligirá abajo de 12, porque los 8 se pierden en el escarpe hasta los 40, porque yr la muralla caýda por de dentro, paralela a la haz de afuera, eso es en algunas partes y no en las frentes reales, que miran al campo raso, donde puede haver batería real de artillería gruesa. // Ufano, Tratado de la Artillería, 1613, pág. 133: Tócale, también, en siendo ya noche, rondar y visitar las baterías, ynformándose de los gentiles hombres si les faltan algunos materiales y petrechos para sus fortificaçiones y cubrimiento de sus pieças y muniçiones de guerra y, si de alguna cosa tuvieren falta, mandarlo al puncto proveer. 
SIN.: plataforma 1 .

ANT.: contrabatería 3 .

ENCICL.: Rubió y Bellvé (1895-1901): La obra de fortificación o parte de ella que contiene una o varias piezas de artillería en condiciones apropiadas para el combate. // Lucuze (1772: 29): "Batería es cualquier lugar cubierto de parapeto, destinado a algún número de piezas de artillería para tirar sobre el enemigo [...]. Cuando no tiene merlones la batería se llama a barbeta. Dispónese así en el caso de situarla sobre una eminencia, cuya altura la cubre naturalmente, o en un frente que corresponde al mar, para dirigir con libertad los tiros a donde convenga. No obstante, si la sitiación es muy baja o a flor del agua, importa siempre cubrirla con merlones, pues la libertad de tirar a cualquier parte se logra con hacer las cañoneras más anchas de lo ordinario. Se hacen también barbetas en los ángulos flanqueados de los baluartes y obras exteriores, levantando la batería cuatro pies y medio sobre el terraplén, para que el cañón pueda disparar sin maltratar el parapeto. De este modo de tirar tomó el nombre de barba o barbeta".

dar $\sim$, o dar la $\sim$ [Montes, Instrucción y regimiento, 1537]. loc. v. Fort. Golpear repetidamente una construcción defensiva, mediante artillería o máquinas de guerra, para derribarla.

Montes, Instrucción y regimiento, 1537, fol. XVIIv: Y si le dieren batería, hagan abastinar la muralla por donde la batería se diere, por la parte de dentro, de tierra y estiércol y fustas gruessas, tapiado todo a manera de tapia que sea muy ancha. Porque, si los enemigos derribaren el muro, que quede otro más fuerte que no el derribado. // Álaba, Perfeto capitán, 1590, fol. XIIIv: Pues de inorar la parte más flaca del lugar que se a de batir y dar la batería por la de mayor resistencia, han venido a parecer muchas fuerças inexpugnables y de extraordinaria fortificación, que, conquistadas por quien tuviera el conocimiento del ancho y largo con que se fundaron, que qualquier geómetra, por lexos que se halle, alcança, quedaran rendidas y desbaratadas. // Âlaba, Perfeto capitán, 1590, fol. 87r: Y las trincheas que se huvieren de hazer procurarse a que se hagan lo más cerca de los fossos que fuere possible y antes que amanezca, porque si la luz del día los coge sin que todo esté dispuesto para dar la batería, será servir todos de terrero y blanco para ser ofendidos de los que tratan de ofender.

SIN.: batir 1 .

batido, batido [de batir. Álaba, Perfeto capitán, 1590]. adj. u. t. c. sust. Fort. Dicho de una construcción defensiva: golpeada repetidamente, mediante artillería o máquinas de guerra, para derribarla.

Álaba, Perfeto capitán, 1590, fol. 88v: Y desde la trinchea más cercana al fosso donde se da la batería aya arcabuzeros que tiren pelotas de dos onças a los que vieren en las partes batidas hazer defensas, como son contrafossas, trincheas, reparos, cavalleros, estorvando el echar leña en las partes batidas, que muchas vezes se haze, para que los que dieren el assalto con fuegos que en ella echen sean estorvados. // Rojas, Teórica fortificación, 1598, 
fol. 106r: Y allí encima se yrá haziendo un trincheón y se atravessará el fosso hasta topar con la esquina del valuarte, que ya estará batida y derribada por el suelo, y en la batería d'ella se alojarán los soldados, haziendo allí pie. // Ufano, Tratado de la Artillería, 1613, pág. 162: GENERAL. - Y Vuestra Merced, ¿de qué paresçer sería en esto? CAPITÁN. Del que tienen los más práticos, que es al arçe del fosso, lo uno por descubrirse, como se a dicho, mejor la muralla; lo otro, con el grande estupendo de las pieças tan propinquo, ayuda mejor a caer lo batido y se goza del tener al enemigo más subjecto y amedrentado.

FAM.: batir, rebatir.

batir, batir, vatir [del lat. battuere 'íd.'. Cid (DECH). Urrea, Vitruvio, Architectura, 1582]. v. tr. Fort. Golpear repetidamente una construcción defensiva, mediante artillería o máquinas de guerra, para derribarla.

Urrea, Vitruvio, Architectura, 1582, fol. 135r: El ariete, que es máchina para batir, dizen que se halló d'esta manera: los carthaginenses pusieron campo sobre Cáliz para tomarla. Y aviendo tomado primero el castillo, se esforçaron de arruynalle. $\mathrm{Y}$ no teniendo instrumento conveniente para ello, tomaron una viga, y sosteniéndola con las manos y la cabeça, hiriendo continuamente el alto muro, derribavan por orden las piedras. // Collado, Plática Artillería, 1592, fol. 2v: Las máquinas, pues, Real Magestad, con que los antiguos solían expugnar las fortalezas y batir las murallas eran éstas: las cathapultas, las balistras, las víneas, los arietes, las testúdines [...], el compago, el escorpión, las sambucas, las faláricas y otras muchas. // Rojas, Teórica fortificación, 1598, fol. 37r: Y lo peor de todo es que, cuando bate el artillería el parapeto, mete en la plaça las piedras y ladrillos d'él, y assí haze andar a los soldados desatinados.

SIN.: dar (la) batería.

FAM.: batido, rebatir.

ENCICL.: DEA: tr. Golpear algo para derribarlo. Tb abs. // Aut.: Golpear, dar golpes con una cosa dura contra otra o para deshacerla, o para apretarla y bajarla o para otro fin, como batir la muralla, batir el papel. // DECH: Verbo de vida poco vigorosa en cast. y port. (bater), mucho menos que en los demás romances (cat., oc., retorrom. batre, fr. battre, it. battere, campid. bàttiri, rum. bate), que manifestó tendencia desde el principio a emplearse sólo en acs. especiales, militares y técnicas.

2 [Cortés de Albacar, Breve compendio sphera, 1556]. v. tr. Art. Someter un lugar, posición o grupo de personas a la amenaza o al efecto de las armas de fuego.

Cortés de Albacar, Breve compendio sphera, 1556, fol. VIIIr: Quando el campo cesáreo, año de 1535, estava sobre la Goleta, Vuestra Señoría, con las galeras de España puesto en lugar peligroso, no dexastes de la batir y, queriéndose entrar, el primero que saltó en ella por parte de la mar fue Vuestra Señoría. // Mendoça, Theórica y práctica, 1596, pág. 109: Es de advertir si el enemigo puede tomar alojamiento con que impedir las vituallas, o tan aventajado cerca del propio que pueda d'él batir la plaça de armas y esquadrones, porque 
en tal caso no conviene mantener el sitio esperándole en los quarteles, ni dividir el exército para combatirle, dexando parte d'él a la guardia, por ser mejor partido yrle a buscar con todo el exército antes del poder hazer uno de los dos efectos, qual impedir las vituallas o batir los esquadrones. // Mendoça, Theórica y práctica, 1596, pág. 118: Se ha de tener grande advertencia en reconocer con la experiencia y ojo de soldado el sitio que ocupa el enemigo y parte donde de razón ha de poner su artillería, para no afirmar los esquadrones de cavallería en puesto donde los pueda batir ni lastimar con furia la mosquetería y arcabuzería enemiga, porque si bien en la guerra la artillería mata los menos, su furor espanta los más.

ENCICL.: DRAE: Dominar con armas de fuego un terreno, una posición, etc. // DEA: Tener un lugar sometido al ataque o a la amenaza de proyectiles.

3 [Ufano, Tratado de la Artillería, 1613]. v. prnl. Mil. Enfrentarse dos o más personas utilizando la fuerza o las armas para vencer al otro.

Ufano, Tratado de la Artillería, 1613, pág. 87: Ni aun todos los días tirarán ygual ni continamente, que por maravilla dará lugar el batirse el un exérçito al otro, puesto en batalla, de que la pelea y combatir vivamente dure tres días, ni aun dos, como sucedió a la Çesárea Magestad del Emperador Carlos Quinto, de gloriosa memoria, en la jornada de Ratisbona con el Lantgrave y el duque de Saxsonia, que durante el combate de una parte y otra expendieron cada 3.000 balas. // Ufano, Tratado de la Artillería, 1613, pág. 150: Querría, Señor Capitán, por el presente, saber de Vuestra Merced, como persona que muchas vezes lo abrá visto y experimentado, que estando sobre la muralla de una villa alojadas algunas pieças yguales contra una batería, y de la misma calidad y condiçión otras tantas alojadas abaxo en la campaña, para batirse unas con otras, quáles tienen más peligro de ser desmontadas y reçebir más daño.

SIN.: combatir ${ }_{1}$, lidiar, luchar 2 , pelear, revolver 2 .

ENCICL.: DRAE: prnl. Combatir, pelear.

batir, V. la estrada.

baybén, $V$. vaivén.

bayvén, $V$. vaivén.

bela, V. vela.

belar, V. velar. 
bélico, bélico, béllico, véllico [tomado del lat. bellicus, derivado de bellum 'guerra'. 1440, Mena, Santillana; 1480, Diego de Valera (DECH). Girava, Fineo, Geometría práctica, 1553]. adj. De la guerra o que tiene relación con ella (DESAL). Girava, Fineo, Geometría práctica, 1553, pág. 9: ¿Y quán dado es a buenas letras y a leer graves y excellentes scriptores, en especial aquéllos que tratan de la governación de república y arte militar, entre los quales no pequeño lugar tienen los de Geometría, de la qual nascen todas las máchinas y ingenios béllicos de que usaron los antiguos y se buelven ya en nuestros tiempos a usar? / García de Palacio, Diálogos militares, 1583, fol. 50r: Conforme a lo que se lee en los Números, la concordia y unidad en todos los actos véllicos resulta del sonido y differencias del atambor y trompetas hazen según la variedad de las cosas y nescessidades. // Valle de la Cerda, Desempeño patrimonio, 1600, fol. 126r: Es terrible el exército ordenado, porque, constando de multitud de personas y tanta variedad de ingenios y humores inquietos, se mueve y corresponde todo al son de una trompeta, atambor o instrumento bélico, y es la causa que está este exército dividido en diversas compañías, governadas las unas y las otras por semejantes ministros y oficiales, y todos ellos guiados por una ley y orden de guerra.

SIN.: belicoso ${ }_{2}$.

belicosamente, bellicosamente [de belicoso. Ufano, Tratado de la Artillería, 1613]. adv. De manera agresiva o propia de la persona amiga o inclinada a la guerra.

Ufano, Tratado de la Artillería, 1613, pág. 121: Solía ser en tiempos passados que, primero que se alojase la artillería sobre una plaça, llegava la ynfantería con las trincheras hasta querer desembocarlas al fosso; pero, de algunos años a esta parte más bellicosamente se a usado el alojar pieças de artillería en los puestos más offensivos la primera noche que se llega a sitiar tal plaça.

FAM.: belicoso.

ENCICL.: DEA: De manera belicosa. // DEA (s.v. bélico): [Persona o pueblo] amigo de la guerra. b) Propio de la pers. o el pueblo belicosos. // DRAE (s.v. belicoso): Agresivo, pendenciero.

belicoso, belicoso, bellicoso, vellicoso [tomado del lat. bellicosus. Mena; h. 1490 (DECH). Fernández de Enciso, Suma de Geographía, 1530]. adj. Dicho de una persona o de un grupo: que tiende a provocar guerras o a intervenir en ellas.

Fernández de Enciso, Suma de Geographía, 1530, fol. XXVIIr: Es buena tierra, abundosa de mantenimientos; la gente no es muy belicosa, pero son inclinados al estudio de las artes y al servicio e trabajo e artes mecánicas. // Fernández de Enciso, Suma de Geographía, 1530, fol. XXVIIIv: Las gentes d'estas provincias de la Germania son gentes bien dispuestas y de 
grandes cuerpos e altos; son tirantes, blancos, altos, belicosos, que aman la guerra, fuertes. // García de Palacio, Diálogos militares, 1583, fol. 51r: Supuesto que tenga el conviniente tiempo, deve hazer su gente en provincias y partes ásperas y de pocos regalos, donde los mancebos se críen más vellicosos, fuertes y exercitados, y que de aquella provincia se tenga experiencia de fidelidad y amor al rey y reyno.

FAM.: belicosamente.

ENCICL.: DEA: [Persona o pueblo] amigo de la guerra. // Zerolo (1895): Llámase belicoso al que tiene inclinación a la guerra y se ocupa en ella; mas por lo común sólo se usa de esta palabra hablando de los pueblos y naciones antiguas cuyo único ejercicio era la guerra, no pudiendo acostumbrarse a vivir en paz [...]. Llámase también belicoso a un príncipe que, aficionado a la guerra, es ésta su principal ocupación.

2 [García de Palacio, Diálogos militares, 1583]. adj. De la guerra o que tiene relación con ella (DESAL: s.v. bélico).

Ufano, Tratado de la Artillería, 1613, 17: Assimismo, deve deleytar y tomar plazer en el saber regularmente haçer cohetes y otros yngenios artifficiales de contento y alegría, para passar el tiempo en cosas bellicosas que dan plazer, solaz y regocijo. // Ufano, Tratado de la Artillería, 1613, pág. 78: No fue malo esse bellicoso ardid y paresçe bien del aljaba que salió. // Ufano, Tratado de la Artillería, 1613, pág. 192: Espántome que Vuestra Señoría, siendo tan prático soldado y de tantos años de meliçia, que no lo aya visto, aviendo militado en las partes de Ungría y las demás do en el bellicoso arte a sido exerçitado.

SIN.: bélico.

ENCICL.: Dicc. Hist. (1933-36): Perteneciente o relativo a la guerra.

béllico, V. bélico.

bellicosamente, $\mathrm{V}$. belicosamente.

bellicoso, $\mathrm{V}$. belicoso.

bençedor, $V$. vencedor.

bençer, $V$. vencer.

bençido, $V$. vencido. 
bestión, V. bastión.

bibandero, V. vivandero.

bíberes, V. víveres.

biga, $\mathrm{V}$. viga.

bínea, V. vínea.

bisoño, bisoño, visoño [del it. bisogno 'necesidad' y éste del verbo bisognare 'necesitar', que se cree procedente del germ. bisônjôn 'poner cuidado'. El término bisogno era aplicado por los italianos en el s. XVI a los soldados españoles recién llegados a Italia, por lo mal vestidos que iban, como reclutas allegadizos. 1517, Torres Naharro; Guevara, Menosprecio (DECH). García de Palacio, Diálogos militares, 1583]. adj. u. t. c. sust. Mil. Dicho de la tropa o de un soldado: nuevo (DRAE).

García de Palacio, Diálogos militares, 1583, fol. 65r-65v: Es justo y nescessario se elijan y busquen soldados valientes, experimentados y diestros, porque los tales, como se dixo de Lúculo en la tercera stança del libro primero, enseñan y aconsejan a sus capitanes, animan y disciplinan a los soldados visoños $\mathrm{y}$, en los casos repentinos y de nescessidad, acuden sin que los manden a ordenarse. // Álaba, Perfeto capitán, 1590, fol. 44r: Y si huviere algunos soldados viejos, será bien que los ponga a la larga, en las hileras del medio de la gente visoña, para que los industrien y guíen en lo que han de hazer para caminar con orden. // Roxas, Sumario milicia, 1607, fol. 65r: Y así, el rey Filipo Segundo, excarmentado d'esto, quando hubo de yr a Portugal trujo para aquella jornada alemanes e italianos, para que si sus vasallos le desamparasen, los extrangeros le sirbiesen; y así fue que, de más de doce mil bisoños que se hizo leba, no quedaron dentro de dos meses dos mil de ellos.

ENCICL.: Almirante (1869): El individuo o tropa novel, no adiestrado, no aguerrido o ejercitado. // Cov.: El soldado nuevo en la milicia. Es nombre casual y moderno. Dióseles con esta ocasión, que pasando a Italia compañías de españoles, y no sabiendo la lengua, la iban deprendiendo conforme a las ocasiones, y como pedían lo necesario para su sustento, aprendieron el vocablo bisoño, que vale tanto como he menester, y decían bisoño pan, bisoño carne, etc. Y por esto se quedaron con el nombre de bisoños [...].

\section{bitoria, $\mathrm{V}$. victoria.}


bitualla, V. vitualla.

bivandero, V. vivandero.

bíveres, V. víveres.

blinda, blinda, blinde [del fr. blinde y éste del alem. blende 'íd.', derivado de blenden 'cegar, tapar', y éste de blind 'ciego'. Variante blinde, 1625. Blinda, 1687 (DECH). Ufano, Tratado de la Artillería, 1613]. sust. f. u. t. c. m. Fort. Bastidor de madera compuesto de dos montantes y dos travesaños, que sirve para contener las tierras y las fajinas en las trincheras (DRAE).

Ufano, Tratado de la Artillería, 1613, 4: Con la moderna fundición del cañón, su medio y quarto, les hazemos ventaja, particularmente en las máchinas [...]; y, de la misma manera, en los pertrechos y diversos materiales, como son salchichas y salchichones, candeleros, blindas, espaldas o reparos. / / Ufano, Tratado de la Artillería, 1613, pág. 63-64: Hizo fundir algunos medianos cañones de 15 a 16 calibres de su boca de largo, y de muy menos estofa y fuerça de metal y gran calibre de bala, de forma que, por ser tan cortos, al tirar, quedando muy ahogados en los parapetos y cubrimientos de sus troneras, quemavan y abrasavan los çestones y deshazían con el ayre y flama de su rebufo las blindes de todo su cubrimiento. // Ufano, Tratado de la Artillería, 1613, pág. 174: Y escusan el gasto de las pieças con ellos, porque, aunque los sitiadores traen sus reparos de mantas y blindas con zestones vazíos, no son bastantes para deffensa de tales moxquetes.

ENCICL.: Sanz (1749: s.v. blindas, quartones o biguetas): Son pedazos de madera que traviesan de un lado de trinchera al otro. Las blindas sostienen las fajinas y zarzos cargados de tierra que cubren los trabajadores. // Almirante (1869): En el tecnicismo especial de ingenieros, la blinda usada en trabajos de sitio es un simple bastidor compuesto de dos montantes y dos travesaños.

2 [Lechuga, Discurso de la Artillería, 1611]. sust. f. u. t. c. m. Fort. Cobertizo defensivo formado de vigas, fajinas, zarzos, tierra, estiércol, etc. $\$$ (fig. 21) Lechuga, Discurso de la Artillería, 1611, pág. 209: Al mismo tiempo, van haziendo la esplanada y poniendo a la parte alta de los cestones, de uno a otro, tres o quatro estacas que asan en los dos y, encima, faxinas escojidas por su mano, dos o tres, de alteza, atándolas con cuerdas muy bien para que quede hecha la tronera y algo assegurados los que an de manejar la pieça. En Flandes, llaman a lo que digo se haze a la parte alta de los cestones, con las estacas y faxina, blindes. // Ufano, Tratado de la Artillería, 1613, pág. 179: Antes que el exérçito contrario se le arrime, tener prudentemente reconosçido de dónde le puede venir más daño, para que no le desmonten sus pieças, mas conservarlas para la mayor occasión, previniéndose con tiempo d'espaldas fuertes sus cubrimientos y blindas, conforme el artillería que tuviere de provecho que cubrir. // Ufano, Tratado de la Artillería, 
1613, pág. 255: Estos candeleros aseguro ser de mucho serviçio para hazer una blinda a prueva, como se a hecho con ellos y dicha faxina la experiençia sobr'el sitio de Ostende en el dique de Busquoy.

ENCICL.: Lucuze (1772: 102-103): "La blinda es un cubrimiento que se hace en parte descubierta, dominada o enfilada de la Plaza, para enmendar el defecto y ocultar el paso o el trabajo". // Ufano, Tratado de la Artillería (1613: pág. 256): "Y aunque no se tiene notiçia del ynventor de la blinde, no dexo de pensar que la pura neçessidad no la aya hecho poner por obra muchos años antes de ahora. Empero, puédese creer verdaderamente que en las repentinas ocasiones de guerra es de mucho serviçio para prestíssima y seguramente cubrirse la gente con ella quando çerca de los enemigos se ofresçiere hazer y fabricar algún obrage de ymportançia; la qual façión es fáçil de meter en obra, y se haze hincando en tierra algunas estacas largas del altura de un hombre, poco más o menos, tan gruesas como el braço o la pierna, entretexendo con ellas, como muestra su figura, de las más largas faxinas que fuere possible, espessa y fuertemente, las que bastaren y, quando no, hazerlas aposta largas y bien ligadas de las más largas ramas de los sauzes o abellanos y rama de renuevos de roble, que cubrirán mucho más la obra que de otros qualesquier árboles o ramage; el qual obrage es tan bueno de hazer que en mitad del día se puede fabricar delante los enemigos en caso que ymporte mucho, como se a hecho algunas vezes, así en la ysla de Bombol como en Ostende y otras partes".

blinde, V. blinda.

boca, boca, voca [del lat. bŭcca 'mejilla'. Cid (DECH). Rojas, Teórica fortificación, 1598]. sust. Fort. En un baluarte con casamata y orejón, la parte del flanco que no está cubierta por este último, esto es, la que linda con la casamata.

Rojas, Teórica fortificación, 1598, fol. 41r: Este recinto se dividirá en cinco partes, el qual supongo que tenga 660 pies desde el punto $\mathrm{A}$ al punto $\mathrm{B}, \mathrm{y}$, partido, como dicho es, será el quinto 132. Los quales se rebatirán de la $\mathrm{AB}$, como lo muestra $\mathrm{AC}$ y $\mathrm{BC}$, dexando las dos CC por cortina franca de 396 pies. Y del punto C se darán 90 de fianco, para la espalda y boca de la casamata. // González de Medina, Examen fortificación, 1599, pág. 53: Y assí, para que esta cortina total nos dé la cortina parcial o franca, que es de la una boca de la casamata a la otra, de trescientos y cincuenta pies de largo, y las golas de los baluartes de cien pies de ancho, serán menester ser las líneas muertas, que constituyeren el pentágono, de quinientos y noventa pies de largo cada una para tomar de cada lado del ángulo ciento $\mathrm{y}$ veynte pies $\mathrm{y}$, desde aquel punto, levantar la perpendicular para la boca de la casamata y su espalda. // González de Medina, Examen fortificación, 1599, pág. 82: Y, hecho esto, mandar que se midan desde los ángulos de las cortinas, como queda dicho, ciento y veynte pies a cada lado y, desde allí, començar las zanjas de las cortinas hasta los otros ciento y veynte pies a cada lado apartados, que será de trezientos y cincuenta pies, y abrir una zanja perpendicular, a los ciento y veynte pies, de cien pies, que es la que ha de servir para la boca de la casamata y su espalda. 
bordo, bordo, vordo [del fr. bord. y éste del fráncico bord 'íd.'. Nebr. (DECH)]. dar $\sim \mathbf{s}$ [Rojas, Teórica fortificación, 1598]. loc. v. Fort. Referido a las trincheras que se abren en el ataque a una plaza: formar una línea en zigzag para facilitar así, en el avance, la comunicación de unas a otras. (fig. 23)

Rojas, Teórica fortificación, 1598, fol. 31v: O. Bordos que van dando las trincheas.

SIN.: dar bordos y ramos.

ENCICL.: Mariátegui (1880: 71): "[Rojas] a los ramales de trinchera [...] los llama bordos, así como dice de éstas que van dando bordos y ramos, frase mucho más castiza y gráfica que nuestro moderno zig-zag, a quien con razón no ha dado hospitalidad la Academia Española en las columnas de su Diccionario". // Estévanez (1897: s.v. ramal): Línea en zigzag por donde se avanza de una paralela a otra, o por donde se comunican baterías y trincheras en los trabajos de aproche contra una plaza sitiada.

dar $\sim \mathbf{s}$ y ramos [Rojas, Teórica fortificación, 1598]. loc. v. Fort. Referido a las trincheras que se abren en el ataque a una plaza: formar una línea en zigzag para facilitar así, en el avance, la comunicación de unas a otras.

Rojas, Teórica fortificación, 1598, fol. 31r-31v: Y, sobre todo, se advertirá el reconocer las trincheas y considerar cómo se van arrimando hasta la estrada cubierta, partiendo desde el punto $\mathrm{S}$, yendo dando bordos y ramos hasta el punto $\mathrm{L}$, assí por la vanda de mano derecha, como por la de mano izquierda, como lo muestran todas las OO que están en la embocadura de cada trinchea. // Rojas, Teórica fortificación, 1598, fol. 32v: Y yo, como digo, le voy arrimando mucho número de gente, porque la frente grande me da lugar de yr dando bordos y ramos con mis trincheas sin que me puedan desembocar ni descubrir de las otras frentes y traveses de la dicha plaça.

SIN.: dar bordos.

bordo, V. dar $\sim$ s y ramos.

botasela, V. botasilla.

botasilla, botasela [del fr. boute-selle (s. XVI). La forma más antigua fue botasela (1595-1794), que más tarde fue castellanizada en botasilla (1705, Gili) (DECH)].

tocar a [Mendoça, Theórica y práctica, 1596]. loc. v. Mil. Ejecutar la música o la señal que indica que los soldados deben ensillar los caballos.

Mendoça, Theórica y práctica, 1596, pág. 68: Vuestra Alteza mandará tocar a botasela a hora que venga a recogerse la gente al alva y sonar entonces a cavallo, tiempo en que estará en la plaça de armas el maestre de campo general, quartelmaestre, capitanes de guías y oficiales de su séguito. // Rojas, Teórica fortificación, 1598, fol. 104v: Y otro día, al 
amanecer, tocan todas las caxas a recoger y las trompetas a botasela, y el capitán de guías o quartel maestre, teniendo todas las guías examinadas y confrontadas, las reparte por su orden, poniendo una de las más práticas e inteligente en la vanguardia, y otra en las vanderas, y otra en el artillería y municiones, y otra en la retaguardia.

ENCICL.: Sobrino (1705: s.v. botasela): Es cuando el trompeta toca a ensillar los caballos en un ejército. Boute-selle, c'est le premier son de la trompete pour faire seller les chevaux. // Sobrino (1705: s.v. tocar a botasela): Sonner le boute-selle. // DRAE (s.v. botasilla o botasillas): Mil. En los cuerpos de caballería, toque de clarín para ordenar a los soldados que ensillen los caballos.

brecha, brexa [del fr. brèche 'íd.' y 'mella', que viene del fráncico breka 'roto, hendidura'. 1643 (DECH). Roxas, Sumario milicia, 1607]. sust. Fort. Rotura o abertura en la muralla de una fortaleza producida por la artillería u otro ingenio militar.

Roxas, Sumario milicia, 1607, fol. 104r: Aviendo hecho el hornillo o mina al baluarte, se le dará fuego con la orden que allí digo en aquel libro, y como ya lo sabrá bien el tal yngeniero; y aviendo bolado el baluarte, se alojarán los soldados en la brexa que se hiçiere, y de allí yrán poco a poco ganando lo demás hasta darle fin por el camino que más conbenga.

SIN.: batería 2 , portillo.

ENCICL.: D'Wartelet (1863): Boquerón o rotura practicada en la muralla de una plaza de guerra o punto fortificado. Según los usos establecidos, para ser practicable debe tener una anchura de 12 metros a lo menos. Los antiguos para abrir la brecha apelaban a los golpes del ariete u otras máquinas bélicas, o bien por medio de la zapa debajo de tierra [...]. En la actualidad se abre la brecha a cañonazos o por medio de las minas. // Almirante (1869): La abertura, rotura o portillo que hace el sitiador en un recinto fortificado por medio de la artillería o de la mina. Toda brecha, después de abierta, necesita hacerse practicable y llana para el asalto con la misma artillería. Si el defensor sostiene la brecha desde un atrincheramiento interior, el sitiador se aloja o se establece en la brecha, es decir, utiliza sus escombros para cubrirse y atrincherarse a su vez, y emprender desde allí el ataque metódico o formal contra la nueva defensa [...]. Es antigua costumbre militar que por la brecha, y no por la puerta, salga la guarnición que capitula. // Rubió y Bellvé (1895-1901): La palabra brecha, que probablemente pasó a nuestro idioma por intermedio del francés, no figura desde muy antiguo en el tecnicismo militar de España. Efectivamente, los historiadores de la Reconquista y de nuestras guerras del siglo XVI llaman casi siempre "portillo" a la abertura practicada en el recinto de las fortalezas.

brexa, V. brecha. 
caba, V. cava.

cabalgada, cavalgada [de cabalgar y éste del lat. vg. caballicare. Kabalkar, S. Juan de la Peña, 1073; cavalgar, Cid (DECH). Celso, Reportorio universal leyes Castilla, 1553]. sust. Mil. Correría o incursión realizada por una tropa de a caballo en territorio enemigo.

Celso, Reportorio universal leyes Castilla, 1553, fol. IXr: Los adalides juzgan sobre las cavalgadas y sobre las cosas que acaescen en ellas, y han de partir el despojo o lo que fuere ganado en el saco, y ponen atalayas, y de noche escuchas y rondas, y han de ordenar las celadas cómo se hagan. // Celso, Reportorio universal leyes Castilla, 1553, fol. CLIXv: Lo mesmo dezimos de lo que fuesse ganado en hazienda, o en lid, o en cavalgada, do fuesse algún capitán por mandado del Rey. // Celso, Reportorio universal leyes Castilla, 1553, fol. CLIXv: Lo mesmo es si lo ganassen en hazienda, o en lid, o en cavalgada, o spolonada, o celada, o entrando en villa o castillo por fuerça, o en navíos de los enemigos, o en qualquier otra manera que se podiesse dezir guerra.

ENCICL.: DSAL: Hist. Expedición militar rápida a caballo, que recorría el campo enemigo para castigarlo o ganar un botín.

2 [Celso, Reportorio universal leyes Castilla, 1553]. sust. Mil. Conjunto de soldados de a caballo que recorre un territorio o un lugar en actitud violenta, devastando, robando, etc. 
Celso, Reportorio universal leyes Castilla, 1553, fol. CVIIIv: Y, haviendo leýdo XX años en Estudio General, deve haver honra de conde e son quitos de pechos, salvo como dezimos de yuso, versículo VII, e no son tenudos de yr en hueste, ni en cavalgada, ni de tornar a otro officio sin su voluntad.

ENCICL.: Cov. (s.v. cavalgada): La tropa de gente de a caballo que sale a correr el campo, y el ganado y presa que han recogido en la tal salida. // Rubió y Bellvé (1895-1901): Era, antiguamente, la tropa que se destacaba de una hueste para "correr" el territorio del adversario.

3 [Celso, Reportorio universal leyes Castilla, 1553]. sust. Mil. Conjunto de cosas que los soldados de a caballo consiguen arrebatar al enemigo en una cabalgada.

Celso, Reportorio universal leyes Castilla, 1553, fol. XXv: No se paga alcavala de las cosas de la Sancta Cruzada. Aý, ley VII, en el dicho Quaderno de las alcavalas. No se paga, ansimesmo, de cavalgadas que se sacaren de tierra de moros. Aý, ley VIII.

ENCICL.: Hevia (1857): El botín que se tomaba a los enemigos cuando se salía en cabalgada.

caballería, caballería, cavallería [de caballero. 1092 (DECH). Montes, Instrucción y regimiento, 1537]. sust. Mil. Conjunto de soldados destinados a servir, desplazarse y combatir a caballo. 1 (fig. 24)

Montes, Instrucción y regimiento, 1537, fol. XVIIr: Y, después que hayan robado el campo, deve el general juntar toda la infantería y cavallería y darles gracias por la vitoria que Dios le ha dado, y prométales muchas mercedes, diziéndoles que el príncipe y señor del exército terná cuydado de gratificarles sus buenos servicios. // Mendoça, Theórica y práctica, 1596, pág. 60: Y aunque antiguamente en las batallas estimaron la cavallería por su furia y presteza más que la infantería, la experiencia los vino a desengañar y poner el fundamento de la milicia en los esquadrones de infantería que se sirven de la pica, a quien se le da el primer lugar en las armas, como a la lança en la gente de a cavallo. // Rojas, Compendio fortificación, 1613, fol. 36r: Y lo mismo corre en la estrada cubierta, que no conviene que sea más ancha de 14 pies y quando mucho 30, y esto aviendo cavallería en la plaza, que, de no averla, bastará que sea de 15 pies de ancho y no más, por muchos respectos.

FAM.: caballero.

ENCICL.: Terr.: En la guerra se dice de los soldados o cuerpo de milicia que va a caballo, y que comúnmente sirve de sostener a la infantería. // Zerolo (1895): Desde los más antiguos tiempos figura la caballería como arma de combate, pudiéndose decir que Egipto fue la cuna de la caballería regular. Los griegos la emplearon como unidad táctica en su célebre falange; Alejandro debió su triunfo de Arbelas (331 ant. de J. C.) a los 7000 caballos con que combatió [...]. El arma propia de la caballería es el arma blanca, y su poder consiste en la fuerza que desarrolla la masa puesta en movimiento. El descubrimiento de las armas de fuego modificó la acción de la caballería, sin que haya llegado a destruirla, 
pero en cambio es un poderoso agente estratégico y táctico, sobre todo para preparar el combate y para terminarlo. Jenofonte dijo hace veintidós siglos que un ejército sin caballería nada gana en la victoria y todo lo pierde en la derrota. // Estévanez (1897): La caballería se divide en pesada (o de línea) y ligera. En España han existido [...] una y otra.

ligera [Collado, Plática Artillería, 1592]. cmpt. sintag. Mil. Conjunto de soldados que, montados en caballos ágiles y de poca alzada, desempeñan empresas de acción rápida, tales como escaramuzas y reconocimientos.

Collado, Plática Artillería, 1592, fol. 2r: Divídela el auctor dicho en dos partes: conviene a saber, en hombre de a pie y de a cavallo; applícala, assimismo, a las partes de el cuerpo humano en esta manera: las manos, dize, son infantería; los pies, la cavallería ligera; los hombres de armas son el cuerpo y la cabeça, el que rije y govierna el exército todo. // Mendoça, Theórica y práctica, 1596, pág. 52: Los sargentos mayores [...] han de venir al maestre de campo general a tomar orden de las vanderas o estandartes que han de entrar de guardia aquella noche y de los puestos donde han de poner los cuerpos de guardia, siendo los hombres de armas, herreruelos y compañías de picas los que la hazen de noche, y la cavallería ligera y compañía de arcabuzeros de día. // Mendoça, Theórica y práctica, 1596, pág. 56: Lo mismo se ha de procurar en el componer un exército en batalla; y si es para representación, darle la forma según el sitio, y a los esquadrones con que la hagan mayor; y si para tentar el enemigo, hazerlo con arcabuzería a cavallo, cavallería ligera, gente desembaraçada y alguna cavallería suelta, travando la escaramuça con tiento.

ENCICL.: D'Wartelet (1863: s.v. caballería ligera): Se compone de los cazadores, húsares, lanceros y otros cuerpos en que los soldados tienen la agilidad propia de los hombres de mediana estatura y de la poca alzada de los caballos que montan, cuyo equipaje, armamento y montura son menos embarazosos. Los escuadrones francos que durante la guerra organiza una nación que está en guerra con otra forman también una excelente caballería ligera, y se emplea en hostilizar constantemente al enemigo en combates y escaramuzas parciales, ataque y defensa de forrajes, servicio avanzado, patrullas, evitar y preparar sorpresas, proteger el despliegue de las columnas, practicar reconocimientos, cubrir retiradas, etc., pues su instituto le permite batirse aun en terrenos quebrados, mucho más si los soldados y caballos son del país en que se hace la guerra.

caballero, caballero, cavallero [del lat. tardío caballarius (s. V). 1076 (DECH). Montes, Instrucción y regimiento, 1537]. sust. Mil. Soldado que sirve, marcha y combate a caballo.

Montes, Instrucción y regimiento, 1537, fol. Xv: Las armas que han de llevar los cavalleros en la guerra son differenciadas de las de la infantería, y los que llevan picas y cosseletes van delante, y los que llevan pica seca van atrás, en medio del esquadrón. // Montes, Instrucción y regimiento, 1537, fol. XIVr: Y por esso, el día de la batalla se haze cuerpo en el escuadrón de infantería, donde fueren los soldados más pláticos en la guerra, porque en ellos está aquel día la fortaleza del exército y ellos han de affrontar los primeros, después que los cavalleros hovieren afrontado, y en ellos se espera la vitoria. // Celso, Reportorio universal leyes Castilla, 1553, fol. CXXXVIv: El cavallero o peón que, siendo con exércitos, 
vendiere o empeñare sus armas, quál pena deven haver el uno y el otro, dezimos de suso, capítulo armas, versículo onze, y capítulo cavallero.

SIN.: caballo 1 .

FAM.: caballería.

ENCICL.: DUE: (empleado solamente cuando se trata de establecer la diferencia con los infantes) Soldado de a caballo.

2 [Lobato, Notas, a. 1585]. sust. Fort. En una fortaleza, defensa muy alta que se construye para descubrir las partes de la campaña por las que el enemigo puede acercarse sin ser visto, o para ofenderle desde allí aunque aún se encuentre lejos; y, en el caso de haber cerca cualquier monte o elevación, para igualar o superar su altura. $\$$ (fig. 25)

Rojas, Teórica fortificación, 1598, fol. 39v: El cavallero es aquél que está señalado con la P, que tendrá de frente y en quadrado sesenta pies, y de alto sobre el terrapleno de la cortina diez pies, con los quales señoreará a los valuartes y a lo demás de la plaça, y por esto le dizen cavallero, porque está a cavallo sobre toda la fábrica. // González de Medina, Examen fortificación, 1599, pág. 18: Los cavalleros, assimesmo, no se tiene por buena fortificación, porque su defensa, aunque para lo largo, antes de llegarse el enemigo, puede ser de algún espanto y de poco daño; llegado cerca, no es de ningún provecho, porque, por estar levantado y descubierto, la artillería del contrario hará mucho daño y ruyna en él, la qual se vendrá al foso y será ayuda y principio de cegarle y subida para el assalto. // Roxas, Sumario milicia, 1607, fol. 79v: Los cavalleros apartados de las cortinas se hazen en la parte que de fuera tiene alguna altura, que desde allí descubre y ofende la çiudad, o en aquella parte donde pudiesen venir cubiertos los enemigos hasta el foso sin que puedan ser vistos; hanse de hazer en tanta altura quanto pidiere el sitio que se pueda limpiar del artillería o otras armas de fuego, que han de ser tan capaçes que quepa muy bien el artillería y soldados a la defensa.

SIN.: plataforma ${ }_{3}$.

ENCICL.: Estévanez (1897): Obra de fortificación más elevada y dominante que las que la rodean. // Aut.: Se llama caballero porque, así como un hombre a caballo señorea a todos los que están a pie, así este caballero domina a toda la plaza y a los enemigos. / / Lucuze (1772: 61-62): "El caballero es una batería elevada [...], que se coloca indiferentemente en cualquier parte del recinto, según la necesidad pidiere [...]. Son muy importantes los caballeros cuando la campaña vecina es de pequeña arena volante o tiene tan poca tierra que, en empezando a cavarla, se encuentra el agua, o si fuere pantanosa porque en estas situaciones, batiendo los caballeros la campaña y dominando los trabajos del sitiador, le obligan a reforzar y levantar los parapetos más de lo regular, y esto le será muy difícil y costoso, careciendo de tierra". // Rubió y Bellvé (1895-1901): Generalmente, los caballeros estaban asentados en el interior de los baluartes, siendo de tamaño variable [...]. Unas veces se colocaban en el centro del baluarte, otras hacia la gola, algunas en medio de la cortina y otras en los extremos de la misma, junto a los ángulos de la espalda. // Díaz 
Capmany (2004: 44): "Se hacía uso de estas obras cuando se quería dominar o descubrir algunas hondonadas en las inmediaciones de la plaza, que al no poderse ver desde otras obras permitirían la aproximación del enemigo a cubierto. La altura de los caballeros dependía del objeto que se pretendía conseguir al establecerlo. La gran dominación de esta obra proporcionaba la ventaja de poder emplear los fuegos de las piezas de artillería en ella situadas desde el primer momento del sitio y durante la mayor parte del ataque".

3 [Collado, Plática Artillería, 1592]. sust. Fort. Cualquier construcción elevada que permite al sitiador, con la artillería allí asentada, batir de forma dominante la fortaleza. \& (fig. 26)

Collado, Plática Artillería, 1592, fol. 91v: Algunas vezes se le offrescerá al artillero la necessidad de alçar el sitio o plaça donde se ha de plantar el artillería, allanarla y ensancharla, y otras, por no haver la comodidad de sitio donde plantarla, levantar bestiones de tierra para, dende allí, batir la fortaleza enemiga, y aun muchas vezes será forçado el ingeniero a querer levantar un baluarte o cavallero de faxina y tierra, para poder después guarnescerlo por defuera con su camisa de muralla. // Mendoça, Theórica y práctica, 1596, pág. 106: Ay muchos ingenios que sería largo referir a Vuestra Alteza, de que se valen en los sitios, aprovechándose del que juzgan, según el estado de las cosas y calidad de la fábrica, ser más conveniente; y algunas vezes lo ha sido el levantar plataformas y cavalleros de fuera con que señorear las de dentro y murallas, viniendo con esto a rendir las plaças. / / Ufano, Tratado de la Artillería, 1613, pág. 157: Pues si esso es assí, ¿por qué se hazen las plataformas y caballeros y, al fin, se buscan los más altos puestos para con ventaja alojar pieças?

SIN.: baluarte ${ }_{3}$, bastión 1 , plataforma 2 .

ENCICL.: Almirante (1869): En general, el caballero de trinchera, de aproche, de acceso, de asalto, de ataque es lo mismo que la terraza [...], el montón de tierra o de otros materiales destinado en la antigüedad a plantar máquinas y, posteriormente, artillería de sitio, que tirase a caballero sobre el defensor de una muralla. // Borreguero Beltrán (2000: s.v. caballero de trinchera): Obras culminantes sobre las demás de ataque a una plaza, que se construyen cerca de las trincheras para instalar las baterías de brecha.

a [Collado, Plática Artillería, 1592]. loc. adv. A mayor altura o desde ella (DRAE). Rojas, Teórica fortificación, 1598, fol. 1v: Y assí, este último requisito es materia de los soldados viejos, de los que han campeado en exércitos a la cara de los enemigos, escogiendo siempre buena plaça de armas, de forma que esté a cavallero sobre la campaña y cortadas las avenidas que huviere. // Rojas, Teórica fortificación, 1598, fol. 78v: Y quando el tiempo y la ocasión de aquella provincia diesse lugar de escoger un sitio fuerte para el tal castillo, es lo más seguro, porque aunque sean las murallas de azero, si las tiene a cavallero algún padrastro, nunca será fuerte la fortificación, como lo podrá considerar bien el ingeniero. // Ufano, Tratado de la Artillería, 1613, pág. 250: Y si, de ventura, uviere en tal sitio y puesto alguna eminente altura, será más útil y conveniente el ocuparla con parte de las dichas pieças para desde allý a caballero señorear más ampliamente al enemigo, y mejor y más libremente descubrir y batir con ellas sus esquadras y batallones. 
SIN.: a caballo ${ }_{2}$.

ENCICL.: DRAE (1780): Mod. adv. con que se significa estar más alta o superior una cosa respecto de otra. // Rubió y Bellvé (1895-1901): Expresión adverbial con que se manifiesta estar una cosa en posición dominante o más elevada que otra; o que califica la acción realizada desde el paraje elevado sobre el más bajo.

caballero, V. a .

caballo, caballo, cavallo [del lat. caballus 'caballo castrado', 'caballo de trabajo', 'caballo malo, jamelgo', que ya en latín vulgar se empleó en el sentido de 'caballo' en general. 932, Oelschl (DECH). Micón, Diario grande cometa, 1578]. sust. Mil. Soldado que sirve, marcha y combate a caballo.

Micón, Diario grande cometa, 1578, pág. 115-116: Y si fuere en los Peces, saldrá de la mar poco pescado, con peligro también de su tempestad y estado calamitoso del pueblo, como se vido en el horrendo cometa del tiempo del emperador Sigismundo, de quien en la guerra murieron como veynte mil soldados, pero de los turcos seycientos mil, cuyo exército era de cien mil infantes y cavallos. // García de Palacio, Diálogos militares, 1583, fol. 65v: Dexo aparte la qüestión que algunos han movido: quáles son más aptos y de provecho en la guerra, los infantes o cavallos, y de quáles se deve usar más, y el subcesso de los numantinos y romanos, porque no creo se puede dar resulición que quadre universalmente. // Mosquera, Comentario disciplina militar, 1596, fol. 45v: Ya sabemos que es cosa cierta la mayor parte de la noticia estar en saber el capitán escoger los lugares para combatir y dar el assalto, como dize Plutarco de Timoleón que junto al río Crimessio, por esta ventaja, venció con cinco mil infantes y mil cavallos sesenta mil cartagineses.

SIN.: caballero 1.

ENCICL.: Moretti (1828): En la milicia se entiende por un soldado de a caballo; y así se dice el ejército tiene tantos mil caballos, acometió con tantos caballos, etc.

2 [Rojas, Teórica fortificación, 1598]. sust. Fort. Armazón o soporte portátil formado por una solera, un pie derecho y dos riostras, que se emplea para sostener el terraplén que, por falta de fajina, debe construirse sin ella.

Rojas, Teórica fortificación, 1598, fol. 51r: Y si, por el contrario, no huviesse estos maderos en el sitio donde se haze la fábrica, y por escusar mucho gasto, se hará una docena de cavallos de madera, que quiere dezir cabrillas, las quales se podrán todas en hilera por la frente del terrapleno, a distancia de seis pies. // Rojas, Teórica fortificación, 1598, fol. 51r$51 \mathrm{v}$ : Y para que se entienda la forma que han de tener las cabrillas o cavallos, haré aquí un par d'ellas para muestra, como parece en la figura siguiente.

SIN.: cabrilla. 
ligero [Fernández de Enciso, Suma de Geographía, 1530]. cmpt. sintag. Mil. Soldado montado en un caballo ágil y de poca alzada, lo que le facilita explorar o correr la campaña, acosar a su enemigo cuando se retira, trabar escaramuzas y demás cometidos similares.

Fernández de Enciso, Suma de Geographía, 1530, fol. XXXVIr: Estos húngaros son buenos hombres de armas, usan arneses y cubiertas, tienen continua guerra con los turcos. Son gentes de medianos cuerpos y robustos, y de dura conversación. Tienen buenos caballos ligeros. // García de Palacio, Diálogos militares, 1583, fol. 56v: Los cavallos ligeros han de ser exercitados en escaramuçar, jugar la lança o zagaya a dos manos, en correr y mandar bien sus cavallos, ayudarse de las espadas y demás armas, con destreza, en subir y descendir cuestas y montañas ásperas, corriendo con gran diligencia. // Álaba, Perfeto capitán, 1590, fol. 130v: Los cavallos lijeros llevarán una celada, un coselete, medios quijotes hasta la rodilla, manoplas, braçales y grandes espaldillas; y la celada sea bien cubierta, la vista quebrada o abierta; una espada ancha, una maça al arzón y una lança larga.

ENCICL.: D'Wartelet (1863): El soldado de caballería ligera.

a [Montes, Instrucción y regimiento, 1537]. loc. adv. Montado en un caballo (DSAL).

Montes, Instrucción y regimiento, 1537, fol. Xv: La gente d'armas y cavallos ligeros son los que hazen fortificar el campo y son differentes en el traer de las armas, porque van a cavallo y las armas que traen son mejores para su propósito que no las picas, porque con las picas no se podrían governar sobre los cavallos. // Álaba, Perfeto capitán, 1590, fol. 6r: Yendo Xenofón, capitán valeroso, marchando con el exército a cavallo, mandó a la gente de a pie que ocupasse cierto cerro, de lo qual como uno murmurasse diziendo que con facilidad mandava las cosas dificultosas y de trabajo, como hombre que yva con tanto descanso en su cavallo, oyendo esto Xenofón, luego se apeó d'él y hizo poner a cavallo al murmurador. // Mendoça, Theórica y práctica, 1596, pág. 149: Reconocido esto, han de hazer subir algún soldado en uno de los árboles, de donde pudiere descubrir más lexos y advertirlos de lo que vee, estando otro soldado a cavallo al pie del árbol para dar aviso a la cabeça de la emboscada de lo que refiere el del árbol.

SIN.: de caballo 1 .

ENCICL.: DUE: Con "estar, ir, montar", etc., sobre una caballería, o sobre cualquier objeto, en posición semejante.

a $\sim_{2}$ [Rojas, Teórica fortificación, 1598]. loc. adv. A mayor altura o desde ella (DRAE: s.v. a caballero).

Rojas, Teórica fortificación, 1598, fol. 39v: Y buelvo a dezir que no le digan al valuarte cavallero, porque el cavallero es aquél que está señalado con la $\mathrm{P}$, que tendrá de frente y en 
quadrado sesenta pies, y de alto sobre el terrapleno de la cortina diez pies, con los quales señoreará a los valuartes y a lo demás de la plaça, y por esto le dizen cavallero, porque está a cavallo sobre toda la fábrica.

SIN.: a caballero.

de a [Apiano, Cosmographía, 1575]. loc. adj. u. t. c. sust. Mil. Dicho de un soldado o de una tropa: que realiza sus funciones a caballo.

Apiano, Cosmographía, 1575, fol. 44r-44v: Fue tan poderosa en tiempo de los machabeos que Antíoco la çercó con ciento y veinte mill hombres de pie y ocho mill de a cavallo. // Álaba, Perfeto capitán, 1590, fol. 67v-68r: Y si particularmente se consideran los efetos que entrambos hazen en la guerra, se hallará que los de la gente de a cavallo son muchos, assí en reconocer el campo de los enemigos como en las correrías y escaramuças que tiene de ordinario con él, en las quales se suele con más facilidad acabar la gente y resistencia de los contrarios que en las batallas declaradas que se dan de poder a poder. // Álaba, Perfeto capitán, 1590, fol. 68r: Y fueran mucho mayores los hechos y hazañas señaladas que hizieran los de a cavallo si en nuestros tiempos no estuviera tan conocido el reparo de picas y arcabuzes de que se usa contra la furia y poder d'esta gente, con que han venido a ser menores los daños y estragos que hazen que los que hazían quando esta manera de ofenderlos no estava tan conocida.

SIN.: de caballo ${ }_{2}$.

ENCICL.: Castro y Rossi (1852): Modo de expresar o distinguir a los que van montados.

de $\sim$ [Celso, Reportorio universal leyes Castilla, 1553]. loc. adv. Montado en un caballo (DSAL: s.v. a caballo).

Celso, Reportorio universal leyes Castilla, 1553, fol. CXXXIVr: Todos los señores y ricos hombres que en las dichas ciudades estuvieren, ansí a pie como de cavallo, aguarden a los dichos pendones y no vayan so capitanía de otra persona, salvo con el Rey, o con el Príncipe, o con quien el Rey mandare, y aguarden los dichos pendones hasta que los tornen a las dichas ciudades. // Celso, Reportorio universal leyes Castilla, 1553, fol. CXXXVIv: Y si fuere de luenga morada, hagan carcavear en derredor el exército, y de noche pónganse sus guardas, assí a pie como de cavallo.

SIN.: a caballo 1 .

ENCICL.: DRAE (1780: s.v. de caballos): mod. adv. ant. Lo mismo que a caballo.

de $\sim_{2}$ [Fernández de Enciso, Suma de Geographía, 1530]. loc. adj. u. t. c. sust. Mil. Dicho de un soldado o de una tropa: que realiza sus funciones a caballo.

Fernández de Enciso, Suma de Geographía, 1530, fol. LIXr: Y en Ipanin le fizieron cierto que avía diez o onze días de camino fasta al Ganges, y que avía allá muchos reyes y que tenía un rey de los de allá treynta mill de cavallo, y tres mill elefantes, e ciento e dozientos mill 
peones, y que no los podría sojuzgar. // Montes, Instrucción y regimiento, 1537, fol. IIIr: Después que la guerra fuere declarada por justa, el señor del exército y los de su consejo de guerra, ante todas las cosas, deven saber la gente que será menester para hazer la guerra, assí de pie como de cavallo, para haver vitoria en la empresa y conquista que quisieren hazer. // Aurel, Arithmética algebrática, 1552, fol. 116r: El Rey, nuestro Señor, embía cierta gente de socorro a una ciudad, con la qual van no sé quántos capitanes, y cada uno d'ellos tiene tres vezes tantos de cavallo, y veynte vezes tantos de pie como son los capitanes.

SIN.: de a caballo.

sonar a $\sim$ [Mendoça, Theórica y práctica, 1596]. loc. v. Mil. Ejecutar la música que anuncia a la caballería que debe montarse en ese instante.

Mendoça, Theórica y práctica, 1596, pág. 68: Vuestra Alteza mandará tocar a botasela a hora que venga a recogerse la gente al alva y sonar entonces a cavallo, tiempo en que estará en la plaça de armas el maestre de campo general, quartelmaestre, capitanes de guías y oficiales de su séguito.

ENCICL.: Moretti (1828: s.v. a caballo): Uno de los toques de la caballería.

caballo, V. a .

caballo, V. de a .

caballo, V. de .

cabar, V. cavar.

cabrilla, cabrilla [de cabra y éste del lat. capra 'íd.'. Cabrilla 'pez que salta mucho', 'ola pequeña que salta en el mar formando espuma' (DECH). Rojas, Teórica fortificación, 1598]. sust. Fort. Armazón o soporte portátil formado por una solera, un pie derecho y dos riostras, que se emplea para sostener el terraplén que, por falta de fajina, debe construirse sin ella. (fig. 27)

Rojas, Teórica fortificación, 1598, fol. 51r: Y si, por el contrario, no huviesse estos maderos en el sitio donde se haze la fábrica, y por escusar mucho gasto, se hará una docena de cavallos de madera, que quiere dezir cabrillas, las quales se podrán todas en hilera por la frente del terrapleno, a distancia de seis pies. // Rojas, Teórica fortificación, 1598, fol. 51r: Y, hecho un troço de sesenta pies de largo, se mudarán las cabrillas más adelante por su orden, y se podrá hazer todo el rodeo del terrapleno con esta invención, porque de otra manera se harán con mucho trabajo los terraplenos, por ser muy altos y gruessos. // Rojas, Teórica fortificación, 1598, fol. 51v-52r: Y assí, aunque se truxesse la fagina de acarreto, de dos, o 
tres leguas del sitio, lo tendré por más acertado que no hazer los enrejados de madera ni andar con las cabrillas apuntalando los terraplenos.

SIN.: caballo ${ }_{2}$.

camarada, camarada [de cámara y éste del lat. vg. camăra (lat. camĕra) 'bóveda'. Camarada 'grupo de soldados que duermen y comen juntos' ant. [1555, Viaje de Turquía], 'compañero' [1592: Eguiluz] (DECH). Lobato, Notas, a. 1585]. sust. m. u. t. c. f. Mil. Respecto a una persona, otra que es compañera suya en el ejército o en la guerra.

Lobato, Notas, a. 1585, pág. 37: Era mi camarada y amigo Diego de Haro, natural de Alcaudete, maestro de las armas, el cual como a hermano me quería y tenía voluntad, y yo a él. Y viéndome padecer mucho mal y dolor de la orina al tiempo del orinar, andando envueltos en la guerra me dijo: «Calla, que si Dios nos deja salir con bien de estas guerras, yo os llevaré por mi tierra y os daré unos polvos con que se os quiten estos dolores y si tenéis piedra se os deshaga». // Mosquera, Comentario disciplina militar, 1596, fol. 92v-93r: Ofreciéronse entonces muchos pleytos entre partes de soldados en materia de presas que se uvieron en el saco, por averse concertado algunas camaradas entre sí de reduzir a comunidad todo lo que cada uno tomasse a su ventura, de suerte que el que no hallasse moneda ni otras manubias que poder traer a partición no por esto avía de ser echado de parte. // Mosquera, Comentario disciplina militar, 1596, fol. 129r: Si en aquella carrera se escapava, no era de suerte que se le permitiesse bolver a su patria ni se atreviesse ninguno de sus camaradas a ospedarlo en su alojamiento, y assí acabava la vida presto el desventurado que quedava con ella.

ENCICL.: Terr.: Compañero, asociado, amigo [...]. En la milicia usan mucho de la voz camaradas, aun los mismos oficiales respecto de los soldados. Camaradas, es menester asaltar esta muralla, etc.

2 [Collado, Plática Artillería, 1592]. sust. f. Art. Conjunto de piezas de artillería, instalado en una posición estratégica y dispuesto para disparar. $\$$ (fig. 28)

Collado, Plática Artillería, 1592, fol. 53v: Las camaradas de los cañones dispararán todas juntas y a un tiempo mismo, porque en esta manera harán un maravilloso effecto y, mientras que los unos artilleros atienden a hazer la batería, como en la letra D y G está figurado, otros de más afuera, con las culebrinas y con las medias, como se vee en las letras C y B, procuren de quitar las defensas de los sitiados, para que al tiempo del assalto no les offendan los traveses E y F. // Rojas, Teórica fortificación, 1598, fol. 105v: Y con este presupuesto se yrá caminando por todas las partes que muestran las trincheas en la planta que queda atrás [...], poniendo en los tres puestos que parecen en ella el artillería; y detrás de cada plataforma y camarada de artillería avrá muy buena guardia de soldados para resistir las salidas que hizieren del dicho castillo. // Rojas, Teórica fortificación, 1598, fol. 105v: Y puesto todo en este estado, començarán las camaradas del artillería a derribar todos los parapetos y defensas, y procurar con toda instancia de desembocar las casas matas que guardan los dos valuartes que se van batiendo. 
SIN.: batería $a_{3}$.

ANT.: contrabatería 2

ENCICL.: Rubió y Bellvé (1895-1901): Art. Por extensión, la batería o conjunto de piezas de artillería que obraban juntas.

camisa, camisa, camissa [del lat. tardío camisia, y a esta lengua parece haber llegado desde el céltico. 899 Oelschl. (DECH). Collado, Plática Artillería, 1592]. sust. Fort. Capa que se hace de diversos materiales para revestir y sostener el terraplén de cualquier obra de fortificación. 3 (fig. 29)

Rojas, Teórica fortificación, 1598, fol. 51v: Buelvo a tratar del terrapleno con fagina, porque es la verdadera fábrica para la guerra y resistencia del artillería, y para hazerse con mucha brevedad y de forma que aguarda, si va bien hecho, el terrapleno quatro y cinco años, hasta que le echan la camisa de piedra. // Rojas, Teórica fortificación, 1598, fol. 68v: Y por esto, es muy necessario que se advierta a dexar plaça vazía fuera del terrapleno, para hazer después la camisa de piedra y los contrafortes, porque, siendo assí, se hará la muralla con menos trabajo y costa, y saldrá la fábrica más fuerte. // González de Medina, Examen fortificación, 1599, pág. 132: No aviendo piedra para la camisa de la muralla, no ay que dar pena ni traerla con excessivo gasto de lexos para ello, si ay de qué hazer ladrillos, que se tiene por bueno, y aun por mejor que de piedra, en las partes sugetas a batería.

SIN.: encamisado 1 .

FAM.: encamisada, encamisado, encamisar.

ENCICL.: Sanz (1749): Es una antigua voz de fortificación que significa el revestimiento de muralla que se da a las obras de tierra, particularmente a las que son de tierra arenosa, sin el cual se necesitaría de declivio para sostenerla y darían facilidad a la subida. Hoy se llama obra revestida o plaza revestida. / Estévanez (1897: s.v. revestimiento): Lo que sirve en cualesquiera obras de fortificación para consolidar, contener y revestir la tierra amontonada. Los revestimientos de campaña son generalmente de cestones, zarzos, tepes, fajinas, tablas, adobes, sacos de tierra; en las obras permanentes hay la misma variedad de revestimientos, desde el ladrillo hasta la sillería, desde el hormigón hasta el hierro y el acero. // Aut.: En la fortificación es la parte de la muralla hacia la campaña, que suele hacerse de piedra o ladrillo. Se llama camisa por vestir la muralla por la parte de afuera.

2 [Álaba, Perfeto capitán, 1590]. sust. Mil. Prenda de vestir que emplean las tropas en un asalto para distinguirse del enemigo.

Álaba, Perfeto capitán, 1590, fol. 90v: Y luego, aquella noche, sin bagaje marchará con mucha presteza a la ciudad que quiere conquistar $\mathrm{y}$, en llegando aquella misma noche o por la mañana en amaneciendo, que es quando más fatiga el sueño, hará que cada uno se 
ponga una camisa sobre las armas, para que con aquella seña no se hagan mal unos a otros, y dará el assalto a la ciudad.

ENCICL.: Moretti (1828: s.v. camisa para sorpresas) Nombre de una camiseta ancha y corta, que no pasa de la cintura, de tela muy blanca, con una o dos mangas, o sin ninguna, según lo determine el general, la cual, a la hora perentoria y con el mayor sigilo, se reparte a las tropas que deban dar un golpe de mano, siendo por la noche, para que se las pongan por encima de los uniformes, y por este medio se conozcan los compañeros mutuamente, y no se ofendan creyéndose enemigos.

3 [García de Palacio, Diálogos militares, 1583]. sust. Mil. ant. Nombre empleado por los griegos para referirse a la longitud del asta que usa cada soldado al combatir en una formación táctica.

García de Palacio, Diálogos militares, 1583, fol. 146r: Los griegos, señor, ordenavan su gente en forma de batallón o esquadrón, a cinqüenta o sesenta por orden, y las cinco o seys órdenes primeras peleavan juntamente, porque la longitud de sus hastas (llamadas entre ellos camissas), passando por las dichas cinco órdenes, podía alcançar a los enemigos que estuviessen juntos con los de la primera orden.

\section{camissa, V. camisa.}

campal, V. batalla .

campaña, campaña, canpaña [del lat. tardío campania 'llanura' (s. VI). Berceo, S. $M$. en el sentido de 'tierra llana', por oposición a 'país montañoso'; la ac. 'conjunto de operaciones de guerra' ya aparece en Ercilla, 1569, con anterioridad a la fecha en que aparecen con este sentido el fr. campagne, 1587, y el it. campagna, 1598 (DECH). Montes, Instrucción y regimiento, 1537]. sust. Mil. Terreno extenso fuera de poblado, y especialmente aquella parte que ocupa o por la que transita una tropa o una fuerza durante alguna empresa u operación de guerra.

Montes, Instrucción y regimiento, 1537, fol. IXv: Hay algunos generales que, desque una vez affirman un campo en una parte, no le levantan hasta a ver el fin de lo que dessean; si aquello se puede alcançar, bueno es, mas si lo que dessean se dilata, es malo para la salud del exército, que está al sereno en la campaña, porque tanto se deve mirar por la salud del exército como por el vencimiento de los enemigos, porque, si su campo enferma, con la gente enferma no se puede hazer guerra. // Álaba, Perfeto capitán, 1590, fol. 75r-75v: Fuera de lo que he dicho que a menester el que está en campaña, es necessario el que está en una ciudad o fuerça se prevenga, antes de verse cercado de los enemigos, pues tiene más comodidad de todo que el que está en campaña, de que todas las partes por donde le pueden ofender y hazer perjuyzio las tengan fortificadas, reparadas y guardadas. // Roxas, Sumario milicia, 1607, fol. 45r: Y así conbiene con tiempo recoger todas las bituallas 
dentro de los castillos y en mucha abundancia, de manera que les haga falta al enemigo en la campaña para que le obligue a levantarse.

SIN.: campo 1 .

ENCICL.: Aut.: 1- El campo igual, que no tiene montes ni peñascos, y generalmente todo el sitio que no tiene casas. 2- El campo que ocupa el ejército cuando está fuera de los alojamientos, aunque sea montuoso y lleno de peñascos. // Mendoça, Theórica y práctica (1596: pág. 65): "Quando se halle paýs áspero y montuoso será de poco provecho la cavallería y más provechosa la infantería, principalmente si ay en ella buena arcabuzería, que viene a combatir en la campaña de las condiciones escritas, hallando reparo en las más partes donde disparar al seguro".

en $\sim$ [Montes, Instrucción y regimiento, 1537]. loc. adv. Mil. En operaciones de guerra.

Montes, Instrucción y regimiento, 1537, fol. VIIr: Bien será que se sepa qué personas han de governar el exército y cómo se han de haver en la governación d'él, porque no dura más en campaña el exército de quanto dura la buena governación d'él. // García de Palacio, Diálogos militares, 1583, fol. 21v: Vitruvio, De Architetura, pintó un architeto perfectíssimo y Vegecio, De Re Militari, pretendió esto mismo y trabajó en dar un exemplar absolutíssimo de un exército, el qual tan acabado y perfecto no se deve de aver visto en campaña. // Roxas, Sumario milicia, 1607, fol. 41r: También los elefantes suelen enturbar a los soldados y a los cavallos en las peleas con su grandeça de cuerpo y la gran voz de su bramido, y con la estrañeza de su talle; el primero que los truxo en campaña contra el exérçito romano fue el rey Pirrho en Lucania.

SIN.: en campo.

ENCICL.: DRAE (s.v. estar, o hallarse, en campaña): frs. Mil. Hallarse en operaciones de guerra.

campaña, V. en $\sim$.

campear, campear [de campo. Alex. en la ac. 'guerrear, estar en campaña' $(\mathrm{DECH})$. Mendoça, Theórica y práctica, 1596]. v. intr. Mil. Dicho de un ejército: salir al campo y desplazarse por él durante una operación militar.

Mendoça, Theórica y práctica, 1596, pág. 76: Y porque de ordinario, campeando, viene a ser forçoso el aver de passar riberas por vado o puentes en que ay por la mayor parte gran peligro, por la ventaja que se les da a los enemigos para poder acometer el passo o defenderle, conviene que Vuestra Alteza lo considere mucho. // Mendoça, Theórica y práctica, 1596, pág. 145: Retirados los exércitos para invernar, no dando la rezura del tiempo comodidad para campear, se pone la gente que no se despide en los presidios y fronteras, assí para que descanse del trabajo de la campaña y refresque, como para que 
guerree desde las villas. // Lechuga, Discurso de la Artillería, 1611, pág. 259: Advierto que, campeando un exército, se offreçe ser necessario hazer muchos fuertes y que es muy ordinario hazerlos sin baluartes ni traveses, de manera que las cortinas en sí se defiendan.

FAM.: acampado, acamparse, campo.

ENCICL.: Ufano, Tratado de la Artillería (1613: pág. 83-84): "Y todo se haze así por aligerar el coste de carros, caballos y conductores, en espeçial siendo penuria de gente y dinero y el prínçipe de la empresa no muy rico y poderoso; pero siéndolo, mucho mejor sería con exérçito cumplido y poderoso llevar de una vez toda la provisión de muniçiones, así del bito como de guerra, y qualesquier máquinas y petrechos aderentes a tal exército y empresa para campear justamente 6 meses, qu'es lo que permite la naturaleza del tiempo, espeçialmente en tierras frías y aquosas, como las d'estos estados, que no se sufre campear con exérçito formado si no es dende los primeros de mayo hasta los últimos de octubre".

2 [Mendoça, Theórica y práctica, 1596]. v. intr. Mil. Salir a combatir en campo raso. Mendoça, Theórica y práctica, 1596, pág. 110: Resolviéndose Vuestra Alteza en yr a campear con el enemigo, buscándole, y dar la jornada, escriví en común las consideraciones que se han de tener para el formar los esquadrones y ponerlos en batalla; y raras vezes se viene a combatir sin averse hecho antes alojamientos y reconocido los exércitos.

ENCICL.: DRAE: Dicho de un ejército: Salir a combatir en campo raso.

campo, campo, canpo [del lat. campus 'llanura', 'terreno extenso fuera de poblado'. 931 (DECH). Fernández de Enciso, Suma de Geographía, 1530]. sust. Mil. Terreno extenso fuera de poblado, y especialmente aquella parte que ocupa o por la que transita una tropa o una fuerza durante alguna empresa u operación de guerra.

Fernández de Enciso, Suma de Geographía, 1530, fol. LXIr: En una isla grande que el Ganges haze en medio [...] está un rey que se llama Paliborto y es muy poderoso, que pone en el campo dozientos mill hombres de pelea e veynte mil de cavallo y tres mil elefantes. // Celso, Reportorio universal leyes Castilla, 1553, fol. IXr: Adalid, es el que es escogido para descobrir el campo y exército y celadas de los enemigos. / / Álaba, Perfeto capitán, 1590, fol. 42r: Y porque el aviso de lo que se descubriere llegue con mayor brevedad, será de importancia que las personas a quien se huviere de dar cargo de allanar el campo sean de los estradiotes y arcabuzeros de a cavallo y que después d'ellos vaya algún número de cavallos ligeros que les hagan espaldas y socorran en los peligros y debates que se les ofrecieren.

SIN.: campaña.

FAM.: acampado, acamparse, campear. 
ENCICL.: Estévanez (1897): Extensión de terreno despoblado en que se establece, acampa o maniobra un ejército. // DRAE: Mil. Terreno o comarca ocupados por un ejército o por fuerzas considerables de él durante las operaciones de guerra.

2 [Ortega, Conpusición Arismética y Geometría, 1512]. sust. Mil. Campamento o conjunto de instalaciones donde se establece temporalmente un ejército en campaña.

Ortega, Conpusición Arismética y Geometría, 1512, fol. 202v: El rey, nostro Señor, manda fazer una tienda en un campo a un maestro, el qual maestro fizo la tienda en que puso un mástil que tiene de largo 100 canas; y el paño que viene desde la cabeça del mástil fasta la tierra tiene de largo 140. / / Montes, Instrucción y regimiento, 1537, fol. XIr: No tendría yo por venturoso al general que se escusasse de dar la tal batalla, llevando la gente tan diestra en la guerra y la demanda tan justa. E quando el campo assentare a vista de los enemigos, los maestros de campo tengan tal aviso que donde el campo se assentare haya tres cosas para el mantenimiento del campo: agua para la gente, yerva para los cavallos, leña para hazer fuegos y choças donde se meta la gente. // Celso, Reportorio universal leyes Castilla, 1553, fol. CLVIIIv: Si la presa que cobraron hoviesse trasnochado en poder de los enemigos, o si la hoviessen metido en su campo o real, o dentro de alguna fortaleza, la tal presa es de los que la cobraren.

SIN.: real $^{2}$.

ENCICL.: Terr.: El espacio en que se acampa y forman las tiendas de campaña. // GagoJover (2002): Campamento, lugar en despoblado donde se establecen temporalmente fuerzas del ejército, resguardadas de la intemperie bajo tiendas de campaña o barracas, distribuidas de modo que dejen entre sí fácil tránsito para la vigilancia y rápida formación en caso de alarma.

3 [Montes, Instrucción y regimiento, 1537]. sust. Mil. Lugar o sitio en el que han combatido o en el que van a combatir dos formaciones militares enemigas.

Montes, Instrucción y regimiento, 1537, fol. XVr: La verdad es que, según la costumbre y ordenança antigua de los vencedores, el que queda señor del campo y lleva los despojos, de aquél es la vitoria. // Álaba, Perfeto capitán, 1590, fol. 132r: No tendiendo estas cinco ventajas, o la mayor parte d'ellas, escusará el capitán de dar la batalla si no estuviere necessitado de mantenimientos y tuviere certidumbre que a sus contrarios les viene socorro. Y, en este caso, dilatará el salir al campo, de suerte que ya estén cansados de esperarle, con que les hará perder parte de sus fuerças. // Roxas, Sumario milicia, 1607, fol. 40r: Falta aora una cosa por enseñar, qu'es de la manera que nos debemos apartar del enemigo, porque los maestros de la guerra y exerçitados en ella confiesan que en ninguna parte ay más peligro que en el retirarse, porque el que se retira del campo sin pelear haçe dos cosas: a los suyos quita la confiança y a los enemigos aumenta la osadía.

SIN.: campo de la batalla.

ENCICL.: Gago-Jover (2002): Sitio en que se desarrolla una lucha. 
4 [Montes, Instrucción y regimiento, 1537]. sust. Mil. Tropa o ejército en operaciones de guerra.

Montes, Instrucción y regimiento, 1537, fol. IXv: Tanto se deve mirar por la salud del exército como por el vencimiento de los enemigos, porque, si su campo enferma, con la gente enferma no se puede hazer guerra. // García de Palacio, Diálogos militares, 1583, fol. 75v: Opuestos dos campos, ¿qué orden terná el uno para consumir y deshazer al otro?, y si es más cordura suffrir con ánimo y ossadía el ímpetu y arremetida de los enemigos o asaltallos y acometellos en sus principios, con toda su furia. // Álaba, Perfeto capitán, 1590, fol. 46r: Y si marchando el campo huviere lengua de la parte por donde quiere acometer el enemigo, la cautela de que podrá usar para desbaratarlo con más facilidad será poner hazia aquel mesmo lugar el vagaje y todas las vituallas del exército, porque se ceve en el robo d'ellas.

ENCICL.: Cov.: Campos se llaman los ejércitos en campaña, y así decimos el campo nuestro y el de los enemigos.

de la batalla [Collado, Plática Artillería, 1592]. cmpt. sintag. Mil. Lugar o sitio en el que han combatido o en el que van a combatir dos formaciones militares enemigas.

Collado, Plática Artillería, 1592, fol. 98r: Verdad es que en algunas batallas me he hallado y visto en la manera que para el día de una batalla se prepara un exército y lo que toca a hazer a un general y a un maestre de campo; he visto poner gran cuydado en reconoscer el campo de la batalla y qué qualidades concurrían en él para aquel día, y quáles eran en nuestro proveho y quáles en nuestro daño. // Collado, Plática Artillería, 1592, fol. 98v: Acerca de la electión del sitio que vuestra señoría demanda respondo que, si en el campo de la batalla se hallasse algún cerro o otra eminencia, deve el general de artillería poner todas sus fuerças en occuparla, porque en tales tiempos estos sitios son muy estimados y se goza de gran ventaja en posseerlos.

SIN.: сampo $_{3}$.

ENCICL.: Aut. (s.v. campo de batalla): El sitio donde se ha dado la batalla, o donde se ha de dar entre dos ejércitos. // Rubió y Bellvé (1895-1901: s.v. campo de batalla): Porción de terreno en que combaten dos ejércitos o tiene lugar una "batalla".

en $\sim$ [Escalante, Discurso de la navegación, 1577]. loc. adv. Mil. En operaciones de guerra.

Escalante, Discurso de la navegación, 1577, fol. 97r: Dizen que es tan gran señor el rei d'esta tierra, que pone en campo trezientos mil ombres y los dozientos mil a cavallo. // Escalante, Discurso de la navegación, 1577, fol. 97v: Con lo que este capitán dize de que pone este rei trezientos mil ombres en campo, sin las guarniciones que de ordinario tiene en las ciudades y fronteras, queda mi parecer aprobado. 
SIN.: en campaña.

campo, V. en $\sim$.

candelero, candelero [de candela y éste del lat. candēla 'íd.'. Berceo, Sacr. 8; h. 1300: Gr. Conq. de Ultr. (DECH). Lechuga, Discurso de la Artillería, 1611]. sust. Fort. Bastidor portátil de madera, compuesto de una solera y dos montantes, entre los cuales se ponen fajinas, salchichas o sacos para defenderse de los enemigos y cubrir los trabajos de sitio. $\quad$ ? (fig. 30)

Lechuga, Discurso de la Artillería, 1611, pág. 206-207: Manda hazer quantidad de candeleros y de estacas y, por concluir, de todas las cosas necessarias a ganar la fuerça, porque todas ellas y lo que qüestan a de passar por su mano, y lo mismo el gasto de las trincheras y de quantos fuertes y fuerças se hazen andando en campaña. // Ufano, Tratado de la Artillería, 1613, pág. 255: Fabrícanse los candeleros en el modo y manera que la presente figura demuestra. Y deven ser tan altos que buenamente con ellos y faxina se pueda de presente cubrir la gente que començare a abrir trincheas y ordenar baterías, y tan ancho el un mástel del otro que puedan entre ambos buenamente caver dos o tres salchichas o gruesas faginas de lado. // Ufano, Tratado de la Artillería, 1613, pág. 259: Y por tal ocasión dexó el embaraço de los salchichones y se fue mejorando y caminando con el uso y compossiçión de las salchichas metidas entre unos candeleros, como los predichos, hasta acabar de llegar con el dicho dique al puesto determinado para tal effeto, como se a contado.

ENCICL.: Lucuze (1772: 102): "Los candeleros son muy importantes para formar un parapeto o hacer de pronto un alojamiento. Consisten en un madero en cuyos extremos se levantan otros dos de la altura de cinco a seis pies, y entre éstos se llena el intermedio de fajinas". / / Ufano, Tratado de la Artillería (1613: pág. 255-256): "De la calidad del maderame no trato más de que se labre de la forma que por ellos se demuestra, de buena madera, y que sean ligeros de transportar de una a otra parte, aunque estén estivados de faxinas y otra qualquiera broza o ramage. Estos candeleros aseguro ser de mucho serviçio para hazer una blinda a prueva, como se a hecho con ellos y dicha faxina la experiençia sobr'el sitio de Ostende en el dique de Busquoy [...]. Puédese servir d'ellos al desembocar de las trincheas y al atrabesar los fossos en sitios de villas y fortalezas, como se començó a servir d'ellos en el sitio de Rimberghe, en la parte y quartel de los españoles; $y$, çierto, es de creer que para tales effetos son de mucha utilidad, espeçialmente en fossos de poca agua y llenos de maleza, donde con mucha façilidad y poco trabajo seguramente se pueden meter en poco tiempo".

canpaña, V. campaña.

canpo, V. campo. 
cañonera, cañonera [de cañón (DECH). Loçano, Alberto, Architectura, 1582]. sust. u. m. en pl. Fort. Agujero o abertura que se hace en las baterías o parapetos para disparar la artillería y reconocer con menos riesgo los movimientos del enemigo. ?ㄱ (fig. 31)

Álaba, Perfeto capitán, 1590, fol. 88v: Y adviértase que los cañones estén assentados sobre tablones que declinen hazia la cañonera, para que con facilidad después de disparados puedan bolver a ella. // Rojas, Teórica fortificación, 1598, fol. 78v: Y hazerse han las cañoneras del artillería que tiren de alto para abaxo, porque no puedan ser desembocadas de los padrastros. // Roxas, Sumario milicia, 1607, fol. 87r: Y quando no se puedan hazer ninguna d'estas dos cosas, es neçesario fortificarse al encuentro del padrastro, de tal suerte que se pueda resistir a todo el daño que d'él se pueda hazer, puniendo delante una gallarda punta de baluarte, si el sitio lo sufriere, de tal forma que no se pueda desde el padrastro desembocar las cañoneras del través que ha de guardar este baluarte.

SIN.: saetera, tronera.

ENCICL.: Moretti (1828): Fort. Abertura que se hace en el parapeto de una obra de fortificación, o en el espaldón de una batería, o lo que es lo mismo, el espacio que hay entre almena y almena de las murallas antiguas, o entre merlón y merlón de las modernas u obras de tierra. // Lopes Pires Nunes (2005: s.v. canhoneira): Intervalo entre os merlões de uma fortificação abaluartada, na qual eram dispostas as bocas de fogo. As canhoneiras, que têm ou seu correspondente medieval nas abertas das ameias, començaram por ser rasgadas no corpo da cortina ou do baluarte, havendo casos em que aparecem em dois níveis -ao alto, entre os merlões, e no corpo do muro. Esta dupla disposição corresponderá à transição da passagem da canhoneira do corpo para o alto da fortaleza, onde acabou por se fixar definitivamente. / / Lucuze (1772: 28): "La cañonera es una abertura, dispuesta en el parapeto, para que pueda tirar el cañón. Empieza la cañonera a tres pies de altura por la parte interior, lo que se llama rodillera, y con declivio hacia la exterior, en donde tiene la latitud de diez pies, para que el rebufo de la pieza no maltrate los costados. La interior latitud es de dos pies y medio". // Lorenzo Celorrio (1996): Presenta un abocinamiento hacia el exterior y generalmente un arco escarzano muy rebajado cuando están cubiertas.

carcavear, carcavear [de cárcava 'zanja o foso defensivo', 'hoya en general, y particularmente la destinada a enterrar muertos', que es alteración del antiguo cácavo, que viene de caccăbus 'olla', 'cazuela', procedente a su vez del gr. xáxxaßos 'íd.'. Carcavar 'fortificar con cárcava' [fin s. XV: G. de Eugui]. Es más antigua la forma carcavear, que ya está en Alex., Partidas, $1 .^{a}$ Crón. Gral. y en A. de Cartagena (DECH). Celso, Reportorio universal leyes Castilla, 1553]. v. tr. Fort. Rodear un campamento o puesto militar con foso.

Celso, Reportorio universal leyes Castilla, 1553, fol. CXXXVIv: Y si [el alojamiento] fuere de luenga morada, hagan carcavear en derredor el exército, y de noche pónganse sus guardas, assí a pie como de cavallo. 
ENCICL.: Almirante (1869): Atrincherar el campo, rodearlo de foso. // Rubió y Bellvé (18951901): Fort. Antiguamente, circundar el aposento o campamento de una hueste de una cárcava o foso.

carço, V. zarzo.

carnero, carnero [del lat. carnārĭus, $-a,-u m$ 'de la carne, relativo a la carne', de cărō, carnis 'trozo de carne', 'carne'. Carnero 'macho de la oveja'. 1049 (destinado a carne, por oposición al morueco, semental) (Segura Munguía 2001). Álaba, Perfeto capitán, 1590]. sust. Fort. ant. Máquina empleada para batir murallas, consistente, fundamentalmente, en una viga o trabe larga y pesada, uno de cuyos extremos está reforzado con una pieza de hierro o bronce, labrada, por lo común, en forma de cabeza de carnero.

Álaba, Perfeto capitán, 1590, fol. 173r: Es verdad que ay otros que dizen que tiene fuerça de abrasar, pues lo ponen en la composición de cosas que son a propósito para quemar, los galápagos, carneros y torres portátiles que usavan los antiguos para combatir y quemar armadas de mar. // Roxas, Sumario milicia, 1607, fol. 27v-28r: También ha de aver lobos, que son unos garabatos de hierro, y hoçes enastadas en lanças y, para haçer las trincheras y fosos, las herramientas ya dichas; y galápagos, y músculos, carneros, víneas, mantas y otras menudençias, que sería larga su declaraçión.

SIN.: ariete, vaivén.

casa, casa [del lat. casa 'choza, cabaña'. 938, Oelschl. (DECH)].

fuerte [Ortega, Conpusición Arismética y Geometría, 1512]. cmpt. sintag. Fort. La que está dotada de algunas fortificaciones o reparos para poder defenderse en ella de los enemigos. 1 (fig. 32)

Ortega, Conpusición Arismética y Geometría, 1512, fol. 202v: Un hombre tiene una casa fuerte, la qual tiene 40 canas de alto. Este hombre tiene una escala que tiene 60 canas de largo y quiérela poner desde encima de la torre fasta la tierra. Demando que quántas canas havrá desde el pie de la torre fasta la punta del pie de la escala. // Celso, Reportorio universal leyes Castilla, 1553, fol. LXXXVv: No consientan que se hagan castillos ni casas fuertes en su jurisdición, y de las hechas nuevamente avisarán al Rey. // Lechuga, Discurso de la Artillería, 1611, pág. 206: Llévanse los petardos para valerse d'ellos contra tierras sin fossos, contra casas fuertes que pueden impedir o hazer daño a un exército y obligarlo a llevar la artillería contra ellos, y otras muchas cosas que se pueden offrecer de effectos necessarios al que campea.

ENCICL.: D'Wartelet (1863): La que se fabricaba en otros tiempos en forma de un edificio común u ordinario, pero suficientemente fortificada para defenderse en ella. 
casa mata, V. casamata.

casamata, casamata, casa mata, cassamata [del it. casamatta (1520), donde matta, propiamente 'loca', parece tener el valor de 'falsa, impropia', probablemente en el sentido de 'algo que parece una casa'. Casamata 'bóveda muy resistente para instalar una o más piezas de artillería'. 1536 (DECH). Montes, Instrucción y regimiento, 1537]. sust. Fort. Cámara abovedada, construida en el interior del terraplén, donde se colocan piezas de artillería. (fig. 33)

Montes, Instrucción y regimiento, 1537, fol. XVIIr: El muro ha de ser bien fraguado; ha de tener sus traveses que jueguen por lo baxo del fosso, con que haya de través a través ciento y cinqüenta passos o, a lo menos, casas matas, para que la artillería pueda jugar dentro d'ellas por lo alto y por lo baxo. / / González de Medina, Examen fortificación, 1599, pág. 2728: Las casas matas han de tener treynta pies de boca para que quepan muy bien dos pieças gruessas y los que las huvieren de manejar, y quarenta pies de ancho para el largo de las pieças y retirada, y sesenta de largo; descubierta, porque el humo no ahogue a los soldados y artilleros que estuvieren en ella a la defensa. / / González de Medina, Examen fortificación, 1599, pág. 29: El orejón ya se ha dicho las medidas que ha de tener, y que sirve de cubrir las casas matas, que es la principal defensa que tiene una fuerça, y que no pueda el enemigo descubrirlas, si no es entrando en el foso y con mucho peligro.

ENCICL.: Clairac y Saénz (1877-1891): Bóveda construida en alguna parte de la muralla de una plaza con objeto de establecer una batería baja para defender el foso y poner a los soldados a cubierto de los proyectiles huecos, formar hospitales de sangre o almacenes de pólvora y víveres. Parece que en 1526 construía Micheli, en Italia, baluartes redondos con casamatas; pero su invención se atribuye por los más de los autores a Alberto Durero. // Aut.: Term. de fortificación. Es una bóveda o subterráneo a prueba de bomba, que ordinariamente se construye debajo de los baluartes o bastiones [...]. // Echarri Iribarren (2000: 525): "Parte del bastión situada en el flanco y protegida por el orejón que alojaba diversas piezas de artillería, cuyo objetivo era defender el paso del foso por parte del asaltante. Bóveda muy resistente para instalar una o más piezas de artillería". // Lucuze (1772: 59): "La experiencia hizo luego conocer su poca utilidad; porque el humo, a los primeros tiros, la dejaba de suerte que los defensores eran obligados a desampararla. Procurose después corregir el defecto haciendo la casamata descubierta detrás del orejón o espalda $[\ldots] "$.

casamuro, casamuro [cmpt. de casa y muro. Casamuro, propiamente 'muro de casa'. 'Pared maestra' arag. (1625), 'muralla ordinariamente sin terraplén' fortif. (1590, B. Mendoza) (DECH). Mendoça, Theórica y práctica, 1596]. sust. Fort. Muralla ordinaria y sin terraplén (DUE).

Mendoça, Theórica y práctica, 1596, pág. 16: Debaxo d'este presupuesto se ha de considerar la calidad del reyno que se acomete, quál es el temple, clima y distancia de su districto, si montuoso o llano, seco o de muchas riberas y bosques, fértil, abundante, muy poblado o no en número de villas y ciudades, si están cercadas con mayor defensa que las murallas 
ordinarias, que llaman casamuro, las entradas que ay y puertos para envestirle con exército o armada [...]. // Mendoça, Theórica y práctica, 1596, pág. 100: Al batir, quando las murallas son casamuro sin terrapleno, se han de plantar las pieças de manera que batan en la muralla al sesgo, porque entonces la quebrantan más con la resistencia que hallan.

FAM.: contramuro, murado, murador, murar, muro.

cassamata, V. casamata.

castellano, castellano [del lat. castellanus. Castellano 'señor o alcaide de un castillo'. Cid (DECH). Collado, Plática Artillería, 1592]. sust. Fort. Persona responsable de la conservación y defensa de un castillo y también, por extensión, de otro tipo de fortalezas.

Collado, Plática Artillería, 1592, fol. 103r: Contávame Sancho Dávila que, hallándose sitiado en el castillo d'Anvers donde, por falta de artilleros spañoles, eran casi todos flamencos los que allí havía y haviéndose de nuevo rebelado los estados y siendo necessario tirar y offender el castillo a los enemigos, que todos los tiros eran vanos porque, o los tiravan sin meter balas o salvavan por encima las trincheras. Lo que visto por el castellano dicho y que su artillería no hazía effecto, fue forçado de retirar de la facción los artilleros flamencos y poner a cargar y disparar las pieças los capitanes españoles mismos y soldados. // Mendoça, Theórica y práctica, 1596, pág. 138: Dándole el contraseño, si lo ay, el tal alcayde o castellano lo ha de dilatar hasta la última hora de las veyntiquatro del día que precissamente se le señaló, cumpliendo d'esta suerte con el obedecer a su príncipe y sin manchar la lealtad devida. // Rojas, Teórica fortificación, 1598, fol. 78v-79r: Y no teniendo agua de pie, se harán cisternas para la llovediza, y generalmente tendrá todos los aproges de guerra dichos, de los quales tendrá una lista por escrito el castellano, de forma que no le falte pieça de su arnés el día que cargare el enemigo, porque se remedia mal lo que faltasse el día que el enemigo huviesse sitiado la tal plaça.

SIN.: alcaide.

ENCICL.: Cov.: El alcaide, a cuyo cargo está el castillo.

castillo, castillo [del lat. castěllum 'fuerte, reducto', diminutivo de castrum 'campamento fortificado', 'fortificación'. Castiello, 972 (DECH). Anónimo, Ordenanças paños, 1527]. sust. Fort. Pequeña fortaleza construida para ocupar un puesto de importancia estratégica (Lorenzo Celorrio 1996: s.v. fuerte).

Montes, Instrucción y regimiento, 1537, fol. XVIIIv-XIXr: Por quatro maneras de batalla se puede ganar un castillo: por batalla de manos, o por batería, o por mina, o por hambre. Si se gana por mina, puédese defender por contramina; si se gana por batería, puédese defender reparando el muro por la parte de dentro [...]; y la batalla de manos puédese defender por batalla, porque más valen los pocos dentro del fuerte que los muchos defuera del fuerte; mas a la hambre no hay defensa, porque si el alcayde no tiene vitualla dentro 
del castillo para los soldados, claro está que se han de rendir, sin dar batalla ni esperar. // Álaba, Perfeto capitán, 1590, fol. 86r: Y no sería menos inexpugnable que las fuerças fuertes por naturaleza donde la artillería y assaltos no pueden hazer sus efetos, como son algunos castillos roqueros de gran altura y los lugares edificados entre lagunales y tremedales, o cercados de mar o de algún gran río hondo. // Rojas, Teórica fortificación, 1598, fol. 21v: En las figuras quadradas se acomodan mal los ángulos y defensas de la fortificación, y el exágono, que quiere dezir figura de seis valuartes, es fortificación muy grande para sólo un castillo y, assí, no sirve sino para rodear una ciudad o para hazer una plaça muy grande, donde huviere de aver mucha guarnición de soldados, que en tal caso se hará conforme al tal presidio.

SIN.: fuerte 2 .

FAM.: encastillarse.

ENCICL.: Terr.: En la fortificación, V. ciudadela y fuerte. // Rubió y Bellvé (1895-1901): Hoy se dice más usualmente "fuerte" [...]. El feudalismo, en toda Europa, y las exigencias de la Reconquista, en España, dieron lugar en todas partes a una enorme profusión de este género de fortalezas. // Estévanez (1897): Fuerte, que en la Edad Media no faltaba en población alguna de importancia.

2 [Fernández de Enciso, Suma de Geographía, 1530]. sust. Fort. Fuerte o pequeña fortaleza que, en ocasiones, se construye en el lugar más ventajoso de una plaza con la finalidad de controlar a sus habitantes, además de que sirve de último refugio a la guarnición.

Montes, Instrucción y regimiento, 1537, fol. VIIIr: Como aconteció sobre Arcilla que, tuviéndola el conde de Borba por el rey de Portugal, los reyes de Fez y Tremezén con otros príncipes de Bervería vinieron sobre él con sesenta mil moros de pelea y ganáronle la ciudad de Arcilla, y él retráxose al castillo que junto a la plaça estava, que tiene la puerta a la banda de Centa, a donde le tenían cercado. / / Celso, Reportorio universal leyes Castilla, 1553, fol. LIXv: Assimesmo, los del pueblo los deven socorrer, mayormente siendo castillos en que los enemigos se pueden hazer fuertes para guerrear al Rey o al reyno. // Mendoça, Theórica y práctica, 1596, pág. 155: Y en caso que aya ciudadela o castillo en la tierra, se ha de acudir a la plaça d'él, impidiendo que no se retire dentro la gente; y quando no ay castillo, a la plaça o partes donde tienen señalado el juntarse en los cuerpos de guardia, señoreando enteramente la tierra, que se ha de dar a saco, y fortificarla, poniendo buena guarnición; y quando el castillo o ciudadela (aviéndola) no se aya rendido, previniendo no les entre socorro por las puertas que de ordinario tienen los castillos a la campaña para el efecto.

SIN.: ciudadela.

ENCICL.: Terr.: En la fortificación, V. ciudadela y fuerte. 
catapulta, catapulta, cathapulta [tomado del lat. catapulta y éste del gr.

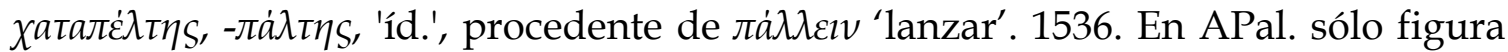
como voz latina (DECH). Urrea, Vitruvio, Architectura, 1582]. sust. Mil. ant. Máquina para arrojar proyectiles de varios tipos, como piedras, dardos, flechas, etc. 3 (fig. 35)

Urrea, Vitruvio, Architectura, 1582, fol. 14r: Las distancias de las torres se han de hazer de manera que no sea una torre más apartada de otra que un tiro de una saeta pueda alcançar, para que, si por alguna parte fuere combatida la ciudad, desde la torre que estuviere a la parte derecha y de la que estuviere a la yzquierda, con vallestas y con los demás instrumentos de arrojar armas, escorpiones y catapultas, y los demás tiros, los enemigos sean echados y apartados del pueblo. // Collado, Plática Artillería, 1592, fol. 2v: Las máquinas, pues, Real Magestad, con que los antiguos solían expugnar las fortalezas y batir las murallas eran éstas: las cathapultas, las balistras, las víneas, los arietes, las testúdines [...], el compago, el escorpión, las sambucas, las faláricas y otras muchas. // Collado, Plática Artillería, 1592, fol. 2v: La máquina llamada catapulta, según Plinio en el libro sexto de la Natural Historia refiere, fue primeramente inventada de los candiotes.

ENCICL.: Aut.: Se componía de dos maderos lisos, altos y derechos, o de un árbol grueso aserrado por medio desde la punta hasta la cuarta parte de abajo, que quedaba entera, la cual para mayor firmeza se guarnecía de hierro, y en él se fijaban unas argollas para poderla mover y asentar en una basa agujereada, hecha de propósito para su seguridad. De las dos mitades del árbol o maderos, al uno se le cortaba por lo alto una tercia o palmo, y allí se le fijaba una tablilla, que servía de asiento para poner las saetas o piedras, y en el otro (que quedaba más alto, y servía de disparador) se ponían unas cadenas de hierro o sogas gruesas, con las cuales se tiraba hacia atrás y se torcía cuanto pudiese dar de sí, y en llegando al punto conveniente, se soltaba y daba tan gran golpe en la cabeza de la saeta o piedra, que las arrojaba y despedía con notable ímpetu. Se hallan figuradas estas máquinas de otras maneras, pero las comúnmente usadas fueron de esta calidad. // Moretti (1828): Había catapultas de diferentes dimensiones, las que se conocían con los nombres de fijas o de sitio, y movibles o de campaña, y todas producían un mismo resultado. Unas se armaban con el auxilio de un torno, otras con poleas, otras con ruedas dentadas, piñones y fiadores, y otras, en fin, con todos o parte de estos resortes.

cathapulta, V. catapulta.

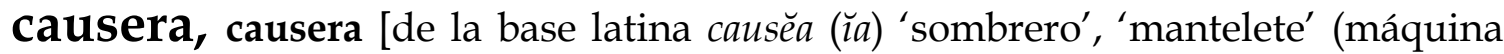
de guerra') (Segura Munguía 2001). Roxas, Sumario milicia, 1607]. sust. Fort. Máquina con que se protegen los soldados para acercarse a los muros enemigos, consistente en una especie de galería desmontable fabricada con maderos ligeros. Roxas, Sumario milicia, 1607, fol. 46r: Los antiguos llamaron bíneas las que aora en el uso militar con nombre bárvaro llaman causeras, que son sombreros.

ENCICL.: Almirante (1869: s.v. vínea): Según Blesson, al reaparecer este aparato [la vínea] en la Edad Media, tomó el nombre de causia. // Domínguez (1853: s.v. causia): Especie de 
sombrero de que se servían antiguamente los griegos para resguardarse del sol. // Zerolo (1895: s.v. causia): Nombre que se daba a la máquina militar llamada también gata. // Almirante (1869: s.v. gata): Aparato o máquina de sitio y de aproche; galería cubierta.

cava, caba, cava [del lat. cava. Cava 'foso, zanja, cueva'. h. 1275 1. $^{a}$ Crón. Gral. (DECH). Loçano, Alberto, Architectura, 1582]. sust. Fort. Zanja profunda que circunda toda la plaza, fortaleza, etc. (Terr.: s.v. foso).

Loçano, Alberto, Architectura, 1582, pág. 139: Por los labrios de dentro de la cava y por la extremidad del vallado, hincarse han espinas, agujas de erizo, anzuelos y cosas semejantes con que se retarde la subida de los enemigos. // Urrea, Vitruvio, Architectura, 1582, fol. 13v: Y hase de procurar que no sea fácil llegarse a combatir el muro, el qual se ha de cercar de buenas cavas, y procurar que las calles de la entrada no estén derechas, sino que estén bolteadas y torcidas; porque si assí estuviere, los que vinieren a entrar y allegarse al muro no podrán encubrir con escudo el lado derecho. // Álaba, Perfeto capitán, 1590, fol. 25v: Los lacedemonios nunca quisieron consentir que en su ciudad huviesse muros, cavas, fosos y otros reparos de guerra, diziendo que la defensa principal en que ellos hazían su fuerça era el valor y esfuerço de sus soldados y no otros artificios y reparos que la necessidad y el arte han descubierto.

SIN.: fosa, foso, fuesa.

ENCICL.: Nebr. (1495): Cava de fortaleza. Fossa.e. // Aut.: Se llama también el foso que se hace alrededor de alguna ciudad para ceñirla y resguardarla, o para encerrarla y embarazar la salida de sus moradores. Y también se llamaba así el que se hacía alrededor de un ejército y servía de fortificación para no ser asaltados con facilidad. // Álaba, Perfeto capitán (1590: fol. 77v-78r): "No es de menos importancia, para acometer al enemigo con el recato y cordura que conviene, considerar la forma de trincheas que tiene en su alojamiento; porque, siendo en figura circular, podrá con facilidad engañarse qualquiera, juzgando aver dentro menor número de gente del que en efeto ay, por parecer esta figura menor de lo que es y que comprehende menos de lo que en sí puede encerrar; y, por el contrario, estendiéndose la gente en unas partes y torciendo y estrechándose en otras, parecerá ser más los enemigos de los que son, mayormente si las trincheas se hazen en algunos cerros o collados, porque siempre en ellos ay lugares pedregosos, cavas o fossos que necessariamente han de quedar vazíos y, por el consiguiente, ser ocasión de que crezca el largo del alojamiento y parezcan muchos más los enemigos de los que están alojados dentro".

cavalgada, V. cabalgada.

cavallería, V. caballería.

cavallero, V. caballero. 
cavallo, V. caballo.

cavamiento, cavamiento [de cavar. Loçano, Alberto, Architectura, 1582]. sust. Excavación (Herráez Cubino 2005).

Loçano, Alberto, Architectura, 1582, pág. 66: Y hazerse ha también que los vicios que (acaso) se suelen seguir semejantes cavamientos, algunas vezes hendiéndose el suelo y cayéndoseos, son menos encubiertos y os dañan menos. // Collado, Plática Artillería, 1592, fol. 62r: Tres cosas, comúnmente, se aplican a la expugnación de las fortalezas, que son: las artillerías, la pala y açadón, y el uso de las minas y hornillos, y otros cavamientos soterraños, los quales se acostumbran de hazer con la pólvora; y éstas están el día de oy en grandíssima reputación y estima acerca de todos aquellos capitanes que siguen la guerra por ser, como lo son, de mucha importancia. // Collado, Plática Artillería, 1592, fol. 62r: Mas se sabe de cierto qu'el conde dicho fue el primero que halló el modo de aplicar la pólvora y el fuego a las minas para bolar las fortalezas y grosíssimos torreones con ellas, lo que no se hazía con las minas antiguas, las quales solamente servían para entrar por debaxo de las murallas a offender y conquistar las tierras enemigas, por lo qual los antiguos llamaron cunículos a los tales cavamientos, que quiere dezir 'conejeras'.

FAM.: cavar.

cavar, cabar, cavar [del lat. cavare 'ahuecar', 'cavar', derivado de cavus 'hueco'. princ. s. XIII Berceo (DECH). Sagredo, Medidas Romano, 1526]. v. tr. u. t. c. intr. Hacer un pozo, zanja, etc. (DUE).

Girava, Fineo, Geometría práctica, 1553, pág. 111: Sea dado un fosso DEF, qual se suele cavar para cercar las ciudades, cuya superficial y más alta anchura, DF, con la hondura EG se dessea saber. // Loçano, Alberto, Architectura, 1582, pág. 139: Cavarse ha la cava con lados derechos, de suerte que sea tan ancha en el hondo como lo que distan los labrios entre sí. // Álaba, Perfeto capitán, 1590, fol. 256v: Lo qual conocido con esta astucia, con cierta invención de fuegos que hizo Alexandrino, echándolos de noche por los agujeros que tenía hechos, en cuyo derecho venía la mina de los contrarios, abrasó los que en ella cavavan y a los demás que estavan dentro.

FAM.: cavamiento.

ENCICL.: Terr.: Ahondar en la tierra o ir formando poco a poco alguna concavidad.

celada, celada [de celar y éste del lat. celare 'encubrir, ocultar'. Celada 'emboscada'. Cid (DECH). Celso, Reportorio universal leyes Castilla, 1553]. sust. Mil. Ardid de guerra que consiste en ocultar gente en un lugar para una operación militar o para asaltar a alguien. 
Celso, Reportorio universal leyes Castilla, 1553, fol. IXr: Adalid, es el que es escogido para descobrir el campo y exército y celadas de los enemigos. Y deven ser escogidos estos tales que sean leales, y esforçados, y de buen seso natural y que conozcan la tierra. // Álaba, Perfeto capitán, 1590, fol. 41v: Es necessario que de la tierra por donde huviere de marchar tenga particular descripción y figurados en ella los montes, sierras, peñas, quiebras, pantanos, passos estrechos, selvas, bosques, valles, ríos, lagunas, arroyos, fuentes, ciudades, castillos, lugares y caserías que huviere, para que tenga presentes todos los puestos en que puede aver alguna emboscada o celada de enemigos que con ventaja le puedan ofender. // Álaba, Perfeto capitán, 1590, fol. 77v: Y el recato con que en semejantes ocasiones se a de proceder mostraron bien los franceses, que, llegando a la ciudad de Alia, que estava sujeta al pueblo romano, y hallando las puertas d'ella abiertas y toda al parecer yerma y desamparada de los ordinarios abitadores, rehusaron el entrar dentro, temiendo alguna celada o astucia de los romanos, que tan práticos eran en la diciplina militar.

SIN.: emboscada 1 .

ENCICL.: Aut.: La emboscada, asechanza, ocultación o encubrimiento de gente armada en lugar, paraje o sitio oculto, para asaltar al contrario descuidado o desprevenido, o para otra facción semejante. // Almirante (1869): El sentido militar, que aún conserva esta voz, es el de emboscada [...]. Una celada se arma, se pone; o bien se da, se cae en ella.

2 [Álaba, Perfeto capitán, 1590]. sust. Mil. Tropa apostada en lugar oculto para sorprender al enemigo (Alemany y Bolufer 1917: s.v. emboscada).

Álaba, Perfeto capitán, 1590, fol. 136r: Podrá mandar el capitán, siendo el lugar acomodado para emboscadas, que en el otro lado del esquadrón, por donde los enemigos no acostumbran acometer, se esconda buena parte de la gente más florida de su campo, y que por el lado donde se suele de ordinario escaramuçar se hagan acometidas a los contrarios, y que, en saliendo a ellas, finjan huyr hazia donde está la celada, alexándolos lo más que pudieren de su real para que, hecha por el capitán la señal con alguna pieça de artillería o de otra suerte, salgan los emboscados y, dando sobre ellos con buen orden, los desbaraten.

SIN.: emboscada .

ENCICL.: Terr.: En la guerra, emboscada, gente escondida para dañar con ventajas al enemigo.

poner en $\sim$ [Álaba, Perfeto capitán, 1590]. loc. v. Mil. Ocultar gente en un sitio para una operación militar o para asaltar a alguien.

Álaba, Perfeto capitán, 1590, fol. 91r: Hecho esto como se les mandó, huyó con todo su campo muy desordenada y descompuestamente; fiados los enemigos en las dissensiones que avían visto para vencer a Cipión, salieron en su seguimiento, en el qual, como fuessen con mucha seguridad de vitoria, fue tanto lo que se alexaron de la villa que la gente que estava puesta en celada esperando esta salida tuvo lugar de acometer y rendirla. // Mendoça, Theórica y práctica, 1596, pág. 149: Aviendo de hazer emboscadas o poner gente en celada, han de tener el mismo aviso de los ramos para borrar la pista y que no se vea 
que están en ella, advirtiendo, si es possible, no relinchar los cavallos, por donde se vienen a descubrir muchas vezes, siendo el mejor remedio, quando no son muchos los cavallos, apartar los más rijosos, que son conocidos por las compañías.

SIN.: emboscar, poner en emboscada.

centinela, centinela, centinella, cintinella, sintinela [del it. sentinella 'servicio de vigilancia que presta un soldado en un lugar fijo', 'el soldado encargado de este servicio', derivado de sentire 'oír', 'sentir'. h. 1530, J. de Oznayo, Relación de la Batalla de Pavía; Garcilaso (DECH). Montes, Instrucción y regimiento, 1537]. sust. f. Mil. Soldado que está de vigilancia en un sitio (DUE).

Montes, Instrucción y regimiento, 1537, fol. XIr: E quando el campo se assentare, el general de los cavallos ligeros embiará sus corredores por la parte donde pensare que haya enemigos, y como venga a la noche, pongan las cintinellas por los caminos y passos por donde los enemigos podrían venir a hazer daño al exército. / / García de Palacio, Diálogos militares, 1583, fol. 191v: Y, en aquellos quarenta pasos que se dexan entre la trinchea y las dichas quatro plaças, y en torno de todo el real, se suelen y es nescessario se pongan las centinelas y esté el artillería y que allí se ordenen los esquadrones y exerciten los soldados en su arte, para el día de la batalla. // Álaba, Perfeto capitán, 1590, fol. 49v: Porque lo que hasta aquí se a dicho es lo principal que se a de considerar en el alojamiento de campaña, quando se huviere de hazer en alguna fuerça, el sargento mayor reconozca la tierra, dentro y fuera, mirando los lugares más cómodos para los cuerpos de guardia y centinelas y las plaças de armas donde estarán mejor.

SIN.: posta 1 .

ENCICL.: Terr.: En la milicia, soldado colocado en algún puesto para velar y hacer la guardia. // Rubió y Bellvé (1895-1901): El soldado que está apostado [...], por un tiempo determinado, con orden de vigilar, reconocer, detener, llamar a las armas, etc., según los casos y con arreglo a una consigna [...]. Indudablemente, la voz de que tratamos empezó a usarse en España durante el período en que más contacto tuvo nuestro ejército con el de Italia (fines del siglo XV y principios del XVI), lo cual ciertamente no quiere decir que no existiesen antes, con otro nombre, los centinelas. La idea de apostar a uno, para que, vigilante, pueda dar aviso a muchos de los peligros, está tan arraigada y es tan sencilla que es más bien innata que adquirida; de modo que hasta ciertos seres irracionales emplean este medio de precaverse de las sorpresas [...]. En España se emplearon los nombres de "atalaya", "escucha", "vela" y otros, según las épocas y la misión especial del vigilante de que se trataba [...]. Si en el centinela se basa la seguridad de una guardia y, como consecuencia, la de un ejército o fracción de él, es justo rodearle de todos los prestigios y exigirle todas las responsabilidades que necesita para cumplir con su misión. // Almirante (1869): No necesitan explicación ciertos adjetivos de centinela, como avanzada, doble, sencilla, suelta. // Rubió y Bellvé (1895-1901): Generalmente el centinela es doble, principalmente con el objeto de que, cuando la pareja observe algo anormal, pueda uno de los soldados dar parte de la novedad al puesto avanzado de que depende, siempre silenciosamente, a menos de que la inminencia del peligro no lo permita, en cuyo caso 
utiliza como señal de alarma repetidos disparos del fusil. // Álaba, Perfeto capitán (1590: fol. 49r): "Las centinelas, por lo menos, estarán apartadas treynta passos de los cuerpos de guardia y una de otra, de manera que se puedan ver; y siempre dobles, porque vean mejor quién entra o sale, pues son para esso, y porque, si una fuere a dar aviso, quede la otra, a las quales darán los mesmo sargentos el nombre con que conocerán los amigos, no consintiendo que sin darle primero entre ni salga nadie en el real". / / Mendoça, Theórica y práctica (1596: pág. 86): "Y en caso que venga alguno a entrar en el campo y trayga el nombre, por avérsele dado el general y querer que le hable a todas horas sin perder tiempo, la centinela senzilla de a pie o cavallo le trae hasta entregalle a las dobles, y uno d'ellos le lleva el cuerpo de guardia a su capitán que le entrega al oficial mayor".

2 [Álaba, Perfeto capitán, 1590]. sust. f. Mil. Servicio de vigilancia que prestan los soldados.

Álaba, Perfeto capitán, 1590, fol. 24v: Estando dormidas las guardas que hazían centinela, con que era forçoso morir todos los que dentro avía por el descuydo con que dormían, con el graznido del ánsar que se alborotó, despertaron y derribaron a todos los que de secreto avían subido. // Álaba, Perfeto capitán, 1590, fol. 50r: A éstas tampoco se les a de dar [el nombre] hasta que estén en sus postas o lugares, pues toda la seguridad de una fuerça o exército está en el nombre, y el darle el soldado que sale de la centinela al que entra en ella es error manifiesto, pues en ningún caso le a de dar a nadie ni se a de mover del lugar que le señalaron hasta que el mesmo oficial se lo mande. // Mendoça, Theórica y práctica, 1596, pág. 129: La forma de rondas, sobrerondas o contrarondas se han de aumentar o disminuyr, según el recelo y sospechas que se tiene del enemigo, sin dar quartel señalado a ninguna nación o vanderas, si es possible escusarlo, principalmente en las murallas y puertas, donde no ha de saber el soldado en la parte que ha de hazer centinela hasta ponerle su oficial en la posta.

SIN.: guardia 2 .

ENCICL.: Salvá (1846): Mil. El acto de velar y guardar un puesto; y así decimos hacer la centinela, estar de centinela.

perdida [Álaba, Perfeto capitán, 1590]. cmpt. sintag. f. Mil. La que se dedica a vigilar y observar de cerca al enemigo.

Álaba, Perfeto capitán, 1590, fol. 49r: Quando se embía alguna centinela a reconocer los disignios del enemigo y si el campo quiere de secreto hazer mudança, que es la que propiamente se llama perdida, no se le a de dar el nombre, por el peligro que ay de que, cogiéndola y apremiándola, lo diga; y, assí, se usará con ella de alguna contraseña particular para que quando buelva sea conocida. // Álaba, Perfeto capitán, 1590, fol. 49r: Llámase perdida esta centinela a causa de que se llega tanto al real contrario que, siendo vista, podrá con gran dificultad retirarse. // Mendoça, Theórica y práctica, 1596, pág. 85: Juntamente se haze otra prevención en tiempo de sospechas, estando vezino el enemigo o desseando saber si embía gente fuera de su campo de noche o desaloja, que es poner centinelas de a pie o de a cavallo tan cerca de su campo que por el peligro d'esto no se les 
da el nombre y se dizen perdidas, llevando otras señas con que sea conocido de las centinelas, si acierta a bolver para dar algún aviso.

ENCICL.: Fernández Mancheño (1822): La que se envía para que recorriendo el campo observe mejor al enemigo, o colocándola muy inmediata a él explore sus movimientos. Se llama así por lo expuesto que es este servicio. // D'Wartelet (1863): La que se envía de descubierta y que, recorriendo el terreno, trata de adquirir noticias de las operaciones del enemigo. Esta facción es muy expuesta, pues no sólo tiene el soldado que la desempeña probabilidades de extraviarse en un sitio que le es desconocido, sino que también es fácil sea sorprendido por las patrullas o avanzadas enemigas. Por eso, no se destacan centinelas perdidas, sino en casos muy urgentes.

centinella, V. centinela.

ceñido, ceñido, señido [de ceñir (DECH). Álaba, Perfeto capitán, 1590]. adj. Mil. Dicho de un arma: que está pendiente de una cinta o cinturón, y sujeta con éstos al cuerpo.

Álaba, Perfeto capitán, 1590, fol. 7v: Y sacando la espada que traía ceñida, se dio la muerte con ella, no usando del poder de capitán en dissimular su error, como con facilidad lo pudiera hazer, juzgando ser indigno del superior no querer sujetarse a las ordenanças y establecimientos a que quiere obligar a sus súbditos.

FAM.: ceñir.

ceñir, ceñir, çeñir [del lat. čngĕre 'íd.'. Cid (DECH). Loçano, Alberto, Architectura, 1582]. v. tr. Fort. Rodear un lugar con cualquier elemento que sirva para protegerlo, como vallas, muros, trincheras, fosos, etc.

Loçano, Alberto, Architectura, 1582, pág. 106: Los carthaginenses ciñeron su ciudad con tres circuytos de muro. Dize Herodoto que los deioceses ciñeron con siete cercas la ciudad de Cebetana, aunque estava puesta en alto. // Loçano, Alberto, Architectura, 1582, pág. 138: Y si faltavan lugares altos y despeñaderos a la redonda, los imitavan con fossas profundíssimas y con montones allegados, y los ceñían con vallado y çarzos. / / Álaba, Perfeto capitán, 1590, fol. 134v: Y si por naturaleza no fuere fuerte, ceñirlo a de hondos fossos y buenas trincheas, suficientes a resistir el ímpetu de los que vinieren a assaltar la artillería, con que la podrá descargar las vezes que le pareciere.

SIN.: cercar $_{1}$.

FAM.: ceñido.

ENCICL.: Cov.: Vale algunas veces cercar. 
2 [García de Palacio, Diálogos militares, 1583]. v. tr. Mil. Envolver el orden de batalla del enemigo.

Mendoça, Theórica y práctica, 1596, pág. 120: Para estas dos cosas es buen aviso guarnecer los costados del campo con la carretería del bagaje, si la ay, que viene a servir de trincheas; y quando no los aya, ni sitio aventajado que poder elegir, se ha de poner la artillería a los costados de los esquadrones para que pueda jugar al sesgo en los de los enemigos con más daño, haziendo la mayor frente que se pudiere al mejorarse con los propios esquadrones, obligando con esto al enemigo, que trae dissinio de ceñir la batalla de su contrario, se alargue mucho para el conseguillo. / / Rojas, Teórica fortificación, 1598, fol. 101v: Y para que vaya con más fundamento, tomaremos esta materia de sus principios, considerando que los esquadrones se acomodan conforme al sitio (como se hizo en la fortificación), porque unas vezes es bueno el esquadrón quadro de terreno y otras es mejor prolongado y de gran frente, especialmente quando la del enemigo se representa pequeña en forma de cuño, porque entonces es bien yrlos ciñendo, para que las mangas puedan tirarle por través para desbaratar el cuño. // Roxas, Sumario milicia, 1607, fol. 68v: Sólo adbierto que el esquadrón de gran frente siempre es bueno, porque el enemigo no lo pueda çeñir, y procurar siempre arrimar las espaldas a algún río o bosque, o lago o cosa semejante, de tal manera que al enemigo le obliguen a benir por la gran frente.

ENCICL.: Almirante (1869): Antiguamente se decía "ceñir la batalla del contrario" por envolver, rebasar la línea de batalla, a causa de la mayor extensión del frente. Es frase que usa don Bernardino de Mendoza en su Teórica y Práctica de la guerra. // DUE (s.v. envolver): Mil. En una acción de guerra, rebasar las líneas del enemigo, de modo que éste queda rodeado.

3 [Álaba, Perfeto capitán, 1590]. v. tr. Mil. Hablando de armas que se llevan pendientes de una cinta o cinturón, sujetarlas con ellos al cuerpo.

Álaba, Perfeto capitán, 1590, fol. 129r: Los mallorquines se armavan con tres hondas: la una ceñían en la cabeça, la otra en la cintura, la otra traían en la mano, con las quales tiravan piedras grandes con tanta fuerça que parecían tiradas con escopeta.

cerca, cerca, çerca [de cercar. 'Asedio', 1076; 'cercado', 1241: F. Juzgo; Apol. (DECH). Celso, Reportorio universal leyes Castilla, 1553]. sust. Fort. Cualquier elemento que se pone alrededor de un lugar para protegerlo.

Celso, Reportorio universal leyes Castilla, 1553, fol. CCXCVv: Deve, ansimesmo, el Rey amar a su tierra, trabajando que sea poblada de buena gente, haziendo poblar en ella villas e ciudades e castillos, y cerrarlos de muros, y fundar hospitales en ella e hazer otras labores y edificios, guardando que los muros y cercas, y otros edificios públicos, no se derriben por mala guarda, y que sea fortalescida la tierra contra los enemigos. // Loçano, Alberto, Architectura, 1582, pág. 98: Assí también començaremos la cosa de las particulares casillas de los necessitados, y de allí vendremos a estas obras, que vemos amplíssimas, con theatros, estatuas y templos, porque es claro que las gentes del mundo habitaron mucho tiempo sin tener ceñidos con ningún tipo de cercas sus ciudades. // Ufano, Tratado de la Artillería, 1613, pág. 94-95: Y assí, Vuestra Señoría se asegure y tenga por bien de que los cañones sean reservados para sólo baterías y arruynas de fuertes murallas, de çercas, 
reparos y bestiones, y para los demás efetos servirse siempre del artillería menuda y ligera que, çierto, basta para el suplimento de quanto es tirar a gente de guerra suelta y descubiertamente.

FAM.: cercado, cercador, cercar, descercar.

ENCICL.: Aut.: Todo lo que se pone alrededor de alguna cosa, como tapia, vallado, muro, dentro de lo cual se contiene alguna heredad, lugar, ciudad u otro sitio, para su guarda, división o señalamiento. // DUE (s.v. cerca ${ }^{2}$ ): Construcción hecha con cualquier material, con que se cerca un terreno.

2 [Fernández de Enciso, Suma de Geographía, 1530]. sust. Fort. Pared que rodea una plaza fuerte o protege un territorio. 3 (fig. 36)

Fernández de Enciso, Suma de Geographía, 1530, fol. XLIIr: E aquí ovo grandes batallas entre él y los moros, e a la fin tomó la cibdad; y de aquí fue a Jerusalén y la tomó por fuerça y fue el primero que entró en Jerusalén por cima del muro, aunque quando él entró dentro falló dentro d'ella al rey de los malatos, que avía horadado la cerca y entrado dentro. // Fernández de Enciso, Suma de Geographía, 1530, fol. LVIIIv: En esta provincia es a do Alexandre entró solo en la cibdad por cima del muro e adonde fue ferido malamente e mató tres hombres; y estando assí, ferido e arrodeado de los sudracas, e teniendo tres d'ellos muertos a los pies y él ya sin fuerças, le socorrieron los suyos, que entraron con escalas e algunos horadaron la cerca por do entraron. // Loçano, Alberto, Architectura, 1582, pág. 106: Los carthaginenses ciñeron su ciudad con tres circuytos de muro. Dize Herodoto que los deioceses ciñeron con siete cercas la ciudad de Cebetana, aunque estava puesta en alto.

SIN.: muralla $_{1}$, muro $_{1}$.

ENCICL.: Cov.: El muro de la ciudad o villa à circundando. Catón Censorio, siendo cónsul, vino a España y habiendo conquistado la Berica o Andalucía, derrocó los muros de todas las ciudades y villas en un propio día y las dejó sin cerca. // Lopes Pires Nunes (2005: s.v. cerca): Muralha que se fecha sobre si mesma.

3 [Celso, Reportorio universal leyes Castilla, 1553]. sust. Mil. ant. Formación de infantería, en forma de cuadrilátero, con la que con cualquiera de sus cuatro caras o lados puede hacerse frente al enemigo, y en la que se deja vacío el centro.

Celso, Reportorio universal leyes Castilla, 1553, fol. CLXv: Y a quál llaman cerca [los antiguos] aý, en la mesma ley.

SIN.: muro $_{2}$.

ENCICL.: DRAE (1780: s.v. cerca, o corral): Milic. ant. Formación de infantería en que la tropa presentaba por todas partes el frente al enemigo, teniendo los flancos cubiertos unos con otros, y dejando el centro vacío. Esta formación es muy semejante a las que hoy se llama 
cuadro. / / Gago-Jover (2002): La tropa podía situarse, o no, detrás de una serie de defensas estáticas, tales como carros o animales.

cercado, cercado, çercado [de cercar (DECH). Celso, Reportorio universal leyes Castilla, 1553]. adj. Fort. Dicho de un lugar: rodeado de un elemento de protección. Celso, Reportorio universal leyes Castilla, 1553, fol. LIIr: Los caminantes pueden meter sus bestias e ganados en los lugares que no son cercados ni defendidos para pacer e descargar. // Poça, Hydrografía, 1585, fol. 81v: Calés es una villa cercada, con muchos torrejones y clocheles, y está en ribera de la mar en una tierra llana y baxa. // Mosquera, Comentario disciplina militar, 1596, fol. 15r: En las jornadas que se hazen por tierra de enemigos no solamente suelen cegar las fuentes, pozos, cisternas y atossigar las aguas, pero agostan los campos, destruyéndolos y dexando de sembrar las tierras, encerrando con tiempo en sus fuertes, o lugares cercados y fortificados, todos los frutos y mantenimientos que pueden para sustentarse y que quando el enemigo llegue no halle cosa de que pueda aprovecharse para refugio de su necessidad.

FAM.: cerca, cercador, cercar, descercar.

2 [Sagredo, Medidas Romano, 1526]. adj. Mil. Dicho de un individuo o un grupo: que ha sido rodeado por otro con el objeto de atacarlo o para impedir que se mueva.

Sagredo, Medidas Romano, 1526, pág. 6: Las quales [tres mil libras de oro], después, passados mil y CCC años, fueron halladas por Hircano, pontífice de los hebreos, según cuenta Josepho, y con ellas dio guerra a Antíocho, rey de Syria, que le tenía cercado y puesto en mucho estrecho. // Loçano, Alberto, Architectura, 1582, pág. 141: El qual dize [Apiano] que como acerca de Perusia tuviesse Octaviano cercado a Lucio, hizo una cava de cinqüenta y seys estadios estendida hasta el Tibre, ancha y honda de treynta pies, y ajuntó, demás d'esto, un muro muy alto y mil y cinqüenta torres de madera levantadas por sesenta pies. / / García de Palacio, Diálogos militares, 1583, fol. 52r: Vareno [...], estando su enemigo Pulsio cercado y en peligro de muerte, le socorrió, metiéndose en lo más peligroso de la batalla, y Pulsio, no ingrato del beneficio rescebido, le sacó de aquel conflicto, hecho, por cierto, digno de nobles romanos.

3 [Sagredo, Medidas Romano, 1526]. adj. Fort. Dicho de un lugar fortificado o de las personas que están dentro: que sufren un sitio, un asedio o un cerco.

Sagredo, Medidas Romano, 1526, pág. 13: De Archímedes se escribe, según cuenta Plutarco, que hizo un artificio ordenado por arte de Geometría contra Marcello, capitán de los romanos, quando tenía cercada la cibdad de Syracusa, en Cecilia, con el qual prendía las naos del dicho Marcello, y las levantava y sacava del agua y las metía dentro de la cibdad. // Loçano, Alberto, Architectura, 1582, pág. 191: Y quando avían de tomar alguna ciudad cercada, porque no pareciesse aver hecho algo contra la reverencia de las religiones, con cierto cantar de cosas sagradas llamavan afuera los dioses defendedores de aquella ciudad, para que se passassen a ellos no forçados. // García de Palacio, Diálogos militares, 1583, fol. 87r-87v: ¿Qué se deve hazer antes de asaltar la ciudad cercada y qué advertencias 
se han de tener en el asaltalla y, después de entrada y rendida, qué se deve hazer con los amigos vencidos y de los despojos y robo?

SIN.: asediado sitiado $_{1}$.

4 [Celso, Reportorio universal leyes Castilla, 1553]. sust. Fort. Persona que se halla en una construcción defensiva sitiada, asediada o cercada.

Celso, Reportorio universal leyes Castilla, 1553, fol. LIXv: Deven ser acorridos los castillos por los alcaydes enfortalesciéndoles, haziendo labrar a todos, sin escusar ninguno, en las lavores d'él, y socorriéndolos con gente si se hallare de fuera y con bastimentos, preferiendo siempre el socorro d'ellos a su proprio peligro y vida; socorriendo, assimesmo, al castillo que tiene más necessidad, si fueren muchos los cercados. / / García de Palacio, Diálogos militares, 1583, fol. 91r: Y que, si el tiempo offresciere alguna occasión para, con cautela y ventaja (sin arriesgar su ciudad), hazer alguna buena suerte en los enemigos, no se dexe ni pierda, que mucho enflaquecerá el brío del que tiene sitiada una ciudad ver que el cercado no solamente se defiende, mas que offende. // Lechuga, Discurso de la Artillería, 1611, pág. 268: Para lo dicho y los effectos que el cercado a de procurar hazer contra el que lo sitiare, conózcase quánto mejor es que el fosso sea seco, pues en él se pueden hazer muchas defensas y alojar parte de la gente o ponerla para una salida y para que el enemigo ni tenga ora segura ni fuerça de soldados tan grande en sus trincheras que puedan resistir a la que puede el sitiado echar contra ellas.

SIN.: asediado $_{2}$, sitiado 2.

ANT.: asediador, cercador, sitiador.

cercador, cercador [de cercar (DECH). Loçano, Alberto, Architectura, 1582]. sust. Fort. Persona que sitia, asedia o cerca.

Loçano, Alberto, Architectura, 1582, pág. 128: La área por dentro se estenderá a cada paso con anchíssimas y gruessas piedras, con dos y también con tres suertes de suelo para que los cercadores no entren a hurtadillas por las minas.

SIN.: asediador, sitiador.

ANT.: asediado $_{2}$, cercado 4 , sitiado 2 .

FAM.: cerca, cercado, cercar, descercar.

cercar, cercar, çercar, sercar [del lat. tardío črrcare 'dar una vuelta, recorrer'. 1099: Cuervo, Dicc. II (DECH). Fernández de Enciso, Suma de Geographía, 1530]. v. tr. Fort. Rodear un lugar con cualquier elemento que sirva para protegerlo, como vallas, muros, trincheras, fosos, etc. 
Celso, Reportorio universal leyes Castilla, 1553, fol. CXXXVIv: Y, para ser más seguros de los enemigos, cerquen el exército con los carros de la requa y con palos hincados, atados con sogas. // Loçano, Alberto, Architectura, 1582, pág. 104: Los antiguos architectos reprovaron los ángulos de los muros en el cercar de los lugares, porque ayudan más a los enemigos en el dar el assalto, que no a los moradores en el deffenderse, y porque también en ninguna manera sean fuertes para suffrir las injurias de las máchinas. // González de Medina, Examen fortificación, 1599, pág. 153: Y assí, lo que yo haría sería retirarme y cercar el lugar con una muy buena trinchea, bien fortificada, con buena y acomodada forma, que se le podrá dar la que se quisiere, y buenos travesses, y muy buen foso, que con la tierra que se cabará para hazer la trinchea quedará casi hecho.

SIN.: ceñir $r_{1}$

FAM.: cerca, cercado, cercador, descercar.

ENCICL.: Aut.: Rodear, circunvalar alguna cosa con vallado, seto, tapia, muro u otra materia, de forma que quede cerrada, resguardada y dividida de otras.

2 [Celso, Reportorio universal leyes Castilla, 1553]. v. tr. Mil. Rodear a alguien para atacarlo o para impedir que se mueva.

García de Palacio, Diálogos militares, 1583, fol. 70v: Y en la misma Sacra Escriptura se dize que, quando acontesciere que pocos soldados se hallen cercados de multitud de enemigos, no se les acometa, mas que se use contra ellos de cautelas y ardides, y se les dé a entender brío y ánimo, y encubra la falta de guerreros, haziéndoles arma de noche, por muchas partes, para que piensen y entiendan que son más en número. // Álaba, Perfeto capitán, 1590, fol. 76v-77r: Sólo quiero advertir que se guarde de caer en un error que muchos inorantes de la milicia apruevan, que es, quando se acomete el enemigo, cercarlo con demasiado número de gente o atajarlo en un estrecho donde no pueda huyr, porque viéndose en semejante aprieto, como hombres desesperados de remedio, el miedo que consigo tienen se les convierte en ánimo y con mayor determinación se ofrece a la muerte el que sabe cierto que a de morir que el que por los pies o de otra manera piensa poder socorrer su vida. // Álaba, Perfeto capitán, 1590, fol. 133v: Para esto también aconseja Vegecio que con el cuerno diestro del esquadrón se acometa al siniestro del enemigo y que el siniestro se aparte tanto del diestro del contrario que su arcabuzería no le pueda dañar $\mathrm{y}$, mientras el diestro haze su efeto, el otro cerque los enemigos y los rompa y desbarate por el lado.

3 [Fernández de Enciso, Suma de Geographía, 1530]. v. tr. Fort. Establecerse en torno a un lugar fortificado para impedir que los que están dentro puedan salir o recibir ayuda, con el fin de obligarlos a rendirse.

Fernández de Enciso, Suma de Geographía, 1530, fol. XXXIr: Quando Aníbal cercó a la ciudad de Calahorra, estuvo tanto tiempo sobre ella que los de la ciudad acabaron las provisiones e manteníanse de la carne de los hombres que matavan del real. // Celso, Reportorio universal leyes Castilla, 1553, fol. CXXXVIv: Y, por lo semejante, hágase quando el exército cercare alguna ciudad o villa o castillo; empero, deven poner la gente donde 
pueda hazer más mal a los cercados, guardándoles las puertas y passos por donde les puede venir socorro de gente o de bastimentos, y por donde ellos puedan entrar en la hueste a hazerles daño o escaramuçarles. // Álaba, Perfeto capitán, 1590, fol. 84r: Y teniendo para esto y otras cosas el dibuxo o planta del lugar que quiere cercar, como es forçoso, mirará en él si puede con facilidad ser batido y el lado por donde podrá recebir más daño y si está sujeto a ser ofendido con minas y otros artificios de fuego.

SIN.: asediar, asitiar, meter (el) asedio, poner asedio, poner (el) cerco, poner (el) sitio, sitiar.

ANT.: alzar el cerco, alzar el sitio, levantar el asedio, levantar el cerco, levantar el sitio.

ENCICL.: Aut:: Sitiar, asediar, ceñir, circunvalar alguna villa, ciudad, plaza, fuerte u otro sitio, cerrándole de calidad que no le pueda entrar bastimento ni socorro.

cerco, cerco, çerco [del lat. črrcus 'círculo', 'circo'. Cerco 'círculo', 'aro y otros objetos circulares', 'asedio de una plaza'. Berceo (DECH). Fernández de Enciso, Suma de Geographía, 1530]. sust. Fort. Operación que se lleva a cabo contra un lugar fortificado con el fin de rendir a los que están dentro.

Fernández de Enciso, Suma de Geographía, 1530, fol. XXXVIIIv: D'estas amazonas ay muchas ystorias que hablan d'ellas; dizen que fueron mugeres de los getas y que fueron al cerco de Troya, y que después fueron a Alexandre y que su reyna procuró de dormir con Alexandre por aver generación d'él. / / García de Palacio, Diálogos militares, 1583, fol. 84v: Deve, ante todas cosas, el que sitiare qualquier castillo o ciudad, offrescer la paz al enemigo, con los partidos que justamente convinieren al negocio y causa de su príncipe, para que, aceptándole la occasión de discordia, se acabe sin los daños y ruynas que el proseguir un cerco trae consigo, y la salud del pueblo sitiado quede salva y segura. // Álaba, Perfeto capitán, 1590, fol. 86r: Y aunque el cerco de muchos d'estos fuertes, ofreciéndose ocasión, es justo que se emprenda, esto a de ser en caso que cerca d'ellos aya alguna montaña, lugar alto o padrastro de donde se pueda juzgar lo que huviere dentro y la artillería pueda jugar, o estén faltos de bastimentos y otras municiones, o se les pueda quitar el agua, o los soldados sean advenedizos y mal pagados, porque todas estas cosas, lo que fuere de suyo inexpugnable, harán fácil de allanar.

SIN.: asedio $_{1}$, sitio.

ENCICL.: DUE: Acción de establecerse un ejército alrededor de una plaza enemiga para incomunicarla con el exterior y conquistarla.

alzar el [Álaba, Perfeto capitán, 1590]. loc. v. Fort. Apartarse, desistir del sitio, asedio o cerco de un lugar fortificado.

Álaba, Perfeto capitán, 1590, fol. 35v: Y assí, lo que Mucio Scévola, uno de los soldados del campo romano, hizo, que fue salir a matar al rey Porsena, que pretendía rendir este imperio, aunque erró el golpe, hiriendo por él a otro, resultó en mucha honra de su general y provecho de Roma, pues con su atrevimiento obligó a su contrario a alçar el cerco y 
dexar su patria libre de molestias y peligros. // Álaba, Perfeto capitán, 1590, fol. 90v: Y assí, unas vezes sin gira alçar el cerco y retirarse para que, viendo esta mudança los cercados, traten de salir y él pueda armarles emboscadas con que matarlos, yendo descompuestos, y entrarles la ciudad cogiéndolos descuydados. // Roxas, Sumario milicia, 1607, fol. 54r: Estando cercada Roma por el rey de los hetruscos Porsena, fue al real para matarle y en su lugar mató a su secretario y, siendo tomado allí y llevado ante el rey, afirmó con ánimo constante aver herrado, porque su determinaçión hera matar al rey; y en pena de que su mano no açertó, la puso en un fuego para que se quemase y, viendo aquel rey la constançia y ánimo, alçó el çerco de la çiudad.

SIN.: alzar el sitio, levantar el asedio, levantar el cerco, levantar el sitio.

ANT.: asediar, asitiar, cercar, meter (el) asedio, poner asedio, poner (el) cerco, poner (el) sitio, sitiar.

ENCICL.: Aut. (s.v. alzar o levantar el cerco): Frase que explica apartarse, desistir del sitio o expugnación de alguna plaza.

levantar el [Mendoça, Theórica y práctica, 1596]. loc. v. Fort. Apartarse, desistir del sitio, asedio o cerco de un lugar fortificado.

Mendoça, Theórica y práctica, 1596, pág. 109: No he apuntado a Vuestra Alteza, en caso que el enemigo caminasse con exército poderoso para hazer levantar el sitio, en la manera que Vuestra Alteza se ha de governar, por ser necessario hazerlo, [...], eligiendo por la consideración d'estas cosas si será mejor esperarle en los quarteles o, dexándolos, y alojamiento, caminar a combatirle con todo el exército o alguna parte d'él, quedando la resta a la guardia de las trincheas, artillería y quarteles o resolver de levantar enteramente el cerco. // González de Medina, Examen fortificación, 1599, pág. 165: No les queda cómo poder esperar ser socorridos, si no es con exército superior que pueda hazer levantar el cerco o darle la batalla, porque a las puertas, por donde pueden entrar, las tendrán muy bien fortalecidas y guardadas. // Roxas, Sumario milicia, 1607, fol. 46v: Muy ordinaria cosa es que los que cercan alguna çiudad siempre ordenen algún engaño para tomarla, y uno es que, aviendo estado algún tiempo, lebanten el cerco como desesperados de no poder tomarla; y finxen que se apartan muy lexos, y los de la ciudad, descuidados con su yda, dexan las murallas casi sin guardas, y dan la buelta de noche y con escalas procuran entrar.

SIN.: alzar el cerco, alzar el sitio, levantar el asedio, levantar el sitio.

ANT.: asediar, asitiar, cercar, meter (el) asedio, poner asedio, poner (el) cerco, poner (el) sitio, sitiar.

ENCICL.: Aut. (s.v. alzar o levantar el cerco): Frase que explica apartarse, desistir del sitio o expugnación de alguna plaza.

poner $\sim$, o poner el $\sim$ [Celso, Reportorio universal leyes Castilla, 1553]. loc. v. Fort. Establecerse en torno a un lugar fortificado para impedir que los que están dentro puedan salir o recibir ayuda, con el fin de obligarlos a rendirse. 
Celso, Reportorio universal leyes Castilla, 1553, fol. CLXVIIIv: Si pusieren cerco sobre alguna ciudad o villa o fortaleza, por haverse aý acogido los tales malhechores, o porque de allí salieron los que robaron o cometieron caso de Hermandad, todos los bienes que aý hallaren, que sean de aquéllos que consintieron en el tal robo o acogimiento, sean de la dicha Hermandad y del Rey, y la cerca y fortaleza y fuerças se derriben si los dueños de las tales villas y fortalezas eran en ellas quando se cometió el caso o casos susodichos. // Loçano, Alberto, Architectura, 1582, pág. 102: Y no menos apruevan en Marsis el castillo de Bisseyo, puesto en el concurso de tres corrientes ríos, que le rodean por una y otra parte, y está en la entrada de valles muy angosta, con accesso diffícil y montes ásperos y sin camino que se levantan al derredor, de suerte que ni el enemigo puede poner cerco en el lugar, ni aun guardar todas las bocas de los valles, estando señaladamente dessembaraçados los del lugar para recebir socorros y vituallas, y para traer los de fuera y para salir a desafiar. // Álaba, Perfeto capitán, 1590, fol. 50v: Prevendrá también, antes del principio de la guerra, si estuviere en tierra de amigos, que los que habitaren en lugares poco fuertes los desamparen y se recojan con todos sus mantenimientos en las ciudades o al lugar donde espera que se pondrá el cerco.

SIN.: asediar, asitiar, cercar, meter (el) asedio, poner asedio, poner (el) sitio, sitiar.

ANT.: alzar el cerco, alzar el sitio, levantar el asedio, levantar el cerco, levantar el sitio.

ENCICL.: Aut. (s.v. poner cerco): Sitiar alguna plaza, castillo o ciudad.

césped, césped, çésped, zésped [del lat. caespes, -ĭtis 'terrón cubierto de césped'. Céspede, 1076, Oelschl.; Cej. VIII (DECH). Loçano, Alberto, Architectura, 1582]. sust. Fort. Pedazo de tierra cubierto de hierba, que, cortado de diversos modos, sirve para construir murallas, o bien para formar parapetos y otras defensas.

Loçano, Alberto, Architectura, 1582, pág. 331: En el hazer los vallados, algunos ay que apruevan que se hagan de céspedes llenos de yerva cortados de un prado. Y a mí también me agradan, porque con el penetramiento de las rayzillas se fortifican. // Rojas, Teórica fortificación, 1598, fol. 52r: Y también se traen algunas faginas del largo de una pica y tan gruessas como el braço [...], y luego, tras esto, por otra mano se traen céspedes, que se entiende por un césped lo mismo que un pedaço de tierra que no esté cultivado, y cada uno suele tener un pie en quadrado y medio de alto, y otros menos y más. // Roxas, Sumario milicia, 1607, fol. 17v: Las trincheras d'este real se haçen de zéspedes, haçiendo foso alrededor de doçe pies de ancho y siete de fondo, mas si ubiere enemigos a de ser mucho mayor el ancho y fondo.

SIN.: gasón, tepe.

ENCICL.: Aut.: Pedazo de tierra cortado con pala, azadón u otro instrumento, mezclado con la hierba y raíces. Puede servir para fortificación y otros usos. 
cesta, cesta, çesta [del lat. cussta 'íd.'. J. Ruiz (DECH). Ufano, Tratado de la Artillería, 1613]. sust. Fort. Recipiente de mimbre, caña u otros materiales similares entretejidos, de forma redondeada y con asas, que, lleno de tierra, sirve para hacer defensas o reparos.

Ufano, Tratado de la Artillería, 1613, pág. 110: Tras los quales siguen todos los carros que llevan la pólvora y máquinas secretas de fuegos artiffiçiales, con las escaleras y tablazón, encadenamientos, clavazón y apunctalage, cestillas de a dos manos y saquillos de tela para servicio de las trincheas y faena de los cubrimientos. // Ufano, Tratado de la Artillería, 1613, pág. 168: 1.000 picas y algunos coseletes; 6.000 quintales de pólvora; 2.500 quintales de balas de plomo; 3.000 quintales de cuerda de arcabuz; 4.000 palas con 2.000 çapas; 1.000 picos con 3.000 çestillas de a dos manos; grande quantidad de saquillos de tela.

SIN.: cesto.

FAM.: cesto, cestón.

ENCICL.: Terr. (s.v. cesto): V. Cesta. // DUE: Recipiente hecho de mimbre, cañas partidas o material semejante, entretejido. El nombre más frecuente es, en general, "cesta"; pero según las distintas regiones se usan palabras equivalentes como "canasta, canasto, cesto", etc., y se da, a veces, aplicación particular a cada una.

cesto, cesto, çesto [de cesta. Cesto 'cesta de forma diferente'. Berceo (DECH). Ufano, Tratado de la Artillería, 1613]. sust. Fort. Recipiente de mimbre, caña u otros materiales similares entretejidos, de forma redondeada y con asas, que, lleno de tierra, sirve para hacer defensas o reparos. (fig. 37)

Ufano, Tratado de la Artillería, 1613, pág. 81: Ynstrumentos: Palas, 6.000. Çapas, 4.000. Picos, 1.000. Marraços, 3.000. Hachas de golpe, 1.000. Çestillos de trinchea, 1.000. Bruetas o carrillos de llevar tierra, 500. Bancos o carros de caballo pa lo mismo, 300. Sacos de trinchea, $2.600[\ldots]$.

SIN.: cesta.

FAM.: cesta, cestón.

ENCICL.: D'Wartelet (1863): Cesta grande construida de mimbres gruesas, varas de sauce u otra materia que rellena de tierra sirve para formar trincheras, parapetos o cualquiera fortificación improvisada.

cestón, cestón, çestón, sestón, sextón, zestón [de cesto (DECH). Loçano, Alberto, Architectura, 1582]. sust. Fort. Recipiente de mimbre, ramas, cañas u otros materiales similares entretejidos, de forma cilíndrica, que, lleno de tierra, sirve para defenderse del fuego enemigo, para construir defensas o reparos, etc. 3 (fig. 38) 
Loçano, Alberto, Architectura, 1582, pág. 139: La parte alta d'él cíñase con palos robustos puestos en lugar de corona, y travados con otros atravessados con çarzos y cestones entretexidos, y assentarse han con greda entremetida y recalcada. Encima se pondrán las almenas salidas. // Mendoça, Theórica y práctica, 1596, pág. 96: En Berbería, donde ay tanta abundancia de arena, poca tierra y falta de árboles, se han armado algunas vezes los cestones, puestas las estacas para ellos, con sogas de esparto en lugar de los ramos, viniéndose a entretexer de suerte que se puedan llenar de arena. // Ufano, Tratado de la Artillería, 1613, pág. 127: Si en la tal plaça ay sospecha o advertençia de pieças gruesas, mucho mejor es el alojamiento de espaldas que no de gabiones o sextones, lo uno por la seguridad y lo otro por ser tan poco durables los gabiones que los desentretege a todos el suflo y rebufo del resuello de la pieça.

SIN.: gavión.

FAM.: cesta, cesto.

ENCICL.: Almirante (1869): Cilindro sin base o fondo, tejido con ramaje, de dimensiones varias, y que, relleno de tierra, sirve en fortificación y trabajos de sitio para cubrirse con rapidez, y también para revestimiento. // Lechuga, Discurso de la Artillería (1611: pág. 182): "Para hazer los reparos a las baterías y contrabaterías y cerrar alguna abertura, muy a propósito se an hallado siempre los cestones. Y porque sirven para todo lo dicho, conviene que el artillero los sepa hazer él y mandarlos hazer a otros. Señalará, pues, un círculo en tierra llana, que tenga seis pies de diámetro alrededor, en el qual, con igual distancia, plantará diez y seis palos gruessos como el brazo, altos, doçe pies; después los irá entretexiendo de buenos mimbres, largos, fuertes y que se doblen; cerrarlos a bien porque no se deshagan, particularmente los últimos, que acaban arriba a los nueve pies, y ponerles ha dos estacas en la mitad d'ellos atravesadas en cruz, para que estén fuertes. Y con ellos se haze reparo a las baterías, hinchéndolos de tierra, y las troneras a las piezas". // Sobre la formación de cestones, vid., asimismo, Collado, Plática Artillería (1592: fol. 56v$57 \mathrm{r})$.

cetiar, V. sitiar.

chocar, chocar [de origen incierto, pues, aunque parece haberse tomado del francés, una onomatopeya autóctona no es imposible. 1600, Mariana; 1604, Palet (Gili); 1605, La Pícara Justina (DECH). Mendoça, Theórica y práctica, 1596]. v. intr. Mil. Dicho de dos fuerzas enemigas: empezar a luchar al encontrarse violentamente una con otra.

Mendoça, Theórica y práctica, 1596, pág. 57: Los esquadrones de lanças no han de ser de mayor número de ciento o ciento y veynte a los más, aunque aya de envestir con esquadrón de quatro cientos o quinientos herreruelos, y d'este número muchos, en que se han de repartir las lanças y que choquen con priessa, que es lo que más desbarata los herreruelos. // Mendoça, Theórica y práctica, 1596, pág. 115: También se ha de advertir de qué suerte el enemigo da principio al combate, si es apressurando demasiadamente las 
cargas para el venir a chocar o sustentando la escaramuça para el buscar buena ocasión. // Rojas, Teórica fortificación, 1598, fol. 102r: Y esto es quanto a estar en ordenança, porque al tiempo que quiere chocar el enemigo con su cavallería, se arriman los soldados unos a otros al calar de las picas y hazen un peñón muy fuerte.

ENCICL.: DUE: intr. Tener un encuentro, entrar en lucha dos fuerzas enemigas.

cintinella, V. centinela.

ciudadela, ciudadela, çitadela [del it. cittadella, diminutivo de città 'ciudad'. Andrés Bernáldez, fallecido en 1513 (DECH). Lobato, Notas, a. 1585]. sust. Fort. Fuerte o pequeña fortaleza que, en ocasiones, se construye en el lugar más ventajoso de una plaza con la finalidad de controlar a sus habitantes, además de que sirve de último refugio a la guarnición. (fig. 39)

Lobato, Notas, a. 1585, pág. 2: Quién hizo la fortaleza que decimos Mota en la ciudadela antigua de Sarabris y quién es el alcaide y teniente... 10. // Mendoça, Theórica y práctica, 1596, pág. 155: Y en caso que aya ciudadela o castillo en la tierra, se ha de acudir a la plaça d'él, impidiendo que no se retire dentro la gente; y quando no ay castillo, a la plaça o partes donde tienen señalado el juntarse en los cuerpos de guardia, señoreando enteramente la tierra, que se ha de dar a saco, y fortificarla, poniendo buena guarnición; y quando el castillo o ciudadela (aviéndola) no se aya rendido, previniendo no les entre socorro por las puertas que de ordinario tienen los castillos a la campaña para el efecto. // Lechuga, Discurso de la Artillería, 1611, pág. 207: Y fue de manera que, con quatro pieças enterradas, obligué a poner en línea todas las suyas, aviendo ciento, y a que dentro de la ciudadela no uviesse cosa sana ni lugar seguro a los que la guardavan.

SIN.: castillo ${ }_{2}$.

ENCICL.: Terr.: En la fortificación es un castillo que se suele hacer pentagonal, con cinco baluartes, en el sitio más ventajoso de una plaza para defenderla y tenerla en sujeción [...]. Oud. la llama en cast. citadela, pero está sin uso. // Corsini (1849): La ciudadela tiene por objeto el que, tomada la plaza, pueda la guarnición refugiarse a aquella y hacer allí la última defensa. Sirve también para castigar a los habitantes, en caso de sublevarse, haciendo fuego desde ella sobre éstos y sobre la población. // Rubió y Bellvé (1895-1901): Una de las más célebres ciudadelas que existieron fue la de Amberes, empezada por Paciotto, en 1567. Tuvieron también celebridad las ciudadelas de Metz, Estrasburgo, Pamplona, Barcelona, Turnay, Lila, etc.

civil, V. guerra $\sim$.

coligarse, coligarse, colligarse [tomado del lat. colliğgare 'íd.'. med. s. XV, Santillana (DECH). Mendoça, Theórica y práctica, 1596]. v. prnl. Mil. Dicho de dos o 
más soberanos, territorios, etc.: unirse o aunarse, en virtud de tratado, para tener más fuerza a la hora de defenderse o de atacar.

Mendoça, Theórica y práctica, 1596, pág. 16-18: Debaxo d'este presupuesto se ha de considerar la calidad del reyno que se acomete [...]; si está el reyno o paýs de años atrás coligado con otros o después que le posseyó rey o príncipe, las ligas que tiene si son personales o sucessivas con sus herederos; finalmente [...].

SIN.: aliarse, confederarse, ligarse.

ENCICL.: Aut.: Unirse, aliarse y confederarse unos con otros para alguna cosa, y particularmente se entiende de los príncipes y soberanos para hacer la guerra ofensiva y defensiva.

colligarse, $\mathrm{V}$. coligarse.

combate, combate [de combatir. Nebr. (DECH). Montes, Instrucción y regimiento, 1537]. sust. Mil. Acción bélica en la que se enfrentan soldados o formaciones militares enemigas.

Montes, Instrucción y regimiento, 1537, fol. XIIr: E por esto, el príncipe o señor del exército, quando hiziere gente, deve de hazer la gente que sea plática en la guerra, y el general que los governare sea maestro de guerra, porque el día que se da una batalla más se pierde por la mala orden que tienen en el ordenar de la batalla que no por combate de los enemigos. // Álaba, Perfeto capitán, 1590, fol. 130r: Y de aver tanto número de arcabuzeros visoños sucede en algunas escaramuças o combates, de quinientos tiros, no acertar uno, porque se contentan con sola la estampida y ruydo. // Mendoça, Theórica y práctica, 1596, pág. 105: Si con las minas se camina tan adelante que se venga a pelear en ellas, convendrá que Vuestra Alteza encomiende el hazello, y su guardia, a los soldados de esfuerço, por ser uno de los más peligrosos combates que ay en los cercos.

SIN.: batalla $a_{1}$ combatimiento ${ }_{1}$, contienda $a_{2}$, debate, facienda, lid, pelea.

FAM.: combatido, combatidor, combatiente, combatimiento, combatir.

ENCICL.: Aut.: La pelea, contienda o batalla que tiene un ejército con otro, o una persona o animal, para vencer a su contrario. // Corsini (1849): El acto de batirse dos tropas o individuos.

2 [Urrea, Vitruvio, Architectura, 1582]. sust. Mil. Acción violenta contra alguien o contra un lugar donde hay personas.

Urrea, Vitruvio, Architectura, 1582, fol. 11v: Las distribuciones de los edificios públicos son tres: la una es para defensión, otra para religión, otra para oportunidad o recreación. Distribución de defensión es una razón de muros y torres y puertas para defender los ímpetus y combate de los enemigos perpetuamente. // García de Palacio, Diálogos 
militares, 1583, fol. 87v: Prevenciones y disposiciones se han referido arriba, que son nescessaríssimas para el combate y asalto de las ciudades y fortalezas sitiadas. Y para lo que vuestra merced pregunta, exemplos tenemos en la Divina Escriptura, que, por ser tan a propósito, es razón se imiten. // Roxas, Sumario milicia, 1607, fol. 96v: Mas otros muchos autores antiguos nos çertifican que ellos sabían bien que el salitre abrasava, porque se serbían d'él en las composiçiones de algunos fuegos para quemar las mantas y baybenes y máquinas, y torres de madera que en aquel tiempo se usavan en los combates de ciudades, y también para abrasar las armadas.

SIN.: acometida, acometimiento, combatimiento 2 , ofensa, ofensiva.

ANT.: defensa 2 .

combatido, combatido [de combatir. Cano, Arte para fabricar naos, 1611]. adj. Mil. Dicho de una persona o de un lugar donde hay personas: atacado.

Cano, Arte para fabricar naos, 1611, fol. 10r: E ya se a visto que muchas damas hermosas, y de grande otro número de mugeres, cortasen y diesen sus cabellos para hazer jarcias y cables a nabíos y otros baxeles, como se hizo en la grande Carthago quando Cipión estubo sobre ella, que por faltar otra jarcia para aprestar sus bageles los carthaginenses contra los romanos, dieron sus cabellos las mugeres y con summa presteza labraron de ellos la jarcia, tanto era lo que deseavan la libertad de su combatida patria.

SIN.: acometido ${ }_{1}$, ofendido 1 .

FAM.: combate, combatidor, combatiente, combatimiento, combatir.

combatidor, combatidor [de combatir (DECH). Celso, Reportorio universal leyes Castilla, 1553]. sust. Mil. Persona que combate o lidia.

Celso, Reportorio universal leyes Castilla, 1553, fol. CCXCIXr: Como diximos de suso, versículo XXIII, los lidiadores no deven salir del campo sin licencia o mandado del Rey o de los fieles. Y qualquier que por su voluntad, o por premia, o fuerça del otro combatidor saliere del campo, es dado por vencido. // Celso, Reportorio universal leyes Castilla, 1553, fol. CCXCIXr: Empero, si por maldad de su cavallo, o por rienda quebrada, o por otra occasión manifiesta, según que fuere bien visto a los juezes, contra su voluntad y no por fuerça del otro combatidor, alguno d'ellos se saliere del campo, si luego que podiere, a pie o a cavallo, tornare al campo, no será por ello vencido.

SIN.: combatiente, lidiador.

FAM.: combate, combatido, combatiente, combatimiento, combatir.

ENCICL.: Aut.: El que pelea, lidia o contiende. Es verbal del verbo combatir. 
2 [Loçano, Alberto, Architectura, 1582]. sust. Mil. Persona que acomete, combate $\mathrm{u}$ ofende.

Loçano, Alberto, Architectura, 1582, pág. 104: Los antiguos architectos reprovaron los ángulos de los muros en el cercar de los lugares, porque ayudan más a los enemigos en el dar el assalto, que no a los moradores en el deffenderse, y porque también en ninguna manera sean fuertes para suffrir las injurias de las máchinas. Y, cierto, los ángulos para las assechanzas y tirar flechas aprovechan algo a los combatidores, teniendo facultad de hazer correrías y recogerse.

SIN.: acometedor, combatiente 2 .

ANT.: acometido 2 , ofendido 2 .

combatiente, combatiente [de combatir. 1601 (DECH). Celso, Reportorio universal leyes Castilla, 1553]. sust. Mil. Persona que combate o lidia.

Celso, Reportorio universal leyes Castilla, 1553, fol. CCXCIXr: Siendo muerto alguno de los combatientes en el campo (como dicho es), el que quedare vivo no finca por ello enemigo de los parientes del muerto, y el Rey dévele hazer perdonar y assegurar a los parientes del muerto, si de alguno se temiere.

SIN.: combatidor, lidiador.

FAM.: combate, combatido, combatidor, combatimiento, combatir.

ENCICL.: Aut.: El que lidia o pelea con otro, y lo mismo que combatidor. // Gago-Jover (2002): Cada una de las personas que participan en un combate.

2 [Collado, Plática Artillería, 1592]. sust. Mil. Persona que acomete, combate u ofende.

Collado, Plática Artillería, 1592, fol. 4r: Applicáronle los antiguos este nombre de testudine, qu'es lo mismo que galápago, por los effectos que con esta máquina se hazían, que muy semejantes a la natura de aquel animal eran, porque, assí como el galápago, cubierto de su dura concha, resiste a qualquiera golpe y lisión que le sea hecha, assimismo, los combatientes de las ciudades y fortaleças se cubrían y reparavan con esta máquina de los pesados golpes de las piedras y de los ardientes olios y inextinguibles fuegos que se echavan sobre ella.

SIN.: acometedor, combatidor ${ }_{2}$.

ANT.: acometido, ofendido 2 . 
combatimiento, combatimiento [de combatir. Celso, Reportorio universal leyes Castilla, 1553]. sust. Mil. Acción bélica en la que se enfrentan soldados o formaciones militares enemigas.

Celso, Reportorio universal leyes Castilla, 1553, fol. LXXIIv: Combatir, tanto quiere dezir como combatimiento que fazen ambas las partes, la una contra la otra. Y esto es en dos maneras: la una, quando son ambas las partes yguales y pugna cada una por vencer a la otra, y quando la una es más flaca y pugna por defenderse de la más fuerte.

SIN.: batalla, combate, contienda $a_{2}$ debate, facienda, lid, pelea.

FAM.: combate, combatido, combatidor, combatiente, combatir.

2 [Ufano, Tratado de la Artillería, 1613]. sust. Mil. Acción violenta contra alguien o contra un lugar donde hay personas.

Ufano, Tratado de la Artillería, 1613, pág. 186: La figura muestra muy bien ser muy secreto y ymportante su alojamiento; y me paresçe que será ympossible que padezcan detrimiento, aunque tengan muchas pieças contrarias a su combatimiento, si no es con el largo y contino tirar quitarles en effecto la mira del punto visual con la tierra y faxina; pero, con todo esso, ella es, çierto, una batería que sería de mucho serviçio en una buena occasión.

SIN.: acometida, acometimiento, ofensa, ofensiva, combate.

ANT.: defensa ${ }_{2}$.

combatir, combatir, conbatir [del lat. combattŭōo, -ӗre 'combatir con', de cum y battǔō. 1220-1250 (Segura Munguía 2007). Fernández de Enciso, Suma de Geographía, 1530]. v. intr. u. t. c. prnl. Mil. Enfrentarse dos o más personas utilizando la fuerza o las armas para vencer al otro.

Fernández de Enciso, Suma de Geographía, 1530, fol. XXXIv: [...] Aníbal entró dentro por una puerta que es acerca del río; e yendo por la calle vio a un cantón estar dos espadas desnudas combatiéndose la una con la otra, y echavan muchas centellas de fuego de los golpes que se davan. Y, llegado a ellas, maravillose de ver cómo se combatían por sí, sin que ninguna persona las mandasse. // Montes, Instrucción y regimiento, 1537, fol. XVIIIv: Y no se deve rendir por batalla ni por otro combate ninguno, porque el alcayde rendido no puede ser alcayde de otro castillo, pues se rendió, porque más sano le sería morir peleando con los enemigos que no vivir habiéndose rendido, porque regla es entre gente de guerra que un hombre rendido no puede combatir con otro sin licencia de aquél a quien le rendió. // Collado, Plática Artillería, 1592, fol. 2v: También se dixo que en aquel tiempo los hombres combatían desnudos, por no haverse hallado el uso de los vestidos, o, a lo menos, peleavan sin aquellas armas que después se inventaron para cubrir el cuerpo con ellas y deffenderse de las percussiones y heridas enemigas.

SIN.: batir ${ }_{3}$, lidiar, luchar, ${ }_{2}$ pelear, revolver 2 . 
FAM.: combate, combatido, combatidor, combatiente, combatimiento.

ENCICL.: Cov.: Lidiar y pelear un ejército contra otro. // Castro y Rossi (1852): Lo mismo que pelear o tratar de vencer. // DUE: intr. Emplear sus fuerzas o sus armas unos contra otros dos personas o dos grupos, cada uno con el fin de someter al otro a su voluntad o de destruirlo.

2 [Mendoça, Theórica y práctica, 1596]. v. tr. Mil. Luchar contra alguien (DEA). Mendoça, Theórica y práctica, 1596, pág. 69: Esto mismo acostumbran los exércitos del explanar las trincheas quando van a combatir el enemigo, dando a entender con semejante demonstración despreciar la fortaleza de los reparos por el valor de sus braços. // Mendoça, Theórica y práctica, 1596, pág. 108-109: Se ha de advertir dexar siempre a la frente del enemigo, de retaguardia, esquadrones de cavallería e infantería, dándose la mano el uno al otro si la campaña lo permite, porque, si se dexa sola cavallería o infantería, el enemigo que llega con las dos cosas a combatir aquella parte de gente es con mayor ventaja. // Mendoça, Theórica y práctica, 1596, pág. 109: No he apuntado a Vuestra Alteza, en caso que el enemigo caminasse con exército poderoso para hazer levantar el sitio, en la manera que Vuestra Alteza se ha de governar [...], eligiendo [...] si será mejor esperarle en los quarteles o, dexándolos, y alojamiento, caminar a combatirle con todo el exército o alguna parte d'él, quedando la resta a la guardia de las trincheas, artillería y quarteles o resolver de levantar enteramente el cerco.

ENCICL.: Domínguez (1853): Contrarrestar las fuerzas de otro, oponiéndole resistencia y procurando vencerlo con las propias.

3 [Celso, Reportorio universal leyes Castilla, 1553]. v. tr. Mil. Lanzarse contra alguien para causarle daño o para vencerle.

Celso, Reportorio universal leyes Castilla, 1553, fol. CLIIr: O el que, siendo d'esta manera, encerrare alguno o lo combatiere en su casa o castillo o en otro lugar, o le prendiere o le hiziere hazer algún pacto en su provecho; o el que hiziere ajuntamiento de gente para quemar o acometer alguna villa o castillo, o otro lugar o edificio, este tal es dicho acometer y hazer fuerça pública. // Urrea, Vitruvio, Architectura, 1582, fol. 14r: Las distancias de las torres se han de hazer de manera que no sea una torre más apartada de otra que un tiro de una saeta pueda alcançar, para que, si por alguna parte fuere combatida la ciudad, desde la torre que estuviere a la parte derecha y de la que estuviere a la yzquierda, con vallestas y con los demás instrumentos de arrojar armas, escorpiones y catapultas, y los demás tiros, los enemigos sean echados y apartados del pueblo. // Álaba, Perfeto capitán, 1590, fol. 5v: Y, siguiendo este mesmo parecer, el Cónsul Evencio, aviendo desbaratado y vencido a los equos y volscos, resuelto de combatir la ciudad de Antio, juntando su campo, les persuadió que ninguna cosa para esto era de tanta importancia como la presteza y repentino acometimiento.

SIN.: acometer, atacar, embestir2, ofender.

ANT.: defender 2 . 
ENCICL.: DRAE: tr. acometer. // DUE (s.v. atacar): El complemento directo puede ser también el sitio donde están las personas o animales atacados.

comboy, V. convoy.

compago, compago [tomado del lat. compāgō, -ĭnis 'trabazón, juntura, ensambladura, articulación', y éste de cum y pangō (Segura Munguía 2001). Collado, Plática Artillería, 1592]. sust. Fort. ant. Especie de cañón en forma de ángulo recto que, colocado perpendicularmente al cimiento de una muralla y una vez prendido el material incendiario del que dispone, sirve para derribar una fortificación. 3 (fig. 40)

Collado, Plática Artillería, 1592, fol. 2v: Las máquinas, pues, Real Magestad, con que los antiguos solían expugnar las fortalezas y batir las murallas eran éstas: las cathapultas, las balistras, las víneas, los arietes, las testúdines [...], el compago, el escorpión, las sambucas, las faláricas y otras muchas. // Collado, Plática Artillería, 1592, fol. 5r: Muchas otras differencias de máquinas murales podría yo, Real Magestad, representar en este tratado, si no me opprimiesse el temor de ser prolixo, las quales son las vineas, los compagos, los cuervos, las sanbucas, y otras muchas. // Ufano, Tratado de la Artillería, 1613, pág. 12: No obstante lo dicho, no ay de qué maravillarse que en aquel tiempo no diesen los hombres en tan manifiesto error de formaçión de pieças, pero que en el nuestro no se sepa conoscer el daño y falta es caso de admiraçión. Y con tal punto concluio en su particular. A ella le llamaron compago.

ENCICL.: Almirante (1869: s.v. compago o cortago): Aunque no se tengan los datos más luminosos e irrecusables sobre el modo de emplear el cortago, puede creerse que esta pieza se colocaba "perpendicularmente" al cimiento del muro, construyendo antes y con este objeto a la zapa una galería y haciendo este cañón las veces del hornillo. El artillero inflamaba desde la boca-mina una larga salchicha adherida al lado horizontal del ángulo que formaba la "manga" de la pieza. Entonces ocurría la explosión y el aire comprimido por el proyectil, pugnando por buscar una salida, sacudía violentamente el seno de la tierra y derribaba el cimiento del muro [...].

conbatir, V. combatir.

confederación, confederación, confederaçión [tomado del lat. confoederātǐō, ōnis 'asociación', de confoeděrō. h. 1469 (Segura Munguía 2007). Álaba, Perfeto capitán, 1590]. sust. Mil. Unión o pacto entre dos o más soberanos, territorios, etc., establecido con el fin de atacar a un enemigo común o para defenderse en alguna ofensiva. 
Álaba, Perfeto capitán, 1590, fol. 84v: Y para saber de qué efeto podrán ser y lo que podrán labrar en los pechos y intenciones de los cercados, a de considerar qué es lo que mueve a defenderse la villa o ciudad que quiere cercar, si la causa que sustenta es suya propia o si acude a ella por sólo seguir la parcialidad de algún príncipe o señor cuya amistad y confederación professa; $y$, siendo suya la defensa, sin tener respeto a nadie, advertir si es necessidad lo que a la resistencia le obliga. // Mendoça, Theórica y práctica, 1596, pág. 1618: Debaxo d'este presupuesto se ha de considerar la calidad del reyno que se acomete [...]; finalmente, si la disposición de aquel reyno o estado es de suerte que lleve a los príncipes convezinos, aunque no tengan confederación con él, a procurar no le ocupe otro mayor, por el rezelo de tanta grandeza y miedo que esto les causa por la conservación de su propio estado. // Valle de la Cerda, Desempeño patrimonio, 1600, fol. 65v: Siempre avrá confederación santa y legítima entre las naciones, por donde avrá quietud en los reynos y más amor entre todas las provincias, como conviene al estado católico y verdadera policía christiana.

SIN.: liga.

ENCICL.: Castro y Rossi (1852): El acto de confederar y confederarse, y también el documento en que se establece un tratado de liga ofensiva y defensiva.

confederaçión, V. confederación.

confederado, confederado [de confederar (DECH). Collado, Plática Artillería, 1592]. adj. Mil. Dicho de un soberano, de un territorio, de un ejército o de un miembro de éste: unido a otro $u$ otros, en virtud de un tratado o convenio, para gozar de esta manera de una mayor fuerza a la hora de defenderse o de atacar.

Collado, Plática Artillería, 1592, fol. 1v: Domaron aquéllos por sola ambición tantos reynos y provincias, pero Vuestras Magestades, por castigar los herejes y rebeldes vassallos, tomaron siempre las armas; aquéllos, por usurpar agenos dominios, Vuestras Magestades, por conservar los suyos propios, favorescer los príncipes amigos y confederados, conquistar y restituyrles reynos y estados. // Mendoça, Theórica y práctica, 1596, pág. 6768: Previniendo con esto, si sucede desgracia, el estar apercebido para que la ocasión d'ella no la dé a otros príncipes al acometer los estados de Vuestra Alteza con el ver rotas sus fuerças y desarmado, quedando el enemigo gallardo y vitorioso, que haze perder la reputación y enflaquecer el brío y ánimo de los soldados, entibiándose la fe y afición de los pueblos amigos y confederados, con que se disminuyen las más vezes las rentas situadas para el gasto de la guerra. // Roxas, Sumario milicia, 1607, fol. 20r: La ynfantería se divide en gente de socorros y lejiones; los socorros benían de los amigos o de naçiones confederadas, mas la fuerça romana se fundava en las lejiones.

SIN.: aliado amigo $_{2}$.

FAM.: confederarse. 
ENCICL.: Gaspar y Roig (1853-1855): adj. Aliado, el que forma parte de una confederación.

2 [Mendoça, Theórica y práctica, 1596]. sust. Mil. Cada miembro de un convenio o alianza militar respecto a los otros.

Mendoça, Theórica y práctica, 1596, pág. 157: El hazer Vuestra Alteza armadas ha de ser atendiendo a medir el número de navíos, soldados y artillería, según la empresa que se ha de acometer y en qué razón, el poder del enemigo, confederados que puede tener y las demás consideraciones que apunté en común averse de tener para formar los exércitos de tierra.

SIN.: aliado amigo $_{4}$.

confederarse, confederarse [tomado del lat. confoederare 'unir por tratado', 'asociar'. h. 1460, Crón. de Álvaro de Luna; Nebr. (DECH). Mendoça, Theórica y práctica, 1596]. v. prnl. Mil. Dicho de dos o más soberanos, territorios, etc.: unirse o aunarse, en virtud de tratado, para tener más fuerza a la hora de defenderse o de atacar.

Mendoça, Theórica y práctica, 1596, pág. 30-31: También podría Vuestra Alteza levantar gente en assistencia de algún príncipe con quien esté confederado en razón de las ligas que tiene con él, las quales se han de guardar con toda puntualidad, estando prendado Vuestra Alteza y todos los príncipes a cumplir su fe y palabra y contratos hechos sobre ella. // Mendoça, Theórica y práctica, 1596, pág. 32: Assimismo podría Vuestra Alteza tomar las armas para ayudar a algún príncipe con quien no esté confederado ni tenga en protección, moviéndole sólo para ello la injusticia que se le haze y ser conveniente que el que acomete tan sin razón no se haga más poderoso, avezinándose a los estados de Vuestra Alteza.

SIN.: aliarse, coligarse, ligarse.

FAM.: confederado.

conqueridor, conqueridor [de conquerir (DRAE). Álaba, Perfeto capitán, 1590]. sust. Mil. ant. Persona que tiene por oficio inspeccionar los soldados sujetos a su autoridad o a su cuidado.

Álaba, Perfeto capitán, 1590, fol. 151r: Conqueridor era el que estava presente a las muestras y reseñas de los soldados. A éste le responde aora el comissario general, a cuyo cargo, fuera d'esto, está proveer de bastimentos, armas y municiones al exército y dar las pagas, y hazer las cuentas. // Álaba, Perfeto capitán, 1590, fol. 261r: Conqueridor en tiempo de romanos: a qué oficio de los de agora responde. Folio 151, página 1.

FAM.: conquista, conquistado, conquistador, conquistar. 
ENCICL.: Moretti (1828: s.v. conquisidor): ant. Comisionado del gobierno romano para la leva de las tropas en las provincias y pueblos sometidos; siendo de su cargo buscar y perseguir a los que por cualquiera medio intentaban sustraerse del servicio de las armas.

conquista, conquista [participio fem. de conquīrěre 'buscar por todas partes, hacer una búsqueda'. Berceo (DECH). Fernández de Enciso, Suma de Geographía, 1530]. sust. Mil. Acción de ganar, mediante una operación de guerra, un territorio, provincia, población, plaza, fortaleza, estado, etc.

Fernández de Enciso, Suma de Geographía, 1530, fol. LVIIv: Y después tornó a passar el Cáucaso por las cumbres Paropanisas, y entró en la conquista de la India por el monte Merón, e passó al río Caspes e fue a la Peña Dorín, la que dizen que no pudieron tomar Hércules ni Perseo, e aun dizen que Perseo fue vencido en el monte Cáucaso, por donde Alexandre passó. // Celso, Reportorio universal leyes Castilla, 1553, fol. CCXXIXr: En los reynos de Nápoles e Secilia, Su Magestad provea de visorreyes que sean naturales d'estos reynos de España, porque aquellos reynos se ganaron con muchos trabajos e derramamientos de sangre de los naturales de España, e con mucho dinero que se gastaron d'estos reynos para la conquista e conservación d'ellos. // Escalante, Discurso de la navegación, 1577, fol. 15v: Informado el Papa, concedió a los Reyes de Castilla la conquista de las Indias, islas y tierras que descubriessen en el rumbo del Ocidente y a los Reyes de Portugal la de África y tierras del Oriente en ygual corredura.

SIN.: presa $a_{1}$ toma.

FAM.: conqueridor, conquistado, conquistador, conquistar.

ENCICL.: Moretti (1828): Adquisición de una plaza, de una provincia o de un estado entero, por medio de la superioridad de las armas, quedando el vencido sometido al vencedor. // Estévanez (1897): Empresa bélica o expedición militar destinada a la adquisición de territorios por la fuerza de las armas.

conquistado, conquistado [de conquistar. Álaba, Perfeto capitán, 1590]. adj. Mil. Dicho de un territorio, población, estado, fortaleza, etc.: ganado mediante una operación de guerra.

Álaba, Perfeto capitán, 1590, fol. 144v: Y él mesmo, después de aver sujetado la Galia, queriendo passar a Italia, para dexar quieta aquella provincia recién conquistada, escogió por el mejor medio el mostrarse comedido, afable, liberal y humano con todos.

FAM.: conqueridor, conquista, conquistador, conquistar.

conquistador, conquistador [de conquistar (DECH). García de Palacio, Diálogos militares, 1583]. sust. Mil. Persona que conquista o que ha conquistado alguna cosa. 
García de Palacio, Diálogos militares, 1583, fol. 44v: En esta virtud, pues, se esmeravan y en ésta instruýan y disciplinavan a sus soldados aquellos conquistadores del mundo, para enseñorearse d'él y de sus competidores y enemigos, y para defenderse d'ellos. / Álaba, Perfeto capitán, 1590, fol. $84 \mathrm{v}$ : Y porque el rendir qualquiera fuerça por el medio de una buena industria y traça assegura más la voluntad y fidelidad de los rendidos y el poco daño de los conquistadores, antes de usar de algún rompimiento y violencia procurará el capitán valerse de algunos medios que adelante se dirán. // Mendoça, Theórica y práctica, 1596, pág. 26: En el salir a buscar al enemigo se puede considerar mostrar mayor ánimo y gallardía el que acomete que el que espera y favorecer de ordinario más los sucessos de la guerra al que acomete que al que aguarda, siendo de advertir en esto que el acometer requiere más fuerças que las del que es acometido, o por lo menos, en razón, han de ser iguales, aviendo semejantes consideraciones de entibiar al conquistador y verse venir a buscar, el qual forçosamente ha de llegar a las manos, si quiere entrar en casa de otro.

FAM.: conqueridor, conquista, conquistado, conquistar.

conquistar, conquistar [de conquista. h. 1334, Conde Luc.; frecuente desde el s. XV, Cuervo (DECH). Sagredo, Medidas Romano, 1526]. v. tr. Mil. Ganar, mediante operación de guerra, un territorio, población, posición, etc. (DRAE).

Sagredo, Medidas Romano, 1526, fol. VIIr: Después los jonios, en la provincia de Caria, que después se llamó Jonia, por nombre de un capitán que la conquistó, que se dezía Jones, queriendo edificar un gran templo al dios Apolo a la manera y forma de los que avían visto por la tierra de Acaya [...]. // Montes, Instrucción y regimiento, 1537, fol. VIIr: Y también se suele dar sueldo a los municioneros que hazen el pan en el exército para el mantenimiento de la gente. Mas si en la provincia que se conquistare hay bastimiento en abundancia, no se deve dar sueldo al municionero del pan, porque de los gastos excessivos no es servido el señor del exército. // Mosquera, Comentario disciplina militar, 1596, fol. 34r: Y, assí, ni Alexandro Magno, ni Aníbal ni otro de los famosos capitanes de la antigüedad llegó a la excelencia de Scipión por aver conquistado a toda África juntamente con la lengua y con las armas, y no se lee aver intentado empresa que no fuesse justificada.

SIN.: tomar 1 .

FAM.: conqueridor, conquista, conquistado, conquistador.

ENCICL.: DUE: Hacerse dueño en la guerra de una plaza, posición o territorio enemigo.

contendedor, contendedor [de contender. Nebr. (DECH). Celso, Reportorio universal leyes Castilla, 1553]. sust. Mil. Con respecto a una persona, otra que lucha contra ella (DUE: s.v. adversario).

Celso, Reportorio universal leyes Castilla, 1553, fol. CCXCIXr: Si no fuere acabada la lid el primero día, dévenlos sacar los fieles del campo, si lo quisieren y el Rey lo mandare, con toda la ygualdad, haziéndolos yguales en el aposento y comer; aunque, si alguno quisiere mas comer que su contendedor, dévenselo dar. 
SIN.: adversario $_{1}$, contrario 2 , enemigo 2 .

ANT.: amigo 3.

FAM.: contienda.

ENCICL.: Aut. (s.v. contendor): El opuesto y contrario, el que pelea, lidia, disputa o contiende con otro.

contienda, contienda [de contender y éste del lat. contĕndĕre 'esforzarse', 'luchar'. Berceo; Nebr. (DECH). Álaba, Perfeto capitán, 1590]. sust. Conflicto o enfrentamiento armado entre dos o más naciones o entre bandos de una misma nación, que dura considerable tiempo, con diversas batallas y episodios.

Álaba, Perfeto capitán, 1590, fol. 23v: Y en la batalla de Mallos le atravessó una saeta de dos codos la loriga y el pecho hasta la cerviz; que son muestras bastantes de que en sus vencimientos y contiendas que con tan varias naciones tuvo no fue de tanto efeto la compañía y favor de la ventura como el de su esfuerço o el valor y excelencia en el arte militar de la gente de su campo. / / Álaba, Perfeto capitán, 1590, fol. 57v-58r: Y pluguiera a los dioses que esta guerra sólo fuera por guardar el decoro y no por las vidas; que aora no se trata de la possessión de Sicilia o Cerdeña, de que en algún tiempo se trató, pues por Italia es la contienda y no ay otro exército adelante que pueda resistir al enemigo. // Ufano, Tratado de la Artillería, 1613, pág. 86: Querría saber la causa por que Vuestra Merced, para el término de 15 días de ordinaria contienda, no da ni pone más tiros para cada pieça, sabiendo que se puede combatir y ser necessario más tiros y más pólvora y balas para ellos.

SIN.: batalla 2 guerra.

ANT.: $p a z_{1}$.

FAM.: contendedor.

ENCICL.: DEA: Guerra, o lucha armada.

2 [Álaba, Perfeto capitán, 1590]. sust. Mil. Acción bélica en la que se enfrentan soldados o formaciones militares enemigas.

Álaba, Perfeto capitán, 1590, fol. 23v: Que la felicidad que en un capitán se puede dessear por adorno de su fortaleza o de la industria y virtud, qual fue la de Quinto Fabio Máximo, no es sólo que en algunas contiendas y refriegas desbarate al enemigo, sino que esto sea con mucho menor número de gente de la que él trae y con poca pérdida d'ella. / / Álaba, Perfeto capitán, 1590, fol. 105r: Concertó con su compañero Petreyo que el uno con el otro peleassen hasta darse la muerte; y como en la contienda cayesse Petreyo, desesperado de no aver sido el muerto él, rogó a un esclavo suyo que le matasse, lo qual hizo como se lo 
mandó. // Roxas, Sumario milicia, 1607, fol. 47v: En algunos tiempos fueron muy poderosas por la mar dibersas probinçias y por esto tubieron dibersos géneros de navíos, mas quando Augusto Çésar peleó en la vatalla que por mar, junto al cabo Actiaco, [tuvo] y como Marco Antonio fuese bençido, prinçipalmente por los socorros de los liburnos, de allí quedó por experiençia d'esta gran contienda que los nabíos de los liburnos haçían mucha ventaja a los demás.

SIN.: batalla ${ }_{1}$, combate 1 , combatimiento ${ }_{1}$, debate, facienda, lid, pelea.

continuar, V. el vencimiento.

contra batería, V. contrabatería.

contrabatería, contrabatería, contra batería, contravatería $[\mathrm{del} f \mathrm{fr}$. contrebatterie (1580-1608) (TLF). González de Medina, Examen fortificación, 1599]. sust. Fort. Acción de golpear repetidamente, mediante la artillería u otras máquinas de guerra, la batería y demás defensas del enemigo, para derribarlas o inutilizarlas. González de Medina, Examen fortificación, 1599, pág. 188: Cañones de quarenta para contrabatería, pondría dos en los baluartes, uno a cada lado, y dos en cada cortina; que, sabida de la noche para la mañana dónde tienen plantada la batería, se les ha de hazer a ellos, al reýr del alva, antes que los enemigos ayan començado, deshaziéndoles las trincheas, cestones y todo lo que tuvieren para defensa. // Ufano, Tratado de la Artillería, 1613, pág. 154: Aloxando Christóval de Lechuga [...] algunas pieças en su muralla, bien a propóssito por tirar de contrabatería quando las del enemigo se descubriesen, así como le començaron a batir, le çegaron las troneras y desembocaduras, aunque bien es verdad que fue con más pieças que las suyas. // Ufano, Tratado de la Artillería, 1613, pág. 170: No quiero aprovar por esso que, pieça contra pieça, no serán mejores los cañones que los medios, empero, por quanto el deffender una plaça y hazer la contra dicha batería a la de afuera, tomaría de mejor gana los medios cañones.

ANT.: batería 1 .

2 [Ufano, Tratado de la Artillería, 1613]. sust. Art. Conjunto de piezas de artillería instalado para hacer fuego contra una batería enemiga.

Ufano, Tratado de la Artillería, 1613, pág. 165: Primeramente, 60 pieças de artillería, a saber: 12 cañones de batir, de a 40 libras de bala para, de dentro de la muralla, con ellos cubiertamente arruynar y batir las trincheas y reparos del enemigo y plantar y ordenar una contrabatería, contra la misma que el enemigo uviere plantado en la campaña o batir y arruynar las murallas de tal fortaleza o plaça. / / Ufano, Tratado de la Artillería, 1613, pág. 170: Si aviendo los de afuera hecho su batería fuesse nesçessario a los de adentro, para ympidirles su operaçión, hazerles una contrabatería para descomponer la suya, ¿cómo se podría hazer sin cañones gruesos y de qué effecto sería? 
ANT.: batería $a_{3}$, camarada $a_{2}$.

ENCICL.: DUE: Artill. Batería con que se dispara contra una batería enemiga.

3 [Mendoça, Theórica y práctica, 1596]. sust. Fort. Cualquier obra de fortificación construida para albergar las piezas de artillería con las que oponerse a las que el enemigo planta en una construcción semejante.

Mendoça, Theórica y práctica, 1596, pág. 127: Debaxo de lo qual no ay imaginar que nadie ponga sitio, si no es teniendo fuerças equivalentes a los cercados, y al respeto artillería; y quando la plaça la tenga, y disposición por los muchos baluartes, cavalleros y plataformas para poner dos o tres contrabaterías a lo que se le plantare, no se ha de estimar poderlas conservar, pues el que sitia de razón no acometerá la empressa sino con fuerças proporcionadas para acaballa. // Lechuga, Discurso de la Artillería, 1611, pág. 182: Para hazer los reparos a las baterías y contrabaterías y cerrar alguna abertura, muy a propósito se an hallado siempre los cestones. // Ufano, Tratado de la Artillería, 1613, pág. 185: Y si acaso en la muralla uviese lugar tan suffiçiente, que se pudiese hazer una contrabatería en la traça y forma dupla, la qual sea d'esta manera: haziendo primero sus espaldas y troneras.

ANT.: batería $_{4}$, plataforma 1 .

ENCICL.: Estévanez (1897): Batería que se asienta o emplaza enfrente de otra enemiga.

contraescarpa, contraescarpa, contrascarpa [del it. contrascarpa 'íd.'. 1572, F. de Herrera, en Terlingen; 1623, Minsheu (DECH). Collado, Plática Artillería, 1592]. sust. Fort. Pared del foso, enfrente de la escarpa, también en pendiente (DUE).

Collado, Plática Artillería, 1592, fol. 53v: Y, finalmente, digo que si no fuesse por evitar el peligro y el daño de estar sugetos los soldados y artilleros a los continuos y muy espessos arcabuzazos, yo querría, si pudiesse ser, plantar la batería encima de la contrascarpa o dentro de los fossos. // Lechuga, Discurso de la Artillería, 1611, pág. 216: Si el capitán general resuelve que la fuerza que sitia la quiere tomar sin el peligro de assalto, la artillería a de servir de quitar defensas, traveses y quanto pudiere impedir que los soldados puedan recevir daño, haziendo que refuerzen los sitiados los parapetos, y que a esta causa no vean las contraescarpas ni puedan tirar a ellas ni a los fossos. // Lechuga, Discurso de la Artillería, 1611, pág. 249: Se a de hazer a toda la estrada cubierta una valla de madera, por la parte de la campaña, de quatro o cinco pies de alteza, o tener lo necessario de leñames para hazerla quando sea tiempo, porque en ocasión servirá de que no puedan de golpe llegar los enemigos a la contraescarpa, pues para salir, se podrá hazer que, por partes, con gonzes se levante y abaxe quando se quisiere.

SIN.: contraescarpe. 
ENCICL.: Lopes Pires Nunes (2005: s.v. contra escarpa): Declive do fosso, oposto à escarpa, tendo no alto o caminho coberto. // Almirante (1869): De los dos taludes o pendientes o caras que forman el foso, la que está del lado exterior o de la campaña. // Lucuze (1772: 37): "Las superficies laterales del foso son la escarpa y contraescarpa. La línea de contraescarpa debe tirarse al ángulo de la espalda del baluarte opuesto, para que todo el flanco defienda el foso. La altura de la contraescarpa es igual a la del foso y se reviste con mampostería de piedra o ladrillo, cimientos o estribos proporcionados, con su declivio. De otra suerte, sería fácil la bajada al foso por el pendiente de las tierras".

contraescarpe, contraescarpe [de escarpe. González de Medina, Examen fortificación, 1599]. sust. f. u. t. c. m. Fort. Pared del foso, enfrente de la escarpa, también en pendiente (DUE: s.v. contraescarpa).

González de Medina, Examen fortificación, 1599, pág. 28: Hase de barrer de las casas matas las cortinas, la frente de los baluartes y el foso hasta la mitad de la contraescarpe, donde haze el ángulo, para estar bien situadas. // González de Medina, Examen fortificación, 1599, pág. 41-42: La contraescarpe tendrá veynte pies de alto del plano del foso, cortado del terreno, encamisado con muralla de piedra de tres pies de ancho, porque se assegura mucho de que con las aguas no se vaya arruynando y comiéndolo de la estrada cubierta y la dexe incapaz, y ayuda a ensuziarse el foso. // González de Medina, Examen fortificación, 1599, pág. 127: Ha de tener el contraescarpe encamisado de muralla de piedra, por estar seguros de que con el açada no desemboque en el foso por debaxo de tierra, sangrado el foso, porque ha de ser con agua, por no estar siempre con sobresalto si les arriman escalas y se la roban.

SIN.: contraescarpa.

FAM.: escarpar, escarpe.

contraforte, contraforte [de la base latina fortǔs, -e. Contraforte (de calzado) 1493, BHisp.; Lope. Antes contrahorte (DECH). Rojas, Teórica fortificación, 1598]. sust. Fort. Refuerzo colocado en el interior del terraplén para fortalecer la muralla.

$$
\text { s? (fig. 43) }
$$

Rojas, Teórica fortificación, 1598, fol. 39v: Toda esta fábrica de piedra ha de tener en el fundamento 28 pies, los 13 para la muralla y los 15 para el largo de los contrafortes, dándole a cada uno tres pies de gruesso, y de hueco entre uno y otro 13 pies. // Roxas, Sumario milicia, 1607, fol. 83v-84r: El largo de los contrafortes serán 15 pies, y de grueso, 3 , y de uno a otro, 12 pies. // Lechuga, Discurso de la Artillería, 1611, pág. 244: Que suelen hazerse los fundamentos solos, al principio de las fuerzas, de piedra o ladrillo, y lo demás de tierra, hasta que a hecho assiento; y que contrafortes o estrivos se an de hazer a un tiempo, travándolos con la muralla, y no de por sí, porque la fuerza sea unida.

SIN.: espolón, estribo.

FAM.: fuerte. 
ENCICL.: Borreguero Beltrán (2000): En fortificación, estribo construido para sostener o fortalecer un muro. // Sanz (1749: s.v. contra-fuertes o estribos): Son ciertos pilares o prismas de muralla distantes uno de otro, de quince hasta a veinte pies, y se construyen desde sus cimientos con un gran talud que va a fenecer su cola en el cordón. Sirve para fortalecer la muralla, sostener el terraplén y el camino de las rondas. // Moretti (1828): Fort. Estribo o machón de mampostería, construido detrás del revestimiento de una muralla para hacerla más fuerte y ayudarla a sostener el empuje de las tierras. Su plan es un trapecio. La parte que toca al revestimiento se llama raíz y la opuesta cola. Se eleva perpendicularmente y se deja su parte superior un poco más baja que la del revestimiento. // González de Medina, Examen fortificación (1599: pág. 35-36): "Los contrafortes son unos estribos que fortifican la muralla y la ayudan a hazerse una con el terrapleno. Han de ser de treze pies de largo y de tres de ancho, y hanse de echar desde la media cortina arriba y de treze en treze pies en todo el largo de la cortina y de la frente de los baluartes, y han de ser más anchos por donde juntan con la muralla que no atrás, porque ayuden algo a tener el terrapleno, entrando por más estrecho, y no se venga luego que la costra de la muralla fuere batida al foso. Han de ser de piedra, y no nada polidos, sino grosseros, y con algunos dientes, para que mejor trabe y se uña el terrapleno, y hanse de echar en ángulos rectos y no obliquos, como muestra la primera figura, que tendrá las calidades que se han dicho, y no la segunda, porque son fáciles de cortar; y hanse de ligar por arriba con la mesma piedra con unos dientes gruessos en que trabe en los contrafortes, para hazer sobre ello la esplanada donde se ha de andar".

contrafosa, contrafossa [de fosa. Álaba, Perfeto capitán, 1590]. sust. Fort. Foso que se hace a veces alrededor de la explanada, paralelo a la contraescarpa (DUE: s.v. contrafoso).

Álaba, Perfeto capitán, 1590, fol. 88v: Y desde la trinchea más cercana al fosso donde se da la batería aya arcabuzeros que tiren pelotas de dos onças a los que vieren en las partes batidas hazer defensas, como son contrafossas, trincheas, reparos, cavalleros, estorvando el echar leña en las partes batidas, que muchas vezes se haze, para que los que dieren el assalto con fuegos que en ella echen sean estorvados.

SIN.: contrafoso.

FAM.: fosa, fuesa.

contrafoso, contrafoso, contrafosso [del it. contraffosso (Terlingen 1967). Collado, Plática Artillería, 1592]. sust. Fort. Foso que se hace a veces alrededor de la explanada, paralelo a la contraescarpa (DUE). 1 (fig. 44)

Collado, Plática Artillería, 1592, fol. 96r: Deve de procurar, con suma diligencia, de haver cierta relación, por medio de las ciertas y verdaderas espías, assí de la interior disposición del sitio como de las defensas qu'el enemigo prepara dentro [...]; si hay dentro contrafossos y si aquéllos tienen agua o son secos; si es sugetta aquella plaça a la mina y más apta a ser minada que no batida [...]. // Ferrofino, Descrizión Artillería, 1599, fol. 170v: 
Medidas de una fortificación, conforme la leyó el Doctor Juan Zedillo Díaz: 600 pies de cortinas. Y tomando 120 pies de cada lado para formar el valuarte, queda de cortina limpia 360 pies. El grueso de la muralla, 13 pies. De contraforte, 13 pies. Grueso de cada contraforte, 3 pies. [...]. Anchura del foso, 80 pies. Anchura del contrafoso, 20 pies [...].

SIN.: contrafosa.

ENCICL.: Estévanez (1897: s.v. antefoso): Nombre de un segundo "foso" que existe en algunas plazas fuertes, al pie del glacis; otros lo llaman contrafoso. Puede convenir a la defensa cuando tiene agua, pero siendo seco más bien pudiera aprovechar al sitiador. De todas maneras, ofrece el inconveniente de hacer dificultosas las "salidas". // Lucuze (1772: 68): "Se ha de convenir en que el antefoso es provechoso en situaciones bajas, con la prevención de darle altura solamente del lado de la campaña; lo que se consigue continuando la inclinación de la explanada principal hasta el fondo del contrafoso, a fin que no puedan acercarse los enemigos cubiertos con él. También es útil cuando la excavación del foso de la Plaza y obras exteriores no da la precisa tierra para terraplenes, parapetos y banquetas".

contrafossa, V. contrafosa.

contrafosso, V. contrafoso.

contramina, contramina [de mina. Montes, Instrucción y regimiento, 1537]. sust. Fort. Mina que se hace en oposición de otra, para que no haga efecto (Aut.).

(fig. 45)

Montes, Instrucción y regimiento, 1537, fol. XVIIIv: Por quatro maneras de batalla se puede ganar un castillo: por batalla de manos, o por batería, o por mina, o por hambre. Si se gana por mina, puédese defender por contramina; si se gana por batería, puédese defender reparando el muro por la parte de dentro, haziendo un contramuro, [...]. // Rojas, Teórica fortificación, 1598, fol. 72r: Y assimesmo, se ha de advertir que esta plaça ha de tener el fosso de 80 pies de ancho y 25 de fondo (como se ha dicho), y su fosseta en medio, que llaman refosso, y la contramina, como parece en el perfil que queda atrás, la qual tendrá sus poços, o respiraderos, a trechos, a 50 pies uno de otro, porque la mina del enemigo no haga bien su efeto. // Ufano, Tratado de la Artillería, 1613, pág. 262: Aunque la prática y operaçión de las minas antiguamente se a usado en las guerras de los persas, parthos y romanos con otras diversas máchinas y petrechos, ningún arte al uso de la guerra a sido más perfeto y conveniente para oprimir a los sitiados ni ay cosa de que más teman los sitiadores que es de las contraminas hechas en su daño por el enemigo viéndose tan çercado y apremiado.

ANT.: cunículo, mina 1.

FAM.: contraminado, contraminar, mina, minable, minado, minador, minar. 
ENCICL.: Nebr. (1495): Cuniculus adversus. // Moretti (1828): Fort. Pozo o excavación profunda y subterránea, desde donde sale una galería y ramales para ir a buscar la mina del enemigo e inutilizarla. Las contraminas se construyen de dos modos: las unas, al mismo tiempo que las plazas, y son unas galerías embovedadas de seis pies de alto y tres a cuatro de ancho, y se llaman galerías principales. Las otras se hacen en tiempo de sitio, y regularmente se construyen en el glacis o en alguna obra destacada, pero son bajas y estrechas, y salen sus bocaminas desde la contraescarpa del foso, las que, prolongándose a la campaña, se reparten en ramales sencillos o dobles, a cuyos extremos se construyen hornillos para esperar al enemigo. // Estévanez (1897): La mina que se hace en una plaza sitiada para oponerse a las minas de ataque del sitiador; las de éste, por consiguiente, serán las verdaderas contraminas si la plaza tiene sistema subterráneo permanente.

contraminado, contraminado [de contraminar. Ufano, Tratado de la Artillería, 1613]. adj. Fort. Dicho de las defensas de un grupo de personas: con contraminas abiertas bajo ellas, con las cuales pretenden detener el avance de los sitiadores, o bien contrarrestar el efecto de sus minas.

Ufano, Tratado de la Artillería, 1613, pág. 200-201: Y el provecho que por allý se halla es sólo el cubrimiento de la çapa y el armar hornillos para volar y yr retirando adentro los deffensores; pero, ultra d'esto, podría estar contraminado, de suerte y manera que, al hazer en él pie la gente del asalto o de otra forma dando fuego a la mina, la buelen por el ayre toda y haga más estrago y menoscabo mucho más que por la cortina.

ANT.: minado.

FAM.: contramina, contraminar, mina, minable, minado, minador, minar.

contraminar, contraminar [de minar (DRAE). Collado, Plática Artillería, 1592]. v. tr. u. t. c. intr. Fort. Excavar o hacer trabajos subterráneos en un terreno para formar la contramina.

Collado, Plática Artillería, 1592, fol. 68r: Otros más modernos, para saber si el enemigo contramina, acostumbran de tener barrenas bien largas y muy gruessas y con ellas, a una parte y a la otra de la mina, dan barrenos en la misma tierra y a la boca de aquel agujero ponen el oýdo; y si el enemigo contramina, luego se siente tan claro como si se estuviesse en su mina propria. // González de Medina, Examen fortificación, 1599, pág. 194: Hase de prevenir, lo primero, con mirar y tantear muy bien por de fuera de dónde le podrán mejor plantar la batería, y, conforme a ello, prevenirse dentro con tener tierra, faxina, madera, botas vacías, cestones de respeto, mucho de todo, porque es muy buena provisión para hazer a cada passo puestos fuertes, quando se perdiessen los hechos, con açadas, picos, palas en gran cantidad, para minar o contraminar. // Ufano, Tratado de la Artillería, 1613, pág. 263: Y advierta de no abançarse sin llevar consigo dos o tres barrenas que para tal arte se usan, una más larga que la otra, con las quales yrá barrenando a todas partes y tentando d'esta forma, por sentir si los contrarios le vienen contraminando o en busca d'él por le aver sentido. 
ANT.: minar 2.

FAM.: contramina, contraminado, mina, minable, minado, minador, minar.

ENCICL.: Nebr. (1495): Cuniculos oppono.

contramuro, contramuro [de muro (DRAE). Montes, Instrucción y regimiento, 1537]. sust. Fort. ant. Muro bajo que para mayor defensa se levanta delante del muro principal (DRAE: s.v. falsabraga).

Montes, Instrucción y regimiento, 1537, fol. XVIIIv: Por quatro maneras de batalla se puede ganar un castillo: por batalla de manos, o por batería, o por mina, o por hambre. Si se gana por mina, puédese defender por contramina; si se gana por batería, puédese defender reparando el muro por la parte de dentro, haziendo un contramuro, echando entre muro y muro muchos barriles de pólvora, [...].

SIN.: barbacana.

FAM.: casamuro, murado, murador, murar, muro.

ENCICL.: Terr. (s.v. contra-muro, contra-muralla): Muralla pequeña arrimada a la principal para fortificarla [...]. La contra-muralla o contra-muro antiguo es lo que se llamó también Barbacana y Falsabraga. Ya no está en uso. V. Casani de Fortif.

contrario, contrario [tomado del lat. contrarius 'íd.'. Berceo, en S. Dom., Mil. (DECH). Celso, Reportorio universal leyes Castilla, 1553]. adj. Mil. Dicho de un individuo, de una colectividad o de un lugar donde hay personas: opuesto o enfrentado a otro $\mathrm{u}$ otros.

Celso, Reportorio universal leyes Castilla, 1553, fol. CLIXv: Allende d'esto, venciéndose alguna batalla, deve aver el Rey el Capitán Mayor del armada contraria, quier sea uno, quier sean muchos; $\mathrm{y}$, ansimesmo, los hijos de aquéllos y los hombres que, señaladamente, fuessen para su servicio de cada día. // Álaba, Perfeto capitán, 1590, fol. 62v-63r: Mandó a uno de sus soldados de quien más confiança tenía que se passasse al campo contrario, fingiendo usar d'esta infidelidad por los malos tratamientos que su capitán le hazía, y que persuadiesse al enemigo que todo el campo de Menón se avía amotinado. // Álaba, Perfeto capitán, 1590, fol. 128v: Los franceses, aviendo de formar un esquadrón de gente de a cavallo, ponían entre ellos algunos que tirassen saetas y llevassen armas de poco peso para detener la furia de la gente de a cavallo contraria y favorecer la suya.

SIN.: enemigo ${ }_{1}$.

ANT.: amigo $_{1}$.

ENCICL.: Cov.: Lo que es opuesto. 
2 [Montes, Instrucción y regimiento, 1537]. sust. Mil. Con respecto a una persona, otra que lucha contra ella (DUE: s.v. adversario).

Montes, Instrucción y regimiento, 1537, fol. XVIr: Y en esto deven mirar mucho los capitanes, que la invidia entre ellos no dañe al señor del exército, porque las divisiones en el exército son dañosas y muy peligrosas al bien del exército, porque los enemigos no querrían otra cosa sino ver gran discordia entre los contrarios para se poder aprovechar d'ellos. // García de Palacio, Diálogos militares, 1583, fol. 190r: Y, si es por hazer mayor estrago en los contrarios que huyen o se retiran, no es justo soltar las armas que para su esquadrón son necessarias, pues con ellas se puede seguir la victoria. // Mosquera, Comentario disciplina militar, 1596, fol. 82r: Y a todo esto, el exército español se fue mejorando y començaron a marchar sus esquadrones y las mangas, que yvan adelante, a dar cargas en los contrarios con tanta priessa y furia que fueron retirando a los enemigos a buen passo.

SIN.: adversario ${ }_{1}$, contendedor, enemigo 2 .

ANT.: amigo $_{3}$.

ENCICL.: DRAE: Persona que lucha, contiende o está en oposición con otra. // D'Wartelet (1863): Enemigo, adversario.

3 [García de Palacio, Diálogos militares, 1583]. sust. Mil. Respecto a un grupo de personas, otro que lucha contra él.

García de Palacio, Diálogos militares, 1583, fol. 161v: ¿Qué orden se tendrá para ensanchar una batalla quadrada por otra, quando el enemigo trae la suya más ancha o quando se quisiere ensanchar más que la del contrario? // Álaba, Perfeto capitán, 1590, fol. 42r-42v: Y en ningún tiempo a de tener más cuydado el capitán o sargento mayor de nuestros tiempos, a cuyo cargo está el orden del marchar, que el campo vaya bien ordenado y la gente compuesta y a punto de guerra como quando se va por las partes donde el contrario está cerca, porque el peligro que ay al tiempo que se llega a las manos con los enemigos no es tan grande como el que tienen caminando. // Rojas, Compendio fortificación, 1613, fol. $44 \mathrm{v}$ : Corona mural es la que da un general al primero que subió en la muralla de los enemigos; y, assí, es hecha esta corona con almenas, en consideración de aver entrado por entre ellas a la plaça del contrario.

SIN.: adversario ${ }_{2}$, enemigo 3.

contraronda, V. contrarronda. 
contrarronda, contraronda, contrarronda [de ronda. Escalante, Discurso de la navegación, 1577]. sust. Mil. Recorrido inverso al de la ronda ordinaria, para asegurar y confirmar más la vigilancia de los puestos.

Escalante, Discurso de la navegación, 1577, fol. 85v: En todos los baluartes en que ay sus garitas, assisten de noche centinelas que las remudan por sus quartos del cuerpo de guardia que es ordinario, andando siempre los oficiales como les toca, con el número de soldados que les parece en ronda y contraronda. // Mendoça, Theórica y práctica, 1596, pág. 53: No me alargo en referir el término que los sargentos mayores y oficiales de la cavallería han de tener en el apercebir los estandartes y vanderas que han de ser aquella noche de guardia, advirtiéndoles desde la mañana, por ser cosa que en particular les toca, siguiendo la forma de milicia que tiene cada nación en mudar las centinelas con caxas o sin ellas y hazer las rondas y contrarondas. // González de Medina, Examen fortificación, 1599, pág. 182: Bolviendo a la que de ordinario ha menester para servirse, tendría por acertado que no se tuviesse con menos soldados que de quatrocientos y cincuenta a quinientos, por razón de que cada cortina requiere dos centinelas, que son diez; los baluartes, tres cada uno, que son quinze; el cuerpo de guardia, uno, que son tres; a casa del castellano, otra, que son otras tres; a la puerta del socorro, otra, que son tres; para ronda, tres, que son nueve; y para contrarronda, dos, que son seys, que hazen quarenta y nueve.

SIN.: sobrerronda 1 .

ANT.: ronda.

FAM.: ronda, rondar, sobrerronda.

ENCICL.: Terr. (s.v. contra-ronda): 1- En la Fortificación, ronda segunda, que se hace por un camino opuesto a la primera. 2- La ronda que se envía a velar sobre la ronda misma. // Rubió y Bellvé (1895-1901): Segunda ronda que tiene por objeto, como ésta, asegurarse de que vigilan los centinelas, aumentando de este modo la seguridad del recinto, campo, etc., durante la noche [...]. Con arreglo a lo dispuesto por las Ordenanzas vigentes, la contrarronda la realizan los Subtenientes (Segundos Tenientes) y Sargentos, marchando por la izquierda para seguir el recinto en oposición a la ronda, que marcha por la derecha.

\section{contrascarpa, V. contraescarpa.}

contraseña, contraseña [de seña y éste del lat. š̆gna. h. 1570, Mármol (DECH). Álaba, Perfeto capitán, 1590]. sust. Mil. Cualquier tipo de señal, como un gesto o una palabra, sólo conocida por los que luchan en el mismo bando, que les sirve, poniéndola de manifiesto, para reconocerse entre sí.

Álaba, Perfeto capitán, 1590, fol. 49r: Quando se embía alguna centinela a reconocer los disignios del enemigo y si el campo quiere de secreto hazer mudança, que es la que propiamente se llama perdida, no se le a de dar el nombre, por el peligro que ay de que, cogiéndola y apremiándola, lo diga; y, assí, se usará con ella de alguna contraseña particular para que quando buelva sea conocida. // Roxas, Sumario milicia, 1607, fol. 31v: 
Las bocales se entienden por voz umana, como quien dijese “¡Bitoria, bitoria!”, o otra cosa semejante, y la semibocal son las trompetas, y las señales mudas son alçar o bajar alguna banderola o maderos en los castillos para dar a entender lo que ay de nuebo, sigún tiene la contraseña ya dada. / / Ufano, Tratado de la Artillería, 1613, pág. 146: Tiene obligaçión cada noche de yr por el nombre y contraseñas al quartel del maestre de campo general y traerlo a su general y tinientes con las demás órdenes y recados $\mathrm{y}$, en bolviendo, repartir las muniçiones de víveres.

SIN.: contraseño.

FAM.: contraseño, reseña.

ENCICL.: Aut.: La señal o palabra que en la milicia se da para conocerse unos a otros y no tenerse por enemigos en la confusión del combate o en la oscuridad de la noche. Y también se da a las centinelas para que no dejen pasar al que no se la diere. // Álaba, Perfeto capitán (1590: fol. 62r): "Y ningún ardid puede ofrecerse de más importancia en la guerra que el saber variar en las traças y engaños, de suerte que si el enemigo huviere alcançado a entender alguna seña secreta, pueda con facilidad ser engañado con otra contraseña o cautela; como hizo un capitán cuyo nombre no escrive quien haze mención de su prudencia, el qual, aviendo puesto por seña conocida en todo su campo para saber quándo marchavan hazia él los enemigos el hazer fuegos de noche y esparcir por el real humo de día, y sabiendo que sus contrarios entendían ya esta seña, para desalumbrarlos y dar ocasión a que cayessen en algún error guiándose por ella, ordenó que de día y de noche se hiziessen fuegos y humo sin cessar, sin que se tuviesse respeto a que viniesse el campo contrario, como antes se hazía, y que, quando le viessen cerca, cessasse lo uno y lo otro. Hecho esto como estava mandado, viendo la persona a cuyo cargo estava el ponerlo en execución que los enemigos estavan cerca, mandó que fuegos y humo parassen, con lo qual, pareciéndoles que sin duda las guardas no los avían sentido venir, pues no se usava de la seña del humo, y que todo el real devía de estar descuidado, acometieron con la desorden que de ordinario acometen los muy confiados de la vitoria; y estando sossegado el prudente capitán que sabía su venida, con menos gente de la que su enemigo traía le desbarató y venció".

contraseño, contraseño [de seño, que es la forma popular del lat. s̆ğnum. Contraseño 'contraseña' ant. y raro. h. 1580, H. de Mendoza (DECH). Mendoça, Theórica y práctica, 1596]. sust. Mil. Cualquier tipo de señal, como un gesto o una palabra, sólo conocida por los que luchan en el mismo bando, que les sirve, poniéndola de manifiesto, para reconocerse entre sí.

Mendoça, Theórica y práctica, 1596, pág. 138: Dándole el contraseño, si lo ay, el tal alcayde o castellano lo ha de dilatar hasta la última hora de las veyntiquatro del día que precissamente se le señaló, cumpliendo d'esta suerte con el obedecer a su príncipe y sin manchar la lealtad devida.

SIN.: contraseña. 
FAM.: contraseña, reseña.

ENCICL.: DRAE: desus. contraseña.

contravatería, V. contrabatería.

convoy, comboy [del fr. convoi 'escolta de soldados o navíos', 'acompañamiento de un entierro', etc., derivado de convoyer 'escoltar, acompañar', y éste del lat. vg. *convĭare, derivado de v̆a 'camino'. 1644-48: convoyes o guardias de gente (DECH). Ufano, Tratado de la Artillería, 1613]. sust. Mil. Conjunto de cosas necesarias a un ejército, como pertrechos y víveres, así como las acémilas y carros en que son trasladadas, que, para seguridad de la marcha, es acompañado por escoltas.

Ufano, Tratado de la Artillería, 1613, pág. 145: Tócale asistirles con gran diligençia al partir de los comboyes y escoltas. Quando van por los víveres oblígale, assimismo, rondar el quartel y, topando con algún malhechor, tomarle en prisión, aunque sea del exérçito.

ENCICL.: DUE: Conjunto de los efectos transportados, los vehículos, barcos, etc., que hacen el transporte y los que les acompañan. // Borreguero Beltrán (2000): Conjunto de medios de locomoción que se destinan al transporte de hombres, material, munición, etc., acompañados por una escolta para seguridad de la marcha. // Rubió y Bellvé (1895-1901): La escolta encargada de custodiar los efectos que se transportan de una parte a otra, por tierra o mar, y también los carruajes, buques, vituallas, pertrechos, etc., que son escoltados [...]. En lo antiguo se expresaba la misma idea sin necesidad de emplear esta voz francesa, denominando, por ejemplo, "recua" de viandas a lo que nosotros, amigos de lo extranjero, llamamos convoy de provisiones.

cordón, cordón [probablemente del fr. antiguo, donde ya se halla desde el s. XII. Cid (DECH). Rojas, Teórica fortificación, 1598]. sust. Fort. Cinta o banda de piedras que se forma donde se concluye la muralla o empieza el parapeto, y circuye toda la plaza (Sanz 1749). 우 (fig. 46)

Rojas, Teórica fortificación, 1598, fol. 69r: Y luego se levantará esta muralla hasta el cordón 40 pies, porque está en tierra llana, y conviene ser assí alta, porque el enemigo no la puede señorear desde la campaña con algunas plataformas. // Rojas, Teórica fortificación, 1598, fol. 69r: Y luego se hará el cordón de un pie de alto, el qual cordón se entiende ser un bocel, y se avisa que tenga la menos salida que se pudiere afuera, porque no cuelgue de allí el enemigo las escalas. Y del cordón arriba se levantará el parapeto, de 7 pies de alto por la parte de fuera, y por la parte de dentro no tendrá más que 6 de alto, porque pueda tirar el soldado. // Roxas, Sumario milicia, 1607, fol. 77v: Altura desde el foso al cordón, 31 pies; y el cordón tendrá 2 pies de alto.

ENCICL.: Terr.: En la Fortificación, fila de piedras, blancas por lo común, que se pone en la muralla. // Corsini (1849): Fort. Especie de moldura formada de una fila de piedras 
redondas que en las obras fortificadas salen hacia fuera al nivel del terraplén del muro y al pie exterior del parapeto. El cordón da vuelta alrededor de la plaza y sirve de fuerza y adorno al revestimiento del muro, que está en declive, y al del parapeto, que es perpendicular. En las murallas revestidas de tepes no se puede poner cordón, pero se le sustituye por lo común con una fila de estacas hincadas horizontalmente o algo inclinadas hacia el foso. // Lucuze (1772: 27): "El cordón es un adorno o moldura en figura de semicírculo que corre por el extremo superior del revestimiento de piedra o por la línea magistral, y distingue las obras exteriores de las interiores, de suerte que las comprendidas por el cordón se llaman interiores y las demás exteriores".

corneta, corneta [probablemente sea el resultado de un cruce, producido en lenguas hispánicas, entre trompeta y el autóctono cuerna 'bocina de cuerno' [1644] y demás representantes iberorromances de cornu. Berceo (DECH). Mendoça, Theórica y práctica, 1596]. sust. f. Mil. Tropa de soldados de a caballo.

Mendoça, Theórica y práctica, 1596, pág. 56: Aviendo lanças y herreruelos en el exército, es muy buena manera de mezclarlos poner al costado izquierdo de las lanças una corneta de herreruelos, que viene a servir como de manga.

FAM.: cuerno.

corredor, corredor [de correr. APal.; como sustantivo de lugar ya está en Cervantes y en Calvete de Estrella, Aut. (DECH). Montes, Instrucción y regimiento, 1537]. sust. Mil. Soldado especializado en explorar o examinar el territorio para localizar al enemigo y analizar sus movimientos.

Montes, Instrucción y regimiento, 1537, fol. XIr: E quando el campo se assentare, el general de los cavallos ligeros embiará sus corredores por la parte donde pensare que haya enemigos, y como venga a la noche, pongan las cintinellas por los caminos y passos por donde los enemigos podrían venir a hazer daño al exército. // García de Palacio, Diálogos militares, 1583, fol. 66v-67r: Movido, pues, el exército, y prevenida la orden del marchar, y corredores de a cavallo que descubran y allanen los caminos, con orden y silencio en los soldados, ha de advertir que, si se huviere de dar algún repente sobre qualquier enemigo, ningún soldado entienda dónde ni contra quién va, que, encubriendo el capitán sus disignios y haziendo esto assí, no podrá el enemigo ser avisado, a cuya causa el exército va y marcha más seguramente. // Mendoça, Theórica y práctica, 1596, pág. 70-71: El maestre de campo general se encaminará con la vanguardia, embiando corredores delante, los quales han de yr a vista siempre de la vanguardia, ganando los altos para descubrir y las partes donde puede aver emboscadas, avisando de ordinario lo que reconocen, siendo assimismo costumbre llevar en la vanguardia algunas pieças de campaña, que irá reforçada con más o menos cavallería o infantería.

SIN.: descubridor.

FAM.: correduría, correr, correría, corrida. 
ENCICL.: DRAE: Soldado que se enviaba para descubrir y observar al enemigo, y para descubrir el campo.

correduría, correduría [de corredor (DECH). Mendoça, Theórica y práctica, 1596]. sust. Mil. Acción de recorrer un territorio con el fin de arrasarlo y de saquearlo. Mendoça, Theórica y práctica, 1596, pág. 113-114: Y quando sean iguales los campos ha de dividir Vuestra Alteza los esquadrones del suyo en otros tantos como trae así formadas el enemigo afrontando los soldados viejos a los del enemigo, que son más exercitados en la guerra y gente robusta, assí de a cavallo como de a pie; de que se tendrá aviso, según razón, y del número de los esquadrones enemigos, por las espías y lenguas que se tomaren en corredurías y escaramuças que se han de travar con solo este dissinio. // Mendoça, Theórica y práctica, 1596, pág. 150-151: Entre otras naciones tienen los capitanes el diezmo de las presas que hazen sus soldados, si bien no se hallan presentes, y otras vezes se dividen las compañías y se embían tantos soldados a correr una vez y después otros diferentes, tocándoles a todas las compañías salir por días a correr, para que trabajen igualmente, y entonces la presa que trae cada tropa se divide entre los soldados d'ella sin tener los otros parte. Fuera de las corredurías que se hazen y daño al enemigo con ella, se intentan tratos en las tierras, que es facción que se ha de platicar con mucho tiento y consideración.

SIN.: correría, corrida, incursión.

FAM.: corredor, correr, correría, corrida.

ENCICL.: Aut.: Vale lo mismo que correría.

correr, correr [del lat. cŭrrěre 'íd.'. Mitad del s. X, Glosas de Silos (DECH). Álaba, Perfeto capitán, 1590]. v. tr. u. t. c. intr. Mil. Examinar o explorar un lugar para localizar al enemigo y obtener información sobre sus posibles maniobras $u$ operaciones militares.

Álaba, Perfeto capitán, 1590, fol. 42r: Y para evitar semejanes emboscadas y repentinos acometimientos de los contrarios, es necessario que el capitán embíe algunos de sus soldados, de cuya prudencia, lealtad y fidelidad tuviere bastante seguro, para que éstos corran la tierra y avisen de los peligros que se pueden ofrecer y del lugar donde está el campo contrario. // Álaba, Perfeto capitán, 1590, fol. 52v: Y, assí, los tribunos y centuriones que Cipión embió en ábito de siervos para acometer a Lelio, que yva con nombre de embaxador a Sifaz, para mejor informarse de todo lo que avía en su real, en llegando a él, fingieron averse soltado un cavallo y, con ocasión de cogerlo, corrieron todo el campo, por cuya relación fue destruydo el exército con fuego. // Mendoça, Theórica y práctica, 1596, pág. 110: Y raras vezes se viene a combatir sin averse hecho antes alojamientos y reconocido los exércitos, de que se tiene nuevas por las espías y otras intelligencias, sin los que se embían a correr o tomar lengua, de que se valen los príncipes y capitanes, generales, procurando certificarse si es maior su campo que el del enemigo, siendo superior en cavallería y infantería, o en alguna parte d'éstas. 
SIN.: descubrir 3.

FAM.: corredor, correduría, correría, corrida.

ENCICL.: Corsini (1849: s.v. correr o recorrer la línea): Log. Reconocer la de puestos del enemigo, a fin de asegurarse de que permanecen en las mismas posiciones que ocupaban, o de notar las novedades que en ellos hayan ocurrido. // DRAE (s.v. correr la campaña): Mil. Reconocerla para saber el estado de los enemigos y observar sus intentos y operaciones.

2 [Montes, Instrucción y regimiento, 1537]. v. tr. u. t. c. intr. Mil. Dicho de los soldados: recorrer un lugar en actitud violenta, devastando, robando, etc.

Montes, Instrucción y regimiento, 1537, fol. IXr: Después de affirmado un exército en una parte, no deven tenello mucho tiempo affirmado, por tres razones [...]: la primera, porque los que están en campaña duermen en el sereno, y al agua, y al sol, y estando d'esta manera vienen a enfermar; lo segundo, que de las tales enfermedades se suele inficionar un exército [...]; lo otro, que quando está mucho tiempo en un sitio, la gente del exército se le derrama, unos a correr, otros a buscar de comer y otros se van a sus tierras, de cansados de la luenga guerra. // García de Palacio, Diálogos militares, 1583, fol. 76r: César, viendo que los picardos y flamencos estavan tan poderosos contra él que buenamente no les podía resistir, trató con los borgoñones, que eran amigos, que entrassen a correrles sus tierras, a cuya causa fueron forçados a dividir su campo, y, con esto, pudo César pelear con commodidad. // Mendoça, Theórica y práctica, 1596, pág. 147: Y quando los labradores y villanage del contorno no se puede despoblar por consideraciones que ay y avituallarse con sus labranças las tierras, se ha de atender tenelle contento y que los soldados no les hagan, saliendo de la plaça a correr, ningún mal tratamiento, porque con esto vienen a dar buenos avisos y espiar con mucho cuydado las acciones del enemigo, juzgando ser el dañarle su mismo provecho.

ENCICL.: Terr. (s.v. correr un país): Asolarle, saquearle, V. // Fernández Mancheño (1822: s.v. correr el campo): Entrar los enemigos a hostilizar y hacer correrías. // Rubió y Bellvé (1895-1901): Recorrer un país en son de guerra, destruyendo las cosechas, cautivando personas, peleando o dañando de cualquier modo al enemigo. Úsase en frases como correr la tierra, el campo, la campaña, etc.

correría, correría [de correr. h. 1572, H. de Mendoza (DECH). Loçano, Alberto, Architectura, 1582]. sust. Mil. Acción de recorrer un territorio con el fin de arrasarlo y de saquearlo.

Loçano, Alberto, Architectura, 1582, pág. 102: Los exercitados en la guerra apruevan muy mucho a Cingolo, en la Marca [...] porque allí no aviene lo que casi en todos los más de los pueblos de montaña: que después que ayáys salido tengáys igual pelea, porque son alançados por una roca salida y despeñadera, y ni tiene el enemigo cómo pueda a su voluntad, con una sola correría, destruyr y robar el campo, ni cercará juntamente todas las 
salidas, ni seguramente se recogerá en los reales puestos cerca, y ni embiará sin peligro por pasto, leña y agua. // Álaba, Perfeto capitán, 1590, fol. 86r: Echarse a luego un vando de las leyes que en el real se han de guardar, como son que en el real aya quietud, que nadie compre vituallas sin estar tassados los precios [...], que ninguno pueda emprestar armas, que ninguno passe plaça en dos compañías, que no vayan a correrías sin licencia, que no esté persona en el campo que no pertenezca a él o sea muy conocida, [...]. / / Collado, Plática Artillería, 1592, fol. 112r: Y por quanto [...] en qualquiera facción de artillería a los artilleros se les da ración del comer y bever doblada de aquélla que se da a la demás gente de guerra, no deven ser ellos negligentes en pedirla ni perezosos en cobrarla y, cobrada aquélla, guardarla y moderamente compartirla, de manera que siempre le sobre del un día para el otro alguna cosa, porque muchas vezes se vee que faltan vituallas en el campo y al artillero, ni le es lícito desamparar su pieça, ni menos hir a forregear, ni hazer correrías en la campaña.

SIN.: correduría, corrida, incursión.

FAM.: corredor, correduría, correr, corrida.

ENCICL.: Cov. (s.v. correrías): Las salidas que la gente de guerra hace en la tierra del enemigo cuando se la corre, robando y talando. // Terr.: Incursión, hostilidad y daño que se suele hacer en tiempo de guerra [...]. Antiguamente se decía corredura y correduría, por correría.

corrida, corrida [de correr. Nebr. (DECH). Muñoz, Libro nuevo cometa, 1573]. sust. Mil. Acción de recorrer un territorio con el fin de arrasarlo y de saquearlo.

Muñoz, Libro nuevo cometa, 1573, fol. 27v-28r: Ptolemeo dize: “Los fuegos transcorrientes o estrellas cayentes por el ayre señalan sequedad. Si solamente salieren de una parte del cielo, señalan que de aquélla se levantarán vientos. Si de muchas partes salen, señalan diminución de las aguas y grandes mudanças o tempestades en el ayre, y assaltos y corridas de exércitos, o guerras. // Loçano, Alberto, Architectura, 1582, pág. 111: Aprovechará también que aya más pequeñas calles, no estendidas a la larga, sino que se acaben y rematen en la primera calle atravessada, como que no dan camino público dessembaraçado, sino solamente la entrada de la casa frontera, y porque esto dará a las casas luzes más aparejadas y a la ciudad la corrida que quieren de el enemigo más impedida.

SIN.: correduría, correría, incursión.

FAM.: corredor, correduría, correr, correría.

ENCICL.: DRAE: ant. correría.

cortadura, cortadura [de cortar. APal., Nebr. (DECH). González de Medina, Examen fortificación, 1599]. sust. Fort. Cualquier tipo de obra o defensa que, tanto 
por parte de los sitiadores como por parte de los sitiados, suele levantarse en lugares estrechos para tratar de impedir el paso al enemigo.

González de Medina, Examen fortificación, 1599, pág. 159: Será bueno, además de los rebellines, como quedan dichos, hazer unas trincheas con sus traveses, que se descubran todas de la muralla y se puedan defender, o, por lo menos, entretener al enemigo mucho tiempo con ello, y con cortaduras y defensas en cada calle del arrabal. // González de Medina, Examen fortificación, 1599, pág. 201: Si, batiéndose un ángulo de un baluarte, se le viniessen a cortar y a meterse allí los enemigos, adonde, por no se lo poder estorvar de ninguna parte, pudiessen hazer cortaduras y hornillos para yrse entrando y ganarse la muralla, ¿qué remedio se tendría para estorvárselo que fuesse bueno? // Rojas, Compendio fortificación, 1613, fol. 32r-32v: Y, assí, conviene mucho que aya fosso en la fortificación y a la orilla y borde d'él su estrada cubierta, y fuera d'ella cortaduras y redutos para detener el enemigo a lo largo.

SIN.: través 3 , traviesa $_{1}$.

ENCICL.: Aut.: La zanja o abertura que se hace en la tierra con su parapeto, así en campaña como en las plazas, para detener al enemigo. // Fernández Mancheño (1822): Fort. Obra que se construye en los pasos estrechos para defenderlos con más ventaja. Comúnmente consta de un foso con su parapeto de tierra y fajinas con dientes de sierra cuando es algo dilatado el frente. Según los terrenos, también se suelen hacer las cortaduras de piedra seca o de árboles, cortándoles las ramas gruesas en punta, tostándolas por el cabo.

2 [González de Medina, Examen fortificación, 1599]. sust. Fort. Nueva construcción defensiva consistente normalmente en un parapeto con cañoneras y merlones $y$, algunas veces, con foso, que suelen hacer los sitiados en los baluartes batidos para impedir que sus enemigos se alojen en la brecha o accedan a la plaza a través de ella. $\quad$ s (fig. 47)

González de Medina, Examen fortificación, 1599, pág. 15-16: [La forma pentágona] se tiene por muy buena, porque se puede franquear con las defensas, de manera que sean dificultosas de quitar y que quede plaça en los baluartes para poder hazer cortaduras y retirada, si se cortare el ángulo de los baluartes. // González de Medina, Examen fortificación, 1599, pág. 25-26: Puédese, batido el ángulo, hazer muy buen reparo y cortaduras con traveses y foso, de manera que esté tan dificultoso de perderse como antes de perdido el ángulo, si es grande y capaz. // Lechuga, Discurso de la Artillería, 1611, pág. 242: Se a acordado que los baluartes se hagan iguales en terrapleno a las cortinas y que lo demás quede vazío para que dentro pueda estar lo que cupiere de gente en esquadrón, sin poder ser offendidos ni vistas sus picas, y para que el día que se pierda un baluarte quede siempre la ventaxa a los que defienden la fuerça, como se verá en que an de baxar forzosamente con trinchera al llano del baluarte, muy a peligro, haziendo una los de dentro delante la gola o corriendo por el terrapleno a riesgo de que, no haziéndolo igualmente por los dos lados, queden descubiertos por las espaldas, pues con facilidad los de dentro podrán hazer dos cortaduras que obliguen a los de fuera a nuevo trabajo.

SIN.: retirada . 
ENCICL.: Corsini (1849): Fort. Parapeto de tierra o ladrillo con cañoneras y merlones, y algunas veces con foso, que se hace en la brecha; en los baluartes grandes, desde uno de los ángulos de la espalda al otro; y en los pequeños, en las golas, a fin de impedir que el enemigo se aloje y fortifique en aquella.

cortina, cortina [del lat. tardío cortinna 'íd.', derivado del lat. vg. cors, -tis, lat. cohors 'recinto'. Cortina 'paño con que se cubren puertas, ventanas, camas, etc.'. Berceo, Mil. (DECH). Álaba, Perfeto capitán, 1590]. sust. Fort. La porción de muralla comprendida entre dos baluartes. 5 (fig. 48)

Álaba, Perfeto capitán, 1590, fol. 88v: Y desde que se començare a batir siempre se vaya continuando con gran priessa de día y de noche, cruzando la batería, dándola a los lados de los baluartes, por estorvar el daño que las pieças de las casamatas hazen, echándolas por tierra, con que quedará el lugar más acomodado de subir la fortaleza, batiendo también la cortina que está en medio de los dichos baluartes. // Rojas, Teórica fortificación, 1598, fol. 35v: Y, supuesto este fundamento, daré principio a mi opinión, guardando por regla general que la mayor cortina que daré en todas las plaças que pusiere será de 400 pies de largo, y la cortina menor será de 350, porque en estas dos medidas se hallan buenos ángulos a los valuartes y buenas espaldas a las casas matas. // Lechuga, Discurso de la Artillería, 1611, pág. 261: En la fuerça de quatro baluartes, cada una de las cortinas que queda entre los dos a de tener quatrocientos pies; éstos repartidos por ocho, que son los dichos que a de guardar un soldado, salen cinqüenta, que son los que a menester la cortina.

SIN.: cortina franca, cortina limpia, cortina parcial.

FAM.: descortinar.

ENCICL.: Díaz Capmany (2004: 30): "La cortina era el tramo de terraplén comprendido entre dos baluartes; por estar entre dos flancos era la parte más defendida. La longitud de las cortinas estuvo siempre íntimamente relacionada con el alcance de las armas empleadas en su defensa, es decir, las que tenían que flanquearlas".

2 [Roxas, Sumario milicia, 1607]. sust. Constr. Trozo continuo de pared o muralla (DSAL: s.v. lienzo).

Roxas, Sumario milicia, 1607, fol. 77r: Largo de la frente o cortina del baluarte, 250 pies. // Lechuga, Discurso de la Artillería, 1611, pág. 241: El fosso a de ser ancho, por la parte de las cortinas de los baluartes, quando menos, 120 pies, y por las otras partes, lo que precisamente pide, para que los baluartes puedan guardar el fosso. // Lechuga, Discurso de la Artillería, 1611, pág. 242: Que los cuerpos de guardia se hagan uno en cada baluarte, al pie del terrapleno, en la parte que se junta la cortina con la [cortina] del través.

SIN.: lienzo. 
ENCICL.: Lorenzo Celorrio (1996): Lienzo. Porción de muralla comprendida entre dos elementos cualesquiera que rompan la uniformidad del muro tales como torres, cubos, esquinas o precipicios.

$\sim$ franca [Rojas, Teórica fortificación, 1598]. cmpt. sintag. Fort. La porción de muralla comprendida entre dos baluartes. (fig. 49)

Rojas, Teórica fortificación, 1598, fol. 40r: De forma que, la AB dividida en quatro partes iguales, quedan las dos $C C$ de cortina franca, y la $C D$ es fianco o través, que tiene 60 pies y la CO es la gola. // Rojas, Teórica fortificación, 1598, fol. 41r: Para hazer el repartimento en esta plaça en triángulo, se dividirá, como dicho es, en cinco partes la frente del recinto, que en este caso es la $\mathrm{AB}$ y tiene de frente 600 pies, que, divididos en cinco partes, caben a cada una a 120. Y éstos se rebatirán de ambos estremos de la frente del recinto para sacar los traveses, como lo muestran AC y CB en la passada figura, dexando la cortina franca, del un través al otro, de 360. / / Rojas, Compendio fortificación, 1613, fol. 34r: D'éstos se tomarán 150 pies para la media gola y casamata, y otros 150 de la otra parte en el otro baluarte, para hazer lo mismo que en el primero, que ambos tomarán 300 pies y quedarán 500 pies de cortina franca.

SIN.: cortina1, cortina limpia, cortina parcial.

ENCICL.: Como puede verse en los ejemplos ofrecidos, existe una cierta tendencia a emplear combinaciones sintácticas tales como cortina franca, en detrimento de la unidad simple cortina, cuando, en vez de una construcción defensiva tal cual, se habla de las líneas y ángulos de la planta de una fortaleza. Seguramente se trate de un recurso empleado por los tratadistas para oponer la cortina total, concepto sólo apreciable en el plano de una fortaleza, con 'la porción de muralla comprendida entre dos baluartes', esto es, con cortina $_{1}$, cortina franca, cortina limpia y cortina parcial, línea visible tanto en una obra defensiva ya concluida como en el diseño en papel de la misma.

limpia [Ferrofino, Descrizión Artillería, 1599]. cmpt. sintag. Fort. La porción de muralla comprendida entre dos baluartes.

Ferrofino, Descrizión Artillería, 1599, fol. 170v: Tomando 120 pies de cada lado para formar el valuarte, queda de cortina limpia 360 pies.

SIN.: cortina, cortina franca, cortina parcial.

parcial [González de Medina, Examen fortificación, 1599]. cmpt. sintag. Fort. La porción de muralla comprendida entre dos baluartes.

González de Medina, Examen fortificación, 1599, pág. 52: Es muy necessario saberse, para lo que queda dicho, que es ángulo y línea perpendicular, cortina total y cortina parcial. // González de Medina, Examen fortificación, 1599, pág. 53: Y assí, para que esta cortina total nos dé la cortina parcial o franca, que es de la una boca de la casamata a la otra, de trescientos y cincuenta pies de largo, y las golas de los baluartes de cien pies de ancho, serán menester ser las líneas muertas, que constituyeren el pentágono, de quinientos y 
noventa pies de largo cada una para tomar de cada lado del ángulo ciento y veynte pies y, desde aquel punto, levantar la perpendicular para la boca de la casamata y su espalda.

SIN.: cortina, cortina franca, cortina limpia.

total [González de Medina, Examen fortificación, 1599]. cmpt. sintag. Fort. En el plano de una fortaleza es la línea que resulta de unir el centro de la gola de uno de sus baluartes con el mismo punto del baluarte contiguo. (fig. 50)

González de Medina, Examen fortificación, 1599, pág. 53: Cortina total es la que llega a cerrar línea recta el pentágono, adonde constituye los cinco ángulos sobre quien se han de hazer los baluartes, que se señalarán con una línea muerta para, por ella, con un compás por medida, poder destribuyr los miembros con proporción, como se ha dicho. // González de Medina, Examen fortificación, 1599, pág. 79: Y repartido en trezientos y sesenta grados, partirlos por cinco, y vendrán a setenta y dos grados, y poner una señal en uno de aquellos grados, levantada con una muesqueçuela en medio, y contar setenta y dos y poner otra, y a otros setenta y dos poner otra, hasta poner cinco señales, que serán los cinco ángulos de donde salen las cortinas totales que forman el pentágono, que es la fuerça que queréys hazer. // González de Medina, Examen fortificación, 1599, pág. 213: Para medir esta fuerça y todas las que quisiéredes, como me avéis preguntado, y deziros los pies de superficie que ocupará, se ha de reduzir toda a triángulos desde el centro a circunferencia de la cortina total.

ENCICL.: Azevedo Fortes (1729: 12): "Polígono interior são as linhas que cercam interiormente a fortificação, e dellas se formam as cortinas e semigolas". // Moretti (1828: s.v. lado interior): Fort. Dícese de la cortina prolongada hasta los radios o lado de un polígono fortificado por fuera, o la línea tirada del centro de un baluarte al centro del baluarte vecino.

costado, costado [del lat. *costātum, derivado del lat. costa 'costado, lado', propiamente 'costilla'. Cid (DECH). García de Palacio, Diálogos militares, 1583]. sust. Mil. En cualquier orden de batalla, cada uno de sus dos lados o partes extremas.

García de Palacio, Diálogos militares, 1583, fol. 155v: Si, yéndose juntando muchos por la orden que se dixo, quedase más ancha que prolongada, se deve hazer del costado derecho avanguardia, y del yzquierdo rectaguardia con presteza, bolviendo los rostros a la parte que ha de ser avanguardia. // García de Palacio, Diálogos militares, 1583, fol. 184v: Deven, pues, también los capitanes traer los mejores soldados de sus compañías apartados de los otros, para hazer d'ellos la avanguardia, rectaguardia y costados. / / Mendoça, Theórica y práctica, 1596, pág. 120: Si el enemigo tiene tanta gente que le parece poder con ella ceñir la batalla de su contrario y el sitio es en llano, donde la naturaleza no fortifica con la calidad d'él algún costado del exército y esquadrones, se ha de advertir si los de la infantería enemiga son en tan gran número que puedan conseguir el efecto o hazerle la multitud de la cavallería sola, abraçando el exército.

SIN.: ala, cuerno. 
ENCICL.: Aut:: En los ejércitos es el lado izquierdo y derecho de ellos, que por otro nombre se llama ala o cuerno.

2 [González de Medina, Examen fortificación, 1599]. sust. Fort. En un baluarte con casamata y orejón, la parte del flanco cubierta por este último, cuya medida ha de ser la adecuada para la protección de las piezas de artillería instaladas en la casamata.

González de Medina, Examen fortificación, 1599, pág. 13-14: De la triángula no ay para qué hablar en ella, sino para de todo punto desecharla por la incapacidad que en sí tiene, y de no poder darle los ángulos de los baluartes sino tan largos y agudos que con cualquier batería, por débil que sea, se pueden cortar luego y tener el enemigo donde se poder meter seguro, que de las casas matas no le puedan descubrir ni hazer ningún daño; no se le puede dar buen costado o espalda (como llaman los que tratan d'esta professión) al baluarte, de manera que las casas matas estén seguras; [...].

SIN.: espalda $a_{3}$.

cuadro, cuadro, quadro [del lat. quadrum 'un cuadrado'. Cuadro 'cuadrado o rectángulo (aplicado esp. a las obras de arte pintadas, a porciones de tierra labrada, etc.). 968, Oelschl. (DECH). Álaba, Perfeto capitán, 1590]. sust. Mil. Formación de infantería en forma de cuadrilátero, esto es, compuesta de cuatro caras o lados.

Álaba, Perfeto capitán, 1590, fol. 123r: En el medio pondré el quadro de terreno, y a los lados los otros dos; y entre un esquadrón y otro aya un espacio suficiente para que los del un esquadrón no se confundan con los del otro y, assí, puedan los cuernos alargarse y encogerse con facilidad. // Mendoça, Theórica y práctica, 1596, pág. 55: Quando se quiere que el esquadrón esté reforçado por todas partes con igual proporción, se ha de formar quadro de gente; queriendo reforçar la frente o retaguardia, combatiendo más soldados, se compone quadro de terreno. // Roxas, Sumario milicia, 1607, fol. 68v: Y para haçerlo en un llano donde no aya ninguna comodidad de las dichas, se hará en quadro del terreno, porque allí son yguales las frentes, aunque el fondo o lado no tiene tantos soldados como la frente, porque en el lado ay de distancia de uno a otro siete pies, y de uno a otro, en la frente, tres, y si el enemigo arremetiese por el lado lo hallaría muy flaco por allí.

ENCICL.: Estévanez (1897): Formación táctica adoptada siempre por la infantería cuando se ve atacada por caballería en terreno favorable a ésta; pero es inútil y perjudicial amasar la infantería si el enemigo dispone de otra infantería o de artillería. En cambio, la caballería sola no romperá jamás un cuadro formado por una infantería sólida, municionada y serena. Los cuadros españoles de la gloriosa infantería de Flandes no fueron nunca rotos por la caballería; en Rocroy, en Lens, en otras batallas fue preciso romperlos a cañonazos, abrir "brechas" en los batallones como en plazas fuertes. 
cuartel, quartel [del fr. quartier 'alojamiento de una tropa en campaña'. h. 1572, Hurtado de Mendoza. Posteriormente (Aut.), 'edificio donde se alojan las tropas' (DECH). García de Palacio, Diálogos militares, 1583]. sust. u. m. en pl. Mil. Cada una de las divisiones de un alojamiento, sea en campaña o dentro de una fortaleza. S (fig. 51)

García de Palacio, Diálogos militares, 1583, fol. 191r: Y suélese poner la frente del campo hazia Oriente y las espaldas, al Poniente, haziendo, para la distinción y apartamiento de los quarteles, dos calles, de a quarenta pasos de ancho y del largor del dicho sitio. // Collado, Plática Artillería, 1592, fol. 97r: La segunda consideración es, si marchando con un campo y haviéndosele de hazer el alojamiento, si aquél ha de ser para una noche sola o por algún espacio de tiempo. Si será por espacio de tiempo, fuerça le será muy bien fortificar los quarteles del artillería con honda y bien entendida trinchera. // Ufano, Tratado de la Artillería, 1613, pág. 121: También le obliga al general procurar que su quartel sea en parte cómoda y muy segura y, finalmente, adonde los enemigos menos puedan descubrir su artillería, y quando el tal puesto, como digo, no se hallase a propósito, alçar una espalda a prueva de cañón con tierra y faxina, o lo que más viniere a qüento.

SIN.: estancia, posada.

FAM.: acuartelar.

ENCICL.: Almirante (1869): Entre las varias acepciones militares, la preferente hoy de edificio destinado especialmente a vivienda de las tropas en guarnición, quizá es la más moderna, puesto que no va más allá del siglo pasado [...]. La necesidad, pues, del cuartel moderno no se hizo sentir en rigor hasta después de la guerra de Sucesión, en que la España militar se replegó en sí misma, teniendo que albergar sus propias tropas, ya más crecidas en número por las ideas políticas o de gobierno que empezaron a dominar [...]. Mucho antes de que cuartel tuviese la significación principal que acabamos de exponer era voz técnica en la milicia en sentido de estancia, de cuerpo táctico establecido en posición, de trozo divisionario de un ejército. // Rubió y Bellvé (1895-1901): En lo antiguo el paraje donde se instalaba cada fracción del ejército hallándose en campaña o en el sitio de alguna plaza; esto es, lo mismo que hoy decimos "acantonamiento" [...]. Esta denominación [...] pasó al español de la voz francesa quartier. Los franceses llamaban quartier de campement (cuarto de campamento) a cada una de las porciones en que se dividía éste; cuyo nombre empleose luego para designar cada uno de los parajes que ocupaban las diversas fracciones del ejército [...]. En español la voz equivalente era estancia. // Borreguero Beltrán (2000): Los modernos cuarteles surgieron en Francia en el siglo XVII. En España, comenzaron a construirse después de la guerra de Sucesión durante el reinado de Felipe V.

cuarto, cuarto, quarto [del lat. quartus 'íd.'. 1074 (Oelschl.), Cid (DECH). Escalante, Discurso de la navegación, 1577]. sust. Mil. Cada una de las cuatro partes en que los centinelas dividen las noches.

Escalante, Discurso de la navegación, 1577, fol. 85v: En todos los baluartes en que ay sus garitas, assisten de noche centinelas que las remudan por sus quartos del cuerpo de guardia que es ordinario, andando siempre los oficiales como les toca, con el número de 
soldados que les parece en ronda y contraronda. // Anónimo, Diálogo fábrica de navíos, ca. 1631, fol. 30r: Que los marineros hagan sus guardias con vigilancia, haziendo que belen todos lo que les tocare el quarto, repartiéndose por popa y proa. // Anónimo, Diálogo fábrica de navíos, ca. 1631, fol. 30r: De noche velará el uno en un quarto y el otro en el otro.

SIN.: vela 2 , vigilia.

cubierto, V. estrada $\sim$.

cuento, cuento, qüento [del lat. cŏntus 'pértiga (de barquero, etc.)', 'fuste de lanza, de pica, etc.', y éste del gr. xovtós 'íd.'. Cuento 'bastón', 'vara de la lanza', ant., 'regatón, pieza de metal que se pone en el extremo inferior de las lanzas, bastones, etc.'. Berceo, S. Or. ('báculo'); 1328-35, Conde Luc. ('fuste de lanza'); 1599, Guzmán de Alfarache ('regatón de lanza') (DECH). Mendoça, Theórica y práctica, 1596]. sust. Fort. Puntal o madero con el que se sostiene momentáneamente una fortificación para que, una vez quemado y al haber socavado previamente el muro, éste se desplome. Mendoça, Theórica y práctica, 1596, pág. 106: Otras vezes se les ponen cuentos [a las murallas], socavando después los cimientos, y quando se vee que solos ellos sustentan la muralla se untan con sebo y brea para que quemen mejor, poniéndoles cerca pólvora, cantidad de paja y leña a que se da fuego en tiempo que está la gente presta para arremeter como cayga la muralla. // Mendoça, Theórica y práctica, 1596, pág. 129-130: Por el mismo respeto, quando se teme que la batería de algún edificio o torre haga grande ruyna sobre el fosso, dando comodidad al enemigo para valerse d'ella, se buela con pólvora o se le ponen cuentos, socavando los cimientos a la parte donde quieren que cayga, cosa que se efectúa con facilidad pegando fuego a los maderos.

ENCICL.: En el intento de asaltar una fortaleza, los sitiadores solían llevar consigo este tipo de cuentos al tratarse de la pieza más importante de uno de los sistemas más conocidos y practicados para abrir brecha, especialmente en la época en la que aún no se había aplicado la pólvora a las minas. De ahí que Rubió y Bellvé (1895-1901) afirme lo siguiente: "En la poliorcética antigua se empleaba [el cuento] como medio de aportillar las murallas, a cuyo efecto, después de disponerlos bajo el conveniente lienzo de las mismas, se daba fuego a los puntales, con el fin de que, a falta de apoyo, la fábrica se derrumbase".

cuerbo, V. cuervo.

cuerno, cuerno, qüerno [del lat. cŏrnu 'íd.'. 945, Oelschl.; Berceo (DECH). Micón, Diario grande cometa, 1578]. sust. Mil. En cualquier orden de batalla, cada uno de sus dos lados o partes extremas. 5 (fig. 52)

García de Palacio, Diálogos militares, 1583, fol. 171v: Y ésta es aún muy más apta a llevar entre los cuernos el carruaje o artillería y a pelear aventajadamente con los cuernos, 
guarnesciéndolos de los soldados escogidos, fuertes, animosos, diestros y bien armados, poniendo los no tales ni tan buenos en el esquadrón quadrado de suelo, que está en medio. // Álaba, Perfeto capitán, 1590, fol. 133v: Para esto también aconseja Vegecio que con el cuerno diestro del esquadrón se acometa al siniestro del enemigo y que el siniestro se aparte tanto del diestro del contrario que su arcabuzería no le pueda dañar $\mathrm{y}$, mientras el diestro haze su efeto, el otro cerque los enemigos y los rompa y desbarate por el lado. // Roxas, Sumario milicia, 1607, fol. 37r-37v: Y los que se avían de poner en el cuerno derecho y en el yzquierdo, y quál en medio, esto se haçía en dos maneras, porque hera costumbre ponerlos según sus méritos o según la calidad de sus enemigos.

SIN.: ala, costado 1 .

FAM.: corneta.

ENCICL.: DRAE: Ala de un ejército o de una escuadra. // Mendoça, Theórica y práctica (1596: pág. 165-166): "Advirtiendo que, siendo gruessa la armada y, por el consiguiente, grande la frente que ha de hazer para ponerse en batalla, es necessario, estando en medio la capitana, repartir los personajes que llevan los navíos más gruessos por toda la batalla y frente, guarneciendo el cuerno de barloviento con los más crecidos y reforçados, para que amparen a los navíos de menos fuerça que han de quedar a sotaviento en el cuerno contrario y puedan con esto animar a los demás y guiallos al envestir, pues la capitana, por la mucha distancia que es fuerça que ocupe una gruessa armada, no podría atender en aquel tiempo a todo con la presteza que se requiere". // Rubió y Bellvé (1895-1901): Antiguamente lo mismo que ala, costado o costanera de una tropa [...]. El cuerno derecho, equivalente a la vanguardia en marcha, era situación de honor para una tropa, y lo ocupaba el cuerpo o nación que disfrutaba del derecho de precedencia sobre los demás que con él se encontraban.

cuerpo, cuerpo, qüerpo [del lat. cŏrpus, -pŏris 'íd.'. 2. ${ }^{a}$ mitad del s. X, Glosas de Silos (DECH). Montes, Instrucción y regimiento, 1537]. sust. Colectividad a la que se supone dotada de personalidad (DUE).

Montes, Instrucción y regimiento, 1537, fol. XVIv: Y la gente más usada en la guerra affruente primero en lo más flaco de los enemigos, porque, después de rotos los más flacos, con menos trabajo romperán a los pláticos, porque con todo el cuerpo del exército darán en los pláticos y, assí, con poco trabajo los romperán y alcançarán la vitoria. // Álaba, Perfeto capitán, 1590, fol. 28r: Y assí, todas las naciones que más han florecido en el govierno y trato de la milicia, han puesto cierto límite a la junta de la gente de guerra, no dando lugar a que el cuerpo que de toda ella se huviesse de hazer passe de cierto número señalado, el qual, aunque entre tanta variedad de provincias, casi fue uno, pues nunca passó de seis a ocho mil hombres. // Mendoça, Theórica y práctica, 1596, pág. 117: Estas mangas de arcabuzería o mosquetes, aunque es costumbre hazerlas de trecientos soldados, tengo por mejor dividirlas en menores cuerpos porque siempre, si la ocasión pide unirse en uno, se puede hazer con facilidad. 
ENCICL.: DEA: Colectividad. Con compl especificador. // DRAE: Conjunto de personas que forman un pueblo, una república, una comunidad o una asociación.

$\sim$ de guarda, o de la guarda [Montes, Instrucción y regimiento, 1537]. cmpt. sintag. Mil. Conjunto de soldados o gente armada que defiende o vigila un puesto (DUE: s.v. guardia).

Montes, Instrucción y regimiento, 1537, fol. XVIIv: Ha de estar muy desvelado en la guarda, porque si viniessen enemigos los sientan antes que lleguen al muro, y en sintiendo, dé aviso al cuerpo de la guarda.

SIN.: cuerpo de guardia, guardia.

$\sim$ de guarda, o $\sim$ de la guarda2 [Montes, Instrucción y regimiento, 1537]. cmpt. sintag. Mil. Lugar, paraje o edificio donde los soldados hacen guardia.

Montes, Instrucción y regimiento, 1537, fol. XVIIv: Y, para la guarda d'ella, deven poner en la plaça principal de la ciudad el cuerpo de la guarda, y el sargento ponga a la primera sus guardas: si fuere en invierno, haga la primera seys horas y la segunda guarda deve hazer cinco horas, y la diana haga el resto, que son tres horas hasta el día. // Ferrofino, Descrizión Artillería, 1599, fol. 171r-171v: La puerta del cuerpo de guarda a de tener 13 pies de ancho. // Ferrofino, Descrizión Artillería, 1599, fol. 171v: El cuerpo de guarda ha de tener de ancho 40 pies y de largo 80 pies.

SIN.: cuerpo de guardia.

de guardia [Escalante, Discurso de la navegación, 1577]. cmpt. sintag. Mil. Conjunto de soldados o gente armada que defiende o vigila un puesto (DUE: s.v. guardia).

Escalante, Discurso de la navegación, 1577, fol. 85v: En todos los baluartes en que ay sus garitas, assisten de noche centinelas que las remudan por sus quartos del cuerpo de guardia que es ordinario, andando siempre los oficiales como les toca, con el número de soldados que les parece en ronda y contraronda. // Mendoça, Theórica y práctica, 1596, pág. 82-83: Si ay valles y bosques por donde puedan venir los enemigos a cortallos, se pongan más centinelas para descubrillo, de suerte que el cuerpo de guardia los pueda ver, que ha de avisar de ordinario a Vuestra Alteza la gente que descubren las centinelas, que sea poca o mucha. // Ufano, Tratado de la Artillería, 1613, pág. 372: La bala que se muestra en la figura con la letra $C$ es muy dañosa a dondequiera que con ella se tira, porque si acierta a caer sobre algún cuerpo de guardia o junta de gente, mata y hiere a muchos enemigos, si con tiempo de su daño no se retiran o quiebran y echan tendidos en tierra.

SIN.: cuerpo de (la) guarda, guardia 3 . 
$\sim$ de guardia2 [Álaba, Perfeto capitán, 1590]. cmpt. sintag. Mil. Lugar, paraje o edificio donde los soldados hacen guardia. 5 (fig. 53)

Álaba, Perfeto capitán, 1590, fol. 50r: Está, fuera d'esto, obligado el sargento mayor a hazer reparar las puertas, cavalleros, garitas y otros lugares amparados en que a de aver gente, proveyendo que de noche aya bastante luz en los cuerpos de guardia y para las rondas. // González de Medina, Examen fortificación, 1599, pág. 47: El cuerpo de guardia ha de ser a la mesma puerta principal, porque es bien que donde está el peligro esté la defensa. Ha de tener ochenta pies de largo, paralelo con la cortina, y quarenta de ancho al centro, que será capaz de la gente que fuere menester meter de guardia. // Lechuga, Discurso de la Artillería, 1611, pág. 242: Que los cuerpos de guardia se hagan uno en cada baluarte, al pie del terrapleno, en la parte que se junta la cortina con la del través.

SIN.: cuerpo de (la) guarda2.

ENCICL.: Sanz (1749): Es un puesto alguna vez cubierto y otras descubierto, destinado para poner en él gente de guerra, que de tiempo en tiempo se relevan por otros para estar con vigilancia en la conservación de algún puesto importante.

$\sim$ de batalla, o de la batalla [Montes, Instrucción y regimiento, 1537]. cmpt. sintag. Mil. Aquella parte del ejército ordenado que está en medio de él, o entre la vanguardia y retaguardia (Terr.: s.v. cuerpo de batalla).

Montes, Instrucción y regimiento, 1537, fol. Xr: Quando el exército començare a marchar la buelta adonde están los enemigos, han de echar de banguardia la gente más plática en la guerra y, tras aquélla, vaya el cuerpo de la batalla, y luego la artillería, y de retaguardia vaya la gente que no es tan plática. // Montes, Instrucción y regimiento, 1537, fol. XVr: Y alcançó el Rey la vitoria porque el Crity, que era general de venecianos, no affrontó a los principios $\mathrm{y}$, quando quiso affrontar con su gente, no pudo porque ya era rota la vanguarda de venecianos y el cuerpo de la batalla, y preso Bartolomé Dalbiano; y éstos perdiéronse aquel día por la mala orden de su general. // Lobato, Notas, a. 1585, pág. 4: Y aquese buen rey Alonso, / ése lleva la vanguardia. / Acompáñale Toledo, / Madrid y Guadalajara, / con Soria, Atienza y Molina / y muchos pueblos de España. / Y aquese buen rey don Pedro, / que en Aragón reinaba, / con los nobles de su reino / llevaba la retaguardia. / Y aquese don Sancho el Fuerte, / que era rey de Navarra, / éste llevaba consigo / a Medina, Segovia y Ávila, / con las gentes de sus pueblos, / que era el cuerpo de batalla.

SIN.: batalla 4 .

cuervo, cuerbo, cuervo [del lat. cŏrous 'íd.'. 1075, como nombre de persona; 132835, Conde Luc. (DECH). Loçano, Alberto, Architectura, 1582]. sust. Fort. ant. Garfio de hierro afianzado en la punta de un gran mástil que, suspendido en un fuerte armazón, servía para combatir el muro agarrando y trastornando los sillares del coronamiento (Zerolo 1895). 
Loçano, Alberto, Architectura, 1582, pág. 366: Cuervo, instrumento de guerra antiguo. // Collado, Plática Artillería, 1592, fol. 5r: Muchas otras differencias de máquinas murales podría yo, Real Magestad, representar en este tratado, si no me opprimiesse el temor de ser prolixo, las quales son las vineas, los compagos, los cuervos, las sanbucas, y otras muchas. // Juanelo Turriano, Veinte y un libros, a. 1605, fol. 439v: Acostumbravan los antigos usar unas máchinas, que las llamavan cuervos, que servían para guerra.

ENCICL.: Terr.: Máquina antigua de guerra, de que hubo varias especies. // Moretti (1828): Había diferentes clases de cuervos que se distinguían con los nombres siguientes: cuervo de asas, de cajón, delfín, demoledor, doble, de garfios, de hoz y de tenaza. / / Uno de esos tipos sería el que se encuentra en nuestro corpus y del que Almirante (1869) dice: "Variedad del ariete, con cabeza puntiaguda en vez de ser chata o de carnero".

cúneo, cúneo [tomado del lat. cŭněus 'cuña'. Duplicado culto de cuño (DECH). Álaba, Perfeto capitán, 1590]. sust. Mil. Orden triangular de batalla en forma de un cono truncado que termina en punta por el frente y se ensancha hacia la base (Moretti 1828). \& (fig. 54)

Álaba, Perfeto capitán, 1590, fol. 117v: Otro modo de cúneo usavan los antiguos, que, aunque procedía por el número binario, no començava de la unidad, sino del número dos, de suerte que en la primera hilera avía dos, en la segunda quatro, en la tercera seys, y assí consiguientemente en las demás yva creciendo el número de dos en dos. // Álaba, Perfeto capitán, 1590, fol. 119r: Los tesalos fueron los primeros que usaron una forma de esquadrón llamada rombo, el qual es una figura de quatro lados yguales que, caminando con uno de los ángulos, no guarda la razón de quadrado, aunque los lados los tiene como él, antes está hecho de dos cúneos, ambos sobre un mesmo basis y con las puntas opuestas, como se verá en la figura que se sigue. // Álaba, Perfeto capitán, 1590, fol. 121r: Y queriendo hazer un esquadrón en la primer forma, que es haziendo solos los dientes de la sierra, partiré el número que me dieren en tantas partes quantos dientes quiero que lleve el esquadrón, y de cada parte de aquéllas haré un cúneo, pues cada diente de la sierra no tiene otra forma que ésta.

SIN.: cuño, diente 2 .

FAM.: cuño.

ENCICL.: Cov. (s.v. cuña): Cúneos en la milicia son cierta forma de escuadrones que empiezan en punta y se van extendiendo a manera de cuños. // Moretti (1828): Le usaron mucho los griegos y romanos para romper la línea enemiga; y generalmente le formaban con las tropas de reserva. Al cúneo se le oponía el orden de tenaza. // Almirante (1869: s.v. cúneo o cuña): Formación táctica conocida y practicada desde la más remota antigüedad especialmente por ejércitos audaces. Se reducía a formar un triángulo, próximamente equilátero, en cuyo vértice y lados adyacentes avanzaban los hombres de más empuje [...]. La oportunidad de su empleo, como del de otra maniobra u orden táctico, depende de la ocasión y del acierto en la comparación de las fuerzas propias con las enemigas, tanto en número como en calidad. A la cuña se opone, como formación envolvente y obligada, la tenaza, 
esto es el ángulo abierto con el vértice hacia dentro, para esquivar el golpe del saliente de la cuña, y tomar por la espalda la base o centro de ésta, donde naturalmente se agrupa la gente más floja.

cunículo, cunículo [tomado del lat. cŭnīcŭlus, - $\bar{\imath}$ 'conejo', 'galería subterránea, mina; trabajo de zapa [en la guerra]', 'conducto subterráneo' (Segura Munguía 2001). Collado, Plática Artillería, 1592]. sust. Fort. Pasaje subterráneo en el que se ponen, al fin de él, materiales incendiarios o explosivos, para que dándoles fuego arruinen las fortificaciones o defensas del enemigo.

Collado, Plática Artillería, 1592, fol. 62r: Mas se sabe de cierto qu'el conde dicho fue el primero que halló el modo de aplicar la pólvora y el fuego a las minas para bolar las fortalezas y grosíssimos torreones con ellas, lo que no se hazía con las minas antiguas, las quales solamente servían para entrar por debaxo de las murallas a offender y conquistar las tierras enemigas, por lo qual los antiguos llamaron cunículos a los tales cavamientos, que quiere dezir 'conejeras', por quanto, en la misma manera, cavando y escarvando, el conejo penetra y camina por debaxo de tierra un grande espacio. / / Roxas, Sumario milicia, 1607, fol. 46r-46v: Otro género ay de ofender, y batería, que se haçe por debaxo de tierra, qu'es la que llaman mina o cunículo, que quiere dezir conegera.

SIN.: $\operatorname{mina}_{1}$.

ANT.: contramina.

ENCICL.: Nebr. (1495: s.v. mina): Soterraña cueva. Cuniculus.i. // Almirante (1869): Cuniculus en latín. Mina de guerra antigua; en general todo paso subterráneo abierto por soldados en trabajos de fortificación y ataque. Plinio (lib. 8 cap. 55) hace el honor a las islas Baleares de gran abundancia de conejos; y de los trabajos subterráneos de este animal, vino, según dicen, a la milicia romana esta voz técnica de poliorcética. // Zerolo (1895): Mina de guerra antigua, trabajo subterráneo. // Estévanez (1897): Mina de guerra llamada así por los romanos.

cuñ̃o, cuño [del lat. cŭnĕus 'cuña'. Cuño 'cuña, sólido terminado en ángulo agudo, para hender o para rellenar un hueco', ant., 'troquel con que se sellan las monedas y medallas', así llamado por el punzón que antiguamente se empleaba para amonedar. 1. ${ }^{a}$ ac., Berceo; 2. ${ }^{a}$ ac., Nebr. (DECH). Rojas, Teórica fortificación, 1598]. sust. Mil. Orden triangular de batalla en forma de un cono truncado que termina en punta por el frente y se ensancha hacia la base (Moretti 1828: s.v. cúneo).

s (fig. 55)

Rojas, Teórica fortificación, 1598, fol. 101v: Se ha de tener gente demasiada fuera del esquadrón, de la qual podamos hazer un pequeño cuño o tixera. // Roxas, Sumario milicia, 1607, fol. 38v: Cuño es un esquadrón en esta forma ??, y la tijera es ansí $>$, la qual reçive dentro de sí d'esta manera ??>. 
SIN.: cúneo, diente 2.

FAM.: cúneo.

ENCICL.: Moretti (1828): ant. Lo mismo que cúneo. (Véase.). 


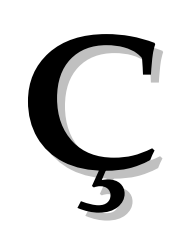

çanja, V. zanja.

çapa, V. zapa.

çapar, V. zapar.

çarço, V. zarzo.

çarzo, V. zarzo.

çeñir, V. ceñir.

çerca, V. cerca.

çercado, V. cercado. 
çercar, V. cercar.

çerco, V. cerco.

çésped, V. césped.

çesta, V. cesta.

çesto, V. cesto.

çestón, V. cestón.

çitadela, V. ciudadela. 
dar, V. a saco.

dar, V. (el) asalto.

dar, V. (la) batería.

dar, V. bordos.

dar, V. bordos y ramos.

dar, V. el salto.

dar, V. rebato.

debate, debate [de debatir y éste del lat. debattŭō, - -̌re, 'batir, golpear, sacudir', de de y battǔō. 1392 (Segura Munguía 2007). Álaba, Perfeto capitán, 1590]. sust. Mil. Acción bélica en la que se enfrentan soldados o formaciones militares enemigas. 
Álaba, Perfeto capitán, 1590, fol. 23r: Y, assí, consta de las historias antiguas aver sujetado en tiempos passados muchas naciones, ajenos imperios y señoríos, más por el favor de la fortuna que por el del escudo y lança, de donde nació lo que Cesar dezía ser necessaria la buena ventura en todas las cosas y en ninguna más que en las ocasiones de rencuentros y debates de enemigos. // Álaba, Perfeto capitán, 1590, fol. 42r: Será de importancia que las personas a quien se huviere de dar cargo de allanar el campo sean de los estradiotes y arcabuzeros de a cavallo y que después d'ellos vaya algún número de cavallos ligeros que les hagan espaldas y socorran en los peligros y debates que se les ofrecieren. // Álaba, Perfeto capitán, 1590, fol. 70v: Lo qual se a de entender en caso que el hazer esto no es necessario, o porque dexándose de hazer no se sigue algún daño conocido o, venciendo, no se acaban del todo las contiendas y debates de los contrarios.

SIN.: batalla $a_{1}$ combate ${ }_{1}$, combatimiento ${ }_{1}$, contienda $a_{2}$ facienda, lid, pelea.

ENCICL.: DRAE: Contienda, lucha, combate.

decercar, V. descercar.

defença, $V$. defensa.

defender, defender, deffender [tomado del lat. defëndĕre 'alejar, rechazar (a un enemigo)', 'defender, proteger'. 1155, Fuero de Avilés; ya frecuente en Berceo, Alex., etc. (DECH). Sagredo, Medidas Romano, 1526]. v. tr. Proporcionar una cosa protección a otra frente a cualquier tipo de peligro o daño.

González de Medina, Examen fortificación, 1599, pág. 47: La puerta principal, que ha de ser, como se ha dicho, de medio a medio la cortina, porque la defienden las dos casas matas de ambos baluartes que la tienen en medio, tendrá diez pies ancho, que cabe qualquier carro cargado, y treze y medio de alto, que es su buena proporción. // González de Medina, Examen fortificación, 1599, pág. 173: Si se quisiere reparar un lugar que tenga agua en el foso y que no tenga traveses, será bueno hazerle rebellines, y a la muralla unos traveses que defiendan la frente de los rebellines, como lo muestran los traveses A de la cortina, que limpian las frentes del rebellín B. // Ufano, Tratado de la Artillería, 1613, pág. 160-161: Como sea qualquier fuerte, es mucho mejor y más seguro batirle por el baluarte o caballero que no por la cortina, por occasión de que las cortinas de un fuerte son muy cortas y las cubren y deffienden mucho sus baluartes.

SIN.: guardar 1 .

FAM.: defendible, defendido, defendimiento.

ENCICL.: DUE: Servir para que no pueda causar daño o llegar a cierta cosa otra perjudicial o dañosa; por ejemplo, cubriéndola o estando delante de ella. // Moretti (1828): Se usa en la fortificación hablando de las obras flanqueantes. El flanco defiende la cortina y la cara 
opuesta del baluarte; la media luna defiende la obra coronada; el camino cubierto defiende los aproches del glacis, etc.

2 [Celso, Reportorio universal leyes Castilla, 1553]. v. tr. Mil. Luchar contra los que atacan alguna cosa o a alguien.

Celso, Reportorio universal leyes Castilla, 1553, fol. CLVIIIv: Ansimesmo, ay otra especie de guerra que dizen de appellido, que quiere tanto dezir como boz de llamamiento que hazen algunos para juntarse y defender lo suyo quando reciben fuerça o daño. // García de Palacio, Diálogos militares, 1583, fol. 12v: D'estas guerras defensivas ay en la Scriptura Sancta muchos exemplos, por los quales se declara su justicia: Débora, prophetiza, y Barac, defendiendo al pueblo de Isrrael, pelearon contra Sifara, general de Jabín, rey de Chanaán; [...]. // Mosquera, Comentario disciplina militar, 1596, fol. 29r: La gente portuguesa no se sabe cómo está repartida para acudir a defender estos desembarcaderos donde están estas compañías de franceses, ni en la orden que está la demás de a pie y de a cavallo, fuera de las treynta y siete compañías arriba dichas.

ANT.: acometer, atacar, combatir ${ }_{3}$, embestir ${ }_{2}$, ofender.

ENCICL.: DUE: tr. Luchar alguien contra los que atacan cierta cosa: 'Los soldados defendieron la posición. Le quería pegar otro chico y yo le defendí'.

3 [Montes, Instrucción y regimiento, 1537]. v. tr. Fort. Aplicado a un lugar fortificado: conservarlo, luchar contra los que se empeñan en apoderarse de él.

Montes, Instrucción y regimiento, 1537, fol. XVIIIr: Los castillos y fortalezas que ganaren, los que conosciere que se pueden defender, dévelos fortalecer, y los que no se pudieren defender, dévelos derrivar, porque no pongan en gasto al señor del exército. // Celso, Reportorio universal leyes Castilla, 1553, fol. LIXv: Si el castillo fuesse cercado de sus enemigos, deve el alcayde, con buen esfuerço, animar la gente del castillo, demostrándoles que, pues no deven dar el castillo a ninguno, salvo a su señor, que le deven defender $\mathrm{y}$, si fuere menester, morir con lealtad. // Collado, Plática Artillería, 1592, fol. 96v: Es tan cierto, señor theniente, lo que vuestra merced dize y lo que acerca de esse particular siempre he notado, que jamás he visto fortaleza, por muy fuerte que ella fuesse y bien munida de todo lo necessario a defenderla, que, a largo andar, no se pierdesse, no pudiéndole dar socorro.

SIN.: guardar 3 .

ENCICL.: DUE: Luchar alguien para impedir que le sea arrebatada una cosa. // Cov.: Defender la fortaleza, no rendirse a los que la tienen cercada. / Domínguez (1853): Hacer fortificaciones en una plaza; sostenerla impidiendo la entrada del enemigo en ella. // Moretti (1828: s.v. defender una plaza): Dícese cuando se hacen esfuerzos para resistir a un enemigo que intenta apoderarse de aquélla; siguiéndose de aquí las expresiones defender bien o mal una plaza, un fuerte, etc. cuando se han empleado todos los medios posibles de resistencia, o cuando ha habido descuidos o faltas en su defensa. 
4 [Montes, Instrucción y regimiento, 1537]. v. tr. Mil. Colocar tropas o hacer otra cosa para que una posición no pueda ser tomada por el enemigo (DUE).

Montes, Instrucción y regimiento, 1537, fol. VIIIr: E todos juntos dimos con las proas en tierra, por echar la gente toda de un golpe en tierra, y esto era en anochesciendo; y aunque los moros defendían la salida, los nuestros tomaron tierra. // Escalante, Discurso de la navegación, 1577, fol. 23v: Siendo informado el rei don Manuel por don Vasco de Gama de todo lo que le avía sucedido en su viaje, determinó de tornar a embiar a la India treze navíos con gente muy luzida y bien en orden, por si acaso, quando llegassen, el Rei de Calicut y los demás señores de aquella tierra les defendiessen sus puertos, y para mostrar su poder. // Mosquera, Comentario disciplina militar, 1596, fol. 50r: Y nos devemos persuadir que todo lo que se puede considerar lo tienen considerado y prevenido, poniendo toda su diligencia y cuydado en defender la entrada y oviar que ninguno de los nuestros pueda poner pie en su tierra.

5 [Fernández de Enciso, Suma de Geographía, 1530]. v. prnl. Mil. Luchar alguien contra el que le ataca (DUE).

Fernández de Enciso, Suma de Geographía, 1530, fol. XXVIIIv: Estas gentes tuvieron en tiempos passados un duque que presidía en ellos e con aquél se defendieron del Imperio Romano, que nunca las pudo ganar, aunque muchas vezes ganó a la Galia fasta al río Regno. // Celso, Reportorio universal leyes Castilla, 1553, fol. XCIIIr: Según diximos en el versículo I, el que vee venir a otro con armas para matarle, no deve esperar que le dé el otro el primer golpe; antes puede, con armas e aun con junta de gente, defenderse e matar sin pena a los que viniessen para offenderle, o sus bienes. // García de Palacio, Diálogos militares, 1583, fol. 12r-12v: Pero, porque vemos que ay dos maneras de guerras, unas en las quales el príncipe acometido no haze más que defenderse en la mejor forma que puede, otras en que acomete y offende, levantando sus gentes y entrando por las tierras de su contrario, pregunto si lo que vuestra merced dize es assí en entrambas maneras de guerra, porque paresce estar la justicia más clara quando alguno se defiende, que no quando offende.

ENCICL.: Zerolo (1895: s.v. defenderse): Hacer frente a los ataques de alguien.

defendible, defendible [de defender (DECH). González de Medina, Examen fortificación, 1599]. adj. Dicho de una cosa: que se puede defender o proteger frente a cualquier tipo de peligro o daño.

González de Medina, Examen fortificación, 1599, pág. 151: Los torreones redondos, algunos sacaría en ángulo y haría d'ellos baluartes con sus casas matas y orejones, los más perfectos que pudiesse, a buena y defendible distancia.

FAM.: defender, defendido, defendimiento. 
defendido, defendido [de defender. Celso, Reportorio universal leyes Castilla, 1553]. adj. Dicho de una cosa o de un lugar: protegido con algo frente a cualquier peligro o daño.

Celso, Reportorio universal leyes Castilla, 1553, fol. LIIr: Los caminantes pueden meter sus bestias e ganados en los lugares que no son cercados ni defendidos para pacer e descargar. // Alonso Barba, Arte de los metales, 1640, fol. 17r: Es, por naturaleza, el más defendido lugar que se conoce en el mundo; es muy eminente y tiene siete leguas de circuito, cercadas todas de altíssimas y inacessibles peñas; por una parte sola ay una pequeña entrada después de muy dificultosa subida.

SIN.: guardado $0_{1}$

FAM.: defender, defendible, defendimiento.

2 [Álaba, Perfeto capitán, 1590]. adj. Mil. Dicho de una posición: protegida por tropas o por medios semejantes para que no pueda ser tomada por el enemigo.

Álaba, Perfeto capitán, 1590, fol. 45v: Usará la cautela de que usó Filipo, rey de Macedonia, que, teniéndole defendidos los atenienses ciertos estrechos por donde le era forçoso passar su armada, para assegurarlos, escrivió a su capitán, Antípatro, que con la gente de más importancia que en su compañía estava le siguiesse luego porque yva a sossegar a Tracia, que se avía rebelado; y dando orden que estas cartas viniessen a mano de los atenienses, creyendo ser assí lo que en ellas venía, retiraron su flota y Filipo, assegurando el passo con tan ingeniosa cautela, passó su armada sin impedimento alguno. // Álaba, Perfeto capitán, 1590, fol. 45v: Y si fuere algún vado el que hallare impedido, divertirá los enemigos como hizo en los estrechos de la tierra, pues lo podrá hazer con más facilidad, por no aver montes o collados y otros lugares defendidos que le puedan estorvar.

defendimiento, defendimiento [de defender (DECH). Celso, Reportorio universal leyes Castilla, 1553]. sust. Acción de proteger frente a un peligro o frente a un daño.

Celso, Reportorio universal leyes Castilla, 1553, fol. LXXXVIv: Y, quanto más cerca de la persona del Rey o de su Corte fuessen cometidos los tales yerros, tanto más gravemente deven ser castigados, salvo si el tal muerto, o herido, o injuriado, de antes, fuesse dado por juyzio por enemigo del que lo matare, o hiriere, o injuriare, o si lo hiziere por mandado del Rey o en defendimiento de su persona. // Celso, Reportorio universal leyes Castilla, 1553, fol. CLIXr: Y si le deshonrare de hecho o de dicho, ha de aver doblada pena que si lo hoviesse hecho en otro lugar que no fuesse Corte del Rey; y si le diere heridas, deve perder el miembro con que le hirió; y si moriere de las heridas, dévenle soterrar so el muerto. Esto se entiende si no hiziesse alguna de las dichas cosas en su defendimiento. // Celso, Reportorio universal leyes Castilla, 1553, fol. CCCXXXVIIv: Yantares deve aver el Rey quando por su persona llegare a qualquier ciudad o villa de sus reynos, o quando fuere en exército, o estuviere en cerco, o quando passare el puerto para yr a la frontera en servicio de Dios, y en defendimiento de la sancta fe y de la tierra. 
SIN.: defensa $a_{1}$, defensión 1 .

FAM.: defender, defendible, defendido.

defensa, defença, defensa, defenssa, deffensa [tomado del lat. tardío defensa. APal.; Ambrosio de Morales; Oudin, 1607 (DECH). Montes, Instrucción y regimiento, 1537]. sust. Acción de proteger frente a un peligro o frente a un daño.

García de Palacio, Instrución náuthica, 1587, fol. 122v: Y con esto se guarnescerán y fajarán las gavias con algunos colchones, para defensa de los tiros y arcabuçazos. // Álaba, Perfeto capitán, 1590, fol. 128v: En la sexta y última orden estavan soldados más valientes que los d'estas órdenes postreras, con escudos de quatro pies de largo y dos y medio de ancho, con dos cercos de hierro, uno por encima para mejor defensa de los golpes y otro por debaxo para que, afirmado en tierra, no entrasse en ella con tanta facilidad. / / Rojas, Teórica fortificación, 1598, fol. 37r: Y assí, con la espalda de tierra y fagina que digo se remedia la defensa de los soldados, porque, quando bata el artillería el parapeto, se pondrán los soldados detrás de la espalda de tierra, todo lo qual se entenderá adelante en su lugar.

SIN.: defendimiento, defensión 1 .

FAM.: defensible, defensivo.

2 [Martínez de Burgos, Reportorio premáticas y Cortes, 1551]. sust. Mil. Acción de luchar contra los que atacan alguna cosa o a alguien.

Martínez de Burgos, Reportorio premáticas y Cortes, 1551, fol. XXXIIIv-XXXIVr: Y nos plaze de convertir y gastar el dicho servicio (que estos nuestros reynos nos hazen) solamente en la guarda y defensa d'ellos y resistencia de los enemigos, si contra ellos vinieren, y no en otra necessidad particular nuestra ni de ninguno de los otros nuestros reynos y servicios. // García de Palacio, Diálogos militares, 1583, fol. 12v-13r: Los machabeos, por defensa de la tierra de Judea, pelearon muchas vezes con los exércitos del rey Antíocho, los quales el excelente capitán Judas Machabeo deshizo muchas vezes. // García de Céspedes, Instrumentos nuevos, 1606, fol. 63r: Quándo conviene hazer esquadrón quadrado de terreno, o quadrado de gente, esto queda a la eleción del Maestro de Campo o Sargento Mayor, porque según el sitio donde se huviere de formar el esquadrón, se tiene de elegir la forma que más conviene a la defensa del enemigo, y en esto no se puede dar regla.

ANT.: acometida, acometimiento, combate 2, combatimiento 2 , ofensa, ofensiva.

ENCICL.: Moretti (1828): La acción de resistir una guarnición o un cuerpo de tropas los ataques del enemigo: la defensa está sujeta a reglas generales y particulares. // Terr.: Acción de defenderse o resistir a la violencia con que acometen a alguno. 
3 [Montes, Instrucción y regimiento, 1537]. sust. Fort. Acción de luchar contra los que quieren apoderarse de un lugar fortificado.

Montes, Instrucción y regimiento, 1537, fol. VIr: E por esto es razón que los generales provean los castillos y fortalezas que ganaren de todos los materiales que son menester para la defensa de las fortalezas y castillos, porque el día de la batalla no les falte ninguna cosa. // Mendoça, Theórica y práctica, 1596, pág. 125: El capitán o cabeça a quien Vuestra Alteza encargare la guardia o defensa de alguna plaça ha de ser esforçado, prudente y soldado de esperiencia, y no aviendo estado sitiado, convendrá que se hallen con él cabos o particulares soldados que lo ayan sido. // González de Medina, Examen fortificación, 1599, pág. 158: ¿Qué os parece que haríamos para enmendar la tacha del ser tan larga la cortina y del edificio del arrabal, pues es tan necessario para defensa de qualquier fortificación no tener cosa delante en que se le pueda encubrir el enemigo y llegársele sin que le vea?

SIN.: defensión.

ENCICL.: Hevia (1857): La resistencia que una guarnición hace a los ataques del sitiador.

4 [Montes, Instrucción y regimiento, 1537]. sust. Mil. Colocación de tropas o realización de otro tipo de maniobras con el fin de impedir que el enemigo tome una posición.

Montes, Instrucción y regimiento, 1537, fol. XVIIv: Y porná el capitán en cada puerta de la ciudad una esquadra de gente a la misma puerta, en cada parte de la suya, en una cabeça que la rija, que guarden la defensa de la puerta, y porque, si algunos de los de dentro quisieren abrir a los enemigos con algún sutil ingenio, no se dé lugar a su trayción. // Âlaba, Perfeto capitán, 1590, fol. 47v-48r: Por la parte de afuera, siendo necessario, le hazían un foso de quatro codos en ancho y hondo, fortificando el alojamiento con gente armada, repartida por diversas partes d'él, teniendo cuydado de que una compañía assistiesse a la defensa y guarda de cada una de las puertas aviendo necessidad d'ello, repartiendo esta assistencia por todas las compañías, dando a cada una quatro horas, poniendo de noche en los castillos gente que velasse y estuviesse a la mira de lo que quería hazer el enemigo y repartiendo guardas que rondassen el real para prevenir a las trayciones o descuydos que podían suceder. / / Ufano, Tratado de la Artillería, 1613, pág. 362-363: Y para tal effeto, entre la dicha manta y su exe se deven engastar terciadamente, por lo menos, una dozena de picas, según y conforme que fueren menester para la deffensa y custodia de tales avenidas y caminos de los reynos, estados y provincias, así que tales mantas deven en todo y por todo hazerse como su figura muestra.

5 [Montes, Instrucción y regimiento, 1537]. sust. u. m. en pl. Fort. Cualquier construcción que sirve para proteger un lugar o una posición de un ataque.

Montes, Instrucción y regimiento, 1537, fol. XVIIr-XVIIv: Y por lo alto tenga el muro sus defensas y andamios, con sus troneras, para que los arcabuzeros puedan tirar a los de fuera. // Mendoça, Theórica y práctica, 1596, pág. 94: Y en algunas partes se plantan pieças a corueña rasa, sin cestones ni trincheas, por no tener defensas la tierra que se quiere 
tomar ni ser necessario hazer más diligencia que el batir puerta o abrir portillo. // Ufano, Tratado de la Artillería, 1613, pág. 10: La segunda d'estas pieças paresçe tiene mejor garbo y forma y, aunque es de las primeras, todavía se podría aplicar algún conveniente serviçio. Pero la terçera es de forma y talle tan ynútil que ni con ella se podrá quitar deffensa, ni batir muralla, ni matar por su punctería hombres ni caballos.

SIN.: defensión 3 , fortificación 3 , muralla 2 , reparo 2 .

ENCICL.: DUE: Construcción, dispositivo o cualquier objeto que sirve para defender algo. // Aut.: Se da asimismo este nombre a las fortificaciones de una plaza o fortaleza, a los fuertes, cortaduras y otros reparos, por lo que defienden y embarazan el paso al enemigo. Se usa comúnmente en plural. // Domínguez (1853): Fortificación y cualquiera de sus partes. // Corsini (1849): Fort. Nombre genérico y colectivo que se da a todas las partes que defienden una obra de fortificación. Las defensas de un baluarte son los flancos de los baluartes colaterales, las caponeras, las tenazas, etc.; las defensas de las medias lunas son las caras de los baluartes que las flanquean, etc. // Corsini (1849): Fort. Aplícase a una obra cualquiera de fortificación cuando está en estado de defenderse, por tener la guarnición que le pertenece, y las bocas de fuego, víveres y pertrechos necesarios para ello. // Borreguero Beltrán (2000: s.v. defensas): En plural, se suele llamar a las obras de fortificación y al conjunto de organizaciones defensivas destinadas a proteger una plaza.

6 [Álaba, Perfeto capitán, 1590]. sust. Mil. Grupo de personas que protege ante un ataque o peligro.

Álaba, Perfeto capitán, 1590, fol. 59r: Como lo hizieron César y Ariovisto, rey de los alemanes, que, aviendo señalado día y lugar para hablarse, concertaron que el verse fuesse trayendo cada qual hasta cierta cantidad de hombres de a cavallo sin otra defensa alguna. // González de Medina, Examen fortificación, 1599, pág. 47: El cuerpo de guardia ha de ser a la mesma puerta principal, porque es bien que donde está el peligro esté la defensa. Ha de tener ochenta pies de largo, paralelo con la cortina, y quarenta de ancho al centro, que será capaz de la gente que fuere menester meter de guardia. // González de Medina, Examen fortificación, 1599, pág. 185: Y assí me parecería que, para poder esperar tres assaltos a un punto, se pongan cinco hileras de a veynte de frente en cada uno, que son ciento, con que estarán muy bien defendidos sesenta pies con mucha orden, porque los más son confusión, que serán estas tres defensas trezientos.

estar en $\sim$ [Rojas, Teórica fortificación, 1598]. loc. v. Fort. Dicho de una fortificación: hallarse en estado de soportar cualquier acción ofensiva por parte del enemigo.

Rojas, Teórica fortificación, 1598, fol. 71r: De la forma y requisitos que deve tener una fortificación real para estar en defensa y poderse defender de un gruesso exército. // Rojas, Teórica fortificación, 1598, fol. 77v-78r: Resuelto, pues, la forma y grandeza que ha de tener la tal fortificación, se començará por la parte más flaca a fabricar, procurando que primero que se derribe ninguna muralla vieja, esté ya en defensa lo que se fabricare de nuevo. // Roxas, Sumario milicia, 1607, fol. 86v: Resuelto, pues, sobre el disigno o modelo, la forma y la grandeza que ha de tener la çiudad o castillo, comenzarse ha, con el favor y ayuda de Dios, de la parte más flaca, procurando que primero que se derribe nada de lo 
viejo esté en defensa lo que se hiziere de nuevo, haçiendo las puertas y salidas, fosos, estradas cubiertas y las demás cosas dichas.

ENCICL.: Sanz (1749: s.v. defensa, estar en defensa): Hallarse en estado de resistir. Dícese: este reducto está en defensa, han puesto este fortín en defensa, el alojamiento no está todavía en defensa. // Fernández Mancheño (1822: s.v. estar en defensa): Hallarse en estado de resistir, como las fortificaciones reparadas, etc.

poner en $\sim$ [Álaba, Perfeto capitán, 1590]. loc. v. u. t. c. prnl. Mil. Preparar algo con todo lo necesario para que resista cualquier acción ofensiva del enemigo.

Álaba, Perfeto capitán, 1590, fol. 70v-71r: Y a esta causa los capitanes [...], lo que con todas sus fuerças procuravan era acossar y descomponer sus enemigos con cautelas, assechanças $\mathrm{y}$ ardides, esperando el acometerlos en tiempo que su resistencia fuesse de muy poco efeto [...], envistiendo con ellos quando, o del largo camino sabían que estavan despeados y fatigados, de suerte que no pudiessen ponerse en defensa, o quando al passar de los vados yvan tan esparcidos que los unos no fuessen de provecho para el socorro y favor de los otros. // Rojas, Teórica fortificación, 1598, fol. 71r: Y assí, trataré aora de poner una plaça en toda defensa, considerando que siempre voy hablando de un castillo de 5 valuartes, que tenga dentro 1.000 soldados de guarnición ordinaria, y que, junto con esto, se ha de entender ser plaça capaz de otros 2.000 hombres de socorro a una grande necessidad. // González de Medina, Examen fortificación, 1599, pág. 15: La trapecia es para muchos lados desiguales, que, si no fuesse obligando el sitio o para ciudades que se quieren poner en defensa y no mudarles su forma, no es necessario hablar aquí d'ella ni de otra que de la pentágona, de que pienso aprovecharme para esta ocasión.

ENCICL.: Aut. (s.v. ponerse en defensa): Frase que explica apercibirse de armas o de otros medios para resistir y propulsar la violencia o fuerza que se intenta ejecutar, o se ha ejecutado, en la mejor forma que se puede. // Fernández Mancheño (1822: s.v. ponerse en defensa): Apercibirse con todo lo necesario para defenderse.

defensible, defensible [de defensar, con influencia de defender (DECH). González de Medina, Examen fortificación, 1599]. adj. Fort. Dicho de un lugar fortificado: que se puede defender o conservar, que es capaz de hacer frente a una invasión o ataque del enemigo.

González de Medina, Examen fortificación, 1599, pág. 153: Tengo, maestro, otra tierra con muy largas murallas y muy ruynes que toma mucho más sitio que la población es, porque se ha despoblado y caýdo las casas, de manera que están apartadas en gran manera las murallas de la población, de suerte que en muchas partes se siembra dentro de los muros. ¿Qué remedio se podría tener para fortificarla y assegurarla y poner en razón defensible?

FAM.: defensa, defensivo. 
ENCICL.: Aut. (s.v. defensable): Adj. de una term. Lo que se puede defender y es capaz de resistirse a alguna invasión o fuerza. // Hevia (1857): Se dice de la fortificación o del puerto que cuenta con recursos para resistir al enemigo.

defensibo, V. defensivo.

defensión, defensión, deffençión, deffensión [tomado del lat. cl. defensio, -onis 'defensa'. Berceo; Ordenamiento de Alcalá, 1348, en Aut.; Nebr. (DECH). Celso, Reportorio universal leyes Castilla, 1553]. sust. Acción de proteger frente a un peligro o frente a un daño.

Celso, Reportorio universal leyes Castilla, 1553, fol. XIIv: El que matare a otro a sabiendas, muera por ello, salvo si fuere en su defensión y en los casos de derecho permitidos, o si el que matare fuesse dado por su enemigo. // Celso, Reportorio universal leyes Castilla, 1553, fol. CLXVIIr: Si el hijo o criado fuere con su padre o con su señor, si él no hiriere, o hiriere y fue por él mandado del dicho su padre o señor, no será tenudo a pena; empero, si hiriere sin su mandado, tenudo será, salvo si lo hiziere en su defensión. // Ufano, Tratado de la Artillería, 1613, pág. 174: La faxina es muy utilíssima para hazer las reparaçiones y cubrimientos con ella y tierra a prueva de artillería sobre la rotura de las baterías y otras qualesquier partes que a su buena deffensión convenga.

SIN.: defendimiento, defensa ${ }_{1}$.

2 [Celso, Reportorio universal leyes Castilla, 1553]. sust. Fort. Acción de luchar contra los que quieren apoderarse de un lugar fortificado.

Celso, Reportorio universal leyes Castilla, 1553, fol. XLIVr: Ballesteros, son muy necessarios para la guarda y defensión de un castillo. // Ufano, Tratado de la Artillería, 1613, pág. 169: Y aunque en esta tratada relación quiero que sirban los cañones de batería, por ser aptos a tan preheminentes y tan fuertes plaças, el no averlos nombrado en la relación que el otro día di a Vuestra Señoría, no a sido por olvido, pero es la causa el no ser artillería a propóssito para la perfecta deffensión de una villa pequeña o fortaleza común.

SIN.: defensa $a_{3}$.

3 [Loçano, Alberto, Architectura, 1582]. sust. u. m. en pl. Fort. Cualquier construcción que sirve para proteger un lugar o una posición de un ataque.

Loçano, Alberto, Architectura, 1582, pág. 143: Los antiguos usaron poner en la proa máchinas que ellos llamavan cuernos, pero los nuestros en la proa y popa levantan torres por causa del mástil, y paños viejos y sacos y otras cosas semejantes en lugar de vallado y deffensión. // Ufano, Tratado de la Artillería, 1613, pág. 102: Y a todos los demás del traén, amonestarles que se contenten, moderándose con aquello que fuere bastante para sustento de los caballos; y de la misma manera al protestor, capitanes y sobrestantes de los gastadores [...] de que no corten y talen árboles fructales ni otros de serviçio alguno, salvo 
lo que les fuere ordenado y previnieren bien escasamente para los obrages de las deffençiones.

SIN.: defensa $a_{5}$, fortificación ${ }_{3}$, muralla $_{2}$, reparo 2 .

defensivo, defensibo, defensivo, deffensivo [de defēnsum, participio latino de dēfendĕre (cast. defender). h. 1440, A. Torre (DECH). González de Medina, Examen fortificación, 1599]. adj. Que defiende o sirve para defender o proteger.

González de Medina, Examen fortificación, 1599, pág. 144: Dezidme, maestro, este fuerte en el agua, como avéys dicho, ¿de qué forma le haríades, y con qué miembros?, pues él, de suyo, es fuerte por naturaleza, el sitio, y no será de importancia hazerle de tantos miembros, ofensivos y defensivos, como los de tierra, que por todas partes se les puede plantar artillería y batirle; y también sería bueno no hazerle tan costoso como los otros.

ANT.: ofensivo.

FAM.: defensa, defensible.

defensivo, V. guerra .

defensor, defensor, deffensor [tomado del lat. defensor, -oris. Nebr. (DECH). Celso, Reportorio universal leyes Castilla, 1553]. adj. Que defiende o protege (DRAE). Celso, Reportorio universal leyes Castilla, 1553, fol. LXIr: Deve el cavallero haver en sí cordura para que sepa guardarse a su pro e sin daño suyo; e deve haver fortaleza para que, con esfuerço e sin cansar, haga lo que es obligado; e mesura, para que haga las cosas como deve e no passe; e justicia, para que la haga derechamente. Aý, ley IV. E por esto los antiguos llamavan los cavalleros defensores de la tierra. // Loçano, Alberto, Architectura, 1582, pág. 196: A Vesta, Júpiter y Minerva, los quales Platón dezía que eran deffensores de la ciudad, los ponían en el medio del pueblo y alcázar. // García de Palacio, Diálogos militares, 1583, fol. 157v: Son puestas allí para que, viéndolas los guerreros en tan manifiesto peligro, trabajen y pugnen por defendellas y vencer a sus enemigos, que muchas vezes han sido causa de que, incitando más a los soldados a pelear, como verdaderos defensores de sus insignias y vanderas, ayan conseguido de sus enemigos victoria.

2 [Loçano, Alberto, Architectura, 1582]. sust. Fort. Persona que lucha contra los que quieren apoderarse de un lugar fortificado.

Loçano, Alberto, Architectura, 1582, pág. 129: Las estancias de las guardas y de los deffensores de la plaça se destribuyrán de suerte que unos tengan cuydado de las partes de abajo del fuerte, otros de las altas y de otras en distinctos assientos y officios. // Collado, Plática Artillería, 1592, fol. 3r: Affírmalo, assimismo, Tito Livio en el libro primero de la Guerra Cartaginense, donde dize: "Estava Aníbal deffendiendo la muralla y 
esforçando sus soldados en aquella parte, contra la qual los romanos aproximavan una torre de madera cuya alteza sobrepujava la más alta parte de la ciudad y descubría todos los reparos que se hazían dentro d'ella, la qual, siendo acercada, despojó los muros de defensores con las cathapultas y balistras que traýa plantadas en sus solares". // Roxas, Sumario milicia, 1607, fol. 72r: Y si fueren los confines del tal reyno marítimos, hase de mirar si ay en la mar algún seno o baýa o alguna boca de río donde metiéndose el enemigo pueda ofender al paýs con su armada, porque las marinas, aunque haçen en alguna manera fuerte al reyno o probinçia, también la hazen fácil a ser [acometida] con armadas de mar, y tiene en mucha suspensión al defensor, porque no save a dónde [va a] acudir la tal armada.

ENCICL.: Fernández Mancheño (1822): El que defiende una plaza o puesto atacado.

3 [Fernández de Enciso, Suma de Geographía, 1530]. sust. Persona que pertenece al ejército o que está especializada en hacer la guerra.

Fernández de Enciso, Suma de Geographía, 1530, fol. LXIIv: Los quintos son los defensores, que andan en la guerra, y en tanto que no tienen guerra exercitan cosas anexas a las armas, porque cuando fuere menester se hallen prestos.

SIN.: guerrero ${ }_{2}$, hombre, hombre de (la) guerra, hombre de pelea, hombre de soldadesca, hombre militar, militar22, mílite, soldado.

defenssa, $V$. defensa.

deffençión, V. defensión.

deffender, V. defender.

deffensa, $V$. defensa.

deffensión, V. defensión.

deffensivo, V. defensivo.

deffensor, $V$. defensor.

desaçer, V. deshacer. 
desalojar, desalojar, desaloxar [de alojar. h. 1572, Hurtado de Mendoza (DECH). Rojas, Teórica fortificación, 1598]. v. tr. Mil. Obligar al enemigo a que abandone el puesto o el lugar en el que está.

Rojas, Teórica fortificación, 1598, fol. 104v: Y aviendo llegado a reconocer la tierra y las partes donde se ha de alojar el exército, repartirá los quarteles, y entretenerse ha hasta que los esquadrones lleguen, de tal suerte que desde el castillo del enemigo no puedan desalojar la gente. // González de Medina, Examen fortificación, 1599, pág. 8: Hase de mirar que media legua alrededor no aya cuesta, que son las que llaman padrastros, quando vienen a estar tan cerca que, puesta artillería en ellas, desaloxan a todos los que están en los reparos y en las estancias y plaça de armas, y que en ninguna parte están seguros. // Roxas, Sumario milicia, 1607, fol. 67v-68r: Y antes que este exérçito comiençe a caminar en la forma dicha, partirá el maese de campo general, o su quartelmaestre, a reconocer el alojamiento que el exérçito a de tener aquella noche, el qual a de tener las calidades siguientes: lo primero, mucha agua; y que no sea el sitio pantanoso, y que tenga mucho forraje y leña, y que en el sitio no aya eminencias sobre él, porque el enemigo no gane alguna y desde allí procure desalojar la jente.

FAM.: alojado, alojamiento, alojar.

ENCICL.: Aut.: Echar de un lugar, hacer por fuerza de armas dejar el alojamiento, casa o lugar donde está alguno alojado o fortificado. // Terr.: Echar a alguno de su puesto, obligarle a salir de algún paraje, casa o lugar [...]. V. Desapostar. // Terr. (s.v. desapostar): Voz de la guerra, arrojar al enemigo del puesto en que estaba apostado. // D'Wartelet (1863): La acción de arrojar a una tropa del punto que ocupa o defiende, sea a fuerza de armas o por medio de estratagemas de guerra.

2 [Álaba, Perfeto capitán, 1590]. v. intr. Mil. Dicho de una tropa o de uno de sus miembros: marcharse o salir de cualquier lugar.

Álaba, Perfeto capitán, 1590, fol. 62r-62v: Aviendo dado orden a su campo que el marchar fuesse por las mañanas y viendo que sus enemigos estavan muy a punto para ofenderle siempre en este tiempo, conoció que su orden era sabida y previno a este daño mandando que nadie desalojasse hasta otro día al medio d'él; con lo qual, los contrarios assegurados de que, pues no avía caminado el campo por la mañana como otras vezes solía, no haría mudança hasta otro día, Marco Antonio, caminando toda aquella tarde sin ser molestado de los enemigos [...], se libró con este ardid del peligro. // Álaba, Perfeto capitán, 1590, fol. 80r: Y si antes que desalojassen entendió el capitán su retirada, es necessario que prevenga el modo como les podrá tomar los passos, teniendo siempre su gente muy apercebida y puesta a punto de guerra. // Mendoça, Theórica y práctica, 1596, pág. 112-113: En el alojarse en esta vezindad [...] se ha de advertir que siempre que dos exércitos están muy cerca acampados, el que desaloja primero es con gran desaventaja, por la que da a su enemigo, moviéndose con todo el embaraço de su exército, y poder su contrario combatir con él sin ninguno. 
ENCICL.: Aut:: Vale también dejar voluntariamente el hospedaje, morada, sitio o habitación. En esta acepción es verbo neutro. // Terr.: Salir del paraje en que se está o vive. // D'Wartelet (1863): Abandonar una posición, un pueblo, etc., bien porque pasen a otro las tropas, o por no convenir conservarle como punto estratégico.

3 [Álaba, Perfeto capitán, 1590]. v. prnl. Mil. Dicho de un grupo de soldados: mudarse o irse del lugar donde ha permanecido durante un tiempo.

Álaba, Perfeto capitán, 1590, fol. 79v: Aviéndose desalojado [...] sin ser sentidos del enemigo, es necessario que en el caminar se aya el capitán prudentemente y que proceda con tanto recato como diligencia, caminando de día y de noche todo lo más que le fuere possible, escogiendo lugares fuertes quando huviere de parar. / Collado, Plática Artillería, 1592, fol. 97v: Al tiempo qu'el exército vadea algún río o passa sobre puentes el exército, o se aloja o se desaloja con priessa el campo, entonces al artillería se le offresce mayores inconvenientes y más peligro y d'ella se deve de tener mayor recelo. // Ufano, Tratado de la Artillería, 1613, pág. 163: Y visto el general (que era estonçes Don Luis de Velasco) en el gran peligro que estavan, por ser puesto muy estrecho y no poder más el metal, hizo alojar un cañón que hería a las enemigas pieças transversalmente y dentro de una hora los enemigos se desalojaron.

ANT.: alojar 2 .

ENCICL.: Terr.: (s.v. desalojarse las tropas) Mudarse de donde estaban alojadas.

desaloxar, V. desalojar.

desazer, V. deshacer.

desbaratado, desbaratado [de desbaratar. Castillo, Tratado de cuentas, 1551]. adj. Dicho de una cosa: destruida o arruinada.

Castillo, Tratado de cuentas, 1551, fol. XXVIIIr- XXVIIIv: Item, puede hazer y renovar el instrumento o contracto del señor que está ya roto $(\mathrm{y})$, o entendiendo instrumento por qualquier edificio de casa, o fortaleza o molino que está roto o desbaratado o para caer, y a menester reparo. / / Álaba, Perfeto capitán, 1590, fol. XIIIv: Pues de inorar la parte más flaca del lugar que se a de batir y dar la batería por la de mayor resistencia, han venido a parecer muchas fuerças inexpugnables y de extraordinaria fortificación, que, conquistadas por quien tuviera el conocimiento del ancho y largo con que se fundaron, que qualquier geómetra, por lexos que se halle, alcança, quedaran rendidas y desbaratadas.

FAM.: desbaratar, desbarate. 
2 [Álaba, Perfeto capitán, 1590]. adj. Mil. Dicho de una tropa: desordenada y desconcertada.

Álaba, Perfeto capitán, 1590, fol. 71r: Acometidos, se fueron retirando y recogiendo a su real con tan buen orden que hizieron esparcir por diferentes partes a sus contrarios para venir en su seguimiento, y cogiéndolos Graco desbaratados, dando sobre ellos con la gente que en su campo le avía quedado, mató gran número de celtíberos. // Álaba, Perfeto capitán, 1590, fol. 77v: Y no se engañe acometiendo siempre que a su contrario viere andar algo descompuesto y desbaratado, porque esto muchas vezes se haze con cuidado para obligar a batalla al enemigo y cogerle con algún ardid o traça secreta.

ENCICL.: Cov. (s.v. desbaratar): Desbaratado, el desconcertado.

3 [Montes, Instrucción y regimiento, 1537]. adj. Mil. Dicho de una persona: que se ha visto obligada a huir a causa de las acciones que el enemigo ha realizado en su contra.

Montes, Instrucción y regimiento, 1537, fol. XVr: En Rávena no llevaron los franceses vitoria conoscida por tres cosas: la una, porque no fueron parte para esecutar la vitoria; la otra, porque no quedaron con exército formado, ca toda la gente del rey de Francia quedó muerta y desbaratada; la tercera, porque fueron muertos el general de los franceses, que era monssiur de Fox, con todos sus capitanes. // Mosquera, Comentario disciplina militar, 1596, fol. 82v: Apretaron de suerte a los franceses y portugueses que desampararon la fuente que con tanto cuydado guardavan y perdieron el artillería y la villa de San Sebastián [...]; y corriendo a toda furia, aunque perdidos, desbaratados y desordenados, fueron seguidos (como se ha dicho con orden, que assí nos lo enseña la Escritura), quando los hijos de Israel seguían a los assirios que precipitadamente huýan. // Mosquera, Comentario disciplina militar, 1596, fol. 99r-99v: Y no uviera Manuel de Silva escogido aquella manida de tan poca seguridad para su salud, si sus propios naturales no le uvieran desfondado la barquilla que tenía prevenida para en ella acogerse al tiempo que se viesse desbaratado y sin remedio.

4 [García de Palacio, Diálogos militares, 1583]. sust. Mil. Persona que se ha visto obligada a huir a causa de las acciones que el enemigo ha realizado en su contra.

García de Palacio, Diálogos militares, 1583, fol. 77v-78r: Si, hallándose con gente y armas tales que entienda sobrepujar las fuerças del enemigo, paresce converná dar la batalla en tiempo que le quede día para proseguilla y seguir el alcance y rota, que, por falta de tiempo, con la obscuridad de la noche, muchas vezes los vencidos y desbaratados se han salvado, rehecho y tornado en sí y podido resisitir a los vencedores, que, si uviera día, no lo hizieran.

desbaratar, desbaratar [de baratar y éste de origen incierto, probablemente prerromano y acaso céltico. Desbaratar ant. 'malbaratar', mod. 'desconcertar, derrotar, descomponer'. ac. ant., fin s. XIII, 1. ${ }^{a}$ Crón Gral.; ac. mod., 1534 (DECH). Pérez Vargas, De re metallica, 1568]. v. tr. u. t. c. prnl. Destruir o arruinar algo. 
Urrea, Vitruvio, Architectura, 1582, fol. 136-137r: De las máchinas para resistir a los enemigos no ay necessidad de escrivir, porque los enemigos no tienen cuenta con lo que está escripto; antes, muchas vezes con presteza de consejo, sin ninguna máchina, desbaratavan las máchinas que contra ellos se hazen. // Álaba, Perfeto capitán, 1590, fol. 141v: Y Claudio Nerón, aviendo vencido a los africanos que passavan de España a Italia con Asdrúbal y muerto a él, cortándole la cabeça, la echó en el real de Aníbal, el qual, viendo muerto a su hermano, cubriéndose la cabeça de luto, perdió gran parte del ánimo, desesperando del socorro, con que se desbarató todo el real. // Álaba, Perfeto capitán, 1590, fol. 256v: Y aunque la traça de las minas en estos tiempos es la mesma que en los passados, los efetos son de mayor importancia, por la violencia notable con que los materiales que en ellas se ponen desbaratan y asuelan qualquier lienço de muro o fortaleza, por fuerte y inexpugnable que parezca.

FAM.: desbaratado, desbarate.

ENCICL.: DUE: Deshacer[se] o arruinar[se] una cosa.

2 [Celso, Reportorio universal leyes Castilla, 1553]. v. tr. u. t. c. prnl. Mil. Desordenar, desconcertar, poner en confusión a los contrarios (DRAE).

Celso, Reportorio universal leyes Castilla, 1553, fol. CLIXv: Ninguno se deve atrever de robar el campo o rastro hasta que del todo sean vencidos los enemigos, porque muchas vezes acaesce que los enemigos que son desbaratados se tornan ayuntar, y dan sobre los vencedores que hallan embaraçados en robar el campo, e fácilmente los vencen antes que se puedan tornar en ordenança. // García de Palacio, Diálogos militares, 1583, fol. 83r: Exemplo [...] para que los varones lo imiten con constancia y fortaleza [...], procurando todo lo que en sí fuere para que la pérdida de su gente sea la menos que pudiere, retirándolos con destreza a lugares de buena commodidad, y en buena ordenança, que, si van desordenados, como se dize en el libro de Iudices, pocos, con concierto y orden, los matarán y destruyrán, y, si la furia fuere tanta que los fuerce a desbaratarse, conveniente será guiarlos y encaminarlos a algún lugar cierto, por diversas vías, donde se pueda tornar a rehazer. // García de Palacio, Diálogos militares, 1583, fol. 145v: Los ballesteros, honderos, tiradores de arco y dardo yvan en la avanguardia y començavan la batalla [...]. Y, si por caso eran desbaratados por el enemigo, como de menos orden y de más flacas armas, se retraýan a las espaldas de los esquadrones, por los lados o por donde mejor podían, y allí se bolvían a poner en ordenança y salían a dañar por los costados a los enemigos, quando los veýan venir a las manos.

ENCICL.: DUE: Descomponer[se] las filas enemigas; introducir[se] en ellas el desorden.

3 [Fernández de Enciso, Suma de Geographía, 1530]. v. tr. Mil. Poner en fuga al enemigo.

Fernández de Enciso, Suma de Geographía, 1530, fol. XXXIVr: Éstos de Atenas, siendo cercados de los persas e viendo que avía mucho tiempo que sufrían la fatiga, deliberaron de morir por su libertad, e salieron de la cibdad y metiéronse en ciertas fustas. Y en la mar pelearon tan rezio, que desbarataron a la flota de los persas e los echaron de su tierra. // 
Álaba, Perfeto capitán, 1590, fol. 140r-140v: Y Quinto Metelo, siendo desbaratado en la batalla que tuvo con Sertorio, hizo, pareciéndole que en esto recebiría menos daño, que su gente y él fuessen huyendo por diferentes partes, señalándoles un puesto donde todos se viniessen a juntar, en el qual tuviessen socorro para su defensa, continuando los enemigos el seguirlos. // Álaba, Perfeto capitán, 1590, fol. 140v: Pocas dudas se ofrecen en la milicia tan grandes y de tanta dificultad como es el saber si, vencido y desbaratado el campo del enemigo, conviene llevar al cabo la vitoria, de suerte que hasta dar cabo de todo él no cesse el yr en su seguimiento, porque los capitanes de mayor fama y nombre siguieron en esto diferentes opiniones.

SIN.: poner en rota.

desbarate, desbarate [de desbaratar. Desbarate 'derrota', 'desconcierto'. 1517, BHisp.; 1564 (DECH). García de Palacio, Diálogos militares, 1583]. sust. Mil. Confusión, desorden y desconcierto generado en la disposición de una tropa.

?ㄱ (fig. 56)

García de Palacio, Diálogos militares, 1583, fol. 181v-182r: Siendo, pues, regla cierta que todo infante toma la orden de su caminar del que marcha delante y los infantes que se hallaren en aquella mesma hilera deven, viendo al compañero que va delante caýdo, passar a su lugar, apresurado su movimiento, y el otro, al otro, de forma que la falta o vazío quede en la rectaguardia, como quedó referido en el citado lugar que hazían los griegos. Y, assí, podrán evitar los rompimientos y desbarates que se podrían seguir del dexallos en la frente.

FAM.: desbaratado, desbaratar.

ENCICL.: Cov. (s.v. desbaratar): Disbarate, el desconcierto. // Toro y Gómez (1901: s.v. desbaratamiento): Descomposición, desconcierto. Sinón. Desorden, desorganización.

descercar, decercar [de cercar. Ya tercer cuarto s. XIII, Fn. Gonz.; Nebr. (DECH). Rojas, Compendio fortificación, 1613]. v. tr. Fort. Obligar al enemigo a levantar el cerco o sitio puesto sobre algún lugar fortificado.

Rojas, Compendio fortificación, 1613, fol. 44r-44v: La obsidional corona es la que los cercados dan al capitán que los decercó; ésta es de grama, y que fuesse de grama que estava nacida dentro de la plaça donde estavan cercados.

SIN.: desitiar.

FAM.: cerca, cercado, cercador, cercar.

ENCICL.: Cov.: Quitar el cerco que está puesto sobre alguna ciudad, villa, castillo o fortaleza, haciendo que le alcen los enemigos y desamparen el campo. A los tales descercadores coronaban de grama, y era una de las coronas más honradas de la milicia. // Almirante (1869): Obligar al enemigo a levantar el cerco o sitio de una fortaleza [...]. Como 
se ve, quien descerca no es el que sitia, sino el que socorre: aquel levanta el cerco, cuando éste descerca.

descobridor, V. descubridor.

descobrir, V. descubrir.

descortinar, descortinar [de cortina. Ufano, Tratado de la Artillería, 1613]. v. tr. Fort. Derribar una cortina o muralla de una fortificación, a cañonazos o de otro modo (DUE).

Ufano, Tratado de la Artillería, 1613, pág. 172: A los de fuera mejor les está con el artillería, porque pretenden arruynar, descoser y descortinar las murallas, y no dexar en manera alguna asomar ni trabaxar a los sitiados para cubrirse. // Ufano, Tratado de la Artillería, 1613, pág. 201: A mi juyzio y mal paresçer antes acometería la batería y asalto por el baluarte que no por la cortina, porque si bien an menester poca gente para guardarla y defenderla essa ventaja tienen los de afuera, que tienen más lugar para offender y quien menos les offenda y resista, pues en el batir bien se echa de veer que en poco tiempo le descortinarán todo su perfil y le dexarán más llano que la palma de la mano.

FAM.: cortina.

ENCICL.: Rubió y Bellvé (1895-1901): Destruir, demoler, arruinar la cortina de una fortaleza, batiéndola a cañonazos, por la mina, etc.

descoser, descoser [de coser y éste del lat. consuĕre. Nebr. (DECH). Ufano, Tratado de la Artillería, 1613]. v. tr. Fort. Abrir una brecha o portillo en el muro de una fortaleza.

Ufano, Tratado de la Artillería, 1613, pág. 172: A los de fuera mejor les está con el artillería, porque pretenden arruynar, descoser y descortinar las murallas, y no dexar en manera alguna asomar ni trabaxar a los sitiados para cubrirse. // Ufano, Tratado de la Artillería, 1613, pág. 350: Se entiende [...] que con mayor furia hará la percusión de una terminada distancia como la predicha en qualquiera resistente, y mucho más romperá y amolentará el muro, descosiéndolo y lebantándolo hazia arriba al avieso o sesgo, atormentándole, que no embaçando la bala retamente en el coraçón del muro sin mover desmolición alguna.

ENCICL.: DRAE (s.v. aportillar): tr. Romper una muralla o pared para poder entrar por la abertura que se haga en ella. 
descubridor, descobridor, descubridor [de descubrir (DECH). Celso, Reportorio universal leyes Castilla, 1553]. sust. Mil. Soldado especializado en explorar o examinar el territorio para localizar al enemigo y analizar sus movimientos.

Celso, Reportorio universal leyes Castilla, 1553, fol. CLIXr: Descobridores se dizen los cavalleros que van delante de la hueste a diestro e a siniestro, porque, si los enemigos vinieren, aperciban a la hueste porque no reciban daño. // Ufano, Tratado de la Artillería, 1613, pág. 107: Y a esto seguirán 2.000 ynfantes en orden como los demás, para la guardia y custodia de la artillería y retaguardia del exérçito. Y en pos d'ellos marcharán, recogiendo a todo el exérçito, 500 caballos bien ordenados en sus tropas, como los descubridores del abanguardia.

SIN.: corredor.

FAM.: descubrir.

ENCICL.: Rubió y Bellvé (1895-1901): Corredor [...], batidor; el que descubre o hace la descubierta. // Gago-Jover (2002): Batidor que descubre y reconoce el campo o el camino para ver si está libre de enemigos.

descubrir, descobrir, descubrir, descuvrir, desqubrir [de cubrir y éste del lat. cŏópěrïre. Cid (DECH). Montes, Instrucción y regimiento, 1537]. v. tr. Dicho de una cosa: dominar algo que está alrededor, por tener mayor altura o estar en una posición más elevada.

Montes, Instrucción y regimiento, 1537, fol. XVIIv: Otras formas se podrían dar para la defensa de una ciudad, assí como bastiones y reparos que descubran la campaña, huviendo abundancia de artillería. Y ha de estar la campaña muy limpia de árboles en torno de la ciudad, y de ribaços, porque éstos son muy dañosos al cuerpo de la ciudad. // Collado, Plática Artillería, 1592, fol. 67r: ¿Y qué mayor padrastro puede ser a una ciudad o fortaleza que tener en estos tiempos sobre de sí una montaña que la sobrepuje y la descubra? // Rojas, Teórica fortificación, 1598, fol. 3v: Se tendrá cuidado de no erigir el castillo cerca de algún valle o cañada donde pueda estar alojado algún exército enemigo, y quando por algunos respetos fuesse fuerça hazerlo allí, se pondrá mucho cuidado en plantar la fortaleza a vista y de forma que descubra y varra todo el valle, de manera que el enemigo no se pueda allí alojar.

SIN.: señorear 1.

FAM.: descubridor.

2 [Escalante, Discurso de la navegación, 1577]. v. tr. Divisar desde una altura determinadas cosas, como una extensión de terreno o las personas que se encuentran allí.

Escalante, Discurso de la navegación, 1577, fol. 34v-35r: Están adornadas de muchos baluartes y torres de trecho a trecho, cubiertos con chapiteles hermosíssimos y rodeadas 
de corredores y petriles, a do se suelen yr a recrear los governadores y ministros para gozar de la vista del campo y riberas, y de otros edificios grandes que d'ellas se descubren. // Mendoça, Theórica y práctica, 1596, pág. 64: D’estos maderos se podía assimismo componer otro ingenio en altura de cinqüenta pies o más, por el qual subía un hombre y baxava con facilidad, descubriendo la campaña en quanto da lugar el altura, viniendo a servir como de atalaya y tocar alerta y arma en caso que viniesse gente. // Lechuga, Discurso de la Artillería, 1611, pág. 241: El parapeto de la estrada cubierta a de ser alto, ocho pies, y a de tener su banqueta tan alta que los soldados puedan, puestos en ella, descubrir la campaña.

SIN.: señorear 2 , sojuzgar 1 .

ENCICL.: D'Wartelet (1863): Dominar desde un paraje elevado el todo o parte de una población, plaza de guerra o extensión de país. / / DUE: Ver cierta cosa desde lejos: 'Desde allí se descubría todo el valle'.

3 [Montes, Instrucción y regimiento, 1537]. v. tr. u. t. c. intr. Mil. Examinar o explorar un lugar para localizar al enemigo y obtener información sobre sus posibles maniobras $\mathrm{u}$ operaciones militares.

Montes, Instrucción y regimiento, 1537, fol. Xr: E los cavallos ligeros han de yr delante de todo el cuerpo del exército, descubriendo la campaña hasta que lleguen a vista de los enemigos. // Celso, Reportorio universal leyes Castilla, 1553, fol. CXXXVIv: Y tenga a la diestra y siniestra cavalleros para descubrir la tierra, que el exército no resciba daño. Y por la mesma razón deven yr los cavalleros armados y apercebidos, para que, si los enemigos vinieren a ellos a desora, se puedan más fácilmente amparar. // Mendoça, Theórica y práctica, 1596, pág. 154: Hecho esto, han de embiar corredores fuera de la tierra para que vayan adelante a descubrir, siguiendo los carros o acémilas con las escalas y barcas.

SIN.: correr $_{1}$.

ENCICL.: DRAE (1803: s.v. descubrir el campo): Milic. Reconocer, explorar la situación del ejército enemigo. // Moretti (1828: s.v. descubrir el campo): Examinar los alrededores de un paraje que debe transitarse, o de un punto que se ocupa, a fin de evitar una emboscada o una sorpresa. / / Domínguez (1853): Explorar, batir el campo, etc.

descuvrir, V. descubrir.

desfazer, V. deshacer.

desguarnecer, desguarnecer, desguarnescer [de guarnecer (DECH). Mendoça, Theórica y práctica, 1596]. v. tr. Mil. Retirar las tropas que tiene un lugar para su defensa. 
Mendoça, Theórica y práctica, 1596, pág. 33: Podría también Vuestra Alteza armarse para el estarlo y, apercebido, para conservar sus vassallos, aviendo entre dos príncipes guerra, cuyos reynos o estados se avezinassen a los de Vuestra Alteza, mostrándose neutral y que no está desguarnecido de fuerças por la sospecha que le puede dar ver a los dos armados, no siendo menos conveniente prevenir la injuria que, recebida, necessario el vengarla.

ANT.: guarnecer 1 .

FAM.: guarnecer, guarnecido, guarnición.

desguarnescer, V. desguarnecer.

deshacer, desaçer, desazer, desfazer, deshacer, deshaçer, deshazer [de hacer y éste del lat. făcěre 'íd.'. Desfer, Berceo (DECH). Sagredo, Medidas Romano, 1526]. v. tr. u. t. c. prnl. Destruir completamente una cosa (DUE).

Urrea, Vitruvio, Architectura, 1582, fol. 135r: Y aviendo tomado primero el castillo, se esforçaron de arruynalle. $\mathrm{Y}$ no teniendo instrumento conveniente para ello, tomaron una viga, y sosteniéndola con las manos y la cabeça, hiriendo continuamente el alto muro, derribavan por orden las piedras. Y assí, de grado en grado, deshizieron toda la muralla. // Collado, Plática Artillería, 1592, fol. 53r: Assí como el intento principal del artillero enemigo es de quitarte las deffensas, enbocarte las troneras con sus balas para matarte y desencavalgarte las pieças, deshazerte los parapetos para dexarte al descubierto por privarte de fuerças y de reparo y hazer que no puedas deffenderte de un assalto riguroso, como se ha dicho, assimismo, tú, para poderlo offender a tu salvo y opponerte a deffender la parte que te toca, deves de procurar de desencavalgarle su artillería. / / González de Medina, Examen fortificación, 1599, pág. 188: Cañones de quarenta para contrabatería, pondría dos en los baluartes, uno a cada lado, y dos en cada cortina; que, sabida de la noche para la mañana dónde tienen plantada la batería, se les ha de hazer a ellos, al reýr del alva, antes que los enemigos ayan començado, deshaziéndoles las trincheas, cestones y todo lo que tuvieren para defensa.

FAM.: deshecho.

ENCICL.: DSAL: Destruir una persona o una cosa una cosa completamente.

2 [Montes, Instrucción y regimiento, 1537]. v. tr. Mil. Vencer completamente al enemigo, aniquilarlo, destrozarlo.

Montes, Instrucción y regimiento, 1537, fol. XVr: E assí fue deshecho el exército de los franceses, por quedar, como quedaron, sin caudillos, porque fueron muertos por la infantería española. // García de Palacio, Diálogos militares, 1583, fol. 75v: Mas desseo entender, opuestos dos campos, ¿qué orden terná el uno para consumir y deshazer al otro?, y si es más cordura suffrir con ánimo y ossadía el ímpetu y arremetida de los enemigos o asaltallos y acometellos en sus principios, con toda su furia. // Roxas, Sumario 
milicia, 1607, fol. 7r: De Sertorio cuenta Plutarco que con siete mil ynfantes y trescientos de a cavallo vençió muy grandes exérçitos que los romanos ymbiaban contra él; Lucullos con pocos más deshizo a Tigranes, rey cuyo exérçito passava de duçientos mil soldados.

\section{deshaçer, V. deshacer.}

deshazer, V. deshacer.

deshecho, deshecho [de deshacer (DECH). Mendoça, Theórica y práctica, 1596]. adj. Mil. Dicho de una persona o de una colectividad: que ha sido vencida completamente, aniquilada o destrozada.

Mendoça, Theórica y práctica, 1596, pág. 116: Y assí la mayor parte de vitorias que se ganan en estos tiempos es aviéndose conseguido con la artillería o presteza de la arcabuzería por las bivas ruziadas, desordenando los esquadrones del enemigo, de suerte que los ponen en rota y deshechos, sin aver visto ya afrontarse, sino raras vezes, los esquadrones de picas. // Mendoça, Theórica y práctica, 1596, pág. 121: No se puede dezir un exército vencido y deshecho hasta verse desordenados todos los esquadrones d'él.

FAM.: deshacer.

deshilada, deshilada [de deshilar y éste de hilar].

a la $\sim$ [Rojas, Teórica fortificación, 1598]. loc. adv. Mil. Dicho de una tropa, por ejemplo al marchar o acometer a su enemigo: con los soldados uno detrás de otro. Rojas, Teórica fortificación, 1598, fol. 32v-33r: Si yo estuviesse dentro en la defensa, con la mitad de la gente, guardaré mejor esta frente pequeña que la grande, y le obligaré al enemigo que venga por estrecho y a la deshilada, con su gente y trinchea, y assí con las salidas que yo hiziere le haré mucho daño, por hallarle en camino estrecho. // Roxas, Sumario milicia, 1607, fol. 39r-39v: Y la otra parte del exérçito se apartará muy lejos de la derecha del enemigo y estenderse hasta ponerse como en punta, porque luego se comenzará a herir al enemigo por la parte siniestra, así por los lados como por las espaldas, sin duda se le hará poner en huyda; el contrario, ni de su parte derecha ni del esquadrón de en medio, puede socorrer a los suyos que así estubieren puestos en trabaxo, porque tu exérçito se va estendiéndose y se pone en forma que llaman a la deshilada, qu'es casi en línea recta, la punta al enemigo, y con ésta forma muchas vezes quando se marcha.

a la $\sim_{2}$ [Mendoça, Theórica y práctica, 1596]. loc. adv. Con disimulo (DRAE). Mendoça, Theórica y práctica, 1596, pág. 142: Visto el estado de la batería y demostraciones que las centinelas descubren que hazen los de fuera para dar el assalto, recogiéndose más vanderas de las que suelen a las trincheas, sin ser hora de guardia, o a la deshilada, como se suele hazer, queriendo reforçarlas, para gozar la ocasión de alguna mina o torreón que 
se aya de ocupar, puesto en el fosso, o otro alguno, la cabeça del sitio ha de advertir si el enemigo, por no poder llegar a la batería sin puente, la ha echado la noche antes o la ha de echar.

ENCICL.: Terr.: Dícese del modo de ir o marchar con disimulo. // Domínguez (1853): Disimuladamente o con disimulo, sin llamar la atención, etc. // Moretti (1828: s.v. deshilada): Mod. adv. [...]. Se usa cuando una espía sigue con disimulo alguna tropa o persona para averiguar el apostadero, emboscada o comisión que lleva.

deshilada, V. a la .

desitiar, dessitiar [de sitiar. González de Medina, Examen fortificación, 1599]. v. tr. Fort. Obligar al enemigo a levantar el cerco o sitio puesto sobre algún lugar fortificado.

González de Medina, Examen fortificación, 1599, pág. 153-154: Y la muralla no tocaría a ella, porque forçoso el enemigo se ha de aloxar dentro d'ella para ganar la tierra, y el socorro que ha de venir, que siempre el sitiado le ha de presuponer a la corta, o a lo largo, por no desanimar a los que la defienden y que con más corage peleen esperando cada passo el socorro, hallará al enemigo sitiado con la muralla, de manera que, con el ayuda de los de dentro, no sólo será fácil desaloxar al enemigo y dessitiar la tierra, pero aun degollarle con mucha facilidad.

SIN.: descercar.

FAM.: asitiar, sitiado, sitiador, sitiar.

ENCICL.: Domínguez (1853): Levantar o hacer levantar el sitio de una plaza, de una fortaleza, etc.

desmantelar, desmantelar [del it. smantellare 'abbattere una construzione militar bombardandola o minandola, in modo de renderla inefficace per la defesa col privarla di guarnigione e di armamenti [...]'. Smantellare en it. desde la 2. ${ }^{a}$ mitad del s. XV. Desmantelar, h. 1570, Ercilla (Battaglia 1961-2002). Álaba, Perfeto capitán, 1590]. v. tr. Fort. Dicho de un lugar fortificado: derribarlo o destruirlo para dejarlo inservible, cuando se teme que puede ser tomado por los enemigos.

Álaba, Perfeto capitán, 1590, fol. 145v-146r: Y si la fuerça que ganó está sujeta a assaltos de los enemigos y a ser muy de ordinario inquietados los que están dentro, el mejor consejo será desmantelalla. Y es negocio muy puesto en disputa entre los que professan la milicia si estas fuerças y las demás ciudades que se teme poder bolver a ser sujetas al enemigo es bien que no sólo se derriben, sino que del todo se abrasen.

ENCICL.: Almirante (1869): No es precisamente echar por tierra, volar, arrasar, demoler una fortaleza: es inutilizarla, dejarla inservible para el enemigo, si la ocupa. // Rubió y Bellvé 
(1895-1901): Derribar, arruinar, echar por tierra las defensas de una plaza u otro lugar fortificado, de modo que resulten inservibles por completo.

\section{desoccupar, V. desocupar.}

desocupar, desoccupar, desocupar [de ocupar (DECH). Álaba, Perfeto capitán, 1590]. v. tr. Mil. Abandonar el lugar estratégico desde el que se intenta dificultar las acciones del enemigo.

Álaba, Perfeto capitán, 1590, fol. 45r-45v: Y hallando las mesmas resistencias en passar sus navíos o galeras por algún estrecho de mar, echará delante algunas d'ellas, las que estuvieren más aprestadas, en cuya caça y seguimiento vayan los enemigos para que con este cebo desocupen el passo.

ANT.: ocupar, tomar $_{2}$.

FAM.: ocupado, ocupar.

despojar, despojar [del lat. despoliare 'despojar, saquear', derivado de spoliare 'íd.', y éste de spolium 'pellejo de los animales', 'botín'. Berceo; doc. de 1215 (Oelschl.) (DECH). Celso, Reportorio universal leyes Castilla, 1553]. v. tr. Quitar a alguien con violencia lo que tiene o lleva en ese momento.

Celso, Reportorio universal leyes Castilla, 1553, fol. CCXXVr: Quál pena merescen los que despojan a los finados y les quebrantan los sepulchros, dezimos en el dicho capítulo injuria, versículo XV; y capítulo Fisco, versículo XIII. // García de Palacio, Diálogos militares, 1583, fol. 47v: Julio César, como bien diestro y sabidor del daño que d'ello se suele seguir, con gran connato hazía y mandava que sus soldados, quando entrassen en alguna ciudad, no despojasen a hombre d'ella ni violassen las cosas sagradas de los templos. // Álaba, Perfeto capitán, 1590, fol. 143v-144r: Como sucedió a Ptolomeo, rey de Egipto, que, aviendo vencido a Demetrio, rey de Asia y despojádole de su tienda y de muchas preseas y joyas que tenía en gran estima, se las embió diziendo que entre ellos no avía de aver batalla por las riquezas, sino por la honra y gloria.

FAM.: despojo.

ENCICL.: DEA: Privar a alguien (cd) de algo con violencia. Tb sin compl de, por consabido. // Cov.: Quitar a uno lo que tiene de alhajas, expoliare. En la guerra, despojar al enemigo, quitarle las armas y todo lo demás que se puede quitar.

2 [García de Palacio, Diálogos militares, 1583]. v. tr. Mil. Dicho de los soldados: apoderarse violentamente de todo lo que encuentran en territorio enemigo.

García de Palacio, Diálogos militares, 1583, fol. 47r: Y cierto entiendo que querer referir los campos y exércitos que, siendo vencedores, han sido vencidos por averse occupado en 
saquear y robar, y contar de los que han ignominiosamente perdido las vidas, sería proceder en infinito, mas, para remedio d'este mal y orden de lo que se deve hazer, en el Primero de los Machabeos se enseña que los soldados no saqueen ni despojen el campo de sus enemigos hasta que consummadamente ayan conseguido victoria y no tengan de quien temerse.

SIN.: dar a saco, saquear.

despojo, despojo, despoxo [de despojar. 1223, M. P., D.L.; 1. ${ }^{a}$ Crón. Gral.; APal.; espojo, 1. ${ }^{a}$ Crón. Gral. (DECH). García de Palacio, Diálogos militares, 1583]. sust. Mil. Acción de apoderarse violentamente de todo cuanto hay en territorio enemigo.

García de Palacio, Diálogos militares, 1583, fol. 83r: Y, si por occuparse en el despojo, regozijos o otras cosas no siguiessen el alcance, oportunidad será para que, juntando los suyos, con buena disposición, torne a tentar su suerte y recuperar la pérdida, offendiendo a los descuydados vencedores. // Mosquera, Comentario disciplina militar, 1596, fol. 86r: Quando se echó este vando fue en tiempo que estava ya apoderado en los castillos y plaças de la ciudad, porque antes d'esto es digno de mucha culpa el capitán que tal permite; y lo mesmo se ha de guardar en el navío, que no se ha de dar lugar a ningún despojo hasta que esté todo enteramente rendido. // Mosquera, Comentario disciplina militar, 1596, fol. 135v: $\mathrm{Y}$, passados los tres días del despojo, saliendo a luz algunos esclavos que estavan escondidos y se escaparon de ser presa de la gente de guerra, pretendieron sus señores tener recurso a ellos y reduzirlos al yugo de la passada sujeción y pusiéronlo por obra, sin acordarse que ellos mesmos les avían puesto las armas en las manos y con ellas la libertad.

SIN.: presa $_{2}$, saco ${ }^{2}$, sacomano.

FAM.: despojar.

ENCICL.: Aut.: La acción de despojar.

2 [Fernández de Enciso, Suma de Geographía, 1530]. sust. u. m. en pl. con el mismo significado que en sing. Mil. Conjunto de cosas que los soldados consiguen arrebatar al enemigo durante una acción militar o tras ella.

Fernández de Enciso, Suma de Geographía, 1530, fol. XLVr: Josué ordenó su hueste, e tomó la cibdad y mató mucha gente; e a los que tomó bivos diolos por esclavos al pueblo de Israel, y partióselos e partioles el despojo. // García de Palacio, Diálogos militares, 1583, fol. 81r: También deve curar los heridos, y enterrar los muertos y agradescer con palabras y dones y mercedes a los victoriosos, repartiendo entre ellos los despojos del campo, para que, con el premio, en alguna manera queden pagados $\mathrm{y}$, con las gracias, se animen a otros casos y victorias semejantes. // Álaba, Perfeto capitán, 1590, fol. 2v-3r: Y Manlio Torquato mandó cortar la cabeça a su hijo en las guerras de los latinos porque, contra su orden, peleó con los enemigos, sin que bastasse a impedir este rigor verle venir cargado de despojos y vitorioso. 
SIN.: presa $_{3}$.

ENCICL.: Cov. (s.v. despojar): Despojo, lo que se trae tomado del enemigo, por otro nombre presa. // D'Wartelet (1863): Se llama así todo lo que el soldado toma al enemigo, ora sean víveres y municiones, ropas o alhajas, armas y caballos, etc. Entre los griegos repartían todos los despojos en el ejército que había conseguido la victoria, al paso que entre los romanos era la república la que sacaba el mejor provecho.

despoxo, V. despojo.

desqubrir, V. descubrir.

dessitiar, V. desitiar.

diana, diana [del it. diana 'íd.' (Citolini, 1561). Se le dio este nombre por llamarse así en italiano la estrella matutina o planeta Venus (ya documentado en la Edad Media), derivado del it. dì 'día' por ser la estrella del día. Terr. (DECH). Montes, Instrucción y regimiento, 1537]. sust. Mil. Toque o música que se hace al comienzo de la jornada, para despertar a la tropa.

Montes, Instrucción y regimiento, 1537, fol. XVIIv: Y esté muy desvelada la guarda de la diana, porque, comúnmente, a aquella hora suelen venir los enemigos. // Mendoça, Theórica y práctica, 1596, pág. 152: Acordado el número de gente con que se ha de dar la escalada, se ha de juntar, después de cerradas las puertas, si sale toda la gente de una tierra y, si no, señalar puesto y hora donde se ha de hallar; y esto, según a la que se ha de efetuar, si ha de ser a la hora de la centinela que llaman modorra, o antes, o a la diana.

ENCICL.: Hevia (1857): Toque militar, común a todas las armas, que en tiempo de paz se oye en los cuarteles al amanecer, y sirve para que la tropa se levante y vista. En los campamentos se toca siempre antes de llegar el día, y es la señal de tomar las armas y formar los cuerpos brigadas o divisiones, permaneciendo sobre las armas mientras se practican los reconocimientos y descubiertas. // Almirante (1869): La noche militar, si así puede decirse, está comprendida entre los dos toques de retreta y diana. // De retrata no hay, sin embargo, ejemplos en el corpus.

2 [Montes, Instrucción y regimiento, 1537]. sust. Mil. Soldado encargado de hacer sonar la diana.

Montes, Instrucción y regimiento, 1537, fol. XVIIv: Y, para la guarda d'ella, deven poner en la plaça principal de la ciudad el cuerpo de la guarda, y el sargento ponga a la primera sus guardas: si fuere en invierno, haga la primera seys horas y la segunda guarda deve hazer cinco horas, y la diana haga el resto, que son tres horas hasta el día. 
diente, diente [del lat. dens, dĕntis, 'íd.'. Cid (DECH). Rojas, Teórica fortificación, 1598]. sust. u. m. en pl. Fort. Cada uno de los ángulos salientes que en ocasiones se forman en una obra fortificada. (fig. 57)

Rojas, Teórica fortificación, 1598, fol. 3r: Y, fuera de todo esto, saber qué es la contramina y las puertas que sirven de surtidas al fosso, y qué son tenazas, y dientes, y tixeras [...], las quales se suelen hazer fuera del fosso, dándose la mano con algún padrastro o fuerte. // Roxas, Sumario milicia, 1607, fol. 81r: Adbiértase que los dientes, tigeras, tenazas no se han de hazer en parte que se pueda poner batería, porque será disparate; sólo sirven de poco más que trincheras, y ansí se ha de entender. // Roxas, Sumario milicia, 1607, fol. 84r: En todo lo demás de los caballeros [...], tenazas, tigeras, dientes, se guardará la medida que está dicho, pues todas son fortificaçión no real, porque sólo se hazen para darse la mano con algún padrastro o otra semejante; y se da liçençia que se crezca o diminuya según la neçesidad pidiere.

ENCICL.: Lucuze (1772: 40): "Dientes de sierra son unos ángulos salientes que se forman en el camino cubierto, cuando es larga la distancia desde la plaza de armas hasta el ángulo saliente, para defenderla mejor con los pequeños flancos o lados de los mismos ángulos". // Sanz (1749: s.v. dientes de sierra o redentes): Ordinariamente se construyen estas obras en el camino cubierto y en las fortificaciones que están situadas en la orilla de un río. // Almirante (1869: s.v. dientes de sierra): Con este nombre o con el de llares se distingue en fortificación el trazado de una línea algo extensa en la que se repiten alternativamente los ángulos entrantes y salientes, imitando, trazados sobre el papel y en pequeño, los de aquel útil de carpintería.

2 [García de Palacio, Diálogos militares, 1583]. sust. Mil. Orden triangular de batalla en forma de un cono truncado que termina en punta por el frente y se ensancha hacia la base (Moretti 1828: s.v. cúneo). 오 (fig. 58)

García de Palacio, Diálogos militares, 1583, fol. 174v: Aprovechávanse también de la dicha forma cúnea para hazer esquadrones en manera de sierra. $Y$, para saberlos hazer, conviene advertir de quántos dientes se quiere formar el dicho esquadrón y qué gente deve llevar en ordenança tras las dichas puntas, para sustentarlas. // Álaba, Perfeto capitán, 1590, fol. 121r: Como si me diessen 100 soldados de que hazer un esquadrón en esta forma, que tuviesse quatro dientes: partiré 100 por quatro y saldrán de la partición 25 para formar cada diente de la sierra. Y porque este número es quadrado, formaré d'él un cúneo o diente, sin que sobre o falte algún número. // Álaba, Perfeto capitán, 1590, fol. 121v: Supongo que me dan trezientos infantes de que hazer un esquadrón en esta figura que tenga quatro dientes y que el estribo tenga notable cantidad; tomaré para él dozientos que, sacados de los trezientos, restarán ciento para los quatro dientes, y para cada uno avrá veynticinco.

SIN.: cúneo, cuño.

ENCICL.: Álaba, Perfeto capitán (1590: fol. 121r): "Y queriendo hazer un esquadrón en la primer forma, que es haziendo solos los dientes de la sierra, partiré el número que me 
dieren en tantas partes quantos dientes quiero que lleve el esquadrón, y de cada parte de aquéllas haré un cúneo, pues cada diente de la sierra no tiene otra forma que ésta, y acomodaré todas las últimas hileras en una línea derecha y avré cumplido con mi intento".

diversión, diversión [de divertir. s. XVII, Aut. (DECH). Mendoça, Theórica y práctica, 1596]. sust. Mil. Ardid de guerra que consiste en distraer al enemigo o en hacer que dirija su atención a objetivos poco importantes para debilitarlo.

Mendoça, Theórica y práctica, 1596, pág. 30: Podría Vuestra Alteza mandar assimismo apercebir gente para defenderse, previniendo algún rey o república con quien tuviesse guerra o sospecha que se la huviesse de romper y en parte donde pudiesse más que en otra alguna trabajar a Vuestra Alteza, usando en este caso del medio de la diversión, empresa que se ha de executar por mar o tierra con mucho secreto y presteza porque no la prevenga el enemigo ganando por la mano.

FAM.: divertir.

ENCICL.: Gaspar y Roig (1853-1855): Mil. Empresa estratégica secundaria, intentada más o menos lejos de la zona de operaciones o de la esfera de actividad del enemigo, para llamar su atención hacia un objeto diverso del principal u obligarlo a desistir de su intento.

divertir, divertir, divirtir [tomado del lat. divertere 'apartarse' (de donde 'distraerse'). Fin s. XVI, Mendoza, Sta. Teresa (DECH). Loçano, Alberto, Architectura, 1582]. v. tr. u. t. c. prnl. Apartar, desviar, alejar (DRAE).

Loçano, Alberto, Architectura, 1582, pág. 113: Nicoris, reyna de los assirios, teniendo aparejadas todas las cosas que convenían para fabricar una puente, y cavado un lago anchíssimo, divertió el río allí, y, entre tanto que el lago se hinchía, fabricó los pilares en la madre seca del río. // Collado, Plática Artillería, 1592, fol. 63r: Procurolo con somma diligencia y grande artificio y costa Francisco de Angulema, rey de Francia, teniendo en el estado de Milán cercada la ciudad de Pavía, donde, por poder plantar la batería y assaltar a aquella ciudad por la parte del río Tesino, que passa junto a la muralla, quiso divertir y alexar de sí aquel río, que es muy mayor que Guadalquivir y más que Ebro. // Collado, Plática Artillería, 1592, fol. 63v: Solamente tres cosas hazen no poderse minar un sitio, que son: o estar fundada la fuerça sobre peñasco que sea alto, gruesso y muy maciço, o que tenga manantial en el fosso, como del castillo de Milán se dixo, o río tan caudaloso de entorno que no le pueda ser divertido ni quitado.

FAM.: diversión.

2 [Álaba, Perfeto capitán, 1590]. v. tr. Mil. Distraer al enemigo, hacer que dirija su atención a objetivos poco importantes para debilitarlo.

Álaba, Perfeto capitán, 1590, fol. 63r: Y aunque sea de noche, escusará el acometer si no tuviere orden para usar de alguna cautela con que divertir y hazer esparcir el real, porque entonces, desbaratándolos de la fortaleza que todos juntos tienen, podrá ofenderlos con 
ventaja. // Collado, Plática Artillería, 1592, fol. 62v: ¡Qué mayor afrenta le puede entrevenir al ingeniero que haviendo él prometido de hazer con la mina un effecto maravilloso y haviendo ya, con tanta costa de dinero y de gente, conduzido al fin su trabajo y tenido ya el general del exército toda a punto la gente diputada para dar el assalto y hecho en diversas partes tocar arma y assaltar la fortaleza, como se usa, para divertir la gente que la guarda, si dando fuego, después de tanto aparato, a la mina, no le sucediesse como desseava! // Mosquera, Comentario disciplina militar, 1596, fol. 39v: Y bolviendo a nuestra historia, se acordó en que fuessen las galeras y pinaças, para que a media noche hiziessen cuerpo de armada, a tocar arma falsa por tres puestos al enemigo, para inquietarlo y divertirlo y que, con este desassossiego, no entendiesse por dónde se avía de acometer.

ENCICL.: Aut. (s.v. divertir al enemigo, o sus fuerzas): Frase usada en la guerra que denota inquietar o atacar al enemigo por diversas partes, para que divida sus tropas o levante el sitio que está haciendo, o le debilite o enflaquezca. // D'Wartelet (1863: s.v. divertir al enemigo): loc. mil. Llamar la atención de las tropas contrarias hacia una o varias partes, para que acudiendo a ellas desmembre sus fuerzas, dejando débil el punto en el que se intenta el ataque verdadero.

\section{divirtir, V. divertir.}

domar, domar [del lat. dŏmare 'íd.'. Doc. de 1030, en Oelschl.; Berceo (DECH). Collado, Plática Artillería, 1592]. v. tr. Mil. Poner una persona bajo su poder a individuos o territorios.

Collado, Plática Artillería, 1592, fol. 1v: Domaron aquéllos por sola ambición tantos reynos y provincias, pero Vuestras Magestades, por castigar los herejes y rebeldes vassallos, tomaron siempre las armas; aquéllos, por usurpar agenos dominios, Vuestras Magestades, por conservar los suyos propios, favorescer los príncipes amigos y confederados, conquistar y restituyrles reynos y estados. / / Mosquera, Comentario disciplina militar, 1596, fol. 141r: Estimó Roma, sin comparación, más el estado de la paz y disciplina política, tanto que se le da gloria particular al emperador Augusto César que, después de aver domado y vencido con pura fuerça de armas diversas provincias, puso a todo el mundo en paz universal y cerró el templo del dios Jano en señal de común reposo. // Roxas, Sumario milicia, 1607, fol. 55v: Finalmente corregido con la fea paz que avía hecho, de allí adelante peleó contra los moros y así domó a Galicia que se lebantava.

SIN.: allanar, domeñar, domesticar, señorear, sojuzgar, someter, sujetar 1 .

ENCICL.: Cov.: Vale sujetar, rendir, traer al punto de lo que se pretende al hombre, al animal, a la materia que resiste [...].

domeñar, domeñar [probablemente del lat. vg. domĭnı̆are, derivado de domĭnĭum 'dominio'. Domellar, 2 ejs. s. XIII, trads. de la Biblia; domeñar, 1529, Guevara, y 
frecuente desde entonces (DECH). Mosquera, Comentario disciplina militar, 1596]. v. tr. Mil. Poner una persona bajo su poder a individuos o territorios.

Mosquera, Comentario disciplina militar, 1596, fol. 6r-6v: No tenemos que admirarnos de los romanos si (como Apiano dize) el Emperador Adriano entretenía dozientos mil hombres de a pie, quarenta mil cavallos, trezientos elefantes, dos mil carretas y en lo que aora es Venecia, en un arçanal, tenía para armar trezientos mil hombres y dos mil navíos medianos, mil y quinientas galeras, y las ochenta d'ellas doradas y talladas, que donde concurría la potencia de Roma, y assí el mundo sujetó a ella, con solamente el estruendo bastava a vencer y domeñar los hombres.

SIN.: allanar 3 , domar, domesticar, señorear, sojuzgar, someter, sujetar 1.

ENCICL.: DRAE: Someter, sujetar y rendir.

domesticar, domesticar [de doméstico. 1386, López de Ayala, testimonio aislado algo sospechoso; frecuente desde fines del s. XVI, Fr. L. de Granada (DECH). Mosquera, Comentario disciplina militar, 1596]. v. tr. Mil. Poner una persona bajo su poder a individuos o territorios.

Mosquera, Comentario disciplina militar, 1596, fol. 97r: Venían juntamente muchos de los naturales de las islas rendidos, de aquellos contra quien no se avía procedido, cosa que estoy por afirmar no acordarse las historias que se aya visto un exército junto, en proporción tan numeroso, y tan opuesto al nuestro y tan sobrado de armas y municiones, encastillado en tierra montuosa y fortificada que assí se aya domesticado, como el que de los nuestros oy se a visto.

SIN.: allanar ${ }_{3}$, domar, domeñar, señorear ${ }_{3}$, sojuzgar ${ }_{2}$, someter, sujetar ${ }_{1}$.

FAM.: doméstico.

doméstico, doméstico [tomado del lat. domestǐcus 'de la casa, doméstico', derivado de dómus 'casa'. h. 1440, A. Torre; h. 1490, Celestina; 1555, Laguna (DECH). Ufano, Tratado de la Artillería, 1613]. adj. Mil. Dicho de un individuo o de un territorio: colocado bajo el dominio o el poder de alguien.

Ufano, Tratado de la Artillería, 1613, pág. 169: El no nombrar cañones ni culebrinas en la primera es la prinçipal çausa, Señor Illustríssimo, el no ser neçessaria la artillería gruesa en otras simples plaças que las de los reales castillos y fortalezas de gran caudal y estendida, que sirven de freno y brida a una ynsigne y populosa çiudad, que en las tales cumple y conviene, para subjetarlas y tenerlas domésticas, aya solamente los cañones de batería con las pieças del artillería menuda tratadas en la anotación de la provisión d'ésta.

SIN.: sojuzgado, sujetado, sujeto 1 .

FAM.: domesticar. 
echo, V. hecho.

ejecutar, V. la victoria.

ejército, ejército, ejérçito, exército, exérçito [del lat. exĕrcŭtus, propiamente 'cuerpo de gente instruida militarmente'. Ex-, Mena, Santillana; APal.; 1545, P. Mejía (DECH). Montes, Instrucción y regimiento, 1537]. sust. Conjunto de tropas militares con los pertrechos correspondientes, unidas en un cuerpo bajo las órdenes de un mando (DRAE).

Montes, Instrucción y regimiento, 1537, fol. Vv: Después que el exército sea junto, deve proveer el general las vituallas que fueren menester para el mantenimiento del exército, conforme a la gente que va en él y conforme a la provincia donde la guerra se ha de hazer. // Álaba, Perfeto capitán, 1590, fol. 66v: De donde vinieron los romanos, gente tan señalada en la diciplina militar, a juzgar por más útiles los exércitos pequeños de soldados esperimentados y exercitados en el trato de las armas que los que tenían muchos millares de hombres de pelea faltos d'este adorno. // Roxas, Sumario milicia, 1607, fol. 63r: Muchos y poderosos exérçitos se an lebantado en el mundo para dibersas conquistas y jornadas. Conforme al pareçer de grandes cappitanes no consisten las vitorias d'ellos y buenos suçesos de la guerra en el número de la jente, sino en el yngenio y valor del general, y en la obediençia y esfuerço de sus soldados; y así bemos que aquel famoso Alexandro con un pequeño exérçito acometió las ynnumerables jentes de Darío y lo vençió.

ENCICL.: DEA: Conjunto importante de tropas reunidas para el combate. 
ejérçito, V. ejército.

embarrar, embarrar [de barra, voz prerromana común a todas las lenguas romances menos el rumano. Embarrar 'introducir una barra', ant. 'encerrar'. h. 1275, 1. ${ }^{a}$ Crón. Gral. (DECH). Celso, Reportorio universal leyes Castilla, 1553]. v. tr. Mil. Acorralar o arrinconar al enemigo (DRAE).

Celso, Reportorio universal leyes Castilla, 1553, fol. CLXr: Embarrar se dize quando en guerra embarran a los contrarios, de manera que a ninguna parte osan salir, e que los han después entrar por fuerça.

FAM.: barrera.

ENCICL.: Domínguez (1853): ant. Cortar el paso, acorralar al enemigo imposibilitándole la salida.

embestir, embestir, envestir [probablemente del it. investire 'acometer, atacar con violencia', procedente del lat. investire 'revestir', 'rodear', derivado de vestire 'vestir'. 1554, 1561, Fr. L. de Granada (DECH). Álaba, Perfeto capitán, 1590]. v. intr. Mil. Ir con ímpetu y furia sobre alguien o sobre algo.

Álaba, Perfeto capitán, 1590, fol. 70v-71r: Los capitanes, [...], lo que con todas sus fuerças procuravan era acossar y descomponer sus enemigos con cautelas, assechanças y ardides, esperando el acometerlos en tiempo que su resistencia fuesse de muy poco efeto, ni los reparos que tenían pudiessen impedir el daño que se les pretendía hazer, envistiendo con ellos quando, o del largo camino sabían que estavan despeados y fatigados, de suerte que no pudiessen ponerse en defensa. // Álaba, Perfeto capitán, 1590, fol. 76v: También juzgo por negocio precisso el acometer quando el capitán viesse su gente, o la mayor parte d'ella, tan dispuesta a envestir con el enemigo que no fuesse bastante a reprimir su furia y, de quererlo hazer, conociesse que le han de desamparar o perder el respeto. // Mendoça, Theórica y práctica, 1596, pág. 57: Assimismo se estima por buena orden de batalla sacar al lado derecho de los esquadrones de picas y lanças unas tropas, en número de la quinta parte de lo que es el esquadrón, para envestir sobre el costado del enemigo al tiempo del cerrar, el qual, si buelve la frente a la tropa, da el costado al esquadrón, y si se afronta con él, forçosamente descubre el lado a la tropa.

SIN.: arremeter, remeter.

ENCICL.: DECH: Nótese la tendencia a construir embestir a como si fuese intransitivo.

2 [García de Palacio, Diálogos militares, 1583]. v. tr. Mil. Lanzarse contra alguien para causarle daño o para vencerle. 
García de Palacio, Diálogos militares, 1583, fol. 71r: Para lo qual es buen exemplo aquel caso que Tito Livio refiere, que subcedió entre Favio, ditador romano, y Minucio, capitán de la cavallería, contra Aníbal, que, porfiando Minucio con el Favio sobre si era razón pelear con Aníbal, apartó sus cavallos y, sin seguir el buen consejo de Fabio, envistió al enemigo, y, si después que Favio lo vio casi roto, no lo socorriera, se perdería por su porfiada inadvertencia y poca experiencia, que paresce tenía. // Álaba, Perfeto capitán, 1590, fol. 131r: Y assí, la artillería pequeña es la que más puede ofender, y para prevenir su ofensa el remedio que yo hallo mejor es envestirla con presteza, señalando para este acometimiento algunos infantes perdidos y algunos arcabuzeros a los lados del esquadrón, y otro número de arcabuzeros de a cavallo y estradiotes. // Ufano, Tratado de la Artillería, 1613, pág. 208: Otra cosa quiero preguntar a Vuestra Merced y es que si, estando batiendo, los contrarios saliesen fuera y, embistiendo y asaltando la batería, enclavasen las pieças, ¿qué remedio se ternía después de recobradas para servirse aquel día d'ellas?

SIN.: acometer, atacar, combatir 3 , ofender.

ANT.: defender 2 .

ENCICL.: Estévanez (1897): Lo mismo que atacar o acometer. // DUE (s.v. atacar): El complemento directo puede ser también el sitio donde están las personas o animales atacados.

emboscada, emboscada, embuscada, enboscada [del it. imboscata (primera mitad del s. XIV) (Battaglia 1961-2002). Montes, Instrucción y regimiento, 1537]. sust. Mil. Ardid de guerra que consiste en ocultar gente en un lugar para una operación militar o para asaltar a alguien.

Montes, Instrucción y regimiento, 1537, fol. XIv: E si la batalla fuere de noche, no se salgan de su fuerte, porque podrían tener algunas embuscadas que los rompiesen, mas deven guardar su fuerte, porque de una manera han de pelear los que son acometidos y de otra manera han de pelear los que van a acometer. // Collado, Plática Artillería, 1592, fol. 97v: Viniendo, pues, a tratar de la horden de marchar con el artillería, será aquesta: que delante de ella, por buen espacio de camino y por los lados, van las escoltas de cavallos ligeros, los quales, en descubriendo alguna enboscada o otra acechança de el enemigo, den inmediatamente aviso en el campo. // Rojas, Teórica fortificación, 1598, fol. 37v: Ay muchas opiniones entre soldados, en que unos dizen que sea el fosso seco, para hazer las salidas y emboscadas en él, y desde allí salir en tropa a ofender al enemigo, porque, siendo con agua, se hazen mal estas salidas, porque son menester varcas o planchadas para salir a la estrada cubierta.

SIN.: celada .

ENCICL.: Aut.: El ardid de guerra de encubrirse alguna gente en algún bosque o parte retirada, para tomar al contrario desapercibido. 
2 [Mendoça, Theórica y práctica, 1596]. sust. Mil. Tropa apostada en lugar oculto para sorprender al enemigo (Alemany y Bolufer 1917).

Mendoça, Theórica y práctica, 1596, pág. 149: Reconocido esto, han de hazer subir algún soldado en uno de los árboles, de donde pudiere descubrir más lexos y advertirlos de lo que vee, estando otro soldado a cavallo al pie del árbol para dar aviso a la cabeça de la emboscada de lo que refiere el del árbol. // Mendoça, Theórica y práctica, 1596, pág. 150: Y la emboscada no ha de salir sobre ellos hasta tanto que aya passado d'ella y los pueda cargar por las espaldas, sin que se les dé lugar para bolver a la tierra, cosa que ha de hazer saliendo con buena orden y apressurar o no la carga con el trote o galope, según el efecto que quiere executar.

SIN.: celada .

ENCICL.: Terr.: Gente escondida para atacar al enemigo con mucha ventaja y poco riesgo.

poner en $\sim$ [Álaba, Perfeto capitán, 1590]. loc. v. Mil. Ocultar gente en un sitio para una operación militar o para asaltar a alguien.

Álaba, Perfeto capitán, 1590, fol. 61r: Y no será ardid de poca importancia, después de aver dado a entender al enemigo que se espera socorro, poner algunos soldados en emboscada con orden que quando estuviere començada la batalla, luego que les fuere hecha la seña concertada, acudan para que los enemigos, viéndolos venir sobre ellos de repente, juzgando que les a venido el socorro que esperavan, se acovarden y descompongan de suerte que puedan recebir el daño que la descompostura y desorden de un campo traen consigo.

SIN.: emboscar, poner en celada.

emboscado, emboscado [de emboscar. Álaba, Perfeto capitán, 1590]. adj. Mil. Dicho de una persona: oculta en un sitio para una operación militar o para asaltar a alguien.

Álaba, Perfeto capitán, 1590, fol. 71v: Y Leponte, siracusano, trayendo guerra con los cartagineses, viniéndole ellos a buscar, mandó poner fuego a algunos de sus propios campos, castillos y lugares, lo qual visto por los cartagineses, imaginando que este estrago lo avían hecho algunos de los suyos, fueron a favorecerlos y a acabar de destruyr lo que quedava, descuydados del daño que se les siguió, que fue ser muertos por los que estavan esperándolos emboscados y puestos al passo por donde avían de venir.

FAM.: emboscar.

2 [Álaba, Perfeto capitán, 1590]. sust. Mil. Persona apostada en lugar oculto para sorprender al enemigo.

Álaba, Perfeto capitán, 1590, fol. 91r: Y Himilco, teniendo cercada una villa llamada Agrigentum, mandó emboscar de noche cerca d'ella parte de su gente, con orden que, en 
alexándose él hasta cierta distancia con su campo, saliessen los emboscados a encender alguna leña verde y otras cosas que levantassen grande humo. // Álaba, Perfeto capitán, 1590, fol. 136r: Hecha por el capitán la señal con alguna pieça de artillería o de otra suerte, salgan los emboscados y, dando sobre ellos con buen orden, los desbaraten y hagan el daño que de ordinario reciben los que se hallan atajados y turbados de algún caso repentino que nunca imaginaron.

ENCICL.: DUE: Participio de emboscar(se). Se aplica al que está emboscado.

emboscar, emboscar, embuscar [del it. imboscare. Ya Nebr. en las acs. 'meter en el bosque', 'convertir en bosque', pero en la de 'poner en emboscada' no aparece hasta Hurtado de Mendoza (1571-75) (DECH). Montes, Instrucción y regimiento, 1537]. v. tr. u. t. c. prnl. Mil. Ocultar gente en un sitio para una operación militar o para asaltar a alguien.

Montes, Instrucción y regimiento, 1537, fol. XVIIIr: Si el castillo está en cerro alto, hágale peñar el cerro, por manera que en todo el cerro donde el castillo estuviere assentado, de lo alto a lo baxo, no haya ningún reparo ni otra cosa donde los enemigos se pudiessen embuscar, sino que todo esté limpio y peñado, porque los soldados del castillo puedan tirar a los enemigos quando subieren el cerro. // Álaba, Perfeto capitán, 1590, fol. 91r: Y Himilco, teniendo cercada una villa llamada Agrigentum, mandó emboscar de noche cerca d'ella parte de su gente, con orden que, en alexándose él hasta cierta distancia con su campo, saliessen los emboscados a encender alguna leña verde y otras cosas que levantassen grande humo. // Ufano, Tratado de la Artillería, 1613, pág. 80: Mandó al governador Hernán Rello, que lo era de la villa de Dorlán, que con la gente de las guarniçiones marchase la buelta de dicha Amiens y que se emboscase secretamente en una abbadía $\mathrm{y}$, al abrir de la puerta, embiasse algunos soldados españoles y valones disfraçados en hábito y lenguage de villanos y otros con un carro de feno para sustener el rastrillo, que no çerrase, metiéndole debaxo, y otro con un saco de nueçes.

SIN.: poner en celada, poner en emboscada.

FAM.: emboscado.

embuscada, V. emboscada.

embuscar, V. emboscada.

empaliçada, V. empalizada.

empalizada, empaliçada, empalizada [de palizada. h. 1640, Ovalle, Aut. (DECH). Loçano, Alberto, Architectura, 1582]. sust. Fort. Conjunto de estacas o de 
palos clavados en el suelo, y normalmente enlazados mediante travesaños de madera, que sirve para impedir el paso al enemigo. (fig. 59)

Loçano, Alberto, Architectura, 1582, pág. 140-141: Y si la empalizada se haze para vedar los socorros a los cercados y las vituallas traýdas de otra parte, cierto, de esta manera los conseguiréys a vuestra voluntad, si queriendo que esto te salga cómmodamente según tu designo, les occupares primero todos los caminos y se los cerrares. // Ufano, Tratado de la Artillería, 1613, pág. 277: Y así, desclavados y apartados [los travesaños], fáçilmente con el troçador se troçarán, romperán o espartirán las estacas de la parte de la empaliçada que bastará a dar amplia y libre entrada a la gente que supliere a la execuçión de tal empresa. // Ufano, Tratado de la Artillería, 1613, pág. 277: Y quando, por eminente peligro, no bastaren los dichos ynstrumentos, por no ser sentidos en la faena del trabajo y golpear de las herramientas y croxido de las estacas, secreta y quietamente, con la obscuridad de la noche, se ligará a la parte que se aya de romper y abrir de la empaliçada con cuerdas de ligamen una rueda artiffiçiada de fuego repentino a tiempo limitado.

SIN.: estacada 1 , palenque, palizada .

FAM.: empalizar, palizada.

ENCICL.: Terr.: Term. de fortificación. Es una cerca o fila que se hace con estacas fijas en el suelo. // DRAE: estacada. // DRAE (s.v. estacada): Obra hecha de estacas clavadas en la tierra para defensa, o para atajar un paso. // Lopes Pires Nunes (2005: s.v. paliçada): Na fortificação abaluartada costumava construir-se sobre a banqueta do caminho coberto.

empalizar, empalizar [de empalizada. Acad. s. XIX o XX (DECH). Loçano, Alberto, Architectura, 1582]. v. intr. Fort. Construir palizadas o empalizadas.

Loçano, Alberto, Architectura, 1582, pág. 102: Y conviene, cierto, guardar que no esté encima levantado algún monte apegado, el qual, occupado, moleste el enemigo, o que no se estienda al enemigo alguna segura llanura tan grande que en tal lugar pueda empalizar para sitiar o ordenar su esquadrón para dar assalto.

FAM.: empalizada, palizada.

empresa, empresa, empressa, enpresa, impressa, ympresa [del it. impresa (siglo XIV) 'guerra, spedizioni e sim.'. (Battisti y Alessio 1975). Montes, Instrucción y regimiento, 1537]. sust. Mil. Combate o cualquier otra operación militar llevada a cabo en una guerra.

Montes, Instrucción y regimiento, 1537, fol. XIv: Se ha de mirar y desvelar cómo y de qué manera y por qué vía, y a qué hora, y con quánta gente se dará el salto a los enemigos, e si al tiempo que se diere se podrá haver vitoria, y qué tanta gente podrá haver para la resistencia. Porque si los capitanes conoscieren que no podrán salir con la empresa, no la deven principiar. // Álaba, Perfeto capitán, 1590, fol. 136r: Y aviendo de embiar algunos soldados a alguna fación o empresa en parte donde huviere peligro, embiará los más inútiles y de menos importancia, porque, quando se pierdan, se aventure poco. // 
Collado, Plática Artillería, 1592, fol. 110v: Ya que vos, artillero hermano, de las facciones de tierra y del modo de servirse en ellas de la artillería havéys dado buena cuenta, veamos agora: ¿cómo os regiríades en una naval empresa y mandándoos hir a servir de capitán de artilleros o de cabomaestro de una nave de armada, o sobre una galera?

SIN.: empresa de (la) guerra, empresa militar, encuentro ${ }_{1}$, facción $_{2}$, facción de guerra, hecho de armas, interpresa $a_{1}$, reencuentro ${ }_{1}$.

ENCICL.: Terr.: Resolución y hecho valeroso, difícil y expuesto [...]. V. Golpe. Dícese de las acciones literarias, militares, de comercio, etc. // Moretti (1828): La acción ardua y dificultosa que valerosamente se comienza; dase el nombre de empresa militar a la resolución de un ataque, de una expedición, de una marcha o retirada arriesgada, de una sorpresa, de un asalto, etc. // López Vallejo (2008): Acción u operación militar.

$\sim$ de guerra, o de la guerra [Collado, Plática Artillería, 1592]. cmpt. sintag. Mil. Combate o cualquier otra operación militar llevada a cabo en una guerra.

Collado, Plática Artillería, 1592, fol. 10v: Después de haver en los precedentes capítulos tratado de la verdadera y perfecta fundición de las pieças de artillería, traýdo diversos advertimientos utilíssimos y muy necessarios, assí a los príncipes que mandan fundirla como a los fundidores y artilleros que han de fundirla y exercitarla en qualquiera enpresa de guerra, en el presente capítulo, de aquellas cosas, instrumentos y herramientas que en las funderías que Su Magestad Cathólica manda hazer en Italia, provee, paga y sustenta a su costa, se trata. // Collado, Plática Artillería, 1592, fol. 54v: Algunas vezes acontesce en las empresas de la guerra ser forçados los generales a haver de romper y hazer pedaços el artillería, y esto unas vezes hallándose sitiados, porque no se sirvan de ellas los enemigos.

SIN.: empresa, empresa militar, encuentro ${ }_{1}$, facción ${ }_{2}$, facción de guerra, hecho de armas, interpresa $a_{1}$ reencuentro 1 .

militar [Collado, Plática Artillería, 1592]. cmpt. sintag. Mil. Combate o cualquier otra operación militar llevada a cabo en una guerra.

Collado, Plática Artillería, 1592, fol. 88v: Y assí como el uso d'estas puentes es de gran servicio en las empresas militares, assí acerca de ellas se han de tener muchas y muy grandes consideraciones.

SIN.: empresa, empresa de (la) guerra, encuentro ${ }_{1}$, facción ${ }_{2}$, facción de guerra, hecho de armas, interpresa $a_{1}$, reencuentro 1 .

empressa, V. empresa.

enboscada, V. emboscada. 
encamisada, encamisada [de encamisar (DECH). Montes, Instrucción y regimiento, 1537]. sust. Mil. Ardid de guerra que consiste en asaltar de noche a los enemigos, para cogerlos desprevenidos.

Montes, Instrucción y regimiento, 1537, fol. XIIv-XIIIr: Otras maneras de guerra se podrían tener para romper a los muchos, assí como emboscadas o encamisadas que les armen de noche, tomándolos sobre seguro o en algún passo estrecho, dándoles algún recuentro por donde les hiziessen perder parte de su exército. // Mendoça, Theórica y práctica, 1596, pág. 112: Juntamente se ha de considerar que la encamisada no sea por la parte donde tiene su plaça de armas el enemigo, porque con un tocarse, dando en sus quarteles, ha de acudir necessariamente allá la gente enemiga, y con esto se impide el no hallar espaldas a la retirada los encamisados. // Ufano, Tratado de la Artillería, 1613, pág. 381: Serán ynstrumentos de mucho provecho y utilidad para resistir el asalto del enemigo y offenderle con tal ynvención y arte dando sobre él, cogiéndole de sobresalto en una encamisada o salida, y quemarle sus quarteles.

FAM.: camisa, encamisado, encamisar.

ENCICL.: Cov.: Es cierto estratagema de los que de noche han de acometer a sus enemigos y tomarlos de rebato, que sobre las armas se ponen las camisas, porque con la oscuridad de la noche no se confundan con los contrarios. // Estévanez (1897): Sorpresa u operación nocturna, llamada así porque se acostumbraba ponerse las camisas, cuando las había, por encima de las armaduras para reconocerse; si no había camisas, recurríase a papeles u otra señal para evitar confusiones, tan fáciles en la noche cuando eran iguales las armaduras de amigos y enemigos. // Mendoça, Theórica y práctica (1596: pág. 111-112): "Quando se acercan más los campos y ay lugar de reconocer los alojamientos, procuran de enflaquecer al enemigo los generales vigilantes, dándole encamisadas, facción en que Vuestra Alteza ha de dar oýdos a los capitanes viejos, gozando con presteza de la ocasión, si se ofrece, porque no se pierda, previniendo el enemigo el daño que se le podría hazer en semejante facción con reforçar las guardias, fortificar los quarteles o mejorar de alojamiento, cosas que anteverán los soldados de experiencia, y el peligro que puede tener la encamisada, que no descubren los más moços con el alboroço del pelear, encomendando la execución d'ella a soldado que sea de experiencia, executivo y de mucho tiento y de quien tengan los que van con él a executar buena opinión, por ser lo que más abiva y anima los soldados la buena dicha en las facciones del que los guía y hallarse en él semejantes partes, pues por ser facción de noche se acierta con puntualidad pocas vezes y se errará todas si los soldados no tienen del que los guía satisfación".

2 [Mendoça, Theórica y práctica, 1596]. sust. Mil. Tropa que asalta de noche a los enemigos, para cogerlos desprevenidos.

Mendoça, Theórica y práctica, 1596, pág. 112: Para salir por otra parte diferente de la entrada han de ser muy pláticos del sitio las cabeças que los guían y tener bien reconocidos los quarteles (lo qual se haze con dificultad) donde ha de entrar la gente, por aver de ser arcabuzería y alavardas, repartidos en tropas, guiando los cabos particulares que se esparzirán por los quarteles, teniendo consigo la cabeça de la encamisada la 
trompeta o atambor con que se ha de hazer seña de la retirada, para que oyéndola acudan todos al puesto acordado por donde han de salir.

encamisado, encamisado [de encamisar (DECH). González de Medina, Examen fortificación, 1599]. sust. Fort. Capa que se hace de diversos materiales para revestir y sostener el terraplén de cualquier obra de fortificación.

González de Medina, Examen fortificación, 1599, pág. 127: Ha de tener el contraescarpe encamisado de muralla de piedra, por estar seguros de que con el açada no desemboque en el foso por debaxo de tierra, sangrado el foso, porque ha de ser con agua, por no estar siempre con sobresalto si les arriman escalas y se la roban, y también por escusar, quando se estuviere con algún temor, de que de noche no se alborote cada passo y se toque arma desassossegando los de la fuerça y de la tierra.

SIN.: camisa 1.

FAM.: camisa, encamisada, encamisar.

2 [Mendoça, Theórica y práctica, 1596]. sust. Mil. Persona que asalta de noche a los enemigos, para cogerlos desprevenidos.

Mendoça, Theórica y práctica, 1596, pág. 112: Juntamente se ha de considerar que la encamisada no sea por la parte donde tiene su plaça de armas el enemigo, porque con un tocarse, dando en sus quarteles, ha de acudir necessariamente allá la gente enemiga, y con esto se impide el no hallar espaldas a la retirada los encamisados.

encamisar, encamisar [de camisa. 1590, B. Mendoza (DECH). González de Medina, Examen fortificación, 1599]. v. tr. Fort. Cubrir o fortalecer con camisa el terraplén de una construcción.

González de Medina, Examen fortificación, 1599, pág. 41-42: La contraescarpe tendrá veynte pies de alto del plano del foso, cortado del terreno, encamisado con muralla de piedra de tres pies de ancho, porque se assegura mucho de que con las aguas no se vaya arruynando y comiéndolo de la estrada cubierta y la dexe incapaz, y ayuda a ensuziarse el foso. // González de Medina, Examen fortificación, 1599, pág. 112: Hanse de hazer unos poços grandes y bien hondos para cisternas, enlosados y encamisados de piedra, muy bien revocados con algún betún, que se pueda tener seguridad de que no se reçumarán ni los podrán sangrar por fuera; y con todas estas comodidades o avisos, siempre que se pudiere escusar el fortificar en alto y áspero será bien.

FAM.: camisa, encamisada, encamisado. 
encastillarse, encastillarse [de castillo. Encastellar, Nebr. (DECH). Mosquera, Comentario disciplina militar, 1596]. v. prnl. Mil. Refugiarse en un castillo o en un paraje alto o de difícil acceso (DEA: s.v. encastillar).

Mosquera, Comentario disciplina militar, 1596, fol. 97r: Venían juntamente muchos de los naturales de las islas rendidos, de aquellos contra quien no se avía procedido, cosa que estoy por afirmar no acordarse las historias que se aya visto un exército junto, en proporción tan numeroso, y tan opuesto al nuestro y tan sobrado de armas y municiones, encastillado en tierra montuosa y fortificada que assí se aya domesticado, como el que de los nuestros oy se a visto. // Mosquera, Comentario disciplina militar, 1596, fol. 109r: Se bolvían a los nuestros con ánimo y escaramuçavan hasta que se recogieron a dos montañuelas que están sobre la fortaleza principal, nombradas las montañas de la Señora, donde se encastillaron y entretuvieron la mayor parte del día.

FAM.: castillo.

ENCICL.: D'Wartelet (1863): 1- Encerrarse en un castillo o fortaleza para defenderse. 2Acogerse a parajes elevados y ásperos, fuertes por naturaleza, para poder resistir a fuerzas superiores. Los riscos, las sierras y demás lugares escabrosos y de difícil acceso son los sitios que generalmente ocupan los guerrilleros para defenderse, quizá mejor que de detrás de fuertes murallas, pues conocedores del terreno tienen salida fácil en caso de descalabro.

encubierto, V. estrada .

encuentro, encuentro, enqüentro [de encontrar y éste de contra. 1283, Libros del Acedrex; h. 1400: Glos. de Toledo; Nebr. (DECH). Montes, Instrucción y regimiento, 1537]. sust. Mil. Combate o cualquier otra operación militar llevada a cabo en una guerra.

Montes, Instrucción y regimiento, 1537, fol. Xv: Y los cavallos ligeros han querido usar las lanças de ristre y hállanse bien con ellas, y no les hallan sino solo un defecto: que las lanças de ristre no se pueden aprovechar d'ellas más de un encuentro, y las lanças ligeras, que comúnmente llaman ginetas, sírvense d'ellas en todo el tiempo que la guerra dure, lo que no hazen de las otras, porque de las otras no se sirven más de para un encuentro. // Montes, Instrucción y regimiento, 1537, fol. XIIIr: Porque a los primeros encuentros no pelean sino las diez hileras primeras $y$, si aquéllas se rompen, es roto el exército, porque siempre se ha visto, rompidas las primeras hileras, ser roto el exército. // Álaba, Perfeto capitán, 1590, fol. 140r: Y aun en este caso digo que si un campo muy poderoso tiene determinación de romper con otro de igual poder $\mathrm{y}$, a los primeros encuentros, alguna parte d'él, justa o injustamente, huyó, que los que quedaron no están obligados a esperar, sino que lícitamente pueden huir.

SIN.: empresa, empresa de (la) guerra, empresa militar, facción 2 , facción de guerra, hecho de armas, interpresa $a_{1}$, reencuentro . $_{1}$ 
FAM.: reencuentro.

ENCICL.: DUE: Acción de guerra.

2 [Álaba, Perfeto capitán, 1590]. sust. Mil. Pelea o enfrentamiento que tiene lugar cuando se topan casualmente dos fuerzas o tropas contrarias.

Álaba, Perfeto capitán, 1590, fol. 41r: El mesmo cuydado tendrá en que sepan nadar [...], principalmente para las batallas de mar y para los sucessos que por tierra se suelen ofrecer, pues no por todos los passos y ríos ay puentes por donde passar y, quando las aya, suceden tantos encuentros en ellas que la mayor parte de los exércitos suelen caer al agua. // Álaba, Perfeto capitán, 1590, fol. 44r: Y tenga recato el capitán en no dar parte a alguno [...], por el peligro que ay de que, sabiéndolo el enemigo de algunas espías que para esto tenga puestas de los suyos, o de la gente del mesmo campo, como muchas vezes sucede, no se fortifique en algún passo peligroso y haga estrago en los que caminan descuydados d'este encuentro y acometimiento. // Ufano, Tratado de la Artillería, 1613, pág. XIII: Y aunque es verdad que ha avido algunos authores que an escrito sobre el usso y manejo del artillería y cosas tocantes d'él, no a sido con la particularidad y esperiençia que Vuestra Merced, pues es claro que se tiene mucha mayor ahora que en el tiempo que los otros authores escrivieron, por las continuas guerras que ha avido después acá, particularmente en estos estados, donde se ha ofreçido tantas veces campear con nuestros exérçitos al opósito de los del enemigo, donde ha avido muchas escaramuças, enqüentros y batallas, sitios de plaças y ser sitiados en ellas.

SIN.: reencuentro 2 .

ENCICL.: Almirante (1869: s.v. batalla): Cuando la acción es casual entre dos pequeñas fracciones se llama encuentro; y si se verifica entre tropas ligeras, sin que ninguno de los dos partidos se comprometa mucho, sino que más bien intenten ambos tantearse las fuerzas y procuren uno $\mathrm{u}$ otro cortarse o envolverse, se llama escaramuza, según el uso común, cualquiera que sean las armas, esto es infantería o caballería. // Corsini (1849): Choque, combate, ataque inopinado e imprevisto, propio de las partidas y tropas de vanguardia, y que les ocurre frecuentemente en sus descubiertas, reconocimientos y expediciones.

enemigo, enemigo, henemigo [del lat. ̌̆nı̆mīcus, derivado privativo de amicus. Cid (DECH). Loçano, Alberto, Architectura, 1582]. adj. Mil. Dicho de un individuo, de una colectividad o de un lugar donde hay personas: opuesto o enfrentado a otro $\mathrm{u}$ otros.

Loçano, Alberto, Architectura, 1582, pág. 304: Los persas avían impedido el río Tygris con ciertos impedimentos que echaron para que ningún navío enemigo pudiesse subir por alguna parte. // Collado, Plática Artillería, 1592, fol. 91v: Algunas vezes se le offrescerá al artillero la necessidad de alçar el sitio o plaça donde se ha de plantar el artillería, allanarla y ensancharla, y otras, por no haver la comodidad de sitio donde plantarla, levantar bestiones de tierra para, dende allí, batir la fortaleza enemiga. // Rojas, Teórica 
fortificación, 1598, fol. 3v: Y también se tendrá cuidado de no erigir el castillo cerca de algún valle o cañada donde pueda estar alojado algún exército enemigo, y quando por algunos respetos fuesse fuerça hazerlo allí, se pondrá mucho cuidado en plantar la fortaleza a vista y de forma que descubra y varra todo el valle.

SIN.: contrario 1 .

ANT.: amigo 1.

ENCICL.: Rubió y Bellvé (1895-1901): Adjetivo que se aplica al estado, ejército, tropa, bando, parcialidad o individuo cuyas aspiraciones son contrarias a las de otra entidad análoga. // DRAE: adj. Dicho de una persona o de un país: Contrarios en una guerra.

2 [Fernández de Enciso, Suma de Geographía, 1530]. sust. Mil. Con respecto a una persona, otra que lucha contra ella (DUE: s.v. adversario).

Fernández de Enciso, Suma de Geographía, 1530, fol. XXXIv: Las mugeres d'estos iberinos son a natura feroces, pelean e ayudan a sus varones varonilmente. Contra los romanos se mostraron hazañosas; si se veýan vencidas, matavan a sus hijos porque no fuessen en poder de sus enemigos. // García de Palacio, Diálogos militares, 1583, fol. 164v: Pónense, pues, estos infantes perdidos o órdenes falsas, para que, yendo assí encubiertos, un poco antes de calar las picas, saliendo por los costados con sus picas arboladas, las echen tendidas sobre las picas caladas de los contrarios, de que pueden los enemigos rescebir gran daño. // González de Medina, Examen fortificación, 1599, pág. 198: El fuego sirve de tres cosas, que son: quemar, y encubrir la vista a los enemigos, que no vean a los que trabajan dentro, y que con el humo y olor de cosas tan malas como se le pueden echar se ahoguen y los ahuyenten de sí.

SIN.: adversario ${ }_{1}$, contendedor, contrario ${ }_{2}$.

ANT.: amigo $_{3}$.

ENCICL.: Aut.: El contrario en la guerra, aquél a quien se le hace o con quien se tiene públicamente.

3 [Montes, Instrucción y regimiento, 1537]. sust. Mil. Respecto a un grupo de personas, otro que lucha contra él.

Montes, Instrucción y regimiento, 1537, fol. XVv: No digo yo que los generales no den batalla, sino que defiendo que la batalla no sea aplaçada, sino que, pues los exércitos están en campaña dessafiados, con desseo de hazerse todo daño el uno al otro, cada uno procure como mejor pudiere de tomar a su enemigo en la cama. // Loçano, Alberto, Architectura, 1582, pág. 102: Y conviene, cierto, guardar que no esté encima levantado algún monte apegado, el qual, occupado, moleste el enemigo, o que no se estienda al enemigo alguna segura llanura tan grande que en tal lugar pueda empalizar para sitiar o ordenar su esquadrón para dar assalto. // Roxas, Sumario milicia, 1607, fol. 67r: Así que se repartieran en esta forma, quatro regimientos que bayan de banguardia, aviendo echado suertes a 
quién le toca la primera bez, y quatro en batalla y otros quatro en retaguardia, y el que queda será de guardia al bagaje con mil cavallos, y si fuere la sospecha del enemigo grande, serán dos mil.

SIN.: adversario 2 , contrario 3 .

ENCICL.: DRAE: Conjunto de personas o de países contrarios a otros en una guerra.

enfortalecer, enfortalescer [de fortalecer. h. 1400, Glos. del Escorial (DECH). Celso, Reportorio universal leyes Castilla, 1553]. v. tr. Fort. Dar protección a un lugar o posición con reparos o defensas.

Celso, Reportorio universal leyes Castilla, 1553, fol. LIXv: Deven ser acorridos los castillos por los alcaydes enfortalesciéndoles, haziendo labrar a todos, sin escusar ninguno, en las lavores d'él, y socorriéndolos con gente si se hallare de fuera y con bastimentos, preferiendo siempre el socorro d'ellos a su proprio peligro y vida; socorriendo, assimesmo, al castillo que tiene más necessidad, si fueren muchos los cercados.

SIN.: fortalecer, fortificar $_{2}$, reparar 2 .

FAM.: fortalecer, fortalecido, fortaleza.

ENCICL.: Aut.: Lo mismo que fortalecer.

enfortalescer, V. enfortalecer.

engenio, $V$. ingenio.

enpresa, V. empresa.

enqüentro, V. encuentro.

enseñorearse, enseñorearse [de señor. Nebr. (DECH). Girava, Fineo, Geometría práctica, 1553]. v. prnl. Apoderarse de algo.

Girava, Fineo, Geometría práctica, 1553, pág. 6: Los romanos también, que por la vezindad y parentesco siempre imitaron la Grecia, en tanto tuvieron sus príncipes y senadores en quanto era cada uno prudente y sabio, y assí, con tales caudillos se pudieron fácilmente enseñorear del mundo. // García de Palacio, Diálogos militares, 1583, fol. 44v: En esta virtud, pues, se esmeravan y en ésta instruýan y disciplinavan a sus soldados aquellos conquistadores del mundo, para enseñorearse d'él y de sus competidores y enemigos, y para defenderse d'ellos. // Álaba, Perfeto capitán, 1590, fol. Vr: Y de aquí sucedió que con 
el mismo siglo y con la mesma naturaleza creció este desseo de gloria y apetito de enseñorearse de lo ageno y mandar a otros, de suerte que casi no tenemos noticia de la paz que no la tengamos luego de la guerra.

SIN.: señorear.

FAM.: señorear.

ENCICL.: DUE: ("de") prnl. Hacerse dueño de una cosa excluyendo a otros. // Terr. (s.v. enseñorearse de algo): Apoderarse de ello.

entrepresa, V. interpresa.

envestir, V. embestir.

enxenio, $V$. ingenio.

escala, escala, scala [del lat. scala 'escalón', 'escala', 'escalera'. APal., Nebr. (DECH). Ortega, Conpusición Arismética y Geometría, 1512]. sust. Escalera portátil. S (fig. 60)

Ortega, Conpusición Arismética y Geometría, 1512, fol. 202r: Un cavallero tiene una torre, la qual tiene 50 canas de alto, y quiere fazer una escala que se aparte 40 canas desde el cimiento de la torre. Demando que quántas canas terná la escala de la punta de la torre fasta el postrero pie de las 40 canas. // Álaba, Perfeto capitán, 1590, fol. 89r: Y porque, aplicadas las escalas al muro, es ordinario en todos los assaltos el subir luego por ellas los hombres más señalados y de mayor importancia de todo el exército. // Mendoça, Theórica y práctica, 1596, pág. 153: Las escalas para semejante efecto han de ser de altura de sólo las murallas, porque, si son mayores, es fácil a los de arriba, asiendo de los palos que sobran, echarlas en tierra con los que están en ellas, y si menores, no se puede subir por ellas a lo alto.

FAM.: escalada, escalar, escalón.

ENCICL.: Cov.: Lo que comúnmente llamamos escalera, salvo que la escala algunas veces es la arrimadiza que se pone y se quita, y es una de las máquinas bélicas que se arriman a los muros de los enemigos. // Agar (1853): Especie de escalera de mano de altura variable según la de las murallas que se hayan de escalar con ella, por cuyo uso se nombra comúnmente escala de asalto. Se sitúa separada del pie del muro próximamente la cuarta parte de la altura de éste, la cual siendo conocida sirve para determinar la de la escala. Suele componerse de dos o tres trozos para que su transporte sea más cómodo, teniendo el más elevado en sus extremos superiores unas roldanillas forradas de fieltro para evitar el ruido al apoyar la escala en la muralla; en los extremos inferiores tiene unas espigas que se 
ajustan y aseguran sólidamente al trozo siguiente; el trozo inferior descansa en el terreno con unas puntas de hierro colocadas en sus extremos inferiores para que no resbalen.

2 [Cortés de Albacar, Breve compendio sphera, 1556]. sust. Geom. Línea dividida en alguna cantidad de partes iguales que representan pies, varas, leguas $u$ otra cualquier medida, y sirve para delinear con proporción en el papel la planta de cualquier terreno o edificio (Aut.). \& (fig. 61)

Rojas, Teórica fortificación, 1598, fol. 36r: Y assimesmo a este pitipié le llaman muchos escala, y los estrangeros ponen en sus traças por medida de petipié, canas, dándole diez palmos de valor a cada una. // González de Medina, Examen fortificación, 1599, pág. 58: Para hazer la figura seságona pláticamente, como se ha propuesto la pentágona, con línea precissa, se ha de hazer lo primero la escala y, en ella, con el compás, tomar la medida que se quisiere que tenga la planta por cada lado y hazer un círculo de líneas muertas, como muestra el de los puntos. // Lechuga, Discurso de la Artillería, 1611, pág. 242: Y assí, de todo pondré adelante parte de las plantas y el profilo de todas con su escala, para que por ellas y él puedan regirse en quantas hizieren, siguiendo con todo lo demás que conviene hazer a los que quisieren fuerças.

SIN.: pie pequeño, pitipié.

ENCICL.: Estévanez (1897): Todo plano militar, y aun el más rudimentario croquis, debe llevar una indicación de la escala en que está hecho. // Lucuze (1772: 17): "En toda delineación del plano o perfil se pone su escala, que consiste en una línea recta dividida en partes iguales que representan igual número de pies o varas, a cuya magnitud están proporcionadas todas las líneas de la figura, de suerte que, transportada sobre la escala cualquier distancia o línea del plano, se sabrá el número de pies o varas que contiene". / / Rojas, Teórica fortificación (1598: fol. 30v): "Todo esto fue poco respeto de lo que me sucedió con unos cavalleros, mostrándoles un modelo de fortificación, en el qual yva al pie d'él hecho un pitipié con letras de oro, y encima dibuxado un compás. Uno de los quales, y señor de título, por señalarse más que los otros, aviendo mirado el modelo, me preguntó que cómo aquel modelo no tenía pitipié. Y yo le respondí señalando con el dedo: "Señor, aquí está el escala". Respondió luego: “¿La escala?, luego ¿no tiene pitipié?”. Por esto entendieron los de la junta aver sido género de vanidad, aver hablado de pitipié sin entenderlo más de por averlo oýdo dezir".

a vista [Collado, Plática Artillería, 1592]. loc. adv. Fort. Haciendo la escalada de día y a vista de los enemigos (DRAE).

Collado, Plática Artillería, 1592, fol. 94r: Pero, como la administración de él sea tan differente de la común y hordinaria soldadesca, la qual sólo atiende a hordenar un esquadrón, travar una escaramuça y muy bien reñirla, entrar a escala vista en una tierra, guardar y defender una trinchera y assaltarla, arremeter con una batería [...]. // Ufano, Tratado de la Artillería, 1613, pág. 182: Y, si acaso los enemigos subieren por las troneras, deffendérselas hasta pelear con los levies o palancas, porque no se venga a dezir - siendo possible - que por tal parte se a entrado a escala vista, porque en tal caso no echarán la 
culpa a otro que al que tiene a cargo la artillería, antes deve perder mil vidas que consentir que por tal puesto se le entrasen.

escalada, escalada [de escalar (DECH). Mendoça, Theórica y práctica, 1596]. sust. Fort. La acción de escalar o poner escalas en los muros (Terr.).

Mendoça, Theórica y práctica, 1596, pág. 151-152: Assimismo se toman tierras por escaladas. Para estas empresas se han de embiar soldados de experiencia y fiados a reconocer los caminos hasta ellas, el ancho y hondo de los fossos, baxada d'ellos, altura de las murallas, calidad de guardia que haze el enemigo, disposición de las centinelas, [...]. / / González de Medina, Examen fortificación, 1599,: Hazerse ha con los advertimientos que se trataron en el fabricar en monte, no le haziendo foso, sino las contraminas y poços muy hondos, con la estrada alrededor para assegurarla de que no se pueda llegar a robarla de noche con escalada, teniendo en ella centinelas que lo adviertan y den aviso para que dentro estén alerta. // Rojas, Compendio fortificación, 1613, fol. 32r: Luego, mandó el Dioneto que se abriese el fosso alrededor de toda la ciudad, conforme aquel pedazo que estava hecho, pues ya se avía visto por esperiencia ser tan bueno contra las escaladas, y mandó echar mucha agua en todo el fosso.

FAM.: escala, escalar, escalón.

ENCICL.: Almirante (1869): [...] Aunque no lo sepamos de cierto, podemos presumir con gran verosimilitud, que en los primeros tiempos de la humanidad, a este medio, que realmente seduce por su "sencillez", estaría reducida toda la poliorcética. Cuando ésta llegó a su apogeo, con la invención de las máquinas, también es presumible la perfección que recibirían las escalas de asalto, y que con gran detenimiento detallan los autores [...]. // Estévanez (1897): Ataque a viva fuerza de un punto fortificado, ya por sorpresa, ya por escala vista, valiéndose de escaleras que se arriman a la escarpa o al recinto murado. En nuestros días es poco frecuente. // Lucuze (1772: 106-107): "La sorpresa por escalada era frecuente en otros tiempos. Al presente es de poco útil y sólo puede practicarse cuando la Guarnición es débil, descuidada o inexperta; cuando no hay foso, o en caso de haberle es poco profundo, seco o con poca agua; cuando la muralla es baja, mal flanqueada, con ángulos muertos y sin obras exteriores".

escalar, escalar [de escala. "Escalar fortaleza", Nebr. (DECH). Celso, Reportorio universal leyes Castilla, 1553]. v. tr. Fort. Entrar en una plaza fuerte u otro lugar valiéndose de escalas (DRAE: s.v. escalar ${ }^{1}$ ).

Celso, Reportorio universal leyes Castilla, 1553, fol. CCLIVv: Los que escalaren los muros o puertas de alguna ciudad o villa o castillo, o salieren por encima de los muros fuera de la tal ciudad o villa o castillo, caygan en pena de muerte. // Mendoça, Theórica y práctica, 1596, pág. 154: Llegados cerca de la tierra que se ha de escalar, descargarán las escalas, barcas y puentes en partes donde no puedan los d'ella oýr el ruydo, dando cargo de cada cosa a quien está señalado. // Rojas, Compendio fortificación, 1613, fol. 27r-27v: El fosso es el más importante en la plaça y castillo, lo principal para que el enemigo no pueda escalar las murallas, porque, aviendo el dicho fosso, y entrando en él el enemigo, luego las casas 
matas y travezes que huviere le hazen mucho daño, por lo qual obliga el enemigo, para poder passar y arrimarse a la muralla, cegar el fosso.

FAM.: escala, escalada, escalón.

escalón, escalón [de escala. Berceo (DECH). Rojas, Teórica fortificación, 1598]. sust. Fort. Peldaño construido en lo interior y al pie de un parapeto.

Rojas, Teórica fortificación, 1598, fol. 69r-70r: Y del cordón arriba se levantará el parapeto, de 7 pies de alto por la parte de fuera, y por la parte de dentro no tendrá más que 6 de alto, porque pueda tirar el soldado; y assimesmo se hará allí un escalón de dos pies de huella y un pie, de forma que el escalón y parapeto tengan 6 pies y medio de alto sobre el terrapleno y el dicho parapeto no tenga más de 5 pies de gruesso / González de Medina, Examen fortificación, 1599, pág. 42: La estrada cubierta será de doze pies de ancho, con un terrapleno cortado de la mesma campaña de seis pies de alto, que sirve de trinchea o parapeto, con un escalón de un pie de alto alrededor del parapeto, para que los pequeños puedan tirar mejor. // Rojas, Compendio fortificación, 1613, fol. 36r-36v: Y para conclusión, buelvo ha dezir que tenga el fosso 80 pies de ancho y 30 de fondo, y 15 de estrada cubierta, y 5 de pies de alto su parapeto sin el escalón.

SIN.: banqueta, grada.

FAM.: escala, escalada, escalar.

escaramuça, V. escaramuza.

escaramuçar, V. escaramuzar.

escaramucha, V. escaramuza.

escaramuza, escaramucha, escaramuça, escaramuza [del it. scaramùccia (López Vallejo 2008). Loçano, Alberto, Architectura, 1582]. sust. Mil. Batalla de poca importancia o con pocas fuerzas (DUE: s.v. refriega).

Loçano, Alberto, Architectura, 1582, pág. 141: A estas cosas se ha de añadir lo que aprovecha para el uso del defenderse y fortificarse, porque conviene aver fortalecido la cava, el vallado, la torre y las semejantes contra los del pueblo y contra las escaramuças de los de la provincia, y para que éstos, con su salida, concurso y acometimiento no dañen. // Collado, Plática Artillería, 1592, fol. 91r: Acostumbraron de preparar los prudentes capitanes, al tiempo que la puente se alarga y se le da al agua para que, llevada de la corriente, vaya ella misma, como antes diximos, a pararse en la ribera contraria, muchos mosqueteros y artillería, con que es fuerça qu'el enemigo se retire y haga al largo, y aun encima de la puente misma hazían entrar algunas compañías de valientes soldados, los 
quales, saltando en tierra, divertían con escaramuças la gente contraria y davan tiempo a que pudiesse passar la suya. // Mosquera, Comentario disciplina militar, 1596, fol. 84r: El comendador Chatres llevó delante de sí toda la más de su gente que pudo por salvarla, entreteniendo con escaramuças a los nuestros que se les acercavan.

SIN.: refriega.

ENCICL.: DSAL: Mil. Combate poco importante, preferentemente entre las partes más adelantadas de dos ejércitos enemigos. // Sanz (1749): Es un pequeño choque de algunos soldados destacados de uno y otro partido, que se mezclan sin llegar a un combate arreglado. La escaramuza es muy esencial en la retirada de una acción o siguiendo al enemigo que se retira. Enséñanse los soldados al ejercicio de la escaramuza, a fin que en la ocasión puedan ejecutarlo con facilidad y sin confusión. / / Hevia (1857): Acción de guerra de muy poca importancia entre dos cuerpos enemigos; la escaramuza es el menor de los combates, y acontece frecuentemente al hacer las descubiertas de las plazas y los reconocimientos de campos enemigos, pues, conseguido el objeto, se retira la partida o cuerpo de tropa comisionada para aquel servicio, sin empeñarse en una acción formal. // Rubió y Bellvé (1895-1901): La lucha [...] sin consecuencias decisivas para el éxito definitivo de una campaña, que traban las vanguardias, puestos avanzados, escoltas, patrullas, etc., etc.

2 [García de Palacio, Diálogos militares, 1583]. sust. Mil. Género de pelea entre soldados de a caballo realizada con gran ligereza.

García de Palacio, Diálogos militares, 1583, fol. 56r: Los cavallos ligeros sirven para escoltas y otros actos de diligencia y sustentar la escaramuça començada por los demás cavallos. // Álaba, Perfeto capitán, 1590, fol. 40v: Y no sólo la gente de a pie a de hazer esto, sino también la de a cavallo, exercitándose en saltar en los cavallos sin poner pie en el estribo, assí por la mano diestra como por la siniestra, començando este exercicio sin armas para abituarse a él con más facilidad, y después con ellas, porque, si le sucediere caer en alguna escaramuça, pueda socorrerse sin esperar ayuda de nadie. // Álaba, Perfeto capitán, 1590, fol. $67 \mathrm{v}-68 \mathrm{r}$ : Y si particularmente se consideran los efetos que entrambos hazen en la guerra, se hallará que los de la gente de a cavallo son muchos, assí en reconocer el campo de los enemigos como en las correrías y escaramuças que tiene de ordinario con él, en las quales se suele con más facilidad acabar la gente y resistencia de los contrarios que en las batallas declaradas que se dan de poder a poder.

ENCICL.: Cov. (s.v. escaramuça): Es un cierto género de pelea entre los jinetes o caballos ligeros, que van picando de rodeo, unas veces acometiendo y otras huyendo con gran destreza y ligereza. Éstos son los que primero solían empezar las peleas, y poco a poco se iban cebando y ensañando los demás, y era como un preludio a la batalla campal. // Rubió y Bellvé (1895-1901): Modo de pelear entre tropas montadas, que consistía en acometer al adversario, si era posible por la espalda, y retirarse a veces con rapidez para embestir de nuevo con más furia [...]. Compréndese la extremada habilidad que se requería para llevar a buen término una acción de guerra tan movida, en que cada jinete o grupo de ellos había de dar muestras de su valor y de su inteligencia, para contribuir al fin común, distrayendo unas fuerzas, atrayendo otras a lugar propicio, dando golpes rudos al 
que aparecía débil, retrocediendo a tiempo y velozmente antes de caer en las redes del más fuerte.

escaramuzar, escaramuçar, escaramuzar [del it. scaramucciare (López Vallejo 2008). Celso, Reportorio universal leyes Castilla, 1553]. v. intr. Mil. Mantener una escaramuza o una refriega.

Celso, Reportorio universal leyes Castilla, 1553, fol. CXXXVIv: Deven poner la gente donde pueda hazer más mal a los cercados, guardándoles las puertas y passos por donde les puede venir socorro de gente o de bastimentos, y por donde ellos puedan entrar en la hueste a hazerles daño o escaramuçarles. // Collado, Plática Artillería, 1592, fol. 97r: Hanse de passar muchos y muy incógnitos ríos, lagunas y lodaceros y otros muchos passos ásperos y peligrosos, pero aun en los caminos largos muchas noches le converná alojarse y alvergar en la campaña, y aun no pocas vezes se hallará ser assaltado de los enemigos y forçado a escaramuçar y pelear con ellos. // Mosquera, Comentario disciplina militar, 1596, fol. 73v: Y, visto esto, escaramuçando con orden, se entretenían los nuestros gastando de los contrarios y comiéndoles su gente poco a poco.

2 [García de Palacio, Diálogos militares, 1583]. v. intr. Mil. Mantener los soldados de a caballo una escaramuza.

García de Palacio, Diálogos militares, 1583, fol. 56r: El officio de los hombres de armas es, resistiendo como un fuerte o bestión, defender de los enemigos su infantería y desbaratar y romper a los contrarios. El de los herreruelos y arcabuzeros de a cavallo es espiarlos y descubrirlos, y escaramuçar con ellos, y traer mantenimientos y guardar algunos pasos. // García de Palacio, Diálogos militares, 1583, fol. 56v: Los cavallos ligeros han de ser exercitados en escaramuçar, jugar la lança o zagaya a dos manos, en correr y mandar bien sus cavallos, ayudarse de las espadas y demás armas, con destreza, en subir y descendir cuestas y montañas ásperas, corriendo con gran diligencia.

escarpa, escarpa, scarpa [del it. scarpa 'íd.', de origen incierto, quizá derivado de scarpa 'zapato' por comparación con el declive que forma el pie de una bota bajo su caña. Escarpa 'declive que forma la parte inferior de la muralla de una fortificación hasta el foso'. 1625 Coloma, Guerra de Flandes (DECH). Collado, Plática Artillería, 1592]. sust. Fort. Plano inclinado de los muros de las fortificaciones (DSAL).

(3) (fig. 62)

Collado, Plática Artillería, 1592, fol. 92r: La escarpa, que es la que en España llamamos lambor, que han de tener estas fábricas de faxina y tierra, es ésta: que por cada seys pies, o palmos, o varas de alteza se le da una de scarpa; pero si al bestión dicho, con el tiempo, se le quisiesse hazer la camisa de muralla de ladrillo o de piedra, entonces se le dan de escarpa, de quatro, uno de caýda; y con esta regla siempre se ha hecho en todas las fábricas de fortificaciones donde yo me he hallado hasta agora. // Rojas, Teórica fortificación, 1598, fol. 51r: Y luego, de una a otra, unas tablas, de forma que, siendo doze cabrillas y a seis pies de hueco una de otra, se hará sesenta pies de largo de frente del terrapleno, teniendo cuydado de poner las cabrillas y tablazón de suerte que vaya el 
terrapleno con una poca de escarpa para poder sustentar en sí. / / Lechuga, Discurso de la Artillería, 1611, pág. 243: [...] hecha por líneas con su escala, lo que diere en el papel sea lo que a de tener en lo alto de ella, dándole para fabricarla, fuera de la hecha en líneas, toda la escarpa que pide la obra, porque, de no tener qüenta en esto, vienen, levantadas las obras a quien se dio principio por el diseño de líneas en la parte baxa, a ser tan estrechas en la alta que les falta la capacidad, causándolo esto las escarpas, hallándose, por no entenderlo o no advertirlo, con error sin remedio y con cosa estropeada, con tan gran defecto como e visto en algunas hechas de ingeniería de gran ciencia.

SIN.: alambor 1 , escarpe 1.

ENCICL.: Salvá (1846): La inclinación de la cara de una pared, cuando va menguando su grueso a medida que sube. // Lorenzo Celorrio (1996): Talud. Plano inclinado del muro de una fortificación en el lado que mira al enemigo. El empleo de la escarpa mejora la cimentación y disuade la zapa. // Almirante (1869): De ningún modo debe confundirse en fortificación esta voz "exclusiva" con las otras más genéricas de talud y declivio.

2 [Collado, Plática Artillería, 1592]. sust. Fort. Plano inclinado que forma la muralla del cuerpo principal de una plaza, desde el cordón hasta el foso. (fig. 63)

Collado, Plática Artillería, 1592, fol. 65v: Conviene a saber que ságoma no es otra cosa sino un nuevo nivel y exquisito, para exquisitas hobras inventado, assí como en el formar las cortinas de las fortalezas con la escarpa, que quanto más o menos decadencia tuviere la muralla, más o menos la ha de tener el nivel o ságoma para hazerla. // Rojas, Teórica fortificación, 1598, fol. 69r: Y assí, siendo el sitio en un plano, como está dicho, se levantará la muralla de los dichos 40 pies hasta el cordón, y en esta altura se avrá ido, en cada 5 pies de alto, retirando uno de escarpa hazia dentro, por manera que en los 40 pies se perderán 8 de los 13 de gruesso con que començó. Y acabará la muralla en el cordón con 5 pies de gruesso. // Lechuga, Discurso de la Artillería, 1611, pág. 240: La muralla a de ser alta, a lo menos, quarenta pies, los veinte y seis, de llano del fosso hasta el cordón, fabricados de ladrillo o piedra, con su escarpa, de quatro pies cada uno.

SIN.: alambor 2 , escarpado2, escarpe 2 .

ENCICL.: Lopes Pires Nunes (2005: s.v. escarpa exterior): Declive do reparo, para o lado de fora do cordão até ao fosso. Constitui o revestimento interno do fosso, sendo normalmente coberto a silharia, denominada de Camisa.

3 [Rojas, Teórica fortificación, 1598]. sust. Fort. Terreno o superficie que desde el parapeto de la estrada cubierta va descendiendo, con una pendiente o declive muy suave, hasta alcanzar el nivel de la campaña.

Rojas, Teórica fortificación, 1598, fol. 2v-3r: Y assimismo, tendrá muy en la memoria los nombres de la fortificación, como son: fosso, y refosso, y estrada cubierta con su escarpa de tierra a la campaña, y la cortina principal, y cassamata con su orejón que la cubre, y espalda y frente de valuarte, y la gola d'él, y ángulo del recinto, [...]. 
SIN.: arce del foso, arcén, arcén del foso, árgine, vallado.

ENCICL.: DRAE: Plano, también inclinado opuestamente, que forma el muro que sostiene las tierras del camino cubierto. // Lucuze (1772: 37-38): "El camino cubierto o estrada encubierta es una especie de corredor al nivel superior de la contraescarpa, que circuye la plaza con sus obras exteriores. Se le da ordinariamente doce varas de ancho, incluyendo la banqueta; y se cubre con un parapeto de ocho pies de altura. La superficie superior de este parapeto forma la explanada. Se llama así por el pendiente muy suave que tiene hasta terminarse insensiblemente en la campaña. Es arbitraria su longitud, de 40,50 o de más varas; pero con la precisa ley de ser vista y defendida de la plaza o de alguna obra exterior. La parte más elevada de la explanada se dice ordinariamente la cresta del parapeto del camino cubierto". // López Vallejo (2008: s.v. explanada): En fortificación: Declive que va desde el parapeto del camino cubierto de la fortaleza hacia el campo raso donde no hay construcción. // Moretti (1828: s.v. explanada): Sirve la explanada para impedir que el enemigo se acerque a la plaza a cubierto; y su alineamiento prolongado hacia las obras debe ser paralelo con el cordón del revestimiento o un poco más arriba. De este modo, el enemigo no puede batir el revestimiento ni hacer brecha hasta que se apodere del camino cubierto.

a [Rojas, Teórica fortificación, 1598]. loc. adv. Fort. De un modo inclinado o escarpado.

Rojas, Teórica fortificación, 1598, fol. 39v: Toda esta fábrica de piedra ha de tener en el fundamento 28 pies, los 13 para la muralla y los 15 para el largo de los contrafortes, dándole a cada uno tres pies de gruesso, y de hueco entre uno y otro 13 pies, advirtiendo que la muralla ha de yr a escarpa, que se entiende, de cada 5 pies de alto, retirarse hazia dentro uno, de forma que, en 40 pies que subirá hasta el cordón, escarpará ocho, y como abaxo es la muralla de 13 pies, será arriba solamente de 5. // Rojas, Teórica fortificación, 1598, fol. 52v: La fagina que vaya bien tendida con buena orden, y sobre todo vaya la tierra bien mojada y pisada, y a escarpa vaya el terrapleno, disminuyendo de cada quatro pies uno hazia dentro, y siendo assí como he dicho, aguardará esta fábrica de tierra tres y quatro años, para que le hagan la camisa de piedra. // Lechuga, Discurso de la Artillería, 1611, pág. 240: A la llanura a de seguir la caída del terrapleno hasta el llano de la fuerza, que a de ser a escarpa de dos pies, el uno para que los soldados puedan subir por todo él.

SIN.: a escarpe.

ENCICL.: DECH (s.v. escarpa): En italiano scarpa en la misma significación se halla desde Guicciardini; pero allí, además de ser término de fortificación, puede referirse a la base de cualquier pared o margen, y la locución adverbial a scarpa, aplicada a construcciones hechas en esta forma figura ya en Leonardo da Vinci y en muchos autores del s. XVI (Soderini, Sassetti, etc.); además el vocablo es popular actualmente en todas las hablas del Norte de Italia, aunque no designando cualquier pendiente, según da a entender Gamillscheg (R. G. I, p. 392), sino precisamente, hasta donde puedo comprobarlo, la de una fortificación o de un margen (así en el Piamonte, y en Génova, según Casaccia). 
escarpa, V. a .

escarpado, escarpado [del it. scarpato 'íd.'. Escarpado 'en pendiente oblicua', 'muy pendiente'. Aplicado a fortificaciones, 1609, Argensola; aplicado a peñas, etc., Aut. (DECH). Rojas, Teórica fortificación, 1598]. adj. Fort. Dicho de una construcción, especialmente de la defensiva: que forma un plano inclinado o tiene mucha pendiente.

Rojas, Teórica fortificación, 1598, fol. 93r: Aunque si la piedra fuere franca, convendrá que no lleve tanta escarpa por la parte que en aquel sitio ofendieren más las aguas y los vientos, porque siendo la muralla muy escarpada, la van corrompiendo y cavando las muchas aguas, y assí convendrá en semejante ocasión dar menos escarpa, que será de 6 pies uno, porque deslize mejor el agua. / / González de Medina, Examen fortificación, 1599, pág. 150: Señor, lo que yo haría en esta tierra que me avéys dicho que queréys fortificar sería que, si no tuviesse foso, se le abriría de nuevo, y si le tuviesse, como suelen ser estrechos y poco hondos, le ensancharía y ahondaría, y de la tierra que d'él sacasse le arrimaría un terrapleno por la parte de fuera, muy escarpado, que servirá contra la batería que se le pusiere, no dando lugar a batir, sino en lo alto de la muralla. // González de Medina, Examen fortificación, 1599, pág. 169: Siempre que el sitio fuere de manera que el enemigo no tenga trabés por donde batir el ángulo del baluarte para cortarle, sino que aya de batir en el mesmo ángulo, es muy mejor agudo que no obtuso, porque no tiene en qué batir y las balas resurtirán sin hazer daño en la muralla, aun más que de una muy escarpada.

SIN.: alamborado.

ENCICL.: Fernández Mancheño (1822): Lo que está hecho a modo de escarpa en el plano que no es paralelo al horizonte, sino inclinado.

2 [González de Medina, Examen fortificación, 1599]. sust. Fort. Plano inclinado que forma la muralla del cuerpo principal de una plaza, desde el cordón hasta el foso. González de Medina, Examen fortificación, 1599, pág. 214: Las cortinas, cimiento, escarpado y parapeto se han de medir de la forma siguiente, y será en el tamaño de la propia muralla que se ha propuesto de la fuerça que se ha tratado. // González de Medina, Examen fortificación, 1599, pág. 215: Y el parapeto, que su ancho es de cinco pies, con tres de alto, hasta que comiença el escarpado, que se ha de multiplicar y cubicarlos con trezientos y cincuenta de largo, hazen cinco mil y dozientos y cincuenta pies. // González de Medina, Examen fortificación, 1599, pág. 218: La muralla, cruz, por el cimiento, quinze pies de ancho, y a la haz de la tierra, treze; y escarpado, ocho; hasta el parapeto, que quede en cinco.

SIN.: alambor 2 , escarpa 2 , escarpe 2 . 
escarpar, escarpar [del it. scarpare. Terr. (DECH). Rojas, Teórica fortificación, 1598]. v. tr. u. t. c. intr. Fort. Disponer en forma inclinada una construcción defensiva.

Rojas, Teórica fortificación, 1598, fol. 39v: La muralla ha de yr a escarpa, que se entiende, de cada 5 pies de alto, retirarse hazia dentro uno, de forma que, en 40 pies que subirá hasta el cordón, escarpará ocho, y como abaxo es la muralla de 13 pies, será arriba solamente de 5 , y luego de allí adentro estarán los contrafortes y terraplenos. // González de Medina, Examen fortificación, 1599, pág. 22-23: Ha de tener dos pies debaxo de tierra y començarle de quinze pies de ancho y, en descubriendo al plano del foso sobre la tierra, tendrá treze pies de ancho e yrá escarpando, que es disminuyendo del ancho por la frente, hasta los quarenta pies del parapeto a cada cinco pies de alto un pie, que vendrá a aver escarpado ocho pies, y quedará en el cimiento del parapeto en cinco pies de ancho. // González de Medina, Examen fortificación, 1599, pág. 30: Los de los baluartes han de ser todos ellos muy bien terraplenados, y las mesmas golas de la mesma manera, línea recta, donde assimismo junta la muralla con el parapeto hasta començar a escarpar la falda, que la ha de tener para lo mesmo que la de la cortina, siendo tres pies más larga por los dos que tiene más de alto el baluarte que la cortina.

FAM.: contraescarpe, escarpe.

ENCICL.: Moretti (1828): Cortar una montaña o terreno, formando un plano inclinado, como el de la muralla de una fortificación.

escarpe, escarpe [de escarpar. Escarpe 'escarpa'. 1884 Acad. (DECH). Loçano, Alberto, Architectura, 1582]. sust. Fort. Plano inclinado de los muros de las fortificaciones (DSAL: s.v. escarpa).

Loçano, Alberto, Architectura, 1582, pág. 20-21: Pero no en todos lugares guardaron esto de que las barbacanas distassen entre sí tanto quanto fuesse alto el mismo escarpe, sino según la firmeza de el monte, o, mejor diziendo, la debilidad, las hizieron, ahora más freqüentes, ahora más raras. // González de Medina, Examen fortificación, 1599, pág. 226: De una respuesta que se da a un objeto que se podría poner del escarpe de los baluartes.

SIN.: alambor ${ }_{1}$, escarpa $_{1}$.

FAM.: contraescarpe, escarpar.

ENCICL.: Almirante (1869): Es muy común confundirlo con escarpa, tanto en fortificación, como en topografía. (Dicc. Acad. no lo trae).

2 [Roxas, Sumario milicia, 1607]. sust. Fort. Plano inclinado que forma la muralla del cuerpo principal de una plaza, desde el cordón hasta el foso.

Roxas, Sumario milicia, 1607, fol. 78r: El escarpe de tierra y fagina será 1/4, que se entiende de quatro pies de alto, uno. // Roxas, Sumario milicia, 1607, fol. 78r-78v: El grueso del fundamento de la muralla será que sea buen repartidor el yngeniero que fundare la 
muralla, adbirtiendo dos cosas: la primera, que ha de subir de alto por lo menos quarenta pies, y ha de tener arriba la muralla 4 pies, porque para el parapeto de 25 pies de grueso se haze con sus contrafortes y arquillos, y lo demás que ya se save, de manera que para acabar la camisa de la muralla de 4 pies de grueso, haviendo de yr a plomo por la parte de dentro, se eligirá abajo de 12, porque los 8 se pierden en el escarpe hasta los 40 . / / Roxas, Sumario milicia, 1607, fol. 84r: Ansimismo, en el fundamento de la obra se guardará la orden que en lo real, y lo mismo en el escarpe; 15 pies.

SIN.: alambor 2 , escarpa 2 , escarpado.

a [González de Medina, Examen fortificación, 1599]. loc. adv. Fort. De un modo inclinado o escarpado.

González de Medina, Examen fortificación, 1599, pág. 33-34: Y, para esto, será bien, siempre que se pudiere, hazer del mesmo terreno el terrapleno cortado a escarpe, aunque se aya de baxar para las casas matas, y las de vivienda y plaça de armas algunos pies. // González de Medina, Examen fortificación, 1599, pág. 148: El corredor, B, tendrá de alto, desde el plano de foso, treynta y cinco pies, los quinze para el foso, que le basta, y hazerse ha a escarpe la muralla.

SIN.: a escarpa.

escarpe, V. a .

escolta, ascolta, escolta [del it. scòrta 'acompañamiento', 'escolta', derivado de scòrgere 'divisar, guiar', que procede del lat. vg. *excorrı̆gĕre 'enderezar', 'rectificar el camino'. h. 1530 y frecuente en la 2. a mitad del s. XVI (DECH). Collado, Plática Artillería, 1592]. sust. f. Mil. Soldado, o conjunto de ellos, que se encarga de acompañar a una persona o una cosa para protegerla o asegurarla.

Collado, Plática Artillería, 1592, fol. 97v: Viniendo, pues, a tratar de la horden de marchar con el artillería, será aquesta: que delante de ella, por buen espacio de camino y por los lados, van las escoltas de cavallos ligeros, los quales, en descubriendo alguna enboscada o otra acechança de el enemigo, den inmediatamente aviso en el campo. // Ufano, Tratado de la Artillería, 1613, pág. 85: Si se ofresçiere, como suele, gastar mucha más pólvora y balas que las proveýdas [...], se yrá, como se a dicho, trayendo de los almagacenes y plaça de armas con bastante custodia de escoltas la demás muniçión y cosas que para tal serviçio fuere menester. // Ufano, Tratado de la Artillería, 1613, pág. 145: Tócale asistirles con gran diligençia al partir de los comboyes y escoltas. Quando van por los víveres oblígale, assimismo, rondar el quartel y, topando con algún malhechor, tomarle en prisión, aunque sea del exérçito.

ENCICL.: Aut.: f. Tropa de soldados que sirve de convoyar, resguardar y conducir sin riesgo alguna persona o cosa al paraje donde se encamina. // Moretti (1828): f. Tropa reunida en 
una o más partidas para vigilar la seguridad de los objetos que deben transitar de uno a otro punto, como son caudales, trenes de artillería, convoyes, prisioneros de guerra, etc.

2 [García de Palacio, Diálogos militares, 1583]. sust. f. Mil. Servicio de protección y seguridad prestado por un soldado o por una tropa, que consiste en acompañar en sus desplazamientos a una persona o alguna cosa.

García de Palacio, Diálogos militares, 1583, fol. 56r: Los cavallos ligeros sirven para escoltas y otros actos de diligencia y sustentar la escaramuça començada por los demás cavallos. // Mendoça, Theórica y práctica, 1596, pág. 86: Este mismo advertimiento se tiene, quando han ydo algunas tropas de infantería o cavallería a hazer escoltas o alguna facción embiar, si es hora de estar puestas las centinelas, avisarlo con algún soldado que viene delante para que no se alteren, tocando arma con el verlos, lo qual han de prevenir. // Roxas, Sumario milicia, 1607, fol. 67v: A de yr de banguardia d'este exérçito los gastadores para acomodar los pasos, y an de yr con ellos algunas compañías de arcabuzeros, que son quien toca hazer esta escolta.

ENCICL.: López Vallejo (2008): f. Vigilancia y seguridad que garantiza un grupo de soldados. // D'Wartelet (1863: s.v. convoy) Es el servicio más penoso a que puede destinarse a un oficial, el que, no hay duda, preferirá los peligros del combate a las incomodidades y responsabilidad que lleva tras sí la escolta de un convoy.

hacer $\sim$ a alguien o algo [Mendoça, Theórica y práctica, 1596]. loc. v. Mil. Dicho especialmente de un grupo de soldados: acompañar a alguien o algo que va de un sitio a otro, para protegerlo.

Mendoça, Theórica y práctica, 1596, pág. 83-84: Al alojar Vuestra Alteza convendrá llegue de buena hora, assí porque lo haga la gente con más comodidad, como porque aya tiempo para fortificarse, si es necessario, estando vezino el enemigo, cosas que se hazen mal de noche; y para assegurar los forrajeros, se ha de advertir, pudiéndolos el enemigo hazer daño, el embiar cavallos a descubrir y hazelles escolta, si lo pide la ocasión.

escorpión, escorpión, scorpión [tomado del lat. scorpio, -ōnis 'íd.' (a su vez derivado del gr. охорлios). Escorpión 'alacrán'. Escorpión, Berceo, Signos (DECH). Urrea, Vitruvio, Architectura, 1582]. sust. Mil. ant. Máquina para lanzar piedras, que tiene una especie de tenaza semejante a las pinzas del escorpión.

Urrea, Vitruvio, Architectura, 1582, fol. 5r-5v: Assí que estuve presente con Marco Aurelio y Publio Minidio y Gneyo Cornelio al aparejar las vallestas y escorpiones y la artillería y todas las otras máchinas de guerra. // Collado, Plática Artillería, 1592, fol. 2v: Las máquinas, pues, Real Magestad, con que los antiguos solían expugnar las fortalezas y batir las murallas eran éstas: las cathapultas, las balistras, las víneas, los arietes, las testúdines [...], el compago, el escorpión, las sambucas, las faláricas y otras muchas. // Mosquera, Comentario disciplina militar, 1596, fol. 5v: Los primeros arietes que salieron a luz en el mundo fueron los que los cartagineses en España inventaron, con que allanaron los muros de la ciudad de Cádiz, y, después, subiendo en la mayor fineza que jamás estuvo, la 
artillería e ingenios de fuego y artificios modernos que sucedieron a las balistas, y a los escorpiones o arcubalistas.

ENCICL.: Cov.: Cierta máquina bélica, a la cual César puso por nombre escorpión, por la forma que tenía de tenaza de escorpión.

escuadrón, escuadrón, esquadrón [del it. squadrone, de donde pasó también al fr. (escadron, fin. s. XV). En it. está ya en Maquiavelo. Fin. s. XV, Crón. de Enrique IV (DECH). Montes, Instrucción y regimiento, 1537]. sust. Mil. Cualquier tipo de unidad o agrupación táctica de soldados.

Montes, Instrucción y regimiento, 1537, fol. XVIr: Si un esquadrón huye el día de la batalla, todos van tras aquél, de manera que ellos mismos no se saben entender ni de sus capitanes se dexan regir. // González de Medina, Examen fortificación, 1599, pág. 121: Hanse de hazer, como queda dicho, estas fuerças de cinco ángulos, y de lados yguales y de las mesmas medidas todos sus miembros, a lo menos una d'ellas, porque, si por de fuera como por de dentro de la ciudad fuere sitiada, sea capaz de tener y recebir gente que la pueda defender; y que si fuere batida y entrada, tenga lugar para hazer retiradas y cortaduras $\mathrm{y}$, a lo peor, la plaça de armas, con el espacio que requiere un buen esquadrón. // Rojas, Compendio fortificación, 1613, fol. 7v: La raýz quadrada sirve de mucho en la guerra al sargento mayor para sus esquadrones, quadros de gente o quadros de terreno. Como si se pidiesse: hágase un esquadrón quadro de gente de 1600 picas, diré que su raýz quadrada son 40 , y tantas tendrá de frente y fondo el tal esquadrón.

SIN.: batallón 1 , tropel.

ENCICL.: Borreguero Beltrán (2000): Antiguamente se dio este nombre a distintas agrupaciones o divisiones militares de infantería y de caballería. // Almirante (1869): Se entendía por escuadrón la formación en un solo cuerpo de todo el ejército o tropa considerable [...]. La voz escuadrón no expresaba el orden, el modo ni la figura de la formación, sino el hecho aislado de estar formado el ejército en un solo cuerpo como formación primitiva, o en varios combinados pero reunidos, como formación compuesta; pues cuando se quería distinguir una formación de otra se decía: escuadrón cuadrado de gente; escuadrón cuadrado de terreno; escuadrón de doble frente que fondo; triangulado [...]. // Para más información, vid. batallón $n_{1}$.

falso [García de Palacio, Diálogos militares, 1583]. cmpt. sintag. Mil. El que, además de otro tipo de soldados, consta de infantes perdidos, los cuales, aunque combaten a pie, se desplazan a caballo. (fig. 65)

García de Palacio, Diálogos militares, 1583, fol. 163r-163v: Suplico a vuestra merced me diga ¿qué orden se tiene en formar un esquadrón falso, que los alemanes llaman de infantes perdidos, y en quántas partes van de la batalla, y qué armas llevan los guerreros que van en él? // García de Palacio, Diálogos militares, 1583, fol. 163v: Los esquadrones falsos, llamados assí por la falsedad y engaño encubierto que en ellos ay, pueden llevar órdenes falsas, dichas también infantes perdidos, en dos o quatro partes. Presuppuesto, pues, que 
van solamente en dos, hanse de poner en la avanguardia a ocho o a nueve órdenes de la parte delantera, poniendo por el lado derecho tantas órdenes quantas por lo ancho toma y occupa el tercio de la batalla, y por el costado o cuerno yzquierdo, otras tantas, que occupen, assimesmo, el otro tercio de la batalla, y el tercio de en medio quede desoccupado, de la forma que esta demonstración o figura señala, entendiendo por los perdidos los sitios y lugares que señalan las letras P P.

volante [Mendoça, Theórica y práctica, 1596]. cmpt. sintag. Mil. En un orden de batalla, el que por alguna razón está separado del principal.

Mendoça, Theórica y práctica, 1596, pág. 57-58: También se acostumbra a hazer uno o dos esquadrones volantes, y esto para sustentar la escaramuça en gruesso, manteniéndola con fin de tirar al enemigo a pelear, y prevenir, quando cargasse con golpe de cavallos, siendo superior en ellos a la arcabuzería y cavallería que la acompaña, poderla socorrer con el esquadrón volante y presteza, sin empeñar los demás de la batalla. // Rojas, Teórica fortificación, 1598, fol. 30r: Un exército en esquadrón no es otra cosa sino una fortificación muy cumplida, porque la frente del esquadrón de las picas sinifica la cortina o lienço de la muralla, y los travesses o fiancos son las mangas de arcabuzeros, y las casas matas son las mangas de mosqueteros, que están a cada lado entre los arcabuzeros, y el esquadrón volante sinifica el rebellín.

ENCICL.: López Vallejo (2008): Conjunto de soldados sacados del cuerpo principal.

escucha, escucha [de escuchar y éste del antiguo ascuchar, que procede de *ascŭltare, forma vulgar del lat. auscultare 'íd.'. Escucha 'centinela nocturno'. 1. ${ }^{a}$ Crón. Gral.; Apal.; Nebr., "escuchas del campo: excubiae"; y frecuente ya en la Edad Media (DECH). Celso, Reportorio universal leyes Castilla, 1553]. sust. m. u. t. c. f. Mil. Centinela que, de noche, se acerca a las posiciones de los enemigos para poder escucharlos y vigilarlos.

Celso, Reportorio universal leyes Castilla, 1553, fol. IXr: Los adalides juzgan sobre las cavalgadas y sobre las cosas que acaescen en ellas, y han de partir el despojo o lo que fuere ganado en el saco, y ponen atalayas, y de noche escuchas y rondas, y han de ordenar las celadas cómo se hagan. // Celso, Reportorio universal leyes Castilla, 1553, fol. CLXr: Y después deven ser pagados, primeramente y ante que los otros, las atalayas, y escuchas, y espías y guardas, porque es razón que los que se ponen en mayor peligro que los otros sean primeramente pagados. // Mendoça, Theórica y práctica, 1596, pág. 82: Aviendo dividido el maestre de campo general los quarteles y plaça de armas en la manera que signifiqué a Vuestra Alteza en el primer alojamiento, el quartelmaestre lo repartirá en particular a los aposentadores o furrieles; lo qual hecho, se yrá a reposar, y los capitanes de escuchas y centinelas, que son los que han de alojarse los primeros para hallarse descansados a las noches.

ENCICL.: Cov.: Es la centinela o atalaya de noche que procura oír lo que tratan los enemigos. // Estévanez (1897): Centinela nocturna de los puestos avanzados, que vigila 
con los oídos más que con los ojos; aplicando el oído a tierra, siente a larga distancia las pisadas de una tropa y singularmente de la caballería.

espalda, espalda, spalda [del lat. tardío spatǔla 'omóplato', antes 'espátula', 'pala de ciertos instrumentos', diminutivo de spatha que tenía esta última ac. y procedía

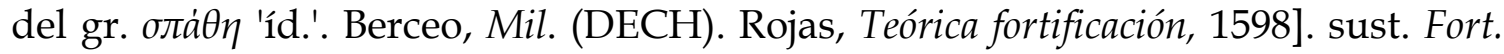
Defensa $\mathrm{u}$ obra de fortificación hecha de tierra, fajinas, cestones y demás pertrechos semejantes, que, en situaciones convenientes, sustituye o complementa a un parapeto permanente. (fig. 66)

Rojas, Teórica fortificación, 1598, fol. 37r: Y assí, con la espalda de tierra y fagina que digo se remedia la defensa de los soldados, porque, quando bata el artillería el parapeto, se pondrán los soldados detrás de la espalda de tierra. // Rojas, Compendio fortificación, 1613, fol. 37v: Para más perfección y fortaleza del baluarte, se hará una espalda en lugar del parapeto que tenga quarenta pies de grueso y cinco pies en alto; y al bordo, por la parte de fuera, se le hará un parapetillo delgado de tres pies de grueso, para defensa contra el mosquete, y quando el enemigo tuviere plantada su artillería, se pondrán los soldados detrás de la espalda para guardar la batería. // Ufano, Tratado de la Artillería, 1613, pág. 121: Quando el tal puesto, como digo, no se hallase a propósito, alçar una espalda a prueva de cañón con tierra y faxina, o lo que más viniere a qüento, la qual se hará con los gastadores y la demás gente que no estuviere occupada muy prestamente.

ENCICL.: DRAE (1791): Fort. Lo mismo que espaldón. // DRAE (1791: s.v. espaldón): Valla artificial de altura y cuerpo correspondiente para resistir y detener el impulso de algún tiro o rechazo. // Rubió y Bellvé (1895-1901): Fort. En lo antiguo, masa cubridora generalmente hecha de tierras y revestida de fajinas, que solía construirse en la defensa y ataque de plazas para preservar a la artillería o al personal del fuego del adversario. // Ufano, Tratado de la Artillería (1613: pág. 405): "GENERAL. - Bien está así; dezidme, ¿qué anchura y altura days a la espalda del cubrimiento de la batería para que la tal sea hecha a prueba de cañón, y en qué altura y de qué forma marcaréys la tronera de cada una pieça? ARTILLERO. - La espalda, Señor, se haze de tierra y faxina, con 23 pies de ancho, dando a cada pie del altura de faxina dos pies de tierra en alto, $y$, de tal modo, un lecho y cama sobre otro, hasta cumplir once pies de altura. $\mathrm{Y}$ a los tres pies de altura se marcan las troneras". // Ufano, Tratado de la Artillería (1613: pág. 407): ¿Cómo days 23 pies a la anchura de la batería formada con espalda de tierra y faxina, y a la de cestones ordenados de 3 en 3 por hilera no más de 21?

2 [Lechuga, Discurso de la Artillería, 1611]. sust. Fort. Parte del baluarte que une su frente con la cortina, o distancia comprendida entre el ángulo de la cortina y la cara o frente del baluarte.

Lechuga, Discurso de la Artillería, 1611, pág. 240: Las cortinas de los baluartes, en las fuerças de quatro, se an de formar sacándolas del prinçipio de la espalda, que es a dozientos pies, o a la quarta parte del fin de la cortina dicha, de ochocientos pies de largo, donde hazen el ángulo cortina y espalda. // Lechuga, Discurso de la Artillería, 1611, pág. 240: El orejón, si lo uviere, a de salir de la espalda, por su mayor medida circular, o como se usa. // 
Lechuga, Discurso de la Artillería, 1611, pág. 270: Muchos tienen por mejor las espaldas de los baluartes sin orejón, siendo claro que las espaldas sin él son capaces para más pieças y más gente.

SIN.: fianco, través 1.

3 [Rojas, Teórica fortificación, 1598]. sust. Fort. En un baluarte con casamata y orejón, la parte del flanco cubierta por este último, cuya medida ha de ser la adecuada para la protección de las piezas de artillería instaladas en la casamata. Rojas, Teórica fortificación, 1598, fol. 41r: Este recinto se dividirá en cinco partes, el qual supongo que tenga 660 pies desde el punto $\mathrm{A}$ al punto $\mathrm{B}, \mathrm{y}$, partido, como dicho es, será el quinto 132. Los quales se rebatirán de la $\mathrm{AB}$, como lo muestra $\mathrm{AC}$ y $\mathrm{BC}$, dexando las dos CC por cortina franca de 396 pies. Y del punto C se darán 90 de fianco, para la espalda y boca de la casamata. // González de Medina, Examen fortificación, 1599, pág. 14: Tiene alguna flaqueza en la espalda de la casamata, mas con algunas emiendas la figura quadrángula se podría usar d'ella, caso que se quisiesse hazer por menos costa o necessidad. // Rojas, Compendio fortificación, 1613, fol. 37r-37v: Quedarán 240 pies de cortina franca; luego se darán 30 pies de ancho a la casamata y 40 de largo, y 20 pies de boca y otros 20 de gruesso a su parapeto, y 60 pies de espalda para cubierta de la dicha casamata en el orejón, el qual tendrá 30 pies de salida afuera de la boca de la casamata para cubrirla.

SIN.: costado 2 .

4 [Rojas, Teórica fortificación, 1598]. sust. Fort. El lado del orejón de un baluarte que mira a la fortaleza. 3 (fig. 68)

Rojas, Teórica fortificación, 1598, fol. 2v-3r: Y assimismo, tendrá muy en la memoria los nombres de la fortificación, como son: fosso, y refosso, y estrada cubierta con su escarpa de tierra a la campaña, y la cortina principal, y cassamata con su orejón que la cubre, y espalda y frente de valuarte, y la gola d'él, y ángulo del recinto [...].

ENCICL.: Moretti (1828: s.v. espalda del orejón): Es el lado del orejón que mira a la plaza, o sea, la parte entrante de aquél, y donde se hacen las poternas.

espía, espía [del gót. *spaîha 'íd.'. h. 1300, Caballero Zifar (DECH). Fernández de Enciso, Suma de Geographía, 1530]. sust. f. Mil. Persona que se envía a observar con cuidado y disimuladamente al enemigo para que, después, informe de sus movimientos.

Fernández de Enciso, Suma de Geographía, 1530, fol. XLVr: E passados todos, embió Josué sus espías, y después embió a requerir a los de Gericó, que era de la sucessión de Canaán, que se fuessen y le dexassen su tierra, porque aquella tierra avía Dios dado a Abraham e a sus sucessores. // Urrea, Vitruvio, Architectura, 1582, fol. 138r: Estando cercada Apolonia, que agora llaman la Belona, y cavando los enemigos una mina, pensaron entrar dentro sin 
ser sentidos. Y como las espías lo dixessen a los de Apolonia, turbados con el temor de la nueva, faltándoles consejo, también les faltava ánimo, porque ni podían saber el tiempo ni el lugar cierto. // Collado, Plática Artillería, 1592, fol. 98r: He visto los generales usar de summa diligencia en saber, por medio de las espías, no sólo lo que el enemigo hazía, pero aun lo que en lo más occulto de su coraçón pensava.

SIN.: explorador.

ENCICL.: Aut.: El que anda disimulado observando y escuchando lo que se dice o hace para dar aviso a la parte de cuya orden lo ejecuta. Regularmente se entiende esta voz por el que anda disimulado entre los enemigos, para dar noticia a los suyos de lo que hacen. Covarr. discurre que el origen de esta voz sea del verbo griego spio, que vale seguir, porque la espía va siguiendo al contrario por todos los pasos que anda. // Moretti (1828): Persona de confianza enviada con secreto y disimulo por un jefe militar para que observe y examine los movimientos del enemigo, penetre sus proyectos y le dé cuenta de ellos. // D'Wartelet (1863): El que por oficio se dedica a observar las acciones, movimientos y conversaciones de otros para referirlas después. Es un oficio de traición, pero admitido en la milicia por la utilidad que reporta, pues con razón se llama a los espías los ojos del ejército, porque, penetrando en una plaza, campamento o cuartel, exploran la situación de las tropas y estado de las fortificaciones para comunicarlas al que le paga.

espiar, espiar [del gót. *spaíhôn 'acechar, atisbar, espiar'. APal., Nebr. (DECH). Celso, Reportorio universal leyes Castilla, 1553]. v. tr. Acechar, observar disimuladamente a alguien o algo (DRAE).

Celso, Reportorio universal leyes Castilla, 1553, fol. CXXXIIIr: De los que espían a los que quieren mal para matarlos o herirlos, dezimos de suso, capítulo aleve, y de yuso, capítulo homezillo. // Roxas, Sumario milicia, 1607, fol. 54r: Finalmente este rey tubo tan ferviente zelo en aumentar la república cristiana que muchas veçes en ávito disimulado espiava los reales de los moros, astucia maravillosa.

ENCICL.: DSAL: tr. Observar o escuchar una persona a una persona o una cosa disimuladamente. Sin. vigilar.

2 [García de Palacio, Diálogos militares, 1583]. v. tr. Mil. Observar secretamente al enemigo para informar de ello.

García de Palacio, Diálogos militares, 1583, fol. 56r: El officio de los hombres de armas es, resistiendo como un fuerte o bestión, defender de los enemigos su infantería y desbaratar y romper a los contrarios. El de los herreruelos y arcabuzeros de a cavallo es espiarlos y descubrirlos, y escaramuçar con ellos, y traer mantenimientos y guardar algunos pasos. // Álaba, Perfeto capitán, 1590, fol. 14v: Y este mesmo recato tuvo Cayo Lelio yendo por legado de Cipión al rey Sifaz, pues, llevando consigo algunos tribunos y centuriones en figura de siervos, porque diligentemente espiassen el real al enemigo, y dando muestras un soldado del campo contrario de conocer a Lucio Estatorio, tribuno, por encubrir su desinio, Cayo Lelio, con lijera causa, le dio de palos para dar a entender que era su esclavo. 
// Álaba, Perfeto capitán, 1590, fol. 40v: Y con mucha razón los animavan a semejantes exercicios, pues el correr es necessario para que con mayor ímpetu acometan a los enemigos y, en la necessidad, con mayor celeridad ocupen los lugares importantes y, queriendo hazer lo mesmo los contrarios, salgan ellos primero con su intento; o para yr con desemboltura a espiar el campo y bolver con presteza, o para alcançar a los que huyen.

ENCICL.: DRAE (1791): Observar, reconocer y notar lo que pasa con gran disimulo y secreto, para comunicarlo al que se lo ha encargado; es muy común en la guerra para saber los designios del enemigo.

esplanada, V. explanada.

esplanar, V. explanar.

esplorador, V. explorador.

espolón, espolón [de espuela. (DRAE). Roxas, Sumario milicia, 1607]. sust. Fort. Refuerzo colocado en el interior del terraplén para fortalecer la muralla.

Roxas, Sumario milicia, 1607, fol. 76r: Es neçesario mostrar un tanto más particularmente las partes o miembros de algún baluarte, que son: través; orejón, que llaman poma o espalda de la casamata; contrafortes o espolones, pretiles o parapetos; plaza para el artillería en el trabés bajo, si lo huviere de tener, y en lo alto, lo mismo; entrada en el uno y en el otro y en la plaza de arriba.

SIN.: contraforte, estribo.

FAM.: espolonada.

ENCICL.: Estévanez (1897): Estribo o refuerzo en las construcciones militares.

2 [Mendoça, Theórica y práctica, 1596]. sust. Fort. Cualquier cara o lado de una fortaleza que conste de una cortina y de dos baluartes. 13 (fig. 69)

Mendoça, Theórica y práctica, 1596, pág. 125-126: Assimismo se ha de advertir si la plaça está fortificada, siendo frontera, o se ha de fortificar de nuevo y en qué manera ha de ser, governándose en esto, según el tiempo que diere el enemigo para ello, con ingenieros y personas que sepan qué es fortificación, por acontecer muchas vezes, queriendo fortificar alguna plaça, ayudándola con revelín, cavallero y bestión, tenaza o espolón, venirse a enflaquecer más por no estar bien entendidos y, assí, no sirven de reparo, sino de dar comodidad al enemigo para ofender mejor. 
ENCICL.: Terr.: En la Fortificación, cierto ángulo saliente [...]. Por la semejanza, se da el mismo nombre a muchas cosas.

espolonada, spolonada [de espolón. Cid (DECH). Celso, Reportorio universal leyes Castilla, 1553]. sust. Mil. Arremetida de algún número de caballería contra el enemigo (Aut.).

Celso, Reportorio universal leyes Castilla, 1553, fol. CLVIIIr: Y, ansimesmo, ay otra especie de guerra que dizen spolonada, para tomar fuerça, o villa, o castillo. // Celso, Reportorio universal leyes Castilla, 1553, fol. CLIXv: Lo mesmo es si lo ganassen en hazienda, o en lid, o en cavalgada, o spolonada, o celada, o entrando en villa o castillo por fuerça, o en navíos de los enemigos, o en qualquier otra manera que se podiesse dezir guerra. Y si el Rey no fuere aý en persona, dévelas cobrar su Capitán General.

FAM.: espolón.

espugnación, V. expugnación.

esquadrón, $V$. escuadrón.

estacada, estacada [de estaca y éste quizá del germánico, si la palabra tuvo en gótico la forma *stakka. Nebr. (DECH). Loçano, Alberto, Architectura, 1582]. sust. Fort. Conjunto de estacas o de palos clavados en el suelo, y normalmente enlazados mediante travesaños de madera, que sirve para impedir el paso al enemigo.

Loçano, Alberto, Architectura, 1582, pág. 138: La razón del vallar los alojamientos es varia. Los ingleses con palos de diez pies tostados y agudos se hazen estacada; la una punta fixada dentro en el suelo y apretada, y la otra que salga afuera, estendida, de suerte que mire azia el enemigo. // González de Medina, Examen fortificación, 1599, pág. 205: Assí es, que con mucha facilidad se pondrá raso el parapeto y quedará descubierta la artillería y los que huvieren de servir y defenderla; pero no es de importancia ni daño de consideración, por poderse valer de hazer una estacada terraplenada en lugar del parapeto o poner cestones, que les será muy buena defensa y encubierta y menos dañosa que la de piedra, porque no harán tanto daño las balas que dieren en ello como en la piedra. // Lechuga, Discurso de la Artillería, 1611, pág. 266: Mucho maderame, gruesso y menudo, de respecto, para lo que se puede offrecer de minas, salidas al fosso, hazer casas matas, rastillos, estacadas, cuerpos de guardia cubiertos para la gente que estuviere en la muralla, $y$ otras muchas cosas que se pueden offrecer en un sitio.

SIN.: empalizada, palenque, palizada1.

ENCICL.: Lorenzo Celorrio (1996): Empalizada. 
2 [Urrea, Vitruvio, Architectura, 1582]. sust. Constr. Conjunto de maderos o de estacas que se pone por cimiento cuando no hay tierra firme para un edificio.

Urrea, Vitruvio, Architectura, 1582, fol. 32r: En lugares de lagunas, debaxo de los fundamentos de los edificios, las estacadas que d'él se hazen, recibiendo en sí lo que tiene de menos humor, permanece incorruptible para siempre, y suffre y sustenta grandíssimas cargas del edificio, y sin vicio lo guarda. De manera que este árbol, que no puede durar fuera de tierra sino poco tiempo, metido en humedad permanece para siempre. // Roxas, Sumario milicia, 1607, fol. 78r: El fundamento de la fábrica del castillo o baluartes será conforme al terreno; si fuere peña viva, fundar luego ençima de ella; y si es terreno blando, será tres pies debajo del suelo del foso; y si fuere muy demasiado de blando, que sea agua o lama çenagosa, será con estacadas de madera. // Rojas, Compendio fortificación, 1613, fol. 41v: Luego, saber hazer en la mar las torres y, especialmente, dentro en el agua o en pantanos, que allí es fuerça hazer en el fundamento grandes estacadas.

SIN.: palizada .

estancia, estancia [de estar y éste del lat. stāre. 1251, Calila; estança, Berceo, Duelo; J. Ruiz; Canc. de Baena; "estança de veladores: statio", "estança donde alguno está: mansio", Nebr.; "ergasterium... erga en griego es obra y sterio estancia para obrar", APal. (DECH). Fernández de Enciso, Suma de Geographía, 1530]. sust. u. m. en pl. Mil. Cada una de las divisiones de un alojamiento, sea en campaña o dentro de una fortaleza. 3 (fig. 70)

Fernández de Enciso, Suma de Geographía, 1530, fol. XXXv: Los hombres d'ella más belicosos biven fuera de los pueblos en sus estancias. // González de Medina, Examen fortificación, 1599, pág. 8: Hase de mirar que media legua alrededor no aya cuesta, que son las que llaman padrastros, quando vienen a estar tan cerca que, puesta artillería en ellas, desaloxan a todos los que están en los reparos y en las estancias y plaça de armas, y que en ninguna parte están seguros. // González de Medina, Examen fortificación, 1599, pág. 14: No es capaz de tener plaça de armas para ponerse en esquadrón ni de sitio para las estancias necessarias de los soldados que la han de defender, ni para las municiones necessarias; en fin, no es para nada buena.

SIN.: cuartel, posada.

estar, V. en defensa.

estrada, estrada [del lat. strata o strata via 'camino empedrado', participio femenino de sternō 'tender, extender'. Estrada, ant. 'camino', fue una voz de escasa frecuencia en la Edad Media (sólo en Alex. y en APal.), así, desde la segunda mitad del s. XVI (Fr. Luis de Granada), esta palabra muerta volvió a tomarse del it. strada, 
especialmente como vocablo militar y de fortificaciones (DECH). Rojas, Teórica fortificación, 1598]. sust. Espacio por donde las personas, animales o vehículos van de un sitio a otro (DSAL: s.v. camino). 3 (fig. 71)

Rojas, Teórica fortificación, 1598, fol. 104v: Todo prevenido y puesto a punto, como dicho es, o antes si conviniere, embiará el capitán general algún golpe de cavallería y arcabuzería, y aun picas si conviniere, que tomen algún puesto, y se pegará a la tierra o castillo procurando tomar las estradas por donde ha de venir gente al castillo o salir de dentro a estorvar el intento que se lleva. // Roxas, Sumario milicia, 1607, fol. 75v-76r: Resuelta, pues, la forma que ha de tener la çiudad, ahora sea de cinco, seis, siete o diez baluartes, o de quantos se quisiere hazer, es neçesario acompañarlos con los miembros que conbiene para hazerla fuerte, que son estos: baluartes, cortinas, cavalleros [...], casamatas, puertas, terraplenos, estrada, detrás del terrapleno; foso grande y refoso pequeño, estrada cubierta, fuera del foso [...]. // Roxas, Sumario milicia, 1607, fol. 84r: Los caminos o estradas a las casamatas, 12 pies.

ENCICL.: Rubió y Bellvé (1895-1901): Camino; tierra hollada por donde habitualmente se marcha de un punto a otro, o vía construida especialmente para el mismo fin. // DUE: Camino. // DUE (s.v. camino): Banda de terreno más llana y cómoda de pisar que el terreno adyacente, que se utiliza para ir de un sitio a otro. / Cualquier clase de construcción, como carretera o ferrocarril, que enlaza un lugar con otro.

2 [Rojas, Teórica fortificación, 1598]. sust. Fort. Especie de vía o camino compuesto de parapeto y banqueta y que, construido sobre la contraescarpa del foso, rodea y protege todas las obras de fortificación de una plaza. (fig. 72)

Rojas, Teórica fortificación, 1598, fol. 38r: Y siendo estrecha la estrada, la cubre mejor la gente de la muralla que no si estuviesse más afuera, porque, al tiempo que el enemigo llegasse con su trinchea al bordo de la estrada, los de la muralla no le podrían ofender, porque darían en las espaldas a los amigos, por estar muy afuera del fosso. // Rojas, Teórica fortificación, 1598, fol. 38r-38v: Y paréceme, conforme a la materia de trincheas y a lo que he visto en ellas, que no deve de tener de ancho la dicha estrada más que hasta 15 pies, porque lo que es salir o entrar cavallería, bastará la plaça [...] y traveses d'ella, y como se ha recogido toda la fortificación, es cosa puesta en razón recoger también la estrada cubierta, de manera que venga a estar todo en proporción. // González de Medina, Examen fortificación, 1599, pág. 111: No se hará con foso, si no fuere quedando mucho terreno fuera de la muralla, por no enflaquezer el edificio, sino muchas contraminas, con muy hondos poços, para reservarse de las minas; y alrededor de la fuerça una estrada con un parapeto, levantado a modo de barbacana, para que sirva de surtida o salida.

SIN.: estrada cubierta, estrada encubierta.

ENCICL.: DUE: Fort. Camino cubierto.

cubierta [Mendoça, Theórica y práctica, 1596]. cmpt. sintag. Fort. Especie de vía o camino compuesto de parapeto y banqueta y que, construido sobre la 
contraescarpa del foso, rodea y protege todas las obras de fortificación de una plaza. $\quad$ ( 3 (fig. 73)

Mendoça, Theórica y práctica, 1596, pág. 137: Antes del descubrirse el enemigo al poner el sitio y cerrar la tierra, se han de tener apuntadas las pieças d'ella a las partes donde de razón se ha de presentar [...], teniendo juntamente reconocidos los puestos donde poner la arcabuzería, fuera de la estrada cubierta, si la ay al borde del fosso, para ayudar a la cavallería que huviere en la tierra, que saldrá a reconocer el enemigo y denuedo con que viene. // Rojas, Teórica fortificación, 1598, fol. 37v: Ay muchas opiniones entre soldados, en que unos dizen que sea el fosso seco, para hazer las salidas y emboscadas en él, y desde allí salir en tropa a ofender al enemigo, porque, siendo con agua, se hazen mal estas salidas, porque son menester varcas o planchadas para salir a la estrada cubierta. // González de Medina, Examen fortificación, 1599, pág. 42: La estrada cubierta será de doze pies de ancho, con un terrapleno cortado de la mesma campaña de seis pies de alto, que sirve de trinchea o parapeto, con un escalón de un pie de alto alrededor del parapeto, para que los pequeños puedan tirar mejor [...]. Es buena esta estrada cubierta para salir a estorvar al enemigo las faciones que ha de hazer para arrimarse. También es buena para más fácilmente recebir socorro.

SIN.: estrada, estrada encubierta.

ENCICL.: Terr. (s.v. camino cubierto): En la fortificación, camino que da vuelta a la plaza por la orilla del foso hacia la parte exterior, y se cubre con otra u otras defensas. // Moretti (1828: s.v. camino cubierto): Está cubierto por el lado del campo por una elevación de tierra de seis pies de alto poco más o menos, que le sirve de parapeto; va a perderse en pendiente suave a la campaña [...]. Al pie del interior del parapeto del camino cubierto hay una banqueta, como al pie del parapeto del terraplén, que tiene el mismo uso, es decir, que sirve para elevar al soldado a fin de que pueda tirar por encima de la explanada [es decir, de la escarpa o arcén]. // Lopes Pires Nunes (2005: s.v. caminho coberto): No caminho coberto e nos seus ângulos localizavam-se as praças de armas denominadas de salientes ou reentrantes, conforme a posição ocupada. // Fernández Mancheño (1822: s.v. camino cubierto): Proporciona la salida de la plaza a las tropas sin ser vistas. // Estévanez (1897: s.v. camino): Sirve para evitar sorpresas y organizar las salidas.

encubierta [González de Medina, Examen fortificación, 1599]. cmpt. sintag. Fort. Especie de vía o camino compuesto de parapeto y banqueta y que, construido sobre la contraescarpa del foso, rodea y protege todas las obras de fortificación de una plaza.

González de Medina, Examen fortificación, 1599, pág. 183: La gente que para defender esta fuerça ha menester, si fuéssemos con las opiniones de los antiguos, son muy diferentes, porque unos han dicho que para cada passo de cinco pies de muralla le pondrían un soldado [...]. Otros han dicho y quieren que sean cada tres pies un soldado, como en un esquadrón [...]. Pero, después que se han hecho estradas encubiertas que defender y guardar, les pareció que serían menester más. // Lechuga, Discurso de la Artillería, 1611, pág. 241: El árgine, que es el terreno que tiene principio de la estrada encubierta y fin en la misma campaña a la parte de afuera, que va siempre a escarpa, tanto quanto fuere necessario para consumir la tierra que se saca del fosso después de dada la que a menester 
la fuerza, a de tener, por lo menos, veinte pies desde el parapeto de la estrada cubierta de la más llanura que se pudiere, para que la gente que estubiere dentro la estrada cubierta esté segura de las balas de cañón, que no lo estará si desde el principio va haziendo la declinación, porque quedará la estrada cubierta poco fuerte y flaca. / / Ufano, Tratado de la Artillería, 1613, pág. 181: Y también se puede de tal puesto hazer del fosso un camino y estrada encubierta, que del fondo y ancho se puedan retirar fáçilmente en tiempo de neçessidad, y en caso que se pierdan, abrá sido de gran fruto el daño que abrán hecho y reçibido los contrarios.

SIN.: estrada, estrada cubierta.

ENCICL.: Aut:: Term. de fortificación. La parte que media entre la contraescarpa y la explanada. Dícese también camino cubierto. // Lucuze (1772: 37-38): "El camino cubierto o estrada encubierta es una especie de corredor al nivel superior de la contraescarpa, que circuye la plaza con sus obras exteriores. Se le da ordinariamente doce varas de ancho, incluyendo la banqueta, y se cubre con un parapeto de ocho pies de altura". // Díaz Capmany (2004: 31): "Además de servir para la vigilancia inmediata, tenía como objeto constituir una línea exterior de defensa que pudiera dar fuegos rasantes que estorbasen los trabajos de aproche del enemigo".

batir la $\sim$ [Roxas, Sumario milicia, 1607]. loc. v. Mil. Dicho de un grupo de soldados de a caballo: reconocer o registrar la campaña.

Roxas, Sumario milicia, 1607, fol. 68r: Y pues hemos dicho que los ofiçiales d'este exérçito an de ser soldados práticos en la guerra, sabrán bien las obligaciones que tienen de las guardias de centinelas perdidas, y la cavallería que bata la estrada aquella noche.

ENCICL.: Sanz (1749: s.v. batir la estrada o caminos): Es enviar soldados de a caballo a la descubierta. // DUE (s.v. descubierta): Mil. Reconocimiento que hace una pequeña tropa dependiente de otra mayor. // Aut.: Frase militar. Reconocer, registrar la campaña por si hay alguna gente enemiga oculta y encubierta, y si en los caminos hay algún embarazo o riesgo.

estradiote, estradiote [del it. stradiotto, vocablo de origen veneciano,

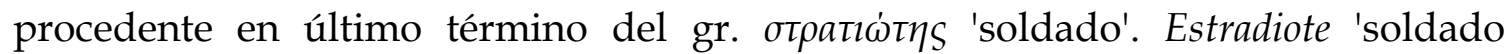
mercenario de a caballo procedente del Epiro o Albania'. 1546-8, Fz. de Oviedo; estradiote "género de cavallería" (Cov.) (DECH). Álaba, Perfeto capitán, 1590]. sust. Mil. Soldado mercenario perteneciente a la caballería ligera.

Álaba, Perfeto capitán, 1590, fol. 30r: Me a parecido advertir que la cavallería en qualquiera reyno se avría de dividir en hombres de armas, cavallos lijeros, estradiotes y arcabuzeros de a cavallo, y que por el orden que los e nombrado se fuessen prefiriendo los unos a los otros. // Álaba, Perfeto capitán, 1590, fol. 42r: Y porque el aviso de lo que se descubriere llegue con mayor brevedad, será de importancia que las personas a quien se huviere de dar cargo de allanar el campo sean de los estradiotes y arcabuzeros de a cavallo y que después d'ellos vaya algún número de cavallos ligeros que les hagan espaldas y socorran 
en los peligros y debates que se les ofrecieren. // Álaba, Perfeto capitán, 1590, fol. 131r: Y assí, la artillería pequeña es la que más puede ofender, y para prevenir su ofensa el remedio que yo hallo mejor es envestirla con presteza, señalando para este acometimiento algunos infantes perdidos y algunos arcabuzeros a los lados del esquadrón, y otro número de arcabuzeros de a cavallo y estradiotes, porque el esquadrón principal no se desordene y desbarate envistiendo de tropel.

ENCICL.: Rubió y Bellvé (1895-1901): El primitivo estradiote era el soldado mercenario, griego, que pasó al servicio de la república de Venecia cuando Constantinopla cayó en poder de los turcos (1453). Más adelante, el nombre de estradiote se aplicó a cualquiera de los soldados mercenarios que, desde los pueblos de Levante, pasaban a Italia, y luego a Francia y España, para servir en los ejércitos de estos países; de modo que no sólo al soldado de origen griego, sino al albanés, búlgaro, etc., se aplicó la citada denominación. Luis XV de Francia tuvo hasta 2000 estradiotes a principios del siglo XVI. En España empiezan a figurar los estradiotes igualmente al comenzar el siglo XVI. // D'Wartelet (1863): Los estradiotes no usaban de avambrazos ni manoplas, y en su lugar llevaban mangas, guantes o lúas de malla. Su cota o sobrevesta de armas era corta y sin mangas, cubriéndose la cabeza con una celada sin visera. Las armas ofensivas eran la espada larga ceñida a la cintura, maza en el arzón de la silla y en la mano la estradiota, lanzagaya o arcegaya, que era su arma favorita. // Álaba, Perfeto capitán (1590: fol. 130v): "Los estradiotes se armarán de la mesma manera que los cavallos lijeros, si no son los braços, porque, en lugar de braçales y manoplas traerán mangas y guantes de malla. Los arcabuzeros de a cavallo difieren de los estradiotes en sola la celada, porque, en lugar d'ésta, traerán un capacete para que tiren mejor y más cierto y tengan la cabeça más libre y desocupada".

estrago, estrago [de estragar y éste del lat. vg. *stragare 'asolar, devastar', derivado de strages 'ruinas', 'devastación', 'matanza'. Astrago, Cortes de 1339, en DHist.; estr-, Nebr. (DECH). Escalante, Discurso de la navegación, 1577]. sust. Mil. Durante una guerra, cualquier tipo de daño que se le hace al enemigo.

Escalante, Discurso de la navegación, 1577, fol. 26r: Y dende allí atravessaron el golfo hasta llegar a Calicut y, aunque fueron bien recebidos del rei, sucedieron las cosas de tal suerte, que el Pedrálvarez se desavino con él y resultó que le mataron algunos portugueses que tenía en tierra y, por satisfazerse, quemó todas las naos que avía en el puerto y lombardeó la ciudad, causando muchas muertes, haziendo gran estrago en las casas y edificios. // Álaba, Perfeto capitán, 1590, fol. 44r-44v: Y porque, como está dicho, el peligro mayor que el campo tiene quando marcha es el de las emboscadas, a ninguna cosa atenderá con mayor cuidado el sargento mayor que a descubrirlas y el maestre de campo en prevenir los inconvenientes d'ellas, pues, descubiertas, es mucho mayor el estrago que reciben que el que hazen. // Álaba, Perfeto capitán, 1590, fol. 71v: Y Leponte, siracusano, trayendo guerra con los cartagineses, viniéndole ellos a buscar, mandó poner fuego a algunos de sus propios campos, castillos y lugares, lo qual visto por los cartagineses, imaginando que este estrago lo avían hecho algunos de los suyos, fueron a favorecerlos y a acabar de destruyr lo que quedava, descuydados del daño que se les siguió. 
ENCICL.: DRAE: Daño hecho en guerra, como una matanza de gente, o la destrucción de la campaña, del país o del ejército. // D'Wartelet (1863): El daño que se hace en la guerra talando los campos, incendiando los caseríos, destruyendo cuanto se encuentra al paso. Más comúnmente se usa de esta voz para significar la gran mortandad que resulta de una gran batalla o acción de guerra muy disputada.

estrella, estrella, strella [del lat. stēlla 'íd.'. h. 1140 (DECH). Rojas, Teórica fortificación, 1598]. sust. Fort. Fuerte hecho en forma de estrella, con varios ángulos entrantes y salientes. (fig. 74)

Rojas, Teórica fortificación, 1598, fol. 46r: Este fuerte, señalado con la T, se llama estrella. Importa mucho hazer en él la tronera en cada ángulo junto al suelo, porque (como he dicho) no arremeta el enemigo de golpe a un ángulo, que con las troneras se remedia todo.

ENCICL.: Aut.: En la fortificación es un fuerte de campaña que imita en su iconografía a la estrella pintada por sus ángulos entrantes y salientes. Se hacen con cuatro, cinco o seis puntas o ángulos salientes, según la capacidad del terreno. Se llaman así por la semejanza con una estrella pintada. // Azevedo Fortes (1729: 16): "Estes fortes tem o seu maior uso na campanha em fortificação de terra e fachina". // Sanz (1749): Las estrellas están poco en uso porque sus ángulos entrantes no son flanqueados. Los reductos cuadrados son mejores, su construcción más breve y hacen el mismo efecto.

estribo, estribo, estrivo [de origen incierto , quizá germánico. 1433, Villena; 1490, Celestina; Nebr. (DECH). Rojas, Teórica fortificación, 1598]. sust. Fort. Refuerzo colocado en el interior del terraplén para fortalecer la muralla. 5 (fig. 75)

Rojas, Teórica fortificación, 1598, fol. 31v: Abecedario en declaración de los nombres de la fortificación. / A. Cortina principal, con los contrafortes o estribos. / B. Terrapleno verdadero [...]. // Lechuga, Discurso de la Artillería, 1611, pág. 244: Que suelen hazerse los fundamentos solos, al principio de las fuerzas, de piedra o ladrillo, y lo demás de tierra, hasta que a hecho assiento; y que contrafortes o estrivos se an de hazer a un tiempo, travándolos con la muralla, y no de por sí, porque la fuerza sea unida.

SIN.: contraforte, espolón.

estrivo, V. estribo.

exército, V. ejército.

exérçito, V. ejército. 
explanada, esplanada, explanada [del lat. explanāta 'allanada' (DRAE). Álaba, Perfeto capitán, 1590]. sust. Espacio de terreno allanado, es decir, aquel del que se han eliminado, entre otras cosas, los árboles, matas, arbustos, altos y bajos.

Álaba, Perfeto capitán, 1590, fol. 48v: Y reconocido el quartel y visto si ay necessidad de hazer algunas explanadas para que, sin algún tropieço, cómodamente pueda acudir y salir la gente al arma, pues es forçoso hazerlas estando alojadas las vanderas en bosques, viñas o jardines, como de ordinario sucede, será muy propio del oficio del sargento mayor saber del maestre de campo general qué vanderas de las de su tercio han de ser de guardia y el puesto donde se han de poner. // Mendoça, Theórica y práctica, 1596, pág. 69: En este tiempo el general de la artillería la yrá poniendo en orden y el carruaje de su séguito, según la anchura del camino, valiéndose de los gastadores, si es necessario hazer algunas explanadas. // Roxas, Sumario milicia, 1607, fol. 67v: A de yr de banguardia d'este exérçito los gastadores para acomodar los pasos, y an de yr con ellos algunas compañías de arcabuzeros, que son quien toca hazer esta escolta; han de llebar palas, hachas, haçadas y las demás cosas necesarias para haçer puentes y explanadas.

ENCICL.: D'Wartelet (1863: s.v. esplanada): Se da este nombre al terreno igual, descubierto y libre.

2 [Collado, Plática Artillería, 1592]. sust. Fort. Terreno acondicionado para poder establecer en él una batería de cañones y demás piezas de artillería.

Collado, Plática Artillería, 1592, fol. 53v: Entre tanto el artillero, havida la orden de su general, deve començar su hobra, conviene a saber, en hazer las esplanadas para plantar sobre ellas las pieças con sus plataformas fuertes de tablones y muy bien entendidas, hazer los cestones como en la letra A se vee y terraplenarlos, cubrir con ellos y con otros reparos su artillería, para que no le sea hecha inútil y desencavalgada. // Mosquera, Comentario disciplina militar, 1596, fol. 29r-29v: La fortaleza de San Sebastián [...] tiene una bóbeda a la parte de tierra que sale a la mar, a la boca de la qual está hecha una esplanada en que están siete o ocho pieças de artillería y un cañón de batir, y d'esta esplanada al agua quinze braças y a lo alto de la fortaleza otras tantas: tienen para cubrir esta artillería cestones terraplenados. // Lechuga, Discurso de la Artillería, 1611, pág. 212: Quantas más pieças se pudieren poner para el hazer las baterías principales juntas en una esplanada ygual, aunque lleguen a veinte, es mejor, como se verá sabiendo que virtus unita valet, $\mathrm{o}$ que virtus unita fortior.

ENCICL.: Moretti (1828): Terreno dispuesto en forma de una explanada para colocar una batería de cañones.

3 [Ferrofino, Descrizión Artillería, 1599]. sust. Art. Pavimento, generalmente de madera o de piedra, sobre el que se colocan las piezas de artillería, para que las ruedas de sus cureñas puedan deslizarse fácilmente.

Ferrofino, Descrizión Artillería, 1599, fol. 160r-160v: Y se hadbertirá qu'el ancho ordinario que ha de tener una esplanada, para que a una pieza pueda jugar en ella libremente, es tanto como el largo del mismo haze y $3 / 4$ más, a causa que se pueda serbir con más 
liberalidad y presteça, y, asimismo, que se alle tan apartada de sus bezinas que, quando se disparare la una, no pegue fuego a las demás. Éstas serán, largas, dos veçes y media que la pieça con su curueña. // Lechuga, Discurso de la Artillería, 1611, pág. 209: Las esplanadas se usan hazer de madera diversa, como es maderos de dos onzas de quadrado, tablones de una onza y media de grosseza para los cañones y de una onza para las demás, tan largas como la caxa de la pieça, yendo desde el fin de la esplanada alçando la parte por donde a de correr la caxa quando se dispara la pieza con tierra, faxina y çarços, de tal manera que las ruedas no suban del fin de su esplanada de madera, por la difficultad que se tiene de bolver las pieças a ella. // Ufano, Tratado de la Artillería, 1613, pág. 124-125: El cañón, Señor, es muy más grave y pesado de mover, y como de ordinario no son más de tres los artilleros que le goviernan, procuran de darle atrás aquella poca de más elevaçión al fondo del terreno [...]; y, por ser más ligero en su movimiento el medio cañón, se puede alojar su explanada más llana y menos pendiente y para con él hazer más çiertos los tiros.

\section{SIN.: lechera, plataforma 5 .}

ENCICL.: Lucuze (1772: 29-30): "La explanada de cañón consiste en un pavimento firme de piedra o madera, para que las ruedas de la cureña no se entierren por el grave peso de la pieza. Su figura es de trapecio, con un pendiente muy suave hacia el parapeto para disminuir el retroceso o reculo del cañón y volverle a poner con facilidad en batería. En los flancos y otros parajes en donde se debe tener algún cañón, se hace la explanada de un enlosado de piedra sillar. Si ha de ser de madera la explanada, se necesitan un batiente, cinco durmientes y dieciocho tablones con ciento ochenta clavos. El batiente es un grueso madero de nueve pies de largo que hace el frente de la explanada, y se dispone cerca y paralelo al parapeto. Los durmientes son cinco maderos de dieciocho pies de largo, cuyas cabezas apoyan en el batiente; y, apartados igualmente unos de otros, ocupan la extensión de la explanada, formando su declivio. El espacio entre los durmientes se maciza de tierra bien pisonada y después se ponen los tablones clavando cada uno a todos los durmientes". // Moretti (1828): La explanada para cañones presenta un trapecio inclinado, y para morteros un cuadrilongo plano.

explanar, esplanar, explanar [tomado del lat. explānō, -āre 'extender, desplegar', 'allanar', de ex y plānus. 1444. En el s. XIII, desplanar (Segura Munguía 2007). Collado, Plática Artillería, 1592]. v. tr. Poner o hacer transitable un camino u otro lugar de paso.

Collado, Plática Artillería, 1592, fol. 53v: La batería se deve de allanar y esplanar lo más que se pueda y facilitar en tal manera el passo qu'el soldado no halle al arremeter impedimento alguno que haga ser el assalto sanguinoso. // Collado, Plática Artillería, 1592, fol. 96v: En aquel assedio, por ser mal considerada la qualidad del sitio, por haver dado demasiado tiempo al enemigo de repararse dentro, por no ser llana la batería ni acabada de esplanar del todo la muralla, antes, por haverse anticipado la hora del assalto y no bien previsto las offensas qu'el enemigo fabricava dentro, murieron en él veynte y dos valientes capitanes españoles. / / Ufano, Tratado de la Artillería, 1613, pág. 64: Y porque aviendo de tirar grande bala con muy poca pólvora [...], la percusión del golpe de la bala era quasi de ningún effecto en las deffensas y baterías, do, por ahorrar costa de carruage y 
caballos, por tan poco effecto y larga de tiempo, demás de gastar mucha más pólvora y balas, costava más caro de gente en los asaltos de las baterías, por no averlas avierto y explanado con propia ygual potençia qual se devía a tal operaçión.

SIN.: allanar 1.

2 [Mendoça, Theórica y práctica, 1596]. v. tr. Rellenar de tierra alguna cosa, por ejemplo una trinchera, o derribar algo, como una montaña o una construcción, para dejar el terreno a nivel del suelo.

Mendoça, Theórica y práctica, 1596, pág. 69: Luego que está recogida la mayor parte del exército en la plaça de armas, el maestre de campo suele ordenar se allanen las trincheas y fortificación del alojamiento, para que pueda salir d'él la gente en esquadrón con mayor comodidad y presteza; y esto mismo acostumbran los exércitos del explanar las trincheas quando van a combatir el enemigo, dando a entender con semejante demonstración despreciar la fortaleza de los reparos por el valor de sus braços. // Mendoça, Theórica y práctica, 1596, pág. 69: Explanada la fortificación, el maestre de campo haze alargar la vanguardia la distancia que le parece de las trincheas, dando lugar con esto para que se encamine la batalla y retaguardia y se ponga en orden el carruaje de la artillería, municiones y bagaje.

SIN.: allanar 2.

explorador, esplorador, explorador [del lat. explōrātŏr, -ōris 'explorador', 'espía', de explōrō. 1732 (Segura Munguía 2007). García de Palacio, Diálogos militares, 1583]. sust. Mil. Persona que se envía a observar con cuidado y disimuladamente al enemigo para que, después, informe de sus movimientos.

García de Palacio, Diálogos militares, 1583, fol. 63r: Y, para esto, conviene imbiar exploradores prudentes, sabios y fieles, y de quienes se tenga confiança que lo sabrán bien hazer, como lo hazía Julio César, según él refiere, en las provincias de que no se tenía entera noticia. // Álaba, Perfeto capitán, 1590, fol. 52r: A cuya causa, los que con más seguridad en saber esto procedían, embiavan esploradores, que son los que comúnmente llamamos espías, dando este oficio a los soldados de más esperiencia y entendimiento. / / Mosquera, Comentario disciplina militar, 1596, fol. 129v-130r: Tienen pena mayor los embaxadores que revelan los secretos a los enemigos, que es de muerte, como se dio en este libro a Amador Viera; y avía de ser la mesma de los exploradores que, por la confiança que d'ellos se haze y el peligro en que ponen un exército, es justo quemarlos bivos, o que perezcan en horcas.

SIN.: espía.

ENCICL.: Stevens (1706: s.v. esplorador): A spye. // Aut.: Vale también el que inquiere y procura saber y averiguar con disimulo y cautela alguna cosa. Se usa con especialidad en puntos de guerra y corresponde a lo que comúnmente se dice espía. 
expugnable, expugnable [tomado del lat. expugnäbĭlı̆s, e 'qu'on peut prendre d'assaut, prenable', 'réfutable' (fig.), 'qui peut être dompté, détruit'. (Gaffiot 1934). Ufano, Tratado de la Artillería, 1613]. adj. Fort. Dicho de un lugar fortificado: que se puede expugnar o es muy fácil hacerlo.

Ufano, Tratado de la Artillería, 1613, pág. 75: Señor mío, soy de paresçer en tal particular que las 30 pieças sean bastantes para salir a campaña contra otro qualquier exérçito por pujante que sea, o bien para ganar alguna villa y expugnable fortaleza, por bien fornida y guardada que sea del adversario.

ANT.: inexpugnable, inexpuñable.

ENCICL.: Estévanez (1897): Fortaleza o posición que puede tomarse fácilmente, a juzgar por los datos que se tengan de sus defensores y de sus recursos defensivos.

expugnación, espugnación, expugnación, expugnaçión [tomado del lat. expugnāť̌o, ōnis 'action de prendre d'assaut, prise', de expugno. (Gaffiot 1934). Escalante, Discurso de la navegación, 1577]. sust. Fort. Acción de ganar cualquier lugar fortificado.

Escalante, Discurso de la navegación, 1577, fol. 9r: El que más se señaló en la espugnación de Ceuta fue el Infante don Enrique con los cavalleros de su milicia, y como era príncipe religiosíssimo y desseoso de aumentar la Fe Cathólica, con su valor procuró de inquirir de los moros las provincias y naciones a ellos comarcanas. // Collado, Plática Artillería, 1592, fol. 62r: Tres cosas, comúnmente, se aplican a la expugnación de las fortalezas, que son: las artillerías, la pala y açadón, y el uso de las minas y hornillos, y otros cavamientos soterraños, los quales se acostumbran de hazer con la pólvora. // Rojas, Compendio fortificación, 1613, fol. 28v: Como el rey huviesse ya assentado su exército, le llamó y le dixo: "Mira, Epímaco, que tengo larga relación de que son muy gruessas estas murallas, por lo qual, no las podrán romper los arietes, y también ya ves que son muy altas para escalarlas, por tanto, conviene que mires bien lo que se hará para esta expugnación".

ENCICL:: Terr.: En la Milicia, la acción de tomar una plaza o de vencer.

expugnaçión, V. expugnación.

expugnar, expugnar, expunar [tomado del lat. expugnare 'íd.'. Mena; princ. s. XVII, Aut. (DECH). Collado, Plática Artillería, 1592]. v. tr. Fort. Ganar, mediante una operación de guerra, cualquier lugar fortificado.

Collado, Plática Artillería, 1592, fol. 2v: Las máquinas, pues, Real Magestad, con que los antiguos solían expugnar las fortalezas y batir las murallas eran éstas: las cathapultas, las balistras, las víneas, los arietes, las testudines [...], el compago, el escorpión, las sambucas, las faláricas y otras muchas que, por no ser a Vuestra Magestad molesto, dexaré de tratar 
de algunas d'ellas. // Collado, Plática Artillería, 1592, fol. 75r: La operación de subir una pieça de artillería en la cumbre y alteza de qualquier montaña para el effecto de artillar alguna fortaleza o para de aquella montaña batir y expugnar otra fortaleza enemiga es en sí diffícil y trabajosa, por haver de subir un tanto peso cuesta arriba. // Roxas, Sumario milicia, 1607, fol. 74r: Eligido ya el sitio para edificar la çiudad o castillo, para que mejor se pueda fortificar es neçesario saber en quántas maneras se han expunado los otros. Hanse expunado o por fuerza manifiesta o por trayçión. Tratarse ha ahora de la fuerza manifiesta, con la qual se toman las çiudades o castillos con baterías, o asaltos y escalas, y con minas y otras ynbençiones.

ENCICL.: DUE: Conquistar una plaza.

expunar, V. expugnar. 


\section{facción, facción, fación, factión, façión, faición, fatión, fayción, fazión [tomado}

del lat. factio, -ōnis 'manera de hacer', 'corporación, partido, facción, liga'. Fación 'hechura', h. 1300, Gr. Conq. de Ultr.; J. Manuel; 'acción, obra', Vida de S. Idelfonso (DECH). Micón, Diario grande cometa, 1578]. sust. Conjunto de personas en lucha con otras o con ideas opuestas respecto a ellas (DUE: s.v. bando ${ }^{1}$ ).

Micón, Diario grande cometa, 1578, pág. 98: Y d'éstos han aparecido muchos, como el que duró 75 días antes de la guerra de Peloponeso, y antes de la rota de los athenienses y de la guerra civil de entre César y Pompeyo; antes de la peste mahomética, año de 594, antes de la secta arriana y de la factión de los güelphos y gevelinos en Italia. // Álaba, Perfeto capitán, 1590, fol. 85r: Y si la villa o ciudad estuviere dividida en vandos y faciones, como muchos lugares de Italia y otras provincias lo están, acudirse a a una de las parcialidades, tentando con recato, si a trueco de ver fuera del lugar la gente del vando contrario, querrán dar alguna entrada para la ciudad. // Collado, Plática Artillería, 1592, fol. 98r: Acerca de [...] el hobrar con el artillería el día de una batalla de tierra, digo que en tal occasión, assí como este acto de milicia es el más importante y terrible que en todos sus exercicios se halla y en el qual, por la mayor parte, consiste el último trance y remate de la guerra y que d'él depende toda la reputación y honra de la una facción y de la otra, assí grandes y muy qualificadas consideraciones han de haver en el conduzir y acomodar el artillería.

ENCICL.: Aut.: Covarr. y otros escriben fación, aunque con menos propiedad, por ser tomado del latino factio, onis. // DSAL: Bando que interviene en una guerra o enfrentamiento. // DSAL (s.v. bando): Grupo de personas que se oponen a otras por sus opiniones o por otra razón. 
2 [Álaba, Perfeto capitán, 1590]. sust. Mil. Combate o cualquier otra operación militar llevada a cabo en una guerra.

Álaba, Perfeto capitán, 1590, fol. 136r: Y aviendo de embiar algunos soldados a alguna fación o empresa en parte donde huviere peligro, embiará los más inútiles y de menos importancia, porque, quando se pierdan, se aventure poco. // Collado, Plática Artillería, 1592, fol. 55r: El artillero que dessea ser tenido por plático y hazer bien su officio, sabiendo que se ha de hallar en una batería o otra facción alguna donde será menester tirar muchos tiros con su pieça, él deve, primero, hazer una buena provisión de agua y que ésta sea la más fría que haver se pueda. // Mendoça, Theórica y práctica, 1596, pág. 110-111: Campeando se embían de ordinario, y en particular quando se está algo lexos, gruessas tropas de cavallería para reconocer el un campo al otro encomendándolas a soldados de pecho y cuerdos, y con esto vienen a hazerse facciones, que se llaman rencuentros.

SIN.: empresa, empresa de (la) guerra, empresa militar, encuentro 1 , facción de guerra, hecho de armas, interpresa $a_{1}$, reencuentro 1 .

ENCICL.: Terr.: Empresa, V. // Almirante (1869): Acción de guerra, acometida, empresa. En este sentido la usa Cervantes (Quij. part. 1. cap. 51.): "Mostraba señales de heridas, que, aunque no se divisaban, nos hacía entender que eran arcabuzazos dados en diferentes reencuentros y facciones". // Estévanez (1897: s.v. acción de guerra): Todo hecho de armas, desde la batalla más solemne hasta la más ligera escaramuza. // Borreguero Beltrán (2000: s.v. acción militar): Acepción muy amplia ya que comprende desde un simple enfrentamiento, incursión, emboscada, etc., hasta un combate o batalla.

$\sim$ de guerra [Escalante, Discurso de la navegación, 1577]. cmpt. sintag. Mil. Combate o cualquier otra operación militar llevada a cabo en una guerra.

Escalante, Discurso de la navegación, 1577, fol. 86v: Son los chinas muy mañosos y astutos en todas las facciones que se ofrecen de guerra $\mathrm{y}$, aunque tienen valor para esperar $\mathrm{y}$ acometer a los enemigos, usan siempre de ardides estraños en todas ellas, y de todo género de máquinas e instrumentos de fuego en las batallas de mar y tierra. // Mendoça, Theórica y práctica, 1596, pág. 89: La relación d'esta información que darán las personas pláticas o naturales de la tierra significará Vuestra Alteza a sus consejeros para tomar ultimada resolución en la manera que se ha de poner el sitio, siguiendo con mucha puntualidad su opinión y parecer, por ser una de las facciones de guerra, el sitiar plaça, que pide mucha consideración. // Ufano, Tratado de la Artillería, 1613, pág. 13: Y aunque d'estas pieças ay algunas de bronçe y hierro modernas, no se usan en nuestro tiempo en las façiones de guerra, por ser pieças torpes en su movimiento y mal manejables.

SIN.: empresa, empresa de (la) guerra, empresa militar, encuentro ${ }_{1}$, facción $n_{2}$, hecho de armas, interpresa $a_{1}$ reencuentro ${ }_{1}$.

ENCICL.: Rubió y Bellvé (1895-1901): Acción de guerra, función de guerra. 
facienda, fazienda, hazienda [tomado del lat. faciěnda 'cosas por hacer', plural neutro del participio de futuro pasivo de facere. Facienda, doc. de 1115, Oelschl.; facinda en el Auto de los Reyes Magos; 'asuntos, ocupación', Berceo, Mil., S. Or.; Alex., 1223; 'estado (de una persona)', Mil.; 'importancia, prestigio', Mil.; 'batalla' (< 'asunto'), J. Ruiz; 'faena, trabajo por hacer', ac. etimológica, común con el cat. faena, en G. de Alfarache (DECH). Celso, Reportorio universal leyes Castilla, 1553]. sust. Mil. Acción bélica en la que se enfrentan soldados o formaciones militares enemigas.

Celso, Reportorio universal leyes Castilla, 1553, fol. CLIXv: Lo mesmo dezimos de lo que fuesse ganado en hazienda, o en lid, o en cavalgada, do fuesse algún capitán por mandado del Rey. // Celso, Reportorio universal leyes Castilla, 1553, fol. CLIXv: Lo mesmo es si lo ganassen en hazienda, o en lid, o en cavalgada, o spolonada, o celada, o entrando en villa o castillo por fuerça, o en navíos de los enemigos, o en qualquier otra manera que se podiesse dezir guerra. Y si el Rey no fuere aý en persona, dévelas cobrar su Capitán General.

SIN.: batalla $a_{1}$, combate ${ }_{1}$, combatimiento ${ }_{1}$, contienda $a_{2}$, debate, lid, pelea.

ENCICL.: Estévanez (1897): En la Edad Media lo mismo que "combate". // DUE: (ant.) Batalla.

fación, V. facción.

factión, V. facción.

façión, $V$. facción.

fagina, V. fajina.

faición, V. facción.

fajina, fagina, fajina, faxina [del it. fascina 'íd.' (derivado de fascio 'haz') en calidad de término militar. 1569, Ercilla (DECH). Álaba, Perfeto capitán, 1590]. sust. Fort. Conjunto de ramas delgadas, fuertemente atado, que se emplea en la guerra, especialmente en la construcción de defensas.

Álaba, Perfeto capitán, 1590, fol. 93r-93v: Y quando la batería començare, tratará de evitar parte de su efeto con su artillería, con trincheas, faxinas y otras coberturas y reparos sustentados con cuerdas y sogas, apartados algo del muro para que, quando no sirvan de mucho reparo, encubran a lo menos el daño que de la batería se recibe. / / Collado, Plática Artillería, 1592, fol. 97v: La esquadra delantera lleva hachas con que van cortando los 
árboles de los bosques; la segunda llevan hocinos para desmenuzar las leñas dichas y hazer de ellas faxinas. // Ufano, Tratado de la Artillería, 1613, pág. 174: La faxina es muy utilíssima para hazer las reparaçiones y cubrimientos con ella y tierra a prueva de artillería sobre la rotura de las baterías y otras qualesquier partes que a su buena deffensión convenga.

FAM.: fajinada.

ENCICL.: Moretti (1828: s.v. fagina): Fort. Haz de ramas menudas. La fajina tiene como seis pies de largo y ocho pulgadas de diámetro. Está atada con varias cuerdas, colocadas a un pie de distancia de las extremidades, poco más o menos, y es de gran uso en la guerra, pues sirve para construir atrincheramientos, espaldones y parapetos; y para trazar las obras, llenar el foso de un atrincheramiento que se ataca, hacer paso por el de una plaza sitiada, construir diques y puentes sobre balsas para las comunicaciones, etc. // Collado, Plática Artillería (1592: fol. 70v): "La qual máquina es de grande servicio para conduzir por tierra llana qualquiera grandíssima pieça y, mayormente, quando, marchando con el artillería, se halla estar elado el suelo o cubierta de nieve la campaña y quando, assimismo, se ha de passar por algún lugar cenagoso y donde se halla algún mal passo, que entonces con poca faxina de ramas de árboles que se eche en tierra, se passa la estruja deslizando por encima, que es cosa maravillosa". // Mendoça, Theórica y práctica (1596: pág. 101): "En este tiempo, si el fosso es seco, se reconocen las cañoneras y casamatas que tienen en él y pie que haze la ruyna de la batería y, teniendo agua, se trata de sangralle, si el terreno da lugar, o agotalle con ingenios que ay para el efecto, o cegalle con faxinas o llenarle de tierra". // Rojas, Teórica fortificación (1598: fol. 70r): "Y en todo lo demás, de fosso, de refosso y estrada cubierta, me remito al abecedario que está junto al perfil, y advierto, de camino, que todos los cavalleros que se hizieren sobre los terraplenos han de ser de tierra, y fagina y céspedes, y no de piedra". // Lechuga, Discurso de la Artillería (1611: pág. 261): "Ay, assimismo, partes de lagunas o fosos llenos de agua en los quales es necessario sacar un baluarte, y dificultoso el hazer los fundamentos, por el agua y por el fondo, y muy costosos. En los tales, se podrá hazer de manera que se hinchan de faxinas echadas hasta que venzan la agua, y encima de ellas echar tierra y formar sobre ella los baluartes; y por esta regla lo que más fuere menester".

fajinada, faxinada [de fajina (DECH). González de Medina, Examen fortificación, 1599]. sust. Fort. Conjunto de fajinas (DRAE).

González de Medina, Examen fortificación, 1599, pág. 195: Todo lo que se ha dicho es necessario para hazer fuegos artificiales: que unos se enciendan con agua, y que con ella no se puedan matar; otros, que sean buenos para quemar faxinada; otros, para que, donde se arrojaren, alumbren más que hachas.

FAM.: fajina.

2 [Ufano, Tratado de la Artillería, 1613]. sust. Fort. Defensa o fortificación hecha con fajinas. 
Ufano, Tratado de la Artillería, 1613, pág. 381: Si se quisiere dar fuego a una barraca o faxinada, hazer un ballestón grande que su berga sea flexible y se dexe vencer en tiempo de su operación, de forma que dulce y fácilmente se arme con un ynstrumento o gaffón y pueda tirar una pequeña bomba encaxada en un flechón, de suerte y manera que en la presente figura se representa.

SIN.: barraca.

falárica, falárica, phalárica [tomado del lat. fălārǐca (phălārǐca), -ae 'falárica' (jabalina untada de pez, guarnecida de estopa, que se arrojaba encendida desde lo alto de las torres de asedio o de las murallas), 'jabalina' (Segura Munguía 2001). Collado, Plática Artillería, 1592]. sust. Mil. ant. Dardo que lleva debajo del hierro o flecha una pelota o madeja de estopas embreadas y empapadas en líquidos inflamables (Almirante 1869).

Collado, Plática Artillería, 1592, fol. 2v: Las máquinas, pues, Real Magestad, con que los antiguos solían expugnar las fortalezas y batir las murallas eran éstas: las cathapultas, las balistras, las víneas, los arietes, las testúdines [...], el compago, el escorpión, las sambucas, las faláricas y otras muchas. // Mosquera, Comentario disciplina militar, 1596, fol. 91v: Y halláronse algunas de aquellas armas arrojadizas que los antiguos llamavan phaláricas, que eran unas astas con hierros fuertes para herir y por de dentro estavan huecas y cargadas de resina, y cierto betum combustible, piedra sufre, y estopas y azeyte que abrasava con pegajosa y vehemente llama lo que tocava.

ENCICL.: Aut.: Arma enastada arrojadiza, a modo de azagaya, con su hierro cuadrado, largo de una vara castellana, y en la juntura del hierro y del asta se ponían unas mechas de estopa untadas con pez, a las cuales ponían fuego cuando las arrojaban. Es voz de las primitivas Españolas según el P. Mariana, lib. I. cap. 5.

falda, falda [probablemente del fráncico *falda 'pliegue', por conducto del catalán o de la lengua de Oc. Berceo (DECH). González de Medina, Examen fortificación, 1599]. sust. Fort. Pasaje o subida, en forma escarpada, por la que los soldados acceden desde la plaza de armas hasta el andamio o parte superior de la fortaleza. s? (fig. 78)

González de Medina, Examen fortificación, 1599, pág. 48: [Las casas] han de estar apartadas del fin de la falda del terrapleno quarenta pies, para que puedan passar pieças de artillería de la una parte y de la otra y gente en el esquadrón. // González de Medina, Examen fortificación, 1599, pág. 146: Lo blanco es el terrapleno, y lo lleno de rayuelas la falda para subir, y lo demás las estancias y viviendas y plaça de armas, que cada cosa se demuestra por sí bien clara. / / González de Medina, Examen fortificación, 1599, pág. 217-218: La falda, $\mathrm{N}$, para subir, treinta pies de ancho. El passo, $\mathrm{O}$, entre la falda y las casas, quarenta pies de ancho.

ENCICL.: González de Medina, Examen fortificación (1599: pág. 30): "Los terraplenos tendrán, los de las cortinas, cincuenta pies de ancho, lo que fuere línea recta por la superficie desde 
donde junta el parapeto con la cortina hasta que comiença la falda, por la gran pujança que las pieças de batir que se usan tienen. La falda ha de començar desde la perpendicular que haze el terrapleno a los cincuenta pies de ancho, y ha de yr tan escarpada del mismo terrapleno que tenga treynta pies de caýda para poder fácilmente subir el artillería y los soldados a la defensa, porque para esto no son buenas escaleras, por muchas y buenas que sean. Los de los baluartes han de ser todos ellos muy bien terraplenados, y las mesmas golas de la mesma manera, línea recta, donde assimismo junta la muralla con el parapeto hasta començar a escarpar la falda, que la ha de tener para lo mesmo que la de la cortina, siendo tres pies más larga por los dos que tiene más de alto el baluarte que la cortina".

falso, V. escuadrón .

fatión, V. facción.

faxina, V. fajina.

faxinada, V. fajinada.

fayción, V. facción.

fazienda, V. facienda.

fazión, V. facción.

fianco, fianco [del it. fianco 'lato que congiunge la faccia del bastione alla cortina', ya en Galileo (Tommaseo y Bellini 1861-1879). Rojas, Teórica fortificación, 1598]. sust. Fort. Parte del baluarte que une su frente con la cortina, o distancia comprendida entre el ángulo de la cortina y la cara o frente del baluarte.

s? (fig. 79)

Rojas, Teórica fortificación, 1598, fol. 37r: Y también está junto al abecedario un valuarte desnudo para saber cómo se han de hazer los fiancos o travesses. // Rojas, Térica fortificación, 1598, fol. 39v-40r: Dividirse ha en quatro partes iguales el recinto, y tomar las dos de en medio para la cortina, y las otras dos, una de cada lado, se dexará para la gola del valuarte, de suerte que siendo BC de 600 pies, tomaré 150 para la gola de cada parte y quedarán 300 para la cortina, de forma que, la $\mathrm{AB}$ dividida en quatro partes iguales, quedan las dos CC de cortina franca, y la CD es fianco o través, que tiene 60 pies y la CO es la gola. // Rojas, Teórica fortificación, 1598, fol. 41r: Y, assí, se ha de huir de no hazer en mitad de una cortina, ni de qualquiera línea recta, ningún género de ángulo interior ni 
exterior, porque todos son ya reprovados. Y assí, iré derechamente haziendo las plaças lisas, con los fiancos o travesses necessarios, huyendo de la mucha costa y daño que causan los muchos ángulos y rebellines.

SIN.: espalda ${ }_{2}$, través 1 .

ENCICL.: Aut. (s.v. flanco): Term. de fortificación. La parte del baluarte que hace ángulo entrante con la cortina y saliente con la frente, el cual suele también llamarse través. Cuando se dice absolutamente flanco, se entiende éste; pero se suele llamar flanco del baluarte, flanco primero, a distinción del flanco segundo cuando lo hay en la fortificación. // Sanz (1749: s.v. flanco de un baluarte): Es la distancia que está comprendida desde el ángulo de la cortina hasta el ángulo de la espalda. No hay cosa más necesaria en una fortificación que el flanco, pues defiende a lo menos la mitad de la cortina, la cara del baluarte y el otro flanco opuesto; ésta es la parte de mayor defensa, y contra la que con mayor aplicación forman el ataque los sitiadores, a fin de privársela a la cara del baluarte opuesto, cortina y la recíproca correspondiente al flanco opuesto, con lo que quitan a uno y otro los fuegos que tienen preparados para defender una brecha e impedir que no se ataque el minador en ninguna parte del recinto, y que sea descubierto y visto. // Lucuze (1772: 33-34): "De su buena disposición y magnitud depende la ventajosa defensa [...]. La extensión del flanco será proporcionada de 40 a 63 varas para una batería respetable de siete piezas de cañón. Toda la dificultad está en disponerle de suerte que, flanqueando bien la cara del baluarte opuesto, no se exponga a ser arruinado fácilmente por las baterías del sitiador. Si se hace perpendicular a la cortina, no quedará expuesto a la campaña, pero no flanqueará bien la cara, que es su principal objeto. Si se dispone perpendicular a la cara, prolongada, o a la línea rasante, la flanqueará bien, pero quedará expuesto. Así, el acertado medio es que el ángulo del flanco con la cortina sea de 100 grados o algo obtuso".

filada, V. hilada.

flanco, flanco, franco [del fr. flanc 'costado, ijada' y éste del fráncico *hlanca. h. 1700, Mateo Ibáñez (DECH). Ufano, Tratado de la Artillería, 1613]. sust. Mil. Espacio o faja de terreno que, en cualquier orden de batalla, se extiende a partir del último hombre situado en el ala o costado de esa formación.

Ufano, Tratado de la Artillería, 1613, pág. 93-94: Ningún súbito reqüentro [...] puede en manera alguna venir tan secretamente cubierto ni tan repentino, que mucho antes del reconosçerse los unos a los otros esquadrones, si se ofresçiese señal de batalla y combate, no uviese y sobrase lugar de montar sobre sus afustes el artillería gruesa, viniendo aprestado todo lo neçessario para ello de cuerdas, guindales y gente $\mathrm{y}$, encabalgada, meterla a los ángulos de los esquadrones para que libremente juegue, de modo que no ympida el pelear a la ynfantería o caballería y que de lleno, transversal o rectamente hiera el flanco de los enemigos esquadrones y su frente.

ANT.: frente ${ }_{2}$. 
FAM.: flanquear.

ENCICL.: Almirante (1869): Es frecuente confundir flanco con ala y costado. // Estévanez (1897): Aun entre militares, se toma a veces por "ala"; pero no es lo mismo. En táctica, es el terreno que está más allá del ala; donde acaba el ala izquierda, allí empieza el flanco izquierdo. // Borreguero Beltrán (2000): El hombre en fila no tiene flanco, tiene costado; quien lo tiene es la tropa.

2 [Ufano, Tratado de la Artillería, 1613]. sust. Fort. Parte de la cortina comprendida entre el punto resultante de prolongar la cara de un baluarte y aquel en el que comienza el flanco del baluarte opuesto, existente sólo en las fortalezas en las que esos dos puntos son distintos.

Ufano, Tratado de la Artillería, 1613, pág. 159: Siendo una villa populosa, a mi poco saber, antes le haría la batería por la cortina que no por el valuarte, en espeçial si los francos de sus traveses distan mucho el uno del otro, y muestra su lienço de muralla más francamente. // Ufano, Tratado de la Artillería, 1613, pág. 160-161: Como sea qualquier fuerte, es mucho mejor y más seguro batirle por el baluarte o caballero que no por la cortina, por occasión de que las cortinas de un fuerte son muy cortas y las cubren y deffienden mucho sus baluartes, por tenerlos más a caballero estendidos sus flancos y traveses sobre dichas cortinas que no las plaças reales de grande capaçidad y estendida.

ENCICL.: Lopes Pires Nunes (2005: s.v. flanco secundário): Parte de la cortina compreendida entre el flanco de um baluarte e a sua linha de defesa rasante. // Lopes Pires Nunes (2005: s.v. linha de defesa rasante): Linha constituída pela rasante à face do baluarte e seu prolongamento para o lado da cortina. // Díaz Capmany (2004: 33): "Cuando la línea de defensa rasante cortaba a la cortina en un punto distinto del encuentro del flanco, el espacio de cortina comprendido entre estos dos puntos recibía el nombre de flanco de la cortina o segundo flanco; se llamaba así porque desde él se podía tomar de flanco a quienes atacaban la cara del baluarte. A los tiros flanqueantes que podían hacerse desde ese sector de la cortina se les denominaba fuegos de cortina".

$\sim$ del orejón [Ufano, Tratado de la Artillería, 1613]. cmpt. sintag. Fort. En un baluarte con orejón, la parte del flanco que se encuentra cubierta por él. s. (fig. 81)

Ufano, Tratado de la Artillería, 1613, pág. 197-198: Demás d'esto deve entender el curioso mílite que esta dicha contrabatería que sale por la frente del baluarte no sólo puede servir su effeto por tal parte; pero también si los sitiadores le batiessen la gola o punta del dicho baluarte, usando trasversalmente de su dicha qüenta y razón, ordenadas las espaldas con sus pieças qual convengan, podrán bien servir a la deffensa de tales baterías, aunque fuesen endereçadas por el flanco del orejón, de forma que por todas partes cómodas a tal arte su pueden armar las dichas contrabaterías y servir d'ellas y, quando no de tanta capaçidad, a lo menos de la que la neçessidad de la occasión conçediere. 
flanquear, franquear [de flanco. 1625, C. Coloma (DECH). González de Medina, Examen fortificación, 1599]. v. tr. Art. Dicho de una posición o de una fortificación: estar situada de tal manera que alcanza y domina a otras con su artillería.

González de Medina, Examen fortificación, 1599, pág. 15-16: La trapecia es para muchos lados desiguales, que, si no fuesse obligando el sitio o para ciudades que se quieren poner en defensa y no mudarles su forma, no es necessario hablar aquí d'ella ni de otra que de la pentágona, de que pienso aprovecharme para esta ocasión; la qual se tiene por muy buena, porque se puede franquear con las defensas, de manera que sean dificultosas de quitar y que quede plaça en los baluartes para poder hazer cortaduras y retirada, si se cortare el ángulo de los baluartes. // Lechuga, Discurso de la Artillería, 1611, pág. 241: La estrada cubierta, ancha, quarenta pies, y en ella, muchas salidas a la campaña, y franqueada con revellines en medio de las cortinas // Ufano, Tratado de la Artillería, 1613, pág. 114: D'estar el artillería alojada, ynstituyda y puesta en alto se sacan dos provechos: la una es el señorear y descubrir mejor y más ampliamente toda la campaña y sus avenidas, y la otra prinçipalmente guardar muy mejor y deffender más bien y libremente todo el campo y, sobre todo, más rasamente franquear la plaça de armas de todo el exérçito.

FAM.: flanco.

ENCICL.: D'Wartelet (1863): La obra de fortificación, fortaleza o posición colocada de manera que, respecto a una plaza, castillo, etc., con su artillería pueda ofender a cualquiera de sus defensas. // DUE: Artill. Estar colocado un castillo, baluarte, monte, etc., de tal manera, respecto de una ciudad, fortificación, etc., que llegue a éstas con su artillería, cruzándolas o atravesándolas con sus fuegos.

fondo, fondo [de perfondo, voz ant. y dial., que procede del lat. profündus 'íd.'. El prefijo per fue probte. interpretado como intensivo y se suprimió. Fondo, como sustantivo, en 1220-50 (Segura Munguía 2007). Mendoça, Theórica y práctica, 1596]. sust. Mil. En cualquier formación táctica, extensión o espacio que ocupan sus soldados pecho con espalda. (fig. 82)

Mendoça, Theórica y práctica, 1596, pág. 54-55: Según el sitio y disposición que mostrare el enemigo, [...] hará estimar si han de ser quadrados de gente o de terreno, de gran frente o prolongados, con mucho fondo o de otras figuras, cosa que se ha de ordenar según el puesto o costumbre que tiene cada nación en combatir más en una suerte de esquadrón o batallón formado que en otra. // Rojas, Teórica fortificación, 1598, fol. 102r: Supongo que tengo tres o quatro mil picas, más o menos, y para mi propósito digo que sean 3.000 y el esquadrón sea quadro de gente. Sacaré la raíz quadrada de los 3.000, que es 54 y algo más, y tantas hileras tiene de frente y fondo el tal esquadrón, dando de distancia entre soldado y soldado por la frente 3 pies, y 7 de pecho a espalda, que se entiende 7 pies de uno a otro hazia las espaldas. // Rojas, Compendio fortificación, 1613, fol. 7v-8r: El quadro de terreno se hará ansí: supongo que las 1600 picas quiero ponerlas en quadro de terreno, sabiendo ya que ha de aver tres pies de distancia de un soldado a otro por la frente, y de pecho a espalda - que se entiende el fondo - siete pies; $\mathrm{y}$, conforme a esto, manda la regla que se multipliquen las 1600 picas por tres, y harán 4800, los quales se partirán por 7, y saldrán a 
la partición 685 , de los quales se sacará su raýz quadrada, que será 26 , y tantas picas tendrá de fondo el quadro de terreno.

ANT.: frente 1.

ENCICL.: Almirante (1869): En táctica, fondo es extensión en sentido de profundidad, contada sobre la perpendicular al frente o batalla. // Rubió y Bellvé (1895-1901): En táctica es el espacio que ocupa una tropa contado en sentido perpendicular a su frente. // DRAE: Mil. Espacio en que se forman las hileras y ocupan los soldados pecho con espalda.

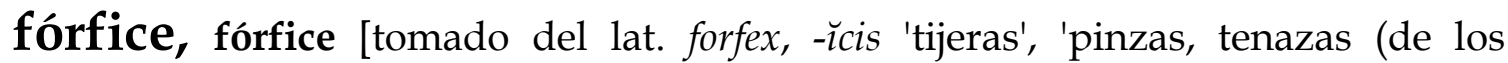
cangrejos), 'orden de batalla en forma de tenazas' (Segura Munguía 2001). García de Palacio, Diálogos militares, 1583]. sust. Mil. Formación angular y cóncava, con el centro más retrasado que las alas, para envolver al enemigo o hacer frente al ataque en cúneo. 1 (fig. 83)

García de Palacio, Diálogos militares, 1583, fol. 183r: Una forma cúnea es apta y sufficiente para romper otra qualquier batalla quadrada, aunque tenga la tercia parte de infantes más, la qual querría que se hiziesse a vista del enemigo, con mucha presteza, para que no tuviesse lugar de hazer la fórfice o tixera, con que podría aventajarse. // Álaba, Perfeto capitán, 1590, fol. 118v: Como ninguna cosa ay que no tenga su contrario, imaginaron los antiguos una forma de esquadrón que pudiesse ser contraria a la cúnea, y ésta llamaron fórfice o tenaza, la qual se dispone con tal traça que, cogiendo a la otra en medio, la hiere por más partes que no es ofendida.

SIN.: tenaza $a_{4}$ tijera ${ }_{2}$.

ENCICL.: García de Palacio, Diálogos militares (1583: fol. 173r-173v): "Y acostumbraron los antiguos formar por esta orden una fórfice o tixera, para, con mucha ventaja, opponerse a los semejantes esquadrones, y dividían, para hazer la dicha fórfice, todo su esquadrón en dos partes yguales, y venían a hazer dos esquadrones en la forma cúnea, por la orden dicha, començando por uno y procediendo tres, cinco, siete, nueve, etc., las quales juntavan, poniendo entrambas puntas hazia los enemigos, y, entre ellas, rescebían la punta del dicho esquadrón cúneo, al qual offendían por un lado y otro, no teniendo los de la forfice que hazer más de por un cabo, como por esta figura paresce".

forno, V. horno.

forrage, V. forraje.

forraje, forrage, forraje, forraxe [del fr. fourrage 'hierba de prados empleada como pienso', derivado del fr. ant. fuerre y éste del fráncico *fôdar 'alimento'. En todo el Siglo de Oro abunda forraje, pero sólo como término militar (DECH). 
Mendoça, Theórica y práctica, 1596]. sust. Mil. Cualquier tipo de pasto, hierba, semillas, cereales, etc. que los soldados dan de comer a sus caballos.

Mendoça, Theórica y práctica, 1596, pág. 46: Ordenará Vuestra Alteza por el mismo respeto caminen, haziendo diferentes caminos, la buelta de las fronteras y confines del reyno donde Vuestra Alteza hallará ser más conveniente juntar el campo, parte donde se ha de eligir sitio que tenga buen terreno, comodidad de leña, agua y forrajes para alojarle. // Rojas, Teórica fortificación, 1598, fol. 36v: Si se encontrasse un sitio en peña viva, y que estuviesse libre de padrastros y de balles y arroyos, y tuviesse agua de pie, y el forraje y leña con buena comodidad, y el sitio saludable, y toda la munición necessaria y soldados y, sobre todo, a propósito para poderla socorrer, en tal caso esta plaça sería la más perfeta de todas. // Rojas, Compendio fortificación, 1613, fol. 25v-26r: Lo primero que se ha de hazer, antes que se eche el cordel ni las estacas en el sitio para fundar las murallas, es bien que se considere la calidad de aquel sitio y la de los enemigos que espera le podrán venir a sitiar, mirando primero el asiento y forma del sitio, si es llano o en monte, o si participa de ambas cosas [...]; y assimismo, si ay comodidad de bastimentos y del forraxe para los cavallos que dentro ha de aver, que, aunque todas estas cosas son menudas, muchas vezes hazen al caso.

FAM.: forrajear, forrajero.

ENCICL.: Aut. (s.v. forrage): Term. de la milicia. La hierba o pasto que van a coger los soldados para dar de comer a los caballos. // Borreguero Beltrán (2000): En la época moderna la abundancia o escasez de forraje determinó el lugar de las campañas.

2 [Roxas, Sumario milicia, 1607]. sust. Mil. Acción de buscar y recoger el alimento necesario para las caballerías del ejército.

Roxas, Sumario milicia, 1607, fol. 68r: Y estando todo prevenido, podrá començar a marchar, procurando llegar siempre de día, porque tengan tiempo para poder yr los soldados a forraje.

ENCICL.: D'Wartelet (1863): Ir al forraje se dice cuando los mismo soldados van a segarle en los campos. // DRAE: Acción de forrajear.

forrajear, forregear [de forraje. 1640, Colmenares (DECH). Collado, Plática Artillería, 1592]. v. intr. Mil. Dicho de un soldado: salir a buscar y recoger el forraje para los caballos.

Collado, Plática Artillería, 1592, fol. 112r: Y por quanto [...] en qualquiera facción de artillería a los artilleros se les da ración del comer y bever doblada de aquélla que se da a la demás gente de guerra, no deven ser ellos negligentes en pedirla ni perezosos en cobrarla y, cobrada aquélla, guardarla y moderamente compartirla, de manera que siempre le sobre del un día para el otro alguna cosa, porque muchas vezes se vee que faltan vituallas en el campo y al artillero, ni le es lícito desamparar su pieça, ni menos hir a forregear, ni hazer correrías en la campaña. 
FAM.: forraje, forrajero.

ENCICL.: Terr.: En particular en la guerra, ir a buscar forraje.

forrajero, forrajero [de forraje (DECH). Mendoça, Theórica y práctica, 1596]. sust. Mil. Soldado que va a buscar forraje para los caballos (Rodríguez Navas 1918: s.v. forrajeador).

Mendoça, Theórica y práctica, 1596, pág. 83-84: Al alojar Vuestra Alteza convendrá llegue de buena hora, assí porque lo haga la gente con más comodidad, como porque aya tiempo para fortificarse, si es necessario, estando vezino el enemigo, cosas que se hazen mal de noche; y para assegurar los forrajeros, se ha de advertir, pudiéndolos el enemigo hazer daño, el embiar cavallos a descubrir y hazelles escolta, si lo pide la ocasión.

FAM.: forraje, forrajear.

ENCICL.: D'Wartelet (1863: s.v. forrajeador): El soldado que va a forrajear, bien sea segándole en el campo o tomándole de los pueblos y lugares habitados.

forraxe, $V$. forraje.

forregear, V. forrajear.

fortaleça, V. fortaleza.

fortalecer, fortalecer, fortalescer, fortaleser, fortalezer, fortelecer [de fortaleza. Fortalecer inicialmente en el lenguaje militar, después en el general. Afortalezar [1. ${ }^{a}$ Crón. Gral., Mem. de Fernando IV], fortalesçer [Gral. Est. I, Nebr.] (DECH). Santa Cruz, Libro de las longitúdines, a. 1567]. v. tr. u. t. c. prnl. Hacer fuerte o más fuerte a una persona o una cosa.

Loçano, Alberto, Architectura, 1582, pág. 103: Finalmente, una vez y otra conviene mirar que el monte, o la roca, o lago, o laguna, o río, o fuente, o otra qualquiera de éstas no se aya de tal suerte, que pueda fortalecer $y$ deffender al enemigo, o acarrear por alguna parte daño a la ciudad y ciudadanos. // García de Palacio, Diálogos militares, 1583, fol. 88r: El que huviere rendido a ciudad de fee differente o que antes tenía de por sí libertad e imperio, nescessidad tiene que, con tiempo, provea cómo se reparen los lugares fuertes y, si no los tuviere, se hagan, para que, si en algún tiempo los subjetos se rebelaren, en ellos se fortalezcan, amparen y defiendan los vencedores, y offendan y subjeten los vencidos // Collado, Plática Artillería, 1592, fol. 88v: La quarta, si por ella ha de passar solamente gente de a pie y de a cavallo, o la artillería gruessa del exército, por quanto, para suffrir el peso de una tan poderosa máquina, conviene que la puente sea muy más fortalecida. 
SIN.: fortificar 1 .

FAM.: enfortalecer, fortalecido, fortaleza.

2 [Montes, Instrucción y regimiento, 1537]. v. tr. Fort. Dar protección a un lugar o posición con reparos o defensas.

Montes, Instrucción y regimiento, 1537, fol. XVIIIv: Por esto, el señor del exército, en las tierras que ganare, ponga tales personas que no hagan falta su persona, y el gasto que hiziere en las fortalescer, sea de manera que aproveche y no sea vicioso, porque el dinero no sea mal gastado. Y como vaya ganando, vaya fortificando las plazas fuertes, porque los enemigos no se puedan amparar d'ellas y en ellas. // Celso, Reportorio universal leyes Castilla, 1553, fol. CCXCVv: Deve, ansimesmo, el Rey amar a su tierra, trabajando que sea poblada de buena gente, haziendo poblar en ella villas e ciudades e castillos, y cerrarlos de muros, y fundar hospitales en ella e hazer otras labores y edificios, guardando que los muros y cercas, y otros edificios públicos, no se derriben por mala guarda, y que sea fortalescida la tierra contra los enemigos. // Loçano, Alberto, Architectura, 1582, pág. 98: Y escriven los historiadores que en el tiempo que anduvo Dionysio por la India, acerca de aquellas gentes no avía ninguna ciudad ceñida con muro. Thucýdides escrive que antiguamente Grecia no estuvo fortalecida con ningún género de muros.

SIN.: enfortalecer, fortificar 2 , reparar 2 .

ENCICL.: Cov. (s.v. fortaleza): Fortificar y hacer fuerte algún sitio o castillo. // Terr.: En la guerra, $\mathrm{V}$. fortificar.

fortalecido, fortalecido, fortaleçido, fortalescido, fortalezido [de fortalecer. Loçano, Alberto, Architectura, 1582]. adj. Fort. Dicho de un lugar o de una posición: protegido con reparos o defensas.

Loçano, Alberto, Architectura, 1582, pág. 137: Otro género de alojamientos será quieto, para donde te estés firme, para apremiar y occupar al enemigo que desconfía de sus huestes de gentes armadas, en tanto que estuviere en algún lugar fortalecido. / / García de Palacio, Diálogos militares, 1583, fol. 63v: Les dio por instrución que, subidos en lo alto de los montes, a la parte del mediodía, viessen y considerassen qué tal era la provincia, y si el que la posseýa y governava era varón fuerte o flaco, y si los moradores d'ella eran pocos o muchos, y si las poblaciones o ciudades eran muradas, torreadas o fortalescidas. // González de Medina, Examen fortificación, 1599, pág. 4-5: Podrá hazer esto un príncipe muy bien, con tener mucho cuydado de que estén bien fortalecidas las plaças principales de su estado, con muy buenos fuertes en las fronteras y passos por donde puede entrar el enemigo, reguladas de manera que el que las huviere de defender tenga satisfación d'ellas.

SIN.: fortificado 2 , fuerte, reparado $_{2}$.

FAM.: enfortalecer, fortalecer, fortaleza. 
fortaleçido, V. fortalecido.

fortalescer, V. fortalecer.

fortalescido, V. fortalecido.

fortaleser, V. fortalecer.

fortaleza, fortaleça, fortaleza [del oc. ant. fortalessa (o -aleza, menos común), hermano del fr. forteresse, ambos derivados de fortis con el sufijo galo e italorrománico -aricius. 'Recinto fortificado', Berceo, Loores; Apol.; Conde Luc.; 'reciedumbre, fuerza', Berceo, S. Lor.; J. Ruiz (DECH). Ortega, Conpusición Arismética y Geometría, 1512]. sust. Fort. Cualquier recinto fortificado de carácter más o menos permanente. (fig. 84)

Ortega, Conpusición Arismética y Geometría, 1512, fol. 193r: Después que en todos los capítulos passados de la Arismética he hablado suficientemente [...] como el arte de la Geometría sea tan necessaria para qualquiera persona, quiero agora brevemente poner aquí adelante el modo y manera cómo qualquiera persona podrá medir y canear qualquiera cosa que sea, agora sea quadrángulo, o triángulo, o arco, o medio arco, o torre, o fortaleza, o pavellones, o fuentes, o otra qualquiera cosa que se pueda mesurar. // Rojas, Teórica fortificación, 1598, fol. 3v: Y también se tendrá cuidado de no erigir el castillo cerca de algún valle o cañada donde pueda estar alojado algún exército enemigo, y quando por algunos respetos fuesse fuerça hazerlo allí, se pondrá mucho cuidado en plantar la fortaleza a vista y de forma que descubra y varra todo el valle, de manera que el enemigo no se pueda allí alojar. // Lechuga, Discurso de la Artillería, 1611, pág. 239: Considerando que, en razón de guerra, toda fortaleza puesta en qualquier lugar deve ser hecha con tanta diligencia quanta sea possible al ingenio humano, para que tenga fuerça de resistir al mayor ímpetu que se puede imaginar en él, y que las fortalezas que se hicieren con la devida orden que pide el uso presente, según lo que e visto por experiencia, tendrán una seguridad casi perpetua, y que el enemigo no se atreverá todas vezes a sitiarlas, y que para hazerlo lo mirará bien, digo que lo primero a de ser no mirar al gasto que, para hazerlas buenas y perfectas, es menester.

SIN.: fuerza $a_{1}$, laza $_{2}$.

FAM.: enfortalecer, fortalecer, fortalecido.

ENCICL.: Terr.: Nombre general que se da a toda plaza fortificada. // Lorenzo Celorrio (1996): Se aplica este apelativo a cualquier construcción de carácter defensivo que destaque por sus grandes dimensiones. // Mora-Figueroa (2006): Voz genérica para designar 
cualquier recinto fortificado, con independencia de su cronología y titularidad. / / Aut.: Se divide en regular e irregular. Fortaleza regular es la que tiene todos sus lados y ángulos iguales. Irregular la que tiene los lados o ángulos desiguales.

fortalezer, V. fortalecer.

fortalezido, V. fortalecido.

fortelecer, V. fortalecer.

fortifficación, $V$. fortificación.

fortifficaçión, V. fortificación.

fortifficado, V. fortificado.

fortifficar, V. fortificar.

fortificación, fortifficación, fortifficaçión, fortificación, fortificaçión, fortificatión [tomado del lat. fortificať̌o, -ōnis 'acción de fortificar' (Gaffiot 1934). Collado, Plática Artillería, 1592]. sust. Ciencia que enseña a disponer todas las fábricas y obras que son necesarias para conseguir el fin de la guerra (Fernández Mancheño 1822).

Collado, Plática Artillería, 1592, fol. 62r: Por ser materia differente de la plática del artillería, dexaré de tratar por agora d'ella, reservándola para otro tiempo, que será quando una mi hobra de fortificación saldrá a la luz, siendo Dios Nuestro Señor servido. // Mendoça, Theórica y práctica, 1596, pág. 125-126: Assimismo se ha de advertir si la plaça está fortificada, siendo frontera, o se ha de fortificar de nuevo y en qué manera ha de ser, governándose en esto, según el tiempo que diere el enemigo para ello, con ingenieros y personas que sepan qué es fortificación. // Rojas, Teórica fortificación, 1598, fol. IIIv: La materia de Fortificación que contiene este libro es parte de la milicia tan importante, que sin ella en estos tiempos ningún efeto puede conseguirse.

SIN.: arquitectura militar.

ENCICL.: Aut:: La ciencia que enseña a disponer todas las fábricas y edificios que son menester para conseguir el fin de la guerra. Se llama también arquitectura militar. // Lucuze (1772: 8): "Divídese la Fortificación en ofensiva, defensiva, natural, artificial, 
compuesta, antigua, moderna, regular, irregular, real y de campaña". // Díaz Capmany (2004: 25): "Bajo la denominación de fortificación abaluartada se comprende el conjunto de sistemas de fortificación permanente que fueron utilizados, en el mundo occidental, desde la segunda mitad del siglo XVI hasta las postrimerías del XVIII. La pieza característica de estos sistemas, y de la cual tomaron el nombre, fue el baluarte. También se conoce a estos sistemas con el nombre de fortificación moderna [...], por contraposición a los anteriores o fortificación a la antigua". // Lorenzo Celorrio (1996: fortificación abaluartada): Sistema constructivo que se desarrolla a partir de la segunda mitad del siglo XVI basado en la defensa contra la artillería. Siguiendo unos principios racionales importados de Italia no tardó en extenderse por toda Europa, América y otras zonas de influencia occidental. Su rápida evolución, pareja siempre de la evolución artillera, inutilizó los sistemas tradicionales de fortificación, dejando obsoletos los castillos medievales. Sus principios, entre otros, son: poca elevación relativa de su fábrica, considerable grosor de las murallas y eliminación de ángulos muertos no batibles desde la fortaleza, sustituyendo las torres cuadradas o redondas de las esquinas por construcciones pentagonales denominadas baluartes". // González de Medina, Examen fortificación (1599: pág. 1): "Mi desinio en este discurso que se sigue no es otro que tratar de defensa y fortificación a lo moderno, para que, contra las grandes máquinas y gruessa artillería que oy usan los poderosos exércitos, pocos puedan defenderse de muchos sin recebir gran daño, con mucha pérdida de los que lo intentaren".

2 [Álaba, Perfeto capitán, 1590]. sust. Fort. Acción de hacer fuerte o más fuerte un lugar o posición con reparos o defensas.

Álaba, Perfeto capitán, 1590, fol. 85r: Conociendo que la ciudad es de tratos, procurará tener conocimiento con algunos de los que en ella fueren más poderosos, tratando de ganarles la voluntad con dádivas, honras y riquezas, para que en el assalto le sean favorables o le den alguna puerta o otra parte por donde pueda entrar, corrompiendo y sobornando algún artífice de los que se ocupan en la fortificación para que, dilatando los reparos, aya lugar de tener ventaja, desanimando a los enemigos y fortaleciendo el ánimo de los suyos. // Collado, Plática Artillería, 1592, fol. 48r: No dexaré de dezir lo que sobre este modo de tirar en algunas partes de Italia me ha acontescido y, señaladamente, estando el año 1576 en el Reyno de Nápoles, en la isla del Puerto de Brindez, hallándome en ella a la fortificación del fuerte que por horden de Su Magestad allí se hazía. // Roxas, Sumario milicia, 1607, fol. 73r: Hase de prosuponer que los confines de un reyno tengan alguna correspondencia con el çircuyto de una ciudad, en la fortificaçión de la qual los baluartes son los más principales miembros que ay, los quales se han de poner en las partes que pueda más ofender al enemigo y defenderse a sí mismos y a la ciudad.

3 [Urrea, Vitruvio, Architectura, 1582]. sust. Fort. Cualquier construcción que sirve para proteger un lugar o una posición de un ataque.

Urrea, Vitruvio, Architectura, 1582, fol. 136v: De las escalas [...] y de las demás máchinas que son fáciles de hazer, no tuve necessidad de escrevir, porque éstas los soldados las suelen hazer, y no pueden, en todos los lugares, ni de una misma manera, ser provechosas, por ser las fortificaciones differentes y las fuerças de las naciones. // Álaba, Perfeto capitán, 1590, fol. 84r: Hechas las trincheas, dexando en ellas algunos soldados con algún 
buen ingeniero y gastadores que queden en guardia de aquel sitio, passará con lo demás del exército a otra parte a donde quiere hazer otra segunda fortificación. // Mosquera, Comentario disciplina militar, 1596, fol. 81r: Él, como soldado y que tenía voto en las cosas de guerra, luego que llegó de Francia y reconoció el sitio de las islas, sus fortificaciones, presidio, municiones y bastimentos, dio a entender no ser poderosa la isla para defenderse y que todo le pareció poco, y aun el número de los soldados menor y menos esperimentados de lo que pensava, y aun la isla no tan áspera e inacessible como le avían encarecido.

SIN.: defensa $a_{5}$, defensión ${ }_{3}$, muralla $_{2}$, reparo 2.

ENCICL.: Terr.: Lo mismo que fortaleza, baluarte, castillo, muralla, V. // Almirante (1869): El círculo del significado técnico [de fortificación] debe comprender desde la cortadura que hacen en minutos unos cuantos gastadores en vados, puentes y desfiladeros, hasta los profundos fosos y robustas murallas de las grandes plazas de guerra, en que se invierten siglos, talentos y tesoros.

\section{fortificaçión, V. fortificación.}

fortificado, fortifficado, fortificado [de fortificar. Montes, Instrucción y regimiento, 1537]. adj. Dicho de un individuo, de una colectividad o de una cosa: que se ha hecho fuerte o más fuerte.

Montes, Instrucción y regimiento, 1537, fol. Xv: Y por los lados, y en las postreras hileras del esquadrón, van también otras hileras de cosseletes; y la arcabuzería va delante, y en torno del esquadrón. Y esto se haze quando son los enemigos muchos, porque el esquadrón vaya más fortificado, y no puede ser roto por ninguna parte que le acometan. // Álaba, Perfeto capitán, 1590, fol. 44r: También es necessario que advierta que la parte del esquadrón que mirare a la que ocupa el enemigo esté más fortificada para lo que puede suceder; y si por todas partes huviere enemigos, como sería caminando por su tierra, importará que estén prevenidos y con las armas en las manos.

FAM.: fortificador, fortificar.

2 [Montes, Instrucción y regimiento, 1537]. adj. Fort. Dicho de un lugar o de una posición: protegido con reparos o defensas.

Montes, Instrucción y regimiento, 1537, fol. Xr: Y si la noche lo tomasse antes que la batalla sea rota, retírense en parte donde su campo esté fortificado y no pueda recebir daño de los enemigos. // Mosquera, Comentario disciplina militar, 1596, fol. 15r: En las jornadas que se hazen por tierra de enemigos no solamente suelen cegar las fuentes, pozos, cisternas y atossigar las aguas, pero agostan los campos, destruyéndolos y dexando de sembrar las tierras, encerrando con tiempo en sus fuertes, o lugares cercados y fortificados, todos los frutos y mantenimientos que pueden para sustentarse y que quando el enemigo llegue no halle cosa de que pueda aprovecharse para refugio de su necessidad. // González de 
Medina, Examen fortificación, 1599, pág. 153: Y assí, lo que yo haría sería retirarme y cercar el lugar con una muy buena trinchea, bien fortificada, con buena y acomodada forma, que se le podrá dar la que se quisiere, y buenos travesses, y muy buen foso, que con la tierra que se cabará para hazer la trinchea quedará casi hecho.

SIN.: fortalecido, fuerte 1 , reparado 2 .

3 [Mendoça, Theórica y práctica, 1596]. adj. Fort. Dicho de una persona: protegido por las defensas o reparos que ha construido.

Mendoça, Theórica y práctica, 1596, pág. 79: Y al momento que esté hecha la puente mandará Vuestra Alteza passen arcabuzeros a cavallo acompañándoles golpe de arcabuzería y algunas lanças, si la campaña diere comodidad, y quatro o seys pieças de campaña, siguiendo luego algunos carros y gastadores con que fortificar los soldados la guarda de la puente, que podrán muy bien guardar quinientos hombres fortificados, sin empeñar más número de gente a los principios por ser bastante éste para el efecto.

fortificador, fortificador [de fortificar. Herrera, Institución Academia, 1584]. sust. Persona que profesa o ejerce la arquitectura militar o fortificación.

Herrera, Institución Academia, 1584, fol. 2v: Que aya [...] architectos y fortificadores fundados y curiosos que, con fábricas magníficas y edificios públicos y particulares, ennoblezcan las ciudades y las fortifiquen y defendan, assegurándolas del ímpetu de los enemigos. // Herrera, Institución Academia, 1584, fol. 16v: Y, entroduzido en los libros del arte de fortificar que de muchos modernos son escriptos, se deve de hazer, por lo menos tres o cuatro años, practicante en algunas fuerças, de tal manera que esté muy diestro y instruydo, y sepa por práctica todas las cosas que a un fortificador pertenece saber.

SIN.: ingeniero, ingeniero militar.

FAM.: fortificado, fortificar.

ENCICL.: Terr.: V. Ingeniero.

fortificar, fortifficar, fortificar [tomado del lat. fortüficōo, -āre 'fortificar, fortalecer', compuesto de fŏrtis y făč̄ō. 1438 (Segura Munguía 2007). Montes, Instrucción y regimiento, 1537]. v. tr. u. t. c. prnl. Hacer fuerte o más fuerte a una persona o una cosa.

Montes, Instrucción y regimiento, 1537, fol. XIVr: Y los arcabuzeros vayan adelante y en torno del escuadrón por las dos alas, y si los enemigos fueren muchos, pongan arcabuzería en la reçaga, porque el esquadrón vaya fortificado por todas partes. // García de Palacio, Diálogos militares, 1583, fol. 186r-186v: Si algún espacio se les concede, los soldados de las ventajas (que son los más expertos y bien armados) son puestos en la delantera, sacándolos de los medios, fortificando con ellos la parte más flaca y nescessitada, a cuya causa, entre los antiguos, eran señalados en los ábitos y traýan escriptos los lugares do 
avían de yr, y allí se mudavan con mucha presteza, aviendo conveniente espacio. // González de Medina, Examen fortificación, 1599, pág. 35: Los contrafortes son unos estribos que fortifican la muralla y la ayudan a hazerse una con el terrapleno.

SIN.: fortalecer 1 .

FAM.: fortificado, fortificador.

2 [Montes, Instrucción y regimiento, 1537]. v. tr. Fort. Dar protección a un lugar o posición con reparos o defensas.

Montes, Instrucción y regimiento, 1537, fol. XVIIIr: Los castillos y fortalezas que se pudieren tener a los enemigos, en estos tales deven los príncipes poner mucho recaudo [...]. Y [...] los alcaydes d'ellos han de ser hombres de guerra de buen género, porque el día de la necessidad sabrá cómo se ha de deffender y, si le quisiere fortificar, mejor lo sabrá hazer el alcayde que fuere hombre de guerra, que no otro. // Álaba, Perfeto capitán, 1590, fol. 91v: Fortificado el lugar donde a de assentar el campo para dar la batería, para mostrar que el cerco a de ser largo y que su intento es no desampararle hasta llevar al cabo lo començado, las trincheas y otros reparos que huviere hecho hará que se cubran de piedra por la parte que miran a la ciudad, edificando casas y choças cubiertas, para que se entienda que ay determinación de assistir al cerco todo el invierno y verano [...], porque con esto desmayen los cercados y se rindan. // Mendoça, Theórica y práctica, 1596, pág. 90: Por esto se procura, quando la tierra tiene tres o quatro puertas o salidas, embiar de día o de noche gente, si el sitio lo permite, que a un mismo tiempo ocupe los puestos d'ellas, haziendo diligencia en fortificarlos con trincheas, fossos y traviessas, con lo qual se le impide el socorro y el hazer salidas a los de dentro.

SIN.: enfortalecer, fortalecer ${ }_{2}$, reparar 2 .

ENCICL.: Moretti (1828): Construir fortificaciones bajo las reglas establecidas y según lo permitan las circunstancias del terreno, medios, objeto y tiempo. // Rubió y Bellvé (18951901): Fort. Hacer más fuerte con obras de defensa una población o un sitio cualquiera a fin de que pueda resistir mejor las acometidas del enemigo.

3 [Montes, Instrucción y regimiento, 1537]. v. prnl. Fort. Hacer construcciones para defenderse (DUE).

Montes, Instrucción y regimiento, 1537, fol. XIv: Si tuvieren nuevas de enemigos, deven fortificarse en los passos por do los enemigos vinieren a dar al exército, haziendo reparos, porque los enemigos no puedan passar adonde estuviere la gente del exército. // Mosquera, Comentario disciplina militar, 1596, fol. 93r-93v: Aviéndose recogido a un sitio fuerte, en los días que allí avían estado se avían fortificado y hecho trincheas de tierra, piedras y fagina, y no estavan por entonces mal reparados porque tenían, assí de agua como de otras cosas, todas las comodidades de más importancia para conservarse algunos días. // Roxas, Sumario milicia, 1607, fol. 17v: Y si el enemigo estubiere muy çerca se echará bando y se repartirán las compañías al travajo y con mucha bijilançia se fortificarán. 
ENCICL.: Rubió y Bellvé (1895-1901): Se usa también el recíproco fortificarse, construir obras para la propia defensa de una tropa, población, etc.

\section{fortificatión, V. fortificación.}

fosa, fosa, fossa [tomado del lat. fŏssa 'excavación', 'fosa', 'tumba', 'canal', propiamente participio femenino de fŏdĕre 'cavar'. 1542 Diego Gracián (DECH). Montes, Instrucción y regimiento, 1537]. sust. Fort. Zanja profunda que circunda toda la plaza, fortaleza, etc. (Terr.: s.v. foso).

Montes, Instrucción y regimiento, 1537, fol. XVIIIr: Mas si el castillo estuviere en llano, no sería tan fuerte, si no tuviesse su fossa de agua en torno, y sus traveses por do jueguen los artilleros. // Loçano, Alberto, Architectura, 1582, pág. 107: Es qüestión acerca de gentes de guerra, si es mejor tener fossa llena de agua, o si tienen en más la seca, porque tienen por más importante el mirar por la salud de los moradores. // Loçano, Alberto, Architectura, 1582, pág. 128: Y no dexo de entender que algunos exercitados en la guerra affirman que los muros muy altos no son muy útiles contra el ímpetu de los tiros, porque con la ruyna de éstos, igualadas las fossas, se les da a los enemigos que acometen entrada dessembaraçada.

SIN.: cava, foso, fuesa.

FAM.: contrafosa, fuesa.

ENCICL.: DRAE: Excavación profunda alrededor de una fortaleza. // Aut. (s.v. fossa): La hoya o lugar cavado que se abre en la tierra para diferentes usos.

foso, foso, fosso [del it. fosso, como término militar que sustituyó los antiguos cava y cárcava. 1547 Pedro de Salazar (DECH). Montes, Instrucción y regimiento, 1537]. sust. Fort. Zanja profunda que circunda toda la plaza, fortaleza, etc. (Terr.). s? (fig. 85)

Montes, Instrucción y regimiento, 1537, fol. XVIIr: El muro ha de ser bien fraguado; ha de tener sus traveses que jueguen por lo baxo del fosso, con que haya de través a través ciento y cinqüenta passos $\mathrm{o}$, a lo menos, casas matas, para que la artillería pueda jugar dentro d'ellas por lo alto y por lo baxo. // Rojas, Teórica fortificación, 1598, fol. 37r: Y lo que toca al fosso, quieren algunos que tenga de ancho 120 pies, y otros quieren a 100, porque siendo tan ancho tendrá el enemigo mucho que cegar. A esso digo que resultan inconvinientes, siendo el fosso muy ancho; lo primero, que para varrer todo el fosso desde la casamata, se adelgaza y enflaqueze la espalda y orejón; y lo segundo, queda la casamata muy desembocada, que lo uno y lo otro es grandísimo defeto en la buena fortificación. Y assí, me parece que no sea más ancho que de 80 pies. // Rojas, Compendio fortificación, 1613 , fol. 27r-27v: El fosso es el más importante en la plaça y castillo, lo principal para que el enemigo no pueda escalar las murallas, porque, aviendo el dicho fosso, y entrando en él 
el enemigo, luego las casas matas y travezes que huviere le hazen mucho daño, por lo qual obliga el enemigo, para poder passar y arrimarse a la muralla, cegar el fosso, en lo qual se detendrá mucho tiempo, que es lo que se pretende con el fosso.

SIN.: cava, fosa, fuesa.

FAM.: refosete, refoso.

ENCICL.: Cov.: El vallado hondo que está alrededor de la fortaleza, que por otro nombre se llama cava, o el que se hace para cercar el real. Algunas veces está con agua y otras seco, y entran a la fortaleza por puente levadiza. // Rojas, Teórica fortificación (1598: fol. 37v): "Antes de passar de aquí, daré qüenta del fosso seco, o con agua, porque importa. Ay muchas opiniones entre soldados, en que unos dizen que sea el fosso seco, para hazer las salidas y emboscadas en él, y desde allí salir en tropa a ofender al enemigo, porque, siendo con agua, se hazen mal estas salidas, porque son menester varcas o planchadas para salir a la estrada cubierta. Y los que quieren que sea con agua dizen que se ciega muy mal el dicho fosso, y que no pueden passarlo mientras estuviere lleno de agua, y con poca gente guardarán mejor su plaça. Y a mi parecer (conforme a lo que he comunicado con los más experimentados en esta materia), será bueno el fosso seco quando la plaça tuviesse mucha pujança de gente dentro que salga a estorvar al enemigo las trincheas, pero si la plaça tiene poca gente, como ya es ordinario, es mejor que sea el fosso con agua, porque las salidas se remedian con hazer unas planchadas para salir desde las casas matas a la estrada cubierta y es cosa muy notoria que, en llegando las trincheas a bordo del fosso, lo primero que se haze es procurar dessangrarle el agua, en lo qual se gasta mucho tiempo y trabajo, y si no pudiesse ser sangrado, es fuerça hazer puentes sobre varcas y se passa con mucho riesgo, y los de la plaça lo defienden con más facilidad que si fuera seco el dicho fosso". // González de Medina, Examen fortificación (1599: pág. 38): "Tiénese muy gran duda y disputa cómo será mejor el foso, seco o con agua; para lo qual digo que, vistos los inconvenientes y pro de lo uno y de lo otro, por mi opinión, sería seco sin agua". / / Lopes Pires Nunes (2005: s.v. fosso): Escavação em todo o circuito da fortaleza ou só nas partes mais expostas que dificultava o acesso às entradas e a aproximação às muralhas. // Almirante (1869): Excavación, zanja de dimensiones variables, que precede o circunda generalmente a las obras de fortificación. Sus partes son: fondo, escarpa y contraescarpa. // Sanz (1749: s.v. fosso): Es una profundidad alrededor de una plaza o de un puesto que se quiere defender [...]. Su latitud y profundidad dependen de la naturaleza del terreno grueso, arenoso, pantanoso o de viva roca por lo cual se arreglan a darle más o menos talud a la escarpa y contraescarpa.

foso, V. arce del .

foso, V. arcén del .

fossa, $V$. fosa. 
fosso, V. foso.

franco, V. flanco.

franco, V. cortina $\sim$.

franquear, V. flanquear.

frente, frente [del lat. frŏns, -tis 'íd.'. Fruente, doc. de 1124 (Oelschl.); frente, Nebr. (DECH). García de Palacio, Diálogos militares, 1583]. sust. f. Mil. En cualquier formación táctica, extensión o espacio que ocupan sus soldados hombro con hombro. 1 (fig. 86)

García de Palacio, Diálogos militares, 1583, fol. 171v: Y, quando el dicho esquadrón de medio tuviesse tanta frente como la del enemigo, pueden yr los dichos cuernos ciñéndole por medio, para, con mucha ventaja y presteza, desbaratalle y deshazerle. // Álaba, Perfeto capitán, 1590, fol. 43r: Si el esquadrón, por ser los passos estrechos o por otros inconvenientes que en el marchar se suelen ofrecer, no pudiere caminar con tan ancha frente como se le da quando ay espacio bastante y lugar acomodado, las órdenes no sean menores que la tercera parte de la frente, como si ella fuesse de veintisiete soldados, cada ylera, por lo menos, será de nueve, porque con facilidad, ofreciéndose necessidad, pueda ordenarse todo el esquadrón. // Rojas, Teórica fortificación, 1598, fol. 102r: Y assí, para hazer qualquiera esquadrón quadro de gente, se tendrá por regla general sacar la raíz quadrada de qualquier número de soldados que huviere, y aquéllas serán las hileras de frente y de fondo que tendrá dicho el esquadrón.

ANT.: fondo.

ENCICL.: Moretti (1828): (s.v. frente de un ejército) Toda la extensión de su línea desde el ala derecha a la izquierda. // Estévanez (1897): Espacio ocupado por una tropa en el sentido de la anchura.

2 [García de Palacio, Diálogos militares, 1583]. sust. f. Mil. Espacio o faja de terreno que, en cualquier orden de batalla, se extiende a partir del primer hombre situado en el ala o costado de esa formación.

García de Palacio, Diálogos militares, 1583, fol. 176r: Y, al tiempo que los enemigos llegavan cerca, abríanse las dos primeras partes por la frente, por donde salían con mucha velocidad los dichos hombres de armas, y asaltavan con grande ímpetu al esquadrón contrario, y los demás acometían y offendían por los costados. // Mendoça, Theórica y práctica, 1596, pág. 47: De la frente de los esquadrones aya espacio para passar esquadrón de cavallería o infantería, sin alterar la orden de los demás. // Ufano, Tratado de la 
Artillería, 1613, pág. 93-94: Ningún súbito reqüentro [...] puede en manera alguna venir tan secretamente cubierto ni tan repentino, que mucho antes del reconosçerse los unos a los otros esquadrones, si se ofresçiese señal de batalla y combate, no uviese y sobrase lugar de montar sobre sus afustes el artillería gruesa, viniendo aprestado todo lo neçessario para ello de cuerdas, guindales y gente y, encabalgada, meterla a los ángulos de los esquadrones para que libremente juegue, de modo que no ympida el pelear a la ynfantería o caballería y que de lleno, transversal o rectamente hiera el flanco de los enemigos esquadrones y su frente.

ANT.: flanco 1.

ENCICL.: Domínguez (1853): Mil. La parte, terreno o espacio que se encuentra delante de los soldados puestos en orden de batalla. // Almirante (1869): El terreno que se extiende delante de una tropa formada, por oposición a flancos.

3 [Rojas, Teórica fortificación, 1598]. sust. f. Fort. En cualquier fortaleza abaluartada, cada uno de los lados de su recinto, los cuales se componen de una cortina y de dos medios baluartes. 1 (fig. 87)

Rojas, Teórica fortificación, 1598, fol. 26r: Sea la plaça grande, que tenga de frente en el recinto, que se entiende desde en medio de la gola del valuarte hasta la mitad de la gola del otro su compañero, aya setecientos y cinqüenta pies, y la frente del recinto de la plaça muy pequeña tendrá 500 pies. // Rojas, Teórica fortificación, 1598, fol. 33r: Y si el enemigo se fuere ensanchando con sus trincheas, porque no cabe en la frente pequeña, entonces le descubriré de las otras frentes de mi plaça y le iré ofendiendo al cruzado y de través, de manera que con mucho peligro y trabajo se me venga allegando. // Rojas, Teórica fortificación, 1598, fol. 74r: Como no ay regla que no tenga su excepción, digo que se ofrecerán algunos sitios adonde es cosa forçosa ser los ángulos de los valuartes acutos, especialmente en una plaça que se hiziesse en la marina, que tuviesse sola una frente a la tierra y lo demás circundado de mar.

ENCICL.: Sanz (1749: s.v. frente de una plaza o tenaza de la plaza) Es lo comprendido entre los ángulos flanqueados de dos baluartes inmediatos, esto es, la cortina, los dos flancos y las dos caras o frentes de baluartes que se miran. // Moretti (1828: frente de fortificación) La parte de las obras de una plaza fuerte comprendida entre las capitales de dos baluartes o ángulos flanqueados; contiene una cortina y dos medios baluartes. // Estévanez (1897): En fortificación se llama frente cada lado del polígono.

4 [Mendoça, Theórica y práctica, 1596]. sust. f. Fort. Cada uno de los dos lados que en un baluarte salen de los extremos de sus flancos y forman su ángulo. $\$ 3$ (fig. 88) Mendoça, Theórica y práctica, 1596, pág. 126: El día de oy [no se bate] la cortina entre los dos travesses, sino la frente del baluarte, estimando por más fácil batería el quitar el un través y casamata que las dos, principalmente si ay en ellos plaça y cañonera para pieça de batir. // González de Medina, Examen fortificación, 1599, pág. 28: Hase de barrer de las casas matas las cortinas, la frente de los baluartes y el foso hasta la mitad de la contraescarpe, donde haze el ángulo, para estar bien situadas. // Rojas, Compendio 
fortificación, 1613, fol. 34v: Tendrá la frente del un baluarte, a lo más largo, 400 pies, teniendo su ángulo y esquina lo más obtuso y fuerte que se pudiere.

ENCICL.: DRAE: Mil. Cada uno de los dos lienzos de muralla que desde los extremos de los flancos se van a juntar para cerrar el baluarte y formar su ángulo. / Díaz Capmany (2004: 29): "Era la parte [del baluarte] más expuesta y donde se abría generalmente la brecha. Las dos caras [o frentes] se unían formando la punta más adelantada del baluarte".

fuerça, V. fuerza.

fuersa, $V$. fuerza.

fuerte, fuerte [del lat. förtis 'íd.'. Como término de fortificación, el sustantivo fuerte pudo imitarse del fr. fort (1265). Orígenes del idioma: doc. de 932 (Oelschl.). Y, como término de fortificación, en Fuenmayor, 1595 (DECH). Fernández de Enciso, Suma de Geographía, 1530]. adj. Fort. Dicho de un lugar o de una posición: protegido con reparos o defensas.

Fernández de Enciso, Suma de Geographía, 1530, fol. XLIIv: En medio de éstos está una sierra pequeña a do está un castillo muy fuerte, que se llama Castro Real, que está sobre los desiertos de Gades a do Moysén vino con el pueblo de Israel. // Celso, Reportorio universal leyes Castilla, 1553, fol. CCCXXVv: Y lo semejante es del rico hombre o gran señor que basteciesse con armas o otros bastimentos alguna villa fuerte o fortaleza para hazer guerra al Rey, o contra el bien de la tierra. / / García de Palacio, Diálogos militares, 1583, fol. 66r: Aunque algunos han querido dezir que [la artillería] trae más costa y daño que provecho [...], me paresce que es provechosíssima y de grandes effectos, si es usada con la sufficiencia e ingenio que ella requiere, y que no es justo que para ninguna cosa béllica se dexe de usar, pues paresce impossible poder offender y subjetar a un poderoso enemigo sin ella, especialmente teniendo, como de ordinario ya todos tienen, torres, castillos, ciudades, fuertes y muradas, y posadas para defenderse.

SIN.: fortalecido, fortificado, reparado 2 .

FAM.: contraforte.

ENCICL.: Toro y Gómez (1901): Dícese del lugar protegido por obras de defensa.

2 [Montes, Instrucción y regimiento, 1537]. sust. Fort. Pequeña fortaleza construida para ocupar un puesto de importancia estratégica (Lorenzo Celorrio 1996).

s? (fig. 89)

Montes, Instrucción y regimiento, 1537, fol. XIv: Si tuvieren nuevas de enemigos, deven fortificarse en los passos por do los enemigos vinieren a dar al exército, haziendo reparos, porque los enemigos no puedan passar adonde estuviere la gente del exército [...]. E si la 
batalla fuere de noche, no se salgan de su fuerte, porque podrían tener algunas embuscadas que los rompiesen, mas deven guardar su fuerte. // Roxas, Sumario milicia, 1607, fol. 102v-103r: Y llegado el exérçito, lo yrá repartiendo y guarneçiendo por sus terçios alrededor de la plaça, ocupando las eminençias y alturas del terreno que hubiere alrededor, haçiendo ante todas cosas quatro o cinco fuertes que çiñan y cubran la plaça de tal manera que cada fuerte se dé la mano el uno al otro, de forma que no pueda salir hombre fuera ni entrar socorro, haçiendo los fuertes mejores y con más guarniçión de soldados a la parte que se entendiere bendrá el enemigo con su socorro. // Ufano, Tratado de la Artillería, 1613, pág. 160-161: Como sea qualquier fuerte, es mucho mejor y más seguro batirle por el baluarte o caballero que no por la cortina, por occasión de que las cortinas de un fuerte son muy cortas y las cubren y deffienden mucho sus baluartes, por tenerlos más a caballero estendidos sus flancos y traveses sobre dichas cortinas que no las plaças reales de grande capaçidad y estendida.

SIN.: castillo 1.

ENCICL.: Lucuze (1772: 10): "Fuerte es una pequeña fortaleza, que suele tener cuatro baluartes, y se construye para ocupar un puesto de importancia o guardar el paso de un río o montaña". // Corsini (1849): Fort. Obra fortificada, aislada por lo común y de reducida extensión. El objeto de los fuertes es guardar y defender pasos importantes, alturas en que podría establecerse ventajosamente el enemigo, esclusas, entradas de caminos, pasos de ríos, etc. // Aut. (s.v. fuerte de campaña): Véase fortín. // Aut. (s.v. fortín): Aquella obra que se levanta para defender el ejército en campaña, que viene a ser una fortaleza que, aunque más débil que la plaza y que sus [sic] líneas de defensa no llegan a seiscientos pies, o las distancias de las puntas y ángulos de los baluartes distan menos de setecientos y veinte pies, es suficiente y de mucha utilidad para el fin a que se dirige. Se llama también fuerte de campaña. / / Rojas, Teórica fortificación (1598: fol. 46r): "Esta figura hecha de quatro medios valuartes es muy a propósito para un fuerte en campaña, echando el ojo a hazerles las troneras en cada ángulo". // Almirante (1869): Como sustantivo, es nombre genérico de toda obra pequeña de fortificación [...], que defiende un paso o constituye parte de un sistema. // Lopes Pires Nunes (2005: s.v. forte): Pequena fortificação isolada que, podendo ser autónoma, depende muitas vezes de uma praça principal.

fuerte, V. casa .

fuerte, V. plaza .

fuerza, fuerça, fuersa, fuerza [del lat. tardío fŏrtı̆a 'íd.'. Forza, doc. de 1115; fuerça, Cid; el leonés forcia en Alex., O; ast. fuercia, V; Cej. IX (DECH). Montes, Instrucción y regimiento, 1537]. sust. Fort. Cualquier recinto fortificado de carácter más o menos permanente. (fig. 90)

Montes, Instrucción y regimiento, 1537, fol. Vv-VIr: E muchas tierras e castillos fuertes se han rendido por falta de vituallas más que por combate de los enemigos; y en esto han de 
mirar mucho los generales, que las fuerças que ganaren que las hagan proveer de vituallas, porque los enemigos no las tomen por hambre, porque mejor es, ya que sucede la fortuna, que una fuerça se pierda por batalla que no por hambre. // Mosquera, Comentario disciplina militar, 1596, fol. 110r: Ya los franceses estavan recogidos en la fortaleza y, pidiendo a don Pedro les concediesse algunos partidos y le entregarían la fuerça, se les negó y, assí, se vinieron a contentar con las vidas, sacando cada uno lo que tuviesse vestido y entre todos treynta espadas para la gente particular. // González de Medina, Examen fortificación, 1599, pág. 7: Maestro, yo querría que, dos leguas alrededor de donde estamos, hagáys la fortaleza que os pido, adonde tenéis en el distrito sitio en monte y campaña llana. Elegid lo que os pareciere mejor, como me hagáis una fuerça real muy fuerte, capaz de gente para defenderla de un exército real que trayga mucha artillería.

SIN.: fortaleza, plaza $a_{2}$.

ENCICL.: Rubió y Bellvé (1895-1901): Fortaleza, serie de obras de fortificación que, con la guarnición correspondiente, sirve para defensa de una ciudad o paraje cualquiera. // Mora-Figueroa (2006): Sinónimo antiguo de fortaleza.

2 [García de Palacio, Diálogos militares, 1583]. sust. pl. Mil. Gente de guerra y demás aprestos militares (DRAE).

García de Palacio, Diálogos militares, 1583, fol. 77v-78r: Si, hallándose con gente y armas tales que entienda sobrepujar las fuerças del enemigo, paresce converná dar la batalla en tiempo que le quede día para proseguilla y seguir el alcance y rota, que, por falta de tiempo, con la obscuridad de la noche, muchas vezes los vencidos y desbaratados se han salvado, rehecho y tornado en sí y podido resisitir a los vencedores, que, si uviera día, no lo hizieran. // Mendoça, Theórica y práctica, 1596, pág. 67: D’este primer alojamiento no ha de partir Vuestra Alteza antes del tener toda la gente junta, artillería, municiones y vituallas, siendo necessarias para la jornada; y si es conquista, aver mandado se aperciban de nuevo fuerças para socorrer el exército. // Mosquera, Comentario disciplina militar, 1596, fol. 62v: Saltó la gente con ímpetu y de improviso, que assí se ha de hazer pudiendo, por coger desapercebido al enemigo en tanto que las fuerças están divisas y antes que vengan a unirse.

ENCICL.: Aut. (s.v. apresto): Prevención, aparejo, y lo que es necesario para cualquier operación, como los aprestos para la guerra, para la armada.

fuesa, fuessa [del lat. fŏssa 'excavación', 'fosa', 'tumba', 'canal', propiamente participio femenino de födĕre 'cavar'. Fuesa tiene, por lo común, la ac. de 'tumba. Doc. de 1200, Burgos; Berceo (DECH). Montes, Instrucción y regimiento, 1537]. sust. Fort. Zanja profunda que circunda toda la plaza, fortaleza, etc. (Terr.: s.v. foso). Montes, Instrucción y regimiento, 1537, fol. XVIIr: Tres cosas ha de tener una ciudad para ser fuerte: la primera, muy buen muro en llano, que no tenga padrasto en torno para que puedan tirar; la segunda, que tenga su fuessa de agua en torno del muro por la parte de fuera, de hondura de una gineta y de ancho de pica y media, o de dos picas, con sus 
puentes levadizas por donde entre y salga la gente de la ciudad; y la tercera, que tenga muchas vituallas para el mantenimiento de la gente de guerra.

SIN.: cava, fosa, foso.

FAM.: contrafosa, fosa.

fuessa, V. fuesa. 
gabión, V. gavión.

gabionada, V. gavionada.

galápago, galápago [del mismo origen que el cat. calàpet o galàpet 'sapo' y que el port. cágado (ant. caágado), port. dial. cácavo, caganapo, 'galápago'; probablemente de un hispánico prerromano *calappăcu, quizá emparentado con *calapaccĕa 'calabaza' y con *carappaceu 'carapacho', 'caparazón'. Galápago 'especie de tortuga'. Aparece ya en su forma moderna en un glosario latino conservado en manuscrito del s. IX; qalápaq (o qalâpaq) en el tunecí Abenalŷazzar, fines del s. X, que recoge nombres españoles; galápago, 1251, Calila (DECH). Álaba, Perfeto capitán, 1590]. sust. Fort. ant. Máquina con que se protegen los soldados para acercarse a los muros enemigos, consistente en una especie de barracón, por lo común, semejante a la concha de un galápago.

Âlaba, Perfeto capitán, 1590, fol. 173r: Es verdad que ay otros que dizen que tiene fuerça de abrasar, pues lo ponen en la composición de cosas que son a propósito para quemar, los galápagos, carneros y torres portátiles que usavan los antiguos para combatir y quemar armadas de mar. // Collado, Plática Artillería, 1592, fol. 4v: Quiere dezir: "en el restante del tiempo començaron a preparar y hazer las torres de madera, iguales a la alteza de la muralla y acercar las hoces y galápagos para conbatirla". // Roxas, Sumario milicia, 1607, fol. 27v-28r: También ha de aver lobos, que son unos garabatos de hierro, y hoçes enastadas en lanças $\mathrm{y}$, para haçer las trincheras y fosos, las herramientas ya dichas; $\mathrm{y}$ 
galápagos, y músculos, carneros, víneas, mantas y otras menudençias, que sería larga su declaraçión.

SIN.: testúdine, testudo.

ENCICL.: Almirante (1869): Lo mismo que tortuga y testudo. Antiguamente máquina tectoria y de aproche, que cubría al sitiador de los tiros de la plaza.

galería, galería [del b. lat. galilaea 'atrio o claustro de una iglesia', que a su vez procede del nombre de Galilea, región de Palestina. 1566 ('espacio para presenciar un espectáculo') en el navarro culterano Arbolanche; h. 1580, doc. de Simancas (DECH). Ufano, Tratado de la Artillería, 1613]. sust. Fort. Parte principal de una mina, la que comunica la boca o entrada con el hornillo. (fig. 91)

Ufano, Tratado de la Artillería, 1613, pág. 168: Más, se proveerá de 1.500 gabiones y otros tantos çarços de mimbres y ramage, con 200.000 faxinas y una grande quantidad de árboles grandes y pequeños para fabricar los bancos y trabeses y armar el aforramiento de las minas; con 1.500 tablas de pino para el uso de las minas, galerías y entablamientos de los hornillos.

ENCICL.: Moretti (1828): Fort. Camino angosto y subterráneo que se hace en las minas para comunicación y uso de los hornillos, sea en el ataque o en la defensa. // Sanz (1749: s.v. galería, ramal, canal, retorno o conducto de una mina): Es un camino subterráneo que a veces sale de un pozo; otros por una abertura de tres o cuatro pies, y se adelanta hasta debajo del terreno de las obras, en donde se quiere conducir la mina o contramina [...]. Los sitiadores y los sitiados adelantan sus galerías, cada uno por su parte. Si se encuentran, procuran de destruirse los unos a los otros o a lo menos se inutilizan. Cuando los minadores oyen trabajar a los del enemigo, su mayor atención es aplicar un petardo en su galería para que atraviese y abra la del enemigo, y esparza tanto humo, que la mayor parte de los trabajadores queden ahogados.

2 [Lechuga, Discurso de la Artillería, 1611]. sust. Fort. Especie de corredor o pasadizo de madera que fabrican los sitiadores en el ataque a una plaza para, una vez cubierto de tierra, céspedes y otros materiales poco combustibles, poder pasar el foso a través de él.

Lechuga, Discurso de la Artillería, 1611, pág. 221: Se usavan galerías para passar los fossos, que se hazían todas de madera, en forma de minas, yendo con ellas cegando los fossos, hechándoles por encima dos palmos y más de tierra para assegurar los que iban trabajando, haziendo dos y tres a un tiempo, la que estava a la parte del través, terraplenada, para guardar las demás, y las otras no, para passage al baluarte y muralla. // Ufano, Tratado de la Artillería, 1613, pág. 266: Si los contrarios usaren el arroxar sobr'ellas [sobre las galerías] fuegos artiffiçiales o de qualquier forma que sea, puédense cubrir con gazones, que por otro nombre se entienden çéspedes, aunque bien ocurra algún riesgo al meterlos por çima de las dichas galerías y sus costados. Es máchina [la galería] de mucho serviçio y a sido ynfinitas vezes usada en diversos sitios de çiudades y fortalezas. 
// Ufano, Tratado de la Artillería, 1613, pág. 428: Cómo se deve hazer una mina y cómo se deve armar una galería para passar un fosso.

SIN.: traviesa $_{2}$.

ENCICL.: Aut.: En la Fortificación es un corredor en arco, formado sobre fajina y tierra, con que se ciega el foso para llegar desde los ataques a la brecha, armándole bien de ramos, tierra y pieles que resistan el fuego de la plaza. // Sanz (1749: s.v. galería para passo de fosso): Es un pequeño pasadizo hecho de carpintería que en piezas de madera se lleva al fondo del foso, y le cubren de tablas cargadas de tierra para que pueda pasar el minador y resista a los fuegos de artificio, y a las piedras que el enemigo echa sobre él.

garita, garita [del fr. ant. garite 'refugio', 'garita de centinela' (hoy guérite), quizá contracción de garite 'refúgiate', imper. sustantivado de se garir, o más probablemente de un participio sustantivado (irregular) de garir; del mismo origen germánico que nuestro guarecer. APal. (DECH). Escalante, Discurso de la navegación, 1577]. sust. Fort. Pequeño habitáculo para resguardo del centinela, colocado en lugares estratégicos de la fortificación, con gran dominio visual del terreno circundante (Lorenzo Celorrio 1996). . 1 (fig. 93)

Escalante, Discurso de la navegación, 1577, fol. 85v: En todos los baluartes en que ay sus garitas, assisten de noche centinelas que las remudan por sus quartos del cuerpo de guardia que es ordinario, andando siempre los oficiales como les toca, con el número de soldados que les parece en ronda y contraronda. // Rojas, Teórica fortificación, 1598, fol. 2v3r: Y assimismo, tendrá muy en la memoria los nombres de la fortificación, como son: fosso, y refosso, y estrada cubierta con su escarpa de tierra a la campaña, y la cortina principal, y cassamata con su orejón que la cubre, y espalda y frente de valuarte, y la gola d'él, y ángulo del recinto, y parapetos, y terraplenos, y garitas para los centinelas, y la plaça de armas con sus calles correspondientes a los valuartes, y los quarteles de alojamientos y almagacenes de munición. // González de Medina, Examen fortificación, 1599, pág. 49: Las garitas para las centinelas han de ser de quatro pies en quadro y de nueve de alto, de tabla, quanto repare al soldado quando llueve, con ventanas a todas partes; y hanse de poner una en medio de las cortinas, y otra en los ángulos de los baluartes y otras dos en las puntas de los orejones, y ansí han de estar repartidas en todas las cortinas y baluartes.

ENCICL.: Moretti (1828): Fort. Pequeña torre de madera o mampostería, con ventanillas angostas y largas a los lados. Se construye generalmente en los ángulos flanqueados de los baluartes, y en todas las obras exteriores, a fin de que el centinela pueda guarecerse y descubrir el foso y la campaña. // Lucuze (1772: 73-74): "La figura es arbitraria, redonda, pentagonal o hexagonal; de cinco pies de diámetro en su latitud interior, y de siete a ocho de altura, con ventanillas en todas las caras, para que la centinela descubra y observe lo que pasa en el foso, obras exteriores y camino cubierto. Para su entrada, al nivel superior del terraplén, se abre en el parapeto un pasadizo de tres pies y medio de ancho. Cuando la muralla está revestida de piedra o ladrillo se hacen las garitas de la misma materia, pero si es de tepes el revestimiento, se construyen de madera fuerte, que resista a la bala de fusil. 
No sólo en el muro principal se ponen garitas, sino también en todos los parajes en donde conviene mantener de continuo centinelas". // Almirante (1869): [...] La caseta de piedra, madera, ramaje en que el centinela se resguarda de la lluvia fuerte [...].

gasón, gazón [del fr. gazon 'césped', 'gleba de césped', y éste del fráncico *waso, uns. Gasón 'césped', arag., 'terrón que deja entero el arado', provinc., 'yesón, pedazo de yeso'. Acad. ya 1817 (DECH). Ufano, Tratado de la Artillería, 1613]. sust. Fort. Pedazo de tierra cubierto de hierba, que, cortado de diversos modos, sirve para construir murallas, o bien para formar parapetos y otras defensas.

Ufano, Tratado de la Artillería, 1613, pág. 266: Y si los contrarios usaren el arroxar sobr'ellas fuegos artiffiçiales o de qualquier forma que sea, puédense cubrir con gazones, que por otro nombre se entienden çéspedes, aunque bien ocurra algún riesgo al meterlos por çima de las dichas galerías y sus costados.

SIN.: césped, tepe.

ENCICL.: Rubió y Bellvé (1895-1901): Césped. Es galicismo peculiar de Aragón.

gastador, gastador [de gastar. Berceo (DECH). Montes, Instrucción y regimiento, 1537]. sust. Mil. Trabajador empleado en el ejército para realizar las distintas labores en las que lo esencial es mover la tierra, como allanar los caminos para facilitar el paso de la artillería, y abrir trincheras, minas y demás obras pasajeras.

Montes, Instrucción y regimiento, 1537, fol. VIv: Y d'esto tenga cargo una persona, el qual se ha de llamar capitán de gastadores. E si las tierras no quisieren venir a abrir los passos y caminos para que la artillería pueda passar, háseles de hazer guerra como a enemigos. // Rojas, Teórica fortificación, 1598, fol. 105v: Y estando hecha esta prevención de materiales, se entregarán las herramientas de picos, palas y açadones a los gastadores, y, si no los huviere, se entregan a los ayudantes de sargentos mayores, para que los den a los soldados, que, donde yo me he hallado, por la mayor parte hemos hecho las trincheas con soldados. // Ufano, Tratado de la Artillería, 1613, pág. 147: Los gastadores sirven de cortar faxinas, hazer carços y sestones, trabajar en las trincheras en el movimiento de la tierra d'ellas, hazer espaldas y reparos para todo cubrimiento de offensa y deffensa, conduzir el artillería quando se marcha.

SIN.: peonero.

FAM.: gastar.

ENCICL.: Cov. (s.v. gastar): En el ejército se dicen gastadores la gente que trabaja con la pala y el azadón, y traen piedra y fajina y lo demás que es menester para hacer fosos, trincheras, revellines, caballeros, plataformas y todo lo demás. // Aut.: Se llama en la Milicia el que sirve en el ejército sin tomar armas, para las operaciones de manos, como abrir trincheras, traer fajinas y otras cosas. // Borreguero Beltrán (2000): Aunque el Gran Capitán, para hacer a su ejército más eficaz, sacaba de sus propias filas un cierto número 
de soldados que con sus picas, espadas y azadas, aplanaran las asperezas del camino, en la Edad Moderna esta labor fue desempeñada, normalmente, por civiles o villanos, y no por los integrantes del ejército en sí.

gastar, gastar [del lat. vastare 'devastar, arruinar', pronunciado *wastare en la baja época por influjo del germ. occid. wôstan o wôstjan 'íd.'. Mozár. waštâțo 'desperdiciado, mal gastado' en el cordobés Abencuzmán, 1. ${ }^{a}$ mitad del s. XII; gastar 'devastar', primeros años del s. XIII, Lib. Reg. aragonés (DECH). Apiano, Cosmographía, 1575]. v. tr. Devastar un territorio (DUE).

Apiano, Cosmographía, 1575, fol. 77v: La provincia de Cali está en unas valles de las montañas de los Andes y ha sido esta provincia muy bien poblada de muy grandes y hermosos pueblos, pero por las guerras que han avido, principalmente quando han sido conquistados de españoles, se han gastado y perdido. // Mosquera, Comentario disciplina militar, 1596, fol. 144v: Y parece que el Marqués (como a quien constava de la intención de Su Magestad) no quiso, según lo que aconsejava Marón, llevar estos pueblos por imperio, por no gastar las tierras y por tenerlas con brevedad en amor y sossiego.

FAM.: gastador.

ENCICL.: Aut.: Vale robar, destruir y asolar alguna provincia, reino, etc., talando los frutos y arruinando cuanto se encuentra.

gavión, gabión, gavión [del it. gabbione 'íd.'. Gavión 'cestón de mimbres lleno de tierra, que sirve para defender de los tiros enemigos'. s. XVI o XVII: Terlingen (DECH). Molina Cano, Descubrimientos geométricos, 1598]. sust. Fort. Recipiente de mimbre, ramas, cañas u otros materiales similares entretejidos, de forma cilíndrica, que, lleno de tierra, sirve para defenderse del fuego enemigo, para construir defensas o reparos, etc. (fig. 94)

Molina Cano, Descubrimientos geométricos, 1598, fol. 45v: De adonde queda asaz manifiesta advirtencia a los ingenieros que mandan hazer puentes sobre que poder yr a dar asaltos, el ser impossible medir justamente la distancia de un fosso sin moverse de un puesto (como ya hizo algunos años ha, sobre plaça de importancia, por no descubrirse del reparo del artillería y sus gaviones, y de la medida que assí tomó resultó el notable daño y pérdida que saven los que lo vieron como yo). // Ferrofino, Descrizión Artillería, 1599, fol. 163r163v: Y no sólo le toca en raçón de ofiçio suyo, sino para la guarda i defensa, conserbación de su persona, cuya causa le haçemos obligado, esto es, en el saver hazer los çestones o gabiones, qu'es todo una misma cosa, detrás de los quales se pone el artillero para poder usar de ella con siguro propio y daño al enemigo. // Ufano, Tratado de la Artillería, 1613, pág. 174: Los gabiones y faxinas aseguro a Vuestra Señoría que es el material más ymportante que puede aver dentro de una villa y que para tales occasiones se puede tener, porque sin ellos padeçe gran trabajo la gente de dentro y mueren tantos, que no la pueden deffender, porque con los gabiones bazíos o llenos y terraplenados se cubren para los 
trabajos de sus fortifficaçiones, y también engañan con ellos a los sitiadores, enpinándolos en differentes partes.

SIN.: cestón.

FAM.: gavionada.

ENCICL.: Terr.: Cestón de mimbres lleno de tierra para cubrirse en la campaña, en las baterías, líneas y alojamientos [...]. V. Cestones. // D'Wartelet (1863): Es una especie de cesto de figura cilíndrica, fijo en tierra por medio de estacas o piquetes, sobre los cuales se tejen mimbres o ramas de árboles, dejando en éste enlazado una estaca dentro y otra fuera en la primera vuelta; en la segunda, la que se quedó fuera ahora dentro, y así sucesivamente hasta dar al gavión la altura necesaria, que por lo común es de dos y medio pies y dos de ancho, y luego se rellena de tierra mojada y apisonada. Se emplea en los trabajos de fortificación de campaña o pasajera, construyéndolos uno al lado de otro hasta cubrir la longitud de terreno marcada para defenderse; encima de esta fila se pone otra hilada, de manera que el gavión se encuentre sobre la separación de otros dos de abajo, y esto mismo se hace si es necesario una tercera fila para dar mayor altura a la trinchera $u$ obra que se construye.

gavionada, gabionada [de gavión. Rojas, Teórica fortificación, 1598]. sust. Fort. Defensa o fortificación hecha con gaviones o cestones.

Rojas, Teórica fortificación, 1598, fol. 74r: Se tendrá por regla general de guardar la munición para quando el enemigo esté a 200 passos del fosso, porque desde allí para dentro hará su efeto el arcabuzería; y de los 200 passos para fuera avrá tirado el artillería del dicho castillo, tirando siempre donde huviere tropa de gente o alguna berraca o las plataformas o gabionadas que huviere. // Ufano, Tratado de la Artillería, 1613, pág. 239: Yo, según mi opinión, los medios cañones los emplearía al tiempo que los sitiadores se aquartelasen, para con ellos deshazerles sus tropas y para barrer toda la campaña y batirles sus gabionadas y reparos que truxesen.

FAM.: gavión.

gazón, V. gasón.

gente, gente, jente, xente [latinización del antiguo yente, procedente del lat. gĕns, gĕntis 'raza', 'familia'; 'tribu', 'el pueblo de un país, comarca o ciudad'. Yente y gente en Cid (DECH). Ortega, Conpusición Arismética y Geometría, 1512]. sust. Grupo regular y organizado de soldados (DEA: s.v. tropa).

Ortega, Conpusición Arismética y Geometría, 1512, fol. 112v: El Rey, nuestro Señor, tiene en una capitanía 50 hombres de armes, y 100 ginetes, y 200 peones y 150 espingarderos [...]. Y manda a sus contadores o pagadores que les repartan estos 15000 ducados a toda esta gente, en tal manera que den cada suerte de hombre según su estado y según lo que gana. 
// Montes, Instrucción y regimiento, 1537, fol. IVv: Los capitanes han de proveer, en los lugares donde su gente tuvieren aloxada, no consientan que sus soldados, en las tierras de su rey, hagan ningunas fuerças ni violencias, sino todo buen tratamiento, porque también son aquéllos buenos vasallos de su rey como ellos. // González de Medina, Examen fortificación, 1599, pág. 183: La gente que para defender esta fuerça ha menester, si fuéssemos con las opiniones de los antiguos, son muy diferentes, porque unos han dicho que para cada passo de cinco pies de muralla le pondrían un soldado, que en esta fuerça, por tener las cinco cortinas mil y setecientos y cincuenta pies, y los baluartes de frentes dos mil y novecientos, y las casas matas trecientos, serían necessarios novecientos y noventa.

SIN.: gente de (la) batalla, gente de guerra, gente de pelea, gente militar, milicia3, tropa.

ENCICL.: DEA: Personas o conjunto de (las) personas. A veces en pl con intención expresiva. Frec con un adj o compl especificador. e) Conjunto de personas, que siguen ideológicamente [a otra (compl de posesión)] o trabajan [para ella (compl de posesión)]. // Roxas, Sumario milicia (1607: fol. 63r): "Conforme al pareçer de grandes cappitanes no consisten las vitorias d'ellos y buenos suçesos de la guerra en el número de la jente, sino en el yngenio y valor del general, y en la obediençia y esfuerço de sus soldados; y así bemos que aquel famoso Alexandro con un pequeño exérçito acometió las ynnumerables jentes de Darío y lo vençió". / / Rubió y Bellvé (1895-1901): Tropa; conjunto de soldados.

$\sim$ de armas [Montes, Instrucción y regimiento, 1537]. cmpt. sintag. Mil. Grupo regular y organizado de soldados de caballería pesada, equipados con armadura completa.

Montes, Instrucción y regimiento, 1537, fol. Xv: La gente d'armas y cavallos ligeros son los que hazen fortificar el campo y son differentes en el traer de las armas, porque van a cavallo y las armas que traen son mejores para su propósito que no las picas, porque con las picas no se podrían governar sobre los cavallos. // Montes, Instrucción y regimiento, 1537, fol. XIVv: Antes que amanesciesse, començaron a passar las puentes, y por la una puente passó la gente d'armas y con ellos el Gran Capitán, y por la otra puente passó la infantería, y por la otra puente passaron los cavallos ligeros, y en la misma orden que passaron las puentes fueron a dar en los enemigos, que estavan en la otra parte del río. // Celso, Reportorio universal leyes Castilla, 1553, fol. CCCXXXv: Los vassallos que por mando del Rey vinieren a la guerra y traxeren gente de armas para servirle deven jurar quánta es la gente que traen, y que no han hecho ni harán fraude ni engaño.

ENCICL.: López Vallejo (2008): Tropa o conjunto de hombres de armas o jinetes equipados con armadura completa.

$\sim$ de batalla, o $\sim$ de la batalla [Mendoça, Theórica y práctica, 1596]. cmpt. sintag. Grupo regular y organizado de soldados (DEA: s.v. tropa).

Mendoça, Theórica y práctica, 1596, pág. 48: En medio de los quarteles y frente de las vanderas se han de plantar las tiendas de Vuestra Alteza y quartel de su corte y guardas, a que seguirá la gente de la batalla, quando estuvieren señalados cuerpos de esquadrones para ello, aviendo en el quartel, entre las calles y pavellones, calles espaciosas para salir la 
gente a la plaça de armas sin embaraço y a las tiendas de Vuestra Alteza. // Rojas, Teórica fortificación, 1598, fol. 103r: Y en mitad de los quarteles, y por el derecho de la frente de las vanderas, se hará el quartel o tiendas del capitán general y el demás quartel de sus camaradas y soldados entretenidos; y luego se seguirá la gente de batalla, señalándoles sus quarteles de tal manera que aya calles espaciosas entre los quarteles para salir de golpe la gente a la plaça de armas.

SIN.: gente, gente de guerra, gente de pelea, gente militar, milicia, tropa.

de guerra [Montes, Instrucción y regimiento, 1537]. cmpt. sintag. Grupo regular y organizado de soldados (DEA: s.v. tropa).

Montes, Instrucción y regimiento, 1537, fol. XIIIv: La tercera cosa que se ha de tener para haver vitoria es que la gente de guerra que tuviere en su exército, que sea tal que ninguna otra la tenga ventaja y procúrese poner el general en tal lugar el día de la batalla que pueda tener ventaja a sus enemigos. // Celso, Reportorio universal leyes Castilla, 1553, fol. LIIv: Capitanes, deven pagar lo que los soldados y gente de guerra comiere y gastare en los lugares donde passaren, y puédenlos compeler a esto los juezes ordinarios. // González de Medina, Examen fortificación, 1599, pág. 12: La bondad o calidades que tiene, Señor, la fuerça puesta a la marina son todas las que tienen las que están en llano y, más, que le es impossible al enemigo sitiarla de manera que no sea socorrida de todo lo necessario, assí de gente de guerra como de municiones y vituallas.

SIN.: gente, gente de (la) batalla, gente de pelea, gente militar, milicia ${ }_{3}$, tropa.

ENCICL.: Almirante (1869: s.v. gente): Gente de guerra es voz genérica y colectiva que corresponde a la moderna tropa, y admite la mayor parte de sus numerosos adjetivos: allegadiza, levantisca, mercenaria, etc. En casi ningún autor del siglo XVI se encuentra todavía la palabra tropa. / / Rubió y Bellvé (1895-1901): Lo mismo que gente, en la acepción genérica de tropa. // Gago-Jover (2002): Tropa de soldados; conjunto de hombres armados dispuestos a hacer la guerra.

de pelea [García de Palacio, Instrución náuthica, 1587]. cmpt. sintag. Grupo regular y organizado de soldados (DEA: s.v. tropa).

García de Palacio, Instrución náuthica, 1587, fol. 128r: Y quando uvieren echado los arpones, aunque se pueda aprovechar de los arcabuzes, la gente de pelea tomará picas y medias picas para deffender su nao y los lombarderos, después que ayan jugado la artillería, tomarán sus bombas, alcancías e instrumentos de fuego y por las saeteras las tirarán y arrojarán a los contrarios. // Álaba, Perfeto capitán, 1590, fol. 129v: Los bretones inventaron un género de carros en los quales yva la gente de pelea y desde ellos peleavan, arrojando gran número de saetas, y con el ruydo de las ruedas espantavan los cavallos de los enemigos. // Mosquera, Comentario disciplina militar, 1596, fol. 52v-53r: Hallávanse para defender cinco plaças, en las quales era menester repartir la poca gente que tenían; y con todas estas condiciones vino sobre ella una armada de 170 galeras y otros muchos navíos con 30 mil soldados y gente de pelea. 
SIN.: gente, gente de (la) batalla, gente de guerra, gente militar, milicia

ENCICL.: Aut. (s.v. gente u hombre de pelea): Se llaman los soldados, a distinción de los gastadores y vivanderos.

$\sim$ de socorro [Aurel, Arithmética algebrática, 1552]. cmpt. sintag. Mil. Tropa que acude en auxilio de otra (DRAE: s.v. socorro).

Aurel, Arithmética algebrática, 1552, fol. 116r: El Rey, nuestro Señor, embía cierta gente de socorro a una ciudad, con la qual van no sé quántos capitanes, y cada uno d'ellos tiene tres vezes tantos de cavallo, y veynte vezes tantos de pie como son los capitanes. // Álaba, Perfeto capitán, 1590, fol. 66r: Y assí, alojará los caudillos de los que de nuevo vinieren con los que avía en su real, capitanes con capitanes, alféreces con alféreces, y los demás oficiales, unos en las tiendas de otros sucessivamente, conforme a la correspondencia que en los cargos y ocupaciones tuvieren; como lo hizo Salinator con la gente que su compañero Nerón le embió de socorro. // Mosquera, Comentario disciplina militar, 1596, fol. 69v-70r: De la parte de los enemigos, acudía mucha gente de socorro escaramuzando, y fue necessario salirles al encuentro con algunos arcabuzeros, y se pusieron en campaña, bien retirados de la marina como más de media legua, donde tenían todo el niervo y fuerça de su exército.

SIN.: SOCOrro $_{2}$.

ENCICL.: Estévanez (1897: s.v. socorro): Tropa de auxilio, especialmente el ejército que acude en ayuda de una plaza amenazada o sitiada.

militar [García de Palacio, Diálogos militares, 1583]. cmpt. sintag. Grupo regular y organizado de soldados (DEA: s.v. tropa).

García de Palacio, Diálogos militares, 1583, fol. 65r: De la gente militar, de qualquier calidad que sea, ¿quál se deve estimar en más y qué cosas deven preparar para la prosecución de la guerra y quáles son las más importantes? // García de Palacio, Diálogos militares, 1583, fol. 81v: Los philósophos antiguos, sin lumbre de fee, dixeron d'ella diversas cosas, que por su prolixidad no las diré, aunque, para que la gente militar entienda bien qué es fortuna, pues la trata comúnmente, sepa vuestra merced que ésta dize el philósopho que es quando algún effecto no pretendido se junta otro que se pretendía.

SIN.: gente, gente de (la) batalla, gente de guerra, gente de pelea, milicia ${ }_{3}$, tropa.

ENCICL.: López Vallejo (2008): Gente de la milicia o conjunto de soldados que luchan en la guerra.

de [García de Palacio, Diálogos militares, 1583]. loc. adj. Mil. Dicho del orden de batalla cuadrado: con el número de soldados de frente exactamente igual al de los de fondo. $\quad$ (fig. 95) 
García de Palacio, Diálogos militares, 1583, fol. 183r: ¿Qé orden se podrá tener para mudar con presteza un exército o batalla quadrada de gente en esquadrón cúneo, sin perder la primera ordenança, ni aver peligro de confusión y desorden? / / Rojas, Teórica fortificación, 1598, fol. 102r: Para hazer qualquiera esquadrón quadro de gente, se tendrá por regla general sacar la raíz quadrada de qualquier número de soldados que huviere, y aquéllas serán las hileras de frente y de fondo que tendrá dicho el esquadrón. // García de Céspedes, Instrumentos nuevos, 1606, fol. 66v: El esquadrón quadrado de gente (como está dicho) ha de tener tantos hombres por el lado como por la frente y, siendo el quadrado de gente, no lo será en la figura, porque, siendo tantos hombres por un lado como por otro, y entre un hombre y otro de los del lado ha de aver siete pies, y entre los de la frente ha de aver tres pies, claro está que vendrá a ser prolongado el esquadrón.

SIN.: de infantes.

ANT.: de suelo, de(l) terreno.

hacer $\sim$, o hacer la $\sim$ [Montes, Instrucción y regimiento, 1537]. loc. v. Mil. Reclutar o buscar y reunir personas para la guerra.

Montes, Instrucción y regimiento, 1537, fol. IVr: Y éstos vayan por toda la provincia a hazer la gente, y la gente que hizieren sea la más usada al exercicio de las armas que se pudiere haver y sean hombres de buena casta: sueltos, ligeros, y ábiles en sus personas, de buena conversación y criança y los que son desseosos del exercicio militar, que son hombres de buen género, desseosos de ganar honra. // Aurel, Arithmética algebrática, 1552, fol. 96v: El Rey, nuestro Señor, haze gente para Alger, entre la qual ay españoles, alemanes e italianos. // Álaba, Perfeto capitán, 1590, fol. 34r: Es necessario que a los capitanes se les dé más tiempo para hazer la gente del que comúnmente se les señala, porque, de tenerle tan limitado, les es forçoso recebir todos los que quisieren yr en su compañía para cumplir el número de los que tienen obligación de llevar, sin tener respeto a lo que es de tanta consideración.

SIN.: levantar 1 .

ENCICL.: Almirante (1869): Gente viene desde los primeros documentos en romance. Se usaban y se usan las locuciones hacer, levantar gente. // DRAE (s.v. hacer alguien gente): reclutar.

gente, V. de .

gente, V. hacer (la) .

ginete, $\mathrm{V}$. jinete. 
gola, gola [del lat. gǔla 'garganta'. Alex., en el sentido de 'gula'. En otros sentidos, como el de 'entrada desde la plaza a un baluarte fortificado' [1705, Casani], será catalanismo, o voz de origen galorromance o italiano (DECH). Rojas, Teórica fortificación, 1598]. sust. Fort. En un baluarte es el intervalo comprendido entre el ángulo que forma uno de sus traveses con la cortina hasta el mismo punto del flanco contrario, el cual constituye la entrada o el acceso desde la plaza de armas a dicho baluarte. (fig. 96)

Rojas, Teórica fortificación, 1598, fol. 36v-37r: Sea la frente del recinto AB, y quiero que tenga desde el punto $\mathrm{A}$ al punto $\mathrm{B} 600$ pies, que se entiende esta frente de recinto desde la mitad de la gola del un valuarte hasta la mitad de la gola del otro, de lo qual rebatiré del punto A y del punto B, cada 120 pies, y quedan 360 de cortina franca. // González de Medina, Examen fortificación, 1599, pág. 14: La seságona: no se puede dezir contra ella nada que no sea muy bueno, capaz de todas las cosas, - que no lo son la triángula y la quadrángula-, y que produze muy obtusos y muy buenos los ángulos de los baluartes, dificultosos de cortar, muy fuertes espaldas de casas matas, muy anchas golas en los baluartes, que son muy necessarias para la buena defensa. // Roxas, Sumario milicia, 1607, fol. 79v: Hanse de hazer en tanta altura quanto pidiere el sitio que se pueda limpiar del artillería o otras armas de fuego, que han de ser tan capaçes que quepa muy bien el artillería y soldados a la defensa; y estos caballeros se suelen hazer en las golas de los baluartes, dejando libres las subidas a ellos.

ENCICL.: Díaz Capmany (2004: 29): "La gola era el quinto lado del pentágono que da a la plaza [...]. También se definía como la abertura entre los extremos de los flancos que tocan a la cortina". // Rubió y Bellvé (1895-1901): Por extensión, la parte posterior, opuesta a la que mira a la campaña, de todo género de obras defensivas. // Lechuga, Discurso de la Artillería (1611: pág. 254): "Adviértase, también, que muchas tierras están fortificadas con revellines hechos fuera del fosso de sola tierra, a tanta distancia que unos a otros se ayudan y guardan; y que sus cortinas siempre an de estar guardadas de las de la tierra, y que tienen sus fossos muy buenos y se dexan sin guardia hasta en tiempos de ocasión, y que en ella, a la parte que se abren trincheras, abraçan los que miran a ellas con la muralla, atravesando el fosso con dos murallas o con dos trincheras con sus fossos, haziendo camino cuvierto o descuvierto, o el uno y el otro, para socorrer el revellín, y que a esto llaman gola del revellín". // Sanz (1749): Diversos modos hay de golas [...]. La gola de una media-luna o de un revellín es el espacio comprendido entre las extremidades de sus dos caras, de parte de la plaza; las de otras obras destacadas es el intervalo de sus alas de parte del foso principal.

media [Rojas, Teórica fortificación, 1598]. cmpt. sintag. Fort. Parte de la cortina total que queda dentro de un baluarte. (fig. 97)

Rojas, Teórica fortificación, 1598, fol. 39r: AC Sitio de la casamata y media gola del valuarte. 120 pies. // Rojas, Compendio fortificación, 1613, fol. 34r: He hallado que la mayor frente que se puede dar será de 800 pies de frente en el recinto, que se entiende desde la mitad de la gola de un baluarte a la mitad del otro. D'éstos se tomarán 150 pies para la media gola y casamata, y otros 150 de la otra parte en el otro baluarte, para hazer lo mismo que en el primero, que ambos tomarán 300 pies y quedarán 500 pies de cortina franca. // Rojas, 
Compendio fortificación, 1613, fol. 37r: En una plaça, la menor que se puede hazer, que tenga baluartes, tendrá 400 pies en la frente del recinto; y d'éstos se tomarán 160 para las dos casas matas y medias golas de cada baluarte, tomando de la una parte 80 pies para casas matas y su media gola, y otros 80 para la otra casamata y media gola; quedarán 240 pies de cortina franca.

ENCICL.: Terr. (s.v. media-gola): En la fortificación, lo que hay desde el ángulo del flanco con la cortina a la capital. // Terr. (s.v. capital): En términos de fortificación es la línea tirada desde el centro del baluarte hasta el ángulo flanqueado, que está en la punta del baluarte mismo. // Lopes Pires Nunes (2005: s.v. meia gola): Linha imaginária que, com outra idêntica, define, no interior do baluarte, o ângulo do polígono ou da praça que se quer fortificar.

grada, grada [de grado. Grada 'peldaño', 'conjunto de escalones'. Berceo, Mil. (DECH). Rojas, Compendio fortificación, 1613]. sust. Fort. Peldaño construido en lo interior y al pie de un parapeto.

Rojas, Compendio fortificación, 1613, fol. 36v: Y el parapeto principal de encima de los baluartes ha de ser muy gruesso, o muy delgado; gruesso, para prueva del cañón; delgado, para sólo el mosquete. Para el cañón, tendrá 20 pies de gruesso, por lo menos, y de alto cinco pies, con su banqueta o grada para subir a ella el soldado que fuere pequeño de cuerpo.

SIN.: banqueta ${ }_{3}$, escalón.

guarda, guarda [del germ. warda. Doc. de 1120 (Oelschl.); Berceo (DECH). Fernández de Enciso, Suma de Geographía, 1530]. sust. f. Persona encargada de la vigilancia y conservación de una cosa (DSAL).

Fernández de Enciso, Suma de Geographía, 1530, fol. LXVr-LXVv: Y fecho el concierto, tomaron los indios e atáronlos como es dicho, y echáronlos en un prado con guardas para que viessen lo que se hiziesse. E [...] llegó Sancta María [...] con un palo en la mano [...] e tocó con el palo al indio del Comendador, que era de su parte, y como lo tocó fue suelto, e todas las ataduras que aquél tenía se passaron al otro indio del Cemi, demás de las que tenía. E al otro día, como las guardas e los que avían atado dixeron lo que avía passado, los caciques dixeron que no podía ser, sino que avía engaño. // Celso, Reportorio universal leyes Castilla, 1553, fol. CXXXVIv: Y si [el alojamiento] fuere de luenga morada, hagan carcavear en derredor el exército, y de noche pónganse sus guardas, assí a pie como de cavallo. // Celso, Reportorio universal leyes Castilla, 1553, fol. CCCIVr: Si fuere necessario, dévense poner guardas en los lugares y passos donde hoviesse peligro a los caminantes, para que vayan seguros.

ENCICL.: Cov.: El que tiene a su cuenta alguna cosa y está obligado a mirar por ella, como la guarda de las viñas, guarda del monte, la guarda del rey o del príncipe [...]. Guardas las que se ponen en los puertos y en las puertas de las ciudades, y en las casas o fortalezas donde están presos de consideración. 
2 [Montes, Instrucción y regimiento, 1537]. sust. f. Grupo de personas encargadas de la vigilancia y conservación de una cosa.

Montes, Instrucción y regimiento, 1537, fol. XVIIr: Después que el señor del exército hoviere havido la vitoria de sus enemigos, deve conquistar las ciudades, villas y castillos comarcanas sobre que se movió la guerra, en las quales deve poner mucha guarda y dévelas fortalecer, a lo menos aquéllas que él conosciere que se pueden defender a los enemigos. // Álaba, Perfeto capitán, 1590, fol. 89v-90r: Y lo mesmo hizo Alcibíades quando, de repente acometiendo una noche a Eutico, la tomó, poniendo en otra parte de la que pensava assaltar sus trompetas, para que, acudiendo los cercados hazia donde sonavan, entrasse por los lugares desamparados y, estando sin guarda la ciudad, la tomasse. // González de Medina, Examen fortificación, 1599, pág. 126-127: Situarse ha esta fuerça al un lado de la tierra, a lo largo della y en medio, por poder mejor alcançar a todas partes, de manera que pueda batir una de las puertas de la ciudad, o por través, o por cortina, para desaloxar de allí la guarda que estuviere y dar lugar a que pueda entrar con más facilidad el socorro de fuera para sugetarla.

ENCICL.: Rubió y Bellvé (1895-1901): Persona o personas que tienen a su cargo y cuidado la conservación o vigilancia de una cosa.

3 [Montes, Instrucción y regimiento, 1537]. sust. Acción de proteger, vigilar o conservar una cosa.

Montes, Instrucción y regimiento, 1537, fol. VIv: Este capitán ha de tener mucho cuydado en la guarda de la artillería y municiones; hase de desvelar en llevar la artillería a muy buen recaudo, al seguro y por passos seguros, donde no pueda haver daño de los enemigos. / / Mendoça, Theórica y práctica, 1596, pág. 99: Plantadas estas pieças con sus lecheras, que se hazen de tablones, maderos o çarzos, se cubren con cestones y fossos, assí para seguridad de los gastadores que asisten al retirarlas con los artilleros, y de otras cosas necessarias, como para la guarda de la artillería. // González de Medina, Examen fortificación, 1599, pág. 39: No puede con agua una fuerça ser escalada, y assí no ha menester mucha gente para su guarda ni ocupar tantas centinelas, que el agua le haze essos oficios y dexa reposar a los de dentro.

ENCICL.: DRAE: Acción de guardar (conservar o retener). // DUE: Acción de guardar, salvaguardar o proteger. // DSAL: Acción de vigilar o proteger una cosa. // Terr.: Se toma también por cuidado, conservación, defensa, protección, etc.

4 [Fernández de Enciso, Suma de Geographía, 1530]. sust. Servicio de vigilancia prestado por una persona o por un grupo.

Fernández de Enciso, Suma de Geographía, 1530, fol. LXVv: E tornaron a atarlos otra vez e passó otro tanto, e dixeron lo mismo, que era engaño, y después bolvieron otra vez a atarlos e pusiéronse en guarda los mismos caciques, e vieron otro tanto como los otros. // Montes, Instrucción y regimiento, 1537, fol. XIr: Y la infantería ponga las mismas cintinellas dobladas por los caminos y passos, porque los unos no se deven descuydar con los otros, 
porque es razón que la gente d'armas haga su guarda y los cavallos ligeros hagan la suya, y la infantería haga la suya, y no se descuyden los unos por los otros. // Escalante, Discurso de la navegación, 1577, fol. 79v-80r: Ay en esta ciudad y en todas las demás que son metrópolis treze cárceles en cada una, grandíssimas, cercadas de muro muy alto y tan espaciosas que, con aver en ellas aposentos para el carcelero mayor y sus ministros, y para los soldados de guarda que de ordinario ay, y estanques y jardines, ay muchas plaças y calles y patios dentro por donde andan y se passean los presos de día.

guarda, V. cuerpo de (la) .

guardado, guardado [de guardar. Álaba, Perfeto capitán, 1590]. adj. Dicho de una cosa o de un lugar: protegido con algo frente a cualquier peligro o daño.

Álaba, Perfeto capitán, 1590, fol. 75r-75v: Es necessario el que está en una ciudad o fuerça se prevenga, antes de verse cercado de los enemigos, pues tiene más comodidad de todo que el que está en campaña, de que todas las partes por donde le pueden ofender y hazer perjuyzio las tengan fortificadas, reparadas y guardadas, assí de las defensas que pueden hazerse de tierra y piedra. // Álaba, Perfeto capitán, 1590, fol. 123v: Este esquadrón de en medio quadro de terreno suelen dividir algunos en dos partes yguales, poniendo la primera mitad de suerte que las primeras hileras de los cuernos con las d'éste hagan una línea recta, dexando la otra mitad en el lugar que estava; y en el espacio que queda entre las dos mitades ponían el bagaje. Y, d'esta suerte, de todos los lados queda guardado. // Lechuga, Discurso de la Artillería, 1611, pág. 205: Si marchan con exército formado que va a pelear con otro, van todas las pieças en sus caxas, prontas a dispararse, delante de los esquadrones, para que puedan, offreciéndose, hazer daño a los del enemigo, y los carros las más vezes sirviendo de muralla a todo el exército, duplicándolos o triplicándolos, conforme a su quantidad, y los de la pólvora siempre a la parte de adentro, para que vaya más guardada.

SIN.: defendido 1 .

FAM.: guardar.

2 [Martínez de Burgos, Reportorio premáticas y Cortes, 1551]. adj. Mil. Dicho de un lugar o de un puesto: vigilado o custodiado por un soldado o una tropa.

Martínez de Burgos, Reportorio premáticas y Cortes, 1551, fol. XXXVIIv: Y en quanto a la guarda de la costa de la mar, avemos mandado a los del nuestro Consejo de la Guerra que den orden, por manera que se provea en que la costa esté segura y bien guardada, y nuestro súbditos no reciban daño. // Álaba, Perfeto capitán, 1590, fol. 92v-93r: Y hará que su gente no sólo guarde las puentes, puertas, rastrillos y cortinas del muro de ordinario, mas también por la parte de afuera la campaña más cercana al fosso, si possible fuere, teniendo particular cuydado de que el entrar y salir sea por algún postigo guardado, y que todas las puertas estén cerradas y guardadas, y que aya cuerpos de guardia y centinelas para que den aviso de todo lo que se ofreciere. // González de Medina, Examen 
fortificación, 1599, pág. 165: No les queda cómo poder esperar ser socorridos, si no es con exército superior que pueda hazer levantar el cerco o darle la batalla, porque a las puertas, por donde pueden entrar, las tendrán muy bien fortalecidas y guardadas.

3 [Lechuga, Discurso de la Artillería, 1611]. adj. Fort. Dicho de un lugar fortificado: dotado de tropas encargadas de conservarlo.

Lechuga, Discurso de la Artillería, 1611, pág. 262: Considerando bien que me e alargado a poner que cada soldado defienda ocho pies, no por regla, sino porque conozcan los que oy tienen fuerzas cómo las tienen guardadas, y dicho ahora por regla general, se deve saver que cada hombre deve defender solo el lugar que ocupa, que son tres pies quadrados. // Lechuga, Discurso de la Artillería, 1611, pág. 262: Todo lo dicho de la fuerza de quatro baluartes servirá de exemplo para que por ella se saque la qüenta de los soldados que a menester qualquiera otra de más baluartes y para saver lo necessario para guardar una fuerza en paz, con la manera de guardarla mejor, ayudándose del tener dentro de ella parte del presidio ordinario de la provincia, pues siempre que sea necessario salir de ella para otra, podrá quedar guardada, como lo está de presente, con la guardia ordinaria que acostumbran poner dentro.

guardar, guardar [del germ. wardôn, derivado de warda y éste de warôn 'atender, prestar atención'. Orígenes del idioma (DECH). Fernández de Enciso, Suma de Geographía, 1530]. v. tr. Proporcionar una cosa protección a otra frente a cualquier tipo de peligro o daño.

Rojas, Teórica fortificación, 1598, fol. 105v: Y puesto todo en este estado, començarán las camaradas del artillería a derribar todos los parapetos y defensas, y procurar con toda instancia de desembocar las casas matas que guardan los dos valuartes que se van batiendo. // Lechuga, Discurso de la Artillería, 1611, pág. 241: El fosso a de ser ancho, por la parte de las cortinas de los baluartes, quando menos, 120 pies, y por las otras partes, lo que precisamente pide, para que los baluartes puedan guardar el fosso. // Rojas, Compendio fortificación, 1613, fol. 35v-36r: El fosso tendrá de ancho, quando sea mayor, 80 pies, y no más, porque, aunque ay opiniones de que sean de 100 pies y de 120, a esso digo que, siendo tan ancho, será campaña del enemigo, porque no lo pueden guardar bien las casas matas y, juntamente, estarán desembocadas del campo, por ser tan ancho el fosso.

SIN.: defender $r_{1}$

FAM.: guardado.

ENCICL.: DUE: Defender o proteger: servir para que a una cosa no le ocurra cualquier daño o no le llegue cualquier cosa perjudicial.

2 [Martínez de Burgos, Reportorio premáticas y Cortes, 1551]. v. tr. Mil. Dicho especialmente de un soldado o de una tropa: vigilar o custodiar alguna cosa, un lugar o un puesto. 
Celso, Reportorio universal leyes Castilla, 1553, fol. CLVIIIr: Ansimesmo, en la guerra deven poner guardas para guardar todas las cosas que ganaren de los enemigos, que no se pierdan, ni las roben, ni hurten. // García de Palacio, Diálogos militares, 1583, fol. 56r: El officio de los hombres de armas es, resistiendo como un fuerte o bestión, defender de los enemigos su infantería y desbaratar y romper a los contrarios. El de los herreruelos y arcabuzeros de a cavallo es espiarlos y descubrirlos, y escaramuçar con ellos, y traer mantenimientos y guardar algunos pasos. // Álaba, Perfeto capitán, 1590, fol. 49v: Deben tener mucho cuydado que éstas no sepan la parte de muro donde han de hazer la guardia, ni tampoco las esquadras y centinelas, hasta la hora que las han de meter, pues siempre que alguna fortaleza o lugar se ha tomado por tratos, a procedido el daño de saber el oficial o centinela la parte que de ordinario le tocava de guardar.

ENCICL.: Terr. (s.v. guardar el puesto): Mantenerle. // Domínguez (1853): Vigilar o velar por la seguridad y conservación de un objeto. // D'Wartelet (1863): Custodiar, vigilar, velar por la seguridad de un puesto, persona, etc.

3 [Montes, Instrucción y regimiento, 1537]. v. tr. Fort. Aplicado a un lugar fortificado: conservarlo, luchar contra los que se empeñan en apoderarse de él.

Montes, Instrucción y regimiento, 1537, fol. XIv: E si la batalla fuere de noche, no se salgan de su fuerte, porque podrían tener algunas embuscadas que los rompiesen, mas deven guardar su fuerte, porque de una manera han de pelear los que son acometidos y de otra manera han de pelear los que van a acometer. // Rojas, Teórica fortificación, 1598, fol. 36v: Si se hiziere la fortificación encima de algún padrastro o montaña, se tendrá gran cuydado de ocupar todo el sitio, o, a lo menos, lo más alto d'él, de manera que el enemigo no tenga cosa eminente sobre la plaça, si no fuesse a distancia de 1.000 passos, y entonces esta plaça se puede guardar con menos gente y munición. // Lechuga, Discurso de la Artillería, 1611, pág. 232: Quando algunos governadores, capitanes o otros que tienen cargo de guardar castillos, villas y otros lugares fuertes dexaren sus cargos y officios, o murieren en ellos, sus mugeres o acreedores avrán de dar y entregar, por inventario, toda la artillería y municiones puestas en ellos.

SIN.: defender 3.

guardia, guardia [del gót. wardja 'el que monta guardia', 'centinela, vigía', influido en su significado por el lat. custodia 'acción de guardar', 'retén de soldados'. h. 1570, dicc. de Cristóbal de las Casas; 1578, Ercilla; Quijote; Góngora; Oudin; Covarr., etc. (DECH). Álaba, Perfeto capitán, 1590]. sust. Mil. Acción de vigilar o custodiar un lugar o alguna cosa.

Álaba, Perfeto capitán, 1590, fol. 84r: Hechas las trincheas, dexando en ellas algunos soldados con algún buen ingeniero y gastadores que queden en guardia de aquel sitio, passará con lo demás del exército a otra parte a donde quiere hazer otra segunda fortificación. // Collado, Plática Artillería, 1592, fol. 90v: A él toca diputar compañías de soldados para la guardia del puente porque el enemigo no lo deshaga, como cada día acontesce, o lo gane o lo queme. // Mendoça, Theórica y práctica, 1596, pág. 109: No he 
apuntado a Vuestra Alteza, en caso que el enemigo caminasse con exército poderoso para hazer levantar el sitio, en la manera que Vuestra Alteza se ha de governar [...], eligiendo por la consideración d'estas cosas si será mejor esperarle en los quarteles o, dexándolos, y alojamiento, caminar a combatirle con todo el exército o alguna parte d'él, quedando la resta a la guardia de las trincheas, artillería y quarteles o resolver de levantar enteramente el cerco.

ENCICL.: DRAE: Acción de guardar (vigilar).

2 [Cortés de Albacar, Breve compendio sphera, 1556]. sust. Mil. Servicio de vigilancia que prestan los soldados.

Cortés de Albacar, Breve compendio sphera, 1556, fol. XLVIr: Deven los marineros hazer guardia por el peligro del mar, por el daño de los cosarios y dividir la noche por quartas, como los hombres de guerra lo hazían e los marineros antiguamente acostumbravan. // Mendoça, Theórica y práctica, 1596, pág. 132: Estando con mucha sospecha de enemigos, si la tierra es flaca, ha de hazer de noche casi toda la gente guardia, durmiendo en las murallas, principalmente si se temen de escalada o trato. // Anónimo, Diálogo fábrica de navíos, ca. 1631, fol. 38r: La guardia es tres horas; éstas es justo se velen, pues va la vida, puesto que en el resto de la noche ay arto tiempo para dormir y el día siguiente que velan todos.

SIN.: centinela 2.

ENCICL.: DEA: Servicio de guardia que, por turno obligatorio, prestan los miembros de una unidad militar. // Sanz (1749): Es una facción o servicio que se debe hacer con vigilancia para asegurarse contra los esfuerzos y sorpresas del enemigo. Dícese: entrar de guardia, salir de guardia, relevar la guardia, oficial de guardia, sargento de guardia. La guardia de cada puesto se debe sortear a fin que algún oficial traidor no pueda ponerse de concierto con el enemigo para entregarle el puesto que ocupa. De las tropas que están de guarnición en una plaza de guerra, entran cada día de guardia la tercera parte, de modo que tienen dos noches buenas para su descanso, y así cada compañía está dividida en tres escuadras, de las cuales siempre hay una de guardia, mientras se preparan las otras a mudarla. // Rubió y Bellvé (1895-1901): Este servicio se considera dividido, generalmente, en turnos o cuartos, para que puedan descansar más o menos los que la desempeñan.

3 [Medina, Regimiento de navegación, 1563]. sust. Mil. Conjunto de soldados o gente armada que defiende o vigila un puesto (DUE).

Álaba, Perfeto capitán, 1590, fol. 48v-49r: Y porque en la distancia que a de aver del cuerpo de guardia a la demás gente del campo ay variedad de pareceres, abreviando en esto, digo que si el alojamiento está cercado de trincheas, hasta ellas se a de alargar la guardia, pues son como muro del exército. // Mendoça, Theórica y práctica, 1596, pág. 140: Quando se ha dado principio al batir, ha de aver muy buena guardia de día y noche en aquella parte, reforçándola a proporción del efecto que hiziere la artillería enemiga, y con orden que no hablen los d'ella con los de fuera, si no es mandándoselo. / / González de Medina, Examen 
fortificación, 1599, pág. 40: Tiene pocas salidas, y essas por partes conocidas, adonde el enemigo pondrá muy buena guardia para defenderlas.

SIN.: cuerpo de (la) guarda, cuerpo de guardia ${ }_{1}$

guardia, V. cuerpo de $\sim$.

guarnecer, guarnecer, guarneçer, guarnescer, guarnesçer, guarneser, guarnezer [de la forma antigua guarnir 'íd.', y éste del germ. occid. warnjan 'amonestar, advertir (contra un peligro o amenaza)', 'proveer, guarnecer, armar'. Guarnir, Cid; guarnecer, h. 1400, Glos. de Toledo (DECH). Loçano, Alberto, Architectura, 1582]. v. tr. Mil. Proveer un lugar de tropas que lo defiendan.

García de Palacio, Diálogos militares, 1583, fol. 189v: Y común opinión es que las hileras que han de calar primero lleven las picas quatro o cinco palmos más largas que las otras, y que d'estas picas tales huviesse para armar la décima parte de los piqueros que huviesse en el exército, con que se guarneciessen a lo menos los lugares más necessarios, porque es muy gran ventaja ser una pica más larga que otra. // Mendoça, Theórica y práctica, 1596, pág. 125: Juntamente se ha de advertir qué calidad de soldados ay en la plaça y de los que se ha de guarnecer, siendo necessario reforçarla, y que no sean bisoños y fáciles a amotinarse. // Rojas, Teórica fortificación, 1598, fol. 105v: Y si cargare el enemigo haziendo fuerça para socorrer su castillo, se suelen guarnecer las trincheas y fuertes, y con el resto de la gente salir al encuentro al enemigo y darle la batalla.

ANT.: desguarnecer.

FAM.: desguarnecer, guarnecido, guarnición.

ENCICL.: DUE: ("con, de") tr. Mil. Colocar fuerzas en una plaza o puesto militar.

2 [Collado, Plática Artillería, 1592]. v. tr. Fort. Reforzar o cubrir una obra de fortificación con otra.

Collado, Plática Artillería, 1592, fol. 91v: Muchas vezes será forçado el ingeniero a querer levantar un baluarte o cavallero de faxina y tierra, para poder después guarnescerlo por defuera con su camisa de muralla.

ENCICL.: D'Wartelet (1863): En fortificación, reforzar un camino cubierto u otra obra defensiva $[\ldots]$.

guarnecido, guarnecido, guarnescido [de guarnecer (DECH). Urrea, Vitruvio, Architectura, 1582]. adj. Mil. Dicho de una posición militar o de un lugar: dotado de tropas. 
Urrea, Vitruvio, Architectura, 1582, fol. 33r: Como César Augusto tuviesse su exército cerca de los Alpes y mandasse a los moradores dar vitualla y bastimento, y allí oviesse un castillo muy guarnecido que llamavan Lariguo, los que estavan en él, confiados en su natural fortaleza y munición, no quisieron obedecer su mandado. // Álaba, Perfeto capitán, 1590, fol. 132r-132v: Y para que marchando quede el esquadrón guarnecido, advierta el sargento mayor que en la primera parte d'él, marchando, a la mano siniestra ponga toda la arcabuzería con que quiere guarnecer todo el esquadrón por aquel lado, y en la vanguardia y retaguardia las que quiere tenga por aquellas partes.

FAM.: desguarnecer, guarnecer, guarnición.

ENCICL.: D'Wartelet (1863): Denominación de la plaza de guerra, fortaleza o punto que está defendido por las tropas.

guarneçer, V. guarnecer.

guarnescer, V. guarnecer.

guarnescido, V. guarnecido.

guarnesçer, V. guarnecer.

guarneser, V. guarnecer.

guarnezer, V. guarnecer.

guarnición, guarnición, guarniçión, guarnizión [de guarnir. Guarnizón, Cid, Alex.; guarnición, Berceo (DECH). Celso, Reportorio universal leyes Castilla, 1553]. sust. Mil. Grupo de soldados que se destina a un lugar o a una posición militar para defenderlos.

Celso, Reportorio universal leyes Castilla, 1553, fol. XXIv: Los herradores no pagan alcavala de todo el herraje que gastaren en los reales y con la gente de las guarniciones. // Álaba, Perfeto capitán, 1590, fol. 43r: Y començando a caminar yrá en esta orden: hará de la arcabuzería tres tercios, de los dos d'ellos hará dos mangas, poniendo la una a la mano diestra y la otra a la siniestra, cerca de los ángulos de la frente del esquadrón; del otro tercio hará dos guarniciones, para el lado diestro y siniestro del esquadrón. // Roxas, Sumario milicia, 1607, fol. 104r-104v: Y ganada esta plaça fuerte, se le rendirán todas las demás que estubieren alrededor, con que dará fin a la guerra de aquella provinçia que va a 
conquistar; luego se meterán guarniçión de soldados a esta plaça, con muchas muniçiones de pólvora, balas, armas ofensibas y defensibas.

FAM.: desguarnecer, guarnecer, guarnecido.

ENCICL.: Terr.: En la milicia es un cuerpo de gente que se pone en una plaza, puesto o frontera que se quiere guardar.

guarniçión, V. guarnición.

guarnizión, V. guarnición.

guerra, guerra [del germ. occid. werra 'discordia', 'pelea'. Orígenes del idioma (DECH). Sagredo, Medidas Romano, 1526]. sust. Conflicto o enfrentamiento armado entre dos o más naciones o entre bandos de una misma nación, que dura considerable tiempo, con diversas batallas y episodios.

Sagredo, Medidas Romano, 1526, pág. 6: Antiguo era el sepulcro de David y sumptuosamente labrado, pues, al tiempo que le fabricaron, hizieron en él ciertas alhazenas secretas donde ascondieron tres mil libras de oro, que fueron la herencia que dexó; las quales, después, passados mil y CCC años, fueron halladas por Hircano, pontífice de los hebreos, según cuenta Josepho, y con ellas dio guerra a Antíocho, rey de Syria, que le tenía cercado y puesto en mucho estrecho. // Montes, Instrucción y regimiento, 1537, fol. IIIr: Cosa muy necessaria es a los cavalleros y grandes señores leer las cosas de famosos hechos del arte militar que los príncipes y sus capitanes hazen en las guerras y batallas que emprenden; e porque después de diestros en la guerra no quieren dar la orden que tienen en el vencer, ni pelear, porque aquella gloria quieren guardar para sí, e por esta razón es cosa necessaria que los cavalleros que siguen la guerra procuren con toda diligencia de la saber exercitar, y el estilo que se deve tener en el principiar de la guerra, y los aparejos que son menester para la hazer. // Roxas, Sumario milicia, 1607, fol. 50v-51r: Dize Appriano Alexandrino en el libro que trata de España que, cansados ya los romanos de la guerra larga que contra los de Numançia, que oy se llama Soria, tubieron, se resolbieron de enbiar contra ellos a Cornelio Cepión, el qual ganó a Cartagena.

SIN.: batalla 2 , contienda 1 .

ANT.: $p a z_{1}$.

FAM.: guerrear, guerrero.

ENCICL.: Cov.: El conflicto de dos ejércitos contrarios enemigos, que uno a otro se hacen guerra y se matan. El francés y el italiano llaman a este rompimiento de reinos, o príncipes o comunidades unos contra otros guerra [...]. La diferencia que hay entre guerra y batalla es que la guerra se entiende por todo el tiempo que no se asientan las paces, y la batalla es 
un conflicto y rompimiento de un ejército con otro. // D'Wartelet (1863): Serie de combates entre dos o más naciones en defensa de los intereses de cada una de ellas.

civil [Fernández de Enciso, Suma de Geographía, 1530]. cmpt. sintag. La sostenida entre naturales de la misma nación (DUE).

Fernández de Enciso, Suma de Geographía, 1530, fol. XXXIIv: Después, andando los tiempos, fueron tomados algunos cavalleros y mancebos, por favores, por senadores, $\mathrm{y}$ como aquéllos fueron rescebidos por senadores, con la mucha codicia y con la poca esperiencia e sciencia que tenían, olvidaron la cosa pública por la particular e por sus passiones e interesses propios, de donde se siguieron las discordias y guerras civiles. // Micón, Diario grande cometa, 1578, pág. 98: Y d'éstos han aparecido muchos, como el que duró 75 días antes de la guerra de Peloponeso, y antes de la rota de los athenienses y de la guerra civil de entre César y Pompeyo. // Mosquera, Comentario disciplina militar, 1596, fol. 88r: Ya en estas islas corría el infortunio que refieren los historiadores en el tiempo de las guerras civiles.

ENCICL.: D'Wartelet (1863): La que tienen entre sí los habitantes de un mismo pueblo o reino, divididos en bandos o parcialidades.

defensiva [García de Palacio, Diálogos militares, 1583]. cmpt. sintag. La que hace un ejército que, contando con fuerzas poco numerosas, no puede arriesgarse a atacar al enemigo que invade su territorio y se limita tan sólo a defenderse en los casos extremos (D'Wartelet 1863).

García de Palacio, Diálogos militares, 1583, fol. 12v: Es verdad que ay esas dos maneras de guerra, y a la una llaman defensiva y a la otra offensiva. Y digo que de entrambas a dos se entiende lo que he affirmado, porque entrambas son lícitas, aunque la justicia de la guerra defensiva, como vuestra merced apuntó, es más clara. // García de Palacio, Diálogos militares, 1583, fol. 12v: Y que la guerra defensiva sea lícita paresce que el defenderse cada uno es de derecho natural. D'estas guerras defensivas ay en la Scriptura Sancta muchos exemplos, por los quales se declara su justicia. // Mendoça, Theórica y práctica, 1596, pág. 15: Queriendo Vuestra Alteza conquistar algún reyno, estado o paýs, o parte d'él, que es la guerra más descansada para los príncipes, por ser voluntaria y no forçosa, como la defensiva, dando lugar para hazer las provisiones en tiempo y tenerlas con él sazonadas, es de considerar ser natural cosa en todos los hombres, quanto más en los reyes, el desseo de conquistar.

ANT.: guerra ofensiva.

ofensiva [García de Palacio, Diálogos militares, 1583]. cmpt. sintag. La que emprende una potencia al atacar a otra sin preceder la declaración o, cuando habiéndola hecho, invade su territorio (D'Wartelet 1863).

García de Palacio, Diálogos militares, 1583, fol. 13r: También es clara la justicia de la guerra offensiva quando se entra por las tierras del enemigo, o para recuperar los bienes que 
lleva robados, o para tomarle otros tantos o para vengar las injurias que ha hecho. // García de Palacio, Diálogos militares, 1583, fol. 13v: Quedo bien enterado, en este primer punto, de que la guerra, aunque sea offensiva, es lícita. // García de Palacio, Diálogos militares, 1583, fol. 14v: Acerca d'esta primer circunstancia requisita para la justicia de la guerra, me queda una dubda, con la qual concluyré, y es si se entiende que sea necessaria la authoridad del príncipe para la guerra defensiva, que de aquí sea necessaria para la offensiva.

ANT.: guerra defensiva.

guerra, V. aproches de $\sim$.

guerra, V. empresa de (la) .

guerra, V. facción de $\sim$.

guerra, V. gente de .

guerra, V. hombre de (la) .

guerra, V. levantamiento de $\sim$

guerra, V. munición de $\sim$.

guerra, V. pertrechos de $\sim$.

guerrear, guerrear [de guerra. Cid (DECH). Celso, Reportorio universal leyes Castilla, 1553]. v. intr. Hacer la guerra (DEA).

Celso, Reportorio universal leyes Castilla, 1553, fol. LIXr: Teniendo alguno un castillo del Rey y se alça con él, o lo da a los enemigos, o lo pierde por su culpa o por engaño que le hazen, haze trayción. Y, ansimesmo, la haze el rico hombre o cavallero, o qualquier otro que basteciesse un castillo o fortaleza para guerrear contra el Rey o el bien público. // Celso, Reportorio universal leyes Castilla, 1553, fol. CCXXVIIv: Naos y navíos. Ay diversas suertes y maneras de naos sobre la mar, de los quales unos son mejores que otros para guerrear. // Mendoça, Theórica y práctica, 1596, pág. 108: En el alojar Vuestra Alteza el exército en la tierra, después de ganada, ha de ser según la grandeza y comodidad d'ella y fin que se 
tiene en el guerrear, siendo lo mejor, si el enemigo no está pujante para venir a combatir los quarteles, el conservarlos, poniendo guarnición en la tierra.

FAM.: guerra, guerrero.

ENCICL.: DUE: ("con, contra" o sin complemento) intr. Hacer [la] guerra.

guerrero, guerrero [de guerra. Doc. de 1076, Oelschl. (DECH). Fernández de Enciso, Suma de Geographía, 1530]. adj. Dicho de una persona o de una colectividad: acostumbrada o habituada a hacer la guerra y, por tanto, conocedora del arte militar.

Fernández de Enciso, Suma de Geographía, 1530, fol. XXXVIIIv: De la otra parte del monte Cáucaso están los nómades, que son pastores, y más al Setentrión, las amazonas, que son gente guerrera. // Apiano, Cosmographía, 1575, fol. 77r: Y, assí, donde primero fueron vistos, llamaron aquel lugar La Loma de los Armados. Es la gente más guerrera y más feroz de toda la India. / / Roxas, Sumario milicia, 1607, fol. 9r: Se tiene por sin duda que los lugares y aldeas rústicas son más propias para las armas, como quien se cría en trabajo y sereno soporta el calor del sol y por la sombra no se les da nada, como se dize de Quinto Cercinato, que los seis messes del año era labrador y los otros seis era soldado guerrero.

FAM.: guerra, guerrear.

ENCICL.: Zerolo (1895: s.v. belicoso): Guerrero indica lo que es propio para la guerra, la persona que está habituada a hacerla y todo lo que tiene relación con ella. Los antiguos germanos, que invadieron parte del imperio romano, formaban una nación belicosa; los alemanes que les han sucedido son una nación guerrera. Los primeros, por inclinación, se ocupan continuamente en la guerra; los segundos sólo cuando la creen necesaria [...]. Es guerrero un príncipe que conoce bien el arte de la guerra y combate al frente de sus ejércitos. Puede uno ser belicoso sin ser guerrero, y lo mismo al contrario. Carlos XIII, rey de Suecia, fue un príncipe belicoso; Federico II, rey de Prusia, guerrero. Las naciones modernas son más bien guerreras que belicosas.

2 [García de Palacio, Diálogos militares, 1583]. sust. Persona que pertenece al ejército o que está especializada en hacer la guerra.

García de Palacio, Diálogos militares, 1583, fol. 70r: Se infiere que el lugar con alguna disposición de ventaja suple el número de los soldados y lo demás se deve entender quando el campo es ygual y el número de los guerreros desygual. // García de Palacio, Diálogos militares, 1583, fol. 70v: Y en la misma Sacra Escriptura se dize que, quando acontesciere que pocos soldados se hallen cercados de multitud de enemigos, no se les acometa, mas que se use contra ellos de cautelas y ardides, y se les dé a entender brío y ánimo, y encubra la falta de guerreros, haziéndoles arma de noche, por muchas partes, para que piensen y entiendan que son más en número. // Roxas, Sumario milicia, 1607, fol. 9r: An de exerçitarse en correr, saltar, que es un bigor militar, porque la ligereza es aquella 
que haze el guerrero diestro, de manera que, como dize Saluçio, los soldados se han de elegir moços y los consexeros viejos y experimentados.

SIN.: defensor, hombre, hombre de (la) guerra, hombre de pelea, hombre de soldadesca, hombre militar, militar ${ }_{2}^{2}$, mílite, soldado.

ENCICL.: Aut.: Se toma algunas veces por soldado. 
hacer, V. escolta a alguien o algo.

hacer, V. retirar.

hacometer, V. acometer.

harte, V. arte.

hasentar, V. asentar.

hazienda, V. facienda.

hecho, echo, hecho [del lat. făctum, $-\bar{\imath}$ 'acto, hecho, acción, obra, trabajo empresa' (Segura Munguía 2001)].

$\sim$ de armas [Celso, Reportorio universal leyes Castilla, 1553]. cmpt. sintag. Mil. Combate o cualquier otra operación militar llevada a cabo en una guerra.

Celso, Reportorio universal leyes Castilla, 1553, fol. CLVIIv: Empero, deve ser gualardonado del Rey en recompensa de la tal pérdida, como lo deve ser el que fuesse preso en guerra en 
servicio del Rey, o hoviesse perdido su cavallo en hecho de armas, recompensándole en cosa que valga tanto y medio de lo que perdió.

SIN.: empresa, empresa de (la) guerra, empresa militar, encuentro, facción 2 , facción de guerra, interpresa $a_{1}$, reencuentro 1 .

ENCICL.: Borreguero Beltrán (2000): Acción de guerra.

henemigo, V. enemigo.

herreruelo, herreruelo [de herrero y éste del lat. ferrarius. Herreruelo 'pájaro', 'soldado de caballería alemán'. Apol., J. Ruiz, J. Manuel (DECH). García de Palacio, Diálogos militares, 1583]. sust. Mil. Soldado alemán perteneciente a la caballería ligera.

García de Palacio, Diálogos militares, 1583, fol. 56r: El officio de los hombres de armas es, resistiendo como un fuerte o bestión, defender de los enemigos su infantería y desbaratar y romper a los contrarios. El de los herreruelos y arcabuzeros de a cavallo es espiarlos y descubrirlos, y escaramuçar con ellos, y traer mantenimientos y guardar algunos pasos. // Mendoça, Theórica y práctica, 1596, pág. 56: Aviendo lanças y herreruelos en el exército, es muy buena manera de mezclarlos poner al costado izquierdo de las lanças una corneta de herreruelos, que viene a servir como de manga. // Mendoça, Theórica y práctica, 1596, pág. 57: Los esquadrones de lanças no han de ser de mayor número de ciento o ciento y veynte a los más, aunque aya de envestir con esquadrón de quatro cientos o quinientos herreruelos, y d'este número muchos, en que se han de repartir las lanças y que choquen con priessa, que es lo que más desbarata los herreruelos.

ENCICL.: DUE (s.v. herreruelo 1 ): Mil. Soldado de los de cierto cuerpo de la antigua caballería alemana; llevaban peto, espaldar y celada negros y usaban como armas flechas, martillos provistos de puntas agudas y dos arcabuces colgados de la silla. // D'Wartelet (1863): Figuraron mucho los herreruelos en las guerras que los monarcas españoles sostuvieron en Flandes. // Rubió y Bellvé (1895-1901): En España se introdujeron los herreruelos en 1560 y se les confiaba ciertos servicios especiales, como el de las granguardias.

hila, hila [del lat. fila, antiguo plural. Hila ant. 'hilera'. Ercilla, Inca Garcilaso, Mariana (DECH). García de Palacio, Diálogos militares, 1583]. sust. Línea recta formada por personas, frecuentemente soldados, o por cosas, una detrás de otra o una al lado de otra. $\quad$ (fig. 98)

García de Palacio, Diálogos militares, 1583, fol. 149v: Es nescessario sacar la raýz quadrada de los infantes que lleva, y, pudiéndose dividir por tres partes yguales, tantos quantos se incluyeren en su tercia parte han de yr por hilera. Assí que, llevándose tres mil y novecientos y sesenta y nueve infantes, hase de sacar su raýz quadrada en la forma dicha y hallarse ha ser sesenta y tres. $Y$, porque esta raýz se puede dividir en tres enteras partes 
yguales, hase de tomar el tercio, que es veynte y uno, y tantos infantes han de ser los que han de yr por hila en cada división.

SIN.: hilada, hilera, orden.

ENCICL.: Aut.: Lo mismo que hilera. // Aut. (s.v. hilera). Número de cosas o personas formado en orden sucesiva de una a otra, como hilera de casas, hilera de soldados, etc. // DRAE (s.v. hila¹): Formación en línea.

hilada, filada, hilada, ilada, ylada [de hilo y éste del lat. filum (DECH). García de Palacio, Diálogos militares, 1583]. sust. Línea recta formada por personas, frecuentemente soldados, o por cosas, una detrás de otra o una al lado de otra.

of (fig. 99)

García de Palacio, Diálogos militares, 1583, fol. 149r: Y, assí, queriendo hazer un esquadrón de ochenta y un soldados en forma quadrada, tomará vuestra merced su raýz, que es el número nueve, porque, multiplicados por otros nueve, son los dichos ochenta y uno; $\mathrm{y}$, assí, porná nueve hiladas de a nueve hombres cada una, guardando la orden de los pies, como queda dicho.

SIN.: hila, hilera, orden.

FAM.: hilera.

ENCICL.: DUE: Serie de cosas colocadas una tras otra en línea recta. Sin. y var. Fila, hilera. // DESAL: Serie de personas, de animales o de cosas puestos uno detrás de otro o uno junto a otro. Sin. hilera. // DRAE: Formación en línea.

hilera, hilera, ilera, ylera [de hilo y éste del lat. filum. 1552, Calvete (DECH). Montes, Instrucción y regimiento, 1537]. sust. Línea recta formada por personas, frecuentemente soldados, o por cosas, una detrás de otra o una al lado de otra.

s? (fig. 100)

Montes, Instrucción y regimiento, 1537, fol. XIIIv: No piense nadie que la mucha gente haze la guerra, ni el día de la batalla podrán pelear todos, si son muchos, porque como son muchos embaráçanse los unos con los otros y pelean solamente las quatorze hileras primeras y, si aquéllas se rompen, es roto el exército de los muchos, porque en las primeras hileras está la fortaleza de todo el exército. // García de Palacio, Diálogos militares, 1583, fol. 148v-149r: Queriendo ordenar un esquadrón de dos mil y quinientos hombres, avía de tener cinqüenta hileras de largo y cinqüenta de ancho, porque este número cinqüenta es la raýz quadrada de los dichos dos mil y quinientos. // Roxas, Sumario milicia, 1607, fol. 17v: Al haçer el esquadrón, está claro que no ay cosa de tanto provecho en la batalla como los soldados se ayan exerçitado en guardar sus hileras en esquadrón, de manera que no se amontonen ni se abran mucho.

SIN.: hila, hilada, orden. 
FAM.: hilada.

ENCICL.: DRAE (1803): El orden o formación en línea recta de un número de cosas o personas. // González de Medina, Examen fortificación (1599: pág. 186-187): La plaça de armas, no haziéndose más de dos hileras de casas, le quedarán cien mil y trezientos pies de superficie pentágona, quedándole a cada soldado veinte y un pies para puestos en esquadrón: caben quatro mil y setecientos y setenta y siete soldados. // Rojas, Teórica fortificación (1598: fol. 102r): "Supongo que tengo tres o quatro mil picas, más o menos, y para mi propósito digo que sean 3.000 y el esquadrón sea quadro de gente. Sacaré la raíz quadrada de los 3.000, que es 54 y algo más, y tantas hileras tiene de frente y fondo el tal esquadrón [...]. Assí, para hazer qualquiera esquadrón quadro de gente, se tendrá por regla general sacar la raíz quadrada de qualquier número de soldados que huviere, y aquéllas serán las hileras de frente y de fondo que tendrá dicho el esquadrón". / / Rojas, Teórica fortificación (1598: fol. 102r-102v): "Para declaración del esquadrón quadro de terreno supongo que son 3.000 picas y me piden que haga d'ellas un esquadrón quadro de terreno. Dize la regla que, por quanto ha de aver de un soldado a otro tres pies por la frente y 7 de pecho a espalda, que se entiende 7 de fondo, se multipicarán los 3.000 por 3, y serán 9.000, que se partirán por 7, y saldrán 1.285, de los quales se sacará la raíz quadrada, que será 35, y tantas hileras tendrá de fondo el esquadrón. Y para sacarle la frente, se partirán las 3.000 picas por el fondo, que es 35, y saldrán 85, y tantas hileras tendrá de frente".

en $\sim$ [Escalante, Discurso de la navegación, 1577]. loc. adv. Dicho de disponer algunas cosas: en línea recta (DRAE: s.v. en fila).

Escalante, Discurso de la navegación, 1577, fol. 36v: Tienen generalmente en las puertas árboles plantados en hilera, que tienen verdura todo el año, para que les hagan sombra y hermoseen las calles. // Mendoça, Theórica y práctica, 1596, pág. 93-94: Vuestra Alteza tomará resolución por la parte que se ha de poner la batería o baterías, considerando [...] si es la muralla fábrica nueva, por ser más fácil de batir; si ay espacio en lo que se bate de un torreón a otro o baluarte para hazer batería por donde puedan entrar ocho o nueve soldados por hilera, la qual estiman por buena, si bien en los assaltos no se arremete en hilera, se tiene por gran batería la de semejante distancia. // Rojas, Teórica fortificación, 1598, fol. 38r: Siendo una plaça recogida de quatro o cinco valuartes y que no tenga más de hasta mil soldados de guarnición, digo que es mucho más fuerte y a propósito una estrada de hasta 12 ó 15 pies de ancho, porque en estos quinze pies de ancho pueden yr cinco soldados en hilera.

hilera, V. en .

hombre, hombre, honbre, ombre, onbre [del lat. hŏmo, -inis 'íd.' (DECH). Ortega, Conpusición Arismética y Geometría, 1512]. sust. Persona que pertenece al ejército o que está especializada en hacer la guerra. 
Ortega, Conpusición Arismética y Geometría, 1512, fol. 112v: El Rey, nuestro Señor, tiene en una capitanía 50 hombres de armes, y 100 ginetes, y 200 peones y 150 espingarderos [...]. Y manda a sus contadores o pagadores que les repartan estos 15000 ducados a toda esta gente, en tal manera que den cada suerte de hombre según su estado y según lo que gana. // Álaba, Perfeto capitán, 1590, fol. 1v: Y Epaminundas, capitán de los tebanos, por el cuydado que tuvo en exercitar su campo en todas las diciplinas necessarias para componer un perfeto soldado, con solos quatro mil hombres, de los quales no avía más que quatrocientos de a cavallo, venció el exército de los lacedeminios, que tenía veynte y quatro mil hombres de a pie y mil y seyscientos de a cavallo. // Roxas, Sumario milicia, 1607, fol. 63v: Y llebó el Basta a esta conquista doze mil ynfantes y tres mil cavallos, estando aquellos reynos con un exérçito de más de cuarenta mil hombres, les dio la vatalla y los vençió, ganándoles más de treçientas vanderas y veinte pieças de artillería.

SIN.: defensor 3 , guerrero ${ }_{2}$, hombre de (la) guerra, hombre de pelea, hombre de soldadesca, hombre militar, militar ${ }_{2}^{2}$, mílite 1 , soldado.

ENCICL.: Nebr. (1495: s.v. ombre armado de guerra): Miles. itis. // DEA: Hombre que forma parte, como subordinado, de una colectividad, esp. un ejército. // López Vallejo (2008): Soldado que participa en la milicia.

$\sim$ de armas [Ortega, Conpusición Arismética y Geometría, 1512]. cmpt. sintag. Mil. Soldado perteneciente a la caballería pesada, completamente armado, al igual que su caballo.

Ortega, Conpusición Arismética y Geometría, 1512, fol. 112v: Mira quántos ducados ganan los 50 hombres de armas en un año, y allarás que ganan 4000 ducados; y, ansimesmo, fallarás que ganan los ginetes 6000 ducados, y los peones, 6000 ducados, y los espingarderos, 6000 ducados. // García de Palacio, Diálogos militares, 1583, fol. 56r: El officio de los hombres de armas es, resistiendo como un fuerte o bestión, defender de los enemigos su infantería y desbaratar y romper a los contrarios. // García de Palacio, Diálogos militares, 1583, fol. 176r: Y, al tiempo que los enemigos llegavan cerca, abríanse las dos primeras partes por la frente, por donde salían con mucha velocidad los dichos hombres de armas, y asaltavan con grande ímpetu al esquadrón contrario, y los demás acometían y offendían por los costados.

ENCICL.: DRAE (1803): El que iba a la guerra armado llevando coraza, morrión, lanza y demás armas de hierro, así en su persona como en los caballos. // Rubió y Bellvé (18951901): Combatiente a caballo, con armadura por lo regular completa, que en lo antiguo formaba parte de la caballería pesada [...]. El hombre de armas fue el caballo de línea, el combatiente más importante durante el largo período de la Edad Media y parte de la Moderna, en que la caballería tuvo preponderancia sobre la infantería [...]. Examinando textos de diversas épocas, se echa de ver que el hombre de armas fue siempre un combatiente de primera clase, de modo que esta circunstancia, más que el detalle de la armadura, le distinguía de los demás géneros de combatientes que formaban parte de la milicia [...]. Era tal la importancia que se concedió a estas tropas, que cada uno de los hombres de armas llevaba su pequeña escolta y disponía de dos cabalgaduras, una de buena calidad, para combatir, y un rocín para suplir la falta de la primera y transportar 
algunos efectos propios del combatiente. // Montes, Instrucción y regimiento (1537: fol. Vv): "E los hombres d'armas trahen dobladas armas y los cavallos doblados, y su officio es de mayor dignidad que el cavallo ligero, porque son llamados entre los príncipes gente de guerra quando están en su campaña el cuerpo de la cavallería; y éstos, puestos en su escuadrón el día de la batalla, hazen cuerpo, porque está entre ellos la flor de la cavallería, y la fortaleza de una batalla está en ellos". / / García de Palacio, Diálogos militares (1583: fol. 56r-56v): "Deven, pues, los hombres de armas exercitarse en estar a pie mucho tiempo armado y caminar a pie, en subir y descendir de los cavallos a todas manos, sin ayuda ni estribos armados de todas pieças, con sus lanças en las manos. Deven también exercitarse en passar armados grandes ríos, a nado, en correr bien lanças, ayudarse de las espadas y maças, en afrontarse con sus enemigos, en huir, seguir el alcance y demás cosas para que los hombres de armas suelen ser menester en la batalla".

$\sim$ de guerra, o de la guerra [Montes, Instrucción y regimiento, 1537]. cmpt. sintag. Persona que pertenece al ejército o que está especializada en hacer la guerra.

Montes, Instrucción y regimiento, 1537, fol. XVIIIr: Los alcaydes d'ellos han de ser hombres de guerra de buen género, porque el día de la necessidad sabrá cómo se ha de deffender y, si le quisiere fortificar, mejor lo sabrá hazer el alcayde que fuere hombre de guerra, que no otro. // García de Palacio, Diálogos militares, 1583, fol. 59v: Dixo, en el principio de su libro, que los suyços eran más valientes y mejores hombres de guerra, y prudentes y expertos en las cosas de la milicia que los franceses, porque, en tiempo de paz, tratavan de la guerra. // Rojas, Teórica fortificación, 1598, fol. 37v-38r: A esto digo que, si fuesse la fortificación de alguna gran ciudad, donde huviesse diez o 12.000 hombres de guerra, en tal caso parece que se podría sufrir ser la estrada algo ancha, porque estuviessen en ella de ordinario tres o quatro mil hombres guardándola; mas siendo una plaça recogida de quatro o cinco valuartes y que no tenga más de hasta mil soldados de guarnición, digo que es mucho más fuerte y a propósito una estrada de hasta 12 ó 15 pies de ancho.

SIN.: defensor ${ }_{3}$, guerrero, ${ }_{2}$, hombre, hombre de pelea, hombre de soldadesca, hombre militar, militar ${ }_{2}$, mílite $_{1}$, soldado.

ENCICL.: D'Wartelet (1863: s.v. hombre de guerra): Soldado, militar; el que sigue la carrera de las armas.

de pelea [Fernández de Enciso, Suma de Geographía, 1530]. cmpt. sintag. Persona que pertenece al ejército o que está especializada en hacer la guerra.

Fernández de Enciso, Suma de Geographía, 1530, fol. Lv: En el tiempo que Scipión la conquistó tenía Cartago setecientos lugares que le obedecían, en los quales avía trezientos mill hombres de pelea, pero todavía los destruyó e tomó Scipión, y quedó aquella vez quasi desierta. // Álaba, Perfeto capitán, 1590, fol. 66v: De donde vinieron los romanos, gente tan señalada en la diciplina militar, a juzgar por más útiles los exércitos pequeños de soldados esperimentados y exercitados en el trato de las armas que los que tenían muchos millares de hombres de pelea faltos d'este adorno. // Mosquera, Comentario disciplina militar, 1596, fol. 31r: Y resolviéronse en dezir que estava la isla muy fortificada y que avía en ella siete mil hombres de pelea y se esperava de Olona un gran socorro por momentos. 
SIN.: defensor, guerrero ${ }_{2}$, hombre, hombre de (la) guerra, hombre de soldadesca, hombre militar, militar $_{2}^{2}$, mílite 1 , soldado.

ENCICL.: Aut. (s.v. gente u hombre de pelea): Se llaman los soldados, a distinción de los gastadores y vivanderos. // Borreguero Beltrán (2000): Soldado que sirve en la milicia.

$\sim$ de socorro [Mosquera, Comentario disciplina militar, 1596]. cmpt. sintag. Mil. Soldado que acude en auxilio de otro u otros.

Mosquera, Comentario disciplina militar, 1596, fol. 30v: Que la gente de la isla está en determinación de defenderse, que esperan de Francia mil hombres de socorro y que todos los pagamentos se hazen a los franceses cada veynte y ocho días del mes y, en no pagándoles, se amotinan. // Rojas, Teórica fortificación, 1598, fol. 71r: Y assí, trataré aora de poner una plaça en toda defensa, considerando que siempre voy hablando de un castillo de 5 valuartes, que tenga dentro 1.000 soldados de guarnición ordinaria, y que, junto con esto, se ha de entender ser plaça capaz de otros 2.000 hombres de socorro a una grande necessidad.

de soldadesca [Loçano, Alberto, Architectura, 1582]. cmpt. sintag. Persona que pertenece al ejército o que está especializada en hacer la guerra.

Loçano, Alberto, Architectura, 1582, pág. 154: De manera que podéys entender que usaron de hogares movibles de hierro y cobre, según requería la dignidad de cada cosa, y aun aquel género de hombres de soldadesca, con la guerra, assí como todos estavan juntos, aún no usavan del hogar, y aun los médicos no permiten que de ordinario usemos de mucho fuego.

SIN.: defensor ${ }_{3}$, guerrero ${ }_{2}$, hombre, hombre de (la) guerra, hombre de pelea, hombre militar, militar ${ }_{2}$, mílite, soldado.

militar [García de Palacio, Diálogos militares, 1583]. cmpt. sintag. Persona que pertenece al ejército o que está especializada en hacer la guerra.

García de Palacio, Diálogos militares, 1583, fol. 46r: Es también nescessario que los soldados sean castos y templados, que, demás de ser cosa tan agradable a Dios, los vicios contrarios les estragan la virtud natural y debilitan, enflaquescen las fuerças y se hazen inútiles para exercitar las armas, suffir la hambre, sed, sol, frío, polvo y demás travajos que consigo trae y accarrea la guerra. $Y$, assí, en nuestros tiempos, hemos visto muchos hombres militares que, por el excesso que en este vicio han tenido, se han tullido con bubas e males.

SIN.: defensor, guerrero ${ }_{2}$, hombre, hombre de (la) guerra, hombre de pelea, hombre de soldadesca, militar $_{2}^{2}$, mílite 1 , soldado.

ENCICL.: López Vallejo (2008): Soldado u hombre que participa en la guerra o profesa la carrera de las armas. 
homenaje, V. roca de $\sim$.

homenaje, V. torre de(l) .

honbre, V. hombre.

horden, V. orden.

hordenança, V. ordenanza.

hordenanza, V. ordenanza.

hornillo, hornillo, ornillo [de horno. 1570, C. de las Casas (DECH). Collado, Plática Artillería, 1592]. sust. Fort. Concavidad o hueco que se abre en el final de la mina, donde se mete la pólvora u otra materia explosiva con la que se pretende volar una fortificación.

Collado, Plática Artillería, 1592, fol. 62v: La quarta causa que hará faltar el intento de la mina es quando, por haver anticipado el tiempo de meter la pólvora dentro del hornillo de la mina, aquélla será tornada húmida, de manera que, o no toma fuego, o pierde de la potencia que antes tenía. // Collado, Plática Artillería, 1592, fol. 64v: Haviendo, pues, llegado al punto G, el qual es el pie de la muralla, allí conviene de pararse con la mina y allí se ha de formar el hornillo para meter la pólvora. // Ufano, Tratado de la Artillería, 1613, pág. 168: Más, se proveerá de 1.500 gabiones y otros tantos çarços de mimbres y ramage, con 200.000 faxinas y una grande quantidad de árboles grandes y pequeños para fabricar los bancos y trabeses y armar el aforramiento de las minas; con 1.500 tablas de pino para el uso de las minas, galerías y entablamientos de los hornillos.

SIN.: horno, mina $_{2}$.

FAM.: horno.

ENCICL.: Estévanez (1897): Cámara o hueco de la mina donde se pone la carga. // Sanz (1749: hornillo o recámara de mina): Su construcción consiste en perfeccionarle cuadrado, a la manera de un dado o cubo, de la longitud, latitud y profundidad que se necesita para contener la pólvora con que se ha de volar la mina. La carga de un hornillo no se puede determinar hasta tener conocimiento del espesor, calidad y naturaleza del terreno o muralla que se quiere hacer saltar; y esto se averigua regularmente en el acto práctico de una mina, en donde se hace el cálculo de la pólvora que le corresponde. 
2 [Rojas, Teórica fortificación, 1598]. sust. Fort. Hueco practicado en el espesor de una muralla, donde se pone una materia explosiva para volar y arruinar esa fortificación.

Rojas, Teórica fortificación, 1598, fol. 74v: Y como el enemigo viesse tanta resistencia en los cubos redondos, descubrieron la çapa, que es el pico y el açada, y llegados a la muralla, levantavan una manta de maderos, y por ser redondo el torreón se encubrían en la circunferencia d'él sin que pudiessen ser ofendidos de los traveses, y assí con seguridad picavan la muralla y hazían el hornillo y la volavan. // González de Medina, Examen fortificación, 1599, pág. 14: La quadrángula tampoco la tengo por muy buena, porque salen también muy agudos los ángulos de los baluartes que sobre ángulos rectos se pueden hazer; y tiene el mesmo inconveniente de cortarlos fácilmente y encubrirse en ellos el enemigo (como queda dicho) y valerse del pico y el açada hazer ornillos y cortaduras y todo lo que quisiere. // Roxas, Sumario milicia, 1607, fol. 103v: Y estando ya el foso çiego y hecho ya en él un dique de quarenta o çinqüenta pies de ancho, se yrá haçiendo ençima un trincherón muy grueso, que tenga 20 pies de groseça, para resistir el artillería que le tiraren de la casamata; y llegado al baluarte, se le abrirá el hornillo o mina, como se suele hazer.

SIN.: mina $_{3}$.

ENCICL.: Terr.: Se llama en la milicia una especie de mina pequeña, en forma de pozo, para hacer saltar alguna obra.

3 [Collado, Plática Artillería, 1592]. sust. Art. Caja de madera llena de pólvora, bombas o explosivos semejantes.

Collado, Plática Artillería, 1592, fol. 62v: Quando el maestro de la mina, por ignorar quánta es la grosseza de la muralla, lo que en tal tiempo mal se atina, no hoviesse plantado el hornillo en el centro d'ella, sino más hazia la una parte o hazia la otra; que, siendo en esta manera, siempre rebentará, como dicho es, por la parte más flaca. // Rojas, Teórica fortificación, 1598, fol. 73r-73v: Y fuera d'esto, ha de tener el dicho rebellín un hornillo secreto dentro de sí, para quando el enemigo se pusiesse encima bolarle a él y al rebellín, de suerte que le pessasse mucho de estar allí.

ENCICL.: Aut.: También se llama así un cajón que entierran debajo de alguno de los trabajos, y está lleno de pólvora o bombas, a que se pega fuego cuando el enemigo se ha hecho dueño del sitio adonde está el cajón enterrado.

horno, forno, horno, orno [del lat. fürnus 'íd.'. Forno, doc. de 1129 (Oelschl.); Berceo; Fn. Gonz., etc. (DECH). Montes, Instrucción y regimiento, 1537]. sust. Fort. Concavidad o hueco que se abre en el final de la mina, donde se mete la pólvora $u$ otra materia explosiva con la que se pretende volar una fortificación.

Montes, Instrucción y regimiento, 1537, fol. XIXr: Si la tierra es arzilla, o greda, o arenosa, puédese hazer la mina; mas en el hazer del horno debaxo del centro del torreón es menester que lo haga el ingeniero, porque otro ninguno no lo acertaría, por no saber dar la 
orden del meter de la pólvora y del cerrar del horno e si la tierra es sufficiente para suffrir la mina, porque, si después de hecho el horno quedasse algún espiradero no podría haver effecto la mina. / Collado, Plática Artillería, 1592, fol. 65r: Haviendo llegado el artífice de la mina al lugar donde ha de formar el horno y encerrar la pólvora, aun ésta es cosa de mucha consideración digna, por quanto o él pretende de bolar muralla para que por aquella rotura su gente con assalto se pueda meter en la fortaleza de el enemigo, o él pretende, bolando la mina, matar la gente que está sobre el terrapleno a la defensa. // Ufano, Tratado de la Artillería, 1613, pág. 262: Guiará la manga de su mina como paresçe en la presente figura, dende el punto de la letra A a la letra B y de la B hasta, con la buelta que va dando, llegar a la letra $C$, donde, con mucho artiffiçio y orden muy çerrado y fuerte, armará el horno de la mina con los toneles de pólvora que bastaren y el ordenado fuego a tiempo que toda la gente d'ella y los çercanos puestos estén en salvo.

SIN.: hornillo 1, mina $_{2}$.

FAM.: hornillo. 
ilada, V. hilada.

ilera, V. hilera.

imbencible, $V$. invencible.

imbençible, $V$. invencible.

imbicto, V. invicto.

impressa, V. empresa.

incursión, incursión [tomado del lat. incurš̄ō, -ōnis 'incursión, invasión, correría, irrupción', de incŭrrō. 1640 (Segura Munguía 2007). Escalante, Discurso de la navegación, 1577]. sust. Mil. Acción de recorrer un territorio con el fin de arrasarlo y de saquearlo.

Escalante, Discurso de la navegación, 1577, fol. 63v: [...] una carta de geografía hecha por los mesmos chinas, a do venía señalado un muro que comiença de la ciudad de Ochioy, que es 
puesta entre dos altíssimas sierras, casi como passo y puerta de aquella región que discurre en quarenta y tres a quarenta y cinco grados dende Poniente a Levante, hasta topar con otra gran serranía, que está beviendo en aquel mar Oriental a manera de cabo, cuya largura parece ser de más de dozientas leguas, el qual mandaron fabricar los reyes passados para defenderse de las incursiones de los tártaros, sus capitales enemigos. // Escalante, Discurso de la navegación, 1577, fol. 86r: Esto se haze con comodidad respeto de que en todas las laderas d'él ay muchas poblaciones grandes $\mathrm{y}$, con tener centinelas puestas que les dan rebato, acuden todos a la defensa quando se ofrece necessidad, hasta que llegue el rei con su exército grande, que tiene de ordinario de mucha gente de a pie y de a cavallo para su guarda y magestad, y para refrenar las incursiones de los enemigos.

SIN.: correduría, correría, corrida.

ENCICL.: Moretti (1828): Lo mismo que correría (Véase). // DUE: Mil. Penetración de fuerzas armadas en un territorio en son de guerra.

inespunable, $\mathrm{V}$. inexpugnable.

inexpugnable, inespunable, inexpugnable, ynespugnable, ynspugnable [tomado del lat. ǐnexpugnābŭlis, e 'imprenable', 'invincible' (fig.), 'impénétrable', 'qu'on ne peut arracher'. (Gaffiot 1934). Escalante, Discurso de la navegación, 1577]. adj. Fort. Dicho de un lugar fortificado: que no se puede expugnar o es muy difícil hacerlo.

Álaba, Perfeto capitán, 1590, fol. 86r: Y no sería menos inexpugnable que las fuerças fuertes por naturaleza donde la artillería y assaltos no pueden hazer sus efetos, como son algunos castillos roqueros de gran altura y los lugares edificados entre lagunales y tremedales, o cercados de mar o de algún gran río hondo. // Álaba, Perfeto capitán, 1590, fol. 256v: Y aunque la traça de las minas en estos tiempos es la mesma que en los passados, los efetos son de mayor importancia, por la violencia notable con que los materiales que en ellas se ponen desbaratan y asuelan qualquier lienço de muro o fortaleza, por fuerte y inexpugnable que parezca. // Roxas, Sumario milicia, 1607, fol. 44r: Las ciudades y castillos se fortifican, o de la misma naturaleza o por obra de manos, o por lo uno o lo otro, qual es lo más seguro. Por naturaleza sería como si estubiese en un lugar eminente de peña tajada o estando cercados de mar, ríos, lagunas. Por manos será con fosos y murallas; en lo primero se tomará consejo más siguro, porque en el llano se requiere la yndustria y maña del fundador, y bemos ciudades muy antiguas en campos abiertos que, con faltarles el ayuda natural del sitio, con todo, con el arte y la obra se han hecho ynespugnables.

SIN.: inexpuñable.

ANT.: expugnable.

FAM.: inexpuñable. 
ENCICL.: Aut.: Lo que no se puede rendir, batir o expugnar. Se aplica regularmente a las plazas o fortalezas. // Sanz (1749): Es una plaza, castillo o puesto que además de estar situado ventajosamente, tiene sus obras tan perfectamente construidas que no se puede tomar por ataques formales, sorpresas ni otro modo, teniendo lo necesario para la subsistencia de la guarnición.

2 [Loçano, Alberto, Architectura, 1582]. adj. Mil. Dicho de una persona o de un grupo de personas: que no se deja vencer ni persuadir.

Loçano, Alberto, Architectura, 1582, pág. 122: Eurípides piensa ser muy fuerte adversario la muchedumbre por su natura, y que ésta se haze del todo inexpugnable si ajuntare la astucia y engaño contra uno. // Álaba, Perfeto capitán, 1590, fol. 62v: Fue traça y astucia muy aprovada por muchos esforçados capitanes de diversas naciones mostrar abundancia de vituallas y mantenimientos, por mucha que fuesse la falta que d'ellos tuviessen; y también el ser gente que se sabría sustentar comiendo muchas cosas de las que nadie acostumbra a comer, porque d'esto venían a cobrar opinión de inexpugnables y de hombres de estraordinario vigor y fortaleza y a poner miedo y espanto a sus contrarios. / / Álaba, Perfeto capitán, 1590, fol. 133r: Y, aviéndose amparado d'este modo, pondrá en la vanguardia los soldados más valientes y animosos y, si los tuviere de diversas naciones, aprovecharse a de todas ellas en la vanguardia, assí porque la competencia les obligue a señalarse más como porque, no lo haziendo, el verse estimar en poco no les haga usar de algún trato falso, aunque algunos tienen por mejor que toda la vanguardia sea de gente de una mesma nación y que tengan particular amistad, pareciéndoles que ésta los haría inexpugnables.

inexpuñable, ynspuñable [del lat. ı̌nexpugnäbĭlis, e 'imprenable', "invincible' (fig.), 'impénétrable', 'qu'on ne peut arracher'. (Gaffiot 1934). Ufano, Tratado de la Artillería, 1613]. adj. Fort. Dicho de un lugar fortificado: que no se puede expugnar o es muy difícil hacerlo.

Ufano, Tratado de la Artillería, 1613, pág. 120: Después hablaremos más largamente en cómo se deve governar el dicho general durante el sitio de una plaça por ynspuñable que sea.

SIN.: inexpugnable 1.

ANT.: expugnable.

FAM.: inexpugnable.

infante, infante, ynfante [del lat. infans, -tis, 'incapaz de hablar', 'niño de mantillas, niño pequeño', derivado de fari 'hablar'. La ac. 'soldado de infantería' se tomó del it. fante, que además de 'muchacho, mozo' significaba 'servidor, criado' y de ahí pasó al significado militar. Ifant(e), Cid; infante, doc. de 1198. La ac. de 
'soldado de infantería' aparece h. 1550, D. Gracián (DECH). Montes, Instrucción y regimiento, 1537]. sust. Mil. Soldado que sirve, marcha y combate a pie.

Montes, Instrucción y regimiento, 1537, fol. Xr-Xv: Assimesmo, son buenas armas arcabuzes y escopetas para hazer la guerra, y si en el campo hoviere treynta mil infantes, los siete mil sean arcabuzeros; y si fueren quinze mil, los quatro mil bastan que sean arcabuzeros. // García de Palacio, Diálogos militares, 1583, fol. 181v-182r: Siendo, pues, regla cierta que todo infante toma la orden de su caminar del que marcha delante y los infantes que se hallaren en aquella mesma hilera deven, viendo al compañero que va delante caýdo, passar a su lugar, apresurado su movimiento, y el otro, al otro, de forma que la falta o vazío quede en la rectaguardia, como quedó referido en el citado lugar que hazían los griegos. // Ufano, Tratado de la Artillería, 1613, pág. 75: Comencemos a tratar ahora, Señor Capitán, enteramente de todo aquello que será nesçessario aperçevir para salir en campaña con treinta pieças de artillería, haziendo qüenta que el exército tenga complidamente quarenta mill hombres de guerra, y los treinta quatro mil ynfantes y los seis mil de a caballo.

SIN.: peón.

ENCICL.: Cov.: En la milicia llaman infantes los soldados que pelean a pie, y son gente lúcida y determinada [...]. Tuvo origen de los romanos porque repartían la gente de a pie en tres clases: la primera era de los astarios, como si dijésemos ahora de los piqueros; la segunda de los príncipes, éstos eran soldados viejos, hombres nobles y principales, de donde tomaron el nombre; la tercera era de los triarios, que guardaban la persona del emperador y no peleaban sino en caso de mucha necesidad. Pues de haber llamado a los de la segunda orden príncipes resultó llamar en la nueva milicia infantes a los que pelean en la primera clase, y quizá por ser más jóvenes, e infantería sus escuadrones. / / Como puede verse, Covarrubias intenta explicar la denominación de infante que reciben los soldados de a pie a partir del sentido recto y etimológico de la voz latina infans, antis, de la que deriva. No obstante, como bien se sabe, el sentido de infante de 'soldado de a pie' se imitó del italiano fante.

$\sim$ perdido [García de Palacio, Diálogos militares, 1583]. cmpt. sintag. u. m. en pl. Mil. Soldado que, aunque combate a pie, se desplaza a caballo, y que participa en la formación del escuadrón falso.

García de Palacio, Diálogos militares, 1583, fol. 164v: Pónense, pues, estos infantes perdidos o órdenes falsas, para que, yendo assí encubiertos, un poco antes de calar las picas, saliendo por los costados con sus picas arboladas, las echen tendidas sobre las picas caladas de los contrarios, de que pueden los enemigos rescebir gran daño. // García de Palacio, Diálogos militares, 1583, fol. 164v: Conviene, pues, para hazer el effecto necessario, sean los tales infantes perdidos fuertes, sueltos y diestros, animosos y acostumbrados a pelear bien. // Álaba, Perfeto capitán, 1590, fol. 131r: Y assí, la artillería pequeña es la que más puede ofender, y para prevenir su ofensa el remedio que yo hallo mejor es envestirla con presteza, señalando para este acometimiento algunos infantes perdidos y algunos arcabuzeros a los lados del esquadrón, y otro número de arcabuzeros de a cavallo y estradiotes, porque el esquadrón principal no se desordene y desbarate envistiendo de tropel. 
ENCICL.: Albi de la Cuesta (2005: 115): "Una última especialidad a la que hay que hacer referencia, aunque realmente se trataba de un Arma mixta, a medio camino entre la caballería y la infantería, era la formada por hombres que se desplazaban montados en el campo de batalla pero que combatían a pie. Los españoles destacan como una gran novedad a este tipo de soldados, que encontraron por primera vez en las campañas de Francia de fines del XVI, bajo el nombre de dragones, y a los que describieron como «mosqueteros en rocines». No obstante, se muestran poco impresionados, tan poco como los propios franceses que les llamaban «enfants perdus»".

de s [García de Palacio, Diálogos militares, 1583]. loc. adj. Mil. Dicho del orden de batalla cuadrado: con el número de soldados de frente exactamente igual al de los de fondo.

García de Palacio, Diálogos militares, 1583, fol. 160v: ¿En qué forma se puede ordenar una batalla quadrada de suelo y no de infantes?

SIN.: de gente.

ANT.: de suelo, de(l) terreno.

infante, $V$. de $\sim$ s.

infantería, infantería, ynfantería [del it. fanterìa 'l'insieme delle truppe composte dai soldati che procedono e combattono a piedi'. Fanteria en it. c. 1362 (Cronaca Sen.). También existió la forma infanterìa. En cast., infantería, 1605, Quijote (TLIO). Montes, Instrucción y regimiento, 1537]. sust. Mil. Conjunto de soldados destinados a servir, desplazarse y combatir a pie. (fig. 102)

Montes, Instrucción y regimiento, 1537, fol. XIIIr: A los primeros encuentros no pelean sino las diez hileras primeras $y$, si aquéllas se rompen, es roto el exército, porque siempre se ha visto, rompidas las primeras hileras, ser roto el exército, si no fue en Rávena, que allí, después de rota la infantería española, se tornó a rehazer y rompió la gente d'armas francesa, y mataron su capitán general, que era mossiur de Fox, con toda la cavallería de Francia, por la mucha bondad y fortaleza de la infantería española. / García de Palacio, Diálogos militares, 1583, fol. 54v: Y, quando los de a cavallo vencían y rompían los cavallos enemigos, se apeavan a ayudar a su infantería. // Roxas, Sumario milicia, 1607, fol. 19v20r: Los campos i begas son apropiados para las cavallerías, y los mares i ríos para las armadas, y los çerros y las çiudades y despeñaderos para ynfantería; de donde se entiende que la ynfantería es más neçesaria para la república como aquélla que puede servir en todas partes, y mayor número de ynfantería se sustenta con menos gasto.

ENCICL.: Aut.: La tropa que sirve a pie en la milicia, que ahora es casi siempre la mayor parte del ejército. // D'Wartelet (1863): Conjunto de soldados que marchan y combaten a pie [...]. De todas las armas la infantería es la primera que se forma y se organiza con 
menos gastos y con utilidad casi inmediata. La mejor es la que tiene cuadros escogidos y mayor número de soldados antiguos o veteranos [...]. En la antigüedad y también en la Edad Media formó con gran fondo y en masas compactas, pero con el descubrimiento y uso de las armas de fuego no necesitó ya de tanta profundidad para resistir a la caballería, su enemigo más temible. Los encuentros al arma blanca se hicieron menos frecuentes y, entonces, la infantería comenzó a adoptar el menor fondo en sus filas y se constituyó otra vez como en el tiempo de los griegos y de los romanos en el arma principal, por cuya razón todas las naciones se apresuraron a tener una infantería numerosa [...]. En sus principios la infantería entraba en batalla en desorden, sin más táctica que lanzarse al enemigo, sin guardar orden ni formación alguna. Los griegos dieron el ejemplo de atacar y defenderse por medio de movimientos combinados. Presentaron una gran masa de peones formada de 100 hombres de frente y 16 de fondo, y esto era la famosa falange [...]. Los romanos, que adoptaron en todos los ramos, y particularmente en la milicia, las instituciones de los griegos y aun de los pueblos bárbaros que sometieron o declararon por aliados suyos, prefirieron siempre la infantería [...]. La legión fue su unidad de combate, con ella vencieron a la falange, derrotaron a todos sus enemigos y conquistaron una gran parte del mundo [...]. Durante la Edad Media la infantería no tenía prestigio alguno. Compuesta de la clase humilde del pueblo, mal equipada y armada, y combatiendo en tropeles, fue despreciada por los orgullosos barones que combatían a caballo, y cubiertos de hierro de pies a cabeza, que les hacía invulnerables. Los peones, al fin, recobraron su importancia. Los suizos restablecieron su honor venciendo a los caballeros de la casa de Austria y a los borgoñeses de Carlos el Temerario [...]. // Estévanez (1897): Una de las armas generales, el arma principal, el núcleo de los ejércitos. Ha merecido el nombre de reina de las batallas, y es la única arma que se basta a sí misma. En España se la distingue por la valerosa, y es que, en efecto, la valerosa infantería ha dado al ejército español y a España bastante gloria para oscurecer la de todos los ejércitos de todos los siglos en todas las naciones y en todos los continentes.

ingeniero, ingeniero, injeniero, yngeniero, ynjeniero [de ingenio, aunque probablemente a imitación del it. ingegnere (2. ${ }^{a}$ mitad del s. XIII). Engeñero, Nebr., derivado de engeño 'máquina de guerra'; engeniero en doc. guadalajareño de 1496, BHisp.; ingeniero 1585, Fr. L. de León; Lz. de Arenas (DECH). Montes, Instrucción y regimiento, 1537]. sust. Persona que profesa o ejerce la arquitectura militar o fortificación.

Montes, Instrucción y regimiento, 1537, fol. XIXr: Y en el hazer de la mina, si la tierra es pantanosa y manantial, no se podría hazer minas; mas si la tierra es arzilla, o greda, o arenosa, puédese hazer la mina; mas en el hazer del horno debaxo del centro del torreón es menester que lo haga el ingeniero, porque otro ninguno no lo acertaría, por no saber dar la orden del meter de la pólvora y del cerrar del horno e si la tierra es sufficiente para suffrir la mina. // Mendoça, Theórica y práctica, 1596, pág. 125-126: Assimismo se ha de advertir si la plaça está fortificada, siendo frontera, o se ha de fortificar de nuevo y en qué manera ha de ser, governándose en esto, según el tiempo que diere el enemigo para ello, con ingenieros y personas que sepan qué es fortificación. // Roxas, Sumario milicia, 1607, fol. 103v: Y estando ya pegados con el foso, se procurará de cegarlo, y si tubiere mucha cantidad de agua y no se pudiere sangrar, se le echarán dentro mucha cantidad de 
salchichas de piedra seca y maderos, como ya el yngeniero lo sabrá haçer, $\mathrm{y}$, a bueltas de ello, mucha fajina y tierra.

SIN.: fortificador, ingeniero militar.

FAM.: ingenio.

ENCICL.: Terr. (s.v. injeniero): El que fortifica las plazas, dispone las líneas de ataques, hace las minas, etc. [...]. De aquí llaman también ingeniero al que inventa algún ingenio o máquina. // Teniendo en cuenta este último comentario de Terr., es fácilmente comprensible el siguiente ejemplo de Herrera, Institución Academia (1584: fol. 2v): "Que aya [...] ingenieros y machinistas entendidos en la arte de los pesos, fundamento para hazer y entender todo género de máchinas de que la vida política y económica se sirve". // Estévanez (1897): Antes de que existiera el cuerpo facultativo actual hubo siempre ingenieros al servicio del Ejército, singularmente italianos (de las provincias de Italia que eran españolas). // Collado, Plática Artillería (1592: fol. 95v): "Digo, señor [...] que los ingenieros, por la mayor parte, son estrangeros y que muchos sirven hoy en nuestro campo y, por una mínima occasión, se passarán mañana a servir al otro, lo que no pocas vezes se ha visto". // Fernández Mancheño (1822): Su nombre [ingeniero] indica la habilidad y talento que debe tener, que no consigue sin el constante estudio de varias ciencias por espacio de muchos años [...]. Un ingeniero debe ser inteligente en el arte de trazar toda especie de obras de fortificación, debe conocer la fuerza y defectos de una plaza de guerra y facilitar el ataque y defensa de toda suerte de puestos. Las ciencias más principales que debe poseer con perfección son la geometría práctica y especulativa, aritmética, arquitectura [...], carpintería, geografía, maquinaria y perspectiva. // Rojas, Teórica fortificación (1598: fol. 1r-1v): "Tres cosas han de concurrir en el soldado o ingeniero que perfetamente quiere tratar la materia de Fortificación. La primera, saber mucha parte de Matemáticas, si fuere possible, los seis primeros libros de Euclides y el undécimo y duodécimo, porque con ellos absolverá todas las dudas que se le ofrecieren [...]. La segunda es la Arismética [...] para muchas cosas que en el discurso d'este libro se verán. La tercera y más principal para la Fortificación es saber reconocer bien el puesto donde se ha de hazer la fortaleza o castillo. Será difícil saberlo dar a entender y enseñar al ingeniero, si no huviere estado en la guerra en ocasiones, y cerca la persona de algún gran soldado".

$\sim$ militar [Roxas, Sumario milicia, 1607]. cmpt. sintag. Persona que profesa o ejerce la arquitectura militar o fortificación.

Roxas, Sumario milicia, 1607, fol. 23r-23v: Y demás del perfecto dicho de la lejión avía otro perfeto de los reales, aunque era en dignidad inferior, mas siempre se ocupava en cosas no medianas, al qual perteneçia el asentar el campo i çercarlo con trincheras, y asentar y repartir el alojamiento, que era como aora en este tiempo el yngeniero militar. / / Roxas, Sumario milicia, 1607, fol. 71r: Reglas de la fortificaçion moderna, con sus medidas, reales y no reales. Por el capitan Christóval de Rojas, Ingeniero Militar de su Magestad. / / Rojas, Compendio fortificación, 1613, IIr: Por parte de vos, el capitán Christóval de Rojas, Ingeniero Militar, nos fue fecha relación que el año passado de noventa y ocho os avíamos dado licencia para imprimir un libro de fortificación, y aora avíades hecho otro nuevo conforme a estos tiempos presentes. 
SIN.: fortificador, ingeniero.

ENCICL.: Rubió y Bellvé (1895-1901): Cuanto a la profesión del ingeniero militar, hombre de ciencia que presta a los empeños de la guerra el fruto de sus conocimientos, es tan antigua como esta misma guerra, tan antigua como la "Fortificación", de origen prehistórico [...]. El carácter científico del ingeniero militar se ha reconocido en todas las épocas, por haber huido de la rutina, por haber empleado los medios más apropiados a cada ocasión y lugar para obtener los fines de la lucha.

ingenio, engenio, enxenio, ingenio, yngenio [tomado del lat. ĭngĕnium 'cualidades innatas de alguien'. Ingenio "es fuerça interior del ánimo con que muchas veces inventamos lo que de otri no aprendimos", APal; ingenio "fuerza natural", Nebr. Y engeño en el sentido de 'máquina de guerra' en el Conde Luc. (DECH). Álaba, Perfeto capitán, 1590]. sust. Mil. ant. Cualquier artefacto o máquina empleado en la guerra para ofender o defenderse.

Álaba, Perfeto capitán, 1590, XIIIr: Admirado el Cónsul de la resistencia de solo un hombre y del admirable ingenio con que abatía su poder, mandó por público pregón a su gente que, quando se entrasse la ciudad, nadie ofendiesse a Arquímedes y, como un soldado, o por no conocerle o por vengarse d'él, le matasse, le castigó. // Mosquera, Comentario disciplina militar, 1596, fol. 10r: El Maestre de Campo General, don Francisco Arias de Bobadilla [...], es el que más en particular ha escrito d'este cargo en nuestra lengua; demás de otros que escrivieron de formar esquadrones, de diversos estratagemas, de leyes de guerra, de artillería y artificios de fuego, de armas, fortificaciones, ingenios y máquinas. // Roxas, Sumario milicia, 1607, fol. 45v: Fuera d'esto, la gente que llebava escalas para subir a los muros, ay otros yngenios con que se combaten, conbiene a saber: testúdines, arietes, hoçes, bíneas, plúteos, músculos y torres.

FAM.: ingeniero.

ENCICL.: D'Wartelet (1863): Epíteto que antiguamente se daba a toda clase de máquinas de guerra que se empleaban en ofender y defender, como la balista, catapulta, ariete, etc.

injeniero, V. ingeniero.

interpresa, antepresa, entrepresa, ynterpresa [del fr. entreprise. Interpresa, término militar. s. XVII (Aut.) (DECH). Ufano, Tratado de la Artillería, 1613]. sust. Mil. Combate o cualquier otra operación militar llevada a cabo en una guerra.

Ufano, Tratado de la Artillería, 1613, pág. 73: Siempre que el exérçito sale en campaña, hora sea por occasión de alguna preçisa ynterpresa, o bien por bien aquartelarse, lleva a su cargo el general del artillería la una partida y, en ausençia del generalíssimo, lo he visto siempre governar el exérçito. // Ufano, Tratado de la Artillería, 1613, pág. 198: Tal diligençia se haze a fin de abreviar el tiempo de la execución de la empresa y no dar lugar 
a que los de adentro se pongan bien y fortifiquen de manera que con algún poco de socorro y alargaçión no se entretenga tal plaça y sea de ningún fruto y valor la entrepresa. // Ufano, Tratado de la Artillería, 1613, pág. 221: Para una entrepresa como esa, Señor, según y como Vuestra Señoría lo signiffica, no se a de hazer qüenta de llevar más de 6 medios cañones y 4 quartos de cañón con 6 pieças de campaña, que cada una tire 6 libras de bala de hierro, y lo que de pólvora y balas será menester para ellas.

SIN.: empresa, empresa de (la) guerra, empresa militar, encuentro ${ }_{1}$ facción ${ }_{2}$, facción de guerra, hecho de armas, reencuentro ${ }_{1}$.

ENCICL.: D'Wartelet (1863): Empresa militar.

2 [Lechuga, Discurso de la Artillería, 1611]. sust. Fort. Ataque impetuoso y decisivo contra un lugar fortificado para entrar y apoderarse de él. (fig. 103)

Lechuga, Discurso de la Artillería, 1611, pág. 270: Dizen, assimismo, algunos que la fuerça que tiene el fosso con agua está más segura de escaladas, entrepresas y accidentes repentinos, y de traiciones hechas por los de dentro. // Ufano, Tratado de la Artillería, 1613, pág. 267: Capítulo que trata de cómo se deve armar un puente sobre una barca para haçer una entrepresa. // Ufano, Tratado de la Artillería, 1613, pág. 269: Al qual puente abono y tengo por muy bueno para tales ocasiones, porque dende la propria barca, estando la villa o fuerte sobre el río, como se a dicho, se puede acostar la barca a ella prestamente y hazer la entrepresa que se quiere, a pessar de los enemigos que por las tales partes uviesse, viniendo al abrigo d'ella de socorro por la otra parte el exérçito o parte de gente de guerra diputada para tal effeto con algunas pieças de artillería.

SIN.: asalto 2.

invencible, imbencible, imbençible, invencible, invençible, ynbensible, ynvincible [de vencible y éste de vencer. Santillana; 1588, armada contra Inglaterra (DECH). Montes, Instrucción y regimiento, 1537]. adj. Mil. Dicho de una persona o de una colectividad: que no se puede vencer o derrotar.

Montes, Instrucción y regimiento, 1537, fol. IIr: En algunos lugares principales hallaron algunas antiguallas debuxadas de vulto y otras de pintura, en las quales manifiestamente parescía y se mostravan los grandes hechos que los invencibles cavalleros de las dichas provincias naturales havían hecho por las armas. // Álaba, Perfeto capitán, 1590, fol. 20v: Y de tal manera los exercitava en todas las obras que el que no veía manchado con sangre del enemigo quería que haziendo fosas y otros exercicios del campo anduviesse mojado con barro y, assí, los hizo casi del todo invencibles. // Roxas, Sumario milicia, 1607, fol. 24v: Alguno que tenga deseo de bençer en batalla aplaçada a los bárbaros, procure con todas sus fuerças que las lejiones tengan sus prinçipios de los tirones nuevos, para que por la boluntad de Dios y por la del emperador buelban a ser imbençibles, porque en brebe tiempo los nuebos, escojidos con cuydado y exerçitándose cada día en toda çiençia de armas o artes de pelear, ygualarán fácilmente a aquellos soldados antiguos que sujetaron todo el mundo. 
FAM.: vencedor, vencer, vencido, vencimiento.

invençible, $V$. invencible.

invicto, imbicto, invicto, invito [tomado del lat. invictus 'no vencido'. 1499, Comend. Griego (DECH). Montes, Instrucción y regimiento, 1537]. adj. Mil. Dicho de una persona: que jamás ha sido vencida o derrotada.

Montes, Instrucción y regimiento, 1537, fol. XIXr: Y, para ello, Dios, que es guiador y criador de todas las cosas, enfunda en la gente christiana tanta gracia y esfuerço, que sean parte para conquistar la tierra que los infieles tienen ocupada, y traherla debaxo de subjeción del invictíssimo César, y ellos vengan en conoscimiento de nuestra santa fe católica. // Collado, Plática Artillería, 1592, fol. 62r: El primero inventor d'ellas fue el conde Pedro Navarro, hombre de summo ingenio en aquel tiempo, tanto que, siendo él un pobre soldado, por la invención de las minas y por las maravillosas cosas que hobró con ellas, meresció ser con honrosa renta y título de conde remunerado de las Magestades del cathólico rey don Fernando y del invicto emperador Carlo Quinto. // Roxas, Sumario milicia, 1607, fol. 21r: Después de aver elejido con diligençia los soldados fuertes i animosos, aviéndose exerçitado cada día por tiempo de quatro meses, por mandado del imbictísimo prínçipe se formava la lejión.

ENCICL.: DUE: Se antepone corrientemente a nombres como "caudillo, general, soldado", como un epíteto elogioso. / / Collado, Plática Artillería (1592: fol. 1r-1v): "¿A qué fin, Real Magestad, vo yo alegando los hechos de tantos héroes estrangeros, teniendo las vidas de vuestro invictíssimo padre Carlos Quinto, Emperador, y la de Vuestra Magestad delante de los ojos, cuyos immortales hechos assí resplandescen entre los de aquéllos nombrados, quanto el mayor planeta entre los otros planetas todos?".

invito, $\mathrm{V}$. invicto.

ir, V. $\sim$ de vencida. 
jente, V. gente.

jinete, ginete [del ár. vg. zenêti (ár. zanātî) 'individuo de Zeneta', tribu bereber que acudió en defensa del reino de Granada en el s. XIII. Jinete significó primeramente 'soldado de a caballo que peleaba con lanza y adarga, y llevaba encogidas las piernas, con estribos cortos'. Cavalleros ginetes, $2 .^{\circ}$ cuarto del s. XIV, Crónica de Alfonso X (DECH). Ortega, Conpusición Arismética y Geometría, 1512]. sust. Mil. Soldado perteneciente a la caballería ligera, el cual lleva estribos cortos y pelea con lanza y adarga.

Ortega, Conpusición Arismética y Geometría, 1512, fol. 112v: El Rey, nuestro Señor, tiene en una capitanía 50 hombres de armes, y 100 ginetes, y 200 peones y 150 espingarderos, en que da de salario a cada un hombre de armas, por un año, 80 ducados, y cada un ginete 60 ducados, y a cada un peón 30 ducados y [a] cada espincardero 40 ducados. // García de Palacio, Diálogos militares, 1583, fol. 54v: Mas en estos nuestros tiempos (según las que se usan), las armas antiguas serían flacas y de poco provecho; las que los hombres de armas, cavallos ligeros, herreruelos y ginetes usan en las guerras y batallas d'estos tiempos son comunes y muy conoscidas, y, ansí, se escusará referillas por menudo. // Mendoça, Theórica y práctica, 1596, pág. 55: Los ginetes, aunque caminan en hileras, se vienen a apiñar como gente suelta al cargar en gruesso.

ENCICL.: Cov. (s.v. ginete): Hombre de a caballo que pelea con lanza y adarga, recogidos los pies con estribos cortos que no bajan de la barriga del caballo. Ésta es propia caballería de alárabes, los cuales vienen desnudos de piernas y brazos, arremangada la manga de la camisa y sin ninguna otra armadura en el cuerpo, con sus turbantes en la cabeza y su 
alfanje o cimitarra colgando del hombro o en el tahalí. / Estévanez (1897): Antiguamente sólo se llamó jinetes a los soldados de caballería ligera que montaban a la jineta como los moriscos. // DRAE (s.v. jineta): Arte de montar a caballo que, según la escuela de este nombre, consiste en llevar los estribos cortos y las piernas dobladas, pero en posición vertical desde la rodilla. Montar a la jineta.

jornada, jornada [del oc. jornada, derivado de jorn 'día', procedente del lat. diŭrnus 'diurno, que ocurre durante el día', adjetivo que en el lat. tardío se sustantivó en el sentido de 'tiempo diurno', por oposición al nocturno. Berceo (DECH). García de Palacio, Diálogos militares, 1583]. sust. Mil. Expedición o viaje que emprende una fuerza militar para llevar a cabo cualquier facción o empresa de guerra en un lugar distante.

García de Palacio, Diálogos militares, 1583, fol. 65v-66r: Nescessaríssima cosa es que el exército sea proveýdo de vituallas, armas, municiones, instrumentos y otras cosas que convengan o ayan de ser menester en la prosecución de la guerra, antes que poner la salud del exército en riesgo y que, por hambre y falta de municiones, se haga inútil y se destruya y pierda, que assí lo hazía César, que todas las jornadas que escrive hizo, proveyéndose primero de todo lo nescessario para ellas. // Álaba, Perfeto capitán, 1590, fol. 27v: Dexado aparte lo que importa que un estado de un rey o señor no esté jamás sin defensa, y más en tiempo de jornadas y empresas, pues es el que los enemigos escogen para hazer con más comodidad sus daños y ofensas, fiados en que con la ausencia de la gente de guerra que en él avía, la resistencia que a su poder se podrá hazer será poca o ninguna. // Collado, Plática Artillería, 1592, fol. 94v: ¿Qué importaría que un general se preparasse para hir en jornada con un sumptuoso apparato de municiones de artillería, gran número de pieças y escogidos artilleros para ponerlas en hobra, gran copia de fuegos artificiales, muchas militares máquinas y otras invenciones, si, llegado después al lugar de la factión del artillería, ni supiesse hazer electión de los sitios ni distinguir de los buenos a los malos?

ENCICL.: DRAE: Expedición militar. // Roxas, Sumario milicia (1607: fol. 65r): "Y así, el rey Filipo Segundo, excarmentado d'esto, quando hubo de yr a Portugal trujo para aquella jornada alemanes e italianos, para que si sus vasallos le desamparasen, los extrangeros le sirbiesen; y así fue que, de más de doce mil bisoños que se hizo leba, no quedaron dentro de dos meses dos mil de ellos".

2 [Álaba, Perfeto capitán, 1590]. sust. Mil. Batalla o combate muy importante o decisivo.

Álaba, Perfeto capitán, 1590, fol. 55v: Y de Cipión se lee que, aviéndose amotinado su gente por falta de vituallas y no pudiendo hazer jornada contra Asdrúbal por causa d'este motín, hizo a los suyos una plática tan eloqüente que con ella quitó sus dissensiones y rebelión, y viniendo a rompimiento contra los cartagineses los desbarató y venció. // Álaba, Perfeto capitán, 1590, fol. 136v: Valiéndose d'esta traça los españoles en la jornada de la Cherinola rompieron el esquadrón de los suízaros, que era todo de piqueros, entrándoseles debaxo de las picas; y quando quisieron valerse de las espadas, no pudieron, a causa de ser muy largas y estar ellos demasiado juntos y apretadas las hileras. 
// Ufano, Tratado de la Artillería, 1613, pág. 87: Como sucedió a la Çesárea Magestad del Emperador Carlos Quinto, de gloriosa memoria, en la jornada de Ratisbona con el Lantgrave y el duque de Saxsonia, que durante el combate de una parte y otra expendieron cada 3.000 balas.

ENCICL.: Almirante (1869): Se usa para grandes y decisivas batallas. // Estévanez (1897): Una batalla o combate decisivo: las jornadas de julio (1856), la jornada del 22 de junio, la jornada de Somorrostro, etc. // Lechuga, Discurso de la Artillería (1611: pág. 201): "Relación sumaria de las cosas que tubieron a cargo los mayordomos de la artillería de el exército de Su Magestad, las jornadas de Alemania, los años de 1546 y 1547, para que, assimismo, vean los muchos cavallos que se avían acordado para ellas, porque no parezcan muchos los de la mía" 
lambor, V. alambor.

lamborado, V. alamborado.

leba, V. leva.

lebadiço, V. levadizo.

lebantado, V. levantado.

lebantar, V. levantar.

lechera, lechera [de lecho y éste del lat. lĕctus 'cama'. Lechera ant. 'litera, lechiga' (DECH). Mendoça, Theórica y práctica, 1596]. sust. Art. Pavimento, generalmente de madera o de piedra, sobre el que se colocan las piezas de artillería, para que las ruedas de sus cureñas puedan deslizarse fácilmente.

Mendoça, Theórica y práctica, 1596, pág. 99: Plantadas estas pieças con sus lecheras, que se hazen de tablones, maderos o çarzos, se cubren con cestones y fossos, assí para seguridad 
de los gastadores que asisten al retirarlas con los artilleros, y de otras cosas necessarias, como para la guarda de la artillería. // Rojas, Teórica fortificación, 1598, fol. 73v: Y hechas todas las diligencias de la buena fortificación, y teniendo en esta plaça mucha cantidad de maderos para hazer estacadas al tiempo de las baterías, y mucha tierra y fagina de respeto, y cantidad de cestones y çarços [...]; y algunos carpinteros, que son de mucha importancia en un presidio para hazer lecheras para el artillería; y que tengan muchas sierras de mano $[\ldots]$.

SIN.: explanada 3 , plataforma ${ }_{5}$.

ENCICL.: DRAE (1803): ant. Milic. Lo mismo que explanada, por el pavimento de tablones o de fábrica sobre que cargan las cureñas en una batería.

lengua, lengua [del lat. lı̆ngua 'órgano muscular situado dentro de la boca, que sirve para comer y pronunciar', 'lenguaje, manera de hablar'. Orígenes del idioma (Cid, etc.). La ac. 'información, noticia' en Alex., G. de Alfarache Cl. C. II (DECH). Álaba, Perfeto capitán, 1590]. sust. Informe o noticia (Aut.).

Álaba, Perfeto capitán, 1590, fol. 46r-46v: Si marchando el campo huviere lengua de la parte por donde quiere acometer el enemigo, la cautela de que podrá usar para desbaratarlo con más facilidad será poner hazia aquel mesmo lugar el vagaje y todas las vituallas del exército, porque se ceve en el robo d'ellas y, entretanto, la gente que estuviere a los otros lados del esquadrón pueda, cogiéndolos descompuestos, cerrar con ellos y herirlos más a su salvo. // Mendoça, Theórica y práctica, 1596, pág. 102: Inconvenientes que es bien mirar antes de echar las puentes para el assaltar y aun del ponerse la batería en aquella parte, considerándolos Vuestra Alteza según la lengua y información que se tuviere de la profundidad del fosso. // Mendoça, Theórica y práctica, 1596, pág. 146-147: Assimismo se permite en las fronteras hombres a quien no se les da otro sueldo más de licencia para yr a correr y bivir en la tierra, trayendo las presas a vender en ella, y éstos son, de ordinario, naturales de la misma provincia; y con saber los caminos y passos hazen gran daño al enemigo, tomando personas de quien se tiene lengua de muchas cosas.

ENCICL.: D'Wartelet (1863): Noticia que un general adquiere de las operaciones del ejército enemigo.

tomar $\sim$ [Celso, Reportorio universal leyes Castilla, 1553]. loc. v. Informarse, tomar o adquirir noticias (DRAE: s.v. tomar $\sim, o \sim s$ ).

Celso, Reportorio universal leyes Castilla, 1553, fol. CXXXIIIr: Y estos tales deven ser fieles, y hombres de buen juyzio, y tales a quien se pueda dar crédito en lo que dixeren. Y si ellos tomaren a alguno de los enemigos, deven procurar de traerle ante aquéllos que los embían para que d'él tomen lengua. / / Mendoça, Theórica y práctica, 1596, pág. 91: Sucede algunas vezes en semejantes cargas matar o prender alguno de los cabos que salen a guiar los sitiados, de quien se toma lengua, cosa que los acobarda grandemente y, en particular, si reciben mucho daño a las primeras vistas, lo qual los lleva a pensar en el rendirse. // Mendoça, Theórica y práctica, 1596, pág. 110: Y raras vezes se viene a combatir sin averse 
hecho antes alojamientos y reconocido los exércitos, de que se tiene nuevas por las espías y otras intelligencias, sin los que se embían a correr o tomar lengua, de que se valen los príncipes y capitanes, generales, procurando certificarse si es maior su campo que el del enemigo.

ENCICL.: Rubió y Bellvé (1895-1901): Adquirir noticias del enemigo.

leva, leba, leva [de levar y éste del lat. lěvare. 1613, Babia 'reclutamiento de tropas'; 'huida' 1604, G. de Alf. (DECH). Mendoça, Theórica y práctica, 1596]. sust. Mil. Reclutamiento o acción de buscar y reunir personas para la guerra.

Mendoça, Theórica y práctica, 1596, pág. 22: En todas las provisiones y levas de gente que se hazen para qualquiera facción de guerra por mar o tierra se da de ordinario a entender ser con diferente motivo del que se tiene, por no dar tiempo al enemigo para apercebirse previniendo los dissinios a su contrario. // Mendoça, Theórica y práctica, 1596, pág. 45: Assimismo teniendo Vuestra Alteza las levas y provisiones a punto y el exército compuesto, ha de tratar, juntando assí las cabeças d'él como los demás personages de su consejo, qué vandos y defensas se han de publicar, assí por tener la gente en buena diciplina como por respeto del bien público. // Roxas, Sumario milicia, 1607, fol. 65v-66r: Verán los reyes la neçesidad que tienen, antes que hagan leba de jente, saver de dónde se an de pagar y el modo que an de tener en premiar los buenos y castigar los malos, porque, haçiendo así, todas las naçiones que hemos dicho servirán con mucho amor y fidilidad.

FAM.: levadizo, levantado, levantamiento, levantar.

ENCICL.: Aut.: La recluta de soldados que los reyes y soberanos hacen en sus estados y reinos, para aumentar sus tropas o completar los regimientos y compañías. // Estévanez (1897): En España se abusó de las levas para el ejército y para la marina, recogiéndose a todos los vagos, hambrientos y viciosos que previamente no se hubieran hecho frailes.

levadizo, lebadiço, levadizo [de levar y éste del lat. lěvare. Alonso de Palencia; Oudin (DECH). Loçano, Alberto, Architectura, 1582]. adj. Dicho de una cosa, y particularmente de un puente: que se puede levantar y bajar por medio de algún mecanismo.

Loçano, Alberto, Architectura, 1582, pág. 253: Por antigua costumbre aún entonces hazían de madera los theatros, y aún por essa razón reprehendieron a Pompeyo, porque puso el assiento del espectáculo, no como antes, con gradas levadizas, sino perpetuas. // González de Medina, Examen fortificación, 1599, pág. 46-47: Ha de tener una parte de la puente levadiza y con un ponteçuelo, también levadizo, que salga por una puerta pequeña a dar en el puente, para si de noche huviere alguna necessidad de salir alguno o entrar dentro para cosa importante, que sea por el ponteçuelo [...], y no se avrá menester calar el grande por el gran peligro y preparamentos que es menester hazer para echar el puente grande de noche para salir o entrar. / J Juanelo Turriano, Veinte y un libros, a. 1605, fol. 389v: Esta puente levadiza ha de tener sus antepechos a los costados. No se ha de entender levadiza como las de las puertas de las ciudades ni de castillos. Llamo yo 
levadiza la cosa que se puede quitar y poner todas las vezes que sea menester, de modo que nadie cayga dentro del agua.

FAM.: leva, levantado, levantamiento, levantar.

ENCICL.: Terr.: Adj. Lo que se puede levantar. Dícese en particular de un puente que se puede quitar y poner sobre algún río, foso, etc.

levadizo, V. puente .

levantado, lebantado, levantado [de levantar (DECH). Roxas, Sumario milicia, 1607]. adj. Mil. Dicho de una persona o de un territorio donde habita gente: que se ha enfrentado, normalmente de forma violenta, a sus superiores o a quienes lo tienen bajo su poder.

Roxas, Sumario milicia, 1607, fol. 55v: En Miturnias, çiudad en Ytalia, fueron puestos en cruz quatrocientos y cinqüenta esclabos cerca de su ciudad; en el reyno de Nápoles fueron muertos quatro mil esclabos levantados, y matólos Quinto Metello y Xeo Çirvilio.

SIN.: rebelado, rebelde.

FAM.: leva, levadizo, levantamiento, levantar.

levantamiento, levantamiento [de levantar. Alonso de Palencia; Nebr. (DECH). Celso, Reportorio universal leyes Castilla, 1553]. sust. Mil. Movimiento colectivo violento, normalmente con armas, contra la autoridad, por lo común por parte de un territorio hacia quienes lo tienen sujeto.

Celso, Reportorio universal leyes Castilla, 1553, fol. CCCXXIVr: Y, sobre todo, el tirano trabaja de estragar a los poderosos, y de matar a los sabios, y siempre defiende en sus tierras las cofradías y ayuntamiento de gentes, recelándose que de allí no le salga algún levantamiento. // Mendoça, Theórica y práctica, 1596, pág. 34: Pueden assimismo venir ocasiones en que Vuestra Alteza aya de levantar gente de guerra, valiéndose d'ella y armas, para castigar alguna sedición o rebelión de sus vassallos, en que no se ha de perder un momento de tiempo por muchas razones, no siendo la más flaca que los príncipes que sufren levantamientos de comunidades, ciudades o provincias dan exemplo a otros a que los sigan, quando no los veen armados, para castigarlos y, estándolo, es causa de acudir con más voluntad a su príncipe los que no están declarados contra él, viéndole con gente y que no se dexa descaecer, fiados de que tiene más ciertos premios que dar, que no los rebeldes. // Mendoça, Theórica y práctica, 1596, pág. 35-36: Esto obliga en los levantamientos de las ciudades y provincias, o motines de gente de guerra, a castigar los que les dieron principio y movimiento siendo autores d'ellos, perdonando, en general, a los demás, pues no es possible castigar la multitud.

SIN.: rebelión. 
FAM.: leva, levadizo, levantado, levantar.

ENCICL.: López Vallejo (2008): Rebelión, sublevación, normalmente con uso de armas.

$\sim$ de guerra [Celso, Reportorio universal leyes Castilla, 1553]. cmpt. sintag. Mil. Movimiento colectivo de protesta contra la autoridad, por lo común por parte de una tropa hacia sus superiores.

Celso, Reportorio universal leyes Castilla, 1553, fol. CCXVIIv: Otros son que ponen los adelantados o merinos mayores, y éstos no pueden hazer justicia, sino sobre cosas señaladas que llaman voz del Rey, ansí como por camino quebrantado, o por ladrón conoscido, o por muger forçada, o por muerte segura, o por robo, o por fuerça manifiesta, e otras tales cosas a que el hombre puede yr, ansí como hablar en trayción contra la persona del Rey, e contra las cosas que son más cercanas d'él, o sobre levantamiento de guerra.

SIN.: motín.

levantar, lebantar, levantar, llebantar, llevantar [de levante, ant. part. act. de levar. h. 950, Glosas Emil.; general desde el Cid (DECH). Escalante, Discurso de la navegación, 1577]. v. tr. Mil. Reclutar o buscar y reunir personas para la guerra.

Escalante, Discurso de la navegación, 1577, fol. 72v: El quarto es el aytao, que es el proveedor general y presidente del consejo de guerra, a quien toca el levantar gente y prevenir navíos, y bastimentos, y municiones para las armadas de mar y exército de la tierra, y para las guarniciones ordinarias de las ciudades y fronteras. // García de Palacio, Diálogos militares, 1583, fol. 51v: Dixe, pues, que convenía que los tales soldados se hiziessen y levantassen en provincias y partes do de su fidelidad se tenga bastante experiencia, y tales que peleen más por su propria gloria y honrra que por sueldo. // Roxas, Sumario milicia, 1607, fol. 64v-65r: Y supuesto estas cosas y que la guerra que hubiere de hazer ha de ser justa, y no biolenta y sin justiçia, a de procurar que el exérçito que lebantare sea de los hombres más práticos y esperimentados que hallare en los casos de la guerra, y adbertir que si el prínçipe fuere ytaliano no a de ser todo el exérçito de ytalianos, y si fuere alemán no a de ser todo de su nación, y si fuere español también no será todo de españoles.

SIN.: hacer (la) gente.

FAM.: leva, levadizo, levantado, levantamiento.

ENCICL.: Cov.: Tiene varias significaciones: como [...] levantar gente de guerra [...] y levantarse como rebelde. 
2 [Montes, Instrucción y regimiento, 1537]. v. tr. Mil. Dicho especialmente de quien ostenta cargos de mando en la milicia: desmontar el real $\mathrm{u}$ ordenar a los soldados que abandonen su alojamiento en el campo.

Montes, Instrucción y regimiento, 1537, fol. IXv: Hay algunos generales que, desque una vez affirman un campo en una parte, no le levantan hasta a ver el fin de lo que dessean; si aquello se puede alcançar, bueno es, mas si lo que dessean se dilata, es malo para la salud del exército, que está al sereno en la campaña. // García de Palacio, Diálogos militares, 1583, fol. 67r: Y él mismo refiere que, queriendo un hijo de Antígono saber de su padre quándo levantaría el exército de do estava, le respondió enojado:"¿temes que tú solo no oyrás la trompeta?", notando, o casi reprehendiendo, la poca experiencia del mancebo, porque en la guerra se deven encubrir los designios, intentos y consejos de los príncipes y capitanes, aun de los muy privados. / / Álaba, Perfeto capitán, 1590, fol. 50r: Y si huviere de levantar el real para passar a otro alojamiento, primero embiará el furriel con los gastadores para que aderecen el camino y fortifiquen el lugar a donde huviere de yr a alojar, y hasta saber que esto se a hecho no començará a marchar con su campo.

ANT.: asentar $_{1}$.

ENCICL.: DUE: tr. Desmontar una cosa que está instalada en un sitio: 'Levantar el campamento [el campo]'. / / Hevia (1857: s.v. levantar el campo): Mudar el campamento o el ejército a otra parte.

3 [Montes, Instrucción y regimiento, 1537]. v. prnl. Mil. Dicho especialmente de un grupo de soldados: abandonar el campo o el lugar en despoblado en el que han permanecido durante un tiempo.

Montes, Instrucción y regimiento, 1537, fol. XVIIv: Y cada esquadra d'éstas se rija por su caporal o capitán, y estén en esta orden hasta el día; e si el campo no se levantare, por la misma orden la pueden defender. // Collado, Plática Artillería, 1592, fol. 50v: Yendo alrededor de la ciudad reconosciendo el sitio el general de la señoría y llevando su ingeniero a las ancas del cavallo, les asestó un sacre de 8 libras de bala un artillero español dende el castillo y los mató a entrambos de un tiro solo, lo que fue causa que se levantó en un instante el campo veneciano y se partió de allí sin hazer ningún effecto. // Roxas, Sumario milicia, 1607, fol. 45r: Y así conbiene con tiempo recoger todas las bituallas dentro de los castillos y en mucha abundancia, de manera que les haga falta al enemigo en la campaña para que le obligue a levantarse.

ANT.: acamparse.

ENCICL.: Moretti (1828: s.v. levantar el campo): Frase que se usa en el idioma militar para expresar que el ejército o parte de él muda de posición o abandona el campo. Los romanos daban la señal para levantar el campo por medio de las trompetas, y los heraldos enseguida gritaban vasa conclamari, que equivalía abatir las tiendas. // Corsini (1849: s.v. levantar el campo): Log. Abandonarlo la tropa o ejército para marchar, avanzar, retroceder, situarse en otra posición, etc. 
4 [Fernández de Enciso, Suma de Geographía, 1530]. v. prnl. Mil. Dicho especialmente de los habitantes de un territorio recién conquistado o sujeto: enfrentarse $u$ oponerse, normalmente con las armas, a quienes los han puesto bajo su poder.

Fernández de Enciso, Suma de Geographía, 1530, fol. XXIVv: Y después se levantaron y revelaron los españoles contra Roma fasta que bolvió Cipión, el Africano, e la tornó a someter al Imperio Romano, e passó en África, y venció a Aníbal y destruyó a Cartago. // Celso, Reportorio universal leyes Castilla, 1553, fol. CCCXXIVr: Y para que pueda más libremente y desembargadamente señorear el reyno o tierra que tiene usurpada, el tirano siempre trabaja que los que biven en la tierra sean necios y medrosos, porque no se osen levantar contra él ni contratar sus voluntades. // Roxas, Sumario milicia, 1607, fol. 55v: Finalmente corregido con la fea paz que avía hecho, de allí adelante peleó contra los moros y así domó a Galicia que se lebantava.

SIN.: rebelar 2 .

ENCICL.: López Vallejo (2008): prnl. Rebelarse, sublevarse con el uso de armas.

levantar, V. el asedio.

levantar, V. el cerco.

levantar, V. el sitio.

lid, lid [del lat. lìs, lìtis 'disputa', 'pleito'. Lide, docs. de 1076 y 1100; lid, Cid, etc. (DECH). Celso, Reportorio universal leyes Castilla, 1553]. sust. Mil. Acción bélica en la que se enfrentan soldados o formaciones militares enemigas.

Celso, Reportorio universal leyes Castilla, 1553, fol. CLVIIIr: Y, ansimesmo, ay otra especie de guerra que dizen spolonada, para tomar fuerça, o villa, o castillo. $Y$ ay otra que dizen lid de uno contra otro, o de más tantos contra tantos. // Celso, Reportorio universal leyes Castilla, 1553, fol. CLIXv: Lo mesmo dezimos de lo que fuesse ganado en hazienda, o en lid, o en cavalgada, do fuesse algún capitán por mandado del Rey. // Celso, Reportorio universal leyes Castilla, 1553, fol. CLIXv: Lo mesmo es si lo ganassen en hazienda, o en lid, o en cavalgada, o spolonada, o celada, o entrando en villa o castillo por fuerça, o en navíos de los enemigos, o en qualquier otra manera que se podiesse dezir guerra. Y si el Rey no fuere aý en persona, dévelas cobrar su Capitán General.

SIN.: batalla $a_{1}$ combate ${ }_{1}$, combatimiento ${ }_{1}$, contienda 2 , debate, facienda, pelea.

ENCICL.: DECH: La ac. castellana 'combate' se explica por la frecuencia del combate judicial en la Edad Media. // Aut.: La batalla o contienda en que lidian o pelean dos o más personas. 
lidiador, lidiador [de lidiar. Cid (DECH). Celso, Reportorio universal leyes Castilla, 1553]. sust. Mil. Persona que combate o lidia.

Celso, Reportorio universal leyes Castilla, 1553, fol. CCXCVIIIv: Y, haviendo reconoscido los fieles los lidiadores e sus armas, para ver si ellos tienen aquellas armas que el Rey les mandó, o más, o menos, deven los fieles meterlos en medio del campo y repartirles el sol. // Celso, Reportorio universal leyes Castilla, 1553, fol. CCXCVIIIv: Y los dichos lidiadores pueden mejorar de armas e cavallo mientras que aý estuvieron los dichos fieles; e, hecho esto, deven salir los fieles, y estar cerca para ver e oýr lo que dixeren e hizieren. // Celso, Reportorio universal leyes Castilla, 1553, fol. CCXCIXr: Como diximos de suso, versículo XXIII, los lidiadores no deven salir del campo sin licencia o mandado del Rey o de los fieles. Y qualquier que por su voluntad, o por premia, o fuerça del otro combatidor saliere del campo, es dado por vencido.

SIN.: combatidor, combatiente 1.

FAM.: lidiar.

ENCICL.: Aut.: El que lidia, combate y contiende.

lidiar, lidiar [del lat. littı̆gare 'disputar, pelearse con palabras' (sólo conservado en cast. y en el port. lidar). doc. de 1074; Cid, etc. (DECH). Medina, Arte de navegar, 1545]. v. intr. Mil. Enfrentarse dos o más personas utilizando la fuerza o las armas para vencer al otro.

Medina, Arte de navegar, 1545, fol. 65r: La fiesta de sanct Miguel es llamada victoria, aparición y consagración. Es dicha victoria porque lidió con el diablo Lucifer quando se quiso ygualar con Dios y fue hecha aquella gran batalla en el cielo entre sanct Miguel y los ángeles malos y, entonce, los echó Dios del cielo. // Celso, Reportorio universal leyes Castilla, 1553, fol. CVIIr: Y, ansimesmo, dispensen con aquéllos que han lidiado con otro, según la costumbre de la tierra, con tanto que no haya muerte o perdimiento de miembros ni finquen ellos lisiados. // Celso, Reportorio universal leyes Castilla, 1553, fol. CCXCVIIIv: Si las partes se avinieren que se libre el riepto por lid, haze la tal provança la tal lid; porque, según diximos, el Rey no lo mandaría hazer si las partes no se aviniessen a lidiar.

SIN.: batir ${ }_{3}$, combatir 1 , luchar, ${ }_{2}$ pelear, revolver 2 .

FAM.: lidiador.

ENCICL.: Corsini (1849): Pelear, batallar, en estilo poético. // García de Palacio, Diálogos militares (1583: fol. 1v): "Si ya se limpia la segura espada / para cevarse en sangre sin tardança / y, por hazer la suerte aventajada, / se está aguzando la azerada lança, / y ya la cruda Parca, ensangrentada, / con su tixera al corte se abalança, / no prestan fuerças, ni ánimo fiero, / si el arte del lidiar falta al guerrero". 
lienço, V. lienzo.

lienso, V. lienzo.

lienzo, lienço, lienso, lienzo [del lat. lĭntěum 'tela de lino', 'lienzo'. Lentio, doc. leonés de 904; lenzo, íd. de 918; lienço, 980. Berceo (DECH). Escalante, Discurso de la navegación, 1577]. sust. Constr. Trozo continuo de pared o muralla (DSAL).

Escalante, Discurso de la navegación, 1577, fol. 40r: En todas ay portal y patio, en que tienen flores y verduras para su recreación, y un estanque de agua pequeño con peces. El un lienço del quadro que haze el patio le tienen ocupado con armarios muy polidos y bien labrados de la traça de los escritorios. // Álaba, Perfeto capitán, 1590, fol. 89v: Pericles, capitán ateniense, queriendo dar assalto a una ciudad muy fuerte, hizo que la gente de su armada que estava hazia la parte donde la mar batía los muros, desde las naos levantassen grandes bozes y alaridos, los quales oýdos por los cercados, creyendo que por aquel lienço del muro avían entrado los enemigos, acudieron todos a estorvar por aquella parte la entrada; entre tanto Pericles, acometiendo y escalando por otra la muralla, entró y rindió la ciudad. // Álaba, Perfeto capitán, 1590, fol. 256v: Y aunque la traça de las minas en estos tiempos es la mesma que en los passados, los efetos son de mayor importancia, por la violencia notable con que los materiales que en ellas se ponen desbaratan y asuelan qualquier lienço de muro o fortaleza, por fuerte y inexpugnable que parezca.

SIN.: cortina 2.

ENCICL.: Cov. (s.v. lienço): Lienzo de pared, la pared seguida y derecha. // Rubió y Bellvé (1895-1901): Pedazo de muralla que corre en línea recta de un ángulo a otro o de una a otra obra flanqueante de una fortaleza. Dícese más usualmente lienzo de muralla. // DUE: Cada trozo continuo de pared o de muro, interior o exterior; por ejemplo, entre dos ventanas. / Fort. Trozo continuo de muralla.

liga, liga [de ligar. Liga 'confederación o pacto' en Nebr. (DECH). García de Palacio, Diálogos militares, 1583]. sust. Mil. Unión o pacto entre dos o más soberanos, territorios, etc., establecido con el fin de atacar a un enemigo común o para defenderse en alguna ofensiva.

García de Palacio, Diálogos militares, 1583, fol. 10v-11r: Y el Papa Pío Quinto, de gloriosa memoria, fue author de la liga que se hizo contra el turco el año passado de setenta y uno, causa y principio de aquella memorable victoria que el armada christiana alcançó contra la del enemigo común en el golfo de Lepanto. // Mendoça, Theórica y práctica, 1596, pág. 1618: Debaxo d'este presupuesto se ha de considerar la calidad del reyno que se acomete [...]; si está el reyno o paýs de años atrás coligado con otros o después que le posseyó rey o príncipe, las ligas que tiene si son personales o sucessivas con sus herederos; finalmente [...]. // Mendoça, Theórica y práctica, 1596, pág. 30-31: También podría Vuestra Alteza levantar gente en assistencia de algún príncipe con quien esté confederado en razón de las 
ligas que tiene con él, las quales se han de guardar con toda puntualidad, estando prendado Vuestra Alteza y todos los príncipes a cumplir su fe y palabra y contratos hechos sobre ella por dos obligaciones: la primera, por ser ley natural mantener los contratos, y la segunda, de príncipe, guardar su fe y palabra.

SIN.: confederación.

FAM.: ligarse.

ENCICL.: Cano, Arte para fabricar naos (1611: fol. 11v-12r): "Siéndolo del mar, lo será por consiguiente de la tierra, bastando a darle una suprema y gloriosa victoria el vencimiento de una poderosa batalla naval, qual lo fue aquella tan célebre, memorable y aun milagrosa que sobre Lepanto tubo contra la gruesa armada del Turco la de la Sancta Liga, de que fue supremo general el señor don Juan de Austria, hijo de nuestro invicto Emperador Carlos Quinto". // Borreguero Beltrán (2000: s.v. Liga Santa): Con este nombre se denominó a diferentes alianzas de distintos reinos a lo largo del siglo XVI. Se denominó así a la formada en 1495 por el papa Alejandro VI, el milanés Ludovico el Moro, la República de Venecia, el emperador Maximiliano y Fernando el Católico para luchar contra el poderío de Carlos VIII de Francia. En 1511-1516 se firmó una nueva alianza entre el papa Julio II, Venecia y Fernando el Católico contra los franceses y su rey Luis XII. Se llamó Liga Santa o Santa Liga la que, por iniciativa del pontífice Pío V, constituyeron en 1571 España, Venecia y Roma para luchar contra el poder naval de Turquía, que pretendía el dominio de todo el Mediterráneo.

ligarse, ligarse [del lat. lı̆gare 'atar'. 1251, Calila (DECH). Mendoça, Theórica y práctica, 1596]. v. prnl. Mil. Dicho de dos o más soberanos, territorios, etc.: unirse o aunarse, en virtud de tratado, para tener más fuerza a la hora de defenderse o de atacar.

Mendoça, Theórica y práctica, 1596, pág. 23: Que otros reyes y potentados no se liguen para ayudar al que se acomete, llevados del humor, de que naturalmente está compuesta la sangre real, en el açorarse de qualquier otro rey a quien veen crecer en poder y fuerças, viniendo a estimar correr su grandeza la suerte de las balanças, por no subir la una sin baxar la otra.

SIN.: aliarse, coligarse, confederarse.

FAM.: liga.

ENCICL.: Aut.: Confederarse y unirse dos o más personas para obrar juntos a un fin, lo que más comúnmente se dice de las potencias o los reyes. // DRAE (s.v. ligar): prnl. aliarse.

ligero, V. caballería . 
ligero, V. caballo .

limpio, V. cortina $\sim$.

llebantar, V. levantar.

llevantar, V. levantar.

llevar, V. $\sim$ de vencida.

lobo, lobo [del lat. lǔpus 'íd.'. Orígenes del idioma (doc. de 1057, Oelschl., etc.) $(\mathrm{DECH})$. Roxas, Sumario milicia, 1607]. sust. Fort. ant. Garfio fuerte de hierro que usan los sitiados desde lo alto de la muralla para defenderse de los sitiadores.

Roxas, Sumario milicia, 1607, fol. 27v-28r: También ha de aver lobos, que son unos garabatos de hierro, y hoçes enastadas en lanças y, para haçer las trincheras y fosos, las herramientas ya dichas; y galápagos, y músculos, carneros, víneas, mantas y otras menudençias.

SIN.: lupo.

FAM.: lupo.

ENCICL.: Terr.: Llamaron los antiguos a una especie de alicates grandes, corvos y dentados, con que volvían a una y otra parte el carnero o ariete, máquina de batir.

lucha, lucha [del lat. lucta 'íd.'. Berceo, Nebr., Cej. (DECH). Loçano, Alberto, Architectura, 1582]. sust. ant. Ejercicio que se hace entre dos lidiando a brazo partido, en que se considera vencedor el que echa a su contrario en tierra (Aut.).

Loçano, Alberto, Architectura, 1582, pág. 17: Porque conviene considerar qué es lo que començamos: obra pública o particular, sagrada o seglar, y las demás cosas de esta suerte, de las quales hablaremos más distinctamente en su lugar. Porque una cosa se deve al mercado, otra al theatro, otra a la escuela de la lucha, y otro espacio y lugar se deve al templo. // Álaba, Perfeto capitán, 1590, fol. 39v: Mandó el mesmo Licurgo que las vírgenes se exercitassen en luchas y otros exercicios honestos, porque los hijos heredassen esta fortaleza, que ellas avían granjeado del averse exercitado. // Álaba, Perfeto capitán, 1590, fol. 40v: Y Alexandro Severo se exercitava en la palestra, que era el lugar deputado para las luchas; y lo mesmo que Mario hizo hazía Catón Uticense siendo de edad de sesenta años, señalándose tanto en todos los exercicios que ninguno de los moços se mostrava tan aventajado en ellos. 
ENCICL.: Estévanez (1897): En la antigüedad era sólo ejercicio atlético o gimnástico sin ninguna significación guerrera. // Moretti (1828): Uno de los cinco juegos o ejercicios gimnásticos o del circo, que usaron los griegos y romanos, no sólo en público sino también en sus mismas casas. Consistía en una pelea entre dos, que abrazándose uno a otro, procuraba cada cual dar con su contrario en tierra. No debe confundirse con el pugilado; pues en la lucha no se daban golpes, y sólo se obtenía el premio derribando a su competidor.

luchar, luchar [del lat. luctari 'íd.'. Berceo (DECH). Urrea, Vitruvio, Architectura, 1582]. v. intr. ant. Contender o lidiar dos personas a brazo partido hasta que alguno caiga en tierra (Aut.).

Urrea, Vitruvio, Architectura, 1582, fol. 20r: A Hércules, en las ciudades en las quales no ay gymnasio, que es donde luchavan, ni aya amphiteatro, se le hará templo en la plaça. // Urrea, Vitruvio, Architectura, 1582, fol. 73r: Agora me parece enseñar claramente cómo se han de edificar los lugares donde se ha de luchar, aunque d'ello no ay costumbre en Italia. Y mostraré cómo se hazen en Grecia. // Álaba, Perfeto capitán, 1590, fol. 40v: Y el luchar es necessario para quando sucediere llegar a braços con alguno de los contrarios, pues d'este exercicio se sacan tretas con que poderle poner fácilmente a sus pies, aunque en las fuerças no le iguale.

2 [Anónimo, Repertorio tiempos, 1554]. v. intr. Mil. Enfrentarse dos o más personas utilizando la fuerza o las armas para vencer al otro.

Anónimo, Repertorio tiempos, 1554, fol. LXXIv: Jacob tuvo dos mugeres hermanas: a Lía, la legañosa, y a Rachel, la hermosa, y dos concubinas: a Celpha y a Bala; engendró dos hijos y una hija. Jacob luchó con el ángel. Joseph, su onzeno hijo, fue vendido por sus hermanos por XXX dineros, y después fue prepósito de Egypto. // Mendoça, Theórica y práctica, 1596, pág. 56: Y queriendo representar un cuerpo humano con aparencia, mirando el fundamento donde poner los pies, dispondrá los miembros de suerte que la muestren mayor; por el consiguiente, si se afirma con otro para combatir, afirmará el pie derecho delante, tendiendo el braço derecho, ladeando el cuerpo para cubrir los demás miembros, mostrando menos blanco donde herirle; y si se dispone a luchar con otro, procurará ayudarse de todos los miembros igualmente con averse de abraçar con el enemigo y servirse d'ellos, uniendo en aquella postura toda la fuerça, para que trabajen a un tiempo.

SIN.: batir 3 , combatir ${ }_{1}$, lidiar, pelear, revolver 2.

luna, luna [del lat. lūna 'íd.'. Orígenes del idioma (DECH)].

media [Mendoça, Theórica y práctica, 1596]. cmpt. sintag. Fort. Obra de fortificación que se construye delante de los baluartes, la cual consta de dos caras que forman un ángulo saliente y de una gola o parte trasera curvada hacia el interior. 
Mendoça, Theórica y práctica, 1596, pág. 142: Y a la fin se ha de [...] procurar mantener siempre la muralla (sin dar lugar al miedo, que es poderoso señor, siempre que se le abre la puerta) para formar detrás d'ella nuevos fossos, reparos o medias lunas, que raras vezes defendieron tierra, perdiéndose la muralla d'ella. // Rojas, Teórica fortificación, 1598, fol. 106r: Y de la mesma manera y a un tiempo se irán haziendo las demás trincheas con sus puentes de madera hasta desembocar el fosso y cegarlo [...], y passar los soldados y alojarse en la otra esquina del valuarte de a mano derecha. Y porque el enemigo podría tener hechas algunas retiradas y medias lunas, se advertirá de no entrar por mitad de la media luna, porque desde sus cuernos darán por las espaldas a los amigos, y assí se procurará yr arrimándose a los estremos y puntas de la media luna, procurando siempre de yr cubiertos y bien atrincheados. // Ufano, Tratado de la Artillería, 1613, pág. 146: A los yngenieros y traçistas les obliga a designar y traçar las trincheas y dar el orden y modo del fabricarlas, hazer fuertes espaldas, plataformas y bestiones offensivos, traveses y medias lunas, mesurar con razón justamente el anchura y travesía de los fossos y riveras, y la de la muralla, sus cortinas y baluartes.

ENCICL.: Sanz (1749: s.v. media-luna): Es obra exterior o destacada, comprendida de dos caras que forman un ángulo saliente haciendo una especie de arco o gola, como la que inventaron los holandeses en otro tiempo, que cubrían con ella el ángulo flanqueado de sus baluartes. Pero estas obras son defectuosas por estar mal flanqueadas. // Lucuze (1772: 44): "Tomó el nombre por la curvatura de su gola".

media $\sim_{2}$ [Ufano, Tratado de la Artillería, 1613]. cmpt. sintag. Fort. Cualquier fortificación o defensa en forma de media luna. 13 (fig. 105)

Ufano, Tratado de la Artillería, 1613, pág. 175: De la misma manera en todo lo que los sitiadores van batiendo se puede por de dentro hazer una media luna con sus buenos y secretos trabeses y alojamientos de pieças. // Ufano, Tratado de la Artillería, 1613, pág. 249: Y en el ýnter que se hiziere este passage, con gastadores y soldados, en la propia orilla de tal ribera, sin empachar ni ympidir a los que passarán de la otra banda, hazer con çapas y palas, tierra y ramage una media luna, la más alta y capaz que el tiempo diere lugar para tal effeto, alojando allí la resta del artillería, de forma que al cruçadillo, al través, descubra, barra y arrase la campaña. // Ufano, Tratado de la Artillería, 1613, pág. 273: Y si aviendo suspeçión de sus contrarios, si se quisiere prestamente amparar y cubrir de algún eminente y válido reparo, se puede al momento hazer, alçar y levantar en alto una media luna o fabricar de cada parte del río un fuerte o reduto para su resguardo y custodia.

ENCICL.: DUE: 1- Figura de la Luna cuando se ve de ella menos de la mitad de su círculo. 2Se emplea mucho esta expresión para designar esa forma y algunos objetos que la tienen.

lupo, lupo [tomado del lat. lǔpus. Mosquera, Comentario disciplina militar, 1596]. sust. Fort. ant. Garfio fuerte de hierro que usan los sitiados desde lo alto de la muralla para defenderse de los sitiadores. 
Mosquera, Comentario disciplina militar, 1596, fol. 5r-5v: Y no están tan fuera d'él los arietes, testúdines, onagros, lupos y otras máquinas que en las guerras de Italia, Francia y Alemania no las ayan usado nuestros españoles.

SIN.: lobo.

FAM.: lobo. 
máchina, V. máquina.

manga, manga [del lat. maň̌ca 'íd.', derivado de manus 'mano'. 1104. La ac. de 'destacamento de soldados o grupo de cazadores' ya en Covarr., Lope (El cuerdo loco) y en Pérez de Hita (DECH). Montes, Instrucción y regimiento, 1537]. sust. Mil. Cada una de las agrupaciones de infantería que, provistas de armas de fuego, normalmente arcabuces y mosquetes, se establecen fuera de un determinado orden de batalla para reforzarlo.

Montes, Instrucción y regimiento, 1537, fol. XIVr: Es bueno dexar algunas mangas de gente fuera de los esquadrones con una cabeça que los rija, porque estas mangas, después que sus esquadrones han affrontado, van a favorecer cada uno a su esquadrón. Y estas mangas sean los más arcabuzeros, porque éstos hazen mucho daño en los enemigos. // Álaba, Perfeto capitán, 1590, fol. 43r: Y començando a caminar yrá en esta orden: hará de la arcabuzería tres tercios, de los dos d'ellos hará dos mangas, poniendo la una a la mano diestra y la otra a la siniestra, cerca de los ángulos de la frente del esquadrón; del otro tercio hará dos guarniciones, para el lado diestro y siniestro del esquadrón. / Mendoça, Theórica y práctica, 1596, pág. 117: Estas mangas de arcabuzería o mosquetes, aunque es costumbre hazerlas de trecientos soldados, tengo por mejor dividirlas en menores cuerpos porque siempre, si la ocasión pide unirse en uno, se puede hazer con facilidad; y quando son pequeñas, con el estar divididas, se goviernan mucho mejor al combatir con ellas, guiándolas capitanes de experiencia.

ENCICL.: Cov.: Cierta forma de escuadrón en la milicia, cual es la manga de arcabuceros, por ser formada a la larga. // Terr. (s.v. mangas): En la milicia, la que guarnece de 
arcabucería y mosquetería los costados de los escuadrones, y se adelantan a trabar la escaramuza. // D'Wartelet (1863): Antiguamente era un pequeño destacamento o partida de tropa que se separaba del cuerpo principal, y cuya corta fuerza se empleaba en operaciones secundarias y poco decisivas. Todavía, aunque poco, se usaba de esta voz en tiempo de Felipe V. // Estévanez (1897): Nombre que se daba a los arcabuceros y mosqueteros que cubrían las alas de una línea de batalla, pues el grueso de la infantería se componía de piqueros mucho después de introducidas las armas de fuego. En el siglo XVIII, cuando ya toda la infantería estaba dotada de fusil, todavía se daba el nombre de manga al piquete de granaderos que se destacaba para cualquier servicio.

manta, manta [de manto y éste del lat. tardío mantum 'manto corto'. El sentido primitivo de manta parece haber sido 'especie de manto', de donde 'manta de viaje' y finalmente 'manta de cama'. Doc. de 969, Oelschl.; 1155, Fuero de Avilés; Berceo, etc.; 'pañuelo de cabeza', 1288, Acedrex; "manta de cama: lodix; manta de pared: auleum", Nebr. (DECH). Rojas, Teórica fortificación, 1598]. sust. Fort. ant. Especie de escudo individual de madera, que emplean los sitiadores para protegerse en los asaltos a castillos.

Rojas, Teórica fortificación, 1598, fol. 74v: Y como los antiguos no ignoravan esta fortaleza, hizieron su fortificación llena de torreones y de cubos redondos con que resistían mucho el artillería. Y como el enemigo viesse tanta resistencia en los cubos redondos, descubrieron la çapa, que es el pico y el açada, y llegados a la muralla, levantavan una manta de maderos, y por ser redondo el torreón se encubrían en la circunferencia d'él sin que pudiessen ser ofendidos de los traveses, y assí con seguridad picavan la muralla y hazían el hornillo y la volavan. // Roxas, Sumario milicia, 1607, fol. 27v-28r: También ha de aver lobos, que son unos garabatos de hierro, y hoçes enastadas en lanças y, para haçer las trincheras y fosos, las herramientas ya dichas; y galápagos, y músculos, carneros, víneas, mantas y otras menudençias, que sería larga su declaraçión. // Roxas, Sumario milicia, 1607, fol. 96v: Mas otros muchos autores antiguos nos çertifican que ellos sabían bien que el salitre abrasava, porque se serbían d'él en las composiçiones de algunos fuegos para quemar las mantas y baybenes y máquinas, y torres de madera que en aquel tiempo se usavan en los combates de ciudades.

ENCICL.: Lopes Pires Nunes (2005: s.v. manta): O mesmo que Mantelete. // Lucuze (1772: 103): "En lo antiguo hacían los manteletes sencillos y dobles. Llamaban sencillos cuando se componían de algunas tablas, a prueba de bala de fusil, de cuatro pies de ancho, y seis de alto, para cubrir al que le llevaba. Los dobles se hacían de dos órdenes de tablas un pie distantes, para rellenar el intermedio de tierra $[\ldots] "$.

2 [Mendoça, Theórica y práctica, 1596]. sust. Fort. Aparato de tablones, movible sobre ruedas, para protección de los soldados y de sus armas en el ataque a las plazas. 5 (fig. 107)

Mendoça, Theórica y práctica, 1596, pág. 105-106: Assimismo se pican las murallas, quando se ha llegado con trincheas o traviessas en el fosso o por otro medio al pie d'ellas, cubriéndose los soldados con mantas al hazerlo, las quales se guarnecen de cueros por de 
fuera, impidiendo con esto, por ser de madera, no se quemen, echando fuego de las murallas los sitiados sobre ellas. // Rojas, Teórica fortificación, 1598, fol. 41r: También se tendrá gran cuenta de echar en una fortificación los menos ángulos que se pudiere, porque una plaça rodeada de muchos ángulos es ya cosa hallada por experiencia ser fortificación flaca, porque, arremetiendo a un ángulo y arrimándole una manta, estará seguro allí el enemigo para poder picar la muralla. // Ufano, Tratado de la Artillería, 1613, pág. 362: No sería mal acordado, principalmente contra la caballería, que se tuviesen de yndustria, como se muestra por la presente figura, unos carrillos armados de forma que en cada uno se pudiese fabricar y componer una manta de madera y de filaças en el medio, a prueva de mosquete, con sus troneras y saeteras por el medio para que con ella cubiertos puedan bien tirar quatro o seis mosqueteros, el qual carrillo o carlino fuese armado y hecho sobre dos ruedas ligeras solamente.

SIN.: mantelete.

ENCICL.: Sanz (1749: s.v. manteletes): Son gruesos tablones, alguna vez revestidos de hojalata, que llevan sobre ruedas los trabajadores de un sitio, haciéndoles rodar delante para cubrirse del enemigo. De éstos hay sencillos, dobles, reforzados y escuadrados para hacer dos caras, a fin de cubrir de frente y de costado. Los manteletes deben tener cinco o seis pies de altura y tres de ancho, su espesor es alguna vez de dos o tres tablas unidas con abrazaderas de hierro. // Lucuze (1772: 103): "Al presente sólo sirve a los zapadores el mantelete, y se forma de gruesas tablas, elevadas verticalmente en un eje con dos ruedas, y puede un hombre adelantarle a proporción que se trabaja".

mantelete, mantelete [del fr. mantelet. Término de blasón o de fortificación o de vestidura. Aut. (DECH). Lechuga, Discurso de la Artillería, 1611]. sust. Fort. Aparato de tablones, movible sobre ruedas, para protección de los soldados y de sus armas en el ataque a las plazas.

Lechuga, Discurso de la Artillería, 1611, pág. 220: Usávase, en el tiempo que yo servía en la artillería en Flandes, una invención nueva del mismo tiempo de unos carros de dos ruedas que llamávamos manteletes, el fondo d'ellos de un tablón a prueva de mosquete, con dos troneras y un lugar para una pieça de tres palmos de largo, y de tanta boca que se pudiesse cargar con quinze balas de mosquete.

SIN.: manta $_{2}$.

ENCICL.: Almirante (1869): En general toda máquina o aparato "locomóvil" para cubrir "individualmente", o en pequeño grupo, al soldado de los proyectiles enemigos. Más particular, y técnico en el día, el aparato de tablones forrado de hierro y acero, movible sobre ruedas y con aspilleras o sin ellas, que usan los ingenieros en trabajos de zapa, y por extensión cualquier tropa en combate de calles o de barricadas [...]. Es [mantelete], por ejemplo, un carretón con colchones, empujado por dos o tres hombres. // Lechuga, Discurso de la Artillería (1611: pág. 220-221): "[Los manteletes] servían para, en llegando a qualquiera parte que fuera menester servirse de ellos, levantando los timones para arriba, quedando cada uno hecho reparo de algunos soldados, para de noche ir seguros a llegar a 
tomar un puesto; para guardar un camino y para assegurarlo, poniéndolos por traviessa en él; para ponerlos delante de alguna obra peligrosa que se uviera de hazer y para otros muchos effectos que por los dichos se pueden sacar, porque la gente que va detrás los va moviendo con facilidad, y vazíos, dos cavallos son hartos para cada uno. Y finalmente me serví de ellos, para, en tierras que no avía artillería, en llegando, ponerlos en lugar de cestones y dar principio a servirme de las pieças, sin más tiempo que llegar y obrar".

máquina, máchina, máquina [tomado del lat. machĭna 'íd.', 'andamio', 'artificio,

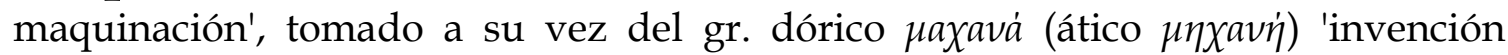
ingeniosa', 'máquina (de teatro, de guerra, etc.)', 'maquinación, astucia'. Fue ya algo usual en los ss. XV-XVI. Está en Juan de Mena, acentuado machína; 1570, C. de las Casas (ed. 1591) (DECH)].

mural [Collado, Plática Artillería, 1592]. cmpt. sintag. Fort. ant. La que sirve para romper muros o murallas, torres y demás elementos de una fortificación.

Collado, Plática Artillería, 1592, fol. 4v: La máquina que los antiguos llamaron eliópole era una de las que, antes de la invención de la pólvora y artillería, applicavan al uso de la guerra para con ella romper qualquier torre y muralla, como con las otras máquinas que ellos llamavan murales se hazía. / / Collado, Plática Artillería, 1592, fol. 5r: Muchas otras differencias de máquinas murales podría yo, Real Magestad, representar en este tratado, si no me opprimiesse el temor de ser prolixo, las quales son las vineas, los compagos, los cuervos, las sanbucas, y otras muchas, las quales será bien differir por agora, para venir a tratar de la invención de la pólvora y artillería. / / Collado, Plática Artillería, 1592, fol. 94v: Donde interviene el artillería, cessan todas las hórdenes, son inútiles las máquinas murales, no han lugar las invenciones, las instructiones y preceptos de la antigua milicia: puesto delante de esta máquina todo cessa y sus effectos son vanos y de ninguna efficacia.

marchar, marchar [del fr. marcher, antiguamente 'pisar, pisotear', y éste del fráncico *markôn 'dejar una huella'. h. 1550; 1568, Eugenio de Salazar, quien afirma que pertenece a la "lengua soldadesca". El mismo carácter militar le reconoce Sigüenza, h. 1600 (DECH). Montes, Instrucción y regimiento, 1537]. v. intr. Mil. Dicho de una fuerza militar: caminar o desplazarse de un lugar a otro.

Montes, Instrucción y regimiento, 1537, fol. XIIr: E no piense nadie que la mucha gente haze la guerra, porque los muchos no se dexan governar de su general como los pocos, por ser la gente mucha, y un solo caudillo no govierna un exército grande como haría un pequeño. Y al tiempo que moviere el campo para marchar, en los passos, y ríos y caminos estrechos no pueden passar en buena orden, como hazen los pocos, y embaráçase. // García de Palacio, Diálogos militares, 1583, fol. 168r: ¿Cómo se podría formar un esquadrón que fuesse apto a pelear, marchar y llevar seguro por lugares peligrosos el carruaje y gente desarmada? // Álaba, Perfeto capitán, 1590, fol. 6v: Y la temperancia que en las comidas es necesaria al buen capitán, pues de los excessos en ellas y desorden de vanquetes suelen resultar pérdidas de muchos reynos, mostró bien Masinisa que, marchando o estando parado su exército, siendo de edad de noventa años, siempre acostumbrava comer a 
mediodía delante de su tienda a vista de todos, sin que hasta esta hora comiesse cosa alguna.

ENCICL.: Cov.: Vale tanto como caminar por la tierra o la mar; y es término militar. // Aut.: Ponerse en movimiento para caminar o hacer viaje. Es voz muy usada en la milicia. // DUE (s.v. caminar): intr. Ir alguien de un sitio a otro en cualquier forma: 'Caminamos durante una semana, unas veces en carros, otras en caballerías y otras a pie'. / / Collado, Plática Artillería (1592: fol. 100r): "Por la misma razón se cargan todos los otros carros de municiones y otras cosas tocantes a la empresa, y los tiran los quatro pares de cavallos dichos, y más, y menos, según la qualidad de los caminos y aun según la priessa o vagar con que marchan los exércitos". // Moretti (1828: s.v. marcha): Táct. Movimiento de un cuerpo de tropas para pasar de un lugar a otro.

medio, V. baluarte.

medio, V. gola.

medio, V. luna.

meliçia, V. milicia.

mercenario, mercenario [tomado del lat. merce(n)narius 'íd.'. Berceo (DECH). Álaba, Perfeto capitán, 1590]. adj. Mil. Dicho de un soldado: que, a cambio de dinero, combate en un ejército extranjero.

Álaba, Perfeto capitán, 1590, fol. 33r: Esto se confirma con el sucesso de los romanos, cuyo imperio floreció en tiempo de Augusto César y començó a caer del más alto lugar que jamás tuvo en abriendo la puerta a soldados mercenarios y estraños, españoles, franceses, y alemanes y de otras naciones. // Álaba, Perfeto capitán, 1590, fol. 33r: Y si en alguno de tres casos que a mi parecer piden el valerse un príncipe de gente estraña: o quando de hazerlo se disminuyen las fuerças del enemigo, o se contentan los aliados, o se granjea la voluntad de los que habitan la tierra donde se a de hazer la guerra, sucediere aver de admitir soldados mercenarios, sea mucho menor el número d'ellos que el de los naturales, porque, si se ofreciere alguna inobediencia de su parte, puedan ser forçados a obedecer y acudir a todo lo que estuviere de hazer a su cargo. // Álaba, Perfeto capitán, 1590, fol. 81r: Del propio ardid y prevención usó Scila aviéndole desamparado sus hombres de armas; y él mesmo, aviendo embiado a algunos de los soldados aliados y mercenarios a que resistiessen cierto daño que el enemigo pretendía hazer, como en la refriega muriessen todos excepto uno y d'esta nueva conociesse averse atemorizado todo su campo, para sossegar sus ánimos mandó pregonar por todo el real que aquellos soldados avían sido muertos por su consejo y traça, porque supo que ellos tenían determinado de seguir el partido de los enemigos. 
2 [Álaba, Perfeto capitán, 1590]. sust. Mil. Soldado que, a cambio de dinero, combate en un ejército extranjero.

Álaba, Perfeto capitán, 1590, fol. 32v-33r: Quando no huviera otro [discurso], bastava lo que cada día vemos en las ocasiones que se ofrecen de hallarse esta mezcla de naciones: que la gloria de la vitoria se reparte entre todos y la nota de ser vencidos es de solos los vassallos del príncipe vencido; pues nunca se dize que los mercenarios fueron causa d'este daño, y siendo su trato acudir a quien mejor se lo pagare, ¿quién duda que sus ánimos han de estar más atentos a que la guerra dure que no a que se acabe, con el peligro o fin de sus vidas, y que, estando fundados en interés, sin otro buen zelo alguno, no estén dispuestos a recebir qualquiera dádiva de los enemigos y ser traydores por ella a la persona en cuyo servicio están?

ENCICL.: Borreguero Beltrán (2000): Soldado u oficial asalariado que sirve en la guerra a un gobierno extranjero. Durante la época moderna, soldados mercenarios estaban al servicio de todos los ejércitos europeos, por ello la característica fundamental de tales ejércitos era su multinacionalidad. Mientras que los españoles no mostraron gran inclinación a combatir como mercenarios, los monarcas Habsburgo españoles tuvieron a su servicio diversos cuerpos de mercenarios extranjeros hasta comienzos del siglo XIX.

merlón, merlón [del it. mèrlo 'almena'. Merlón 'cada uno de los trozos de parapeto que hay entre cañonera y cañonera', cast. ant. merlo. Tanto merlo como merlón en Acad. 1817 (DECH). Roxas, Sumario milicia, 1607]. sust. Fort. Macizo de una batería o de un parapeto comprendido entre dos troneras o cañoneras contiguas (Estévanez 1897).

Roxas, Sumario milicia, 1607, fol. 77r: Ancho del merlón, que es aquel torreón que está en medio de las dos troneras, quando se aya de hechar, que será en parte que no aya batería, a la boca de la casamata, espeçial si cae hazia la mar o a parte preçipitosa que no se pueda poner batería en forma, si no fuere alguna pieça mediana, que esa no haçe al caso, 30 pies. // Roxas, Sumario milicia, 1607, fol. 83v: El merlón, si lo huviere, tendrá la mitad del que se haze en la fortificaçión real; 15 pies.

ENCICL.: Terr.: En la fortificación, el plan del parapeto que hay entre los huecos para los cañones. // Lopes Pires Nunes (2005: s.v. merlão): Cada uma das partes maciças do parapeito de uma fortaleza abaluartada, separadas umas das outras pelo intervalo da canhoneira. O merlão correspondia, na fortificação abaluartada, à ameia da fortificação medieval. // Sanz (1749): Ordinariamente lo ancho del merlón es de nueve pies de parte de las piezas, y de seis de parte de la campaña, su altura es de seis pies y medio, y de dieciocho de espesor.

metator, metator [tomado del lat. mètātŏr, ōris 'el que delimita o mide, medidor', de mētor (Segura Munguía 2001). Roxas, Sumario milicia, 1607]. sust. Mil. ant. En la 
milicia romana, la persona que reparte y distribuye a las tropas y su material de guerra por los distintos cuarteles o posadas de un alojamiento.

Roxas, Sumario milicia, 1607, fol. 22r-22v: Signíferos se llaman los que llevan las banderas, a los quales llamavan dragoneros o alférez; teserarios se llamavan los denunçiadores de los soldados; metatores son los aposentadores; los benefiçiarios se llamaban los entretenidos $[\ldots]$.

ENCICL.: Alemany Bolufer 1917: Mil. Oficial de la milicia romana, encargado de determinar el terreno y colocación del campamento. // Moretti (1828: s.v. metadores): ant. Oficiales del ejército romano, cuyo cargo era adelantarse en las marchas para señalar el terreno del campamento, y trazar el lugar que debía ocupar cada legión, cada centuria, etc.

meter, V. $\sim($ el) asedio.

milicia, meliçia, milicia, miliçia, militia [tomado del lat. mīlŭtŭa. 1140, A. Torre (DECH). Loçano, Alberto, Architectura, 1582]. sust. Arte o técnica que enseña los conocimientos y preceptos necesarios para hacer la guerra.

Loçano, Alberto, Architectura, 1582, pág. 138: Los romanos tenían de costumbre proveer de tal manera a los acontecimientos de la fortuna y del tiempo, que nunca se uviessen de arrepentir, y al soldado no menos le exercitavan en el fortalecer los alojamientos que en toda la demás milicia. // García de Palacio, Diálogos militares, 1583, fol. 8v-9r: En las Indias ya se sabe todo lo necessario al arte militar, assí las partes, subjeto y sciencia que deven tener los officiales de la guerra, como la ordinata de los esquadrones y su buena administración, municiones e instrumentos, su uso y otras muchas curiosidades necessarias en la milicia, para buenos y diversos effectos. // Collado, Plática Artillería, 1592, fol. 2r: Pero Aristóteles en otra differente manera divide en tres partes la milicia, que son éstas: la buena naturaleza de el soldado, la primera; la doctrina, que es la sciencia de la guerra, la segunda; el exercicio y plática, la tercera.

SIN.: arte militar.

ENCICL.: Terr.: Arte militar. // DSAL: Arte y ciencia de hacer la guerra. // Fernández Mancheño (1822): No hay ningún arte que tenga más complicaciones ni necesite de más estudio que éste; por lo que, para ser un militar consumado, es indispensable aplicarse a las ciencias infinitas que abraza desde los primeros años de la juventud hasta la ancianidad, y tal vez no conseguirá pasar de mediano como no tenga un talento superior. // Collado, Plática Artillería (1592: fol. 1r): "Que la milicia, Cathólica y Real Magestad, entre todas las artes y disciplinas que de comodidad y hornamento sirven a los mortales, sea la más alta, más noble, digna y necessaria de todas ellas, no sólo se aprueva por el parescer de los hombres doctos y de todos lo reyes y patriarcas sanctos, los quales se sirvieron de ella como de un conveniente y proprio medio para expeller los enemigos, reprimir los tiranos, castigar los rebeldes, acrescentar las repúblicas $\mathrm{y}$, finalmente, conservarlas, pero aun sabemos que, por castigo de Lucifer y de su superbo vando, fue en 
el cielo impíreo por el mismo Dios Omnipotente y Sumo inventada la milicia, y por aquella angélica y celestial soldadesca en execución puesta".

2 [Apiano, Cosmographía, 1575]. sust. Profesión que ejercen los militares o soldados. Apiano, Cosmographía, 1575, fol. 78v: Éstos, como digo, son de la gente más principal, como en España los hidalgos, y servían a los señores ingas en esta provincia de guarda y reputación y eran los que más se señalavan en la guerra. $Y$, assí, calçavan çapatos y andavan con grandes plumajes y con otras señales de hombres ricos y nobles, ennoblecidos y privilegiados por la milicia. // Álaba, Perfeto capitán, 1590, fol. 34v: El arte en que se exercitavan consideravan los antiguos, aprovando de las mecánicas solas aquéllas que podían ser de provecho para el exercicio de las fuerças y utilidad de la guerra, como son las de los carpinteros, herreros, canteros y otros semejantes, desechando a todos los que tratavan de obras afeminadas y que son comunes a hombres y mugeres, como texedores, confiteros, cereros y otros d'esta manera, por ser inútiles para la milicia a causa de no tener exercitadas las fuerças. // Ferrofino, Descrizión Artillería, 1599, fol. 164v: Últimamente deben advertir los a cuyo cargo está hazer eleçión de los artilleros, por ser la máquina de la artillería tan peligrosa, que sean hombres de mucho ánimo y pláticos en la miliçia, ábiles de inguenio, para que puedan prebenir con diligenzia y presteza ejecutar las cosas tocantes a este ministerio.

SIN.: soldadesca.

3 [Martínez de Burgos, Reportorio premáticas y Cortes, 1551]. sust. Grupo regular y organizado de soldados (DEA: s.v. tropa).

Martínez de Burgos, Reportorio premáticas y Cortes, 1551, fol. XLVr: Es nuestra merced y voluntad, y mandamos que, de aquí adelante, el nuestro receptor general, de las penas pertenescientes a la nuestra Cámara, no libre a ningún corregidor ni official de milicias maravedís algunos de los que Nos les mandaremos dar de merced o de ayuda de costa en las dichas penas, salvo que los pague de los maravedís de nuestra Cámara que vinieren a su poder. // Mendoça, Theórica y práctica, 1596, pág. 61-62: Significo a Vuestra Alteza esta opinión, para que de ninguna manera permita que sus milicias de a cavallo dexen las lanças, pues aunque no lo persuadiera otra razón que el aver acostumbrado todas las naciones muchos siglos el traerlas la gente de a cavallo, y continuado después de averse hallado la invención de la pólvora y hecho prueva de su violencia, es bastante demonstración del ser la mejor arma para la gente de a cavallo. // Ufano, Tratado de la Artillería, 1613, pág. 106: Y en pos del dicho, marchará el común y particular vagaje de la miliçia que marcha de banguardia y parte de la batalla.

SIN.: gente, gente de (la) batalla, gente de guerra, gente de pelea, gente militar, tropa.

ENCICL.: DRAE: Tropa o gente de guerra. 
4 [Mendoça, Theórica y práctica, 1596]. sust. Mil. Cuerpo que se establece excepcionalmente y que está formado por personas que carecen de instrucción militar, el cual toma las armas sólo en caso de necesidad.

Mendoça, Theórica y práctica, 1596, pág. 17: [Se ha de considerar] si es monarchía y rey electivo y consiste más su autoridad en el cuerpo y boz de los prelados, nobles y ciudades del reyno, que no en la persona real, no pudiendo hazer milicias, ni otra ninguna ley, ni poner tributos ni pechos sin consentimiento de los miembros del reyno hallándose en cortes. // Lechuga, Discurso de la Artillería, 1611, pág. 278-279: Que en todas las provincias aya artilleros obligados a saber y a servir en ocasiones, y un gentilhombre en cada una, pues a Vuestra Magestad le será fácil tenerlos como soldados de milicia, concediendo a tantos como le pareciere la franqueza y essenciones que fuere servido.

ENCICL.: Aut.: (s.v. milicias): Se llaman los cuerpos formados de vecinos de algún país o ciudad, que se alistan para salir a campaña en su defensa, cuando lo pide la necesidad y no en otra ocasión. // Sanz (1749: s.v. milicias): Son tropas formadas de los vasallos del rey para guarnecer los estados mientras las veteranas están en alguna expedición, por cuyo medio se defiende el insulto que pudieran hacer los enemigos si no las hubiese. Todas las provincias están obligadas a contribuir con el número de gente que a proporción les señala el príncipe, tanto para defensa del reino como para reemplazar las de campaña. // Estévanez (1897): El uso ha desnaturalizado un tanto su significación desde que se aplicó a "reservas", como las antiguas milicias provinciales y a fuerzas populares como la Guardia Nacional, la Guardia Urbana, la Guardia Cívica y la Milicia nacional. Todas estas milicias que prestaron servicios importantes en varias ocasiones carecían de disciplina y de instrucción militar, por lo que las gentes dieron a la palabra milicia un sentido antimilitar. // DEA: Cuerpo armado, gralm. de carácter paramilitar. Frec con un adj especificador: burguesa, popular, provincial, nacional, etc.

\section{miliçia, V. milicia.}

militar ${ }^{1}$, militar [tomado del lat. mìlĭtare 'practicar el ejercicio de las armas'. Alonso de Palencia; Quijote; Aut. (DECH). García de Palacio, Diálogos militares, 1583]. v. intr. Profesar la milicia o combatir en una guerra bajo el mando de un determinado ejército.

Álaba, Perfeto capitán, 1590, fol. 36v: Y de aquí procedió el vencer Marco Marcelo a Aníbal porque, siendo sus soldados los más valientes de quantos militavan debaxo del poder de los príncipes y capitanes de aquel tiempo, en Capua se debilitaron y entorpecieron con el trato y excesso d'este vicio, de suerte que todo su valor se convirtió en torpeza y poca osadía. // Rojas, Teórica fortificación, 1598, fol. 32v: Si Carlo Teti y Gerónimo Catanio bolvieran a escribir el día de oy, aviendo militado con los soldados d'este tiempo y considerando bien la materia de trincheas y sobre todo el mayor enemigo, que es la zapa (que es en español azada y la milicia la nombra con vocablo italiano), estoy cierto que acomodaran sus fortificaciones más recogidas y con menos frente que aquéllas que escrivieron en sus libros. // Ufano, Tratado de la Artillería, 1613, pág. 115: Esso, en verdad, mejor lo sabrá Vuestra Señoría, aviendo sido tanto tiempo soldado y militado en las 
guerras de Saboya y de Ungría, y assí sería esso enseñar el dicípulo ynábil al maestro y corrector de tanta experençia y discurso en casos militares.

ENCICL.: Cov. (s.v. militar): Puede ser verbo y vale ser soldado debajo de algún príncipe o capitán. // Aut. (s.v. militar): v. n. Servir en la guerra, ejercitarse en la milicia.

militar ${ }^{2}$, militar [tomado del lat. mîlĭtaris 'perteneciente al soldado o a la guerra', derivado de miles, -itis. h. 1440, A. Torre (DECH). Montes, Instrucción y regimiento, 1537]. adj. De la milicia, del ejército o que tiene relación con ellos.

Montes, Instrucción y regimiento, 1537, fol. IVr: Y éstos vayan por toda la provincia a hazer la gente, y la gente que hizieren sea la más usada al exercicio de las armas que se pudiere haver y sean hombres de buena casta: sueltos, ligeros, y ábiles en sus personas, de buena conversación y criança y los que son desseosos del exercicio militar, que son hombres de buen género, desseosos de ganar honra. // Álaba, Perfeto capitán, 1590, fol. 52v: Traían también lista de la gente de a pie y de a cavallo que avía, notando quáles d'éstos eran de mayores fuerças y exercicio en la diciplina militar, para que d'ello se coligiesse el puesto que el enemigo escogería para batalla y el que a ellos les estaría mejor elegir. // Rojas, Compendio fortificación, 1613, fol. 40v: Conviene mucho que el tal ingeniero sea arquitecto prático, y que lo sea antes que vaya a la guerra, porque en ella no puede aprender sino cosas militares, las quales, juntas con la Arquitectura, hazen al ingeniero capaz del arte que professa.

ENCICL.: DUE (s.v. militar1): Por oposición a "civil", de la milicia o del ejército. // Zerolo (1895: s.v. belicoso): Todo lo que concierne a la ciencia de la guerra, lo que es necesario para hacerla bien, lo que tiene relación con la administración de un ejército es militar. El arte militar, la disciplina militar, ejercicios militares. Se dice hazañas, empresas militares y no guerreras porque estas dos palabras suponen grandes designios y grandes combinaciones, todo lo cual pertenece rigurosamente al arte militar. Se suele decir virtud guerrera y también virtud militar; la primera será, pues, la que se ejerza en el campo de batalla y la segunda tanto en el campo cuanto en los ejercicios militares, por medio de la exactitud, la subordinación, el amor a la buena disciplina y por la escrupulosa observancia de las leyes, ordenanzas y reglamentos. No se dice talentos guerreros, pero sí militares porque la palabra talento se refiere aquí al arte, a la ciencia. Valor guerrero es el que se despliega en la acción misma, y por medio de ella en el instante del peligro y que con él cesa. El valor militar es un valor habitual que proviene del mismo ejercicio de la milicia formando su principal calidad.

2 [García de Palacio, Diálogos militares, 1583]. sust. Persona que pertenece al ejército o que está especializada en hacer la guerra.

García de Palacio, Diálogos militares, 1583, fol. 91v-92r: De las chrónicas e historias griegas y romanas se sabe cómo, entendiendo bien los antiguos militares quán nescessaria cosa era el premio, honor para los buenos hechos de la guerra, inventaron tropheos, triumphos, nombres, coronas, previlegios, immunidades, arcos, estatuas y otras cosas que enseñasen a los siglos venideros que la virtud en la guerra tenía y conservava inmortal memoria, paga 
y honrra. // Roxas, Sumario milicia, 1607, fol. 29v: Y que se guarde el exérçito de no beber aguas dañosas ni encharcadas, aunque, como diçen los sabios militares, la mejor mediçina de todas es el exerçiçio de cada día, que no la que dan los médicos, porque la costumbre del travajo en los reales puede dar salud y en la batalla vitoria.

SIN.: defensor, guerrero ${ }_{2}$, hombre, hombre de (la) guerra, hombre de pelea, hombre de soldadesca, hombre militar, mílite 1 , soldado.

ENCICL.: Terr.: sust. El soldado u hombre de guerra. // D'Wartelet (1863: s.v. militar): El que profesa la carrera de las armas, sea la que sea su clase y graduación.

militar, V. arquitectura $\sim$.

militar, V. arte $\sim$.

militar, V. empresa $\sim$.

militar, V. gente .

militar, V. hombre .

militar, $V$. ingeniero $\sim$.

mílite, mílite [tomado del lat. miles, -itis. El latinismo crudo mílite (1578, Ercilla; Aut. lo registra h. 1600) es raro (DECH). Juanelo Turriano, Veinte y un libros, a. 1605]. sust. Persona que pertenece al ejército o que está especializada en hacer la guerra.

Juanelo Turriano, Veinte y un libros, a. 1605, fol. 420r: Y aunque las cosas de Architectura se hallen escritas en cosas de milicia, no por esso son ellas hechas por hombres de miliçia; de modo que las cosas de la milicia primero las fabrican los artífices, antes que las exercite el soldado, ni el cavallero, ni el artillero. De modo que si el artífice no las hiziesse, el mílite no se serviría d'ellas. // Ufano, Tratado de la Artillería, 1613, pág. 77: Çiertamente, señor, se suele competir y disputar entre mílites este puncto, pero sé dezir a Vuestra Señoría que no ay ley precisa ni regla sobre ello. // Ufano, Tratado de la Artillería, 1613, pág. 197: Demás d'esto deve entender el curioso mílite que esta dicha contrabatería que sale por la frente del baluarte no sólo puede servir su effeto por tal parte.

SIN.: defensor, guerrero 2 , hombre, hombre de (la) guerra, hombre de pelea, hombre de soldadesca, hombre militar, militar ${ }_{2}^{2}$, soldado. 
2 [Celso, Reportorio universal leyes Castilla, 1553]. sust. Mil. ant. Soldado que sirve, marcha y combate a caballo.

Celso, Reportorio universal leyes Castilla, 1553, fol. LXIr: Los antiguos llamaron a los cavalleros mílites porque los escogían d'entre mil fuertes hombres.

ENCICL.: Cov. (s.v. militar): Dijéronse mílites los caballeros porque han de ser escogidos uno entre mil.

militia, V. milicia.

mina, mina [probablemente del fr. mine 'íd.' y éste procedente de un galo *mina, celta primitivo *mein-, conservado hasta hoy en los idiomas célticos insulares, con el significado de 'mineral' y en la forma *mēn. 2. ${ }^{\text {a }}$ mitad s. XIII, raro hasta fines del XV (DECH). Montes, Instrucción y regimiento, 1537]. sust. Fort. Pasaje subterráneo en el que se ponen, al fin de él, materiales incendiarios o explosivos, para que dándoles fuego arruinen las fortificaciones o defensas del enemigo. (fig. 109) Montes, Instrucción y regimiento, 1537, fol. XIXr: Y en el hazer de la mina, si la tierra es pantanosa y manantial, no se podría hazer minas; mas si la tierra es arzilla, o greda, o arenosa, puédese hazer la mina; mas en el hazer del horno debaxo del centro del torreón es menester que lo haga el ingeniero, porque otro ninguno no lo acertaría. // Álaba, Perfeto capitán, 1590, fol. 256v: Aunque la traça de las minas en estos tiempos es la mesma que en los passados, los efetos son de mayor importancia, por la violencia notable con que los materiales que en ellas se ponen desbaratan y asuelan qualquier lienço de muro o fortaleza, por fuerte y inexpugnable que parezca. // González de Medina, Examen fortificación, 1599, pág. 10-11: Mas, con todo, esto se tienen por mejor las fuerças en llano por estar seguras de minas, porque si se comiençan hazer de cerca, son luego echadas de ver de los que defienden la fuerça, y ponen remedio en ello con salirles con una contramina a encontrar la suya; si de lexos, pássase mucho tiempo y trabajo, y el foso y refosete que están alrededor de la fuerça les impide mucho.

SIN.: cunículo.

ANT.: contramina.

FAM.: contramina, contraminado, contraminar, minable, minado, minador, minar.

ENCICL.: D'Wartelet (1863): Cavidad subterránea, excavación o pozo que se abre debajo de tierra, bien sea para llegar hasta el enemigo o para destruir las murallas y toda clase de obras de fortificación. La invención de las minas, consideradas en general, no es de los tiempos modernos [...]. Los antiguos conocieron dos clases de minas: la primera fue una galería subterránea que, abierta muchas veces a una gran distancia, conducía al sitiador hasta el interior de la ciudad; la segunda servía para abrir las brechas excavando debajo de 
la muralla por medio de la zapa, sosteniendo después su techo con puntales o pies derechos que envolvían con materias combustibles y, aplicándolas fuego, se retiraban, los puntales ardían y se consumían y la muralla, falseada por debajo de sus cimientos, se hundía por su propio peso. Esta costumbre siguió por mucho tiempo, aun después de haber aplicado la pólvora a los usos de la guerra. En el sitio de Serazanella en 1487, aunque de una manera imperfecta, se intentó la mina de voladura por medio de la fuerza explosiva de la pólvora. El famoso ingeniero español Pedro Navarro, compañero del Gran Capitán, presenció el ensayo y, después de estudiarlo y mejorarlo, lo repitió con buen éxito en la conquista de Cefalonia. La explosión de una mina cargada con barriles de pólvora, en 22 de julio de 1503, abrió una ancha brecha en los muros de Nápoles facilitando a los españoles la posesión de la plaza. El nombre de Navarro corrió con aplauso por la Europa entera, y pronto adoptaron las demás naciones el terrible uso de las minas. Con ellas se derribaron las contraescarpas, se abrieron brechas o hicieron más practicables las que había comenzado el cañón [...]. La galería que abre el sitiador se llama propiamente mina; a la que construye el sitiado, contramina. // Lucuze (1772: 48): "La mina, o contramina, se compone de galería, ramales y cámara del hornillo".

2 [Collado, Plática Artillería, 1592]. sust. Fort. Concavidad o hueco que se abre en el final de la mina, donde se mete la pólvora u otra materia explosiva con la que se pretende volar una fortificación.

Collado, Plática Artillería, 1592, fol. 63r: Y deve, assimismo, muy bien considerar el intento que le mueve a hazer el tal officio, conviene a saber, que o se pone a él por sólo abrirse bocas a la contrascarpa y meterse en el fosso a picar la muralla enemiga o quiere, passando por debaxo de el fosso, hir a hazer la mina debaxo de ella. // Lechuga, Discurso de la Artillería, 1611, pág. 269: A mi pareçer, [puede fallar] quando no se fabrica bien el escaño o banco, o quando los maderos no se hazen bien, cosas en que se ponen los barriles de la pólvora dentro del hueco que llaman mina o hornillo de ella.

SIN.: hornillo 1 , horno.

3 [Rojas, Teórica fortificación, 1598]. sust. Fort. Hueco practicado en el espesor de una muralla, donde se pone una materia explosiva para volar y arruinar esa fortificación.

Rojas, Teórica fortificación, 1598, fol. 32r: Al tiempo que el enemigo ha metido sus trincheas hasta el bordo de la estrada cubierta (como parece en la planta que queda atrás), y quiere passar el fosso por el derecho de la esquina del valuarte y arrimarse a él para picarlo y hazerle la mina, si estuviesse la defensa a tiro de artillería, passarían los enemigos, uno a uno, casi al descubierto, por ser muy lexos la defensa. // Rojas, Teórica fortificación, 1598, fol. 50v: Y esto lo digo como testigo de vista, porque he hecho minas en ambos terraplenos, y en el que estava sin fagina se hizo la mina en una noche, y en otro terrapleno que tenía fagina no la pudimos hazer en quatro, porque las ramas y troncones nos embaraçavan mucho, y debaxo de la tierra no se puede hazer fuerça, ni dar buelo a las herramientas para cortar, por ser tan estrecho aquel lugar donde se haze el hornillo. // Roxas, Sumario milicia, 1607, fol. 103v: Y estando ya el foso çiego y hecho ya en él un dique de quarenta o çinqüenta pies de ancho, se yrá haçiendo ençima un trincherón muy grueso, 
que tenga 20 pies de groseça, para resistir el artillería que le tiraren de la casamata; y llegado al baluarte, se le abrirá el hornillo o mina, como se suele hazer.

SIN.: hornillo ${ }_{2}$.

ENCICL.: Domínguez (1853): Cavidad subterránea practicada debajo de un baluarte, de una muralla, de una roca, etc., para hacerla saltar en pedazos por medio de la pólvora.

minable, minable [de minar. Collado, Plática Artillería, 1592]. adj. Fort. Dicho de un terreno: que en él pueden llevarse a cabo trabajos subterráneos para formar una mina.

Collado, Plática Artillería, 1592, fol. 63r: Y a considerado, assimismo, si era minable o no el sitio, lo que él podrá saber haziendo primero juyzio de algún pozo, si alrededor se halla hecho y, si no, lo haga hazer él mismo, el qual tenga tanta hondura quanto ha de ser hondo el suelo o llano de la mina; por la fábrica del qual pozo él podrá certificarse de la qualidad de el terreno, si es gredoso o arenoso, si hay peña que le haga impedimento. // Collado, Plática Artillería, 1592, fol. 63v: He querido hazer esta digressión para dar a entender cómo, por ser minable aquel sitio, la fortificación dicha no huvo effecto y que ni aquella costra de peña ni otra alguna asseguran de no poder ser minada una fortaleza, por quanto siempre debaxo de aquélla, como dicho es, se halla o cascajo o greda, la qual es aptíssima a ser minada.

FAM.: contramina, contraminado, contraminar, mina, minado, minador, minar.

minado, minado [de minar. Álaba, Perfeto capitán, 1590]. adj. Fort. Dicho de la construcción defensiva de un grupo de personas: con minas abiertas bajo ella.

Álaba, Perfeto capitán, 1590, fol. 93v: Los de Apolonia, sabiendo que sus enemigos los tenían minados y el lugar por dónde, echaron por unos agujeros que passassen a la mina un cozimiento de agua hirviendo y pez encima, con que no sólo destruyeron la mina, mas dieron la muerte a los que en ella estavan. // Álaba, Perfeto capitán, 1590, fol. 93v-94r: Los ambracienses, sintiéndose minados, pusieron un vaso de hierro muy grande en el remate de la mina de los enemigos $\mathrm{y}$, cubriéndolo y poniéndole una cubierta agujerada en diversas partes, estando lleno de pluma, le acomodaron una caña, en la qual pusieron un poco de fuego que soplando con un fuelle encendió la pluma, de que salió tanta cantidad de humo y mal olor que los forçó a desamparar la mina y a los que no lo hizieron causó la muerte. // Collado, Plática Artillería, 1592, fol. 68r: Sabido, pues, que él trae contramina, conviene salirle al encuentro por estorvarla y no incurrir en el peligro de ser minado y recibir el daño que se preparava para otro.

ANT.: contraminado.

FAM.: contramina, contraminado, contraminar, mina, minable, minador, minar. 
minador, minador [de minar. Nebr. (DECH). Lechuga, Discurso de la Artillería, 1611]. sust. Fort. Persona que se dedica a hacer pasajes subterráneos o minas.

Lechuga, Discurso de la Artillería, 1611, pág. 228: Y siendo assí, mire el general de la artillería lo que estará obligado a hazer para salir con las que emprendiere con ella, siendo servido de artilleros, carreteros, marineros, minadores y gastadores, toda gente que sirve por solo interés, y que entre toda ella ay muy pocas personas que hagan cosa por el premio de gloria que esperan. // Ufano, Tratado de la Artillería, 1613, pág. 100-101: A todos estos maestros se les da ayudantes: çinqüenta minadores con su cabo y artíffiçe; dos maestros de carretería; dos toneleros; más, otros treinta carpinteros extraordinarios con su maestro yngeniero. // Ufano, Tratado de la Artillería, 1613, pág. 266: Y meterá la esquadra y con ella el cordel, estacas y la calamita a nivel, justamente tomada la reta vía del dicho primero rumbo, y de tal modo caminar los passos que faltan con la dicha obra, la qual prática creo bastará con lo que se muestra por figura, para que los práticos minadores y artíffiçes consigan el fin que en tal arte se pretende.

FAM.: contramina, contraminado, contraminar, mina, minable, minado, minar.

ENCICL.: DRAE: Ingeniero o artífice que abre minas. // Sanz (1749: s.v. minadores): Son soldados destinados para el trabajo de las minas [...]. Cuando los minadores trabajan se cubren con un capote en forma de capuz para defender la vista de la tierra y polvo.

minar, minar [de mina. Nebr. (DECH). Montes, Instrucción y regimiento, 1537]. v. tr. Fort. Alcanzar con una mina la construcción defensiva que se quiere destruir o volar.

Montes, Instrucción y regimiento, 1537, fol. XIXr: Por esto, el que ha de fraguar un castillo ha de mirar estos inconvenientes, que, antes que eche los cimientos, deve hazer las contraminas, porque el castillo no pueda ser minado. // Álaba, Perfeto capitán, 1590, fol. 256v: Y el modo con que una mina se encaminará es éste: sabida la distancia orizontal, que es lo que ay desde el lugar donde quiero que comience la mina hasta el que tengo de minar [...], lo que con mayor cuydado se a de procurar es continuar la línea del espacio que halló, que es el que sale del punto donde comiença la mina hasta el lugar que se a de minar, de suerte que vaya derecho caminando por ella sin inclinar más a una mano que a otra, pues en esto consiste el poner con puntualidad en execución su intento. // Collado, Plática Artillería, 1592, fol. 63v: Solamente tres cosas hazen no poderse minar un sitio, que son: o estar fundada la fuerça sobre peñasco que sea alto, gruesso y muy maciço, o que tenga manantial en el fosso, como del castillo de Milán se dixo, o río tan caudaloso de entorno que no le pueda ser divertido ni quitado.

FAM.: contramina, contraminado, contraminar, mina, minable, minado, minador.

ENCICL.: Rubió y Bellvé (1895-1901): Abrir galerías de mina y poner, en lugares convenientes de ellas, hornillos para volar muros, edificios, etc. 
2 [Álaba, Perfeto capitán, 1590]. v. tr. u. t. c. intr. Fort. Excavar o hacer trabajos subterráneos en un terreno para formar la mina.

Álaba, Perfeto capitán, 1590, fol. 257r: Y apartándose del lugar donde començó a minar en línea recta un punto atrás hará la entrada o boca de la mina, baxando por ella como por gradas hasta venir a dar al primer hoyo. Y si la tierra fuere movediza, con tablones y puntales se hará firme la baxada, y lo mesmo se hará en todas las otras partes que se fueren minando, si el alto d'ellas no fuere tierra firme. // Álaba, Perfeto capitán, 1590, fol. 257v: Y siguiéndose derecho por este cordel y por el plano del nivel, quando se huviere minado la distancia verdadera que ay del primer hoyo hasta la torre, dirá el que mina que está debaxo de la perpendicular que atrás figuré salir de la torre y hazer ángulo recto con el estremo de lo que se a minado, que será lo mesmo que el remate de la línea orizontal. // Collado, Plática Artillería, 1592, fol. 65r: La causa por que, labrando la vía de la mina dicha y llegando al punto $C$ por línea recta, nos bolvimos con la vía a la parte de tramontana y minamos la parte $\mathrm{C} D$, que fueron 23 passos, fue porque, si acaso viniere contraminándonos el enemigo, por lexos que él venga de nuestra mina, o será de nos sentido o, por fuerça, vendrá a desbocar con su mina a la buelta dicha.

ANT.: contraminar.

ENCICL.: Fernández Mancheño (1822): Cavar, abrir camino por debajo de tierra.

3 [Ufano, Tratado de la Artillería, 1613]. v. tr. Fort. Colocar una carga explosiva en el hueco hecho previamente en una muralla, para volarla.

Ufano, Tratado de la Artillería, 1613, pág. 57: De modo que, arrimada al pie exterior del torreón, ofenda gravíssimamente la percusión de tal bala o artiffiçio a la gente del enemigo que a su pie se arrimare para çapar, picar y minar su muralla. // Ufano, Tratado de la Artillería, 1613, pág. 341: Propone la escuela el siguiente exemplo de que al artillero se le ofrece trabucar balas ardientes o armadas, bombas, granadas y otros qualesquier artifficios de fuego, o simples balas de piedra o disformes guijarros y otras semejantes cosas sobre los enemigos que acaso se le vayan arrimando con la çapa para picarle y minarle el muro.

modorra, modorra [de modorro y éste de origen incierto. Nebr., modorra "la segunda vela" (DECH). Mendoça, Theórica y práctica, 1596]. sust. Mil. Segunda de las cuatro partes en que los centinelas dividen las noches.

Mendoça, Theórica y práctica, 1596, pág. 152: Acordado el número de gente con que se ha de dar la escalada, se ha de juntar, después de cerradas las puertas, si sale toda la gente de una tierra y, si no, señalar puesto y hora donde se ha de hallar; y esto, según a la que se ha de efetuar, si ha de ser a la hora de la centinela que llaman modorra, o antes, o a la diana. // González de Medina, Examen fortificación, 1599, pág. 182: Bolviendo a la que de ordinario ha menester para servirse, tendría por acertado que no se tuviesse con menos soldados que de quatrocientos y cincuenta a quinientos, por razón de que cada cortina requiere dos centinelas, que son diez; los baluartes, tres cada uno, que son quinze [...]; que, aviendo de remudarse los de prima a la modorra, y los de la modorra, los del alva, vienen 
a ser menester entrar cada noche de guardia para este servicio ciento y quarenta y siete soldados [...].

ENCICL.: Nebr. (1495: s.v. modorra la segunda vela): Vigilia secunda. // La forma lexicalizada modorrilla es también un tecnicismo militar, pues designa, como bien afirma el DRAE, el "tercero de los cuartos en que para los centinelas se dividía la noche, comprendido entre el de la modorra y el del alba". Ahora bien, mientras que las otras tres partes de la noche (el primer cuarto o prima, el segundo o modorra y el cuarto o alba), según el sistema manejado por la vigilancia militar, sí cuentan con ocurrencias en nuestro corpus, no sucede lo mismo con la tercera parte o modorrilla.

montaraz, montaraz [de monte y éste del lat. mons, montis. 'Guardabosque' (doc. vallisoletano de 1140, M. P., D. L.), 'mayordomo de campo' (R. de Reinosa, fin del s. XV, Philol. Q. XXI), 'leñador que fabrica carbón' (en el argentino Ascasubi, S. Vega) (DECH). Celso, Reportorio universal leyes Castilla, 1553]. sust. Fort. Cualquier vela, tanto la principal como la sobrevela, que desarrolle su labor de vigilancia nocturna en un recinto fortificado.

Celso, Reportorio universal leyes Castilla, 1553, fol. CCXXIIIv: Montarazes, llaman a las velas e sobrevelas que tienen los alcaydes en los castillos.

motín, motín, mutín [del fr. med. mutin 'íd.', sustantivación del adjetivo mutin 'revoltoso', antes meutin, derivado del fr. ant. muete 'rebelión, motín', y éste del lat. mŏvĭta 'movimiento'. h. 1580, A. de Morales, H. de Mendoza, Aut. (DECH). Micón, Diario grande cometa, 1578]. sust. Mil. Movimiento colectivo de protesta contra la autoridad, por lo común por parte de una tropa hacia sus superiores.

Micón, Diario grande cometa, 1578, pág. 105: Como aconteció en semejante coyuntura, año de 1538, del cometa que apareció en Pisces [...], a donde passó el segundo año después de Carlos 5, de gloriosa memoria, sojusgando a la rebellada ciudad de Gante y prendiendo a las cabeças de los que avían sido la causa del motín, quitándoles por ello privilegios y libertades muchas. // Mendoça, Theórica y práctica, 1596, pág. 35-36: Esto obliga en los levantamientos de las ciudades y provincias, o motines de gente de guerra, a castigar los que les dieron principio y movimiento siendo autores d'ellos, perdonando, en general, a los demás, pues no es possible castigar la multitud. // Mendoça, Theórica y práctica, 1596, pág. 108: Ofreciéndose el aver de levantar el sitio por motines de la gente, faltándole pagas, ruynes temporales que acaban un exército, o por rezelo del aver reforçado el enemigo y disminuydo las fuerças propias, y otras muchas consideraciones que puedan obligar a ello, se entiende lo primero en retirar la artillería y municiones.

SIN.: levantamiento de guerra.

FAM.: amotinador, amotinar. 
ENCICL.: Cov.: La alteración de soldados y gente de guerra [...]. Esto suele suceder por deberles muchas pagas, y particularmente en los que son conducidos en forma que están siempre aparejados para quien mejor partido les hiciere. // Hevia (1857): Se llamaba así, en la antigua milicia española, al tropel o tumulto que promovían las tropas insubordinadas, ya por queja de que no se les pagaban sus haberes o ya por cualquier otro motivo. // D'Wartelet (1863): Son notables en la historia los motines de los soldados españoles en el siglo XVI en los Países Bajos, cuando exigían el pago de los sueldos atrasados. Fuera del acto culpable de insubordinación, todo se ejecutaba con el mayor orden. Tomaban por jefe a uno de los insurrectos, a quien llamaban electo, y nombraban un consejo militar, que tenía el encargo de evitar los desórdenes castigando con el mayor rigor los excesos que se cometían, mostrando así que si se veían obligados a pedir a la fuerza los atrasos de uno o más años, no por eso toleraban la licencia. Para mantenerse imponían contribuciones de víveres y de dinero a los habitantes del territorio. Contrasta este proceder con el de los soldados extranjeros, que siempre esperaban a amotinarse en vísperas de una batalla u otro acontecimiento importante.

muestra, muestra [de mostrar y éste mōnstrāre. 1288, Acedrex.; s. XIII, Buenos Prov.; J. Ruiz; Conde Luc. (DECH). Álaba, Perfeto capitán, 1590]. sust. Mil. Revista o inspección de una tropa o fuerza para comprobar su estado.

Álaba, Perfeto capitán, 1590, fol. 151r: Conqueridor era el que estava presente a las muestras y reseñas de los soldados. / / Collado, Plática Artillería, 1592, fol. 100r-100v: Vistos por los generales los cavallos y admitidos aquéllos que serán buenos y excluydos los otros, el commissario de la muestra los herrará y marcará todos con el marco o hierro por el general del artillería diputado, lo qual se haze para que por aquel hierro sean conoscidos los cavallos del servicio; y que aquellos cavallos qu'el día de la muestra fueron presentados y passados por buenos no le sean trasportados fuera del exército y en su lugar traýdo otros inútiles y de poco servicio, como muchas vezes se ha hecho. // Mosquera, Comentario disciplina militar, 1596, fol. 76r-76v: Gastose todo el día sin cessar hasta la noche en las escaramuças de una y otra parte, y de los nuestros saldrían muertos y heridos más de quatrocientos hombres, como después pareció por la muestra que se hizo de la gente de todo el exército.

SIN.: alarde1, reseña.

ENCICL.: Aut.: En la milicia significa la reseña que se hace de la gente de guerra, para reconocer si está cabal o para otras cosas. // Almirante (1869): La frase técnica no era "pasar muestra", como algunos dicen, sino "tomar muestra". / / Collado, Plática Artillería (1592: fol. 101r): "Le toca de hallarse con todos los demás officiales presente a tomar la muestra y veer si se hallan tantos hombres, tantos cavallos y carros de servicio como se pagan en aquel estado; veer si estos hombres, cavallos y carros son todos ellos aptos y sufficientes para servir en sus officios".

munición, munición, muniçión [tomado del lat. mūnittio, -onis 'trabajo de fortificación', derivado de munire y éste a su vez de moenia. APal. En la ac. de 
'bastimentos, pertrechos en general' ya en Mariana, h. 1600 (DECH). Montes, Instrucción y regimiento, 1537]. sust. u. m. en pl. con el mismo significado que en sing. Mil. Pertrechos y bastimentos necesarios en un ejército o en una plaza de guerra (DRAE).

Montes, Instrucción y regimiento, 1537, fol. VIr: Y de las vituallas que vinieren al exército, hágase casa de munición y gástese por orden, de manera que no haya falta en el exército; y gástense de contino las vituallas más viejas, gastándose de continuo las más frescas para la postre, porque d'esta manera se conservará la vitualla y el exército será sustentado. // Álaba, Perfeto capitán, 1590, fol. 86r: Y aunque el cerco de muchos d'estos fuertes, ofreciéndose ocasión, es justo que se emprenda, esto a de ser en caso que cerca d'ellos aya alguna montaña, lugar alto o padrastro de donde se pueda juzgar lo que huviere dentro y la artillería pueda jugar, o estén faltos de bastimentos y otras municiones, o se les pueda quitar el agua, o los soldados sean advenedizos y mal pagados, porque todas estas cosas, lo que fuere de suyo inexpugnable, harán fácil de allanar. // González de Medina, Examen fortificación, 1599, pág. 48: Los magazenes se harán a buen arbitrio mayores o menores, conforme a las municiones que se huvieren de poner en ellos, assí para defensa de la fortaleza como para comida y bebida, con que se advierta que pueden hazerse debaxo de tierra y tomarse el espacio que se quisiere, con que las del vivir se han de poner de la parte que bate el ayre.

FAM.: amunicionar, municionero.

ENCICL.: DSAL: (preferentemente en plural) Conjunto de provisiones y material de guerra de los ejércitos. // Aut.: Divídense en municiones de boca y municiones de guerra. // Almirante (1869): Esta voz, puramente latina, ha restringido en el día su antigua y lata significación [...]. En rigor, la palabra sola municiones ya no comprende hoy más que la pólvora y proyectiles para el servicio exclusivo de las armas de fuego. // Collado, Plática Artillería (1592: fol. 81v): "Acostúmbrase, assimismo, para el effecto dicho de alumbrar de noche la campaña, hazer una zebratana de cobre o de madera, la qual sea derecha lo más que se pueda y de dos varas o dos y media de largueza, y que en el hueco d'ella pueda caber un cohete de 5 ó 6 onças de munición y passar holgado por ella".

de guerra [Apiano, Cosmographía, 1575]. cmpt. sintag. u. m. en pl. con el mismo significado que en sing. Mil. Toda clase de materiales e instrumentos, como pueden ser armas o máquinas, necesarios para cualquier empresa militar.

Apiano, Cosmographía, 1575, fol. 36r: Ay, más, muy ricos templos, sabios regidores, grand fortaleza en las murallas y abundançia de toda munición de guerra. // Lechuga, Discurso de la Artillería, 1611, pág. 232: El dicho general de la artillería avrá de ir una vez cada año, o embiar su teniente o gentilhombre, a las villas de fronteras y castillos a visitar el artillería y municiones de guerra y llevar, el uno, al contador, y el otro, al recividor, trayendo por escrito lo que hallaren gastado o dañado / / Ufano, Tratado de la Artillería, 1613, pág. 138: Tócales yr a las villas y lugares con partidas de carros, a traer provisión de muniçiones de guerra y llevar recaudo y serviçio de todo menester a las baterías.

SIN.: aproche, aproches de guerra, pertrechos, pertrechos de guerra. 
ENCICL.: Aut. (s.v. munición): Las [municiones] de guerra se reducen a todo género de armas defensivas y ofensivas, vestidos y otros pertrechos. // DRAE (s.v. municiones de guerra): pl. Mil. Armas ofensivas y defensivas, pólvora, balas y demás pertrechos.

del sustento [Ufano, Tratado de la Artillería, 1613]. cmpt. sintag. u. m. en pl. con el mismo significado que en sing. Mil. Conjunto de comestibles destinados a la alimentación de un ejército.

Ufano, Tratado de la Artillería, 1613, pág. 120: Quando se va a sitiar una plaça por maravilla se hallará ningún general del artillería, por vía d'espías y especuladores, no tenga bien entendido si dentro d'ella el enemigo se halla con gruesas pieças de artillería o pequeñas, muchas o pocas, y si tiene bastantes muniçiones o penuria, tanto de las de guerra que de las del sustento.

SIN.: bastimento, bastimiento, munición del victo, vitualla, víveres.

ENCICL.: Aut. (s.v. munición): Las [municiones] de boca son los bastimentos y provisión para comer. // DUE (s.v. munición [o municiones] de boca): Víveres del ejército.

$\sim$ del victo [Ufano, Tratado de la Artillería, 1613]. cmpt. sintag. u. m. en pl. con el mismo significado que en sing. Mil. Conjunto de comestibles destinados a la alimentación de un ejército.

Ufano, Tratado de la Artillería, 1613, pág. 83: Todo se haze así por aligerar el coste de carros, caballos y conductores, en espeçial siendo penuria de gente y dinero y el prínçipe de la empresa no muy rico y poderoso; pero siéndolo, mucho mejor sería con exérçito cumplido y poderoso llevar de una vez toda la provisión de muniçiones, así del bito como de guerra.

SIN.: bastimento, bastimiento, munición del sustento, vitualla, víveres.

ENCICL.: DUE (s.v. victo): Alimento diario.

municionero, municionero [de munición (DECH). Montes, Instrucción y regimiento, 1537]. sust. Mil. Persona que tiene a su cargo proveer o abastecer de municiones a un ejército o a una plaza de guerra.

Montes, Instrucción y regimiento, 1537, fol. VIIr: Y también se suele dar sueldo a los municioneros que hazen el pan en el exército para el mantenimiento de la gente. Mas si en la provincia que se conquistare hay bastimiento en abundancia, no se deve dar sueldo al municionero del pan, porque de los gastos excessivos no es servido el señor del exército. // Collado, Plática Artillería, 1592, fol. 103v: Dipútase, señor, por el general de artillería un hombre de confiança y aqueste se le da una póliça con que vaya a tomar de los municioneros 4 ó 6 barriles de pólvora, de la qual éste se encarga, y la encierra en una casilla que ha de haver por fuerça en la escuela. // Lechuga, Discurso de la Artillería, 1611, 
pág. 224: Aunque en muchas ay municioneros que tienen a su cargo las municiones, y los governadores o castellanos están obligados a tener otra llave, que impida el poder abrir los lugares donde están sin ella, dándola todas las vezes que se quisiere abrir a persona de quien se fían, puede suceder que se acuerde con el municionero o que el castellano, olvidándose de lo que deve a sí y a lo que tiene a cargo, usando del mando supremamente, como algunos entienden lo pueden hazer, aya tenido poco cuidado de las municiones y que a estas causas le falten muchas.

FAM.: amunicionar, munición.

ENCICL.: Terr.: V. en proveedor. // Terr. (s.v. proveedor): Tratante que está obligado a abastecer de municiones de guerra y boca a un ejército. // Almirante (1869): Antiguamente el contratista o proveedor de municiones de toda especie.

muniçión, V. munición.

munir, munir [del fr. munir 'proveer'. Es grosero y superfluo galicismo (DECH). Collado, Plática Artillería, 1592]. v. tr. Mil. Proveer a un ejército o a una plaza de guerra de municiones o de los efectos necesarios para su defensa y manutención. Collado, Plática Artillería, 1592, fol. 91r: Teniendo a las espaldas el enemigo, el qual espera que comiençe a passar su contrario para assaltarlo, acostumbraron de hazer con presteza grande algún fuerte y munir aquél de buena gente y pieças de campaña, con que se hazían frente al enemigo, para tener tiempo a que passe el artillería y todo el campo.

SIN.: amunicionar.

ENCICL.: DEA: (raro) Proveer o pertrechar a alguien de algo. // Rubió y Bellvé (1895-1901): Voz que alguna vez se empleó por proveer.

murado, murado [de murar. García de Palacio, Diálogos militares, 1583]. adj. Fort. Dicho de un terreno, una plaza, etc.: rodeado de muros o murallas.

García de Palacio, Diálogos militares, 1583, fol. 63v: Les dio por instrución que, subidos en lo alto de los montes, a la parte del mediodía, viessen y considerassen qué tal era la provincia, y si el que la posseýa y governava era varón fuerte o flaco, y si los moradores d'ella eran pocos o muchos, y si las poblaciones o ciudades eran muradas, torreadas o fortalescidas. // García de Palacio, Diálogos militares, 1583, fol. 66r: No es justo que para ninguna cosa béllica se dexe de usar, pues paresce impossible poder offender y subjetar a un poderoso enemigo sin ella, especialmente teniendo, como de ordinario ya todos tienen, torres, castillos, ciudades, fuertes y muradas y posadas para defenderse. // Mendoça, Theórica y práctica, 1596, pág. 64: Esto dará tiempo para poner en orden de buen hora el exército y bagaje al caminar, sin impedírselo el enemigo, estando a la vista en batalla, aviendo forçosamente, si no tiene villas muradas cerca, venir de lexos. 
FAM.: casamuro, contramuro, murador, murar, muro.

murador, murador [de murar. González de Medina, Examen fortificación, 1599]. sust. Constr. Obrero que trabaja en hacer paredes y otros elementos de construcción en que se unen piedras, ladrillos, etc. con un material aglomerante (DUE: s.v. albañil).

González de Medina, Examen fortificación, 1599, pág. 130: Y esto en ninguna manera se haze mejor que tomando luz de los muradores que fabrican en la propia tierra que se huviere de hazer, que por la larga experiencia tienen ya conocimiento de la calidad de la piedra, cal, arena, y aun del agua con que se liga. // González de Medina, Examen fortificación, 1599, pág. 139: Y esto nace muchas vezes de dar crédito a los muradores, que su desinio le tienen puesto, y la mira, en ganar de comer, o, por mejor dezir, robar, y no dárseles nada que se caya para tornar a tener que hazer.

SIN.: albañil.

FAM.: casamuro, contramuro, murado, murar, muro.

ENCICL.: Palet (1604): Masson.

mural, V. máquina .

muralla, muralla [del it. muraglia 'pared', 'muralla', y éste del lat. mūralia, pl. n. del adjetivo muralis 'relativo a los muros'. s. XV, Santillana; 1570, Crist. de las Casas; 1594, B. de Mendoza; Cov. (DECH). Montes, Instrucción y regimiento, 1537]. sust. Fort. Pared que rodea una plaza fuerte o protege un territorio. $\$$ (fig. 110)

Montes, Instrucción y regimiento, 1537, fol. XVIIv: Y si le dieren batería, hagan abastinar la muralla por donde la batería se diere, por la parte de dentro, de tierra y estiércol y fustas gruessas, tapiado todo a manera de tapia que sea muy ancha. // Rojas, Teórica fortificación, 1598, fol. 69r: Y assí, siendo el sitio en un plano, como está dicho, se levantará la muralla de los dichos 40 pies hasta el cordón, y en esta altura se avrá ido, en cada 5 pies de alto, retirando uno de escarpa hazia dentro, por manera que en los 40 pies se perderán 8 de los 13 de gruesso con que començó. Y acabará la muralla en el cordón con 5 pies de gruesso. // González de Medina, Examen fortificación, 1599, pág. 132: No aviendo piedra para la camisa de la muralla, no ay que dar pena ni traerla con excessivo gasto de lexos para ello, si ay de qué hazer ladrillos, que se tiene por bueno, y aun por mejor que de piedra, en las partes sugetas a batería.

SIN.: cerca $_{2}$, muro $_{1}$.

ENCICL.: Lucuze (1772: 25): "Por muralla o muro se entiende la fábrica que ciñe y cierra la Plaza. Consiste en un grueso terraplén, revestido en la parte exterior de tepes, piedra o ladrillo". // Rojas, Teórica fortificación (1598: fol. 70v): "Sólo digo que la fábrica de ladrillo, 
siendo bueno y bien fabricado (como diré en su lugar adelante), es muralla más fuerte contra el artillería que no la piedra, porque es fábrica hecha de pieças muy pequeñas, y quando da una vala de artillería en la muralla de ladrillo no atormenta ni rompe más cantidad de aquello en que da la pelota, lo que no tiene en la cantería, porque dando la vala en un sillar, demás de cascarlo y romperlo, atormenta aquel sillar a los demás que están alrededor d'él, por ser cuerpo grande, y assí es cosa muy notoria ser más a propósito la fábrica de ladrillo para la fortificación que no la cantería". / / Sanz (1749): Una muralla revestida es la que circuye una plaza fortificada. A ésta se le da dieciocho pies de altura, desde el plano del foso hasta el cordón, con un pie de declivio por cada seis pies, y cuatro pies y medio desde el cordón hasta la altura del parapeto. Cuando la mezcla del revestimiento es buena, sólo se le da tres pies de espesor al cordón y es el que hace la salida de la obra, construido de piedra cortada en redondo por fuera, y sobre su línea se asientan las garitas. Detrás del revestimiento de la muralla está el terraplén plantado de olmos, pues son los mejores porque sus raíces unen y ligan la tierra, la madera gruesa sirve para cureñas de cañón y de la delgada se hacen fajinas. En el terraplén están los contrafuertes o estribos y las contraminas de la plaza [...].

2 [Loçano, Alberto, Architectura, 1582]. sust. pl. Fort. Cualquier construcción que sirve para proteger un lugar o una posición de un ataque.

Loçano, Alberto, Architectura, 1582, pág. 106: No aprovamos el parecer y opinión de aquéllos que quisieron que la ciudad fuesse del todo desnuda, ni tampoco el de los otros que parece pusieron toda esperança de defenderla en la fábrica y edificios de las murallas. // Rojas, Teórica fortificación, 1598, fol. 78r: El mejor y más seguro remedio de todos es, si fuere possible, tomar las alturas y padrastros con las murallas de la ciudad. // Rojas, Compendio fortificación, 1613, fol. 25v: Lo primero que se ha de hazer, antes que se eche el cordel ni las estacas en el sitio para fundar las murallas, es bien que se considere la calidad de aquel sitio y la de los enemigos que espera le podrán venir a sitiar, mirando primero el asiento y forma del sitio, si es llano o en monte, o si participa de ambas cosas.

SIN.: defensa ${ }_{5}$, defensión ${ }_{3}$, fortificación ${ }_{3}$, reparo . $_{\text {. }}$

ENCICL.: DUE: (en pl.). Fortificación. // Estévanez (1897): [...] si se dice murallas, en plural, se comprenden todas las obras de la plaza, las exteriores como las del recinto.

murar, murar [de muro. Murar 'cercar con muro' (DECH). Celso, Reportorio universal leyes Castilla, 1553]. v. tr. Fort. Rodear de muros o murallas un terreno, una plaza, etc. (DUE: s.v. murar $^{2}$ ).

Celso, Reportorio universal leyes Castilla, 1553, fol. CCXXVIIv: Las ciudades e villas que fueren muradas de muros y torres son más honradas que los otros lugares que no lo fueren. Y deven, ansimismo, ser más honradas por la mucha segurança que el Rey puso en ellas quando las hizo o consintió murar. // Mendoça, Theórica y práctica, 1596, pág. 129: Assimismo, se cierran algunas puertas, murándolas para assegurar más la tierra, derribando los torreones, murallas y otros edificios que no se pueden defender, previniendo a que el enemigo no los ocupe con el sitio. // Lechuga, Discurso de la 
Artillería, 1611, pág. 254: En otras, golas y sortidas a un tiempo, poniéndoles sus puertas o murando las salidas, dejarlas assí para escusarse del cuidado del peligro o miedo causado del effecto que se vee an hecho los petardos.

FAM.: casamuro, contramuro, murado, murador, muro.

muro, muro [del lat. mūrus 'muralla', 'muro', 'pared'. Berceo (DECH). Sagredo, Medidas Romano, 1526]. sust. u. m. en pl. con el mismo significado que en sing. Fort. Pared que rodea una plaza fuerte o protege un territorio.

Fernández de Enciso, Suma de Geographía, 1530, fol. XLIIr: E aquí ovo grandes batallas entre él y los moros, e a la fin tomó la cibdad; y de aquí fue a Jerusalén y la tomó por fuerça y fue el primero que entró en Jerusalén por cima del muro, aunque quando él entró dentro falló dentro d'ella al rey de los malatos, que avía horadado la cerca y entrado dentro. // Montes, Instrucción y regimiento, 1537, fol. XVIIv: Por esto, ha de estar muy desvelado en la guarda, porque si viniessen enemigos los sientan antes que lleguen al muro, y en sintiendo, dé aviso al cuerpo de la guarda, en el qual se dé arma y reparta el capitán su gente por el muro. / / González de Medina, Examen fortificación, 1599, pág. 158: Querría saber de vos, maestro, en una ciudad de muy fuertes muros, con baluartes y foso, muy puesta en razón, aunque tiene las cortinas muy largas y están los baluartes tan lexos que no alcança arcabuz ni mosquete a defenderles la frente; y también que se han desmandado los vezinos, con la paz y sossiego que han tenido, a edificar fuera de la muralla, de manera que tiene una gran población el arrabal de casas, yglesias y jardines $[\ldots]$.

SIN.: cerca muralla $_{1}$.

FAM.: casamuro, contramuro, murado, murador, murar.

2 [Celso, Reportorio universal leyes Castilla, 1553]. sust. Mil. ant. Formación de infantería, en forma de cuadrilátero, con la que con cualquiera de sus cuatro caras o lados puede hacerse frente al enemigo, y en la que se deja vacío el centro.

Celso, Reportorio universal leyes Castilla, 1553, fol. CLVIIIv: Muro llaman los antiguos a los que estavan en la guerra todos ayuntados en uno, en manera de quadra.

SIN.: $\mathrm{cerca}_{3}$.

ENCICL.: Almirante (1869): La voz muro tuvo antiguamente la significación de orden de batalla o disposición táctica de un ejército.

músculo, músculo [tomado del lat. mūscŭlus - $-\bar{\imath}$ 'especie de galería cubierta y móvil (que protegía a los sitiadores)', dim. de mūs (Segura Munguía 2001). Roxas, Sumario milicia, 1607]. sust. Fort. ant. Especie de cobertizo de madera recia para defensa de los minadores de las murallas. 
Roxas, Sumario milicia, 1607, fol. 27v-28r: También ha de aver lobos, que son unos garabatos de hierro, y hoçes enastadas en lanças $\mathrm{y}$, para haçer las trincheras y fosos, las herramientas ya dichas; y galápagos, y músculos, carneros, víneas, mantas y otras menudençias, que sería larga su declaraçión. // Roxas, Sumario milicia, 1607, fol. 45v: Fuera d'esto, la gente que llebava escalas para subir a los muros, ay otros yngenios con que se combaten, conbiene a saber: testúdines, arietes, hoçes, bíneas, plúteos, músculos y torres. // Roxas, Sumario milicia, 1607, fol. 46r: Un baluarte se lebanta de tierra y fajina enfrente de la muralla para señorear desde allí la plaça y tirar. Llámase músculos unas máquinas menores.

ENCICL.: Almirante (1869): Antigua máquina tectoria o cubridora [...] para cubrir de los tiros de la plaza al zapador o minador que "picaba el muro" [...]. Es admitido que el nombre musculus no viene realmente de la "figura" de la máquina, sino del "oficio" de los soldados a quienes cubría, los cuales hacían agujeros como los ratones. // Moretti (1828): ant. Máquina de guerra parecida a nuestro mantelete $(V$.) que usaron los romanos en el ataque de plazas. Consistía en un grueso barracón de madera cuadrado o cuadrilongo sin suelo, colocado sobre un telar formado con cuatro vigas, debajo del cual había varios cilindros o polines movibles, que con el auxilio de palancas le daban dirección en todos sentidos. El techo era triangular a manera de un tejado, y estaba cubierto de hojas de hierro y ladrillos. Cuando había que aproximarle a los muros de una plaza enemiga, le cubrían con pieles frescas empapadas en agua y vinagre, a fin de embotar las armas arrojadizas y apagar los combustibles que les tiraban desde lo alto de la muralla. El músculo se empleaba principalmente para llenar una parte del foso con fajinas y tierra apisonada, a fin de formar una calzada cubierta de tablones para conducir cerca de la plaza las torres movibles $(V$.); o para aproximarse al muro, socavarle y pegar fuego a los maderos con que los entrelazaban los antiguos; cuyas operaciones verificaban los minadores a cubierto de las ramas y mixtos de los enemigos, colocados debajo del músculo.

mutín, V. motín. 
nombre, nombre, nonbre [del lat. nōmen, -̌nis. Orígenes del idioma (DECH). Álaba, Perfeto capitán, 1590]. sust. Mil. Palabra o frase sólo conocida por los que luchan en el mismo bando, que les sirve, diciéndola, para reconocerse entre sí.

Álaba, Perfeto capitán, 1590, fol. 49r: Las centinelas, por lo menos, estarán apartadas treynta passos de los cuerpos de guardia y una de otra, de manera que se puedan ver; y siempre dobles, porque vean mejor quién entra o sale, pues son para esso, y porque, si una fuere a dar aviso, quede la otra, a las quales darán los mesmos sargentos el nombre con que conocerán los amigos, no consintiendo que sin darle primero entre ni salga nadie en el real. // Mendoça, Theórica y práctica, 1596, pág. 85: Estas tropas, saliendo de noche del campo, no llevan el nombre, si bien el mismo cabo les da entre sí otro, como están fuera, para que se conozcan, assegurando que, si se pierden, no le tenga el enemigo. // Mendoça, Theórica y práctica, 1596, pág. 121: Se da al tiempo de la escaramuça nombre en público a todos los esquadrones con el qual se pueden differenciar del enemigo y conocerse.

ENCICL.: DUE: Palabra establecida para intercambiarla con un vigilante, a fin de darse a conocer como amigo. // Corsini (1849): Se llama así la palabra de orden y seña que se da secretamente a los puestos y fuerza de servicio de una plaza, campamento, ejército, etc., para darse a reconocer recíprocamente, en particular por la noche, y evitar ser sorprendidos por el enemigo. // Aut.: Regularmente en el ejército de los cristianos es el nombre de algún santo, por lo cual se llama también el santo. // Mosquera, Comentario disciplina militar (1596: fol. 21v-22r): "Y, si por caso forçoso no pudiere tomar nombre, sea el suyo Santiago de España; y que no se tire pieça de artillería al tomar del nombre".

nonbre, V. nombre. 
occupado, V. ocupado.

occupar, V. ocupar.

ocupado, occupado, ocupado [de ocupar. Montes, Instrucción y regimiento, 1537]. adj. Mil. Dicho de un territorio: que ha pasado a ser posesión de un grupo después de haberlo invadido por la fuerza.

Montes, Instrucción y regimiento, 1537, fol. XIXr: Y, para ello, Dios, que es guiador y criador de todas las cosas, enfunda en la gente christiana tanta gracia y esfuerço, que sean parte para conquistar la tierra que los infieles tienen ocupada, y traherla debaxo de subjeción del invictíssimo César. // García de Palacio, Diálogos militares, 1583, fol. 17r: A éstos qualquiera príncipe christiano les puede hazer guerra, ansí por ser enemigos comunes, como porque matan y roban los christianos, dondequiera que se pueden aprovechar d'ellos, porque nos tienen injustamente (y con injuria) occupadas nuestras tierras, sin querer ni tratar de restituyrnoslas. // Collado, Plática Artillería, 1592, fol. 6r: En el año 1366, y en la sazón quando entre las señorías de Génova y de Venecia havía discordia grandíssima [...], hallándose el campo de los venecianos en el assedio de una de sus tierras que la señoría de Génova tenía occupada, [...], parescieron dos tudescos en el campo de los venecianos, los quales truxeron dos pecezuelas de artillería de hierro con una quantidad de pólvora y balas de plomo.

FAM.: desocupar, ocupar. 
2 [Álaba, Perfeto capitán, 1590]. adj. Mil. Dicho de un lugar estratégico: que se han instalado en él personas para dificultar las acciones del enemigo.

Álaba, Perfeto capitán, 1590, fol. 44v: Si el passo que está ocupado del enemigo fuere de algún camino estrecho, acometerá a passar por otro diferente del que le quieren impedir, imitando a Nicóstrato, capitán de los étolos, que, dando señal que quería romper por otro camino estraordinario por tenerle ocupado los epirotas el ordinario, que era muy angosto, obligándolos a acudir a la defensa d'este intento, quedándose con alguna gente de secreto, passó por el lugar que desampararon los enemigos. // Mendoça, Theórica y práctica, 1596, pág. 131: En caso que se tenga sospecha de los naturales de la tierra, temiéndose de su poca fe, es buen medio tener ocupadas las torres de las puertas, que son más cómodas para ello, la gente de guerra con soldados ordinarios y fortificarlos como mejor se puede contra los de la tierra, poniendo en ellas algunas vituallas y municiones. // González de Medina, Examen fortificación, 1599, pág. 184: No tiene menester siempre tener ocupados los puestos, porque, quando se hazen salidas, no tienen por entonces que defender la estrada cubierta ni las murallas, aunque han de estar todos en arma para tornarlos a recebir, no sea que a las bueltas se les entre el enemigo.

ocupar, occupar, ocupar [tomado del lat. occüpare 'íd.', derivado del radical de capere. Ya en Juan de Mena; Nebr.; ejs. abundantes del Siglo de Oro en Cuervo (DECH). Apiano, Cosmographía, 1575]. v. tr. Mil. Entrar una persona o un grupo en un territorio por la fuerza o la violencia, e instalarse en él.

Loçano, Alberto, Architectura, 1582, pág. 98: Y aun hallo que la primera ciudad fue Biblo, occupada por los de Foenicia, la qual ciñó Saturno con muro rodeando a las cosas. // Urrea, Vitruvio, Architectura, 1582, fol. 29v: Assí que después de la muerte del rey Mansolo, reynando la reyna Arthemisa, su muger, los de Rodas, indignándose que una muger mandasse y señoreasse a todas las ciudades de Caria con una armada, se partieron con intento de ocuparle el reyno. // García de Palacio, Diálogos militares, 1583, fol. 36r: Y del Emperador Theodosio se lee en las historias romanas que, como supiesse que Eugenio y Abirogastes, occupando los Alpes, venían contra el gran exército, compuesto de muchos esquadrones y bien ordenados, estuvo toda aquella noche en oración.

FAM.: desocupar, ocupado.

ENCICL.: DUE: Entrar en un sitio instalándose en él o adueñándose de él, o invadirlo en una acción de guerra.

2 [Loçano, Alberto, Architectura, 1582]. v. tr. Mil. Instalarse en lugares estratégicos para dificultar las acciones del enemigo.

Loçano, Alberto, Architectura, 1582, pág. 102: Y conviene, cierto, guardar que no esté encima levantado algún monte apegado, el qual, occupado, moleste el enemigo, o que no se estienda al enemigo alguna segura llanura tan grande que en tal lugar pueda empalizar para sitiar o ordenar su esquadrón para dar assalto. // Álaba, Perfeto capitán, 1590, fol. 45r: Procurará también que alguna parte del exército vaya a ocupar algún lugar alto o otro 
puesto de donde pueda ofender al enemigo, para que, acudiendo él a esta defensa, dexe libre el passo y, sin ser sentido, de noche lo pueda sin impedimento passar. // Roxas, Sumario milicia, 1607, fol. 86v-87r: Ay otras çiudades que son ofendidas en torno de algunas alturas, de tal manera que los soldados no pueden estar a la defensa que no sean ofendidos o por la frente, o por través, o por las espaldas: el mejor y más seguro remedio será tomar o ocupar las dichas alturas de la çiudad.

SIN.: tomar 2 .

ANT.: desocupar.

ENCICL.: Terr. (s.v. ocupar algún puesto ventajoso) Apostarse en él. // Fernández Mancheño (1822): Posesionarse de alguna plaza o punto interesante en campaña.

3 [Loçano, Alberto, Architectura, 1582]. v. tr. Mil. Embarazar o estorbar a alguien (DRAE).

Loçano, Alberto, Architectura, 1582, pág. 137: Otro género de alojamientos será quieto, para donde te estés firme, para apremiar y occupar al enemigo que desconfía de sus huestes de gentes armadas, en tanto que estuviere en algún lugar fortalecido.

ofender, ofender, offender [tomado del lat. offënděre 'chocar', 'atacar', derivado, junto con defendere, de un primitivo común prehistórico. Mena, pero en el sentido de 'salir al encuentro, precipitarse'; APal.; empléalo ya Fr. Luis de Granada, y es frecuente en todo el Siglo de Oro (DECH). Celso, Reportorio universal leyes Castilla, 1553]. v. tr. u. t. c. intr. Mil. Lanzarse contra alguien para causarle daño o para vencerle.

Celso, Reportorio universal leyes Castilla, 1553, fol. XCIIIr: Según diximos en el versículo I, el que vee venir a otro con armas para matarle, no deve esperar que le dé el otro el primer golpe; antes puede, con armas e aun con junta de gente, defenderse e matar sin pena a los que viniessen para offenderle. // García de Palacio, Diálogos militares, 1583, fol. 75v-76r: Común opinión es de los que la milicia entienden que es más provechoso suffrir el primer ímpetu de los enemigos y, passado aquél, acometellos, que no poner luego toda su furia y brío en offendellos, que mejor se rendirán estando cansados y perdida la primer furia. // Álaba, Perfeto capitán, 1590, fol. 78r: Y esté advertido el capitán que los mesmos ardides y traças que a imaginado para acometer a su enemigo puede él aver traçado para ofenderle a él, y que antes que las ponga en execución prevenga el daño del ardid contrario que puede aver al que él quiere poner por obra.

SIN.: acometer, atacar, combatir 3 , embestir.

ANT.: defender 2 .

FAM.: ofendido. 
ENCICL.: López Vallejo (2008): Atacar [al enemigo]. // DUE (s.v. atacar): El complemento directo puede ser también el sitio donde están las personas o animales atacados.

ofendido, ofendido, offendido [de ofender (DECH). García de Palacio, Diálogos militares, 1583]. adj. Mil. Dicho de una persona o de un lugar donde hay personas: atacado.

García de Palacio, Diálogos militares, 1583, fol. 166r: Y, si fueren puestos en dos partes, los unos se han de poner al lado derecho de la batalla, tras las vanderas, y los otros, al lado yzquierdo, delante d'ellas. Y, aviéndose de poner entre los otros, se ponen en la rectaguardia, para acudir a la parte más offendida o adonde más pueden dañar, en la forma siguiente. // García de Palacio, Diálogos militares, 1583, fol. 168r: Y, aviendo artillería, suélese poner, y estará bien, a las quatro partes de la batalla, y notorio es el provecho que d'esta forma de esquadrón se sigue, porque pueden pelear por todos los lados y, si es acometida de los enemigos por todas partes, acostumbran y deven calarse cinco o seys órdenes de picas o tantas que basten a resistirles, según su número, quedando siempre algunas enarboladas, para calarlas hazia la parte más flaca y offendida.

SIN.: acometido1, combatido.

FAM.: ofender.

2 [García de Palacio, Diálogos militares, 1583]. sust. Mil. Persona que recibe un ataque o una ofensa.

García de Palacio, Diálogos militares, 1583, fol. 107v: Esto proprio se suele hazer ordenando un cohete de papel, de dos o tres doblezes, sobre el cabo de la vaqueta y, plegado por una parte, se echa por la otra el azogue y, ansí echado, se torna a plegar por la otra y métese en el arcabuz sobre la carga de pólvora, y, tirando ansí a treynta o quarenta passos, haze el mismo effecto, sin que se halle ni pueda ver herida en ninguno de los offendidos o muertos. // Álaba, Perfeto capitán, 1590, fol. 57r: Mas, por ventura, convino assí que los dioses desbaratassen nuestro enemigo y su exército sin alguna humana ayuda, como quebrantador de los conciertos, y que nosotros, pues somos los ofendidos, ayamos de concluyr con lo que ellos començaron.

SIN.: acometido.

ANT.: acometedor, combatidor ${ }_{2}$, combatiente 2 .

ENCICL.: Cov. (s.v. ofender): Ofendido, el que ha recibido ofensa.

ofensa, ofensa, offensa [tomado del lat. offensa 'choque', 'ofensa'. Mena, Yl.; 1582-5, Fr. L. de Granada (DECH). Álaba, Perfeto capitán, 1590]. sust. Mil. Acción violenta contra alguien o contra un lugar donde hay personas. 
Álaba, Perfeto capitán, 1590, fol. 83v: Quando traté del alojar y acometer dixe ser necessario en qualquiera ofensa que se pretende hazer al enemigo saber la planta del lugar y sitio donde está alojado, las armas, vituallas, municiones y gente de que está apercebido. // Collado, Plática Artillería, 1592, fol. 95r: Señor, sí que hay differencia quanto a la sciencia theórica, que es dependiente de aquélla que arriba llamamos prespectiva; pero sin essa, ¿quántos pobretos soldados tienen muy mayor experiencia y plática de las offensas y deffensas de una fortaleza, que no tienen muchos hinchados ingenieros que conozco que tiran sueldo de la Magestad Cathólica? / / González de Medina, Examen fortificación, 1599, pág. 110-111: Adonde pareciere que de alguna parte puede aver mayor fuerça en la ofensa, por ser el puesto aparejado para ello más que los otros, será bien contra ello poner en frente una cortina antes que el ángulo del baluarte, porque, aunque la bata y arruyne toda, tiene más defensas y mejores que el baluarte por las casas matas que tiene a entrambos traveses.

SIN.: acometida, acometimiento, combate 2 , combatimiento ${ }_{2}$, ofensiva.

ANT.: defensa 2 .

FAM.: ofensiva, ofensivo.

ENCICL.: DRAE (1803): La acción de ofender o acometer al enemigo.

ofensibo, V. ofensivo.

ofensiva, offensiva [de ofensivo. Ufano, Tratado de la Artillería, 1613]. sust. Mil. Acción violenta contra alguien o contra un lugar donde hay personas.

Ufano, Tratado de la Artillería, 1613, pág. 46: Y aunque estas pieças son pessadas y trabajosas de moverles las culatas, al asestarlas hazen el tiro más seguro y çierto y, al fin, son mejores, porque no reculan tanto como las ligeras, locas y cabuzadoras, y se tira siempre con ellos muy derecho el bote de la percusión de las balas, de tal modo que offenden grandemente al enemigo, assí en romper de los puentes de los ríos, baxeles, torreones y garitas, como en las offensivas.

SIN.: acometida, acometimiento, combate 2 , combatimiento 2 , ofensa.

ANT.: defensa ${ }_{2}$.

FAM.: ofensa, ofensivo.

ENCICL.: DSAL: Mil. Ataque de una fuerza militar. 
ofensivo, ofensibo, ofensivo, offensibo, offensivo [de offensum, participio latino de offendere (cast. ofender). h. 1440, A. Torre (C. C. Smith) (DECH). Medina, Arte de navegar, 1545]. adj. Que ataca o sirve para atacar (DRAE).

González de Medina, Examen fortificación, 1599, pág. 144: Dezidme, maestro, este fuerte en el agua, como avéys dicho, ¿de qué forma le haríades, y con qué miembros?, pues él, de suyo, es fuerte por naturaleza, el sitio, y no será de importancia hazerle de tantos miembros, ofensivos y defensivos, como los de tierra, que por todas partes se les puede plantar artillería y batirle; y también sería bueno no hazerle tan costoso como los otros. // Ufano, Tratado de la Artillería, 1613, pág. 121: De algunos años a esta parte más bellicosamente se a usado el alojar pieças de artillería en los puestos más offensivos la primera noche que se llega a sitiar tal plaça; regla, çierto, mejor y más verdadera, tomando siempre para tal effecto la parte mejor del campo, así para offender de allý a los sitiados, como por el resguardo y seguridad de los soldados. // Ufano, Tratado de la Artillería, 1613, pág. 146: A los yngenieros y traçistas les obliga a designar y traçar las trincheas y dar el orden y modo del fabricarlas, hazer fuertes espaldas, plataformas y bestiones offensivos, traveses y medias lunas, mesurar con razón justamente el anchura y travesía de los fossos y riveras, y la de la muralla, sus cortinas y baluartes, con su justa altura y distançia, y todo lo demás competente que de su arte y offiçio les fuere mandado.

ANT.: defensivo.

FAM.: ofensa, ofensiva.

ofensivo, V. guerra $\sim$.

offender, V. ofender.

offendido, V. ofendido.

offensa, V. ofensa.

offensibo, $V$. ofensivo.

offensiva, $\mathrm{V}$. ofensiva.

offensivo, V. ofensivo.

ombre, V. hombre. 
onagro, onagro [tomado del lat. ŏnăgĕr (-grus), -grī 'onagro, asno salvaje', 'máquina de guerra (que lanzaba piedras)', y éste del gr. óvarpos, compuesto de óvos 'asno' y àrplos 'silvestre' (Segura Munguía 2007). Mosquera, Comentario disciplina militar, 1596]. sust. Mil. ant. Máquina con que se arrojan piedras, de forma semejante a una oreja de burro.

Mosquera, Comentario disciplina militar, 1596, fol. 5r-5v: Y no están tan fuera d'él los arietes, testúdines, onagros, lupos y otras máquinas que en las guerras de Italia, Francia y Alemania no las ayan usado nuestros españoles // Roxas, Sumario milicia, 1607, fol. 45v: Y asimismo es necesario recojer gran copia de nierbos con mucha diligencia para los onagros o ballestones, los quales son buenos de las cerdas y clines de cavallos y bueyes y otros animales semejantes $\mathrm{y}$, aun a falta, los cavellos de las mugeres son buenos.

ENCICL.: Terr. (s.v. onagra): Cierta máquina de guerra antigua que servía para arrojar grandes piedras. // Moretti (1828: s.v. onagra): ant. Especie de ballesta de que se servían los antiguos para lanzar piedras de grueso tamaño. (Véase catapulta). // Almirante (1869: s.v. máquinas antiguas): [...] la reacción de nervios o cuerdas que se retuercen se utilizó en el onagro, etc. Pero hay un incidente, digno de notarse, que complica extrañamente la cuestión: por desgracia ninguna máquina se ha "conservado" hasta nosotros en museos o armerías; ningún monumento, ni dibujo contemporáneo las representa; sólo tenemos de ellas la rápida mención de los historiadores. Éstos, en sus diferentes tiempos, les dan nombres peregrinos, diversos, que a muchos hacen presumir "diversidad" en el aparato. De modo que al entrar sin guía por el campo abierto de las "conjeturas", puede ser cada paso un tropezón y cada hallazgo una mentira [...].

onbre, V. hombre.

opprimido, V. oprimido.

opprimir, V. oprimir.

oprimido, opprimido, oprimido [de oprimir. Pérez Vargas, De re metallica, 1568]. adj. Mil. Dicho de un individuo o de un territorio: colocado, de manera violenta, bajo el dominio o el poder de alguien, y tratado con despotismo.

Pérez Vargas, De re metallica, 1568, fol. IIIr: Y assí como estos valerosos y fuertes hombres ayudaron con su fortaleza sus opprimidas repúblicas, assí uvo innumerables otros que con la grandeza de su saber, entendimiento y letras, que con trabajo adquirieron, destruyeron el ygnorancia. // Álaba, Perfeto capitán, 1590, fol. 35v: Esta plaga en nuestros tiempos es mayor que en otros jamás a sido y por esso es razón que sea mayor la consideración que en esto a de aver que nunca huvo, pues los alborotos y molestias de 
soldados suelen resultar en daño notable de los príncipes, por la rebelión que muchas vezes sucede aver en los lugares oprimidos y maltratados.

FAM.: oprimir.

ENCICL.: DRAE: adj. Que está sometido a la vejación, humillación o tiranía de alguien.

oprimir, opprimir, oprimir [tomado del lat. opprĭměre 'íd.' . Apremir, Alex., forma alterada empleada todavía en el s. XV por APal. y Castrogeriz; oprimir, Mena; APal.; ejs. desde princ. s. XVII, en Aut (DECH). Loçano, Alberto, Architectura, 1582]. v. tr. Mil. Poner una persona bajo su poder, de manera violenta, a individuos o territorios, y tratarlos con despotismo.

Loçano, Alberto, Architectura, 1582, pág. 102: Al contrario es a los del lugar, porque mediante los montes que tienen en bajo juntados entre sí por todas partes con muchos valles entre ellos, tienen por donde puedan salir luego a acometer y en un improviso a qualquiera súbita esperança y occasión opprimir. // García de Palacio, Diálogos militares, 1583, fol. 89v-90r: Y, si paresciere conviene deservar la tierra de los escándalos y de quien se deva tener sospecha, hazerse ha, para que los demás se quieten, como se dize en el Éxodo lo quisieron hazer los egipcios con el pueblo isrraelítico, temiendo y recelándose que en algún tiempo (según su muchedumbre) se podrían alçar con la tierra y opprimir y subjetar los naturales señores d'ella. // Álaba, Perfeto capitán, 1590, fol. 35v: De los tarentinos se lee que, apretados de los malos tratamientos de los romanos que estavan en su ciudad, los echaron d'ella, teniendo por mejor sujetarse al poder de Aníbal, a quien tenían por capital enemigo, que sufrir el ser oprimidos de sus amigos.

SIN.: sojuzgar 3.

FAM.: oprimido.

ENCICL.: Cov.: Lat. opprimere, apretar a uno demasiado y afligirle. // DRAE: Someter a una persona, a una nación, a un pueblo, etc., vejándolos, humillándolos o tiranizándolos. // DSAL: Ejercer una persona dominio sobre otra persona o un pueblo limitándole o quitándole su libertad o sus derechos mediante la fuerza o el abuso de autoridad.

opugnar, opugnar [tomado del lat. oppugnare 'íd.'. 1515, Fz. Villegas (DECH). Herrera, Institución Academia, 1584]. v. tr. Fort. Acometer o atacar impetuosamente un lugar fortificado para entrar en él y tomarlo.

Herrera, Institución Academia, 1584, fol. 5r-5v: D'éstas, como principales, se derivan y decienden todas las demás que participan d'este nombre. Porque de la Mechánica depende la hazedora de instrumentos béllicos para opugnar y deffender las ciudades y fortalezas.

SIN.: asaltar 2 , dar (el) asalto 2 . 
ENCICL.: Terr.: Asaltar una plaza. V. Asaltar.

orden, horden, orden [descendiente semiculto del lat. ōrdo, -̌nnis. Cid (DECH). Ortega, Conpusición Arismética y Geometría, 1512]. sust. f. Línea recta formada por personas, frecuentemente soldados, o por cosas, una detrás de otra o una al lado de otra.

García de Palacio, Diálogos militares, 1583, fol. 164v: Pónense, pues, estos infantes perdidos o órdenes falsas, para que, yendo assí encubiertos, un poco antes de calar las picas, saliendo por los costados con sus picas arboladas, las echen tendidas sobre las picas caladas de los contrarios, de que pueden los enemigos rescebir gran daño. $Y$, siendo quatro las dichas órdenes falsas, las otras dos se han de poner en la rectaguardia, por la orden que van puestas las de la avanguardia. // García de Palacio, Diálogos militares, 1583, fol. 178r: Pueden también los arcabuzeros de a pie yr puestos en una o dos partes del esquadrón, e, yendo en una, han de yr en la avanguardia, después de tres órdenes de picas, $y$, si fueren en dos, la mitad d'ellos se ha de poner en el lugar dicho y la otra mitad en la rectaguardia, a tantas órdenes como en la avanguardia. // Álaba, Perfeto capitán, 1590, fol. 136v: Y no tendría por negocio poco importante, ordenado el campo en qualquiera de las formas que están referidas, poner delante de las primeras órdenes de los piqueros alguna orden o hilera de rodeleros, los quales llevassen alcancías o otros instrumentos de fuego para arrojarlos en medio del campo del enemigo diez o quinze passos antes de llegar a él.

SIN.: hila, hilada, hilera.

ENCICL.: Terr.: De cosas. V. Fila, serie. // Terr. (s.v. fila): Serie dilatada de personas, árboles, plantas, columnas, soldados, etc., principalmente si se ordenan en línea recta.

$\sim$ de batalla, $\mathrm{u} \sim$ de la batalla [García de Palacio, Diálogos militares, 1583]. cmpt. sintag. f. u. t. c. m. Mil. Disposición de las tropas que se juzga más adecuada para un combate, para atacar o para operaciones militares similares.

García de Palacio, Diálogos militares, 1583, fol. 157v-158r: Y, si acaso yo no me he dado bien a entender, suplirá la siguiente demonstración y figura, donde vuestra merced podrá ver la orden de la tal batalla y los lugares y partes do se ponen las dichas vanderas y alavarderos. // Mendoça, Theórica y práctica, 1596, pág. 57: Assimismo se estima por buena orden de batalla sacar al lado derecho de los esquadrones de picas y lanças unas tropas, en número de la quinta parte de lo que es el esquadrón, para envestir sobre el costado del enemigo. // Ufano, Tratado de la Artillería, 1613, pág. 104: Señor Capitán, mucho holgaría saber el orden y manera que se tiene en el marchar ordenada y conçertadamente con ynfantería, caballería, bagage, carruage, muniçiones de guerra y víveres, con el artillería y sus máquinas y elementos, y enterarme muy bien del puesto conviniente de cada una de las dichas cosas en el orden de batalla.

SIN.: batalla. 
ENCICL.: Moretti (1828: s.v. orden de batalla): Disposición para el combate, por cuyo medio los batallones o escuadrones de un cuerpo de tropas o de un ejército se colocan sobre una o más líneas en todos sentidos, según la naturaleza del terreno y el plan del que manda la acción, o las circunstancias que le preceden o provocan.

\section{ordenança, V. ordenanza.}

ordenanza, hordenança, hordenanza, ordenança, ordenanza [de ordenar y éste del lat. ōrdīnō, -āre. Ordenança, 1100; h. 1295, 1. ${ }^{a}$ Crón. Gral.; APal. (DECH). García de Palacio, Diálogos militares, 1583]. sust. Mil. Cada una de las líneas o partes de que consta un orden de batalla, y conjunto de soldados que las integran.

García de Palacio, Diálogos militares, 1583, fol. 161v: Quando se vee y sabe que el enemigo trae su esquadrón más ancho o se quiere ensanchar más que el del enemigo, como vuestra merced dize, deve, quando viene una batalla o ordenança tras otra, la de la avanguardia hazer alto, arbolando las picas, para que la batalla o ordenança que viene en pos d'ella entre por ella con sus picas, entretexiéndose en la forma que se sigue, hasta poner los lados yguales. // García de Palacio, Diálogos militares, 1583, fol. 183r: ¿qé orden se podrá tener para mudar con presteza un exército o batalla quadrada de gente en esquadrón cúneo, sin perder la primera ordenança, ni aver peligro de confusión y desorden? // Roxas, Sumario milicia, 1607, fol. 37r: En el primer lugar, qu'es la banguardia, se ponían los soldados viejos y exerçitados, a los quales llamavan príncipes, y en la segunda hordenança se ponían los flecheros, con petos y espaldares, y dardos o lanças.

SIN.: batalla 5 .

orejón, orejón [de oreja y éste del lat. aurĭcŭla (DECH). Collado, Plática Artillería, 1592]. sust. Fort. Parte saliente del flanco del baluarte, redonda o cuadrada (Moretti 1828). $\$$ (fig. 111)

Collado, Plática Artillería, 1592, fol. 95r: ¿Quién le enseñó que las fortalezas, o son fuertes por la materia o son fuertes por la forma?: por la materia, quando son fabricadas de grosíssimas murallas, y por la forma, por tener baluartes anchos y plaças espaciosas, gruessos y maçiços orejones, anchos terraplenos, arzenes altos, gruessos parapetos y no pedregosos, [...]. // González de Medina, Examen fortificación, 1599, pág. 17: Si es verdad que los orejones en los baluartes son necessarios para encubrir las defensas de las casas matas, se seguirá que el rebellín no puede ser bueno, pues todas sus defensas están descubiertas. // González de Medina, Examen fortificación, 1599, pág. 167: El orejón, aunque el de esquina viva tiene algo menos en qué batir que el redondo, pero, con todo esso, el redondo encubre más y es más dificultoso de derribar. Y aunque tenga más que caer en el foso, no es en parte que el enemigo se determinará a dar por allí assalto, por estar el través tan cerca y no quitado.

ENCICL.: Aut.: En la fortificación es un cuerpo que, prolongada la frente del baluarte, sale fuera formando oreja a todo él. // Terr.: Término de fortificación, es una obra que se hace 
sobre el tercio del flanco del baluarte al lado del ángulo de la espalda, y sirve para cubrir el flanco, las plazas bajas y la artillería que está en los flancos o casas matas. Fr. Orillon, cuando el orejón es redondo, y cuando es cuadrado le llaman epaulement. / González de Medina, Examen fortificación (1599: pág. 166): ¿CCómo será mejor el orejón, redondo o [a] esquina viva?". // Sanz (1749): Dos modos de orejones hay: unos en figura redonda y otros que se aproximan a figura cuadrada. // Lopes Pires Nunes (2005: s.v. orelhão): Podia haver orelhão apenas num dos lados do baluarte ou em ambos. O orelhão destinava-se a resguardar peças de artilharia que atiravam sobre o inimigo, quando atravessava o fosso e atacava a cortina.

orejón, V. flanco del .

ornillo, V. hornillo.

orno, V. horno.

ovación, ovación [tomado del lat. ovatio, -ōnis 'triunfo menor, que concedían los romanos por una victoria de no mucha consideración', derivado de ovare 'hacer una entrada triunfal', 'manifestar júbilo'. h. 1580, A. de Morales (DECH). Álaba, Perfeto capitán, 1590]. sust. Mil. ant. Ceremonia parecida al triunfo, aunque menos solemne, que conmemora una victoria de no mucha consideración.

Álaba, Perfeto capitán, 1590, fol. 147r-147v: La otra manera de triunfo, que se llamava ovación, era de menor solenidad y pompa, porque el que triunfava no yva en carro, sino en un cavallo con una corona de mirto y, acompañado de los plebeyos o de los cavalleros, subía al Capitolio, donde se sacrificava cierto número de ovejas, y de aquí tomó nombre de ovación este triunfo. // Álaba, Perfeto capitán, 1590, fol. 147v: Sabino Masurio afirma que el que triunfava con triunfo de ovación no yva a cavallo, sino a pie, acompañado de todo el senado. // Álaba, Perfeto capitán, 1590, fol. 147v-148r: A esta causa, Lucio Manlio, viniendo de España y pidiendo en el templo de Belona el triunfo al senado, aunque las hazañas que avía hecho lo avían merecido, por no averse acostumbrado a dar, se le negó; y assí, entró en la ciudad no con triunfo, sino con ovación.

ENCICL.: Almirante (1869): Ceremonia usada entre los romanos para aplaudir y recompensar al general vencedor, cuando sus victorias no llegaban a merecer los grandes honores del triunfo. En rigor era este mismo menos solemne: el héroe no entraba en carro, sino a pie, y llevaba corona de mirto en vez de laurel. // Moretti (1828): ant. Triunfo de segunda clase que concedía el senado romano, sin necesidad del consentimiento del pueblo, a los generales que habían obtenido ventajas sobre enemigos poco temibles, piratas, etc., y se verificaba con mucho menos aparato que el de primera clase. El vencedor hacía su entrada a pie o a caballo, y nunca en carro triunfal, vestido con la túnica palmata, y un ramo de olivo en la mano. Le precedían los primeros oficiales de su legión y algunos legionarios también con ramos de olivo, seguían los músicos, que sólo podían tocar 
flautas, y no trompetas ni clarines; y como no reasumía las autoridades del gobierno, no le acompañaban lictores, y sí el senado, los caballeros y los principales del pueblo. Se dirigían al Capitolio, en donde se hacía el sacrificio de algunas ovejas, por ser un animal dócil y tímido; y de ahí es que a este pequeño triunfo se le llamaba ovación. 
pabellón, pabellón, pavellón [del fr. ant. paveillon 'tienda de campaña', que vino del lat. papilio, -ōnis 'mariposa' y más tarde 'tienda de campaña'. h. 1475, G. de Segovia; APal. (DECH). Ortega, Conpusición Arismética y Geometría, 1512]. sust. Mil. Especie de tienda cónica, sostenida mediante un grueso palo central y sujeta al terreno alrededor de la base con cuerdas y estacas. (fig. 112)

Ortega, Conpusición Arismética y Geometría, 1512, fol. 193r: Después que en todos los capítulos passados de la Arismética he hablado suficientemente [...] como el arte de la Geometría sea tan necessaria para qualquiera persona, quiero agora brevemente poner aquí adelante el modo y manera cómo qualquiera persona podrá medir y canear qualquiera cosa que sea, agora sea quadrángulo, o triángulo, o arco, o medio arco, o torre, o fortaleza, o pavellones, o fuentes, o otra qualquiera cosa que se pueda mesurar. // Collado, Plática Artillería, 1592, fol. 27r: Las medias culebrinas sirven de quitar a los sitiados las deffensas y de cortar de alto abaxo las murallas en las baterías, de tirar de puntería cierta de noche o de día a qualquier pavellón o tienda o otra particular cosa de mucha importancia. // Roxas, Sumario milicia, 1607, fol. 61v: Luego que se tomava resolución en escojer el lugar donde se avía de alojar, lo primero que se hacía hera buscar un lugar para el pavellón del capitán general, el qual se ponía en parte donde desde él pudiese ver todo el exérçito, y encima una vandera.

ENCICL.: Cov. (s.v. pavellón): Es una manera de tienda de campo. // Aut.: Especie de tienda de campaña, de hechura redonda por abajo y que fenece en punta por arriba. La sostiene un palo grueso, que se hinca en la tierra, y extendiéndola por abajo se afirma con cordeles en unas estacas. Ordinariamente se hacen de lana o de lienzo muy grueso, y sirve para que los soldados estén a cubierto en campaña, y los que caminan por despoblados. 
pacificación, pacificación [tomado del lat. pācǔficătīō, -ōnis 'pacificación', 'reconciliación', de pācĭficicō. 1495 (Segura Munguía 2007). García de Palacio, Diálogos militares, 1583]. sust. Mil. Acción de acabar de someter un país y dominarlo en paz. García de Palacio, Diálogos militares, 1583, fol. 7v-8r: Y, si en Italia, como dize, tiene algún honesto entretenimiento, siendo su presupuesto seguir la guerra, me paresce le estará mejor conservalle que no, dexándole, poner en duda hallar en las Indias otra tal. Que, aunque en ellas ay algunas [...] pacificaciones començadas, son más propiamente cansancio y costa, que provecho ni comodidad. // García de Palacio, Diálogos militares, 1583, fol. 62v: Entendiendo bien en esto aquellos maestros militares del consulado romano, a quien es razón que en las cosas de prudencia y buen govierno de la guerra imiten y sigan los que la usan, lo hazían con sus capitanes, dándoles todo lo que era nescessario y avían menester para las conquistas y pacificaciones que hazían, como si las ovieran de hazer y proseguir por sí y para sí solos.

ENCICL.: DUE: Acción de pacificar.

pacificar, pacificar [tomado del lat. pacĭficare 'íd.'. Santillana; APal. (DECH). García de Palacio, Diálogos militares, 1583]. v. tr. Mil. Acabar de someter un país y dominarlo en paz (DUE).

García de Palacio, Diálogos militares, 1583, fol. 8v: Aunque parezca a vuestra merced que las Indias están distantes de la pulicía de la guerra que en Europa se ha usado y usa, es cierto que ay en ellas capitanes y soldados de tanta sufficiencia que, no ahora, mas en los tiempos de aquellos famosos, Gonçalo Hernández de Córdova, Antonio de Leyva, Juan de Urbina y otros, fueron estimados por su ingenio, arte y valentía, los quales, después de aver visto y sabido las cosas de Italia y otras partes, pasaron a conquistar y pacificar aquel Nuevo Mundo y aprendieron la manera de pelear que, en particular, allí es necessario, con la qual suplieron y aventajaron la que llevavan sabida.

pacífico, pacífico [tomado del lat. pācíficus, - $a,-u m$ 'que hace la paz', 'amante de la paz', de pāx y făcīo. 1220-50 (Segura Munguía 2007). Álaba, Perfeto capitán, 1590]. adj. Mil. Dicho de un individuo, un territorio, un pueblo, etc.: que está ya completamente sometido o sujeto y en paz.

Álaba, Perfeto capitán, 1590, fol. VIIr: Vemos todo el universo arder en bivas llamas de guerras [...]: la África, que hasta aquí estava pacífica, en las Indias y Etiopía y otras regiones, rebelarse contra los que las han conquistado. // Álaba, Perfeto capitán, 1590, fol. 147v: También se le negava la facultad de triunfar a quien, aviendo llevado el exército a una provincia, no la dexava [...] pacífica al capitán sucessor. // Mosquera, Comentario disciplina militar, 1596, fol. 142v: Como refiere Francisco Modio, jurisconsulto, por loable costumbre de los passados estava que ninguno de los que governavan exércitos triunfasse si no dexasse ante todas cosas la provincia que avía conquistado sujeta y pacífica. 
padrasto, V. padrastro.

padrastro, padrasto, padrastro [del lat. vg. patraster, -tri, que en la baja época sustituye al clásico vitricus. J. Ruiz (DECH). Montes, Instrucción y regimiento, 1537]. sust. Art. Cualquier elevación del terreno o lugar alto que domina una fortificación o una posición, desde donde pueden ser ofendidas por los fuegos del enemigo. F (fig. 113)

Montes, Instrucción y regimiento, 1537, fol. XVIIr: Tres cosas ha de tener una ciudad para ser fuerte: la primera, muy buen muro en llano, que no tenga padrasto en torno para que puedan tirar; la segunda, que tenga su fuessa de agua en torno del muro por la parte de fuera [...]; y la tercera, que tenga muchas vituallas para el mantenimiento de la gente de guerra. // Álaba, Perfeto capitán, 1590, fol. 86r: Y aunque el cerco de muchos d'estos fuertes, ofreciéndose ocasión, es justo que se emprenda, esto a de ser en caso que cerca d'ellos aya alguna montaña, lugar alto o padrastro de donde se pueda juzgar lo que huviere dentro y la artillería pueda jugar, o estén faltos de bastimentos y otras municiones, o se les pueda quitar el agua, o los soldados sean advenedizos y mal pagados, porque todas estas cosas, lo que fuere de suyo inexpugnable, harán fácil de allanar. // Rojas, Teórica fortificación, 1598, fol. 78r: Ay algunos assientos de ciudades que son ofendidas de algunas alturas o padrastros que tienen alrededor, de tal suerte que los soldados no pueden estar a la defensa sin ser ofendidos, o por la frente, o por traveses, o por las espaldas. El mejor y más seguro remedio de todos es, si fuere possible, tomar las alturas y padrastros con las murallas de la ciudad.

ENCICL.: Rubió y Bellvé (1895-1901): Se llama así, respecto de una posición o fortaleza, a la altura desde que se domina a éstas. // Lorenzo Celorrio (1996): Cualquier elevación del terreno que se encuentre cerca de un castillo y que, fortificado o no, pueda caer en poder del enemigo, haciéndose fuerte en él y comprometer seriamente la seguridad de la fortaleza. // Collado, Plática Artillería (1592: fol. 67r): "Antes que de la artillería se tuviesse alguna noticia en el mundo, muchas ciudades y fortalezas se hallan fundadas de aquel tiempo, las quales, acerca de sí tienen cerros y montañas que están superiores a ellas, que en estos tiempo en gran manera les son offensivas, por quanto, en tiempo de un assedio y plantándoles el artillería encima el enemigo, las baten y las sojuzgan de tal manera que los sitiados no pueden un punto estar a la defensa ni tenerse por seguros tan sola una hora, de donde viene el ser constreñidos a rendirse con increýble presteza y jamás pensada. Acostumbran nuestros capitanes españoles de llamar padrastros a las semejantes altezas, y con mucha razón, por quanto, según el proverbio dize: "Los padrastros y las madrastras ni aun de açúcar no son buenas". ¿Y qué mayor padrastro puede ser a una ciudad o fortaleza que tener en estos tiempos sobre de sí una montaña que la sobrepuje y la descubra donde, como dicho es, plantada el artillería, con ninguna industria humana se le puede impedir la offensa, porque de aquella alteza le descubre plaças y calles y le mata, inquieta y desasosiega las gentes?". // Rojas, Teórica fortificación (1598: fol. 71v): Siempre se ha de huyr de hazer la plaça donde esté sujeta a padrastros, antes ella ha de ser la eminente y padrastro de toda la campaña. 
palenque, palenque [del cat. palenc 'empalizada, estacada donde se celebra una justa, etc.' [h. 1450, Curial, Cl. C. II], aunque también podría venir de su hermano el oc. palenc [h. 1200, Gavaldan]. s. XIII, Partidas; Cej., Voc.; med. s. XV, Crón. de Juan II, Aut. (DECH). Montes, Instrucción y regimiento, 1537]. sust. Fort. Conjunto de estacas o de palos clavados en el suelo, y normalmente enlazados mediante travesaños de madera, que sirve para impedir el paso al enemigo.

Montes, Instrucción y regimiento, 1537, fol. XVIIIv: Si se gana por batería, puédese defender reparando el muro por la parte de dentro, haziendo un contramuro, echando entre muro y muro muchos barriles de pólvora, haziendo algunos palenques para que los arcabuzeros puedan tirar dende a los enemigos quando entraren por el portillo. // Juanelo Turriano, Veinte y un libros, a. 1605, fol. 439v-440r: En los árboles ponen peñascos muy gruessos, sacos, cuerdas, para defensa de la nave; sirven como de un palenque a la redonda de la nave.

SIN.: empalizada, estacada 1 , palizada 1 .

ENCICL.: Gago-Jover (2002): Véase también empalizada [...]. Valla de madera o estacada que se hace para la defensa de un puesto. // Gago-Jover (2002: s.v. empalizada): Véase también palenque [...]. Valla de madera o estacada que se hace para la defensa de un puesto.

paliçada, V. palizada.

palizada, paliçada, palizada [probablemente del oc. ant. palissada 'íd.' (de donde asimismo el fr. palissade), en vista de las citadas formas en ç, que no serían normales en castellano. Paliçada, 1475, G. de Segovia; APal. y Nebr. (DECH). Loçano, Alberto, Architectura, 1582]. sust. Fort. Conjunto de estacas o de palos clavados en el suelo, y normalmente enlazados mediante travesaños de madera, que sirve para impedir el paso al enemigo.

Loçano, Alberto, Architectura, 1582, pág. 140: Para alcançar lo que desseas, aprovecharán estas cosas: combatir y cercar de palizada para no ser opprimido; tampoco dañarán dos cosas, que son defenderos y fortificaros. // Loçano, Alberto, Architectura, 1582, pág. 140: El cerco de la palizada, por muchas causas se pondrá con buen consejo propinquo a los muros cercados, porque con menos camino y trabajo del soldado, y con más liviana copia de materia y gasto sea acabado; $y$, acabada, tendrá necessidad de menos guardas. // Ufano, Tratado de la Artillería, 1613, pág. 428: Figuras de instrumentos para romper paliçadas, puertas, rexas y barras.

SIN.: empalizada, estacada, palenque.

FAM.: empalizada, empalizar.

ENCICL.: DUE: Fort. Empalizada. 
2 [González de Medina, Examen fortificación, 1599]. sust. Constr. Conjunto de maderos o de estacas que se pone por cimiento cuando no hay tierra firme para un edificio. 3 (fig. 114)

González de Medina, Examen fortificación, 1599, pág. 141: En Benecia se hazen dos paliçadas, y con ellas ciñen el sitio, y entre medias lo terraplenan de lodo, que no le passa el agua. Pero hase de mirar mucho de qué madera se sirven para ello; porque, si es en agua dulce, será buena de roble, encina y castaño, porque esto no puede servir en agua salada, que (según dice Plinio) se carcomen y podrezen; para en agua salada son buenos de pino, álamo negro, olibo y nogal. / / González de Medina, Examen fortificación, 1599, pág. 172: La madera que se huviere de cortar para estas fábricas, si fuere para hazer paliçada en lugar lodoso, mojado y húmedo, ha de aprovecharse d'ella acabada de cortar.

SIN.: estacada $a_{2}$

ENCICL.: Terr.: Los maderos o estacas que se ponen por cimiento cuando no hay tierra firme para un edificio.

parapecto, V. parapeto.

parapeto, parapecto, parapeto [del it. parapetto (usual desde el s. XIV), compuesto con petto 'pecho' 1557 Terlingen (DECH). Loçano, Alberto, Architectura, 1582]. sust. Fort. Terraplén o defensa formada con tierra, sacos de arena, piedras, etc., para guarecerse tras ella en una lucha (DUE). . 8 (fig. 115)

Rojas, Teórica fortificación, 1598, fol. 76v: Y como cosa suya digo esta opinión, afirmando que los parapetos de buena tierra y fagina son mejores que de piedra. // González de Medina, Examen fortificación, 1599, pág. 131: Desde allí arriba hasta lo alto del parapeto, que es adonde está sugeta la muralla a batería, no han de ser grandes las piedras, porque qualquiera bala que dé en una d'ellas, siendo tan grandes, atruena lo demás qualquier movimiento suyo, $y$, quando cae, haze una gran ruyna, y no se pueden desviar de donde caen, haziendo escalera para mejor subir. // González de Medina, Examen fortificación, 1599, pág. 204-205: El parapeto de las cortinas y de los baluartes queréys que sean muy delgados, porque no tengan materia que pueda caer en el foso, y para que mejor pueda la artillería y arcabuzería pescar en él. Bien estoy con essa opinión; pero paréceme que, para los que estuvieren al artillería y a defender la muralla, es poca defensa, porque a quatro cañonaços lo arrasarán y quedarán todos descubiertos y con gran peligro.

SIN.: pretil.

ENCICL.: Moretti (1828): Fort. Parte superior de una muralla, formada de una masa de tierra a prueba de cañón que se eleva por la parte anterior del terraplén y sirve para cubrir la tropa destinada a la defensa de aquella muralla. Su espesor debe ser de dieciocho a veinte pies y su altura de seis de parte de la plaza y de cuatro a cinco de parte de la campaña. 
Esta diferencia de altura forma debajo del parapeto un declive o pendiente que facilita a los soldados que guarnecen el parapeto el poder tirar de alto a bajo al foso, o a lo menos sobre la contraescarpa. En general se llama parapeto a cuanto circuye una línea que resguarda del fuego del enemigo; y así, hay parapetos de cestones llenos de tierra, de sacos a tierra y de fajinas. // Almirante (1869): En general, todo lo que cubre y resguarda; pero técnico, en fortificación, es el terraplén, montón o masa de tierra, ya insista sobre el terreno, ya sobre otro terraplén [...], que cubre hasta el pecho al que tira desde la banqueta. La voz, de origen latino, la tomaríamos de los italianos [...]. / / Rojas, Teórica fortificación (1598: fol. 37r): "Y porque en nuestro tiempo ay muchas diferencias sobre el gruesso que ha de tener el parapeto, y el ancho del fosso y el de la estrada cubierta, será bien dezir lo que siento d'ello, y es que los ingenieros antiguos davan de gruesso a los parapetos 27 pies, y otros en el tiempo presente les dan a 15. Digo que de la mesma manera que se han avido en las defensas largas, assí fue en los parapetos, porque aunque sean de 30 pies de gruesso, por estar en lo alto de la muralla, lo derriba todo el artillería, y con solos los parapetos bastará para cegar el fosso. Y lo peor de todo es que, cuando bate el artillería el parapeto, mete en la plaça las piedras y ladrillos d'él, y assí haze andar a los soldados desatinados. Y, por esto, me parece que no deve tener el parapeto de gruesso más que hasta cinco o seis pies (quanto sea suficiente para sustentar un cañón de artillería a barva, que no pueda caer abaxo). Y, luego, de allí adentro una espalda de tierra y fagina de 25 pies de gruesso, de forma que por encima d'esta espalda que digo andarán los soldados al tiempo del escaramuçar, y, por ser el parapeto delgado, descubrirán hasta la estrada cubierta, lo que no pueden descubrir siendo el parapeto muy gruesso. $\mathrm{Y}$ assí, con la espalda de tierra y fagina que digo se remedia la defensa de los soldados, porque, quando bata el artillería el parapeto, se pondrán los soldados detrás de la espalda de tierra, todo lo qual se entenderá adelante en su lugar".

parcial, V. cortina $\sim$.

pataforma, V. plataforma.

pavellón, V. pabellón.

paz, paz [del lat. pax, -cis. Cid (DECH). Martínez de Burgos, Reportorio premáticas y Cortes, 1551]. sust. Estado o circunstancia de no haber guerra en un país o de no estar en guerra con otros (DEA).

Martínez de Burgos, Reportorio premáticas y Cortes, 1551, fol. IIv: Otrosí, porque aya siempre memoria de las hystorias y corónicas de las hazañas hechas por los Reyes de Castilla, de gloriosa memoria, en guerra y paz, se haga un cuerpo y volumen de todas ellas. // Celso, Reportorio universal leyes Castilla, 1553, fol. CXVIr: El Emperador, en tiempo de paz, deve usar de consejo de letrados y sabios varones, quales de suso, capítulo consejeros, diximos. $\mathrm{Y}$ en tiempo de guerra, de armas y de todas otras cosas de que se podiesse ayudar por mar e por tierra contra sus enemigos, en el qual tiempo deve tomar 
consejo con hombres honrados y cavalleros sabidores en fechos de guerra. // García de Palacio, Diálogos militares, 1583, fol. 59v: Julio César dezía que, en tiempo de paz, se avían de prevenir las cosas nescessarias a la milicia, pensar y tratar d'ella, para conseguir prósperos y felices subcessos y gloriosas victorias, al tiempo que se huvieren de poner en prática y obra.

ANT.: batalla, contienda, guerra.

ENCICL.: Estévanez (1897): Estado normal de las naciones; la guerra tiene por objeto restablecer la paz. // García de Palacio, Diálogos militares (1583: fol. 16r): "Otra circunstancia ay [...] y es que la intención en las guerras sea justa: es, a saber, que no se mueva por cobdicia o por crueldad, sino con desseo de que, por medio de la guerra, se consiga paz en la república, y los malos sean castigados y reprimidos, y los buenos relevados, amparados y defendidos".

2 [Celso, Reportorio universal leyes Castilla, 1553]. sust. Mil. Tratado o convenio por el que las partes enfrentadas ponen fin a una guerra (DESAL).

Celso, Reportorio universal leyes Castilla, 1553, fol. CCLXXXVIIIr: El hombre libre, aunque no se pueda empeñar, como dize la ley III, título XIII de la V Partida, empero puédese dar por rehenes el hombre libre por razón de paz [...] que firmassen entre sí algunos buenos o grandes señores. // García de Palacio, Diálogos militares, 1583, fol. 84v: Deve, ante todas cosas, el que sitiare qualquier castillo o ciudad, offrescer la paz al enemigo, con los partidos que justamente convinieren al negocio y causa de su príncipe, para que [...] se acabe sin los daños y ruynas que el proseguir un cerco trae consigo, y la salud del pueblo sitiado quede salva y segura. // Álaba, Perfeto capitán, 1590, fol. 10r-10v: Publio Licinio [...], siendo vencido y desbaratado del rey Perseo de Macedonia, con pérdida de dos mil y ochocientos de a cavallo, siendo parte d'ellos muertos y parte presos, como después de la batalla le embiasse el rey embaxadores que tratassen de conciertos y paz, no dexándose llevar de su desgracia y mal sucesso, tuvo tanta entereza y constancia de ánimo que embió a dezir al rey que dexasse lo que pedía al arbitrio y voluntad de los romanos.

ENCICL.: Aut.: El ajuste o convenio que se concuerda entre los príncipes para dar la quietud a sus pueblos, especialmente después de las guerras.

pelea, pelea [de pelear. Berceo (DECH). Celso, Reportorio universal leyes Castilla, 1553]. sust. Mil. Acción bélica en la que se enfrentan soldados o formaciones militares enemigas.

Celso, Reportorio universal leyes Castilla, 1553, fol. CLXXIVr: El que matare a otro, aunque sea en pelea, ansimesmo muera por ello, salvo si fuesse en uno de los casos que dezimos de suso, versículo I. // García de Palacio, Diálogos militares, 1583, fol. 148r-148v: Y, aunque es verdad que, en el hervor de la pelea, no se puede guardar esta orden entera y limitadamente, siendo los soldados acostumbrados en paz a guardar la dicha orden, quedarán abituados a guardarla, si en todo no, a lo menos en parte. // Álaba, Perfeto capitán, 1590, fol. 77r-77v: Y ninguna cosa con más advertencia a de considerar el capitán 
quando acomete que la disposición en que tiene su gente: si está descansada para perseverar en la batalla, porque acometer con ella estando cansada de aver caminado jornada larga es ponerse a tener un mal sucesso muy conocido por la falta de aliento que tendrá para durar en la pelea.

SIN.: batalla ${ }_{1}$ combate ${ }_{1}$, combatimiento ${ }_{1}$, contienda $a_{2}$, debate, facienda, lid.

FAM.: pelear.

ENCICL.: Cov.: Es la batalla. // Moretti (1828): Combate, batalla, contienda entre muchos.

pelea, $V$. gente de .

pelea, V. hombre de .

pelear, pelear [de pelo y éste del lat. pŭlus 'íd.', pues el sentido primero hubo de ser 'venir a las manos, reñir' y anteriormente 'agarrarse por el pelo'. Peliare, 1131, en el fuero latino de Calatayud; pelear, princ. s. XIV, Zifar; J. Ruiz (DECH). Fernández de Enciso, Suma de Geographía, 1530]. v. intr. Mil. Enfrentarse dos o más personas utilizando la fuerza o las armas para vencer al otro.

Fernández de Enciso, Suma de Geographía, 1530, fol. XXXIVr: Éstos de Atenas, siendo cercados de los persas e viendo que avía mucho tiempo que sufrían la fatiga, deliberaron de morir por su libertad, e salieron de la cibdad y metiéronse en ciertas fustas. Y en la mar pelearon tan rezio, que desbarataron a la flota de los persas e los echaron de su tierra. // Montes, Instrucción y regimiento, 1537, fol. XVIr: E todo hombre de guerra deve pensar que la mucha gente en la guerra está más subjeta al peligro que la poca [...], porque, como arriba es dicho, el exército copioso de gente no puede dar la orden en el pelear como los pocos, y los pocos son más prestos a combatir que los muchos. // Álaba, Perfeto capitán, 1590, fol. 52v: Y por la relación que tuvo Cipión en Lidia que la gente de Antíoco peleava con arcos, pareciéndole que, por aver llovido un día entero y noche, las cuerdas estarían mojadas y de ningún provecho, acometiéndolos, los venció y sujetó.

SIN.: batir 3 , combatir 1 , lidiar, luchar, ${ }_{2}$ revolver ${ }_{2}$.

FAM.: pelea.

ENCICL.: Terr.: V. Combatir. // DUE: ("a": 'a mordiscos'; "con": 'con armas; con sus amigos; con furia'; "en": 'en defensa de'; "por": 'por una presa, por la patria') intr. Emplear sus fuerzas o sus armas dos personas o animales o grupos de ellos para imponerse, hacerse daño, arrebatarse algo, inutilizarse o aniquilarse uno a otro.

peltrechos, V. pertrechos. 
peón, peón [del lat. vg. pedo, -onis. Pedones, doc. de 1074, Oelschl.; peón, doc. de 1100; Cid; Berceo, Mil.; Acedrex (DECH). Ortega, Conpusición Arismética y Geometría, 1512]. sust. Mil. Soldado que sirve, marcha y combate a pie.

Ortega, Conpusición Arismética y Geometría, 1512, fol. 112v: Farás ansí: mira quántos ducados ganan los 50 hombres de armas en un año, y allarás que ganan 4000 ducados; y, ansimesmo, fallarás que ganan los ginetes 6000 ducados, y los peones, 6000 ducados. // Celso, Reportorio universal leyes Castilla, 1553, fol. CXXXVIv: El cavallero o peón que, siendo con exércitos, vendiere o empeñare sus armas, quál pena deven haver el uno y el otro, dezimos de suso, capítulo armas, versículo onze, y capítulo cavallero. // Álaba, Perfeto capitán, 1590, fol. 80r: Y si la parte por donde se quieren retirar es campaña tan rasa que no aya passo que poder impedir yendo en su seguimiento, hará que los arcabuzeros de a cavallo y estradiotes con algún número de peones acometan muy a menudo a los de la retaguardia, de suerte que los obliguen a parar para que, acudiendo al favor d'éstos los que después d'ellos se siguen, necessariamente, por la mesma razón, aya de parar todo el exército.

SIN.: infante.

FAM.: peonero.

ENCICL.: Cov.: El soldado de a pie dicho infante, y de allí se dijeron los peones del ajedrez.

peonero, peonero [de peón, pero con influencia, en el significado, del francés pionnier (DECH). Mendoça, Theórica y práctica, 1596]. sust. Mil. Trabajador empleado en el ejército para realizar las distintas labores en las que lo esencial es mover la tierra, como allanar los caminos para facilitar el paso de la artillería, y abrir trincheras, minas y demás obras pasajeras.

Mendoça, Theórica y práctica, 1596, pág. 49: No lexos d'este quartel ha de estar en la parte más conveniente el general de la artillería con la pólvora, balas y otras municiones y pertrechos d'ella, los capitanes y oficiales de su cargo y el coronel y capitanes de los gastadores o peoneros que han de alojar en el mesmo quartel.

SIN.: gastador.

FAM.: peón.

ENCICL.: Estévanez (1897): Lo mismo que "gastador".

pequeño, $V$. pie .

perdido, V. centinela $\sim$. 
perdido, $V$. infante $\sim$.

pertrechos, peltrechos, pertrechos, petrechos [probablemente del lat. protactum, part. pas. de protahere 'hacer salir, revelar, producir' (DECH). García de Palacio, Diálogos militares, 1583]. sust. pl. Mil. Toda clase de materiales e instrumentos, como pueden ser armas o máquinas, necesarios para cualquier empresa militar.

García de Palacio, Diálogos militares, 1583, fol. 91r: Y procure saber el camino y orden que los enemigos traen y por qué lugares vienen, para que, como se enseña en el Libro de Judith, si huviere oportunidad, se le tomen los passos angostos y montuosos, que, de ordinario, son más fuertes y de donde, con menos gente y armas, se puede hazer mayor resistencia y aun deshazer y dañar al enemigo, e inquietalle, y gastarle la gente y pertrechos de su exército. // Roxas, Sumario milicia, 1607, fol. 102r: Una plaça fuerte a de estar muy amuniçionada de todo lo necesario, así de bastimentos, pertrechos, gente de guerra y las demás cosas necesarias. // Ufano, Tratado de la Artillería, 1613, pág. 132: Y en tiempo de sitio le toca acudir a las tiendas de muniçiones sobre tarde y hallarse presente al dar las muniçiones y pertrechos necessarios para las trincheras y vaterías, y para sus fortifficaçiones y cubrimiento.

SIN.: aproche2, aproches de guerra, munición de guerra, pertrechos de guerra.

ENCICL.: Terr. (s.v. pertrecho): En la milicia, armas, municiones, máquinas, etc. para la defensa o expugnación de una plaza, o para una batalla [...]. Comúnmente se dice en pl. pertrechos. Algunos dicen peltrechos, pero mal. // DRAE: Municiones, armas y demás instrumentos, máquinas, etc., necesarios para el uso de los soldados y defensa de las fortificaciones o de los buques de guerra. // García de Palacio, Instrución náuthica (1587: fol. 127v): "Alguna differencia ha de aver entre la nao y gente que acomete a la que es acometida y se defiende, aunque en quanto a las armas de los soldados, artillería, municiones, pertrechos y prevenciones ha de ser como en el capítulo passado se ha dicho".

de guerra [García de Palacio, Diálogos militares, 1583]. cmpt. sintag. pl. Mil. Toda clase de materiales e instrumentos, como pueden ser armas o máquinas, necesarios para cualquier empresa militar.

García de Palacio, Diálogos militares, 1583, fol. 20v: En nuestro propósito fue nescessario, para conseguir la victoria, un cuerpo, que es un exército compuesto de mucha variedad de cosas, unas que biven vida racional, como son los capitanes y soldados; otras, vida sensitiva, como los cavallos de que se usa en la guerra; otras que son insensibles y mudas, meneadas por los soldados, porque son sus instrumentos, como son las armas, los tiros y todos los pertrechos de guerra. // Rojas, Teórica fortificación, 1598, fol. 36v: Si se ofreciere hazer la fortificación en un sitio plano, se haga muy perfeta, con todos los requisitos y reparos que son necessarios, assí como es buenos ángulos en los valuartes y muy cubiertas las casas matas con grandes espaldas, y, sobre todo, buena guarnición de soldados y 
mucha munición y pertrechos de guerra. // Ufano, Tratado de la Artillería, 1613, pág. 82: Sería menester, para conseguir en una jornada larga, gran máquina y aparato de carros y caballos para llevar todos los montages, pólvora y balas de artillería y otros ynfinitos y diversos pertrechos de guerra que propiamente serían menester y son muy convinientes para ello, y para lo neçessario para el acompañamiento de la gente de guerra.

SIN.: aproche 2, aproches de guerra, munición de guerra, pertrechos.

ENCICL.: DEA (s.v. pertrechos): Armas, maquinaria, municiones y demás instrumentos de guerra. $T b \sim$ de guerra.

petipié, V. pitipié.

petrechos, V. pertrechos.

petril, V. pretil.

phalárica, V. falárica.

picamiento, picamiento [de picar. Ufano, Tratado de la Artillería, 1613]. sust. Fort. Acción de golpear, mediante un pico u otra herramienta semejante, la muralla de una fortificación con el fin de abrir brecha en ella.

Ufano, Tratado de la Artillería, 1613, pág. 147: Qualquiera sería muy animoso y mostraría diligençia y brío al emprender qualquiera obrage, por diffíçil que fuesse, en los desembocaderos de los fossos y picamiento de la muralla.

FAM.: picar.

picar, picar [voz común a todos los romances de Occidente, de creación expresiva. Cid (DECH). Collado, Plática Artillería, 1592]. v. tr. Fort. Golpear la muralla de una fortificación, mediante un pico u otra herramienta semejante, para abrir brecha en ella.

Collado, Plática Artillería, 1592, fol. 63r: Y deve, assimismo, muy bien considerar el intento que le mueve a hazer el tal officio, conviene a saber, que o se pone a él por sólo abrirse bocas a la contrascarpa y meterse en el fosso a picar la muralla enemiga o quiere, passando por debaxo de el fosso, hir a hazer la mina debaxo de ella. / / Mendoça, Theórica y práctica, 1596, pág. 105: Assimismo se pican las murallas, quando se ha llegado con trincheas o traviessas en el fosso o por otro medio al pie d'ellas, cubriéndose los soldados con mantas al hazerlo. // Rojas, Teórica fortificación, 1598, fol. 32r: Al tiempo que el enemigo ha metido 
sus trincheas hasta el bordo de la estrada cubierta (como parece en la planta que queda atrás), y quiere passar el fosso por el derecho de la esquina del valuarte y arrimarse a él para picarlo y hazerle la mina, si estuviesse la defensa a tiro de artillería, passarían los enemigos, uno a uno, casi al descubierto, por ser muy lexos la defensa.

FAM.: picamiento.

pie, pie [del lat. pēs, pĕdis 'íd.'. Orígenes del idioma (Cid, etc.) (DECH)].

pequeño [Rojas, Teórica fortificación, 1598]. cmpt. sintag. Geom. Línea dividida en alguna cantidad de partes iguales que representan pies, varas, leguas $u$ otra cualquier medida, y sirve para delinear con proporción en el papel la planta de cualquier terreno o edificio (Aut.: s.v. escala).

Rojas, Teórica fortificación, 1598, fol. 35v: El pitipié es nombre francés, que peti en francés quiere dezir 'pequeño' o 'chico', y assí es lo mesmo dezir en nuestra lengua castellana "pequeño pie", como en francés "pitipié". // González de Medina, Examen fortificación, 1599, pág. 52: El pie pequeño, Señor, es tomar una distancia, qual se quisiere, por pequeña que sea, y ponerla el nombre que se quisiere: pie, passo, vara, milla o legua, y con ella distribuir la planta, y que quepa aquella medida tantas vezes en lo que se haze como cupiera el pie, passo, vara, milla o legua en la cosa que queremos de desiniar, que se trata de hazer o está ya hecha, para sacar su planta al justo. // Lechuga, Discurso de la Artillería, 1611, pág. 90: Y advierta que la escala menor de esta figura contiene tres onças milanesas, que es la quarta parte de un brazo, por donde he regulado todas las cosas de madera, y que una de las tres onças de ella va repartida en doze partes yguales en pie pequeño, que se entiende en onças menores yguales a la figura que por ellas se haze pequeña.

SIN.: escala $a_{2}$ pitipié.

$\mathbf{a} \sim$ [Celso, Reportorio universal leyes Castilla, 1553]. loc. adv. Andando (DSAL). Celso, Reportorio universal leyes Castilla, 1553, fol. CLVIIIv: Y se hazen estos appellidos en tiempo de paz y de guerra. $Y$ en qualquier tiempo que se hizieren, todos deven salir al dicho appellido, ansí a pie como a cavallo. // Rojas, Teórica fortificación, 1598, fol. 38r: Estando el enemigo al bordo del fosso con sus trincheas, no sale la cavallería si no es a pie con la infantería a defender la estrada cubierta. // Lechuga, Discurso de la Artillería, 1611, pág. 234: Y servirán los dichos conductores a cavallo, quando el campo estuviere en algún sitio que uviere batería, de estar en las trincheras cerca del general, teniente y gentileshombres, para venir quando fuere menester, a pie o a cavallo, por municiones de balas, pólvora, pieças y otras cosas necessarias.

ENCICL.: DUE: Andando y no llevado en una caballería, en un vehículo, etc.

de a [Escalante, Discurso de la navegación, 1577]. loc. adj. u. t. c. sust. Mil. Dicho de un soldado o de una tropa: que realiza sus funciones a pie. 
Escalante, Discurso de la navegación, 1577, fol. 86r: Esto se haze con comodidad respeto de que en todas las laderas d'él ay muchas poblaciones grandes $\mathrm{y}$, con tener centinelas puestas que les dan rebato, acuden todos a la defensa quando se ofrece necessidad, hasta que llegue el rei con su exército grande, que tiene de ordinario de mucha gente de a pie y de a cavallo para su guarda y magestad, y para refrenar las incursiones de los enemigos. // Álaba, Perfeto capitán, 1590, fol. 68r: Muchos que resuelven la qüestión que he propuesto son de parecer que la gente de a pie es más útil que la de a cavallo y que en los casos en que sucediere pelear los unos con los otros, desbaratará la infantería a la cavallería. // Roxas, Sumario milicia, 1607, fol. 32r-32v: Mas si el río fuere tan hondo que ni los de a pie ni de a caballo lo pudieren badear, se hará d'esta forma: si fuere el río por tierra llana, se dividirá abriendo fosos a trechos de manera que se hagan muchos ríos de poca agua; mas si el sitio fuere precipitoso, se harán barcas, las quales llevarán en el carruaje, y en la ocasión se echará al agua y de una a otra con tablas se hará puente.

SIN.: de pie.

ENCICL.: DEA: loc. adj. [Soldado] que va a pie o realiza su función a pie.

de $\sim$ [Montes, Instrucción y regimiento, 1537]. loc. adj. u. t. c. sust. Mil. Dicho de un soldado o de una tropa: que realiza sus funciones a pie.

Montes, Instrucción y regimiento, 1537, fol. IIIr: Después que la guerra fuere declarada por justa, el señor del exército y los de su consejo de guerra, ante todas las cosas, deven saber la gente que será menester para hazer la guerra, assí de pie como de cavallo, para haver vitoria en la empresa y conquista que quisieren hazer. // Aurel, Arithmética algebrática, 1552, fol. 116r: El Rey, nuestro Señor, embía cierta gente de socorro a una ciudad, con la qual van no sé quántos capitanes, y cada uno d'ellos tiene tres vezes tantos de cavallo, y veynte vezes tantos de pie como son los capitanes. / García de Palacio, Diálogos militares, 1583, fol. 69r: Y del gran Epaminonda se qüenta que, assimismo, dezía que, en la guerra, ninguna ventaja avía tan conoscida como era saber las fuerças, costumbres de pelear, cantidad de gente, de pie o de cavallo, las determinaciones, conciertos y partidos del enemigo, para, sabido y conoscido, opponerse con el remedio y defensa, y offendelle por la orden y camino que él elije por seguro.

SIN.: de a pie.

pie, V. a .

pie, V. de a $\sim$.

pie, V. de .

pilotage, V. pilotaje. 
pilotaje, pilotage [de pilote. Pilotaje 'conjunto de pilotes' (DECH). Ufano, Tratado de la Artillería, 1613]. sust. Fort. Conjunto de pilotes.

Ufano, Tratado de la Artillería, 1613, pág. 138: Tócales yr a las villas y lugares con partidas de carros, a traer provisión de muniçiones de guerra y llevar recaudo y serviçio de todo menester a las baterías, así de muniçiones como de petrechos, pilotage, çestones y faxinas, para la fábrica y trabajo d'ellas, acompañando siempre los carros. // Ufano, Tratado de la Artillería, 1613, pág. 272: Y si acaso uviere mucha maleza y fango en las orillas de la ribera y gran lamedal, que causa no poder bien ancorar las barcas para estar firmes en un ser y puesto unidas, converná hazer con mucha rama, faxina y pilotage en cada una parte de la ribera un pie y cabeça a modo de bestión fuertemente fabricado, hasta que su altura yguale con los bordos de las barcas o bien poco menos.

FAM.: pilote, pilotear.

pilote, pilote [del fr. ant. pilot (hoy sólo el derivado pilotis). Acad. s. XIX (DECH). Ufano, Tratado de la Artillería, (1613)]. sust. Fort. Palo o pieza cilíndrica de madera, con uno de sus extremos acabado en punta, frecuentemente empleado en la guerra, especialmente en la construcción o reparación de defensas. (fig. 116) Ufano, Tratado de la Artillería, 1613, pág. 165-167: Relaçión y nota de lo que de provisiones de guerra y otros furnimientos propiçios,que ordinariamente deve tener dentro de sí una fortaleza [...]; gran cantidad de fuertes y gruesas planchas o tablones de roble para formar las explanadas sobre las quales deve jugar el artillería y para, presto, con ellas y pilotes reparar los portillos y la royna de las baterías. // Ufano, Tratado de la Artillería, 1613, pág. 190-191: Si con la pala y çapa se puede hazer un pequeño asiento, puestas, como dicho tengo, de 3 en 3 [las sacas de lana] y clavadas y affirmadas con sus estacones y pilotes [...], yrlas lo mejor que se pudiere presando y coligando unas con otras; y de las de medio cuerpo, como se a praticado, meter una o dos por debaxo de la barba, tan holgadamente que la pieça por dos pies muestre su boca delante d'ellas después de asestada, según y como fuere el artillería que uviere dentro de tal villa.

FAM.: pilotaje, pilotear.

ENCICL.: Moretti (1828: s.v. piquete): Fort. Palo o estaca puntiaguda, que sirve, en la fortificación pasajera, para clavar y asegurar las fajinas.

pilotear, pilotear [de pilote. Ufano, Tratado de la Artillería, 1613]. v. tr. Fort. Clavar pilotes o piezas de madera semejantes.

Ufano, Tratado de la Artillería, 1613, pág. 261: Lo qual deve entender el que con ellos uviere de hazer obra de qualquier reparo a prueva de artillería, porque no entremezclando tierra con la faxina, por mucho que a ella sola la apriete y ligue, a menester el doble grueso y través de cuerpo que si juntamente con ella y tierra se fabricase, aunque fuesen tan 
apretados, ligados y piloteados con sus estacas como se demuestra por la presente figura, así en el grande como en el pequeño salchichón.

FAM.: pilotaje, pilote.

pina, pina, pinna [tomado del lat. p̌̆nna 'pluma', 'ala', 'almena', etc. (DRAE). Urrea, Vitruvio, Architectura, 1582]. sust. Fort. ant. Cada uno de los bloques de piedra que hay en la parte superior del muro de una fortaleza, utilizados como escudo por los defensores. (DSAL: s.v. almena).

Urrea, Vitruvio, Architectura, 1582, fol. 142r: Pinna: almena y remate, y lo más alto del edificio.

SIN.: almena.

pinna, $V$. pina.

pitapié, V. pitipié.

pitipié, petipié, pitapié, pitipié [del fr. petit, a partir de la locución adverbial fr. au petit pied 'en pequeño'. Pitipié 'escala cartográfica o arquitectónica'. 1633, Lz de Arenas; Aut. (DECH). Alcega, Geometría prática, 1589]. sust. Geom. Línea dividida en alguna cantidad de partes iguales que representan pies, varas, leguas $u$ otra cualquier medida, y sirve para delinear con proporción en el papel la planta de cualquier terreno o edificio (Aut.: s.v. escala).

Rojas, Teórica fortificación, 1598, fol. 36r: Y assimesmo a este pitipié le llaman muchos escala, y los estrangeros ponen en sus traças por medida de petipié, canas, dándole diez palmos de valor a cada una. // Rojas, Teórica fortificación, 1598, fol. 82v: Y estando tomada la planta con las diligencias dichas, para sacarla en limpio en otro papel, se hará un pitipié a voluntad, que sea su distribución por pies, passos, o varas. // González de Medina, Examen fortificación, 1599, pág. 51: Es menester primero advertiros que, para que salga bien esta planta y sus miembros proporcionados y con las medidas que hemos dicho, y la podáys reconocer si es assí como se dize, hazer un petipié, que es un pequeño pie, para que sirva de medida para hazerse y para que después se pueda reconocer con un compás si es verdad lo que se haze en un papel, por pequeño que sea, como se podría hazer en un campo capaz de la dicha fuerça.

SIN.: escala, pie pequeño.

ENCICL.: Rojas, Teórica fortificación (1598: fol. 35v): "Siempre que el arquiteto quiere hazer una traça, lo primero que haze antes que la comiençe es hazer el pitipié. Y porque avrá muchos que no sepan qué cosa es pitipié, pongo aquí su declaración. El pitipié es nombre 
francés, que peti en francés quiere dezir 'pequeño' o 'chico', y assí es lo mesmo dezir en nuestra lengua castellana pequeño pie, como en francés pitipié".

plaça, V. plaza.

plataforma, pataforma, plataforma [término de fortificación tomado del fr. plate-forme (s. XV). 1595 (DECH). Mendoça, Theórica y práctica, 1596]. sust. Fort. Cualquier obra de fortificación construida para alojar cañones y otras piezas de artillería. 3 (fig. 117)

Mendoça, Theórica y práctica, 1596, pág. 28: Raras vezes se acomete reyno o estado que tenga todas las entradas d'él de suerte que las dificulte el mismo sitio de naturaleza; quando lo sean y passos, siempre se tiene inteligencia en ellas o esperança de ganarlas por ardid o estratagema; y si es acometiéndole por mar, buscar puerto o playa donde la artillería de los castillos y plataformas no pueda alcançar a sus navíos al poner gente en tierra. // Rojas, Teórica fortificación, 1598, fol. 74r: Se tendrá por regla general de guardar la munición para quando el enemigo esté a 200 passos del fosso, porque desde allí para dentro hará su efeto el arcabuzería; y de los 200 passos para fuera avrá tirado el artillería del dicho castillo, tirando siempre donde huviere tropa de gente o alguna berraca o las plataformas o gabionadas que huviere. // Rojas, Teórica fortificación, 1598, fol. 105v: Y con este presupuesto se yrá caminando por todas las partes que muestran las trincheas en la planta que queda atrás [...], poniendo en los tres puestos que parecen en ella el artillería; y detrás de cada plataforma y camarada de artillería avrá muy buena guardia de soldados para resistir las salidas que hizieren del dicho castillo.

SIN.: batería 4 .

ANT.: contrabatería ${ }_{3}$.

ENCICL.: Como puede concluirse por el hecho de haber detectado cinco acepciones de plataforma en nuestro corpus, esta voz no gozaba de una gran precisión semántica en el campo de la milicia, por lo menos en la época renacentista si bien todavía en el siglo XVIII encontramos recopilados en un diccionario militar, el de Almirante, varios de sus múltiples sentidos: "Mayern, autor alemán de fortificación, dice que se dio el nombre italiano piattaforma a las primeras medias lunas. Otros llaman también así a los resaltos de la muralla, que no son baluartes, sino a manera de torres cuadradas irregulares. Plataforma llama el P. Casani (Fortif. pág. 112 y Comp. pág. 92) al caballero de trinchera. Plataforma se ha llamado también a la explanada de batería, que en francés es plate-forme. La parte superior de una torre es plataforma para Moretti. Especie de caballero para Dicc. Acad. 5". De hecho, es tal la abundancia de acepciones que este lexicógrafo acaba su artículo con el siguiente comentario: "Basta de plataforma". Resulta curioso, por tanto, el siguiente comentario que hace Rojas en su tratado de 1598, fol. 30r: "Para esto, advierto se sepa con fundamento, de suerte que a lo que se llama valuarte no le digan cavallero, ni a lo que es cavallero, plataforma, pues todas tres cosas son apartadas y conocidas en la fortificación". Es decir, advierte, de manera rotunda, que no deben confundirse, entre otras voces, caballero y 
plataforma, precisamente dos voces que, en algunas acepciones, son sinónimas. Para Rojas, en 1598, confundir caballero con plataforma es un síntoma de ignorancia, a la luz de la siguiente anécdota que incluye en su tratado, fol. 30v: "Es muy conveniente que cada cosa se conozca lo que es, y no les suceda a muchos lo que a algunos les ha sucedido conmigo, y fue que, enseñándoles a unos soldados cierta traça de fortificación, tomó la mano uno de la quadrilla, mostrando ser el más curioso, y començó a dezir: «Esta fortificación fuera mejor si tuviera los ángulos más tusos, y las pataformas más altas que los cavalleros, porque siempre las pataformas han de señorear la campaña, que aunque yo no he estudiado Jometría, todavía entiendo algo de triánganos, y sé muy bien que el triángano tuso es más fuerte para la guerra que no el triángano agudo»". Ahora bien, Rojas debió de cambiar de opinión muy pronto, puesto que en su manuscrito del año 1607 ya emplea plataforma como sinónimo de caballero ${ }_{2}$.

2 [Collado, Plática Artillería, 1592]. sust. Fort. Cualquier construcción elevada que permite al sitiador, con la artillería allí asentada, batir de forma dominante la fortaleza.

Collado, Plática Artillería, 1592, fol. 110r: THENIENTE. - Si estando en una batería os conviniesse alçar algún bestión o plataforma por beneficio de la empresa, ¿cómo haríades acerca del modo de alçarla? ARTILLERO. - Procuraría de alçarla con maderos, estacas, clavos, céspedes y faxina o hacezillos y tierra. // Rojas, Teórica fortificación, 1598, fol. 69r: Levantando el enemigo en la campaña una plataforma de 12 o 15 pies de alto y puesta encima alguna artillería, daría con las valas en los pies de los soldados que estarán dentro de la plaça, y andarían todos desassossegados, por estar sojuzgados de la parte de afuera, que sería la mayor falta que una plaça puede tener. // González de Medina, Examen fortificación, 1599, pág. 203-204: Si el enemigo se dispusiesse a hazer bestiones o plataformas, como las quisiéredes llamar, como los turcos hazen para igualar con las fortificaciones y quitar las defensas, y otras vezes para sobrepujar y señorearlas y descubrirlas, que nadie se pueda assomar a ningún servicio ni defensa, ¿qué es lo que haríades para contra ello?

SIN.: baluarte 3 , bastión 1 , caballero 3.

ENCICL.: Terr.: Según el Comp. mil. p. 92, son unos torreones de fajina y céspedes que hacen los expugnadores, más altos que los muros de la plaza, para incomodar con la artillería que colocan en ellos. // Estévanez (1897): El mismo nombre [plataforma] se dio [...] también al caballero de trinchera.

3 [Collado, Plática Artillería, 1592]. sust. Fort. En una fortaleza, defensa muy alta que se construye para descubrir las partes de la campaña por las que el enemigo puede acercarse sin ser visto, o para ofenderle desde allí aunque aún se encuentre lejos; y, en el caso de haber cerca cualquier monte o elevación, para igualar o superar su altura.

Collado, Plática Artillería, 1592, fol. 57v: Plataforma, entre los ingenieros es, assimismo, un edificio o máquina y género de defensa que se acostumbra de hazer de fábrica en el medio 
de la cortina de qualquier fortaleza y entre una casamata y la otra, las quales, por la mayor parte, se hazen y toman la figura de una planta exágona, que es aquélla que de 6 ángulos se forma. // Roxas, Sumario milicia, 1607, fol. 80v: Las tenazas se hazen en lugar de las plataformas metidas en la muralla, y semejantemente se hazen en los sitios montuosos en alguna buelta que pueda hazer el balle, para dar la mano a un padrastro. // Lechuga, Discurso de la Artillería, 1611, pág. 240-241: Si se uvieren de hazer plataformas, que son las que italianos llaman cavalleros, an de estar en las cortinas, sin que toquen a los baluartes, de manera que lo llano que se a dicho a de seguir a los parapetos no lo impidan y que vean parte del fosso, capazes cada una de seis pieças de artillería.

SIN.: caballero 2.

ENCICL.: Aut.: Term. de fortificación. Especie de caballero, y sólo se distingue en que éste suele ponerse en los baluartes y la plataforma sobre el terraplén de la muralla o cortina. // Rubió y Bellvé (1895-1901): Fort. Especie de "caballero" o adarve elevado que a veces se construía en las antiguas obras defensivas.

4 [Lechuga, Discurso de la Artillería, 1611]. sust. Fort. Obra exterior que se construye delante de las cortinas demasiado largas o enfrente de un ángulo entrante, para mejorar las posibilidades de defensa de las fortalezas que cuentan con uno de estos dos inconvenientes. $\$$ (fig. 118)

Lechuga, Discurso de la Artillería, 1611, pág. 253-254: Adviértase que, haviendo de fortificar alguna tierra de cortinas largas, que se pueden en sus ángulos hazer los baluartes y entre dos baluartes, en forma de triángulo, otro asido con la muralla, para que d'él se puedan guardar las cortinas de los baluartes, y que ay en algunas, entre dos baluartes, un través hecho en forma de un paralelogramo con sus dos ángulos y la cortina de la frente derecha, que italianos llaman plataformas, y que no las tengo por tan fuertes como los triangulares, por no poderse guardar sus frentes de las cortinas de la ciudad, villa o lugar que las tiene.

ENCICL.: Díaz Capmany (2004: 49): "La plataforma era una batería que se construía en los frentes muy grandes o en los ángulos entrantes cuando no había espacio suficiente para colocar un baluarte plano. Su forma, generalmente, era rectangular y entre ella y la plaza se dejaba un pequeño foso. Desde sus flancos debían defenderse las caras de los baluartes inmediatos, y los flancos de éstos debían flanquear la cara de la plataforma. Esta obra podía cubrirse a vanguardia con un revellín". Aunque no hay en el corpus ocurrencias de baluarte plano, es necesario, para entender perfectamente esta acepción de plataforma, saber qué se entendía por este compuesto. Así, según Díaz Capmany (2004: 49), "era una obra propia de la fortificación irregular". Y continúa su explicación con las siguientes palabras: "Sus semigolas formaban una línea recta, y generalmente se colocaba en un tramo recto de cortina cuando la distancia entre los baluartes era de tal extensión que las líneas de defensa excedían del alcance del mosquete o del fusil. También se llamaba así al que fortificaba un ángulo entrante muy obtuso aunque sus semigolas no formasen línea recta". 
5 [Álaba, Perfeto capitán, 1590]. sust. Art. Pavimento, generalmente de madera o de piedra, sobre el que se colocan las piezas de artillería, para que las ruedas de sus cureñas puedan deslizarse fácilmente.

Álaba, Perfeto capitán, 1590, fol. 228r: Y porque el artillero tiene necessidad de nivel, assí para saber quánto una caça es más alta que otra como para hazer una plataforma, de suerte que los tablones estén muy iguales, es necessario añadir al nivel de la artillería el nivel común. // Collado, Plática Artillería, 1592, fol. 57v: Aquel lecho compuesto de tablones y de maderos que se acostumbra de hazer sobre los quales juega el artillería en qualquiera plaça, través o casa mata se llama, comúnmente, una plataforma. // Collado, Plática Artillería, 1592, fol. 57v: Mi intento en este lugar no es de tratar de éstas, mas solamente entiendo de aquellas plataformas sobre las quales, según diximos, juega el artillería, y se hazen de madera para que las ruedas de las pieças no se hundan y se atasquen en el suelo con el continuo tirar que en semejantes tiempos se ha usado.

SIN.: explanada, lechera.

ENCICL.: Estévanez (1897): Nombre que damos a la "explanada" de una batería. / / Collado, Plática Artillería (1592: fol. 57v): "Las quales plataformas en dos maneras se acostumbra de construyrlas: la primera es de madera que sea sufficiente a sufrir el peso de la pieça, conviene a saber, haziendo sobre el suelo llano y duro un fuerte maderamiento de maderos que, a lo menos, tengan una quarta de vara de grosseza y cruzados por encima de fuertes tablones de robre o de olmo que tengan una ochava de vara de grosseza cada uno; el segundo modo de hazer las plataformas dichas se haze solando toda aquella plaça de losas de piedra muy bien picadas la largueza d'éstas ha de ser tanta como dos vezes y media es larga la misma pieça, digo el cañón de metal sin su caxa, y la ancheza será tanta como una pieça y media; y esto por quanto la plataforma siempre ha de ser proporcionada a la pieça que ha de jugar encima, de manera que tenga tanta plaça alrededor de ella que la gente pueda caminar libremente por servicio del artillería y que se halle la pieça tan apartada de sus vezinas que, disparando, no se den fuego las unas a las otras.

Pero sobre la forma que han de tener y cómo han de ser plantadas hay, entre hombres pláticos, opiniones diversas; porque unos quieren que la plataforma, quanto al suelo, penda hazia atrás y otros hazia adelante; otros hay que quieren que en una parte sea llana y que en otras penda. Quanto a la opinión del primero, que quiere que penda hazia atrás la plataforma, quiere que sea aprovada porque, acabando de dar fuego a la pieça y hallando aquella dependencia detrás de sí a la culata, torna tanto atrás que queda escondida y cubierta, de manera que no puede ser offendida ella ni el artillero que la carga; a lo que contradize el otro diziendo que, después de cargada en aquella hondura la pieça, para haverla de subir cuesta arriba es menester, a cada tiro, mucho mayor número de hombres, más tiempo y más trabajo para tornarla a la barba de el parapeto, y que su opinión es muy más conforme a razón, por quanto, haviendo disparado la pieça y hallando pendiente hazia adelante la plataforma, después de haver ella hecho su retirada, se torna al lugar donde ha de ser cargada ella misma. Viene otro tercero y dize que él quiere hazer sus plataformas differentemente de las passadas y que éstas serán más útiles y provechosas; conviene a saber, que tanto espacio o plaça de la plataforma quanta es la largueza de la caxa hazia la parte del parapeto sea llana, y el resto d'ella, que es lo que cae debaxo de la culata, vaya subiendo cuesta arriba, y esto por quanto, disparada que será la pieça, ella por sí misma se torne al lugar donde ha de ser cargada". 
plaza, plaça, plaza [del lat. vg. * plattěa (lat. platěa) 'calle ancha', 'plaza', y éste del gr. $\pi \lambda a \tau \varepsilon \tilde{I} a$ 'calle ancha', propiamente femenino de $\pi \lambda a \tau \dot{s}$ 'ancho', 'plano'. Cid (DECH). Montes, Instrucción y regimiento, 1537]. sust. Fort. Población fortificada, esto es, la fuerza o fortaleza que, además de su presidio ordinario, comprende a los habitantes de una ciudad o villa. (fig. 120)

Montes, Instrucción y regimiento, 1537, fol. VIIIr: Como aconteció sobre Arcilla que, tuviéndola el conde de Borba por el rey de Portugal, los reyes de Fez y Tremezén con otros príncipes de Bervería vinieron sobre él con sesenta mil moros de pelea y ganáronle la ciudad de Arcilla, y él retráxose al castillo que junto a la plaça estava, que tiene la puerta a la banda de Centa, a donde le tenían cercado. // Mendoça, Theórica y práctica, 1596, pág. 135: El governador o capitán de la plaça ha de hazer cerca de toda la suerte de vituallas que huviere en ella, recelando sitio, como trigo, granos, carnes saladas, vino, harina, sal , y al contar, según el número de la gente de la tierra y soldados, los días que se podrán mantener con ellas, avisando a Vuestra Alteza d'ello. // Ufano, Tratado de la Artillería, 1613, pág. 227: En una plaça, Señor, me hallé y fue en el reyno de Françia, quando el prínçipe de Parma baxó de Flandes a favoresçer la liga cathólica y socorrer la çiudad de París y fue en una villa que se dize Corbe, que es la que en una de las dichas qüestiones se dixo aberla batido por el caballero o baluarte de la parte del río Tarne.

SIN.: plaza fuerte.

ENCICL.: Almirante (1869): Su sentido militar más general es el de ciudad murada, aunque no se le añadan adjetivos, como fortificada, fuerte o de guerra. Si Madrid y otros puntos sin fortificar son militarmente plazas es por extensión. // Mendoça, Theórica y práctica (1596: pág. 128-129): "Siendo tierra donde no ay guarnición ordinaria, al entrar la cabeça con la gente que la ha de guardar, convendrá que reconozca todo el circuyto d'ella de dentro y fuera; el fosso, si es seco o tiene agua en algunas partes d'él o por todas; qué compostura de murallas, para señalar los puestos donde se han de poner los cuerpos de guardia y centinelas de día y de noche, afirmando un cuerpo de guardia, dos o más, principal en medio de la villa o plaça para socorrer a los demás".

2 [Rojas, Teórica fortificación, 1598]. sust. Fort. Cualquier recinto fortificado de carácter más o menos permanente.

Rojas, Teórica fortificación, 1598, fol. 36v: Si se hiziere la tal fortaleza en un islote dentro en la mar, a donde no le pueden batir, ni meter trincheas ni minas, esta tal se guardará con menos gente que todas las demás, aunque suele ser plaça costosa, por ser de acarreto la leña y agua y la demás munición. // Rojas, Teórica fortificación, 1598, fol. 38v: Conforme a esto, se hará el tamaño de la plaça respeto de la gente que se ha de tener en ella de guarnición y de aquélla que le ha de socorrer quando sea necessario, de forma que, si me piden una plaça que la puedan cubrir y guardar 800 hombres, la haré de cinco valuartes, y si la quieren que no sea más de para trezientos o quatrocientos, la haré de quatro. // Ufano, Tratado de la Artillería, 1613, pág. 164: Ahora [...] querría que Vuestra Merced, distinta y cumplidamente, me dixese y diese a entender en cómo se avernía una plaça o 
fortaleza, semejante a la que se a tratado, que del enemigo exérçito espera ser sitiada poderosamente de un estrecho y largo sitio.

SIN.: fortaleza, fuerza $a_{1}$

ENCICL.: Terr.: En términos generales de guerra comprende toda especie de fortificación en que se puede defender un sitio dispuesto de tal modo que unas partes protejan y flanqueen a otras. // Como puede comprobarse en los ejemplos seleccionados así como en la definición que de plaza ofrece Terreros, aunque no era lo más habitual, plaza también se empleaba en ocasiones como término genérico, esto es, como uno de los varios hiperónimos existentes para designar cualquier tipo de construcción capaz de soportar un asedio o sitio.

3 [Collado, Plática Artillería, 1592]. sust. Mil. Terreno libre y espacioso que, en las fortalezas, en los reales y en otros lugares en que coinciden muchos soldados, se deja para poder reunirse en él y realizar allí diversos ejercicios militares.

Collado, Plática Artillería, 1592, fol. 95r: ¿Quién le enseñó que las fortalezas, o son fuertes por la materia o son fuertes por la forma?: por la materia, quando son fabricadas de grosíssimas murallas, y por la forma, por tener baluartes anchos y plaças espaciosas, gruessos y maçiços orejones [...]. // González de Medina, Examen fortificación, 1599, pág. 20: Aunque los baluartes y cortinas se perdiessen, teniendo buena plaça en que poder estar un buen esquadrón, no se puede tener por perdida la fuerça, porque no son menos fuertes baluartes y terraplenos, hombres armados con concierto en esquadrón que no se pueda esperar d'ellos que sustentarán y defenderán la entrada y que tornarán a echar fuera al enemigo para poderse reparar. // González de Medina, Examen fortificación, 1599, pág. 33: Es muy bueno plantar holmos, porque las raýzes que echan hazen muy bien los efetos que se han dicho y encubren al enemigo que no descubra lo que se haze en la muralla ni aun en la plaça.

SIN.: plaza de armas.

4 [Rojas, Teórica fortificación, 1598]. sust. Fort. Cada uno de los espacios más amplios establecidos en una estrada cubierta, que sirven de lugar de reunión a las tropas que participan en su defensa. (fig. 121)

Rojas, Teórica fortificación, 1598, fol. 31v: K. Plaça o rebellín de la estrada cubierta. // Rojas, Teórica fortificación, 1598, fol. 38r: Y en la mitad d'ella [de la estrada cubierta] una plaça a manera de rebellín, en que caben 200 cavallos, porque todos han de salir por la puente, que es más estrecha dos vezes que la estrada, y allí se juntarán para su efeto. // Rojas, Teórica fortificación, 1598, fol. 38r-38v: Y paréceme, conforme a la materia de trincheas y a lo que he visto en ellas, que no deve de tener de ancho la dicha estrada más que hasta 15 pies, porque lo que es salir o entrar cavallería, bastará la plaça [...] y traveses d'ella, y como se ha recogido toda la fortificación, es cosa puesta en razón recoger también la estrada cubierta, de manera que venga a estar todo en proporción.

SIN.: revellín 2 . 
ENCICL.: Lopes Pires Nunes (2005: s.v. praça de armas): Lugar de reunião dos defensores, no caminho coberto para as sortidas. Denomina-se praça de armas saliente ou reentrante, conforme o ângulo do caminho coberto em que se localiza.

alta [Collado, Plática Artillería, 1592]. cmpt. sintag. Fort. Espacio o lugar elevado sobre el terraplén de un baluarte y paralelo a su fianco o través, donde se establece una batería provista de parapeto, banqueta, cañoneras y merlones.

(3) (fig. 122)

Collado, Plática Artillería, 1592, fol. 95r: ¿Quién le enseñó que las fortalezas, o son fuertes por la materia o son fuertes por la forma?: por la materia, quando son fabricadas de grosíssimas murallas, y por la forma, por tener baluartes anchos y plaças espaciosas, gruessos y maçiços orejones, anchos terraplenos, arzenes altos, gruessos parapetos y no pedregosos, las plaças, alta y baxa, de las casas matas bien cubiertas, con bien hondas y secretas contraminas. // Roxas, Sumario milicia, 1607, fol. 76r: Los baluartes se ponen sobre los ángulos; y de qualquier parte del ángulo se toman ciento y treinta pies para las plazas del artillería altas y bajas, si las tubiere.

SIN.: plaza de arriba, plaza superior, través alto.

ENCICL.: Aut.: La fortificación que se hace superior al terraplén, y viene a ser lo mismo que el caballero; sólo se diferencia en la situación, porque su propio lugar es en la semigola y paralela al flanco, y no es tan alta como el caballero, porque conviene que éste la domine. // Lucuze (1772: 61): "En el dictamen de muchos se juzga por obra siempre conveniente; pero no es dudable su importancia cuando el flanco es pequeño, si lo permite la capacidad de la gola, pues aumenta la defensa sobre el paso del foso. Es también útil en las situaciones bajas para dominar las baterías que contra el flanco ponga el sitiador".

baja [Collado, Plática Artillería, 1592]. cmpt. sintag. Fort. Batería descubierta que se establece a veces en una fortaleza, detrás del orejón de un baluarte con flanco retirado hacia dentro. 3 (fig. 123)

Collado, Plática Artillería, 1592, fol. 95r: ¿Quién le enseñó que las fortalezas, o son fuertes por la materia o son fuertes por la forma?: por la materia, quando son fabricadas de grosíssimas murallas, y por la forma, por tener baluartes anchos y plaças espaciosas, gruessos y maçiços orejones, anchos terraplenos, arzenes altos, gruessos parapetos y no pedregosos, las plaças, alta y baxa, de las casas matas bien cubiertas, con bien hondas y secretas contraminas. // Roxas, Sumario milicia, 1607, fol. 76r: Los baluartes se ponen sobre los ángulos; y de qualquier parte del ángulo se toman ciento y treinta pies para las plazas del artillería altas y bajas, si las tubiere. // Lechuga, Discurso de la Artillería, 1611, pág. 178: Pues supuesta la pieça, consideremos los accidentes y diversidades de effetos que pueden resultar. Éstos nacen de la varia situación del llano sobre el qual está puesta la pieça. Los llanos suelen hazerse de tres maneras: unos a nivel, otros pendientes y, de éstos, algunos penden adelante y otros atrás. En las plaças bajas de través se hazen pender adelante, pero en los llanos de los baluartes se hazen pender al contrario. 
SIN.: plaza de abajo, través bajo.

ENCICL.: Terr.: Es una especie de flanco retirado. // Lopes Pires Nunes (2005: s.v. praça baixa): [A] Local abaixo do plano do baluarte destinado a uma ordem de bocas de fogo a descoberto. // Para más datos sobre las plazas bajas, vid. Lucuze (1772: 58-61). Entre otras cosas, en esas páginas se señala que las plazas bajas tuvieron su origen en las casamatas o cámaras abovedadas con artillería.

$\sim$ de abajo [Roxas, Sumario milicia, 1607]. cmpt. sintag. Fort. Batería descubierta que se establece a veces en una fortaleza, detrás del orejón de un baluarte con flanco retirado hacia dentro.

Roxas, Sumario milicia, 1607, fol. 77v: Anchura de las estradas que van a la plaça de abajo, 12 pies.

SIN.: plaza baja, través bajo.

$\sim$ de armas [Álaba, Perfeto capitán, 1590]. cmpt. sintag. Mil. Terreno libre y espacioso que, en las fortalezas, en los reales y en otros lugares en que coinciden muchos soldados, se deja para poder reunirse en él y realizar allí diversos ejercicios militares.

Álaba, Perfeto capitán, 1590, fol. 44r: Conviene, también, tenga reconocido el alojamiento a donde va $\mathrm{y}$, en llegando, forme su esquadrón en la plaça de armas, sin consentir que alguno se desmande hasta que se dé licencia a las vanderas, que será quando el alojamiento estuviere del todo fortificado. // Mendoça, Theórica y práctica, 1596, pág. 80: Alojándose en ladera, se señala de ordinario la plaça de armas en lo alto d'ella, advirtiendo que no aya tanta distancia de los quarteles a ella que los soldados lleguen con el arma desalentados por la subida a combatir [...]; si se baxa de las laderas y quarteles a la plaça de armas, al llano, es assimismo con desaventaja, por venir descubierta toda la disposición y poder, el que le espera, tirar cubierto y de manpuesto. // González de Medina, Examen fortificación, 1599, pág. 20: La roca que dezís, o torre del homenage, en el centro de la plaça de armas por ningún caso se ha de tratar de que la aya, porque [...] ella embaraça la plaça de armas y la ocupa, y quita que no se pueda hazer muy buen esquadrón y la vista para la distribución d'él para embiar a las defensas los que fueren menester, que es muy importante.

SIN.: plaza $_{3}$.

ENCICL.: DUE: Lugar destinado a ejercicios militares. // Terr.: 1- En un lugar murado es una plaza grande en que se juntan los soldados para la revista, o para recibir las órdenes de sus cabos. 2- En un asedio es un lugar espacioso y cortado a cubierto para resguardar los trabajos de la trinchera y para juntar los soldados y darles las órdenes conducentes. 3(s.v. plaza de armas en un campo) Lugar espacioso a la testa de un ejército para ordenarle en batalla, para juntar cada cuerpo en particular. // Sanz (1749: s.v. plaza de armas de una ciudad de guerra): Es un terreno libre y espacioso, sea en medio de ella, a donde concurren 
las principales calles, o bien entre el terraplén y las últimas casas. Esta sirve de paraje señalado para concurrir en ella la guarnición cuando hay una alarma inopinada, o en general cuando es necesario ejecutar las órdenes del gobernador. // Sanz (1749: s.v. plaza de armas de un campo): Es un gran terreno escogido a la cabeza o sobre los lados de un campamento para disponer las tropas en batalla.

$\sim$ de arriba [Roxas, Sumario milicia, 1607]. cmpt. sintag. Fort. Espacio o lugar elevado sobre el terraplén de un baluarte y paralelo a su fianco o través, donde se establece una batería provista de parapeto, banqueta, cañoneras y merlones.

Roxas, Sumario milicia, 1607, fol. 77v-78r: Los parapetos en la plaza de arriba, en el baluarte, 8 pies; el largo de estas plazas para recular el artillería, 70 pies. / / Roxas, Sumario milicia, 1607, fol. 87r-87v: Si las plazas de arriba fuesen ofendidas, alçarse ha tanto la muralla que los cubra con una gruesa bóveda de tierra cubierta; y si esto no bastare a cubrirlos, siendo los parapetos más altos que se acostumbran, alçarlos tanto más quanto bastare.

SIN.: plaza alta, plaza superior, través alto.

$\sim$ fuerte [Montes, Instrucción y regimiento, 1537]. cmpt. sintag. Fort. Población fortificada, esto es, la fuerza o fortaleza que, además de su presidio ordinario, comprende a los habitantes de una ciudad o villa.

Montes, Instrucción y regimiento, 1537, fol. XVIIIv: Y, por esto, el señor del exército, en las tierras que ganare, ponga tales personas que no hagan falta su persona, y el gasto que hiziere en las fortalescer, sea de manera que aproveche y no sea vicioso [...]. Y como vaya ganando, vaya fortificando las plazas fuertes, porque los enemigos no se puedan amparar d'ellas y en ellas. // Escalante, Discurso de la navegación, 1577, fol. 85v-86r: Ay en todas las fronteras y plaças fuertes, que tiene muchas en los confines de los laos, y bramenes y tártaros y massagetas, las guarniciones ordinarias y necessarias para la defensa d'ellas. // Roxas, Sumario milicia, 1607, fol. 104r: Y ganada esta plaça fuerte, se le rendirán todas las demás que estubieren alrededor, con que dará fin a la guerra de aquella provinçia que va a conquistar.

SIN.: plaza 1 .

ENCICL.: DUE (s.v. plaza): Plaza fuerte. // DUE: Población fortificada.

superior [Lechuga, Discurso de la Artillería, 1611]. cmpt. sintag. Fort. Espacio o lugar elevado sobre el terraplén de un baluarte y paralelo a su fianco o través, donde se establece una batería provista de parapeto, banqueta, cañoneras y merlones.

Lechuga, Discurso de la Artillería, 1611, pág. 240: Los dozientos pies de cortina que viene a quedar dentro del baluarte se reparten en esta manera: treinta pies, que entran dentro del través hasta la casamata; veinte pies para el parapeto o muralla de la casamata; cinqüenta 
pies de hueco la casamata, para reculada de las pieças; veinte pies para el parapeto de la plaça superior; ochenta pies, que quedan, an de servir a la retirada de las pieças de la plaça superior y al tránsito de la gola del baluarte.

SIN.: plaza alta, plaza de arriba, través alto.

plúteo, plúteo [tomado del lat. plŭteŭs 'armazón de tablas, fija o móvil, con que los soldados se guarecían de los tiros del enemigo'. Plúteo 'anaquel', sentido que también tenía la voz latina $(\mathrm{DECH})$. Roxas, Sumario milicia, 1607]. sust. Fort. ant. Especie de cubierta hecha de mimbres y semejante en su forma a un gran casco, que, cubierta con pieles mojadas, sirve para proteger de los fuegos a los soldados que pretenden alcanzar las murallas enemigas.

Roxas, Sumario milicia, 1607, fol. 45v: Fuera d'esto, la gente que llebava escalas para subir a los muros, ay otros yngenios con que se combaten, conbiene a saber: testúdines, arietes, hoçes, bíneas, plúteos, músculos y torres. // Roxas, Sumario milicia, 1607, fol. 46r: Los antiguos llamaron bíneas las que aora en el uso militar con nombre bárvaro llaman causeras, que son sombreros. Plúteos se llaman aquellos a modo de un morrión.

ENCICL.: Moretti (1828): ant. Casco grande hecho de mimbres y cubierto con pieles mojadas que usaban los soldados griegos y romanos (a más de los manteletes) cuando trabajaban en la zapa bajo de las murallas sitiadas, para ponerse a cubierto de las armas arrojadizas de los enemigos. // Borreguero Beltrán (2000): Los sitiadores lo utilizaban para avanzar contra la fortaleza sitiada a fin de poder tender las escalas de asalto.

poner, V. asedio.

poner, V. (el) cerco.

poner, V. en celada.

poner, V. $\sim$ en defensa.

poner, V. en emboscada.

poner, V. $\sim$ en rota.

poner, V. (el) sitio. 
portillo, portillo [del lat. portellum. Doc. de 942, Oelschl.; "p. de muro: minae muri" Nebr. (DECH). Montes, Instrucción y regimiento, 1537]. sust. Fort. Rotura o abertura en la muralla de una fortaleza producida por la artillería u otro ingenio militar.

Montes, Instrucción y regimiento, 1537, fol. XVIIIv: Por quatro maneras de batalla se puede ganar un castillo: [...].Si se gana por batería, puédese defender reparando el muro por la parte de dentro, haziendo un contramuro, echando entre muro y muro muchos barriles de pólvora, haziendo algunos palenques para que los arcabuzeros puedan tirar dende a los enemigos quando entraren por el portillo. // Rojas, Compendio fortificación, 1613, fol. 26r26v: Que los baluartes sean muy terraplenados y macizos, de buena tierra y no de arena, porque con esto tendrán todas tres cosas, que son: fortaleza, convenencia y comodidad. Fortaleza contra la artillería que le plantare el enemigo para batirle. Comodidad para que los soldados puedan andar de la una parte a la otra libremente a defender el portillo que le hizieren con la batería o mina [...]. // Ufano, Tratado de la Artillería, 1613, pág. 371: La qual bala va por dentro machinada de pólvora fuerte para que, metida dentro de la pieça, tirando con ella a una muralla o terraplén en estando embaçada dentro, rebiente y con el estruendo que hiziere abra del muro o fuerça un grande portillo.

SIN.: batería 2 , brecha.

ENCICL.: Terr.: En la milicia, V. boquerón, brecha.

posada, posada, possada [de posar y éste del lat. pausāre 'cesar', 'pararse'. Cid; ahí y en Fn. Gonz. y 1. ${ }^{a}$ Crón. Gral. es 'lugar donde acampa la hueste o un guerrero'; 'casa propia', Berceo, Mil.; 'albergue, fonda', Nebr. (DECH). García de Palacio, Diálogos militares, 1583]. sust. u. m. en pl. Mil. Cada una de las divisiones de un alojamiento, sea en campaña o dentro de una fortaleza.

García de Palacio, Diálogos militares, 1583, fol. 66r: Aunque algunos han querido dezir que [la artillería] trae más costa y daño que provecho [...], me paresce que es provechosíssima y de grandes effectos, si es usada con la sufficiencia e ingenio que ella requiere, y que no es justo que para ninguna cosa béllica se dexe de usar, pues paresce impossible poder offender y subjetar a un poderoso enemigo sin ella, especialmente teniendo, como de ordinario ya todos tienen, torres, castillos, ciudades, fuertes y muradas, y posadas para defenderse. // Lechuga, Discurso de la Artillería, 1611, pág. 234: Avrá tantos conductores a cavallo quantos fueren menester, según el trein fuere grande, los quales servirán de estar cerca de las pieças y municiones para hazerlas caminar antes que otros qualesquier carros; y el uno de los dichos conductores servirá de aposentador para alojar y tomar posadas para el general, tenientes, officiales, artillería y municiones, y todos los que sirven en ella.

SIN.: cuartel, estancia.

FAM.: aposentador. 
possada, V. posada.

posta, posta [del it. ant. posta 'puesto militar'. Posta 'centinela' [a. 1600, P. de Hita, Rivad. III] (DECH). Anónimo, Diálogo fábrica de navíos, ca. 1631]. sust. f. Mil. Soldado que está de vigilancia en un sitio (DUE: s.v. centinela).

Anónimo, Diálogo fábrica de navíos, ca. 1631, fol. 25v: Visitará de ordinario las postas que se pusieren, encargándoles la vigilancia y cuydado, debajo del qual viven con descuydo los que van enbarcados en dicho galeón. // Anónimo, Diálogo fábrica de navíos, ca. 1631, fol. 26r: Ha de aver ronda perpetuamente, desde que se enbarcare la compañía asta que se desenbarque, para que de día y noche bisite las postas; y si alguna d'ellas le llamare, acudir a saver lo que quiere, para dar noticia a sus oficiales, si es cosa de ymportancia. // Anónimo, Diálogo fábrica de navíos, ca. 1631, fol. 26r: Las postas que los cabos de esquadra pusieren en sus puestos an de apercevir en la memoria la orden que se les da, para observarla sin que por ningún caso consienta que se quebrante, y si se le ofreciere alguna dificultad en orden a ella, llamará la ronda para hazérselo saver.

SIN.: centinela 1.

ENCICL.: Almirante (1869): En la milicia española de los siglos XVI y XVII esta voz, posta, era militar y técnica, sin que podamos asignarle un significado estricto [...]. Unas veces posta y apostadero es puesto militar en su actual sentido [...]; otras el centinela; otras el sitio, puesto o lugar donde se coloca el centinela.

2 [Álaba, Perfeto capitán, 1590]. sust. Mil. Lugar o sitio donde realiza su misión el centinela.

Álaba, Perfeto capitán, 1590, fol. 50r: Y hasta que las puertas del presidio se cierren, no conviene que el sargento mayor dé el nombre al sargento; y en campaña, hasta que las centinelas se pongan, y a éstas tampoco se les a de dar hasta que estén en sus postas o lugares, pues toda la seguridad de una fuerça o exército está en el nombre. / / Mendoça, Theórica y práctica, 1596, pág. 53: Y assí, a las centinelas de a cavallo como de a pie, no se les ha de dar el nombre hasta ponerlas en sus postas, debaxo de lo qual nadie podrá passar, entrar ni salir en el campo sin orden de Vuestra Alteza o dando el nombre. / / Mendoça, Theórica y práctica, 1596, pág. 88: Y muchas vezes sucede venir la voz del arma de dentro del mismo campo, sin averla tocado las centinelas, las quales no se han de retirar de sus postas si no es forçándolos el enemigo o viniendo su oficial a ello por el arma.

ENCICL.: López Vallejo (2008): Lugar en el que se ejerce el servicio de centinela o vigilancia.

3 [Collado, Plática Artillería, 1592]. sust. Mil. Lugar o punto ocupado, o que es susceptible de estarlo, por una tropa o por un soldado.

Collado, Plática Artillería, 1592, fol. 53r: Tirar en el undécimo modo es quando, hallándose sitiado dentro de alguna fortaleza el artillero, le tocará su posta a defender alguna casa mata o través con su artillería al tiempo de un assalto y, de allí, offender al enemigo. 
SIN.: puesto.

ENCICL.: Cov.: En la milicia, el lugar señalado al soldado para defenderlo.

postigo, postigo [del lat. postīcum 'puerta trasera'. 1144, BHisp.; Berceo; J. Ruiz (DECH). Loçano, Alberto, Architectura, 1582]. sust. Puerta disimulada de algún modo en la pared (DUE: s.v. puerta falsa).

Loçano, Alberto, Architectura, 1582, pág. 155: Al varón y a su muger se les deve a cada uno su dormitorio; y esto, no sólo para que pariendo, o estando mala la muger, no sea molesta y cause importunidad al varón, como aun para que passe los sueños de la siesta sin perjuyzio del otro el que se le antojare. Cada uno tendrá su puerta, $\mathrm{y}$, fuera d'esto, avrá un común postigo para que se puedan passar y comunicar el uno al otro sin registro ni sin que nadie los vea y note. / / Álaba, Perfeto capitán, 1590, fol. 92v-93r: Hará que su gente no sólo guarde las puentes, puertas, rastrillos y cortinas del muro de ordinario, mas también por la parte de afuera la campaña más cercana al fosso, si possible fuere, teniendo particular cuydado de que el entrar y salir sea por algún postigo guardado, y que todas las puertas estén cerradas y guardadas, y que aya cuerpos de guardia y centinelas para que den aviso de todo lo que se ofreciere. // Mendoça, Theórica y práctica, 1596, pág. 133-134: $\mathrm{Al}$ abrir las puertas principales, si cerca d'ellas ay arrabales, cuevas, o cavernas o partes donde se puede esconder gente, se han de embiar por los postigos centinelas a reconocerlo $\mathrm{y}$, assegurados, buelven a dar aviso al capitán, que abre todas las puertas, hallándose los soldados en orden con las armas en las manos.

ENCICL.: DRAE: Puerta falsa que ordinariamente está colocada en sitio excusado de la casa. // Almirante (1869): Puerta falsa de una plaza de guerra, antes de introducirse la voz francesa poterna. // Almirante (1869: s.v. poterna): Puerta pequeña, falsa o escondida, que antiguamente se abría detrás del orejón, o en la cortina, cerca del ángulo del flanco, para bajar al foso.

presa, presa, pressa [del cat. presa y éste del lat. praeda 'íd.'. Presa 'cosa apresada'. J. Ruiz; "praeda", Nebr. (DECH). Apiano, Cosmographía, 1575]. sust. Mil. Acción de ganar, mediante una operación de guerra, un territorio, provincia, población, plaza, fortaleza, estado, etc.

Apiano, Cosmographía, 1575, fol. 75r: Y, assí, nunca indios, como algunos se engañan, comieron carne de hombre que fuesse su amigo, sino que lo tomassen o matassen en la guerra, como se vio claramente en la presa de México, en la qual murieron tantos mexicanos de hambre por no tener de comer y no poder ni serles lícito comer de la carne de muchos amigos suyos y vezinos, que continuamente de cada día se morían. / / Collado, Plática Artillería, 1592, fol. 96v: Por cierto, en esso vuestra merced tiene muy gran razón, por quanto en no pocas empresas de nuestro tiempo he visto incurrir en el error dicho y, señaladamente en Flandres, en la presa de Mastrique, donde en aquel assedio [...] por haverse anticipado la hora del assalto y no bien previsto las offensas qu'el enemigo fabricava dentro, murieron en él veynte y dos valientes capitanes españoles. // Ufano, 
Tratado de la Artillería, 1613, pág. 129: Y, rendida la tierra por su buena diligençia, la tendrá también con ynfinito cuidado de yr a dar el parabién de la presa y victoria al generalíssmo, por quien y de quien será tenido en mucho.

SIN.: conquista, toma.

ENCICL.: Terr.: Toma, conquista, expugnación.

2 [Celso, Reportorio universal leyes Castilla, 1553]. sust. Mil. Acción de apoderarse violentamente de todo cuanto hay en territorio enemigo.

Celso, Reportorio universal leyes Castilla, 1553, fol. CLXr: Si por caso no se avinieron en cierta cosa los dichos atalayas, y guardas, y escuchas y espías de la presa o saco, dévense escojer tres o cinco buenas personas que sepan qué es de los tales hechos, y tassen lo que deven aver, y lo que la mayor parte d'ellos tassare y hiziere deve ser cumplido como si todos lo hoviessen hecho.

SIN.: despojo 1 , saco2 ${ }^{2}$ sacomano.

3 [Martínez de Burgos, Reportorio premáticas y Cortes, 1551]. sust. u. t. en pl. con el mismo significado que en sing. Mil. Conjunto de cosas que los soldados consiguen arrebatar al enemigo durante una acción militar o tras ella.

Martínez de Burgos, Reportorio premáticas y Cortes, 1551, fol. XXXVIIv: Otrosí, dezimos que tenemos en servicio a todas las personas que quisieren hazer navíos para armar en la mar, en defensa de los puertos y costas de mar, y para ayuda a los gastos que en ello hizieren, les avemos mandado hazer y hazemos merced durante nuestro real beneplácito del quinto, a Nos pertenesciente, de las presas que tomaren. // García de Palacio, Diálogos militares, 1583, fol. 35r: Y assí lo hazía el partriarcha Abraham, general del pueblo de Dios, quando, aviendo vencido a Codalaomor y otros quatro reyes y tomádoles la presa que avían hecho al rey de Sodoma y sus compañeros, no quiso para sí cosa d'ello, aunque era precioso y de mucha estima. // Mendoça, Theórica y práctica, 1596, pág. 150: Puesta la presa en salvo, se ha de repartir según la costumbre que se tiene en la plaça y la que guarda cada nación, porque en unas se da el quinto al príncipe, sacando joya el general o governador, dividiendo la resta entre toda la gente a proporción de los sueldos, de suerte que les cabe ygual parte al capitán, oficial y soldado que quedó de guardia en la plaça como al que fue a correr.

SIN.: despojo 2 .

ENCICL.: Cov.: Presa, término militar, lo que se ha robado del campo enemigo. / / Moretti (1828): El pillaje, botín o robo que se hace y toma al enemigo en la guerra, así por tierra como por mar. Las leyes romanas no sólo no permitían al General tomar y repartir cosa alguna del botín o presa a los soldados, sino que los obligaba a presentarlo íntegro al tesoro público, para que el cuestor, vendiendo todo lo que eran efectos y muebles, depositase en las arcas su producto; pero, a pesar de todo, los Generales hacían siempre algún reparto a la tropa tomándose para sí lo que les parecía, dando cuenta al Senado de 
las razones que habían tenido para ello, las que siempre parecían justas. Generalmente el botín se dividía en tres porciones: la una se guardaba para un año de sueldo de las legiones que componían aquel ejército; otra se repartía a la tropa por medio de los tribunos, de la que tomaba el General su parte, que solía ser la mitad; y la tercera se depositaba en el tesoro público. // Álaba, Perfeto capitán (1590: fol. 143r-143v): "Y el seguir esta orden fue ocasión que, yendo en seguimiento de los contrarios que yvan huyendo, no huviesse desorden ni descompostura en los soldados, como la ay siempre que se da lugar a que la presa sea de quien la huviere a las manos; y el daño que la codicia podía hazer, viendo huir los enemigos, se previno con dar el cargo de seguir la vitoria a los soldados de lijeras armas y, con el cuidado que d'esto tenían, al que principalmente acudía la demás gente de las legiones era a guardar el orden que se les dava, sin salir un punto d'él, y a vencer sin tener puesta la mira en saquear y robar, porque, aunque, como he dicho, les cabía parte de los despojos, no se repartían todos entre ellos, por reservar el cónsul lo que de la presa mejor le parecía para pagar el exército y acudir a favorecer los heridos y enfermos, y otras cosas semejantes".

4 [García de Palacio, Instrución náuthica, 1587]. sust. Mil. Mar. La embarcación enemiga que se rinde o se toma por fuerza (Salvá 1846).

García de Palacio, Instrución náuthica, 1587, fol. 127r: Y si Dios le diere victoria, hará que los enemigos rendidos se metan debaxo de cubierta y allí mandará desarmallos y que curen los heridos; y a todos los tratará con amor y buen término, mandando que se les dé lo nescessario para su sustento y considerará la gente útil que le queda para ver si le conviene llevar consigo la pressa. / / García de Palacio, Instrución náuthica, 1587, fol. 127r: Y pudiendo llevar la presa, partirá la gente rendida de marineros y oficiales entre entrambas naos, haziendo tener con ellos particular cuydado y que estén debaxo de cubierta, sin confiarse d'ellos en cosa alguna. // Anónimo, Diálogo fábrica de navíos, ca. 1631, fol. 21r: Y no está lleno siempre este número, porque unos se uyen, otros enferman, y si se toma alguna presa, es precisso hechar algunos en ella.

ENCICL.: Almirante (1869): Se dice algunas veces por pillaje, botín; pero es más bien técnica de la marina.

presidio, presidio [tomado del lat. praeš̆dŭum 'protección', 'guarnición, puesto militar'. Presidio 'guarnición que se pone a una plaza', especialmente hablando de las de Marruecos, y como a éstas se enviaban los castigados, 'establecimiento penitenciario'. 1570, Mármol (DECH). García de Palacio, Diálogos militares, 1583]. sust. Fort. Grupo de soldados destinado a la defensa de una plaza o cualquier otro lugar fortificado.

García de Palacio, Diálogos militares, 1583, fol. 19v-20r: Puede también tomar, de los bienes del enemigo, todos los gastos que ha hecho en la guerra; y puede, más, hazer, todo aquello que viere convenir para la seguridad de su reyno, como es derribar las fuerças del enemigo, o poner presidios en ellas. // Mendoça, Theórica y práctica, 1596, pág. 128: En las tales plaças de frontera y castillos donde residen guarniciones y presidios ordinarios ay casas de municiones y vituallas, como carne salada, pescados, harina, sal; semillas, qual 
garvanços, lantejas; vino, vinagre, azeyte y otras provisiones. // Roxas, Sumario milicia, 1607, fol. 88r-88v: No basta que la çiudad o castillo esté bien fortificada en la manera dicha o en otra mejor, si no está muy bien proveýda, así de presidio para su defensa como de lo demás, porque sería cuerpo sin alma.

ENCICL.: DUE: Guarnición de soldados de un castillo, fortaleza, etc.

2 [Loçano, Alberto, Architectura, 1582]. sust. Fort. Fortaleza o recinto fortificado que consta de guarnición.

García de Palacio, Diálogos militares, 1583, fol. 15v: Y, para que puedan, tiene el rey en muchas partes puestos presidios en las fronteras, para que las defiendan entre tanto que él acude con socorro, y quiere que no rindan las fuerças, sino que las defiendan hasta lo último de potencia y, si esto no hazen y se rinden, suele castigar al capitán. // Álaba, Perfeto capitán, 1590, fol. 50r: Y hasta que las puertas del presidio se cierren, no conviene que el sargento mayor dé el nombre al sargento; y en campaña, hasta que las centinelas se pongan, y a éstas tampoco se les a de dar hasta que estén en sus postas o lugares, pues toda la seguridad de una fuerça o exército está en el nombre. // Ufano, Tratado de la Artillería, 1613, pág. 135: Tócale, asimismo, hallarse en todas las visitas que el general hiziere por los presidios de las villas y castillos, para enterarse de la suerte y modo que están tratadas las muniçiones.

ENCICL.: Cov.: Comúnmente llamamos presidio al castillo o fuerza donde hay gente de guarnición.

pressa, V. presa.

pretil, petril, pretil [de petril y éste del lat. pectorale 'que cubre el pecho'. Pretil 'barandilla, antepecho'. h. 1625, Céspedes, Aut. (DECH). Roxas, Sumario milicia, 1607]. sust. Fort. Terraplén o defensa formada con tierra, sacos de arena, piedras, etc., para guarecerse tras ella en una lucha (DUE: s.v. parapeto).

Roxas, Sumario milicia, 1607, fol. 76r: Es neçesario mostrar un tanto más particularmente las partes o miembros de algún baluarte, que son: través; orejón, que llaman poma o espalda de la casamata; contrafortes o espolones, pretiles o parapetos; plaza para el artillería en el trabés bajo, si lo huviere de tener, y en lo alto, lo mismo; entrada en el uno y en el otro y en la plaza de arriba.

SIN.: parapeto.

FAM.: apretilar.

prima, prima [del lat. prima, femenino de primus 'primero'. 'Hora primera de la noche (Nebr.) o del día (s. XVII, Aut.)', 'primera de las cuerdas de un instrumento' 
(Nebr.) (DECH). González de Medina, Examen fortificación, 1599]. sust. Mil. Primera de las cuatro partes en que los centinelas dividen las noches.

González de Medina, Examen fortificación, 1599,: Bolviendo a la que de ordinario ha menester para servirse, tendría por acertado que no se tuviesse con menos soldados que de quatrocientos y cincuenta a quinientos, por razón de que cada cortina requiere dos centinelas, que son diez; los baluartes, tres cada uno, que son quinze [...]; que, aviendo de remudarse los de prima a la modorra, y los de la modorra, los del alva, vienen a ser menester entrar cada noche de guardia para este servicio ciento y quarenta y siete soldados [...].

ENCICL.: Nebr. (1495: s.v. prima en la vela): Vigilia prima. // DRAE: Mil. Primero de los cuartos en que para los centinelas se dividía la noche, y comprendía desde las ocho a las once.

principal, V. puerta .

proseguir, V. la victoria.

puente, puente [del lat. pons, pontis. Orígenes (DECH). Fernández de Enciso, Suma de Geographía, 1530]. sust. m. u. t. c. f. Construcción de cualquier clase, fija, provisional, desmontable, etc., hecha sobre un río o un corte del terreno para pasar de una orilla o de un lado a otro (DUE).

Fernández de Enciso, Suma de Geographía, 1530, fol. XXXIVv: Desde este cabo de Galípolli al de Armenia Menor ay una legua escassa de mar. Éste es el estrecho a donde Xerxes, rey de los persas y medos, fizo la puente sobre navíos por donde passó sus huestes contra Grecia y Macedonia. // González de Medina, Examen fortificación, 1599, pág. 46: El puente sobre el foso, para entrar, ha de ser línea recta desde el plano de la contraescarpe, de medio a medio la cortina, adonde ha de ser la puerta principal. Tendrá de largo ciento y sesenta pies, porque es por lo más ancho del foso, y quinze de ancho. // Juanelo Turriano, Veinte y un libros, a. 1605, fol. 208v: Ay otras maneras de puentes, las quales son hechas en diversas maneras, las quales no sirven para paso ordinario; mas estas puentes sirven totalmente para passar exércitos de presto, que no para otro efecto, porque estas puentes se pueden llevar en carros, que dentro de un día son armadas para poder passar de presto el exército, por no ser sentido del enemigo.

ENCICL.: Terr.: Al castellano unos le hacen masculino el puente y otros femenino la puente. // Aut.: 1- amb. Fábrica de piedra o madera que se construye y forma sobre los ríos, fosos y otros sitios que tienen agua para poder pasarlos. 2- Se llama también la máquina que se forma sobre barcas o pellejos, poniendo tablas encima, para poder pasar los ríos; y también se llama así otro cualquier artificio para el mismo fin. // Collado, Plática Artillería (1592: fol. $88 \mathrm{v}$ ): "Las puentes quánto sean necessarias al uso de la guerra, se prueva en esto: que hasta el día de hoy se halla haver havido emperador ni príncipe poderoso al mundo que de puentes no se haya en sus empresas servido". / / Rubió y Bellvé (1895-1901): Existe una 
gran variedad de puentes [...]. Por ejemplo, el puente militar es el que se establece en campaña para facilitar los movimientos de las tropas sobre el teatro de operaciones, teniendo por lo tanto carácter eventual y construyéndose de un modo simple y rápido, con materiales que se hallan sobre el terreno o bien utilizando los elementos que al efecto se tienen preparados y marchan con las mismas tropas. Los puentes militares son de apoyos fijos, de apoyos flotantes y suspendidos. Los primeros pueden ser de caballetes, pilotes, carros, cestones, etc. Los segundos, de pontones, barcas o balsas de distintas clases, y los últimos de cuerdas. // Díaz Capmany (2004: 58): "[En las fortalezas] los puentes servían para establecer el paso sobre el foso. Generalmente unían las puertas con el revellín que las cubría; y a éste con el camino cubierto".

levadizo [Montes, Instrucción y regimiento, 1537]. cmpt. sintag. m. u. t. c. f. El que, por medio de poleas y cadenas, puede levantarse girando sobre uno de sus extremos. $\$$ (fig. 126)

Montes, Instrucción y regimiento, 1537, fol. XVIIr: Tres cosas ha de tener una ciudad para ser fuerte: la primera, muy buen muro en llano, que no tenga padrasto en torno para que puedan tirar; la segunda, que tenga su fuessa de agua en torno del muro por la parte de fuera, de hondura de una gineta y de ancho de pica y media, o de dos picas, con sus puentes levadizas por donde entre y salga la gente de la ciudad; y la tercera, que tenga muchas vituallas para el mantenimiento de la gente de guerra. // Loçano, Alberto, Architectura, 1582, pág. 128-129: En el fuerte se levantará una torre principal, por mucha parte d'ella maciza, robusta en toda la obra, de todas partes fortalecida, más alta que las demás, difficultosa de allegar a ella, con entrada que no sea sino con puente levadiza. // Lechuga, Discurso de la Artillería, 1611, pág. 214: Hallándose tierras sin travesses que se ayan de batir, se advierta que por los lados de las puertas se pueden hazer las baterías, de manera atravesadas que, cayendo la muralla, caiga juntamente el puente levadizo, para que sirva a los soldados de dar el assalto o de entrar por él, escusando con esto el travajo de çegar el fosso.

ENCICL.: Terr.: Es una puente que se quita y pone según la necesidad. // El empleo mayoritario de este tipo de puentes en las fuerzas o fortalezas explicaría la presencia en el Diccionario de Autoridades (s.v. puente levadiza) de una definición tan contextualizada como la siguiente: "La que regularmente hay en los fosos de los castillos o plazas fuertes, y se reduce a una compuerta de madera muy fuerte, engoznada por un lado y por el otro con cadenas que están pendientes del muro, desde donde tiran y, alzando la compuerta, queda sin uso el paso del foso hasta que le vuelvan a echar". // Rubió y Bellvé (1895-1901): El que suele haber en las entradas de las fortalezas para salvar el foso de las mismas y suele consistir en un fuerte tablero de madera engoznado por el lado del recinto, y por el otro sujeto con dos cadenas inclinadas, tirando de las cuales se levanta el tablero y queda cortado el paso hasta que se vuelve a echar el puente. Los puentes levadizos se levantan por medio de tornos instalados al lado de la puerta de la plaza; pero, para que el esfuerzo de tracción necesario no sea tan considerable, se equilibra el peso del tablero con un contrapeso, de modo que para levantar y echar el puente levadizo no hay que hacer más esfuerzo que el necesario para vencer las resistencias pasivas. 
puerta, puerta [del lat. pŏrta 'portón, puerta grande'. Orígenes ( $\mathrm{Cid}$, etc.) (DECH). Sagredo, Medidas Romano, 1526]. sust. Paso o abertura hecha en una pared para dar entrada a un edificio, y la madera que cierra esta abertura (Terr.).

s. (fig. 127)

Sagredo, Medidas Romano, 1526, pág. 13: Platón mandó escrevir sobre la puerta de su escuela que ninguno fuesse osado de entrar a oýr sin que primero fuesse instruto en las sciencias de Geometría y Arismética, que es arte de contar. // Álaba, Perfeto capitán, 1590, fol. 50r: Está [...] obligado el sargento mayor a hazer reparar las puertas, cavalleros, garitas $\mathrm{y}$ otros lugares amparados en que a de aver gente, proveyendo que de noche aya bastante luz en los cuerpos de guardia y para las rondas; y aviendo de abrir las puertas, hará que esté presente el sargento de guardia y sus soldados con las armas en las manos, reconociendo primero alrededor de la puerta si está seguro, procurando que lo que saliere y entrare sea muy reconocido. // Roxas, Sumario milicia, 1607, fol. 81v-82r: Las puertas de la çiudad se han de hazer en las partes que estén más a propósito para entrar y salir la gente fuera y meter los carros y bastimentos acomodadamente, aunque aya guerra, pues se puede remediar con que el arzén del foso cubra la dicha puerta, de manera que de la campaña no la descubra el enemigo.

ENCICL.: DUE: 1- Abertura en una pared que permite el paso de un lado a otro de ella. 2Placa, generalmente de madera, que, sujeta con bisagras en un lado o en cada lado de una puerta, puede girar y obstruirla o dejar paso por ella. // Almirante (1869): Las plazas y fortalezas tienen puertas. // Sanz (1749): Es una unión de tablas que sirve para cerrar la entrada de un recinto. La puerta de una plaza de guerra debe estar colocada en medio de una cortina para ser bien defendida de los flancos y de las caras. Las que están colocadas en los flancos embarazan la parte más necesaria de la fortificación, y cuando lo están en una cara embarazan el terraplén del baluarte, cuyo terreno debe estar libre y propio para las cortaduras o retrincheramientos que se hacen en caso necesario. Cuantas menos puertas haya en una plaza es mejor. // Lucuze (1772: 75): "Los antiguos, y aun los modernos, quieren muchas puertas con la idea de más prontas salidas y mayor facilidad de comunicarse con la campaña. Pero es mejor el dictamen contrario porque en las muchas puertas crece el número de las guardias y la vigilancia contra las sorpresas; así, la plaza sólo ha de tener las que son necesarias para hacer salidas, recibir socorros y comunicarse con la campaña, a proporción de la magnitud del recinto y calidad de la población".

$\sim$ del socorro [Rojas, Teórica fortificación, 1598]. cmpt. sintag. Fort. En una fortaleza, la reservada a la entrada del socorro, situada a cubierto del enemigo. (fig. 128) Rojas, Teórica fortificación, 1598, fol. 73r: Y la puerta del socorro se hará a la parte más conveniente, haziéndola pequeña de 5 pies de ancho y 7 de alto, la qual estará muy cubierta y secreta. // González de Medina, Examen fortificación, 1599, pág. 128: Hase de poner al lado de la ribera la puerta del socorro, porque por el agua, mejor que por ninguna parte, puede venir; y tener siempre barca de respeto para el servicio de la fuerça y para que entren y salgan los que quisieren en la fuerça. // González de Medina, Examen fortificación, 1599, pág. 182: Tendría por acertado que no se tuviesse con menos soldados que de quatrocientos y cincuenta a quinientos, por razón de que cada cortina requiere dos centinelas, que son diez; los baluartes, tres cada uno, que son quinze; el cuerpo de guardia, 
uno, que son tres; a casa del castellano, otra, que son otras tres; a la puerta del socorro, otra, que son tres [...].

ENCICL.: Estévanez (s.v. socorro): En todas las plazas y fortalezas hay una puerta de socorro. // Almirante (s.v. puerta): Puerta de socorro suele lamarse [...] a la que da al campo, por la que efectivamente entraba el socorro. // González de Medina, Examen fortificación (1599: pág. 47): "La puerta del socorro será de cinco pies de ancho y siete de alto; hase de poner en la parte que pareciere que mejor y con más comodidad se puede recebir el socorro; $y$, assí, si la fuerça tuviere algún bosque, monte o cañada, cuesta o algún ribaço, qualquier cosa que pueda encubrir algo a los que vinieren a socorrerla que no los vea el enemigo, aunque no esté muy cerca, se pondrá hazia aquella parte esta puerta de que se trata".

principal [Loçano, Alberto, Architectura, 1582]. cmpt. sintag. En cualquier edificio con varias puertas, la más importante y por la que normalmente se accede a él.

s? (fig. 129)

Loçano, Alberto, Architectura, 1582, pág. 276: Adornaréys las ventanas con obra corinthia; la puerta principal, con jónica; las puertas de las salas y cámaras, y de las semejantes, con dórica. // Rojas, Teórica fortificación, 1598, fol. 73r: Y la puerta principal se hará de forma que esté cubierta de la campaña, dándole de hueco o entrada de 10 a 12 pies, quanto quepan los carros del artillería, y de alto tendrá de 14 a 15 pies. // González de Medina, Examen fortificación, 1599, pág. 46: El puente sobre el foso, para entrar, ha de ser línea recta desde el plano de la contraescarpe, de medio a medio la cortina, adonde ha de ser la puerta principal.

ENCICL.: Díaz Capmany (2004: 55): "Las fortalezas o las ciudadelas, normalmente, sólo tenían dos puertas: la principal y la de socorro [...]. La puerta principal de una fortaleza era de grandes dimensiones, unos cuatro metros de ancho por cinco de alto, y solía estar abovedada en toda la anchura del terraplén que atravesaba. La puerta era de madera, de gruesos tablones reforzados con clavos y barras de hierro". // González de Medina, Examen fortificación (1599: pág. 47): "La puerta principal, que ha de ser, como se ha dicho, de medio a medio la cortina, porque la defienden las dos casas matas de ambos baluartes que la tienen en medio, tendrá diez pies ancho, que cabe qualquier carro cargado, y treze y medio de alto, que es su buena proporción".

puesto, puesto [de poner y éste del lat. pōnō, -ěre. El empleo militar de puesto como sustantivo probablemente proceda del it. Participio, Glosas de Silos; m. 'lugar señalado para hacer algo, para estar algo, etc.', 1595, D. de Yepes, Aut. (DECH). García de Palacio, Diálogos militares, 1583]. sust. Mil. Lugar o punto ocupado, o que es susceptible de estarlo, por una tropa o por un soldado.

García de Palacio, Diálogos militares, 1583, fol. 146r: Y, si acaso todas las dichas tres órdenes eran desbaratadas, se retiravan por los lados y peleavan los del armadura grave y pesada, con sus escudos y espadas, y los de a cavallo de sus puestos, de donde peleavan y socorrían a las partes más flacas y nescessitadas. // Roxas, Sumario milicia, 1607, fol. 12r: Los que son más moços se han de enseñar a correr para que a su tiempo corran con maior 
ýmpetu, llebando la delantera a sus enemigos para occuparles el puesto y para que con más facilidad alcanzen a los que huieren. // Ufano, Tratado de la Artillería, 1613, pág. 262263: Guiará la manga de su mina [...] con mucho artiffiçio y orden muy çerrado y fuerte, armará el horno de la mina con los toneles de pólvora que bastaren y el ordenado fuego a tiempo que toda la gente d'ella y los çercanos puestos estén en salvo, de modo que al reventar del diabólico terromoto no puedan reçibir daño.

SIN.: $\operatorname{posta}_{3}$.

ENCICL.: Terr.: En la guerra, el que ocupan un ejército, cuerpo de él o algún soldado. // Sanz (1749): Es toda suerte de terreno, sea o no fortificado, pero capaz de apostar soldados. Dícese: se ha tomado tal puesto espada en mano, desalojar al enemigo de su puesto, se ha relevado la guardia de los puestos. // D'Wartelet (1863): El paraje o lugar que, fortalecido o no, ocupa cualquiera tropa para algún servicio de vigilancia o defensa. 
quadro, V. cuadro.

quartel, V. cuartel.

quarto, V. cuarto.

qüento, V. cuento.

qüerno, V. cuerno.

qüerpo, V. cuerpo. 
ramo, V. dar bordos $\mathrm{y} \sim \mathrm{s}$.

rastrillo, rastillo, rastrillo [del lat. rastellum, diminutivo de rastrum. La $r$ de rastrillo se debe al influjo de rastro. Nebr. "r., pequeño rastro: rastellum" (DECH). Lobato, Notas, a. 1585]. sust. Fort. Especie de reja de que constan las puertas de las fortalezas, que, al ser bajada rápidamente gracias a un preciso mecanismo, impide el acceso al recinto fortificado. (fig. 130)

Lobato, Notas, a. 1585, pág. 27: Y las dos torres estén tanto desviadas una de otra como lo que fuere menester para salir las dichas barcas y subir; y de la una torre a la otra, hecha una trampa de fuertes maderos gruesos, que en dos canales hechas en las dichas torres, donde la trampa pudiese subir como un rastrillo de puerta. // Roxas, Sumario milicia, 1607, fol. 44v: Se a de adbertir que no puedan ser quemadas las puertas, aunque les pongan fuego, y para su remedio se an de cubrir con cueros y planchas de hierro; y lo más siguro es haçer en la puerta una torre y en ella un rastillo pendiente, y allí unos agujeros para echar de arriba agua y alquitrán ardiente para quemar a los enemigos y también para echar agua fría para apagar el fuego que allí hubiere. // Roxas, Sumario milicia, 1607, fol. 81v-82r: Las puertas de la çiudad se han de hazer en las partes que estén más a propósito para entrar y salir la gente fuera y meter los carros y bastimentos acomodadamente, aunque aya guerra, pues se puede remediar con que el arzén del foso cubra la dicha puerta, de manera que de la campaña no la descubra el enemigo; tendrá su buen rastillo de madera o de hierro, que será mejor.

ENCICL.: Aut.: La compuerta formada como una reja, o verja fuerte y espesa que se echa en las puertas de las plazas de armas para defender la entrada, y se levanta cuando se quiere 
dejar libre, estando afianzada en unas cuerdas fuertes o cadenas a este efecto. // Terr.: En la fortificación, especie de reja colgada de lo alto que se deja caer de golpe por una canal para cerrar e impedir las sorpresas. // Lorenzo Celorrio (1996): Elemento defensivo colocado en las puertas formado por una reja metálica o de madera reforzada y acabado inferiormente en puntas. Se encuentra alojado en la parte superior de las puertas, en un habitáculo preparado al efecto. De forma instantánea podía interrumpir el acceso a la fortaleza al caer repentinamente, guiado por unas acanaladuras en las jambas.

rastro, rastro [del lat. rastrum 'rastrillo de labrador'. Rastro debía de tener en latín una acepción de 'séquito' en su aspecto especial de 'equipaje de guerra', 'impedimenta de un ejército'. Cid (DECH). Celso, Reportorio universal leyes Castilla, 1553]. sust. Mil. Conjunto de cosas que forman el equipaje de un ejército o de una tropa en marcha, así como las bestias de carga o carros imprescindibles para su traslado.

Celso, Reportorio universal leyes Castilla, 1553, fol. CXXXVIr-CXXXVIv: Haviéndose de venir el exército o hueste de un lugar a otro, deven ser los capitanes muy sobre aviso de ordenar la gente según la tierra por donde ellos hovieren de passar, ante que la gente mueva, como vaya el rastro todo por un lugar, y no se parta por muchas partes, proveyendo quáles deven yr a la delantera y quáles a la trasera, poniendo más poder en la çaga que en la delantera. // Celso, Reportorio universal leyes Castilla, 1553, fol. CXXXVIv: Los que fueren por bastimentos para el exército, los capitanes que los guiaren llévenlos, según diximos de suso, versículo II, con trasera y delantera, y no vayan muy desparzidos, y tengan hombres para descobrir, y traygan el rastro como aý diximos. // Celso, Reportorio universal leyes Castilla, 1553, fol. CLIXv: Ninguno se deve atrever de robar el campo o rastro hasta que del todo sean vencidos los enemigos, porque muchas vezes acaesce que los enemigos que son desbaratados se tornan ayuntar, y dan sobre los vencedores que hallan embaraçados en robar el campo, e fácilmente los vencen antes que se puedan tornar en ordenança.

SIN.: bagaje.

ENCICL.: D'Wartelet (1863): Huella, pista o señal que queda impresa en la tierra por los pies de los hombres, las herraduras de los caballos y las llantas de las ruedas de las cureñas y carruajes, por lo cual se conjetura la fuerza de que se componía el cuerpo de tropas que ha pasado por el sitio o lugar en que se hace la observación. // Gago-Jover (2002): Bagaje, equipaje militar de un ejército o tropa cualquiera en marcha.

real1, real [del lat. regalis. Real 'perteneciente al rey'. Doc. de 1188; Berceo (DECH). Collado, Plática Artillería, 1592]. adj. Fort. Dicho de una construcción defensiva: permanente, sólida y mayor que otras de su misma clase.

Collado, Plática Artillería, 1592, fol. 53v: La ancheza de la batería esta, assimismo, digo que ha de ser proporcionada a la qualidad de la fortaleza y del artillería con que se bate la muralla y conforme al número de gente que ha de assaltarla y aun de aquélla que de dentro se ha de oponer a defenderla; pero, por lo menos, una batería real ha de ser tan ancha que nueve soldados puedan entrar en hordenança por ella. // Rojas, Teórica 
fortificación, 1598, fol. 38v: Se entenderá que muy diferentes han de ser las fortificaciones que se hizieren a la frente del turco que las de la frente de luteranos, y mucho diferentes las que se hizieren en tierra de amigos, como es en Italia, que allí bastaría un pequeño castillo a la marina para resistir a las galeotas que quieren desembarcar en tierra, porque a la cara del turco es menester hazer fortificación muy real y capaz de mucha gente. // Ufano, Tratado de la Artillería, 1613, pág. 160-161: Como sea qualquier fuerte, es mucho mejor y más seguro batirle por el baluarte o caballero que no por la cortina, por occasión de que las cortinas de un fuerte son muy cortas y las cubren y deffienden mucho sus baluartes, por tenerlos más a caballero estendidos sus flancos y traveses sobre dichas cortinas que no las plaças reales de grande capaçidad y estendida.

ENCICL.: Almirante (1869: s.v. real. reales): Antiguamente el adjetivo real solía dar idea de una cosa más grande o perfecta que lo ordinario. Así se decía: fuerte real, batería real, baluarte real. // Rubió y Bellvé (1895-1901: s.v. fortificación real): Fortificación permanente, sólida, de verdadera importancia defensiva [...]. Aplicábase el mismo adjetivo a las partes de la fortificación, como fuertes, baluartes, baterías, caballeros, etc. // Roxas, Sumario milicia (1607: fol. 75r): "Tratarse ha aquí de dos maneras de fortificaçiones: la una será real, y la otra, no real; la real será bastante a resistir artillería gruesa; la otra no real será sufiçiente de suyo fuerte y será a medida de los señores de menos fuerças que los reyes".

real $^{2}$, real [del ár. raḥl (vulgar rahál) que significa 'lugar donde se hace alto en un camino', 'campamento', 'majada, redil', 'rebaño'. Real 'predio rústico', 'campamento', 'cabaña'. Reyal, Cid; real, doc. murciano de 1275 (DECH). Fernández de Enciso, Suma de Geographía, 1530]. sust. u. t. en pl. con el mismo significado que en sing. Mil. Campamento o conjunto de instalaciones donde se establece temporalmente un ejército en campaña.

Fernández de Enciso, Suma de Geographía, 1530, fol. XXXIr: Quando Aníbal cercó a la ciudad de Calahorra, estuvo tanto tiempo sobre ella que los de la ciudad acabaron las provisiones e manteníanse de la carne de los hombres que matavan del real. // Álaba, Perfeto capitán, 1590, fol. 71v: Y Aníbal, yendo contra los africanos, sabiendo que era gente apassionada del vino, echó en mucha cantidad d'él mandrágora, la qual es medio entre ponçoña y sueño; y travando escaramuça con ellos, fingiendo yr de vencida, huyendo desamparó sus reales, en los quales entrando los enemigos, se entregaron de suerte en el vino inficionado que luego les cargó un sueño grandíssimo y, hallándolos como muertos Aníbal, los passó todos a cuchillo. // Roxas, Sumario milicia, 1607, fol. 17r: Digo que los reales, mayormente estando el enemigo çerca, se an de asentar en lugar siguro y donde aya abundançia de forraje, leña y agua; y si el real ubiere de estar algunos días a de ser sitio sano, que no se anegue aunque llueva, y que no sea pequeño el sitio porque no estén amontonados los soldados, ni sea muy grande porque no estén apartados.

SIN.: campo $_{2}$.

ENCICL.: DRAE (s.v. real ${ }^{3}$ : Campamento de un ejército. 
2 [Álaba, Perfeto capitán, 1590]. sust. Mil. Tropa acampada (DRAE: s.v. campamento). Álaba, Perfeto capitán, 1590, fol. 62r: Pareciéndoles que sin duda las guardas no los avían sentido venir, pues no se usava de la seña del humo, y que todo el real devía de estar descuidado, acometieron con la desorden que de ordinario acometen los muy confiados de la vitoria; y estando sossegado el prudente capitán que sabía su venida, con menos gente de la que su enemigo traía le desbarató y venció. / / Álaba, Perfeto capitán, 1590, fol. 63r: Y aunque sea de noche, escusará el acometer si no tuviere orden para usar de alguna cautela con que divertir y hazer esparcir el real, porque entonces, desbaratándolos de la fortaleza que todos juntos tienen, podrá ofenderlos con ventaja. // Álaba, Perfeto capitán, 1590, fol. 143v: Dará también lugar el capitán a que todo su real se alegre y regozije con fiestas y torneos, de suerte que, mientras estas alegrías duran, crezca su vigilancia en prevenir los daños que en semejantes tiempos suelen recebir los vencedores de los enemigos vencidos.

ENCICL.: Salvá (1846: s.v. real): Ejército acampado.

rebatir, rebatir, revatir [de batir. APal. (DECH). García de Palacio, Diálogos militares, 1583]. v. tr. Mil. Hacer retroceder al enemigo que ataca (DUE: s.v rechazar).

García de Palacio, Diálogos militares, 1583, fol. 68r-68v: Y en este particular era César vigilantíssimo y cuydadoso, de que sacó mucho fructo y escusó grandes daños a sí y a su gente, especial en lo que refiere de un asalto y repentino acometimiento que los burgueses hizieron, los quales, rebatidos por las buenas guardas y velas que tenía, desesperaron de poderse defender de un capitán tan cuydadoso y se le rindieron y subjetaron. // García de Palacio, Instrución náuthica, 1587, fol. 126v: Assimesmo, suelen muchas vezes vencer los que al principio yvan casi de vencida y se començavan a rendir por accidentes que las occassiones de la guerra offrescen, en especial quando, aviéndose defendido y rebatido los contrarios, con aver muerto muchos y hécholes otros daños, se suelen animar y atrever a acometer los enemigos de que antes se temían.

SIN.: hacer retirar, rebotar, rechazar, retirar.

FAM.: batido, batir.

ENCICL.: DUE: Rechazar un ataque. // Terr. (s.v. rebatir vivamente al enemigo que se adelantó): Rechazarle, hacerle retirar.

rebato, rebato [del ár. ribât 'ataque contra los infieles', derivado de râbat 'dedicarse con celo a un asunto', 'amenazar las fronteras enemigas'. med. s. XIII, Fn. Gonz. (DECH). Mosquera, Comentario disciplina militar, 1596]. sust. Mil. Llamada precipitada que se hace a los habitantes de un pueblo para que acudan a la defensa, ante una súbita incursión enemiga, la cual se hace tocando las campanas en cierta forma.

Mosquera, Comentario disciplina militar, 1596, fol. 140r-140v: Resultó, de la confessión y declaración que Manuel de Silva hizo en el tormento, advertir de una armada que se hazía 
en Francia secretamente [...], que saldría por fin de setiembre. El Marqués embió luego a dar aviso en dos pataches d'este negocio y en las demás partes de las Indias para que, demás de que esta nueva llegasse a su noticia y estuviessen apercebidos para qualquier rebato, supiessen también que estas islas estavan por de Su Magestad, para que pudiessen venir por ellas los de las Indias con seguridad, como de antes lo hazían.

ENCICL.: Cov. (s.v. rebatir): Rebato, la defensa que se hace al fraudulento y súbito acometimiento del enemigo, porque él viene a batir que es herir, y salimos a rebatirle. / / Hevia (1857): Toque de campanas por el cual se llama apresuradamente a los vecinos de un pueblo y su comarca, para que acudan con armas a su defensa y a batir al común enemigo.

dar [Escalante, Discurso de la navegación, 1577]. loc. v. Mil. Tocar las campanas para avisar al pueblo de una incursión enemiga (DUE: s.v. tocar a rebato).

Escalante, Discurso de la navegación, 1577, fol. 86r: Esto se haze con comodidad respeto de que en todas las laderas d'él ay muchas poblaciones grandes $y$, con tener centinelas puestas que les dan rebato, acuden todos a la defensa quando se ofrece necessidad, hasta que llegue el rei con su exército grande, que tiene de ordinario de mucha gente de a pie y de a cavallo para su guarda y magestad, y para refrenar las incursiones de los enemigos.

ENCICL.: Salvá (1846: s.v. tocar a rebato): Avisar a los vecinos de un pueblo a son de campana, para que tomen las armas con motivo de alguna sorpresa de los enemigos.

rebelado, rebellado, revelado [de rebelar. Micón, Diario grande cometa, 1578]. adj. Mil. Dicho de una persona o de un territorio donde habita gente: que se ha enfrentado, normalmente de forma violenta, a sus superiores o a quienes lo tienen bajo su poder.

Micón, Diario grande cometa, 1578, pág. 105: Como aconteció en semejante coyuntura, año de 1538, del cometa que apareció en Pisces [...], a donde passó el segundo año después de Carlos 5, de gloriosa memoria, sojusgando a la rebellada ciudad de Gante y prendiendo a las cabeças de los que avían sido la causa del motín, quitándoles por ello privilegios y libertades muchas.

SIN.: levantado, rebelde 1 .

FAM.: rebelar.

rebelar, rebelar, rebellar, revelar [tomado del lat. rěbellō, -āre 'reanudar la guerra', 'rebelarse', de re y bellō. 1220-50 (Segura Munguía 2007). Álaba, Perfeto capitán, 1590]. v. tr. Mil. Poner a un grupo de personas, preferentemente soldados o a los habitantes de un territorio, en contra de sus superiores o del poder establecido. 
Álaba, Perfeto capitán, 1590, fol. 83r: Marcelo, conociendo que Barceo Nolano de secreto tratava de rebelarle toda la gente plebeya, por favorecer a Aníbal en recompensa de que en la de Canas le avía hecho curar y dado después licencia de bolverse a Roma, no quiso matarle por no inquietar y alborotar los cómplices d'este delito; y para quietarlo y ponerlo en razón y camino lo llamó, y en una plática que le hizo dixo que nunca avía sabido que en su campo tenía tan valiente soldado y luego le amonestó que perseverasse en su servicio.

SIN.: amotinar 1.

FAM.: rebelado.

2 [Fernández de Enciso, Suma de Geographía, 1530]. v. prnl. Mil. Dicho especialmente de los habitantes de un territorio recién conquistado o sujeto: enfrentarse $u$ oponerse, normalmente con las armas, a quienes los han puesto bajo su poder.

Fernández de Enciso, Suma de Geographía, 1530, fol. XXIVv: Y después se levantaron y revelaron los españoles contra Roma fasta que bolvió Cipión, el Africano, e la tornó a someter al Imperio Romano, e passó en África, y venció a Aníbal y destruyó a Cartago. // García de Palacio, Diálogos militares, 1583, fol. 88r: Y, assí, el que huviere rendido a ciudad de fee differente o que antes tenía de por sí libertad e imperio, nescessidad tiene que, con tiempo, provea cómo se reparen los lugares fuertes y, si no los tuviere, se hagan, para que, si en algún tiempo los subjetos se rebelaren, en ellos se fortalezcan, amparen y defiendan los vencedores, y offendan y subjeten los vencidos. // González de Medina, Examen fortificación, 1599, pág. 117-118: Y aun los romanos (quando sujetavan el mundo) eran de opinión derribar las murallas a los pueblos de quien se temían que se les avían de rebelar.

SIN.: levantar 4 .

rebelde, rebelde, revelde [tomado del lat. rebĕllis 'íd.', derivado de bellum, con desarrollo semiculto del grupo -ll-. s. XIII, rebele, F. Juzgo, rebelle en el Fuero de Zorita, rebelle y rebelde en las obras alfonsíes; más tarde interesa la forma rebelles en Fz. de Heredia, rebel en los Fueros de Aragón, rebele, APal; la forma rebelde queda fijada desde Nebr. (DECH). Montes, Instrucción y regimiento, 1537]. adj. Mil. Dicho de una persona o de un territorio donde habita gente: que se ha enfrentado, normalmente de forma violenta, a sus superiores o a quienes lo tienen bajo su poder.

Montes, Instrucción y regimiento, 1537, fol. VIr: E si, por caso, las otras tierras hizieren lo mismo y fueren rebeldes, hágase en ellos el mismo castigo, porque la guerra hase de hazer con daño de los enemigos y de todos aquéllos que siguen su opinión, y no a provecho suyo. // Mosquera, Comentario disciplina militar, 1596, fol. 12r: Y porque todas estas causas estorvaron el designio d'esta empresa para acabar de sujetar y reduzir aquellas Islas que estavan rebeldes, haziendo relación del estado d'estas cosas a Su Magestad, dexó en la isla de San Miguel dos mil y quinientos hombres de guarnición. / Anónimo, Diálogo fábrica de navíos, ca. 1631, fol. 45r: En la villa de Santander, quando don Fadrique de Toledo Osorio 
arribó a aquel puerto, el año de 1628, del viaje que hizo con la armada a Mormian, y contra la armada ynglesa que estava dando ayuda a aquella ciudad revelde a su rey, se levantó una enfermedad tan grande que murió cantidad de gente.

SIN.: levantado, rebelado.

2 [García de Palacio, Diálogos militares, 1583]. sust. Mil. Persona que se enfrenta u opone, normalmente con las armas, a sus superiores o al poder establecido en el territorio en que habita.

García de Palacio, Diálogos militares, 1583, fol. 15r: Esta pregunta será occasión para que este punto quede más declarado, a la qual respondo, señor, que levantar exército para yr a resistir al enemigo que entra por el reyno, o para yr a castigar a los rebeldes que se han levantado con parte de la provincia, o para entrar por las tierras del enemigo a offenderle es propria del príncipe. // García de Palacio, Diálogos militares, 1583, fol. 87v: Manda Dios que, entrada por fuerça de armas y rendida, que maten y destruyan los hombres que no huvieren querido darse de paz y que sólo dexen y den la vida a las mugeres y niños, como a gente inútil para tomar las armas y que no pudo avelles offendido, que, con el exemplo de la benevolencia con los que se rinden y del rigor con los rebeldes, fácilmente se rendirán las demás ciudades y provincias del reyno que se fueren combatiendo y conquistando. // Mendoça, Theórica y práctica, 1596, pág. 34: Pueden assimismo venir ocasiones en que Vuestra Alteza aya de levantar gente de guerra, valiéndose d'ella y armas, para castigar alguna sedición o rebelión de sus vassallos, en que no se ha de perder un momento de tiempo por muchas razones, no siendo la más flaca que los príncipes que sufren levantamientos de comunidades, ciudades o provincias dan exemplo a otros a que los sigan, quando no los veen armados, para castigarlos y, estándolo, es causa de acudir con más voluntad a su príncipe los que no están declarados contra él, viéndole con gente y que no se dexa descaecer, fiados de que tiene más ciertos premios que dar, que no los rebeldes.

ENCICL.: Cov.: El que no responde al mandato del superior [...], y rebeldes se llaman los que se han rebelado contra su rey y señor. // Domínguez (1853): El que con las armas en la mano combate facciosamente al que impera.

rebelín, $V$. revellín.

rebelión, rebelión, rebellión [tomado del lat. rebellio, -onis. h. 1440, A. Torre; APal. (DECH). Montes, Instrucción y regimiento, 1537]. sust. Mil. Movimiento colectivo violento, normalmente con armas, contra la autoridad, por lo común por parte de un territorio hacia quienes lo tienen sujeto.

Montes, Instrucción y regimiento, 1537, fol. VIr: Mas si acontesciere que alguna villa o ciudad no quisiere traher vituallas al exército, a esta tal hágasele guerra como al enemigo, por la rebellión que haze. // Álaba, Perfeto capitán, 1590, fol. 145r: Alexandro Magno, aviendo sujetado a Tracia poco tiempo avía y temiendo que la gente d'ella se le rebelasse 
mientras él passava a Asia con su exército, ocupó en él con muy honrados oficios a los hombres más señalados d'esta provincia y a los lugares más principales embió mucha gente ordinaria y baxa, con lo qual quedó la tierra sin guarnición, las cabeças contentas con sus ocupaciones y entretenimientos honrados y el vulgo desesperado de poder salir bien de su rebelión, faltándole sus caudillos principales de quien poderse valer. // Mendoça, Theórica y práctica, 1596, pág. 34: Pueden assimismo venir ocasiones en que Vuestra Alteza aya de levantar gente de guerra, valiéndose d'ella y armas, para castigar alguna sedición o rebelión de sus vassallos, en que no se ha de perder un momento de tiempo por muchas razones.

SIN.: levantamiento.

ENCICL.: Aut.: Levantamiento o conspiración de muchos contra su rey, patria o gobierno. // Estévanez (1897): Sublevación, resistencia armada a los superiores o a las autoridades constituidas.

rebellado, $V$. rebelado.

rebellar, V. rebelar.

rebellín, V. revellín.

rebellión, V. rebelión.

rebolber, V. revolver.

rebolver, V. revolver.

rebotado, rebotado [de rebotar. Mendoça, Theórica y práctica, 1596]. adj. Mil. Dicho de una persona: que, al ir a atacar a su enemigo, éste ha conseguido hacerlo retroceder.

Mendoça, Theórica y práctica, 1596, pág. 155: Negocio [abrir puertas] que se ha de hazer con diligencia para que pueda entrar en la tierra la cavallería o infantería que para este efecto huviere sido de retaguardia de todos y quedádose en esquadrón en la campaña; y quando sucediesse mal, poder ayudar a los soldados, viniendo rebotados.

FAM.: rebotar. 
rebotar, rebotar [de botar y éste del fr. ant. boter 'golpear, empujar, poner', del fráncico *bōtan 'empujar, golpear'. h. 1600, Oña, Aut. (DECH). Mendoça, Theórica y práctica, 1596]. v. tr. Mil. Hacer retroceder al enemigo que ataca (DUE: s.v rechazar). Mendoça, Theórica y práctica, 1596, pág. 92: Rebotados los enemigos dentro de la plaça, el maestre de campo general hará el alojamiento, señalando los quarteles lo más cerca que se pudiera d'ella. // Mendoça, Theórica y práctica, 1596, pág. 103: Y rebotando los cercados la gente del assalto, si se retira, es bueno de creer que será con desorden y esparzidos, por no ser possible que lo hagan de otra suerte. // Mendoça, Theórica y práctica, 1596, pág. 140: En algunas salidas apuntan la artillería a la parte que han de cargar de los quarteles a rebotar a los cercados dentro de la tierra para poderles hazer mayor daño.

SIN.: hacer retirar, rebatir, rechazar, retirar.

FAM.: rebotado.

ENCICL.: DRAE (1803): Rechazar.

rechaçar, V. rechazar.

rechazar, rechaçar, rechazar [del fr. ant. y med. rechacier 'íd.', derivado de chacier (hoy chasser 'expulsar, perseguir') del mismo origen que nuestro cazar. 1430, Juan de Mena; Gómez Manrique; escrito con -ç- en ambos, Cuervo, Obr. Inéd.; "rechaçar: repello", Nebr.; Cej. (DECH). Loçano, Alberto, Architectura, 1582]. v. tr. Mil. Hacer retroceder al enemigo que ataca (DUE).

Loçano, Alberto, Architectura, 1582, pág. 140: Por tanto (como diximos), se ha de advertir y procurar que el fuerte sea poderoso, fuerte, firme y aparejado para se defender, y para enflaquecer al enemigo y rechazalle, y seguro y no dañado contra todos los ímpetus y porfía del ser cercado. // Rojas, Teórica fortificación, 1598, fol. 106r: Y assimesmo, se irán haziendo en la dicha çanja unos reductos o espacios para que aya allí cuerpos de guardia para rechaçar al enemigo quando salga a estorvar el trabajo.

SIN.: hacer retirar, rebatir, rebotar, retirar.

ENCICL.: DECH (s.v. cazar): [Rechazar] entraría como término militar, valor que ya tiene específicamente en el Siglo de Oro. // Terr.: Hacer volver atrás, echar o hacer pasar de un lugar a otro [...]. Los enemigos entraron hasta la mitad del reino y luego los rechazaron [...].

reconocer, reconocer, reconoçer, reconoscer, reconosçer, reconoser, reconozer [del lat. rĕcognōscō, -ěre 'reconocer', 'inspeccionar, examinar', de re y cognōscō. h. 1280 (Segura Munguía 2007). Montes, Instrucción y regimiento, 1537]. v. tr. Examinar un lugar u otra cosa detenidamente. 
Montes, Instrucción y regimiento, 1537, fol. VIr: Es de culpar el alcayde que tiene bien proveýda su fortaleza y se puede defender de sus enemigos y se rende, y a este tal nunca le falta un color con que cierre las bocas a todos. E, por ende, los generales, señores que tienen castillos y fortalezas y se temen de sus enemigos, no se deven descuydar en las visitar y reconoscer. // Collado, Plática Artillería, 1592, fol. 98r: He visto la cavallería reconoscer qualquiera valle, bosque y sierra para ver si allí se hallava alguna emboscada enemiga. // Mendoça, Theórica y práctica, 1596, pág. 79-80: Antes de llegar al sitio donde Vuestra Alteza piensa alojar, se ha de adelantar el maestre de campo general para reconocerle y hazer el alojamiento, en que es de considerar, fuera de las partes que apunté del agua, leña, buen terreno y ayre sano, si ha de ser en montaña, porque en los tales sitios ay falta de ordinario de agua y pastos.

FAM.: reconocido, reconocimiento.

ENCICL.: Aut.: Examinar con cuidado alguna cosa, enterarse de lo que no se tiene toda la claridad o noticia que se necesita.

reconocido, reconocido, reconoçido, reconoscido, reconozido [de reconocer (DECH). Álaba, Perfeto capitán, 1590]. adj. Dicho de un lugar: examinado detenidamente.

Álaba, Perfeto capitán, 1590, fol. 44r: Conviene, también, tenga reconocido el alojamiento a donde va $\mathrm{y}$, en llegando, forme su esquadrón en la plaça de armas, sin consentir que alguno se desmande hasta que se dé licencia a las vanderas, que será quando el alojamiento estuviere del todo fortificado. // Mendoça, Theórica y práctica, 1596, pág. 72: Lo qual remediava hallándose en vanguardia, y tener, con esto y primer aviso que le llegasse del venir el enemigo, reconocida la campaña y sitio donde combatir, que mandava al momento fortificar; y con tanto, no tenía que hazer su exército, mas, de como llegava al puesto, ponerse en batalla, siéndole d'esta suerte superior en sitio para pelear siempre con ventaja. // Mendoça, Theórica y práctica, 1596, pág. 137: Antes del descubrirse el enemigo al poner el sitio y cerrar la tierra, se han de tener apuntadas las pieças d'ella a las partes donde de razón se ha de presentar con los esquadrones de su cavallería jugando en ellos, sirviéndose para esto de las culebrinas y medias en las plataformas y cavalleros, por ser pieças que alcançan y passan más [...]; y cantidad de pieças ligeras, por llevarse con facilidad a todas partes y retirarse con la misma en disparando, teniendo juntamente reconocidos los puestos donde poner la arcabuzería.

FAM.: reconocer, reconocimiento.

reconocimiento, reconocimiento, reconoçimiento, reconoscimiento, reconosçimiento [de reconocer. APal. (DECH). García de Palacio, Diálogos militares, 1583]. sust. Examen cuidadoso de un lugar o de otra cosa.

García de Palacio, Diálogos militares, 1583, fol. 69r: Razón es que los tales reconoscimientos se hagan discreta y attentamente, mirando por menudo los sitios del campo, considerando la tierra que occupa y si está assentado en forma redonda, quadrada, triangulada o 
perlongada. // Ufano, Tratado de la Artillería, 1613, pág. 252: Apartado de allý el dicho general atendiendo al reconosçimiento de trincheas, cubrimientos y baterías, en el ýnter que la dicha artillería passava por no perder tiempo a la ocasión preçisa, la postrera pieça de artillería, por ser algo más grave que las primeras y aver ellas y el agua robado y abarrancado con sus rodadas el camino de passo, se ahondaron y embazaron tanto sus ruedas en el terreno que no la podían tirar ni sacar fuera los caballos.

FAM.: reconocer, reconocido.

ENCICL.: Moretti (1828): La acción de reconocer y examinar una posición, una plaza y a veces una provincia entera, una formación, un campamento enemigo o propio; los movimientos, fuegos, avanzadas y marchas del contrario, etc., en todo cuanto diga relación al ataque y defensa de lo que se reconoce, a fin de poder caminar con acierto y tomar las providencias que más convengan al objeto que motiva el reconocimiento.

reconoçer, $V$. reconocer.

reconoçido, V. reconocido.

reconoçimiento, $\mathrm{V}$. reconocimiento.

reconoscer, $\mathrm{V}$. reconocer.

reconoscido, V. reconocido.

reconoscimiento, $\mathrm{V}$. reconocimiento.

reconosçer, $\mathrm{V}$. reconocer.

reconosçimiento, $\mathrm{V}$. reconocimiento.

reconoser, V. reconocer.

reconozer, $\mathrm{V}$. reconocer. 
reconozido, V. reconocido.

rectaguardia, $V$. retaguardia.

recuentro, V. reencuentro.

reçaga, $V$. rezaga.

reducto, reducto, reduto [del it. ridotto 'íd.' (s. XIV), de donde procede también el fr. redoute. 1595 (DECH). Mendoça, Theórica y práctica, 1596]. sust. Fort. Fuerte de varios lados y sin baluartes, pero con foso, parapeto, banqueta y terraplén.

s (fig. 131)

Mendoça, Theórica y práctica, 1596, pág. 92: Y quando ay recelo de venir el enemigo con golpe de exército a socorrerla, se fortifica el alojamiento assí a la parte de las murallas como de la campaña, que se ha de reconocer con mucho cuidado, previniendo las venidas que puede tener el enemigo para meter socorro o llegar a combatir el alojamiento, las quales han de estar fortificadas como mejor fuere, haziendo traviessas, redutos, fuertes o trincherones, si lo pide la ocasión. // Rojas, Teórica fortificación, 1598, fol. 106r: Y assimesmo, se irán haziendo en la dicha çanja unos reductos o espacios para que aya allí cuerpos de guardia para rechaçar al enemigo quando salga a estorvar el trabajo. // Rojas, Compendio fortificación, 1613, fol. 32r-32v: Y, assí, conviene mucho que aya fosso en la fortificación y a la orilla y borde d'él su estrada cubierta, y fuera d'ella cortaduras y redutos para detener el enemigo a lo largo.

ENCICL.: Almirante (1869): Obra de fortificación, cerrada, que ordinariamente tiene cuatro lados y cuya condición característica es no tener flanqueo. Generalmente es obra de campaña; pero los hay también que forman parte integrante de la fortificación permanente; y en este caso son segunda defensa, refugio, abrigo, como el reducto de la media luna, de la plaza de armas entrante, etc. Entonces pueden tener forma varia y recorrer desde la simple estacada hasta el muro más sólido y robusto. // Díaz Capmany (2004: 51): "El reducto era una pequeña obra cerrada y atrincherada, sin ángulos entrantes, de mediana capacidad, para ocupar un lugar importante a los efectos de la defensa. Aunque podía tener cualquier figura, únicamente se usaban los de planta cuadrada o cuadrangular". // Lopes Pires Nunes (2005: s.v. reduto): Pequena obra, geralmente quadrangular, num baluarte ou revelim, outras vezes já fora da esplanada mas ao alcance do fogo do caminho coberto. Também se construíam nas obras de aproximação dos sitiadores, normalmente com quatro lados e sem flancos.

reduto, $\mathrm{V}$. reducto. 
reencuentro, recuentro, reencuentro, rencuentro, reqüentro [de encuentro (DECH). Montes, Instrucción y regimiento, 1537]. sust. Mil. Combate o cualquier otra operación militar llevada a cabo en una guerra.

Montes, Instrucción y regimiento, 1537, fol. IIIv: Mas él tenga tal cuydado en la governación del exército, que no les haga falta la presencia de su rey natural, y en las afrentas y recuentros que se halle de continuo presente con valeroso ánimo, porque sus soldados no conozcan ni sientan en él flaqueza de ánimo, sino todo el esfuerço y osadía. // Álaba, Perfeto capitán, 1590, fol. 23r-23v: Y assí, aunque Alexandro sujetó en pocos años tanta parte del mundo, salió siempre de los rencuentros muy mal parado, recibiendo muchas heridas y golpes que le pusieron muy a lo último de su vida. // Álaba, Perfeto capitán, 1590, fol. 128r: Los de tercero y quarto lugar, que yvan con armas arrojadizas, servían para el primer rencuentro $y$, si podían hazer huir al enemigo, le seguían juntamente con los de a cavallo.

SIN.: empresa, empresa de (la) guerra, empresa militar, encuentro 1 , facción $n_{2}$ facción de guerra, hecho de armas, interpresa.

FAM.: encuentro.

ENCICL.: Estévanez (1897): Encuentro, combate, choque; todos los escritores del siglo XVI escriben rencuentro por "encuentro".

2 [Montes, Instrucción y regimiento, 1537]. sust. Mil. Pelea o enfrentamiento que tiene lugar cuando se topan casualmente dos fuerzas o tropas contrarias.

Montes, Instrucción y regimiento, 1537, fol. XIIv-XIIIr: Otras maneras de guerra se podrían tener para romper a los muchos, assí como emboscadas o encamisadas que les armen de noche, tomándolos sobre seguro o en algún passo estrecho, dándoles algún recuentro por donde les hiziessen perder parte de su exército, porque, después, si los enemigos quisiessen dar batalla, fuessen yguales en la gente / / Álaba, Perfeto capitán, 1590, fol. 1v-2r: Y los griegos, yendo a socorrer al rey Cyro contra Artaxerxes, vencieron en un rencuentro que tuvieron con los bárbaros, cien mil d'ellos, siendo el número de los que fueron a este socorro solos catorze mil. // Roxas, Sumario milicia, 1607, fol. 35r: Si entendiere que el contrario tiene ventaja reusará dar la campal, que los pocos en número y en fuerças ynferiores, debajo buenos capitanes, con recuentros y emboscados an alcançado muchas vezes la vitoria, porque todas las artes van cada día aprobechando con el huso cotediano y perpetuo exerçiçio.

SIN.: encuentro 2.

ENCICL.: Como puede verse en algún ejemplo, un ardid de guerra frecuentemente empleado en aquella época consistía en ir al encuentro de un pequeña partida de tropas, la cual, sin preverlo, se veía envuelta en una pelea que no deseaba. Los soldados que propiciaban el encuentro o reencuentro gozaban de una gran ventaja, puesto que, al pillar desprevenidos a sus contrarios, solían vencer en estos pequeños enfrentamientos. Esta estratagema les era muy útil cuando se esperaba una batalla o contienda, $y$, al saber que 
los contrarios contaban con un gran ejército, pretendían reducirlo con pequeños combates previos.

refosete, refosete, refoseto [de refoso. González de Medina, Examen fortificación, 1599]. sust. Fort. Segundo foso pequeño que se forma dentro del foso, en medio de su superficie ínfima (Aut.: s.v. cuneta). (fig. 132)

González de Medina, Examen fortificación, 1599, pág. 41: El refoseto ha de ser de treynta pies de ancho y diez de hondo alrededor de toda la fuerça por en medio del foso. Y si fuere seco el foso, se ha de cortar en ángulo algo obtuso porque se descubra todo él de la muralla y quien se metiere en él; y, si fuere con agua, se cortará perpendicular en quadro que haga ángulos rectos. // González de Medina, Examen fortificación, 1599, pág. 105: Házese sin foso ni refoseto, porque la mar le sirve de foso; sin contraescarpe, pues no tiene foso que assegurar ni miedo que le desemboquen en él encubiertos por mina; no tendrá estrada cubierta, por no tener que estorvar al enemigo el trabajar para aproximarse a plantar la batería, ni arzen para defender, ni tienen para qué salir de la muralla los que la han de defender. // González de Medina, Examen fortificación, 1599, pág. 218: El refoseto, $\mathrm{S}$, de treinta pies de ancho, y diez de hondo en medio del foso, entre las murallas y el contraescarpe.

SIN.: refoso.

FAM.: foso, refoso.

ENCICL.: Aut. (s.v. cuneta): Term. de Fortificación [...]. Se llama también Refosseto. // Terr. (s.v. contra-foso, o refosete): Foso pequeño hecho a fin de ceñir y defender el foso principal, supliendo su poca profundidad. // Terr. (s.v. refosete): En la fortificación. V. Contra-foso y Cuneta. También dicen refoseto [...]. V. Oud. Dicc.

refoseto, V. refosete.

refoso, refoso, refosso [de foso. Rojas, Teórica fortificación, 1598]. sust. Fort. Segundo foso pequeño que se forma dentro del foso, en medio de su superficie ínfima (Aut.: s.v. cuneta). 1 (fig (fig. 133)

Rojas, Teórica fortificación, 1598, fol. 72r: Y assimesmo, se ha de advertir que esta plaça ha de tener el fosso de 80 pies de ancho y 25 de fondo (como se ha dicho), y su fosseta en medio, que llaman refosso, y la contramina, como parece en el perfil que queda atrás. // Roxas, Sumario milicia, 1607, fol. 75v-76r: Resuelta, pues, la forma que ha de tener la çiudad [...], es neçesario acompañarlos con los miembros que conbiene para hazerla fuerte, que son estos: baluartes, cortinas, cavalleros, al largo de la cortina; plataformas o bastardos, caballeros, de dentro y apartados de las cortinas; tenazas, tijeras, dientes, casamatas, puertas, terraplenos, estrada, detrás del terrapleno; foso grande y refoso pequeño, estrada cubierta, fuera del foso; campaña rasa, al torno del foso. // Roxas, Sumario milicia, 1607, 
fol. 87v: Harase el foso bien profundo, con su fosillo, que se llama el refoso, con muchos poços por las cortinas porque no pasen las minas sin sentirlas.

SIN.: refosete.

FAM.: foso, refosete.

refosso, V. refoso.

refriega, refriega [de refregar y éste del lat. rĕfrŭcō, -āre 'refregar, frotar de nuevo', de re y frĭcō. h. 1600 (Segura Munguía 2007). Álaba, Perfeto capitán, 1590]. sust. Mil. Batalla de poca importancia o con pocas fuerzas (DUE).

Álaba, Perfeto capitán, 1590, fol. 23r-23v: Y assí, aunque Alexandro sujetó en pocos años tanta parte del mundo, salió siempre de los rencuentros muy mal parado, recibiendo muchas heridas y golpes que le pusieron muy a lo último de su vida, pues de una refriega que tuvo junto al río Granico, salió cortado el yelmo de una cuchillada hasta los cabellos. // Álaba, Perfeto capitán, 1590, fol. 33v: Tales fueron los que Rómulo escogió entre todos lo que en su ciudad avía, prefiriendo siempre los que estavan exercitados en los negocios del campo a los ciudadanos d'ella, como a gente menos dispuesta para que d'ellos se esperassen obras señaladas en las ocasiones de refriegas y rencuentros que se ofreciessen. // Álaba, Perfeto capitán, 1590, fol. 81r: Él mesmo, aviendo embiado a algunos de los soldados aliados y mercenarios a que resistiessen cierto daño que el enemigo pretendía hazer, como en la refriega muriessen todos excepto uno y d'esta nueva conociesse averse atemorizado todo su campo, para sossegar sus ánimos mandó pregonar por todo el real que aquellos soldados avían sido muertos por su consejo y traça, porque supo que ellos tenían determinado de seguir el partido de los enemigos.

SIN.: escaramuza 1.

ENCICL.: Estévanez (1897): Batalla parcial; reencuentro de vanguardia; combate de fuerzas importantes en un reconocimiento.

remeter, remeter [de meter y éste del lat. mǔttěre 'enviar', 'soltar', 'arrojar, lanzar'. Desde el Cid, se dijo remeter con el sentido de 'arremeter' (DECH). Rojas, Teórica fortificación, 1598]. v. intr. Mil. Ir con ímpetu y furia sobre alguien o sobre algo.

Rojas, Teórica fortificación, 1598, fol. 32r: Y si el enemigo huviesse hecho batería en la esquina del valuarte y mandasse remeter su gente a ella, digo que les hará mucho más daño la mosquetería y arcabuzería desde la defensa que no la pieça de artillería.

SIN.: arremeter, embestir.

FAM.: arremeter, arremetida, remetida. 
remetida, remetida [de remeter. Rojas, Teórica fortificación, 1598]. sust. Mil. Acción de ir con ímpetu y furia sobre alguien o sobre algo.

Rojas, Teórica fortificación, 1598, fol. 106r: Y teniendo ya al enemigo afligido y no se queriendo rendir, se dará el assalto, teniendo en arma todo el exército y principalmente teniendo la remetida y batería fácil de subir, de manera que se tenga por muy cierta la ganancia del tal assalto, por causa de estar muy reforçados y con todo el cuydado dicho.

SIN.: arremetida.

FAM.: arremeter, arremetida, remeter.

rencuentro, $V$. reencuentro.

rendido, rendido [de rendir. Berceo (DECH). Montes, Instrucción y regimiento, 1537]. adj. Mil. Dicho de una persona, un pueblo, una fortaleza, etc.: que se ha entregado al enemigo.

Montes, Instrucción y regimiento, 1537, fol. XVIIIv: Y no se deve rendir por batalla ni por otro combate ninguno, porque el alcayde rendido no puede ser alcayde de otro castillo, pues se rendió, porque más sano le sería morir peleando con los enemigos que no vivir habiéndose rendido, porque regla es entre gente de guerra que un hombre rendido no puede combatir con otro sin licencia de aquél a quien le rendió. // García de Palacio, Diálogos militares, 1583, fol. 89v: Que, assí, aviendo perdonado el gran Alexandro a los persas dos vezes, lo hizo la tercera: quando venció a Darío, destruyó y mató gran parte de su exército. Y César qüenta aver hecho lo mismo con Niducio Marco y en otras occasiones que con sus rendidos enemigos se le offrescieron. / Álaba, Perfeto capitán, 1590, fol. XIIIv: Pues de inorar la parte más flaca del lugar que se a de batir y dar la batería por la de mayor resistencia, han venido a parecer muchas fuerças inexpugnables y de extraordinaria fortificación, que, conquistadas por quien tuviera el conocimiento del ancho y largo con que se fundaron, que qualquier geómetra, por lexos que se halle, alcança, quedaran rendidas y desbaratadas.

FAM.: rendir.

2 [Mosquera, Comentario disciplina militar, 1596]. adj. Mil. Dicho de un soldado: que ha realizado con armas y banderas determinados actos en señal de homenaje, sumisión o respeto.

Mosquera, Comentario disciplina militar, 1596, fol. 94v: Y, no queriendo el Marqués dar oýdos a nada d'esto, salió con su campo a desbaratalles; y después de aver embiado con otras nuevas importunaciones un poco más humildes, se resolvió el Marqués, a instancia de don Pedro de Padilla, y de don Lope de Figueroa, y del conde de Lodrón y de otros cavalleros, que, rindiendo los franceses las armas y vanderas, quedando para ser 
castigados muchos franceses que de antes estavan presos en las galeaças, se les diesse embarcación a los soldados rendidos, sin entrar en este número soldado portugués.

3 [García de Palacio, Diálogos militares, 1583]. sust. Mil. Persona que se ha entregado o que ha dejado de luchar u oponerse.

García de Palacio, Diálogos militares, 1583, fol. 79v: Y Licurgo, entre sus leyes, dize y ordena que, avida y conseguida victoria de los enemigos, los persigan hasta tenella cierta y segura; hecho esto, los dexen y se buelvan, porque no tenía por digno de griegos el matar a los rendidos. // Álaba, Perfeto capitán, 1590, fol. 84v: Y porque el rendir qualquiera fuerça por el medio de una buena industria y traça assegura más la voluntad y fidelidad de los rendidos y el poco daño de los conquistadores, antes de usar de algún rompimiento y violencia procurará el capitán valerse de algunos medios que adelante se dirán. // Mosquera, Comentario disciplina militar, 1596, fol. 80r-80v: Era de su natural el Marqués afable y blando con los inferiores, y compassivo y agradable con los prisioneros y rendidos, y desseoso de reduzir a los que vía yr mal encaminados porque no creciessen sus culpas.

rendir, rendir [del lat. vg. *rĕndĕre, alteración del lat. rĕddĕre 'devolver', 'entregar', bajo el influjo del contrapuesto prendere 'tomar'. Render, Cid; rendir, h. 1325, Juan Manuel (DECH). Montes, Instrucción y regimiento, 1537]. v. tr. Restituir algo a quien lo tenía antes (DRAE: s.v. devolver).

Montes, Instrucción y regimiento, 1537, fol. IXr: Quando los franceses ganaron a Apulla, el Gran Capitán se metió en Barleta con muy poca gente española que tenía y el visorrey de Francia, con poderoso exército, venía la vuelta d'él para le assitiar dentro, en Barleta. Y embiole a dezir con un trompeta que rendiesse la ciudad y le dexasse la artillería y se fuesse, si no, que le pornía sitio.

FAM.: rendido.

ENCICL.: DUE: Devolver una cosa a alguien.

2 [Montes, Instrucción y regimiento, 1537]. v. tr. Mil. Entregar al poder o al dominio del enemigo una fortaleza, un castillo, una posición, una ciudad, un territorio, etc. Montes, Instrucción y regimiento, 1537, fol. XVIIIv: Pues, assimesmo, el alcayde que rendió un castillo, no puede ser alcayde de otro castillo si por su persona no torna a ganar el castillo que rendió. // García de Palacio, Diálogos militares, 1583, fol. 15v: Y, para que puedan, tiene el rey en muchas partes puestos presidios en las fronteras, para que las defiendan entre tanto que él acude con socorro, y quiere que no rindan las fuerças, sino que las defiendan hasta lo último de potencia. // García de Palacio, Diálogos militares, 1583, fol. 85v: La cautela y engaño es lícito con los enemigos, y, assí, al que tratare en qualquier manera de rendir y entregar su ciudad es razón hazelle mucha merced, buen tratamiento y commodidad, para que, quando otra cosa tal se offrezca, no falte quien, por 
el premio y favor que esperará, haga otros semejantes, y que en los partidos y conciertos que con él se hizieren se guarde lo assentado.

ENCICL.: Aut.: Entregar alguna cosa, sujetarla a ajeno dominio. // Moretti (1828: s.v. rendir una plaza) Entregarla al enemigo. Una plaza se entrega después de una defensa obstinada, y abiertas las brechas, etc., por falta de víveres, municiones, gente, etc.; o por efecto de traición o cobardía en los que la defienden.

3 [García de Palacio, Diálogos militares, 1583]. v. tr. Mil. Obligar a una tropa, pueblo, ciudad, fortaleza, nación, armada enemiga, etc. a que se entregue.

García de Palacio, Diálogos militares, 1583, fol. 77r: Deve también animar a sus soldados con palabras graves y amorosas, y dezirles quán honrroso es el vencer y morir por ello y quán reprovado y vergonçoso el bolver las espaldas al enemigo y dexalle en las manos la honrra, vida y hazienda y reputación de su príncipe, y traerles a la memoria hechos de sus antepassados y de historias antiguas y las obligaciones proprias, para que, pospuesto todo temor, con próspero brío, acometan y rindan a sus enemigos. // Álaba, Perfeto capitán, 1590, fol. 5v: Y Marco Catón, figurándosele que podía rendir una ciudad de España acometiéndola repentinamente y poniéndole cerco con brevedad, andando en dos días por lugares desiertos y fragosos el camino que se solía comúnmente andar en quatro, venció y rindió a los que estavan dentro. // Álaba, Perfeto capitán, 1590, fol. 35v: Y assí, lo que Mucio Scévola, uno de los soldados del campo romano, hizo, que fue salir a matar al rey Porsena, que pretendía rendir este imperio, aunque erró el golpe, hiriendo por él a otro, resultó en mucha honra de su general y provecho de Roma, pues con su atrevimiento obligó a su contrario a alçar el cerco y dexar su patria libre de molestias y peligros.

ENCICL.: Almirante (1869): Del latín reddere, compuesto de re y dare, que vale tanto como si dijéramos redar, volver a dar, dar con repetición... Notándose que quien da repetidamente vence al enemigo, pasó a significar la idea de vencimiento; pero de un vencimiento más general y más absoluto. El vencido puede quedar soberbio y rebelde. El rendido queda postrado. Catón, vencido en Utica, resiste aún, puesto que se mata. Vencida Numancia, resiste también, puesto que enciende fuego y todo arde. La plaza que se rinde, se entrega. Vencer es poder. Rendir es dominar. El que vence triunfa. El que rinde avasalla. // Estévanez (1897): Obligar al enemigo a entregarse; es más que vencerlo.

4 [Montes, Instrucción y regimiento, 1537]. v. prnl. Mil. Dicho de una persona, un pueblo, una fortaleza, etc.: entregarse al enemigo, dejar de resistir u oponerse.

Montes, Instrucción y regimiento, 1537, fol. Vv-VIr: E muchas tierras e castillos fuertes se han rendido por falta de vituallas más que por combate de los enemigos; y en esto han de mirar mucho los generales, que las fuerças que ganaren que las hagan proveer de vituallas. // Álaba, Perfeto capitán, 1590, fol. 141v: Y quando el capitán consintiere que huya, de donde vino a hazerse fuerte en alguna parte, aviendo de yr en su seguimiento para reduzirlo a que se dé y rinda, podrá usar de algunos ardides para desmayarle y acovardarle, como es darle a entender la pérdida de los hombres señalados de su exército. // Roxas, Sumario milicia, 1607, fol. 104r: Y ganada esta plaça fuerte, se le rendirán todas 
las demás que estubieren alrededor, con que dará fin a la guerra de aquella provinçia que va a conquistar.

ENCICL.: Corsini (1849: s.v. rendirse a discreción): Entregarse sin condiciones ni estipulación alguna, y contando sólo con la generosidad del vencedor. // Corsini (1849: s.v. rendirse una plaza o tropa): Entregarse una u otra, por capitulación o a discreción. // DUE: Lleva generalmente un complemento con "a" que expresa la persona o cosa que obliga o mueve a rendirse: 'Rendirse al enemigo [a la razón, a la fuerza, a la evidencia]'.

5 [Mosquera, Comentario disciplina militar, 1596]. v. tr. Mil. Refiriéndose a armas y banderas, realizar con ellas determinados actos en señal de homenaje, sumisión o respeto.

Mosquera, Comentario disciplina militar, 1596, fol. 94v: Se resolvió el Marqués, a instancia de don Pedro de Padilla, y de don Lope de Figueroa, y del conde de Lodrón y de otros cavalleros, que, rindiendo los franceses las armas y vanderas, quedando para ser castigados muchos franceses que de antes estavan presos en las galeaças, se les diesse embarcación a los soldados rendidos, sin entrar en este número soldado portugués. // Mosquera, Comentario disciplina militar, 1596, fol. 95v: Y, mirando a los cavalleros que en este auto assistían, hizo su acatamiento y passó adelante; el qual, ya apercebido de discreta prevención, poco antes que llegasse al lugar donde todos avían de rendir las armas, se despojó del cosselete que traía y lo embió al Marqués, quedando con sola la espada él y algunos mosiures. // Mosquera, Comentario disciplina militar, 1596, fol. 95v: Y, luego, los alférezes llegaron con sus vanderas inclinadas y recogidas y las rindieron y entregaron, que fueron diez y ocho de las viejas de Francia, con dos mil y dozientos hombres, por una parte $y$, por otra, treynta y seys vanderas portuguesas, con mil y ochocientos soldados.

ENCICL.: DRAE: Mil. Hacer con ciertas cosas actos de sumisión y respeto. Rendir el arma, la bandera. // Corsini (1849: s.v. rendir las armas y banderas): Honores militares que se hacen en los casos determinados por las ordenanzas del ejército.

renqüentro, $V$. reencuentro.

reparación, reparación, reparaçión [tomado del lat. reparātǐ̄o, -ōnis 'restablecimiento, renovación, reparación', de repărō. 1433 (Segura Munguía 2007). Ufano, Tratado de la Artillería, 1613]. sust. Fort. Cualquier obra o trabajo provisional que se hace tras perder alguna defensa importante, para poder seguir resistiendo. Ufano, Tratado de la Artillería, 1613, pág. 174: La faxina es muy utilíssima para hazer las reparaçiones y cubrimientos con ella y tierra a prueva de artillería sobre la rotura de las baterías y otras qualesquier partes que a su buena deffensión convenga.

SIN.: reparo3. 


\section{reparaçión, V. reparación.}

reparado, reparado [de reparar (DECH). Mendoça, Theórica y práctica, 1596]. adj. Dicho de una cosa: que se ha arreglado o dejado en buen estado.

Mendoça, Theórica y práctica, 1596, pág. 104-105: Acontece dar un assalto y descubrirse en él no sólo traveses, pero dar fuego a alguna mina o minas con que dificulte la entrada, y tener reparada la batería, de suerte que, aunque aya parecido buena, no lo es.

FAM.: reparar, reparo.

2 [Álaba, Perfeto capitán, 1590]. adj. Fort. Dicho de un lugar o de una posición: protegido con reparos o defensas.

Álaba, Perfeto capitán, 1590, fol. 75r-75v: Es necessario el que está en una ciudad o fuerça se prevenga, antes de verse cercado de los enemigos, pues tiene más comodidad de todo que el que está en campaña, de que todas las partes por donde le pueden ofender y hazer perjuyzio las tengan fortificadas, reparadas y guardadas.

SIN.: fortalecido, fortificado, fuerte $_{1}$.

3 [Álaba, Perfeto capitán, 1590]. adj. Dicho de una persona: que se ha puesto al abrigo de alguna cosa para protegerse.

Álaba, Perfeto capitán, 1590, fol. 85v: Y, aviéndose de intentar públicamente un cerco, ay necessidad de mucha consideración, porque los enemigos estarán bien reparados, especialmente en los assaltos.

reparar, reparar [tomado del lat. reparare. J. Ruiz; APal.; 1492, Woodbr. (DECH). Montes, Instrucción y regimiento, 1537]. v. tr. Arreglar algo que está roto o estropeado (DRAE).

Montes, Instrucción y regimiento, 1537, fol. XVIIIv: Por quatro maneras de batalla se puede ganar un castillo: por batalla de manos, o por batería, o por mina, o por hambre. Si se gana por mina, puédese defender por contramina; si se gana por batería, puédese defender reparando el muro por la parte de dentro, haziendo un contramuro, echando entre muro y muro muchos barriles de pólvora, [...]. // Celso, Reportorio universal leyes Castilla, 1553, fol. LXIXv: Al Rey pertenesce de guardar que las ciudades e villas no se despueblen ni cayan los muros, y le pertenesce de hazerlos reparar. // Mendoça, Theórica y práctica, 1596, pág. 101: Al anochecer, dada la postrer ruziada, cargadas las pieças, se apuntan en la manera que si se huviessen de disparar luego, para impedir que los sitiados no continúen en reparar lo batido, lo qual se haze disparando de noche cada pieça de por sí a la hora que más es conveniente.

FAM.: reparado, reparo. 
ENCICL.: DUE: tr. Dejar en buen estado un objeto que estaba roto o deteriorado; el complemento puede ser el desperfecto o el objeto: 'Reparar un coche. Reparar las goteras de un edificio'. // Fernández Mancheño (1822): También se aplica a las fortificaciones que han sido arruinadas por efecto de un sitio, explosión o terremoto, y por las vicisitudes del tiempo.

2 [Celso, Reportorio universal leyes Castilla, 1553]. v. tr. Fort. Dar protección a un lugar o posición con reparos o defensas.

Celso, Reportorio universal leyes Castilla, 1553, fol. CCVIIIv: Que las cosas de mar se defiendan y reparen, que estén seguras y bien guardadas. // Álaba, Perfeto capitán, 1590, fol. 85v-86r: Y assí, el tiempo que en semejantes conquistas se gastare se podrá llamar perdido y los medios de que se usare serán de ningún momento, guiados por fuerça y no por maña, como sería quando se pusiesse cerco a una ciudad o villa bien reparada de muros y tan proveýda de gente y de todo lo demás como lo está quien le quiere poner sitio. // Collado, Plática Artillería, 1592, fol. 56v: [...] saber hazer electión de el sitio donde cómodamente se puede plantar el artillería y ocupar con ella aquellos lugares que más aptos son para offender al enemigo y cubrir y reparar aquéllos de trincheas, reparos y cestones que cubran su artillería y la gente que trabaja acerca de ella.

SIN.: enfortalecer, fortalecer 2 , fortificar 2 .

ENCICL.: D'Wartelet (1863): Oponer, ofrecer, hacer alguna defensa.

3 [Collado, Plática Artillería, 1592]. v. prnl. Ponerse una persona al abrigo de cualquier cosa que pueda protegerla.

Collado, Plática Artillería, 1592, fol. 4r: Applicáronle los antiguos este nombre de testudine, qu'es lo mismo que galápago, por los effectos que con esta máquina se hazían, que muy semejantes a la natura de aquel animal eran, porque, assí como el galápago, cubierto de su dura concha, resiste a qualquiera golpe y lisión que le sea hecha, assimismo, los combatientes de las ciudades y fortaleças se cubrían y reparavan con esta máquina de los pesados golpes de las piedras y de los ardientes olios y inextinguibles fuegos que se echavan sobre ella. // Collado, Plática Artillería, 1592, fol. 56v: Pero el tirar y hazer los cestones toca al artillero, y como el repararse y cubrirse con los cestones sea el más presto y más conveniente reparo, del modo de hazerlos y terraplenarlos será mi razonamiento en este capítulo. // Collado, Plática Artillería, 1592, fol. 57v: Hazer, como hizo Francisco Sarmiento con aquellos valerosos soldados españoles [...] en el assedio de Castel Novo de Levante, donde 4.000 hombres solos sitiados mataron más de 30.000 turcos $\mathrm{y}$, no teniendo al último con qué repararse ni cubrirse de la artillería de los enemigos, hizieron de delante de sí un muy alto bestión de los cuerpos de los turcos muertos, de manera que no podían aquellos canes tirar bala que no diesse en los cuerpos de su gente misma.

ENCICL.: Rubió y Bellvé (1895-1901: s.v. repararse): Abrigarse detrás de un reparo o defensa; fortificarse. // López Vallejo (2008: s.v. repararse): Cubrirse, protegerse con reparos u otras fortificaciones. 
4 [Álaba, Perfeto capitán, 1590]. v. prnl. Fort. Construir, para poder seguir defendiéndose, obras de fortificación pasajeras o provisionales.

Álaba, Perfeto capitán, 1590, fol. 40v: Y el saltar es de importancia para atravessar un foso, arrojarse en alto para passar una pared o otro impedimento que se les ofrezca; y en el herir estos tales antes tienen hecho el daño que el enemigo tenga lugar de repararse. // González de Medina, Examen fortificación, 1599, pág. 159: Quanto a la población de los arrabales, tendría por el más sano consejo de todos derribarlos y ponerlo todo muy raso y meter dentro los materiales, porque no le sirvan al enemigo para repararse y fortificar, que aun una espuerta de tierra no se la dexaría, si pudiesse, porque todo le cueste trabajo y tiempo el averlo de traer para repararse. // Lechuga, Discurso de la Artillería, 1611, pág. 183: La distancia y la commodidad del puesto nos resuelve en esta duda; y assí, estando la una y la otra parte en devida distancia, se plantará la batería en aquella parte desde la qual mejor se pueda offender la muralla y que mejor se pueda estorvar a los de dentro el repararse.

reparo, reparo [de reparar. Berceo; APal.; 1492, Woodbr. (DECH). Castillo, Tratado de cuentas, 1551]. sust. Arreglo de una cosa que está rota o estropeada.

Castillo, Tratado de cuentas, 1551, fol. XXVIIIr-XXVIIIv: Puede hazer y renovar el instrumento o contracto del señor que está ya roto $(y)$, o entendiendo instrumento por qualquier edificio de casa, o fortaleza o molino que está roto o desbaratado o para caer, y a menester reparo. // Celso, Reportorio universal leyes Castilla, 1553, fol. LXIIr: Los cavalleros no son tenudos a contribuyr en los reparos de muros de las ciudades e villas do moraren con los otros vezinos. // Lechuga, Discurso de la Artillería, 1611, pág. 182: Para hazer los reparos a las baterías y contrabaterías y cerrar alguna abertura, muy a propósito se an hallado siempre los cestones.

FAM.: reparado, reparar.

ENCICL.: DUE: Trabajo hecho en una cosa para repararla.

2 [Montes, Instrucción y regimiento, 1537]. sust. u. m. en pl. Fort. Cualquier construcción que sirve para proteger un lugar o una posición de un ataque.

Montes, Instrucción y regimiento, 1537, fol. XIv: Si tuvieren nuevas de enemigos, deven fortificarse en los passos por do los enemigos vinieren a dar al exército, haziendo reparos, porque los enemigos no puedan passar adonde estuviere la gente del exército. // Álaba, Perfeto capitán, 1590, fol. 25v: Los lacedemonios nunca quisieron consentir que en su ciudad huviesse muros, cavas, fosos y otros reparos de guerra, diziendo que la defensa principal en que ellos hazían su fuerça era el valor y esfuerço de sus soldados. // González de Medina, Examen fortificación, 1599, pág. 8: Hase de mirar que media legua alrededor no aya cuesta, que son las que llaman padrastros, quando vienen a estar tan cerca que, puesta artillería en ellas, desaloxan a todos los que están en los reparos y en las estancias y plaça de armas, y que en ninguna parte están seguros. 
SIN.: defensa $a_{5}$, defensión $n_{3}$, fortificación ${ }_{3}$, muralla $_{2}$.

ENCICL.: Terr.: En la fortificación, defensa [...]. El reparo de las casas es la muralla. // Terr. (s.v. defensa): En la milicia, reparo, todo aquello que sirve para conservar los soldados y plazas [...]. V. Fuertes, baluartes, etc.

3 [Álaba, Perfeto capitán, 1590]. sust. Fort. Cualquier obra o trabajo provisional que se hace tras perder alguna defensa importante, para poder seguir resistiendo.

s (fig. 134)

Álaba, Perfeto capitán, 1590, fol. 87r-88v: Y aviendo puesto libremente y sin contraste alguno de enemigos la artillería en el puesto que se pretendía, començarse a a batir con buenos cañones que arrojen pelota de sesenta libras, usando de pelota de hierro para tirar al muro, baluarte o cavallero, por ser de materia más dura, y de plomo para trincheas, cestones, sacos y reparos, que son de materia menos maciça y dura. // Collado, Plática Artillería, 1592, fol. 96r: En los lugares dichos y en aquéllos donde, por ser estrechos los terraplenos, no gozan comodidad y aparejo de hazer retiradas ni otros convenientes reparos los sitiados, contra los tales se deve de plantar la batería, si algún particular impedimento no lo estorva. / González de Medina, Examen fortificación, 1599, pág. 25-26: Puédese, batido el ángulo, hazer muy buen reparo y cortaduras con traveses y foso, de manera que esté tan dificultoso de perderse como antes de perdido el ángulo, si es grande y capaz.

SIN.: reparación.

ENCICL.: Almirante (1869: s.v. repararse): [...] [Reparo] antes era voz técnica de fortificación pasajera, como atrincheramiento, obra del momento o de campaña, barricada, albarrada.

representar, V. (la) batalla.

reseña, reseña [de seña y éste del lat. š̆gna. s. XVI, Ant. Agustín; Covarr.; "la muestra que se hace de la gente de guerra" Aut. (DECH). Montes, Instrucción y regimiento, 1537]. sust. Mil. Revista o inspección de una tropa o fuerza para comprobar su estado.

Montes, Instrucción y regimiento, 1537, fol. IVv: Y en el hazer de la gente, tenga el capitán especial cuydado de dar los officios a personas que los merezcan tener, que sea solícitos y diligentes, y tales que de noche y de día estén desvelados en cómo podrán mejor servir a su rey, dando orden en la gente de la compañía, y que estén proveýdos de las armas que les fueren dadas en el tiempo de la reseña, porque no les falte al tiempo del pelear. // Álaba, Perfeto capitán, 1590, fol. 90v: Y para yr a la empresa, publique que quiere hazer reseña general de su gente y de todos juntos escojerá los más importantes y suficientes para ella. / / Álaba, Perfeto capitán, 1590, fol. 151r: Conqueridor era el que estava presente a las muestras y reseñas de los soldados. 
SIN.: alarde, muestra.

FAM.: contraseña, contraseño.

ENCICL.: Cov.: La muestra que se hace de la gente de guerra. Lat. recensio (de donde pudo tomar el nombre) à recensendo, porque se cuenta y mira el número que hay de soldados, el talle y brío y cómo van armados. O se dijo reseña porque segunda vez se enseñan y muestran los tales soldados al general, después de la primera elección que de ellos han hecho sus capitanes.

resestir, $V$. resistir.

resistencia, resistencia, resistençia, resistentia [tomado del lat. rěsistentĭa, -ae 'íd.', de rěsistens, ppr. de rěsistō. h. 1525 (Segura Munguía 2007). Montes, Instrucción y regimiento, 1537]. sust. Mil. Acción de resistir u oponerse a la persona o cosa que ataca, para no someterse a ella sin lucha.

Montes, Instrucción y regimiento, 1537, fol. XIv: Y en esto se ha de mirar y desvelar cómo y de qué manera y por qué vía, y a qué hora, y con quánta gente se dará el salto a los enemigos, e si al tiempo que se diere se podrá haver vitoria, y qué tanta gente podrá haver para la resistencia. // Martínez de Burgos, Reportorio premáticas y Cortes, 1551, fol. XXXIIIv-XXXIVr: Y nos plaze de convertir y gastar el dicho servicio (que estos nuestros reynos nos hazen) solamente en la guarda y defensa d'ellos y resistencia de los enemigos, si contra ellos vinieren, y no en otra necessidad particular nuestra ni de ninguno de los otros nuestros reynos y servicios. // Mosquera, Comentario disciplina militar, 1596, fol. 71r: Tenían los enemigos ocho pieças de artillería en el campo con que hazían daño en los nuestros [...], que al parecer davan muestras de querer cerrar, pero en esto siempre detenían la rienda, y quando los nuestros se disponían a la resistencia luego se retiravan por la experiencia que tienen de la conocida ventaja que los españoles hazen en esta suerte de batalla con las espadas desnudas.

ENCICL.: Terr.: En la milicia y en otros usos de la vida, acción con que uno se defiende y opone a quien le acomete.

2 [García de Palacio, Instrución náuthica, 1587]. sust. Mil. Capacidad de alguien para oponerse o combatir con la persona o cosa que le ataca.

García de Palacio, Instrución náuthica, 1587, fol. 124v: Reconoscida la nao que se quisiere acometer, debe el capitán considerar la fuerça, cantidad de gente, que pueda tener, de dónde y de qué naciones, qué trato tiene y qué vusca para que, entendiendo por esto la resistencia que en ella pueda hallar, ordene lo que convenga para conseguir victoria. // Álaba, Perfeto capitán, 1590, fol. 133v: Aunque otros son de parecer que éstos se pongan en la parte que huviere de pelear con la más flaca del enemigo, como lo hizo Filipo, rey de Macedonia, yendo contra los isirios, poniendo los más valientes en el cuerpo derecho, porque vio estar en el siniestro del enemigo los de poca resistencia. // Ufano, Tratado de la 
Artillería, 1613, pág. 107: Y, marchando d'esta manera, si el enemigo cargare la retaguardia del exército, la hallará fuerte y quasi de ygual resistençia que la banguardia, si acaso la acometiese, y muy más fuerte la batalla y más cumplida de gente y artillería.

\section{resistençia, $V$. resistencia.}

resistentia, V. resistencia.

resistir, resestir, resistir [tomado del lat. resistĕre 'íd.'. Registir, h. 1440, Pero Tafur, y algo más tarde en Gómez Manrique; resistir, Corbacho, APal. (DECH). Celso, Reportorio universal leyes Castilla, 1553]. v. intr. Mil. Luchar alguien con la persona o cosa que le ataca y no someterse a ella sin lucha (DUE).

Celso, Reportorio universal leyes Castilla, 1553, fol. CLXXIIIv: Si de noche dieron bozes de algún mesón, que matavan a un huésped, y, viniendo algunos a ayudar al que matavan, otros resistiessen con armas para que no podiessen ayudar al que matavan, o diéronles escala o lugar a los que lo mataron para que se fuessen o escapassen, si no se provare que los susodichos fuessen en hazer el homezillo, no caen en pena de homezillo, aunque se prueve contra ellos lo que es dicho. / / García de Palacio, Diálogos militares, 1583, fol. 76r: Y a imitación d'esto, César, viendo que los picardos y flamencos estavan tan poderosos contra él que buenamente no les podía resistir, trató con los borgoñones, que eran amigos, que entrassen a correrles sus tierras, a cuya causa fueron forçados a dividir su campo, y, con esto, pudo César pelear con commodidad. // Álaba, Perfeto capitán, 1590, fol. 40v: Y estos exercicios será de importancia que el soldado los haga armado, porque el peso de las armas le haga más alentado y se acostumbre a sufrirlo para los tiempos que fuere forçoso durar mucho armado resistiendo al enemigo.

ENCICL.: DUE: ("a") intr. Luchar alguien con la persona o cosa que le ataca y no someterse a ella sin lucha: 'Resistir al invasor [al tirano, al desánimo, al sueño]'. // Estévanez (1897): Dar frente al enemigo, haciendo lo posible por rechazarlo.

retaguarda, retaguarda [del cat. reraguarda (formado con rera 'tras', del lat. retro). Covarr.; Oudin y Aut. (DECH). García de Palacio, Diálogos militares, 1583]. sust. Mil. Parte de una fuerza armada que en una marcha, ataque, etc., va detrás.

García de Palacio, Diálogos militares, 1583, fol. 146r: En cayendo, pues, alguno de los de la primera hilera, entrava luego el que estava detrás d'él, en la segunda, y el de la tercera, en la segunda; el de la quarta, en la tercera. Y, assí, con mucha presteza se rehazían todas las órdenes, consumiéndose y cevando solamente de la retaguarda, que todas las otras siempre avían de estar enteras y pelear ordinaria y ordenadamente, de manera que antes eran consumidas, que rotas ni desbaratadas.

SIN.: retaguardia, rezaga. 
ANT.: avanguarda, avanguardia, vanguarda, vanguardia.

FAM.: retaguardia.

ENCICL.: Cov.: El escuadrón postrero.

retaguardia, rectaguardia, retaguardia [del cat. reraguarda (formado con rera 'tras', del lat. retro), modificado luego bajo el influjo del it. retroguardia. 1590, Juan de Castellanos, Hist. N. Granada; Oudin y Aut. (DECH). Montes, Instrucción y regimiento, 1537]. sust. Mil. Parte de una fuerza armada que en una marcha, ataque, etc., va detrás.

Montes, Instrucción y regimiento, 1537, fol. Xr: Quando el exército començare a marchar la buelta adonde están los enemigos, han de echar de banguardia la gente más plática en la guerra y, tras aquélla, vaya el cuerpo de la batalla, y luego la artillería, y de retaguardia vaya la gente que no es tan plática [...]. Mas si conosciere que los enemigos estuvieren más pujantes que no ellos y se quisieren retirar, echen la gente más plática de retaguardia y la que no es tan plática vaya de banguardia con la artillería. // García de Palacio, Diálogos militares, 1583, fol. 162v: Y si por caso la batalla quedase más ancha que prolongada, deve hazerse del cuerpo derecho avanguardia y del yzquierdo, rectaguardia, bolviendo la cara a la frente que quieren hazer, guardando el compás de las órdenes, como queda dicho. // Álaba, Perfeto capitán, 1590, fol. 43r-43v: Y el lugar del vagaje será considerando el puesto que tiene el enemigo respeto del esquadrón, de manera que, si el enemigo está delante, el vagaje vaya en la retaguardia, y al contrario; y si está en la mano derecha, vaya en la siniestra, y al trocado.

SIN.: retaguarda, rezaga.

ANT.: avanguarda, avanguardia, vanguarda, vanguardia.

FAM.: retaguarda.

ENCICL.: Terr.: Término de la milicia [...]. Es aquella parte del ejército que está colocada o marcha en el último lugar. // DSAL: Mil. Parte de un ejército que se mantiene o avanza en último lugar. Ant. vanguardia.

en [Álaba, Perfeto capitán, 1590]. loc. adv. En cualquier acción, en última posición o detrás de todos los demás.

Álaba, Perfeto capitán, 1590, fol. 60v: Y assí, dexando poca gente de guarnición en la ribera, se subió a un monte muy alto con todo lo demás que restava del campo y, atribuyendo los tebanos esta subida a temor y covardía, caminaron tras ellos $\mathrm{y}$, haziendo huir los que quedaron en retaguardia, muy confiados de la vitoria, acometiendo a los demás que estavan en lo alto, hallaron tanta resistencia en ellos, por la dificultad de la subida y passos ásperos, que salieron vencidos de los lacedemonios. // Roxas, Sumario milicia, 1607, fol. 67v: Ase de entender que si el enemigo quedare en retaguardia, a de yr el bagaje en la 
abanguardia y el artillería en la retaguardia. // Ufano, Tratado de la Artillería, 1613, pág. 107-108: Y si marchase el exérçito, asimismo, en solo un cuerpo, marcharía el artillería del modo preferido en abanguardia y retaguardia.

SIN.: en rezaga.

ANT.: a la avanguardia, en avanguardia, en vanguardia.

retaguardia, $V$. en $\sim$.

retirada, retirada [de retirar. Quijote (DECH). Álaba, Perfeto capitán, 1590]. sust. Mil. Acción de abandonar el campo de batalla, alejándose del enemigo.

Álaba, Perfeto capitán, 1590, fol. 79r-79v: Y advierta en estas retiradas el capitán no caya en el error en que muchos han caýdo, que, por no poder llevar la artillería con secreto, dexan de retirarse, teniendo por menos daño el aventurar su exército que el dexarla. // Mendoça, Theórica y práctica, 1596, pág. 108: Se entiende lo primero en retirar la artillería y municiones, encaminándola, y el bagaje, según las nuevas que se tienen del enemigo; y esto, dexando reforçada la retaguardia, para que, si los cercados salen a cargarlos, impedírselo, y de manera que no se desaloge con confusión y desorden, pareciendo huyda la retirada. // Roxas, Sumario milicia, 1607, fol. 40v: También se a de procurar que los enemigos no sientan la retirada porque no carguen de golpe; y por esto es bien poner delante la cavallería para que desbelen al enemigo y, venida la noche, se pueda retirar con gran horden, saviendo ya los caminos y pasos peligrosos por donde an de yr.

FAM.: retirar.

ENCICL.: Aut.: En la milicia, la acción de apartarse o excusar el encuentro con el enemigo, con arte, reflexión y estudio. // D'Wartelet (1863): La marcha retrógrada, pero ordenada, que ejecuta una tropa en dirección opuesta al enemigo, con el cual ha tenido un combate desgraciado o rehusa tenerlo. Muy difícil es hacer una buena retirada, pues las mismas tropas suelen causar dificultades, que, añadidas a los obstáculos del terreno y a los frecuentes y repetidos ataques de un enemigo animado por las ventajas conseguidas, dan gran nombre al general o jefe que cede el terreno con orden y tranquilidad, sin perder más gente y material de guerra que el puramente indispensable.

2 [Collado, Plática Artillería, 1592]. sust. Fort. Nueva construcción defensiva consistente normalmente en un parapeto con cañoneras y merlones y, algunas veces, con foso, que suelen hacer los sitiados en los baluartes batidos para impedir que sus enemigos se alojen en la brecha o accedan a la plaza a través de ella.

Collado, Plática Artillería, 1592, fol. 96r: En los lugares dichos y en aquéllos donde, por ser estrechos los terraplenos, no gozan comodidad y aparejo de hazer retiradas ni otros convenientes reparos los sitiados, contra los tales se deve de plantar la batería, si algún particular impedimento no lo estorva. // Rojas, Teórica fortificación, 1598, fol. 106r: Y 
porque el enemigo podría tener hechas algunas retiradas y medias lunas, se advertirá de no entrar por mitad de la media luna, porque desde sus cuernos darán por las espaldas a los amigos, y assí se procurará yr arrimándose a los estremos y puntas de la media luna, procurando siempre de yr cubiertos y bien atrincheados. // González de Medina, Examen fortificación, 1599, pág. 201-202: Aviendo el enemigo cortado el ángulo del baluarte, sería forçoso hazer retirada, que se ha de mirar mucho que sea segura, no se cayga luego, que es muy fácil. Ha de tener su foso del largo de lo batido, que tenga de ancho diez y seis o diez y ocho pies, bien hondo.

SIN.: cortadura 2 .

ENCICL.: Sanz (1749: s.v. retirada o cortadura): Es un retrincheramiento que ordinariamente se hace en las dos caras de uno o algunos baluartes formando un ángulo entrante, disponiéndolo en el cuerpo de una obra de tal modo, que se puede disputar el terreno de pie a pie, cuando las primeras defensas están ya destruidas. Algunas veces se hacen con foso guarnecido de un parapeto, y otras veces la retirada no es más que un parapeto de fajinas cargadas de tierra, de cestones o sacos a tierra, con un foso o sin él, con palizadas o sin ellas.

retirar, retirar [de tirar y éste de origen incierto. 1570, C. de las Casas; ya frecuente en el Quijote (DECH). Mosquera, Comentario disciplina militar, 1596]. v. tr. Mil. Hacer retroceder al enemigo que ataca (DUE: s.v. rechazar).

Mosquera, Comentario disciplina militar, 1596, fol. 82r: Y a todo esto, el exército español se fue mejorando y començaron a marchar sus esquadrones y las mangas, que yvan adelante, a dar cargas en los contrarios con tanta priessa y furia que fueron retirando a los enemigos a buen passo.

SIN.: hacer retirar, rebatir, rebotar, rechazar.

FAM.: retirada.

ENCICL.: Rubió y Bellvé (1895-1901): Rechazar, obligar a uno a que se retire.

2 [Montes, Instrucción y regimiento, 1537]. v. prnl. Irse a un lugar para protegerse o para ponerse a salvo.

Montes, Instrucción y regimiento, 1537, fol. Xr: Y si la noche lo tomasse antes que la batalla sea rota, retírense en parte donde su campo esté fortificado y no pueda recebir daño de los enemigos. // Álaba, Perfeto capitán, 1590, fol. 142r: Y Domicio Córbulo, teniendo cercados los armenios que, huyendo, se retiraron en Certa, cortando la cabeça a uno de los magesanos que tenían cautivos, con un ballestón la arrojó en los reales de sus enemigos, con cuya vista desmayando ellos, se vinieron a rendir y sujetar. // Mosquera, Comentario disciplina militar, 1596, fol. 83v: Viose tan necessitado Mosiur de Chatres que se retiró a la montaña de nuestra Señora de Guadalupe, donde le avía informado Manuel de Silva que 
avía un lugar fuerte en que poder entretenerse hasta que llegasse el invierno y a la armada del Rey Católico le fuesse forçoso partirse.

3 [Montes, Instrucción y regimiento, 1537]. v. prnl. Mil. Abandonar un ejército o alguien que lucha el campo de batalla.

Montes, Instrucción y regimiento, 1537, fol. Vv: Mas en el proveer de la vitualla tenga el general tal instinto que en tiempo de la mayor necessidad no falte, porque sería al exército gran falta. Porque muchas vezes se ha visto retirarse los exércitos, toviendo vitoria conoscida contra sus enemigos, por falta de la vitualla. // Álaba, Perfeto capitán, 1590, fol. 78v: Aviendo de retirarse antes de entrar en batalla el capitán, por reconocer grandes ventajas en su enemigo, a menester tener algunos preceptos generales de que poderse valer para no desanimar su gente, porque el que antes de començar a pelear se retira acovarda su campo y anima el del contrario. // Roxas, Sumario milicia, 1607, fol. 12v: Todos los soldados, sin que quede ninguno, combiene se enseñen a nadar en los messes del estío, porque no siempre se pasan los ríos por puentes, y muchas vezes el exérçito, o retirándose o yendo en alcanze, es fuerça que pasen nadando, espeçial si ay arroyos que ayan salido de madre con llubias o nubes.

ENCICL.: Sanz (1749: s.v. retirarse, volver la espalda, recular, plegar): Es empezar a abandonar los puestos en una acción. Una ala de ejército que empieza a desmayar y a retirarse necesita de un pronto refuerzo y de un general vigilante que, por medio del socorro y su presencia, les estimula a hacer su deber. Sin lo cual, la derrota de una parte del ejército suele ser causa de la otra.

hacer [García de Palacio, Instrución náuthica, 1587]. loc. v. Mil. Hacer retroceder al enemigo que ataca (DUE: s.v. rechazar).

García de Palacio, Instrución náuthica, 1587, fol. 128r: Que se aprovechen de los montantes, rodelas y partesanas; lo harán hasta hazer retirar al enemigo o, si vieren occasión, vencello. // Álaba, Perfeto capitán, 1590, fol. 59v: Las tres condiciones que pedía Agesilao a un bueno y perfeto capitán, que son: osadía contra los enemigos, benevolencia con los súbditos, buena razón y discurso para considerar la oportunidad del lugar y tiempo, hallo ser principalmente necessarias para vencer o hazer retirar con poco número de gente otro que sea muy mayor. // Mosquera, Comentario disciplina militar, 1596, fol. 109r: Nuestra gente marchava a buen passo, y cargando sobre el enemigo le hizo retirar; aunque guardando a ratos buen orden, se bolvían a los nuestros con ánimo y escaramuçavan hasta que se recogieron a dos montañuelas que están sobre la fortaleza principal, nombradas las montañas de la Señora.

SIN.: rebatir, rebotar, rechazar, retirar 1 .

ENCICL.: Terr. (s.v. hacer retirar): Rechazar.

revatir, V. rebatir. 
revelado, V. rebelado.

revelar, V. rebelar.

revelde, $V$. rebelde.

revelín, V. revellín.

revellín, rebelín, rebellín, revelín, revellín [del cat. rivellí, donde se trata de un italianismo (de rivellino) (Colón 2008: 118-120). Collado, Plática Artillería, 1592]. sust. Fort. Obra de fortificación exterior, normalmente situada delante de alguna cortina, compuesta de dos frentes o caras que forman un ángulo saliente hacia la campaña. (fig. 135)

Collado, Plática Artillería, 1592, fol. 65r: Lo qual siempre se remite al parescer y discreción de el operante, porque si en la muralla de una cortina delgada quiere hazer un hornillo de dos o tres varas de ancho, cosa cierta es que ha de rebentar por el un lado o por el otro; pero debaxo de un torreón, o de un revellín, o de un orejón, que son edificios maciços, pueden de la medida dicha, y aun de otra mayor, ser formados los hornos. // González de Medina, Examen fortificación, 1599, pág. 107: Harásele en medio de la cortina que mira a la mar un rebellín para poder limpiar desde él la cortina, porque sale muy larga y no tiene otra parte de donde la limpiar; y hase de hazer el rebellín de manera que desde la cortina, por la una parte y por la otra, se pueda limpiar, y en tal ocasión como ésta no es malo el rebellín, como se ha dicho // Lechuga, Discurso de la Artillería, 1611, pág. 268: Saque de esto el alcaide, castellano o governador quán provechoso le será tener, en tiempo de sitio, personas práticas en minas y en hornillos, pues con la campaña, revellines y fortificaciones que hiziere en ella podrá servirse de ellas, como en las murallas.

ENCICL.: Lorenzo Celorrio (1996): Obra de fortificación situada en el exterior del recinto amurallado que protege una entrada o una cortina. La parte que se ofrece al enemigo es la arista de dos lienzos que se juntan en forma de flecha, mientras que la parte que da a la fortaleza puede variar en sus formas. // Lucuze (1772: 43-44): "El rebellín delante de la cortina es obra importante a la defensa de cualquier frente fortificado, porque cubre los flancos, obligando al sitiador a que establezca sus baterías sobre el parapeto del camino cubierto para arruinarlos. Puede ser sencillo, con flancos y doble o cortado. El sencillo, o sin flancos, consiste en un ángulo saliente algo agudo, para que sus lados o caras sean bien defendidas por las de los baluartes. La gola se forma por la contraescarpa, en cuya altura tiene su plano el revellín [...]. Delante de las caras se hace un foso, que se comunica con el de la plaza [...]. El revellín con flancos es semejante a un baluarte, y sólo se distingue del antecedente en que los pequeños flancos tienen mejor disposición para defender el camino cubierto. El revellín doble o cortado consiste en poner en la gola un pequeño revellín o 
reducto con su foso por delante, que sirve de cortadura, para que el sitiador no se haga dueño del todo y se halle incómodo en su alojamiento cuando haya montado la brecha".

2 [Rojas, Teórica fortificación, 1598]. sust. Fort. Cada uno de los espacios más amplios establecidos en una estrada cubierta, que sirven de lugar de reunión a las tropas que participan en su defensa. 5 (fig. 136)

Rojas, Teórica fortificación, 1598, fol. 31v: K. Plaça o rebellín de la estrada cubierta. // Rojas, Teórica fortificación, 1598, fol. 39r: M Rebellín de la estrada cubierta. 100 pies. // Rojas, Teórica fortificación, 1598, fol. 41r: Y assí, iré derechamente haziendo las plaças lisas, con los fiancos o travesses necessarios, huyendo de la mucha costa y daño que causan los muchos ángulos y rebellines, todo lo qual daré mejor a entender adelante, quando fortifique y trate de sitios irregulares y trapezias.

SIN.: $p l a z a_{4}$.

revolber, V. revolver.

revolver, rebolber, rebolver, revolber, revolver [del lat. rĕvŏlvō, -ěre 'volver hacia atrás', 'retroceder rodando', 'revolver', de re y vŏlvō. 1220-50 (Segura Munguía 2007). Montes, Instrucción y regimiento, 1537]. v. intr. Mil. Tras haber huido del enemigo, volverse hacia él para atacarlo o para hacerle por fin frente.

Montes, Instrucción y regimiento, 1537, fol. XVIv: Como los enemigos sean rotos, sigan la vitoria y no se occupen en robar el campo, porque podrían rebolver los enemigos sobre ellos y donde eran vencedores quedar vencidos. // Álaba, Perfeto capitán, 1590, fol. 71r: Reconociendo su campo y fingiendo averse acovardado de su gran poder y número de gente, mostrando ponerse en huyda, se subió a un lugar muy alto, con la qual muestra de covardía, encarniçados en su seguimiento los enemigos, yendo en su alcance sin orden ni concierto, apartados unos de otros, rebolvió sobre ellos y los que antes no se atreviera esperar, venció y sujetó acometiéndolos con este ardid. // Álaba, Perfeto capitán, 1590, fol. 71r-71v: Y los egypcios, aviendo de combatir en unos campos de muchas lagunas y atolladeros, cubriéndolos de ovas, luego que se començó la batalla fingieron huyr, y huyendo, como gente que conocía la tierra, por partes seguras, metieron a los que en su seguimiento venían por aquellas lagunas y pantanos y, rebolviendo sobre ellos, salieron vencedores.

ENCICL.: Stevens (1706: s.v. rebolver sobre los enemigos): To rally, and turn back upon the enemy. // Almirante (1869): Excelente verbo para expresar en táctica lo que suele decirse reacción ofensiva, traduciendo el retour offensif de los franceses: la acción de volver caras, de hacer frente al enemigo victorioso que persigue.

2 [Álaba, Perfeto capitán, 1590]. v. prnl. Mil. Enfrentarse dos o más personas utilizando la fuerza o las armas para vencer al otro. 
Álaba, Perfeto capitán, 1590, fol. 85r-85v: Y si la villa o ciudad estuviere dividida en vandos y faciones [...], acudirse a a una de las parcialidades, tentando con recato, si a trueco de ver fuera del lugar la gente del vando contrario, querrán dar alguna entrada para la ciudad o, no siendo parte para esto, ocupando los mejores puestos, querrán rebolverse con sus contrarios, de suerte que, acudiendo por la parte de fuera a batir la muralla y dar el assalto, pueda darse sin dificultad y la entrada y resistencia se faciliten. // Mosquera, Comentario disciplina militar, 1596, fol. 23r: Que todos vayan en paz y concordia y no se rebuelvan unos con otros, ni causen rumor ni alteración, que es de gran inconveniente. // Ufano, Tratado de la Artillería, 1613, pág. 118: Pero, volviendo a lo que Vuestra Señoría dize de alojar el artillería a los costados, no es bien, porque en rebolviéndose los unos con los otros esquadrones, jugando las pieças, dañifficarían más a los propios amigos que a los contrarios.

SIN.: batir ${ }_{3}$, combatir 1 , lidiar, luchar, ${ }_{2}$ pelear.

ENCICL.: DRAE: prnl. Enfrentarse a alguien o algo. Se revolvió contra mí.

rezaga, reçaga [de zaga y éste del ár. sâqa 'retaguardia de un ejército'. 1300 (DECH). Montes, Instrucción y regimiento, 1537]. sust. Mil. Parte de una fuerza armada que en una marcha, ataque, etc., va detrás.

Montes, Instrucción y regimiento, 1537, fol. XIVr: Y estas mangas sean los más arcabuzeros, porque éstos hazen mucho daño en los enemigos. Y los arcabuzeros vayan adelante y en torno del escuadrón por las dos alas, y si los enemigos fueren muchos, pongan arcabuzería en la reçaga, porque el esquadrón vaya fortificado por todas partes. // Celso, Reportorio universal leyes Castilla, 1553, fol. CXXXVIv: Y, en llegando cerca de algún lugar de sus enemigos, deven hazer estar la delantera, hasta que llegue tanta gente de cavalleros y infantería que puedan guardar el rastro hasta que llegue la reçaga.

SIN.: retaguarda, retaguardia.

ANT.: avanguarda, avanguardia, vanguarda, vanguardia.

ENCICL.: Terr.: En la milicia, lo mismo que retaguardia.

en [Montes, Instrucción y regimiento, 1537]. loc. adv. En cualquier acción, en última posición o detrás de todos los demás.

Montes, Instrucción y regimiento, 1537, fol. Vr: Y vayan los arcabuzeros delante, y tras ellos los soldados de cosseletes, y en la tercera hilera de los cosseletes vaya la bandera, y tras los cosseletes, vayan los soldados de pica seca, y en reçaga vayan algunas hileras de cosseletes, porque va la compañía muy más honrada, y más vistosa y en mejor orden si hoviesse necessidad.

SIN.: en retaguardia. 
ANT.: a la avanguardia, en avanguardia, en vanguardia.

rezaga, $V$. en $\sim$.

riça, V. riza.

riza, riça, riza [alteración de triza, en virtud de una etimología popular que lo relacionó secundariamente con el antiguo enrizar 'irritar o azuzar'. Riza 'estrago, destrozo' (DECH). García de Palacio, Diálogos militares, 1583]. sust. Mil. Gran matanza o mortandad que resulta de una acción de guerra.

Álaba, Perfeto capitán, 1590, fol. 59r: Como lo hizieron César y Ariovisto [...], que, aviendo señalado día y lugar para hablarse, concertaron que el verse fuesse trayendo cada qual hasta cierta cantidad de hombres de a cavallo sin otra defensa alguna [...]; y la distancia que d'estos soldados [de César] a los que escogió Ariovisto huvo fue de dozientos passos [...], temiendo el peligro y daño que de juntarse más podía aver; $y$, con todo esso, le huviera, por averse descompuesto los alemanes con los franceses, si César no lo atajara, pareciéndole no ser vitoria honrosa la que allí podía alcançar, por la ocasión que dava de que se juzgasse averlos juntado fiados en su palabra para sólo hazer riza y estrago en ellos. // Álaba, Perfeto capitán, 1590, fol. 67v: Ni los infantes podrán hazer la riza y estrago que en los enemigos cada día hazen sin el favor de los de a cavallo, ni éstos saldrían bien de los hechos que emprenden sin el socorro de los de a pie. // González de Medina, Examen fortificación, 1599, pág. 189: Y [el medio cañón] servirá también para deshazer los reparos y máquinas que entraren en el foso, como el cañón, y limpiará, assimesmo, la frente del baluarte; y un tiro pedrero, para quando vinieren al assalto, cargado con dados de hierro y cadenas y con guijarros, hará una gran riça en el enemigo.

roca, roca, rocha [voz tardía en cast. y port., sin duda tomada del cat. o el oc. y de origen incierto, seguramente prerromano. Primer cuarto del s. XIV; APal. (DECH). Poça, Hydrografía, 1585]. sust. Fort. ant. En una fortaleza medieval, la torre más destacada, fuerte e importante, con elementos defensivos propios que le permitían, en caso de necesidad, independizarse del resto de las fortificaciones del recinto. Poça, Hydrografía, 1585, fol. 9v: Si quisieres entrar en Cádiz con Poniente, vete al Este quarta del Sueste, que assí yaze la baýa, vete acerca de la gran roca que es descubierta, a un ajuste de la qual al pie d'ella ay siete braças. Dexarás la baýa de media proa de ababor, y no apremies la tierra hasta que descubras la siniestra de la torre de omenage, y después, cierra con la tierra y posa en las cinco o seys braças. // González de Medina, Examen fortificación, 1599, pág. 17: Dezidme, maestro, ¿cómo no os avéys acordado de poner en lo que avéys nombrado rebellines, cavalleros ni torre de homenage o roca, como la llaman otros, pues es tenida por muy buena manera de fortificación y muy fuerte? // González de Medina, Examen fortificación, 1599, pág. 20: La roca que dezís, o torre del homenage, en el centro de la plaça de armas por ningún caso se ha de tratar de que la aya, porque es a lo 
antiguo y de quando se combatía con piedras, y mala manera de fortificar, porque [...] ella embaraça la plaça de armas y la ocupa, y quita que no se pueda hazer muy buen esquadrón.

SIN.: roca de homenaje, torre de(l) homenaje.

ENCICL.: Mora-Figueroa (2006): Sinónimo genérico de castillo o de torre-refugio de época temprana en algunas zonas del Mediterráneo noroccidental como Cataluña y Provenza, o en diversas regiones itálicas en las que eran denominadas "rocae castrorum" en el siglo X.

de homenaje [González de Medina, Examen fortificación, 1599]. cmpt. sintag. Fort. ant. En una fortaleza medieval, la torre más destacada, fuerte e importante, con elementos defensivos propios que le permitían, en caso de necesidad, independizarse del resto de las fortificaciones del recinto.

González de Medina, Examen fortificación, 1599, pág. 17: No he dexado de poner y nombrar los rebellines, cavalleros y rocas de homenage por no me aver acordado d'ellos, sino por no tenerlos por tan buena fortificación como de los demás miembros que he nombrado.

SIN.: roca, torre de(l) homenaje.

rocha, V. roca.

rodapié, rodapié [cmpt. de rodar y pie. Lobato, Notas, a. 1585]. sust. Constr. En un cimiento, partes laterales de su grosor cuando éstas exceden la anchura del muro que se levanta sobre él (Paniagua Soto 1998: s.v. zarpa).

Lobato, Notas, a. 1585, fol. 31: Allí, al fin de la vuelta escondido, se había de hacer una pared de ladrillo con grande rodapié en talud, y de ésta ha de empezar la pesquera al hilo del agua ganando el corriente por aquel llano que está enfrente, que fuese a salir el cauce a donde salía el de Carreño. // Rojas, Teórica fortificación, 1598, fol. 97r: Y si se ofreciere hazer la fábrica en alguna ladera o cuesta arriba, se procurará que las murallas de la parte de abaxo de la cuesta sean más gruessas que las de la parte de arriba, y que corra su nivel hazia la cuesta, dexando por la parte baxa gran banqueta o rodapié a la muralla, de suerte que no sea bastante todo el peso del edificio a cascar ni hender las murallas de la parte de abaxo.

SIN.: banqueta 4 .

ENCICL.: Lucuze (1772: 26): "Toda obra de mampostería, como el muro y estribos, requiere firme cimiento, que se profunda más o menos según el terreno; pero se hace de mayor latitud, para dejar a cada lado el rodapié con que se aseguran más el cimiento, muro y estribo". 
romper, romper [del lat. rŭmpĕre 'íd.'. Cid (DECH). Montes, Instrucción y regimiento, 1537]. v. tr. Mil. En un combate u otro tipo de enfrentamiento, desordenar o dividir al adversario atravesando o penetrando su orden de batalla.

Montes, Instrucción y regimiento, 1537, fol. $\mathrm{Xv}_{\mathrm{v}}$ : Y esto se haze quando son los enemigos muchos, porque el esquadrón vaya más fortificado, y no puede ser roto por ninguna parte que le acometan. // Montes, Instrucción y regimiento, 1537, fol. XIv: E si la batalla fuere de noche, no se salgan de su fuerte, porque podrían tener algunas embuscadas que los rompiesen, mas deven guardar su fuerte, porque de una manera han de pelear los que son acometidos y de otra manera han de pelear los que van a acometer. // Roxas, Sumario milicia, 1607, fol. 69v-70r: Sólo buelbo a adbertir que quando se ofresca la ocasión de recevir al enemigo, que se aprieten y junten las picas, como haçían los macedones, para que no sean rompidos.

FAM.: rompimiento.

ENCICL.: Terr.: Romper un escuadrón, ejército, desbaratarlo, deshacerlo, dividirlo, discontinuarlo entrando por medio de los soldados. // Corsini (1849): Penetrar un cuerpo de tropas en una línea enemiga, abriéndose en ella paso. // D'Wartelet (1863): Penetrar un cuerpo de tropas en una línea enemiga, introduciendo la confusión y el desorden precursores de la dispersión y de la fuga.

rompimiento, rompimiento [de romper. "Ruptura" Nebr. (DECH). García de Palacio, Diálogos militares, 1583]. sust. Mil. Acción de desordenar o dividir al enemigo atravesando o penetrando su orden de batalla.

García de Palacio, Diálogos militares, 1583, fol. 181v-182r: Todo infante toma la orden de su caminar del que marcha delante y los infantes que se hallaren en aquella mesma hilera deven, viendo al compañero que va delante caýdo, passar a su lugar, apresurado su movimiento, y el otro, al otro, de forma que la falta o vazío quede en la rectaguardia [...]. Y, assí, podrán evitar los rompimientos y desbarates que se podrían seguir del dexallos en la frente. // Álaba, Perfeto capitán, 1590, fol. 42r-42v: El peligro que ay al tiempo que se llega a las manos con los enemigos no es tan grande como el que tienen caminando, a causa de que, estando presente el rompimiento de la batalla, los soldados, viendo cerca la gente con quien han de pelear, llevan el ánimo dispuesto para resistir a qualquier ímpetu furioso, mas marchando, siendo el acometimiento repentino, turba los sentidos y pone horror y espanto la vista y golpes de los contrarios. / / Ufano, Tratado de la Artillería, 1613, pág. 117: GENERAL. - ¿Sería bueno, Señor Capitán, en una batalla campal alojar todas las pieças a los dos costados y fondos del batallón, dexando la plaça de armas franca y libre? CAPITÁN. - No me paresçe, Señor, que estaría bien, porque, viendo los contrarios la frente sin pieças, sería ocasión de darles ánimo a querer çerrar y embestir al rompimiento.

FAM.: romper.

ENCICL.: DRAE: Acción y efecto de romper o romperse. 
ronda, ronda [del ár. rubt, pl. de râbita que también significa 'patrulla de jinetes guerreros'. Arobda, Cid; arrobda, Partidas, Fuero de Castelfabib y una Biblia arag.; robda y ronda, Partidas; ronda, Gr. Conq. de Ultr., Corbacho; "r., lugar por do rondan: pomerium; $r$. el rondador: lustrator orbis; $r$. , la obra del rondar: custodia urbis", Nebr.; Cej., V (DECH). Escalante, Discurso de la navegación, 1577]. sust. Recorrido, normalmente nocturno, de una población o de un lugar para vigilarlos o para mantener en ellos el orden.

Escalante, Discurso de la navegación, 1577, fol. 80r: De estas treze cárceles están siempre ocupadas las seis con ombres condenados a muerte, y en cada una d'ellas cien soldados, y más para su custodia con su capitán que les reparte las guardias y haze la ronda.

FAM.: contrarronda, rondar, sobrerronda.

2 [Escalante, Discurso de la navegación, 1577]. sust. Mil. Recorrido, normalmente nocturno, de los distintos puestos de centinelas que hay en una plaza o campamento, para verificar que el trabajo de éstos se desempeña correctamente.

Escalante, Discurso de la navegación, 1577, fol. 85v: En todos los baluartes en que ay sus garitas, assisten de noche centinelas que las remudan por sus quartos del cuerpo de guardia que es ordinario, andando siempre los oficiales como les toca, con el número de soldados que les parece en ronda y contraronda. // Álaba, Perfeto capitán, 1590, fol. 48v: Será muy propio del oficio del sargento mayor saber del maestre de campo general qué vanderas de las de su tercio han de ser de guardia y el puesto donde se han de poner, mandando al atambor mayor que por la mañana las aperciba, instruyendo a los sargentos en el modo que se a de tener en hazer las rondas y en poner las centinelas, mandándoles que las pongan de noche, porque el enemigo no lo entienda. // Álaba, Perfeto capitán, 1590, fol. 49r: Las centinelas, por lo menos, estarán apartadas treynta passos de los cuerpos de guardia y una de otra, de manera que se puedan ver; y siempre dobles, porque vean mejor quién entra o sale, pues son para esso, y porque, si una fuere a dar aviso, quede la otra [...]. Y para que mejor se haga la ronda, es menester que aya mucho silencio.

ANT.: contrarronda, sobrerronda.

ENCICL.: Moretti (1828): Patrulla que hace de noche un oficial alrededor del rampar o muralla de una plaza de guerra, en un campamento, etc., para observar si las centinelas hacen su deber con vigilancia y fidelidad. Los romanos, cuando hacían la ronda, llevaban una campanilla (tintinnabulum) que tocaban de tiempo en tiempo, a cuyo sonido las centinelas daban la voz de alerta, para manifestar que no estaban dormidos, ni habían desamparado el puesto. / / Borreguero Beltrán (2000): En combate o servicio de guarnición o vigilancia, recorrido efectuado, generalmente de noche, para impedir posibles desórdenes y proceder a la inspección de guardias o centinelas.

3 [Celso, Reportorio universal leyes Castilla, 1553]. sust. Mil. Grupo de soldados encargado de rondar o recorrer los puestos de centinelas de una plaza o campamento. 
Celso, Reportorio universal leyes Castilla, 1553, fol. IXr: Los adalides juzgan sobre las cavalgadas y sobre las cosas que acaescen en ellas, y han de partir el despojo o lo que fuere ganado en el saco, y ponen atalayas, y de noche escuchas y rondas, y han de ordenar las celadas cómo se hagan. / Álaba, Perfeto capitán, 1590, fol. 49v: Esto se entiende si la ronda habla y passa por dentro de las centinelas; pero si viniere de fuera del campo, en caso que pidiéndole el nombre no lo quisiere dar, le podrá tirar la centinela como a enemigo. // Lechuga, Discurso de la Artillería, 1611, pág. 240: La muralla de tierra de los catorze pies de alto a de tener principio a seis apartada del fin de la de ladrillo o piedra, porque entre el fin de la una y principio de la otra quede lugar por donde pueda andar la ronda.

ANT.: sobrerronda.

ENCICL.: Cov.: Ronda se toma algunas veces por los soldados que van rondando, y asegurándose de lo que puede haber de inconveniente y perjuicio.

4 [Loçano, Alberto, Architectura, 1582]. sust. Fort. Espacio que hay entre la parte interior del muro y las casas de una plaza fuerte (DRAE).

Loçano, Alberto, Architectura, 1582, pág. 250: Y paréceme que fue inventado el arco por los que estendieron el imperio, porque éstos, dize Tácito que por antigua costumbre también engrandecían la ronda entre el muro y las casas, lo qual dizen aver hecho Claudio.

ENCICL.: Estévanez (1897): Ronda se llama también, en una ciudad fortificada, el espacio comprendido entre el casco de la ciudad y las fortificaciones.

rondar, rondar [de ronda. Robdar, Cid, 1. ${ }^{a}$ Crón. Gral.; roldar, Gr. Conq. de Ultr.; rondar, íd.; Danza de la Muerte; "r.: lustrare urbem" Nebr. (DECH). Martínez de Burgos, Reportorio premáticas y Cortes, 1551]. v. tr. u. t. c. intr. Recorrer una población o un lugar, especialmente de noche, para vigilarlos o para mantener en ellos el orden.

Martínez de Burgos, Reportorio premáticas y Cortes, 1551, fol. XVIIr: Y mandamos a los dichos nuestros corregidores y alcaldes y otras justicias de estos nuestros reynos y señoríos, que ronden de noche y tengan especial cuydado para que no se hagan delictos ni excessos en los lugares donde tuvieren los dichos officios. // Martínez de Burgos, Reportorio premáticas y Cortes, 1551, fol. XLVIIIv: Corregidores: que no estén en los corregimientos más tiempo del que mandan las leyes, y tengan cuydado de visitar los términos y rondar de noche los pueblos. // Escalante, Discurso de la navegación, 1577, fol. 35r: Ay un espacio de tierra dende los muros al fosso que pueden andar por él seis ombres a cavallo y por la parte de dentro tienen el mesmo distrito hasta las casas para que se puedan rondar sin impedimento alguno.

FAM.: contrarronda, ronda, sobrerronda. 
2 [Álaba, Perfeto capitán, 1590]. v. tr. u. t. c. intr. Mil. Recorrer, normalmente de noche, los diferentes puestos donde hay centinelas en una plaza fuerte $\mathrm{o}$ campamento, para cerciorarse de que su servicio se desempeña correctamente.

Álaba, Perfeto capitán, 1590, fol. 48r: Que una compañía assistiesse a la defensa y guarda de cada una de las puertas aviendo necessidad d'ello, repartiendo esta assistencia por todas las compañías, dando a cada una quatro horas, poniendo de noche en los castillos gente que velasse y estuviesse a la mira de lo que quería hazer el enemigo y repartiendo guardas que rondassen el real para prevenir a las trayciones o descuydos que podían suceder. // Álaba, Perfeto capitán, 1590, fol. 49v: Aunque la centinela tiene obligación de no dexar llegar a nadie que no le diere el nombre, aunque sea el maestre de campo o sargento mayor, poniendo el arcabuzero la cuerda en la serpentina y el piquero terciando su pica, no es necessario dar el nombre quando el oficial que ronda quiere passar de largo, por hallar vigilante y con cuydado la centinela, y sin pedirle se puede bolver al cuerpo de guardia. // Ufano, Tratado de la Artillería, 1613, pág. 133: Tócale, también, en siendo ya noche, rondar y visitar las baterías, ynformándose de los gentiles hombres si les faltan algunos materiales y petrechos para sus fortificaçiones y cubrimiento de sus pieças y muniçiones de guerra y, si de alguna cosa tuvieren falta, mandarlo al puncto proveer.

ENCICL.: Rubió y Bellvé (1895-1901): Andar de noche visitando la ciudad o plaza para estorbar los desórdenes o inspeccionar los guardias y centinelas.

rota, rota [del lat. rupta, femenino del participio de pasado ruptus. Rota 'derrota' (Segura Munguía 2007). Montes, Instrucción y regimiento, 1537]. sust. Mil. Durante una guerra, serio e importante revés que sufre uno de los bandos.

Montes, Instrucción y regimiento, 1537, fol. XVIr: E todo hombre de guerra deve pensar que la mucha gente en la guerra está más subjeta al peligro que la poca, como paresce por esta rota tan grande de los venecianos, porque, como arriba es dicho, el exército copioso de gente no puede dar la orden en el pelear como los pocos, y los pocos son más prestos a combatir que los muchos. // García de Palacio, Diálogos militares, 1583, fol. 78v: Conviene que el capitán, tan solamente el día de la batalla, se occupe en el govierno y orden de sus soldados, en animallos, con andalles delante persuadiendo con dulces y animosas palabras y con buenas y dichosas esperanças [...], procurando en todo la salud y el brío de los suyos, y el daño y rota de los contrarios. // Collado, Plática Artillería, 1592, fol. 90v: Y, como quiera que en este lugar y a este propósito podría traer mill exemplos de exércitos que han sido desbaratados y rotos por hallarse divididos al passar de los ríos, solamente representaré aquí la rota tan memorable qu' el Gran Capitán dio a los franceses en el reyno de Nápoles al passar de un río, donde todo el campo de Francia fue muerto y preso.

FAM.: roto.

ENCICL.: Terr.: Término de guerra, estrago, rompimiento.

poner en $\sim$ [Mendoça, Theórica y práctica, 1596]. loc. v. Mil. Poner en fuga al enemigo. 
Mendoça, Theórica y práctica, 1596, pág. 116: Y assí la mayor parte de vitorias que se ganan en estos tiempos es aviéndose conseguido con la artillería o presteza de la arcabuzería por las bivas ruziadas, desordenando los esquadrones del enemigo, de suerte que los ponen en rota. // Mendoça, Theórica y práctica, 1596, pág. 121: Aunque se ponga en rota, no se ha de executar descomponiéndose los principales esquadrones de la batalla, porque sería aventuralla no teniendo cuerpos formados para seguir el alcance de manera que el enemigo no se rehaga en él.

SIN.: desbaratar 3.

roto [del lat. ruptus, $-a,-u m$, pp. de rŭmpō (Segura Munguía 2007). Montes, Instrucción y regimiento, 1537]. adj. Mil. Dicho del orden de batalla de una tropa: desordenado o destruido por su adversario, que se ha abierto paso por entre la multitud de soldados.

Montes, Instrucción y regimiento, 1537, fol. XVr: Y alcançó el Rey la vitoria porque el Crity, que era general de venecianos, no affrontó a los principios y, quando quiso affrontar con su gente, no pudo porque ya era rota la vanguarda de venecianos y el cuerpo de la batalla, y preso Bartolomé Dalbiano; y éstos perdiéronse aquel día por la mala orden de su general. // Montes, Instrucción y regimiento, 1537, fol. XVv: Y como los sesenta mil que estavan por los passos vieron su campo roto, no quisieron esperar batalla, antes huyeron por las montañas como hombres desesperados, sin llevar consigo ninguna orden. // Álaba, Perfeto capitán, 1590, fol. 10r: Y, preguntado de los suyos qué fuesse la causa de aquella novedad y si acaso le avía sucedido alguna ocasión de tristeza, respondió que no, sino que él se hallava tan presumptuoso y arrogante con el buen sucesso passado, que le pareció ser necessario con la tristeza que mostrava templar el demasiado regozijo que avía tenido, viendo rotos y desbaratados los enemigos.

FAM.: rota. 
saca, saca [de saco. "S., saco grande: saccus magnus" Nebr.; 'medida de carbón de cinco palmos de largo y tres de diámetro' cub., Ca.; Carrizo, Canc. de Tucumán, s.v. (DECH). Álaba, Perfeto capitán, 1590]. sust. Fort. Bolsa o recipiente de lienzo u otro material semejante que, relleno de tierra, arena o lana, se emplea para hacer defensas o reparos. (fig. 137)

Álaba, Perfeto capitán, 1590, fol. 98v: Y en caso que se huviesse de usar d'esta mistura para abrasar sacas de lana, será necessario añadirle resina negra, pez nabal y azogue, y causará admiración lo que d'esta suerte obrare. // Lechuga, Discurso de la Artillería, 1611, pág. 266: Algunos cestones, teniendo cuidado de renovarlos, y quantidad de faxina, con el mismo cuidado, no aviendo de qué hazerla dentro de la fuerza, por ser dos cosas con que mejor se repara una batería y la artillería; y muchas sacas de lana, para que supplan los defectos de faxina y cestones en todo tiempo. / / Ufano, Tratado de la Artillería, 1613, pág. 189-190: Para deffensa de golpe de cañón se pongan tres sacas juntas, de lado, a la larga, entre tronera y tronera, para que la espalda d'ellas quede a prueva de cañón.

SIN.: balón, saco' ${ }^{1}$.

FAM.: $\mathrm{saco}^{1}$.

ENCICL.: DUE (s.v. saca ${ }^{2}$ ): Se aplica a los sacos destinados a un uso especial. // Terr.: 1- V. Saco. 2- O saco lleno de lana. // Como apunta Terreros, y puede comprobarse perfectamente en el corpus, existía una tendencia a emplear el significante saca, en detrimento de saco, cuando con lo que se rellenaban estos recipientes o bolsas era con lana. 
sacamano, V. sacomano.

saco1, saco [del lat. saccus 'saco de trigo, de dinero, etc.', 'vestido grosero', gr. ó́xxos 'íd.' y 'arpillera', voz de origen fenicio. Berceo (DECH). Loçano, Alberto, Architectura, 1582]. sust. Fort. Bolsa o recipiente de lienzo u otro material semejante que, relleno de tierra, arena o lana, se emplea para hacer defensas o reparos. \& (fig. 138)

Loçano, Alberto, Architectura, 1582, pág. 143: Los antiguos usaron poner en la proa máchinas que ellos llamavan cuernos, pero los nuestros en la proa y popa levantan torres por causa del mástil, y paños viejos y sacos y otras cosas semejantes en lugar de vallado y deffensión. // Álaba, Perfeto capitán, 1590, fol. 87r-88v: Y aviendo puesto libremente y sin contraste alguno de enemigos la artillería en el puesto que se pretendía, començarse a a batir con buenos cañones que arrojen pelota de sesenta libras, usando de pelota de hierro para tirar al muro, baluarte o cavallero, por ser de materia más dura, y de plomo para trincheas, cestones, sacos y reparos, que son de materia menos maciça y dura. / / Collado, Plática Artillería, 1592, fol. 57r-57v: Y si para hazer reparos al artillería ni huviesse comodidad de cestones, ni de pipas, ni de céspedes, ni tampoco de saquillos, ni otra cosa de las que diximos, ni aun por esso deven de fallecer de ánimo los artilleros, que con colchones y traspontines y con las velas y gúmenas de las galeras y naves y aun con las esclavinas de los forçados saben y pueden cobrirse los hombres pláticos y animosos.

SIN.: balón, saca.

FAM.: saca.

ENCICL.: Terr. (s.v. saco): De lana, de tierra, etc., en la fortificación. Comúnmente suelen decir saca de lana, hablando de ésta. / / Fernández Mancheño (1822: s.v. saco a tierra): Es un saco de tela que contiene cerca de un pie y medio cúbico de tierra; esto es, un pie y medio de alto, y lo mismo de espesor. Se sirven de ellos para hacer con prontitud un parapeto, ponerse a cubierto y hacer fuego al enemigo. // Corsini (1849: s.v. saco de lana): Fort. Saco muy grande de tela que se llena de lana, y sirve para los mismos usos, en la fortificación pasajera, que el saco de tierra o a tierra. // Borreguero Beltrán (2000: s.v. saco): Saco terrero, saco relleno de arena $u$ otros elementos, usado por las tropas en operaciones de campaña para construir parapetos y fortificaciones ligeras. // López Vallejo (2008): Talega o receptáculo cilíndrico de lienzo, lleno de tierra, que se emplea en las defensas. $U$. frec. en dimin.

saco $^{2}$, saco [del it. sacco 'saqueo' (med. s. XIV). Saco de Roma en 1527; ej. de G. de Alfarache en Aut. (DECH). Celso, Reportorio universal leyes Castilla, 1553]. sust. Mil. Acción de apoderarse violentamente de todo cuanto hay en territorio enemigo.

Celso, Reportorio universal leyes Castilla, 1553, fol. IXr: Los adalides juzgan sobre las cavalgadas y sobre las cosas que acaescen en ellas, y han de partir el despojo o lo que fuere ganado en el saco, y ponen atalayas, y de noche escuchas y rondas, y han de ordenar las celadas cómo se hagan. // Mosquera, Comentario disciplina militar, 1596, fol. 86r: Concedió 
el Marqués saco por tres días, reservando iglesias y monasterios con grave pena, porque los lugares sagrados han de ser guardados por los capitanes, y han sido castigados los que les han perdido el respeto, como se halla en muchos lugares de la Escritura divina. // Mosquera, Comentario disciplina militar, 1596, fol. 92r: Y ya que se cumplieron los tres días señalados del saco y las presas que entre los soldados que ganaron la tierra y pelearon se avían dividido (costumbre antigua en las guerras que trae su origen de la sagrada historia ), luego el Marqués, movido de compassión [...], mandó que se publicasse perdón general y que los vezinos se viniessen a la ciudad y a las casas donde solían vivir con seguridad de la vida.

SIN.: despojo 1 , presa $a_{2}$ sacomano.

ENCICL.: Aut. (s.v. saco): Vale lo mismo que saqueo. // Aut. (s.v. saqueo): Lo mismo que saco de plaza o la acción de saquear. // Estévanez (1897: s.v. saco): Lo mismo que "saqueo". // Estévanez (1897: s.v. saqueo): Antiguamente "saco"; y todavía se dice entrar a saco y no entrar a saqueo. Es el hecho de apoderarse de todo cuanto se encuentra en una plaza o ciudad tomada al enemigo, como era costumbre en los antiguos ejércitos. En la actualidad se respeta escrupulosamente la propiedad particular de amigos o enemigos; si hay alguna vez reparto de botín, es sólo de comestibles. Y todo lo perteneciente al Estado o al Ejército enemigos, se toma pero no se distribuye: es del Estado.

dar a [Mendoça, Theórica y práctica, 1596]. loc. v. Mil. Dicho de los soldados: apoderarse violentamente de todo lo que encuentran en territorio enemigo.

Mendoça, Theórica y práctica, 1596, pág. 155: Y en caso que aya ciudadela o castilo en la tierra, se ha de acudir a la plaça d'él, impidiendo que no se retire dentro la gente; y quando no ay castillo, a la plaça o partes donde tienen señalado el juntarse en los cuerpos de guardia, señoreando enteramente la tierra, que se ha de dar a saco, y fortificarla, poniendo buena guarnición. // Mosquera, Comentario disciplina militar, 1596, fol. 36v: Concede y haze gracia a todos los vezinos de la dicha isla y las demás de perdón general otorgando, juntamente con las vidas, seguridad de bienes y haziendas, assegurando, demás d'esto, que no serán dados a saco por alguna manera, antes serán amparados en sus comercios y sossiego con tal que, sin hazer resistencia alguna, se quieran rendir y sugetar a su obediencia, como a Señor y Rey natural, admitiendo y dexando desembarcar en tierra a toda la gente que viene en esta Real Armada.

SIN.: despojar, saquear.

ENCICL.: Pagés (1902-1931: s.v. dar a saco): fr. Saquear.

sacomano, sacamano, sacomano [del it. saccomanno 'saqueador' (med. s. XIV), que en la locución far saccomanno tomó el sentido de 'saqueo'; dicha voz italiana se tomó del alem. sackmann 'mozo de bagajes de un ejército', 'encargado de las requisas', 'saqueador' (compuesto de mann 'hombre' y sack 'saco', por el que llevaban siempre). Sacomano 'saqueo', poner a 'saquear'. Carta de la reina María, a 
su marido Alfonso el Magnánimo de Cataluña-Aragón-Nápoles, Canc. de Stúñiga; Crón. del Condestable M. Lucas, a. 1461, Memorial Hist. Esp. VIII; "sacamano para robar: saccularius", "sacomano", Nebr. s.v. robar; poner o meter a sacomano o hazer s.; Covarr.; desusado ya según Aut.; sacomano 'saqueador' sólo una vez en Fz. de Oviedo (DECH). Roxas, Sumario milicia, 1607]. sust. Mil. Acción de apoderarse violentamente de todo cuanto hay en territorio enemigo.

Roxas, Sumario milicia, 1607, fol. 61v: Y luego haçían de allí otro quadrado de quarenta mil pies por cada lado, y por el un lado, por donde se salía fuera por el agua, forraje y sacamano, y otras cosas del serviçio del exérçito, se alojavan las romanas legiones, aviendo en cada legión, según que abemos dicho, seis tribunos.

SIN.: despojo 1 , presa $_{2}$, saco $^{2}$.

ENCICL.: DRAE: saqueo.

saetera, saetera [de saeta y éste del lat. sagĭtta 'íd.'. "Saetera o tronera: cavum ballistarium" Nebr. (DECH). Loçano, Alberto, Architectura, 1582]. sust. u. m. en pl. Fort. Agujero o abertura que se hace en las baterías o parapetos para disparar la artillería y reconocer con menos riesgo los movimientos del enemigo.

Collado, Plática Artillería, 1592, fol. 68r: El segundo es que por aquellas troneras o saeteras con los arcabuzes se offende en gran manera al enemigo. // Ufano, Tratado de la Artillería, 1613, pág. 49: No se deve de maravillar el artillero porque las pieças pequeñas proporçionalmente sean más largas y reforçadas que las grandes y de gran calibre, porque, al operar con ellas cubiertamente en la façión de guerra, se usa de tal superaçión para que no queden, por ser demasiadamente cortas, ahogadas en sus reparos, para que libremente desemboquen por sus troneras o saeteras. // Ufano, Tratado de la Artillería, 1613, pág. 263: Y por si, de ventura, se viniesen a encontrar en el camino de la mina, le sería de mucho serviçio llevar un banquete o mantón con muchas troneras o saeteras que fuesse a prueva de mosquete.

SIN.: cañonera, tronera.

salchicha, salchicha [del it. salciccia, que probablemente procede del lat. tardío salsicia 'íd.', abreviación de farta salsicia 'embutidos salados', el cual a su vez deriva de salsus 'salado'. APal. (DECH). Roxas, Sumario milicia, 1607]. sust. Fort. Fajina que, al hacerse con las ramas más largas y gruesas de los árboles, es mayor que las ordinarias. $\mathbf{F}^{3}$ (fig. 139)

Roxas, Sumario milicia, 1607, fol. 103v: Y estando ya pegados con el foso, se procurará de cegarlo, y si tubiere mucha cantidad de agua y no se pudiere sangrar, se le echarán dentro mucha cantidad de salchichas de piedra seca y maderos, como ya el yngeniero lo sabrá haçer, y, a bueltas de ello, mucha fajina y tierra. / / Ufano, Tratado de la Artillería, 1613, pág. 255: Fabrícanse los candeleros en el modo y manera que la presente figura demuestra. $Y$ deven ser tan altos que buenamente con ellos y faxina se pueda de presente cubrir la gente 
que començare a abrir trincheas y ordenar baterías, y tan ancho el un mástel del otro que puedan entre ambos buenamente caver dos o tres salchichas o gruesas faginas de lado. // Ufano, Tratado de la Artillería, 1613, pág. 257: Estando Su Alteza en el sitio de Ostende se presentó a tal ocasión un hombre bassallo suyo, cuyo nombre era Adrián Hermansen, muy yngenioso de la maestrança de diques y poldrages, el qual propuso a Su Alteza ser muy buena y provechosa la ynvençión de la salchicha de guerra para atajar las aguas, hazer y fortifficar los diques con bastante fuerça contra la furiosa corriente y cresçimiento d'ellas.

ENCICL.: Toro y Gómez (1901: s.v. salchichón): Mil. Especie de fajina. // Sanz (1749: s.v. salchichones) Son fajos hechos de ramas de árboles; y se diferencian de las fajinas en que están formadas de las ramas y hojarasca más débil, y los salchichones se construyen con mayor atención, tienen más ligaduras y perfección; porque éstos deben servir para las construcciones de baterías, que es blanco donde se sufre el fuego del cañón, y las fajinas sirven para parapetar las trincheras cargadas de tierra. // Lucuze (1772: 100): "El salchichón es una especie de fajina, hecha de gruesas ramas, y de tres a cuatro pies de diámetro, sobre diez o doce de largo, que se rellena de piedras. Sirven los salchichones para cegar un foso de agua y formar sobre ellos el paso o la galería del minador. Se hacen también salchichones del grueso y longitud que se necesita para la formación de la rodillera, merlones y cañoneras de las baterías".

2 [Lechuga, Discurso de la Artillería, 1611]. sust. Art. Recipiente de tela largo y delgado que se emplea, relleno de pólvora, para dar fuego a los hornillos de las minas.

Lechuga, Discurso de la Artillería, 1611, pág. 269: Quinto, quando, después de puesta la pólvora y atacada la mina como deve estar, faltare su effecto por falta de la salchicha, que es una manga de tela que ponen llena de pólvora desde dentro de la mina hasta la parte de afuera, para dar el fuego.

ENCICL.: Terr.: En la guerra, saco embetunado que sirve para dar fuego a una mina. // Sanz (1749): Es un cilindro de pólvora puesto dentro de tela común o encerada, redonda y cosida, de la figura de una verdadera salchicha, cuyo diámetro es de una pulgada y media, y su longitud de la que se necesita según las distancias de las comunicaciones que ha de comprender, desde donde se da fuego a la mina hasta comunicarlo a los hornillos. // D'Wartelet (1863): Especie de mecha que se emplea para dar fuego a las minas. Se compone de un rollo de tela fuerte bien encerada y relleno después de pólvora bien apretada. Su diámetro es variado, lo mismo que su largura, que es adecuada a la distancia a que debe emplearse.

salchichón, salchichón [del it. salsiccione (s. XIV) 'íd.' (TLIO). Lechuga, Discurso de la Artillería, 1611]. sust. Fort. Salchicha muy grande formada por la unión de varias. (fig. 140)

Lechuga, Discurso de la Artillería, 1611, pág. 206: En todas las partes dichas manda hazer quantidad de faxinas de salchichas para salchichones, que son nombres que se an dado a la invención nueva que sirvió de ganar a Ostende, llamando salchichas a los líos de faxinas 
juntas y atadas por muchas partes, largas lo que pareze, y gruessas como un muslo, y salchichones a muchos líos de éstos, hecho uno tan gruesso como se quiere. // Ufano, Tratado de la Artillería, 1613, pág. 259: Y fue que un hombre llamado Chritóval, proboste, en su pensamiento que de muchas salchichas coligadas en uno se podría hazer un grande y grueso salchichón, el qual, para que sobre tal caso le diesen crédito se apadrinó de un cavallero para que sobr'ello hablasse a Su Alteza, lo qual se pusso luego por obra. // Ufano, Tratado de la Artillería, 1613, pág. 260: Ya está tratado en la ynvención de la salchicha quién la ynventó y fue su author, y, asimesmo, del salchichón, cuya figura sigue a la de la salchicha. El qual salchichón, çierto, es una de las más grabes y pessadas máchinas usadas en la façión de guerra aviendo de caminar con él prestamente algún trecho, aunque más corto sea, para meterle en obra.

salida, salida [de salir y éste del lat. salìre 'saltar, brincar'. Cid (DECH). Mendoça, Theórica y práctica, 1596]. sust. Fort. Durante el sitio de una fortaleza, acción ofensiva y defensiva que realiza un grupo de sitiados, la cual consiste en desplazarse generalmente hasta el foso o hasta la estrada cubierta para, además de atacar a los sitiadores, tratar de impedir sus trabajos de aproche.

Mendoça, Theórica y práctica, 1596, pág. 99: Juntamente se acompañan estas pieças en las baterías, como he apuntado, con culebrinas medias, quartos de cañones y medios sacres y pieças de campaña, que de ordinario se llevan quando ay comodidad para ello, por traerse en los grandes exércitos semejante suerte de artillería por todo buen respeto, poniendo las pieças menudas en los sitios y partes más convenientes para impedir las salidas de los cercados. // Mendoça, Theórica y práctica, 1596, pág. 138: Por alargar esto no ha de aventurar en las salidas tantos soldados que le vengan a faltar para la defensa de las murallas, que es en la que se ha de hazer el último esfuerço y donde al cabo vienen los cercados, siendo mucho menor número de gente a combatir con maior ventaja. // Rojas, Teórica fortificación, 1598, fol. 74r: Y juntamente tener siempre los çarços y estacadas prevenidas para tapar las baterías, haziendo en ellas medias lunas y travesses para guardarlas, y hazer buenas salidas a estorvar las trincheas al enemigo, de suerte que la salida sea a una distancia moderada, de manera que los cubran y amparen los de la muralla, quando se retiren los que hizieren la salida.

SIN.: surtida 1 .

ENCICL.: Borreguero Beltrán (2000): Operación de ataque de los defensores de una plaza sobre los sitiadores. // Rojas, Teórica fortificación (1598: fol. 37v): "Y a mi parecer (conforme a lo que he comunicado con los más experimentados en esta materia), será bueno el fosso seco quando la plaça tuviesse mucha pujança de gente dentro que salga a estorvar al enemigo las trincheas, pero si la plaça tiene poca gente, como ya es ordinario, es mejor que sea el fosso con agua, porque las salidas se remedian con hazer unas planchadas para salir desde las casas matas a la estrada cubierta y es cosa muy notoria que, en llegando las trincheas a bordo del fosso, lo primero que se haze es procurar dessangrarle el agua, en lo qual se gasta mucho tiempo y trabajo, y si no pudiesse ser sangrado, es fuerça hazer puentes sobre varcas y se passa con mucho riesgo, y los de la plaça lo defienden con más facilidad que si fuera seco el dicho fosso". // Rojas, Teórica fortificación (1598: fol. 73v): 
"Quiero dezir que no hagan las salidas a 1.000 passos del fosso, porque no son de ningún efeto, porque a esta distancia tirará y ofenderá el artillería del castillo, porque la salida tan larga, demás de gastar la munición, tiene mala la retirada, pues no la cubre la muralla. Dígolo esto como testigo de vista, que vi perderse una plaça por salir d'ella 1.000 passos de distancia a escaramuçar con el enemigo, el qual se reía de verles gastar la munición al ayre, $\mathrm{y}$, por ser tan lexos la salida, davan la carga a mucha distancia del enemigo, bolviendo luego las caras a retirarse. Y con esta escaramuza se entretuvo el enemigo dos días, dexando gastar la munición a los del castillo".

2 [Loçano, Alberto, Architectura, 1582]. sust. Fort. Paso o puerta que atraviesan los sitiados para poder llevar a cabo, durante un sitio, una salida u ofensiva contra los sitiadores.

Loçano, Alberto, Architectura, 1582, pág. 127: Conviene que del todo tenga la fortaleza dessembaraçadas salidas, por donde pueda acometer a los enemigos y a los ciudadanos y a los suyos del castillo, si algún alboroto o trayción lo demande, y pueda pedir y meter socorros suyos y agenos libremente, por tierra, río, lago y mar. // Loçano, Alberto, Architectura, 1582, pág. 129: Tendrá también salidas por donde pueda salir contra los suyos, aunque no quieran, y por donde pueda meter socorros pedidos. // Rojas, Teórica fortificación, 1598, fol. 78r: Se començará por la parte más flaca a fabricar, procurando que primero que se derribe ninguna muralla vieja, esté ya en defensa lo que se fabricare de nuevo; y hazerse han puertas y salidas al fosso y todas las demás cosas necessarias a la buena fortificación.

SIN.: surtida ${ }_{2}$.

ENCICL.: DUE: Sitio o abertura por donde se sale de un sitio. // Almirante (1869): La parte por donde se sale de una plaza fuerte, que también se llama surtida.

saltear, saltear [de salto. J. Ruiz; "s. a alguno: compilo" Nebr. (DECH). Celso, Reportorio universal leyes Castilla, 1553]. v. tr. Mil. Acometer o atacar repentinamente y por sorpresa a una persona o a un grupo.

Celso, Reportorio universal leyes Castilla, 1553, fol. CXLIVv: El feudatario pierde el feudo en su vida si él no cumpliere al señor o a sus herederos el servicio que le prometió hazer por razón del feudo; o si desamparare a su señor en batalla [...]; o si se confederare con algunos enemigos de su señor; o si le salteare por sí, con otros, en algún lugar, queriéndole herir, o matar, o prender, o deshonrar. // Ufano, Tratado de la Artillería, 1613, pág. 115: Muy bien está traçado que la plaça de armas sea en la forma qu'está y en mostrarla así tiene Vuestra Merced mucha razón; que, si fuere salteada y asaltada del enemigo y no se hallase tan bien puesta y aperçevida, vendría a perder mucha reputaçión el general.

SIN.: asaltar ${ }_{1}$, dar (el) asalto ${ }_{1}$, dar el salto.

FAM.: salto. 
ENCICL.: DUE: Atacar a alguien por sorpresa. Sin. y var. Asaltar.

salto, salto [del lat. saltus, $-\bar{u} s$ 'salto'. Cid; Berceo, etc.; 'sobresalto, espanto' Alex. (DECH). González de Medina, Examen fortificación, 1599]. sust. Mil. Ataque repentino y por sorpresa contra una persona o grupo.

González de Medina, Examen fortificación, 1599, pág. 103: Maestro, yo me hallo muy necessitado de remediar una isla que tengo en la mar, pequeña, que toda ella es abrigaños, porque está poblada de un espesíssimo bosque de grandes árboles y, boxando la isla, de qualquier viento están seguros los baxeles que a ella se arriman y es ocasión que siempre está llena de cossarios que, por estar tan cerca de mis marinas, surgen allí, y recibo mucho daño d'ellos por los repentinos saltos y porque no puede salir baxel de mis marinas ni atravessar por allí que no reciba gran daño.

SIN.: asalto 1.

FAM.: saltear.

dar el $\sim$ [Montes, Instrucción y regimiento, 1537]. loc. v. Mil. Acometer o atacar repentinamente y por sorpresa a una persona o a un grupo.

Montes, Instrucción y regimiento, 1537, fol. XIv: Y en esto se ha de mirar y desvelar cómo y de qué manera y por qué vía, y a qué hora, y con quánta gente se dará el salto a los enemigos, e si al tiempo que se diere se podrá haver vitoria, y qué tanta gente podrá haver para la resistencia.

SIN.: asaltar ${ }_{1}$, dar (el) asalto ${ }_{1}$, saltear.

sambuca, sambuca, sambuco, sanbuca [tomado del lat. sambūca 'arpa', 'máquina de guerra en forma de puente levadizo', y éste del gr. $\sigma a \mu \beta \dot{v} \chi \eta$ (DECH). Urrea, Vitruvio, Architectura, 1582]. sust. f. u. t. c. m. Fort. ant. Máquina consistente fundamentalmente en una plataforma que se tiende sobre los muros de una fortaleza para facilitar el asalto.

Urrea, Vitruvio, Architectura, 1582, fol. 138r: También en Chío, aviendo los enemigos hecho las máchinas de los sambucos sobre las naves, los de Chío echaron en el mar, delante del muro, tierra, arena y piedras. Y queriendo los otros allegarse el día siguiente, encalláronse las naos sobre aquel montón que estava ya debaxo del agua, y ni pudieron llegar al muro ni retirarse. // Collado, Plática Artillería, 1592, fol. 2v: Las máquinas, pues, Real Magestad, con que los antiguos solían expugnar las fortalezas y batir las murallas eran éstas: las cathapultas, las balistras, las víneas, los arietes, las testúdines [...], el compago, el escorpión, las sambucas, las faláricas y otras muchas. // Collado, Plática Artillería, 1592, fol. 5r: Muchas otras differencias de máquinas murales podría yo, Real Magestad, representar en este tratado, si no me opprimiesse el temor de ser prolixo, las quales son las vineas, los compagos, los cuervos, las sanbucas, y otras muchas, las quales será bien differir por agora, para venir a tratar de la invención de la pólvora y artillería. 
ENCICL.: DRAE: Máquina antigua de guerra, formada por una armazón de maderos y en ellos una plataforma levadiza, que subía y bajaba con cuerdas, para caer como puente sobre los muros de una ciudad y facilitar el asalto. // Almirante (1869): Escala grande de asalto montada sobre un bastidor con ruedas, y con un mecanismo para darle la conveniente inclinación. La marítima se apoyaba sobre dos galeras [...]. Las más formidables e históricas son las cuatro de Marcelo contra Siracusa. Cada una se apoyaba en dos galeras. No era invención nueva, sino conocida en tiempo de Alejandro; y aunque de esta máquina se ignoren, como de todas, pormenores, lo averiguado es, que no derribaba ni batía nada, que servía exclusivamente para escalar.

sanbuca, V. sambuca.

saquear, saquear [del it. saccheggiare (s. XVI, y probte. ya existente en 1376, a juzgar por un italianismo provenzal). 1570, C. de las Casas (DECH). Micón, Diario grande cometa, 1578]. v. tr. Mil. Dicho de los soldados: apoderarse violentamente de todo lo que encuentran en territorio enemigo.

Micón, Diario grande cometa, 1578, pág. 107-108: Y Scicilia fue por los moros saqueada en tiempo de Georgio Trapezuntio, año de 1403, a quien luego siguió la horrenda venida de Levante a la Asia Menor de Thamyris, Grande Tamorlán allanando con un millón de soldados toda la Turquía o Natolia. // Álaba, Perfeto capitán, 1590, fol. 17r: Alarico, rey de los godos, que, aunque era bárbaro y inhumano, aviendo entrado por fuerça de armas en la ciudad de Roma, no permitió el saquearla a su gente hasta que todos jurassen delante d'él que no robarían cosa alguna de las que hallassen en los templos de los apóstoles. / / Mendoça, Theórica y práctica, 1596, pág. 154: Señalados los cabos, se les ha de dar orden cómo han de caminar y las hileras que han de poner primero las escalas o echar las barcas y troços de puente al agua, y esto con particularidad que no venga a aver confusión y ruydo al executarse, siendo entre las órdenes que se les han de dar la más precissa de todas que, ganando las murallas, no se ponga soldado a saquear hasta estar assegurados de la tierra, porque entonces la tendrán para ello.

SIN.: dar a saco, despojar.

ENCICL.: DUE: tr. o abs. Apoderarse los soldados, al entrar en un país enemigo, de lo que encuentran: 'Saquear una ciudad. Los soldados se dedicaron a saquear'. // Collado, Plática Artillería (1592: fol. 112r): "Y porque, supuesto lo arriba dicho, qu'el artillero no tiene libertad de desamparar el artillería ni hallarse en saquear en otra manera, el artillero cuerdo procure siempre de tener algún dinero sobrado".

scala, V. escala.

scarpa, V. escarpa. 
scorpión, V. escorpión.

sedición, sedición, seditión [tomado del lat. seditio, -onis 'discordia', 'rebelión'. 1515, Fz. de Villegas; Covarr. (DECH). Micón, Diario grande cometa, 1578]. sust. Mil. Movimiento colectivo contra una autoridad, más violento que el motín pero menos que la rebelión.

Micón, Diario grande cometa, 1578, pág. 97: Si fuere de Venus, suele ser grande y redonda, que lo más haze mal, ho le sigue daño para muchos de todos estados, como el que pone Haly, grande como el quarto de la Luna, a quien siguieron hambres, peste, seditiones y guerras crudas. // Mendoça, Theórica y práctica, 1596, pág. 34: Pueden assimismo venir ocasiones en que Vuestra Alteza aya de levantar gente de guerra, valiéndose d'ella y armas, para castigar alguna sedición o rebelión de sus vassallos, en que no se ha de perder un momento de tiempo por muchas razones. // Mendoça, Theórica y práctica, 1596, pág. 37: De la parte contraria, comprueva la experiencia aver combatido y guerreado hartos años grandes capitanes con exércitos de diferentes naciones, sin aver avido motines ni sedición en ellos y ganado muchas vitorias.

ENCICL.: DRAE: Alzamiento colectivo y violento contra la autoridad, el orden público o la disciplina militar, sin llegar a la gravedad de la rebelión. // DUE: Acción de declararse en contra de la autoridad establecida y de empezar la lucha contra ella. / Particularmente, sublevación militar.

seditión, V. sedición.

seguir, V. la victoria.

señido, V. ceñido.

señorear, señorear [de señor. h. 1275, 1. ${ }^{a}$ Crón. Gral.; Conde Luc., APal. (DECH). Escalante, Discurso de la navegación, 1577]. v. tr. Dicho de una cosa: dominar algo que está alrededor, por tener mayor altura o estar en una posición más elevada.

Rojas, Teórica fortificación, 1598, fol. 4r: Y si se huviesse de hazer el tal castillo sobre alguna villa, se tendrá, assimesmo, cuidado de que esté a cavallero sobre la campaña y juntamente que señoree la villa. // Rojas, Teórica fortificación, 1598, fol. 39v: Y buelvo a dezir que no le digan al valuarte cavallero, porque el cavallero es aquél que está señalado con la $\mathrm{P}$, que tendrá de frente y en quadrado sesenta pies, y de alto sobre el terrapleno de la cortina diez pies, con los quales señoreará a los valuartes y a lo demás de la plaça, y por esto le dizen cavallero, porque está a cavallo sobre toda la fábrica. // Roxas, Sumario milicia, 1607, fol. 
73v: De los sitios en llano son fuertes aquéllos que son çircundados de lagos, de profundas riberas o paludes, o aquéllos que pueden ser alrededor hanegados de agua en tiempo de neçesidad, o aquéllos que tienen campaña rasa alrededor y están lejos de toda cosa que los pueda señorear.

SIN.: descubrir 1 .

FAM.: enseñorearse.

ENCICL.: Terr.: Un lugar, castillo, monte, etc. a otro, dominarle, V.

2 [Montes, Instrucción y regimiento, 1537]. v. tr. Divisar desde una altura determinadas cosas, como una extensión de terreno o las personas que se encuentran allí.

Montes, Instrucción y regimiento, 1537, fol. Vv: Y los cavallos ligeros tienen otra orden, que son más ligeros para combatir, porque andan a la ligera y de continuo andan a vista de los enemigos, y éstos sirven mucho en la guerra porque señorean la campaña, lo que no hazen los hombres d'armas, que éstos no salen sino a cosa de hecho y, si salen, salen sobre cosa pensada. // Roxas, Sumario milicia, 1607, fol. 46r: Un baluarte se lebanta de tierra y fajina enfrente de la muralla para señorear desde allí la plaça y tirar. // Ufano, Tratado de la Artillería, 1613, pág. 157-158: CAPITÁN. - Pues si esso es assí, ¿por qué se hazen las plataformas y caballeros y, al fin, se buscan los más altos puestos para con ventaja alojar pieças? GENERAL. - Esso no me paresçe que será para el effecto de tirar mejor ni más largo, sino para mejor descubrir y señorear la campaña, de modo que siempre se esté a caballero del enemigo y se vea quanto haze y trama.

SIN.: descubrir ${ }_{2}$, sojuzgar ${ }_{1}$.

3 [Sagredo, Medidas Romano, 1526]. v. tr. Mil. Poner una persona bajo su poder a individuos o territorios.

Sagredo, Medidas Romano, 1526, pág. 12: Quando los romanos començaron a señorear el mundo, procuraron de noblecer a Roma de todo lo mejor y más notable que en él se hallasse. // Fernández de Enciso, Suma de Geographía, 1530, fol. XXIVv: Este infante don Pelayo fue el primero rey de España que en ella ha avido que sea natural d'ella; e fue de Cantabria, que es en Iberia, adonde primero començó a poblar la España Túbal, nieto de Noé, e después que España tomó rey natural de su tierra, nunca más fue sojuzgada de griegos ni de romanos, ni de africanos ni de otra ninguna nación, antes los de España han señoreado a otras naciones con ayuda del apóstol Santiago, su patrón. // Roxas, Sumario milicia, 1607, fol. 52v: Y beniendo al propósito, diçe que el húltimo rey de los godos fue don Rodrigo y, muriendo éste en batalla, los moros señorearon a España.

SIN.: allanar, ${ }_{3}$ domar, domeñar, domesticar, sojuzgar ${ }_{2}$, someter, sujetar 1.

ENCICL.: Cov. (s.v. señoría): Señorear, es sujetar. 
4 [Álaba, Perfeto capitán, 1590]. v. prnl. Apoderarse de algo.

Álaba, Perfeto capitán, 1590, fol. 25v-26r: Y, assí, trataron de fortalecer y adelantar tanto los ánimos de sus ciudadanos que con sola su determinación y brío resistieron el poder y contiendas de sus vezinos y de otros enemigos que no con menor ansia y cuydado trataron muchas vezes de señorearse d'ellos y de hazerse señores y dueños de toda su tierra. // Álaba, Perfeto capitán, 1590, fol. 90v: Y Fabio Máximo, queriendo conquistar una ciudad llamada Regio en la Calabria, fingió querer su amistad y con aparencias d'ella pidió que por su dinero le diessen los bastimentos necessarios para sustentar su exército; otorgando esto, después de averse entretenido algún tiempo con los mantenimientos que para sí tenía la gente del lugar, quando sintió que començava a aver falta d'ellos, declarándose por enemigo, se apoderó y señoreó de la ciudad.

SIN.: enseñorearse.

ENCICL.: Almirante (1869): Señorearse, apoderarse de una posición [...].

5 [Álaba, Perfeto capitán, 1590]. v. prnl. Mil. Dicho de un grupo de personas o de un territorio: someterse o ponerse bajo el poder de alguien.

Álaba, Perfeto capitán, 1590, fol. 85v: Monsiur de Fox, aviéndose señoreado los venecianos de Bresa, de consentimiento de los moradores d'ella, y teniendo él por suyo el castillo, los saqueó y desbarató.

SIN.: sujetar 2 .

sercar, V. cercar.

sestón, V. cestón.

sextón, V. cestón.

sintinela, V. centinela.

sitiado, sitiado [de sitiar (DECH). García de Palacio, Diálogos militares, 1583]. adj. Fort. Dicho de un lugar fortificado o de las personas que están dentro: que sufren un sitio, un asedio o un cerco.

García de Palacio, Diálogos militares, 1583, fol. 85v: Si, como ha acontecido muchas vezes, algún enemigo se offresciesse dar por trayción la ciudad sitiada, ¿qué se deve hazer con él, y, en los casos de confiança, qué fee es razón se le dé? // Collado, Plática Artillería, 1592, fol. 53v: Por lo menos, una batería real ha de ser tan ancha que nueve soldados puedan 
entrar en hordenança por ella, no obstante que en semejantes occasiones de assaltar con pura violencia una ciudad o fortaleza sitiada ni se guarda a hordenança alguna ni se tiene cuenta con hilera. // Ufano, Tratado de la Artillería, 1613, pág. 173-174: A causa de estar tan espessa y agregada la gente en tales partes, hazen mucho daño y estrago en ella y la descomponen y atemorizan mucho. Y, por tanto, aseguro a Vuestra Señoría que son de mucho serviçio en una plaça sitiada.

SIN.: asediado $_{1}$, cercado 3.

FAM.: asitiar, desitiar, sitiador, sitiar.

2 [Loçano, Alberto, Architectura, 1582]. sust. Fort. Persona que se halla en una construcción defensiva sitiada, asediada o cercada.

Collado, Plática Artillería, 1592, fol. 63r: Las aguas manantiales, si las hay en los fossos, éstas son muy favorables a los sitiados, porque ni les pueden ser sangradas ni menos con la mina se puede passar por debaxo de ellas. // Mendoça, Theórica y práctica, 1596, pág. 105-106: Assimismo se pican las murallas, quando se ha llegado con trincheas o traviessas en el fosso o por otro medio al pie d'ellas, cubriéndose los soldados con mantas al hazerlo, las quales se guarnecen de cueros por de fuera, impidiendo con esto, por ser de madera, no se quemen, echando fuego de las murallas los sitiados sobre ellas. // Mosquera, Comentario disciplina militar, 1596, fol. 89r: Harto mayor crueldad que la de Olofernes, que quando cercó la ciudad de Betulia mandó cortar la cañería por donde entrava el agua a la ciudad y, assí, no les quedó a los pobres sitiados más que un delgado manantial, a raíz del muro, donde con recelo y a hurto humedecían los labios con algunas gotas del agua que podían alcançar con ellos.

SIN.: asediado $_{2}$, cercado 4 .

ANT.: asediador, cercador, sitiador.

ENCICL.: Fernández Mancheño (1822): El que se halla en una plaza sitiada o cercada.

sitiador, sitiador [de sitiar (DECH). Ufano, Tratado de la Artillería, 1613]. sust. Fort. Persona que sitia, asedia o cerca.

Ufano, Tratado de la Artillería, 1613, pág. 180: Y esto se puede tener por çierto: que no ay de que mayor daño reciban los sitiadores que de las pieças que se alojan fuera; y bien en este puncto nos lo a mostrado la villa de Ostende y las demás plaças que an sido sitiadas por el feliçe exérçito de Su Magestad, el daño que de las tales pieças a resultado y lo que tan crudamente se a reçibido en él por se aver d'esta forma alojado fuera. // Ufano, Tratado de la Artillería, 1613, pág. 198: Y también, Señor, se haze por mostrar su furiosa fuerça los sitiadores y poner pavor y espanto a los sitiados, aunque ellos, por otra parte, no mondan níspolas, que lo mismo machinan, traffican, urden y traman por de dentro que los de afuera y aun con mucha más ansia, soliçitud, cuidado y diligençia. // Ufano, Tratado de la Artillería, 1613, pág. 262: Aunque la prática y operaçión de las minas antiguamente se a 
usado en las guerras de los persas, parthos y romanos con otras diversas máchinas y petrechos, ningún arte al uso de la guerra a sido más perfeto y conveniente para oprimir a los sitiados ni ay cosa de que más teman los sitiadores que es de las contraminas hechas en su daño por el enemigo viéndose tan çercado y apremiado.

SIN.: asediador, cercador.

ANT.: asediado $_{2}$, cercado 4 , sitiado 2 .

FAM.: asitiar, desitiar, sitiado, sitiar.

ENCICL.: Aut.: El que sitia alguna plaza o fortaleza, solicitando ganarla con violencia y con armas, o el que está y sirve en el sitio de ella.

sitiar, cetiar, sitiar [adaptación occitana del b. lat. situare. Sitiar 'sitiar' y 'situar' está en el aragonés Fdz. de Heredia, Grant Crónica; Cov.; Oudin; ejs. del s. XVII, en Aut. (DECH). En el CORDE, en cambio, los primeros ejemplos son de finales del s. XII. Loçano, Alberto, Architectura, 1582]. v. tr. Fort. Establecerse en torno a un lugar fortificado para impedir que los que están dentro puedan salir o recibir ayuda, con el fin de obligarlos a rendirse.

García de Palacio, Diálogos militares, 1583, fol. 84v: Deve, ante todas cosas, el que sitiare qualquier castillo o ciudad, offrescer la paz al enemigo, con los partidos que justamente convinieren al negocio y causa de su príncipe, para que, aceptándole la occasión de discordia, se acabe sin los daños y ruynas que el proseguir un cerco trae consigo, y la salud del pueblo sitiado quede salva y segura. // Rojas, Teórica fortificación, 1598, fol. 78v-79r: Y no teniendo agua de pie, se harán cisternas para la llovediza, y generalmente tendrá todos los aproges de guerra dichos, de los quales tendrá una lista por escrito el castellano, de forma que no le falte pieça de su arnés el día que cargare el enemigo, porque se remedia mal lo que faltasse el día que el enemigo huviesse sitiado la tal plaça. // González de Medina, Examen fortificación, 1599, pág. 12: La bondad o calidades que tiene, Señor, la fuerça puesta a la marina son todas las que tienen las que están en llano y, más, que le es impossible al enemigo sitiarla de manera que no sea socorrida de todo lo necessario, assí de gente de guerra como de municiones y vituallas, porque, para sitiarla por parte de la mar, ha menester el enemigo muy grande armada, superior a la que el príncipe, cuya es la fuerça, pueda tener.

SIN.: asediar, asitiar, cercar, meter (el) asedio, poner asedio, poner (el) cerco, poner (el) sitio.

ANT.: alzar el cerco, alzar el sitio, levantar el asedio, levantar el cerco, levantar el sitio.

FAM.: asitiar, desitiar, sitiado, sitiador.

ENCICL.: DUE: Rodear en la guerra con fuerzas propias otras del enemigo o una plaza o posición, para atacarlas o tomarlas sin que puedan eludir la lucha retirándose, ni recibir refuerzos o auxilio. // Sanz (1749): Es hacer el sitio de una plaza y campear un ejército 
alrededor de ella para impedir la entrada, a fin de tomarla por hambre o por fuerza. Presentemente las plazas que se sitian, la mayor parte se toman, a menos que no sean socorridas. Antes de emprender un sitio se debe saber y conocer perfectamente la fuerza de la plaza, el país que la circuye y la ventaja que se puede conseguir de su conquista. Un príncipe que forma el proyecto de un sitio lo debe ejecutar con el menor número de tropas que sea posible, a fin de tener su idea oculta; pero no puede dejar de comunicarla al ministro, en cuyo departamento se encuentra la plaza, al ingeniero general, que debe conducir el sitio y puede mejor juzgar la facilidad o imposibilidad de la empresa, al director general, porque está encargado de los preparativos necesarios, al intendente, al comandante de la artillería, al comisario general de víveres, para que las municiones de guerra y artillería, como todo lo correspondiente a víveres, se pueda aprontar con tiempo $[\ldots]$.

sitio, sitio [de origen incierto. Quizá sea una alteración semiculta del lat. š̀tus, - $\bar{u} s$ 'íd.', con influencia de asedio (lat. obsidio) o del verbo sitiar para la terminación -io. Sito, Alex.; sitio, invent. arag. de 1331. Sitio 'asedio' no se encuentra hasta Nebr. (DECH). Micón, Diario grande cometa, 1578]. sust. Fort. Operación que se lleva a cabo contra un lugar fortificado con el fin de rendir a los que están dentro.

$$
\text { s (fig. 142) }
$$

Mendoça, Theórica y práctica, 1596, pág. 135: Assentadas las órdenes para la guardia, el governador o capitán de la plaça ha de hazer cerca de toda la suerte de vituallas que huviere en ella, recelando sitio, como trigo, granos, carnes saladas, vino, harina, sal, y al contar, según el número de la gente de la tierra y soldados, los días que se podrán mantener con ellas, avisando a Vuestra Alteza d'ello, artillería y armas que ay, para que según las listas pueda mandar proveerlas de lo que conviene. // González de Medina, Examen fortificación, 1599, pág. 192-193: Ha de ser soldado que tenga noticia de todas las maneras de ofensas y máquinas que el enemigo puede hazer en un sitio contra una fuerça, para saber reguardarse d'ellas; leýdo en las historias, que ellas le mostrarán un retrato al vivo de mil ardides que se han usado, y otras tantas máquinas, para ganar fuerças, y cómo se han defendido, para quando se hallare en la ocasión no le tome desalumbrado y sepa valerse de algunas. // Ufano, Tratado de la Artillería, 1613, pág. 266: Es máchina de mucho serviçio y a sido ynfinitas vezes usada en diversos sitios de çiudades y fortalezas, espeçialmente en la toma de Ostende, donde se hazían a fuerça de çarços y de tierra, y algunas servían con yr cubiertas de çarços solamente.

SIN.: asedio 1 , cerco.

ENCICL.: Moretti (1828): La acción de acampar un ejército alrededor de una plaza, fortaleza o castillo o líneas enemigas, cercándolas de manera que se impida la entrada en ellas de tropas, víveres, municiones, etc., a fin de tomarlas por hambre o por fuerza. El sitio puede ser formal o violento; es formal cuando los sitiadores, habiendo concluido las líneas de circunvalación fuera de los tiros de la plaza etc., van adelantando sus obras hacia aquella por medio de las líneas paralelas y otros trabajos. Es violento cuando el sitiador, dejando de practicar los trabajos preliminares de un sitio, se coloca desde luego sobre el glacis y se atrinchera en él para obrar hostilmente. // Corsini (1849): El conjunto de disposiciones, 
operaciones y trabajos puestos en práctica por un ejército o tropa, para verificar el ataque científico y metódico de una plaza o recinto fortificado. // Terr.: Los más famosos sitios de la antigüedad fueron el de Troya, Tiro, Alexia y Numancia, y entre los modernos el de Ostende, Candia y Grave. // Además, muchísima información en Sanz (1749) sobre los sitios de plazas, fortalezas, ciudades, etc.

alzar el $\sim$ [Rojas, Compendio fortificación, 1613]. loc. v. Fort. Apartarse, desistir del sitio, asedio o cerco de un lugar fortificado.

Rojas, Compendio fortificación, 1613, fol. 32r: Y viendo que avía perdido lo mejor de su gente y que en la ciudad avía aquel valeroso defensor d'ella, alzó el sitio y se fue.

SIN.: alzar el cerco, levantar el asedio, levantar el cerco, levantar el sitio.

ANT.: asediar, asitiar, cercar, meter (el) asedio, poner asedio, poner (el) cerco, poner (el) sitio, sitiar.

levantar el [Mendoça, Theórica y práctica, 1596]. loc. v. Fort. Apartarse, desistir del sitio, asedio o cerco de un lugar fortificado.

Mendoça, Theórica y práctica, 1596, pág. 108: Ofreciéndose el aver de levantar el sitio por motines de la gente, faltándole pagas, ruynes temporales que acaban un exército, o por rezelo del aver reforçado el enemigo y disminuydo las fuerças propias, y otras muchas consideraciones que puedan obligar a ello, se entiende lo primero en retirar la artillería y municiones, encaminándola, y el bagaje, según las nuevas que se tienen del enemigo. // Mendoça, Theórica y práctica, 1596, pág. 109: No he apuntado a Vuestra Alteza, en caso que el enemigo caminasse con exército poderoso para hazer levantar el sitio, en la manera que Vuestra Alteza se ha de governar, por ser necessario hazerlo, según lo que estimaren más conveniente los capitanes y consejeros que Vuestra Alteza tiene en él y el número de la gente del exército y estado en que se halla.

SIN.: alzar el cerco, alzar el sitio, levantar el asedio, levantar el cerco.

ANT.: asediar, asitiar, cercar, meter (el) asedio, poner asedio, poner (el) cerco, poner (el) sitio, sitiar.

ENCICL.: DRAE: fr. Desistir del de una plaza o fortaleza sitiadas.

poner $\sim$, o poner el $\sim$ [Montes, Instrucción y regimiento, 1537]. loc. v. Fort. Establecerse en torno a un lugar fortificado para impedir que los que están dentro puedan salir o recibir ayuda, con el fin de obligarlos a rendirse.

Montes, Instrucción y regimiento, 1537, fol. IXr: Y embiole a dezir con un trompeta que rendiesse la ciudad y le dexasse la artillería y se fuesse, si no, que le pornía sitio y que no le tomarían después a partido. // Mendoça, Theórica y práctica, 1596, pág. 89: La relación d'esta información que darán las personas pláticas o naturales de la tierra significará Vuestra Alteza a sus consejeros para tomar ultimada resolución en la manera que se ha de poner el sitio, siguiendo con mucha puntualidad su opinión y parecer, por ser una de las 
facciones de guerra, el sitiar plaça, que pide mucha consideración. // Juanelo Turriano, Veinte y un libros, a. 1605, fol. 93r: La segunda manera ha sido inventada de los que ponen sitio sobre las ciudades para tomarlas a fuerça de armas. De modo que esta segunda ha sido inventada por gente de guerra para poder minar las murallas de las ciudades $y$, con mucha cantidad de pólvora, dándoles fuego, que por ello caygan los muros de las ciudades y con más facilidad tomarlas.

SIN.: asediar, asitiar, cercar, meter (el) asedio, poner asedio, poner (el) cerco, sitiar.

ANT.: alzar el cerco, alzar el sitio, levantar el asedio, levantar el cerco, levantar el sitio.

ENCICL.: DRAE (s.v. poner ): fr. Sitiar, asediar.

sobreronda, V. sobrerronda.

sobrerronda, sobreronda [de ronda. Mendoça, Theórica y práctica, 1596]. sust. Mil. Recorrido inverso al de la ronda ordinaria, para asegurar y confirmar más la vigilancia de los puestos.

Mendoça, Theórica y práctica, 1596, pág. 128-129: Siendo tierra donde no ay guarnición ordinaria, al entrar la cabeça con la gente que la ha de guardar, convendrá que reconozca todo el circuyto d'ella de dentro y fuera; el fosso, si es seco o tiene agua en algunas partes d'él o por todas; qué compostura de murallas, para señalar los puestos donde se han de poner los cuerpos de guardia y centinelas de día y de noche, afirmando un cuerpo de guardia, dos o más, principal en medio de la villa o plaça para socorrer a los demás; la forma de rondas, sobrerondas o contrarondas, que se han de aumentar o disminuyr, según el recelo y sospechas que se tiene del enemigo.

SIN.: contrarronda.

ANT.: ronda 2 .

FAM.: contrarronda, ronda, rondar.

ENCICL.: Rubió y Bellvé (1895-1901): Contrarronda.

2 [Collado, Plática Artillería, 1592]. sust. Mil. Grupo de soldados encargado de hacer la sobrerronda o contrarronda.

Collado, Plática Artillería, 1592, fol. 97v: Tornando al razonamiento de la buena guardia de el artillería, digo que el general deve de hordenar que las rondas y sobrerondas, y otras centinelas secretas, diputadas a la guardia de la artillería, todas se redoblen en la noche, según que el caso y necessidad se offresciere. // Mosquera, Comentario disciplina militar, 1596, fol. 29r: De noche no rondan los franceses, sino los portugueses, de los quales entran 
tres compañías de guardia, que ocupan las dos fortalezas que están dentro de la ciudad, y las sobrerondas son también portugueses de a pie y de a cavallo.

ANT.: ronda $a_{3}$.

sobrevela, sobrevela [de vela. Celso, Reportorio universal leyes Castilla, 1553]. sust. f. Mil. Segunda vela, la cual desempeña su función sólo algunas noches, para mayor seguridad.

Celso, Reportorio universal leyes Castilla, 1553, fol. CCXXIIIv: Montarazes, llaman a las velas e sobrevelas que tienen los alcaydes en los castillos.

FAM.: vela, velar.

ENCICL.: Gago-Jover (2002): Segunda vela que suele ponerse para más seguridad.

socorrer, socorrer [del lat. succŭrrō, -ĕre 'correr debajo, pasar por debajo', de sub y cŭrrō. 1323 (Segura Munguía 2007). Fernández de Enciso, Suma de Geographía, 1530]. v. tr. Mil. Dicho de un soldado o de alguien que interviene en un combate: acudir en auxilio de otra persona de su bando que lo necesita.

Fernández de Enciso, Suma de Geographía, 1530, fol. LVIIIv: En esta provincia es a do Alexandre entró solo en la cibdad por cima del muro e adonde fue ferido malamente e mató tres hombres; y estando assí, ferido e arrodeado de los sudracas, e teniendo tres d'ellos muertos a los pies y él ya sin fuerças, le socorrieron los suyos, que entraron con escalas e algunos horadaron la cerca por do entraron. // García de Palacio, Diálogos militares, 1583, fol. 145r-145v: Tenían, pues, los romanos, para formar y hazer sus batallas, en cada esquadrón, por la frente, tres maneras de hombres escogidos, que se llamaron hastarios o lanceros, príncipes y triarios; en la rectaguardia, ponían otras órdenes de hombres armados con escudos y espadas, que llamavan de armas pesadas; $\mathrm{y}$, a los lados, la cavallería, para que, travada la batalla, socorriessen la parte más nescessitada. / / Álaba, Perfeto capitán, 1590, fol. 129r: Y llevavan dos espadas quando avían de pelear con gente de a cavallo, y ésta estava muy diestra en apearse a socorrer la de a pie.

FAM.: socorro.

2 [Celso, Reportorio universal leyes Castilla, 1553]. v. tr. Fort. Proporcionar a un lugar fortificado o a las personas que están dentro todo lo que necesitan, por ejemplo víveres, pertrechos o soldados, para poder seguir soportando el sitio que sufren.

Celso, Reportorio universal leyes Castilla, 1553, fol. LIXv: Y, assimesmo, los del pueblo los deven socorrer, mayormente siendo castillos en que los enemigos se pueden hazer fuertes para guerrear al Rey o al reyno. // Collado, Plática Artillería, 1592, fol. 77r: El modo de acrescentar con la orina el salitre dicho se puede usar en una ciudad o fortaleza sitiada donde huviesse temor de que, a largo andar, vendría a acabarse la pólvora y no hoviesse esperança de ser tan presto socorrida. // González de Medina, Examen fortificación, 1599, 
pág. 12: La bondad o calidades que tiene, Señor, la fuerça puesta a la marina son todas las que tienen las que están en llano y, más, que le es impossible al enemigo sitiarla de manera que no sea socorrida de todo lo necessario, assí de gente de guerra como de municiones y vituallas, porque, para sitiarla por parte de la mar, ha menester el enemigo muy grande armada, superior a la que el príncipe, cuya es la fuerça, pueda tener.

ENCICL.: Aut. (s.v. socorrer la plaza): Frase que vale entrarla algún socorro de soldados o víveres cuando está asediada o sitiada. // Sanz (1749: s.v. socorrer una plaza): Es hacer levantar el sitio a un ejército que la ataca. El socorro que se debe dar a una plaza sitiada consiste en hombres, municiones y víveres [...]. El mejor modo de socorrer una plaza es con un buen ejército, para combatir con él al de los sitiadores en cualquier modo que estuviese apostado, a fin de obligarlo a levantar el sitio. Si el que sitia saliere de sus líneas para ir a encontrar a los que quieren entrar el socorro y durante la acción se lograse ocasión, con la mayor prontitud se deben hacer entrar en la plaza todas las tropas y socorros que sea posible, pues no se puede saber con certitud por quién quedará la victoria. Esta acción debe estar ya concertada con el gobernador de la plaza, por medio de algunas espías, a fin que en el espacio de tiempo que dura la acción, pueda hacer por su parte todos los esfuerzos posibles para lograrlo y hacer una vigorosa defensa [...].

socorro, socorro [de socorrer. Gral. Est. II (aunque lo normal en este texto y en la 1. ${ }^{a}$ Crón. Gral. es acorrer); Mena; APal. (DECH). Montes, Instrucción y regimiento, 1537]. sust. Mil. En una batalla, acción de unirse o de acudir en ayuda de cualquier amigo que lo necesita.

Montes, Instrucción y regimiento, 1537, fol. VIIIr: E un soldado que se llamava Contreras el tuerto [...] arremetió a la puerta con una espada y una rodela, y otro que se llamava Alborado, con una pica, y començaron a pelear con los moros que estavan delante la puerta en su esquadrón y, a la bozería, fueron otros soldados al socorro, porque no los matassen. // Álaba, Perfeto capitán, 1590, fol. 1v-2r: Y los griegos, yendo a socorrer al rey Cyro contra Artaxerxes, vencieron en un rencuentro que tuvieron con los bárbaros, cien mil d'ellos, siendo el número de los que fueron a este socorro solos catorze mil, acompañados del favor de la ciencia militar, que de tanta importancia les fue. // Roxas, Sumario milicia, 1607, fol. 67r: Adbirtiendo que el que llebare la abanguardia a de caminar con tanta orden que jamás pierda de bista la retaguardia y el bagaje, por si fuere necesario socorrerlo, y que se pueda haçer el socorro a tiempo que no sea perdido o desbaratado.

FAM.: socorrer.

ENCICL.: DUE: Acción de socorrer. // DRAE (1884): En la guerra, incorporación de soldados a la tropa o presidio que padece riesgo. // Rodríguez Navas (1918): Mil. y Mar. Agregación, llegada de tropas o buques a punto donde hay riesgo en la batalla o asedio.

2 [García de Palacio, Diálogos militares, 1583]. sust. Mil. Tropa que acude en auxilio de otra (DRAE). 
García de Palacio, Diálogos militares, 1583, fol. 76v: Y nuestro invicto emperador Carlos Quinto, de gloriosa memoria, en la guerra que en Alemania hizo a los lutheranos, hallándose al principio con poco número de soldados, porque aún no avían llegado los socorros de Italia y Flandes, tuvo tanta prudencia que, dilatándose y entreteniéndose en los fuertes, desmembró el campo de Lanzgrave. // Álaba, Perfeto capitán, 1590, fol. 61r: Y no será ardid de poca importancia, después de aver dado a entender al enemigo que se espera socorro, poner algunos soldados en emboscada con orden que quando estuviere començada la batalla, luego que les fuere hecha la seña concertada, acudan para que los enemigos, viéndolos venir sobre ellos de repente, juzgando que les a venido el socorro que esperavan, se acovarden y descompongan. // Álaba, Perfeto capitán, 1590, fol. 66r: Y si [...] al capitán, le viniere el socorro que pedía y quisiere aprovecharse d'él sin que los enemigos conozcan aumento de gente en su campo para poderlos con más comodidad ofender, cogiéndolos descuydados y ignorantes, es necessario que esté advertido de no consentir que el sitio que ocupa su exército se alargue ni se armen nuevas tiendas, ni muestren vanderas, ni se haga otra cosa alguna que pueda causar novedad.

SIN.: gente de socorro.

ENCICL.: DUE: Fuerzas militares que acuden a reforzar a otras.

3 [Álaba, Perfeto capitán, 1590]. sust. Fort. Acción de proporcionar a un lugar fortificado o a las personas que están dentro lo que necesitan para seguir soportando el sitio que sufren.

Álaba, Perfeto capitán, 1590, fol. 94r: También será medio no de poca importancia para obligar a dexar el cerco hazer que los capitanes amigos o la persona de quien espera socorro acuda a cercar otro lugar de los enemigos, para que, viéndose acossados, los cercados pidan favor a los que a él le tenían cercado y, acudiendo a darle, lo dexen libre. // Mendoça, Theórica y práctica, 1596, pág. 139-140: Al labrar el enemigo las trincheas y plantar la batería, no se puede dezir Vuestra Alteza en la manera que se ha de dañar, por averse de hazer [...] según la disposición de los fossos, murallas y defensas que ay, tirando de ordinario d'ellas a las trincheas con los arcabuzes y mosquetes, y grande vigilancia en descubrir cómo caminan con las trincheas, apressurando o no las salidas según la gente que se tuviere y esperança del socorro. // Rojas, Teórica fortificación, 1598, fol. 48v: Y puesto pie el enemigo por aquella parte, se irá derecho a la ciudad y, por estar abierta, se meterá en ella, y desde allí se irá arrimando al castillo, que, como dicho es, se supone estar a la parte de tierra, y assí, conforme a esto, estaría cortado el socorro al dicho castillo, y en breve tiempo, assí por la parte de tierra como desde la ciudad, lo ganaría el enemigo.

ENCICL.: Almirante (1869): Aunque el sentido vulgar sea de auxilio y ayuda, en la guerra es casi técnico y exclusivo de una plaza sitiada y fuertemente estrechada. // Moretti (1828): Auxilio que recibe una plaza que se halla bloqueada o sitiada y próxima a entregarse. Consiste en municiones y víveres, y algunas veces en fuerza armada.

4 [Celso, Reportorio universal leyes Castilla, 1553]. sust. Fort. Soldados, víveres, pertrechos $u$ otras cosas con las que se socorre una plaza sitiada. 
Celso, Reportorio universal leyes Castilla, 1553, fol. CXXXVIv: Deven poner la gente donde pueda hazer más mal a los cercados, guardándoles las puertas y passos por donde les puede venir socorro de gente o de bastimentos, y por donde ellos puedan entrar en la hueste a hazerles daño o escaramuçarles. // Loçano, Alberto, Architectura, 1582, pág. 127: Conviene que del todo tenga la fortaleza dessembaraçadas salidas, por donde pueda acometer a los enemigos y a los ciudadanos y a los suyos del castillo, si algún alboroto o trayción lo demande, y pueda pedir y meter socorros suyos y agenos libremente, por tierra, río, lago y mar. / / Collado, Plática Artillería, 1592, fol. 53v: La diligencia y presteza del buen artillero ha de ser tanta que al romper del alva tenga ya plantada y puesta a punto su batería y comiençe a saludar con ella la fortaleza enemiga, por quanto que es la cosa que más importa, assí para quitarles la comodidad de poderse reparar de dentro como para romper su designio de poderles entrar socorro.

ENCICL.: DUE: Cosa con que se socorre. / Provisiones que se llevan a una fuerza militar; por ejemplo, a una plaza sitiada.

socorro, V. gente de .

socorro, V. hombre de .

socorro, V. puerta del $\sim$.

sojusgar, V. sojuzgar.

sojuzgado, sojuzgado [de sojuzgar. Fernández de Enciso, Suma de Geographía, 1530]. adj. Mil. Dicho de un individuo o de un territorio: colocado bajo el dominio o el poder de alguien.

Fernández de Enciso, Suma de Geographía, 1530, fol. LXIIIv: Esta isla de la Trinidad tiene de longitud veynte e cinco leguas, e otras tantas de latitud. Está en ocho grados. Está poblada de mucha gente, pero no está sojuzgada.

SIN.: doméstico, sujetado, sujeto . $_{\text {. }}$

FAM.: sojuzgar.

sojuzgar, sojusgar, sojuzgar [del lat. sŭbjŭgare 'íd.', con -z- por influjo de juzgar (judicare). Sujuzgar, 3. ${ }^{\mathrm{r}}$ cuarto s. XIII, Fn. Gonz.; sujudgar, Rim. de Palacio, 1462; sojudgar, -djar, Gower, Conf. del Amante; sujuzgar "subjicio, subjugo" Nebr. (DECH). 
Álaba, Perfeto capitán, 1590]. v. tr. Divisar desde una altura determinadas cosas, como una extensión de terreno o las personas que se encuentran allí.

Álaba, Perfeto capitán, 1590, fol. 74r: El que está en lo alto señorea y sojuzga mejor al enemigo y, peleando con igualdad de armas, alcança más para poderle herir. // Rojas, Teórica fortificación, 1598, fol. 69r: Y quando la tal plaça se hiziesse en algún sitio alto, en tal caso bastará de 20 a 25 pies de alto la muralla, que como ya queda dicho en el discurso primero, el sitio es el que haze el caso en esta materia, y assí el curioso ingeniero tendrá por regla general tener su fortificación tan eminente sobre la campaña, que el enemigo no la pueda sojuzgar. // Roxas, Sumario milicia, 1607, fol. 46r: Las dichas torres se llaman unas máquinas de madera sobre ruedas para sojuzgar la muralla desde afuera.

SIN.: descubrir 2 , señorear 2 .

FAM.: sojuzgado.

2 [Fernández de Enciso, Suma de Geographía, 1530]. v. tr. Mil. Poner una persona bajo su poder a individuos o territorios.

Fernández de Enciso, Suma de Geographía, 1530, fol. XXIVv: E después que España tomó rey natural de su tierra, nunca más fue sojuzgada de griegos ni de romanos, ni de africanos ni de otra ninguna nación, antes los de España han señoreado a otras naciones con ayuda del apóstol Santiago, su patrón. // Fernández de Enciso, Suma de Geographía, 1530, fol. XXXIXv: Estas gentes de los arrios e batrianos señorearon mucho tiempo a las Indias e a otras muchas provincias, en especial en el tiempo de Menánder, rey de los arrios e sodianos. Este Menánder y el hijo del rey de los batrianos tomaron toda la India e a Patalena, e passaron al Ganges e sojuzgaron la tierra fasta a los seras e paunos, que son al fin de la India. // Collado, Plática Artillería, 1592, fol. 1v: De aquéllos en sólo este emispherio se estendió su señorío, pero vos, Señor, del Ártico Polo al Artárctico todo lo havéys sojuzgado y a la santa fe de Christo reduzido.

SIN.: allanar, domar, domeñar, domesticar, señorear, someter, sujetar 1.

ENCICL.: Cov.: Vale sujetar, casi subiugar, poner debajo de yugo. // Terr.: Vencer, domar, dominar.

3 [Micón, Diario grande cometa, 1578]. v. tr. Mil. Poner una persona bajo su poder, de manera violenta, a individuos o territorios, y tratarlos con despotismo.

Micón, Diario grande cometa, 1578, pág. 105: Como aconteció en semejante coyuntura, año de 1538, del cometa que apareció en Pisces [...], a donde passó el segundo año después de Carlos 5, de gloriosa memoria, sojusgando a la rebellada ciudad de Gante y prendiendo a las cabeças de los que avían sido la causa del motín, quitándoles por ello privilegios y libertades muchas. // Mosquera, Comentario disciplina militar, 1596, fol. 56v-57r: Y Julio César refiere que en el pago Tigurino, donde fue muerto Lucio Cassio, cónsul, allí fue sojuzgado el exército debaxo de yugo, pero no de la suerte ni con las circunstancias con que aquí se hizo, con afrenta pública, con palabras y pregones llenos de inhumanidad y desacato contra Su Magestad y de monstruosa crueldad. // Mosquera, Comentario 
disciplina militar, 1596, fol. 137r: Y le sucedió tan bien como a Roma, que viendo que los cónsules usavan duramente contra el pueblo de aquel rigor de las desnudas leyes, como personas a quien les era concedido por el pueblo la suprema potestad, y que con esta rigurosa puntualidad se ponían a riesgo las haziendas y el sossiego de los ciudadanos, y que bivían sojuzgados de los poderosos, queriendo sacar a los hombres de las manos d'esta tyranía o (por mejor dezir) d'esta suma injuria, para remedio d'esto criaron pretor o governador.

SIN.: oprimir.

ENCICL.: Moretti (1828): Sujetar, dominar y mandar a otro con violencia. Dícese cuando un general conquistador sujeta a los pueblos conquistados con demasiado rigor y sin miramiento.

soldadesca, soldadesca [de soldado. 1596, Aut. (DECH). Álaba, Perfeto capitán, 1590]. sust. Profesión que ejercen los militares o soldados.

Álaba, Perfeto capitán, 1590, fol. 34v: Y en otro caso no hallo por qué devan ser escluydos los que professan otros oficios, pues puede aver en ellos hombres de importancia para professar la soldadesca. // González de Medina, Examen fortificación, 1599, pág. XI: La nación española ha tratado muy poco d'ello, por injustamente no la aver estimado ni tenido en lo que merece, aviendo siempre andado esta manera de soldadesca y professión en estrangeros, y servídose d'ellos en todas las ocasiones que se han ofrecido. // Rojas, Compendio fortificación, 1613, fol. 6r-6v: Tres cosas son muy necessarias para esta materia: la principal es reconocer el sitio donde se ha de hazer la tal fortificación, considerando bien los enemigos que les pueden venir a sitiar, porque, si son turcos, ya se sabe que baten con gruessa artillería, y, si son flamencos o ingleses, çapan las murallas y hazen minas, y, si son moros baharíes, no son tan belicosos como los enemigos dichos, pero en buena soldadesca será bien apercebirse contra todos.

SIN.: milicia $_{2}$.

FAM.: soldadesco, soldado.

soldadesca, V. hombre de $\sim$.

soldadesco, soldadesco [de soldado. Princ. s. XVII, Aut. (DECH). Mosquera, Comentario disciplina militar, 1596]. adj. De los soldados o que tiene relación con ellos (DESAL).

Mosquera, Comentario disciplina militar, 1596, fol. 96r: Passaron los atambores, y assimismo yvan entregando sus caxas ya sordas y destempladas, con los pífaros, con todos los demás instrumentos que dexavan en manos de los nuestros, y desarmándolos uno por uno de sus mosquetes, arcabuzes, picas y alabardas y de todas armas, se apartaron despojados de 
toda la gloria soldadesca y, casi desconocidos, por estar desautorizados y carecer del ornamento de sus personas, quedaron en una profunda tristeza.

FAM.: soldadesca, soldado.

soldado, soldado [del it. soldato (s. XIV), que pasó también al francés y demás lenguas europeas. 1463, Juan de Lucena con referencia a Sicilia; "soldado: mercenarius stipendiatus" Nebr.; todavía evita usarlo Boscán, h. 1530, en su versión de Castiglione (DECH). Montes, Instrucción y regimiento, 1537]. sust. Persona que pertenece al ejército o que está especializada en hacer la guerra.

Montes, Instrucción y regimiento, 1537, fol. XIVr: El día de la batalla se haze cuerpo en el escuadrón de infantería, donde fueren los soldados más pláticos en la guerra, porque en ellos está aquel día la fortaleza del exército y ellos han de affrontar los primeros, después que los cavalleros hovieren afrontado, y en ellos se espera la vitoria y, por aquella honra tan grande que se les da, son obligados a morir o vencer los tales soldados pláticos por la vitoria que d'ellos se espera aquel día. // Rojas, Teórica fortificación, 1598, fol. 36v: Si se hiziere la fortaleza en un lago, que esté rodeado de agua, también será sitio fuerte, aunque no es saludable para los soldados; mas si se hiziere la tal fortaleza en un islote dentro en la mar, a donde no le pueden batir, ni meter trincheas ni minas, esta tal se guardará con menos gente que todas las demás. // Lechuga, Discurso de la Artillería, 1611, pág. 216: Si el capitán general resuelve que la fuerza que sitia la quiere tomar sin el peligro de assalto, la artillería a de servir de quitar defensas, traveses y quanto pudiere impedir que los soldados puedan recevir daño, haziendo que refuerzen los sitiados los parapetos.

SIN.: defensor, guerrero ${ }_{2}$, hombre, hombre de (la) guerra, hombre de pelea, hombre de soldadesca, hombre militar, militar ${ }_{2}^{2}$, milite ${ }_{1}$.

FAM.: soldadesca, soldadesco.

ENCICL.: Sanz (1749): Generalmente significa todo hombre de guerra que sirve a pie y a caballo.

someter, someter [del lat. sŭbmŭttĕre 'íd.'. Berceo (DECH). Fernández de Enciso, Suma de Geographía, 1530]. v. tr. Mil. Poner una persona bajo su poder a individuos o territorios.

Fernández de Enciso, Suma de Geographía, 1530, fol. XXIVv: Y después se levantaron y revelaron los españoles contra Roma fasta que bolvió Cipión, el Africano, e la tornó a someter al Imperio Romano, e passó en África, y venció a Aníbal y destruyó a Cartago.

SIN.: allanar 3 , domar, domeñar, domesticar, señorear 3 , sojuzgar 2 , sujetar 1.

ENCICL.: Cov.: Es sujetar. 
sonar, V. a caballo.

sortida, V. surtida.

spalda, V. espalda.

spolonada, V. espolonada.

strella, V. estrella.

subjeción, V. sujeción.

subjectar, V. sujetar.

subjectión, V. sujeción.

subjecto, V. sujeto.

subjetar, V. sujetar.

subjeto, V. sujeto.

suelo, suelo [del lat. sŏlum 'base', 'fondo', 'suelo', 'tierra en que se vive'. Cid $(\mathrm{DECH})]$.

de $\sim$ [García de Palacio, Diálogos militares, 1583]. loc. adj. Mil. Dicho del orden de batalla cuadrado: que la extensión de terreno ocupada por cada una de sus dos alas es igual a la de la vanguardia o retaguardia.

García de Palacio, Diálogos militares, 1583, fol. 160v: ¿En qué forma se puede ordenar una batalla quadrada de suelo y no de infantes? // García de Palacio, Diálogos militares, 1583, fol. 161r: Imagínase, señor, una batalla de tres hileras de a siete infantes cada una, la qual es quadrada de suelo, a causa de que las tres hileras occupan veinte e un pies de largo y los siete infantes, a tres pies cada uno, piden, assimismo, veinte y uno de ancho. / / García de Palacio, Diálogos militares, 1583, fol. 171v: Y ésta es aún muy más apta a llevar entre los cuernos el carruaje o artillería y a pelear aventajadamente con los cuernos, 
guarnesciéndolos de los soldados escogidos, fuertes, animosos, diestros y bien armados, poniendo los no tales ni tan buenos en el esquadrón quadrado de suelo, que está en medio.

SIN.: de(l) terreno.

ANT.: de gente, de infantes.

suelo, V. de .

sugeción, V. sujeción.

sugetar, V. sujetar.

sugeto, V. sujeto.

sujeción, subjeción, subjectión, sugeción, sujeción [tomado del lat. subjectio 'íd.'. 1611 (DECH). Fernández de Enciso, Suma de Geographía, 1530]. sust. Mil. Colocación de personas o territorios bajo el dominio o el poder de alguien.

Fernández de Enciso, Suma de Geographía, 1530, fol. XXIVv: E assí ganó a toda España con ayuda de los españoles que lo llamaron y le ayudaron contra Gedeón e contra Caco por salir de su sugeción. // Álaba, Perfeto capitán, 1590, fol. 2r: Y el mesmo socorro de la diciplina y exercicio militar libró a los tebanos de la sujeción de los lacedemonios y hizo que los romanos, como dize Vegecio, sujetassen la multitud de los galos, el poder de los españoles, la grandeza de los alemanes, las riquezas y cautelas de los africanos y la prudencia y agudeza de los griegos, con ser su poder inferior al de todas estas naciones. // Mosquera, Comentario disciplina militar, 1596, fol. 135v: Y, passados los tres días del despojo, saliendo a luz algunos esclavos que estavan escondidos y se escaparon de ser presa de la gente de guerra, pretendieron sus señores tener recurso a ellos y reduzirlos al yugo de la passada sujeción y pusiéronlo por obra, sin acordarse que ellos mesmos les avían puesto las armas en las manos y con ellas la libertad.

sujecto, V. sujeto.

sujetado, sujetado [de sujetar. Mosquera, Comentario disciplina militar, 1596]. adj. Mil. Dicho de un individuo o de un territorio: colocado bajo el dominio o el poder de alguien. 
Mosquera, Comentario disciplina militar, 1596, fol. 96v: Y verdaderamente el ser vencido y sujeto se deve sentir mucho por el hombre, porque no sólo es suyo el gemir este justo dolor, pero las bestias, que carecen de razón natural y discurso humano, lo sienten, pues quando los elefantes entraron por Roma, en el despojo que se uvo contra Pirro, venían entre los esquadrones vencedores inclinadas las cabeças y las grandes trompas arrastrando, sintiendo ellos tristemente el captiverio de sus señores vencidos y sujetados.

SIN.: doméstico, sojuzgado, sujeto1.

FAM.: sujetar.

sujetar, subjectar, subjetar, sugetar, sujetar [tomado del lat. subjectare, frecuentativo de subjicere 'poner debajo'. Ya en el s. XVI, Fdo. de Herrera según el Vocab. de Kossof; 1611 (DECH). Celso, Reportorio universal leyes Castilla, 1553]. v. tr. Mil. Poner una persona bajo su poder a individuos o territorios.

García de Palacio, Diálogos militares, 1583, fol. 52r: Según Salustio, una de las principales causas, fuera de su gran virtud, por que los romanos vinieron a subjetar tantos reynos fue porque los ciudadanos peleavan a porfía sobre quál lo haría mejor o se mostraría más valeroso, para adquirir glorioso renombre y fama immortal. // Álaba, Perfeto capitán, 1590, fol. 92r-92v: Y esperando esta ocasión Aristipo, lacedemonio, en la guerra que traía con los tegeates, estando todos ocupados en celebrar la fiesta de Minerva, embió a la ciudad de Tegea los mejores soldados de su campo en ábito de labradores con muchas bestias cargadas de paja, los quales, entrando con este dissimulo dentro, abrieron las puertas del lugar y, viniendo de repente Aristipo, la cogió y sujetó a todos los que en ella avía. // Álaba, Perfeto capitán, 1590, fol. 144v: Y él mesmo, después de aver sujetado la Galia, queriendo passar a Italia, para dexar quieta aquella provincia recién conquistada, escogió por el mejor medio el mostrarse comedido, afable, liberal y humano con todos.

SIN.: allanar, domar, domeñar, domesticar, señorear, sojuzgar, someter.

FAM.: sujetado.

2 [García de Palacio, Diálogos militares, 1583]. v. prnl. Mil. Dicho de un grupo de personas o de un territorio: someterse o ponerse bajo el poder de alguien.

García de Palacio, Diálogos militares, 1583, fol. 68r-68v: Y en este particular era César vigilantíssimo y cuydadoso, de que sacó mucho fructo y escusó grandes daños a sí y a su gente, especial en lo que refiere de un asalto y repentino acometimiento que los burgueses hizieron, los quales, rebatidos por las buenas guardas y velas que tenía, desesperaron de poderse defender de un capitán tan cuydadoso y se le rindieron y subjetaron. // Álaba, Perfeto capitán, 1590, fol. 35v: De los tarentinos se lee que, apretados de los malos tratamientos de los romanos que estavan en su ciudad, los echaron d'ella, teniendo por mejor sujetarse al poder de Aníbal, a quien tenían por capital enemigo, que sufrir el ser oprimidos de sus amigos. // Roxas, Sumario milicia, 1607, fol. 14r: Porque de verdad no ay cossa más firme ni más loable a la república que haver en ella soldados diestros, que ni el 
resplandor de las vestiduras ni la copia de la plata y oro o piedras preçiosas inclinan a los enemigos a nuestra obediençia o amistad, antes con sólo el espanto de las armas bienen a sugetarse.

SIN.: señorear.

ENCICL.: Terr. (s.v. sujetarse): Rendirse, someterse [...]. V. Obedecer, rendirse, ceder, conformarse.

sujeto, subjecto, subjeto, sugeto, sujecto, sujeto [tomado del lat. subjectus, -tum 'sometido', 'sujeto', participio de subjicere 'poner debajo'. APal., como sustantivo y como adj.; sobjeto adj., s. XV, Biblia med. rom., Gén. (DECH). Loçano, Alberto, Architectura, 1582]. adj. Mil. Dicho de un individuo o de un territorio: colocado bajo el dominio o el poder de alguien.

Loçano, Alberto, Architectura, 1582, pág. 138: Dezía Xenophón que con el mudar de los alojamientos se hazía daño a los enemigos y se ayudava a los proprios. Y, sin duda, es cosa honrada y de valientes hollar las cosas agenas, aunque para commodidad y seguridad aprovechará recogerse en su proprio suelo. Pero ordenémoslo de suerte que presupongamos que los alojamientos se han con toda la región que les está subjecta y obedece. // García de Palacio, Diálogos militares, 1583, fol. 88r: Pues no es menos virtud conservar lo ganado que conquistallo, ¿qué guarniciones se deve poner en la ciudad subjeta para que se quiete y sossiegue y el nuevo señorío permanezca en ella?// Álaba, Perfeto capitán, 1590, fol. 83r: Y porque la razón y larga esperiencia enseña la dificultad con que se tiene en sujeción la gente nuevamente puesta en ella, conviene que en el cuydado sea tratada como enemiga, poniendo guarnición a las ciudades y provincias sujetas.

SIN.: doméstico, sojuzgado, sujetado.

ENCICL.: Aut.: Segundo participio del verbo sujetar, y más conforme a su origen.

2 [García de Palacio, Diálogos militares, 1583]. sust. Mil. Persona colocada bajo el poder de alguien.

García de Palacio, Diálogos militares, 1583, fol. 88v: Y que los tengan siempre proveýdos y bastecidos de las municiones y bastimentos que, para conservar qualquier ciudad rendida con un largo cerco, son nescessarios para que, por falta de todo ello o parte, los vencedores no sean constreñidos a dexar la plaça y los subjetos puedan alcançar la libertad que pretenden. / / García de Palacio, Diálogos militares, 1583, fol. 89v: Y, assí, si los subjetos se rebellaren y convocaren contra el príncipe victorioso, razonable será perdonalles su desconcierto con alguna coloreada occasión, una y aun dos vezes, si el hecho lo puede suffrir. // Álaba, Perfeto capitán, 1590, fol. 144r-144v: Y el que puede ser de más importancia para sossegar estas voluntades dañadas y hazer de enemigos amigos, es no hazerles malos tratamientos en sus personas, hiriendo o matando algunos d'ellos, ni deshonrándoles las mujeres o hijas o profanando los lugares sagrados, [...], antes, con 
buenas y suaves razones, acariciándolos con trato no de sujetos y rendidos, guardándoles las capitulaciones y conciertos que con ellos se huvieren hecho [...].

\section{superior, V. plaza .}

surtida, sortida, surtida [del fr. sortie. Surtida 'salida de los sitiados', 'paso secreto para salir de una plaza'. Ya en autores del s. XVII (Aut.) (DECH). Rojas, Teórica fortificación, 1598]. sust. Fort. Durante el sitio de una fortaleza, acción ofensiva y defensiva que realiza un grupo de sitiados, la cual consiste en desplazarse generalmente hasta el foso o hasta la estrada cubierta para, además de atacar a los sitiadores, tratar de impedir sus trabajos de aproche.

Rojas, Teórica fortificación, 1598, fol. 3r: Y, fuera de todo esto, saber qué es la contramina y las puertas que sirven de surtidas al fosso, y qué son tenazas, y dientes, y tixeras [...], las quales se suelen hazer fuera del fosso, dándose la mano con algún padrastro o fuerte. // González de Medina, Examen fortificación, 1599, pág. 168: Maestro, no avéys tratado por dónde han de ser las surtidas para la estrada cubierta y cómo se ha de subir a ella. Dezídmelo, pues es de sustancia. // Lechuga, Discurso de la Artillería, 1611, pág. 175: Al contrario, daría esto grande utilidad a la plaça, porque de noche se podrían desencavalgar las pieças de la batería, tirar a las trincheras, estorvar que no se hiziessen plataformas y otras semejantes máchinas, favorecer las surtidas secretas, y también aprovecharía a los exércitos en campaña para desaloxarse de noche el uno al otro.

SIN.: salida 1 .

ENCICL.: DRAE: Salida oculta que hacen los sitiados contra los sitiadores. / González de Medina, Examen fortificación (1599: pág. 168-169): "Las salidas o surtidas, que dezís, a la estrada cubierta y al foso para defenderlo y estorvar a los enemigos que no se lleguen, para no ser sentidos ni vistos (pues importa tanto), han de ser por las casas matas, y en los fosos sin agua, las escaleras pegadas con los orejones de la parte de dentro, que estarán harto encubiertas al enemigo; y si no se quisieren de aquella manera, por no aver de tenerlas aun en tiempo de paz con recato, se podrán hazer de dos vigas quajadas de tablones, con unas cintas de madera, con bordes para que no se vayan los pies. Y si fuere con agua, sobre botas bacías entablar encima, haziendo una plancha, que venga a dar en ella la baxada; y con una maroma assida a la estrada cubierta, tirando d'ella, allegarán la plancha con cien hombres y más a las escaleras que ha de tener el foso por la parte de adentro, a la contraescarpe".

2 [Rojas, Teórica fortificación, 1598]. sust. Fort. Paso o puerta que atraviesan los sitiados para poder llevar a cabo, durante un sitio, una salida u ofensiva contra los sitiadores.

Rojas, Teórica fortificación, 1598, fol. 73r: Se hará en cada casamata, digo por el lado del orejón que pega con la boca de la casamata, una puerta pequeña, de 5 pies de ancho y 7 de alto, que servirá de surtida para hazer salidas al fosso y a la estrada cubierta. / / González 
de Medina, Examen fortificación, 1599, pág. 40-41: Dirase que es sujeto a minas, para lo qual se hazen las contraminas; que se podrá henchir y cegar con fagina y madera, tierra y piedra: la madera y fagina se podrá muy bien quemar con fuegos artificiales, que ay mucha diversidad d'ellos; si fuere con tierra o piedras, por las surtidas se le podrá yr quitando de día lo que fuere echando de noche, y podrá servir dentro de mucho para nuevos reparos. // Lechuga, Discurso de la Artillería, 1611, pág. 241: En cada través an de tener una sortida çerrada y terraplenada, hasta la ocasión, con la entrada por el baluarte.

SIN.: salida 2.

ENCICL.: Terr.: En la fortificación, paso o puerta por debajo del terraplén para salir al foso y campo y dar sobre las obras de los sitiadores.

3 [Ferrofino, Descrizión Artillería, 1599]. sust. Fort. Camino o pasaje subterráneo que comunica una casamata con otra.

Ferrofino, Descrizión Artillería, 1599, fol. 170v: Ancho de la surtida de una casa mata a otra, 13 pies. // Rojas, Compendio fortificación, 1613, fol. 35v: Que [...] considere el tal ingeniero lo que deve hazer conforme al discurso que hasta aquí ha corrido, teniendo siempre por blanco la fortaleza de la fábrica y la comodidad para pelear, no haziendo retiradas, sino que los soldados las vayan haziendo palmo a palmo quando fuesen perdiendo la plaza, acordándose que de una casamata a la otra se suele hazer una surtida que sirve de mina maestra, y por allí se puede defender de la mina del enemigo.

sustento, V. munición del . 
talayar, talayar [de atalaya, con posible influencia del cat. talaiar. Atalayar, Partidas (DECH). Juanelo Turriano, Veinte y un libros, a. 1605]. v. tr. Mil. Registrar el campo o el mar desde una atalaya o altura, para dar aviso de lo que se descubre (DRAE: s.v. atalayar).

Juanelo Turriano, Veinte y un libros, a. 1605, fol. 439v: La nave que va dibuxada va con tres timones, A B C. Las gabias sirven para talayar los enemigos y defenderse.

FAM.: atalaya, atalayador.

tenaça, V. tenaza.

tenaçante, V. tenazante.

tenaçón, V. tenazón.

tenasante, $V$. tenazante.

tenaza, tenaça, tenaza [alteración (a causa del género) de un más antiguo tenazes y éste del b. lat. hispánico tenāces 'íd.', abreviación de forcipes tenaces 'tenazas 
resistentes, pertinaces', expresión que con el carácter de epíteto emplea Virgilio. Berceo; Juan Ruiz; Nebrija, etc. (DECH). Pérez Vargas, De re metallica, 1568]. sust. u. $\mathrm{m}$. en pl. con el mismo significado que en sing. Herramienta metálica formada por dos brazos unidos por un eje que permite abrirlos y cerrarlos para sujetar, arrancar o apretar una cosa (DSAL). 13 (fig. 143)

Mendoça, Theórica y práctica, 1596, pág. 155: Ganadas las murallas, caminarán a la puerta más vezina de la parte donde se diere la escalada, teniendo consigo tenazas, limas, martillos, pies de cabra y otros instrumentos para abrir puertas, negocio que se ha de hazer con diligencia para que pueda entrar en la tierra la cavallería o infantería que para este efecto huviere sido de retaguardia de todos y quedádose en esquadrón en la campaña. // Lechuga, Discurso de la Artillería, 1611, pág. 188: Quantidad de martillos azerados y de tenazas y barrenas, grandes y pequeñas. // Ufano, Tratado de la Artillería, 1613, pág. 278: O bien servirá la dicha ynvençión para, arrimada a una ventana de una torre o casa fuerte, con el tenaçante, tenaças, maço y hachuela romper sus guardaportes y enrexamientos y, abierta totalmente, entrar dentro la gente que vastare a ganarla o saquearla.

FAM.: tenazante, tenazón.

ENCICL.: Almirante (1869): Tenazas. En los talleres de artillería e ingenieros hay varios útiles con este nombre.

2 [Mendoça, Theórica y práctica, 1596]. sust. Fort. Cualquier cara o lado de una fortaleza que conste de una cortina y de dos medios baluartes, o de dos puntas y un ángulo entrante en el centro.

Mendoça, Theórica y práctica, 1596, pág. 125-126: Assimismo se ha de advertir si la plaça está fortificada, siendo frontera, o se ha de fortificar de nuevo y en qué manera ha de ser, governándose en esto, según el tiempo que diere el enemigo para ello, con ingenieros y personas que sepan qué es fortificación, por acontecer muchas vezes, queriendo fortificar alguna plaça, ayudándola con revelín, cavallero y bestión, tenaza o espolón, venirse a enflaquecer más por no estar bien entendidos y, assí, no sirven de reparo, sino de dar comodidad al enemigo para ofender mejor.

ANT.: espolón ${ }_{2}$.

ENCICL.: Terr.: Obra de fortificación, es la cara de la plaza compuesta de una cortina y de dos medios baluartes [...]. El ángulo de la tenaza es el que se forma por la interjección de las líneas que se formarían de las dos caras de los baluartes, si se prolongasen. // Almirante (1869): En lenguaje táctico designa genéricamente cualquier orden, disposición o formación de tropas en figura angular, cóncava, entrante, con el centro más retirado que las alas, para resistir al ataque inverso en cúneo y cuña, en embolon, en figura angular saliente, en punta. En fortificación, expresa, también genéricamente, la misma idea. Es la traza en ángulo entrante, rompiendo, o mejor tronzando, hacia dentro los lados del polígono exterior o envolvente. De ahí, línea, frente atenazado, de tenazas, de ángulos alternativamente entrantes y salientes [...]. 
3 [Rojas, Teórica fortificación, 1598]. sust. Fort. Obra exterior de una fortaleza con uno o dos ángulos retirados, que suele construirse sobre una altura o elevación del terreno.

Rojas, Teórica fortificación, 1598, fol. 3r: Y, fuera de todo esto, saber qué es la contramina y las puertas que sirven de surtidas al fosso, y qué son tenazas, y dientes, y tixeras [...], las quales se suelen hazer fuera del fosso, dándose la mano con algún padrastro o fuerte. // Roxas, Sumario milicia, 1607, fol. 80v: Las tenazas se hazen en lugar de las plataformas metidas en la muralla, y semejantemente se hazen en los sitios montuosos en alguna buelta que pueda hazer el balle, para dar la mano a un padrastro. // Roxas, Sumario milicia, 1607, fol. 84r: En todo lo demás de los caballeros [...], tenazas, tigeras, dientes, se guardará la medida que está dicho, pues todas son fortificaçión no real, porque sólo se hazen para darse la mano con algún padrastro o otra semejante; y se da liçençia que se crezca o diminuya según la neçesidad pidiere.

ENCICL.: Sanz (1749): Este nombre tiene muchos significados en la fortificación. La tenaza se distingue en simple y doble. Tenaza simple es una obra exterior, cuya cabeza se forma de dos frentes, que hacen un ángulo entrante, y las alas o costados van seguidas desde la cabeza a la gola. Tenaza doble es una obra exterior, que su frente o cabeza está compuesta de cuatro caras que forman dos ángulos entrantes y tres salientes y sus alas van seguidas desde la cabeza a la gola. Cuando las alas de esta obra son paralelas no se conoce por otro nombre que el de tenaza simple o doble; pero cuando por el frente son más anchas que por la gola, se llaman cola de golondrina. // Lucuze (1772: 54-55): "Las tenazas, así dobles como sencillas, son muy defectuosas por los ángulos entrantes o muertos de su frente, y nunca deben aplicarse en parte atacable. Sólo pueden servir sobre una eminencia de un pendiente rápido, de impracticable ataque [...]. También el uso propio de las tenazas es en obras de campaña, de tierra y fajina, para cubrir la cabeza de un puente, defender un importante paso o avenida sobre las líneas de un ejército atrincherado".

4 [Álaba, Perfeto capitán, 1590]. sust. Mil. Formación angular y cóncava, con el centro más retrasado que las alas, para envolver al enemigo o hacer frente al ataque en cúneo. (fig. 146)

Álaba, Perfeto capitán, 1590, fol. 118v: Como ninguna cosa ay que no tenga su contrario, imaginaron los antiguos una forma de esquadrón que pudiesse ser contraria a la cúnea, y ésta llamaron fórfice o tenaza, la qual se dispone con tal traça que, cogiendo a la otra en medio, la hiere por más partes que no es ofendida.

SIN.: fórfice, tijera 2 .

ENCICL.: Moretti (1828: formación de tenaza): Formación que usaron los antiguos para resistir al cúneo, y consistía en pasar desde el orden de batalla al de tenaza, en la forma siguiente: el centro o la batalla formaba un semicírculo angosto por su garganta; y las alas, apoyando los extremos de aquélla, se abrían a manera de una cola de golondrina, por lo que el enemigo que había formado el cúneo para romper la batalla del contrario, se veía obligado a entrar por las alas de aquél hasta llegar al frente que formaba el semicírculo, pasando 
precisamente por su garganta y teniendo que sufrir las armas arrojadizas que por frente y flancos le batían.

tenazante, tenaçante, tenasante, tenazante [de tenazar. Ufano, Tratado de la Artillería, 1613]. sust. m. Instrumento, semejante a unas tenazas, que sirve para romper barras de hierro, rejas, cadenas, etc. 5 (fig. 147)

Ufano, Tratado de la Artillería, 1613, pág. 278: Mostraré en la presente figura con todos los dichos juntamete la ynvención del escalivante o escalapuente, que es la figura que entre la estacada y el tenasante y torre se muestra sobre quatro ruedas con algunos hombreçillos ençima. // Ufano, Tratado de la Artillería, 1613, pág. 278: O bien servirá la dicha ynvençión para, arrimada a una ventana de una torre o casa fuerte, con el tenaçante, tenaças, maço y hachuela romper sus guardaportes y enrexamientos $\mathrm{y}$, abierta totalmente, entrar dentro la gente que vastare a ganarla o saquearla. // Ufano, Tratado de la Artillería, 1613, pág. 279: El tenazante o rompedora tenaça se puede, çiertamente, creer que con su poca fuerça romperá fáçilmente las barras o rexas de hierro, aunque sean más gruesas que la muñeca del braço de un hombre, como las he visto romper en las ventanas de un castillo y barras tan fuertes como tengo dicho.

FAM.: tenaza, tenazón.

tenazón, tenaçón [de tenaza (DECH). Ufano, Tratado de la Artillería, 1613]. sust. Tenazas grandes que sirven de complemento al tenazante. (fig. 148)

Ufano, Tratado de la Artillería, 1613, pág. 278: [...] el qual también servirá para romper de las ventanas sus enrexamientos y guardaportes de hierro o de madera con mucha façilidad, a cuyo ministerio aprovechará un tenaçón, marcado con la letra $\mathrm{C}$, y un maço de madera o martillo de orejas con la hachuela de mano, apuntada con el punto 2.

FAM.: tenaza, tenazante.

tepe, tepe [probablemente de origen onomatopéyico. Tepe 'gleba de césped' (ast. tapín 'íd.'). 1708, Tosca, Aut.: "Pedazo de tierra mui trabado con las raíces de la grama, que se corta en forma de cuña, y sirve para hacer murallas, acomodándolos unos sobre otros" (DECH). Lechuga, Discurso de la Artillería, 1611]. sust. Fort. Pedazo de tierra cubierto de hierba, que, cortado de diversos modos, sirve para construir murallas, o bien para formar parapetos y otras defensas. (fig. 149) Lechuga, Discurso de la Artillería, 1611, pág. 188: Veynte mil palas de hierro azeradas para cavar y hechar tierra, y entre ellas, dos mil para cortar tepes en los prados casi como adobes.

SIN.: césped, gasón. 
ENCICL: Sanz (1749: s.v. tepes o céspedes): Son pedazos de tierra fresca, blanda y ordinariamente cubierta de grama, y cortada de la figura de una cuña, de un pie de longitud y medio de ancho, y lo mismo de alto por la cabeza, con lo cual acostumbran revestir las obras de tierra para sostenerlas, por medio de un mediano talud. Cuando se hacen traversas para pasar un foso, ordinariamente se cubren de tepes, puestos sobre los tablones, para defensa de los fuegos artificiales. // D'Wartelet (1863): Trozo de tierra blanda cubierta de hierba fresca y que, cortada en forma de ladrillo o adobe, sirve para construir parapetos, acomodándolos los unos sobre los otros, o bien para revestir murallas construidas de tierra. / / Lucuze (1772: 101): "El tepe o césped es un pedazo de corteza de la tierra que se cría con hierba en los parajes húmedos, y se corta de diverso modo según el fin a que se destinan. Cuando sirven para revestir el terraplén de una obra, se cortan en figura de prisma triangular para formar el declivio, y se clavan a la tierra con estaquillas. Si han de servir, como los cestillos y sacos de tierra, para formar sobre los parapetos las troneras para el fusil, se cortan de figura cuadrada o rectángula".

terraplén, terraplén [del fr. terre-plein (1561), como término de fortificación. Aut., en los ss. XVI-XVII (DECH). Ufano, Tratado de la Artillería, 1613]. sust. Fort. Fábrica de tierra apretada y oprimida con que se llena algún vacío o se levanta para defensa $(A u t$.$) .$

Ufano, Tratado de la Artillería, 1613, pág. 161: Para batir bien una plaça, hora sea de puro terraplén su muralla o de piedra, mientras más cañones se le metieren, mejor y más prestamente será abierta su batería. // Ufano, Tratado de la Artillería, 1613, pág. 371: La qual bala va por dentro machinada de pólvora fuerte para que, metida dentro de la pieça, tirando con ella a una muralla o terraplén en estando embaçada dentro, rebiente y con el estruendo que hiziere abra del muro o fuerça un grande portillo.

SIN.: terrapleno 1 .

ENCICL.: Echarri Iribarren (2000: 528): "Macizo de tierra con que se rellena un muro de contención de un recinto amurallado, o que se levanta previamente para hacer una defensa y posteriormente revestirla de mampostería encamisándola". // Lucuze (1772: 25): "El terraplén es una masa de tierra, cuya regular altura es de siete varas, lo que basta para cubrir los edificios de la Plaza. Su latitud superior se proporciona de suerte que, formado el parapeto y la banqueta, quede suficiente espacio para la Artillería y paso de la Tropa. Este camino se llama el Adarve, por estar cubierto del parapeto, y se le da una pequeña inclinación hacia la Plaza, para que las aguas corran sin detenerse". // Almirante (1869): En general, montón o masa de tierra apisonada. En fortificación tiene este sentido genérico; pero también se llama terraplén lo que pudiera ser adarve, la parte superior de una muralla, es decir, del terraplén mismo que la forma.

2 [Ufano, Tratado de la Artillería, 1613]. sust. Fort. Camino situado detrás del parapeto y en lo alto de una fortificación (DUE: s.v. adarve).

Ufano, Tratado de la Artillería, 1613, pág. 186: Qüestión del modo que se pueden alojar pieças aunque bien no tenga bastante terraplén la muralla. 
SIN.: andamio, ándito, terrapleno 2.

ENCICL.: Sanz (1749): Es la superficie horizontal de la muralla, esto es, la parte superior de ella, que poco más o menos, es paralelo al plano horizontal. El terraplén está determinado de parte de la campaña por un parapeto y de parte de la plaza por un talud interior. // Lopes Pires Nunes (2005: s.v. terrapleno): Plataforma rasgada longitudinalmente no reparo e protegida pelo parapeito, destinado à manobra das bocas de fogo e ao movimento dos homens. // Paniagua Soto (1998: s.v. adarve): Camino que corre por la parte superior de una fortificación, protegido por un parapeto, y que da paso a los puestos de vigilancia (a partir de fines del siglo XVI).

terraplenado, terraplenado [de terraplenar. Escalante, Discurso de la navegación, 1577]. adj. Fort. Dicho de una construcción, especialmente de la defensiva: llena de tierra.

Escalante, Discurso de la navegación, 1577, fol. 38v: Está rodeada, por la parte do no la toca el río, de un hondo y estendido fosso de agua que la haze fortíssima por ser navegable. Los muros son fabricados de piedra, cal y ladrillo, assentados sobre la faz de la tierra, sin cimientos ni çanja alguna, bien terraplenados y anchos. // Rojas, Compendio fortificación, 1613, fol. 26r: La segunda, proporción y buena correspondencia en las defensas y comodidades y convenencias para que los soldados puedan defender la tal plaça, advirtiendo que los baluartes sean muy terraplenados y macizos, de buena tierra y no de arena, porque con esto tendrán todas tres cosas, que son: fortaleza, convenencia y comodidad. // Ufano, Tratado de la Artillería, 1613, pág. 174: Los gabiones y faxinas aseguro a Vuestra Señoría que es el material más ymportante que puede aver dentro de una villa y que para tales occasiones se puede tener, porque sin ellos padeçe gran trabajo la gente de dentro y mueren tantos, que no la pueden deffender, porque con los gabiones bazíos o llenos y terraplenados se cubren para los trabajos de sus fortifficaçiones.

FAM.: terraplenar, terrapleno.

ENCICL.: Aut.: Part. pas. del verbo terraplenar. Lo así lleno de tierra. // Terr.: Part. pas. macizado, sólido, lleno de tierra.

terraplenar, terraplenar [de la forma terrapleno, pues la variante terraplén se documenta más tarde que este verbo (López Vallejo 2008). Collado, Plática Artillería, 1592]. v. tr. Fort. Llenar de tierra algún vacío o hueco, o levantarla para defensa (Aut.).

Collado, Plática Artillería, 1592, fol. 53v: Entre tanto el artillero, havida la orden de su general, deve començar su hobra, conviene a saber, en hazer las esplanadas para plantar sobre ellas las pieças con sus plataformas fuertes de tablones y muy bien entendidas, hazer los cestones como en la letra A se vee y terraplenarlos, cubrir con ellos y con otros reparos su artillería, para que no le sea hecha inútil y desencavalgada. / / González de Medina, Examen fortificación, 1599, pág. 34: La tierra con que se huviere de terraplenar se ha de 
mezclar primero fuera con agua y paja, y empastallo bien, y si le quisieren mejor, se ha de echar en cada veinte partes de tierra una de cal deshecha en el agua con que se majare. // González de Medina, Examen fortificación, 1599, pág. 196-197: Señor, lo que yo haría en lo que me avéis preguntado, sería tomar vigas y ponerlas las cabeças a los enemigos, y en cada una hincar con un gran clavo una tabla delgada y bien escarpada hazia arriba para tener la tierra, y terraplenar como quatro pies de alto, y de ancho todo lo más que se pudiere y cupiere muy bien, y echarle segundo lecho, haziendo lo mesmo tercero y quarto, $\mathrm{y}$ todos los que fueren menester, hasta ponerlo en el estado que antes que se batiesse.

FAM.: terraplenado, terrapleno.

terrapleno, terrapleno [del it. terrapieno, como término de fortificación. 1612, Diego de Villalobos, Coment. de las cosas sucedidas en los Países Baxos; Autoridades (DECH). Álaba, Perfeto capitán, 1590]. sust. Fort. Fábrica de tierra apretada y oprimida con que se llena algún vacío o se levanta para defensa (Aut.: s.v. terraplén). (fig. 150)

Collado, Plática Artillería, 1592, fol. 62r: Se deve notar que las camisas o cortinas de las fortalezas no deven de ser más gruessas de muralla de quanto aquélla sea sufficiente a sustentar el terrapleno de la fuerça, porque la fortaleza, como dicho es, no consiste en la grosseza de la muralla, sino en el boníssimo terrapleno de ella, que sea de buena tierra, bien calcada y bien maciça. // González de Medina, Examen fortificación, 1599, pág. 35: Los contrafortes son unos estribos que fortifican la muralla y la ayudan a hazerse una con el terrapleno. // Roxas, Sumario milicia, 1607, fol. 82r: El terrapleno es único remedio contra el artillería; se haze detrás de la muralla, así del baluarte como de la cortina, de cada cosa, y se ha de haçer de tal manera que después de caýda la muralla parezca un monte espantoso a los enemigos.

SIN.: terraplén 1 .

FAM.: terraplenado, terraplenar.

ENCICL.: Rojas, Teórica fortificación (1598: fol. 50v): "Y assí, en quanto a que no lleve fagina el terrapleno, digo que fuera muy bueno quando fuera la fábrica de la yglesia Mayor de Toledo, o otra semejante, porque entonces tratáramos de fabricar muy sólidamente. En cosas de la guerra, donde ay tantas invenciones y cautelas, es necessario salir del camino de las fábricas generales y acudir a los particulares que son necessarios en la buena fortificación, porque, aunque un terrapleno esté fabricado con el mayor cuydado del mundo, no es tan fuerte como con fagina.

Por esta razón, supongo que tengo metidas las trincheas hasta la muralla, y picada, y hecho agugero en ella hasta el terrapleno. Digo que en una noche haré el horno de la mina escarbando con las manos, sin otra herramienta, por estar la tierra desatada y limpia sin fagina, lo que no se podrá hazer si el terrapleno estuviesse travado con faginas. Y esto lo digo como testigo de vista, porque he hecho minas en ambos terraplenos, y en el que estava sin fagina se hizo la mina en una noche, y en otro terrapleno que tenía fagina no la pudimos hazer en quatro, porque las ramas y troncones nos embaraçavan mucho, y 
debaxo de la tierra no se puede hazer fuerça, ni dar buelo a las herramientas para cortar, por ser tan estrecho aquel lugar donde se haze el hornillo.

Y assí, en lo tocante a este particular, por averlo visto por la esperiencia, seré siempre de parecer que el terrapleno se hiziesse con fagina, que en lo que toca a no ser fábrica tan sólida como la que va con tierra sola, a esto se responde que se fabrique con mucho cuydado, pisando muy bien las tongas sobre cada fagina, que quando al cabo de 20 años estén las faginas podridas ya avrá hecho el terrapleno su assiento".

2 [Álaba, Perfeto capitán, 1590]. sust. Fort. Camino situado detrás del parapeto y en lo alto de una fortificación (DUE: s.v. adarve).

Collado, Plática Artillería, 1592, fol. 20r: Pero si la plaça o plataforma sobre la qual juega el artillería, o por ser el terrapleno estrecho o tener detrás de sí algún otro impedimento, será corta más de lo que conviene a la retirada del artillería, ni puede, como diversas vezes acaesce, jugar libremente en aquella plaça, en tal caso, digo que se puede hazer la caxa más corta, y esto porque sería cosa muy peligrosa y aun vergonçosa dexar al tiempo del menester aquella parte de muralla desprovehída y privada de defensa. // Collado, Plática Artillería, 1592, fol. 96r: Digo, pues, que en los lugares dichos y en aquéllos donde, por ser estrechos los terraplenos, no gozan comodidad y aparejo de hazer retiradas ni otros convenientes reparos los sitiados, contra los tales se deve de plantar la batería, si algún particular impedimento no lo estorva. // Rojas, Teórica fortificación, 1598, fol. 70r: Y assí, porque esta plaça que voy significando se entiende ser plaça real y porque ha de tener cavalleros en los terraplenos, digo que tendrá de terrapleno 80 pies, en los quales me retiraré desde el parapeto hazia dentro 15 pies, como muestra el punto G, y de allí levantaré un cavallero de 10 pies de alto, como muestra el punto $\mathrm{H}$.

SIN.: andamio, ándito, terraplén 2.

terreno, terreno [del lat. terrēnus 'terrenal'. Berceo, con variante terreño; éste para 'tierra, puerto' se halla también en las Leyes de Moros de los ss. XIV-XV, Memorial Hist. Esp. (DECH)].

de $\sim$, o del $\sim$ [Álaba, Perfeto capitán, 1590]. loc. adj. Mil. Dicho del orden de batalla cuadrado: que la extensión de terreno ocupada por cada una de sus dos alas es igual a la de la vanguardia o retaguardia. $\quad 5$ (fig. 152)

Álaba, Perfeto capitán, 1590, fol. 112v: La verdadera resolución sea que el quadrado de gente es el que tiene fuerça igual por todas partes y el que importa para la resistencia, que el de terreno de poco efeto puede ser, pues falta la igualdad de fuerça por los lados. // Mendoça, Theórica y práctica, 1596, pág. 55: Quando se quiere que el esquadrón esté reforçado por todas partes con igual proporción, se ha de formar quadro de gente; queriendo reforçar la frente o retaguardia, combatiendo más soldados, se compone quadro de terreno. // Roxas, Sumario milicia, 1607, fol. 68v: Y para haçerlo en un llano donde no aya ninguna comodidad de las dichas, se hará en quadro del terreno, porque allí son yguales las frentes, aunque el fondo o lado no tiene tantos soldados como la frente, porque en el lado ay de distancia de uno a otro siete pies, y de uno a otro, en la frente, tres, y si el enemigo arremetiese por el lado lo hallaría muy flaco por allí. 
SIN.: de suelo.

ANT.: de gente, de infantes.

ENCICL.: Sanz (1749: quadrado, batallón quadrado): Batallón cuadrado de terreno es el que tiene el terreno de cada una de sus alas igual en extensión al terreno de la vanguardia o retaguardia.

terreno, V. $\operatorname{de}(1) \sim$.

testúdine, testúdine [tomado del lat. testūdĭnis 'tortuga' (Segura Munguía 2001). García de Palacio, Diálogos militares, 1583]. sust. f. u. t. c. m. Fort. ant. Máquina con que se protegen los soldados para acercarse a los muros enemigos, consistente en una especie de barracón, por lo común, semejante a la concha de un galápago. (fig. 153)

García de Palacio, Diálogos militares, 1583, fol. 94r: No me acuerdo, señor, que ninguno de los dichos authores diga que se aprovechavan d'él para otra cosa que para medicamentos, mas algunos dizen y affirman que se aprovechavan para quemar los testúdines, arietes y torres que se usavan para ganar las ciudades en aquellos tiempos, y para, también, quemar las armadas en la mar. // Collado, Plática Artillería, 1592, fol. 4v: Era llevada la testúdine sobre algunas ruedas que debaxo de sí tenía, las quales la hazían muy fácil a ser mudada y más cómoda a acercarse a qualquiera fortaleza. // Roxas, Sumario milicia, 1607, fol. 45v: Las testúdines se hacen de maderos y tablas, y porque no los quemen los cubren con cueros de baca.

SIN.: galápago, testudo.

FAM.: testudo.

ENCICL.: Collado, Plática Artillería: (1592: fol. 4r): "Acostumbravan, assimismo, Cathólica Magestad, otra máquina los antiguos, la qual applicavan a las baterías de las ciudades y fortalezas y, aunque con excessivo trabajo, conseguían con ella finalmente su intento, y ésta llamavan testúdine. Era una armazón hecha de madera, a modo de un galápago y en la manera misma que aquí se vee en dibuxo. Applicáronle los antiguos este nombre de testúdine, qu'es lo mismo que galápago, por los effectos que con esta máquina se hazían, que muy semejantes a la natura de aquel animal eran, porque, assí como el galápago, cubierto de su dura concha, resiste a qualquiera golpe y lisión que le sea hecha, assimismo, los combatientes de las ciudades y fortaleças se cubrían y reparavan con esta máquina de los pesados golpes de las piedras y de los ardientes olios y inextinguibles fuegos que se echavan sobre ella; y assí como aquel animal a vezes esconde su cabeça y la encubre debaxo de su concha y a vezes la echa fuera, assimismo se hazía con la trabe metálica que la máquina dentro de sí tenía; era esta trabe una tirante de madera fuerte y muy dura, y de barras de hierro bien herrada. A la punta tenía una gruessa y muy pesada maça de bronzo, 
hecha al natural de como es la cabeça de un galápago o tortuga, como en la presente figura se demuestra".

testudo, testudo [tomado del lat. testūdo 'tortuga', 'caparazón que cubre un grupo de guerreros' (DECH). Loçano, Alberto, Architectura, 1582]. sust. f. Fort. ant. Máquina con que se protegen los soldados para acercarse a los muros enemigos, consistente en una especie de barracón, por lo común, semejante a la concha de un galápago. $\$$ (fig. 154)

Loçano, Alberto, Architectura, 1582, pág. 107: Pero la fossa requiérenla ancha y muy hondo, porque ésta excluyrá la testudo y la torre movediza, y las semejantes máchinas para que no puedan ser allegadas, y, hallada la agua o piedra, será en balde qualquiera porfía de minar. // Urrea, Vitruvio, Architectura, 1582, fol. 136r: La testudo que se haze para cegar los fossos, en la qual bien se puede también allegar al muro, se hará assí: aderécese una basa quadrada, que en griego se llama eschara, la qual tenga en cada lado veynte y cinco pies y quatro de traviessa.

SIN.: galápago, testúdine.

FAM.: testúdine.

ENCICL.: Estévanez (1897: s.v. tortuga): Voz que tenía diversas acepciones en los ejércitos griegos y romanos; las unas poliorcéticas, tácticas las otras. En Poliorcética era máquina cubridora para acercarse a la plaza combatida, máquina tectoria llamada también testudo; en Táctica era formación compacta y apiñada, en la cual se cubrían los soldados uniendo los escudos por encima de todas las cabezas, con que la masa parecía en efecto una tortuga. Esta disposición era la que los romanos llamaban tegular, porque los escudos se convertían en tejas. Los griegos la llamaban "sinapismo".

arietaria [Urrea, Vitruvio, Architectura, 1582]. cmpt. sintag. Fort. ant. La que porta un ariete para batir las murallas. 5 (fig. 155)

Urrea, Vitruvio, Architectura, 1582, fol. 135r: Y de las junturas de los maderos colgó el ariete y cubriolo con cuero de buey, porque estuviessen más seguros dentro los que tenían de herir el muro con la máchina. Esta invención llamó testudo arietaria, porque tardamente demuestra sus fuerças. // Urrea, Vitruvio, Architectura, 1582, fol. 135r-135v: La testudo arietaria se hazía de la misma manera: el intervalo XXX cobdos; la altura XVI, sacado el remate. La altura de la cumbre del suelo a lo alto, cobdos VII, salía también en lo alto, y sobre el sobrado del techo de medio una torrezilla, no menos ancha de XII. // Urrea, Vitruvio, Architectura, 1582, fol. 138v: Y llegándose la testudo arietaria al muro para lo herir, echaron abaxo un lazo. Y teniendo enlazado al arietes, no consintieron que tocasse el muro con la cabeça.

ENCICL.: Almirante (1869): Tortuga. Voz genérica en las milicias griega y romana, y de muy extensa significación en sus tácticas. Distinguían: testudo simplex, arietaria, fossoria, oppugnatoria, navalis, rostrata, etc. Unas veces era máquina tectoria, aparato cubridor y de 
acceso contra los muros de una plaza [...]. Cuando el aparato cubría el ariete, tomaba el adjetivo arietaria, como se lee en Vitrubio (lib. 10. cap. 19) y la pintan, según les parece, Justo Lipsio y Steuwecckio. Cuando cubría al minador, o a los que picaban el muro, era fossoria, etc. $[\ldots]$.

tienda, tienda [del b. lat. ant. tĕnda 'íd.' (documentado en escritores bizantinos desde el s. VII), derivado de tendere. Doc. de 982, Oelschl.; Cid, etc. (DECH). Ortega, Conpusición Arismética y Geometría, 1512]. sust. Mil. Construcción desmontable hecha con una armazón cubierta con lonas o pieles, que se emplea como alojamiento en el campo (DEA). 주 (fig. 156)

Ortega, Conpusición Arismética y Geometría, 1512, fol. 202v: El rey, nostro Señor, manda fazer una tienda en un campo a un maestro, el qual maestro fizo la tienda en que puso un mástil que tiene de largo 100 canas; y el paño que viene desde la cabeça del mástil fasta la tierra tiene de largo 140. // Mendoça, Theórica y práctica, 1596, pág. 47-48: En algunas partes me he hallado a guerrear donde era menester plantar tiendas para amparar los soldados que la hazían de los terribles fríos y ruynes temporales y, en otras, del excessivo resistero y calor del sol. // Lechuga, Discurso de la Artillería, 1611, pág. 190: Para todas estas tiendas a de aver lo necessario para plantarlas y de respecto para lo que se puede offrecer, alguna quantidad de los palos que las tienen, de cuerdas y estacas, y de las telas de que se hizieren.

ENCICL.: DRAE: Armazón de palos hincados en tierra y cubierta con telas o pieles sujetas con cuerdas, que sirve de alojamiento o aposentamiento en el campo, especialmente en la guerra.

\section{tigera, V. tijera.}

tijera, tigera, tijera, tisera, tixera [del lat. (forfices) tonsōrias '(tijeras) de esquilar' (unas tonsorias en doc. de Toro de h. 1050, M. P., Oríg.), de donde el ant. tiseras. Tiseras [Berceo; Aranceles santand. s. XIII; Sem Tob; APal.; Nebr.; J. de Valdés], tigera(s) [Cantar de Mío Cid, Percivale, Oudin, Covarrubias] y tixeras [1385, Lz. de Ayala, Aves de Caça; Vélez de Guevara, La Serrana de la Vera] (DECH). Rojas, Teórica fortificación, 1598]. sust. Fort. Obra exterior de una fortaleza que cuenta con tres ángulos muy agudos, uno entrante y dos salientes, y que suele construirse sobre una altura o elevación del terreno. $\$$ (fig. 157)

Rojas, Teórica fortificación, 1598, fol. 3r: Y, fuera de todo esto, saber qué es la contramina y las puertas que sirven de surtidas al fosso, y qué son tenazas, y dientes, y tixeras [...], las quales se suelen hazer fuera del fosso, dándose la mano con algún padrastro o fuerte. // Roxas, Sumario milicia, 1607, fol. 81r: Adbiértase que los dientes, tigeras, tenazas no se han de hazer en parte que se pueda poner batería, porque será disparate; sólo sirven de poco más que trincheras, y ansí se ha de entender. // Roxas, Sumario milicia, 1607, fol. 84r: En todo lo demás de los caballeros [...], tenazas, tigeras, dientes, se guardará la medida que 
está dicho, pues todas son fortificaçión no real, porque sólo se hazen para darse la mano con algún padrastro o otra semejante; y se da liçençia que se crezca o diminuya según la neçesidad pidiere.

ENCICL.: Aut. (s.v. tixera): Se llama también cualquier cosa que se forma en su figura. // Rojas, Teórica fortificación (1598: fol. 77v): "Hecho este reconocimiento general, se tomará la planta de la tal ciudad o castillo y se pondrá en diseño muy particular y puntualmente, y con las reglas y medidas que atrás quedan se reduzirá la dicha planta en la forma mejor que se pudiere, haziéndola de suerte que no aya mucha ruina en las casas ni en los templos, acomodando lo más que se pudiere la muralla que huviere vieja, haziendo cavalleros y tenaças donde lo pidiere el sitio, huyendo siempre de no hazer tenaza ni tixera en llano, porque son dañosas; sólo sirven para dar la mano a un padrastro o para entrar a la mar". // La función que desempeñan las tijeras en un recinto fortificado es la misma que la de las tenazas, por lo que vid. tenaza $a_{3}$ y, especialmente, su información enciclopédica.

2 [García de Palacio, Diálogos militares, 1583]. sust. Mil. Formación angular y cóncava, con el centro más retrasado que las alas, para envolver al enemigo o hacer frente al ataque en cúneo. (fig. 158)

García de Palacio, Diálogos militares, 1583, fol. 173r-173v: Acostumbraron los antiguos formar por esta orden una fórfice o tixera, para, con mucha ventaja, opponerse a los semejantes esquadrones, y dividían, para hazer la dicha fórfice, todo su esquadrón en dos partes yguales, y venían a hazer dos esquadrones en la forma cúnea. / García de Palacio, Diálogos militares, 1583, fol. 183r: Una forma cúnea es apta y sufficiente para romper otra qualquier batalla quadrada, aunque tenga la tercia parte de infantes más, la qual querría que se hiziesse a vista del enemigo, con mucha presteza, para que no tuviesse lugar de hazer la fórfice o tixera, con que podría aventajarse. // Roxas, Sumario milicia, 1607, fol. 38v: Cuño es un esquadrón en esta forma ??, y la tijera es ansí $>$, la qual reçive dentro de sí d'esta manera ??>.

SIN.: fórfice, tenaza $a_{4}$.

tirón, tirón [tomado del lat. tìro, -ōnis 'recluta, quinto', 'aprendiz, novicio'. Tirón 'aprendiz'. Acad. 1843, no 1817 (DECH). Roxas, Sumario milicia, 1607]. adj. u. t. c. sust. Mil. ant. En la milicia romana, lo mismo que bisoño.

Roxas, Sumario milicia, 1607, fol. 8r-8v: Y para fundar bien este caso combiene saber de qué regiones se han de elegir los tirones, que se entiende los soldados vissoños, porque es cossa clara que en todos los lugares naçen buenos y malos, mas por qué una naçión haze ventaja a otra en la guerra cáusalo porque la región del çielo ymporta mucho. // Roxas, Sumario milicia, 1607, fol. 18r: E recopilado en breve i tratado hasta aquí aquellas cosas que escribieron Vegeçio, De re militari, y los demás autores que de la diçiplina militar escrivieron, para que, si alguno ubiere que quisiere ser diligente en la electión y en el exerçiçio de los soldados tirones, fáçilmente pueda corroborar un exérçito y restaurarle a la imitaçión de los antiguos y de su balor. // Roxas, Sumario milicia, 1607, fol. 25r: Demás 
d'esto avía muchas escuelas adonde acudían los soldados de letras y, así, combiene que los que tienen cargo de aprovar los tirones, demás de que han de mirar atentamente de que sean de buena estatura y tengan fuerça en el cuerpo y que sean de alegre semblante, han también de procurar que sepan los más escribir y contar.

ENCICL.: Moretti (1828: s.v. tirones): ant. Apodo con que se distinguían en Roma a los reclutas y soldados bisoños que aún no habían hecho la guerra, y que aspiraban al empleo de legionario. En tiempo de paz los tirones (armados con honda, flechas y espada de madera y broquel de mimbres, todo con doble peso que los comunes de la tropa) se ejercitaban en el campo de Marte, tirando y esgrimiendo contra una estaca plantada en tierra, que presentaba una elevación de cinco pies y medio, y figuraba ser el contrario contra quien se batían. Los legionarios veteranos que habían obtenido la corona cívica o vallar les servían de maestros y dirigían aquellos ejercicios que a veces se ejecutaban a presencia de los generales, cónsules y de los mismos emperadores. En tiempo de guerra los tirones seguían las legiones, sin estar alistados en ellas: peleaban a su lado, y a veces mezclados entre los legionarios; y cuando había alguna vacante o se mandaba aumentar su fuerza, eran admitidos los más expertos y valientes como efectivos, disfrutando todas las ventajas que eran anexas al empleo de legionario.

tisera, V. tijera.

tixera, V. tijera.

tocar, V. a botasilla.

toma, toma [de tomar. APal., Nebr. (DECH). García de Palacio, Diálogos militares, 1583]. sust. Mil. Acción de ganar, mediante una operación de guerra, un territorio, provincia, población, plaza, fortaleza, estado, etc.

García de Palacio, Diálogos militares, 1583, fol. 47r-47v: En el Primero de los Machabeos se enseña que los soldados no saqueen ni despojen el campo de sus enemigos hasta que consummadamente ayan conseguido victoria y no tengan de quien temerse, para cuyo exemplo y doctrina, porque en la toma de Jericó, contra lo que Dios avía mandado a los del pueblo de Isrrael, Acham tomó una regla y otras cosas, fue apedreado y le quemaron todo lo que tenía. // Lobato, Notas, a. 1585, fol. 37: Y plugo a Dios que, acabada la toma de Galera, que fue día de antruejo del dicho año de 71, yo y él nos salimos del campo con lo que del saco hubimos, y nos vinimos a dar a Cazorla y Quesada, y de allí fuimos a Jaén y Martos y Alcaudete, adonde me hizo, en casa de una hermana suya, mucho regalo ocho días. / / Ufano, Tratado de la Artillería, 1613, pág. 160: Y, asimismo, en la toma de Cambray, se batió la villa por la cortina, aunque a su deffensa tenía un fuerte baluarte por el costado, y aseguro a Vuestra Señoría que, si por él se uviera acometido, no se ganara tan presto.

SIN.: conquista, presa $_{1}$. 
FAM.: tomar.

ENCICL.: Almirante (1869): No es frecuente el uso de este sustantivo que expresa la acción y resultado del verbo tomar. Sin duda por ser toma voz de "medicina", se prefiere conquista.

tomar, tomar [de origen incierto. Doc. de Castilla de 1074 (Oelschl.) (DECH). Fernández de Enciso, Suma de Geographía, 1530]. v. tr. Mil. Ganar, mediante operación de guerra, un territorio, población, posición, etc. (DRAE: s.v. conquistar). Fernández de Enciso, Suma de Geographía, 1530, fol. XXIVv: Y después de aquello passó Aníbal desde África y destruyó a Cigüença, e tomó mucha parte de España, e la dexó a sus hermanos y se bolvió; y después embiaron desde Roma a los dos Cipiones hermanos, que la cobraron. // Montes, Instrucción y regimiento, 1537, fol. Vv-VIr: E muchas tierras e castillos fuertes se han rendido por falta de vituallas más que por combate de los enemigos; y en esto han de mirar mucho los generales, que las fuerças que ganaren que las hagan proveer de vituallas, porque los enemigos no las tomen por hambre, porque mejor es, ya que sucede la fortuna, que una fuerça se pierda por batalla que no por hambre. // Mosquera, Comentario disciplina militar, 1596, fol. 140r-140v: Resultó, de la confessión y declaración que Manuel de Silva hizo en el tormento, advertir de una armada que se hazía en Francia secretamente - un navío en cada puerto, porque menos se sintiesse, con dos mil hombres para tomar la isla de Santo Domingo - , que saldría por fin de setiembre.

SIN.: conquistar.

FAM.: toma.

ENCICL.: DUE: Conquistar una posición en la guerra.

2 [Montes, Instrucción y regimiento, 1537]. v. tr. Mil. Instalarse en lugares estratégicos para dificultar las acciones del enemigo.

García de Palacio, Diálogos militares, 1583, fol. 15r: Pero, para defenderse del enemigo que entra por la provincia y cerca las fuerças, qualquier comunidad tiene derecho para resistir y ampararse, y, si para esto fuere nescessario, puede salir de sus pueblos, y tomar los passos difficultosos entre las sierras, y resistir allí al enemigo, y no dexarlo passar, y entretenerlo hasta que el príncipe acuda con exército. // Mendoça, Theórica y práctica, 1596, pág. 72: El cabo que fuere de retaguardia ha de dexar atrás de todos una compañía de lanças o arcabuzeros a cavallo con un capitán plático que ha de sacar corredores, los quales han de caminar lexos de su compañía o retaguardia, pero no tanto que la pierda de vista, y esto si el paýs es llano; y siendo doblado, los corredores han de tomar siempre los altos y montañas para que el enemigo no los ocupe y d'ellos descubra en la orden que se camina. // Roxas, Sumario milicia, 1607, fol. 86v-87r: Ay otras çiudades que son ofendidas en torno de algunas alturas, de tal manera que los soldados no pueden estar a la defensa que no sean ofendidos o por la frente, o por través, o por las espaldas: el mejor y más seguro remedio será tomar o ocupar las dichas alturas de la çiudad; mas quando por algún 
respeto no se pudiesen tomar, en tal caso conviene retirarse adentro, de tal manera que la ofensa de aquel monte, por quedar ya lejos, no sea de ningún balor.

SIN.: ocupar 2 .

ANT.: desocupar.

ENCICL.: DUE: Ocupar un paso, entrada, salida, etc., para impedir que pase el enemigo. // Terr.: Tomar un puesto ventajoso en la Milicia, etc. V. Ocupar, apoderarse. // Terr. (s.v. ocupar algún puesto ventajoso): Apostarse en él.

tomar, V. lengua.

torno, $V$. ballestón de $\sim$.

toro, toro [tomado del lat. tŏrus 'hinchazón en una planta', 'bulto o protuberancia en el terreno, en un madero, una cuerda, un músculo, etc.'. Como cultismo arquitectónico, toro 'cordón', está ya en Aut. (DECH). Urrea, Vitruvio, Architectura, 1582]. sust. Fort. ant. Especie de madero o de barra de hierro cuya cabeza, dependiendo de la máquina mural de la que forma parte, adopta diferentes formas.

Urrea, Vitruvio, Architectura, 1582, fol. 135v: Poníase también en ella la máchina arietaria, que en griego se llama criedochi, que es viga arietaria, en la qual estava el toro, que es un gruesso leño y redondo, hecho a torno, adonde está puesto el ariete. Hazía grandes effectos arrojándolo y recogiéndolo con las maromas. // Urrea, Vitruvio, Architectura, 1582, fol. 143v: Toro: un leño gruesso torneado de la máchina arietaria, en el qual, puesto el ariete, arrojándolo y recogéndolo, haze grandes effectos.

SIN.: trabe, viga.

torre, torre [del lat. tŭrris 'íd.'. Doc. de 929, Oelschl. (DECH). Ortega, Conpusición Arismética y Geometría, 1512]. sust. Fort. Edificio fuerte, más alto que ancho, y que sirve para defenderse de los enemigos desde él, o para defender una ciudad o plaza (DRAE). .

Ortega, Conpusición Arismética y Geometría, 1512, fol. 202r: Un hombre tiene dos fortalezas, en que la una tiene 50 canas de alto y la segunda tiene 30 canas de alto. Estas dos torres están apartadas la una de la otra 20 canas, y el dueño d'estas dos torres quiere fazer un passadizo de la una punta de la una torre fasta la otra punta de la otra torre. Demando que quántas canas terná de largo el tal passadizo. // Loçano, Alberto, Architectura, 1582, pág. 109: $Y$ hanse de aplicar al muro torres de cincuenta en cincuenta cobdos [...], que salgan las frentes en redondo y en altura más altas que el muro, para que el que se allegare cerca 
oponga su lado desnudo a los tiros y sea muerto, porque assí el muro por las torres, y las torres por la torre, sean defendidos. // Rojas, Teórica fortificación, 1598, fol. 38v: Si me piden una plaça que la puedan cubrir y guardar 800 hombres, la haré de cinco valuartes, y si la quieren que no sea más de para trezientos o quatrocientos, la haré de quatro; mas si me pidiessen una plaça para solos 100 hombres, haré una torre sin valuartes, porque 100 hombres no pueden guardar ninguna plaça que tenga cortinas y valuartes.

SIN.: torreón.

FAM.: torreado, torreón.

ENCICL.: Cov.: Edificio fuerte para defenderse del enemigo y esperar socorro de los amigos cercanos. Es menos que fortaleza o castillo, y suele ser parte de ellos, porque en los lienzos de los muros suelen fabricarse algunas torres más altas que ellos para defenderlos. También llamamos torre el campanario de las iglesias por ser, en efecto, una torre donde están las campanas; y muchas veces sirve de defensa y de atalaya y aviso de que hay enemigos, y se tañe en ella a rebato. // Lorenzo Celorrio (1996): Edificio más alto que ancho. Por sí sola o adosada a otras construcciones defensivas, está presente y es elemento principal de defensa en la práctica totalidad de la arquitectura militar medieval. // Estévanez (1897): Las torres de la Edad Media eran, en general, redondas; pero también las había triangulares, cuadrangulares y esquinadas en ángulo agudo muy saliente.

2 [Loçano, Alberto, Architectura, 1582]. sust. Fort. ant. Máquina alta de madera, semejante a una torre y con ruedas, con la que los sitiadores se acercan a las murallas enemigas para tratar de sobrepujarlas o dominarlas. $\$$ (fig. 160)

Loçano, Alberto, Architectura, 1582, pág. 107: Pero la fossa requiérenla ancha y muy hondo, porque ésta excluyrá la testudo y la torre movediza, y las semejantes máchinas para que no puedan ser allegadas, $\mathrm{y}$, hallada la agua o piedra, será en balde qualquiera porfía de minar. // García de Palacio, Diálogos militares, 1583, fol. 94r: No me acuerdo, señor, que ninguno de los dichos authores diga que se aprovechavan d'él [del salitre] para otra cosa que para medicamentos, mas algunos dizen y affirman que se aprovechavan para quemar los testúdines, arietes y torres que se usavan para ganar las ciudades en aquellos tiempos, y para, también, quemar las armadas en la mar. / / Collado, Plática Artillería, 1592, fol. 3r: Estava Aníbal deffendiendo la muralla y esforçando sus soldados en aquella parte, contra la qual los romanos aproximavan una torre de madera cuya alteza sobrepujava la más alta parte de la ciudad y descubría todos los reparos que se hazían dentro d'ella, la qual, siendo acercada, despojó los muros de defensores con las cathapultas y balistras que traýa plantadas en sus solares.

ENCICL.: Terr.: (s.v. torre movible de guerra) La que hacían antiguamente para cercar una ciudad. // Roxas, Sumario milicia (1607: fol. 46r): "Las dichas torres se llaman unas máquinas de madera sobre ruedas para sojuzgar la muralla desde afuera; y para que se queme esta torre se prebienen muchas maneras: la primera es que si en los soldados hubiere confiança haçer una salida de repente, con fuegos artificiales y otras cosas con que procuran romper y quemar la torre; también se adbierte que aquella parte de la muralla haçia donde la máquina se allega se puede haçer más alta de presto con andanes de tablas, 
y quedando la máquina ynferior no será de provecho; también algunas veçes contraponen la máquina unas vigas aforradas con hierro porque tope en ellas y no llegue a la muralla; $\mathrm{o}$, si no, abrir en el derecho que biene la máquina un pedaço de foso, como hiçieron los de Rodas".

$\sim$ de homenaje, o $\sim$ del homenaje [Poça, Hydrografía, 1585]. cmpt. sintag. Fort. ant. En una fortaleza medieval, la torre más destacada, fuerte e importante, con elementos defensivos propios que le permitían, en caso de necesidad, independizarse del resto de las fortificaciones del recinto. 5 (fig. 161)

Poça, Hydrografía, 1585, fol. 9v: Si quisieres entrar en Cádiz con Poniente, vete al Este quarta del Sueste, que assí yaze la baýa, vete acerca de la gran roca que es descubierta, a un ajuste de la qual al pie d'ella ay siete braças. Dexarás la baýa de media proa de ababor, y no apremies la tierra hasta que descubras la siniestra de la torre de omenage, y después, cierra con la tierra y posa en las cinco o seys braças. // González de Medina, Examen fortificación, 1599, pág. 17: Dezidme, maestro, ¿cómo no os avéys acordado de poner en lo que avéys nombrado rebellines, cavalleros ni torre de homenage o roca, como la llaman otros, pues es tenida por muy buena manera de fortificación y muy fuerte? // González de Medina, Examen fortificación, 1599, pág. 20: La roca que dezís, o torre del homenage, en el centro de la plaça de armas por ningún caso se ha de tratar de que la aya, porque es a lo antiguo y de quando se combatía con piedras, y mala manera de fortificar, porque [...] ella embaraça la plaça de armas y la ocupa, y quita que no se pueda hazer muy buen esquadrón.

SIN.: roca, roca de homenaje.

ENCICL.: Cov. (s.v. torre del homenaje): La más alta y más fuerte del castillo o fortaleza. Y se dijo así por haberse acostumbrado tomar en ella el juramento y pleito homenaje al alcaide. // Mora-Figueroa (2006: s.v. torre del homenaje): La más destacada, fuerte y defendible de una fortaleza, concebida como su último reducto de resistencia y que por tanto debe poderse aislar del resto de las fortificaciones de la plaza y ofrecer un cierto grado de autonomía funcional, particularmente para la aguada.

torreado, torreado [de torrear y éste de torre. García de Palacio, Diálogos militares, 1583]. adj. Fort. Dicho de una construcción defensiva o de un terreno: fortificado con torres.

García de Palacio, Diálogos militares, 1583, fol. 63v: Les dio por instrución que, subidos en lo alto de los montes, a la parte del mediodía, viessen y considerassen qué tal era la provincia, y si el que la posseýa y governava era varón fuerte o flaco, y si los moradores d'ella eran pocos o muchos, y si las poblaciones o ciudades eran muradas, torreadas o fortalescidas.

FAM.: torre, torreón.

ENCICL.: Aut.: Part. pas. del verbo torrear. Guarnecido y fortalecido con torres. 
torreón, torreón [de torreyón, variante fonética leonesa de torrejón. h. 1570, Mármol, Aut. (DECH). Montes, Instrucción y regimiento, 1537]. sust. Fort. Edificio fuerte, más alto que ancho, y que sirve para defenderse de los enemigos desde él, o para defender una ciudad o plaza (DRAE: s.v. torre). (fig. 162)

Montes, Instrucción y regimiento, 1537, fol. XIXr: Y en el hazer de la mina, si la tierra es pantanosa y manantial, no se podría hazer minas; mas si la tierra es arzilla, o greda, o arenosa, puédese hazer la mina; mas en el hazer del horno debaxo del centro del torreón es menester que lo haga el ingeniero, porque otro ninguno no lo acertaría, por no saber dar la orden del meter de la pólvora y del cerrar del horno. // Collado, Plática Artillería, 1592, fol. 73v: Capítulo XXIII Del modo que ha de tener el artillero quando se le offrescerá de haver de subir una o más pieças de artillería sobre una torre muy alta / Offresciéndose al artillero de haver de subir una pieça de artillería encima de algún torreón muy alto, como muchas vezes acontesce, para de allí offender de lexos el enemigo, la qual operación es de importancia grandíssima y, por la misma razón, muy conveniente, a mi parescer, el escrivir el modo de exercitarla. // Mendoça, Theórica y práctica, 1596, pág. 141: Viniendo los que sitian a caminar con la çapa picando los cimientos de la muralla o torreones, el remedio es poner allí buena guardia y caminar cavando a buscarlos para echarlos del puesto y reparar siempre, como mejor se puede, la batería.

SIN.: torre $_{1}$.

FAM.: torre, torreado.

ENCICL.: Lopes Pires Nunes (2005: s.v. torreão): O mesmo que torre. // González de Medina, Examen fortificación (1599: pág. 150-151): "PRÍNCIPE. - Por tanto, yo tengo una ciudad con muralla vieja y flaca, sin barbacana, a lo antiguo, con sus torreones redondos y muy juntos: ¿cómo lo remendaríades que quedasse en defensa? MAESTRO.- [...] Los torreones redondos, algunos sacaría en ángulo y haría d'ellos baluartes con sus casas matas y orejones, los más perfectos que pudiesse, a buena y defendible distancia. Y si los torreones estuviessen tan menudos, como suelen tener murallas viejas, por ser pequeños, que no estorvarán la defensa de las casas matas, y aun se podrán defender con tiros de mano, dexaría algunos entre los baluartes, porque sería tener aquellos traveses más, y el enemigo más cuydado en llegarse y más trabajo en batirlos y quitarlos para poderse arrimar".

total, V. cortina $\sim$.

trabado, trabado, travado [de trabar (DECH). Álaba, Perfeto capitán, 1590]. adj. Dicho especialmente de una acción de guerra, como una batalla o una escaramuza: comenzada o iniciada.

Álaba, Perfeto capitán, 1590, fol. 41r: También les consentiría, fuera d'estos, otros exercicios que no sean viles, sucios ni infames; y el exercicio no sólo sea de uno a uno, sino de 
muchos a muchos, exercitándose en esquadrón unos con otros, travando escaramuças, como si peleassen con sus contrarios, embiando parte de la gente a que, corriendo, ocupe algún lugar alto y otro tanto número de soldados con armas yguales para que con escaramuça travada les procuren quitar el puesto.

FAM.: trabar, trabe.

trabar, trabar, travar [probablemente de traba y éste del femenino lat. trabs, -is. Travar, 1155, Fuero de Avilés (DECH). Montes, Instrucción y regimiento, 1537]. v. tr. Comenzar o iniciar acciones de guerra, como batallas o escaramuzas.

Montes, Instrucción y regimiento, 1537, fol. VIIIr: Muchas vezes se ha visto, por el esfuerzo de un solo soldado, ser vitorioso un exército, por acometer aquél cosa que cinqüenta juntos no osaran acometer, y los otros, por vergüença, seguirle y travarse la batalla con los enemigos de tal arte, que, donde pensavan ser vencedores, quedavan vencidos. / / Álaba, Perfeto capitán, 1590, fol. 71v: Y Aníbal, yendo contra los africanos, sabiendo que era gente apassionada del vino, echó en mucha cantidad d'él mandrágora, la qual es medio entre ponçoña y sueño; y travando escaramuça con ellos, fingiendo yr de vencida, huyendo desamparó sus reales, en los quales entrando los enemigos, se entregaron de suerte en el vino inficionado que luego les cargó un sueño grandíssimo y, hallándolos como muertos Aníbal, los passó todos a cuchillo. // Mosquera, Comentario disciplina militar, 1596, fol. 70v: Y assí, fue menester sacar barriles de los navíos en abundancia, aunque esto no bastava para mitigar la gran necessidad en que estavan los soldados cansados y aquexados de las escaramuças, que fueron tan bravas y tan constantes que, desde las seis de la mañana que se travaron, duraron todo el día sin cesar un punto.

FAM.: trabado, trabe.

ENCICL.: Estévanez (1897): Se dice del combate, de la batalla, de la simple escaramuza, en el sentido de empeñarlos, de empezarlos, de iniciar la acción.

trabe, trabe, trave [tomado del lat. trabs, -is. Lope (DECH). Collado, Plática Artillería, 1592]. sust. Fort. ant. Especie de madero o de barra de hierro cuya cabeza, dependiendo de la máquina mural de la que forma parte, adopta diferentes formas. 3 (fig. 163)

Collado, Plática Artillería, 1592, fol. 4r: Y assí como aquel animal a vezes esconde su cabeça y la encubre debaxo de su concha y a vezes la echa fuera, assimismo se hazía con la trabe metálica que la máquina dentro de sí tenía; era esta trabe una tirante de madera fuerte y muy dura, y de barras de hierro bien herrada. // Collado, Plática Artillería, 1592, fol. 4v: Llamáronla de este nombre y aun diéronle la figura y forma de aquel animal por el effecto que con ella se hazía y modo como se exercitava, porque, assí como el carnero con los duros cuernos conbate con otros animales y, para de nuevo y con mayor ímpetu arremeter, torna atrás, assimismo se hazía con esta máquina y con la trabe aretina que dentro de sí llevava. / Collado, Plática Artillería, 1592, fol. 4v: Era esta trabe semejante a 
aquélla de la testudine, pero aquella cabeça de bronzo que atormentava las murallas era semejante a una gruessa cabeça de carnero.

SIN.: toro, viga.

FAM.: trabado, trabar.

trabés, V. través.

trabiesa, V. traviesa.

trabucco, V. trabuco.

trabuco, trabucco, trabuco [del cat. trabuc 'íd.'. Berceo; como máquina de guerra está ya en J. de Mena (DECH). Mosquera, Comentario disciplina militar, 1596]. sust. Mil. ant. Máquina para arrojar grandes piedras, constituida, esencialmente, por un armazón de madera que sostiene un largo brazo, el cual posee, en uno de sus extremos, una especie de funda para el proyectil y, en el otro, un contrapeso.

s? (fig. 164)

Mosquera, Comentario disciplina militar, 1596, fol. 5v: Y en la mesma antigüedad (como dize Vitruvio) los primeros arietes que salieron a luz en el mundo fueron los que los cartagineses en España inventaron, con que allanaron los muros de la ciudad de Cádiz, y, después, subiendo en la mayor fineza que jamás estuvo, la artillería e ingenios de fuego y artificios modernos que sucedieron a las balistas, $\mathrm{y}$ a los escorpiones $\mathrm{o}$ arcubalistas, $\mathrm{y}$ a los trabucos tiradores de piedras, de que fue inventor el famosíssimo filósofo y mathemático Arquímedes Siracusano. // Mosquera, Comentario disciplina militar, 1596, fol. 14v: El qual [César], advirtiendo que las galeras no eran usadas ni conocidas por los bárbaros, y que eran más ligeras para correr por la mar, dexó las naves redondas de alto borde y puso en las largas trabucos, hondas, saetas, máquinas y todo género de armas arrojadizas con que hizo retraer los enemigos.

ENCICL.: Aut.: Máquina bélica que se usaba antes de la pólvora y artillería y con ella se arrojaban piedras muy gruesas con mucho ímpetu. // Gago-Jover (2002): Máquina de guerra usada para batir las murallas, torres, etc. El proyectil, colocado en una especie de honda en el extremo más largo de la viga, era lanzado al caer un contrapeso situado en el extremo opuesto. / / Lopes Pires Nunes (2005: s.v. trabuco): Para utilizar o engenho, traziase a funda ao nível do solo, com auxílio de um sistema de engrenagens, para ser carregada com pedras, que podiam ter grandes dimensões [...]. Soltando a engrenagem, o contrapeso fazia balouçar a funda com um movimento rápido e violento, lançando os objectos nela depositados contra a muralha ou para o interior do castelo. Manobrado por homens experientes, os trabucos eram muito eficazes, pois as pedras atingiam sempre a muralha 
no mesmo local e este acabava por ruir. Todavia, como os trabucos eram engenhos de tiro curvo, tinham o inconveniente de não poderem atingir as fundações das muralhas.

travado, V. trabado.

travar, V. trabar.

trave, V. trabe.

través, trabés, través, travez [del lat. transvěrsus 'transversal, atravesado, oblicuo'. A. de Palencia; Nebr.; de través y al través, Aut., con ej. de aquél en A. de Morales; través m. 'obra exterior de fortificación para estorbar el paso', fin s. XVI, Pz. de Hita (DECH). Montes, Instrucción y regimiento, 1537]. sust. Fort. Parte del baluarte que une su frente con la cortina, o distancia comprendida entre el ángulo de la cortina y la cara o frente del baluarte. 3 (fig. 165)

Montes, Instrucción y regimiento, 1537, fol. XVIIr: El muro ha de ser bien fraguado; ha de tener sus traveses que jueguen por lo baxo del fosso, con que haya de través a través ciento y cinqüenta passos $\mathrm{o}$, a lo menos, casas matas, para que la artillería pueda jugar dentro d'ellas por lo alto y por lo baxo. // Rojas, Teórica fortificación, 1598, fol. 41r: Para hazer el repartimento en esta plaça en triángulo, se dividirá, como dicho es, en cinco partes la frente del recinto, que en este caso es la $\mathrm{AB}$ y tiene de frente 600 pies, que, divididos en cinco partes, caben a cada una a 120. Y éstos se rebatirán de ambos estremos de la frente del recinto para sacar los traveses, como lo muestran $A C$ y $C B$ en la passada figura, dexando la cortina franca, del un través al otro, de 360. // González de Medina, Examen fortificación, 1599, pág. 167: El orejón, aunque el de esquina viva tiene algo menos en qué batir que el redondo, pero, con todo esso, el redondo encubre más y es más dificultoso de derribar. Y aunque tenga más que caer en el foso, no es en parte que el enemigo se determinará a dar por allí assalto, por estar el través tan cerca y no quitado.

SIN.: espalda , fianco.

FAM.: traviesa.

ENCICL.: Terr.: El flanco del baluarte. // Al igual que ocurre con gola, muchas veces se llama través (o fianco o flanco) a la parte semejante de otros elementos de fortificación distintos a un baluarte, como puede ser un revellín: "Y lo que a mí mejor me parece, y para ello haría, sería, en medio de la cortina de la otra parte del foso, sacarle un rebellín, de tal manera que desde los baluartes y casas matas se defienda y limpie las frentes del rebellín, y él, que tenga sus traveses encubiertos con muy fuerte espalda, y que d'ellos se limpie la frente del baluarte" (González de Medina, Examen fortificación 1599: pág. 158-159). Obsérvese, asimismo, la aplicación que en este fragmento se hace de la voz frente para 
designar, en el revellín del que se habla, la parte de éste que es semejante a la frente de un baluarte.

2 [Rojas, Teórica fortificación, 1598]. sust. u. m. en pl. Fort. Cada uno de los parapetos u obstáculos transversales que hay en la estrada cubierta de una fortaleza. \& (fig. 166)

Rojas, Teórica fortificación, 1598, fol. 38r: Es mucho más fuerte y a propósito una estrada de hasta 12 ó 15 pies de ancho, porque en estos quinze pies de ancho pueden yr cinco soldados en hilera, y todos los mil hombres que están en la plaça caben en la una frente d'esta estrada cubierta, porque lleva sus travesses. // Rojas, Teórica fortificación, 1598, fol. $38 \mathrm{r}-38 \mathrm{v}$ : Y paréceme, conforme a la materia de trincheas y a lo que he visto en ellas, que no deve de tener de ancho la dicha estrada más que hasta 15 pies, porque lo que es salir o entrar cavallería, bastará la plaça [...] y traveses d'ella, y como se ha recogido toda la fortificación, es cosa puesta en razón recoger también la estrada cubierta, de manera que venga a estar todo en proporción. // González de Medina, Examen fortificación, 1599, pág. 42: La estrada cubierta será de doze pies de ancho, con un terrapleno cortado de la mesma campaña de seis pies de alto, que sirve de trinchea o parapeto, con un escalón de un pie de alto alrededor del parapeto, para que los pequeños puedan tirar mejor. Hase de hazer este parapeto muy franqueado con traveses para mejor defenderle.

ENCICL.: Lopes Pires Nunes (2005: s.v. través): Pequeno obstáculo colocado transversalmente no caminho coberto, para ir detendo o inimigo e evitar o fogo enfiado, se ele ocupasse parte desse caminho. // Lucuze (1772: 38-39): "Las plazas [de la estrada cubierta] se cierran con traveses [...], que consisten en unos parapetos a prueba con su banqueta de la misma altura de la explanada, atravesados en toda la latitud del camino cubierto, dejando un estrecho paso de cuatro pies entre el través y el parapeto de la estrada encubierta. También se ponen en diversas distancias, especialmente en donde las caras del baluarte o del revellín continuadas cortan la contraescarpa, y son muy provechosas contra la enfilada que puede hacer el cañón enemigo".

3 [Mendoça, Theórica y práctica, 1596]. sust. Fort. Cualquier tipo de obra o defensa que, tanto por parte de los sitiadores como por parte de los sitiados, suele levantarse en lugares estrechos para tratar de impedir el paso al enemigo.

Mendoça, Theórica y práctica, 1596, pág. 47: Estando la gente en batalla, aya lugar conveniente [...] para passar entre las espaldas de los esquadrones y la frente de los quarteles qualquier esquadrón de cavallería y infantería sin desordenarse [...]; y assimismo, de la frente de los esquadrones aya espacio para passar esquadrón de cavallería o infantería, sin alterar la orden de los demás, y salir fuera de las trincheas, y no tan grande que quede desabrigada la arcabuzería y pieças de campaña o otras que se ponen a las trincheas y travesses d'ellas. // Rojas, Teórica fortificación, 1598, fol. 74r: Consiste toda la buena defensa en la buena guarnición de soldados, y que aprieten los puños y trabajen bien, porque en la guerra el que más trabaja, ésse es el que vence. $Y$ juntamente tener siempre los çarços y estacadas prevenidas para tapar las baterías, haziendo en ellas medias lunas y travesses para guardarlas, y hazer buenas salidas a estorvar las trincheas al enemigo. // González de Medina, Examen fortificación, 1599, pág. 
159: Será bueno, además de los rebellines, como quedan dichos, hazer unas trincheas con sus traveses, que se descubran todas de la muralla y se puedan defender, o, por lo menos, entretener al enemigo mucho tiempo con ello, y con cortaduras y defensas en cada calle del arrabal.

SIN.: cortadura 1 , traviesa $_{1}$.

ENCICL.: Terr.: En la fortificación, es una obra exterior que se pone en donde hay pasos angostos. Sus figuras son diversas y todas buenas como consigan el fin de estorbar el paso al enemigo.

alto [Roxas, Sumario milicia, 1607]. cmpt. sintag. Fort. Espacio o lugar elevado sobre el terraplén de un baluarte y paralelo a su fianco o través, donde se establece una batería provista de parapeto, banqueta, cañoneras y merlones.

Roxas, Sumario milicia, 1607, fol. 76r: Es neçesario mostrar un tanto más particularmente las partes o miembros de algún baluarte, que son: través; orejón [...]; contrafortes o espolones, pretiles o parapetos; plaza para el artillería en el trabés bajo, si lo huviere de tener, y en el alto, lo mismo.

SIN.: plaza alta, plaza de arriba, plaza superior.

$\sim$ bajo [Roxas, Sumario milicia, 1607]. cmpt. sintag. Fort. Batería descubierta que se establece a veces en una fortaleza, detrás del orejón de un baluarte con flanco retirado hacia dentro.

Roxas, Sumario milicia, 1607, fol. 76r: Es neçesario mostrar un tanto más particularmente las partes o miembros de algún baluarte, que son: través; orejón [...]; contrafortes o espolones, pretiles o parapetos; plaza para el artillería en el trabés bajo, si lo huviere de tener, y en el alto, lo mismo.

SIN.: plaza baja, plaza de abajo.

travez, V. través.

traviesa, trabiesa, traviesa, traviessa [de travieso (nominalización de un adjetivo) y éste del lat. transvĕrsus 'transversal'. Traviesa 'travesía'. h. 1600, Inca Garcilaso (DECH). Mendoça, Theórica y práctica, 1596]. sust. Fort. Cualquier tipo de obra o defensa que, tanto por parte de los sitiadores como por parte de los sitiados, suele levantarse en lugares estrechos para tratar de impedir el paso al enemigo. Mendoça, Theórica y práctica, 1596, pág. 90: Se procura, quando la tierra tiene tres o quatro puertas o salidas, embiar de día o de noche gente, si el sitio lo permite, que a un mismo tiempo ocupe los puestos d'ellas, haziendo diligencia en fortificarlos con trincheas, fossos y traviessas, con lo qual se le impide el socorro y el hazer salidas a los de dentro. // 
Mendoça, Theórica y práctica, 1596, pág. 92: Quando ay recelo de venir el enemigo con golpe de exército a socorrerla, se fortifica el alojamiento assí a la parte de las murallas como de la campaña, que se ha de reconocer con mucho cuidado, previniendo las venidas que puede tener el enemigo para meter socorro o llegar a combatir el alojamiento, las quales han de estar fortificadas como mejor fuere, haziendo traviessas, redutos, fuertes o trincherones, si lo pide la ocasión. // Mendoça, Theórica y práctica, 1596, pág. 130: Se ponen lienços a las bocas de las calles, para que los cercados no vean blanco a donde tirar en tanto que las fortifican con fossos y traviessas para impedir las salidas de las puertas sobre los quarteles.

SIN.: cortadura 1 , través 3 .

FAM.: través.

2 [Mendoça, Theórica y práctica, 1596]. sust. Fort. Especie de corredor o pasadizo de madera que fabrican los sitiadores en el ataque a una plaza para, una vez cubierto de tierra, céspedes y otros materiales poco combustibles, poder pasar el foso a través de él.

Mendoça, Theórica y práctica, 1596, pág. 96: Las trincheas no es possible dezir a Vuestra Alteza el puesto de donde se les da principio, ni si serán largas o cortas, ni si han de llegar a cubrir la artillería con que se bate hasta el arzén del fosso o venir a desembocar en él, ni caminar con traviessas por el mismo fosso adelante, si la calidad d'él lo permite. // Mendoça, Theórica y práctica, 1596, pág. 105-106: Assimismo se pican las murallas, quando se ha llegado con trincheas o traviessas en el fosso o por otro medio al pie d'ellas, cubriéndose los soldados con mantas al hazerlo, las quales se guarnecen de cueros por de fuera, impidiendo con esto, por ser de madera, no se quemen, echando fuego de las murallas los sitiados sobre ellas. // Mendoça, Theórica y práctica, 1596, pág. 126: Se estima por más fácil batería el quitar el un través y casamata que las dos, principalmente si ay en ellos plaça y cañonera para pieça de batir, contra quien resisten mal traviessas, aunque se camine por el fosso.

SIN.: galería 2 .

ENCICL.: Sanz (1749: s.v. galería para passo de fosso): El nombre de traversa se toma alguna vez por galería.

3 [Rojas, Teórica fortificación, 1598]. sust. Fort. En una fortaleza susceptible de ser dominada por un padrastro es la masa de tierra que se levanta en la parte que puede ser vista por el enemigo, la cual sirve para ocultar determinados elementos defensivos.

Rojas, Teórica fortificación, 1598, fol. 71v: Y si, por dicha, fuere el padrastro muy alto en demasiado, en tal caso se pondrán unas traviessas muy espessas y altas, de suerte que cubra las casas matas y el artillería d'ellas esté mirando al pie del padrastro, para quando el enemigo decienda a dar el assalto poderle ofender en campaña rasa. // Rojas, Teórica 
fortificación, 1598, fol. 71v: Y si, por ventura, huviesse otro padrastro por las espaldas, se harán assimesmo otras traviessas y terraplenos que cubran aquella parte del segundo padrastro. // Rojas, Teórica fortificación, 1598, fol. 78v: Y si fuessen ofendidos por las espaldas, se hará el mesmo remedio, poniendo traviessas contra aquella parte; y en qualquier caso d'éstos son buenos los árboles, porque con ellos no vee el enemigo desde afuera lo que haze adentro.

ENCICL.: Moretti (1828: s.v. traversa contra dominante): Fort. Dase este nombre a una masa de tierra que se eleva sobre un bastión de la cortina, o en cualquier otro punto de la fortificación de una plaza, para cubrir una obra que pueda ser vista y enfilada por el enemigo apostado en una altura que la domine.

\section{traviessa, V. traviesa.}

trinchea, V. trinchera.

trincheón, V. trincherón.

trinchera, trinchea, trinchera [del fr. tranchée 'íd.'. Trinchea [h. 1570, A. de Morales, Argote de Molina, en Aut.; Quijote], ant. Más tarde cambiado en trinchera, que ya está en Oudin (y según Aut. en la Pícara Justina) (DECH). Loçano, Alberto, Architectura, 1582]. sust. Fort. Zanja o defensa hecha de tierra en la cual o tras la cual quedan los soldados a cubierto (DUE). \& (fig. 167)

Álaba, Perfeto capitán, 1590, fol. 87r: Y las trincheas que se huvieren de hazer procurarse a que se hagan lo más cerca de los fossos que fuere possible y antes que amanezca, porque si la luz del día los coge sin que todo esté dispuesto para dar la batería, será servir todos de terrero y blanco para ser ofendidos de los que tratan de ofender. // Rojas, Teórica fortificación, 1598, fol. 37v: Y a mi parecer (conforme a lo que he comunicado con los más experimentados en esta materia), será bueno el fosso seco quando la plaça tuviesse mucha pujança de gente dentro que salga a estorvar al enemigo las trincheas, pero si la plaça tiene poca gente, como ya es ordinario, es mejor que sea el fosso con agua. // Roxas, Sumario milicia, 1607, fol. 103r: Y estando todo el rodeo de la dicha plaça ocupado con gran fortaleza, se començará a travajar en las trincheras, entrando al travajo cada día 4 terçios de los treze que son en el exérçito, los quales començarán a meter las trincheras por la parte más flaca de la plaça.

FAM.: atrincherado, atrincherar, trincherón.

ENCICL.: Terr.: Voz de la Milicia y Arquitectura militar, foso que se abre en la tierra para acercarse a la fortaleza sitiada, a cubierto de su fuego [...]. También le llaman trinchera, o atrincheramiento a cierta fortificación que se hace en un campo de varios modos para impedir los acontecimientos y daño de los enemigos. // Almirante (1869): En general toda 
zanja, no muy grande, abierta en el suelo, cuyas tierras excavadas se amontonan al lado. En el tecnicismo de ingenieros, se comprenden bajo la voz trincheras, como genérica, todos los trabajos de sitio, es decir, los de ataque o aproche que hace el que ataca o sitia una plaza, para aproximarse a cubierto de los fuegos. / / Sanz (1749: s.v. trinchera o línea de ataque): Es un trabajo que hacen los sitiadores para ganar el camino cubierto, foso y aún hasta el cuerpo de la plaza. Ésta se construye de diversos modos y según la calidad del terreno por donde se empieza; porque si el terreno alrededor de la plaza es peñascoso, la trinchera es una elevación de fajinas, sacos a tierra, cestones, sacos de lana, de espaldones de tierra traída de otra parte y generalmente de todo aquello que puede cubrir al sitiador sin causarle daño; pero si las tierras se pueden sacar de la trinchera, quedará un camino cubierto que puede servir de foso, haciéndole un parapeto contra la plaza. Las trincheras en buen terreno tienen diez pies de ancho, tres de profundo, y el parapeto de cuatro y medio de ancho y de seis a siete de alto, a fin de poner los soldados a cubierto. De cualquier naturaleza que sea la trinchera, se debe construir sin ser enfilada de la plaza, conduciéndola de modo que los sitiados no puedan descubrir ni disparar contra su longitud, por lo que se conduce a retornos o recodos, que en algún modo forman líneas paralelas a la plaza que se ataca. La trinchera la trazan los ingenieros después de haber hecho un serio reconocimiento de la plaza los generales y director de ingenieros [...]. El arte de defender las trincheras ha sido muy perfeccionado por el mariscal de Vauban y ha dado tan buenas luces para ello como otro alguno. En todos tiempos se ha procurado empezar la trinchera por paraje que el soldado esté menos expuesto al peligro. En otro tiempo se empezaba a abrir más vecino a la plaza, porque no eran tantas las obras exteriores, pero hoy se abre fuera del tiro de mosquete y aun del cañón.

abrir [Mendoça, Theórica y práctica, 1596]. loc. v. Fort. Empezarla para emprender el ataque o ataques de una plaza (Corsini 1849).

Mendoça, Theórica y práctica, 1596, pág. 94: En esto se ha de proceder según la gente que huviere dentro, compostura de las murallas y fossos, si los ay, porque quando se pueden entretener los de dentro, no es bien caminar en batirla sin cubrir la artillería y abrirse trincheas, por averse de aventurar mucha gente sin las dos cosas y darse ánimo a los de dentro con ver la que pierden los de fuera. // Lechuga, Discurso de la Artillería, 1611, pág. 227: El general de la artillería deve saber todo lo contenido en este discurso de experiencia $\mathrm{y}$, mucho más, pudiendo, por quanto a las plazas o fuerzas, no se a de abrir trinchera sin su pareçer, ni hazer batería, máchina ni otra cosa, sin que la aprueve. // Ufano, Tratado de la Artillería, 1613, pág. 255: Fabrícanse los candeleros en el modo y manera que la presente figura demuestra. Y deven ser tan altos que buenamente con ellos y faxina se pueda de presente cubrir la gente que començare a abrir trincheas y ordenar baterías, y tan ancho el un mástel del otro que puedan entre ambos buenamente caver dos o tres salchichas o gruesas faginas de lado.

ENCICL.: Sanz (1749: s.v. abrir la trinchera): Es empezar el trabajo de un ataque. En el primer trabajo que hace el sitiador para ir a cubierto hasta el cuerpo de la plaza sitiada, rara vez deja de hallarse el general del ejército para animar al soldado y hacer adelantar el trabajo. La abertura de una trinchera no debe ser enfilada ni vista de ningún paraje de la plaza. Es necesario que ella se flanquee y sea bien alta para cubrir al soldado; los parapetos deben ser a prueba de cañón y que haya reductos de distancia en distancia, plazas de armas para 
alojar los soldados, defenderse en ellas, contra las salidas de la plaza y sean bien guardadas. Mientras que los ingenieros y trabajadores empiezan la trinchera, las tropas están echadas vientre a tierra con sus fusiles, para sostener los trabajadores en caso que la guarnición haga alguna salida. Al empezar la trinchera, si el gobernador de la plaza es hábil, incomoda los trabajadores con frecuentes salidas y con un gran fuego. Para cubrirse de los primeros tiros sería bueno hacer provisión de manteletes, pues su dispendio costaría menos que la pérdida de los hombres; además que los trabajadores hallándose a cubierto, trabajarían con más desembarazo y se adelantaría más en una hora, que de lo contrario en un día, y los soldados rechazarían con más vigor las salidas de la guarnición.

trincherón, trincheón, trincherón [de trinchera (DECH). Rojas, Teórica fortificación, 1598]. sust. Fort. La trinchera grande o fuerte (Aut.).

Rojas, Teórica fortificación, 1598, fol. 34v: Y la AB es conforme a la opinión de los antiguos, por la qual se vee muy claro que, levantando un trincherón gruesso en el punto B de siete pies en alto, passará el enemigo con mucha facilidad el fosso, porque, por estar muy lexos la defensa, cubre el trincherón más de 200 pies la superficie de la tierra, y por allí podría passar en esquadrón. // Rojas, Teórica fortificación, 1598, fol. 35r: La segunda opinión que muestra la CD es la distancia que pone Carlo Teti y Gerónimo Catanio, en la qual, levantando el mesmo trincheón de 7 pies de alto en el punto $\mathrm{D}$, viene a cubrir de superficie más de 150 pies, por donde passaría el enemigo con gran comodidad, en ordenança, que viene a ser el mesmo daño que en lo passado. // Roxas, Sumario milicia, 1607, fol. 103v: Y estando ya el foso çiego y hecho ya en él un dique de quarenta o çinqüenta pies de ancho, se yrá haçiendo ençima un trincherón muy grueso, que tenga 20 pies de groseça, para resistir el artillería que le tiraren de la casamata.

FAM.: atrincherado, atrincherar, trinchera.

2 [Mendoça, Theórica y práctica, 1596]. sust. Fort. Trinchera imperfecta, inacabada, excavada repentinamente (Estévanez 1897).

Mendoça, Theórica y práctica, 1596, pág. 92: Y quando ay recelo de venir el enemigo con golpe de exército a socorrerla, se fortifica el alojamiento assí a la parte de las murallas como de la campaña, que se ha de reconocer con mucho cuidado, previniendo las venidas que puede tener el enemigo para meter socorro o llegar a combatir el alojamiento, las quales han de estar fortificadas como mejor fuere, haziendo traviessas, redutos, fuertes o trincherones, si lo pide la ocasión. / / Rojas, Teórica fortificación, 1598, fol. 106r: Y aun para que de la muralla con fuegos no quemen la dicha fagina y madera, es bien tener qüeros de vaca para cubrirlo, y teniéndole ciego hasta el ras del agua, de suerte que esté hecho un dique o passo mazizo de 30 o quarenta pies de gruesso por lo menos; y allí encima se yrá haziendo un trincheón y se atravessará el fosso hasta topar con la esquina del valuarte, que ya estará batida y derribada por el suelo.

ENCICL.: Almirante (1869): No es en rigor aumentativo de trinchera, como no lo es de mosquete, mosquetón. Trincherón se llamaba a la fortificación de campaña "a medio hacer", imperfecta, la excavación irregular del foso y sin perfilar el parapeto [...]. Hoy, que ya son 
necesarios los atrincheramientos rápidos en el campo de batalla, las baterías improvisadas, las trincheras-abrigos, los pozos de tirador, en una palabra, los movimientos de tierra, precipitados, irregulares, momentáneos, bien puede resucitarse el trincherón, como voz genérica y expresiva.

triumfante, $V$. triunfante.

triumphante, V. triunfante.

triumphar, V. triunfar.

triumpho, V. triunfo.

triunfador, triunfador [de triunfar (DECH). Álaba, Perfeto capitán, 1590]. sust. Mil. ant. Persona que entra en la ciudad solemnemente, como reconocimiento o premio a su victoria.

Álaba, Perfeto capitán, 1590, fol. 146v: Y en tanta estima era tenido el triunfo en Grecia que no querían que el triunfador entrasse por alguna de las puertas de la ciudad; y assí, para este propósito derribavan un pedaço de muro y no lo tornavan a rehazer, dando a entender que las ciudades que tales hombres criavan no avían menester muros.

SIN.: triunfante $_{2}$.

FAM.: triunfante, triunfar.

triunfante, triumfante, triumphante, triunfante [de triunfar. Santillana (DECH). Loçano, Alberto, Architectura, 1582]. adj. Mil. ant. Dicho de una persona o de una colectividad: que entra en la ciudad solemnemente, como reconocimiento o premio a su victoria.

Loçano, Alberto, Architectura, 1582, pág. 250: Y también el arco, como la puente, tendrá tres sendas para andar: la de en medio servirá para los soldados, y las dos de los lados para las madres y para los que acompañaren al exército triumphante que buelve a su tierra para saludar a los dioses de su patria, y que se regozijan y dan el parabién a los que triumphan.

FAM.: triunfador, triunfar.

2 [Álaba, Perfeto capitán, 1590]. sust. Mil. ant. Persona que entra en la ciudad solemnemente, como reconocimiento o premio a su victoria. 
Álaba, Perfeto capitán, 1590, fol. 147r: En todos los triunfos, delante del triunfante, yvan unos litores, que nosotros llamamos maceros, vestidos con vestiduras blancas, acompañados de músicos de vihuelas, harpas y flautas y todos coronados con coronas de oro. // Álaba, Perfeto capitán, 1590, fol. 147r: Puesto todo el acompañamiento en este orden, yva el triunfante al Capitolio, al templo de Júpiter Capitolino, en el qual sacrificavan alguno de los capitanes presos y, acabado este sacrificio, baxavan al palacio, donde avía gran aparato de comidas, y allí comían todos públicamente, acompañando el comer con mucho regozijo y fiesta.

SIN.: triunfador.

ENCICL.: DUE: Triunfador.

triunfar, triumphar, triunfar, triunphar [tomado del lat. triumphare 'íd.'. Pz. de Guzmán, Santillana; APal.; Nebr. (DECH). Loçano, Alberto, Architectura, 1582]. v. intr. Mil. Resultar vencedor en un combate o batalla.

Loçano, Alberto, Architectura, 1582, pág. 186-187: Otros añidieron las basis y capiteles de cobre y dorados, como en Roma se vee en el portal doblado, la qual assentaron en el consulado de aquel Octavio que triumphó de Perseo. // Álaba, Perfeto capitán, 1590, fol. 38r: Y muchas vezes por su ocasión sucede que los soldados que avían triunfado de los enemigos, rindiéndolos y desbaratándolos, vengan a perecer y morir por su mesma culpa. // Álaba, Perfeto capitán, 1590, fol. 142v: No tuvo diferente paga de la fortuna César, su competidor, el qual, aviendo vencido a Pompeyo, triunfado de los franceses, alexandrinos, pónticos, africanos y españoles, conjurándose contra él Cayo Casio y Decio Bruto, con veyntitrés puñaladas fue d'ellos herido y muerto en el senado.

FAM.: triunfador, triunfante.

2 [Loçano, Alberto, Architectura, 1582]. v. intr. Mil. ant. Dicho del vencedor: entrar en la ciudad solemnemente, como reconocimiento o premio a su victoria.

Loçano, Alberto, Architectura, 1582, pág. 250: Y también el arco, como la puente, tendrá tres sendas para andar: la de en medio servirá para los soldados, y las dos de los lados para las madres y para los que acompañaren al exército triumphante que buelve a su tierra para saludar a los dioses de su patria, y que se regozijan y dan el parabién a los que triumphan. // Álaba, Perfeto capitán, 1590, fol. 146v: Este solene acto de triunfar se celebrava saliendo toda la gente de las ciudades, assí hombres como mugeres, de qualquier edad que fuessen, a hazer un solene recebimiento a todos los que bolvían vencedores, dando públicas muestras de regozijo por la muerte y destruyción de sus contrarios. // Álaba, Perfeto capitán, 1590, fol. 147v: Y la licencia del triunfar estava tan limitada por los romanos que el que en una batalla no huviesse muerto cinco mil enemigos, aunque saliesse vencedor en muchas, no tenía facultad de celebrar su vitoria con triunfo; y en la averiguación d'esta cantidad se procedía con gran rigor. 
ENCICL.: Aut. (s.v. triumphar): Entre los romanos era hacer pública ostentación de la victoria conseguida de los enemigos, entrando el vencedor con grande fausto, pompa y acompañamiento de soldados y pueblo, llevando delante de los carros triunfales las principales personas de quienes se había logrado la victoria, y caminando con grande aplauso hasta el capitolio o templo.

triunfo, triumpho, triunfo, triunpho [tomado del lat. trŭumphus 'íd.'. Mena, Pz. de Guzmán, APal. (DECH). Anónimo, Repertorio tiempos, 1554]. sust. Mil. ant. Ceremonia de entrar solemnemente el vencedor en la ciudad.

Anónimo, Repertorio tiempos, 1554, fol. XIIIr-XIIIv: El mes de agosto fue llamado por Rómulo sextil, porque era el sexto mes contado dende março. Después fue llamado del nombre de Augusto César, el qual en tal mes desbarató a Marco Antonio y a Cleopatra, y en tal mes como éste entró con tres triumphos en Roma. // Álaba, Perfeto capitán, 1590, fol. 146v: Y en tanta estima era tenido el triunfo en Grecia que no querían que el triunfador entrasse por alguna de las puertas de la ciudad; y assí, para este propósito derribavan un pedaço de muro y no lo tornavan a rehazer, dando a entender que las ciudades que tales hombres criavan no avían menester muros. // Álaba, Perfeto capitán, 1590, fol. 147v: Y la licencia del triunfar estava tan limitada por los romanos que el que en una batalla no huviesse muerto cinco mil enemigos, aunque saliesse vencedor en muchas, no tenía facultad de celebrar su vitoria con triunfo; y en la averiguación d'esta cantidad se procedía con gran rigor.

ENCICL.: Estévanez (1897): En la antigua Roma se llamaba triunfo la consagración de la victoria, la entrada triunfal del héroe o de los héroes, el galardón o premio que se les ofrecía. Al general que obtenía los honores del triunfo se le ceñía corona de laurel y entraba en carro; el que sólo era acreedor a la "ovación" entraba a pie y con corona de mirto. // Álaba, Perfeto capitán (1590: fol. 146v-148r): "El triunfo se ordenava d'esta manera, según se cuenta del de Paulo Emilio, en el qual yvan delante dozientos y cincuenta carros que llevavan despojos de batallas, colunas y colosos; tras éstos seguían otros muchos carros cargados de diversas armas que en la batalla se avían quitado; después venían tres mil hombres [...]; tras éstos se seguían los menestriles con otros varios instrumentos de música; consiguientemente yvan ciento y veynte bueyes [...]; luego se seguían cierto número de muchachos que llevavan bacías de oro y plata para recoger la sangre; tras éstos yvan los que llevavan gran cantidad de moneda de oro [...]; tras esto yva el carro de Perseo con sus armas y la diadema d'este Rey puesta sobre ellas; después venían los hijos del mesmo Perseo con sus ayos y maestros, cercados de gente que llorava; después yva Perseo con una vestidura negra y con pantuflos, a uso de su tierra, cercado de sus familiares, todos muy tristes; más atrás venían quatrocientas coronas que las ciudades de Grecia avían dado a Perseo; luego se seguía Paulo Emilio sobre un carro dorado, vestido de púrpura bordada de oro, con un ramo de laurel en la mano siniestra y un cetro de marfil en la diestra, cercado de muchas compañías de soldados que le yvan diziendo motes [...].

Puesto todo el acompañamiento en este orden, yva el triunfante al Capitolio, al templo de Júpiter Capitolino, en el qual sacrificavan alguno de los capitanes presos y, acabado este sacrificio, baxavan al palacio, donde avía gran aparato de comidas, y allí comían todos públicamente, acompañando el comer con mucho regozijo y fiesta [...]. 
Y la licencia del triunfar estava tan limitada por los romanos que el que en una batalla no huviesse muerto cinco mil enemigos, aunque saliesse vencedor en muchas, no tenía facultad de celebrar su vitoria con triunfo; y en la averiguación d'esta cantidad se procedía con gran rigor $[\ldots]$.

También fue condición necessaria, algún tiempo guardada para triunfar, que aquello que avía allanado y sujetado el vencedor fuesse adquirido de nuevo al imperio y juridición romana; y si alguna vez avía salido d'ella y en aquella batalla se avía buelto a incorporar, no tenía derecho el capitán de pedir triunfo [...].

Fuera d'esto, era necessario que el que llevando a su cargo alguna jornada venciesse, fuesse a ella teniendo dignidad de magistrado o de ditador, cónsul o pretor, porque la vitoria desacompañada de alguna d'estas dignidades no era bastante razón de triunfar [...].

También se le negava la facultad de triunfar a quien, aviendo llevado el exército a una provincia, no la dexava llana y pacífica al capitán sucessor [...].

Otra causa avía, no sólo de negar el triunfo, mas aun de no recebirlo, ofreciéndose, quando de la parte de los romanos la pérdida y muerte de la gente era notable".

triunphar, V. triunfar.

triunpho, V. triunfo.

tronera, tronera [de trueno en el sentido de 'detonación de una arma de fuego'. "Cavus machinarius" Nebr.; 1570, C. de las Casas; 1600, Aut. (DECH). Montes, Instrucción y regimiento, 1537]. sust. u. $\mathrm{m}$. en pl. Fort. Agujero o abertura que se hace en las baterías o parapetos para disparar la artillería y reconocer con menos riesgo los movimientos del enemigo. 6 (fig. 168)

Montes, Instrucción y regimiento, 1537, fol. XVIIr-XVIIv: Y por lo alto tenga el muro sus defensas y andamios, con sus troneras, para que los arcabuzeros puedan tirar a los de fuera. // Roxas, Sumario milicia, 1607, fol. 77r: Ancho de la boca de la tronera dentro y fuera, que será como aquí pareze, 10 y 10 pies a lo de fuera y 5 en medio. // Lechuga, Discurso de la Artillería, 1611, pág. 242: Concluyose, assimismo, que no aya de aver más de una casamata en cada través, y no dos, porque quede mayor lugar a la entrada de los baluartes; y que en ella no aya más costa de la muralla que la del través, y que las pieças queden con sus troneras hechas en el terrapleno, de manera que puedan tirar a la mitad de la cortina y dar en el llano del fosso de ella.

SIN.: cañonera, saetera.

ENCICL.: Díaz Capmany (2004: 28): "Cañonera o tronera era la abertura practicada en el parapeto para que asomando por ella el cañón pueda tirar en un campo de acción limitado. La cañonera se llamaba "directa" cuando su eje era normal a la escarpa, y se llamaba "oblicua" cuando no lo era. La abertura interior debía ser lo más limitada posible para que por ella no quedaran descubiertos los artilleros, pero debían pasar por ella de manera desahogada los tubos de los cañones". 
tropa, tropa [del fr. troupe 'bandada de animales o de gente', 'tropa', que parece ser derivado regresivo de troupeau, fr. ant. tropel 'rebaño'. La $o$ de tropa se debe al influjo del cast. tropel. 1605, Cervantes, Góngora; Oudin (DECH). Mendoça, Theórica y práctica, 1596]. sust. Grupo regular y organizado de soldados (DEA).

Mendoça, Theórica y práctica, 1596, pág. 85: Fuera del cuydado que se ha de poner para buscar buenas espías, cosa de tanta importancia en la guerra, es buen medio tener de día y de noche sobre el enemigo una, dos o más tropas de cavallos que vayan por diferentes partes. // Mendoça, Theórica y práctica, 1596, pág. 148: Y no llevando más que una guía con los corredores, quando se hallan dos caminos, si es de noche escura, ha de dexar la primera tropa de los corredores un soldado en el camino para advertir a la segunda el camino que ha de hazer, y ella otro para que los pueda seguir la tercera y no errarse. // Ufano, Tratado de la Artillería, 1613, pág. 104-105: Y, en tal caso, delante de toda la ynfantería deven en buena orden marchar 500 caballos de guerra, en una o dos tropas, como mejor les viniere a qüento, descubriendo advertidamente de una parte y otra de los caminos toda la campaña.

SIN.: gente, gente de (la) batalla, gente de guerra, gente de pelea, gente militar, milicia $a_{3}$

ENCICL.: Aut.: La gente militar o de guerra, infantes o de a caballo, a distinción de los paisanos. // Estévanez (1897): Reunión de soldados, sean pocos o muchos, y sea cualquiera el instituto o arma a que pertenezcan. // DUE: (gralm. pl.) Conjunto de soldados, o sea, de hombres armados y organizados.

tropel, tropel [del fr. ant. tropel 'rebaño', diminutivo de trop, primitivamente 'rebaño' (luego empleado adverbialmente en el sentido de 'mucho' y 'demasiado'), a su vez de origen incierto, probablemente tomado de un fránc. *throp 'asamblea'. Ya en la trad. de Lucano atr. a Alfonso X (Almazán), en el Zifar y en J. Ruiz, y principalmente como voz militar (DECH). García de Palacio, Diálogos militares, 1583]. sust. Mil. Cualquier tipo de unidad o agrupación táctica de soldados.

García de Palacio, Diálogos militares, 1583, fol. 145r: Los antiguos que la milicia professaron ordenavan, señor, sus gentes, para entrar en batalla, por esquadrones o tropeles, los quales, aunque sean llamados de diversos nombres, casi siempre han correspondido a una qüenta e número, por manera que cada esquadrón o batallón de aquéllos antiguos se ordenava y hazía de siete $\mathrm{u}$ ocho mil hombres, a los quales los escriptores romanos llamaron legiones y los griegos falanjes.

SIN.: batallón 1, escuadrón. 
vagage, $\mathrm{V}$. bagaje.

vagaje, V. bagaje.

vaivén, baibén, baybén, bayvén, vaybén [quizá sea palabra de procedencia forastera; comp. fr. va-et-vient (que parece ser moderno) y cat. vaivé 'íd.' (que ya ha de ser medieval, pues el derivado vaiver, -era, 'movedizo', 'haragán', 'frívolo, débil', hoy mallorquín, ya aparece en Jaume Roig, y una variante vayvarea en otro texto antiguo). Calderón, Aut. (DECH). Roxas, Sumario milicia, 1607]. sust. Fort. ant. Máquina empleada para batir murallas, consistente, fundamentalmente, en una viga o trabe larga y pesada, uno de cuyos extremos está reforzado con una pieza de hierro o bronce, labrada, por lo común, en forma de cabeza de carnero.

Roxas, Sumario milicia, 1607, fol. 44v: Y la tercera pared de más adentro sea más baxa que su compañera, de tal manera que la gente que estubiere en lo llano de la plaça suba por la qüesta dulçe a las defensas de los arietes o baybenes. // Roxas, Sumario milicia, 1607, fol. 96v: Otros muchos autores antiguos nos çertifican que ellos sabían bien que el salitre abrasava, porque se serbían d'él en las composiçiones de algunos fuegos para quemar las mantas y baybenes y máquinas, y torres de madera que en aquel tiempo se usavan en los combates de ciudades, y también para abrasar las armadas.

SIN.: ariete, carnero. 
ENCICL.: Cov. (s.v. baybén): El golpe que se da con alguna máquina, movida primero en el aire con que toma más fuerza, como aquella que los antiguos llamaban ariete, máquina militar para derrocar puertas y muros. Era una viga muy grande sustentada en el aire con maromas sobre puntales, guarnecida al cabo de fuerte acero en forma de cabeza de carnero, y dando vaivenes con ella derrocaban cualquier reparo. De este ariete hace mención Virgilio, libro 2. Eneidos [...]. Se dijo vaivén de va y viene, porque va para atrás y viene para adelante, con notable y desapoderada furia [...].

valla, balla, valla [del lat. valla, plural de vallum 'empalizada', 'muralla de tierra o piedra'. Covarr. (DECH). Mendoça, Theórica y práctica, 1596]. sust. Fort. Defensa o pared, hecha de madera, tierra o de cualquier otro material, destinada a impedir el acceso a un lugar. (fig. 169)

Mendoça, Theórica y práctica, 1596, pág. 48: En medio de los quarteles y frente de las vanderas se han de plantar las tiendas de Vuestra Alteza y quartel de su corte y guardas, a que seguirá la gente de la batalla, quando estuvieren señalados cuerpos de esquadrones para ello, aviendo en el quartel, entre las calles y pavellones, calles espaciosas para salir la gente a la plaça de armas sin embaraço y a las tiendas de Vuestra Alteza, que han de tener al contorno una balla de lienço a manera de pared, de la altura que llegue a los pechos de un hombre, y un pequeño fosso al pie d'ella. // Lechuga, Discurso de la Artillería, 1611, pág. 249: Acavada la fuerça dentro y fuera, se a de hazer a toda la estrada cubierta una valla de madera, por la parte de la campaña, de quatro o cinco pies de alteza, o tener lo necessario de leñames para hazerla quando sea tiempo, porque en ocasión servirá de que no puedan de golpe llegar los enemigos a la contraescarpa, pues para salir, se podrá hazer que, por partes, con gonzes se levante y abaxe quando se quisiere. // Lechuga, Discurso de la Artillería, 1611, pág. 249: Todo lo dicho, fuera de la valla, hasta aquí se entienda para todas las fuerzas de quatro baluartes, porque, respecto de tener más baluartes las demás, son los ángulos differentes, y a esta causa sacan differencia en algunas cosas que se verán en ellas.

SIN.: valladar, vallado 2 .

ENCICL.: Terr.: Lo mismo que vallado.

valladar, valladar [de vallado. B-, 942, Oelschl., con otros muchos textos de los ss. X-XIII; v-, J. Ruiz; "v. de tierra: agger" Nebr. (DECH). Celso, Reportorio universal leyes Castilla, 1553]. sust. Fort. Defensa o pared, hecha de madera, tierra o de cualquier otro material, destinada a impedir el acceso a un lugar.

Celso, Reportorio universal leyes Castilla, 1553, fol. LIv: El que cerca la calle para que no puedan libremente passar, pague XXX sueldos al Rey. Ley I, título VI, libro IV del Fuero; e ley XXIV, título IV, libro VIII del Fuero Juzgo. E qualquiera puede, sin pena alguna, deshazer la tal cerradura o valladar. // Loçano, Alberto, Architectura, 1582, pág. 71: Y aquí hará algo al propósito aquello de Varrón, que dize que los tusculanos solían guiar los valladares para las villas con fábrica de piedra, pero en el campo Gállico, de ladrillos cozidos; en los Sabinos, de crudo; en España, de tierra compuesta con piedras pequeñas. 
// Loçano, Alberto, Architectura, 1582, pág. 139: Y assí, sembrados de manera que dañen, hechas y aparejadas las cavas, se assentará un valladar tan gruesso, que no se deshaga con qualquiera pequeña máchina de guerra, y tan alto, que no sólo no se puedan aplicar hachas para arrebatar, pero ni aun se puedan tirar fácilmente con la mano dardos para espantar al soldado.

SIN.: valla, vallado ${ }_{2}$.

FAM.: vallado.

ENCICL.: DRAE: vallado. // DEA: Valla.

vallado, ballado, vallado [del lat. vallatus, part. pasivo de vallare 'cerrar con empalizada, fortificar'. APal.: "caecum... dixieron al v. en que los palos agudos fincados en tierra están cobiertos de yerbas y de fojas"; "vallum" Nebr. (DECH). Loçano, Alberto, Architectura, 1582]. adj. Fort. Dicho de una construcción o de un lugar: rodeado o cerrado con un vallado o una valla.

Loçano, Alberto, Architectura, 1582, pág. 139: Y es cosa necessaria que lo que de las cavas se saca se amontone en el valladar. Para esta obra aprovaron los antiguos los céspedes, quitados de la corteza de los prados, donde están las raýzes de las yervas; otros entremezclan mimbres verdes de salce, que affirmen la obra vallada con el brotar y plegar de las hebras.

FAM.: valladar.

ENCICL.: Aut.: Part. pas. del verbo vallar. Lo así cercado y cerrado.

2 [Anónimo, Repertorio tiempos, 1554]. sust. Fort. Defensa o pared, hecha de madera, tierra o de cualquier otro material, destinada a impedir el acceso a un lugar.

Loçano, Alberto, Architectura, 1582, pág. 132: Y no han de estar tan fortalecidos los reales de los exércitos, con vallado y fossa, quanto se han de cercar los encerramientos de éstas con muros altos y enteros, no dexando por parte alguna aberturas ningunas por donde puedan ser metidos. // Loçano, Alberto, Architectura, 1582, pág. 138: Y si faltavan lugares altos y despeñaderos a la redonda, los imitavan con fossas profundíssimas y con montones allegados, y los ceñían con vallado y çarzos. // Álaba, Perfeto capitán, 1590, fol. 48v-49r: Y porque en la distancia que a de aver del cuerpo de guardia a la demás gente del campo ay variedad de pareceres, abreviando en esto, digo que si el alojamiento está cercado de trincheas, hasta ellas se a de alargar la guardia, pues son como muro del exército; y que, no aviéndolas, lo más que se podrá alejar serán ochenta passos y que alguna vez podrá passar adelante, quando huviere ribaços, fosos o vallados, porque éstos servirán por trincheas.

SIN.: valla, valladar. 
ENCICL.: Aut:: El cerco que se hace a algún sitio formado de tierra levantada, o de otra cualquier cosa que le sirva de defensa, que le cierre e impida la entrada. // Almirante (1869: s.v. valladar): Vallado es cerca de estacas, tablas, tierra, setos, árboles.

3 [González de Medina, Examen fortificación, 1599]. sust. Fort. Terreno o superficie que desde el parapeto de la estrada cubierta va descendiendo, con una pendiente o declive muy suave, hasta alcanzar el nivel de la campaña. (fig. 170)

González de Medina, Examen fortificación, 1599, pág. 42: Es buena esta estrada cubierta para salir a estorvar al enemigo las faciones que ha de hazer para arrimarse. También es buena para más fácilmente recebir socorro y defender el arzen o ballado, por si de al largo huviesse quitado el enemigo las defensas de la muralla. // González de Medina, Examen fortificación, 1599, pág. 42-43: El arzen del foso o vallado, que se dize, ha de descender desde lo alto del parapeto de la estrada cubierta muy pendiente, que apenas se eche de ver que le ay. Hase de descubrir todo él de lo alto de la muralla para poderle defender. Házese para que encubra la muralla y que se vea poquíssimo que batir d'ella. // González de Medina, Examen fortificación, 1599, pág. 219: El vallado, de cien pies por lo menos, escarpado a lo largo.

SIN.: arce del foso, arcén, arcén del foso, árgine, escarpa 3.

vallar, vallar [del lat. vallare 'cerrar con empalizada, fortificar'. Aut. (DECH). Celso, Reportorio universal leyes Castilla, 1553]. v. tr. Fort. Rodear o cerrar un lugar con vallado o valla.

Celso, Reportorio universal leyes Castilla, 1553, fol. CCLXIVv: Y lo mesmo sería si los metiessen en algún lugar grande, aunque fuesse vallado o cercado. // Loçano, Alberto, Architectura, 1582, pág. 128: Si el fuerte fuere marítimo, los vados de ala redonda serán impedidos con palos y piedras, para que alguna vez no puedan acercarse las máchinas. Si estuviere en plano, rodearse ha con fossa de agua; y para que ésta no traya lago de ayre hediondo, cavarse ha mucho para que mane agua viva. Si estuviere en monte, vallarse ha como despeñaderos, y donde fuere lícito usaremos de todas estas cosas. // Loçano, Alberto, Architectura, 1582, pág. 138: Empero, la razón del vallar los alojamientos es varia. Los ingleses con palos de diez pies tostados y agudos se hazen estacada; la una punta fixada dentro en el suelo y apretada, y la otra que salga afuera, estendida, de suerte que mire azia el enemigo. Los franceses, dize César aver acostumbrado opponer al enemigo los carros por vallado.

vallesta, V. ballesta.

vallestero, V. ballestero.

vallestrero, V. ballestero. 
valuarte, V. baluarte.

vanguarda, vanguarda [del cat. avantguarda (formado con avant 'ante'), modificado luego bajo el influjo del it. vanguardia. Montes, Instrucción y regimiento, 1537]. sust. Mil. Parte de una fuerza armada que en una marcha, ataque, etc., va delante (DUE: s.v. vanguardia).

Montes, Instrucción y regimiento, 1537, fol. XVr: Y alcançó el Rey la vitoria porque el Crity, que era general de venecianos, no affrontó a los principios y, quando quiso affrontar con su gente, no pudo porque ya era rota la vanguarda de venecianos y el cuerpo de la batalla, y preso Bartolomé Dalbiano; y éstos perdiéronse aquel día por la mala orden de su general.

SIN.: avanguarda, avanguardia, vanguardia.

ANT.: retaguarda, retaguardia, rezaga.

FAM.: avanguarda, avanguardia, vanguardia.

vanguardia, banguardia, vanguardia [del cat. avantguarda (formado con avant 'ante'), modificado luego bajo el influjo del it. vanguardia. Covarr. (DECH). Montes, Instrucción y regimiento, 1537]. sust. Mil. Parte de una fuerza armada que en una marcha, ataque, etc., va delante (DUE).

Montes, Instrucción y regimiento, 1537, fol. Xr: Quando el exército començare a marchar la buelta adonde están los enemigos, han de echar de banguardia la gente más plática en la guerra y, tras aquélla, vaya el cuerpo de la batalla, y luego la artillería, y de retaguardia vaya la gente que no es tan plática [...]. Mas si conosciere que los enemigos estuvieren más pujantes que no ellos y se quisieren retirar, echen la gente más plática de retaguardia y la que no es tan plática vaya de banguardia con la artillería. // Álaba, Perfeto capitán, 1590, fol. 133r-133v: Y, no teniendo reparo alguno por razón del sitio, dispondrá su gente en forma quadrada, poniendo en la vanguardia, retaguardia y lados los más animosos y valientes, para que la fuerça por todas partes sea igual, pues por todas le pueden acometer. // Rojas, Teórica fortificación, 1598, fol. 104v: Y se hará con tal forma este alojamiento que rodee todo el castillo, repartiendo o mezclando las naciones como convenga, y todos de tal manera que se den la mano unos a otros, sin que pueda entrar ni salir ninguna persona al castillo. Y, hecho este repartimiento, llegará el exército y se alojará la vanguardia en la parte que estuviere señalada, y de allí irán passando los demás, alejándose por su orden.

SIN.: avanguarda, avanguardia, vanguarda.

ANT.: retaguarda, retaguardia, rezaga.

FAM.: avanguarda, avanguardia, vanguarda. 
ENCICL.: Sanz (1749): Es la primera línea de un ejército formado en batalla o la primera división que marcha a la cabeza de todo. // Terr.: Frente o parte delantera de un ejército [...]. V. Banguardia. // Terr. (s.v. banguardia): Todo el ejército se compone de vanguardia, cuerpo de batalla y retaguardia. // Mendoça, Theórica y práctica (1596: pág. 59-60): "Quando ay poca gente se divide el exército en dos partes para caminar, que es vanguardia y retaguardia; y de ordinario, si ay número de esquadrones, en tres, haziendo batalla con parte que tenga igual proporción con la vanguardia y retaguardia, con lo qual viene a ser medio, sin participar de los dos extremos, y cuerpo proporcionado".

en $\sim$ [Mendoça, Theórica y práctica, 1596]. loc. adv. En cualquier acción, en primera posición o delante de todos los demás.

Mendoça, Theórica y práctica, 1596, pág. 73: Luego que descubren los corredores en vanguardia o retaguardia, los cargan con resolución, a quien es forçoso, siendo tan inferiores, retirarse y los cavallos enemigos avezinarse al exército, reconociéndole mejor. // Mendoça, Theórica y práctica, 1596, pág. 75: Y en caso que el enemigo pueda cargar, assimismo, en la retaguardia, se reforçará, dividiendo la batalla de suerte que en medio se ponga la artillería y bagaje con la mayor parte de la cavallería, pues no es de efecto, llevando en vanguardia y retaguardia pieças de campaña y arcabuzería a cavallo o lanças de que fuere capaz la disposición del paýs. // Mendoça, Theórica y práctica, 1596, pág. 90: $\mathrm{Al}$ executar esta empresa ha de caminar el exército, según la disposición del paýs, en una de las maneras que he apuntado; y en vanguardia el maestre de campo general, tan reforçado en cavallería y ynfantería que sea superior a los de la tierra, pudiendo debaxo d'esto (si hazen salida) cargarlos con determinación y presteza que los haga bolver las espaldas.

SIN.: a la avanguardia, en avanguardia.

ANT.: en retaguardia, en rezaga.

vanguardia, $V$. en $\sim$.

vanqueta, $V$. banqueta.

vatalla, V. batalla.

vatería, $V$. batería.

vatir, V. batir. 
vaybén, $V$. vaivén.

vela, bela, vela [de velar. Vela 'acción o tiempo de velar', 'centinela, guarda', 'candela'. 'Centinela, guarda' (h. 1275, 1. ${ }^{a}$ Crón. Gral.; s. XV, Aut.), 'acción o tiempo de velar' (APal.; Nebr.) y 'candela' (Nebr.; Quevedo, Aut.) (DECH). Celso, Reportorio universal leyes Castilla, 1553]. sust. f. Mil. Centinela nocturno.

Celso, Reportorio universal leyes Castilla, 1553, fol. CCXXIIIv: Montarazes, llaman a las velas e sobrevelas que tienen los alcaydes en los castillos. // Loçano, Alberto, Architectura, 1582, pág. 384: Velas o atalayas en las torres. // García de Palacio, Diálogos militares, 1583, fol. 68r-68v: Y en este particular era César vigilantíssimo y cuydadoso, de que sacó mucho fructo y escusó grandes daños a sí y a su gente, especial en lo que refiere de un asalto y repentino acometimiento que los burgueses hizieron, los quales, rebatidos por las buenas guardas y velas que tenía, desesperaron de poderse defender de un capitán tan cuydadoso y se le rindieron y subjetaron.

FAM.: sobrevela, velar.

ENCICL.: DRAE: Centinela o guardia que se ponía por la noche en los ejércitos o plazas.

2 [Loçano, Alberto, Architectura, 1582]. sust. f. Mil. Cada una de las cuatro partes en que los centinelas dividen las noches.

Loçano, Alberto, Architectura, 1582, pág. 117: A Sena, ciudad principal en la Toscana, la falta, para ser magnífica cumplidamente, que no tiene albañares, por lo qual, no solamente a la primera vela y postrera de la noche, en las quales horas se derraman por las ventanas los vasos de las suciedades recogidas, está toda hediendo, pero que por esto esté siempre sucia y muy pesadamente húmeda.

SIN.: cuarto, vigilia.

ENCICL.: Gago-Jover (2002: s.v. vela $)$ : Cada una de las partes en que se divide la noche para el servicio militar.

velar, belar, velar [del lat. vĭgĭlare 'íd.' y 'estar atento, vigilar'. Velar 'estar sin dormir'. Cid (DECH). Celso, Reportorio universal leyes Castilla, 1553]. v. tr. u. t. c. intr. Mil. Dicho especialmente de un soldado: vigilar o hacer centinela por la noche.

Celso, Reportorio universal leyes Castilla, 1553, fol. CCXXVIIv: Los que dormieren velando los muros en tiempo de necessidad, amonestados por tres vezes, los antiguos los despeñavan. // Cortés de Albacar, Breve compendio sphera, 1556, fol. XLVv: Asimesmo, por estas horas los antiguos dividen la noche en quatro quarteles, dando tres horas a cada quartel, y en estas quatro partes hazían velar la gente de guerra. // Álaba, Perfeto capitán, 1590, fol. 48r: Que una compañía assistiesse a la defensa y guarda de cada una de las puertas aviendo necessidad d'ello, repartiendo esta assistencia por todas las compañías, 
dando a cada una quatro horas, poniendo de noche en los castillos gente que velasse y estuviesse a la mira de lo que quería hazer el enemigo y repartiendo guardas que rondassen el real para prevenir a las trayciones o descuydos que podían suceder.

FAM.: sobrevela, vela.

véllico, $V$. bélico.

vellicoso, $\mathrm{V}$. belicoso.

vencedor, bençedor, vencedor, vençedor, venzedor [de vencer. Berceo (DECH). Sagredo, Medidas Romano, 1526]. adj. Mil. Dicho de una persona o de un grupo: que ha derrotado a su enemigo en un combate o batalla.

Sagredo, Medidas Romano, 1526, pág. 6-7: Los romanos tenían por mejor la memoria de los mausoleos que hazían a sus capitanes vencedores, para mejor perpetuar su fama, que la memoria de las estatuas de metal, diziendo que ya podría venir tiempo que por codicia o necessidad de metal rompiessen o robassen la estatua, de lo qual el mausoleo o sepulcro estava bien seguro. // Álaba, Perfeto capitán, 1590, fol. 146v: Este solene acto de triunfar se celebrava saliendo toda la gente de las ciudades, assí hombres como mugeres, de qualquier edad que fuessen, a hazer un solene recebimiento a todos los que bolvían vencedores, dando públicas muestras de regozijo por la muerte y destruyción de sus contrarios. // Mosquera, Comentario disciplina militar, 1596, fol. 96v: Y verdaderamente el ser vencido y sujeto se deve sentir mucho por el hombre, porque no sólo es suyo el gemir este justo dolor, pero las bestias, que carecen de razón natural y discurso humano, lo sienten, pues quando los elefantes entraron por Roma, en el despojo que se uvo contra Pirro, venían entre los esquadrones vencedores inclinadas las cabeças y las grandes trompas arrastrando, sintiendo ellos tristemente el captiverio de sus señores vencidos y sujetados.

SIN.: victorioso 1 .

ANT.: vencido ${ }_{1}$.

FAM.: invencible, vencer, vencido, vencimiento.

ENCICL.: Cov. (s.v. vencer): El que ha vencido.

2 [Montes, Instrucción y regimiento, 1537]. sust. Mil. Persona que ha derrotado a su enemigo o que ha sido superior a su contrario en un combate o batalla.

Montes, Instrucción y regimiento, 1537, fol. XVr: La verdad es que, según la costumbre y ordenança antigua de los vencedores, el que queda señor del campo y lleva los despojos, de aquél es la vitoria. / / Celso, Reportorio universal leyes Castilla, 1553, fol. CLIXv: Ninguno 
se deve atrever de robar el campo o rastro hasta que del todo sean vencidos los enemigos, porque muchas vezes acaesce que los enemigos que son desbaratados se tornan ayuntar, y dan sobre los vencedores que hallan embaraçados en robar el campo, e fácilmente los vencen antes que se puedan tornar en ordenança. // Álaba, Perfeto capitán, 1590, fol. 146r: Y entre todos los premios que se usavan para estimar y mostrar público reconocimiento de su buena industria y trabajo a los vencedores, el que era tenido generalmente por de mayor estima y autoridad era el permitir que entrassen triunfando en sus ciudades los capitanes.

SIN.: victorioso 2 .

ANT.: vencido.

vencer, bençer, vencer, vençer, venzer [del lat. vinncĕre 'íd.'. Cid (DECH). Fernández de Enciso, Suma de Geographía, 1530]. v. tr. Mil. Derrotar al enemigo, imponerse o ser el más fuerte en un combate o batalla.

Fernández de Enciso, Suma de Geographía, 1530, fol. XLIv: Aquí fue la primera batalla de Darío e Alexandre, a do Darío fue vencido, e su muger e hijos e un hermano presos. // Celso, Reportorio universal leyes Castilla, 1553, fol. CLIXv: Ninguno se deve atrever de robar el campo o rastro hasta que del todo sean vencidos los enemigos, porque muchas vezes acaesce que los enemigos que son desbaratados se tornan ayuntar, y dan sobre los vencedores que hallan embaraçados en robar el campo, e fácilmente los vencen antes que se puedan tornar en ordenança. // Álaba, Perfeto capitán, 1590, fol. 59v: Las tres condiciones que pedía Agesilao a un bueno y perfeto capitán, que son: osadía contra los enemigos, benevolencia con los súbditos, buena razón y discurso para considerar la oportunidad del lugar y tiempo, hallo ser principalmente necessarias para vencer o hazer retirar con poco número de gente otro que sea muy mayor.

FAM.: invencible, vencedor, vencido, vencimiento.

ENCICL.: DUE: A diferencia de "derrotar", que exige siempre complemento directo, "vencer" puede ser usado en forma absoluta: 'vencer o morir'.

vencido, bençido, vencido, vençido [de vencer. Fernández de Enciso, Suma de Geographía, 1530]. adj. Mil. Dicho de una persona o de un grupo: derrotado en un combate o batalla.

Fernández de Enciso, Suma de Geographía, 1530, fol. XLv: Aquí se halló él vençido el día que provó el passo, porque le hirieron e mataron mucha gente, e le fue forçado bolverse; e nunca fasta aquel día, antes ni después, se halla en sus ystorias que Alexandre fuesse vencido. // Montes, Instrucción y regimiento, 1537, fol. VIIIr: Muchas vezes se ha visto, por el esfuerzo de un solo soldado, ser vitorioso un exército, por acometer aquél cosa que cinqüenta juntos no osaran acometer, y los otros, por vergüença, seguirle y travarse la batalla con los enemigos de tal arte, que, donde pensavan ser vencedores, quedavan vencidos. // García de Palacio, Diálogos militares, 1583, fol. 87r-87v: ¿Qué se deve hazer 
antes de asaltar la ciudad cercada y qué advertencias se han de tener en el asaltalla y, después de entrada y rendida, qué se deve hazer con los amigos vencidos y de los despojos y robo?

ANT.: vencedor ${ }_{1}$, victorioso ${ }_{1}$.

FAM.: invencible, vencedor, vencer, vencimiento.

2 [Fernández de Enciso, Suma de Geographía, 1530]. sust. Mil. Persona que ha sufrido una derrota o que ha sido inferior a su contrario en un combate o batalla. Fernández de Enciso, Suma de Geographía, 1530, fol. XXXIVv: Éste fue gran varón en esfuerço de ánimo y de su persona valiente, hombre franco, liberal, dadivoso, cruel, clementíssimo con los vencidos. // Álaba, Perfeto capitán, 1590, fol. 57r: Tened, pues, en esta batalla contra ellos el ánimo que los vencedores suelen tener contra los vencidos, pues ellos no vienen a la batalla por valentía, sino porque no pueden escusarlo. // Álaba, Perfeto capitán, 1590, fol. 144v: Como lo hizo César con un rey de Armenia, su enemigo, viniendo delante d'él con la tristeza y congoxa que un vencido podía mostrar en presencia de un vencedor, que, para animarle y esforçarle, le puso la corona que, humillándose a sus pies, se avía quitado, y le restituyó en su estado, diziéndole que tenía por igual vencer los reyes y el hazerlos.

ANT.: vencedor ${ }_{2}$, victorioso ${ }_{2}$.

ENCICL.: DUE: Participio adjetivo de vencer[se]. / Persona vencida: '¡Ay de los vencidos!'.

ir de a [García de Palacio, Instrución náuthica, 1587]. loc. v. f. Mil. Empezar a ser vencido (Salvá 1846: s.v. ir alguno de vencida).

García de Palacio, Instrución náuthica, 1587, fol. 126v: Assimesmo, suelen muchas vezes vencer los que al principio yvan casi de vencida y se començavan a rendir por accidentes que las occassiones de la guerra offrescen, en especial quando, aviéndose defendido y rebatido los contrarios, con aver muerto muchos y hécholes otros daños, se suelen animar y atrever a acometer los enemigos de que antes se temían. // Álaba, Perfeto capitán, 1590, fol. 71v: Y Aníbal, yendo contra los africanos, sabiendo que era gente apassionada del vino, echó en mucha cantidad d'él mandrágora, la qual es medio entre ponçoña y sueño; y travando escaramuça con ellos, fingiendo yr de vencida, huyendo desamparó sus reales, en los quales entrando los enemigos, se entregaron de suerte en el vino inficionado que luego les cargó un sueño grandíssimo y, hallándolos como muertos Aníbal, los passó todos a cuchillo.

ENCICL.: Terr.: Llevar la peor parte.

llevar de a [García de Palacio, Diálogos militares, 1583]. loc. v. f. Mil. Comenzar a vencer al enemigo. 
García de Palacio, Diálogos militares, 1583, fol. 165v: Y si por caso las dichas órdenes de la avanguardia, que son los que acometen y llevan el esquadrón principal descubierto, se desbaratan y son seguidas de los enemigos, que desordenadamente van sobre ellos, entendiendo que a toda la batalla llevan de vencida, fácilmente caen en el esquadrón, que está paliado y muy en orden, y son vencidos y muertos d'él. // Álaba, Perfeto capitán, 1590, fol. 58r: "Inmortales dioses, gracias os doy infinitas de que ya que el enemigo os llevava, ¡o soldados!, de vencida y con tanto miedo caíades en las fosas y entradas del alojamiento, dexó de acometeros en él".

ENCICL.: Salvá (1846: s.v. llevar a alguno de vencida): Comenzar a vencerle. // Terr.: Lo mismo que alcanzar o conseguir la victoria, el triunfo, el vencimiento.

vencimiento, vencimiento [de vencer. h. 1280, $1 .{ }^{a}$ Crón. Gral.; J. Ruiz; J. Manuel (DECH). Álaba, Perfeto capitán, 1590]. sust. Mil. Acción de vencer, superioridad que se consigue sobre el enemigo en un combate o batalla.

Álaba, Perfeto capitán, 1590, fol. 5v: Preguntado de los suyos qué fuesse la causa de tan fácil vencimiento, como de gente incrédula y admirada de lo que avía hecho, respondió que la causa d'esta vitoria avía sido el andar en dos días el camino que era de quatro. / Álaba, Perfeto capitán, 1590, fol. 9r: Sus amigos le vinieron a dezir que todos en las tiendas estavan concertando de no traerle nada de los despojos que hallassen después de vencidos los enemigos, sino que se avían de apoderar d'ellos para repartirlos entre todos, y riyéndose d'esta acusación, dixo: "Muy buenas nuevas me avéys dado, porque éssas son pláticas y intentos de hombres que están más dispuestos a vencer que a huyr", despreciando en esto Alexandro el interés que del vencimiento se le podía seguir. // Álaba, Perfeto capitán, 1590, fol. 60v: De hallarle el enemigo en un campo raso, sin ningún género de reparo, a esperarle en algún passo estrecho, monte, viñas o collado, donde el sitio pueda ayudarle a pelear, supliendo parte del defeto de armas y gente, ay tanta diferencia que lo uno haze cierto el daño y rompimiento y lo otro promete mucha parte de vencimiento y buen sucesso.

SIN.: victoria.

FAM.: invencible, vencedor, vencer, vencido.

2 [Montes, Instrucción y regimiento, 1537]. sust. Mil. Acción de ser vencido.

Montes, Instrucción y regimiento, 1537, fol. IXv: Hay algunos generales que, desque una vez affirman un campo en una parte, no le levantan hasta a ver el fin de lo que dessean; si aquello se puede alcançar, bueno es, mas si lo que dessean se dilata, es malo para la salud del exército, que está al sereno en la campaña, porque tanto se deve mirar por la salud del exército como por el vencimiento de los enemigos, porque, si su campo enferma, con la gente enferma no se puede hazer guerra. // Álaba, Perfeto capitán, 1590, fol. 138r: Y aunque esta dissimulación de la pérdida y vencimiento que le sucedió al capitán importa mucho para animar su gente, no es de menos inportancia para acovardar a su enemigo. // Álaba, Perfeto capitán, 1590, fol. 138v: Aconsejándole Hermón, governador de su nao, que 
se retirasse, pues veía claro y descubierto su vencimiento, respondió que en ningún caso lo haría, por ser el huir entre los de Esparta condenado por el acto de mayor afrenta que a un hombre que pretendía nombre de esforçado le podía suceder, y el esperar la ventura para morir o vencer muy honesto y aprovado.

continuar el $\sim$ [Álaba, Perfeto capitán, 1590]. loc. v. Mil. Completarlo definitivamente, hacerlo decisivo y concluyente.

Álaba, Perfeto capitán, 1590, fol. 141r: Esta mesma falta se conoció en Pompeyo Magno, del qual se lee que, si continuara los vencimientos con las veras y buena traça con que procedía hasta alcançarlos, huviera muchas vezes desbaratado a César y sido señor de todo, lo que, a esta causa, dexó perder.

SIN.: ejecutar la victoria, proseguir la victoria, seguir la victoria.

vençedor, $V$. vencedor.

vençer, $V$. vencer.

vençido, $V$. vencido.

venzedor, $V$. vencedor.

venzer, $V$. vencer.

viandero, viandero [de vianda y éste del fr. viande. Viandero ant. 'el que da o suministra vianda', cub. 'vendedor de yucas, ñames, plátanos, calabazas y malangas'. s. XIV. Castigos de D. Sancho (DECH). Álaba, Perfeto capitán, 1590]. sust. Mil. Persona que vende víveres a las tropas (DUE: s.v. vivandero).

Álaba, Perfeto capitán, 1590, fol. 48r-48v: Y las plaças se ocupan d'esta suerte: en las dos mayores de cada quartel se pone la infantería; en otra de las dos que restan, los vianderos y mercaderes; en la otra que queda en todos los quarteles, en cada dos contrarias, va la artillería y el capitán general d'ella y sus gastadores y oficiales y una compañía; en las otras dos, la gente de a cavallo.

SIN.: vivandero.

vibandero, V. vivandero. 
victo, V. munición del $\sim$.

victoria, bitoria, victoria, vitoria [tomado del lat. vǔctōrĭa 'íd.', derivado de victor 'vencedor'. Berceo (DECH). Montes, Instrucción y regimiento, 1537]. sust. Mil. Acción de vencer, superioridad que se consigue sobre el enemigo en un combate o batalla. Montes, Instrucción y regimiento, 1537, fol. XIIr: Por esto, los que el día de la batalla están bien ordenados, aunque sean pocos, antes alcançarán la vitoria que no los muchos, por la buena orden que dan en el día de la batalla y por ser la gente plática en la guerra. // García de Palacio, Diálogos militares, 1583, fol. 29v: Según lo que vuestra merced a dicho, casi paresce no deve de aver necessidad de armas ni de la theórica ni prática de las cosas de la guerra, sino escojer un capitán virtuoso, devoto y bueno, para que, morijerando bien sus soldados, ruegue a Dios le dé victoria y confunda a sus enemigos, para vencerlos sin costa ni effusión de sangre. // Álaba, Perfeto capitán, 1590, fol. 5v: Preguntado de los suyos qué fuesse la causa de tan fácil vencimiento, como de gente incrédula y admirada de lo que avía hecho, respondió que la causa d'esta vitoria avía sido el andar en dos días el camino que era de quatro.

SIN.: vencimiento ${ }_{1}$.

FAM.: victorioso.

ENCICL.: Nebr. (1495): Vencimiento. // Aut.: Es voz puramente latina, y frecuentemente dicen vitoria suavizando la pronunciación. // Moretti (1828) Grito de guerra de casi todas las naciones, por el que aclaman la que se ha conseguido del enemigo. A veces es un ardid del general para animar a sus tropas a que concluyan la derrota del contrario e introducir la confusión entre las filas enemigas, haciendo gritar victoria. // Roxas, Sumario milicia (1607: fol. 31r-31v): "Ninguna cosa es más de provecho para conseguir vitoria que obedeçer a lo que por las señales se amonesta, por manera que es cosa sabida que ay tres géneros de señales: bocal y semibocal y muda; la bocal y semibocal se entiende por los oýdos, el mudo se entiende por la vista con las señales, porque las bocales se entienden por voz umana, como quien dijese “¡Bitoria, bitoria!”, o otra cosa semejante, y la semibocal son las trompetas, y las señales mudas son alçar o bajar alguna banderola o maderos en los castillos para dar a entender lo que ay de nuebo, sigún tiene la contraseña ya dada".

ejecutar la $\sim$ [Montes, Instrucción y regimiento, 1537]. loc. v. Mil. Completarla definitivamente, hacerla decisiva y concluyente.

Montes, Instrucción y regimiento, 1537, fol. XVr: Mas esto se entiende que no solamente han de señorear el campo, mas son obligados a executar la vitoria hasta llevar la guerra a devido effecto, ca por esto se llaman vencedores, y el que esto no haze, no se le atribuye vitoria conoscida. / / Montes, Instrucción y regimiento, 1537, fol. XVIv: Como los enemigos sean rotos, sigan la vitoria y no se occupen en robar el campo, porque podrían rebolver los 
enemigos sobre ellos y donde eran vencedores quedar vencidos. $Y$, por esso, deven los generales de executar la vitoria hasta que los enemigos sean del todo rotos y desbaratados. // Montes, Instrucción y regimiento, 1537, fol. XVIv-XVIIr: Por ende, está defendido que no se dé la honra de la vitoria sino al general que la executa, porque, executando la vitoria, assegura a su exército de peligro, y, por esso, el día que los generales alcançan vitoria de sus enemigos, no se deven descuydar en seguir la vitoria hasta rompellos de todo punto, porque no se rehagan.

SIN.: continuar el vencimiento, proseguir la victoria, seguir la victoria.

ENCICL.: Almirante (1869: s.v. victoria): Nuestros clásicos usan la feliz expresión ejecutar la victoria por completarla y hacerla decisiva con una encarnizada persecución.

proseguir la [García de Palacio, Diálogos militares, 1583]. loc. v. Mil. Completarla definitivamente, hacerla decisiva y concluyente.

García de Palacio, Diálogos militares, 1583, fol. 80r: Y mucho, si bien se mira los hechos del valeroso Aníbal, le quitó de la reputación que tuviera el no proseguir las victorias como devía, que, por reposar más de lo nescessario, dexó de sojuzgar de todo punto a los romanos quando los venció en Canas. // García de Palacio, Diálogos militares, 1583, fol. 80r: Y no menos perdió por ésta Pompeyo Magno, pues, si prosiguiera las victorias con la destreza y sagacidad que las ordenava, pudiera deshazer al César y no dexarle el derecho del mundo en las manos. Por lo qual es nescessario, avidas y ganadas, proseguillas, como Licurgo por su ley ordena.

SIN.: continuar el vencimiento, ejecutar la victoria, seguir la victoria.

seguir la $\sim$ [Montes, Instrucción y regimiento, 1537]. loc. v. Mil. Completarla definitivamente, hacerla decisiva y concluyente.

Montes, Instrucción y regimiento, 1537, fol. XVIv: Como los enemigos sean rotos, sigan la vitoria y no se occupen en robar el campo, porque podrían rebolver los enemigos sobre ellos y donde eran vencedores quedar vencidos. Y, por esso, deven los generales de executar la vitoria hasta que los enemigos sean del todo rotos y desbaratados. // Apiano, Cosmographía, 1575, fol. 74v: Los albardaos son astutíssimos en el pelear y pelean de noche rastrando casi por tierra. Si sienten flaqueza en el enemigo, lo acometen; pero, venciendo, no siguen la vitoria. // García de Palacio, Diálogos militares, 1583, fol. 190r: Y, si es por hazer mayor estrago en los contrarios que huyen o se retiran, no es justo soltar las armas que para su esquadrón son necessarias, pues con ellas se puede seguir la victoria.

SIN.: continuar el vencimiento, ejecutar la victoria, proseguir la victoria.

victorioso, victorioso, vitorioso [de victoria. Santillana; 1499, Comend. Griego, Aut. (DECH). Montes, Instrucción y regimiento, 1537]. adj. Mil. Dicho de una persona o de un grupo: que ha derrotado a su enemigo en un combate o batalla. 
Montes, Instrucción y regimiento, 1537, fol. VIIIr: E cumple mucho a los generales del exército mirar por la vida de los tales soldados, por la mucha lealtad que tienen a su príncipe y valentía que Dios les dio, que muchas vezes se ha visto, por el esfuerzo de un solo soldado, ser vitorioso un exército, por acometer aquél cosa que cinqüenta juntos no osaran acometer, y los otros, por vergüença, seguirle y travarse la batalla con los enemigos de tal arte, que, donde pensavan ser vencedores, quedavan vencidos. // Álaba, Perfeto capitán, 1590, fol. 141r: De contrario parecer fue Licurgo, mandando en sus leyes que siempre que los griegos de alguna batalla saliessen vitoriosos y con buen sucesso siguiessen los enemigos hasta assegurar la vitoria. // Mosquera, Comentario disciplina militar, 1596, fol. 130r: No trato de los soldados que roban, que a estos con bravo exemplo castigava Pompeyo, demás de ser grande la ofensa que a Dios se haze en consentirlos, que por ello suelen venir castigos a los exércitos y, de vitoriosos, verse vencidos.

SIN.: vencedor ${ }_{1}$.

ANT.: vencido 1.

FAM.: victoria.

ENCICL.: Terr.: El que ha vencido y deshecho a sus enemigos. // Aut.: Se dice también vitorioso.

2 [García de Palacio, Diálogos militares, 1583]. sust. Mil. Persona que ha derrotado a su enemigo o que ha sido superior a su contrario en un combate o batalla.

García de Palacio, Diálogos militares, 1583, fol. 81r: También deve curar los heridos, y enterrar los muertos y agradescer con palabras y dones y mercedes a los victoriosos, repartiendo entre ellos los despojos del campo, para que, con el premio, en alguna manera queden pagados $\mathrm{y}$, con las gracias, se animen a otros casos y victorias semejantes.

SIN.: vencedor 2 .

ANT.: vencido 2 .

viga, biga, viga [probablemente del lat. bigga 'tronco de dos caballerías que tiran de un carro', 'carro tirado por ese tronco', suponiendo que tuviera más tarde el sentido 'timón de carreta'. Cid (DECH). Urrea, Vitruvio, Architectura, 1582]. sust. Fort. ant. Especie de madero o de barra de hierro cuya cabeza, dependiendo de la máquina mural de la que forma parte, adopta diferentes formas. Urrea, Vitruvio, Architectura, 1582, fol. 135r: El ariete, que es máchina para batir, dizen que se halló d'esta manera: los carthaginenses pusieron campo sobre Cáliz para tomarla. Y aviendo tomado primero el castillo, se esforçaron de arruynalle. $\mathrm{Y}$ no teniendo instrumento conveniente para ello, tomaron una viga, y sosteniéndola con las manos y la cabeça, hiriendo continuamente el alto muro, derribavan por orden las piedras. // Urrea, Vitruvio, Architectura, 1582, fol. 135v: Poníase también en ella la máchina arietaria, que en 
griego se llama criedochi, que es viga arietaria, en la qual estava el toro, que es un gruesso leño y redondo, hecho a torno, adonde está puesto el ariete. Hazía grandes effectos arrojándolo y recogiéndolo con las maromas. // Urrea, Vitruvio, Architectura, 1582, fol. 143v: Testudo: arietaria máchina en que estava metida la viga para herir dicha ariete.

SIN.: toro, trabe.

vigilia, vigilia [tomado del lat. vĭgŭlı̆a 'vela', 'vigilia'. Cid (DECH). Apiano, Cosmographía, 1575]. sust. Mil. Cada una de las cuatro partes en que los centinelas dividen las noches.

Apiano, Cosmographía, 1575, fol. IIv: Y Sóphocles cuenta de los soldados de Héctor que, por las estrellas Pléyades, situadas en el signo de Taurus, sabían quándo se avía de mudar la tercera vigilia o guarda de la noche. // Álaba, Perfeto capitán, 1590, fol. 54v: Mitrídates, teniéndole cercado Pompeyo, tratando de escaparse del cerco el día siguiente, encubriendo su determinación a la gente de su campo, hizo nuevas demostraciones de assistencia, mandando que por todo el real hiziessen muchas hogueras y regozijos; y a la segunda vigilia de la noche, quando con más seguridad estavan sus soldados y enemigos, ordenó que marchasse su campo, el qual passó por el del enemigo, que estava descuydado d'este hecho, por la dissimulación con que Mitrídates procedió en él.

SIN.: cuarto, vela 2 .

ENCICL.: DRAE: Cada una de las partes en que se divide la noche para el servicio militar.

vínea, bínea, vínea [tomado del lat. viněa, ae 'mantelete (máquina de guerra; especie de barraca con ruedas, usada en los asedios)', de vinum (Segura Munguía 2001). Collado, Plática Artillería, 1592]. sust. Fort. ant. Máquina con que se protegen los soldados para acercarse a los muros enemigos, consistente en una especie de galería desmontable fabricada con maderos ligeros.

Collado, Plática Artillería, 1592, fol. 2v: Las máquinas, pues, Real Magestad, con que los antiguos solían expugnar las fortalezas y batir las murallas eran éstas: las cathapultas, las balistras, las víneas, los arietes, las testúdines [...], el compago, el escorpión, las sambucas, las faláricas y otras muchas. // Roxas, Sumario milicia, 1607, fol. 27v-28r: También ha de aver lobos, que son unos garabatos de hierro, y hoçes enastadas en lanças y, para haçer las trincheras y fosos, las herramientas ya dichas; y galápagos, y músculos, carneros, víneas, mantas y otras menudençias, que sería larga su declaraçión. // Roxas, Sumario milicia, 1607, fol. 46r: Los antiguos llamaron bíneas las que aora en el uso militar con nombre bárvaro llaman causeras, que son sombreros.

ENCICL.: Moretti (1828): Máquina de guerra en forma de barracón, como la tortuga, construida de maderos menos pesados que aquélla, y servía de galería de aproche. Tenía siete pies de elevación sobre ocho de latitud y dieciséis de longitud, con doble techado de tablones, guarnecidos de zarzos y pieles frescas, para precaver los combustibles que arrojaban los enemigos sobre ella; y reunidas en mucho número servían de cobertizo a los 
trabajadores empleados en formar las líneas de trinchera, etc. Generalmente se colocaba la vínea cerca de la muralla, para cubrir a los que tiraban armas arrojadizas contra los sitiados, o abrían brechas con el ariete y demás instrumentos de guerra. // Estévanez (1897): Aparato movible que usaban los romanos de los tiempos de César, para avanzar a cubierto y acercarse a los muros de las fortalezas que sitiaban.

visoño, V. bisoño.

vista, V. a escala .

vitoria, $\mathrm{V}$. victoria.

vitorioso, V. victorioso.

vitualla, bitualla, vitualla [del lat. tardío victualia 'íd.'. Vituallas "commeatus", Nebr.; Hurt. de Mendoza, en M. P. (DECH). Montes, Instrucción y regimiento, 1537]. sust. u. m. en pl. con el mismo significado que en sing. Mil. Conjunto de comestibles destinados a la alimentación de un ejército.

Montes, Instrucción y regimiento, 1537, fol. Vv: Mas en el proveer de la vitualla tenga el general tal instinto que en tiempo de la mayor necessidad no falte, porque sería al exército gran falta. Porque muchas vezes se ha visto retirarse los exércitos, toviendo vitoria conoscida contra sus enemigos, por falta de la vitualla. E muchas tierras e castillos fuertes se han rendido por falta de vituallas más que por combate de los enemigos. / Collado, Plática Artillería, 1592, fol. 102v: Por quanto en la guerra y en las facciones del artillería muchas vezes se vee haver falta de vituallas, por la difficultad que suele haver en hallarlas y proveerlas, conviene que el artillero sea hombre sobrio y templado en el comer, y bever, y en el dormir y en las demás cosas tocantes al victo humano. // Rojas, Teórica fortificación, 1598, fol. 78v: Y no basta que la ciudad o castillo esté bien fortificada con todos los dichos requisitos o con otros mejores, si no está muy bien proveýda de conveniente presidio para su defensa, con mucha provisión de vituallas, de carne salada, pescado, vino, azeite, vinagre, sal, agua dulce y las demás legumbres, y sobre todo mucho vizcocho de respeto, y harina para hazer pan fresco.

SIN.: bastimento, bastimiento, munición del sustento, munición del victo, víveres.

FAM.: avituallar.

ENCICL.: Cov.: Es la provisión que se hace para el mantenimiento y sustento de la hueste o campo, y la que se recoge en las fuerzas y castillos. // Terr. (s.v. vituallas): Voz de la Milicia, víveres o municiones de boca. 
vivandero, bibandero, bivandero, vibandero, vivandero [del fr. vivandier 'íd.'. Vivandero, término militar. 1646 Estebanillo, Aut. (DECH). Álaba, Perfeto capitán, 1590]. sust. Mil. Persona que vende víveres a las tropas (DUE).

Álaba, Perfeto capitán, 1590, fol. 51r: Y si acudieren vivanderos a proveer de vituallas el exército, dévense reconocer que sean buenas y ordenar que se vendan a moderados precios $\mathrm{y}$, antes de darles entrada, den noticia de lo que traen. Y mientras acudiere esta gente es bien se conserven los mantenimientos que en el real huviere. // Mendoça, Theórica y práctica, 1596, pág. 49: Y en esta plaça se ha de tener levantado lugar donde executar justicia y castigar los delinqüentes, previniendo, con el estar cerca las tiendas de Vuestra Alteza y assistencia del prevoste, no se haga desorden en la compra y ventas ni fuerça a los vivanderos, que es de tanto momento para la conservación del campo. // Roxas, Sumario milicia, 1607, fol. 32v-33r: Aunque aviendo ya río de por medio combiene aver algunos castillos fáçiles, que se llaman castros, porque d'este nombre se deriba castillos; estos sirven para asigurar el bastimento al real y que bayan los que llevan el bastimento, que en este tiempo se llaman bibanderos, porque llevan bíberes.

SIN.: viandero.

ENCICL.: Moretti (1828): Una especie de revendedor de comestibles y líquidos, que con el conocimiento y beneplácito del jefe de una tropa, división o ejército, sigue en tiempo de guerra a retaguardia, para vender al soldado las provisiones de boca que necesite. Los vivanderos están sujetos a los reglamentos de policía del ejército a que pertenecen, y campan donde y como disponga el mayor general o el oficial de Estado Mayor encargado de la distribución del terreno. Las caballerías de los vivanderos están exentas de la carga de bagajes, etc.

víveres, bíberes, bíveres, víveres [del fr. vivres 'íd.' (s. XII), aunque no puede descartarse que venga en realidad del it. viveri (princ. s. XVI, Guicciardini). Viveres, término militar. 1684, Solís; 1685, Alcázar; Aut.; falta aún en Oudin y Covarr. (DECH). Roxas, Sumario milicia, 1607]. sust. pl. Mil. Conjunto de comestibles destinados a la alimentación de un ejército.

Roxas, Sumario milicia, 1607, fol. 32v-33r: Aunque aviendo ya río de por medio combiene aver algunos castillos fáçiles, que se llaman castros, porque d'este nombre se deriba castillos; estos sirven para asigurar el bastimento al real y que bayan los que llevan el bastimento, que en este tiempo se llaman bibanderos, porque llevan bíberes. // Ufano, Tratado de la Artillería, 1613, pág. 104: Señor Capitán, mucho holgaría saber el orden y manera que se tiene en el marchar ordenada y conçertadamente con ynfantería, caballería, bagage, carruage, muniçiones de guerra y víveres, con el artillería y sus máquinas y elementos, y enterarme muy bien del puesto conviniente de cada una de las dichas cosas en el orden de batalla. // Ufano, Tratado de la Artillería, 1613, pág. 145: Al provoste le toca ayudar a sacar el trahín del quartel en campaña y, más, el temulto de los bivanderos que asisten en la artillería; meter los carros en su puesto y orden y donde les toca [...]; poner el preçio y justa tassa en los víveres, conforme a razón y los tiempos en que se hallare, y conforme los preçios que en las villas y lugares valieren las vituallas y bastimientos. 
SIN.: bastimento, bastimiento, munición del sustento, munición del victo, vitualla.

ENCICL.: Aut.: Usado siempre en plural, se llaman las provisiones de boca de algún ejército o plaza. // Terr.: En la milicia, mantenimiento o comida para alimentarse la gente de guerra. // Sanz (1749): No se puede dejar de esperar un glorioso suceso de un ejército que tiene abundantes los víveres. Éste es el primer objeto que se presenta a la vista cuando se debe hacer alguna expedición militar. El general da su disposición de modo que no falte nada al soldado y que según la intención del soberano sea provisto regularmente. Un comandante de plaza que teme un sitio, examina con grande atención lo que tiene en ella y hacer proveer lo que considera necesario para hacer una vigorosa defensa [...]. Tanto sea para atacar como para defender, nunca deben faltar víveres a las tropas. Un soberano que ha de hacer guerra da providencia para que a sus tropas no les falte la subsistencia diaria y arreglada; para cuyo fin hay un proveedor general o muchos, si la necesidad lo requiere $[\ldots]$.

voca, V. boca.

volante, V. escuadrón .

vordo, V. bordo. 


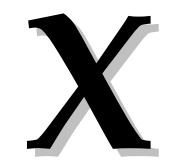

xente, $V$. gente. 
ylada, V. hilada.

ylera, V. hilera.

ympresa, V. empresa.

ynbensible, V. invencible.

ynespugnable, $\mathrm{V}$. inexpugnable.

ynfante, $V$. infante.

ynfantería, $V$. infantería.

yngeniero, V. ingeniero. 
yngenio, $\mathrm{V}$. ingenio.

ynjeniero, V. ingeniero.

ynspugnable, $V$. inexpugnable.

ynspuñable, $V$. inexpuñable.

ynterpresa, V. interpresa.

ynvincible, V. invencible. 


\section{$\mathbf{Z}$}

zanja, çanja, zanja [del mismo origen incierto que el port. sanja 'cortadura para que se escurran las aguas'. 'Cortadura que forma obstáculo', 1595, Fuenmayor; "çanja para cimientos de pared" 1571, A. de Molina, Vocab. en lengua cast. y mexicana y ya 1505 PAlc. (DECH). Sagredo, Medidas Romano, 1526]. sust. Excavación larga y estrecha hecha en el suelo (DSAL).

Escalante, Discurso de la navegación, 1577, fol. 38v: Los muros son fabricados de piedra, cal y ladrillo, assentados sobre la faz de la tierra, sin cimientos ni çanja alguna, bien terraplenados y anchos. // Rojas, Teórica fortificación, 1598, fol. 105v: Y teniendo derribadas todas las defensas, como dicho es, se meterán las trincheas derechas a desembocar el fosso, començando desde la plataforma del punto $\mathrm{D}$, la qual trinchea será una çanja de 15 pies de ancho y 5 de fondo, y con su tierra se irá echando a los bordos o lados para hazer más altura, y a trechos se irán poniendo unas puentes de madera para cubrir los soldados dentro de la çanja, como lo muestra el punto E. // González de Medina, Examen fortificación, 1599, pág. 82: Y, hecho esto, mandar que se midan desde los ángulos de las cortinas, como queda dicho, ciento y veynte pies a cada lado y, desde allí, començar las zanjas de las cortinas hasta los otros ciento y veynte pies a cada lado apartados, que será de trezientos y cincuenta pies.

zapa, çapa, zapa [término militar tomado del it. zappa 'azada', derivado probablemente de zappo, que en los dialectos del Centro de Italia designa el chivo, por comparación de las dos puntas de las azadas antiguas con los dos cuernos de este animal. 1594 Bernardino de Mendoza (DECH). Mendoça, Theórica y práctica, 1596]. sust. Fort. Zanja de la trinchera (DRAE 1817). 
Mendoça, Theórica y práctica, 1596, pág. 141: Viniendo los que sitian a caminar con la çapa picando los cimientos de la muralla o torreones, el remedio es poner allí buena guardia y caminar cavando a buscarlos para echarlos del puesto y reparar siempre, como mejor se puede, la batería . // Rojas, Compendio fortificación, 1613, fol. 26v-27r: Conviene mirar bien $\mathrm{y}$, sobre todo, acordarse que el turco bate con muy gruessa artillería, y el flamenco y el inglés se vale de la zapa, y el moro alarbe de ninguna cosa, si no es de algazara y dar vozes; pero bien es ponerse en defensa contra todos. // Ufano, Tratado de la Artillería, 1613, pág. 341: Propone la escuela el siguiente exemplo de que al artillero se le ofrece trabucar balas ardientes o armadas, bombas, granadas y otros qualesquier artifficios de fuego, o simples balas de piedra o disformes guijarros y otras semejantes cosas sobre los enemigos que acaso se le vayan arrimando con la çapa para picarle y minarle el muro.

ENCICL.: Sanz (1749): Es una profundidad o excavación que se ejecuta en el terreno, cortándolo a escalones de arriba abajo, de modo que queden cubiertos del fuego de la plaza por ambos costados y para estarlo por encima, se cubre de tablones, blindas y fajinas cargadas de tierra, en los retornos de la zapa. En otro tiempo significaba la zapa un agujero que hacían debajo de un edificio para demolerlo. El trabajo de la zapa es muy lento y su cabeza muy peligrosa; hasta hoy no se ha hallado modo de emplear mucha gente de una vez en ella, lo que da lugar al enemigo para contraminarla y hacerla saltar. La zapa es parte muy considerable de la trinchera y se llama zapa la cabeza de ella, que se adelanta de pie a pie, trabajando igualmente de día y de noche. En apariencia adelanta poco la zapa, pero hace mucho camino, pues se trabaja continuamente [...] Cuando la zapa está ya en estado, muda el nombre de zapa al de trinchera. Para muchísima más información sobre esta importante labor desarrollada en la guerra de sitios, vid. este diccionario. // Almirante (1869): Especie o variedad de la trinchera. Toma el nombre en el tecnicismo de ingenieros y exclusivamente en sus trabajos de sitio, cuando, al echar la tierra excavada del lado de la plaza, el montón se sostiene por la parte interior con cestones, sacos $\mathrm{u}$ otro apoyo que pueda colocarse prontamente, para cavar a su abrigo y cubrirse con rapidez.

2 [Mendoça, Theórica y práctica, 1596]. sust. Fort. Instrumento parecido a una azada, que emplean los gastadores para levantar la tierra y excavar.

Mendoça, Theórica y práctica, 1596, pág. 70: Todos los carros del traýn o séguito de la artillería han de ser los primeros, caminando con ellos los gastadores, sin mezclarse entre los carros de munición y artillería otro ninguno, los quales caminan de ordinario en esta forma, que es llevar el primer carro cargado de çapas y açadones, a quien sigue un afuste para señalar las rodadas del camino que se ha de hazer, y luego las pieças ligeras. // Rojas, Teórica fortificación, 1598, fol. 74v: Y como el enemigo viesse tanta resistencia en los cubos redondos, descubrieron la çapa, que es el pico y el açada, y llegados a la muralla, levantavan una manta de maderos, y por ser redondo el torreón se encubrían en la circunferencia d'él sin que pudiessen ser ofendidos de los traveses, y assí con seguridad picavan la muralla y hazían el hornillo y la volavan. // Ufano, Tratado de la Artillería, 1613, pág. 109: Precisamente a los gastadores siguen algunos carros de palas y çapas cargados y otros ynstrumentos aptos y propios al servicio de los dichos gastadores, a los quales ordenadamente siguen las pieças de artillería menuda, a saber, de campaña. 
ENCICL.: Rojas, Teórica fortificación (1598: fol. 32v): "Si Carlo Teti y Gerónimo Catanio bolvieran a escribir el día de oy, aviendo militado con los soldados d'este tiempo y considerando bien la materia de trincheas y sobre todo el mayor enemigo, que es la zapa (que es en español azada y la milicia la nombra con vocablo italiano), estoy cierto que acomodaran sus fortificaciones más recogidas y con menos frente que aquéllas que escrivieron en sus libros". // DECH (s.v. zapaI): Como era voz técnica de gastadores y no de uso general, no es extraño que falte en C. de las Casas (1570) (quien traduce el it. zappa solamente por açada), Percivale y Covarr.; lo trae, en cambio, Oudin [...]. La restricción de este nombre a la zapa militar en los préstamos cast., fr., etc., se explica por el gran influjo internacional que tuvo la terminología militar italiana en el s. XVI. / / Aut.: Instrumento de gastadores en la guerra para levantar tierra, y es una especie de pala herrada de la mitad abajo, con un corte acerado. El mango remata en una muesca hueca grande en la que se mete la mano para hacer fuerza.

zapar, çapar [del it. zappare (ya en el s. XIII) 'lavorare con la zappa (un terreno da dissodare, un filare, un campo a coltura) smuovendo e rincalzando il terreno' (TLIO). Mendoça, Theórica y práctica, 1596]. v. tr. Fort. Excavar por debajo del muro de una fortificación para debilitar sus cimientos y lograr así que se desplome.

Rojas, Teórica fortificación, 1598, fol. 35r: Al contrario, para ofender al enemigo, querría tenerle cerca la defensa, y pues es el cuchillo de una plaça el meterle las trincheas y el çaparla, assí es muy necessario estar muy prevenido con las defensas cortas. // Roxas, Sumario milicia, 1607, fol. 6r-6v: Tres cosas son muy necessarias para esta materia: la principal es reconocer el sitio donde se ha de hazer la tal fortificación, considerando bien los enemigos que les pueden venir a sitiar, porque, si son turcos, ya se sabe que baten con gruessa artillería, $\mathrm{y}$, si son flamencos o ingleses, çapan las murallas y hazen minas. // Ufano, Tratado de la Artillería, 1613, pág. 56-57: Sirben [...] para matar con ellas, atemoriçar y desasosegar la gente del enemigo [...], de manera que tirando con estas pieças de dentro de la muralla, del pie de un torreón, o caballero, cubierta y salvamente hazia arriba, recta y orthogonalmente, de moto mixto, al declinar salvando toda el altura por los punctos, subiendo de la esquadra o quadrante, caygan a plomo de sopessete, de alto abaxo, de moto natural, por el otro lado de afuera, como se verá en su figura, de modo que, arrimada al pie exterior del torreón, ofenda gravíssimamente la percusión de tal bala o artiffiçio a la gente del enemigo que a su pie se arrimare para çapar, picar y minar su muralla.

ENCICL.: Almirante (1869): Por una de tantas irregularidades del lenguaje, este verbo, que actualmente debería significar marchar, caminar o trabajar a la zapa, esto es, abrir o cavar trincheras en la tierra para guarecerse de los fuegos de una plaza, sólo tiene técnicamente el significado de demoler a brazo un muro, dándole por el pie o los cimientos para que se derrumbe. / / Rubió y Bellvé (1895-1901): Demoler un muro por su pie. Véase "cuento".

zarço, V. zarzo. 
zarzo, carço, çarço, çarzo, zarço, zarzo [del ant. sarzo, con -z- sonora, y éste probablemente de sarzir, variante de zurcir existente en castellano antiguo y en catalán. Zarzo 'tejido de varas'. 1190 (DECH). Loçano, Alberto, Architectura, 1582]. sust. Fort. Tejido de cañas, juncos, mimbres o cosas semejantes, que forma una superficie plana, y que cuenta con diferentes usos en la guerra, especialmente en la construcción de defensas. 5 (fig. 173)

Loçano, Alberto, Architectura, 1582, pág. 139: Por los labrios de dentro de la cava y por la extremidad del vallado, hincarse han espinas, agujas de erizo, anzuelos y cosas semejantes con que se retarde la subida de los enemigos. La parte alta d'él cíñase con palos robustos puestos en lugar de corona, y travados con otros atravessados con çarzos y cestones entretexidos. // Rojas, Teórica fortificación, 1598, fol. 74r: Y juntamente tener siempre los çarços y estacadas prevenidas para tapar las baterías, haziendo en ellas medias lunas y travesses para guardarlas, y hazer buenas salidas a estorvar las trincheas al enemigo. // Lechuga, Discurso de la Artillería, 1611, pág. 261: Puédese usar en tales fortificaciones, en los quadrados que salen a la parte de afuera y hazen muralla, de poner unos çarços de salzes, mimbres o qualquiera otro leñame, asidos con estacas delgadas en forma que los asgan y mantengan unidos con la tierra.

ENCICL.: Sanz (1749: s.v. zarzos): Son tejidos de mimbres o de ramas verdes entrelazadas unas con otras fuertemente. Éstos se emplean para cubrir las traversas y alojamientos, que después de colocadas se cargan de tierra para librarlos de fuegos artificiales y de las piedras que tira el enemigo ordinariamente. Cuando se quiere pasar un foso que se le ha sangrado o quitado el agua se echan sobre su plano los zarzos, con lo que se afirma el paso. // Lucuze (1772: 102): "El zarzo es un tejido de mimbres o ramas, de figura rectángula, que sirve a muchos fines: el principal es cuando la tierra es floja y arenisca, para contenerla; y formar un parapeto colocando los zarzos a distancia proporcionada. En el mismo caso, sirven para guardar los merlones de las baterías. Son también provechosos en terrenos pantanosos para tenderlos sobre las fajinas o salchichones y facilitar el paso a la tropa". // Almirante (1869): Tejido plano de ramaje en piquetes aguzados por la punta, conocido desde la más remota antigüedad y usado especialmente por los romanos, con el nombre de crates, para guarecer en los sitios sus líneas de tiradores. Contra las piedras o las flechas esto bastaba a falta de cueros o tejidos de crin [...]. En el día lo usan los zapadores en campaña como revestimiento en obras de tierra, especialmente para taludes interiores o caras de cañonera.

zésped, V. césped.

zestón, V. cestón. 
Apéndices 


\title{
Índice de variantes gráficas
}

\author{
A \\ abanguarda: avanguarda \\ abanguardia: avanguardia \\ abrojo: abrojo \\ acampado: acampado \\ acamparse: acamparse \\ acometedor: acometedor \\ acometer: acometer \\ acometida: acometida \\ acometido: acometido \\ acometimiento: acometimiento \\ acosar: acosar \\ acossado: acosado \\ acossar: acosar \\ adbersario, adversario \\ adversario: adversario \\ ahumada: ahumada \\ ala: ala \\ alambor: alambor
}

alamborado: alamborado

alarde: alarde

alba: alba

albañí: albañil

albañil: albañil

albañir: albañil

alborada: alborada

alcaide: alcaide

alcayde: alcaide

algazara: algazara

aliado: aliado

aliarse: aliarse

alistado: alistado

alistar: alistar

allanar: allanar

allañar: allanar

almena: almena

alogamiento: alojamiento

alojado: alojado

alojamiento: alojamiento

alojar: alojar 
aloxamiento: alojamiento

aloxar: alojar

alva: alba

amigo: amigo

amotinador: amotinador

amotinar: amotinar

amuniçionar: amunicionar

andamio: andamio

ándito: ándito

antepresa: interpresa

apellidar: apellidar

apellido: apellido

aposentador: aposentador

appellido: apellido

appremiar: apremiar

apremiado: apremiado

apremiar: apremiar

apretado: apretado

apretar: apretar

apretilar: apretilar

aproge: aproche

aproje: aproche

aproxe: aproche

aquartelar: acuartelar

arce: arce

arcén: arcén

architectura: arquitectura

architettura: arquitectura

architetura: arquitectura

architeturia: arquitectura

arcubalista: arcubalista

arçe: arce

arço: arce

aretino: arietino

árgine: árgine

arietario: arietario

ariete: ariete

arietino: arietino

arquictectura: arquitectura

arquitectura: arquitectura

arquitetura: arquitectura

arremeter: arremeter

arremetida: arremetida arte: arte

arze: arce

arzén: arcén

asaltar: asaltar

asalto: asalto

ascolta: escolta

asediador: asediador

asedio: asedio

asentado: asentado

asentar: asentar

assaltante: asaltante

assaltar: asaltar

assalto: asalto

assediado: asediado

assediar: asediar

assedio: asedio

assentado: asentado

assentar: asentar

assitiar: asitiar

atacar: atacar

atalaya: atalaya

atalayador: atalayador

atrincheado: atrincherado

atrinchear: atrincherar

atrincherado: atrincherado

atrincherar: atrincherar

avanguardia: avanguardia

avituallar: avituallar

B

bagage: bagaje

bagaje: bagaje

bagaxe: bagaje

baibén: vaivén

balista: balista

balistra: balista

balla: valla

ballado: vallado

ballesta: ballesta

ballestero: ballestero 
ballestón: ballestón

balón: balón

baluarte: baluarte

banguardia: vanguardia

banqueta: banqueta

barbacana: barbacana

barraca: barraca

barrera: barrera

barrunte: barrunte

barvacana: barbacana

bastimento: bastimento

bastimiento: bastimiento

bastión: bastión

batalla: batalla

batallón: batallón

batería: batería

batido: batido

batir: batir

baybén: vaivén

bayvén: vaivén

bela: vela

belar: velar

bélico: bélico

belicoso: belicoso

béllico: bélico

bellicosamente: belicosamente

bellicoso: belicoso

bençedor: vencedor

bençer: vencer

bençido: vencido

bestión: bastión

bibandero: vivandero

bíberes: víveres

biga: viga

bínea: vínea

bisoño: bisoño

bitoria: victoria

bitualla: vitualla

bivandero: vivandero

bíveres: víveres

blinda: blinda

blinde: blinda

boca: boca bordo: bordo

botasela: botasilla

brexa: brecha

C

caba: cava

caballería: caballería

caballero: caballero

caballo: caballo

cabar: cavar

cabrilla: cabrilla

camarada: camarada

camisa: camisa

camissa: camisa

campaña: campaña

campear: campear

campo: campo

candelero: candelero

canpaña: campaña

canpo: campo

cañonera: cañonera

carcavear: carcavear

carço: zarzo

carnero: carnero

casa: casa

casamata: casamata

casa mata: casamata

casamuro: casamuro

cassamata: casamata

castellano: castellano

castillo: castillo

catapulta: catapulta

cathapulta: catapulta

causera: causera

cava: cava

cavalgada: cabalgada

cavallería: caballería

cavallero: caballero

cavallo: caballo

cavamiento: cavamiento 
cavar: cavar

celada: celada

centinela: centinela

centinella: centinela

ceñido: ceñido

ceñir: ceñir

cerca: cerca

cercado: cercado

cercador: cercador

cercar: cercar

cerco: cerco

césped: césped

cesta: cesta

cesto: cesto

cestón: cestón

cetiar: sitiar

chocar: chocar

cintinella: centinela

ciudadela: ciudadela

coligarse: coligarse

colligarse: coligarse

combate: combate

combatido: combatido

combatidor: combatidor

combatiente: combatiente

combatimiento: combatimiento

combatir: combatir

comboy: convoy

compago: compago

conbatir: combatir

confederación: confederación

confederaçión: confederación

confederado: confederado

confederarse: confederarse

conqueridor: conqueridor

conquista: conquista

conquistado: conquistado

conquistador: conquistador

conquistar: conquistar

contendedor: contendedor

contienda: contienda

contrabatería: contrabatería

contra batería: contrabatería contraescarpa: contraescarpa

contraescarpe: contraescarpe contraforte: contraforte contrafoso: contrafoso contrafossa: contrafosa contrafosso: contrafoso contramina: contramina contraminado: contraminado contraminar: contraminar contramuro: contramuro contrario: contrario contraronda: contrarronda contrarronda: contrarronda contrascarpa: contraescarpa contraseña: contraseña contraseño: contraseño contravatería: contrabatería cordón: cordón corneta: corneta corredor: corredor correduría: correduría correr: correr correría: correría corrida: corrida cortadura: cortadura cortina: cortina costado: costado cuadro: cuadro cuarto: cuarto cuento: cuento cuerbo: cuervo cuerno: cuerno cuerpo: cuerpo cuervo: cuervo cúneo: cúneo cunículo: cunículo cuño: cuño

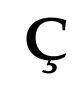

çanja: zanja 
çapa: zapa

çapar: zapar

çarço: zarzo

çarzo: zarzo

çeñir: ceñir

çerca: cerca

çercado: cercado

çercar: cercar

çerco: cerco

çésped: césped

çesta: cesta

çesto: cesto

çestón: cestón

çitadela: ciudadela

\section{D}

debate: debate

decercar: descercar

defença: defensa

defender: defender

defendible: defendible

defendido: defendido

defendimiento: defendimiento

defensa: defensa

defensible: defensible

defensibo: defensivo

defensión: defensión

defensivo: defensivo

defensor: defensor

defenssa: defensa

deffençión: defensión

deffender: defender

deffensa: defensa

deffensión: defensión

deffensivo: defensivo

deffensor: defensor

desaçer: deshacer

desalojar: desalojar

desaloxar: desalojar

desazer: deshacer desbaratado: desbaratado

desbaratar: desbaratar

desbarate: desbarate

descobridor: descubridor

descobrir: descubrir

descortinar: descortinar

descoser: descoser

descubridor: descubridor

descubrir: descubrir

descuvrir: descubrir

desfazer: deshacer

desguarnecer: desguarnecer

desguarnescer: desguarnecer

deshacer: deshacer

deshaçer: deshacer

deshazer: deshacer

deshecho: deshecho

deshilada: deshilada

desmantelar: desmantelar

desoccupar: desocupar

desocupar: desocupar

despojar: despojar

despojo: despojo

despoxo: despojo

desqubrir: descubrir

dessitiar: desitiar

diana: diana

diente: diente

diversión: diversión

divertir: divertir

divirtir: divertir

domar: domar

domeñar: domeñar

domesticar: domesticar

doméstico: doméstico

E

echo: hecho

ejército: ejército

ejérçito: ejército 
embarrar: embarrar

embestir: embestir

emboscada: emboscada

emboscado: emboscado

emboscar: emboscar

embuscada: emboscada

embuscar: emboscar

empaliçada: empalizada

empalizada: empalizada

empalizar: empalizar

empresa: empresa

empressa: empresa

enboscada: emboscada

encamisada: encamisada

encamisado: encamisado

encamisar: encamisar

encastillarse: encastillarse

encuentro: encuentro

enemigo: enemigo

enfortalescer: enfortalecer

engenio: ingenio

enpresa: empresa

enqüentro: encuentro

enseñorearse: enseñorearse

entrepresa: interpresa

envestir: embestir

enxenio: ingenio

escala: escala

escalada: escalada

escalar: escalar

escalón: escalón

escaramucha: escaramuza

escaramuça: escaramuza

escaramuçar: escaramuzar

escaramuza: escaramuza

escaramuzar: escaramuzar

escarpa: escarpa

escarpado: escarpado

escarpar: escarpar

escarpe: escarpe

escarpidor: escarpidor

escolta: escolta

escorpión: escorpión escuadrón: escuadrón

escucha: escucha

espalda: espalda

espía: espía

espiar: espiar

esplanada: explanada

esplanar: explanar

esplorador: explorador

espolón: espolón

espugnación: expugnación

esquadrón: escuadrón

estacada: estacada

estancia: estancia

estrada: estrada

estradiote: estradiote

estrago: estrago

estrella: estrella

estribo: estribo

estrivo: estribo

exército: ejército

exérçito: ejército

explanada: explanada

explanar: explanar

explorador: explorador

expugnable: expugnable

expugnación: expugnación

expugnaçión: expugnación

expugnar: expugnar

expunar: expugnar

\section{F}

facción: facción

fación: facción

factión: facción

façión: facción

fagina: fajina

faición: facción

fajina: fajina

falárica: falárica

falda: falda 
fatión: facción

faxina: fajina

faxinada: fajinada

fayción: facción

fazienda: facienda

fazión: facción

fianco: fianco

filada: hilada

flanco: flanco

fondo: fondo

fórfice: fórfice

forno: horno

forrage: forraje

forraje: forraje

forrajero: forrajero

forraxe: forraje

forregear: forrajear

fortalecer: fortalecer

fortalecido: fortalecido

fortaleça: fortaleza

fortaleçido: fortalecido

fortalescer: fortalecer

fortalescido: fortalecido

fortaleser: fortalecer

fortaleza: fortaleza

fortalezer: fortalecer

fortalezido: fortalecido

fortelecer: fortalecer

fortifficación: fortificación

fortifficaçión: fortificación

fortifficado: fortificado

fortifficar: fortificar

fortificación: fortificación

fortificaçión: fortificación

fortificado: fortificado

fortificador: fortificador

fortificar: fortificar

fortificatión: fortificación

fosa: fosa

foso: foso

fossa: fosa

fosso: foso

franco: flanco franquear: flanquear

frente: frente

fuerça: fuerza

fuersa: fuerza

fuerte: fuerte

fuerza: fuerza

fuessa: fuesa

$G$

gabión: gavión

gabionada: gavionada

galápago: galápago

galería: galería

garita: garita

gastador: gastador

gastar: gastar

gavión: gavión

gazón: gasón

gente: gente

ginete: jinete

gola: gola

grada: grada

guarda: guarda

guardado: guardado

guardar: guardar

guardia: guardia

guarnecer: guarnecer

guarnecido: guarnecido

guarneçer: guarnecer

guarnescer: guarnecer

guarnescido: guarnecido

guarnesçer: guarnecer

guarneser: guarnecer

guarnezer: guarnecer

guarnición: guarnición

guarniçión: guarnición

guarnizión: guarnición

guerra: guerra

guerrear: guerrear

guerrero: guerrero 


\section{H}

hacometer: acometer

harte: arte

hasentar: asentar

hazienda: facienda

hecho: hecho

henemigo: enemigo

herreruelo: herreruelo

hila: hila

hilada: hilada

hilera: hilera

hombre: hombre

honbre: hombre

horden: orden

hordenança: ordenanza

hordenanza: ordenanza

hornillo: hornillo

horno: horno

\section{I}

ilada: hilada

ilera: hilera

imbencible: invencible

imbençible: invencible

imbicto: invicto

impressa: empresa

incursión: incursión

inespunable: inexpugnable

inexpugnable: inexpugnable

infante: infante

infantería: infantería

ingeniero: ingeniero

ingenio: ingenio

injeniero: ingeniero

invencible: invencible

invençible: invencible invicto: invicto

invito: invicto

J

jente: gente

jornada: jornada

L

lambor: alambor

lamborado: alamborado

leba: leva

lebadiço: levadizo

lebantado: levantado

lebantar: levantar

lechera: lechera

lengua: lengua

leva: leva

levadizo: levadizo

levantado: levantado

levantamiento: levantamiento

levantar: levantar

lid: lid

lidiador: lidiador

lidiar: lidiar

lienço: lienzo

lienso: lienzo

lienzo: lienzo

liga: liga

ligarse: ligarse

llebantar: levantar

llevantar: levantar

lobo: lobo

lucha: lucha

luchar: luchar

luna: luna

lupo: lupo 


\section{M}

máchina: máquina

manga: manga

manta: manta

mantelete: mantelete

máquina: máquina

marchar: marchar

meliçia: milicia

mercenario: mercenario

merlón: merlón

metator: metator

milicia: milicia

miliçia: milicia

militar: militar $^{1}$

militar: militar $^{2}$

mílite: mílite

militia: militia

minable: minable

minado: minado

minador: minador

minar: minar

modorra: modorra

montaraz: montaraz

motín: motín

muestra: muestra

munición: munición

municionero: municionero

muniçión: munición

munir: munir

murado: murado

murador: murador

muralla: muralla

murar: murar

muro: muro

músculo: músculo

mutín: motín
$\mathbf{N}$

nombre: nombre

nonbre: nombre

O

occupado: ocupado occupar: ocupar ocupado: ocupado ocupar: ocupar ofender: ofender ofendido: ofendido ofensa: ofensa ofensibo: ofensivo ofensivo: ofensivo offender: ofender offendido: ofendido offensa: ofensa offensibo: ofensivo offensiva: ofensiva offensivo: ofensivo ombre: hombre onagro: onagro onbre: hombre opprimido: oprimido opprimir: oprimir oprimido: oprimido oprimir: oprimir opugnar: opugnar orden: orden ordenança: ordenanza ordenanza: ordenanza orejón: orejón ornillo: hornillo orno: horno ovación: ovación 
pabellón: pabellón pacificación: pacificación pacificar: pacificar pacífico: pacífico padrasto: padrastro padrastro: padrastro palenque: palenque paliçada: palizada palizada: palizada parapecto: parapeto parapeto: parapeto pataforma: plataforma pavellón: pabellón

paz: paz

pelea: pelea pelear: pelear peltrechos: pertrechos peón: peón peonero: peonero pertrechos: pertrechos petipié: pitipié petrechos: pertrechos petril: pretil phalárica: falárica picamiento: picamiento picar: picar pie: pie pilotage: pilotaje pilote: pilote pilotear: pilotear pina: pina pinna: pina pitapié: pitipié pitipié: pitipié plaça: plaza plataforma: plataforma plaza: plaza plúteo: plúteo portillo: portillo posada: posada possada: posada posta: posta postigo: postigo presa: presa presidio: presidio pressa: presa pretil: pretil prima: prima puente: puente puerta: puerta puesto: puesto

Q

quadro: cuadro quartel: cuartel quarto: cuarto qüento: cuento qüerno: cuerno qüerpo: cuerpo

$\mathbf{R}$

rastillo: rastrillo rastrillo: rastrillo rastro: rastro real: real ${ }^{1}$ real: real $^{2}$ rebatir: rebatir rebato: rebato rebelar: rebelar rebelde: rebelde rebelín: revellín rebelión: rebelión rebellado: rebelado rebellar: rebelar rebellín: revellín rebellión: rebelión 
rebolber: revolver

rebolver: revolver

rebotado: rebotado

rebotar: rebotar

rechaçar: rechazar

rechazar: rechazar

reconocer: reconocer

reconocido: reconocido

reconocimiento: reconocimiento

reconoçer: reconocer

reconoçido: reconocido

reconoçimiento: reconocimiento

reconoscer: reconocer

reconoscido: reconocido

reconoscimiento: reconocimiento

reconosçer: reconocer

reconosçimiento: reconocimiento

reconoser: reconocer

reconozer: reconocer

reconozido: reconocido

rectaguardia: retaguardia

recuentro: reencuentro

reçaga: rezaga

reducto: reducto

reduto: reducto

reencuentro: reencuentro

refosete: refosete

refoseto: refosete

refoso: refoso

refosso: refoso

refriega: refriega

remeter: remeter

remetida: remetida

rencuentro: reencuentro

rendido: rendido

rendir: rendir

reparación: reparación

reparaçión: reparación

reparado: reparado

reparar: reparar

reparo: reparo

reqüentro: reencuentro

reseña: reseña resestir: resistir

resistencia: resistencia

resistençia: resistencia

resistentia: resistencia

resistir: resistir

retaguarda: retaguarda

retaguardia: retaguardia

retirada: retirada

retirar: retirar

revatir: rebatir

revelado: rebelado

revelar: rebelar

revelde: rebelde

revelín: revellín

revellín: revellín

revolber: revolver

revolver: revolver

riça: riza

riza: riza

roca: roca

rocha: roca

rodapié: rodapié

romper: romper

rompimiento: rompimiento

ronda: ronda

rondar: rondar

rota: rota

roto: roto

S

saca: saca

sacamano: sacomano

saco: saco $^{1}$

saco: saco $^{2}$

sacomano: sacomano

saetera: saetera

salchicha: salchicha

salchichón: salchichón

salida: salida

saltear: saltear 
salto: salto

sambuca: sambuca

sambuco: sambuca

sanbuca: sambuca

saquear: saquear

scala: escala

scarpa: escarpa

scorpión: escorpión

sedición: sedición

seditión: sedición

señido: ceñido

señorear: señorear

sercar: cercar

sestón: cestón

sextón: cestón

sintinela: centinela

sitiado: sitiado

sitiador: sitiador

sitiar: sitiar

sitio: sitio

sobreronda: sobrerronda

sobrevela: sobrevela

socorrer: socorrer

socorro: socorro

sojusgar: sojuzgar

sojuzgado: sojuzgado

sojuzgar: sojuzgar

soldadesca: soldadesca

soldadesco: soldadesco

soldado: soldado

someter: someter

sortida: surtida

spalda: espalda

spolonada: espolonada

strella: estrella

subjeción: sujeción

subjectar: sujetar

subjectión: sujeción

subjecto: sujeto

subjetar: sujetar

subjeto: sujeto

suelo: suelo

sugeción: sujeción sugetar: sujetar

sugeto: sujeto

sujeción: sujeción

sujecto: sujeto

sujetado: sujetado

sujetar: sujetar

sujeto: sujeto

surtida: surtida

$\mathbf{T}$

talayar: talayar

tenaça: tenaza

tenaçante: tenazante

tenaçón: tenazón

tenasante: tenazante

tenaza: tenaza

tenazante: tenazante

tepe: tepe

terraplén: terraplén

terraplenado: terraplenado

terraplenar: terraplenar

terrapleno: terrapleno

terreno: terreno

testúdine: testúdine

testudo: testudo

tienda: tienda

tigera: tijera

tijera: tijera

tirón: tirón

tisera: tijera

tixera: tijera

toma: toma

tomar: tomar

toro: toro

torre: torre

torreado: torreado

torreón: torreón

trabado: trabado

trabar: trabar

trabe: trabe 
trabés: través

trabiesa: traviesa

trabucco: trabuco

trabuco: trabuco

travado: trabado

travar: trabar

trave: trabe

través: través

travez: través

traviesa: traviesa

traviessa: traviesa

trinchea: trinchera

trincheón: trincherón

trinchera: trinchera

trincherón: trincherón

triumfante: triunfante

triumphante: triunfante

triumphar: triunfar

triumpho: triunfo

triunfador: triunfador

triunfante: triunfante

triunfar: triunfar

triunfo: triunfo

triunphar: triunfar

triunpho: triunfo

tronera: tronera

tropa: tropa

tropel: tropel

\section{V}

vagage: bagaje

vagaje: bagaje

valla: valla

valladar: valladar

vallado: vallado

vallar: vallar

vallesta: ballesta

vallestero: ballestero

vallestrero: ballestero

valuarte: baluarte vanguarda: vanguarda

vanguardia: vanguardia

vanqueta: banqueta

vatalla: batalla

vatería: batería

vatir: batir

vaybén: vaivén

vela: vela

velar: velar

véllico: bélico

vellicoso: belicoso

vencedor: vencedor

vencer: vencer

vencido: vencido

vencimiento: vencimiento

vençedor: vencedor

vençer: vencer

vençido: vencido

venzedor: vencedor

venzer: vencer

viandero: viandero

vibandero: vivandero

victoria: victoria

victorioso: victorioso

viga: viga

vigilia: vigilia

vínea: vínea

visoño: bisoño

vitoria: victoria

vitorioso: victorioso

vitualla: vitualla

vivandero: vivandero

víveres: víveres

voca: boca

vordo: bordo

$X$

xente: gente 


\author{
Y \\ ylada: hilada \\ ylera: hilera \\ ympresa: empresa \\ ynbensible: invencible \\ ynespugnable: inexpugnable \\ ynfante: infante \\ ynfantería: infantería \\ yngeniero: ingeniero \\ yngenio: ingenio \\ ynjeniero: ingeniero \\ ynspugnable: inexpugnable \\ ynspuñable: inexpuñable
}

ynterpresa: interpresa

ynvincible: invencible

Z

zanja: zanja

zapa: zapa

zarço: zarzo

zarzo: zarzo

zésped: césped

zestón: cestón 
Catálogo de ilustraciones comentadas 
오 (fig. 1) Abrojo

Lucuze (1772: lám. IV)

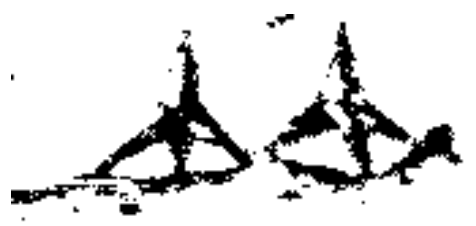

García de Palacio (1583: fol. 164r)

En el orden de batalla presente se han señalado sus dos alas
요 (fig. 2) Ala

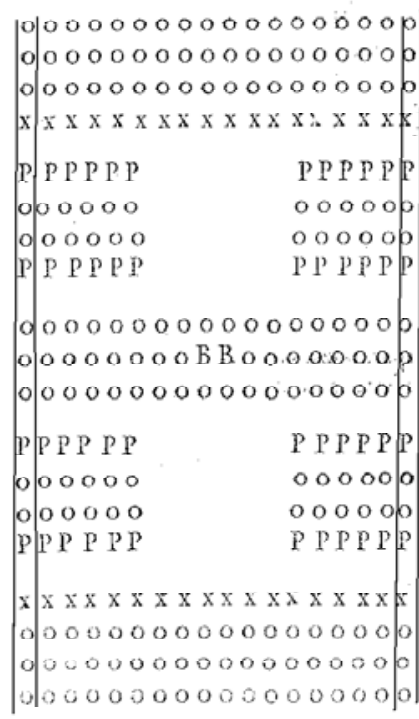

구 (fig. 3) Alamborado

Juanelo Turriano (a. 1605: fol. 398v)

Construcción en la que la parte que da al mar tiene una pared alamborada
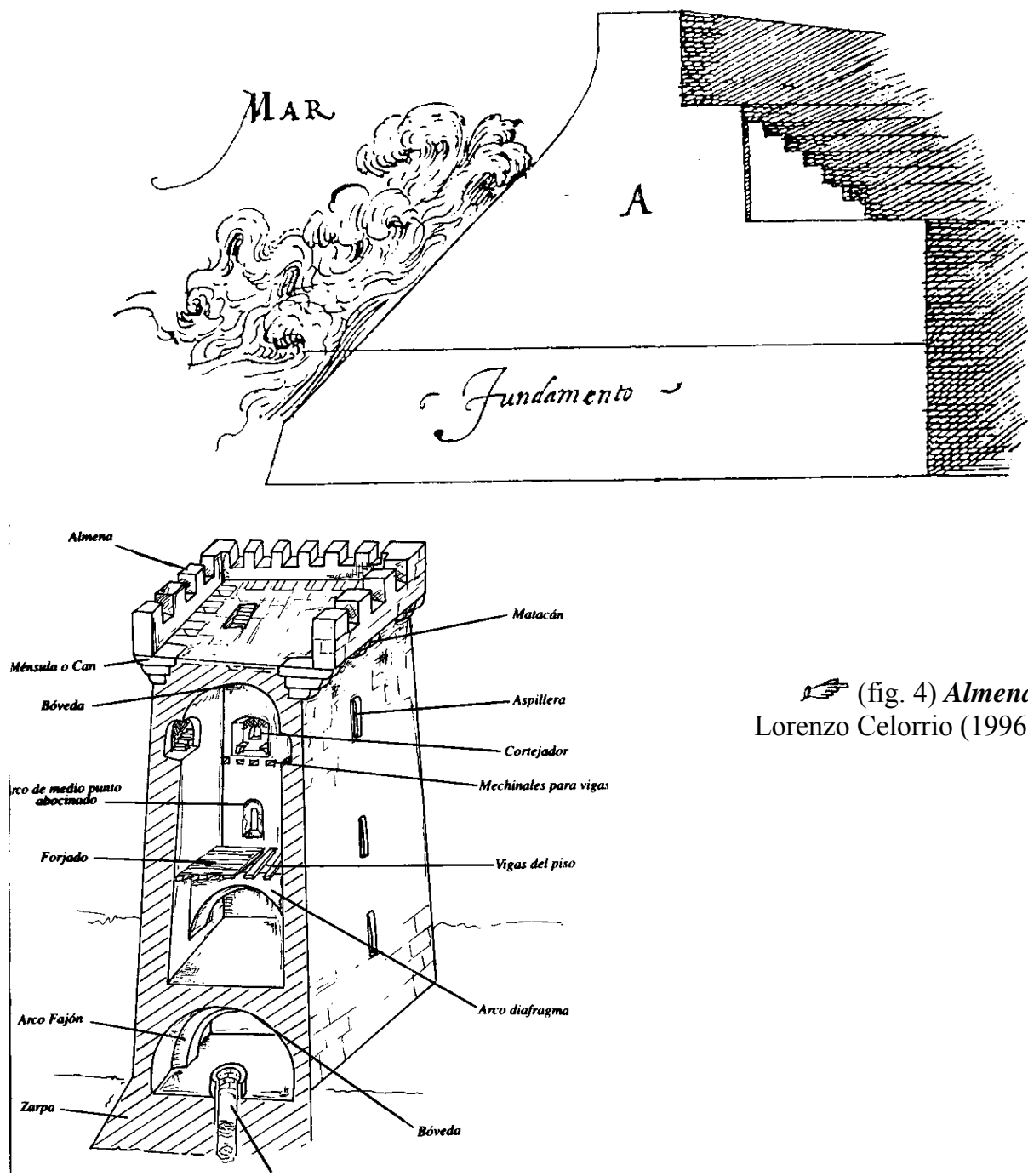

(fig. 4) Almena

Lorenzo Celorrio (1996: 17) 


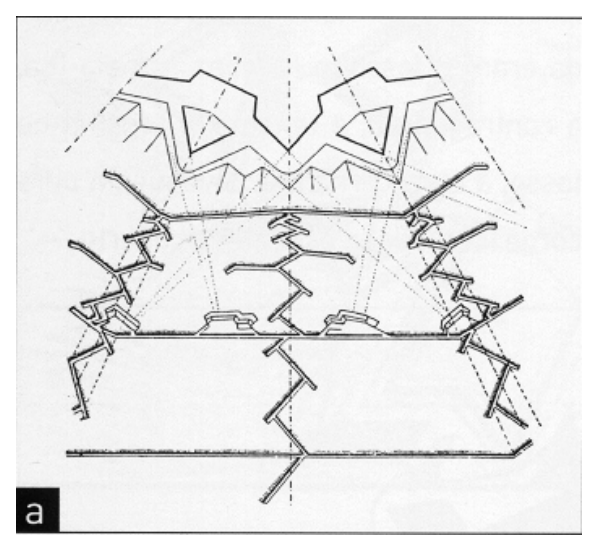

(fig. 5) Aproche

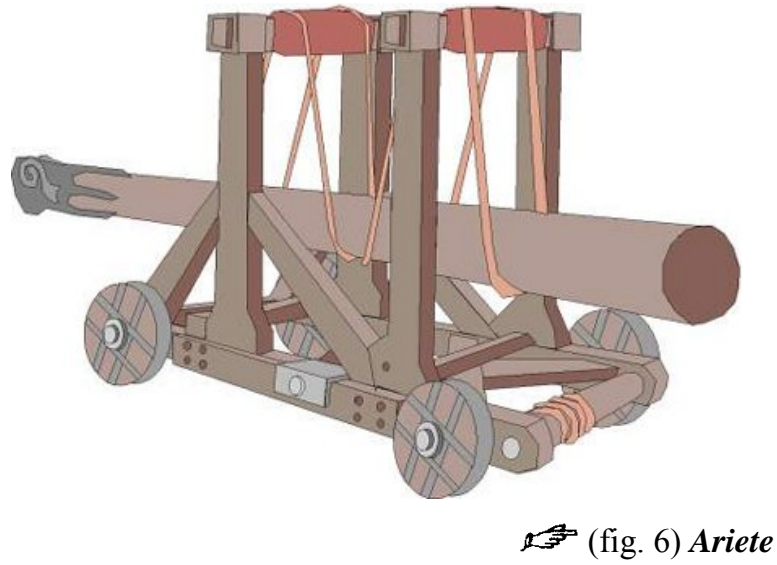

Lopes Pires Nunes (2005: s.v. obras de aproximação)

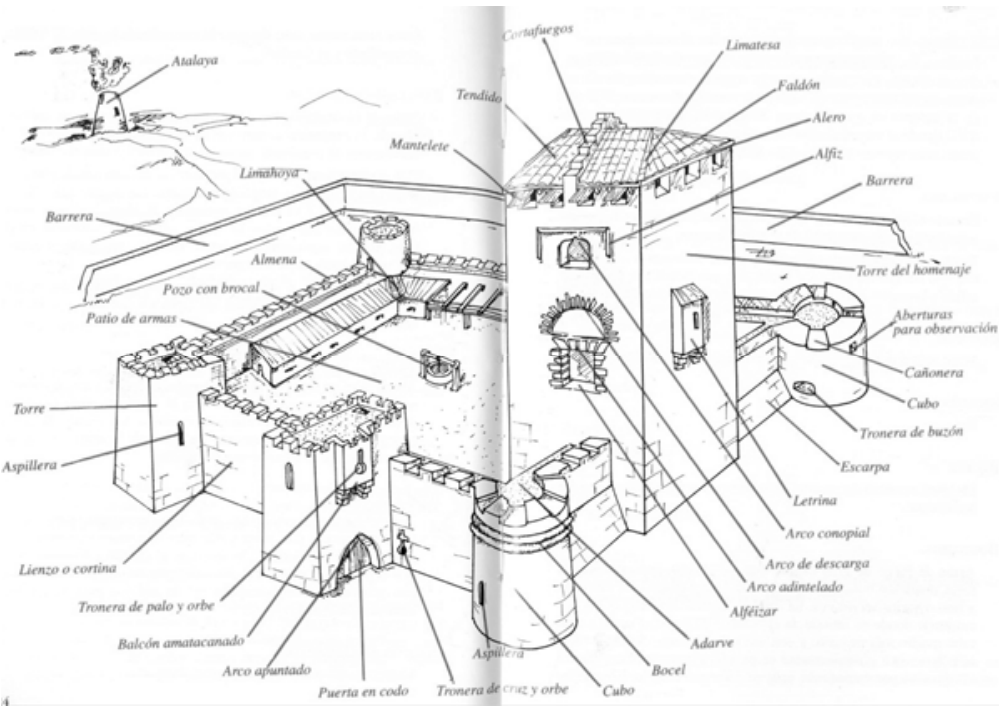

Lorenzo Celorrio (1996: 24)

(fig. 7) Atalaya

Dibujo en el que se representa, entre otras cosas, una atalaya medieval (margen superior izquierdo). Aunque solian construirse separadas del recinto defensivo principal, se hallaban comunicadas con éste. Ya en la época medieval las atalayas fueron, por tanto, una construcción defensiva o un elemento de fortificación muy explotado.

(fig. 9) Ballesta Martinena Ruiz (1994: 499)

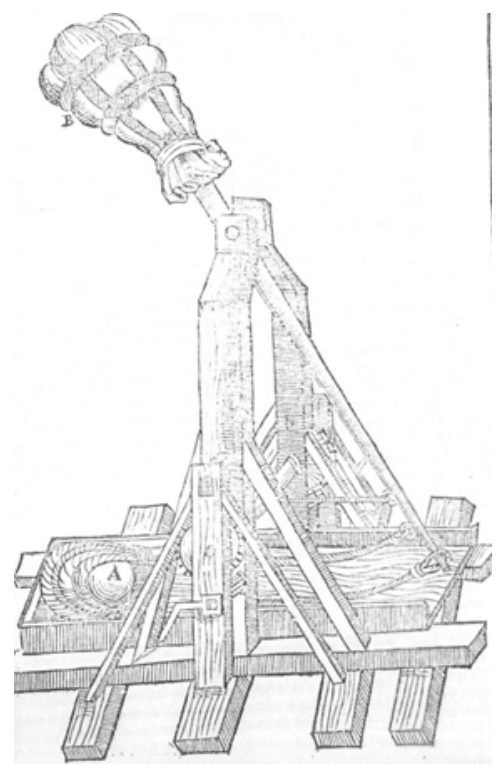

(fig. 8) Balista

Collado (1592: fol. $3 \mathrm{v}$ )

La letra $\boldsymbol{B}$ representa el contrapeso de la balista, mientras que la letra A demuestra la bala de piedra que se tira.

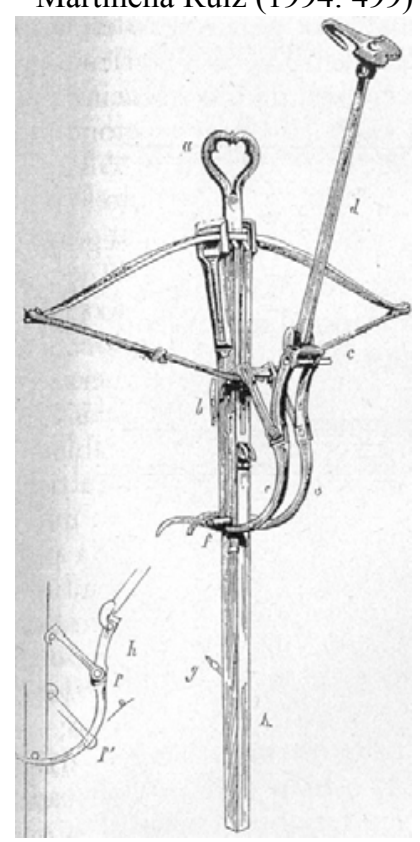


(fig. 10) Baluarte

González de Medina (1599: 27)

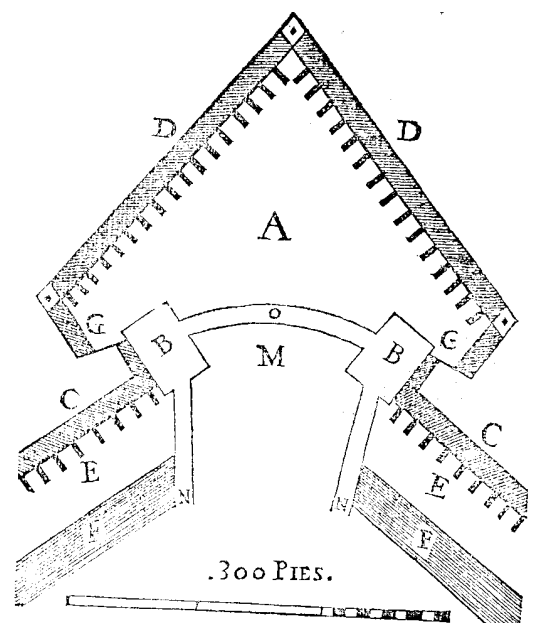

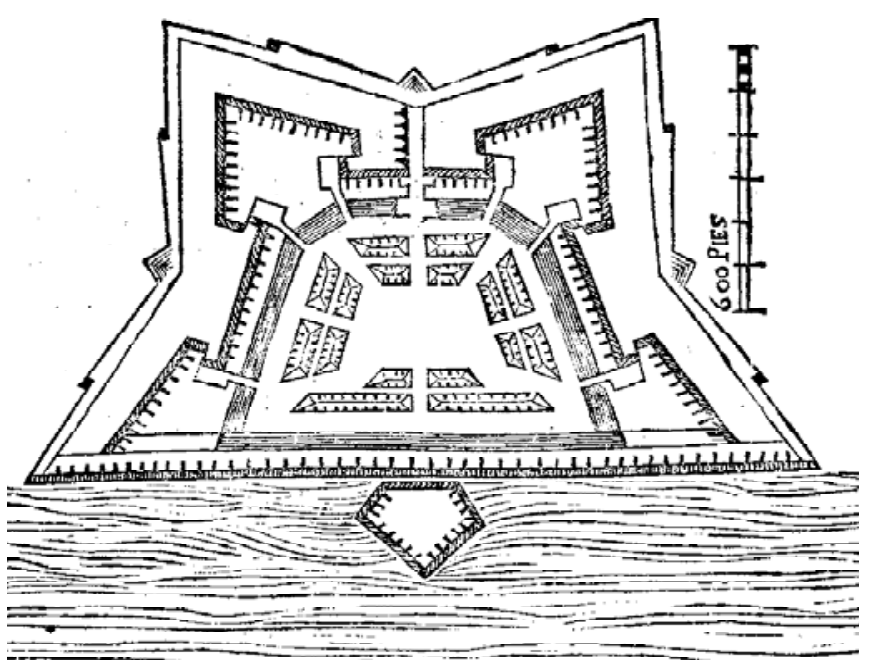

González de Medina (1599: 107): "Señor, para hazer lo que me mandáys que os muestre, yo fortificaría todo lo que estuviesse a la parte de tierra con dos baluartes muy fuertes, regulados de la manera que se ha mostrado en los baluartes de pentágono, y otros dos medios baluartes, para cerrar con una cortina que se hará a lo largo de la mar, que se ha de tener por espaldas". Como puede verse, consta, además, en medio de esta cortina con dos medios baluartes de un revellín.

González de Medina (1599: 25-26): "Sirve el baluarte para cubrir el ángulo de los pentágonos, que no se pueden defender de ninguna parte, y de encubrir las casas matas (y assegurarlas con la fortaleza de su espalda), adonde están las defensas de las cortinas, porque desde $B$, que son las casas matas, se limpian las cortinas $C$, y la frente del baluarte D, y estrada cubierta y foso. Puédese, batido el ángulo, hazer muy buen reparo y cortaduras con traveses y foso, de manera que esté tan dificultoso de perderse como antes de perdido el ángulo, si es grande y capaz".

González de Medina (1599: 26): "Este es un baluarte, el qual está señalado con A, y las casas matas con B, y la frente con D; y los orejones, $G$; el passo de la una casamata a la otra, $O$; y la gola, $M$; la entrada de las casas matas, $N$; la cortina, C; y el terrapleno, E, y la falda, $F^{\prime \prime}$

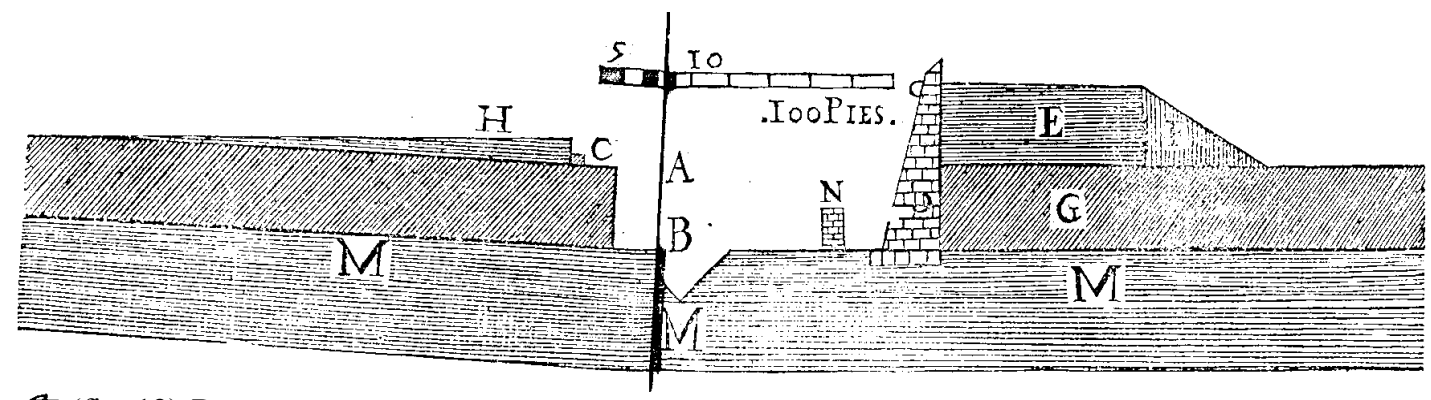

(fig. 12) Banqueta

González de Medina (1599: 44)
Con la letra $N$ se representa la banqueta de esta fortificación.

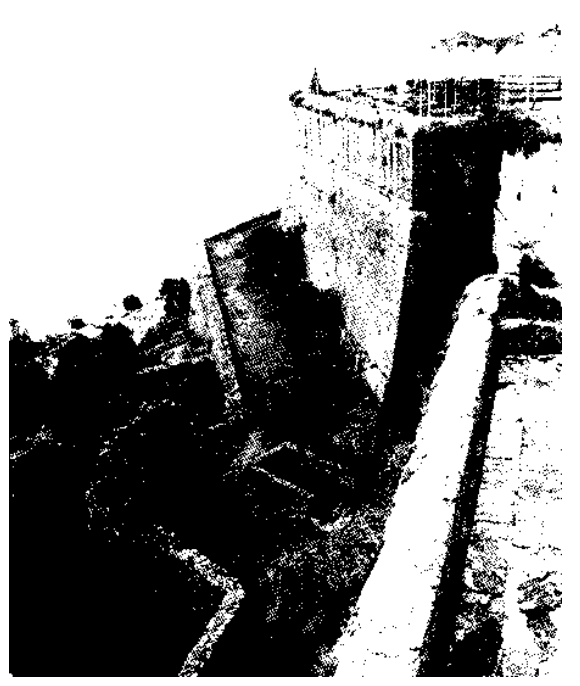




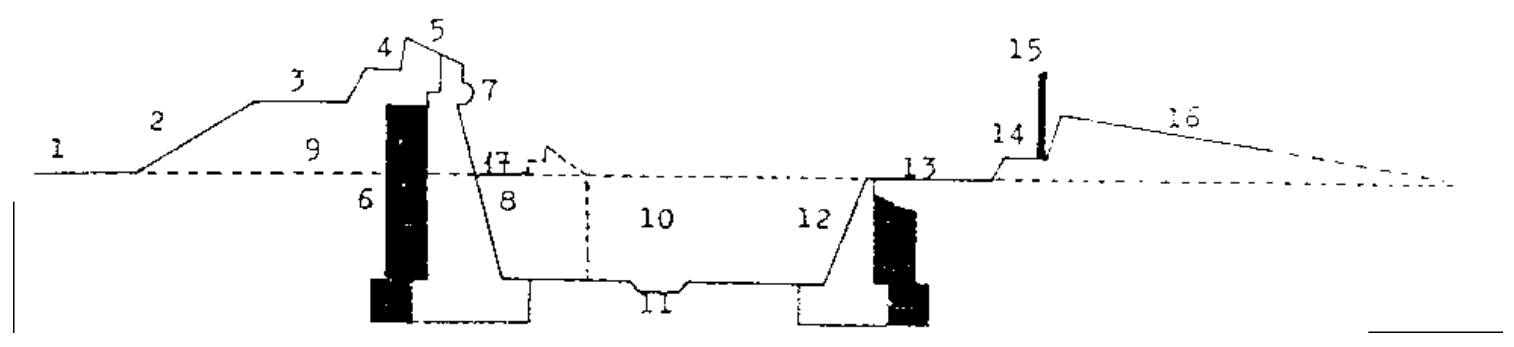

of (fig. 14) Banqueta $_{3} \quad$ Lopes Pires Nunes (2005: s.v. perfil de praça abaluartada)

Perfil de una fortificación donde el número 4 representa la banqueta del parapeto.

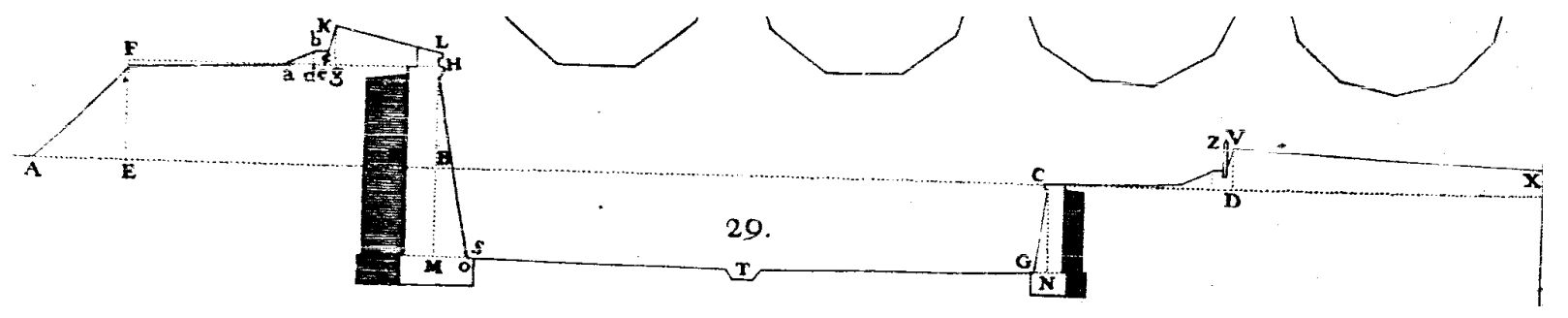

承 (fig. 15) Banqueta 4 Lucuze (1772: lám. I)

Perfil de una fortificación, donde OS representa la banqueta o rodapié del cimiento, "que corre por la parte exterior y alrededor del estribo".

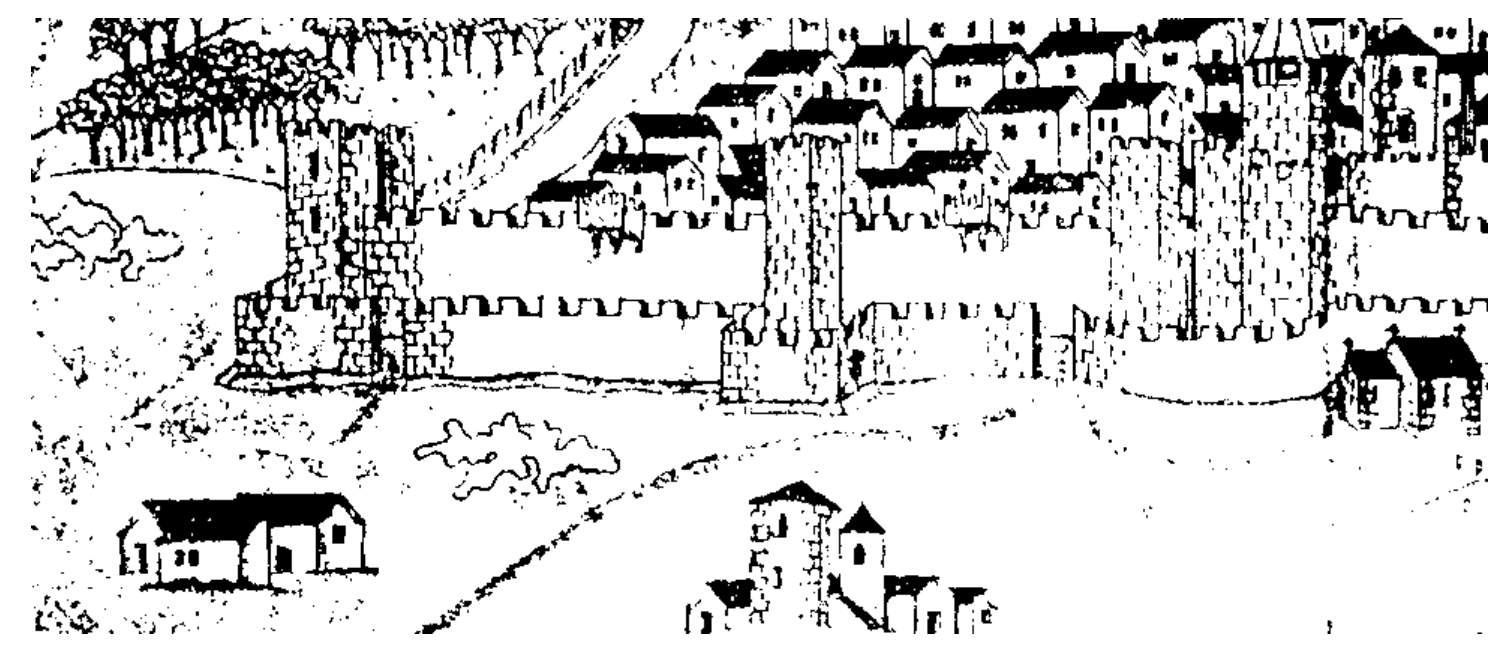

₹̧ (fig. 16) Barbacana Lopes Pires Nunes (2005: s.v. barbacã) Diseño de Duarte d'Armas en el que se representa el castillo de Castelo Branco con su barbacana. 


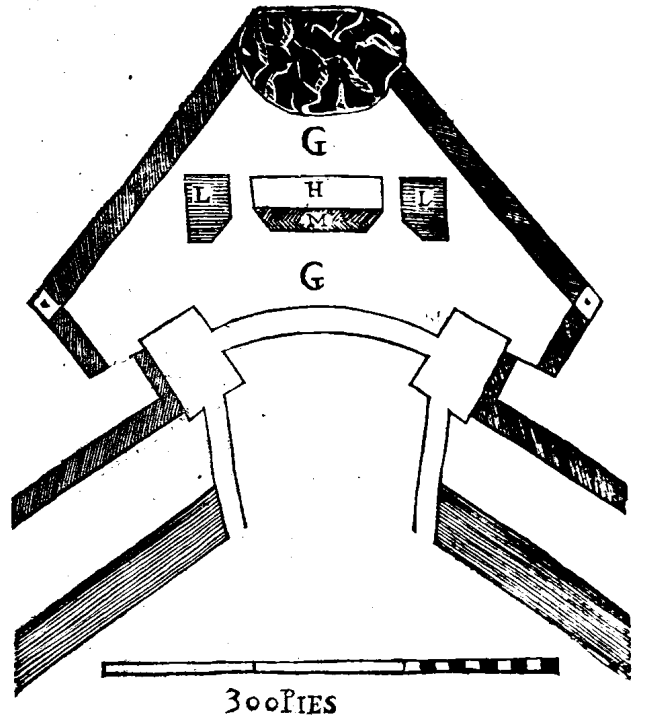

s? (fig. 18) Batería

Ufano (1613: 191)

En esta imagen vemos cómo los sitiadores han optado, dentro de las múltiples acciones de guerra posibles para expugnar una fortaleza, por la batería. Además, en este caso, la construcción que han levantado para alojar las piezas de artillería, también llamada batería, está hecha con sacas de lana.

\section{3 (fig. 17) Bastión}

González de Medina (1599: 203)

Reparo que hacen los sitiados tras haber conseguido los sitiadores abrir brecha en uno de sus baluartes. Aqui el reparo consiste en hacer en el baluarte batido (G) un foso $(H)$, dos bastiones (L) y una trinchera (M). Concluye González de Medina Barba la explicación de su imagen con las siguientes palabras: "Se ha de procurar con estos reparos estar siempre más alto que él" (González de Medina 1599: 202).

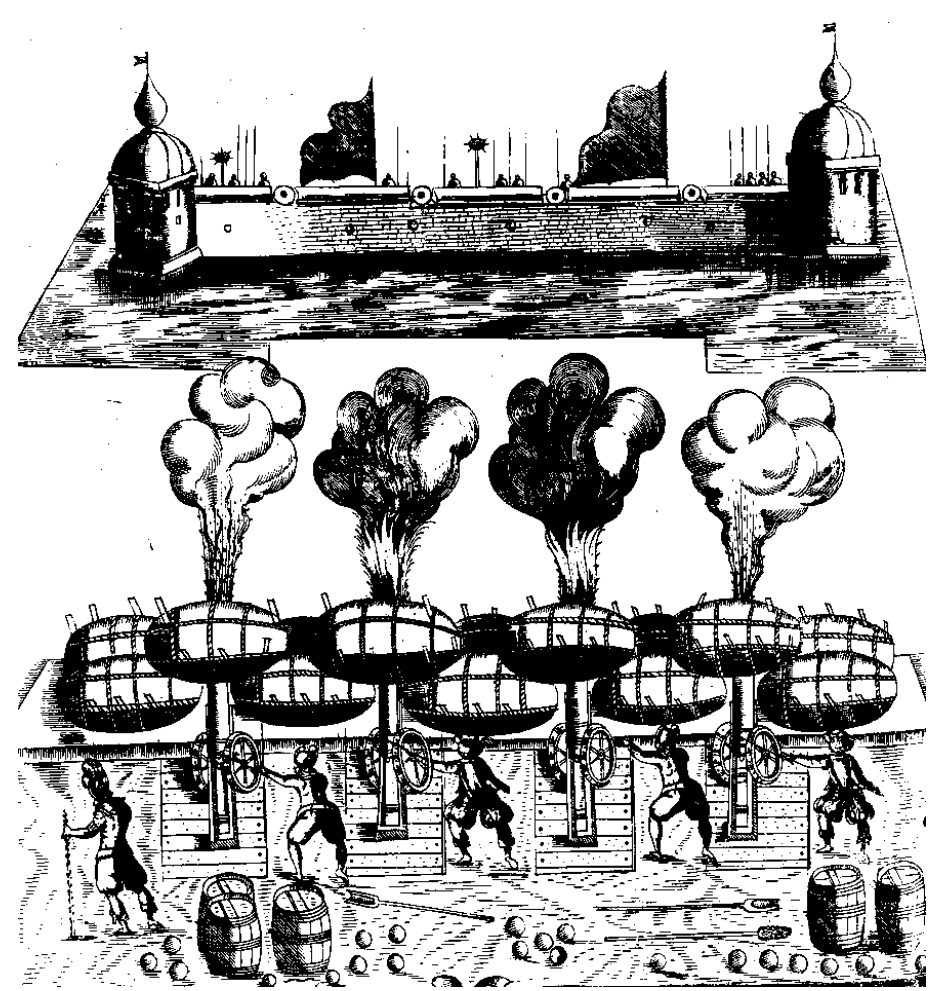

(fig. 19) Batería

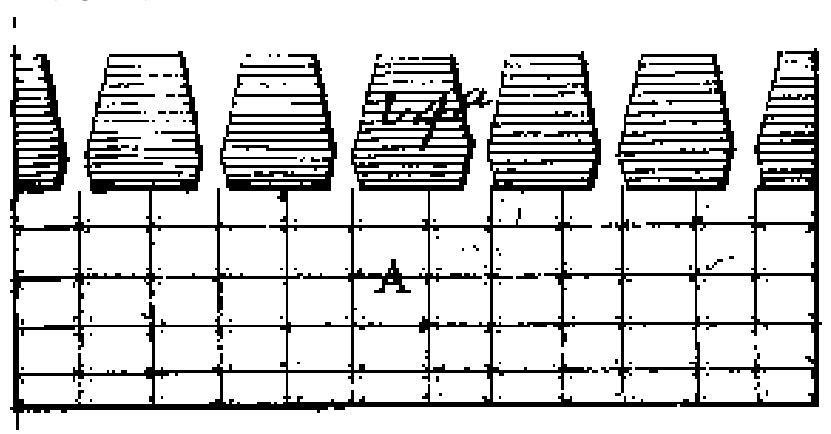

Azevedo Fortes (1729: 16-17): "Bateria é um parallelogramo sobre citio conveniente en que se faz um leito sólido com massame de pedra e cal, ou de pranchoens para jogar a artelharia por canhoneiras abertas no seu parapeito, como mostra a letra A. O seu leito se chama ordinariamente plata-forma. Esta bateria se chama levantada quando se levanta o seu terrapleno e parapeito na campanha sobre a altura do terreno; e se diz bateria enterrada a que se faz no plano dos approches, ou trincheiras abrindo as canhoneiras na terra sólida. Chamão-se baterias horizontaes quando as peças se põem no nivel da campanha, e se the fazem os parapeitos com cestões, sacos de terra, ou sacas de lã" 
s? (fig. 20) Blinda

Lucuze (1772: lám. VI)

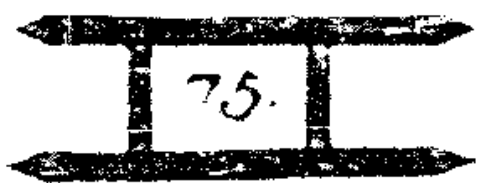

s? (fig. 21) Blinda $_{2}$

Ufano (1613: 254)

Blinda construida con un bastidor de madera, también llamado blinda, $y$, en este caso, con fajinas.
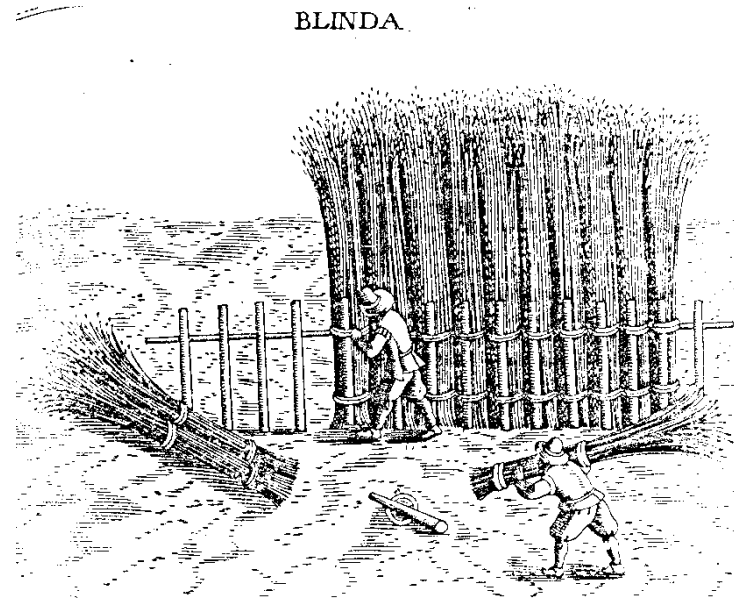

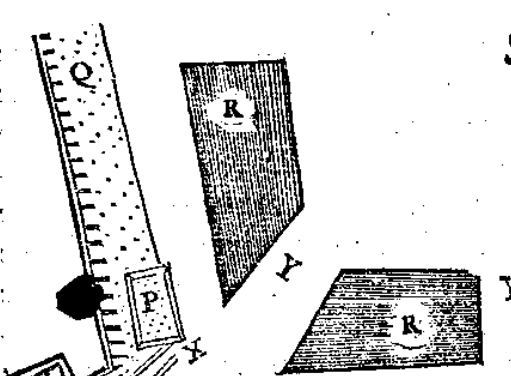

$S$

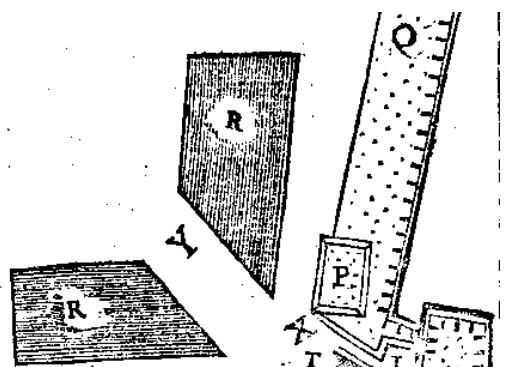

$$
\text { 今 (fig. 22) Boca }
$$

Rojas (1598: fol. 39r)

Planta de una fortaleza en la que CD

representa la boca de la casamata $L$.

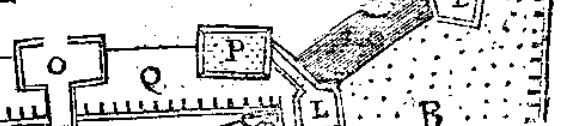

\section{(fig. 23) Dar bordos}

Rojas (1598: fol. 31r)

En esta planta, las trincheras, representadas con la letra $O$, dan bordos, es decir, forman una especie de línea en zigzag en su avance desde el punto S hasta la estrada cubierta, marcada con la letra $L$.
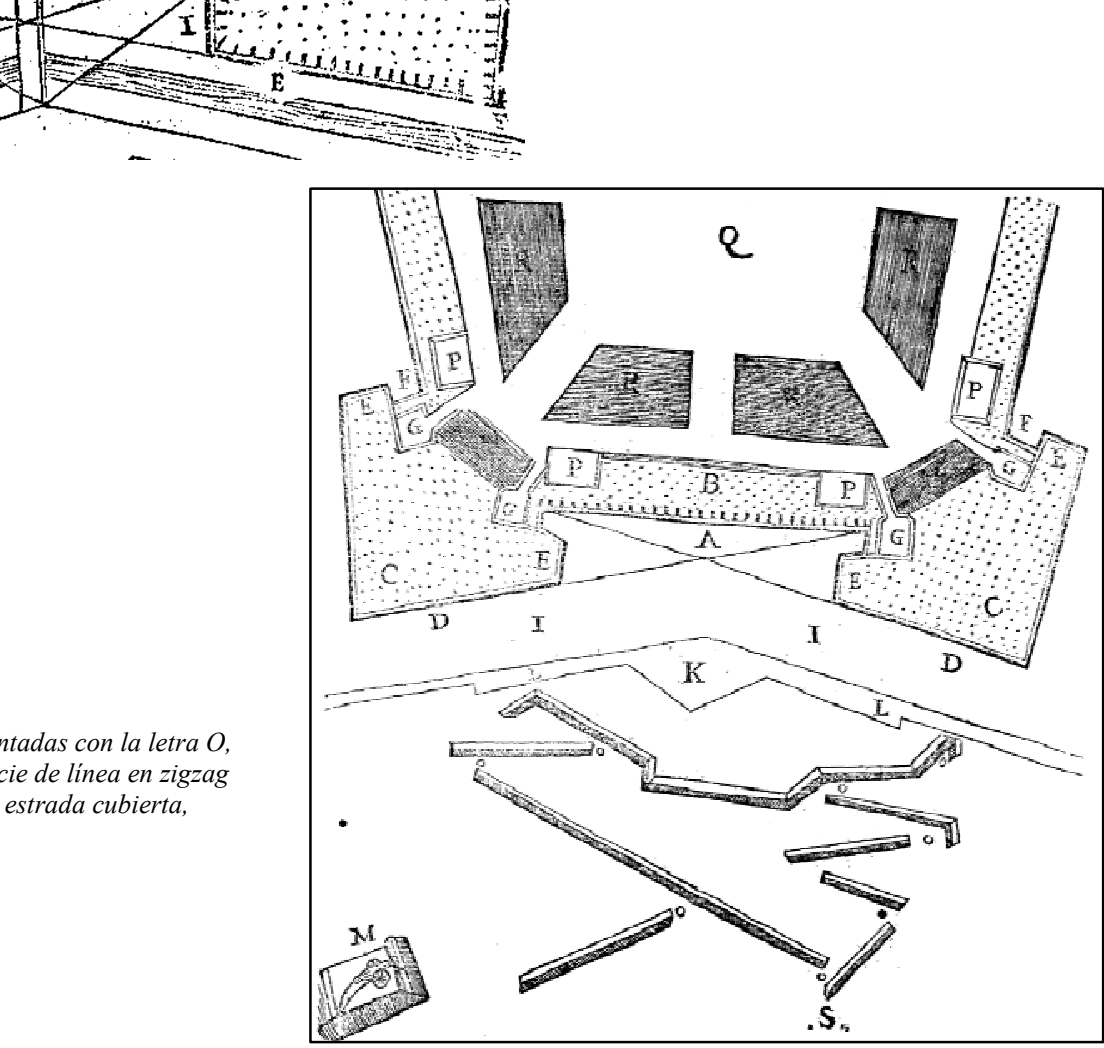


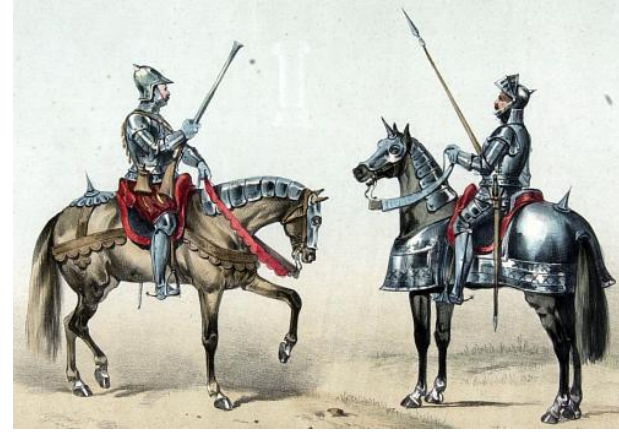

s? (fig. 24) Caballería
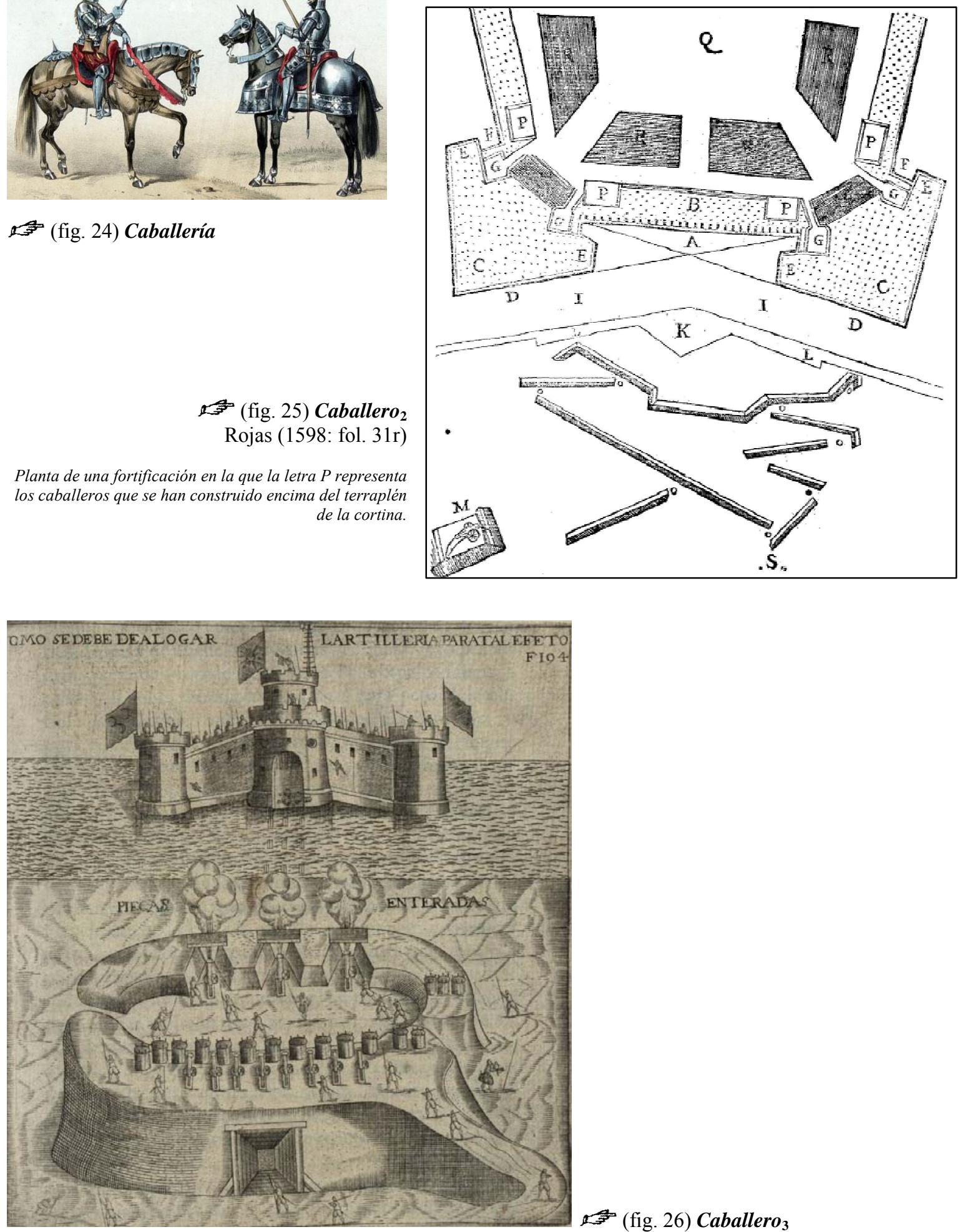

Ufano, Tratado de la Artillería (1613: 194): "Qüestión de cómo, dentro de un caballero o baluarte, se puede hazer una contrabatería y alojar en ella pieças secretamente cubiertas con espaldas, para con ellas, sin peligro alguno, desmontar la enemiga artillería". 


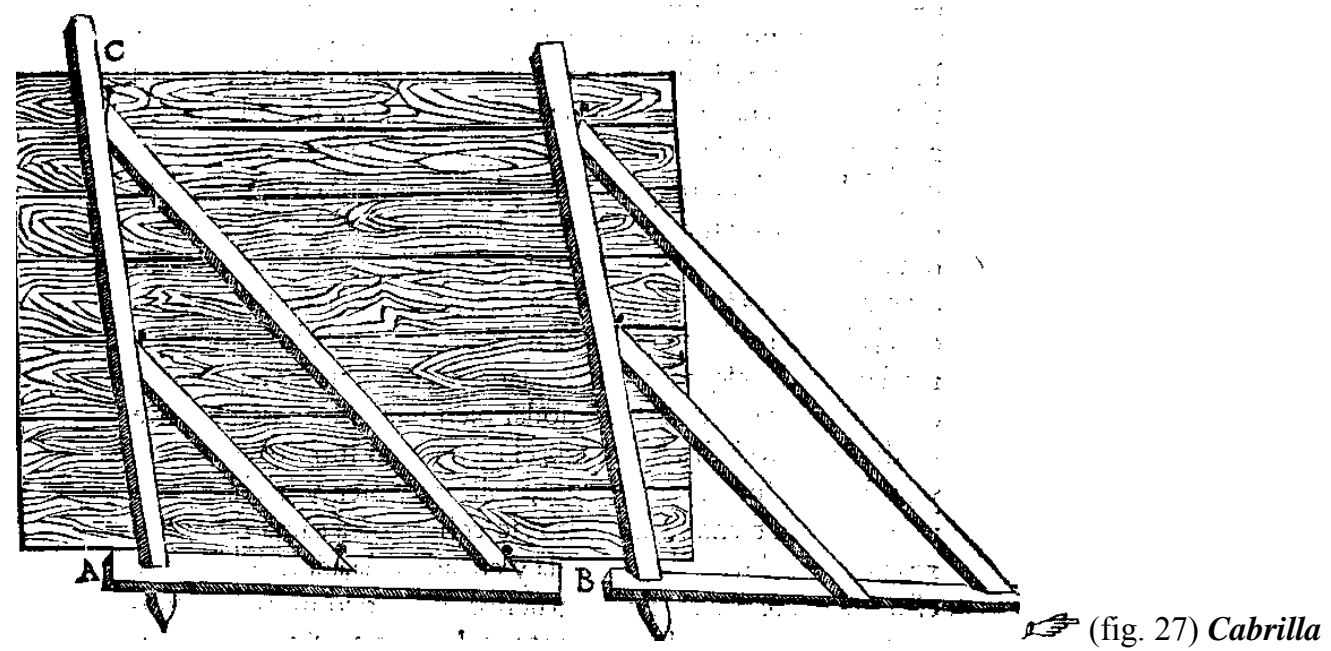

En esta imagen pueden verse dos cabrillas o caballos. Rojas (1598: fol. 51v) explica el siguiente dibujo: "Ingenio para hazer los terraplenos sin fagina [...]. El madero, que es la solera que muestra AB, será de diez pies de largo; y el madero de pie derecho, que muestra $A C$, será del alto que tuviere el terrapleno; y las dos riostras serán del largo que parecen alli en su traça, y de gruesso tendrán a medio pie, más o menos, como los tuvieren a la mano".

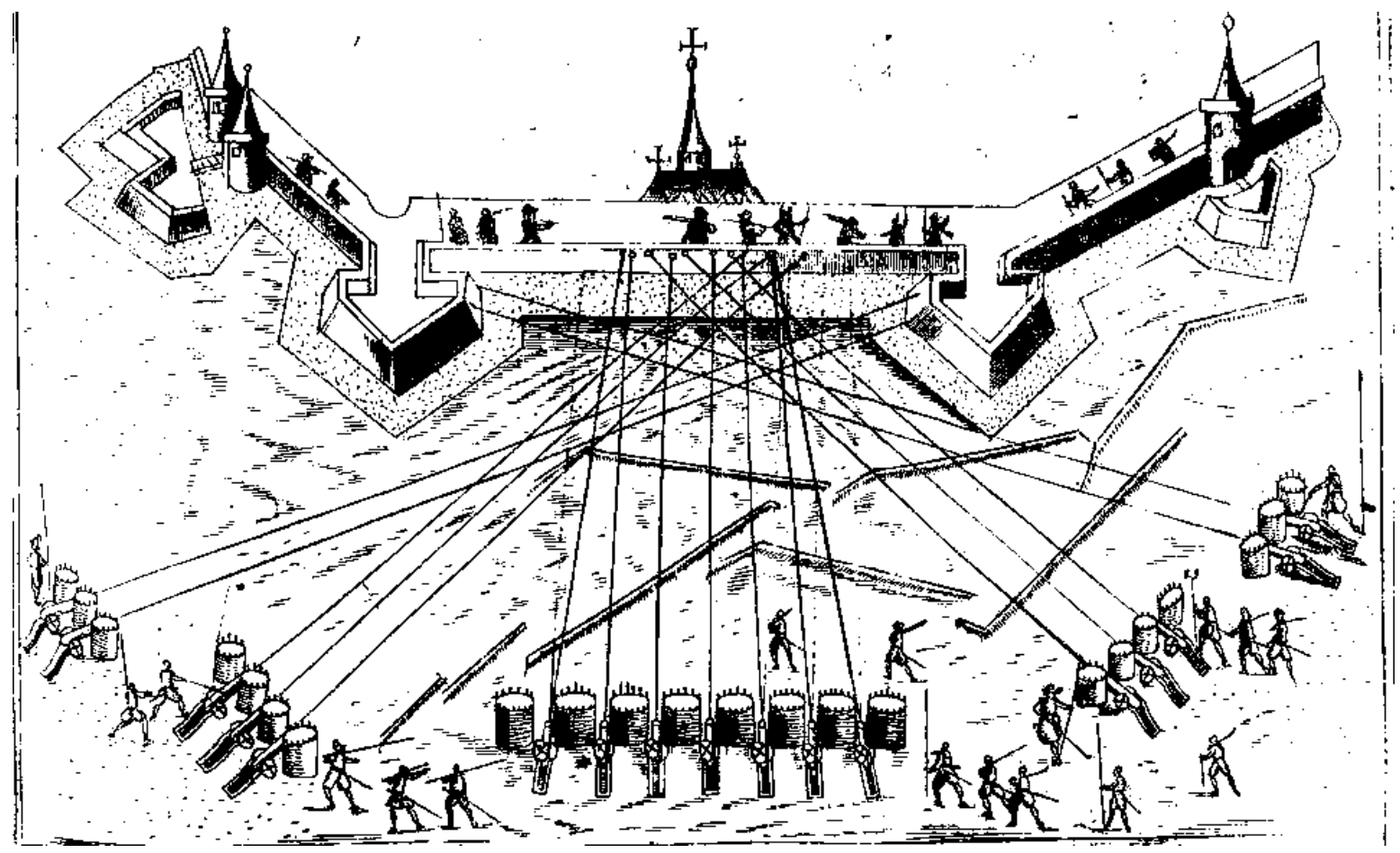

F (fig. 28) Camarada

Ufano (1613: 162): "De los 8 cañones se ha de hazer una camarada que hiera el muro por ángulo recto; y de los 6 medios cañones, dos camaradas que al sesgo hieran transversalmente, como por la figura presente se muestra; y los quatro quartos de cañón a las deffensas". Como puede comprobarse, de la primera camarada de la que habla Ufano, la de los ocho cañones, ha olvidado dibujar uno, puesto que, en la imagen, sólo siete cañones forman ese conjunto. 


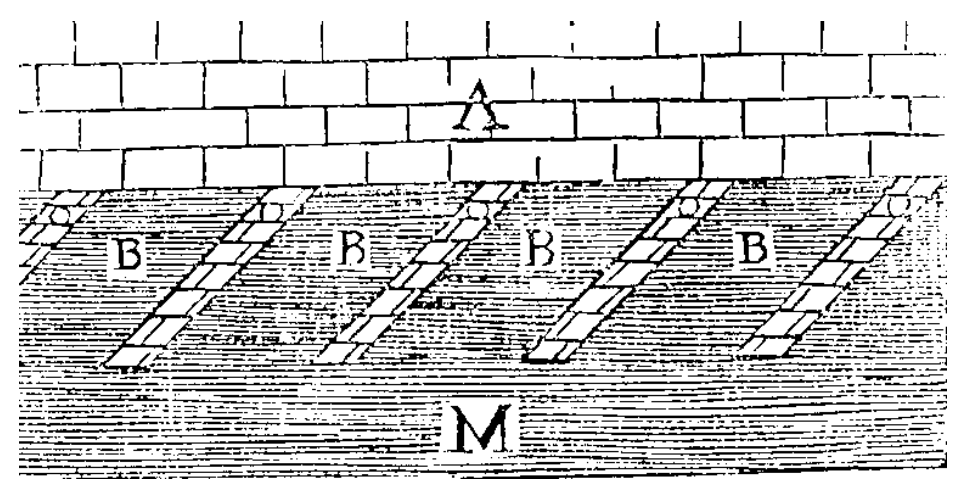

야 (fig. 29) Camisa

González de Medina (1599: 37)

$A$ es la camisa de esta muralla, formada, además, por el terraplén, representado por $B$, y por unos contrafuertes oblicuos, señalados con $O$.

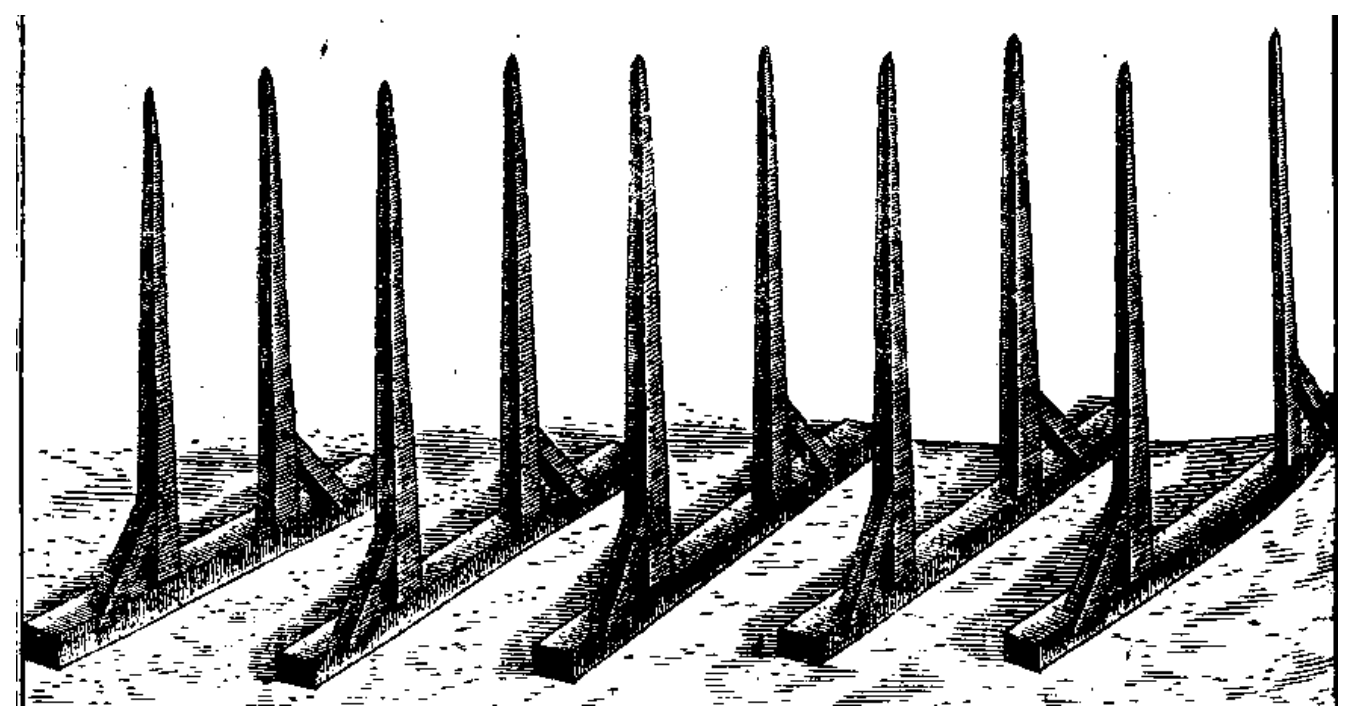

(fig. 30) Candelero Ufano (1613: 254)

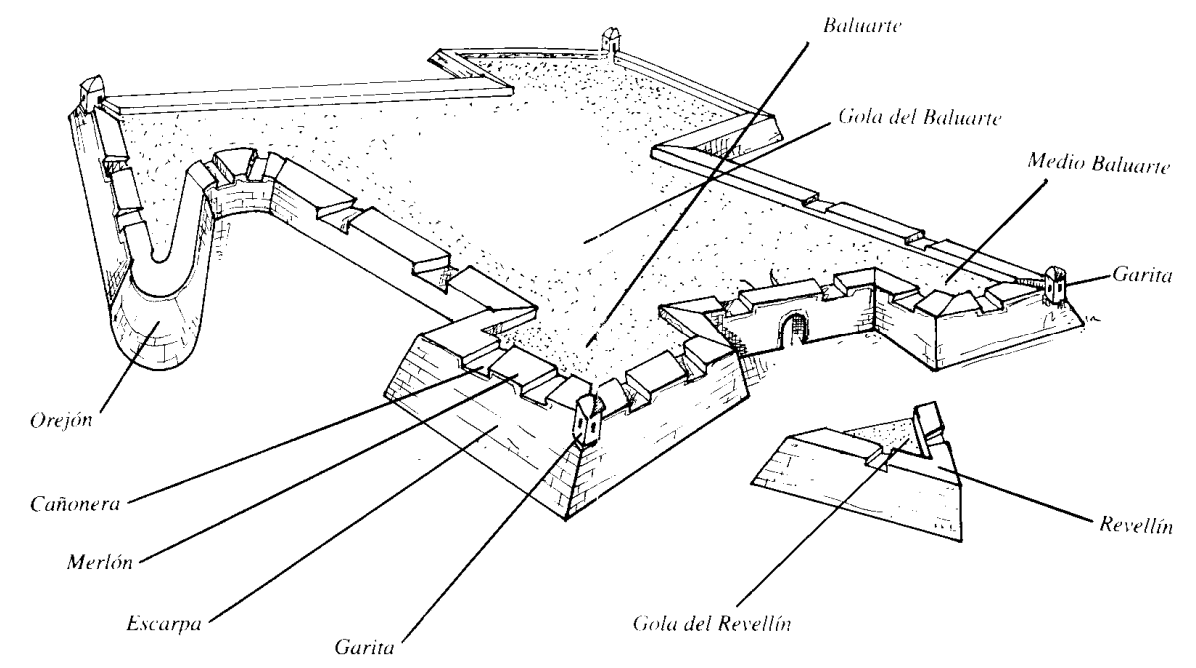

న (fig. 31) Cañonera Lorenzo Celorrio (1996: 56)

Dibujo de una fortificación abaluartada donde se representa, entre otros elementos, una serie de cañoneras. 
(fig. 32) Casa fuerte Mora-Figueroa (2006: s.v. casa-fuerte) Casa fuerte de Hormaza (Burgos)
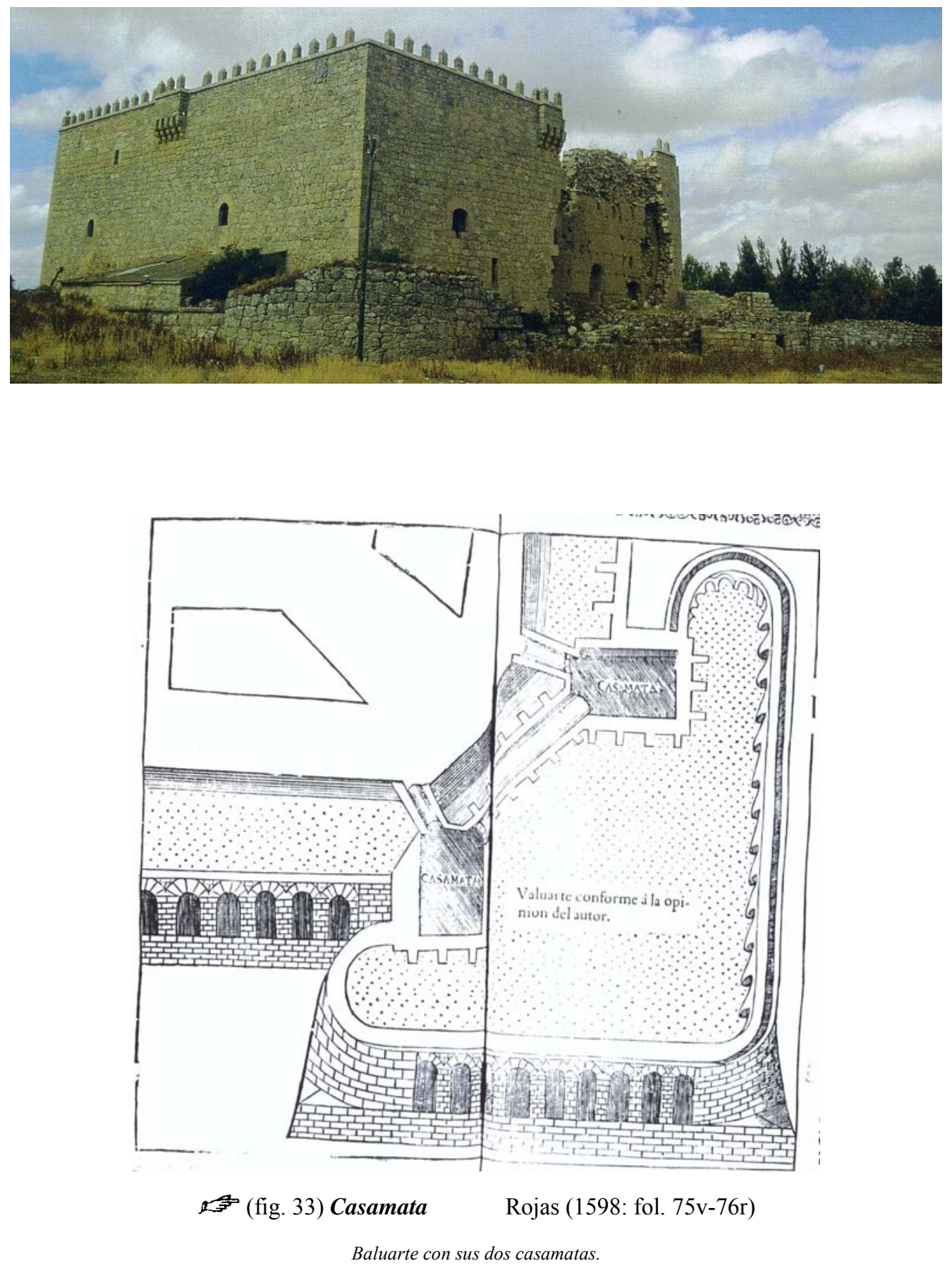


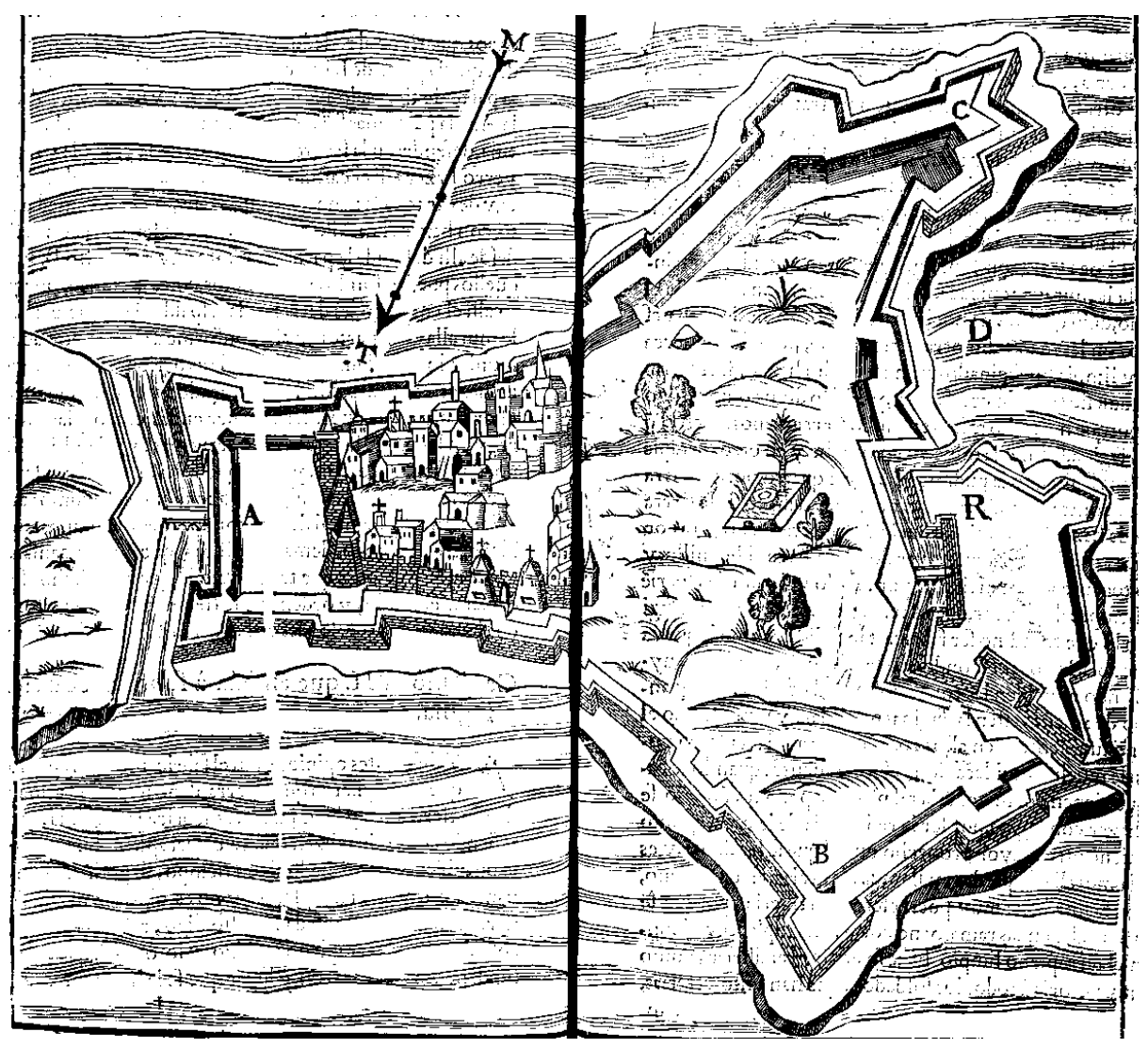

우 (fig. 34) Castillo $\quad$ Rojas (1598: fol. 49v-50r)

Con esta imagen Rojas trata de demostrar que el lugar donde ha ubicado la ciudadela o el castillo (señalado con R) de esta isla fortificada es el más conveniente para la conservación y defensa de todo este territorio. Rojas (1598: fol. 48v-49r): "Todos los quales inconvinientes cessarian si se hiziesse el dicho castillo a la parte del puerto, como muestra el punto R, porque toda aquella parte de isla es lo más flaco de todo, por estar lexos de la ciudad, y por la comodidad de aquel puerto y por los demás desembarcaderos que tiene alrededor, por lo qual consta claramente que toda aquella parte de hazia el puerto es toda la flaqueza de la isla; y la parte de tierra, donde estarán los dos valuartes señalados con la A, es la parte más fuerte, y assí con aquellos dos valuartes y cortina defenderán la frente de tierra los de la ciudad, y fuera gran yerro hazer alli el castillo, porque fuera poner toda la fuerça junta y dexar toda la flaqueza a una parte. Y assí, se remedia todo esto con hazer el castillo en la parte dicha señalada con la $R$, porque desde alli defiende la parte del punto $C y$ del punto B, porque aquellos puestos son los más dañosos contra la ciudad [.... Y. Y assí, conforme a esto, y por averlo comunicado con algunos soldados de experiencia, me parece se deve hazer el castillo donde está traçado".

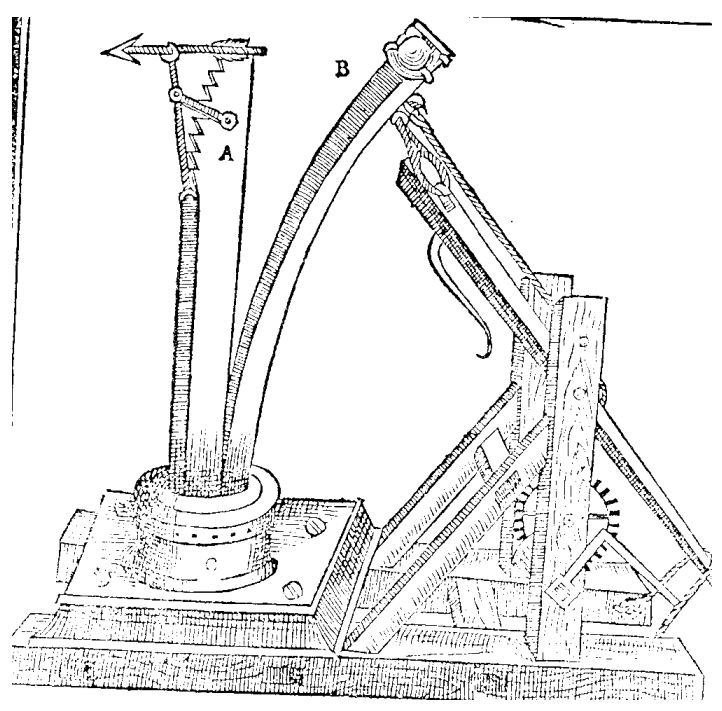

\section{S3 (fig. 35) Catapulta}

Collado (1592: fol. 3r)

"[La catapulta] era hecha en la forma que representa la siguiente figura. Aquel mástel falcado que está en pie era todo de hierro, el qual está notado con la letra A, pero aquella verga que con la violencia del árgano torna atrás y se flecha y se dobla, que se vee notada con la letra B, era toda de azero muy finamente templado. Aquel pedestal o fundamento redondo, notado con la letra C, era de bronzo" (Collado 1592: fol. 2v). 


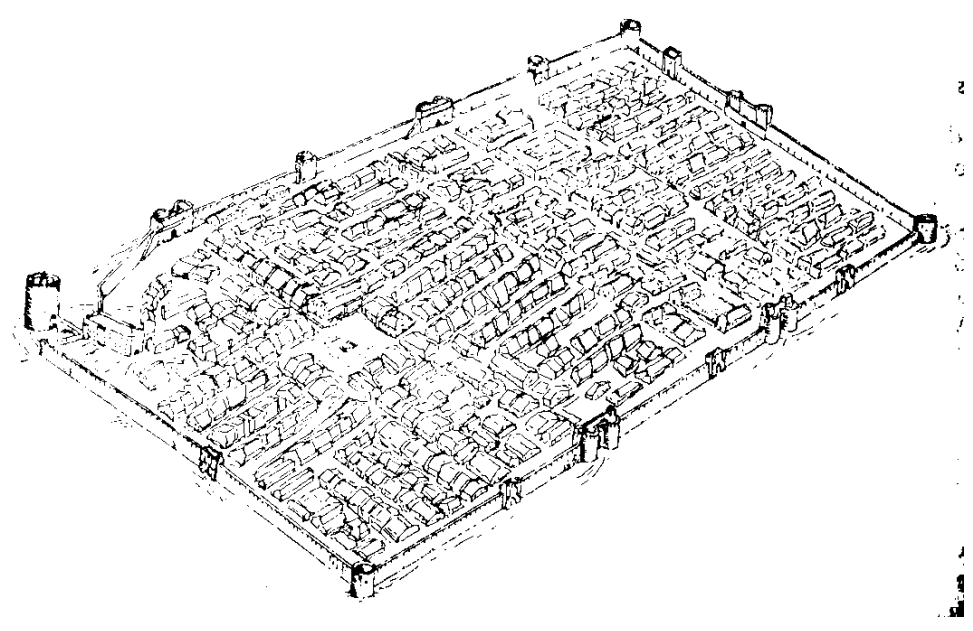

r? (fig. 36) Cerca $_{2}$

Mora-Figueroa (2006:

s.v. muralla urbana)

Ciudad o núcleo urbano rodeado por una cerca o muralla.

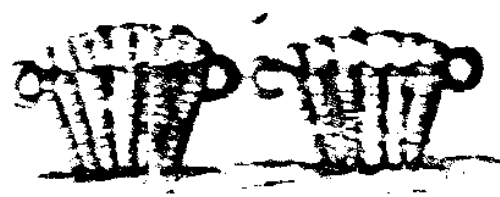

If (fig. 37) Cesto

Lucuze (1772: lám. VI)

Lucuze (1772: 104): "Cestilios, que forman una tronera". Lucuze (1772: 101): "Los cestillos de trinchera sirven para ponerlos sobre el parapeto y, llenos de tierra, cubren las cabezas de los soldados, a cuyo fin se hacen de dos pies de alto, lo mismo de ancho en la parte superior y de uno en la inferior; con lo cual se forma la tronera para el uso del fusil".

공 (fig. 38) Cestón

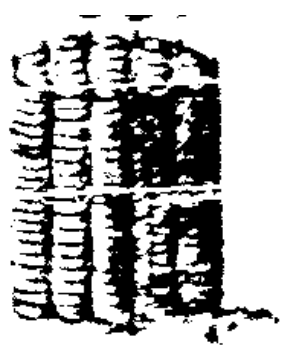

Lucuze (1772: 100-101): "Los cestones se hacen de diversa magnitud y figura. Consisten en un tejido de mimbres o delgadas ramas alrededor de estacas delgadas o palos dispuestos circularmente. Cuando sirven para cubrimiento, y llenándolos de tierra forman baterías, se les da ordinariamente de siete a ocho pies de alto y cinco de diámetro. Los que se aplican a la formación de la zapa tienen tres pies y medio de alto, lo mismo de diámetro. En lugar de los grandes cestones para un cubrimiento, suelen ponerse dos pequeños, el uno sobre el otro, haciéndolos para esto algo más delgados de la parte superior, a fin que el uno encaje sobre el otro".

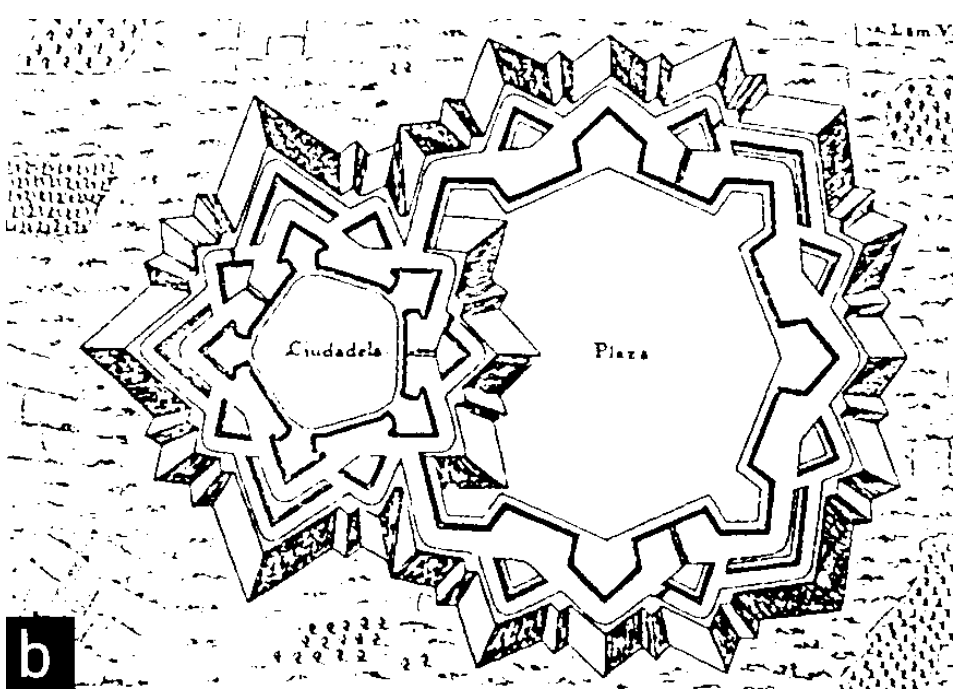

Lopes Pires Nunes (2005: s.v. cidadela).

En este caso, la ciudadela se ha construido junto a la plaza fuerte.

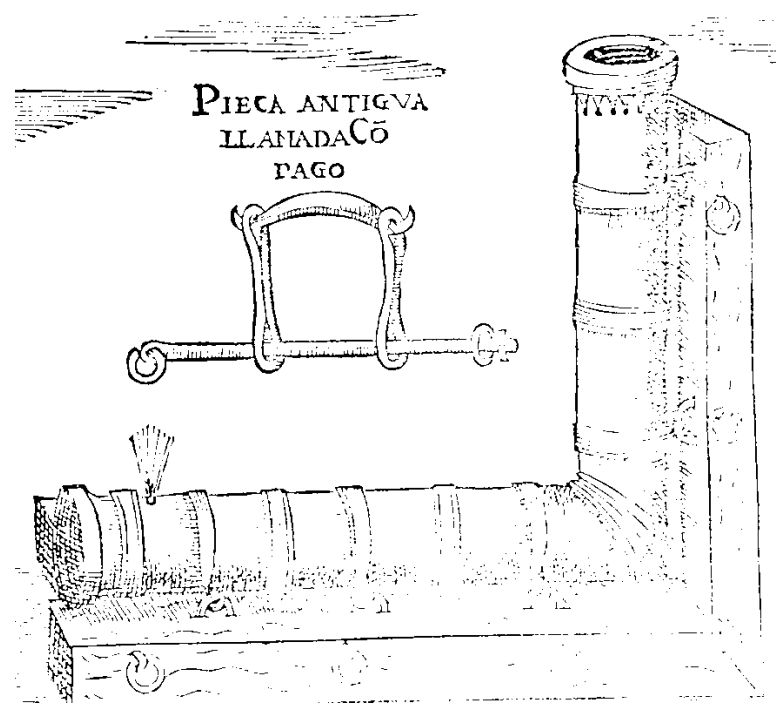



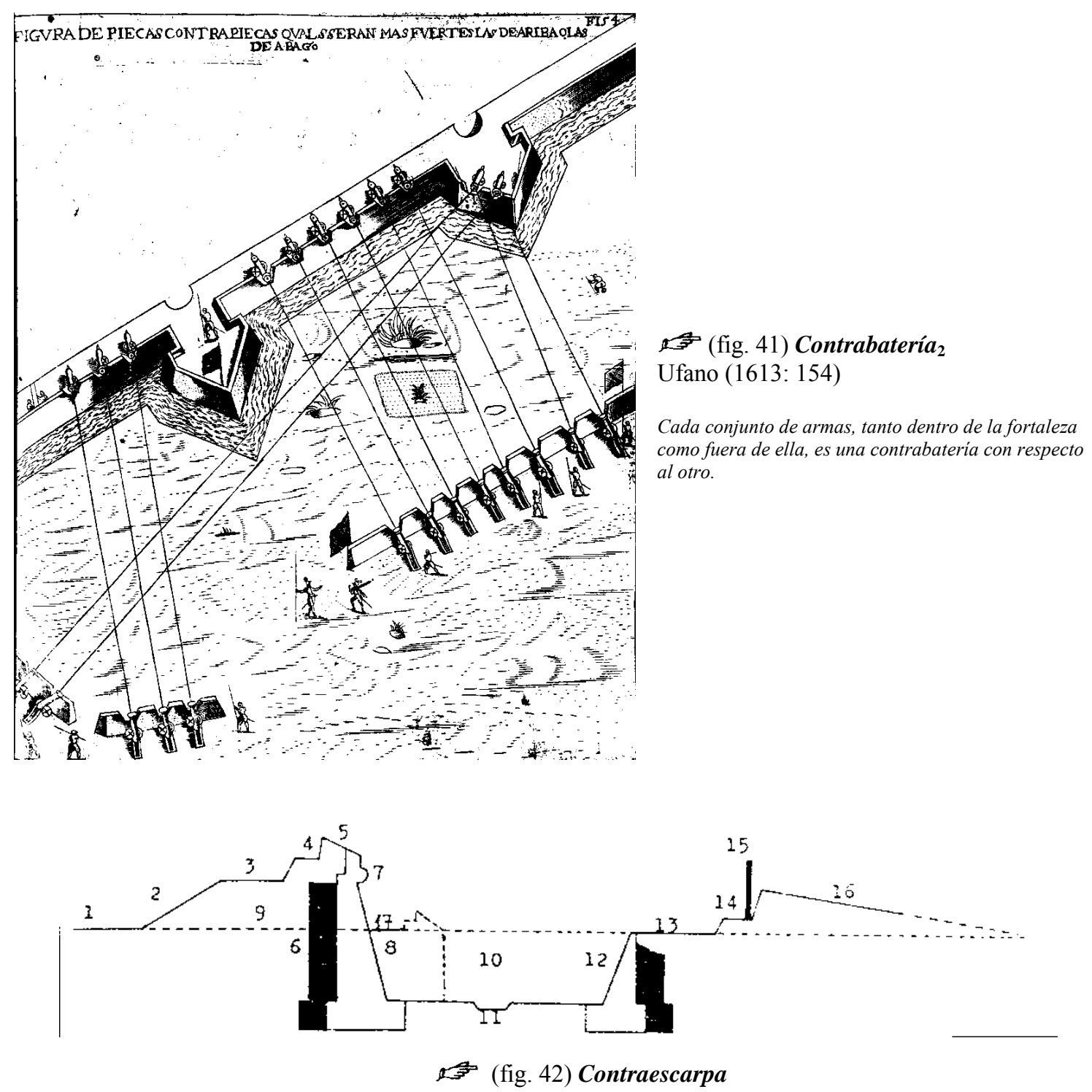

Lopes Pires Nunes (2005: s.v. perfil de praça abaluartada)

Perfil de una fortificación donde el número 12 representa la contraescarpa.

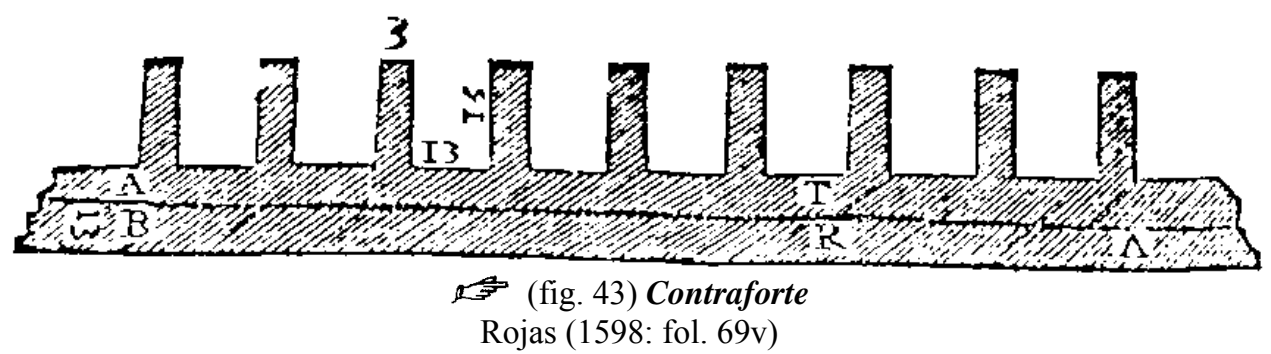

Cristóbal de Rojas acompaña esta planta del siguiente comentario: "El gruesso del cimiento de la muralla tendrá treze pies, y por lo alto cinco, porque tendrá ocho en la escarpa, perdiendo de cinco uno; y cada contraforte tendrá quinze de largo y tres de gruesso". 


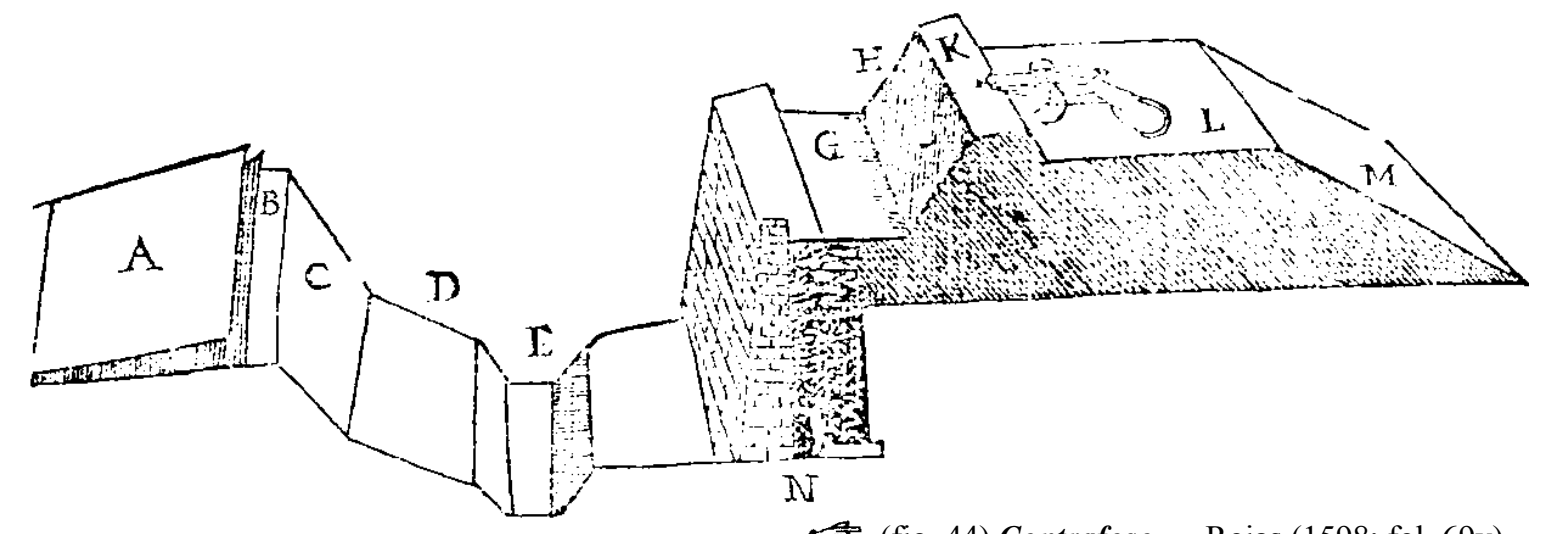

(fig. 44) Contrafoso Rojas (1598: fol. 69v)

Perfil de una fortificación donde se representa con $\mathrm{C}$ la pared del contrafoso.

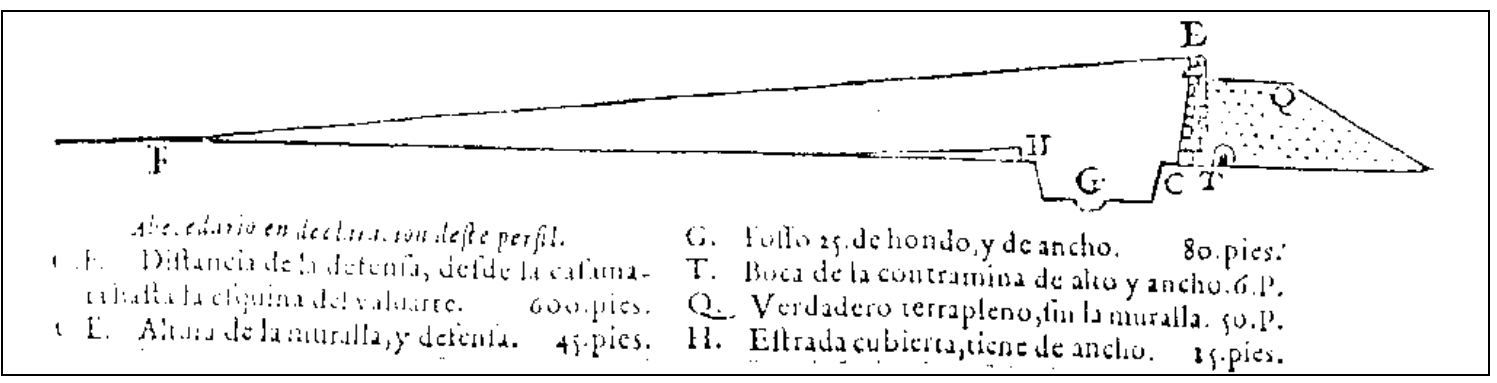

$\$$ (fig. 45) Contramina Rojas (1598: fol. 39r)

Perfil de una fortificación donde se representa la boca de una contramina permanente.

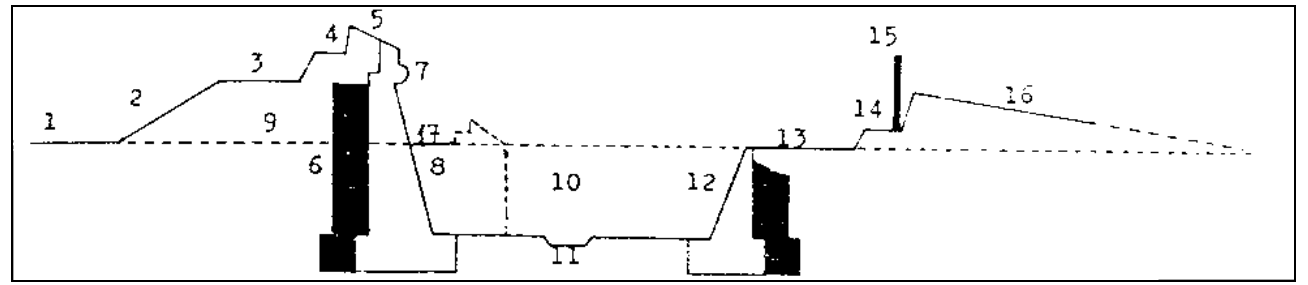

(fig. 46) Cordón Lopes Pires Nunes (2005: s.v. perfil de praça abaluartada) Perfil de una fortificación donde el número 7 representa el cordón.

(fig. 47) Cortadura

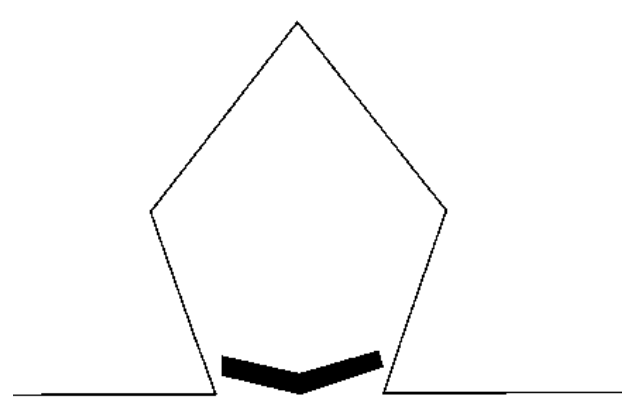

Lopes Pires Nunes (2005: s.v. cortadura)

Pequeño baluarte con cortadura en la gola. En este caso, lo significativo es que esta cortadura se ha hecho antes del ataque del enemigo, es decir, antes de que los sitiadores hayan hecho brecha en el baluarte, opción que, si bien no era la más frecuente, podía darse en algunas ocasiones, como señala por ejemplo Lucuze (1772: 42) en su tratado: "Considerando que, abierta la brecha en la cara, son precisas las cortaduras en el baluarte, algunos se anticipan a formarlas al tiempo de la construcción y de diversos modos". Teniendo en cuenta esta imagen de Lopes Pires Nunes, es lógico que defina cortadura de la siguiente manera: "Terrapleno com parapeito e canhoneiras que se construía na gola dos baluartes, para o caso de o inimigo abrir neles uma brecha". 
(fig. 48) Cortina

Rojas (1598: fol. 31r)

Planta de una fortificación en la que la letra A representa una de sus cortinas.
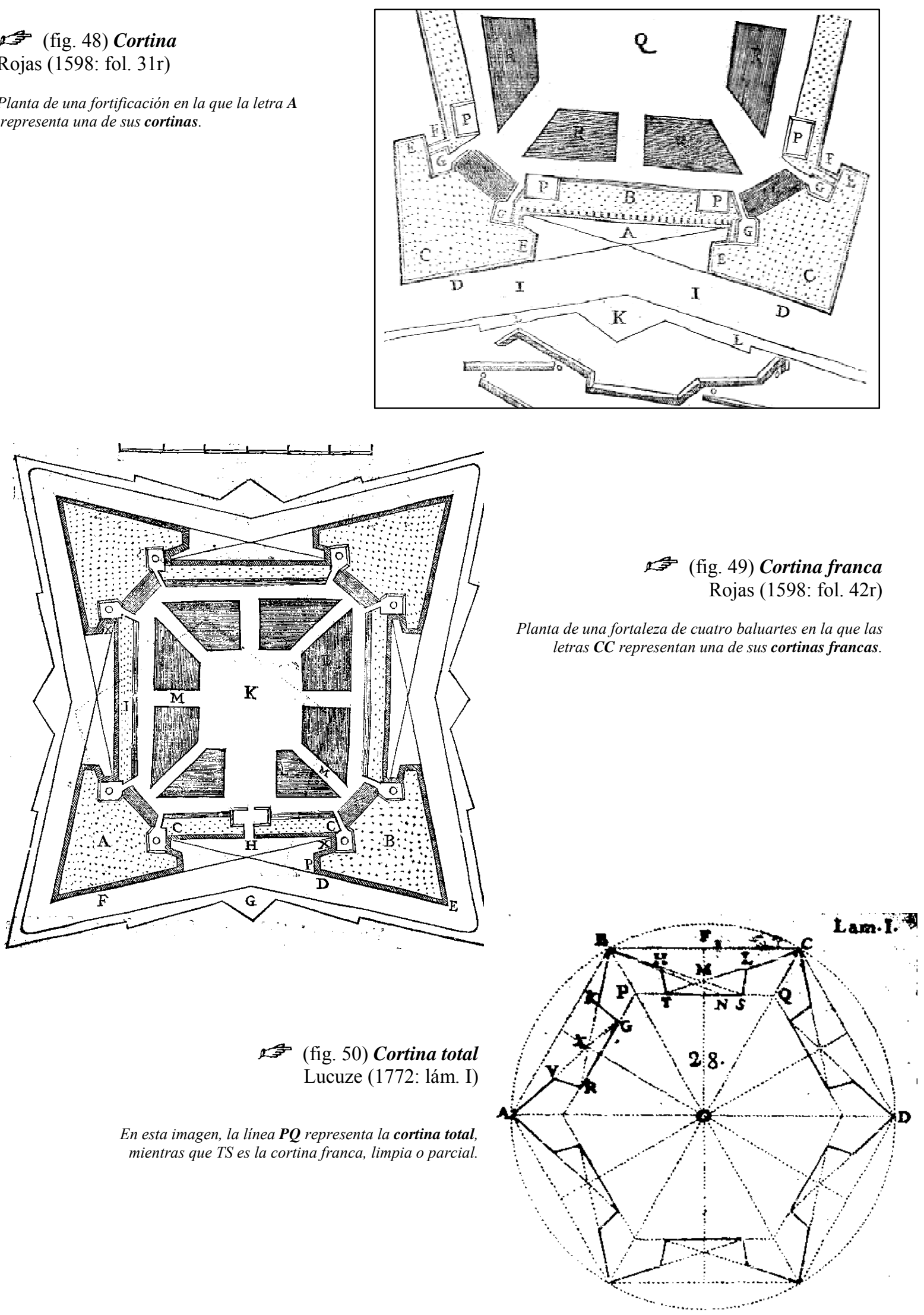


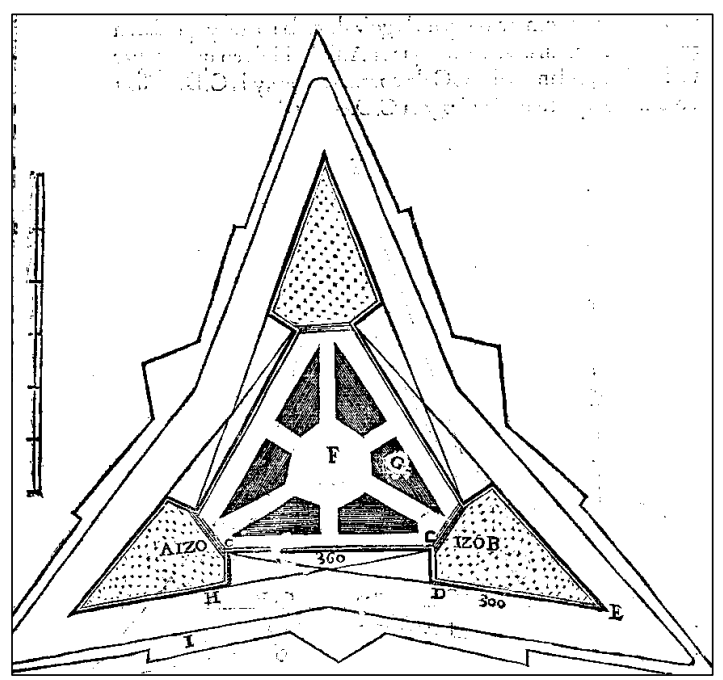

(fig. 51) Cuartel

Rojas (1598: fol. 40v)

En esta planta de tres baluartes, la letra $\boldsymbol{G}$ representa uno de los seis cuarteles en los que se encuentra dividido el espacio en el que se aloja el presidio de esta fortaleza.

\section{s (fig. 52) Cuerno}

García de Palacio (1583: fol. 173v).

En los dos órdenes de batalla que aparecen en esta imagen se han señalado sus cuernos o alas.

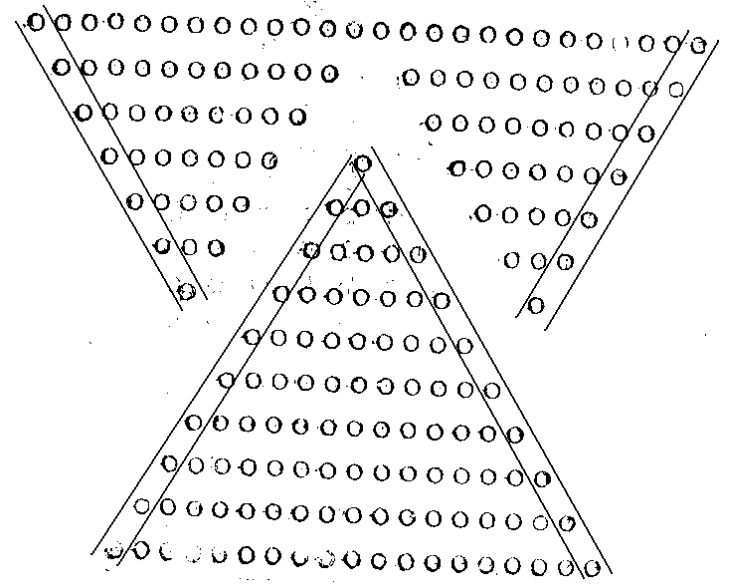

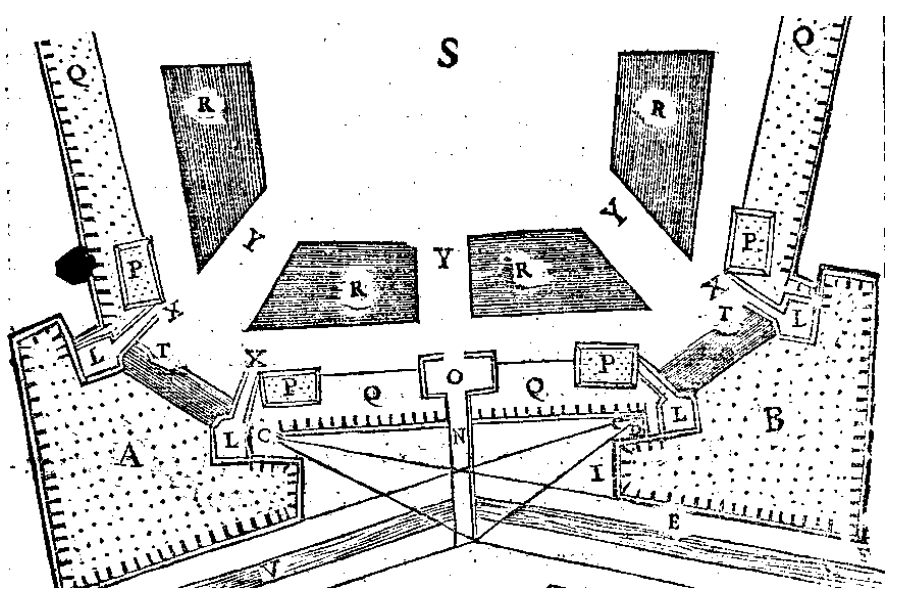

\section{(fig. 53) Cuerpo de guardia}

Rojas (1598: fol. 39r)

Planta de una fortificación en la que la letra O representa el lugar, llamado cuerpo de guardia, desde el que los soldados vigilan. 


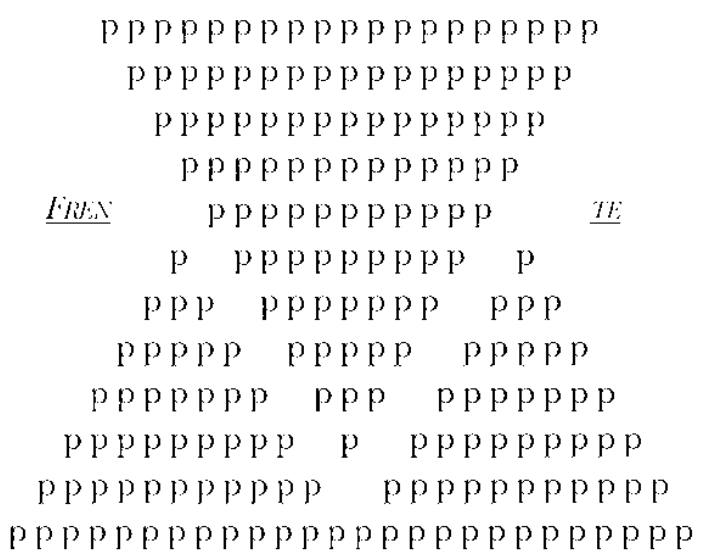

Orden de batalla llamado cúneo (el de arriba) en oposición a una tenaza o fórfice (formación de abajo).

\section{న⿶ (fig. 54) Cúneo}

Álaba (1590: fol. 118v).
Roxas (1607: fol. 38v). 争 (fig. 55) Cuño

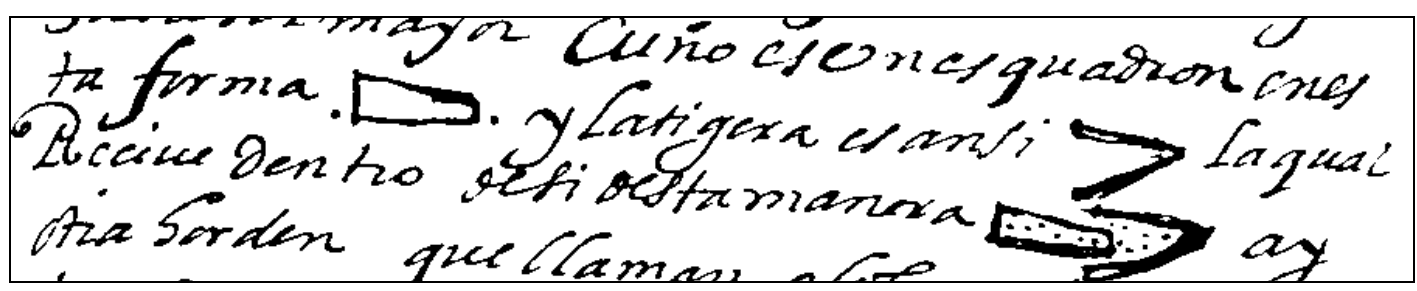
$0 \quad 000000$
- 0000000 0.000000000 O O O OOQOOOO 0000000000 0000000000 0000000000 0000000000 0000400000 0000000000 F (fig. 56) Desbarate García de Palacio (1583: fol. 173v)

Orden de batalla cuadrado que, a causa de la muerte de algunos soldados, sufre un desbarate en la frente. Según García de Palacio (1583: fol. $182 v$ ), en estos casos los militares deben ocupar los vacios de vanguardia y que,

(fig. 57) Diente Lucuze (1772: lám. II)

Llos dientes de la estrada cubierta están representados por la letras.

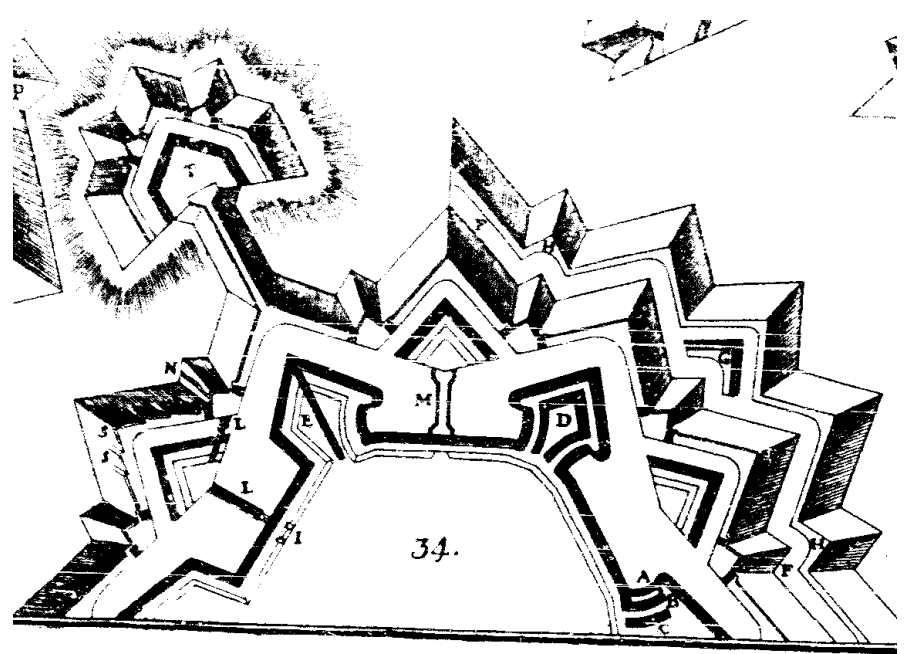


(fig. 58) Diente

García de Palacio (1583: fol. 174v)

Orden de batalla compuesto por cuatro dientes, cúneos o cuños.

$\begin{array}{cccc}0 & 0 & 0 & 0 \\ 000 & 000 & 000 & 000 \\ 00000 & 00000 & 00000 & 00000 \\ 0000000 & 0000000 & 0000000 & 0000000\end{array}$

000000000000000000000000000000000000

Esta imagen muestra una de las varias manera que hay para destruir la empalizada que, para mayor defensa, rodea un lugar fuerte. Ufano (1613: pág. 277): "Se ligará a la parte que se aya de romper y abrir de la empaliçada con cuerdas de ligamen una rueda artiffiçiada de fuego repentino a tiempo limitado, de la manera que se presenta en la figura, porque, çiertamente, encendida que sea, hará bastante portillo y libre entrada para la gente de guerra que aya de effetuar tal empresa".

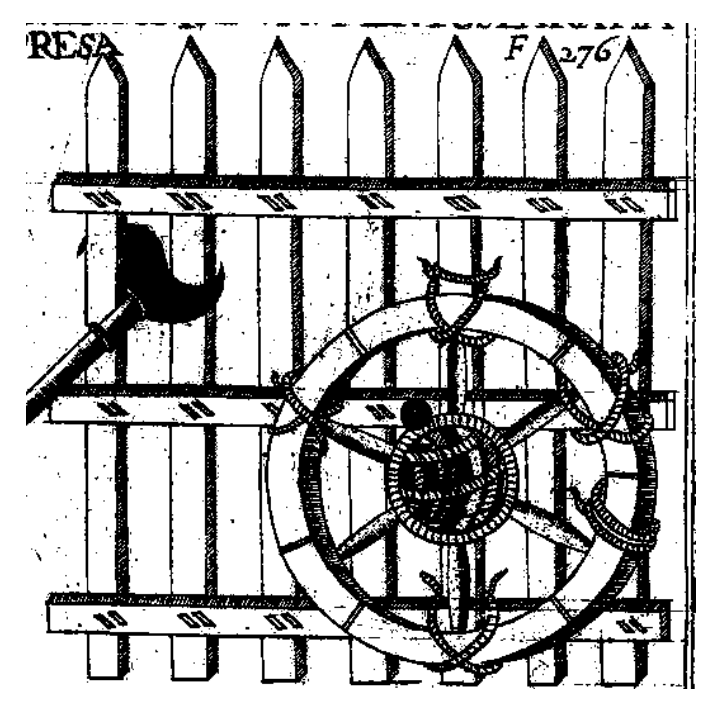

买 (fig. 60) Escala Lopes Pires Nunes (2005: s.v. escala)
중 (fig. 59) Empalizada

Ufano (1613: 276)

Distintos tipos de escalas empleadas en el asalto a una fortificación.

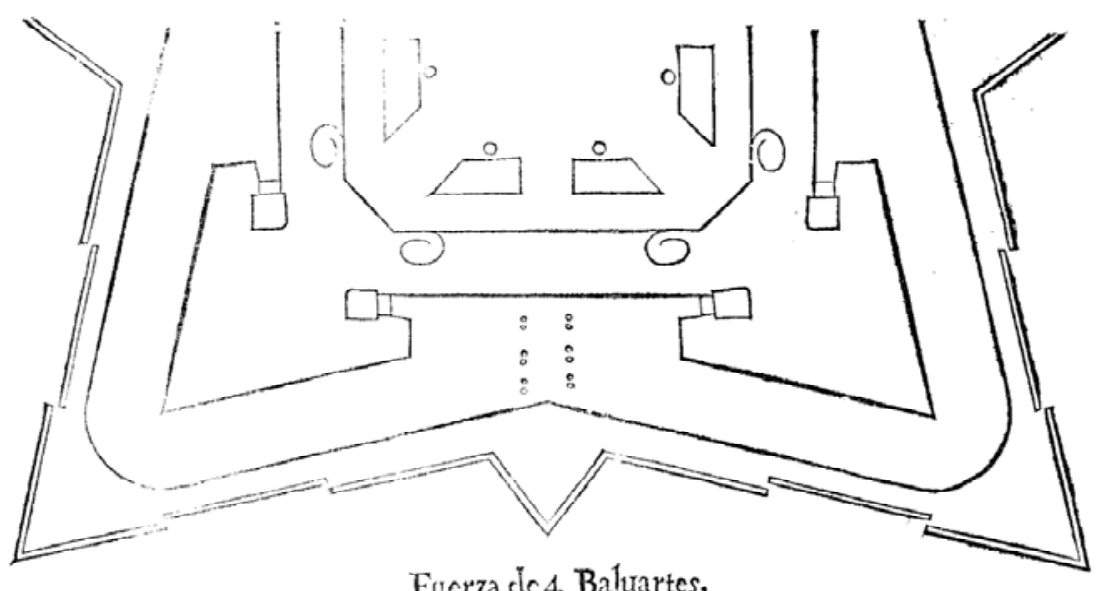

Fincrza dic 4 Baluartes,
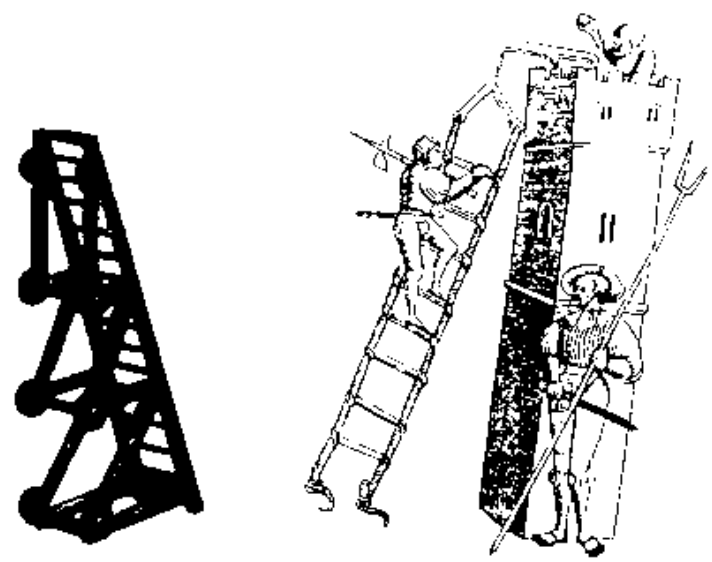

Efcala de $800 \cdot$ pies.

웅 (fig. 61) Escala

Lechuga (1611: 255)

Figura, con escala de 800 pies, que representa una fuerza de cuatro baluartes. 


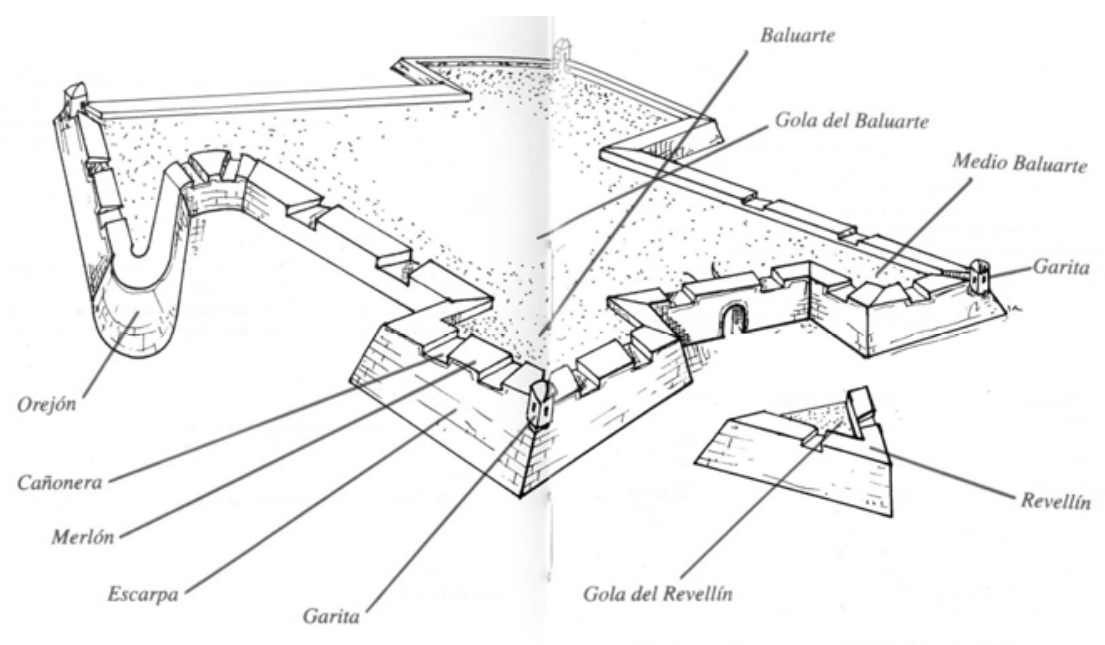

Lorenzo Celorrio (1996: 56-57).

(fig. 62) Escarpa

Fortificación abaluartada donde es posible apreciar la escarpa o inclinación que presentan los muros defensivos.

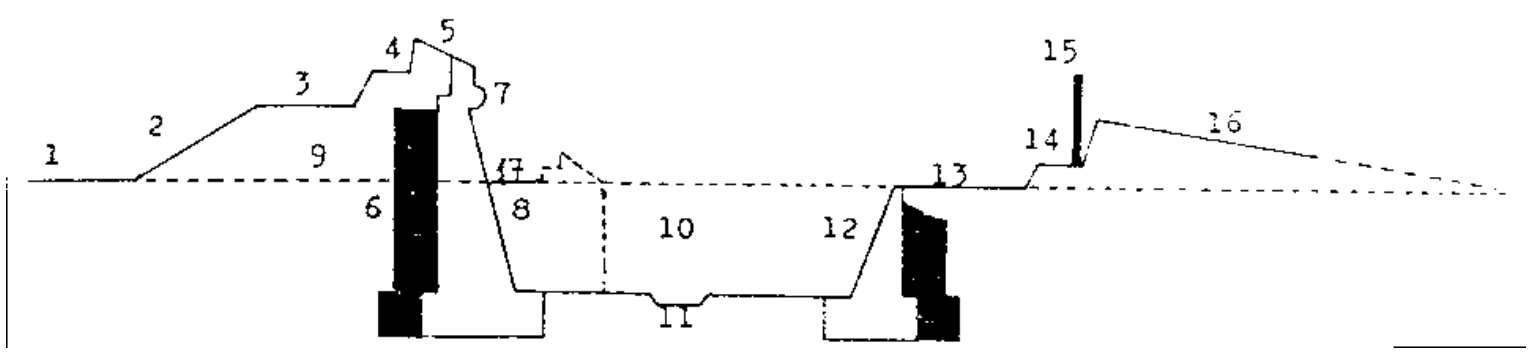

(fig. 63) Escarpa $_{2}$ Lopes Pires Nunes (2005: s.v. perfil de praça abaluartada)

Perfil de una fortificación donde el número 8 representa la escarpa.

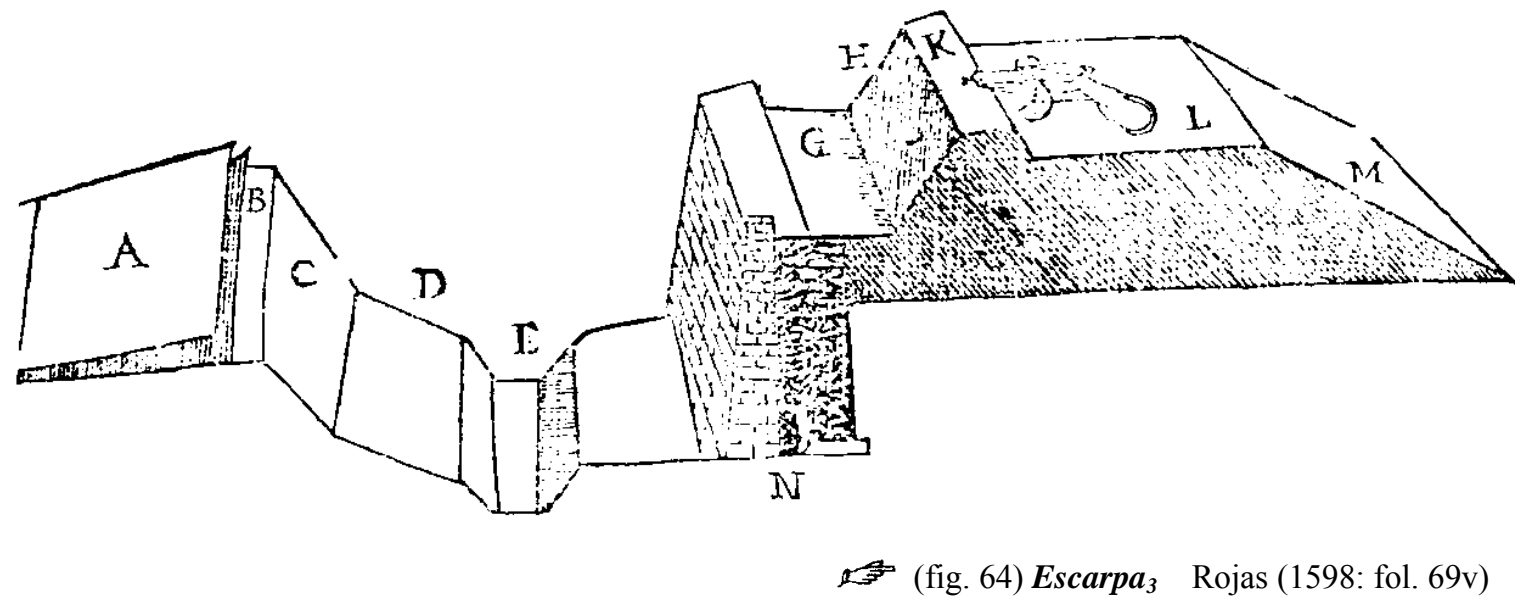

Perfil de una fortificación donde la letra A corresponde a "escarpa de tierra de la estrada cubierta a la campaña". 
En esta formación, llamada escuadrón falso, la letra $P$ representa a los infantes perdidos, $x$ a los alabarderos y $B$ a las banderas.

(fig. 65) Escuadrón falso García de Palacio (1583: fol. 164r)
000000000000000000

000000000000000000 000000000000000000 $\mathrm{x} \times \mathrm{x} \times \mathrm{x} \times \mathrm{x} \times \mathrm{x} \times \mathrm{x} x \mathrm{x}$

PPPPPP

PPPPPP

000000

000000

000000

PPPPP

000000000000000000 00000000 B B 0000000 000000000000000000

PPPPPP

PPPPPP

000000

000.000

000000

000000

PPPPPP

P P PPP

$x \times x \times x \times x \times x \times x \times x \times x \times x$ 000000000000000000 000000000000000000 ,00000000000000000

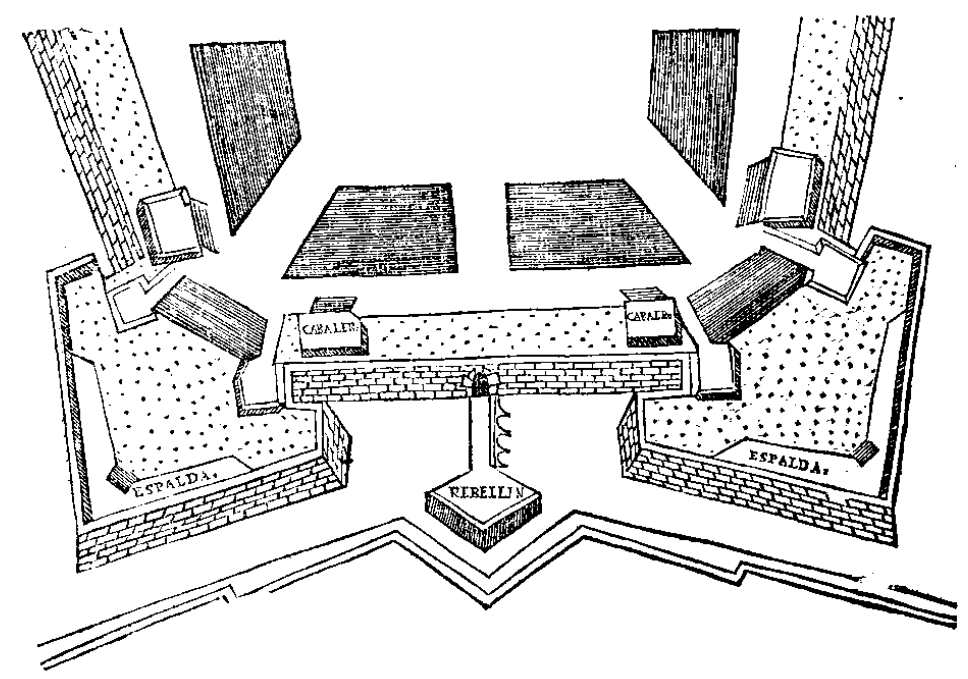

Rojas (1598: fol. 72v-73r): "Y con esto, y con hazer en lugar de parapetos en cada valuarte una espalda de tierra y fagina de 30 pies de gruesso, y 150 pies de frente, desde la esquina del valuarte hazia el orejón, y esta espalda ha de correr desde la esquina del dicho valuarte por ambas frentes, y luego a la haz de fuera d'esta espalda correrá el parapeto de piedra, que será de los cinco pies de gruesso que tiene alli la muralla sin los contrafortes; $y$ assimesmo, tendrá de alto el dicho parapeto 5 pies sobre la espalda, y quedarán, de los 30 pies que tenía de gruesso, 25 de espacio franco para andar por cima los soldados escaramuçando. Y quando el enemigo batiesse los parapetos, se pondrán los soldados detrás de la espalda, la qual tendrá de alto poco más de 5 pies, porque, en aviendo derribado el enemigo el parapeto de piedra y peynado toda la delantera de la dicha espalda, quedará en forma lamborada, porque el enemigo lo avrá puesto assí con su batería".

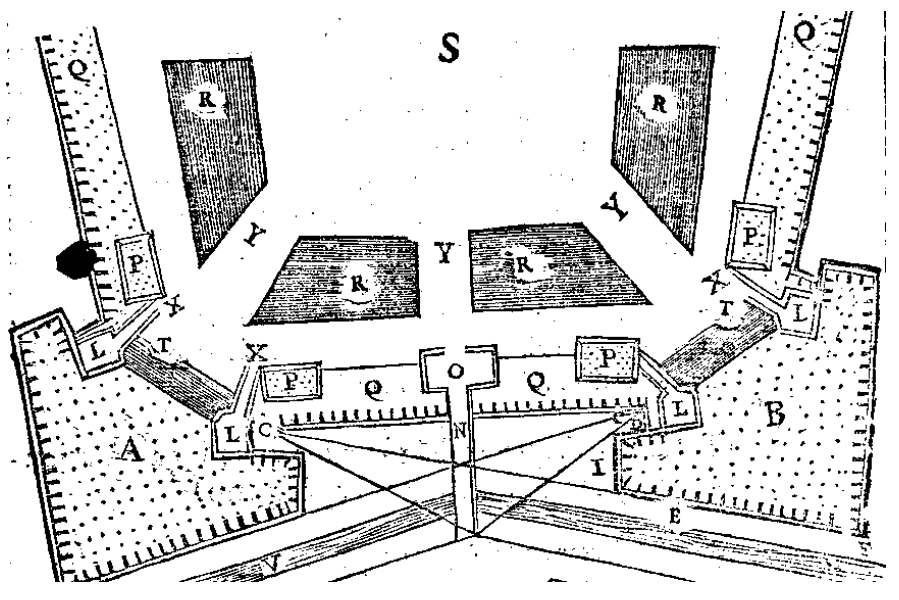

\section{(fig. 67) Espalda $_{3}$}

Rojas (1598: fol. 39r)

Planta de una fortaleza en la que DE representa la espalda del baluarte B, el cual cuenta con dos casamatas, que son las que están representadas por la letra $L$. 


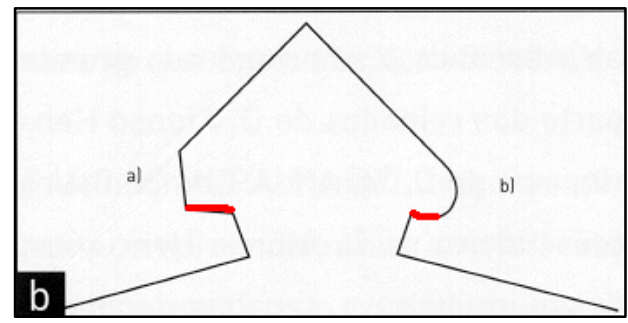

?ㄱ (fig. 68) Espalda $_{4}$

Lopes Pires Nunes (2005: s.v. orelhão)

Las partes señaladas en rojo constituyen las respectivas espaldas de cada uno de esos dos orejones.

La planta de esta fortaleza muestra baluartes clásicos, solución a la que se denomina espolón.

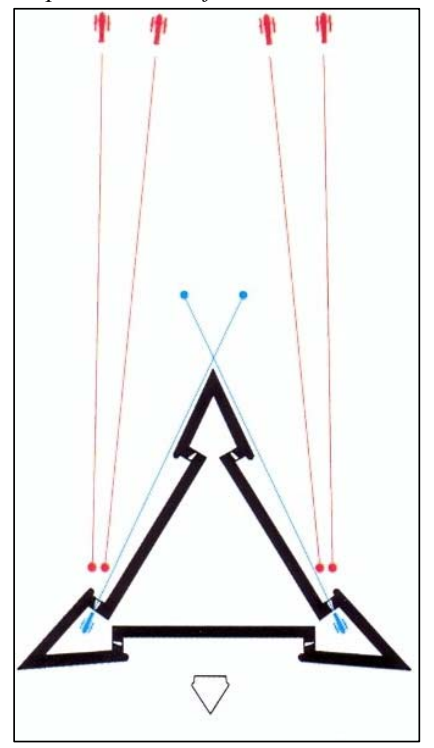

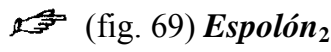

Castro Fernández y Cobos Guerra (2000: 251).

\section{(fig. 70) Estancia}

González de Medina (1599: 78)

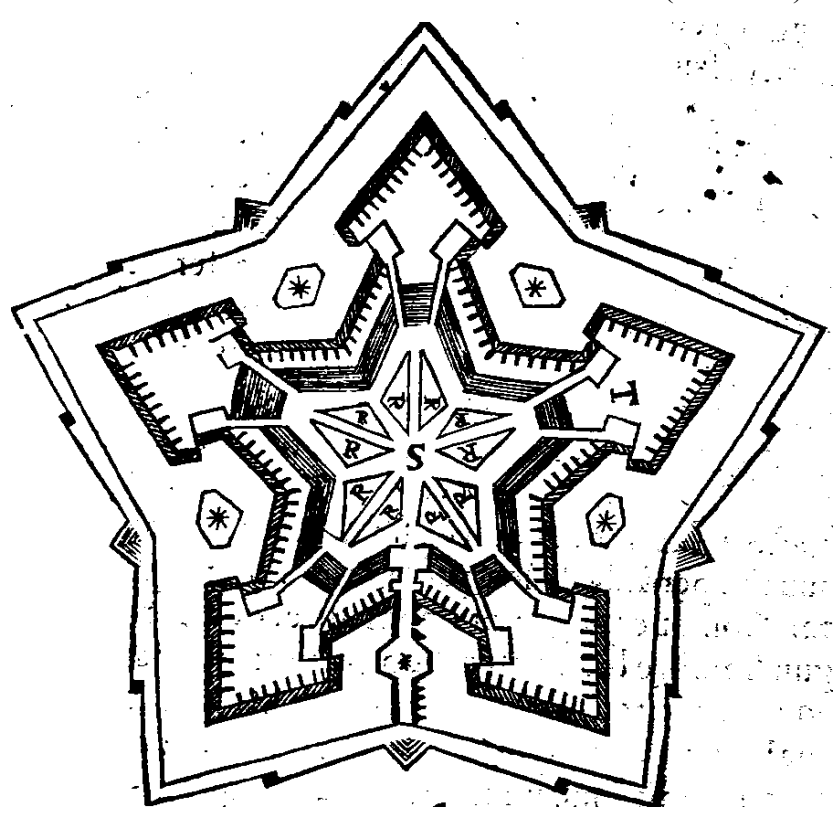

Al ser defectuosas, por constar de un ángulo hacia dentro, las cortinas de esta fortaleza de cinco baluartes, apenas hay espacio dentro de su plaza de armas para las estancias, las cuales están marcadas con la letra $\mathrm{R}$.

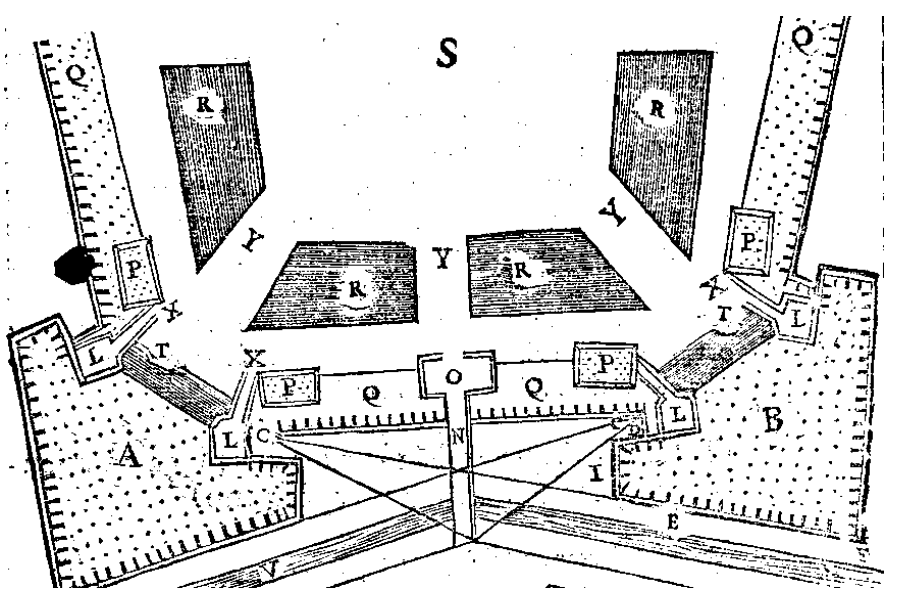

今 (fig. 71) Estrada

Rojas (1598: fol. 39r)

Planta de una fortificación en la que la letra X representa las estradas, de 25 pies, que conducen a las casamatas $(L)$. 


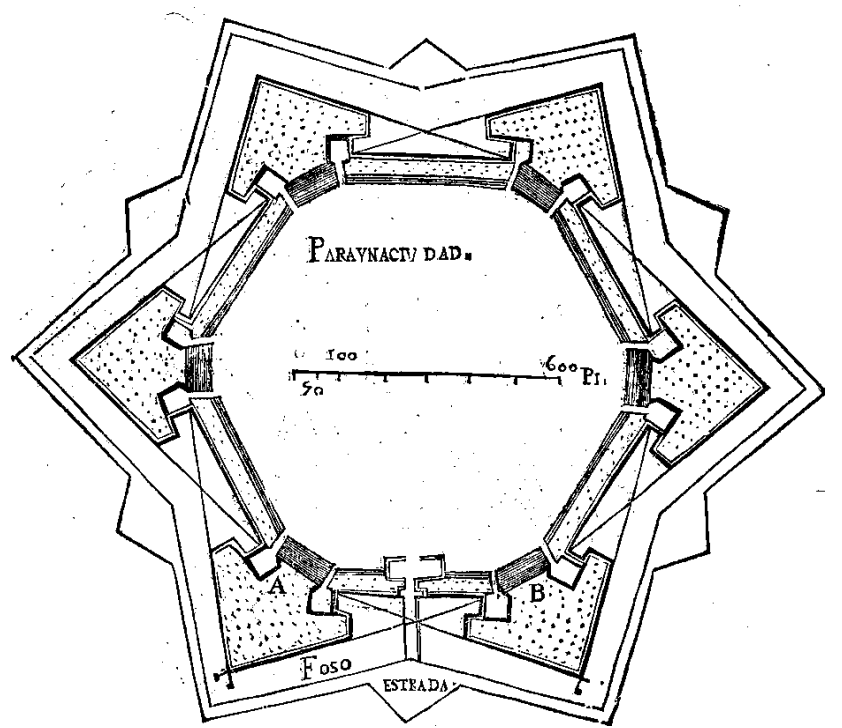

중 (fig. 72) $\boldsymbol{E s t r a d a}_{2}$

Rojas (1598: fol. 43v)

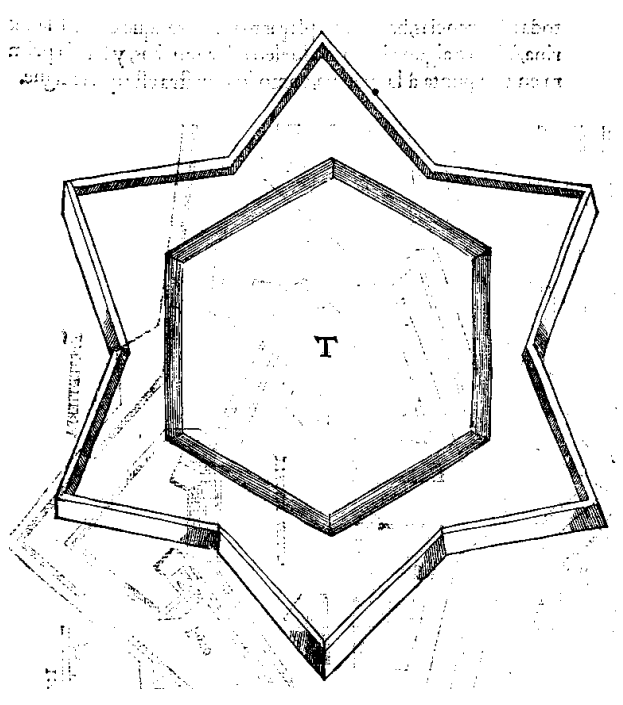

(fig. 74) Estrella

Rojas (1598: fol. 46r)

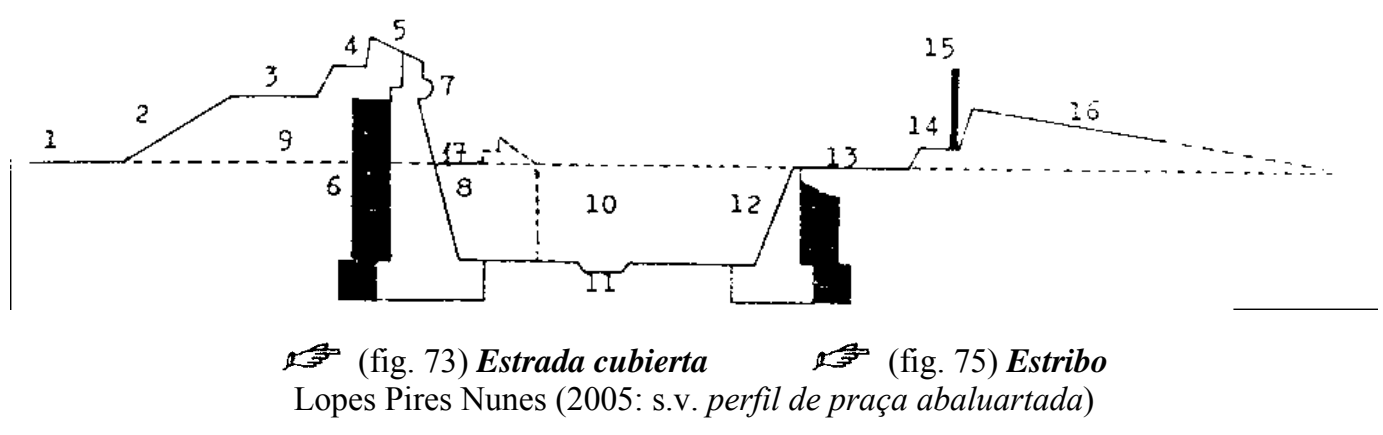

Perfil de una fortificación donde el número 13 representa la estrada cubierta. Puede verse, además, en el número 14, la banqueta del parapeto que posee la estrada cubierta. El número 6 representa el contraforte o estribo de la muralla.

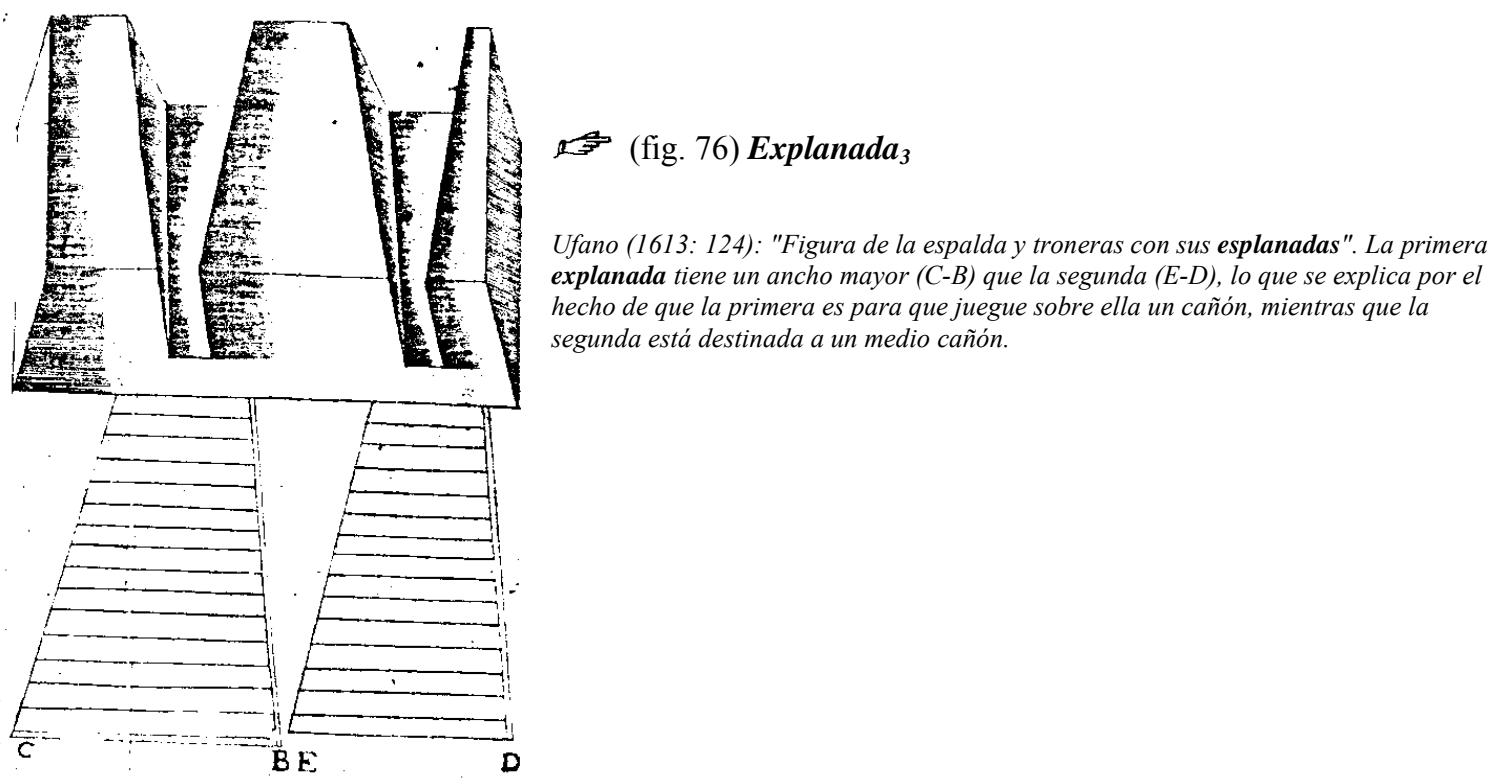




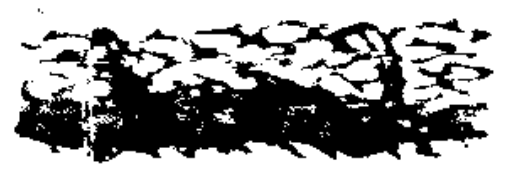

s? (fig. 77) Fajina

Lucuze (1772: lám. VI)

Se representan, con la letra $M$ el terreno, con $G$ el terraplén cortado del terreno, con E el terraplén hecho a mano y, por último, con $\boldsymbol{F}$ la falda, por la que se accede a la parte superior de esta fortaleza.

González de Medina

(1599: 44)

(fig. 78) Falda
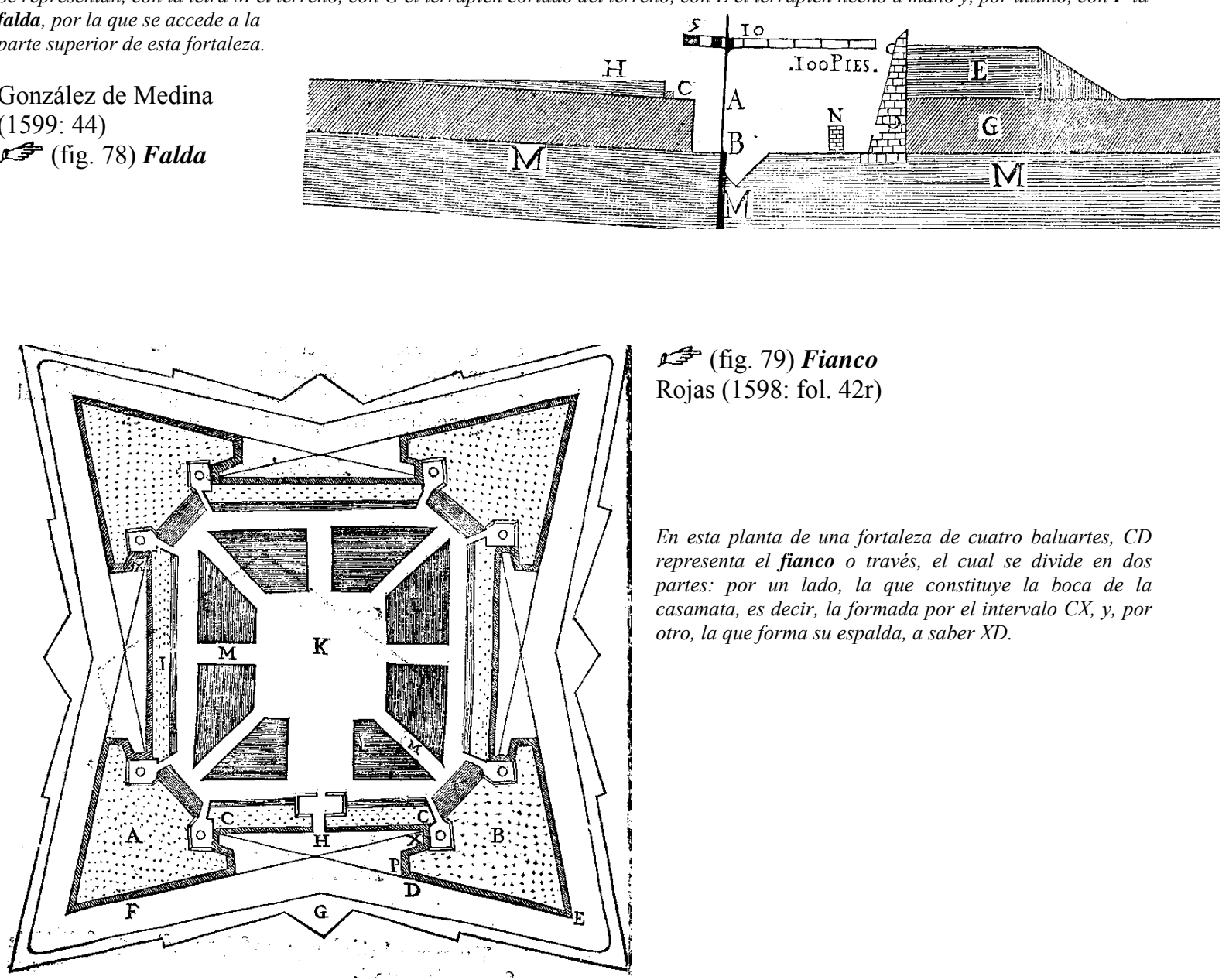

주 (fig. 79) Fianco

Rojas (1598: fol. 42r)

En esta planta de una fortaleza de cuatro baluartes, $C D$ representa el fianco o través, el cual se divide en dos partes: por un lado, la que constituye la boca de la casamata, es decir, la formada por el intervalo $C X, y$, por otro, la que forma su espalda, a saber $X D$.

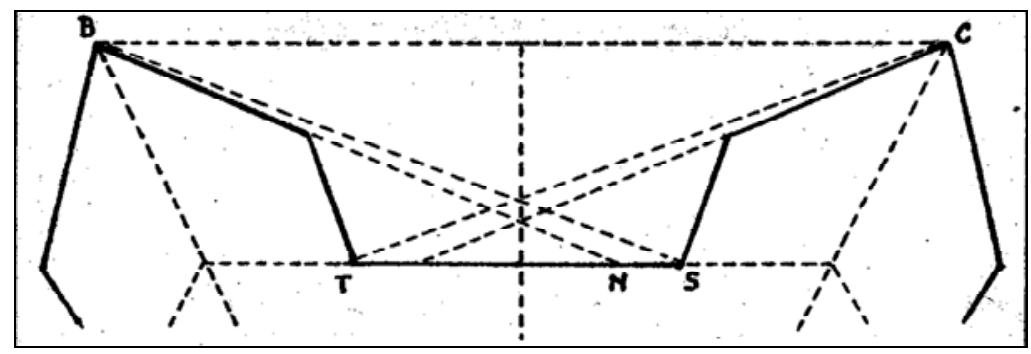

F (fig. 80) Flanco $_{2}$

En esta imagen, NS representa el flanco de la cortina o, como lo llaman otros, segundo flanco. Díaz Capmany (2004: 21) 

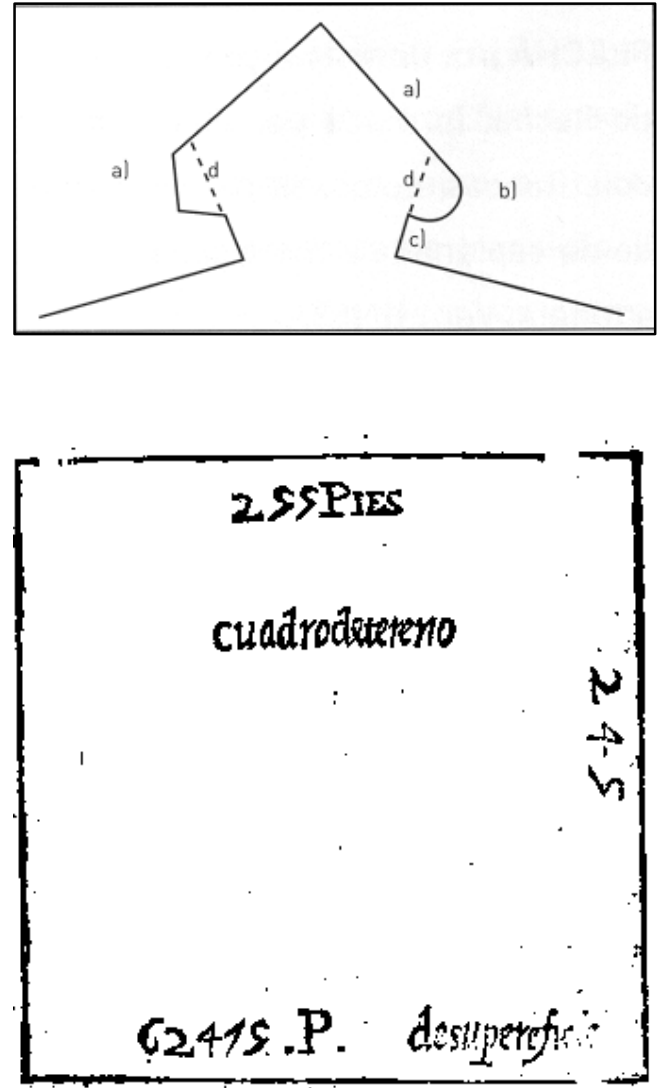

\section{(fig. 81) Flanco del orejón}

Lopes Pires Nunes (2005: s.v. flanco)

La letra d representa el flanco del orejón. Ahora bien, mientras que la d de la izquierda muestra un flanco cubierto por un orejón directo o en forma semejante a la cuadrada, en la d de la derecha el flanco cubierto lo está a través de un orejón curvo.

\section{1주 (fig. 82) Fondo}

Rojas (1598: fol. 102v)

Rojas (1598: fol. 102r): "Para declaración del esquadrón quadro de terreno supongo que son 3.000 picas y me piden que haga d'ellas un esquadrón quadro de terreno. Dize la regla que, por quanto ha de aver de un soldado a otro tres pies por la frente y 7 de pecho a espalda, que se entiende 7 de fondo, se multipicarán los 3.000 por 3, y serán 9.000, que se partirán por $7, y$ saldrán 1.285, de los quales se sacará la raíz quadrada, que será 35, y tantas hileras tendrá de fondo el esquadrón. Y para sacarle la frente, se partirán las 3.000 picas por el fondo, que es 35 , y saldrán 85 , y tantas hileras tendrá de frente, como parece en esta figura. Y para saber quánta superficie ocupa el tal esquadrón, se multiplicarán las 85 hileras de la frente por 3, y serán 255, y tantos pies tendrá de frente el terreno; $y$ el fondo, que es 35, se multiplicará por 7 y saldrá 245 , y tantos tendrá de fondo, que viene a tener 10 pies más de frente que de fondo, que por maravilla vendrá justo. Y assí, multiplicando el fondo por la frente, saldrá toda la superficie, que serán 62.475 pies".

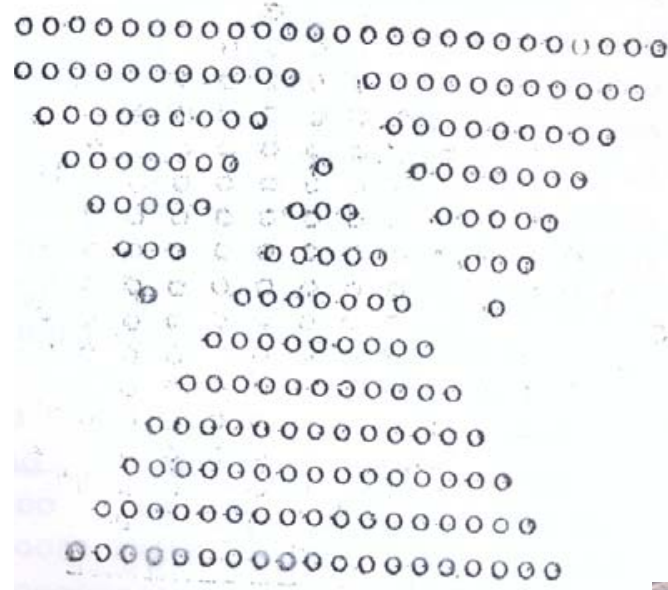

Fortaleza o construcción militar perteneciente a la época moderna o abaluartada.

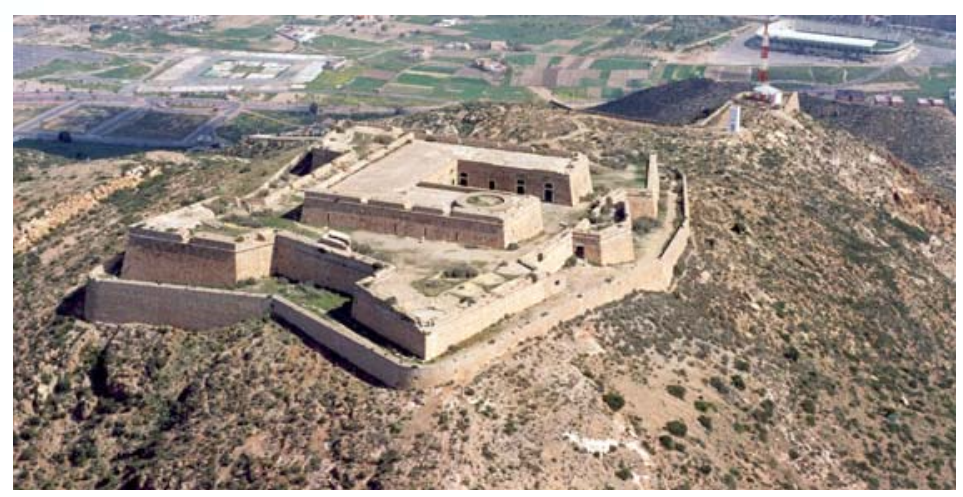

Orden de batalla llamado fórfice, tenaza o tijera (el de arriba) en oposición al cúneo (formación de abajo). 
If (fig. 85) Foso

Forte da Graça, en Elvas (Portugal), con su foso.

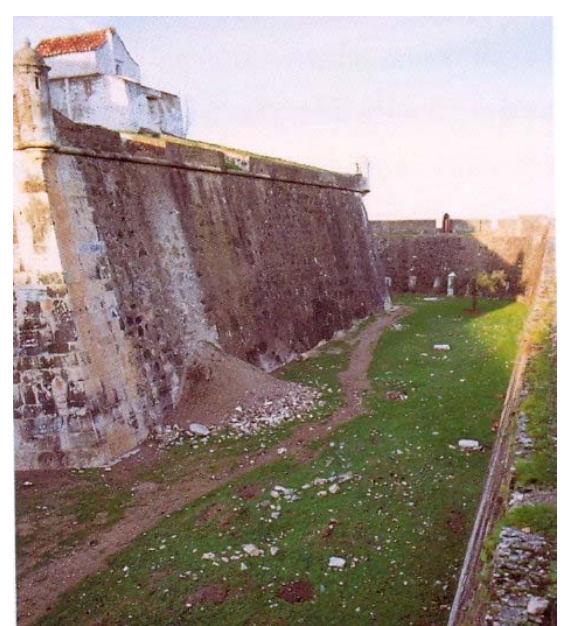

(fig. 87) Frente $_{3}$

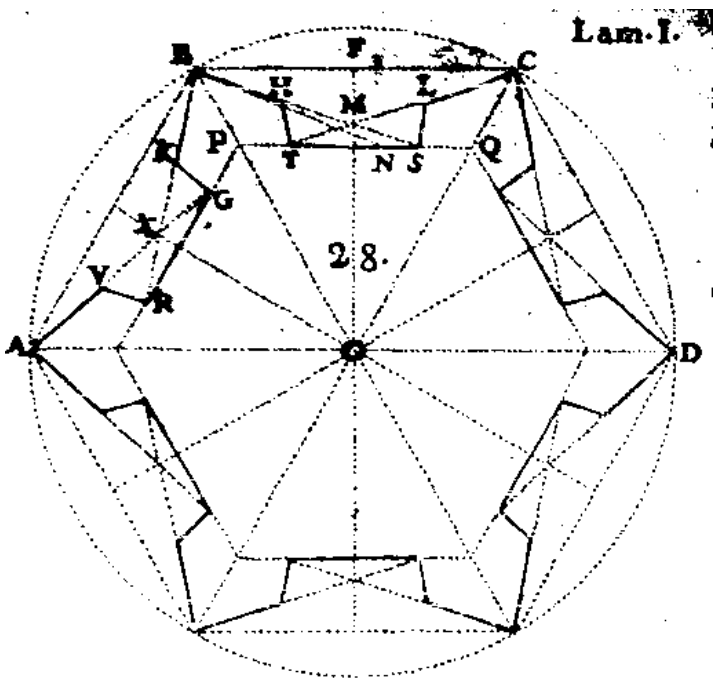

Lucuze (1772: lám. I) AVRGKB constituye una de las seis frentes con las que cuenta el plano de esta plaza.

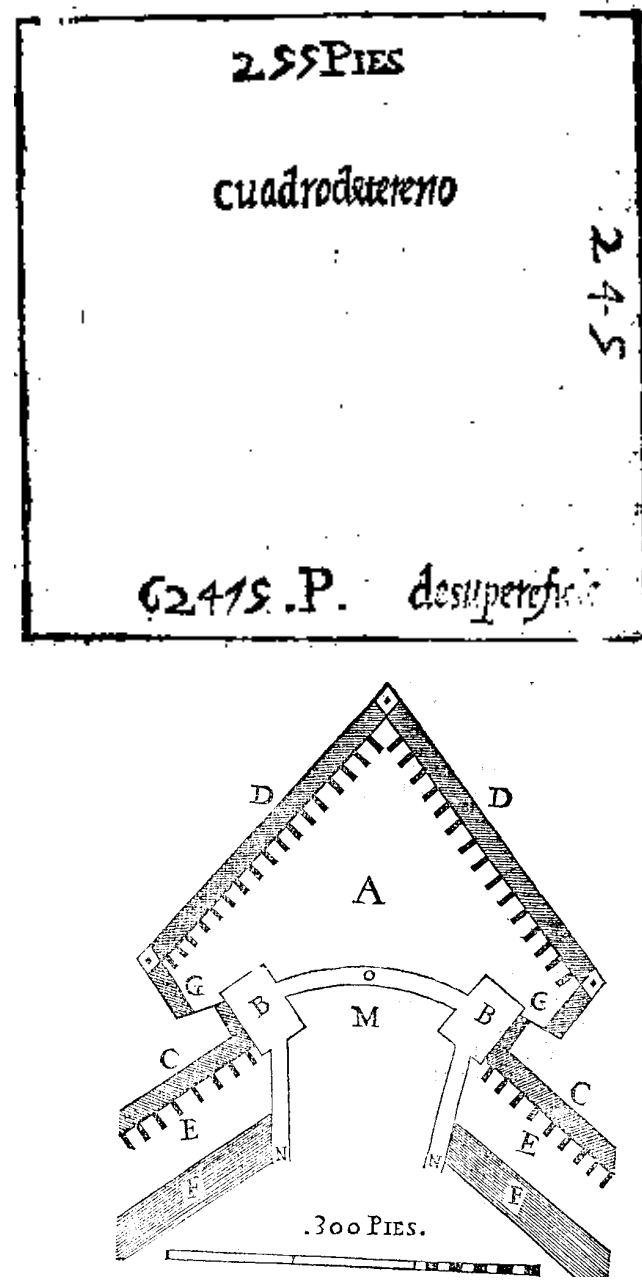

(fig. 86) Frente

Rojas (1598: fol. 102v)

Rojas (1598: fol. 102r-102v): "Para declaración del esquadrón quadro de terreno supongo que son 3.000 picas y me piden que haga d'ellas un esquadrón quadro de terreno. Dize la regla que, por quanto ha de aver de un soldado a otro tres pies por la frente y 7 de pecho a espalda, que se entiende 7 de fondo, se multipicarán los 3.000 por 3, y serán 9.000, que se partirán por 7, y saldrán 1.285, de los quales se sacará la raíz quadrada, que será 35, y tantas hileras tendrá de fondo el esquadrón. Y para sacarle la frente, se partirán las 3.000 picas por el fondo, que es 35, y saldrán 85 , $y$ tantas hileras tendrá de frente, como parece en esta figura. Y para saber quánta superficie ocupa el tal esquadrón, se multiplicarán las 85 hileras de la frente por 3, y serán 255, y tantos pies tendrá de frente el terreno; $y$ el fondo, que es 35, se multiplicará por 7 y saldrá 245 , y tantos tendrá de fondo, que viene a tener 10 pies más de frente que de fondo, que por maravilla vendrá justo. Y assí, multiplicando el fondo por la frente, saldrá toda la superficie, que serán 62.475 pies"

\section{艿 (fig. 88) Frente $_{4}$}

Figura en la que se representan, con la letra D, las dos frentes del baluarte $\mathrm{A}$.

González de Medina (1599: 27) 


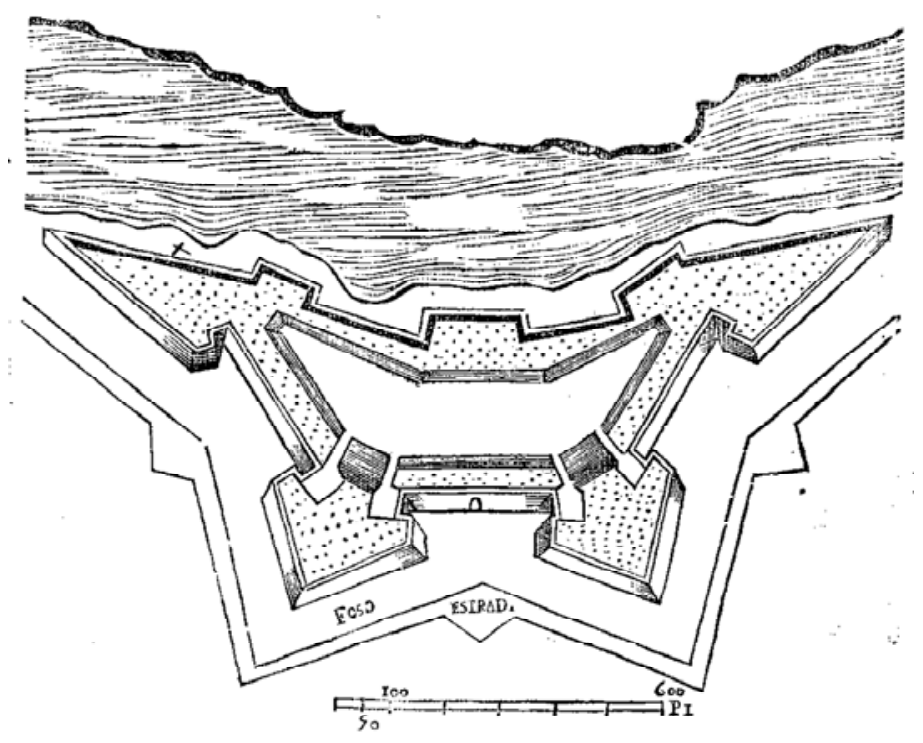

우 (fig. 89) Fuerte $_{2}$

Rojas (1598: fol. 47v): "Este fuerte es a propósito sobre un río o en la canal de un puerto. Su medida se entenderá por este pitipié".

(fig. 90) Fuerza

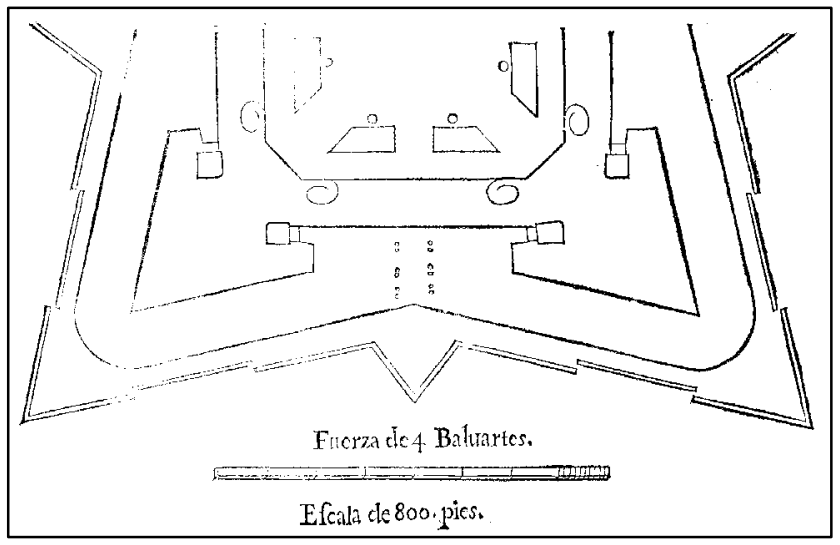

Figura, con escala de 800 pies, que representa una fortaleza o fuerza de cuatro baluartes.

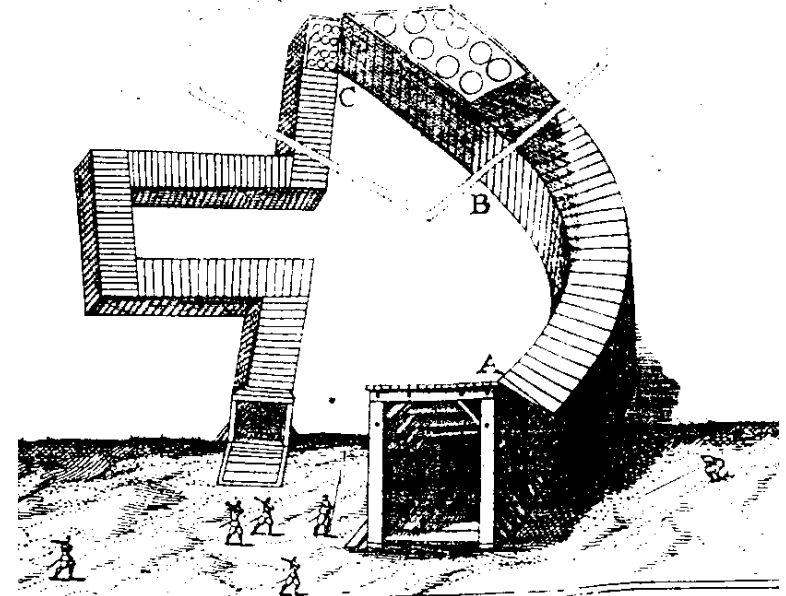

Ufano (1613: 262)

\section{争 (fig. 91) Galería}

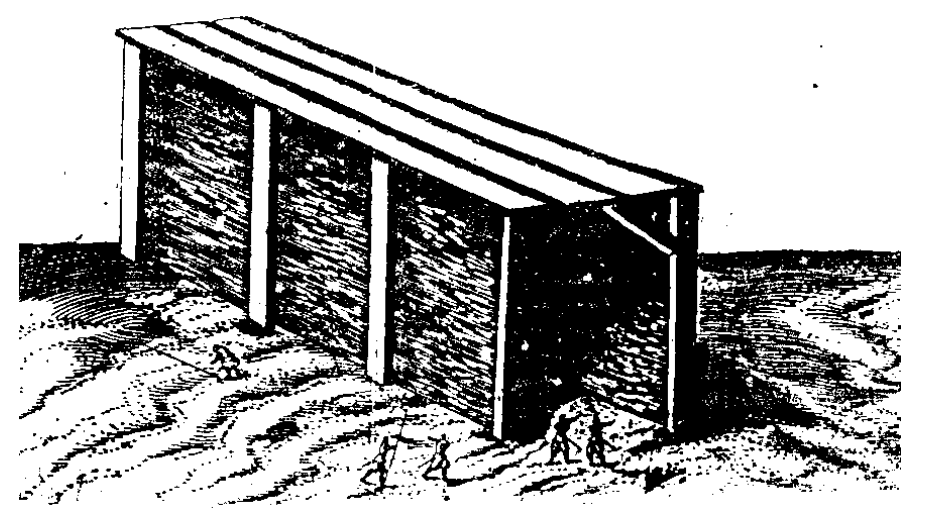

En esta figura, la mina formada por los sitiadores, que está marcada con las letras $A, B$ y $C$, consta de dos partes: la galería o camino principal (letras A y B) y el hornillo donde se coloca la pólvora (letra C).

予 (fig. 92) Galería

Ufano (1613: 262) 

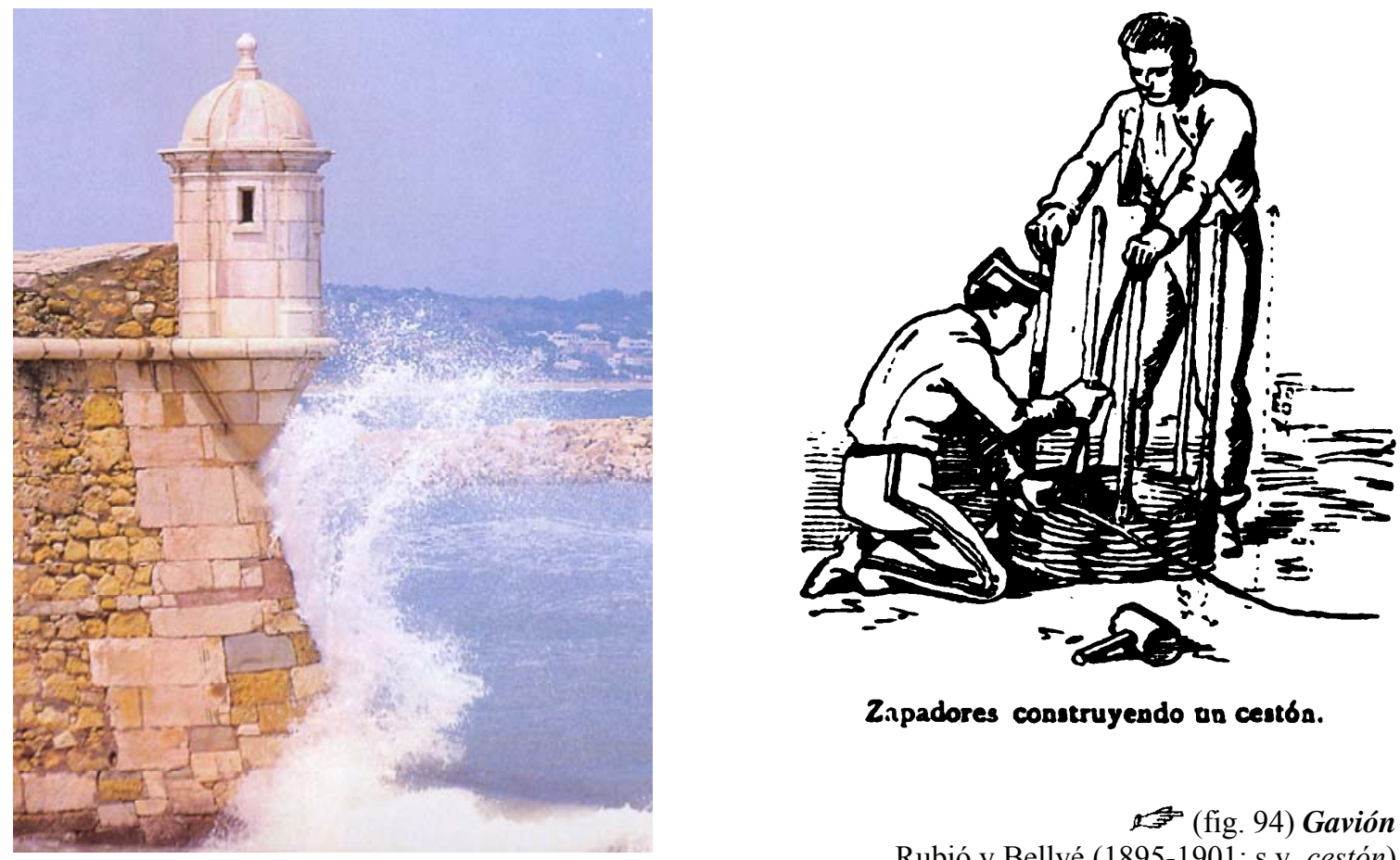

Znpadores construyendo un cestón.

r\} (fig. 94) Gavión

Rubió y Bellvé (1895-1901: s.v. cestón)

(fig. 93) Garita

Garita del Forte da Ponta da Bandeira, en Lagos (Portugal). Lopes Pires Nunes (2005: S.v. guarita)

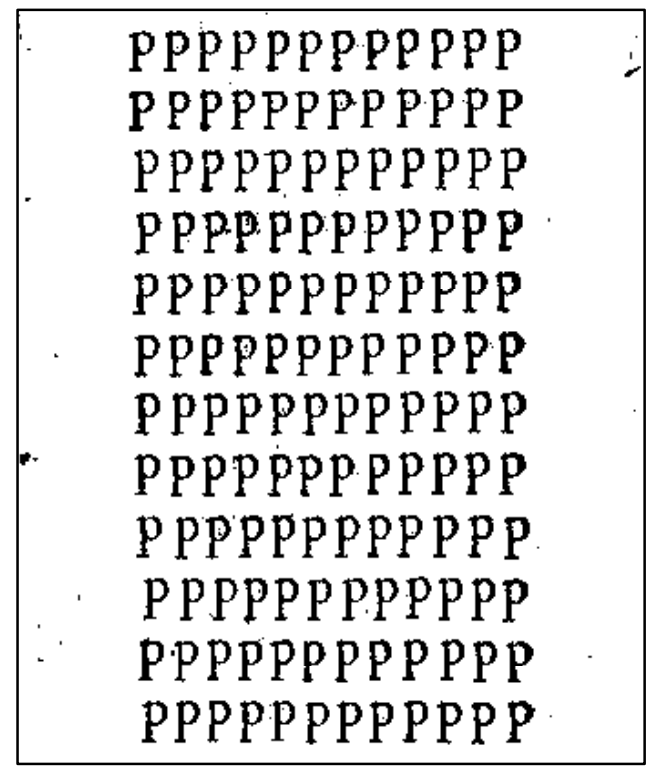

우 (fig. 95) Cuadro de gente Álaba (1590: fol. 112v) (fig. 96) Gola

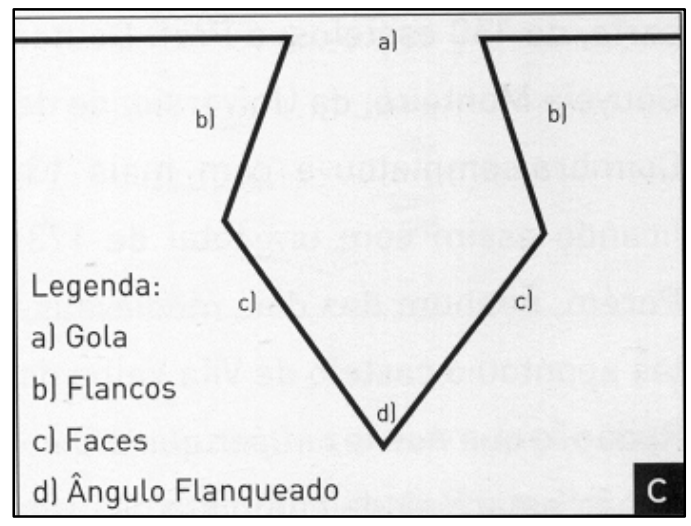

Lopes Pires Nunes (2005: s.v. gola): Linha imaginária que ligava as uniões dos flancos de um baluarte às cortinhas da praça. Pela gola fazia-se a ligação do baluarte à praça. Lopes Pires Nunes (2005: s.v. baluarte) 

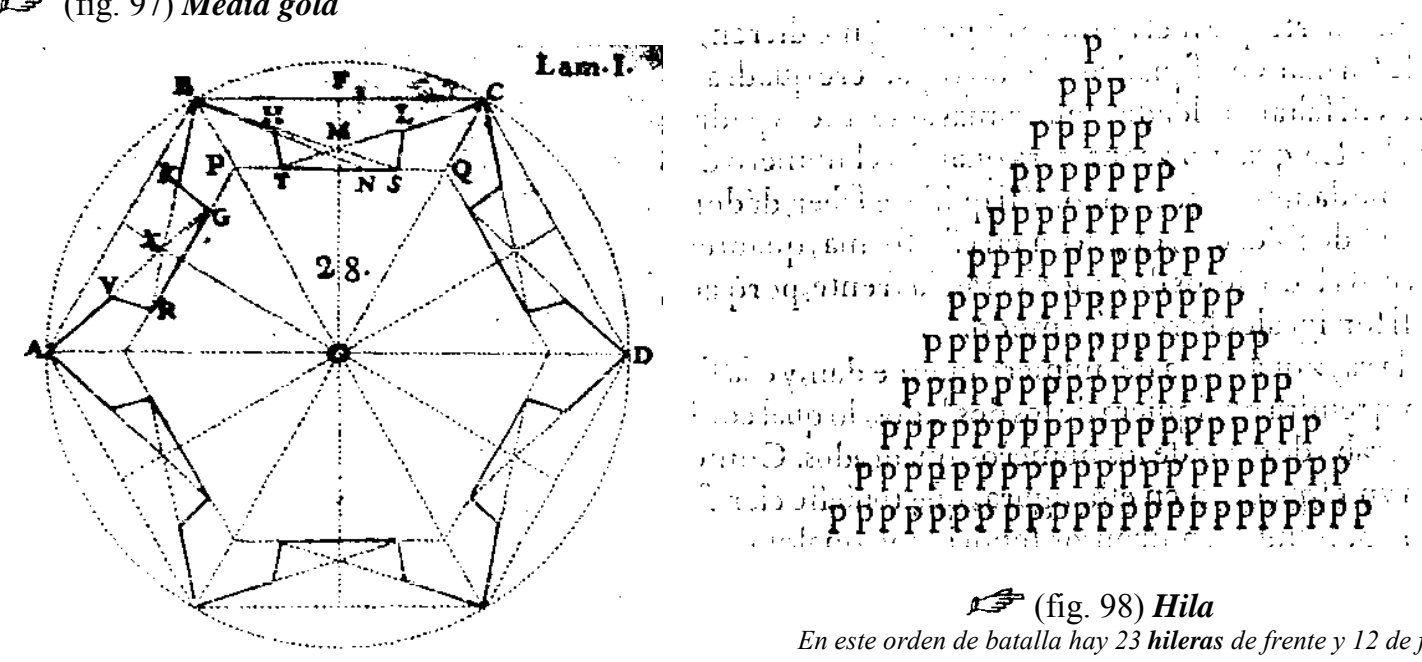

Álaba (1590: fol. 117v)

En este orden de batalla hay 23 hileras de frente y 12 de fondo. Lucuze (1772: lám. I)

$T P$ y SO representan dos de las varias semigolas o medias golas con las que cuenta este hexágono fortificado, concretamente las que entran a formar parte de la cortina total $P Q$.

중 (fig. 99) Hilada

García de Palacio (1583: fol. 174v)

En este orden de batalla hay 36 hileras de frente y 17 de fondo (cada uno de los cúneos que lo integran, que son cuatro, poseen cuatro hileras de

fondo, por tanto, 16 en total, a las que hay que sumar una más, la que constituye la base de toda la batalla).
오 (fig. 100) Hilera

García de Palacio (1583: fol. 164r)

En este orden de batalla hay 18 hileras de frente y 4 de fondo.
OOOOOOOOO0000000000

000000000000000000

000000000000000000

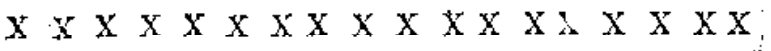

\section{(fig. 101) Hornillo Ufano (1613: 262)}

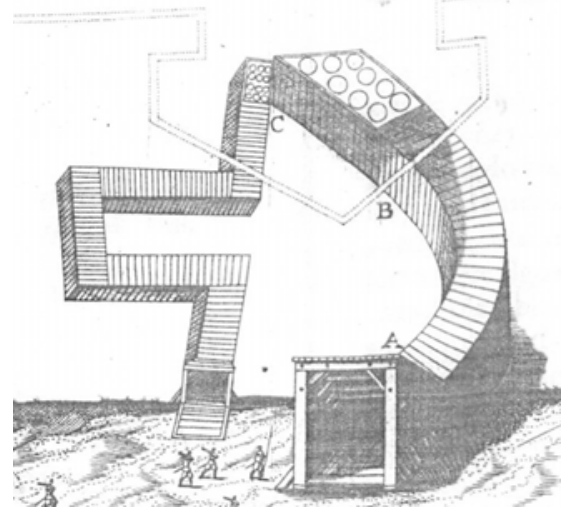

Mina para destruir o volar una fortaleza, en la que la letra C representa el hornillo donde se colocan los toneles de pólvora.

주 (fig. 102)

Infantería

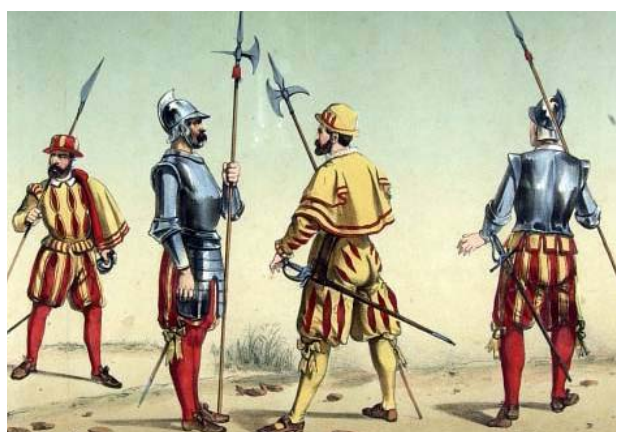




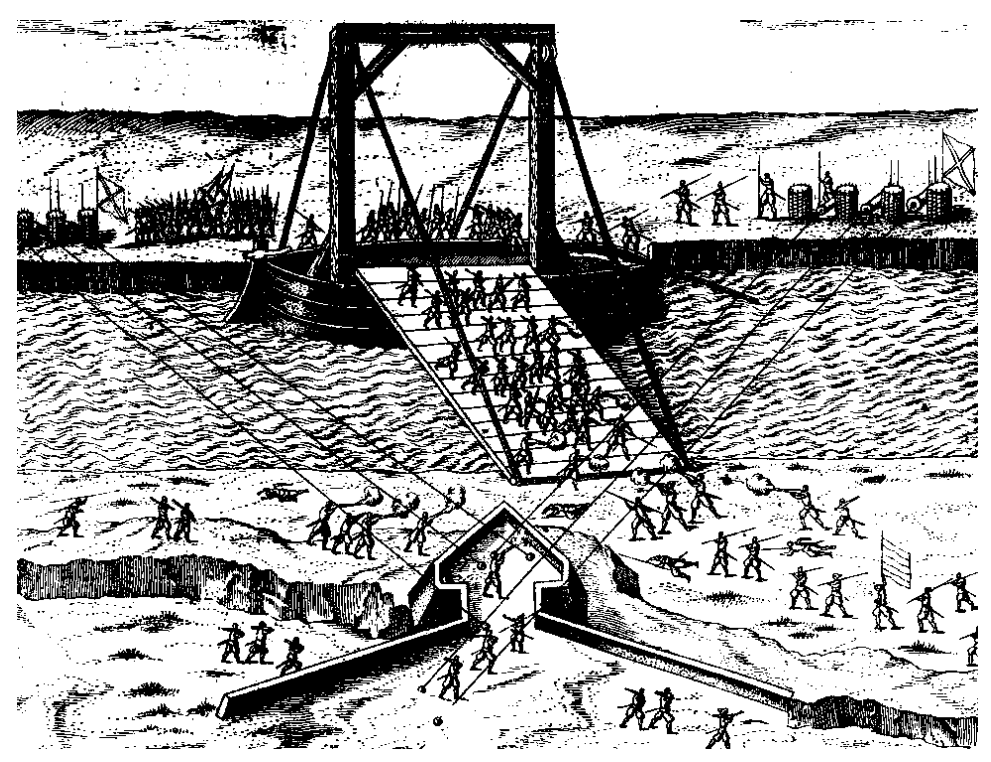

\section{If (fig. 103) Interpresa}

Ufano (1613: 267): "Figura que muestra cómo sobre una barca se debe de harmar un puente para hacer una antepresa".

우 (fig. 104) Media luna

Lopes Pires Nunes (2005: s.v. meia lua): Obra exterior, com 2 faces e 2 flancos, que cobre o ângulo do baluarte. É uma obra do tipo do revelim, mais pequena e com a gola curvilínea em forma de meia lua.

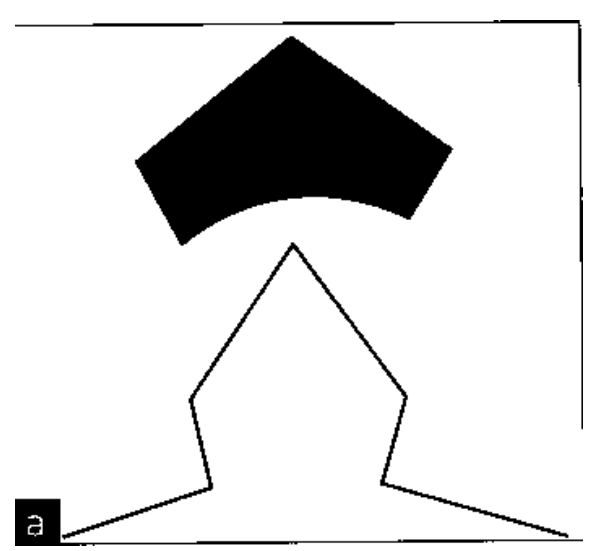

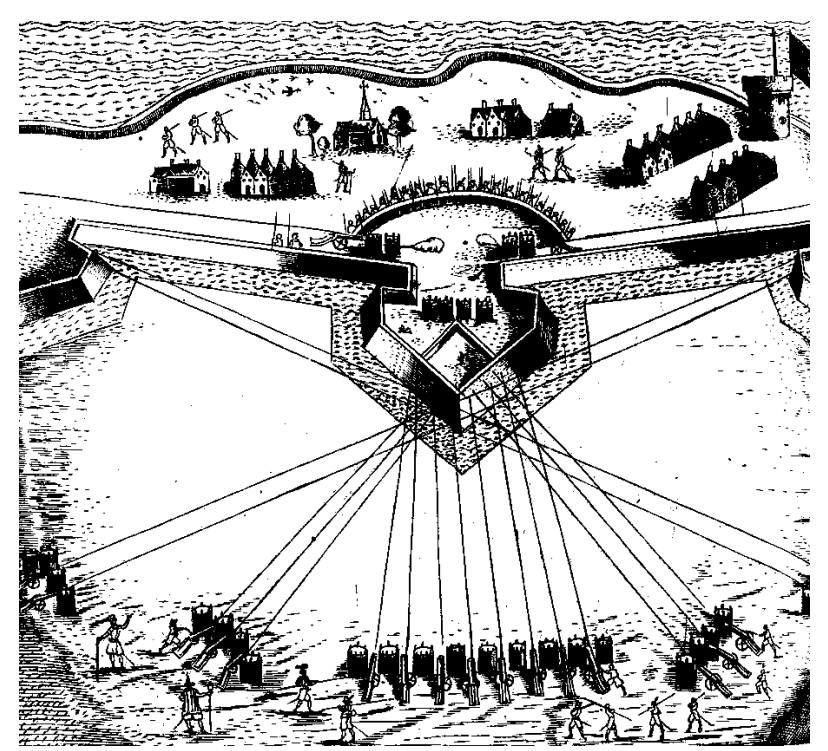

1 $\$$ (fig. 106) Manta

Lopes Pires Nunes (2005: s.v. mantelete)

El soldado de la izquierda porta una manta de protección individual, para protegerse en el ataque al castillo. (fig. 105) Media luna

En la imagen puede verse cómo los defensores de esta fortaleza intentan contrarrestar con un reparo en forma de media luna, denominado, por tanto, media luna, la batería que han abierto los sitiadores por la punta de uno de los baluartes. 


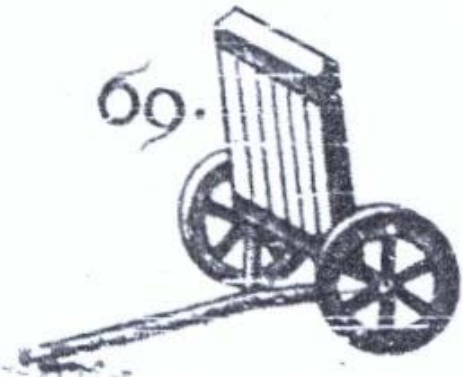

$\$$ (fig. 107) Manta

Lucuze (1772: lám. VI)

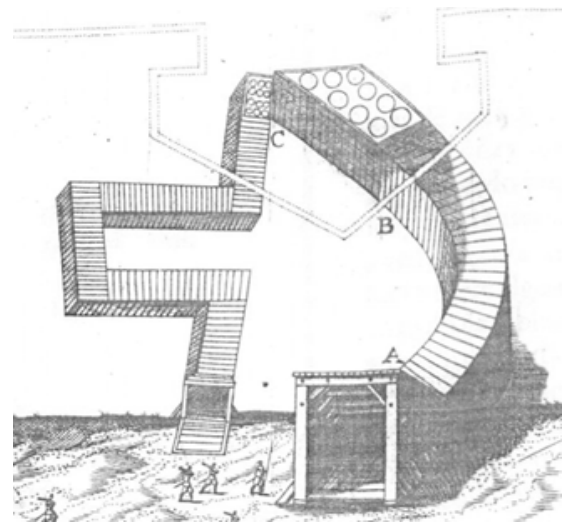

న (fig. 110) Muralla

En esta figura, $A$, que es la camisa de piedra, $O$, que son los contrafuertes, y $B$, que es el terraplén, conforman la muralla de esta fortaleza, construida sobre el terreno $M$.

González de Medina (1599: 36)

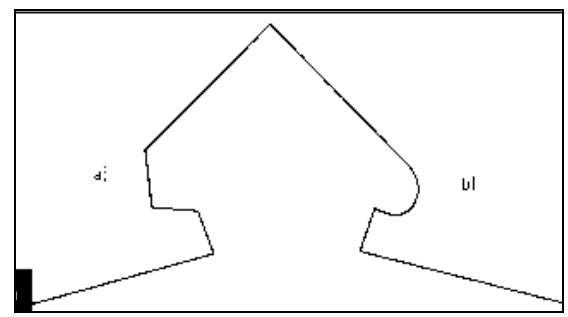

우 (fig. 111) Orejón
承 (fig. 108) Merlón

Lopes Pires Nunes (2005: s.v. merlão)

Representación del conjunto cañonera y merlón. (fig. 109) Mina

Ufano (1613: 262): "Figura que muestra la armaçón de la mina cómo se debe guiar". Esta mina esta representada por las letras $A, B$ y $C$.

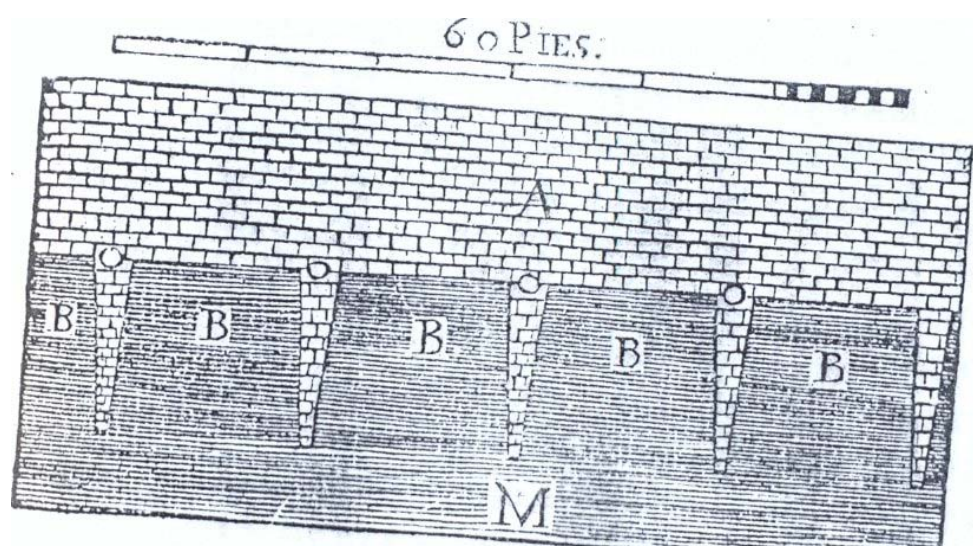

En este baluarte, el orejón de la izquierda a) posee forma cuadrada, mientras que b), el de la derecha, es un orejón circular o curvo.

(fig. 112)

Pabellón

Lopes Pires Nunes (2005: s.v. orelhão) 


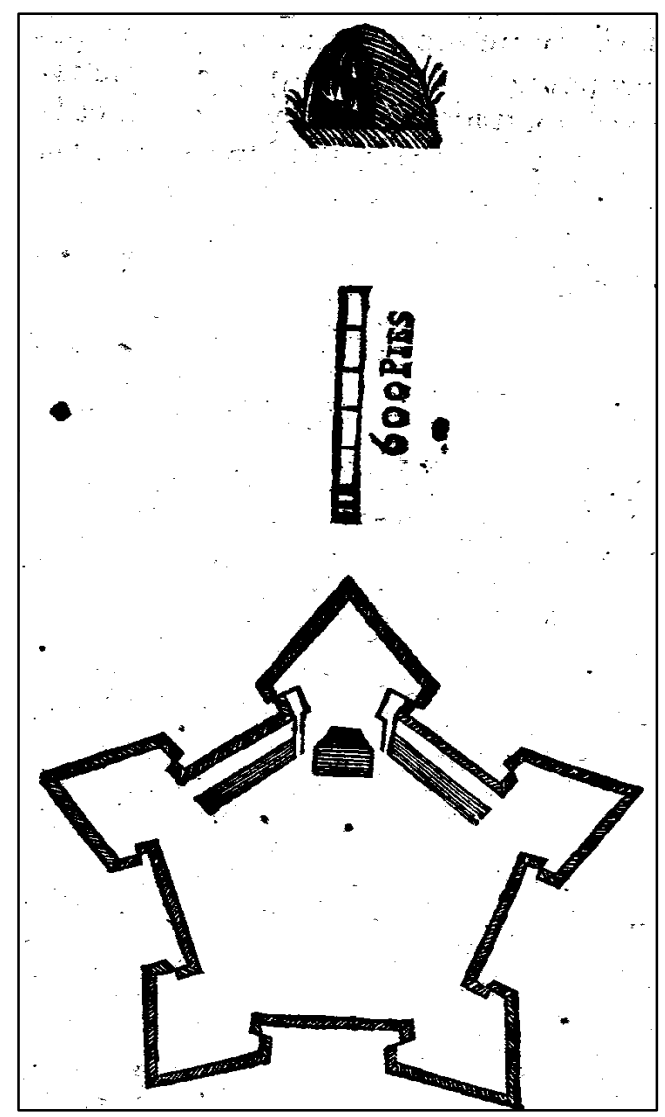

of (fig. 114) Palizada

González de Medina (1599: 143)

González de Medina (1599: 140-141): "Echar los fundamentos de un fuerte debaxo del agua dificil es, pero bien se haze, y aun de diferentes maneras, porque unos lo han hecho con vigas de más de pie de diámetro, hechas estacas d'ellas, puntiagudas, para hincarlas en el suelo con un gran maço de hierro, dando sobre un instrumento de metal que se le ha de poner a la cabeça de la estaca, encima, porque no se hienda y entre entera [...], de seys pies de largo, hueco. Y, clavadas unas con otras, entre ellas inchirlo de carbón y tierra, y házese el fundamento bien fuerte".

\section{(fig. 113) Padrastro}

González de Medina (1599: 100) apartada, el mejor remedio de todos es poner en frente el ángulo del baluarte y detrás d'él un cavallero bien levantado, y será muy buena defensa, porque estorvará la vista de toda la plaça de armas y de las estancias y reparos donde se ha de estar a la defensa. Y en esta ocasión enos los cavalleros y se tiene necessidad d'ellos y, por estar algo lexos el padrastro, no será la batería que haga en él con tanta furia que le desaga y, caso que si hiziesse, no padecerá el daño de caer en el foso los materiales, sino donde serán de provecho para muchas cosas".

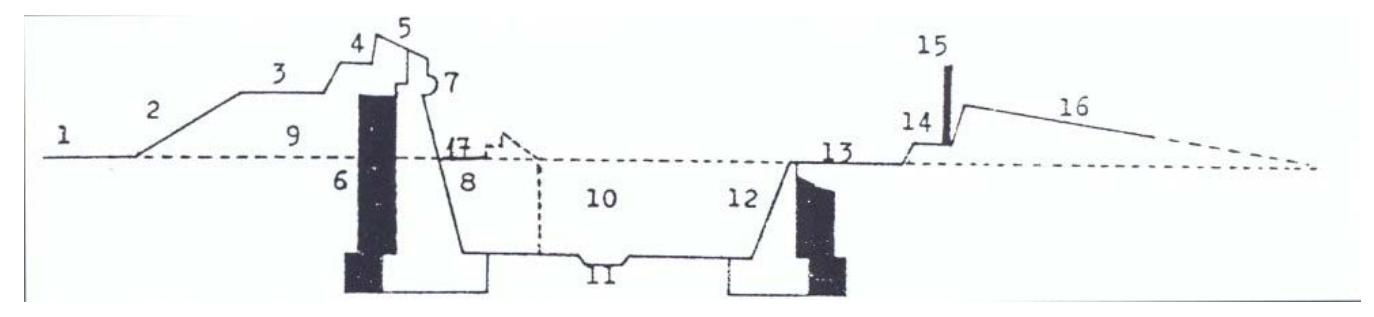

of (fig. 115) Parapeto

Lopes Pires Nunes (2005: s.v. perfil de praça abaluartada)

El número 5 representa el parapeto del que dispone toda obra fortificada en la parte superior de su muralla. 


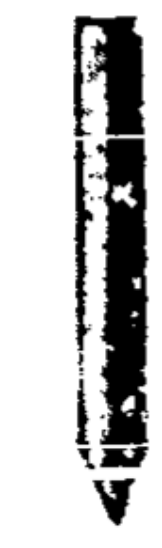

of (fig. 117) Plataforma

Rojas (1598: fol. 105r)

Sitio o asedio de una fortaleza, en el que, entre otras construcciones, el ejército sitiador ha establecido tres plataformas desde donde poder batirla.
Lucuze (1772: lám. VI)

Lucuze (1772: 102): "Los pilotes son unas gruesas estacas de longitud arbitraria, que sirven para formar los cimientos de alguna obra o batería en terrenos flojos o pantanosos, los cuales se introducen hasta hallar el terreno firme, por medio de gruesos mazos o alguna máquina, y sobre ellos se fabrica con seguridad".
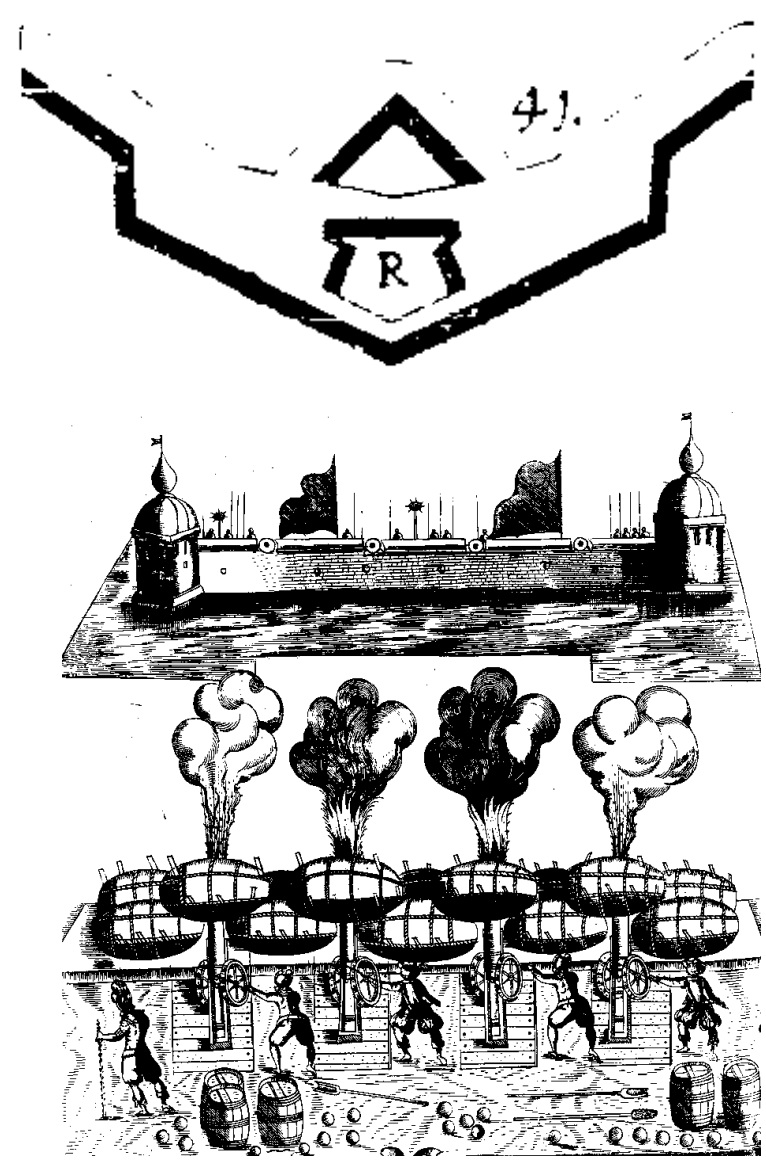

1 3 (fig. 118) Plataforma 4

Lucuze (1772: lám. IV)

En esta imagen, la letra $R$ representa una plataforma cuyos flancos se han cubierto con orejones, la cual se ha construido, en este caso, delante de una cortina con ángulo entrante. Puede observarse, igualmente, que delante de la plataforma se ha levantado, además, un revellín.

(fig. 119) Plataforma

Ufano (1613: 191)

En esta batería hecha con sacas de lana, pueden verse perfectamente las plataformas de madera sobre las que están asentadas cada una de las piezas de artillería. 
Esta imagen representa una plaza o ciudad fortificada en figura trapecia.

(fig. 120) Plaza

González de Medina (1599: 68-69)
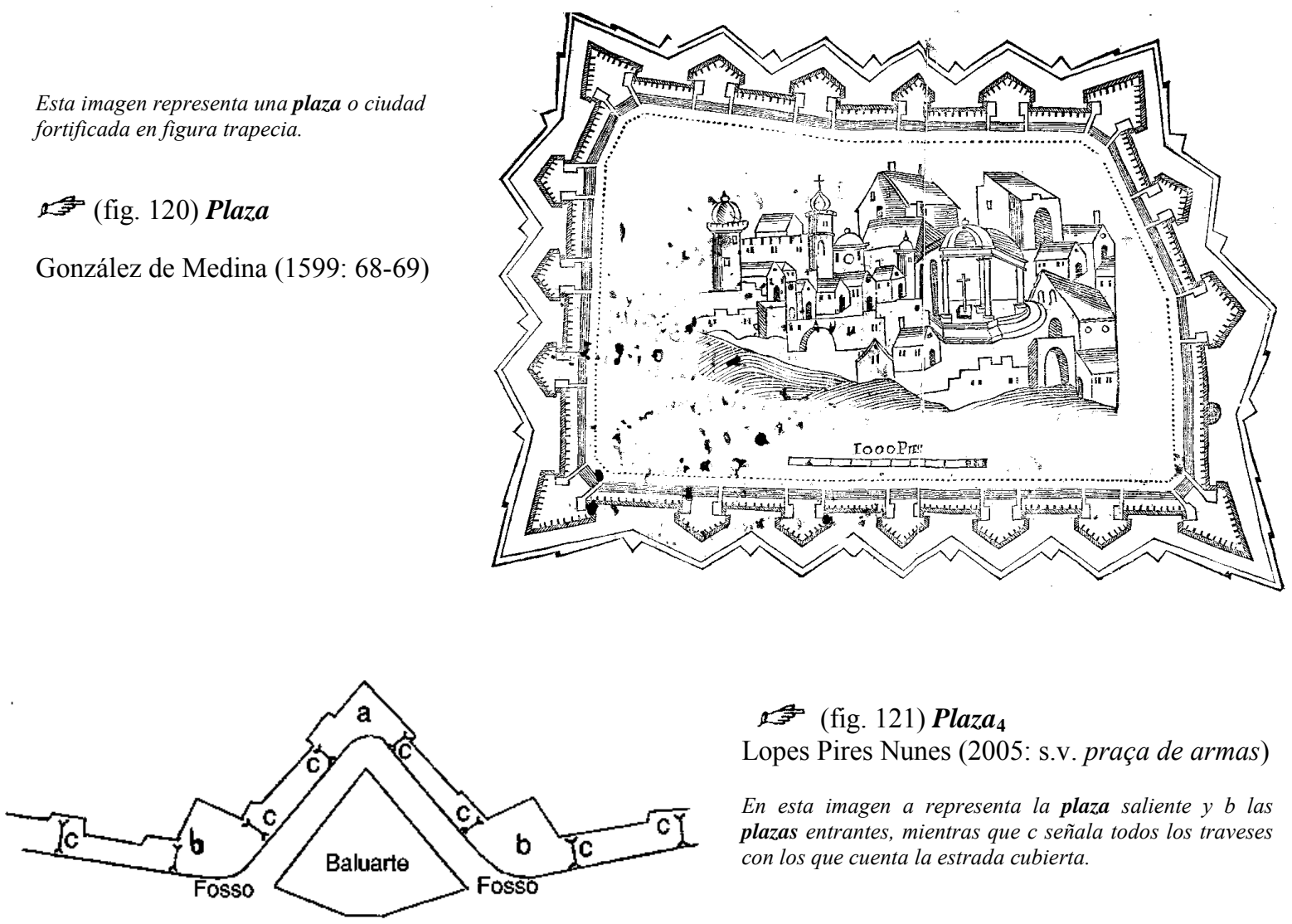

of (fig. 121) Plaza $_{4}$

Lopes Pires Nunes (2005: s.v. praça de armas)

En esta imagen a representa la plaza saliente y $b$ las plazas entrantes, mientras que c señala todos los traveses con los que cuenta la estrada cubierta.

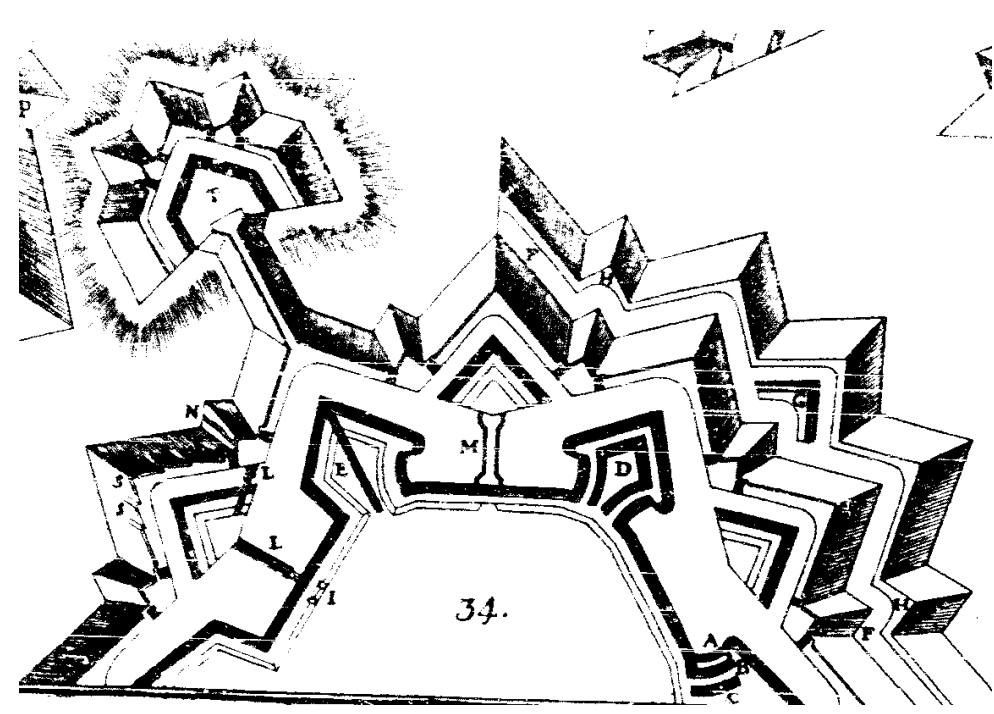

o (fig. 122) Plaza alta

En esta figura, la plaza alta que posee uno de los baluartes viene representada por la letra C.

주 (fig. 123) Plaza baja

En esta figura, la plaza baja que posee uno de los baluartes viene representada por la letra A, mientras que el flanco retirado hacia dentro de ese baluarte es $B$.

Lucuze (1772: lám. II) 


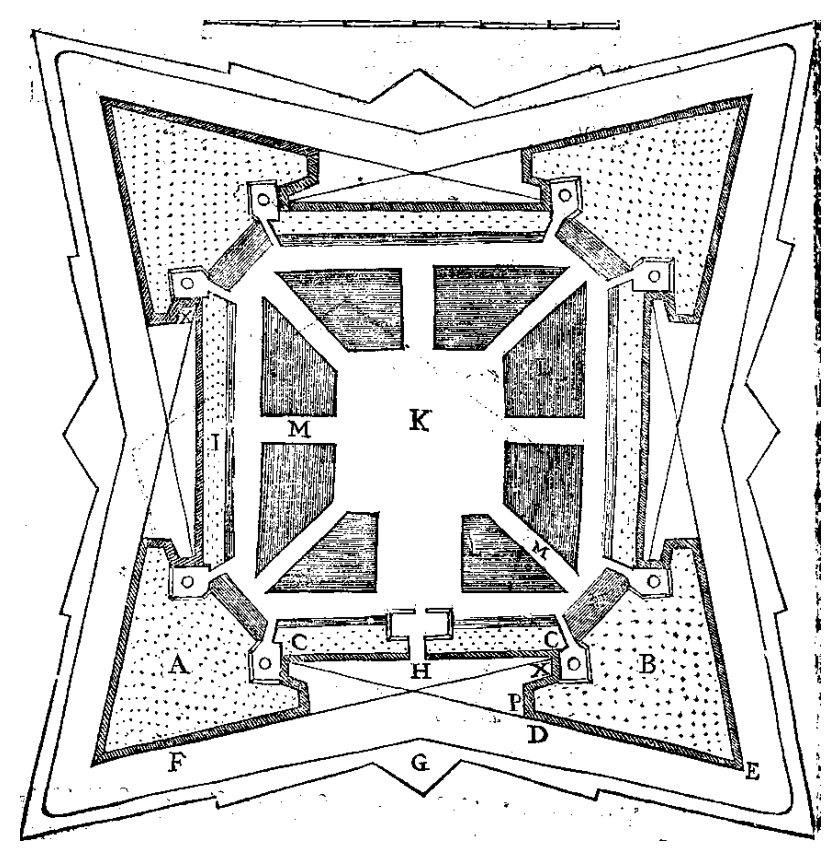

s (fig. 124) Plaza de armas

Planta de una fortaleza de cuatro baluartes en la que la letra $K$ representa su plaza de armas.

Rojas (1598: fol. 42r)

\section{t주 (fig. 125) Puente}

Collado (1592: fol. 89v)

Esta imagen muestra cómo se va fabricando un puente flotante y provisional sobre barcas, sistema muy común empleado por los ejércitos en sus marchas cuando precisan cruzar un río que no posee ningún puente fijo o permanente.

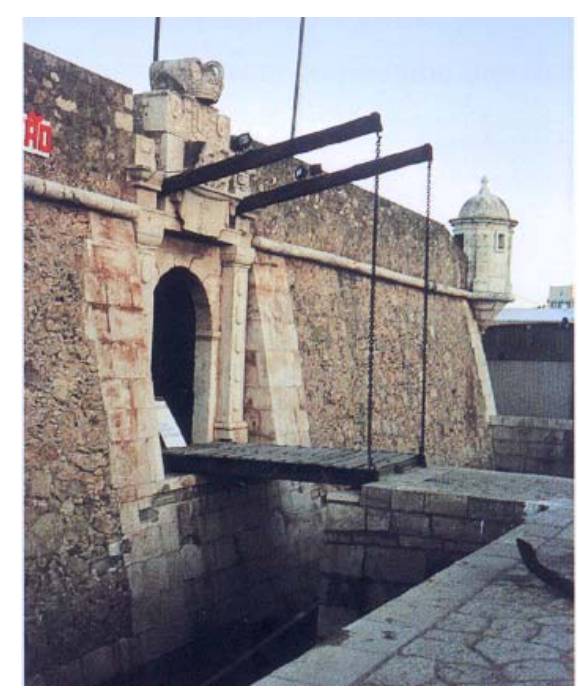

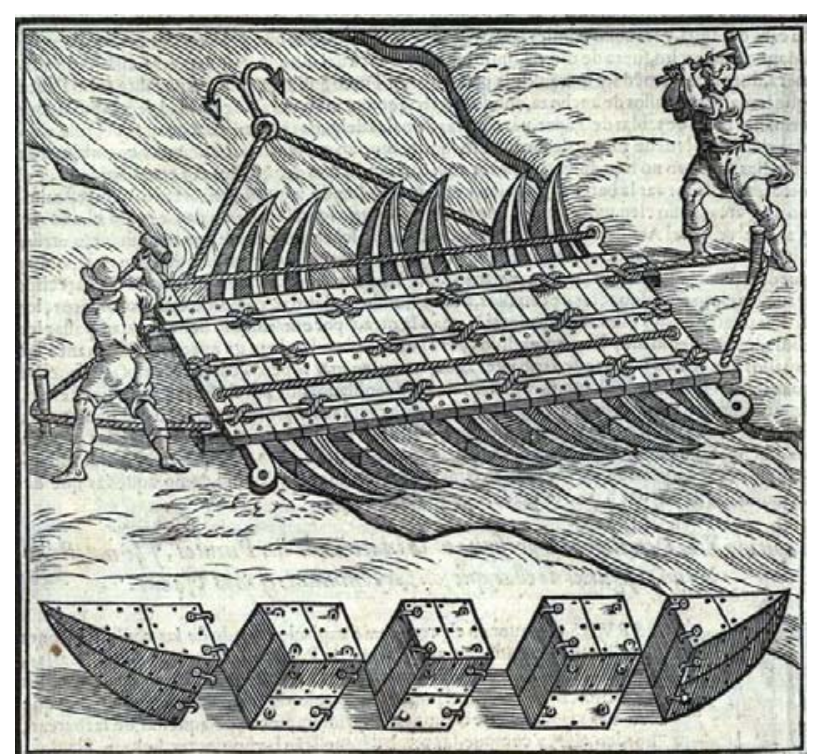

(fig. 126) Puente levadizo

Lopes Pires Nunes (2005: s.v. ponte levadiça)

Puente levadizo del Forte da Ponta da Bandeira, en Lagos (Portugal). 


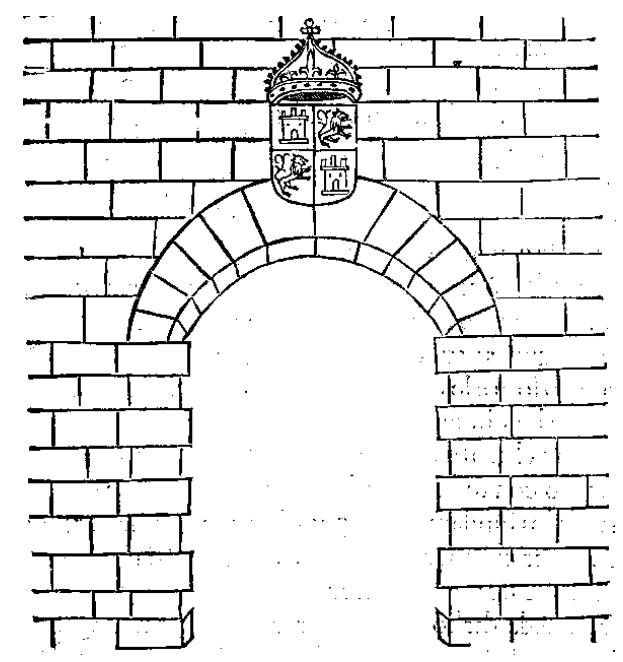

今 (fig. 127) Puerta

Rojas (1598: fol. 97v)

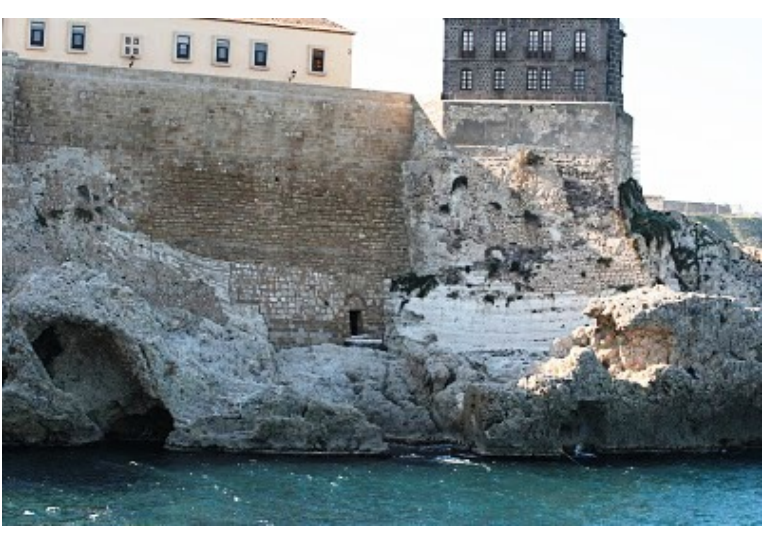

(fig. 128) Puerta del socorro

Puerta del socorro de la ciudadela de Melilla.

Planta de una fortaleza de cuatro baluartes en la que la letra H representa la puerta principal.

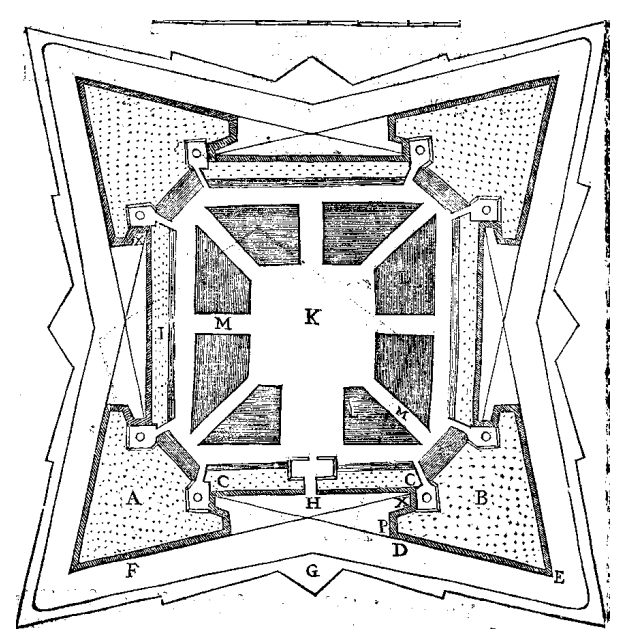

? 3 (fig. 129) Puerta principal

Rojas (1598: fol. 42r)

f? (fig. 130) Rastrillo

Mora-Figueroa (2006): "Restitución del esquema de funcionamiento de un rastrillo, con torno y contrapeso para su elevación y frenado en descenso".

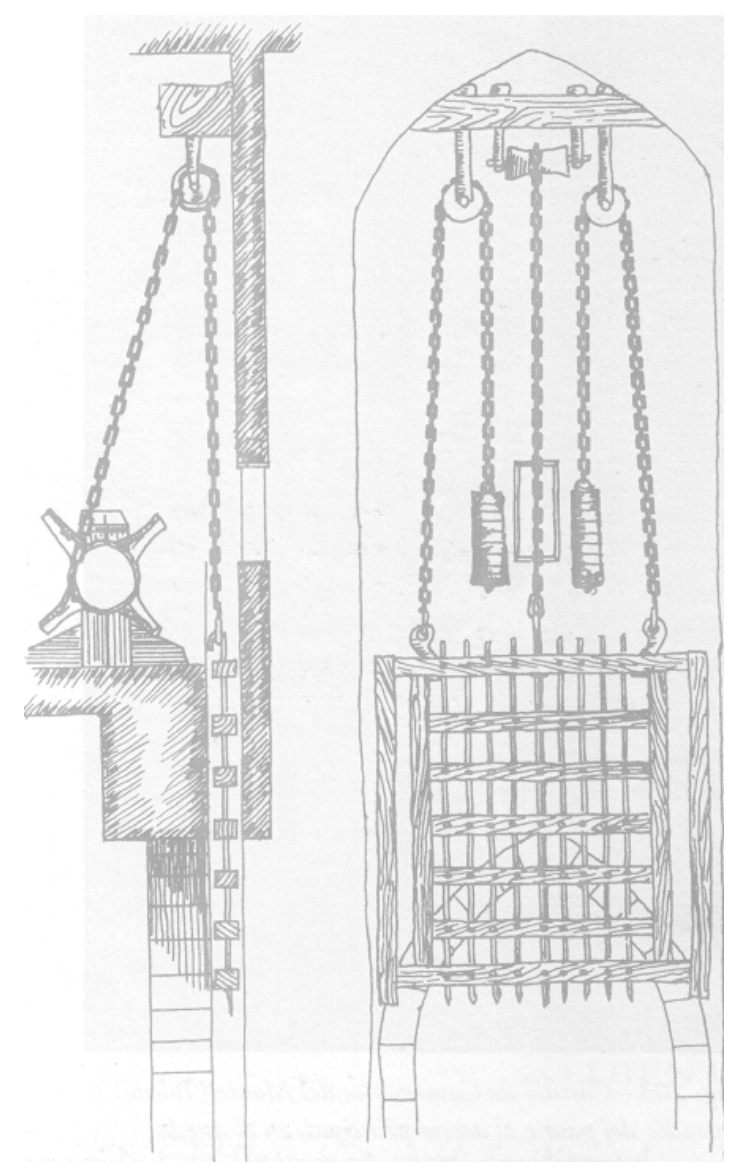




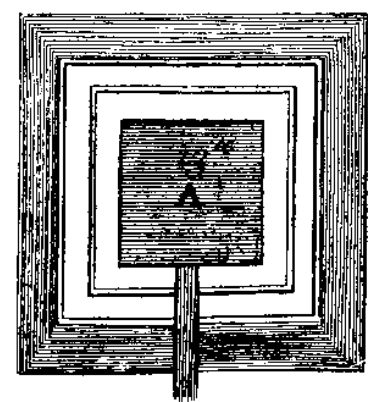

(fig. 131) Reducto

Azevedo Fortes (1729: Estampa 1, figura 13)

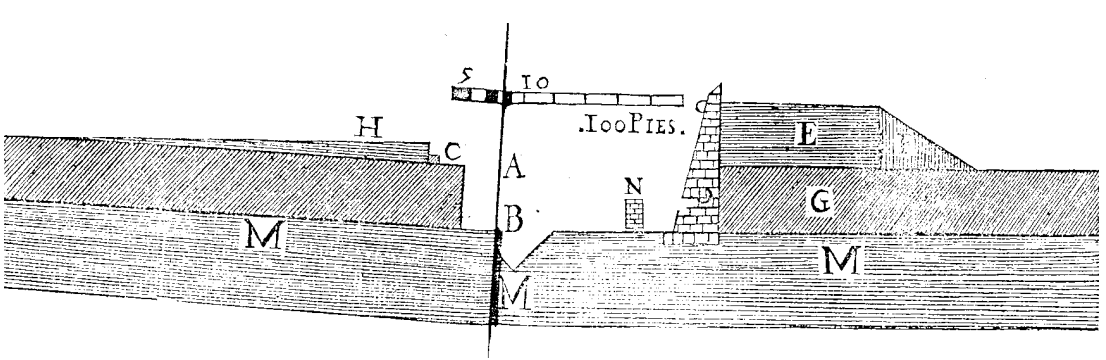

(fig. 132) Refosete

González de Medina (1599: 44-45)

Perfil de una fortificación donde se representa con A el foso y con B el refosete.

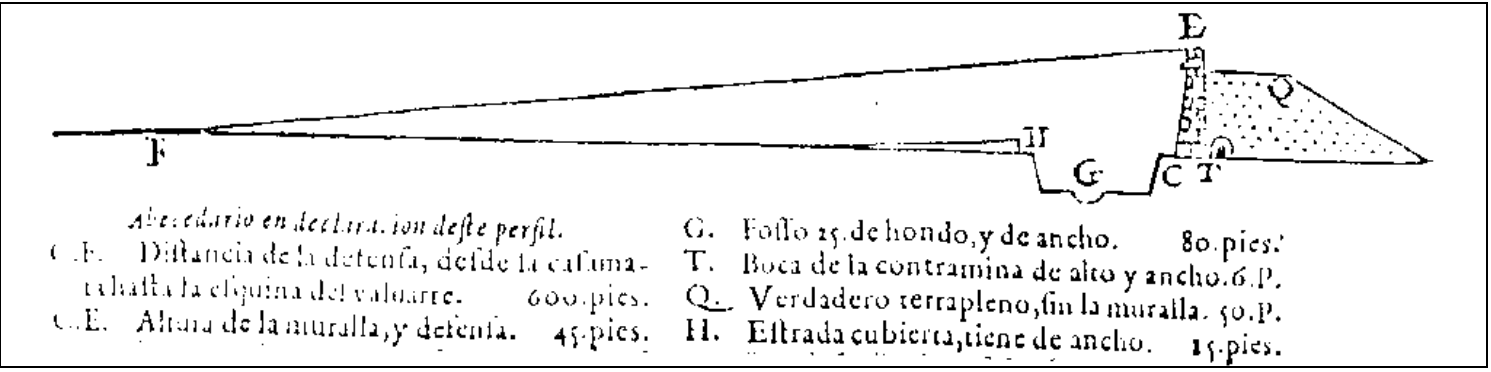

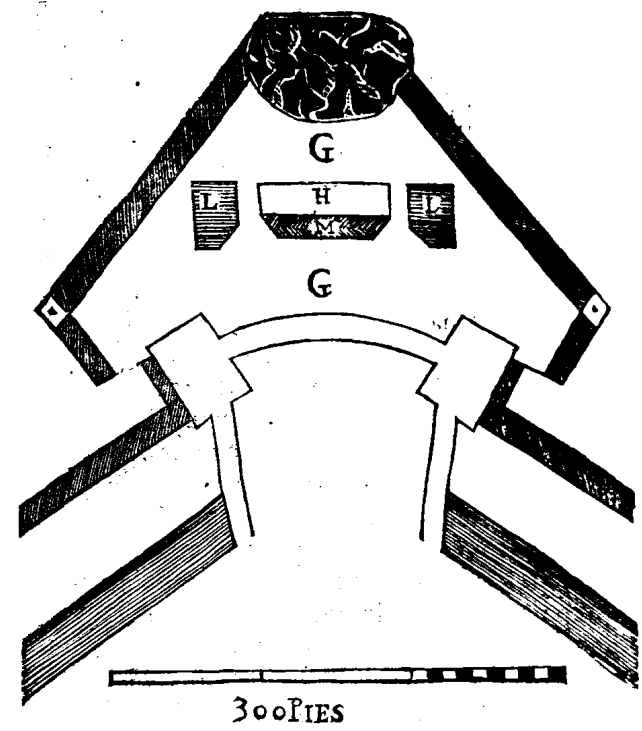

F (fig. 134) Reparo

González de Medina (1599: 203)

Reparo que hacen los sitiados tras haber conseguido los sitiadores abrir brecha en uno de sus baluartes. Aqui el reparo consiste en hacer en el baluarte batido $(G)$ un foso $(H)$, dos bastiones $(L)$ y una trinchera $(M)$.

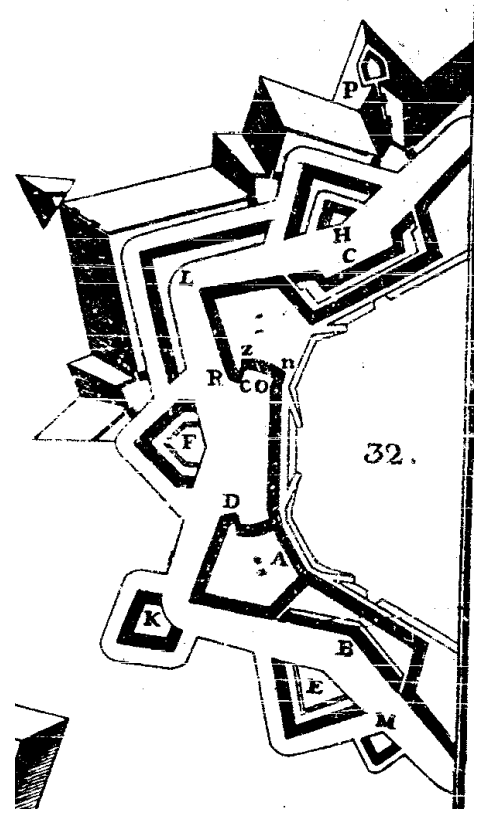

S (fig. 135) Revellín

Lucuze (1772: lám. II)

La letra E representa un revellín sencillo, o sin flancos; la letra $F$ un revellín con flancos; por último, $H$ muestra un revellín doble o cortado. 
1구 (fig. 136) Revellín

Rojas (1598: fol. 31r)

Planta de una fortificación en la que la letra $K$ representa la plaza o revellín de la estrada cubierta (L).

(fig. 137) Saca

Ufano (1613: 191)

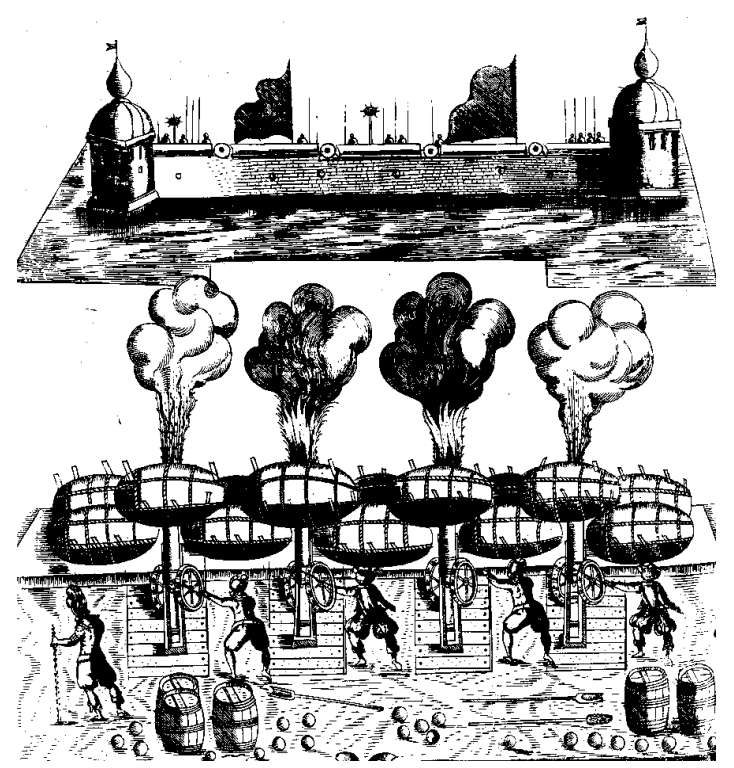

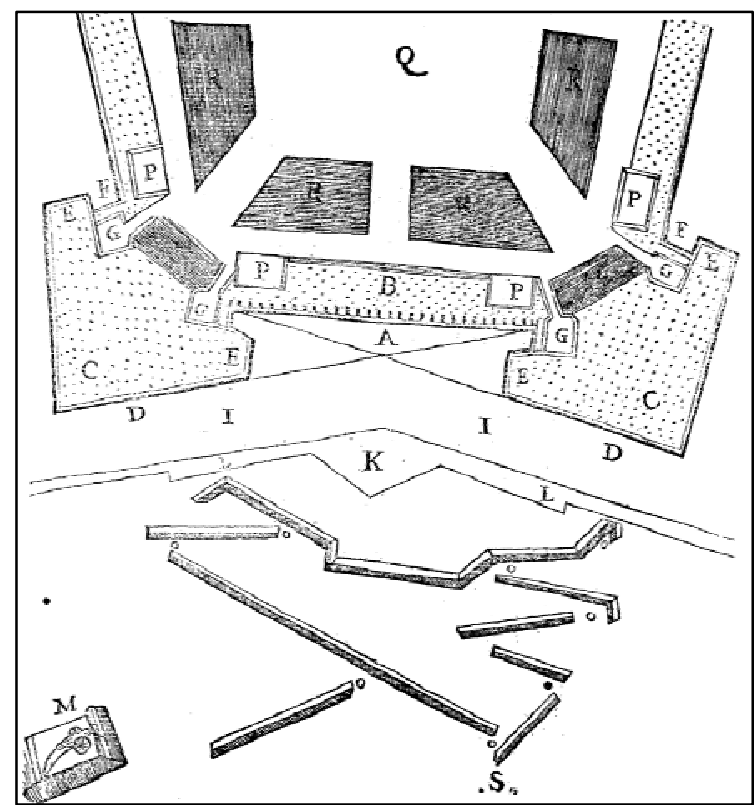

야 (fig. 138) Saco ${ }^{1}$

Lucuze (1772: lám. VI)

Lucuze (1772: 104): "Saquillos de tierra, que forman tronera". Corsini (1849: s.v. sacos de tierra o a tierra): Fort. Sacos de tela, de dos pies de largo y uno de ancho, que deben contener sobre pie y medio cúbico de tierra cada uno. Estos sacos sirven para construir con prontitud un parapeto, o para atrincherarse: con tres de ellos se

forma una tronera que cubre la cabeza y hombros del soldado.

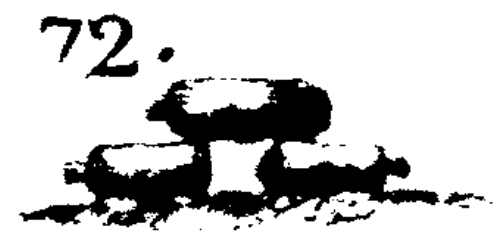

중 (fig. 139) Salchicha

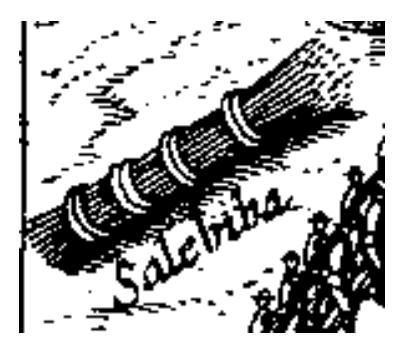

Ufano (1613: 259-260): "Hago d'esto aquí memoria porque todo nasçió del uso de las dichas salchichas de guerra, las quales se forman, como paresçe por la presente figura, de las más largas y flegibles ramas que ay en los árboles, cuyo cuerpo se forma y façiona a manera de un gruesso fogote o haz de leña, tan largos como requiere la obra que con ellas se a de hazer; liganse por muchas partes, si llevan piedras o ladrillos dentro de si, la qual operaçión y arte fue una de las mejores y más provechosas ynvençiones que en el dicho sitio se usaron y metieron por obra. $Y$ porque son propios a semejante servicio y provechossissimos a qualquier útil de guerra, las llaman algunas vezes salchichas de guerra, las quales particularmente serán aplicadas al sitiar de las tierras marítimas o çegamiento de fossos de çiudades y fortalezas de agua corriente y fuerte. Porque, en effeto, de verdad serán muy provechosas y de gran serviçio contra la fuerça del mar y de algunas riberas que çircundan y sirven de fosso a alguna tierra populossa". 


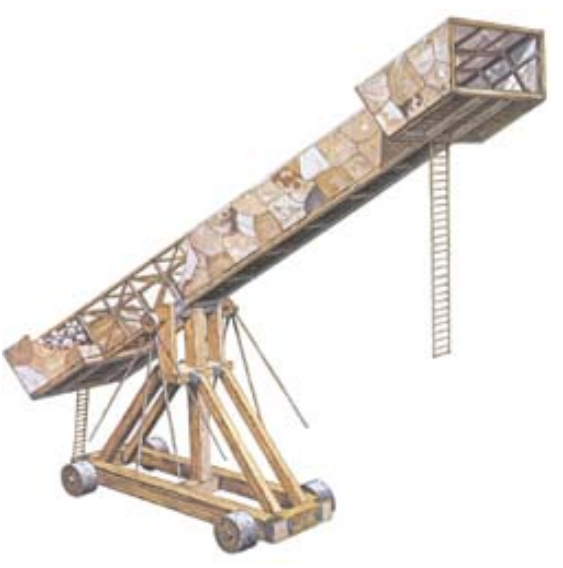

주 (fig. 141) Sambuca

\& (fig. 143) Tenaza

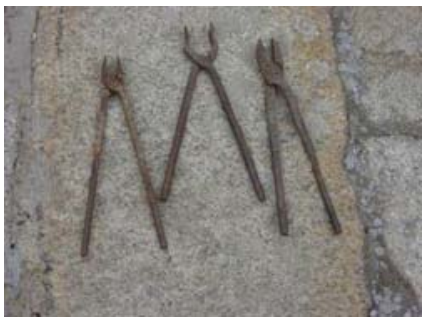

Distintos tipos de tenazas
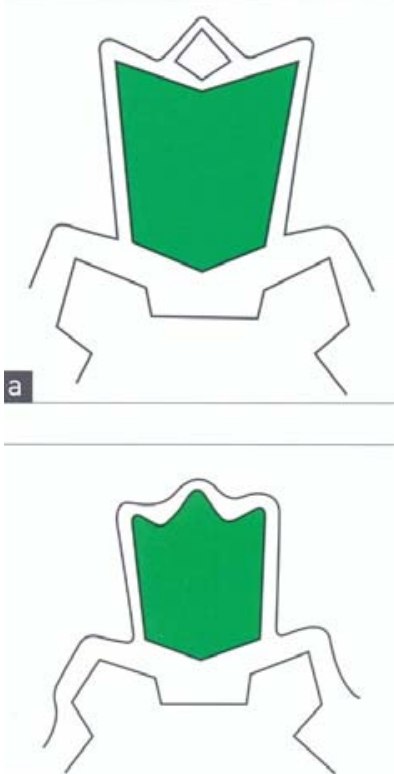

b

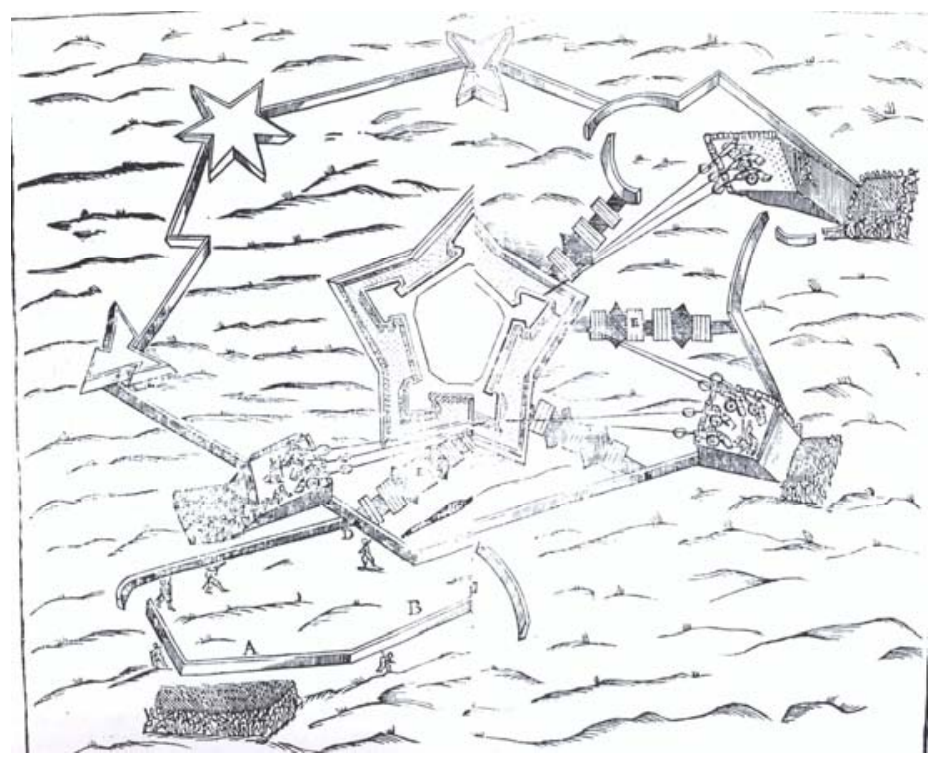

궁 (fig. 142) Sitio

Rojas (1598: fol. 105r)
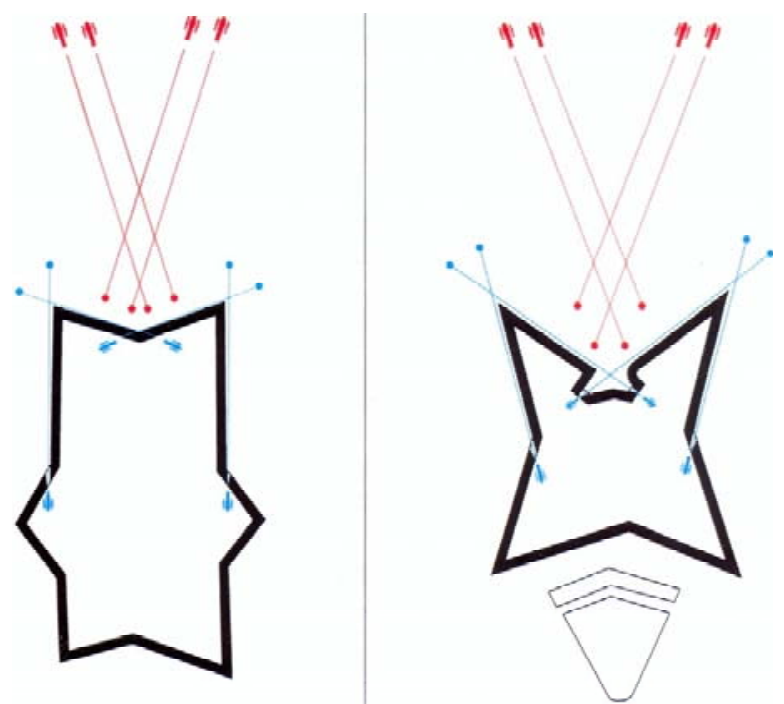

(fig. 144) Tenaza $_{2}$

Las plantas de estas dos fortalezas muestran distintos tipos de tenazas. Castro Fernández y Cobos Guerra (2000: 251)

s? (fig. 145) Tenaza $_{3}$

La imagen a muestra una tenaza simple, mientras que la b representa una tenaza doble o compuesta.

En Lopes Pires Nunes (2005: s.v. tenalha). 


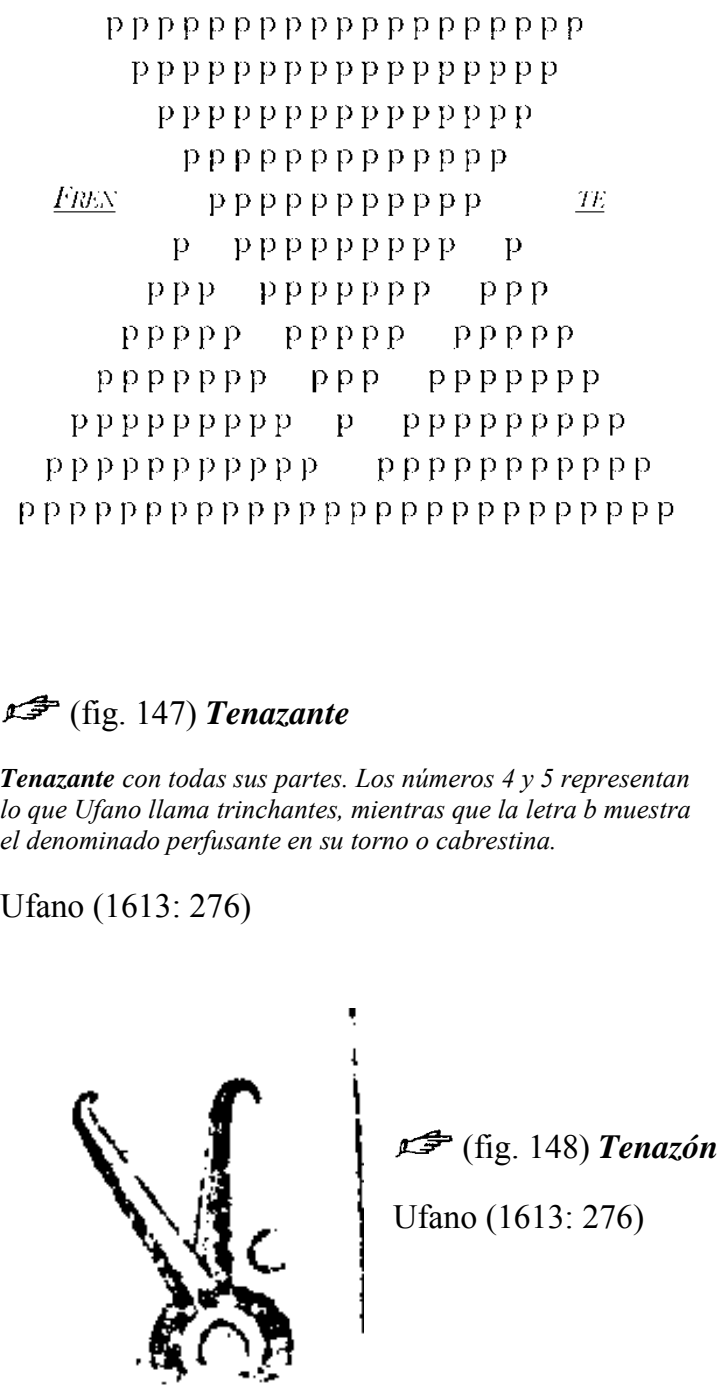

శ్ (fig. 146) Tenaza

Álaba (1590: fol. 118v).

Formación de tenaza, también llamada fórfice y tijera, (la de abajo) en oposición al cúneo (la de arriba).
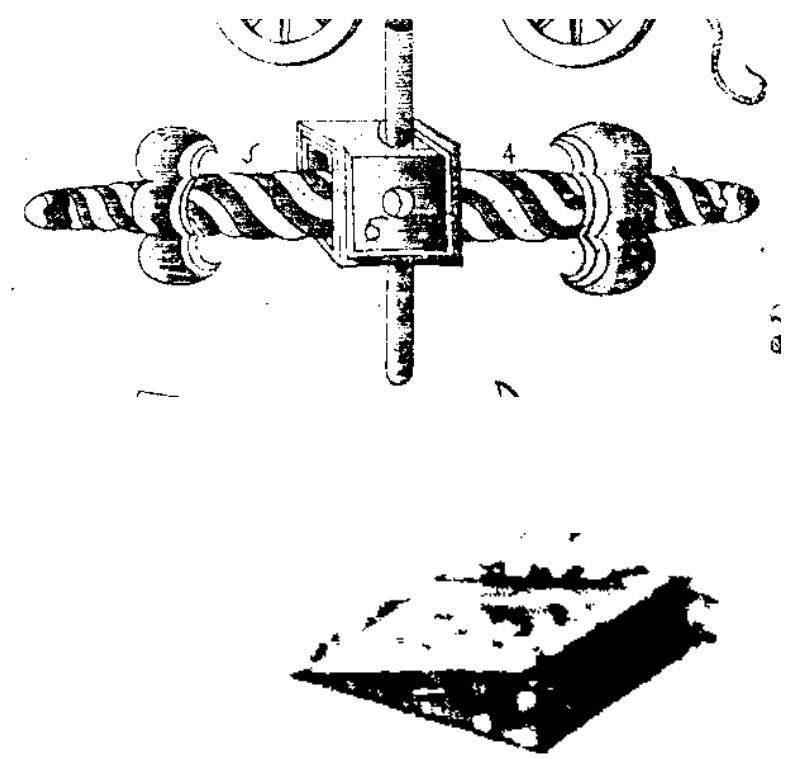

(f) (fig. 149) Tepe

Lucuze (1772: Lám. VI) Lucuze (1772: 104): "Tepe de figura triangular".

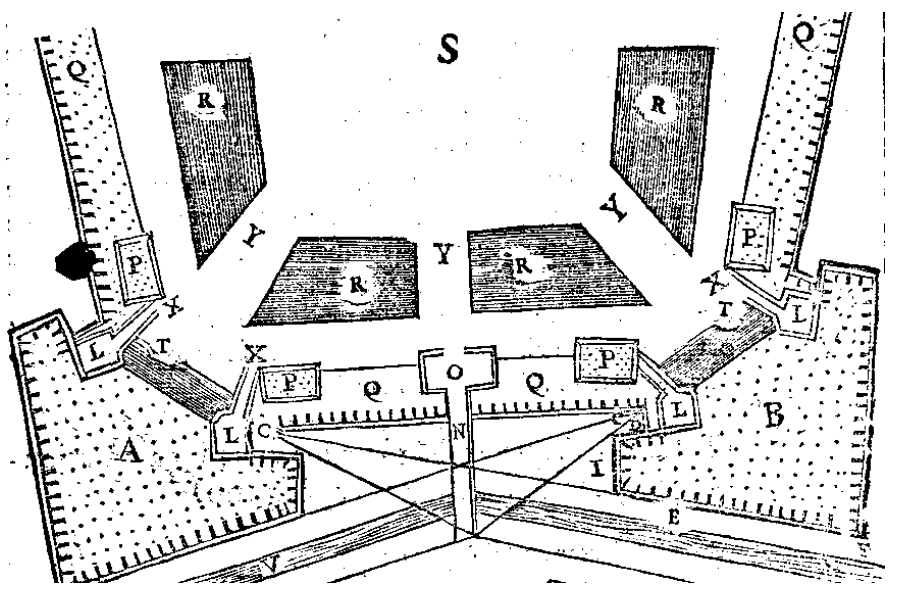

(fig. 150) Terrapleno

Rojas (1598: fol. 39r)

Planta de una fortificación en la que la letra $Q$ representa el terrapleno o terraplén. 


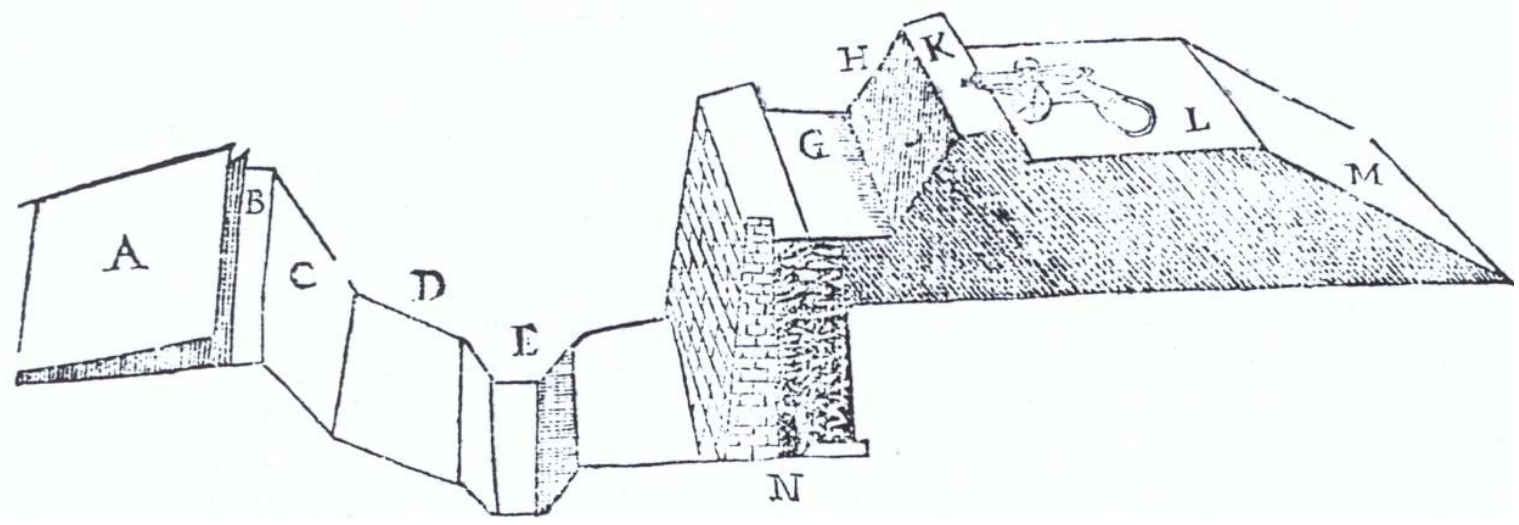

Rojas (1598: fol. 69v)

Perfil de una fortificación donde la letra $G$ representa el terrapleno en lo alto de la muralla, esto es, el espacio que hay detrás del parapeto de la cortina hasta el parapeto del caballero (K).

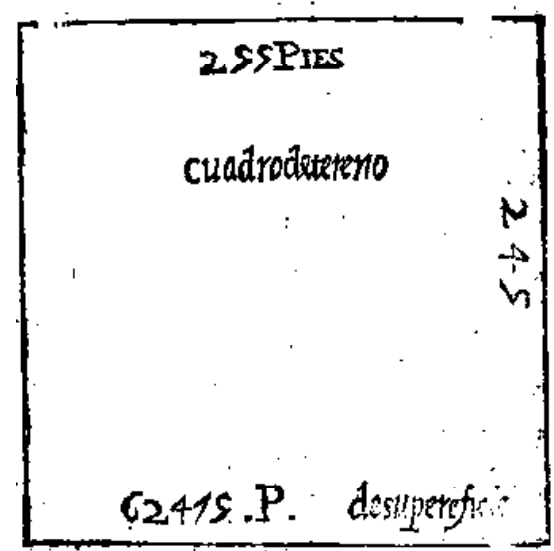

$\$$ (fig. 152) Cuadro de terreno

Rojas (1598: fol. 102v)

F (fig. 154) Testudo

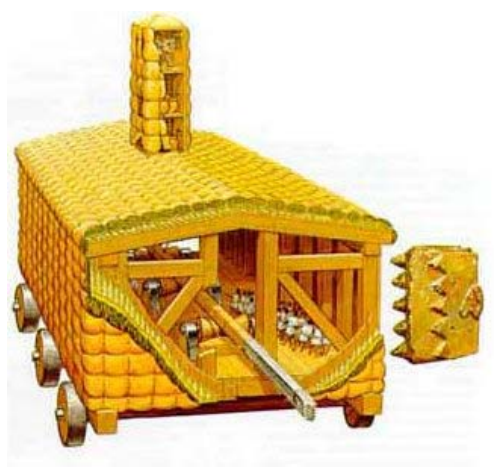

Ataque a un castillo antiguo con una testudo arietaria

Collado (1592: fol. 4v)

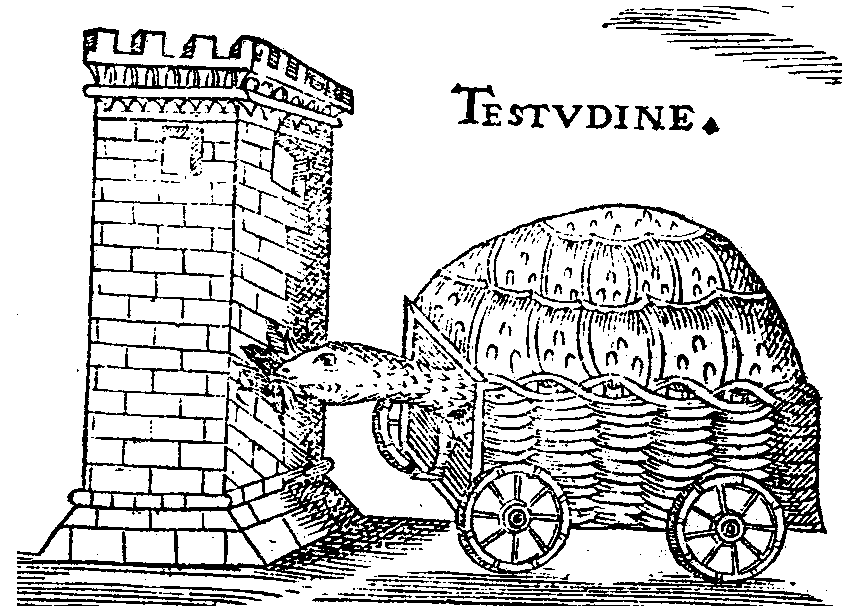

(fig. 153) Testúdine

Collado (1592: fol. 4r)

Testudo o testúdine con una trabe o viga, en forma de cabeza de tortuga, para poder, además de defenderse, batir las murallas.

\section{(fig. 155) \\ Testudo arietaria}

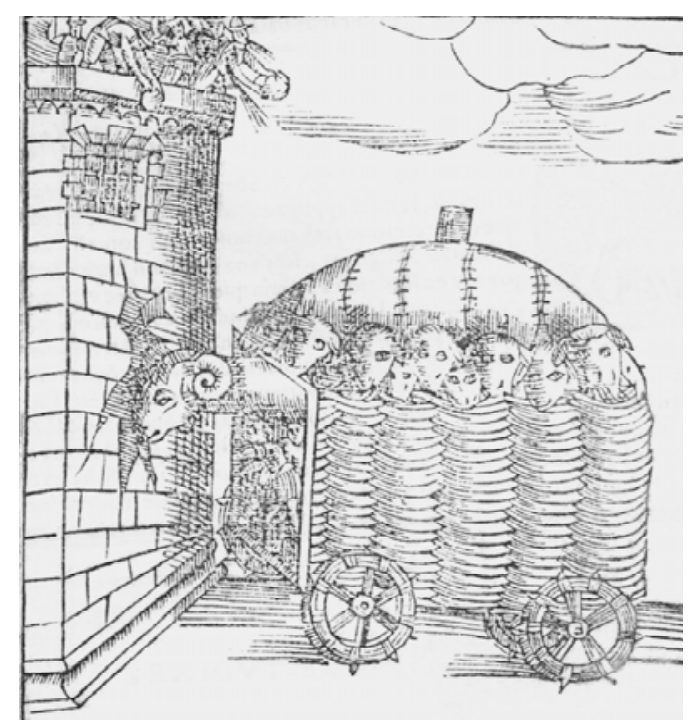



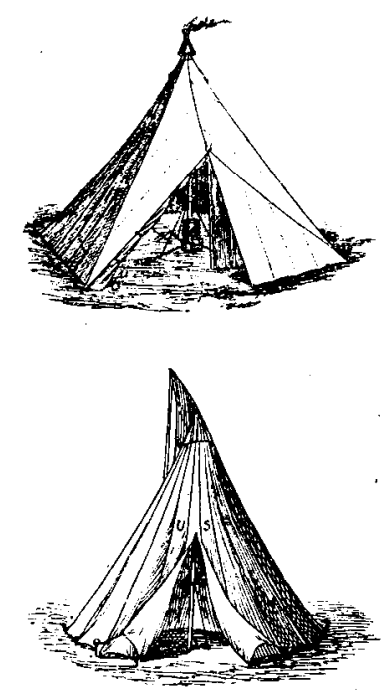

r 3 (fig. 156) Tienda

Rubió y Bellvé (1895-1901)

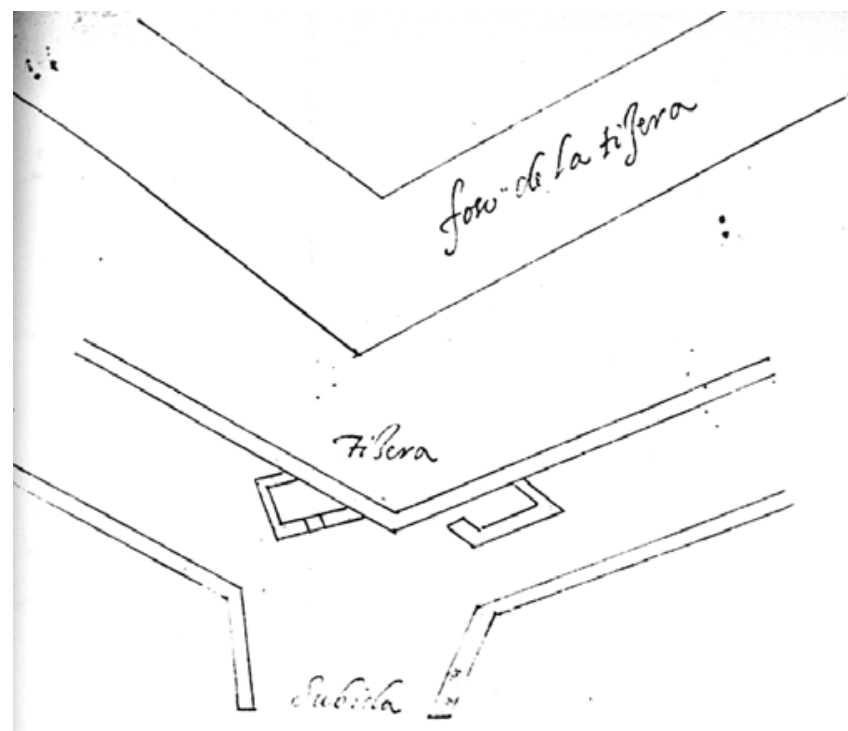

우 (fig. 157) Tijera

Roxas (1607: fol. 81v).

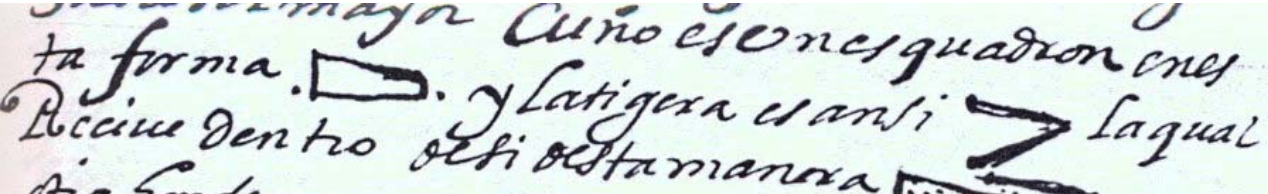

$$
\begin{aligned}
& \text { siasorden quellamain is ay } \\
& \text { (fig. 158) Tijera } \\
& \text { Roxas (1607: fol. 38v). }
\end{aligned}
$$

SF (fig. 159) Torre

Castillo de Molina de Aragón (Guadalajara), en el que destacan tres altas torres.

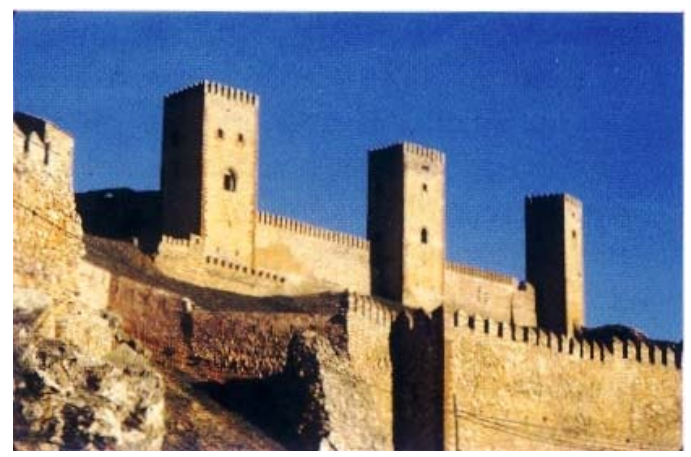

承 (fig. 160) Torre En Lopes Pires Nunes (2005: s.v. torre de assédio)

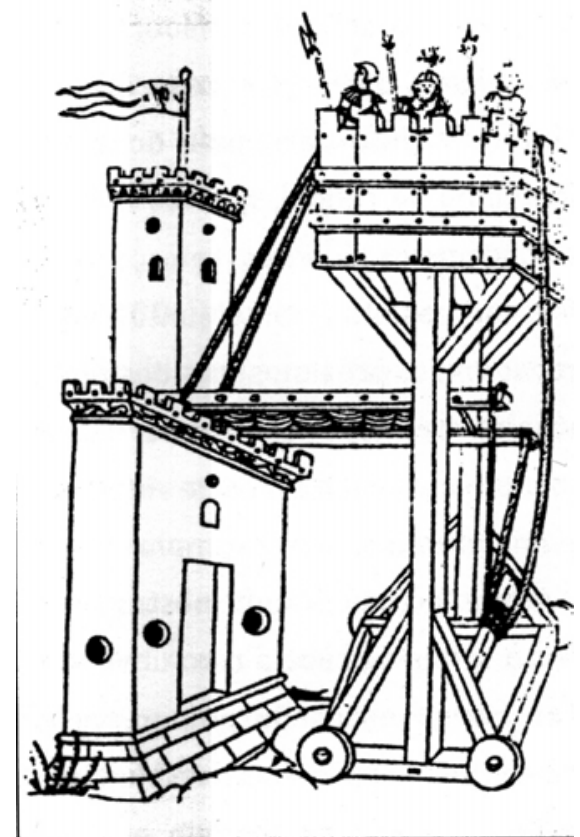




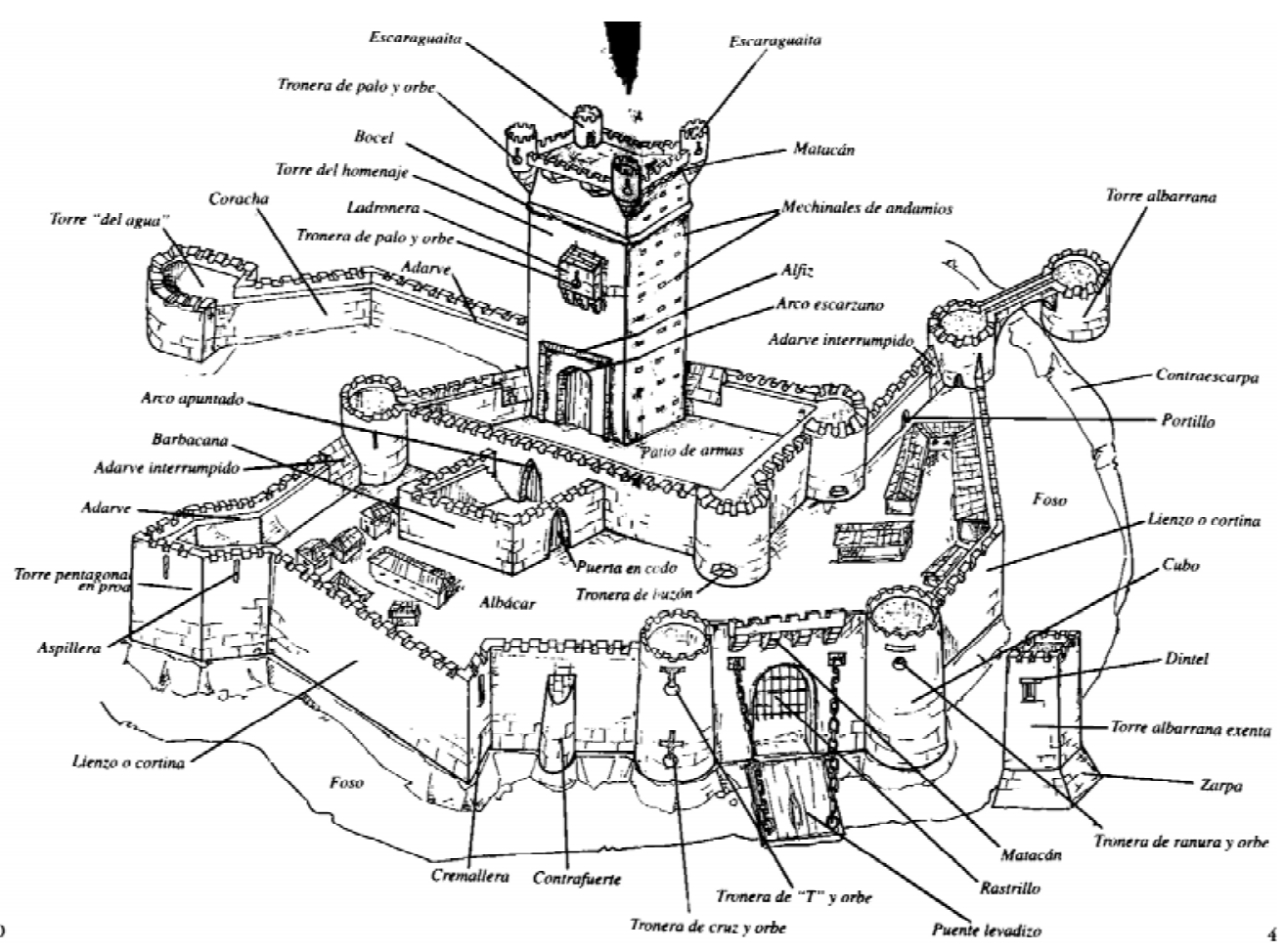

주 (fig. 161) Torre del homenaje

En esta imagen destaca la torre del homenaje, entre otro tipo de torres.

Lorenzo Celorrio (1996: 40-41).

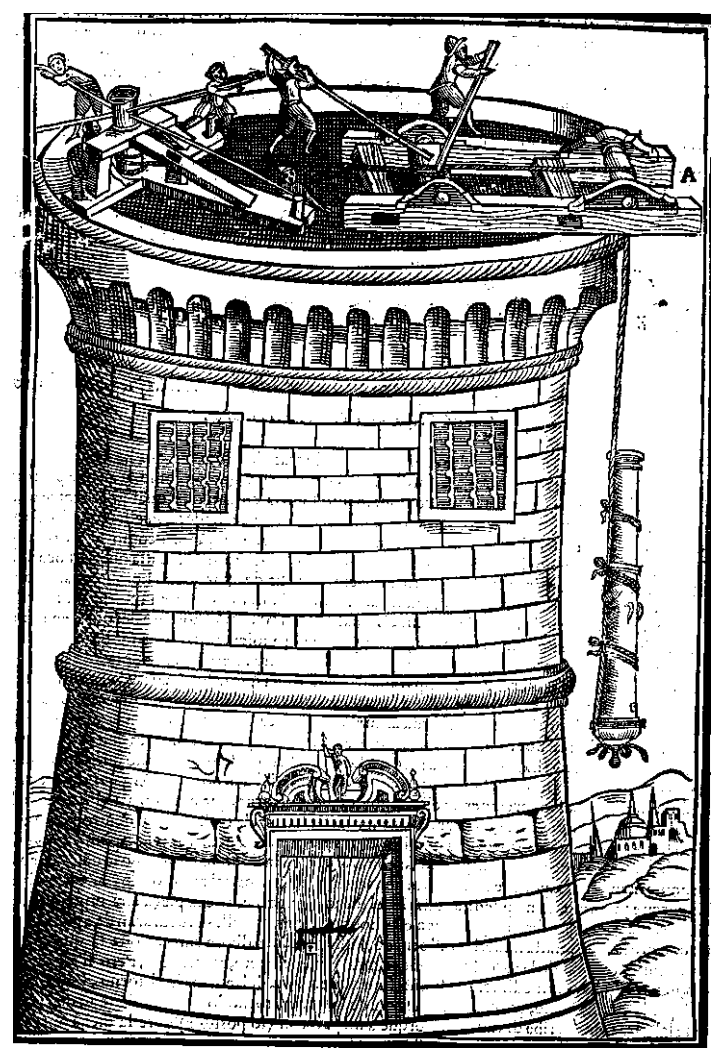

今 (fig. 162) Torreón

Esta imagen muestra cómo procede un grupo de artilleros para subir a una torre o torreón muy altos alguna pieza de artillería. Collado (1592: fol. 74r)

ş (fig. 163) Trabe

Collado (1592: fol. 4r)

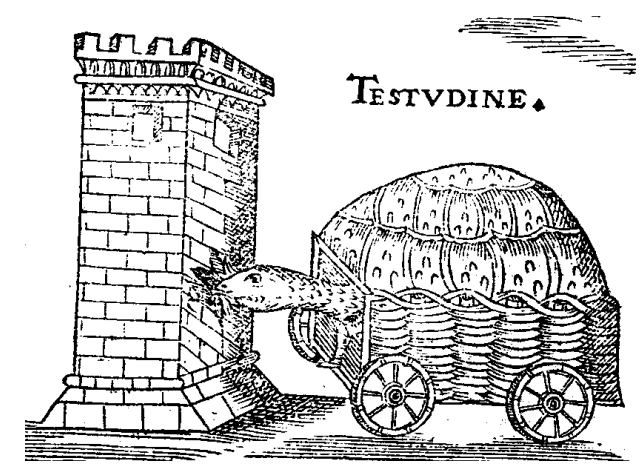

Testúdine con una trabe o viga, en forma de cabeza de tortuga, para poder, además de defenderse, batir las murallas 
16 (fig. 164) Trabuco

Lopes Pires Nunes (2005: s.v. trabuco)

Esquema de un trabuco, diseñado por A. Rubim.
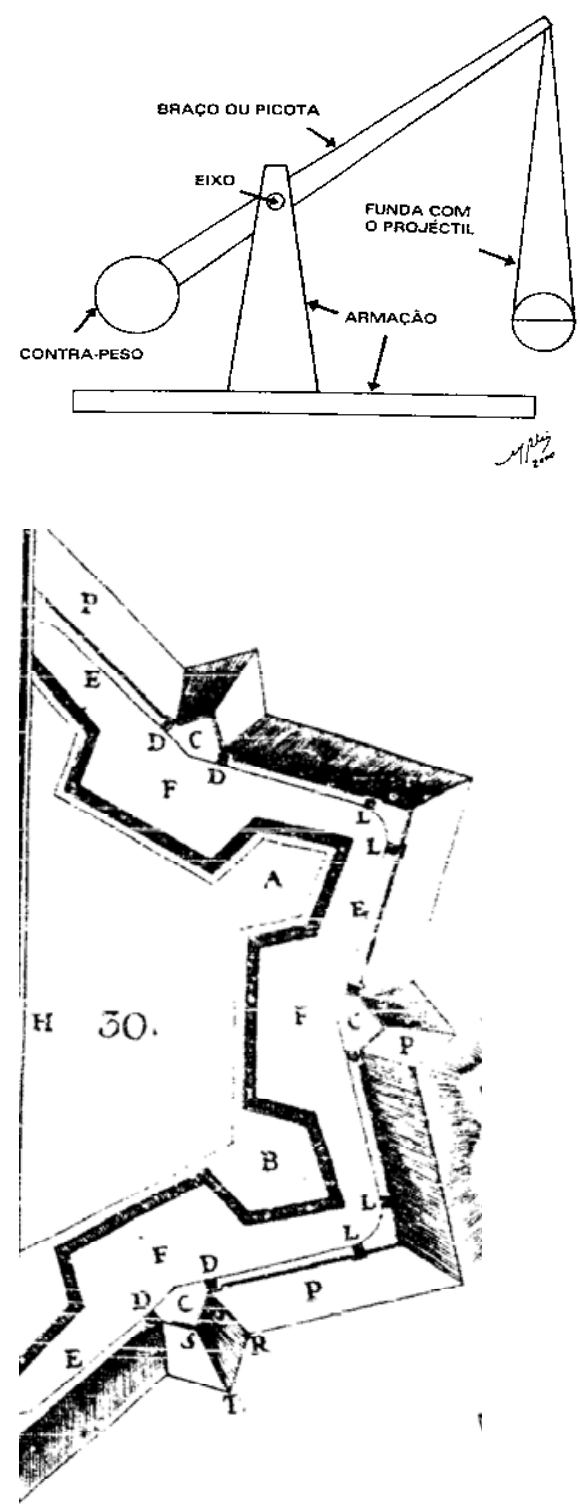

Rojas (1598: fol. 105r) Asedio a una fortificación con trincheras.

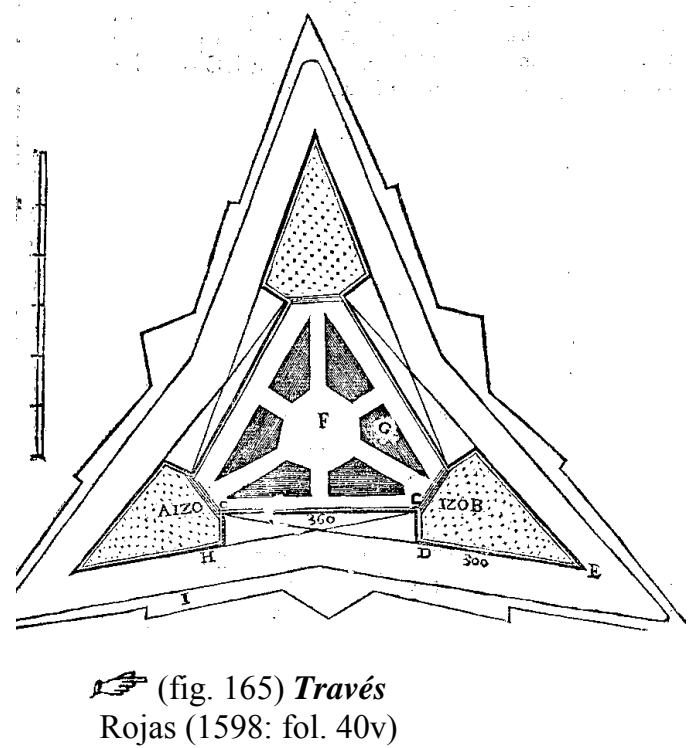

En esta planta de una fortaleza en figura triangular, $C D$ representa uno de los fiancos o traveses.

주 (fig. 166) Través

Lucuze (1772: lám. II)

Las letras D y L representan los traveses de la estrada cubierta E.

우 (fig. 167) Trinchera

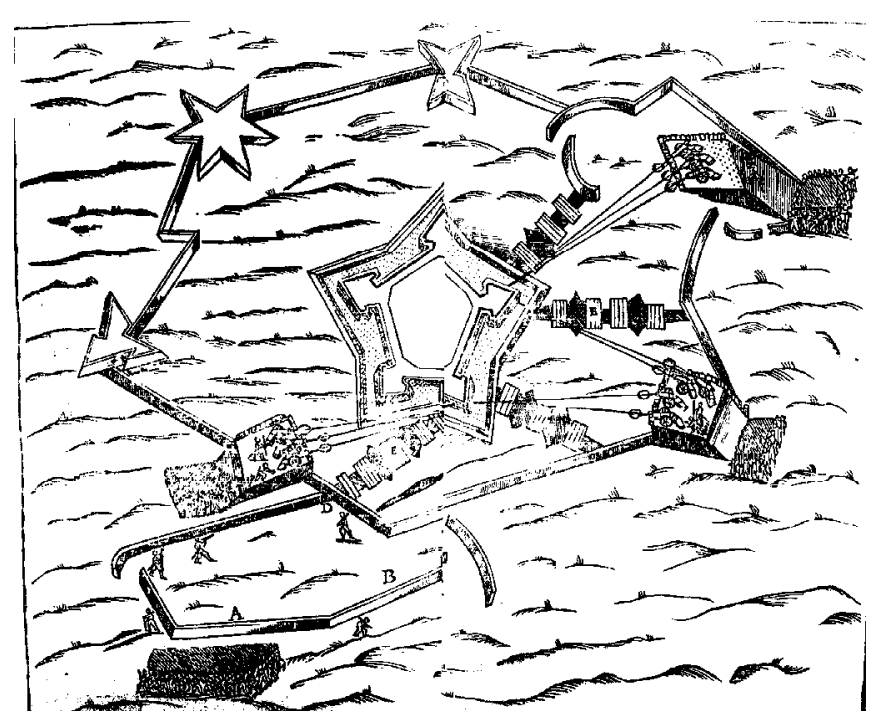


If (fig. 168) Tronera

"Figura de la espalda y troneras con sus esplanadas"

Ufano (1613: 124)

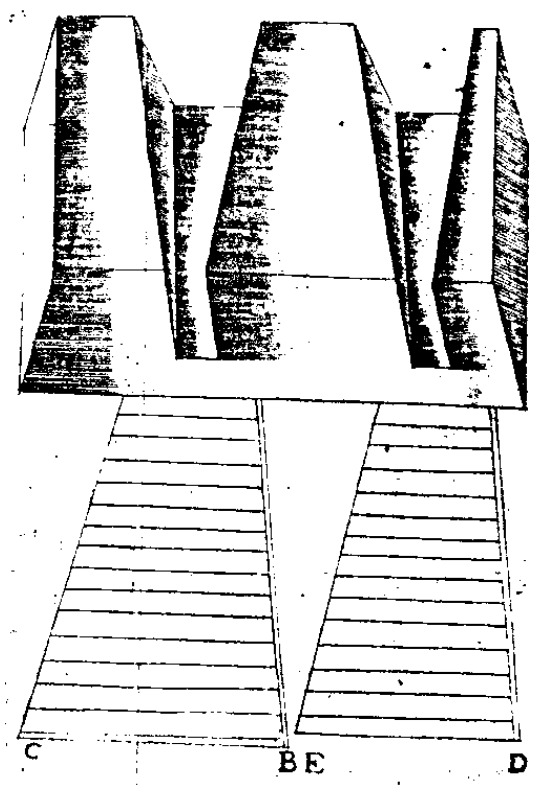

(fig. 169) Valla

Lucuze (1772: lám. IV)

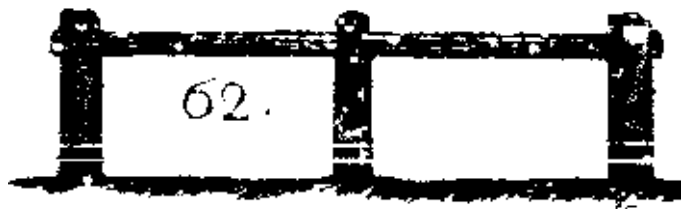

1 (fig. 170) Vallado $_{3} \quad$ González de Medina (1599: 44-45)

La letra C representa la estrada cubierta y la $\mathrm{H}$ el vallado de esta fortaleza.
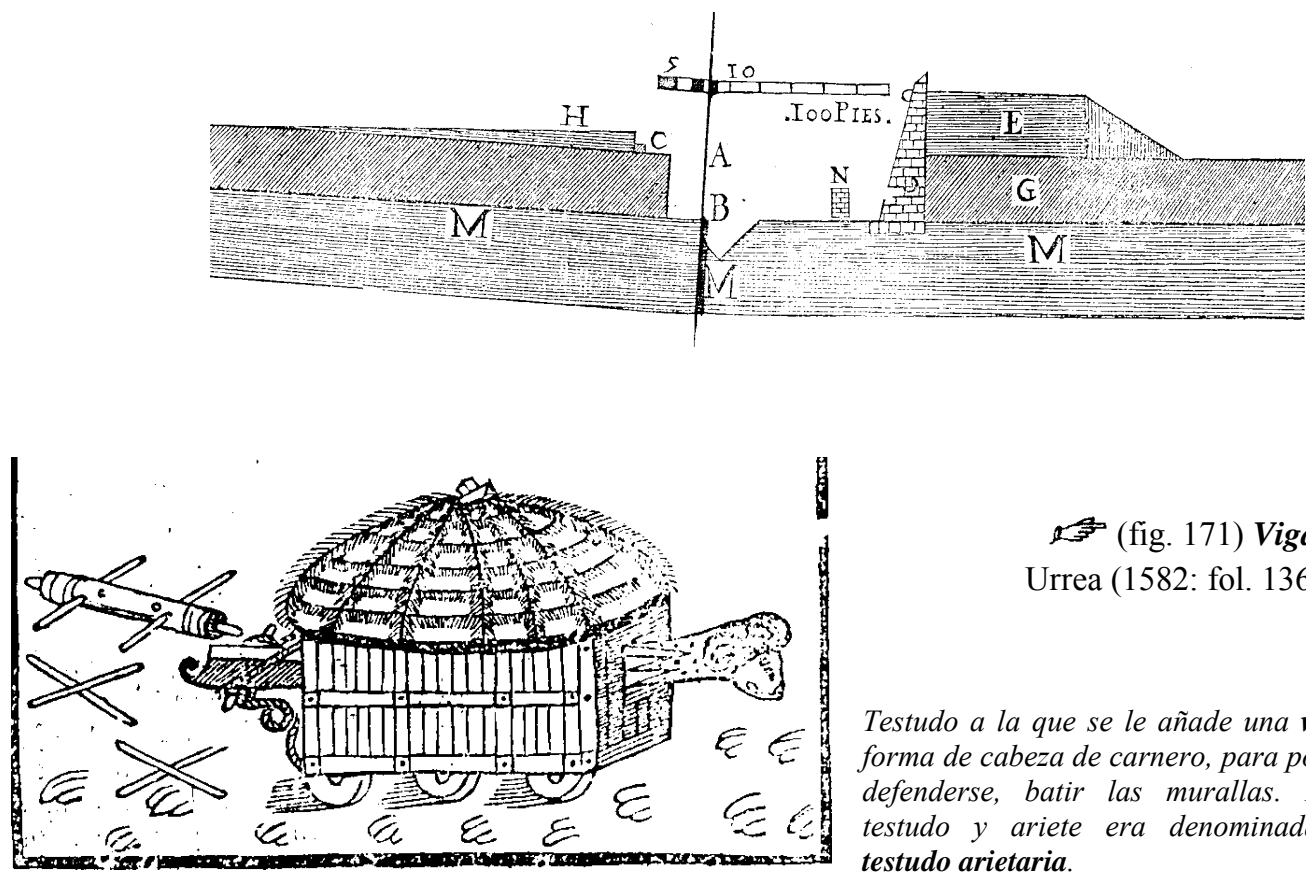

(fig. 171) Viga

Urrea (1582: fol. 136v)

Testudo a la que se le añade una viga o trabe, en forma de cabeza de carnero, para poder, además de defenderse, batir las murallas. Esta unión de testudo y ariete era denominada normalmente testudo arietaria. 
주 (fig. 172) Zapa

Plano, perfil y vista interior de la zapa Lucuze (1772: Lám. VIII).

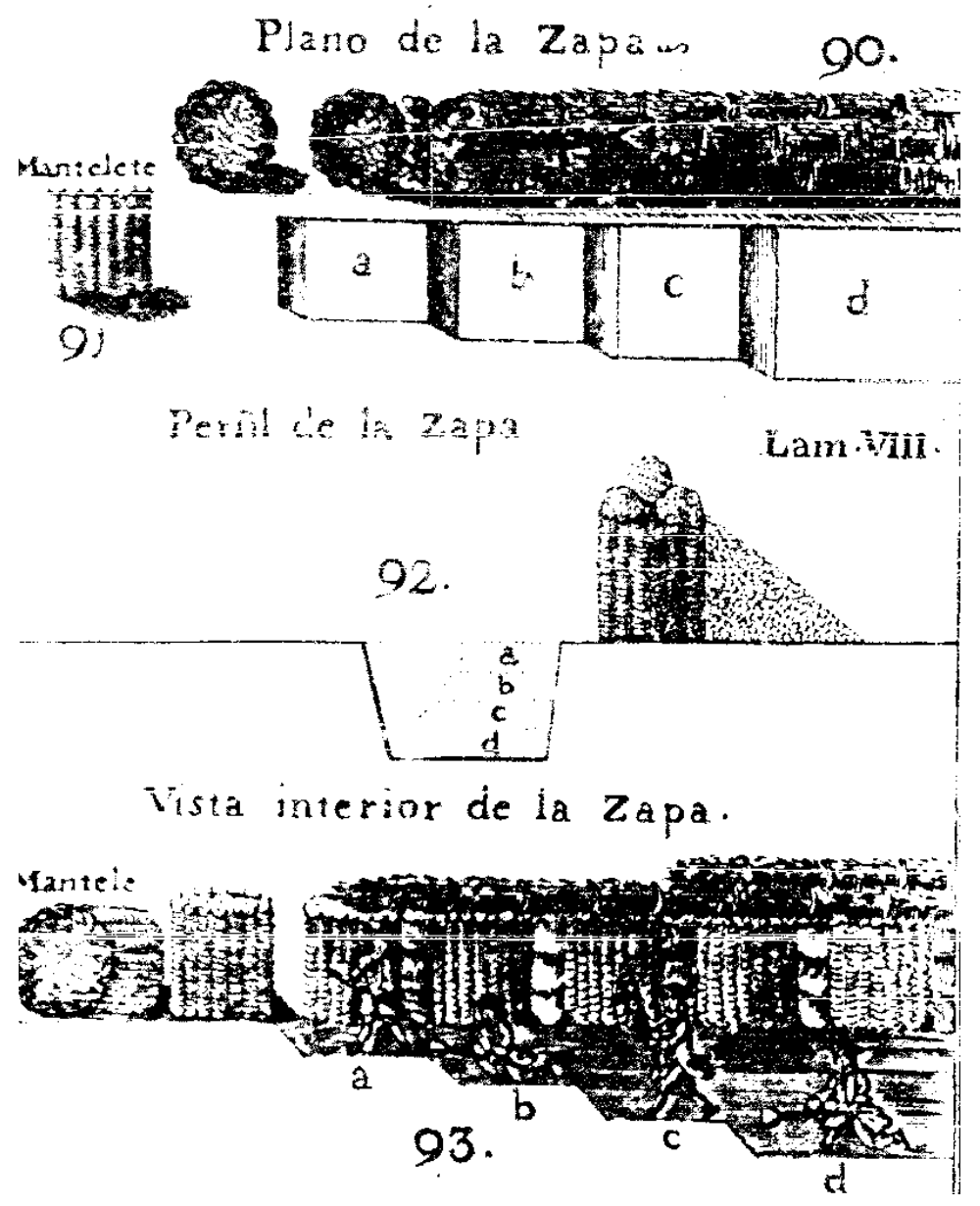

옥 (fig. 173) Zarzo Lucuze (1772: Lám. VI).

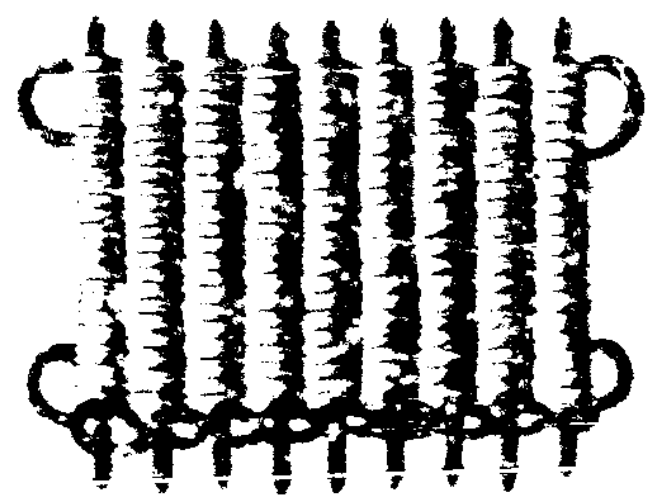




\section{Índice de ilustraciones}

\begin{tabular}{|c|c|}
\hline abrojo & fig. 1 \\
\hline ala & fig. 2 \\
\hline alamborado & fig. 3 \\
\hline almena & fig. 4 \\
\hline aproche & fig. 5 \\
\hline ariete & fig. 6 \\
\hline atalaya & fig. 7 \\
\hline balista & fig. 8 \\
\hline ballesta $_{2}$ & fig. 9 \\
\hline baluarte & fig. 10 \\
\hline banqueta & fig. 12 \\
\hline banqueta $_{2}$ & fig. 13 \\
\hline banqueta $_{3}$ & fig. 14 \\
\hline banqueta $_{4}$ & fig. 15 \\
\hline barbacana & fig. 16 \\
\hline bastión $_{2}$ & fig. 17 \\
\hline batería & fig. 18 \\
\hline batería $_{4}$ & fig. 19 \\
\hline blinda & fig. 20 \\
\hline blinda 2 & fig. 21 \\
\hline boca & fig. 22 \\
\hline caballería & fig. 24 \\
\hline caballero 2 & fig. 25 \\
\hline caballero $_{3}$ & fig. 26 \\
\hline cabrilla & fig. 27 \\
\hline camarada $_{2}$ & fig. 28 \\
\hline camisa & fig. 29 \\
\hline candelero & fig. 30 \\
\hline
\end{tabular}




\begin{tabular}{|c|c|}
\hline cañonera & fig. 31 \\
\hline casa fuerte & fig. 32 \\
\hline casamata & fig. 33 \\
\hline castillo $_{2}$ & fig. 34 \\
\hline catapulta & fig. 35 \\
\hline $\mathrm{cerca}_{2}$ & fig. 36 \\
\hline cesto & fig. 37 \\
\hline cestón & fig. 38 \\
\hline ciudadela & fig. 39 \\
\hline compago & fig. 40 \\
\hline contrabatería 2 & fig. 41 \\
\hline contraescarpa & fig. 42 \\
\hline contraforte & fig. 43 \\
\hline contrafoso & fig. 44 \\
\hline contramina & fig. 45 \\
\hline cordón & fig. 46 \\
\hline cortadura $_{2}$ & fig. 47 \\
\hline cortina & fig. 48 \\
\hline cortina franca & fig. 49 \\
\hline cortina total & fig. 50 \\
\hline cuartel & fig. 51 \\
\hline cuerno & fig. 52 \\
\hline cuerpo de guardia & fig. 53 \\
\hline cúneo & fig. 54 \\
\hline cuño & fig. 55 \\
\hline dar bordos & fig. 23 \\
\hline de gente & fig. 95 \\
\hline desbarate & fig. 56 \\
\hline de terreno & fig. 152 \\
\hline diente & fig. 57 \\
\hline diente $_{2}$ & fig. 58 \\
\hline empalizada & fig. 59 \\
\hline escala & fig. 60 \\
\hline escala $_{2}$ & fig. 61 \\
\hline escarpa & fig. 62 \\
\hline escarpa $_{2}$ & fig. 63 \\
\hline escarpa $_{3}$ & fig. 64 \\
\hline escuadrón falso & fig. 65 \\
\hline espalda & fig. 66 \\
\hline espalda 3 & fig. 67 \\
\hline espalda $a_{4}$ & fig. 68 \\
\hline espolón 2 & fig. 69 \\
\hline estancia & fig. 70 \\
\hline
\end{tabular}




\begin{tabular}{|c|c|}
\hline estrada & fig. 71 \\
\hline estrada 2 & fig. 72 \\
\hline estrada cubierta & fig. 73 \\
\hline estrella & fig. 74 \\
\hline estribo & fig. 75 \\
\hline explanada 3 & fig. 76 \\
\hline fajina & fig. 77 \\
\hline falda & fig. 78 \\
\hline fianco & fig. 79 \\
\hline $\mathrm{flancO}_{2}$ & fig. 80 \\
\hline flanco del orejón & fig. 81 \\
\hline fondo & fig. 82 \\
\hline fórfice & fig. 83 \\
\hline fortaleza & fig. 84 \\
\hline foso & fig. 85 \\
\hline frente & fig. 86 \\
\hline frente $_{3}$ & fig. 87 \\
\hline frente $_{4}$ & fig. 88 \\
\hline fuerte $_{2}$ & fig. 89 \\
\hline fuerza & fig. 90 \\
\hline galería & fig. 91 \\
\hline galería $_{2}$ & fig. 92 \\
\hline garita & fig. 93 \\
\hline gavión & fig. 94 \\
\hline gola & fig. 96 \\
\hline hila & fig. 98 \\
\hline hilada & fig. 99 \\
\hline hilera & fig. 100 \\
\hline hornillo & fig. 101 \\
\hline infantería & fig. 102 \\
\hline interpresa $_{2}$ & fig. 103 \\
\hline media gola & fig. 97 \\
\hline media luna & fig. 104 \\
\hline media luna 2 & fig. 105 \\
\hline medio baluarte & fig. 11 \\
\hline manta & fig. 106 \\
\hline manta $_{2}$ & fig. 107 \\
\hline merlón & fig. 108 \\
\hline mina & fig. 109 \\
\hline muralla & fig. 110 \\
\hline orejón & fig. 111 \\
\hline pabellón & fig. 112 \\
\hline padrastro & fig. 113 \\
\hline
\end{tabular}




\begin{tabular}{|c|c|}
\hline palizada $_{2}$ & fig. 114 \\
\hline parapeto & fig. 115 \\
\hline pilote & fig. 116 \\
\hline plataforma & fig. 117 \\
\hline plataforma $_{4}$ & fig. 118 \\
\hline plataforma & fig. 119 \\
\hline plaza & fig. 120 \\
\hline $\mathrm{plaza}_{4}$ & fig. 121 \\
\hline plaza alta & fig. 122 \\
\hline plaza baja & fig. 123 \\
\hline plaza de armas & fig. 124 \\
\hline puente & fig. 125 \\
\hline puente levadizo & fig. 126 \\
\hline puerta & fig. 127 \\
\hline puerta del socorro & fig. 128 \\
\hline puerta principal & fig. 129 \\
\hline rastrillo & fig. 130 \\
\hline reducto & fig. 131 \\
\hline refosete & fig. 132 \\
\hline refoso & fig. 133 \\
\hline reparos 3 & fig. 134 \\
\hline revellín & fig. 135 \\
\hline revellín 2 & fig. 136 \\
\hline saca & fig. 137 \\
\hline $\operatorname{saco}^{1}$ & fig. 138 \\
\hline salchicha & fig. 139 \\
\hline salchichón & fig. 140 \\
\hline sambuca & fig. 141 \\
\hline sitio & fig. 142 \\
\hline tenaza & fig. 143 \\
\hline tenaza $_{2}$ & fig. 144 \\
\hline tenaza $_{3}$ & fig. 145 \\
\hline tenaza $_{4}$ & fig. 146 \\
\hline tenazante & fig. 147 \\
\hline tenazón & fig. 148 \\
\hline tepe & fig. 149 \\
\hline terrapleno & fig. 150 \\
\hline terrapleno $_{2}$ & fig. 151 \\
\hline testúdine & fig. 153 \\
\hline testudo & fig. 154 \\
\hline testudo arietaria & fig. 155 \\
\hline tienda & fig. 156 \\
\hline tijera & fig. 157 \\
\hline
\end{tabular}




tijera $_{2}$
torre
torre $_{2}$
torre de homenaje
torreón
trabe
trabuco
través
través 2
trinchera
tronera
valla
vallado3
viga
zapa
zarzo

fig. 158

fig. 159

fig. 160

fig. 161

fig. 162

fig. 163

fig. 164

fig. 165

fig. 166

fig. 167

fig. 168

fig. 169

fig. 170

fig. 171

fig. 172

fig. 173 


\section{RESUMO}

Nesta Tese de Doutoramento estudámos a terminologia militar numa etapa de grande desenvolvimento tanto linguístico como científico: o Renascimento.

O nosso principal contributo é constituído pelo Glosario de fortificación y arte militar renacentistas que incluímos nela. A sua elaboração responde à constatação da falta em castelhano de um dicionário militar assente sobre sólidos princípios linguísticos. É acompanhado por uma série de apêndices sobre variantes ortográficas, abreviaturas, siglas e marcas, juntamente com um catálogo de ilustrações comentadas.

O resto de seções da presente Tese complementa o glossário. Em primeiro lugar, proporcionamos um panorama da arte militar no Século de Ouro, em que destacamos os seus aspetos mais relevantes. Deste modo, revemos o conceito de "revolução militar" postulado pelos especialistas em referência à época estudada. Ressaltamos, ainda, as nações protagonistas desta revolução, enquanto analisamos a transcendência das respetivas atuações. Quanto à informação histórica, detemonos, por último, na enumeração das repercussões que o extraordinário avanço experimentado pela milícia durante o Renascimento acarretou, entre as quais sobressai a supremacia alcançada pela guerra passiva ou de posição, em detrimento de outras modalidades bélicas mais ativas.

Por outro lado, incluímos um breve estudo lexicológico das unidades terminológicas reunidas no glossário, com especial finca-pé na classificação por campos nocionais do vocabulário militar, bem como nas dificuldades que a profusa sinonímia detetada neste âmbito entranha. Além disso, disponibilizamos os dados conclusivos acerca dos tipos de empréstimos localizados, junto aos dois procedimentos de formação de palavras mais explorados na formação do léxico militar. Em suma, baseámo-nos nos mecanismos de que o espanhol dispõe para a 
obtenção de neologismos, o que permitirá lograr um maior conhecimento do léxico da milícia e da fortificação e contribuir para completar um dos vazios existentes na lexicologia histórica.

Anexamos finalmente um capítulo em que reconstruimos a história da lexicografia militar castelhana, principalmente dos Séculos XVIII e XIX, o período de máximo apogeu na publicação deste tipo de repertórios de especialidade. Após constatarmos que nenhum deles foi elaborado de um ponto de vista linguístico, dado que a maioria das definições que incluem se caracterizarem por possuir um marcado caráter enciclopédico, julgámos pertinente a realização deste Glosario Militar, com o qual pretendemos paliar a carência de inventários léxicos sobre o registo da milícia em espanhol, confecionado com uma focalização filológica.

\section{Apresentação e justificação do trabalho}

Desde que no início do Século XV começaram a generalizar-se o uso e a fabricação de pólvora, tendem a aparecer e a difundir-se novas formas bélicas,

especialmente patentes nos alvores da Idade Moderna. É possível falar-se de uma verdadeira revolução militar, já que a aplicação da pólvora à artilharia provocou importantes processos de modernização nas armas, nas construções militares, nas técnicas, nas táticas e nos métodos de fazer a guerra que tinham imperado até ao momento.

Ora bem, é especialmente significativo o caso da arquitetura militar, dado que o emprego da pólvora nos conflitos bélicos contribuiu de maneira decisiva para o nascimento de um dos tipos de fortificação mais relevante na história da Europa: a fortificação abaluartada.

Já nos princípios do Século XVI ficou patente o desequilíbrio surgido entre os meios de ataque e os de defesa, inexistente antes. As obsoletas fortificações medievais não podiam fazer frente ao enorme avanço patente no terreno artilheiro. Em consequência, iniciou-se um período de transição em que os engenheiros 
ensaiaram novas fórmulas capazes de resistir aos estragos das armas de fogo. $\mathrm{O}$ elemento fundamental no novo sistema defensivo implantado desde então foi o baluarte, em cuja volta foram surgindo o resto de membros ou elementos das novas fortalezas.

Temos perante nós um vasto campo de investigação com o qual pretendemos lograr um maior conhecimento do léxico da fortificação e da arte militar no Renascimento, e contribuir, na medida das nossas possibilidades, para completar uma das múltiplas carências na lexicografia histórica.

Este projeto de Tese relaciona-se, além do mais, com outros trabalhos que se têm vindo a desenvolver ao longo destes últimos anos no Departamento de Lengua Española e, concretamente, no Centro de Investigaciones Lingüísticas, centrados na língua da ciência e da técnica do Renascimento. É, portanto, dentro desta linha de investigação onde inserimos a consecução da nossa Tese de Doutoramento, cuja realização poderá servir como material importante para a elaboração do Diccionario de la ciencia y de la técnica del Renacimiento español (DICTER), dirigido pela Dra. María Jesús Mancho Duque.

\section{Objetivos do trabalho}

O nosso objetivo é a análise e estudo do léxico militar numa etapa de grande desenvolvimento, tanto do ponto de vista linguístico, como científico.

Para isso, a nossa investigação vai acompanhada de uma consulta de obras especializadas no âmbito filológico e de referência sobre a ciência e a técnica no Renascimento, centrando-nos nas diversas disciplinas militares: fortificação, artilharia, arte militar, tática, etc.

É sabido que a época humanista assistiu ao arranque do conhecimento devido à difusão de textos impressos e manuscritos de distinta condição, incluindo os procedentes de autores clássicos (Vitrúvio, Euclides, Arquímedes, etc.) que foram editados em língua vernácula. Precisamente, um dos objetivos da criação da 
Academia Real Matemática por Felipe II foi fomentar, além do ensino da geometria e da aritmética, o emprego da língua espanhola nos textos científicos. Mas, além do mais, tendo em conta o marcado caráter prático alcançado pela geometria nesse momento, a formação matemática de engenheiros e arquitetos militares foi outra das razões fundamentais que levou o rei a estabelecer este importante centro de ensino, já que, entre outras coisas, os limites do Império dependiam da posse de uma sólida instrução militar por parte dos responsáveis pela defesa do território espanhol. Com efeito, o mais importante engenheiro militar do Século XVI espanhol, Cristóbal de Rojas, tratou de ensinar nesta instituição «fortificação» e «teoria e prática dos esquadrões».

\section{Grau de inovação}

A escolha deste período responde, por um lado, à importância que a língua espanhola adquire como veículo de transmissão de saberes, e por outro, ao impulso que a linguagem científico-técnica vai revestir-se a começos da Modernidade.

Paralelamente, ao situar-se a origem da milícia moderna no início do Renascimento, sistema que permanece no essencial sem alteração até ao Século XIX, consideramos que o Século XVI é o mais significativo aquando de empreender um estudo lexicológico e lexicográfico sobre estes aspetos, em grande medida porque se assiste à busca, desenvolvimento e posterior estabelecimento da terminologia precisa para esta nova disciplina. E, tendo em conta que o castelhano se converteu nesse momento em veículo de divulgação científica, face à supremacia da língua latina em épocas anteriores, consideramos que o presente trabalho de investigação centrado na análise da terminologia militar renascentista é sumamente rico e interessante.

Como assinalam vários investigadores, nos últimos anos foi crescendo, paulatinamente, o interesse dos historiadores, dos arquitetos e de outros 
estudiosos espanhóis pela fortificação moderna, aproximando-se do que já era habitual, há já mais tempo noutros países europeus, afirmação que fica demonstrada pelos numerosos dicionários, glossários ou vocabulários existentes sobre arquitetura defensiva e aspetos afins. Agora, julgamos que a nossa língua requer também trabalhos sobre fortificação elaborados de um ponto de vista filológico e linguístico, em que se compilem e elaborem definições estritamente lexicográficas. E faltam, igualmente, estudos léxicos sobre a terminologia militar. Estas vão ser, em suma, as nossas principais contribuições para o âmbito da fortificação e da arte militar renascentistas.

\section{Metodologia}

O ponto de partida do nosso estudo é o corpus do Diccionario de la ciencia y de la técnica del Renacimiento español (DICTER), que é formado por 74 obras científico-técnicas altamente especializadas.

Ora, para a elaboração do glossário sobre a terminologia da fortificação e da arte militar do Renascimento, numa primeira instância, realizámos a delimitação das obras centrais, que sobressaem por albergar maior conteúdo sobre este âmbito: entre outras, Examen de fortificación de Diego González de Medina Barba; Teórica y práctica de fortificación, Sumario de la milicia antigua y moderna e Compendio y breve resolución de fortificación, las tres de Cristóbal de Rojas; Discurso en que trata de la artillería y de todo lo necesario a ella, con un tratado de fortificación y otros advertimientos del capitão Cristóbal Lechuga; os Diálogos militares de Diego García de Palacio ou El perfecto capitán instruido en la disciplina militar y nueva ciencia de la artillería de Diego de Álaba y Viamont. Deve destacar-se, igualmente, a tradução de Miguel de Urrea do tratado De Architectura de Marco Vitruvio Pollión, ao dar conta dos conhecimentos clássicos em torno da fortificação, uma arte que já vem, portanto, da Antiguidade clássica, se bem que não se pode falar de fortificação abaluartada antes de finais do Século XV e começo do XVI. De qualquer forma, graças a um 
programa de pesquisas complexas (UltraEdit) pudemos rastrear o resto dos textos que integram o corpus do projeto, tarefa imprescindível se tivermos em conta que a relevância alcançada pela fortificação, entre outras disciplinas, durante o Renascimento torna possível a sua presença em obras sobre os mais variados temas.

Portanto, as diretrizes desta Tese requerem recursos informáticos que permitam trabalhar de uma maneira mais rápida e fiável com os textos. Em consequência, valemo-nos dos meios materiais imprescindíveis que nos disponibilizava o Centro de Investigaciones Lingüísticas de la Universidad de Salamanca (CILUS), como a base de dados Fichero de Vaciado (recentemente atualizada e melhorada), que nos permitiu a constituição da macroestrutura e microestrutura do nosso glossário léxico especializado.

Metodologicamente, procedemos, partindo do estudo do corpus, à seleção e estabelecimento dos tecnicismos, para, em seguida, nos dedicarmos à análise, o que nos permitiu um melhor conhecimento do léxico próprio destes campos e da língua científica do Renascimento em geral, bem como estabelecer uma síntese do comportamento da linguagem técnica da fortificação e da arte militar nesse momento histórico.

Após a seleção do conjunto de tratados e obras renascentistas que constituem a base da nossa Tese, empreendemos a respetiva leitura meditada para podermos, depois, proceder à triagem, seleção e estabelecimento do vocabulário científico e especializado relativo à fortificação e à arte militar.

Posteriormente, a imediata inclusão dos tecnicismos numa base de dados informática e sua posterior exportação a um formato Word - mediante as precisas alterações - permitiu a elaboração do nosso glossário.

A nossa base de dados contempla as seguintes informações: gráfica, gramatical, histórica e etimológica, morfológica, semântica e técnica, definição, informação lexicográfica, documentações, exemplos e imagens. Simultaneamente tivemos de abordar todos os problemas que foram surgindo, por exemplo a 
ordenação das distintas aceções, delimitação das unidades terminológicas, adscrição a um campo determinado, tanto das lexias como dos sintagmas compostos, etc.

Seguidamente, efetuámos uma revisão bibliográfica imprescindível para a análise dos mecanismos de adoção das vozes, procedimentos morfológicos e aspetos semânticos e terminológicos. Paralelamente, a nossa investigação requereu a consulta de obras especializadas e de referência sobre a ciência e a técnica no Renascimento.

Tudo isso possibilitou a conclusão do trabalho e permitiu, finalmente, que tenhamos alcançado um melhor conhecimento do comportamento desta parcela da linguagem científica no Renascimento e da língua do Século de Ouro em geral.

\section{Aproximação à arte de fazer a guerra na época moderna}

\section{a) A revolução militar do Renascimento}

Nas últimas centúrias da Idade Média deixa-se sentir um incipiente processo de mudança que, acompanhado de uma sucessão de transformações nas ordens social, cultural, económica e política, vai conduzir, a começos do Século XVI, ao início da ciência moderna.

Pois bem, a arte militar resultou ser uma das disciplinas onde mais se deixou sentir a influência de todas estas importantes inovações científico-técnicas. De facto, foi de tal envergadura o impacto da nova mentalidade renascentista na milícia que, ao longo do período estudado, se assiste à configuração e posterior consolidação de uma nova maneira de conceber e enfrentar a guerra.

Em primeiro lugar, já nos alvores do Renascimento se torna evidente o progressivo declinar da cavalaria em prol da infantaria, face à preponderância mantida pela primeira durante toda a Idade Média. Esta inversão foi condicionada, entre outros motivos, pelo crescente emprego de projéteis nas inúmeras batalhas 
que se iam sucedendo (Parker 2002: 52). Ora bem, ao passo que esta decadência da cavalaria é visível no tratado Arte della guerra (1521) de Maquiavel, obra citada entre os primeiros expoentes textuais do sistema bélico que o Renascimento implica; nela o autor subtrai importância aos distintos avanços ocorridos no terreno artilheiro (Campillo 20082: 47). Isto é, neste importante tratado da época moderna não se valoriza a transcendência do uso das armas de fogo, o que, segundo a maioria dos autores, foi o principal fator que desencadeou a revolução militar. Portanto, esta constatação aponta para que, na realidade, a transformação da cavalaria deva ser explicada a partir da mudança de mentalidade própria da época renascentista, em definitiva, pela inadequação do sistema feudal cavaleiresco à nova ordem.

Pouco a pouco, graças ao arranque da ciência artilheira, foi-se incrementando o emprego das armas de fogo de tipo portátil, principalmente arcabuzes e, em menor medida, mosquetes, por parte das distintas agrupações bélicas de infantaria, o que condicionou que a partir desse momento fosse uma tarefa recorrente a experimentação de novas disposições táticas capazes de multiplicar as possibilidades de fazer fogo.

Ao âmbito da tática moderna devemos acrescer, aliás, a constante preocupação, manifestada tanto nas obras militares como nos campos de batalha, acerca da exata composição e formação que, segundo as circunstâncias, devia adotar o esquadrão para ser efetivo. Assim, face ao valor e à iniciativa individual próprios dos cavaleiros nas batalhas medievais, nos numerosos conflitos bélicos do Renascimento sobressai como fator determinante a ordem e a disciplina conjuntas (Maravall 1972: 529).

Quanto à artilharia, como é bem sabido, a aplicação da pólvora ao lançamento de projéteis influiu de forma radical na direção e nas condições dos subsequentes conflitos armados, se bem que a generalização do seu uso não foi rápida. Com efeito, ao longo do Século XVI ainda se sucedem melhorias dentro do 
âmbito artilheiro, o que determina que o período estudado se caracterize por possuir um caráter profundamente experimental no que se refere à prática artilheira.

À medida que a aplicação da pólvora nos conflitos bélicos foi sendo cada vez maior, o desequilíbrio gerado entre os meios de ataque e os de defesa problema anteriormente inexistente - tornou-se cada vez mais evidente. Ora bem, o âmbito onde esta desigualdade se manifestou de maneira mais palpável foi o da fortificação ou construção defensiva, já que, a partir desse momento, as fortalezas medievais começaram a dar mostras da sua ineficácia perante as novas armas de fogo.

As fortificações da Idade Média distinguiram-se por constar de muros extremamente altos, além de que a sua localização soía estabelecer-se em lugares de muito difícil acesso. Pelo contrário, ao transformar-se este tipo de atitude estática numa participação sumamente ativa por parte dos defensores renascentistas, como consequência do aparecimento das novas armas de fogo, o que caracteriza a poliorcética moderna é a defesa assente no plano horizontal:

Se redujeron las alturas para ofrecer el menor blanco posible y aumentose, en cambio, el diámetro o proporción horizontal para gozar de ventaja en la instalación de la artillería; son los sensibles cambios que se producen en la fortificación permanente antigua en su paso a la moderna o abaluartada (Zapatero 1963: 91).

Como se depreende desta passagem, as primeiras reformas no âmbito da arquitetura militar consistiram tanto em cobrir de terra a parte interior das muralhas como em alargar os reduzidos espaços das torres, tipicamente medievais, com o fim de dar cabimento à nova artilharia.

Além disso, após a preferência pela localização dos distintos recintos fortificados em zonas orograficamente complexas, isto é, em enclaves de difícil acesso, própria da Idade Média, assistimos ao pleno convencimento da superioridade estratégica dos lugares em planície. 
Como é lógico, nesta importante parcela militar, antes que o principal membro defensivo da nova fortificação, o baluarte, alcance a sua forma pentagonal definitiva, o que se impõe é uma evolução que costuma qualificar-se de gradual, apesar do seu precoce caráter irreversível.

A seguinte imagem extraída da obra de Francesco di Giorgio Martini - um dos primeiros engenheiros modernos - serve para exemplificar a passagem das formas triangulares ao baluarte pentagonal propriamente dito, cuja última manifestação constitui a localizada na esquina superior esquerda:

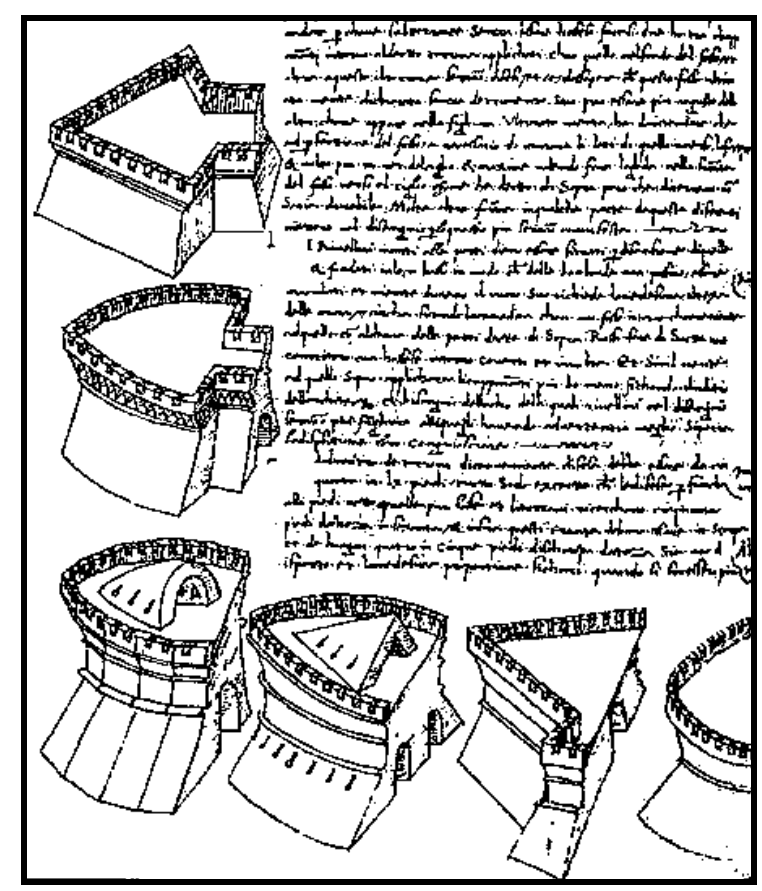

Em Francesco di Giorgio Martini, Trattati di Architettura, Ingegneria e Arte Militare, ápud Echarri Iribarren (2000: 53)

O elemento mais importante da arquitetura militar moderna é indubitavelmente o baluarte, em cujas redondezas foram surgindo o resto de membros das novas fortalezas.

Cabe apontar também como rasgo típico do período analisado a constante aplicação das ciências matemáticas às distintas disciplinas científico-técnicas 
existentes. Como não podia ser de outra forma, dada a sua relevância, os distintos ramos militares também se beneficiaram da excelência concedida à matemática durante a modernidade. No que concerne a fortificação, por exemplo, para uma correta representação do plano, planta ou perfil de uma determinada construção defensiva, a geometria aliada à perspetiva converteram-se nos instrumentos apropriados. E, a propósito de artilharia, todos os tratados centrados neste tema "ponen de manifiesto lo imprescindible del dominio matemático por parte de los artilleros para efectuar el cálculo de los alcances de los cañones y, en último término, para conseguir precisión en el tiro" (Echarri Iribarren 2000: 41). Igualmente, os distintos exércitos participantes numa guerra concederam uma posição privilegiada às disciplinas matemáticas, entre outras tantas aplicações, por diminuir as probabilidades de erro de uma mina no instante de alcançar o objetivo desejado.

Por último, o impacto do humanismo renascentista na milícia foi muito notável, propiciado pela indústria da imprensa, o que contribuiu aliás para a sua legitimação social. Assim, o exercício da guerra beneficiou-se imensamente da preocupação dos humanistas pela redescoberta, tradução e difusão dos textos antigos. As obras dos historiadores, militares e arquitetos gregos e romanos mais destacados - de Vegécio, Vitrúvio, Philon de Bizâncio, Eliano o Táctico e Procópio, entre outros - proporcionaram aos soldados e engenheiros do Renascimento os conhecimentos técnicos a partir dos quais desenvolveram o seu labor profissional.

\section{b) Os protagonistas}

Todos os investigadores coincidem em assinalar a campanha realizada em Itália em 1494 pelas tropas francesas de Carlos VIII como o ponto de viragem que separa a guerra medieval da moderna. Como demonstra este episódio bélico, os numerosos estados italianos converteram-se em "el primer escenario de contiendas 
internacionales durante la época moderna" (Merino Peral 2002: 78). Posteriormente, com o eclodir da chamada Rebelião dos Países Baixos em 1567, os campos de batalha mais frequentados passaram a ser territórios de alguma das 17 províncias vinculadas à dinastia dos Habsburgo.

Pois bem, nestes novos cenários bélicos sobressai de maneira extraordinária o exército espanhol, provavelmente devido ao seu marcado caráter guerreiro propiciado pelo estado permanente de guerras em que o nosso país esteve imerso durante a Idade Média. Ora bem, o principal responsável desta hegemonia militar espanhola é constituído pelo seu acertado sistema de articulação da infantaria em terços. Estas unidades compostas por um número variável de soldados de pé viveram uma etapa de máximo esplendor durante a vigência do chamado Caminho Espanhol, isto é, desde 1567 até 1659. Este corredor militar, que cruzava meia Europa ao longo de aproximadamente 1000 quilómetros, de Génova a Namur, supôs uma das peças chave do sistema espanhol ao permitir as comunicações e o envio de tropas por terra de Itália até aos Países Baixos. Mediante esta rota puderam enviar-se continuamente para as guerras da Flandres, procedentes dos presídios italianos, soldados espanhóis sumamente experientes, o que em boa medida propiciou a fama militar de Espanha.

Em suma, ao mesmo tempo que, como exporemos doravante, os engenheiros italianos foram os precursores da teoria abaluartada, as tropas espanholas foram as mais inovadoras no que à forma de conceber os distintos aspetos da guerra se refere. Isto permitiu-lhes consagrar-se como os dominadores do panorama efetivo da guerra até 1630 aproximadamente (Merino Peral 2002: 390391).

Nas palavras de Echarri Iribarren (2000: 72), "fue en las cortes de los distintos estados italianos donde en primer lugar los hombres de ciencia, favorecidos por los mecenas y las numerosas guerras que allí se desarrollaron, escribieron tratados de fortificación", daí que o sistema defensivo abaluartado 
tenha sido também conhecido com o nome de trace italienne (cf. Parker 2002). Ora bem, como não podia deixar de ser, o território italiano não só destaca por ter dado à luz os primeiros textos centrados neste importante ramo militar, mas também por ser o lugar onde se levantaram as primeiras obras defensivas que observavam princípios militares modernos.

Estamos de acordo com Echarri Iribarren (2000: 53) quando assegura que "la invención del bastión, del sistema de fortificación bastionado que se impuso brillantemente durante el siglo XVI, no fue el resultado de la acción individual de un ingeniero, sino que fue el producto de una evolución gradual". Em qualquer caso, há uma série de figuras, na sua maioria italianas, que, devido às suas relevantes contribuições nos primeiros compassos da arte da fortificação, destacam acima de todas as demais: Leonardo, Miguel Angelo, Durero, Bramante, Antonio da Sangallo o Jovem, Sanmicheli e Francesco di Giorgio Martini, entre outros. No que respeita ao nosso país, deve citar-se como figura sobressalente desta primeira etapa o engenheiro militar Ramiro López, por ter desenhado em 1497 o castelo de Salses em Rosellón, fortificação que supôs um enorme avanço, embora ainda seja possuidora de múltiplas reminiscências medievais.

Sin embargo, la fortificación española no se desarrolló durante el siglo XVI al ritmo de este primer impulso debido a los constantes conflictos e ingentes esfuerzos que hubo de mantener la corona en los diversos dominios europeos y americanos. La labor de fortificación más importante se llevó a cabo en Hispanoamérica, norte de África, Flandes, Nápoles y Milanesado, mientras que, de fronteras adentro, no pudo efectuarse una renovación de la fortificación acorde con las exigencias defensivas modernas (Echarri Iribarren 2000: 59).

Na opinião de Merino Peral, isso deve-se a que

tras la Guerra Civil con los Reyes Católicos y la Guerra de Granada, se fue imponiendo una paz interior, que fue dejando de lado las necesidades defensivas urgentes de la arquitectura, convirtiendo los castillos en castillos-palacio más que en modernas fortificaciones, y en los que predominaron los rasgos civiles, e incluso decorativos en la construcción (Merino Peral 2002: 92). 
Devido às hostilidades com França, bem como ao perigo turco, as únicas zonas sensíveis de defesa da Península Ibérica foram os Pirenéus e as costas, sobretudo as do Mediterrâneo.

Devemos apontar que tanto para a execução como para a direção da maioria das obras defensivas peninsulares, os monarcas espanhóis contrataram engenheiros italianos, entre os quais destacam Gian Battista Antonelli, Tiburzio Spanocchi, Gian Battista Calvi, Fratín e Francesco Paciotto, só para citar alguns.

Além do mais, perante a escassez de artilheiros na nossa península, também "los monarcas [...] hubieron de recurrir a importar artilleros extranjeros de los dominios europeos, principalmente alemanes e italianos" (Echarri Iribarren 2000: $42)$.

\section{c) Consolidação e repercussões da revolução militar}

"Estos nuevos modos de hacer la guerra fueron acompañados, sobre todo, por un notable aumento en el tamaño de los ejércitos" (Parker 2002: 52), o que se pôde conseguir com relativa facilidade graças a que pela primeira vez os poderes políticos dos distintos estados se converteram nos máximos responsáveis pela tarefa de recrutamento de soldados. Além disso, como traço característico da guerra moderna deve citar-se a existência de um exército permanente, face à Idade Média, etapa em que somente se recrutavam soldados em caso de necessidade.

Paralelamente, a transcendência outorgada pelas distintas nações à expugnação do máximo número possível de fortalezas condiciona que tanto no Século XVI como no XVII quase todas as operações militares empreendidas girassem em torno do ataque e da defesa dos distintos tipos de recintos fortificados. Os Séculos de Ouro constituem, enfim, a etapa de maior florescimento para a denominada guerra passiva ou de posição. 
Los dos sistemas que habitualmente se utilizaban para realizar con éxito la toma de una fortaleza eran abrir brecha mediante el fuego intenso aplicado en los puntos débiles, o la voladura puntual del terraplén y la escarpa del recinto principalmente mediante una mina. Al hacer practicable la brecha en ambos casos se pasaba a realizar el asalto final (Echarri Iribarren 2000: 68).

Ora bem, como à medida que transcorria o tempo foram sendo construídas fortificações cada vez mais perfeitas, a extraordinária complexidade da conquista obrigou os exércitos sitiadores a decidir-se quase sempre pela modalidade bélica do bloqueio total.

Como é lógico, a supremacia de que gozaram durante os Séculos XVI e XVII as operações bélicas dirigidas contra lugares fortificados trouxe também consigo mudanças nas disciplinas militares mais vinculadas à poliorcética, a saber, a logística, a tática, a estratégia e a castrametação.

Outra das repercussões que os progressos militares do Renascimento propiciaram refere-se aos constantes motins e levantamentos registados nas filas dos distintos exércitos, questão lógica se tivermos em conta que os soldados que os integravam, além de participarem em cercos que pareciam não ter fim - muitas vezes, aliás, sem receberem o pagamento devido pelos respetivos serviços, permaneceram longas temporadas fora do seu lugar de origem, longe incluso do território peninsular.

Finalmente, desde finais do Século XVI, assistimos a um notável incremento no que se refere à publicação de tratados militares em língua castelhana. Para Merino Peral, esta abundante tratadística responde em boa medida ao desejo dos nossos militares de estabelecerem uma comunicação fluida com a Península Ibérica.

Seguidamente, para dar conta do estado de evolução em que se encontra a fortificação abaluartada permanente na tratadística manejada, procedemos a 
classificar as obras defensivas que registámos no nosso glossário em essenciais, convenientes, acidentais e acessórias:

\begin{tabular}{|c|c|}
\hline $\begin{array}{l}\text { Obras } \\
\text { essenciais }\end{array}$ & 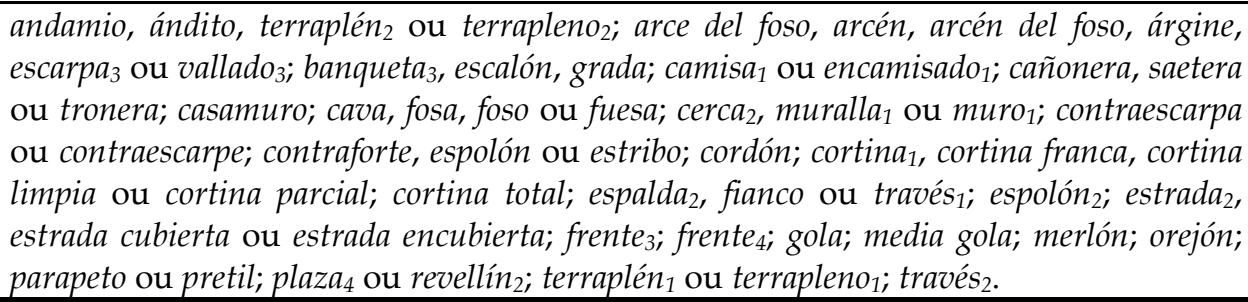 \\
\hline $\begin{array}{l}\text { Obras } \\
\text { convenientes }\end{array}$ & $\begin{array}{l}\text { banqueta }_{1}, \text { banqueta }_{2} \text {, boca, casamata, costado } \\
\text { media lun } a_{1} \text {, revellín } n_{1} \text {. }\end{array}$ \\
\hline $\begin{array}{l}\text { Obras } \\
\text { acidentais }\end{array}$ & $\begin{array}{l}\text { bastión }_{2} ; \text { caballero }_{2} \text { ou plataforma }{ }_{3} ; \text { contrafosa ou contrafoso; espalda } a_{1} ; \text { flanco }_{2} ; \\
\text { plataforma } ; \text { plaza alta, plaza de arriba, plaza superior ou través alto; plaza baja, plaza de } \\
\text { abajo ou través bajo; refosete ou refoso; tenaza } a_{2} ; \text { tenaza } a_{3} ; \text { tijera }_{1} ; \text { traviesa }_{3} \text {. }\end{array}$ \\
\hline $\begin{array}{l}\text { Obras } \\
\text { acessórias }\end{array}$ & falda, garita, puerta del socorro, rastrillo, salida ${ }_{2}$ ou surtida $a_{2}$, surtida $_{3}$. \\
\hline
\end{tabular}

Classificação em campos semânticos ou nocionais do léxico militar objeto de estudo

Após a leitura detalhada dos textos que no corpus do Diccionario de la ciencia y de la técnica del Renacimiento español (DICTER) versam sobre a milícia, a impressão ou sensação que acima de todas as restantes predomina é a de que o objetivo de confecionar um glossário sobre o léxico militar renascentista em termos gerais resulta demasiado presunçoso.

Tendo em conta os múltiplos aspetos que durante o transcorrer de um conflito ou confronto armado estão presentes, tivemos de decidir de que parcela especializada tomaríamos as unidades léxicas que mais tarde conformariam a macroestrutura do nosso glossário.

Desta maneira, chegámos à conclusão de que o mais acertado era prescindir dos vocábulos que, se bem que aparecem com assiduidade em tratados militares, a sua maior frequência de uso tem lugar noutro tipo de textos, o que faz supor que, em lugar de tecnicismos militares, são termos especializados da economia, arquitetura, construção, matemática, náutica, etc. mas, além do mais, devido à 
amplitude semântica do conceito designado através das unidades léxicas arte militar e milícia, nos vimos obrigados a descartar do nosso trabalho palavras ou unidades pluriverbais que, ao contrário do caso anterior, não têm cabimento fora de um contexto bélico. Se tivermos em conta que o primeiro dicionário académico que inclui a unidade pluriverbal arte militar, o DRAE de 1817, a define como: "El arte de ofender y defenderse los ejércitos, atacar las plazas y defenderlas y de todo lo demás que corresponde a la guerra", é fácil supor que quando alguém emprega a etiqueta designativa arte de fazer a guerra, entre outras, se está a referir não a uma única disciplina ou ramo científico, mas sim ao conjunto formado por várias deles. Deste modo, a milícia, além de dar a conhecer a história militar das potências que despontaram no exercício da guerra e analisar a organização interna, os cargos e graus militares existentes no exército, se encarrega também do estudo da fortificação, da poliorcética, da artilharia, da tática, da estratégia, da castrametação, da logística, etc. De todas estas questões militares suscetíveis de ser contempladas, a presente investigação dedicou-se de maneira prioritária à análise do léxico da fortificação e da poliorcética, se bem que os termos relativos à tática militar tenham sido objeto de uma atenção preferente. Já num segundo plano foi objeto de atenção a grande quantidade de termos pertencentes a outros ramos militares que designam conceitos relativos à estratégia, à logística e à castrametação.

Por outro lado, descartámos fazer eco do campo da artilharia. A principal razão que justifica esta ausência tem a ver com a necessidade de culminar a nossa investigação num período de tempo razoável, dado que um estudo sobre o léxico artilheiro produziria um trabalho da mesma extensão ou incluso maior do que o presente, o que ficou demonstrado após o Estudio léxico de los tratados de artillería españoles del siglo XVI de Cristina Blas Nistal.

Por outro lado, se contemplarmos a importância que o Renascimento outorga à Antiguidade clássica, resulta lógico que os tratados militares examinados aludam tanto à milícia grega como à romana. Daí que sejam habituais, por exemplo, as enumerações das distintas funções ou cargos militares existentes na 
época romana. Dada a complexidade e amplitude do conjunto formado pelas vozes pertencentes à arte militar greco-romano, descartámos a sua introdução, dado que a análise requereria um estudo particular.

Igualmente ficam excluídas deste estudo unidades terminológicas tais como capitán, furriel, maestre de campo, coronel, general, etc., a saber, as que designam cargos ou graus militares existentes no exército moderno, as quais integram um conjunto léxico muito amplo. Este é o principal motivo de ter prescindido delas, mas é que, além disso, dada a sua complexidade, pois trata-se de vozes cujo significado varia muito inclusive em períodos de tempo mais curtos, assim como de uns lugares para outros, cremos que um trabalho centrado só neste grupo léxico seria já suficientemente rico e importante para não ter de uni-lo a outros.

Pois bem, uma vez decidido que o léxico selecionado se referiria exclusivamente à fortificação, poliorcética, tática, estratégia, logística ou castrametação, o seguinte passo consistiu em determinar quais das vozes presentes nos tratados sobre estas disciplinas militares eram termos especializados e quais não. Finalmente decidimos que, à parte os termos utilizados somente pelos autores de tratados militares, lematizaríamos aqueles outros que, embora pertençam à linguagem geral ou inclusive à especializada de algum outro âmbito técnico, a sua presença em contextos bélicos é também relevante, dado que, aliás, parecem designar importantes conceitos da milícia.

Após todas estas decisivas matizações e precisões, procedemos a classificar em distintos campos semânticos ou nocionais as unidades léxicas que constituem a macroestrutura do nosso glossário.

Em primeiro lugar, registámos dois termos referidos a técnicas ou artes (arquitectura militar ou fortificación 1 e arte militar ou milicia $a_{1}$ ), e outros dois para uma profissão (milicia 2 ou soldadesca). 
Damos conta, ainda assim, de uma série de vozes que designam ações ou operações próprias da estratégia militar: alarde, muestra ou reseña; aliarse, coligarse, confederarse ou ligarse; alistar ou asentar 2 ; apellidar; apellido ${ }_{1}$; asentar 3 ; confederación ou liga; hacer (la) gente ou levantar; ; leva e paz.

Já as seguintes são, pelo contrário, atividades de logística: amunicionar ou munir, avituallar, campear ${ }_{1}$, contrarronda ou sobrerronda $a_{1}$, ronda $a_{2}$, desalojar ${ }_{2}$, forraje ${ }_{2}$, forrajear, jornada, marchar e rondar 2 .

Por sua vez, acamparse, levantar, ${ }_{3}$ acuartelar 1 , acuartelar 2 , alojamiento 1 , alojar ${ }_{1}$, alojar 2 , desalojar, asentar 1 e levantar 2 pertencem ao âmbito da castrametação.

Ora bem, o âmbito militar mais representado é, com grande diferença, o das ações bélicas, dado que a ele pertence toda esta terminologia: acometer, atacar, combatir $_{3}$, embestir 2 ou ofender; defender 2 ; acometida, acometimiento, combate, combatimiento ${ }_{2}$, ofensa ou ofensiva; defensa 2 ; acosar, apremiar ou apretar 1 algazara; allanar, domar, domeñar, domesticar, señorear, sojuzgar, someter ou sujetar, alojar, amotinar $_{1}$ ou rebelar1; amotinar 2 ; apretar 2 ; apretilar; arremeter, embestir ${ }_{1}$ ou remeter; arremetida ou remetida; asaltar, dar (el) asalto 1 , dar el salto ou saltear; asaltar, dar (el) asalto $_{2}$ ou opugnar; asalto 1 ou salto; asalto 2 ou interpresa $a_{2}$; asediar, asitiar, cercar, ${ }_{3}$, meter (el) asedio, poner asedio, poner (el) cerco, poner (el) sitio ou sitiar; alzar el cerco, alzar el sitio, levantar el asedio, levantar el cerco ou levantar el sitio; asedio, cerco ou sitio; asedion; atrincherar 2 ; batalla 1 , combate 1 combatimiento 1 , contienda $a_{2}$ debate, facienda, lid ou pelea; batalla campal; representar (la) batalla; batería $a_{1}$ contrabatería $;$; batería ${ }_{2}$ brecha ou portillo; dar (la) batería ou batir ${ }_{1}$; batir ${ }_{2}$; batir, combatir $_{1}$, lidiar, luchar, pelear ou revolver 2 ; dar bordos ou dar bordos y ramos; cabalgada ; campear $_{2}$; celada $a_{1}$ ou emboscada $a_{1}$ poner en celada, emboscar ou poner en emboscada; centinela 2 ou guardia 2 ; ceñir 2 ; cercar2; chocar; combatir ${ }_{2}$; conquista, presa $_{1}$ ou toma; conquistar ou tomar ${ }_{1}$ correduría, correría, corrida ou incursión; correr $_{1}$ ou descubrir 3 ; correr $_{2}$; defender 3 ou guardar gefender $_{4}$; defender 5 ; defensa $_{3}$ ou defensión $n_{2}$; defensa $;$; poner en defensa; desalojar $;$; desbaratar ${ }_{1}$; desbaratar 2 ; desbaratar 3 ou poner en rota; desbarate; descercar ou desitiar; descortinar; descoser; descubrir $_{2}$, señorear 2 ou sojuzgar; desguarnecer; guarnecer ${ }_{1}$; deshacer ${ }_{1}$; deshacer 2 ; a la 
deshilada 2 ; desmantelar; desocupar; ocupar 2 ou tomar 2 ; despojar ${ }_{1}$; despojar, dar a saco ou saquear; despojo $1, \operatorname{presa}_{2}$, saco $^{2}$ ou sacomano; diversión; divertir 2 ; embarrar; empresa, empresa de (la) guerra, empresa militar, encuentro1, facción, facción de guerra, hecho de armas, interpresa $a_{1}$ ou reencuentro ${ }_{1}$; encamisada $a_{1}$ encastillarse; encuentro ${ }_{2}$ ou reencuentro 2 ; enseñorearse ou señorear 4 ; a escala vista; escalada; escalar; escaramuza 1 ou refriega; escaramuza 2 ; escaramuzar ${ }_{1}$; escaramuzar 2 ; escolta 2 ; hacer escolta; espiar espiar $_{2}$; espolonada; batir la estrada; estrago; expugnación; expugnar; fortalecer 1 ou fortificar1; gastar; guarda $;$ guarda; guardar $_{2} ;$ guardia $;$ jornada 2 lengua; tomar lengua; levantamiento ou rebelión; levantamiento de guerra ou motín; levantar 4 ou rebelar2; lucha; luchar $_{1}$; minar 1 ; minar $;$; ocupar 1 ; ocupar 3 ; oprimir ou sojuzgar 3 ; pacificación; pacificar; picamiento; picar; rebatir, hacer retirar, rebotar, rechazar ou retirar1; reconocer; reconocimiento; rendir ${ }_{1}$; rendir ${ }_{2}$; rendir ${ }_{3}$; rendir 4 ; reparar 3 ; resistencia 1 ; resistir; retirada ${ }_{1}$; retirar $_{2}$; retirar 3 ; revolver 1 ; riza; romper; rompimiento; ronda 1 ; rondar ${ }_{1}$; rota; salida 1 ou surtida $_{1}$; sedición; señorear 5 ou sujetar 2 ; socorrer s $_{1}$ socorrer $_{2}$; socorro $_{1}$; socorro s $_{3}$; sujeción; talayar; trabar; abrir trinchera; triunfar 1 velar; vencer; ir de vencida; llevar de vencida; vencimiento $_{1}$ ou victoria; vencimiento ${ }_{2}$; continuar el vencimiento, ejecutar la victoria, proseguir la victoria ou seguir la victoria e zapar.

Muitos dos verbos inseridos neste último grupo geram substantivos que assinalam os agentes ou sujeitos que participam nas distintas operações bélicas, os quais pertencem ao seguinte conjunto. À parte estes, integram também esta secção os múltiplos termos que existem para designar os membros das distintas unidades militares: acometedor, combatidor 2 ou combatiente 2 ; acometido ${ }_{2}$ ou ofendido 2 ; adversario ${ }_{1}$, contendedor, contrario 2 ou enemigo 2 ; amigo 3 ; alcaide ou castellano; aliado ${ }_{2}$, amigo $0_{4}$ ou confederado $;$; aposentador; asaltante; asediado ${ }_{2}$, cercado $_{4}$ ou sitiado 2 ; asediador, cercador ou sitiador; atalaya 2 ; ballestero; barrunte; caballero ${ }_{1}$ ou caballo ${ }_{1}$; caballo ligero; camarada ${ }_{1}$; centinela ${ }_{1}$ ou posta $a_{1}$ centinela perdida; combatidor 1 , combatiente 1 ou lidiador; conqueridor; conquistador; corredor ou descubridor; defensor 2 ; defensor 3 , guerrero 2 , hombre, hombre de (la) guerra, hombre de pelea, hombre de soldadesca, hombre militar, militar ${ }_{2}^{2}$, mílite 1 ou soldado; desbaratado $;$ diana 2 ; emboscado 2 ; encamisado 2 escolta 1 ; escucha; espía ou 
explorador; estradiote; forrajero; herreruelo; hombre de armas; hombre de socorro; infante ou peón; infante perdido; jinete; mercenario 2 ; metator; mílite 2 ; montaraz; rebelde 2 ; rendido; sobrevela; sujeto 2 ; vela ; vencedor $_{2}$ ou victorioso ${ }_{2}$ e vencido 2 .

Dada a sua alta representatividade, decidimos compilar separadamente as unidades léxicas que se referem aos conjuntos de pessoas que intervêm ou se formam numa guerra: adversario ${ }_{2}$, contrario $_{3}$ ou enemigo $o_{3}$; batalla $a_{6}$ ou batallón ${ }_{2}$; batallón 3 ; cabalgada2; caballería; caballería ligera; campo4; celada 2 ou emboscada2; corneta; cuerpo; cuerpo de (la) guarda 1 , cuerpo de guardia 1 ou guardia 3 ; defensa $a_{6}$ ejército; encamisada 2 ; facción 1 ; fuerza 2 ; gente, gente de (la) batalla, gente de guerra, gente de pelea, gente militar, milicia 3 ou tropa; gente de armas; gente de socorro ou socorro 2 ; guarnición; infantería; milicia 4 ; presidio $;$; real ${ }_{2}^{2}$; ronda 3 e sobrerronda.

Por sua vez, albañil ou murador; fortificador, ingeniero ou ingeniero militar; gastador ou peonero; guarda 1 guarda $;$; minador; municionero e viandero ou vivandero devem ser classificados no campo das pessoas que ora desempenham um ofício ou uma profissão, ora cultivam uma técnica.

Outro importante conjunto é aquele constituído pelos adjetivos que indicam qualidades próprias dos soldados, dos exércitos ou de qualquer outra coletividade que esteja envolvida numa contenda: acampado; acometido, combatido ou ofendidor; acosado, apremiado ou apretado ${ }_{1}$; aliado 1 , amigo ${ }_{2}$ ou confederado 1 ; alistado ou asentado $;$ alojado1; alojado2; amigo 1 contrarion ou enemigor; amotinador; asediado 1 , cercados ou sitiado ${ }_{1}$; atrincherado; belicoso $0_{1}$; bisoño; de a caballo ou de caballo $;$ cercado $;$ defensivo; ofensivo; defensor1; desbaratado2; desbaratado3; deshecho; doméstico, sojuzgado, sujetado ou

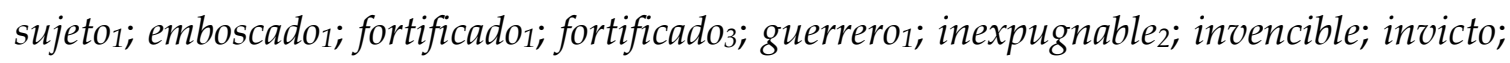
levantado, rebelado ou rebelde1; mercenarion; oprimido; pacífico; de a pie ou de pie; rebotado; rendido 1 ;eparado 3 ; roto; tirón; vencedor ${ }_{1}$ ou victorioso $o_{1}$ e vencido ${ }_{1}$.

Contamos, ainda assim, com uma série de verbos e substantivos que denotam atividades próprias da arquitetura militar: atrincherar1; carcavear; ceñir 1 ou cercar 1 ; contraminar; minar 2 ; estar en defensa; empalizar; encamisar; enfortalecer, 
fortalecer, $_{2}$ fortificar2 ou reparar 2 ; escarpar; flanquear; fortificación 2 ; fortificar 3 ; guarnecer2; murar; pilotear; reparar, terraplenar e vallar.

Outra área lexical profusa é a composta pelos elementos existentes em qualquer recinto fortificado, ou que formam parte de construções defensivas de caráter mais provisório: almena ou pina; andamio, ándito, terraplén 2 ou terrapleno; arce del foso, arcén, arcén del foso, árgine, escarpa 3 ou vallado; baluarte 1 ou bastión ${ }_{3}$; medio baluarte; banqueta $a_{1}$ banqueta 2 ; banqueta $a_{3}$, escalón ou grada; barbacana ou contramuro;

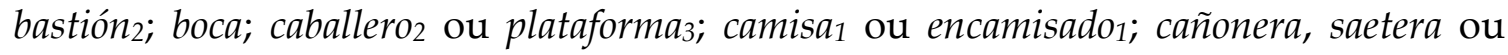
tronera; casamata; casamuro; cava, fosa, foso ou fuesa; cerca 2 , muralla 1 ou muro1; contraescarpa ou contraescarpe; contraforte, espolón ou estribo; contrafosa ou contrafoso; cordón; cortina 1 , cortina franca, cortina limpia ou cortina parcial; cortina total; costado 2 ou espalda $a_{3}$ espalda 1 ; espalda $a_{2}$, fianco ou través 1 ; espalda 4 ; espolón ${ }_{2} ;$ tenaza $_{2}$; estrada $a_{2}$ estrada cubierta ou estrada encubierta; falda; flanco 2 ; flanco del orejón; frente 3 ; frente 4 ; galería 1 garita; gola; media gola; hornillo, horno ou mina $;$; media luna $;$; merlón; orejón; parapeto ou pretil; plataforma $;$; plaza 4 ou revellín 2 ; plaza alta, plaza de arriba, plaza superior ou través alto; plaza baja, plaza de abajo ou través bajo; puerta del socorro; rastrillo; refosete ou refoso; revellín 1 ; roca, roca de homenaje ou torre de(l) homenaje; ronda; salida 2 ou surtida 2 ; surtida 3 ; tenaza 3 ; terraplén 1 ou terrapleno; tijera $_{1}$; través 2 ; traviesa $a_{3}$ e zapa 1.

O seguinte campo semântico reúne todas as construções defensivas detetadas no corpus. Queremos precisar que com esta denominação nos referimos a todas aquelas fábricas ou edifícios que, embora possam formar parte de um recinto maior, o normal é que sejam já por si sós defesas suficientemente efetivas: aproche $_{1} ;$ atalaya $_{1} ;$ baluarte $_{2} ;$ baluarte $_{3}$, bastión $n_{1}$, caballero $_{3}$ ou plataforma 2 ; barraca ou fajinada $_{2}$; barrera; batería 4 ou plataforma; contrabatería 3 ; blinda 2 ; casa fuerte; castillo 1 ou

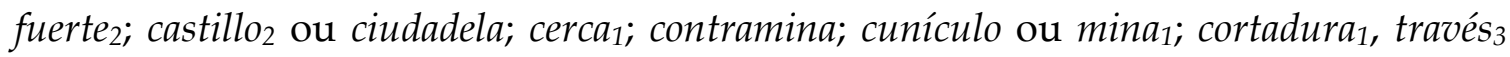
ou traviesa $a_{1}$ cortadura $a_{2}$ ou retirada 2 ; empalizada, estacada $a_{1}$ palenque ou palizada 1 estrella; fortaleza, fuerza 1 ou plaza 2 ; galería 2 ou traviesa 2 ; gavionada; hornillo ${ }_{2}$ ou mina; media luna 2 ; plaza 1 ou plaza fuerte; presidio 2 ; reducto; reparación ou reparo 3 ; torre 1 ou torreón; trinchera; trincherón 1 ; trincherón 2 e valla, valladar ou vallado 2. 
Devemos mencionar, igualmente, uma série de qualidades suscetíveis de aplicar-se às fábricas de fortificação, bem como ao lugar ou ao terreno que alberga

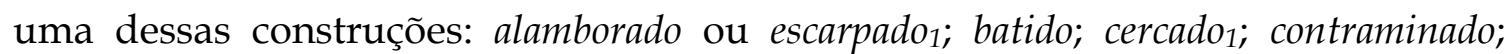
minado; defensible; expugnable; inexpugnable 1 ou inexpuñable; fortalecido, fortificado, fuerte $_{1}$ ou reparado ${ }_{2}$ guardado ${ }_{3}$; minable; murado; real ${ }^{1}$; terraplenado; torreado e vallado1.

No âmbito militar são muito importantes as munições, que são identificadas no DRAE com os "pertrechos y bastimentos necesarios en un ejército o en una plaza de guerra". Por sua vez, ao passo que pertrechos designa 'toda clase de materiales e instrumentos, como pueden ser armas o máquinas, necesarios para cualquier empresa militar', bastimento refere-se ao 'conjunto de comestibles destinados a la alimentación de un ejército'. Assim pois, além destes três termos, bem como dos seus possíveis sinónimos, pertencem a este campo os seguintes: abrojo; bagaje ou rastro; balón, saco ${ }^{1}$ ou saca; blinda ; cabalgada $_{3}$; caballo ou cabrilla; camisa $_{2}$; candelero; césped, gasón ou tepe; cesta ou cesto; cestón ou gavión; convoy; cuento; despojo 2 ou presa $a_{3}$; escala 1 fajina 1 fajinada f forraje $_{1}$; manta 1 ; pabellón; pilotaje; pilote; presa 4 ; salchicha $;$; salchichón; socorro 4 ; tienda e zarzo.

Um tipo especial de munições é constituído pelas distintas máquinas de guerra que compilámos: arcubalista; ariete, carnero ou vaivén; balista, ballesta ${ }_{1}$, ballestón ou ballestón de torno; catapulta; causera; compago; cuervo; escorpión; galápago, testúdine ou testudo; lobo ou lupo; manta $a_{2}$ ou mantelete; máquina mural; músculo; onagro; plúteo; sambuca; testudo arietaria; torre, trabuco e vínea.

Por outro lado, menor número de vozes são as que designam armas ou explosivos empregues na guerra: ballesta $_{2} ;$ batería $_{3}$ ou camarada $a_{2}$ contrabatería $a_{2}$; ceñido; ceñir 3 ; explanada, lechera ou plataforma; falárica; hornillo 3 e salchicha 2 . São poucos os instrumentos ou ferramentas tidos em consideração: tenaza $a_{1}$, tenazante, tenazón e zapa 2 .

Ao contrário dos anteriores, as vozes relacionadas com a tática constituem um grupo de entidade. Devemos mencionar, em primeiro lugar, batalla 3 , assim como o seu sinónimo orden de (la) batalla, já que designam a 'disposición de las 
tropas que se juzga más adecuada para un combate, para atacar o para operaciones militares similares'. Denotam, pelo contrário, formações táticas concretas os seguintes termos: batallón, escuadrón ou tropel; cerca 3 ou muro $;$ cuadro; cúneo, cuño ou diente 2 ; escuadrón falso e fórfice, tenaza 4 ou tijera 2 . Por sua vez, ala, costado 1 ou cuerno; avanguarda, avanguardia, vanguarda ou vanguardia; retaguarda, retaguardia ou rezaga; batalla $a_{4}$ ou cuerpo de (la) batalla; batalla ${ }_{5}$ ou ordenanza; escuadrón volante; flanco ${ }_{1}$; frente2; hila, hilada, hilera ou orden e manga aludem a partes ou elementos constituintes das distintas agrupações criadas com o fim de lutar, marchar e realizar as empresas próprias dos soldados. Completam esta série as seguintes locuções adverbiais: en ala; a la avanguardia, en avanguardia ou en vanguardia; en retaguardia ou en rezaga; a la deshilada ${ }_{1}$ e en hilera.

Damos conta, em seguida, de todos os vocábulos relacionados com cerimónias ou acontecimentos militares: alarde 2 ; ovación; rendido 2 ; rendir 5 ; triunfador ou triunfante $_{2} ;$ triunfante $_{1}$; triunfar 2 e triunfo. Pelo contrário, batalla $a_{2}$, contienda 1 ou guerra; paz1; en campaña ou en campo; guerra civil; guerra defensiva; guerra ofensiva; guerrear e militar ${ }^{1}$ sugerem estados ou situações que se prolongam ao longo do tempo.

Também teve lugar neste trabalho a terminologia concernente aos sinais, tanto verbais, como musicais e inclusive visuais, de que se servem os exércitos com múltiplos objetivos: ahumada, alborada, apellido2, tocar a botasilla, sonar a caballo, contraseña ou contraseño, diana, nombre, rebato e dar rebato.

Por sua vez, as seguintes indicam localizações espaciais de relevância no âmbito da milícia: alojamiento ${ }_{2}$, campaña ou campo 1 , campo ou real ${ }_{1}{ }_{1}$, campo ou campo de la batalla, cuerpo de (la) guarda 2 ou cuerpo de guardia 2 , explanada, padrastro, plaza 3 ou plaza de armas, posta 2 e posta 3 ou puesto.

Finalmente, recolhemos escala, pie pequeño ou pitipié, termos relativos ao instrumento geométrico em que estão representadas uma série de medidas, cujo uso era imprescindível na elaboração do plano ou perfil de uma fortaleza. Devemos mencionar, por último, uma série de magnitudes temporais (alba, cuarto, 
modorra e prima) e espaciais (camisa $a_{3}$ cuartel, estancia ou posada, fondo e frente 1 ) próprias da arte militar.

\section{Considerações linguísticas sobre o léxico da tratadística militar renascentista}

Mesmo quando a precisão, a neutralidade e a estabilidade são as propriedades mais repetidas no momento de falar do léxico técnico, "los términos constituyentes de cada terminología se saltan con frecuencia alguno de estos rasgos, lo que origina no pocos problemas en el uso cotidiano" (Gutiérrez Rodilla 1998: 94). Pois bem, dos vários fenómenos cuja simples presença no discurso especializado pode complicar a sua interpretação, sublinhamos, em primeiro lugar, a sinonímia, seguida da polissemia e da homonímia.

No que respeita à existência de sinónimos, se tivermos em conta que nos períodos iniciais de qualquer disciplina científica ou técnica é quando a necessidade de encontrar denominações precisas para os novos conceitos resulta mais premente, não deve parecer-nos estranho que para a formação dos novos termos se acorra de maneira simultânea a diversos mecanismos neológicos, o que, inevitavelmente, "lleva aneja la concurrencia sinonímica” (Gutiérrez Rodilla 1998: 95).

No momento histórico que nos ocupa, os neologismos por empréstimo foram o recurso linguístico mais explorado perante a necessidade de denominar as novas realidades que iam aparecendo no âmbito da milícia. E é lógico que tanto os italianismos como os galicismos sejam os empréstimos mais representados nesta investigação, já que Itália e França foram as potências cuja presença resultou mais habitual nos distintos cenários bélicos do Renascimento, além de que os principais avanços nesta área do saber tiveram a sua origem nestas nações. Igualmente, os contínuos contactos de alguns espanhóis com franceses e italianos possibilitaram muitos destes derrames léxicos. 
Por exemplo, na tratadística militar renascentista constatamos que para referir-se à "fábrica de tierra apretada y oprimida con que se llena algún vacío o se levanta para defensa" (Aut.) os distintos autores vacilam entre a voz terrapleno, de origem italiano, ou terraplén, de ascendência francesa.

Ora bem, foi tal o prestígio alcançado por Itália e França que se tomaram emprestados vários dos seus termos, inclusive em ocasiões em que não era preciso. Esta é a explicação da abundância de sinónimos resultantes da manutenção do termo tradicional juntamente com outros de ascendência italiana e francesa. Para não resultar prolixos enumeramos tão só alguns deles:

- Desde a sua agregação, a voz víveres, de origem gaulesa, vê-se obrigada a competir com as mais castiças bastimento e vitualla.

- O galicismo tropa, que aparece por primeira vez na primeira metade do Século XVI, acabará eliminando as múltiplas unidades pluriverbais, formadas a partir de gente, com as quais o castelhano contava para se referir ao "grupo regular y organizado de soldados" (DEA: s.v. tropa): gente de (la) batalla, gente de guerra, gente de pelea, gente militar, etc.

- No que concerne o italianismo ciudadela, os primeiros exemplos datam de princípios do Século XVI. Nesta aquisição, além de razões derivadas da autoridade dos engenheiros italianos em matéria de fortificação, deveram também desempenhar um importante papel outras circunstâncias, como pode ser o facto de que castillo, a forma que o castelhano possuía para designar o mesmo conceito que cittadella em italiano, se utilizava já desde a Idade Média em referência a outro tipo de construção defensiva, à que também era possível nomear mediante o vocábulo fuerte. 
Por sua vez, o fenómeno da polissemia é constatável "en el lenguaje de la ciencia, incluso dentro de una misma zona de conocimiento, cuya presencia puede también dificultar la precisión" (Gutiérrez Rodilla 1998: 100). Quiçá o caso mais extremo no léxico militar renascentista seja o do galicismo plataforma. Para esta voz fornecemos no nosso glossário até cinco aceções relevantes.

Em último lugar devemos mencionar o procedimento da homonímia. $\mathrm{Na}$ caracterização desta o que se sublinhou continuamente foi o peso decisivo desempenhado pela etimologia. Assim, face à polissemia, produz-se homonímia só quando dois étimos distintos chegaram no seu desenvolvimento a uma confluência na sua forma fónica, o que implica que haja uma independência semântica. Em consonância com este critério, só encontrámos três casos de homónimos no léxico militar renascentista. 


\section{CONCLUSÕES}

No nosso modo de ver, era necessário e urgente dar vida a um dicionário de especialidade centrado na arte militar, fortificação e temas afins, no qual, por exemplo, não tivessem lugar os nomes próprios e que, como consequência do rigor filológico aplicado na sua composição, oferecesse definições estritamente lexicográficas.

Aspiramos a que o nosso glossário sirva para facilitar a interpretação dos quantiosos tratados militares surgidos ao longo do Século XVI e primeiro quarto do XVII, época em que se assiste, como já pusemos de manifesto anteriormente, ao apogeu na produção deste tipo de textos.

Este trabalho lexicográfico está restringido à análise do léxico da fortificação e da poliorcética, além da tática, estratégia, logística e castrametação. Podemos afirmar que os campos léxicos representados pelos vocábulos que constituem a macroestrutura do nosso glossário são muito variados.

Em primeiro lugar, o âmbito militar mais fecundo, sem dúvida, corresponde às ações bélicas, ao dispor de até 160 manifestações.

Consequentemente, outra área semântica profusa é a constituída pelos numerosos sujeitos que intervêm nalguma operação de guerra. Dentro deste conjunto devemos incluir também os membros das distintas unidades ou grupos militares, o que gera um total de 50 conceitos, face aos 26 que se referem antes aos grupos ou conjuntos militares em si.

$\mathrm{O}$ facto de termos atendido aos personagens que atuam numa guerra, conduziu-nos a recompilar igualmente os adjetivos que indicam qualidades próprias dos soldados, dos exércitos ou de qualquer outra coletividade suscetível de participar num conflito armado, dos quais contabilizámos um total de 59.

Os tratados manuseados revelam distintos tipos de qualidades ou atributos, como demonstra a deteção de outras 24 propriedades aplicáveis não a indivíduos, 
mas sim a objetos de relevância na fortificação e inclusive ao lugar que alberga alguma construção defensiva, por exemplo.

As vozes técnicas que designam as partes que compõem um recinto fortificado constituem outro campo semântico importante, ao aglutinar 69 elementos suscetíveis de se encontrarem numa fortaleza moderna e 3 mais específicos das medievais.

Por sua vez, as 37 construções achadas que, face às do grupo anterior, podem constituir por si sós defesas suficientemente efetivas dão boa conta da alta representatividade de que goza este âmbito na nossa parcela terminológica.

Também atendemos a uma série de verbos e substantivos que denotam até 31 trabalhos distintos tipicamente desenvolvidos na edificação de fortalezas.

Devemos destacar, assim, o campo das munições, isto é, o dos "pertrechos y bastimentos necesarios en un ejército o en una plaza de guerra" (DRAE: s.v. munición), encarnado por 31 modalidades diferentes. Somos conscientes de que as 24 máquinas de guerra de que nos ocupámos deveriam ser contabilizadas juntamente com o resto dos apetrechos militares, no entanto, dada a sua transcendência, considerámos mais oportuno consigná-las à parte.

Os tecnicismos da tática resultam igualmente numerosos, ao passo que outras áreas lexicais menos produtivas são as da logística, castrametação e estratégia, além das constituídas pelas unidades lexicais que designam distintos tipos de acontecimentos ou cerimónias militares, por um lado, e as técnicas ou ofícios, bem como as pessoas que as cultivam, por outro.

Vejamo-lo de maneira gráfica: 


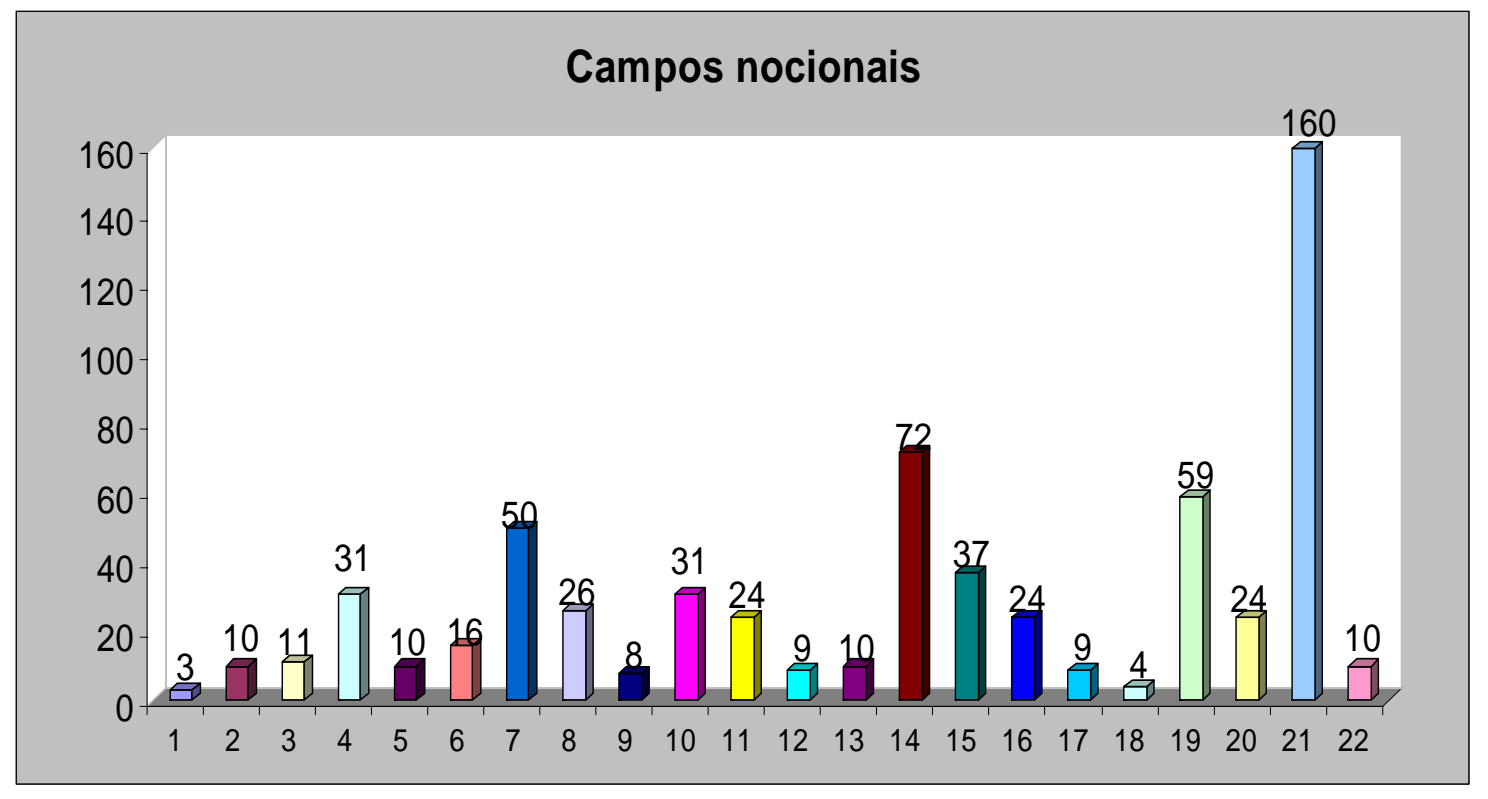

\begin{tabular}{|l|r|}
\hline \multicolumn{2}{|c|}{ LEmpo nocional } \\
\hline \multicolumn{2}{|c|}{ CampA } \\
\hline Técnicas ou artes e profissões & $N^{o}$ \\
\hline Ações de castrametação & 2 \\
\hline Ações de logística & 3 \\
\hline Ações de fortificação e de construção & 4 \\
\hline Ações de estratégia & 5 \\
\hline Acontecimentos ou cerimónias militares & 6 \\
\hline Membro de unidades ou grupos militares & 7 \\
\hline Unidades ou grupos militares & 8 \\
\hline Pessoa que desempenha ofício/cultiva técnica & 9 \\
\hline Munições & 10 \\
\hline Tática & 11 \\
\hline Magnitudes temporais e espaciais & 12 \\
\hline Toques e sinais militares & 13 \\
\hline Elementos de fortificação & 14 \\
\hline Construções defensivas & 15 \\
\hline Máquinas de guerra & 16 \\
\hline Armas ou explosivos & 17 \\
\hline Instrumentos ou ferramentas & 18 \\
\hline Qualidades militares & 19 \\
\hline Qualidades de fortificação & 20 \\
\hline Ações bélicas & 21 \\
\hline Lugares militares & 22 \\
\hline
\end{tabular}


Da consideração de todas estas esferas da arte militar resulta uma macroestrutura constituída por 1149 entradas, que se repartem da seguinte maneira: 593 lemas encabeçam o artículo lexicográfico, 133 são remissões de unidades pluriverbais (estruturas sintagmáticas e locuções) e 423 são remissões de variantes ortográficas. Outras 421 fichas lexicográficas correspondem a subentradas tratadas na microestrutura, as quais se repartem entre aceções (290) e unidades sintagmáticas e locuções (131 no total), respetivamente.

No que concerne as entradas, estas compreendem 387 substantivos, 121 verbos, 84 adjetivos e um único advérbio, se bem que esta última classe de palavras conta com uma maior representação graças às 16 locuções adverbiais listadas. Como também tivemos em consideração o resto das unidades pluriverbais, as distintas categorias gramaticais viram o seu domínio acrescentado. Desta forma, ao incluir no nosso glossário 8 locuções adjetivas e 36 verbais, 92 foram os adjetivos definidos ao todo, ao passo que a quantia exata de verbos é 157.

No que respeita os compostos sintagmáticos, um total de 71 unidades pluriverbais do nosso glossário podem ser catalogadas como tais. Graças a este peculiar mecanismo de formação de palavras, cujo produto final equivale a um nome, finalmente integram o nosso trabalho lexicográfico 458 formas nominais. Em qualquer caso, a este cômputo deveriam somar-se mais 25 substantivos, produto de um processo de recategorização, também designado neologia sintática, “consistente en el cambio de categoría gramatical de un elemento o en su cambio de función" (Gutiérrez Rodilla 1998: 152). 


\section{Categorias gramaticais}
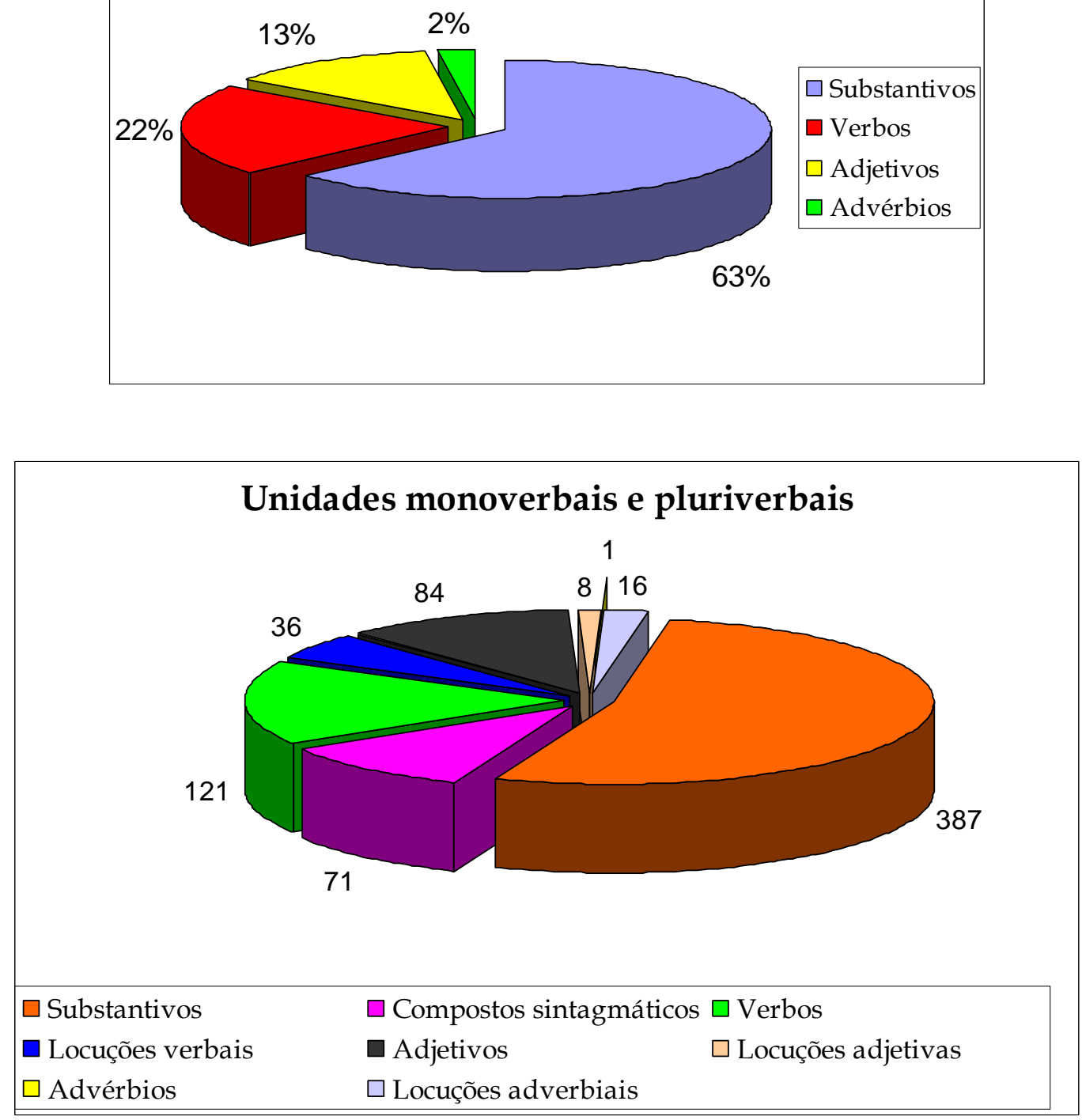

Por outro lado, a elaboração da nossa investigação de um ponto de vista linguístico possibilitou-nos advertir uma questão que praticamente não foi contemplada: a exploração no âmbito da milícia dos distintos recursos de formação de neologismos existentes, processo motivado pela necessidade imperiosa de alcançar uma terminologia eficaz com a qual aludir às novas realidades militares que o início da modernidade acarreta. 
No que respeita à procedência dos termos lematizados, a língua latina é sem lugar a dúvida a mais representada, dado que das 336 vozes castelhanas devidas a influências externas, a maioria (209, um pouco mais de 62\%), deriva única e exclusivamente dela. Por outro lado, ao contabilizar 123 vozes patrimoniais e 86 latinismos, resulta evidente a supremacia do caudal hereditário ou popular, muito embora seja certo que o culto também conta com uma forte presença.

Os restantes termos, que computam quase $38 \%$, ou são empréstimos de outras línguas ou criações de origem expressivo, como tepe e picar. Embora no caso de chocar "una onomatopeya autóctona no es imposible" (DECH), como a nossa língua também poderia ter adotado esta voz a partir da francesa choquer, considerámos finalmente a sua origem incerta, em consonância com Corominas e Pascual. Ora bem, não é esta a única etimologia duvidosa existente no léxico militar moderno, segundo acreditam os outros 7 vocábulos cuja origem também é considerada problemática pelo DECH: alambor, estribo, galápago, sitio, tomar, vaivén e zanja.

A propósito das línguas emprestadoras, os tecnicismos militares detetados provêm, além do latim, do árabe, germânico, francês, occitano, catalão e italiano, se bem que o mais certo é que também possamos falar, no caso da palavra barrunte, de um basquismo.

Como não podia ser de outra maneira, os italianismos, primeiro, e os galicismos, depois, com 47 e 35 casos cada um, depois dos de origem latina, são os tipos de empréstimos mais representados. São também numerosos os catalanismos, entre os quais deparamos com construções defensivas, como barraca, palenque e revellín, partes ou elementos de que constam algumas formações táticas, por exemplo vanguardia e retaguardia, junto a outras realidades militares bem diferentes destas.

Apesar da limitada influência árabe a que o nosso sistema militar se viu submetido durante o Renascimento, face à situação detetada em épocas anteriores, 
pudemos localizar 9 arabismos, se bem que seja certo que muitos já eram usuais na Idade Média (alarde, atalaya, barbacana e real).

Por último, enquanto 4 vocábulos possuem uma origem occitana, 7 devem a sua presença em castelhano a alguma modalidade linguística germânica.
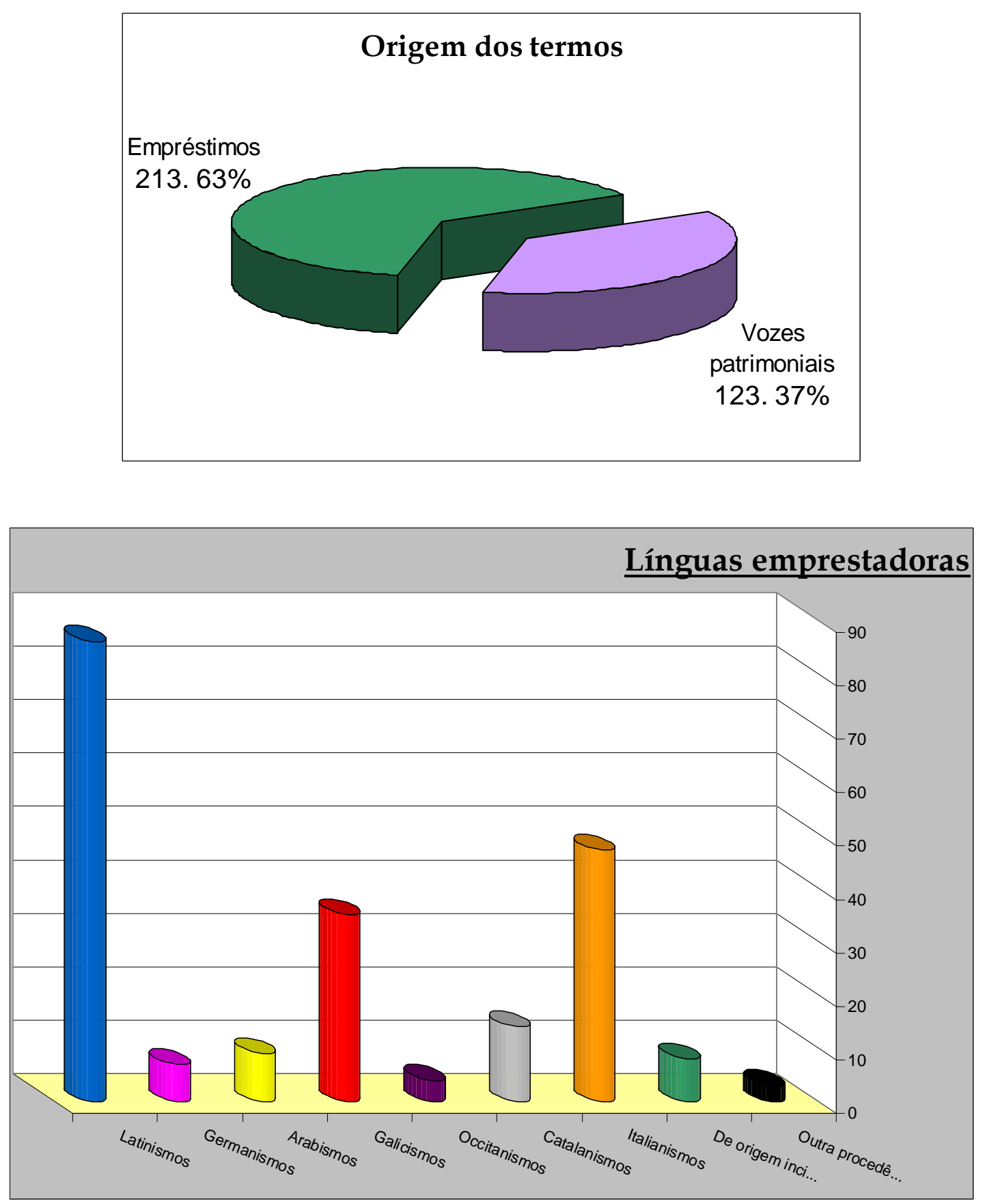
De acordo com o anteriormente exposto, dos 593 lemas de cabeceira estabelecidos 123 resultaram ser vozes patrimoniais e 213 empréstimos de outras línguas, pelo que, em definitiva, 257 termos do nosso âmbito terminológico respondem a alguns dos mecanismos internos de criação léxica disponíveis em castelhano, entre os que sobressaem a derivação e a composição.

A respeito destes mecanismos, as unidades criadas por meio da sufixação nominal são as mais numerosas (contabilizámos 126 vozes), grupo do qual despontam em especial os nomina actionis, originados mediante uma grande variedade de sufixos: os átonos pós-verbais $-a,-e$ e -0 , além de -miento, -sión e os alomorfes $-a d a$, no caso de acrescer-se a verbos da primeira conjugação (escalada e retirada, entre outros exemplos), e -ida, para os verbos da segunda e terceira (como manifestam acometida, arremetida, corrida e salida).

De todas as formas, entre os sufixados nominais também encontramos outros significados, dos quais sublinhamos os seguintes:

- Coletividade ou pluralidade com o afixo - ada, e nesta ocasião a partir de bases nominais: estacada, fajinada, gavionada e hilada.

- Nomina agentis, entre os quais devemos ressaltar, dada a sua profusão, os originados mediante o sufixo deverbal -dor e o denominal -ero: asediador, acometedor, conquistador, fortificador, murador, ballestero, forrajero e viandero, citando só alguns. Também destacamos um par de casos portadores de -nte: asaltante $\mathrm{e}$ combatiente.

- Por sua vez, o alomorfe feminino de -ero desenvolve a capacidade de derivar substantivos que designam lugares: barrera, cañonera, saetera e tronera.

De igual forma, na configuração do léxico militar desempenha uma função capital o fenómeno da lexicalização de vários sufixos apreciativos, sobretudo -ón 
(ballestón, cestón, escalón e trincherón, entre outros), mas também -ete (refosete), o seu alomorfe-eta (banqueta), bem como-illo (hornillo) e-uelo (herreruelo).

Por último, recolhemos 7 termos que respondem ao procedimento morfológico da derivação genérica ou relação derivativa: cesto, grada, manta, modorra, ofensiva, saca e traviesa.

Por sua vez, contabilizámos 56 adjetivos formados com algum destes sufixos: -ble, -do, -dor, -ero, -esco, -ivo, -izo, -nte y -oso. Constituem outra modalidade derivativa os 22 sufixados verbais, portadores dos afixos -ar e -ear, que são predominantes, enquanto são limitados os derivados com -ecer.

A propósito da categoria verbal, encontrámos 18 verbos resultado de um procedimento de derivação prefixal: acometer, arremeter, asitiar, contraminar, desalojar, desbaratar, descercar, descoser, descubrir, desguarnecer, deshacer, desitiar, desocupar, enfortalecer, rebatir, rebotar, remeter e retirar. Como se pode constatar, é chamativa a produtividade do prefixo des-, e especialmente com a função de transferir para os verbos resultantes um significado reversivo.

$\mathrm{Na}$ origem de numerosos tecnicismos verbais da arte militar, subjaz o mecanismo morfológico da parassíntese. Dos vários esquemas existentes, devemos sublinhar a relevância de $a_{-}+$sustantivo $+-a r$, de que dão boa conta acampar, acosar, acuartelar, alistar, amotinar, amunicionar, apremiar, apretilar, atrincherar $\mathrm{e}$ avituallar.

Por outro lado, contamos com 15 substantivos portadores de prefixos: contraescarpe, contraforte, contrafosa, contramina, contramuro, contrarronda, contraseña, contraseño, empalizada, reencuentro, refoso, reseña, rezaga, sobrerronda e sobrevela. Como evidenciam os 8 casos citados, o prefixo mais rentável é sem dúvida contra-, quer com um significado posicional quer com o de oposição.

Finalmente, os procedimentos derivativos menos rentáveis, com um representante cada um, são a prefixação adjetival (invencible, de vencible) e a sufixação adverbial (belicosamente). 


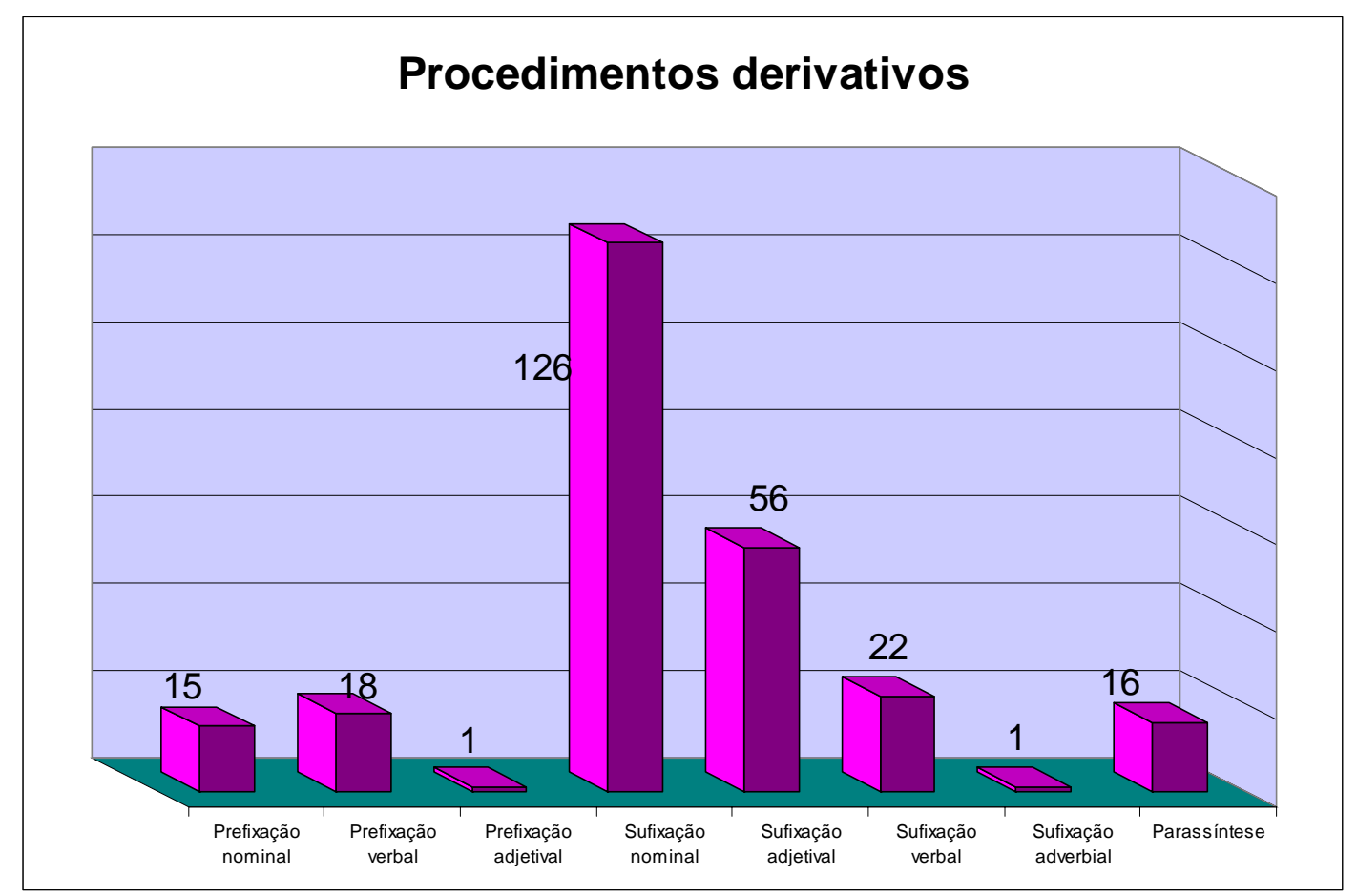

Em consequência, enquanto 255 lemas foram gerados mediante algum dos distintos mecanismos derivativos de que dispõe a nossa língua, só 2 entradas respondem ao procedimento morfológico da composição léxica: casamuro e rodapié. Pode observar-se a representatividade dos distintos procedimentos morfológicos no seguinte gráfico, em que se contemplam igualmente as unidades pluriverbais.

\section{Procedimentos morfológicos}

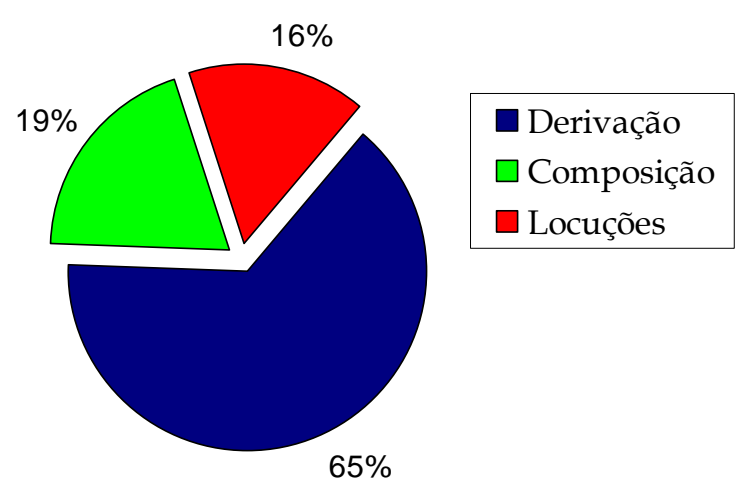




\section{REFERENCIAS BIBLIOGRÁFICAS CONSULTADAS}

\section{Corpus del Diccionario de la ciencia y de la técnica del Renacimiento español (DICTER)}

ACOSTA, Joseph de (1590): Historia natural y moral de las Indias. Libro IV. Sevilla: Juan de León.

Álaba y Viamont, Diego de (1590): El perfeto capitán instruido en la diciplina militar y nueva ciencia de la Artillería. Madrid: Pedro Madrigal.

Alberto, León Baptista (1582): Los diez libros de Architectura. Madrid: Alonso Gómez, trad. Francisco Loçano.

AlCEGA, Juan de (1589): Libro de Geometría prática y traça. Madrid: Guillermo Drouy. AlONSO BARBA, Álbaro (1640): Arte de los metales. Madrid: Imprenta del Reyno.

ANÓNIMO (1527): Ordenanças sobre el obraje de los paños, lanas, bonetes y sombreros, nuevamente hechas. Burgos: s. n.

ANÓNIMO (1538): Leyes, ordenanças, premáticas y declaraciones de las ordenanças antiguas que hablan del obrage de las lanas e paños. Sevilla: s. n., (1. ${ }^{\text {ed., Toledo, }}$ s. n., 1528).

ANÓNIMO (1552): La premática que Su Magestad ha mandado hazer... para que ningún mercader ni tratante... no traten ni vayan a las ferias de León... Alcalá de Henares: Joán de Mey.

ANÓNIMO (1554): Repertorio de los tiempos. Valladolid: Francisco Fernández de Córdova.

ANÓNIMO (1574): Pragmática y declaración sobre juegos. Madrid: Alonso Gómez.

ANÓNIMO (mss. ca. 1631): Diálogo entre un bizcaýno y un montañés sobre la fábrica de navíos.

APIANO, Pedro (1575): Cosmographía. Anvers: Juan Bellero, trad. anónimo (1. a ed., Enveres, Gregorio Bontio, 1548).

ARPHE DE VILlAFAÑE, Joán (1572): Quilatador de la plata, oro y piedras. Valladolid: Alonso y Diego Fernández de Córdova.

ARPHE Y VILLAFAÑE, Juan de (1585-87): De varia conmensuración para la Escultura y Arquitectura. Sevilla: Andrea Pescioni y Juan de León. 
Aurel, Marco (1552): Libro primero de Arithmética algebrática. Valencia: Joán de Mey.

BELVEDER, Joán de (1597): Libro general de la reduciones de plata y oro. Lima: Antonio Ricardo.

BESSON, Diego (1602): Teatro de los instrumentos y figuras matemáticas y mecánicas. León de Francia, Horacio Cardon.

CANO, Thomé (1611): Arte para fabricar, fortificar y aparejar naos de guerra y merchante. Sevilla: Luis Estupiñán.

Castillo, Diego del (1551): Tratado de cuentas. Salamanca: Juan de Junta (1. ${ }^{\text {a }}$ ed., Burgos, Alonso de Melgar, 1522).

CELSO, Hugo de (1553): Reportorio universal de todas las leyes d'estos reynos de Castilla. Medina del Campo: Juan María da Terranova y Jacome de Liarcari (imprenta de Francisco del Canto), comp. Andrés Martínez de Burgos.

Collado De LebriXA, Luys (1592): Plática manual de Artillería. Milán: Pablo Gotardo Poncio.

CORTÉS DE AlBACAR, Martín (1556): Breve compendio de la sphera y de la arte de navegar. Sevilla: Antón Álvarez, (1. a ed., Sevilla, Antón Álvarez, 1551).

ÇAMORANO, Rodrigo (1588): Compendio del arte de navegar. Sevilla: Joán de León (1. ${ }^{a}$ ed., Sevilla, Alonso de la Barrera, 1581).

DAÇA DE VALDÉS, Benito (1623): Uso de los antojos para todo género de vistas. Sevilla: Diego Pérez.

Escalante, Bernardino de (1577): Discurso de la navegación. Sevilla: Biuda de Alonso Escrivano.

EUCLIDES (1584-85): La perspectiva y especularia. Madrid: Viuda de Alonso Gómez, trad. Pedro Ambrosio Ondériz.

FALERO, Francisco (1535): Tratado del esphera y del arte del marear. Sevilla: Juan Cromberger.

FERNÁNDEZ DE ENCISO, Martín (1530): Suma de Geographía. Sevilla: Juan Cromberger, (1. a ed., Sevilla, Jacobo Cromberger, 1519).

FERROFINO, Julián (mss. 1599): Descrizión y tratado muy breve y lo más probechoso de Artillería.

FINEO, Oroncio (mss. 1553): Los dos libros de la Geometría práctica, trads. Hierónimo Girava y Pedro Juan de Lastanosa.

GARCÍA DE CÉSPEDES, Andrés (1606): Libro de instrumentos nuevos de Geometría. Madrid: Juan de la Cuesta.

García de PAlacio, Diego (1583): Diálogos militares. México: Pedro Ocharte.

GARCÍA de PALACIO, Diego (1587): Instrucción náuthica. México: Pedro Ocharte.

GonZÁlez de MedinA, Diego (1599): Examen de fortificación. Madrid: Pedro Várez de Castro. 
Helt Frisio, Hugo (1549): Declaración y uso del relox español. Salamanca: Juan de Junta, trad. Francisco Sánchez de las Broças.

HerrerA, Juan de (1584): Institución de la Academia Real Mathemática. Madrid: Guillermo Droy.

LechugA, Cristóval (1611): Discurso del Capitán Cristóval Lechuga, en que trata de la Artillería y de todo lo necessario a ella. Milán: Marco Tulio Malatesta.

LlANOS, García de (mss. ca. 1609-11): Diccionario y maneras de hablar que usan en las minas.

LOBATO, Francisco (mss. a. 1585): Notas.

LÓPEZ DE ARENAS, Diego (mss. 1619): Primera y sigunda parte de las reglas de la carpintería.

MARTÍNEZ DE ARANDA, Xinés (mss. ca. 1599): Zerramientos i trazas de montea.

MARTíNEZ DE BuRGOS, Andrés (1551): Reportorio de todas las premáticas y capítulos de Cortes (1523-1551). Medina del Campo: Guillermo de Millis.

MedinA, Pedro de (1545): Arte de navegar. Valladolid: Francisco Fernández de Córdova.

MEDINA, Pedro de (1563): Regimiento de navegación. Sevilla: Simón Carpintero.

MENDOÇA, Bernardino de (1596): Theórica y práctica de guerra. Anveres: Imprenta Plantiniana (1. ${ }^{\mathrm{a}}$ ed., Madrid, Viuda de P. Madrigal, 1595).

Micón, Josepe (1578): Diario y juyzio del grande cometa. Barcelona: Jayme Sendrat.

Molina CANO, Joán Alfonso de (1598): Descubrimientos geométricos. Anveres: Andrea Bacx.

Molina CANO, Joán Alfonso de (1599): Nuevos descubrimientos geométricos. Anveres: Andrea Bacx.

MONTES, Diego (1537): Instrucción y regimiento de guerra. Zaragoza: George Coci.

Mosquera DE FIgueroA, Christóval (1596): Comentario en breve compendio de disciplina militar. Madrid: Luis Sánchez.

MuÑoz, Hierónimo (1573): Libro del nuevo cometa. Valencia: Pedro de Huete.

NebrijA, Antonio de (s. a. [1517]): Tabla de la diversidad de los días y horas. s. 1. (Alcalá de Henares): s. n. (Arnao Guillén de Brocar).

NúÑEZ, Pedro (1567): Libro de Álgebra en Arithmética y Geometría. Anvers: Herederos de Arnoldo Birckman.

OrtegA, Juan de (1512): Conpusición de la arte de la Arismética y de Geometría. León de Francia, Maistro Nicolau de Benedictis (por Joannes Trinxer).

PÉREZ DE MOYA, Juan (1562): Arithmética práctica y speculativa. Salamanca: Mathías Gast.

PÉreZ DE MoYA, Juan (1589): Manual de contadores. Madrid: Pedro Madrigal.

PÉREZ VARGAS, Bernardo (1568): De re metallica. Madrid: Pierres Cosin. 
PoçA, Andrés de (1585): Hydrografía. Bilbao: Mathías Mares.

PSEUdo JuANELO TuRriAnO (mss. a. 1605): Los veinte y un libros de los yngenios y máquinas.

RoIZ, Pedro (1575): Libro de los reloges solares. Valencia: Pedro de Huete.

RojAS, Christóval de (1598): Teórica y práctica de fortificación. Madrid: Luis Sánchez.

ROJAS, Christóval de (1613): Compendio y breve resolución de fortificación. Madrid: Juan de Herrera.

ROXAS, Christóval de (mss. 1607): Sumario de la milicia antigua y moderna.

SACRobosco, Juan de (1545): Tractado de la sphera. Sevilla: Juan de León, trad. Hierónymo de Chaves.

SAGREDO, Diego de (1526): Medidas del Romano. Toledo: Remon de Petras.

SANCTIAGO, Diego de (1598): Arte separatoria. Sevilla: Francisco Pérez (por Rodrigo Cabrera).

SANTA CRUZ, Alonso de (mss. a. 1567): Libro de las longitúdines.

TOVAR, Simón de (1595): Examen i censura del modo de averiguar las alturas de las tierras. Sevilla: Rodrigo de Cabrera.

UfAnO, Diego (1613): Tratado de la Artillería. Brusselas: Juan Momarte.

VALLE DE LA CERDA, Luys (1600): Desempeño del patrimonio de Su Magestad por medio de los erarios públicos y montes de piedad. Madrid: Pedro Madrigal.

VALLES DE COVARRUBIAS, Francisco de (1592): Tratado de las aguas destiladas. Madrid: Luis Sánchez.

VANDELVIRA, Alonso de (mss. ca. 1591): Libro de traças de cortes de piedras.

VignOLA, Jacome de (1619): Regla de las cinco órdenes de Architectura. Madrid: Vicencio Carducho, trad. Patritio Caxesi.

Vitruvio Pollión, Marco (1582): De Architectura. Alcalá de Henares: Juan Gracián, trad. Miguel de Urrea. 


\section{1. LISTADO ABREVIADO DE AUTORES}

Acosta, Historia natural, 1590

Álaba, Perfeto capitán, 1590

Alcega, Geometría prática, 1589

Alonso Barba, Arte de los metales, 1640

Anónimo, Ordenanças paños, 1527

Anónimo, Leyes lanas e paños, 1538

Anónimo, Premática ferias de León..., 1552

Anónimo, Repertorio tiempos, 1554

Anónimo, Pragmática juegos, 1574

Anónimo, Diálogo fábrica de navíos, ca. 1631

Apiano, Cosmographía, 1575

Arphe, Quilatador de la plata, 1572

Arphe, Varia Commensuración, 1585-87

Aurel, Arithmética algebrática, 1552

Belveder, Reduciones plata y oro, 1597

Besson, Teatro instrumentos, 1602

Cano, Arte para fabricar naos, 1611

Castillo, Tratado de cuentas, 1551

Caxesi, Vignola, Regla cinco órdenes, 1593 = VignOLA, Jacome de (1619): Regla de las cinco órdenes de Architectura. Madrid: Vicencio Carducho, trad. Patritio Caxesi.

Celso, Reportorio universal leyes Castilla, 1553

Chaves, Sacrobosco, Sphera, 1545 = SACROBOsCO, Juan de (1545): Tractado de la sphera. Sevilla: Juan de León, trad. Hierónymo de Chaves.

Collado, Plática Artillería, 1592

Cortés de Albacar, Breve compendio sphera, 1556

Çamorano, Compendio arte de navegar, 1588

Daça de Valdés, Uso de los antojos, 1623

Escalante, Discurso de la navegación, (1577)

Falero, Tratado del espera, 1535

Fernández de Enciso, Suma de Geographía, 1530

Ferrofino, Descrizión Artillería, 1599

García de Céspedes, Instrumentos nuevos, 1606

García de Palacio, Diálogos militares, 1583 
García de Palacio, Instrución náuthica, 1587

Girava, Fineo, Geometría práctica, 1553 = FINEO, Oroncio (mss. 1553): Los dos libros de la Geometría práctica, trads. Hierónimo Girava y Pedro Juan de Lastanosa.

González de Medina, Examen fortificación, 1599

Herrera, Institución Academia, 1584

Juanelo Turriano, Veinte y un libros, a. 1605 = PSEUdO JUANELO TURRIANO (mss. a. 1605): Los veinte y un libros de los yngenios y máquinas.

Lechuga, Discurso de la Artillería, 1611

Llanos, Diccionario minas, ca. 1609-11

Lobato, Notas, a. 1585

Loçano, Alberto, Architectura, 1582 = ALBERTO, León Baptista (1582): Los diez libros de Architectura. Madrid: Alonso Gómez, trad. Francisco Loçano.

López de Arenas, Reglas de la carpintería, 1619

Martínez de Aranda, Zerramientos montea, ca. 1599

Martínez de Burgos, Reportorio premáticas y Cortes, 1551

Medina, Arte de navegar, 1545

Medina, Regimiento de navegación, 1563

Mendoça, Theórica y práctica, 1596

Micón, Diario grande cometa, 1578

Molina Cano, Descubrimientos geométricos, 1598

Molina Cano, Nuevos descubrimientos, 1599

Montes, Instrucción y regimiento, 1537

Mosquera, Comentario disciplina militar, 1596

Muñoz, Libro nuevo cometa, 1573

Nebrija, Tabla días y horas, 1517

Núñez, Álgebra en Arithmética, 1567

Ondériz, Euclides, Perspectiva y especularia, 1584-85 = EUCLIDES (1584-85): La perspectiva y especularia. Madrid: Viuda de Alonso Gómez, trad. Pedro Ambrosio Ondériz.

Ortega, Conpusición Arismética y Geometría, 1512

Pérez de Moya, Arithmética práctica, 1562

Pérez de Moya, Manual de contadores, 1589

Pérez Vargas, De re metallica, 1568

Poça, Hydrografía, 1585

Roiz, Reloges solares, 1575

Rojas, Teórica fortificación, 1598

Rojas, Compendio fortificación, 1613 
Roxas, Sumario milicia, 1607

Sagredo, Medidas Romano, 1526

Sánchez de las Broças, Helt Frisio, Relox español, 1549 = Helt Frisio, Hugo (1549):

Declaración y uso del relox español. Salamanca: Juan de Junta, trad. Francisco Sánchez de las Broças.

Sanctiago, Arte separatoria, 1598

Santa Cruz, Libro de las longitúdines, a. 1567

Tovar, Examen alturas, 1595

Ufano, Tratado de la Artillería, 1613

Urrea, Vitruvio, Architectura, 1582 = VITRUVIO POLlión, Marco (1582): De Architectura. Alcalá de Henares: Juan Gracián, trad. Miguel de Urrea.

Valle de la Cerda, Desempeño patrimonio, 1600

Valles, Tratado aguas destiladas, 1592

Vandelvira, Traças de cortes, ca. 1591 


\section{Repertorios lexicográficos generales y especializados}

AGAR, Luis de (1853-1866): Diccionario ilustrado de los pertrechos de guerra y demás efectos pertenecientes al material de artillería. Madrid: Lit. Tormentaria de C. Echauri.

Alcover, Antoni M ${ }^{\mathrm{a}}$ y F. de B. Moll (1935): Diccionari català-valencià-balear. Palma de Mallorca: Imprenta Mn. Alcover. (DCVB).

Alemany y Bolufer, José (1917): Diccionario de la lengua española. Barcelona: Ramón Sopena.

AlmiRANTE, José (2002 [1869]): Diccionario militar. Madrid: Ministerio de Defensa.

BAtTAGLiA, Salvatore (1961-2002): Grande dizionario della lingua italiana. Torino: Unione Tipografico-Editrice Torinese, 21 vols.

BATTISTI, Carlo y Giovanni AlESSIO (1975): Dizionario etimologico italiano. Firenze: G. Barbèra Editore, Università degli Studi, 5 vols.

Beltrami, Pietro (dir.) (en red): Tesoro della lingua italiana delle origini. (TLIO): $<$ http://tlio.ovi.cnr.it/TLIO $>$.

Borreguero Beltrán, Cristina (2000): Diccionario de historia militar. Barcelona: Ariel.

CAÑADA y GISBERT, Antonio (1878): Diccionario tecnológico inglés-español. Segovia: Imprenta de P. Ondero.

CASTAÑÓN, Luis (1791-1792): Encyclopedia metódica. Madrid: Imprenta de Sancha, 2 vols.

CASTRO y RossI, Adolfo de (1852): Biblioteca universal. Gran diccionario de la lengua española [...]. Madrid: Oficinas y establecimiento tipográfico del Seminario Pintoresco y de la Ilustración.

Clairac y SÁenZ, Pelayo (1877-1891): Diccionario general de arquitectura e ingeniería. Madrid: Zaragozano y Jayme. Madrid: A. Pérez Dubrull, 5 vols.

COROMINAS, Joan (1998): Breve diccionario etimológico de la lengua castellana. Madrid: Gredos.

COROMINAS, Joan y José Antonio PASCUAL (1980-1991): Diccionario crítico etimológico castellano e hispánico. Madrid: Gredos. (DECH).

CORSINI, Luis (1849): Vocabulario militar. Madrid: Imprenta del Semanario e Ilustración.

Covarrubias Horozco, Sebastián de (2006 [1611]): Tesoro de la lengua castellana o española. Edición integral e ilustrada de Ignacio Arellano y Rafael Zafra. Madrid: Iberoamericana. (Cov.).

CROOKE y NAVARrot, Juan [conde viudo de Valencia de Don Juan] (1898): "Glosario", en Catálogo histórico-descriptivo de la Real Armería de Madrid. Madrid: Fototipias de Hauser y Menet, pp. 411-431. 


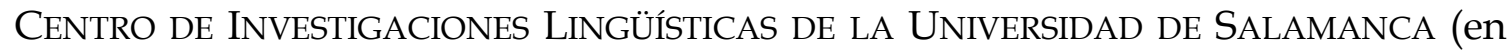
red): Diccionario de la ciencia y de la técnica del Renacimiento español (DICTER): <http://dicter.eusal.es/>.

DOMíNGUEZ, Ramón Joaquín (18535): Diccionario nacional o gran diccionario clásico de la lengua española. Madrid-París: Establecimiento de Mellado, 2 vols.

D’ WARTELET, Jorge (1863): Diccionario militar. Madrid: L. Palacios.

ENRILE, Joaquín María (1853): Vocabulario militar francés e inglés-español. París: H. Vrayet de Surcy.

EsTÉVANEZ, Nicolás (1897): Diccionario militar con un vocabulario español-francésalemán. París: Garnier Hermanos.

FERNÁNDEZ MANCHEÑO, José (1822): Diccionario militar portátil, o recopilación alfabética de todos los términos propios de las ciencias militares, explicación de los empleos de la milicia y sus obligaciones [...]. Madrid: Imprenta de Miguel de Burgos.

GAFFIOT, Félix (2000 [1934]): Le Grand Gaffiot: dictionnaire latin-français. París: Hachette.

GAGO-Jover, Francisco (2002): Vocabulario militar castellano (siglos XIII-XV). Granada: Universidad de Granada.

GARCíA PÉREZ, Antonio (1907): Vocabulario militar hispano-mogrebino. Melilla: Imprenta de El Telegrama.

García Salinero, Fernando (1968): Léxico de alarifes de los Siglos de Oro. Madrid: Real Academia Española.

GARRIDO, Antonio (1885): Vocabulario militar español-alemán. Madrid: Diego Pacheco.

GASPAR y RoIG (eds.) (1853-1855): Diccionario enciclopédico de la lengua española, con todas las vozes, frases, refranes y locuciones usadas en España y las Américas Españolas [...]. Madrid: Imprenta y Librería de Gaspar y Roig, 2 vols.

GILLE, E. (1885²): Vocabulario militar. París: Librairie Abél Pilon.

GutiÉRrez CuAdrAdo, Juan (dir.) (1996): Diccionario Salamanca de la lengua española. Madrid: Santillana, Ediciones Universidad de Salamanca. (DSAL).

HeviA, Deogracias (1857): Diccionario general militar de voces antiguas y modernas. Madrid: Imprenta y estereotipia de M. Rivadeneyra.

IMBS, Paul (dir.) (1971-1986): Trésor de la langue française. Dictionnaire de la langue du XIXe et du XXe siècle. París: Centre National de la Reserche ScientifiqueGallimard. (TLF).

LEGUINA, Enrique de (1912): Glosario de voces de armería. Madrid: Librería de Felipe Rodríguez.

LLAVE, Pedro de la (1848): Vocabulario francés-español de términos de artillería, y de los oficios y artes militares y civiles que tienen relación con ella. Segovia: Imprenta de D. Eduardo Baeza. 
LOPES PIRES Nunes, António (2005): Dicionário de arquitectura militar. Casal de Cambra: Caleidoscópio.

LÓPEZ PiÑERO, José María; GLICK, Thomas F.; NAVARRO BROTÓNS, Víctor y Eugenio PORTEla MARCo (eds.) (1983): Diccionario histórico de la ciencia moderna en España. Barcelona: Ediciones Península, 2 vols.

LÓPEZ VALLejo, María Ángeles (2008): “Glosario de términos militares”, en Historia del léxico militar en el español áureo: La conquista de Granada, el conflicto hispanoitaliano y las guerras de Flandes. Granada: Repositorio Institucional de la Universidad de Granada, Tesis Doctoral, pp. 199-1240.

LORENZO CELORRIO, Ángel (1996): Compendio de vocablos referidos a los castillos. Madrid: Ediciones Lancia.

MARIÁTEGUI, Eduardo de (1876): Glosario de algunos antiguos vocablos de Arquitectura $y$ de sus Artes auxiliares. Madrid: Imprenta de Memorial de Ingenieros.

MARTíneZ DEL ROMERO, Antonio (1849): “Glosario compuesto de varias palabras cuya esplicación es necesaria para la intelijencia del catálogo que antecede", en Catálogo de la Real Armería. Madrid: Aguado.

Miguel, Raimundo de (2003): Nuevo diccionario latino-español etimológico. Madrid: Visor Libros.

Moliner, María (19982): Diccionario de uso del español. Madrid: Gredos. (DUE).

MORA-FIgUEROA, Luis de (20063): Glosario de arquitectura defensiva medieval. Madrid: Ministerio de Defensa.

MORETTI, Federico (1828): Diccionario militar español-francés. Madrid: Imprenta Real.

NebrijA, Antonio de (1951 [1495]): Vocabulario español-latino. Madrid: Real Academia Española. (Nebr.).

Oudin, César (1607): Tesoro de las dos lenguas francesa y española. París: Marc Orry.

PAGÉS, Aniceto de (1902-31): Gran diccionario de la lengua castellana, autorizado con ejemplos de buenos escritores antiguos y modernos [...]. Madrid: Sucesores de Rivadeneyra. Barcelona: Pedro Ortega. Barcelona: Fomento comercial del libro, 5 vols.

PALET, Juan (1604): Diccionario muy copioso de la lengua española y francesa [...]. París: Matthieu Guillemot.

PANiAgua SOTO, José Ramón (1998): Vocabulario básico de arquitectura. Madrid: Cátedra.

PHARIES, David (2002): Diccionario etimológico de los sufijos españoles. Madrid: Gredos.

Real Academia Española (1933-36): Diccionario histórico de la lengua española. Madrid: Casa Editorial Hernando.

ReAl ACADEMia EsPaÑola (1960-): Diccionario histórico de la lengua española, proyectado y dirigido inicialmente por Julio Casares, director Rafael Lapesa Melgar. Madrid: Real Academia Española. 
Real Academia Española (1990 [1726-39]): Diccionario de Autoridades. Madrid: Gredos. (Aut.).

Real Academia EsPañola (2001): Nuevo tesoro lexicográfico de la lengua española (edición DVD). Madrid: Espasa Calpe. (NTLLE).

Real ACADEMia EsPaÑola (200122): Diccionario de la lengua española. Madrid: Espasa Calpe. (DRAE).

RodríGUEZ NAVAS Y CARRASCO, Manuel (1918): Diccionario general y técnico hispanoamericano. Madrid: Cultura Hispanoamericana.

RuBió y BELlVÉ, Mariano (1895-1901): Diccionario de ciencias militares. Barcelona: Administración de la Revista científico-militar y Biblioteca militar, 3 vols.

SAlVÁ, Vicente (1846): Nuevo diccionario de la lengua castellana, que comprende la última edición íntegra, muy rectificada y mejorada del publicado por la Academia Española [...]. París: Vicente Salvá.

SÁnchez, Trinidad; Herrero, José Luis y Atilano LuCAS (coords.) (2007): Diccionario estudio Salamanca. Barcelona: Ediciones Octaedro. (DESAL).

SÁNCHEZ CISNEROS, Juan (1826): Ensayo de un diccionario razonado sobre la ciencia de la guerra. Barcelona: Oficina de la viuda de Don Agustín Roca.

SANTA Olalla Millet, Fausto (1909): "Vocabulario hispano-árabe militar", en Compendio de gramática árabe vulgar. Tánger: Establecimiento tipográfico S. Benaioun.

SANZ, Raimundo (1749): Diccionario militar, o recolección alfabética de todos los términos propios al arte de la guerra [...]. Barcelona: Imprenta de Juan Piferrer.

SANZ, Raimundo (17942): Diccionario militar, o recolección alfabética de todos los términos propios al arte de la guerra [...]. Madrid: Oficina de D. Gerónimo Ortega y herederos de Ibarra.

SANZ, Raimundo (2007 [1749]): Diccionario militar. Edición y estudio de Francisco Gago-Jover y Fernando Tejedo-Herrero. Zaragoza: Institución “Fernando el Católico".

SECO, Manuel; ANDRÉS, Olimpia y Gabino RAMOS (1999): Diccionario del español actual. Madrid: Grupo Santillana de Ediciones. (DEA).

SEgura Munguía, Santiago (2001): Nuevo diccionario etimológico latín-español y de las voces derivadas. Bilbao: Universidad de Deusto.

SEgura MunguíA, Santiago (2007): Diccionario por raíces del latín y de las voces derivadas. Bilbao: Universidad de Deusto.

SOBRINO, Francisco (1705): Diccionario nuevo de las lenguas española y francesa. Bruselas: Francisco Foppens.

STEVENS, John (1706): A new Spanish and English dictionary [...]. Londres: George Sawbridge.

TAMARIT, Emilio (1853): Vocabulario técnico del material de artillería e ingenieros. Madrid: Imprenta de la Biblioteca del Notariado. 
TERREROS Y PANDO, Esteban de (1987 [1786-1793]): Diccionario castellano con las voces de las ciencias y las artes. Madrid: Arco/Libros. (Terr.).

TOMmASEO, Nicolò y Bernardo BELLINI (1861-1879): Dizionario della lingua italiana. $<$ http://www.dizionario.org/>.

TORO y GómEZ, Miguel de (1901): Nuevo diccionario enciclopédico ilustrado de la lengua castellana. París-Madrid: Librería Armand Colin-Hernando y Cía.

TRÉPIED, Henri (1889): Vocabulaire militaire espagnol-français. París: Librairie militaire de L. Baudoin.

VAREla SOARES, Vicente Henrique y Eduardo Augusto das NeVES AdeliNO (19621963): Diciónario da terminologia militar. Edição dos autores.

VERA BOTI, Alfredo (2004): Elucidario: arquitectura del Renacimiento: significado de los términos según los tratadistas y evolución histórica de los elementos utilizados en la arquitectura, sus oficios y en el urbanismo. Murcia: Real Academia Alfonso X el Sabio.

WiLlson, James (1794): A pocket vocabulary in six languages, viz. English, German, Dutch, French, Italian and Spanish; containing such words, terms and questions, as are most generally in use, particularly in military service. Londres: $\mathrm{R}$. Hindmarsh.

Zerolo, Elías (1895): Diccionario enciclopédico de la lengua castellana. París: Garnier Hermanos.

\section{Estudios lingüísticos e históricos}

AHUMADA, Ignacio (2001): "Problemas de la definición enciclopédica en las palabras especializadas", en Bargalló et alii (eds.), Las lenguas de especialidad y su didáctica. Actas del Simposio Hispano-Austriaco. Tarragona: Universitat Rovira i Virgili, pp. 59-68.

Albi De la Cuesta, Julio (2005): De Pavía a Rocroi. Los tercios de infantería españoles en los siglos XVI y XVII. Madrid: Balkan editores.

AlONSO ACERO, Beatriz (2004): «Estudio preliminar», en Cristóbal de Rojas, Sumario de la milicia antigua y moderna. Madrid: Ministerio de Defensa, pp. 13-49.

AlONSO BAqUeR, Miguel (2000): “Pedro Navarro, precursor de los ingenieros militares", en José Hernando Sánchez (coord.), Las fortificaciones de Carlos V. Madrid: Ediciones del Umbral, pp. 321-337.

Alvar EZQUerRA, Manuel (19952): La formación de palabras en español. Madrid: Arco/Libros.

AlVAR, Manuel y Sebastián MARINER (1967): "Latinismos", en M. Alvar et alii (dirs.), Enciclopedia lingüística hispánica. Elementos constitutivos, II. Madrid: Consejo Superior de Investigaciones Científicas, pp. 3-49. 
Álvarez de Miranda, Pedro (1993): “El alomorfo de la y sus consecuencias”, en Lingüística Española Actual, XV, pp. 5-43.

Álvarez DE MiRANDA, Pedro (2008): “Las discontinuidades en la historia del léxico", en Company Company y Moreno de Alba (eds.), Actas del VII Congreso Internacional de Historia de la Lengua Española. Madrid: Arco/Libros, vol. 1, pp. 1-44.

Álvarez-Ossorio AlvariÑo, Antonio (2000): “Nido de tiranos o emblema de la soberanía: las ciudadelas en el gobierno de la monarquía", en Hernando Sánchez (coord.), Las fortificaciones de Carlos V. Madrid: Ediciones del Umbral, pp. 117-155.

AmbadiAnG, Théophile (1999): “La flexión nominal. Género y número”, en Ignacio Bosque y Violeta Demonte (dirs.), Gramática descriptiva de la lengua española. Madrid: Espasa Calpe, vol. 3, pp. 4843-4913.

ARNTZ, Reiner y Heribert PICHT (1995): Introducción a la terminología. Madrid: Fundación Germán Sánchez Ruipérez, Pirámide.

AZEVEDO ForTES, Manoel (1993 [1728-1729]): O engenheiro português. Lisboa: Direcção da arma de engenharia, 2 vols.

AzOFrA SIERRA, María Elena (1996): "Problemática de la integración de los cultismos en español actual", en Ana María Aldama (ed.), De Roma al Siglo $X X$. Madrid: Sociedad de estudios latinos, Universidad Nacional de Eduación a Distancia, Universidad de Extremadura, pp. 447-471.

AzOFrA SIERrA, María Elena (2006): “Consideraciones sobre el concepto de cultismo", en Revista de Filología Románica, vol. 23, pp. 229-240.

AZORÍN FERnÁndeZ, Dolores (2004): Los diccionarios del español en su perspectiva histórica. Alicante: Publicaciones de la Universidad de Alicante.

BAJO PÉREZ, Elena (1997a): La derivación nominal en español. Madrid: Arco/Libros.

BAJO PÉREZ, Elena (1997b): “La clasificación de las voces según su procedencia etimológica, con especial referencia al DCECH", en Moenia, 3, pp. 411-458.

BECERRA DE BECERRA, Emilio (1997): "Estudio descriptivo e histórico de una fortaleza abaluartada: el real fuerte de la Concepción", en Revista de historia militar. Servicio Histórico Militar y Museo del Ejército, n. ${ }^{\circ}$ 82. Madrid: Ministerio de Defensa, Secretaría General Técnica, pp. 13-42.

BibliotecA NACIONAL DE España (BNE) (en red): <http://www.bne.es/es/inicio/index.html>.

Blas Nistal, Cristina (2007): Estudio léxico de los tratados de artillería españoles del siglo XVI. Tesis Doctoral, Universidad de Salamanca.

BOSQUE, Ignacio (1999): “El sintagma adjetival. Modificadores y complementos del adjetivo. Adjetivo y participio", en Ignacio Bosque y Violeta Demonte (dirs.), Gramática descriptiva de la lengua española. Madrid: Espasa Calpe, vol. 1, pp. 217-310. 
BuenAfuentes DE LA MATA, Cristina (2007): Procesos de gramaticalización y lexicalización en la formación de compuestos en español. Tesis Doctoral, Universitat Autònoma de Barcelona [disponible en <http:/ / www.tdx.cat/handle/10803/4879;jsessionid=C49B7580C3EB0C570 5BAA8AEB1BEB35E.tdx2>].

Bustos GISBERT, Eugenio de (1986): La composición nominal en español. Salamanca: Ediciones Universidad de Salamanca.

Bustos Tovar, José Jesús (1974): Contribución al estudio del cultismo léxico medieval (1140-1252). Madrid: RAE (Anejos del Boletín de la Real Academia Española XXVIII).

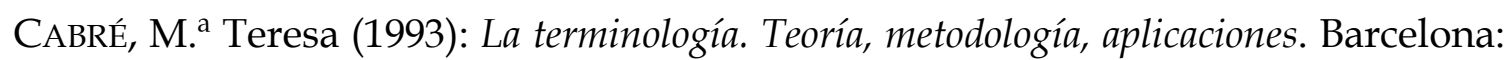
Antártida/Empúries.

CABRÉ, M. ${ }^{a}$ Teresa (2003): “El lenguaje científico desde la terminología”, en Gutiérrez Rodilla (ed.), Aproximaciones al lenguaje de la ciencia. Burgos: Colección Beltenebros, pp. 19-52.

CABrÉ, M. ${ }^{a}$ Teresa y Josefa GómEZ DE ENTERRÍA (2006): La enseñanza de los lenguajes de especialidad. La simulación global. Madrid: Gredos.

CAlABro, Mateo (1991 [1733]): Tratado de Fortificación o Arquitectura Militar. Estudio introductorio, notas y glosario de Fernando R. de la Flor. Transcripción de María Isabel Toro Pascua. Salamanca: Ediciones Universidad de Salamanca.

CÁMARA MuÑoz, Alicia (1989): “La fortificación de la monarquía de Felipe II", en

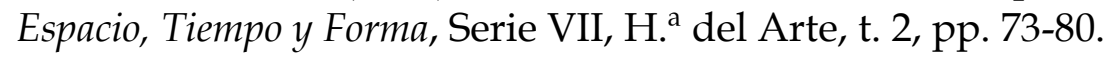

CÁMARA MuÑOZ, Alicia (1990): “Las torres del litoral en el reinado de Felipe II: una arquitectura para la defensa del territorio (I)", en Espacio, Tiempo y Forma,

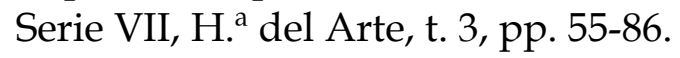

CÁmARA MuÑoz, Alicia (1991a): “Las torres del litoral en el reinado de Felipe II: una arquitectura para la defensa del territorio (y II)", en Espacio, Tiempo y Forma, Serie VII, H. ${ }^{a}$ del Arte, t. 4, pp. 53-94.

CÁmARA MuÑoz, Alicia (1991b): “El sistema de fortificación de costas en el reinado de Felipe II: la costa norte de África y la fortificación de Melilla en el siglo XVI", en Melilla en la historia de sus fortificaciones. Madrid: Ministerio de Cultura, Dirección General de Bellas Artes y Archivos, pp. 31-41.

CÁmARA Muñoz, Alicia (1991c): “Fortificación, ciudad y defensa de los reinos peninsulares en la España imperial. Siglos XVI y XVII", en Cesare de Seta y Jacques le Goff (eds.), La ciudad y las murallas. Madrid: Cátedra, pp. 89-112.

CÁmara Muñoz, Alicia (1992): “Modelos del Viejo Mundo en las primeras fortificaciones de Indias", en Reales Sitios, n. ${ }^{\circ} 113$, pp. 22-30.

CÁmARA Muñoz, Alicia (1993a): "Juan de Herrera y la arquitectura militar", en Juan de Herrera y su influencia. Actas del Simposio Camargo. Santander: Universidad de Cantabria, pp. 91-99. 
CÁMARA MuÑOz, Alicia (1993b): “Murallas para la guerra y para la paz. Imágenes de la ciudad en la España del siglo XVI", en Espacio, Tiempo y Forma, Serie VII, H. ${ }^{a}$ del Arte, t. 6, pp. 149-174.

CÁmARA Muñoz, Alicia (1994): “La fortificación de la ciudad en los tratados del siglo XVI", en Tiempo y espacio en el arte. Homenaje al profesor Antonio Bonet Correa. Madrid: Editorial Complutense, pp. 685-693.

CÁmARA MuÑoz, Alicia (1997): "La fortaleza de Felipe II en la Aljafería de Zaragoza”, en Reales Sitios, n. ${ }^{\circ} 134$, pp. 23-30.

CÁmARA Muñoz, Alicia (1998a): Fortificación y ciudad en los reinos de Felipe II. Madrid: Editorial Nerea.

CÁMARA MuÑoz, Alicia (1998b): "Fortificaciones y control del territorio", en Felipe II, un monarca y su época. Las tierras y los hombres del rey. Madrid: Sociedad Estatal para la Conmemoración de los Centenarios de Felipe II y Carlos V, pp. 121-134.

CAMPILlo, Antonio (20082): La fuerza de la razón. Guerra, estado y ciencia en el Renacimiento. Murcia: Universidad de Murcia.

CAMPOS SOUTO, Mar (2007): “Hacia la ordenación morfológica del NDHE: primer esbozo", en Verba: Anuario Galego de Filoloxía, 34, pp. 125-155.

CAmpos Souto, Mar y José Ignacio Pérez PASCuAl (2003): “El diccionario y otros productos lexicográficos", en Antonia M. Medina Guerra (coord.), Lexicografía española. Barcelona: Ariel, pp. 53-78.

CANTillo Nieves, M. ${ }^{a}$ Teresa (2005): “El uso de la metáfora y la extensión metonímica en el léxico de la destilación quinientista", en Estudios de Historia de la Lengua e Historiografía Lingüística. Actas del III Congreso Nacional de la AJIHLE. Madrid: Compañía Española de Reprografía y Servicios, pp. 101115.

CARPINTERo FERnÁNDEZ, Ana (2010): “Federico Moretti, un enigma descifrado”, en Anuario Musical, n. ${ }^{\circ}$ 65, pp. 79-110.

CARRASCO, Inés (1992): Los cargos de la hueste real en tiempos de Alfonso X. Estudio onomasiológico. Granada: Universidad de Granada.

CARRIAZO RuIZ, José Ramón y María Jesús MANCHO DUQUE (2003): “Los comienzos de la lexicografía monolingüe", en Antonia M. Medina Guerra (coord.), Lexicografía española. Barcelona: Ariel, pp. 205-234.

CAstillo Carballo, M. a Auxiliadora (2003): "La macroestructura del diccionario", en Antonia M. Medina Guerra (coord.), Lexicografía española. Barcelona: Ariel, pp. 79-101.

CASTRO FERNÁNDEZ, José Javier de y Fernando CoBOS GUERRA (2000): “El debate en las fortificaciones del Imperio y la Monarquía española, 1535-1574", en Hernando Sánchez (coord.), Las fortificaciones de Carlos V. Madrid: Ediciones del Umbral, pp. 245-267. 
Catálogo Colectivo del Patrimonio Bibliográfico español (CCPB) (en red): <http://www.mcu.es/bibliotecas/MC/CCPB/index.html>.

Clavería NADAL, Gloria (1991): El latinismo en español. Bellaterra: Universitat Autònoma de Barcelona.

Clavería NADAL, Gloria (2004): “Los caracteres de la lengua en el siglo XIII: el léxico", en Rafael Cano (coord.), Historia de la lengua española. Barcelona: Ariel, pp. 473-504.

Clavería NADAL, Gloria (2012): "Nuevas perspectivas en el estudio de la evolución del léxico", en Clavería Nadal, Freixas Alás, Prat Sabater y Torruella i Casañas (eds.), Historia del léxico: perspectivas de investigación. Madrid: Iberoamericana. Frankfurt am Main: Vervuert, pp. 13-90.

Clavería NADAL, Gloria y Joan TORRUella (1993): “Formación de términos en los léxicos especializados de la lengua española", en Juan C. Sager, Curso práctico sobre el procesamiento de la terminología. Madrid: Fundación Germán Sánchez Ruipérez, Pirámide, pp. 315-344.

Cobos Guerra, Fernando (2004): “La formulación de los principios de la fortificación abaluartada en el siglo XVI. De la Apología de Escrivá (1538) al Tratado de Rojas (1598)", en Silva Suárez (ed.), Técnica e ingeniería en España. El Renacimiento. Zaragoza: Institución "Fernando el Católico"-Diputación de Zaragoza, pp. 401-438.

Cobos Guerra, Fernando y José Javier de CASTRo Fernández (2000): “Diseño y desarrollo técnico de las fortificaciones de transición españolas", en Hernando Sánchez (coord.), Las fortificaciones de Carlos V. Madrid: Ediciones del Umbral, pp. 219-243.

Cobos Guerra, Fernando; CASTRO FernándeZ, José Javier de y Antonio SÁncheZGIJón (2000): Luis Escrivá: Su Apología y la fortificación imperial. Valencia: Generalitat Valenciana.

COLÓn DOMÉNECH, Germán (1967a): “Occitanismos”, en M. Alvar et alii (dirs.), Enciclopedia lingüistica hispánica. Elementos constitutivos, II. Madrid: Consejo Superior de Investigaciones Científicas, pp. 153-192.

COlón DOMÉNECH, Germán (1967b): “Catalanismos”, en M. Alvar et alii (dirs.), Enciclopedia lingüística hispánica. Elementos constitutivos, II. Madrid: Consejo Superior de Investigaciones Científicas, pp. 193-238.

COLÓN DOMÉNECH, Germán (2002a): “Elementos constitutivos del léxico español”, en Albert Soler y Núria Mañé (eds.), Para la historia del léxico español, vol. 1. Madrid: Arco/Libros, pp. 19-44.

COLÓN DOMÉNECH, Germán (2002b): “De arabismos interhispanos”, en Albert Soler y Núria Mañé (eds.), Para la historia del léxico español, vol. 1. Madrid: Arco/Libros, pp. 45-54. 
COLÓN DOMÉNECH, Germán (2002c): “El Diccionario Crítico Etimológico de la lengua castellana de Corominas", en Albert Soler y Núria Mañé (eds.), Para la historia del léxico español, vol. 1. Madrid: Arco/Libros, pp. 70-111.

COLÓN DOMÉNECH, Germán (2002d): "Sobre los estudios de etimología española", en Albert Soler y Núria Mañé (eds.), Para la historia del léxico español, vol. 1. Madrid: Arco/Libros, pp. 112-125.

COLÓN DOMÉNECH, Germán (2008): “Joan Coromines i les llengües romàniques” en Teresa Cabré, Marta Prat y Joan Torruella (eds.), Joan Coromines i la filologia romànica. Bellaterra: Universitat Autònoma de Barcelona, pp. 115-122.

CORPAS PASTOR, Gloria (1996): Manual de fraseología española. Madrid: Gredos.

CORRIENTE CóRdOBA, Federico (2004): “El elemento árabe en la historia lingüística peninsular: actuación directa e indirecta. Los arabismos en los romances peninsulares (en especial, en castellano)", en Rafael Cano (coord.), Historia de la lengua española. Barcelona: Ariel, pp. 185-206.

CROOKE y NAVARrot, Juan [conde viudo de Valencia de Don Juan] (1898): Catálogo histórico-descriptivo de la Real Armería de Madrid. Madrid: Fototipias de Hauser y Menet.

DÍAZ CAPMANY, Carlos (2004): La fortificación abaluartada. Una arquitectura militar y política. Madrid: Ministerio de Defensa.

Díez DE REVEngA TORRES, Pilar y Miguel Ángel Puche LoREnZO (2007): "Preocupaciones lingüísticas y mecanismos léxicos en la obra de Guillermo Bowles Introducción a la Historia Natural y a la Geografía Física de España", en Dynamis, 27, pp. 187-210.

Díez de Revenga Torres, Pilar y Miguel Ángel Puche Lorenzo (2008): Viage metalúrgico por el litoral del mediterráneo. Edición y estudio lingüístico. Anexos Revista de Lexicografía, 10. A Coruña: Servizo de Publicacións, Universidade da Coruña.

ECHARRI IRIBARREN, Víctor (2000): Las murallas y la ciudadela de Pamplona. Pamplona: Gobierno de Navarra, Institución Príncipe de Viana.

EsPinOSA ElorZA, Rosa María (2009): “El cambio semántico”, en Elena de Miguel (ed.), Panorama de la lexicología. Barcelona: Ariel Letras, pp. 159-188.

FAJARDO AGUIRRE, Alejandro (1996-1997): “Las marcas lexicográficas: conceptos y aplicación práctica en la Lexicografía española”, en Revista de Lexicografía, III, pp. 31-57.

FERNÁNDEZ RAMíREZ, Salvador (1986): La derivación nominal. Ordenado, anotado y dispuesto por Ignacio Bosque. Madrid: Imprenta Aguirre, Anejo XL, Boletín de la Real Academia Española.

FERRANDO ARAMO, Verónica (2002): “Colocaciones y compuestos sintagmáticos: dos fenómenos léxicos colindantes", en Alexandre Veiga, Miguel González 
Pereira y Montserrat Souto Gómez (eds.), Léxico y gramática. Lugo: TrisTram, pp. 99-107.

GaGo-Jover, Francisco (2007): “Léxico militar del siglo XVIII: El Diccionario militar de Raimundo Sanz", en Mar Campos Souto, Rosalía Cotelo García y José Ignacio Pérez Pascual (eds.), Historia de la lexicografía española, Anexos Revista de Lexicografía, 7. A Coruña: Servizo de Publicacións, Universidade da Coruña, pp. 59-67.

GAGO-Jover, Francisco (2008): “Glosarios y diccionarios militares del siglo XIX”, en Dolores Azorín et alii (eds.), El diccionario como puente entre las lenguas y culturas del mundo. Actas del II Congreso Internacional de Lexicografía Hispánica. Alicante: Universidad de Alicante-Fundación Biblioteca Virtual Miguel de Cervantes, pp. 670-677.

Gago-Jover, Francisco y Fernando Tejedo-Herrero (2007): “Introducción”, en Raimundo Sanz, Diccionario militar. Zaragoza: Institución "Fernando el Católico", pp. VII-XXI.

GAMILLSCHEG, Ernst (1967): “Germanismos”, en M. Alvar et alii (dirs.), Enciclopedia lingüística hispánica. Elementos constitutivos, II. Madrid: Consejo Superior de Investigaciones Científicas, pp. 79-91.

GARCÍA EsCRIBANO, Cecilio (2003): “La microestructura del diccionario: las informaciones lexicográficas", en Antonia M. Medina Guerra (coord.), Lexicografía española. Barcelona: Ariel, pp. 103-126.

GARCía MedALL, Joaquín (1994): La prefijación verbal. Un estudio de morfología integrada del español. Valladolid: s. n.

García Pérez, Rafael y José Antonio Pascual (2009): “Relaciones de significado entre las palabras", en Elena de Miguel (ed.), Panorama de la lexicología. Barcelona: Ariel Letras, pp. 117-131.

García Platero, Juan Manuel (2003): “La lexicografía no académica en los siglos XVIII y XIX", en Antonia M. Medina Guerra (coord.), Lexicografía española. Barcelona: Ariel, pp. 263-280.

GARCÍA TAPIA, Nicolás (1990): Ingeniería y arquitectura en el Renacimiento español. Valladolid: Secretariado de Publicaciones, Universidad de Valladolid.

GARRIGA EscribANO, Cecilio (2003): “La microestructura del diccionario: las informaciones lexicográficas", en Antonia M. Medina Guerra (coord.), Lexicografía española. Barcelona: Ariel, pp. 103-126.

Gómez CAPUZ, Juan (1998): El préstamo lingüístico. Conceptos, problemas y métodos. Valencia: Universitat de València.

GonzÁlez CALvo, José Manuel (2006): “La morfología en relación con la lexicología", en Felíu Arquiola, La morfología a debate. Jaén: Servicio de Publicaciones, Universidad de Jaén, pp. 121-130. 
GutiÉRREZ CuADRADO, Juan (1993): “Sobre algunos desdoblamientos léxicos del siglo XV", en Francisco Abad et alii, Antiqua et Nova Romania. Estudios Filológicos en honor de José Mondéjar en su sexagésimoquinto aniversario, vol. I. Granada: Servicio de Publicaciones de la Universidad de Granada, pp. 331345.

GutiérRez CuAdrado, Juan (2008): “Desafíos de la definición”, en Bernal y DeCesaris (eds.), Proceedings of the XIII EURALEX Internacional Congress. Barcelona: IULA, pp. 525-533.

GutiÉRrez OrdoÑEZ, Salvador (2003): “Semántica española en el fin de siglo", en LEA, XXV, pp. 115-143.

GuTIÉRREZ RodiLlA, Bertha (1998): La ciencia empieza en la palabra. Análisis e historia del lenguaje científico. Barcelona: Ediciones Península.

GutiÉRREz Rodilla, Bertha (2003): “Los diccionarios, instrumentos importantes en la reconstrucción del lenguaje científico", en Bertha Gutiérrez Rodilla (ed.), Aproximaciones al lenguaje de la ciencia. Burgos: Colección Beltenebros, pp. 453-463.

GutiÉRreZ RodillA, Bertha (2005): El lenguaje de las ciencias. Madrid: Gredos.

Herráez CubiNo, Guillermo (2005): El léxico de los tratados de cortes de cantería españoles del siglo XVI. Tesis Doctoral, Universidad de Salamanca.

Herrero Fernández-Quesada, María Dolores (1992): Catálogo de la Biblioteca del Real Colegio de Artillería de Segovia. II. Fondos artilleros y de fortificación. Segovia: Academia de Artillería de Segovia.

Herrero FernÁndez-QuesadA, María Dolores (2000): “Cañones y castillos. La artillería y la renovación de la arquitectura militar", en Hernando Sánchez (coord.), Las fortificaciones de Carlos V. Madrid: Ediciones del Umbral, pp. 171-193.

HERRERO INGELMO, José Luis (1994-1995): Cultismos renacentistas (cultismos léxicos y semánticos en la poesía del siglo XVI). Madrid: Imprenta Aguirre, separata del BRAE (tomos LXXIV y LXXV).

JIMÉNEZ RíOS, Enrique (1999): “La presencia de los participios pasivos en el diccionario de la Academia", en Hesperia. Anuario de Filología Hispánica, II, pp. 55-77.

JiMÉNEZ Ríos, Enrique (2001): Variación léxica y diccionario: Los arcaísmos en el diccionario de la Academia. Madrid: Iberoamericana-Vervuert.

KREMER, Dieter (2004): “El elemento germánico y su influencia en la historia lingüística peninsular", en Rafael Cano (coord.), Historia de la lengua española. Barcelona: Ariel, pp. 133-148.

LANG, Mervyn F. (200233): Formación de palabras en español. Morfología derivativa productiva en el léxico moderno. Madrid: Cátedra.

LAPESA, Rafael (19819): Historia de la lengua española. Madrid: Gredos. 
LÁZARO MORA, Fernando A. (1999): “La derivación apreciativa”, en Ignacio Bosque y Violeta Demonte (dirs.), Gramática descriptiva de la lengua española. Madrid: Espasa Calpe, vol. 3, pp. 4645-4682.

LERAT, Pierre (1997): Las lenguas especializadas. Barcelona: Ariel.

LINDBERG, David C. (2002): Los inicios de la ciencia occidental. La tradición científica europea en el contexto filosófico, religioso e institucional (desde el 600 a.C. hasta 1450). Barcelona: Paidós.

LÓPEZ PIÑERO, José María (1979): Ciencia y técnica en la sociedad española de los siglos XVI y XVII. Barcelona: Labor universitaria.

López VALLejo, María Ángeles (2006): “Italianismos militares en el Renacimiento. La palabra centinela, un ejemplo", en Rodríguez Molina y Sáez Rivera (coords.), Diacronía, lengua española y lingüística. Actas del IV Congreso Nacional de la AJIHLE. Madrid: Síntesis, pp. 355-368.

LÓPeZ VAllejo, María Ángeles (2007): “El procedimiento de la metáfora en el léxico de la milicia. Los animales, importantes protagonistas", en Cercós Carcía, Molina Rivero y Ceballos-Escalera Gila (coords.), Retos del hispanismo en la Europa Central y del Este. Madrid: Palafox y Pezuela, pp. 265-272.

López VAllejo, María Ángeles (2008a): Historia del léxico militar en el español áureo: La conquista de Granada, el conflicto hispano-italiano y las guerras de Flandes. Granada: Repositorio Institucional de la Universidad de Granada, Tesis Doctoral.

LÓPeZ VALLejo, María Ángeles (2008b): “Infante e infantería, desde la «età molto tenera» a la milicia", en Company Company y Moreno de Alba (coords.), Actas del VII Congreso Internacional de Historia de la Lengua Española. Madrid: Arco/Libros, 2. ${ }^{\circ}$ vol., pp. 1409-1427.

LuCUZE, Pedro de (1772): Principios de fortificación. Barcelona: Thomas Piferrer.

MagAlHÃEs, Natércia (2008): Algarve. Castelos, cercas e fortalezas. Faro: Letras Várias, Edições e Arte.

MALKIEL, Yakov (1951): "La historia lingüística de peón”, en Thesaurus, tomo VII, núms. 1, 2 y 3, pp. 201-244.

MALKIEL, Yakov (1993): "El análisis genético de la formación de palabras", en Varela Ortega (ed.), La formación de palabras. Madrid: Taurus Universitaria, pp. 71-115.

MANCho Duque, María Jesús (1987a): "Estudio de los adjetivos en -al/-ar en el «Tratado de los apostemas» de Diego el Covo, en Cahiers de Linguistique Hispanique Médiévale, 12, pp. 27-47.

MANCho DuQue, María Jesús (1987b): “Formaciones adjetivas en -oso en cinco prosistas del s. XV", en Studia Zamorensia Philologica, VIII, pp. 35-49.

MANCHO DuQUe, María Jesús (1989): “Particularidades del registro culto de finales de la Edad Media en el campo de la formación adjetiva”, en Dieter Kremer 
(ed.), Actes du XVIII Congrès International de Linguistique et de Philologie Romanes. Tübingen: Max Niemeyer Verlag, pp. 373-380.

MANCHO DuQUe, María Jesús (2001): “La lengua española, vehículo de divulgación científica en el Renacimiento", en M. ${ }^{a}$ Jesús Mancho Duque (ed.) y Cristina Blas Nistal (coord.), Pórtico a la ciencia y a la técnica del Renacimiento. Salamanca: Junta de Castilla y León, Universidad de Salamanca, pp. 45-84.

MANCHO DuQue, María Jesús (2003): “Aproximación al léxico de la ciencia aplicada en el Renacimiento hispano", en Asclepio, Vol. LV-2, pp. 27-42.

MANCHO DuQue, María Jesús (2004a): “La divulgación técnica: características lingüísticas", en Silva Suárez (ed.), Técnica e ingeniería en España. El Renacimiento. Zaragoza: Institución "Fernando el Católico"-Diputación de Zaragoza, pp. 307-340.

MANCHO DuQue, María Jesús (2004b): “Los prólogos de la literatura científica del Renacimiento: la cuestión de la lengua", en Actas del VI Congreso de la Asociación Internacional Siglo de Oro. Madrid: Iberoamericana Vervuert, pp. 1229-1243.

MANCho Duque, María Jesús (2005a): “La divulgación científica y técnica en castellano en la época de Cervantes", en La ciencia y la técnica en la época de Cervantes: libros científicos y técnicos de la Biblioteca General Universitaria de Salamanca. Salamanca: Ediciones Universidad de Salamanca y Centro de Investigaciones Lingüísticas CILUS, pp. 17-49.

MANCHO DuQue, María Jesús (2005b): "La divulgación científica y sus repercusiones léxicas en la época de El Quijote", en José Manuel Sánchez Ron (dir.), La ciencia y El Quijote. Barcelona: Crítica, pp. 257-278.

MANCHO DuQUE, María Jesús (2005c): “La metáfora corporal en el lenguaje científico-técnico del Renacimiento", en Filología y Lingüística. Estudios ofrecidos al profesor Antonio Quilis. Madrid: CSIC-UNED-Universidad de Valladolid, pp. 791-805.

MANCHO DuQUE, María Jesús (2012): “Reflexiones metodológicas sobre el léxico de la ciencia y de la técnica del Renacimiento hispano", en Clavería Nadal, Freixas Alás, Prat Sabater y Torruella i Casañas (eds.), Historia del léxico: perspectivas de investigación. Madrid: Iberoamericana. Frankfurt am Main: Vervuert, pp. 169-197.

Mancho Duque, María Jesús; Herráez Cubino, Guillermo; Cantillo Nieves, Ma Teresa y José Ramón CARRIAzO RUIZ (2004): "Léxico especializado y lexicografía del Renacimiento", en Paz Batanner y Janet DeCesaris (eds.), De Lexicografia. Actes del I Symposium Internacional de Lexicografia. Barcelona: Institut Universitari de Lingüística Aplicada, Universitat Pompeu Fabra, pp. 503-546. 
MANChO DuQUe, María Jesús (dir.) y Mariano Quirós GARCíA (coord.) (2005): La ciencia y la técnica en la época de Cervantes: textos e imágenes. Salamanca: Ediciones Universidad de Salamanca (CD).

MARAVAlL, José Antonio (1972): Estado moderno y mentalidad social. Siglos XV a XVII. Madrid: Ediciones de la Revista de Occidente, 2 tomos.

MARCHESI, José María (1849): “Prólogo”, en Antonio Martínez del Romero, Catálogo de la Real Armería. Madrid: Aguado, pp. III-XII.

MARIÁTEGUI, Eduardo de (1985 [1880]): El capitán Cristóbal de Rojas. Ingeniero militar del siglo XVI. Madrid: Centro de Estudios y Experimentación de Obras Públicas, Comisión de Estudios Históricos de Obras Públicas y Urbanismo.

MARTín GARCía, Josefa (2007): “La definición de las palabras derivadas: los adjetivos en -oso", en Mar Campos Souto, Eugenia Conde Noguerol, José Ignacio Pérez Pascual, José-Alvaro Porto Dapena (eds.), Reflexiones sobre el diccionario, Anexos Revista de Lexicografía, 6. A Coruña: Universidade da Coruña, pp. 253-263.

MARTín GARcíA, Josefa (2008): “Los participios adjetivos pasivos en los diccionarios del español", en Pena y Rodríguez Espiñeira (eds.), Categorización lingüística y categorías híbridas, Verba (anejo 61), pp. 149-163.

MARTINENA RUIZ, Juan José (1994): Castillos reales de Navarra (siglos XIII al XVI). Pamplona: Gobierno de Navarra, Institución Príncipe de Viana.

Martínez del Romero, Antonio (1849): Catálogo de la Real Armería. Madrid: Aguado.

MEDiNA GUeRRA, Antonia M. (2003): “La microestructura del diccionario: la definición", en Antonia M. Medina Guerra (coord.), Lexicografía española. Barcelona: Ariel, pp. 127-146.

MERINO PERAL, Esther (2002): El arte militar en la época moderna: los tratados «de re militari» en el Renacimiento. 1536-1671. Aspectos de un arte español. Madrid: Ministerio de Defensa, Secretaria General Técnica, Centro de Publicaciones.

MORA PIRIS, Pedro (2000): “Arte y técnica en la fortificación”, en Hernando Sánchez (coord.), Las fortificaciones de Carlos V. Madrid: Ediciones del Umbral, pp. 157-169.

MorAles RuIZ, Carmen (1998): Las relaciones del léxico en el diccionario. Bellaterra: Universitat Autònoma de Barcelona-Servei de Publications.

MORERA, Marcial (2001-2002): “Familia de palabras vs. campo semántico. Los casos particulares de las familias punt-, punz- y pinch-“, en Revista de Lexicografía, VIII, pp. 149-222.

NAVARro LOIDI, Juan Miguel (2004): Las ciencias matemáticas y las enseñanzas militares durante el reinado de Carlos II. Madrid: Ministerio de Defensa, Secretaria General Técnica, Centro de Publicaciones. Leioa: Universidad del País Vasco, 2 vols. 
Otaola Olano, Concepción (2004): Lexicología y semántica léxica. Teoría y aplicación a la lengua española. Madrid: Ediciones Académicas.

PARKER, Geoffrey (1991): El ejército de Flandes y el Camino Español. 1567-1659. Madrid: Alianza Editorial.

PARKER, Geoffrey (2002): La revolución militar. Innovación militar y apogeo de Occidente. 1500-1800. Madrid: Alianza Editorial.

PAscual Rodríguez, José Antonio (1974): La traducción de la Divina Commedia atribuida a D. Enrique de Aragón. Estudio y edición del Infierno. Salamanca: Universidad de Salamanca.

Pascual Rodríguez, José Antonio Pascual (2003): “El comentario lexicográfico: tres largos paseos por el laberinto del diccionario", en Antonia M. Medina Guerra (coord.), Lexicografía española. Barcelona: Ariel, pp. 353-385.

Pascual Rodríguez, José Antonio y Rafael GArcía PÉrez (2007): Límites y horizontes en un diccionario histórico. Salamanca: Diputación de Salamanca.

PAVÓN LUCERO, Ma Victoria (1999): “Clases de partículas: preposición, conjunción y adverbio", en Ignacio Bosque y Violeta Demonte (dirs.), Gramática descriptiva de la lengua española. Madrid: Espasa Calpe, vol. 1, pp. 565-655.

PENA, Jesús (1993): "La formación de verbos en español: la sufijación verbal" en Soledad Varela (ed.), La formación de palabras. Madrid: Taurus Universitaria, pp. 217-281.

PENA, Jesús (1999): “Partes de la morfología. Las unidades del análisis morfológico", en Ignacio Bosque y Violeta Demonte (dirs.), Gramática descriptiva de la lengua española. Madrid: Espasa Calpe, vol. 3, pp. 4305-4366.

PENA, Jesús (2002): "Morfología derivativa y diccionario", en Alexandre Veiga, Miguel González Pereira y Montserrat Souto Gómez (eds.), Léxico y gramática. Lugo: TrisTram, pp. 285-298.

PENA, Jesús (2003): “La relación derivativa”, en ELUA, 17. Universidad de Alicante, pp. 505-517.

PENA, Jesús (2005): “Nombres deverbales con lectura deadjetival”, en Santos Río, Borrego Nieto, García Santos, Gómez Asencio y Prieto de los Mozos (eds.), Palabras, norma, discurso. En memoria de Fernando Lázaro Carreter. Salamanca: Ediciones Universidad de Salamanca, pp. 881-896.

PENADÉS MARTíNEZ, Inmaculada (2001): “¿Colocaciones o locuciones verbales?”, en LEA, XXIII, pp. 57-88.

PENSADO, Carmen (1999): “Morfología y fonología. Fenómenos morfofonológicos”, en Ignacio Bosque y Violeta Demonte (dirs.), Gramática descriptiva de la lengua española. Madrid: Espasa Calpe, vol. 3, pp. 4423-4504.

PORTO DAPENA, José-Álvaro (2002): Manual de técnica lexicográfica. Madrid: Arco/Libros. 
PORTO DAPENA, José-Álvaro (2009): Lexicografía y metalexicografía. Estudios, propuestas y comentarios. Anexos Revista de Lexicografía, 12. A Coruña: Servizo de Publicacións, Universidade da Coruña.

PotTIER, Bernard (1967): "Galicismos", en M. Alvar et alii (dirs.), Enciclopedia lingüística hispánica. Elementos constitutivos, II. Madrid: Consejo Superior de Investigaciones Científicas, pp. 127-151.

QUATREFAGES, René (1983): "La fortificación en España durante el Renacimiento", en Temas de historia militar, I. Madrid: Servicio de Publicaciones del EME, pp. 133-142.

RAINER, Franz (1999): “La derivación adjetiva”, en Ignacio Bosque y Violeta Demonte (dirs.), Gramática descriptiva de la lengua española. Madrid: Espasa Calpe, vol. 3, pp. 4595-4643.

Real ACAdemia Española (2009): Nueva gramática de la lengua española. Madrid: Espasa, 2 vols.

ReAl ACADEMia Española (en red): Corpus diacrónico del español (CORDE): <http:/ / www.rae.es $>$.

Rodríguez HERNÁNDEZ, Antonio José (2007): España, Flandes y la Guerra de Devolución (1667-1668). Guerra, reclutamiento y movilización para el mantenimiento de los Países Bajos españoles. Madrid: Ministerio de Defensa.

RuIz GuRILlO, Leonor (2002): “Compuestos, colocaciones, locuciones: intento de delimitación", en Alexandre Veiga, Miguel González Pereira y Montserrat Souto Gómez (eds.), Léxico y gramática. Lugo: TrisTram, pp. 327-339.

SALVADOR, Gregorio (1985): Semántica y lexicología del español. Estudios y lecciones. Madrid: Paraninfo.

SÁNCHEZ MARTíN, Francisco Javier (2009): Estudio del léxico de la geometría aplicada a la técnica en el Renacimiento hispano. Salamanca: Ediciones Universidad de Salamanca.

SÁnchez MARTín, Francisco Javier (2010a): "El Glosario de Geometría aplicada del Renacimiento (GLOGEAR): Análisis de su estructura", en Encinas Manterola (comp.): Ars longa, diez años de AJIHLE. Buenos Aires: Voces del Sur, pp. 395411.

SÁNCHEZ MARTíN, Francisco Javier (2010b): “La recepción de los tecnicismos matemáticos en la lexicografía española decimonónica", en Ianua, Revista Philologica romanica, vol. 10, pp. 143-174.

SÁNCHEZ MARTíN, Francisco Javier (2011): “Recursos para definir los términos geométricos: acerca del círculo y la esfera", en Díez de Revenga Torres y Puche Lorenzo (eds.), Nuevas claves para el estudio de la lengua española: usos especializados en la comunicación. Murcia: Universidad de Murcia, pp. 129-144.

SÁnchez MARTín, Francisco Javier y Marta SÁnchez Orense (2009): “Ciencia y léxico: la terminología en la Teórica y práctica de fortificación (1598) de Cristóbal de Rojas", en Res Diachronicae, n. 7, pp. 229-249. 
SÁNCHEZ ORENSE, Marta (2007): Estudio del léxico de la industria textil y de la sastrería en la época renacentista. Trabajo de Grado, Universidad de Salamanca.

SÁNCHEZ ORENSE, Marta (2008): "Particularidades del léxico de la moda renacentista: dificultades en su análisis", en Cuadernos del Instituto Historia de la Lengua, núm. 1, pp. 65-74.

SÁNCHEZ ORENSE, Marta (2009): "La fortificación y el arte militar en los tratados renacentistas: Estudio léxico", en Cuadernos del Instituto Historia de la Lengua, núm. 3, pp. 225-232.

SÁNCHEZ ORENSE, Marta (2010a): "Los nombres de las telas en el siglo XVI", en Encinas Manterola et alii (comp.), Ars longa, diez años de la AJIHLE. Buenos Aires: Voces del Sur, pp. 413-430.

SÁNCHEZ ORENSE, Marta (2010b): “El tratamiento lexicográfico de los tecnicismos textiles", en Ignacio Ahumada (ed.), Metalexicografía variacional. Diccionarios de regionalismos y diccionarios de especialidad. Málaga: Universidad de Málaga, pp. 495-517.

SÁNCHEZ ORENSE, Marta (en prensa-a): “La pervivencia del léxico antiguo en la tratadística militar renacentista", en Actas de las III Jornadas de la Red temática "lengua y ciencia": Lengua de la ciencia y diccionarios (Coimbra, 28-30 de octubre de 2009).

SÁnchez Orense, Marta (en prensa-b): “Aproximación al léxico de la poliorcética renacentista: Cuestiones lexicográficas", en Actas del IV Congreso Internacional de Lexicografía Hispánica.

SÁNCHEZ-PRIETO BORJA, Pedro (1992): “Alternancia entre el lexema con y sin prefijo en castellano medieval (el verbo)", en Manuel Ariza, Rafael Cano et alii (eds.), Actas del II Congreso Internacional de Historia de la Lengua Española. Madrid: Pabellón de España, pp. 1323-1336.

SANTIAGO LACUESTA, Ramón y Eugenio Bustos GisBert (1999): “La derivación nominal", en Ignacio Bosque y Violeta Demonte (dirs.), Gramática descriptiva de la lengua española. Madrid: Espasa Calpe, vol. 3, pp. 4505-4594.

SECO, Manuel (1987): Estudios de lexicografía española. Madrid: Paraninfo.

SERRANO-DOlADER, David (1999): “La derivación verbal y la parasíntesis", en Ignacio Bosque y Violeta Demonte (dirs.), Gramática descriptiva de la lengua española. Madrid: Espasa Calpe, vol. 3, pp. 4683-4756.

SERRÃo PIMENTEL, Luís (1993 [1680]): Método lusitânico de desenhar as fortificações das praças regulares e irregulares. Lisboa: Direcção da arma de engenharia, Direcção do serviço de fortificações e obras do exército.

STEIGER, Arnald (1967): "Arabismos", en M. Alvar et alii (dirs.), Enciclopedia lingüística hispánica. Elementos constitutivos, II. Madrid: Consejo Superior de Investigaciones Científicas, pp. 93-126. 
Tejedo-Herrero, Fernando y Francisco Gago-Jover (2006): “El Diccionario militar de Raimundo Sanz en el contexto de la lexicografía especializada del siglo XVIII", en Dieciocho, 29.1, pp. 85-106.

TERLINGEN, Juan (1967): "Italianismos", en M. Alvar et alii (dirs.), Enciclopedia lingüística hispánica. Elementos constitutivos, II. Madrid: Consejo Superior de Investigaciones Científicas, pp. 263-305.

VAl ÁlVARO, José Francisco (1999): “La composición”, en Ignacio Bosque y Violeta Demonte (dirs.), Gramática descriptiva de la lengua española. Madrid: Espasa Calpe, vol. 3, pp. 4757-4842.

VAREla Merino, Elena (2009): Los galicismos en el español de los siglos XVI y XVII. Madrid: CSIC, 2 vols.

VARELA ORTEGA, Soledad (2002): “Gramática y formación de palabras”, en GarcíaMedall (ed.), Aspectos de morfología derivativa del español. Lugo: Tris Tram, pp. 167-187.

VARELA ORTEGA, Soledad (2005): Morfología léxica: la formación de palabras. Madrid: Gredos.

VARELA ORTEGA, Soledad (2007): “Las categorías mixtas: morfología y semántica léxica", en Delgado Cobos Puigvert Ocal (eds.), Ex admiratione et amicitia. Homenaje a Ramón Santiago. Madrid: Ediciones del Orto, tomo II, pp. 11331147.

VARELA, Soledad y Josefa MARTín GARCÍA (1999): “La prefijación”, en Ignacio Bosque y Violeta Demonte (dirs.), Gramática descriptiva de la lengua española. Madrid: Espasa Calpe, vol. 3, pp. 4995-5040.

VERDONK, Robert (1980): La lengua española en Flandes en el siglo XVII. Contribución al estudio de las interferencias léxicas y de su proyección en el español general. Madrid: Ínsula.

VERDONK, Robert (1990): “La importancia de las Guerras de Flandes para la neología en los Siglos de Oro", en Anglada y Bargalló (eds.), El cambio lingüístico en la Romania. Lleida: Virgili y Pagès, pp. 113-125.

VERDONK, Robert (1994): “Contribución al estudio de los extranjerismos en el «Tratado de la Artillería» de Diego Ufano (Bruselas, 1612)", en Pallares et alii (eds.), Sin fronteras. Homenaje a M. J. Canellada. Madrid: Editorial Complutense, pp. 571-577.

VERDONK, Robert (2004): “Cambios en el léxico del español durante la época de los Austrias", en Rafael Cano (coord.), Historia de la lengua española. Barcelona: Ariel, pp. 895-916.

VIDOS, Benedek Elemér (1972): "Relaciones antiguas entre España y los Países Bajos, y problemas de los préstamos holandeses (flamencos) en castellano", en Revista de filología española 55, 3-4, pp. 233-242. 
ViLLENA, Leonardo (1987): “Sobre la terminología comparada de los elementos fortificativos", en Arqueología medieval española. II Congreso. Madrid: Dirección Gral. de Patrimonio Cultural, Asociación Española de Arqueología Medieval, pp. 303-318.

VILLENA, Leonardo (2000): “Libros sobre fortificaciones. La circulación de los saberes técnicos", en Hernando Sánchez (coord.), Las fortificaciones de Carlos $V$. Madrid: Ediciones del Umbral, pp. 271-299.

ZAPATERO, Juan Manuel (1963): "Síntesis histórica de la fortificación abaluartada", en Revista de historia militar, n. ${ }^{\circ}$ 13. Madrid: Servicio histórico militar del Estado Mayor Central, pp. 85-109.

ZAPATERO, Juan Manuel (1968): “La escuela de fortificación hispanoamericana”, en Revista de historia militar, n. ${ }^{\circ}$ 25. Madrid: Servicio histórico militar del Estado Mayor Central, pp. 7-24. 